\title{
ACBAR
}

\section{DIRECTORY OF HUMANITARIAN AGENCIES}

\section{WORKING FOR AFGHANS}

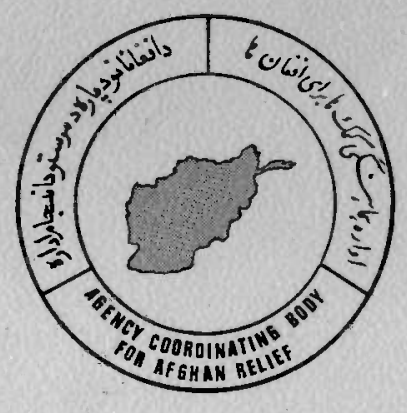

AGENCY COORDINATING BODY FOR AFGHAN RELIEF

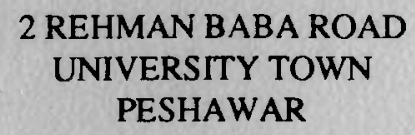

TEL: (0521) $44392 / 40839$ 
Introduction

I am delighted to make available the 1993 "Directory of Humanitarian Agencies working for Afghans".

Some 200 agencies are listed in the Directory, including those agencies that work out of Peshawar, Quetta and Islamabad in Pakistan as well as agencies based in Kabul and other parts of Afghanistan. There are certainly a number of agencies that are not 1 isted but I am confident that the vast majority are covered.

The information is as reported by agencies and ACBAR has only limited ability to confirm the statistical information provided. However, there is no doubt that this publication provides as accurate as possible a picture of the various agencies undertaking activities related to Afghanistan and refugees.

I would like to express my thanks to the staff of the agencies for providing the information. I must also extend my gratitude to the staff of the ACBAR Programme Office, especially Mohammad Ismail shakir. Much work has been done over many weeks to produce this Directory. A considerable amount of time has been spent collecting the required information, checking it and preparing the final version for publication.

We hope that the users, especially the donor community, the Afghan Government and Provincial authorities, the Pakistani authorities and the many others will find the publication extremely useful.

Charles MacFadden

Executive Director

January 1994 
CONTENTS

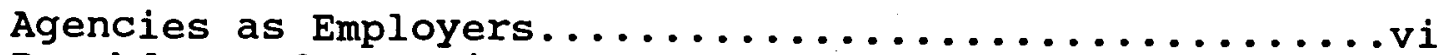

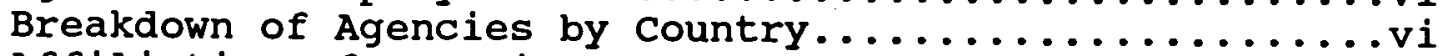

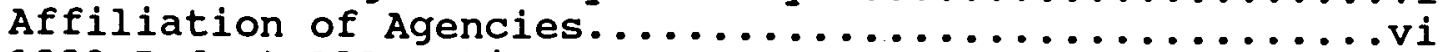

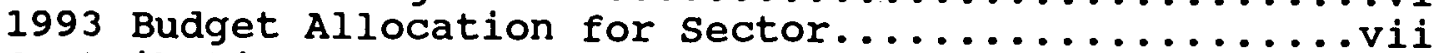

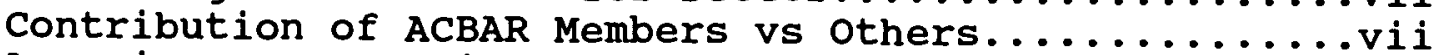

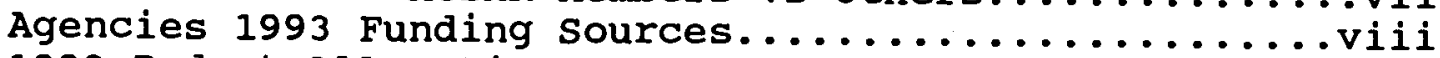
1993 Budget Allocation for Different

Provinces of Afghanistan.....................

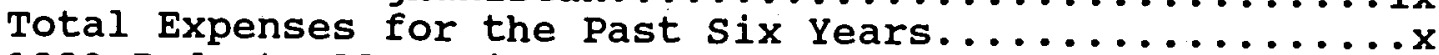
1993 Budget Allocation for Pakistan

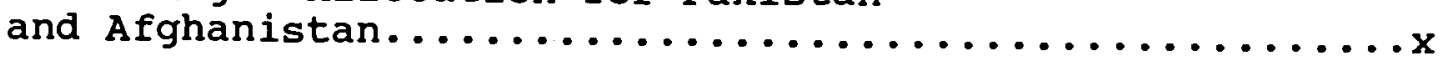

AGENCIES

PAGE

ABADY CONSTRUCTION AGENCY ... . . . . . . . . . . . . . . . .

AFGHAN AGENCY FOR INFRASTRUCTURE DEVELOPMENT $\ldots \ldots \ldots \ldots \ldots \ldots \ldots \ldots \ldots \ldots \ldots \ldots$

AFGHAN AGENCY FOR WAR DISABLED \& VICTIMS $\ldots \ldots \ldots \ldots \ldots \ldots \ldots \ldots \ldots \ldots \ldots \ldots$

AFGHAN AGRICULTURAL AND ENGINEERING AGENCY $\ldots \ldots \ldots \ldots \ldots \ldots \ldots \ldots \ldots \ldots$

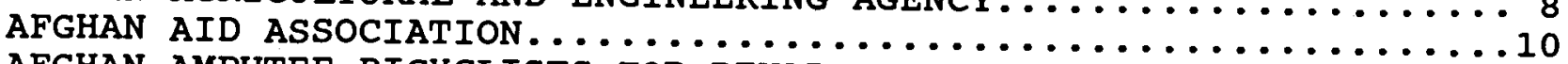

AFGHAN AMPUTEE BICYCLISTS FOR REHABILITATION \& RECREATION $\ldots \ldots \ldots 12$

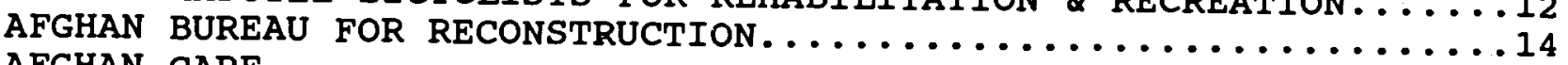

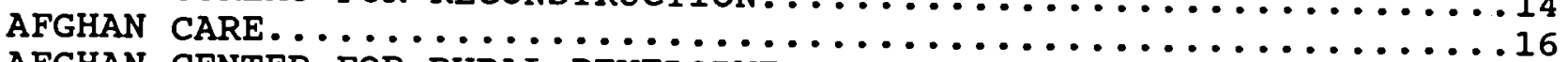

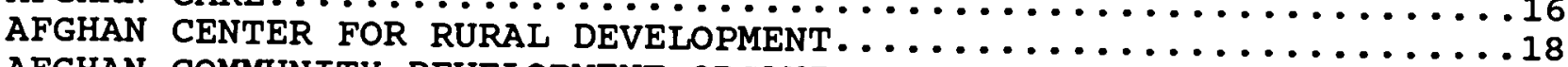

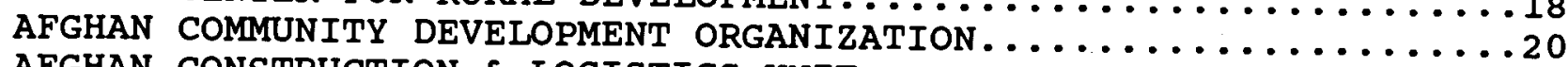

AFGHAN CONSTRUCTION \& LOGISTICS UNIT ... . . . . . . . . . . . . . .

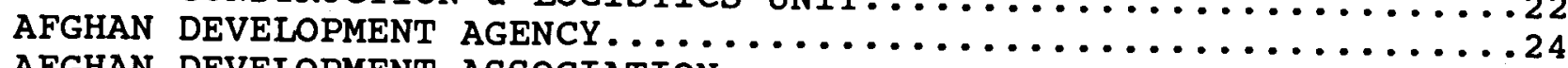

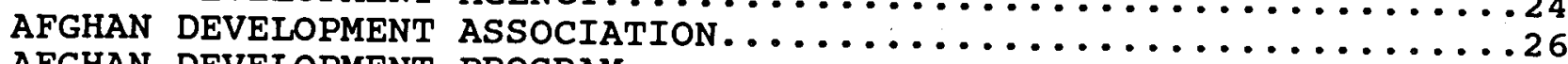

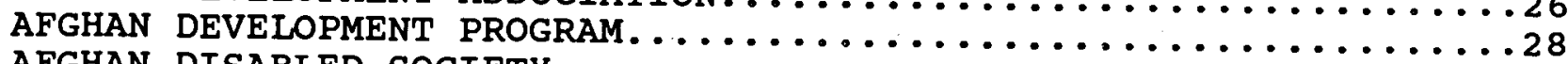

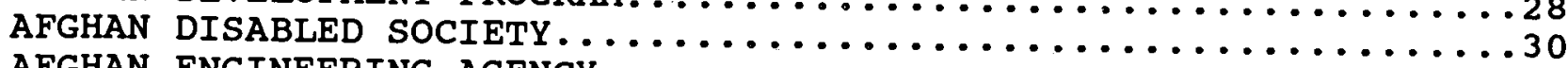

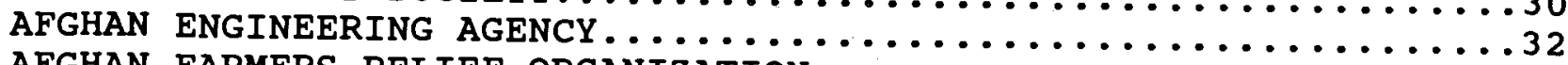

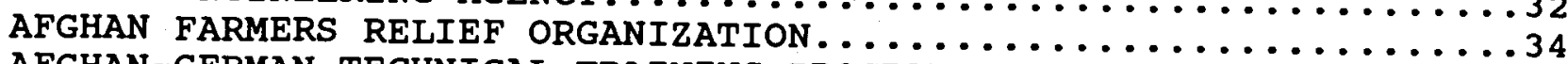

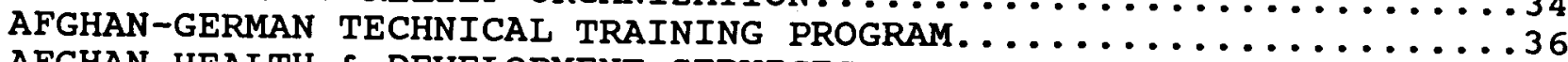

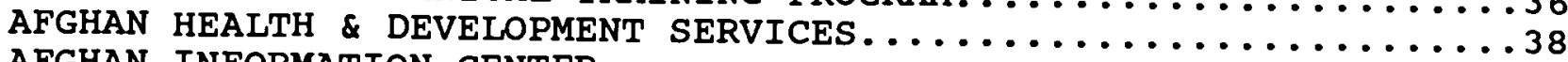

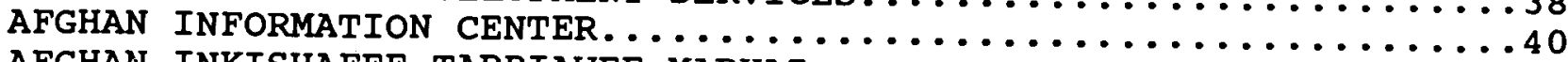

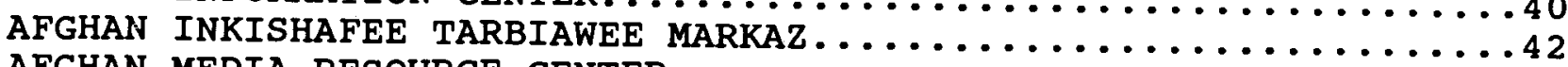

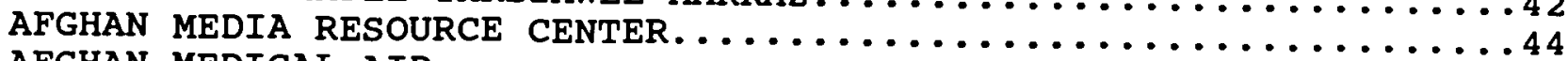

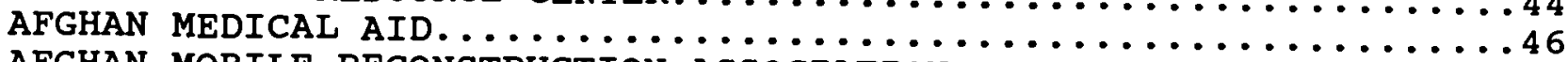

AFGHAN MOBILE RECONSTRUCTION ASSOCIATION $\ldots \ldots \ldots \ldots \ldots \ldots \ldots \ldots \ldots \ldots \ldots \ldots$

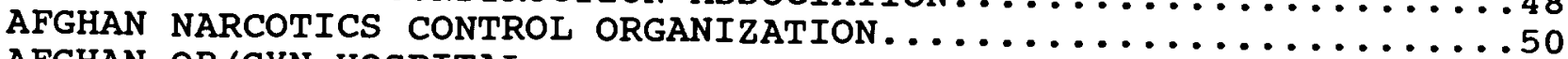

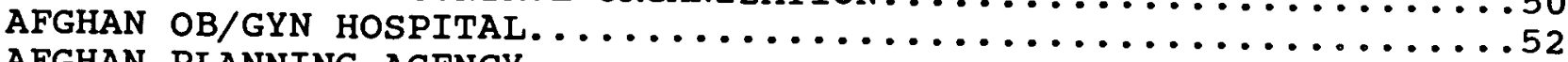

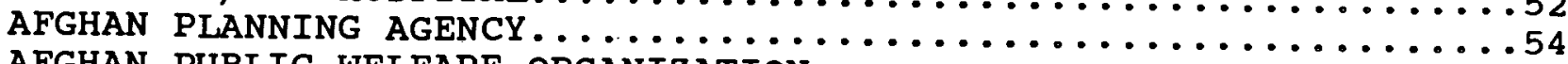

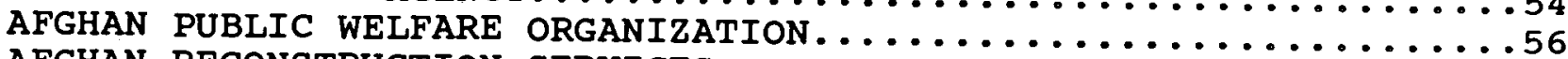

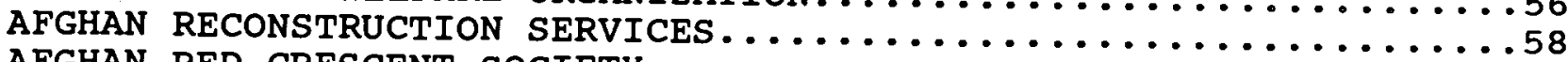

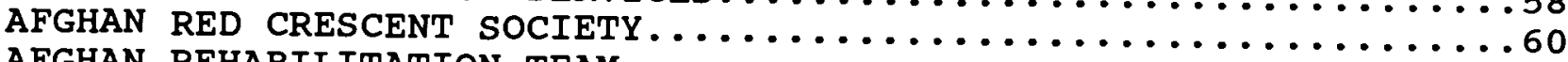

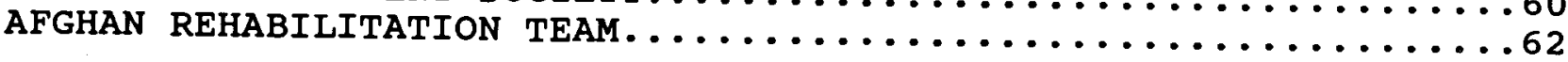


AFGHAN RELIEF FOUNDATION............................. . . . 64 AFGHAN RELIEF \& REHABILITATION........................66

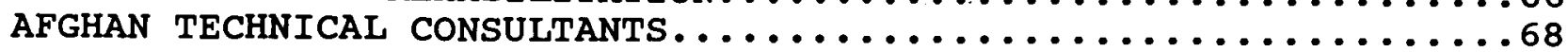

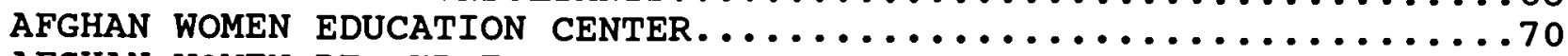

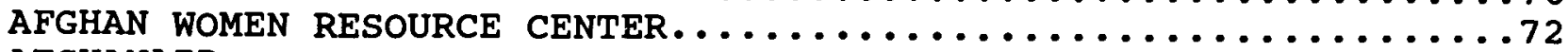
AFGHANAID . . . . . . . . . . . . . . . . . . . . . . . . . . . AFGHANISTAN HUMAN RESOURCES DEVELOPMENT PROJECT. . . . . . . . . .76 AFGHANISTAN NOTHILFE e.V. . . . . . . . . . . . . . . . . . . . 78 AFGHANISTAN RECONSTRUCTION CONSULTANTS .................. . . . . . AFGHANISTAN RECONSTRUCTION \& PLANNING DEPARTMENT. . . . . . . . . . 82 AFGHANISTAN REHABILITATION \& DEVELOPMENT PROGRAM. . . . . . . . . . 84 AFGHANISTAN VACCINATION \& IMMUNIZATION CENTER............... AFGHANS' HEALTH \& SOCIAL ASSISTANCE ORGANIZATION ............ AGENCY FOR FARMING SUPPORT........................90 AGENCY FOR REHABILITATION ASSIST. \& DEVELOPMENT OF AFGHANISTAN. 92 AGENCY FOR REHABILITATION \& RECONSTRUCTION OF AFGHANISTAN......94 AGENCY FOR RURAL DEVELOPMENT OF AFGHANISTAN . . . . . . .......96 AGRICULTURE REHABILITATION OF AFGHANISTAN . . . . . . $\ldots \ldots \ldots \ldots \ldots$ AIDE MEDICALE INTERNATIONLE-AFGHANISTAN . . . . . . . . . . . . . . 100 AL-DAWA ISLAMIC CULTURAL CENTER. . . . . . . . . . . . . . . . . . . 102 AMITE FRANCO-AFGHANE AIDE HUMANITAIRE ET INFORMATION $\ldots \ldots \ldots \ldots \ldots 104$ ANTI-TB ASSOCIATION/AFGHANISTAN PROGRAM . . . . . . . . . . . . 106 ARIANA REHABILITATION COMMITTEE FOR AFGHANISTAN RECONSTRUCTION. 108 ARIANA UNITY RECONSTRUCTION COUNCIL. ................... 110

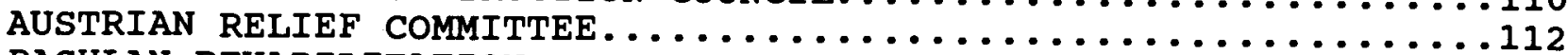

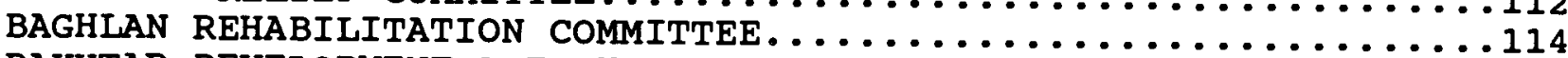

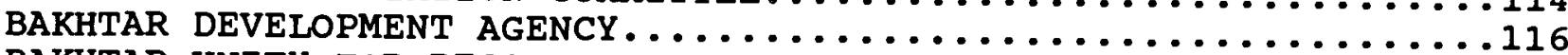

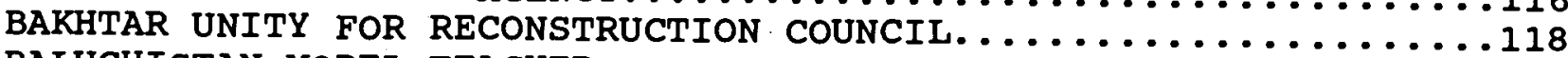

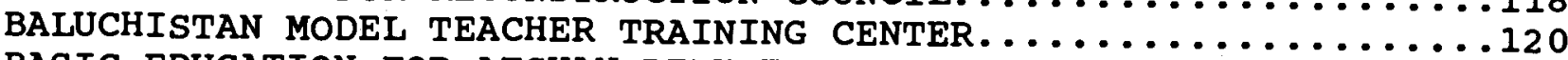

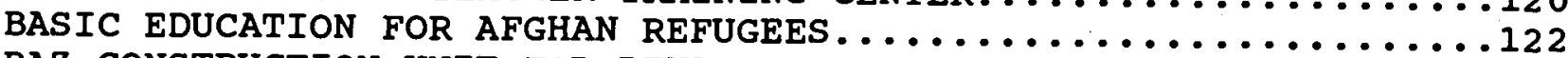
BAZ CONSTRUCTION UNIT FOR REHABILITATION OF AFGHANISTAN $\ldots \ldots \ldots \ldots 124$ BEHZAD REHABILITATION-CONSTRUCTION ORGANIZATION . . . . . . . . 126 BOMB DISPOSAL SERVICES . . . . . . . . . . . . . . . . . . . . . 128

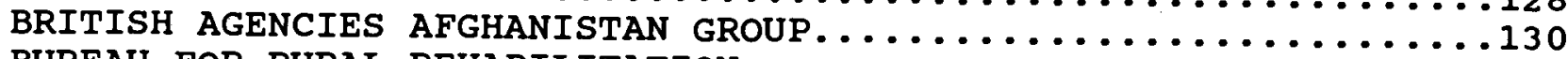

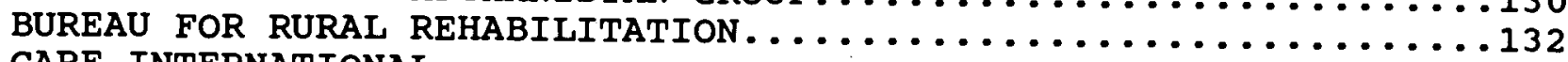

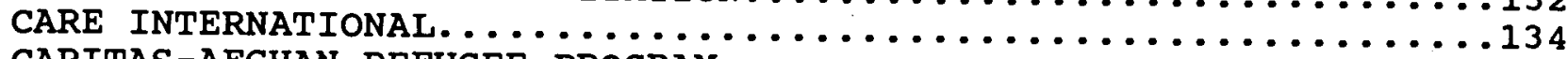
CARITAS-AFGHAN REFUGEE PROGRAM. . . . . . . . . . . . . . . . CATHOLIC RELIEF SERVICES. . . . . . . . . . . . . . . . . . . . .

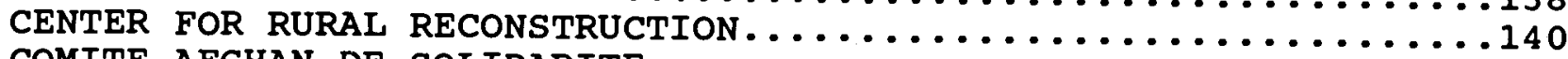

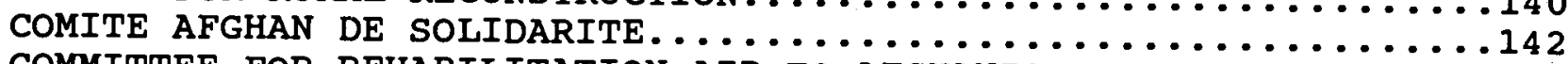
COMMITTEE FOR REHABILITATION AID TO AFGHANISTAN . . . . . . . . . . . . . 144 COMMITTEE SHURA-I-FARHANGI ISLAMI AFGHANISTAN . . . . . . . . . . . 146

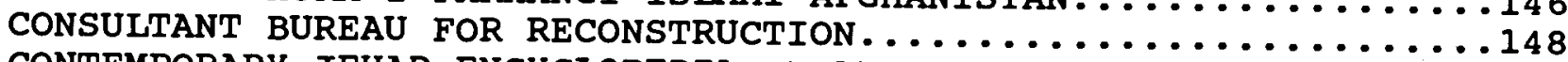

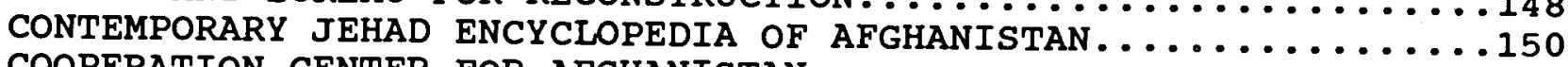

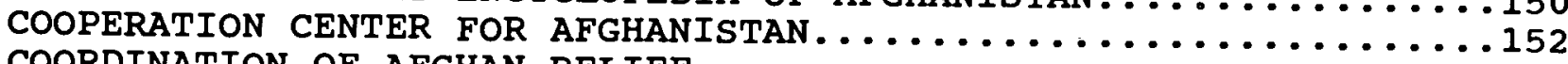

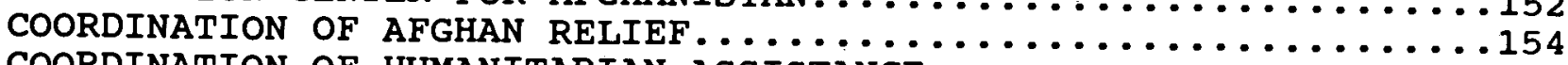

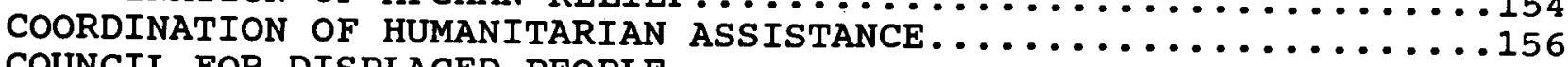

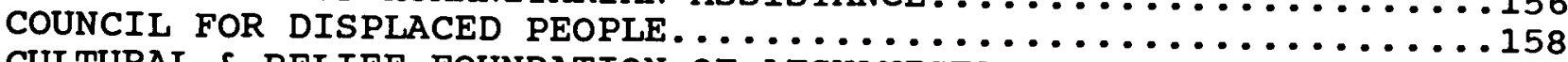
CULTURAL \& RELIEF FOUNDATION OF AFGHANISTAN.................. $\ldots$ 
DANISH COMMITTEE FOR AID TO AFGHAN REFUGEES .............. 162

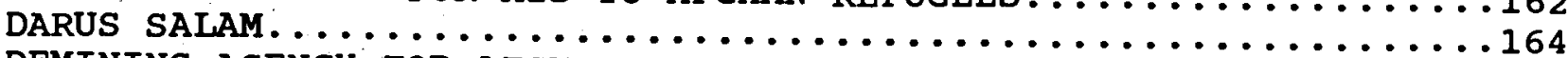

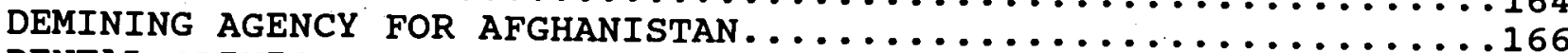

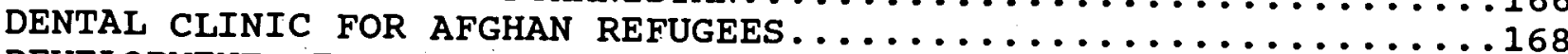

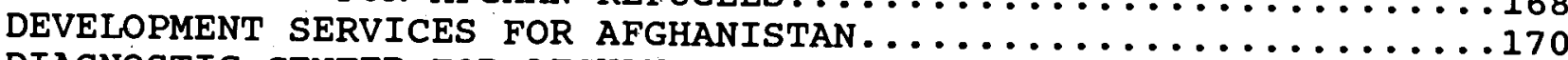
DIAGNOSTIC CENTER FOR AFGHAN REFUGEES . . . . . . . . . . . . . . 172

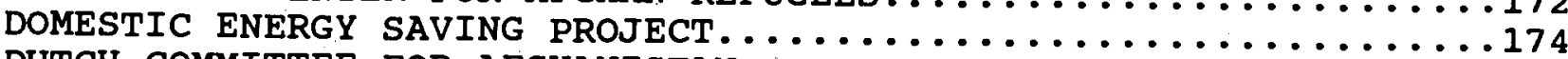

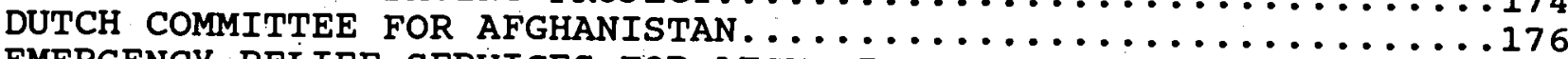

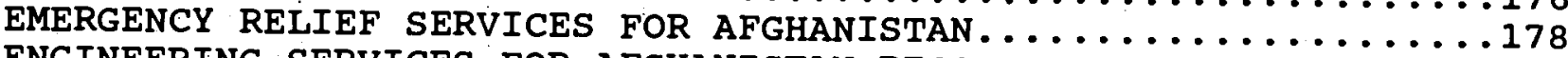
ENGINEERING SERVICES FOR AFGHANISTAN RECONSTRUCTION $\ldots \ldots \ldots \ldots \ldots 180$ EYE CLINIC FOR AFGHAN REFUGEES . . . . . . . . . . . . . . . . . 182

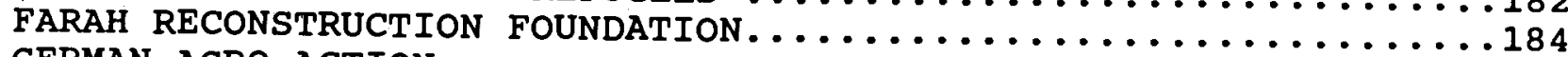

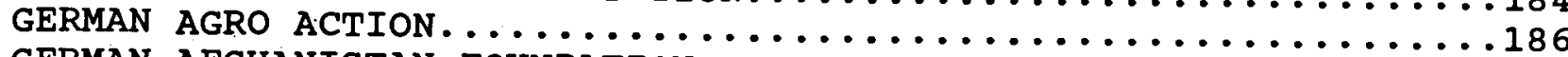

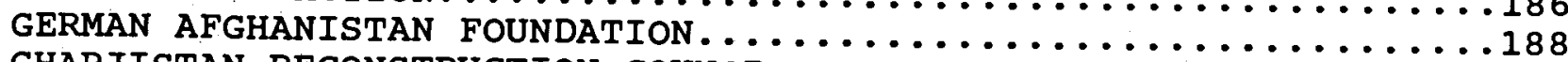

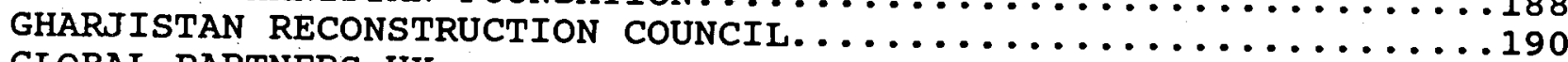
GLOBAL PARTNERS-UK. .................................. 192

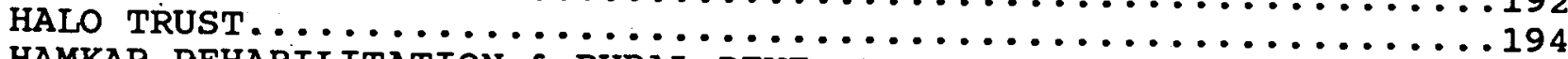
HAMKAR REHABILITATION \& RURAL DEVELOPMENT ORGANIZATION . . . . . 196

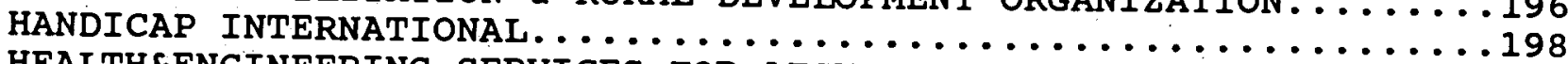
HEALTH\&ENGINEERING SERVICES FOR AFGHANISTAN REHABILITATION $\ldots \ldots 20$

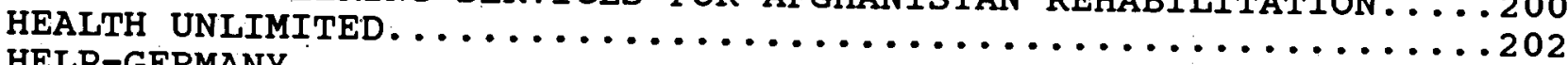

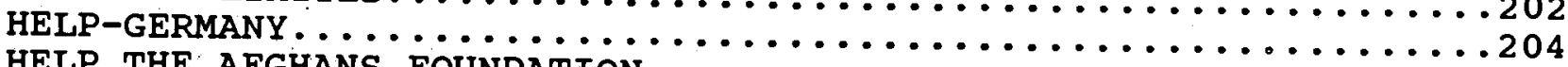

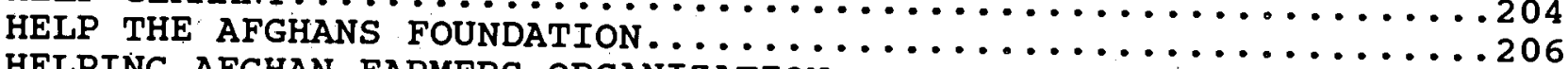

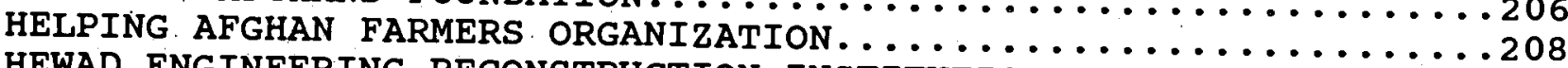

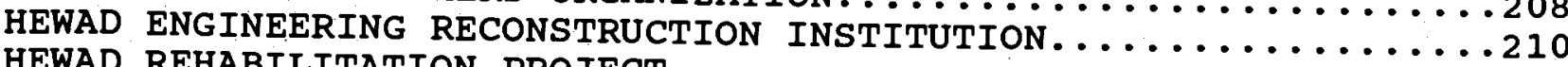

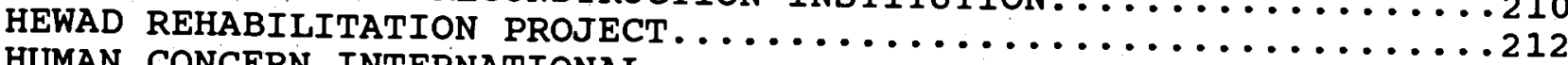

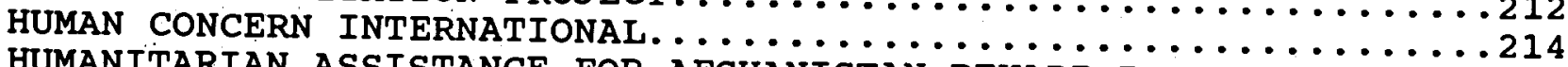
HUMANITARIAN ASSISTANCE FOR AFGHANISTAN REHABILITATION $\ldots \ldots \ldots \ldots 216$

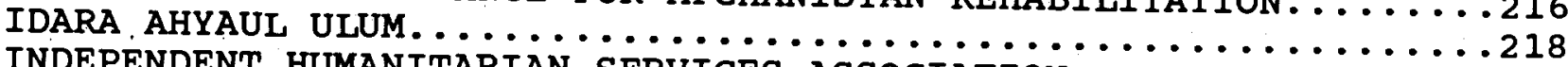

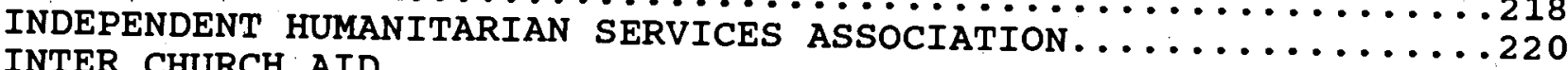

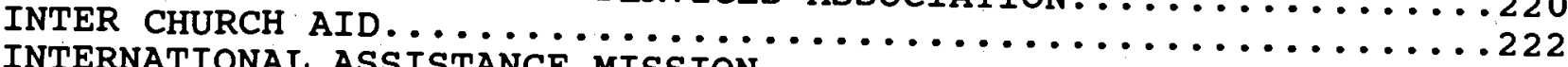

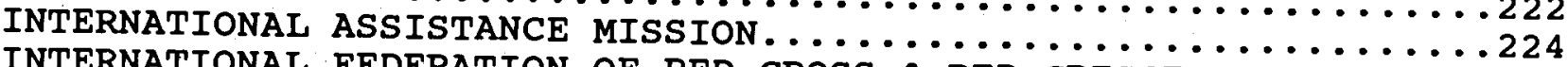
INTERNATIONAL FEDERATION OF RED CROSS \& RED CRESCENT SOCIETIES.226 INTERNATIONAL ISLAMIC RELIEF ORGANIZATION. ............... 228 INTERNATIONAL MEDICAL CORPS ....................... 230

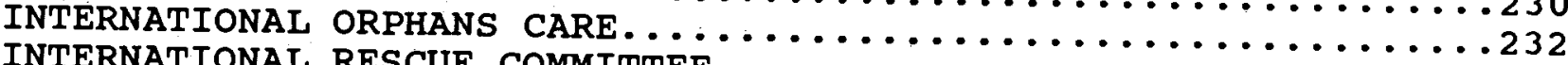

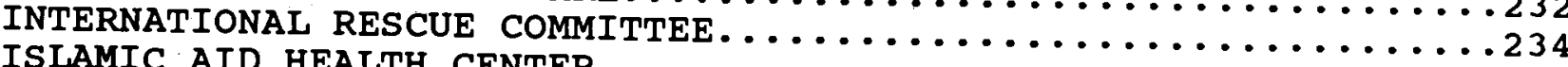

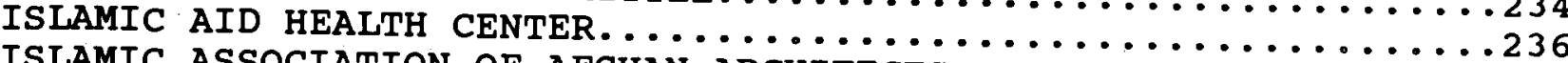
ISLAMIC ASSOCIATION OF AFGHAN ARCHITECTS AND ENGINEERS .......238 ISLAMIC RELIEF AGENCY............................. 240

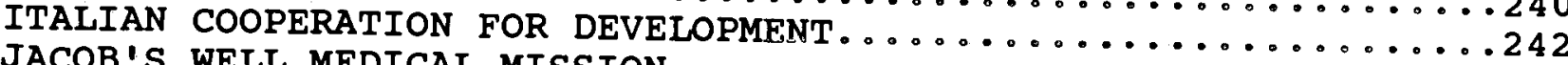

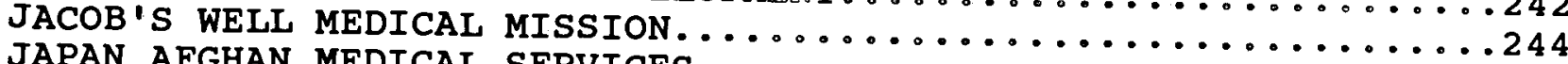

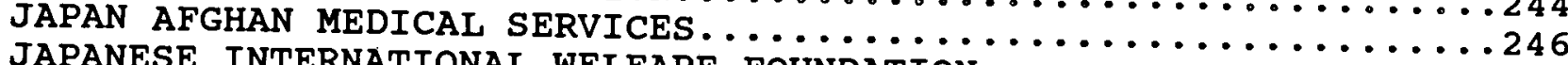
JAPANESE INTERNATIONAL WELFARE FOUNDATION . . . . . . . . . . . 248

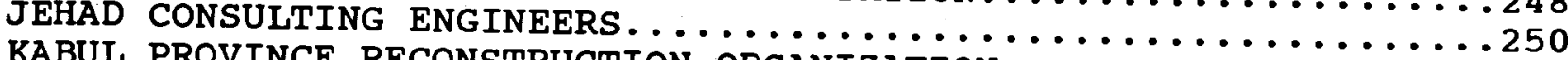
KABUL PROVINCE RECONSTRUCTION ORGANIZATION . . . . . . . . . . . 252

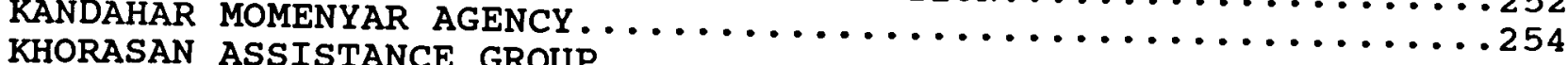

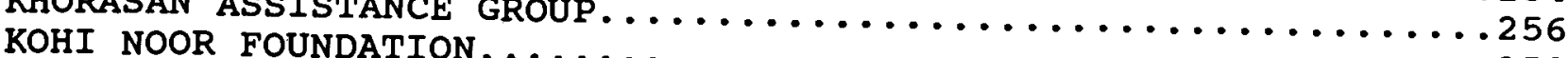

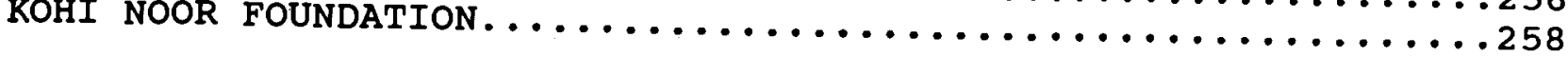


KUWAIT RED CRESCENT SOCIETY........................260

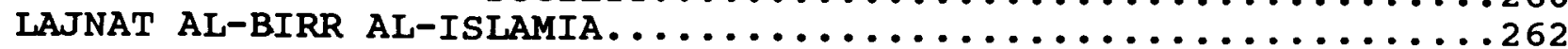

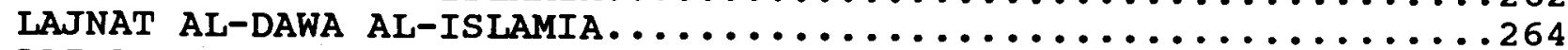

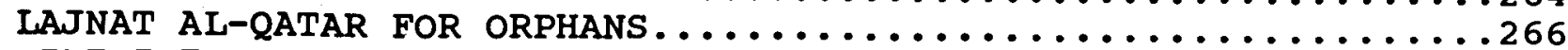

LIFELINE AND RELIEF ORGANIZATION . . . . . . . . . . . . . . . . . . . 268

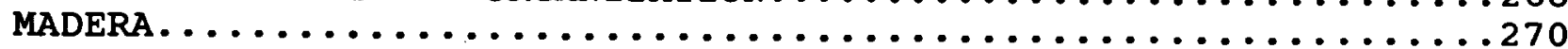

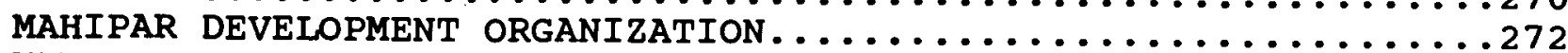

MAMAR CONSTRUCTION\&BUILDING MATERIALS PRODUCTION ORGANIZATION. 274

MANAGEMENT SCIENCES FOR HEALTH....................276

MARUF RELIEF ORGANIZATION FOR RECONSTRUCTION OF AFGHANISTAN $\ldots 278$

MAYWAND DEVELOPMENT PROJECT........................ . 280

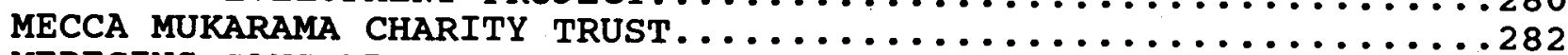

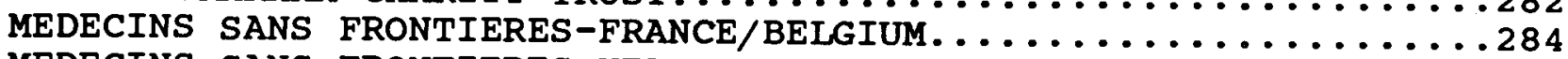

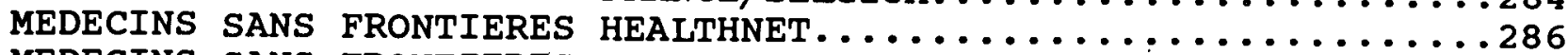

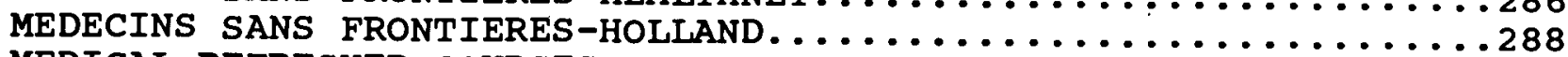

MEDICAL REFRESHER COURSES FOR AFGHANS ... . . . . . . . . . . . . 290

MERCY CORP INTERNATIONAL. . . . . . . . . . . . . . . . . . . . . 292

MINE CLEARANCE PLANNING AGENCY ... . . . . . . . . . . . . . . . 294

MUJAHID EMERGENCY MEDICAL CENTER. . . . . . . . . . . . . . . . . . . . . . . . . . . . . . . . . . .

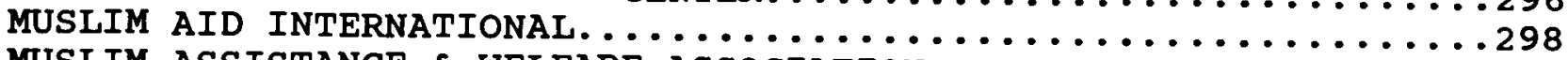

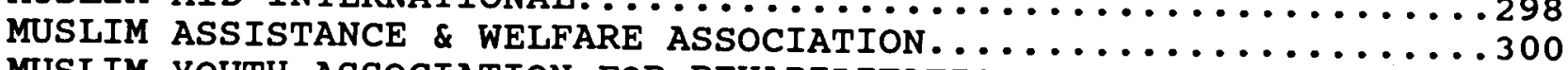

MUSLIM YOUTH ASSOCIATION FOR REHABILITATION OF AFGHANISTAN $\ldots \ldots 302$

NATIONAL ASSOCIATION OF DISABLED OF AFGHANISTAN . . . . . . . . . 304

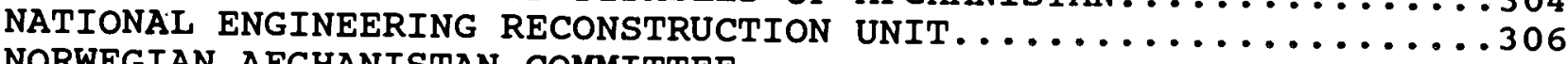

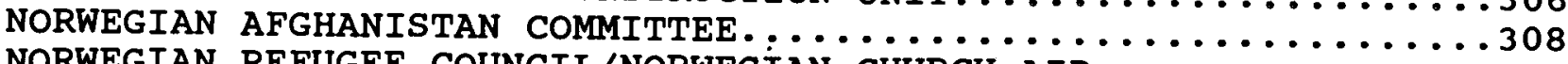

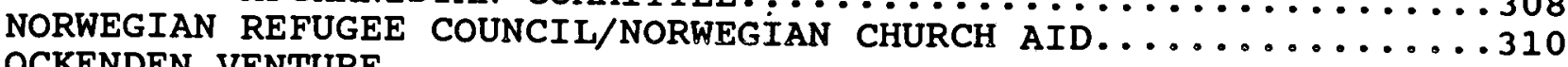

OCKENDEN VENTURE . . . . . . . . . . . . . . . . . . . . . . .

ORGAN. FOR MANAGEMENT OF AID FOR INFRASTRUCTURE DEVELOPMENT $\ldots$

ORGANIZATION FOR MINE-CLEARANCE AND AFGHAN REHABILITATION . . . . 316

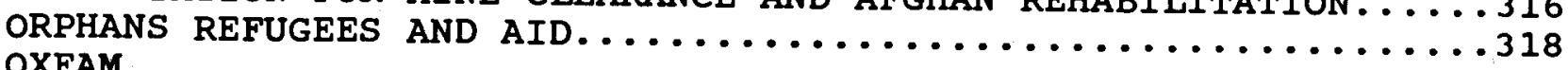

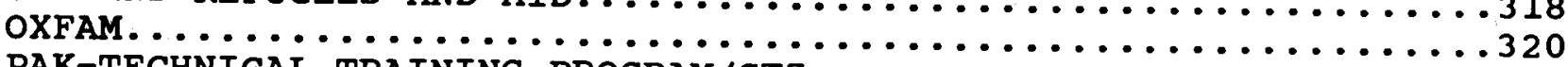

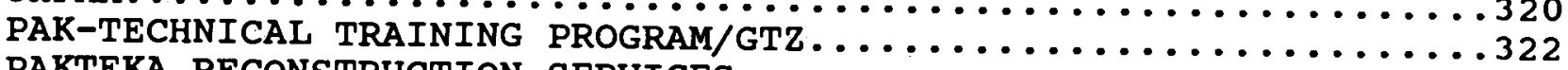

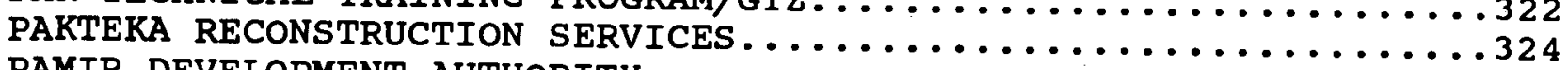

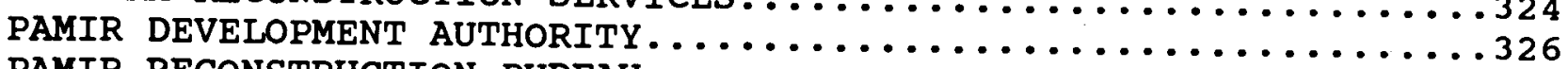

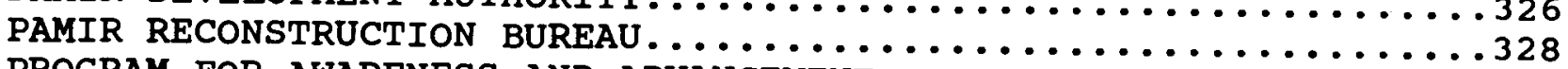

PROGRAM FOR AWARENESS AND ADVANCEMENT OF AFGHAN WOMEN $\ldots \ldots \ldots \ldots . . \ldots 330$

RADDA BARNEN-SWEDISH SAVE THE CHILDREN ................. $\ldots \ldots 32$

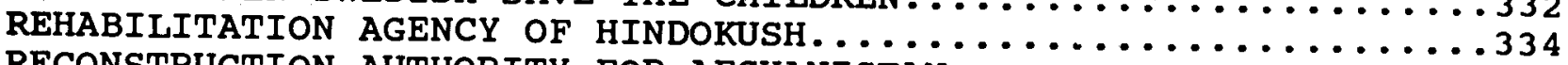

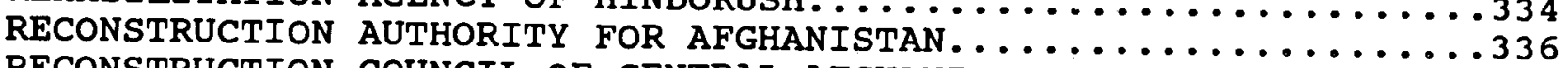

RECONSTRUCTION COUNCIL OF CENTRAL AFGHANISTAN . . . . . . . . . . 338

RECONSTRUCTION AND DEVELOPMENT ASSOCIATION . . . . . . . . . . 340

RECONSTRUCTION AND RURAL DEVELOPMENT OF MAIHAN . . . . . . . . . . . 342

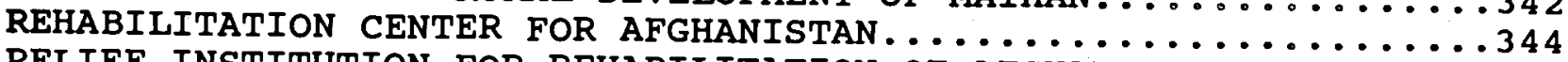

RELIEF INSTITUTION FOR REHABILITATION OF AFGHANISTAN $\ldots \ldots \ldots \ldots \ldots 34$

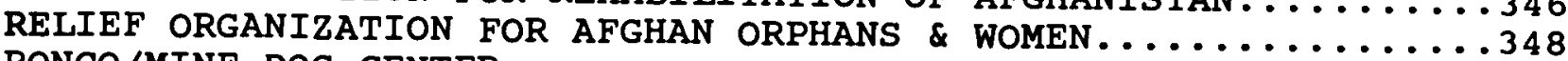

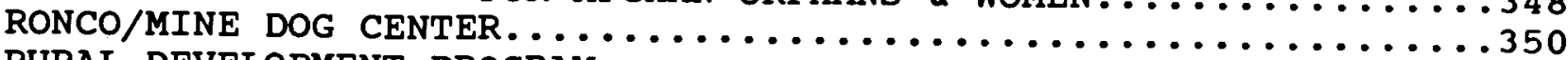

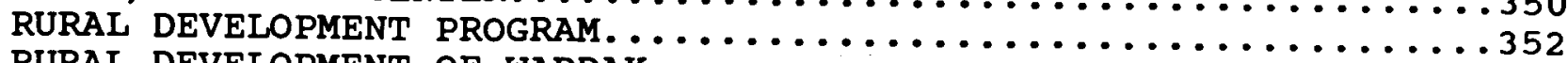

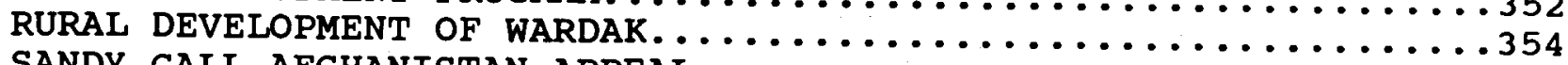

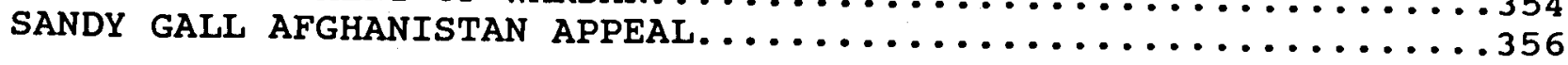


SAYYED JAMALUDDIN AFGHAN WELFARE ORGANIZATION .............366 SERVING EMERGENCY RELIEF \& VOCATIONAL ENTERPRISES . . . . . . . . 368

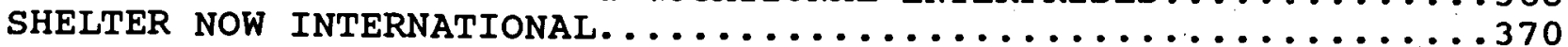
SHORAWAK REHABILITATION ORGANIZATION . . . . . . . . . . . . . . . 372 SHORT TERM ASSISTANCE FOR REHABILITATION-TEAM. ............. 374

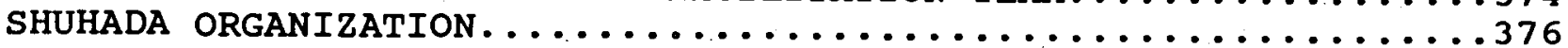

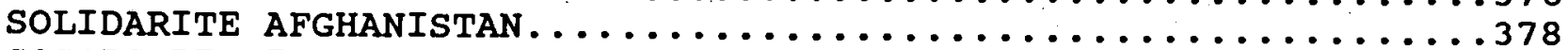

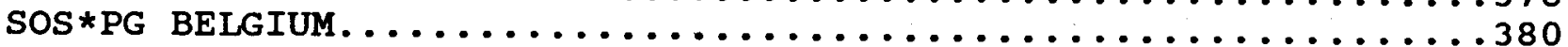
SOUTH-WEST AFGHANISTAN REHABILITATION ORGANIZATION $\ldots \ldots \ldots \ldots \ldots \ldots 38$ SOUTH-WEST FARMERS ASSISTANCE ORGANIZATION . . . . . . . . . . . 384

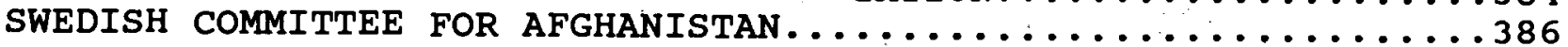

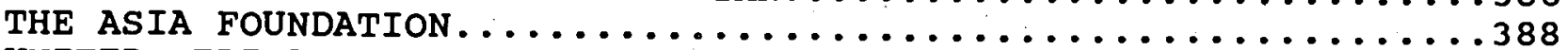

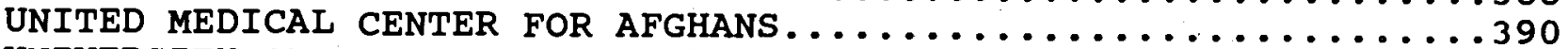
UNIVERSITY OF NEBRASKA AT OMAHA. . . . . . . . . . . . . . . . . . 392 VOLUNTARY ASSOCIATION FOR REHABILITATION OF AFGHANISTAN . . . . . . 394

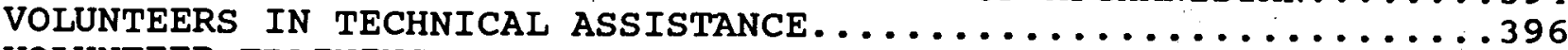
VOLUNTEER TRAINING SCHOOL. . . . . . . . . . . . . . . . . . . .

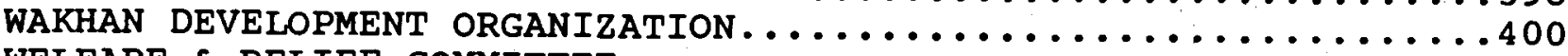

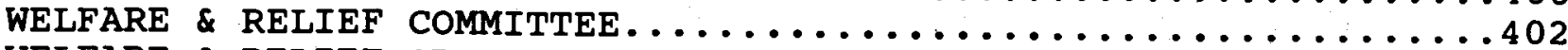
WELFARE \& RELIEF ORGANIZATION FOR RECONSTRUCTION................. WRITERS UNION OF FREE AFGHANISTAN ....................406

\section{COORDINATING BODIES}

AGENCY COORDINATING BODY FOR AFGHAN RELIEF...............410 AFGHAN NGOS COORDINATION BUREAU. .................... 414

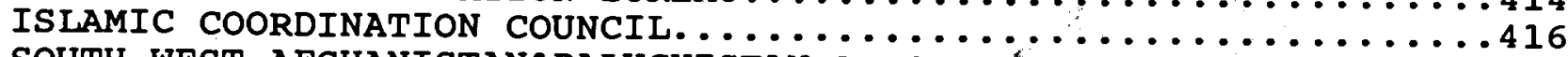
SOUTH-WEST AFGHANISTAN\&BALUCHISTAN ASSOC.FÓR COORDINATION . . . . 418 


\begin{tabular}{|c|c|c|c||}
\hline \multicolumn{4}{|c|}{ AGENCIES AS EMPLOYERS } \\
\hline \hline AFGHAN & PAKISTANI & EXPATRIATES & TOTAL \\
\hline 17,240 & 1,410 & 366 & 19,016 \\
\hline TECHNICAI & ADMINISTRATIVE & SUPPORT & TOTAL \\
\hline 7,360 & 3,844 & 7,812 & 19,016 \\
\hline PAKISTAN BASED & AFGHANISTAN B. & CROSS-BORDER & TOTAL \\
\hline 9,086 & 6,091 & 3,839 & 19,016 \\
\hline
\end{tabular}

\begin{tabular}{|c|c|c|c|}
\hline \multicolumn{4}{|c|}{ BREAKDOWN OF AGENCIES BY COUNTRY } \\
\hline EUROPE & \% & ARABIC COUNTRIES & $\#$ \\
\hline $\begin{array}{l}\text { Austria } \\
\text { Belgium } \\
\text { Denmark } \\
\text { France } \\
\text { Germany } \\
\text { Netherlands } \\
\text { Norway } \\
\text { Sweden } \\
\text { Switzerland } \\
\text { United Kingdom } \\
\quad \text { TOTAL: } \\
\end{array}$ & $\begin{array}{r}1 \\
2 \\
1 \\
7 \\
8 \\
4 \\
2 \\
2 \\
1 \\
15 \\
43\end{array}$ & TOTAL: & $\begin{array}{l}2 \\
1 \\
5 \\
1 \\
9\end{array}$ \\
\hline NORTHERN AMERICA & 4 & OTHER COUNTRIES & $\#$ \\
\hline $\begin{array}{l}\text { Canada } \\
\text { USA }\end{array}$ & $\begin{array}{r}2 \\
14 \\
16\end{array}$ & \begin{tabular}{l} 
Afghan \\
Australia \\
Japan \\
Pakistan \\
OTHERS \\
\multicolumn{1}{c}{ TOTAL: }
\end{tabular} & $\begin{array}{r}127 \\
1 \\
2 \\
4 \\
6 \\
140\end{array}$ \\
\hline $\begin{array}{l}\text { TOTAL NUMBER OF AGE } \\
\text { WHICH INCLUDES } 4 \text { CO }\end{array}$ & $\begin{array}{l}\text { COV } \\
\text { TIC }\end{array}$ & $\begin{array}{l}\text { D IN THIS DIRECTORY } \\
\text { ODIES. }\end{array}$ & 08 \\
\hline
\end{tabular}

\begin{tabular}{|c|c|c|c|c|}
\hline \multicolumn{5}{|c|}{ AFFILIATION OF AGENCIES } \\
\hline \hline $\begin{array}{c}\text { ACBAR } \\
\text { MEMBERS }\end{array}$ & $\begin{array}{c}\text { ANCB } \\
\text { MEMBERS }\end{array}$ & MCC & SWABAC & OTHER \\
\hline $66^{1}$ & 45 & 10 & 30 & AGENCIES \\
\hline
\end{tabular}

- * 17 members of ACBAR are at the same time members of ANCB

* 8 ACBAR members are members of SWABAC

* 2 members of ACBAR are also members of ICC.

* 2 agencies are members of three coordination bodies. 


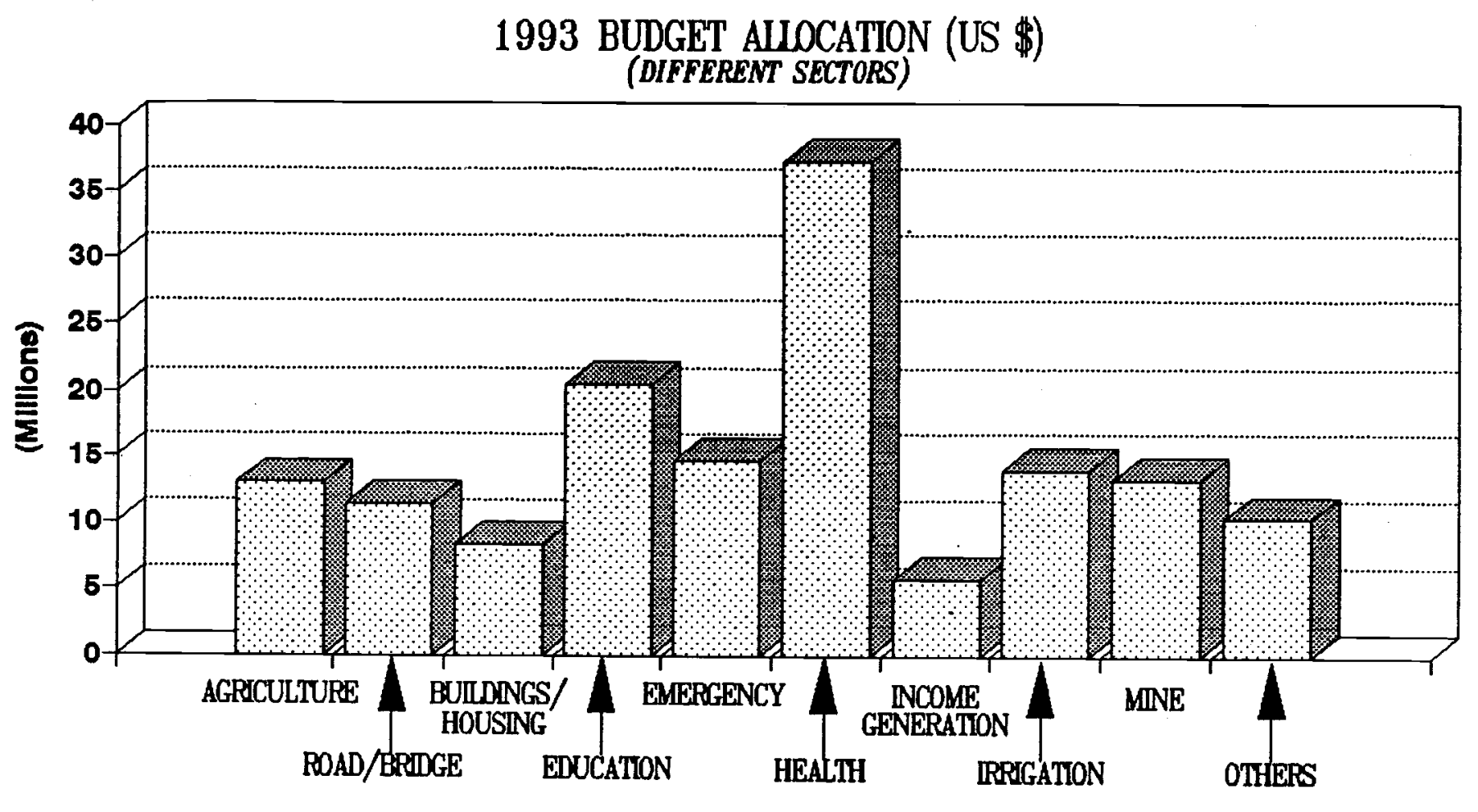

\section{CONTRIBUTION OF ACBAR MEMBERS VS OTHERS}

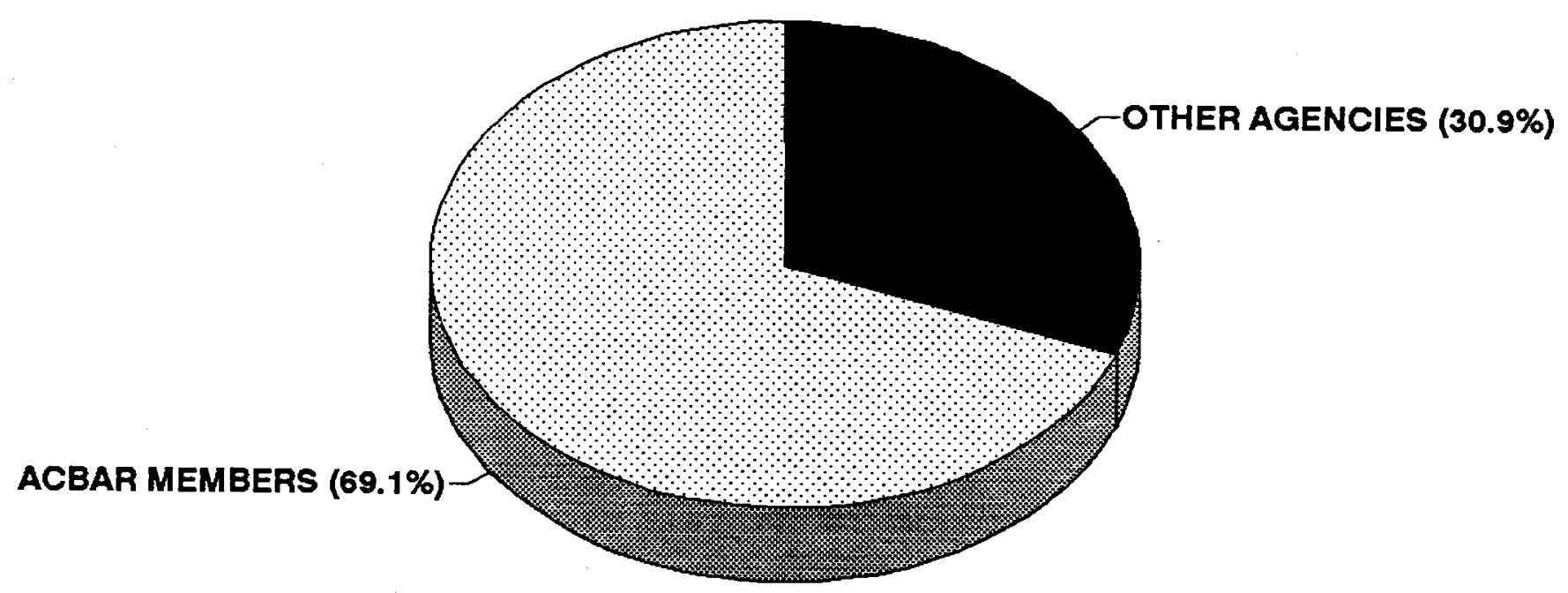




\section{AGENCIES 1993 FUNDING SOURCES}

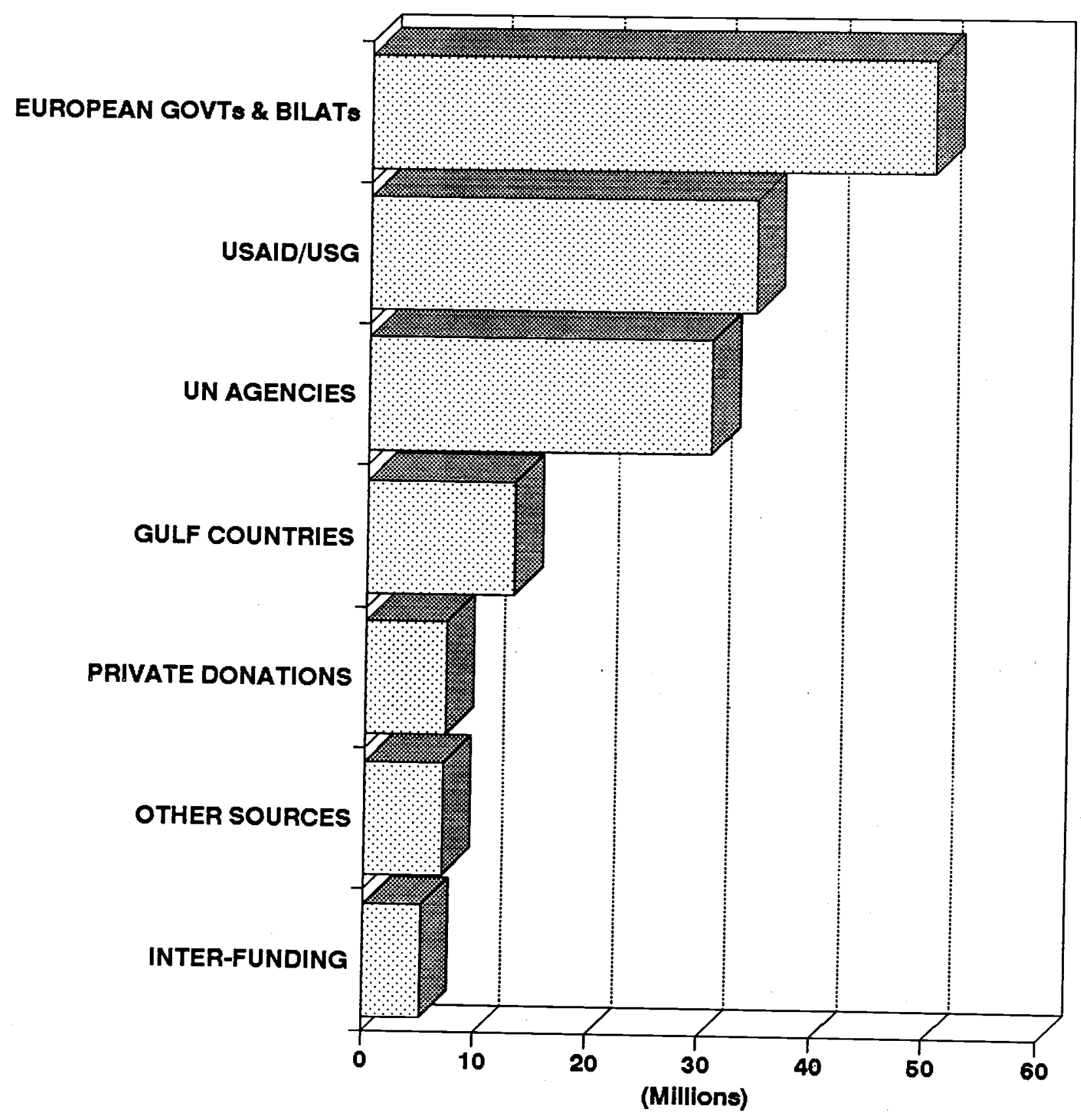




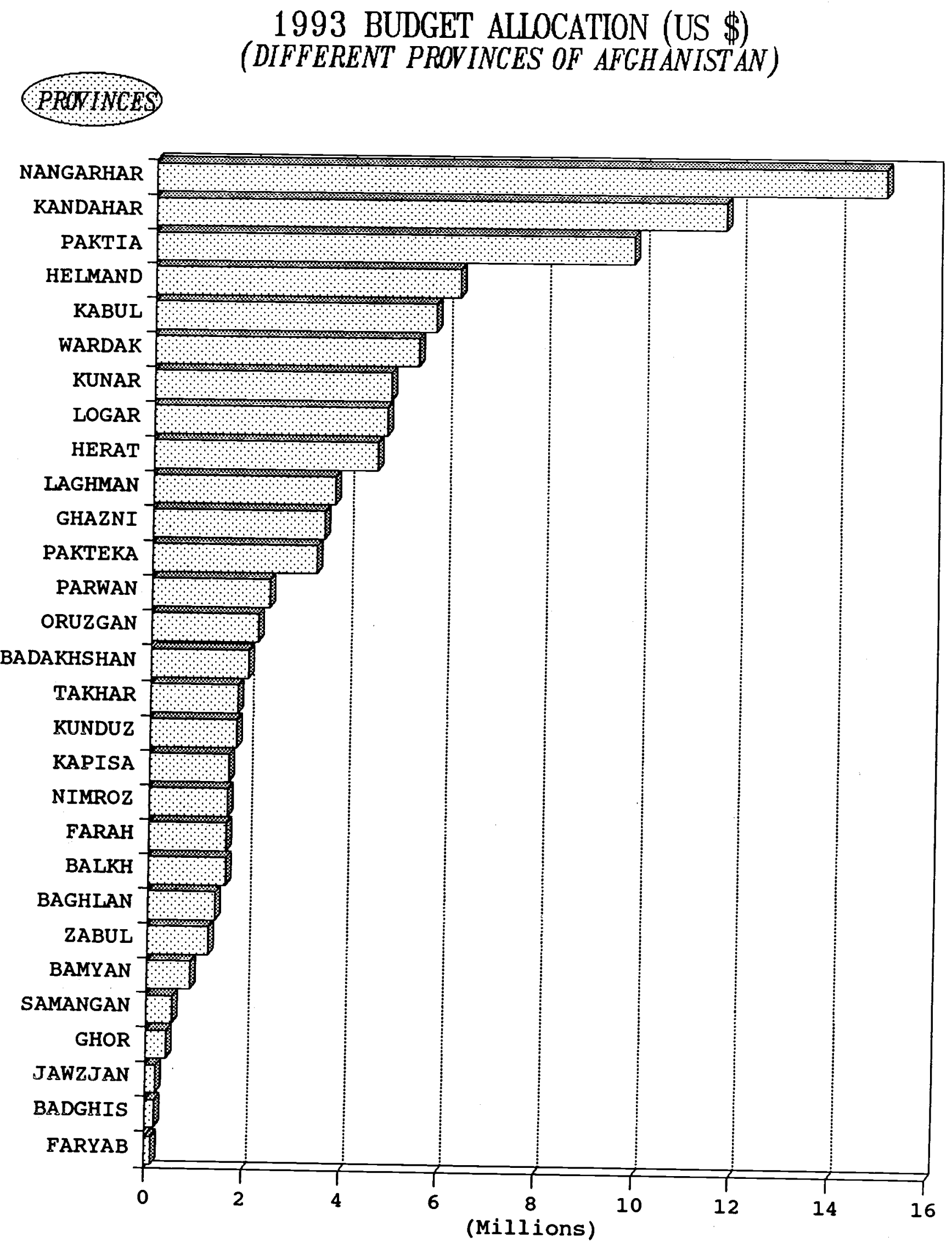


TOTAL BUDGET EXPENDITURE FOR PERIOD 1988 - 1993

(US\$ MILLION)

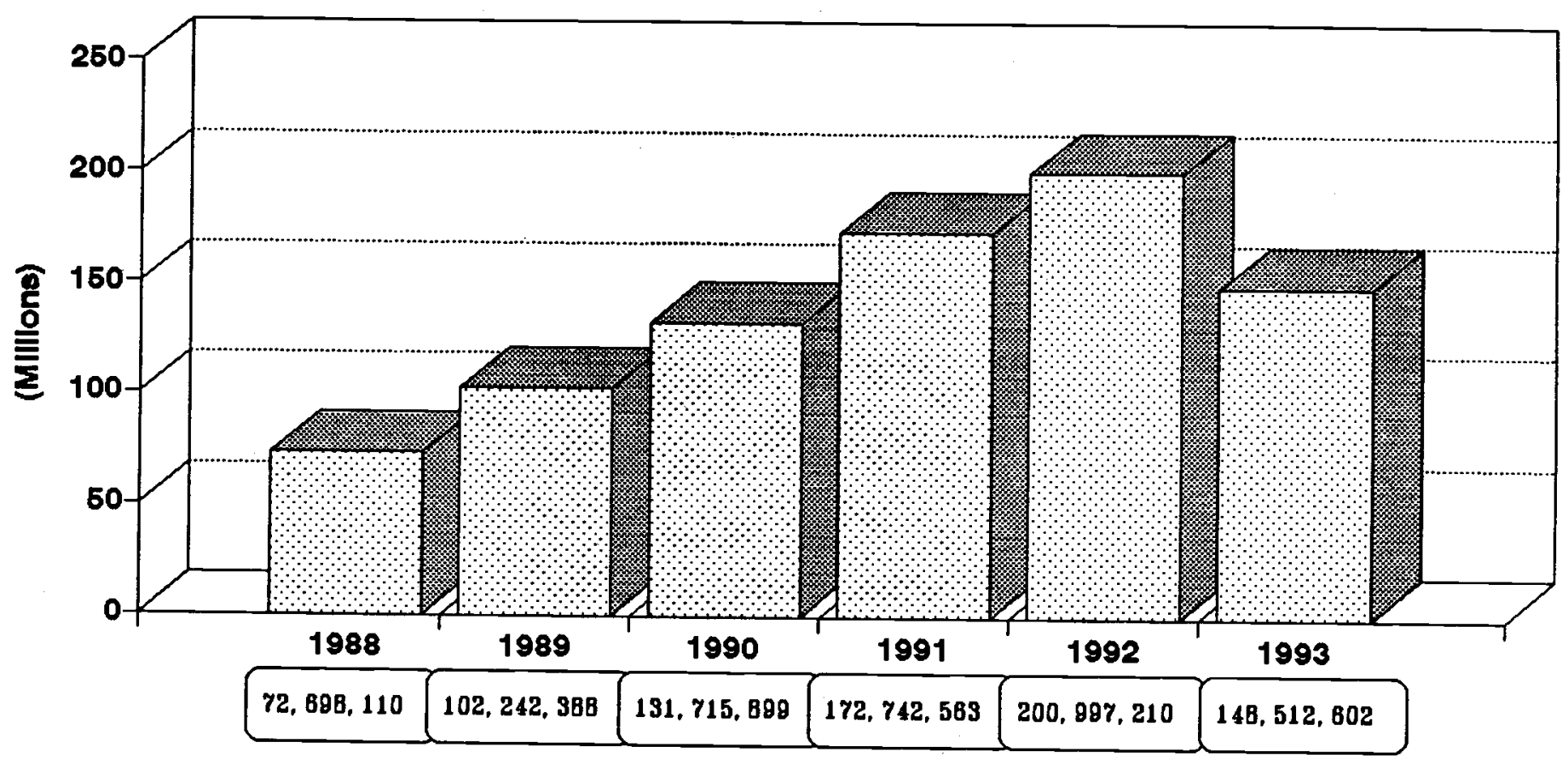

\section{BUDGET ALLOCATION}

(PAKISTAN \& AFGHANISTAN)

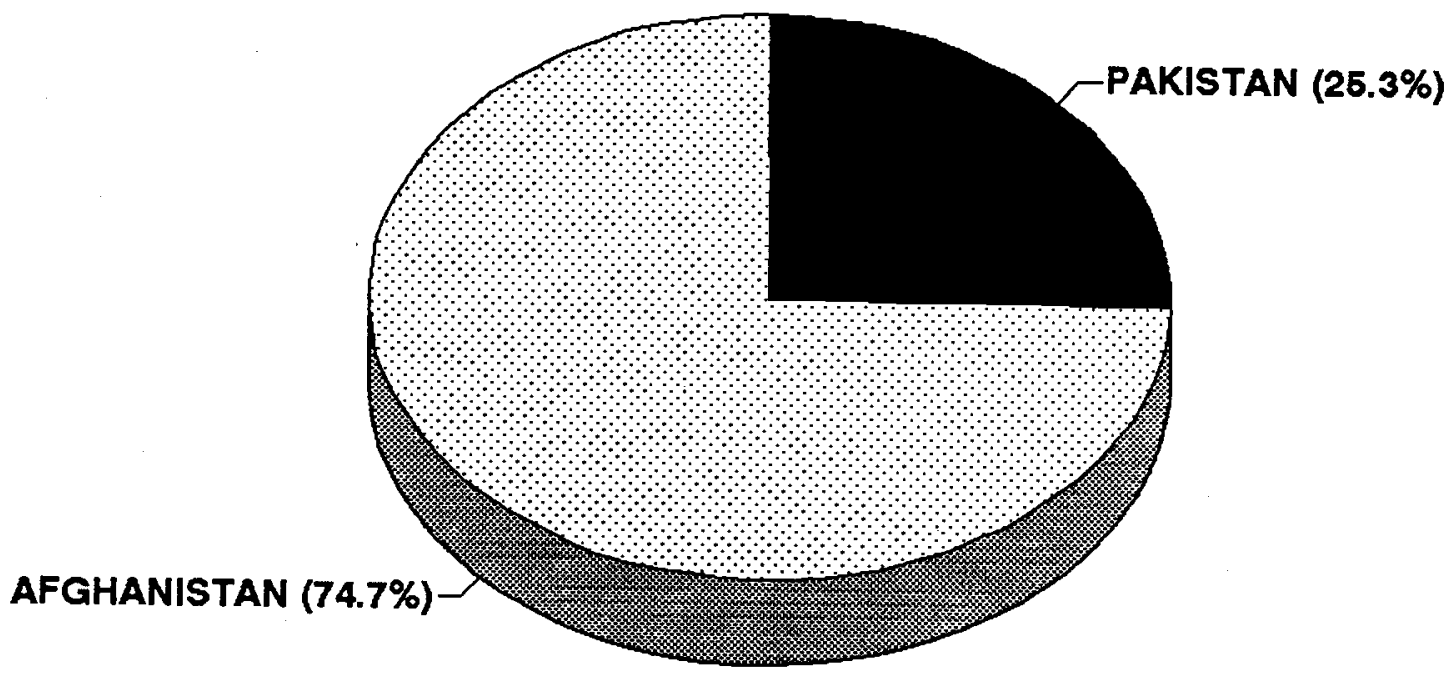




\section{THE AGENCIES}


ABADY CONSTRUCTION AGENCY-ACA

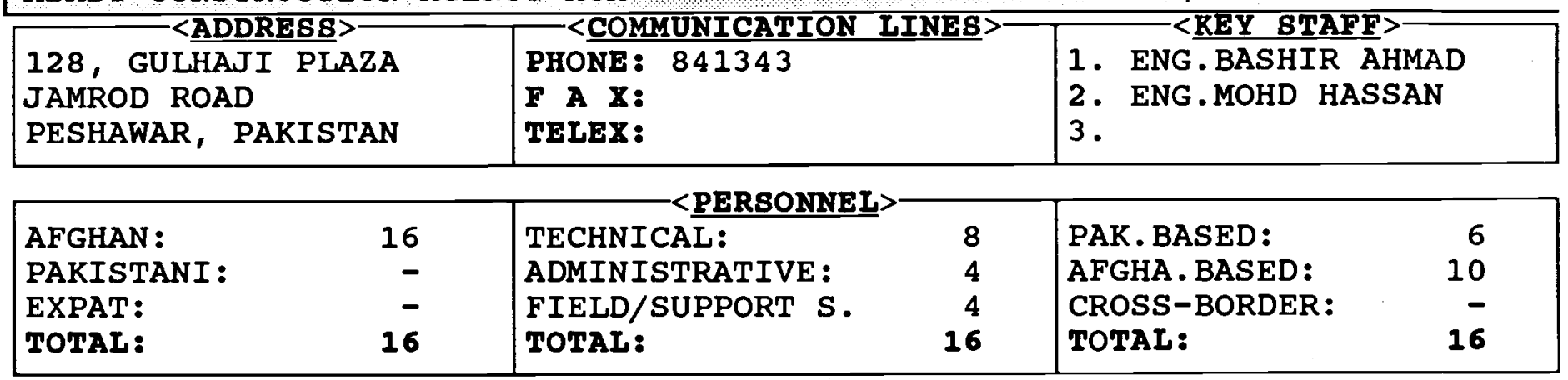

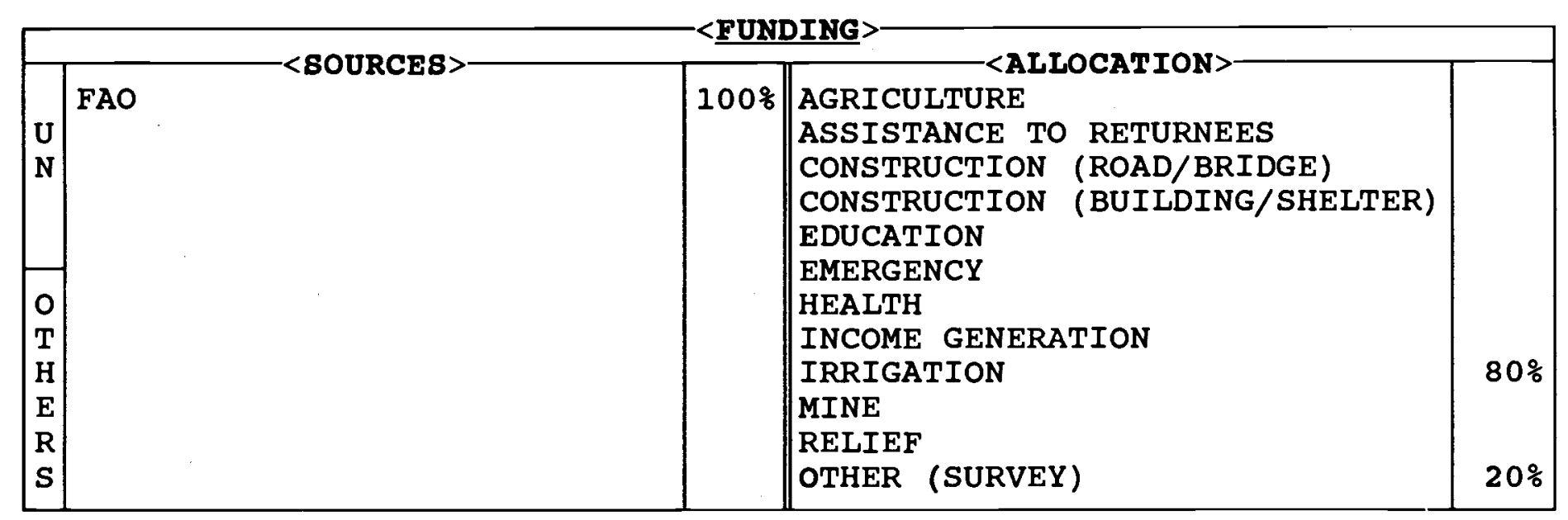

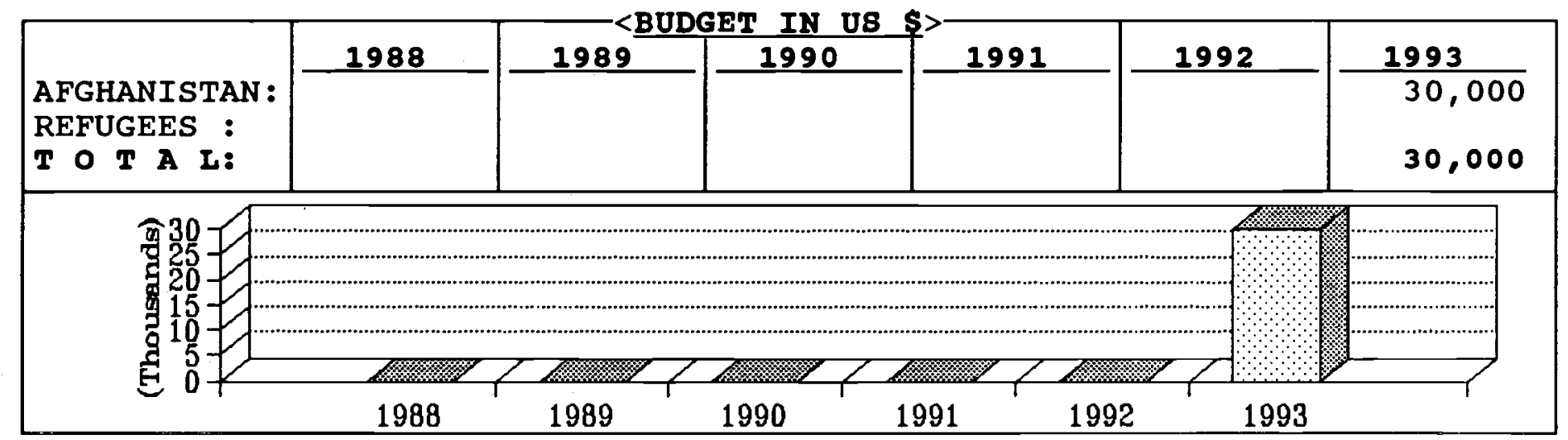

\begin{tabular}{|c|c|c|c|c|c|}
\hline PROVINCES & SECTOR & $\because \mathrm{AGE}$ & PROVINCES & SECTOR & $\% \mathrm{AGE}$ \\
\hline $\begin{array}{l}\text { BADAKSHAN } \\
\text { BADGHIS } \\
\text { BAGHLAN } \\
\text { BALKH } \\
\text { BAMYAN } \\
\text { FARAH } \\
\text { FARYAB } \\
\text { GHAZNI } \\
\text { GHOR } \\
\text { HELMAND } \\
\text { HERAT } \\
\text { JAWZJAN } \\
\text { KABUL } \\
\text { KANDAHAR } \\
\text { KAPISA }\end{array}$ & & & $\begin{array}{l}\text { KUNAR } \\
\text { KUNDUZ } \\
\text { LAGHMAN } \\
\text { LOGAR } \\
\text { NANGARHAR } \\
\text { NIMROZ } \\
\text { ORUZGAN } \\
\text { PAKTEKA } \\
\text { PAKTIA } \\
\text { PARWAN } \\
\text { SAMANGAN } \\
\text { TAKHAR } \\
\text { WARDAK } \\
\text { ZABUL }\end{array}$ & $\begin{array}{l}\text { Irrign/survey } \\
\text { Irrign }\end{array}$ & $\begin{array}{l}40 \% \\
60 \%\end{array}$ \\
\hline
\end{tabular}


is an indigenous Afghan nongovernmental organization founded in 1993. The headquarters of the organization are currently located in Peshawar.

The objectives of ACA are as follows:

* to survey, plan, design and implement construction and reconstruction projects in war affected Afghanistan,

* to take active part in the rehabilitation and improvement of agriculture in the country,

* to assist refugee repatriation and provide aid to the war affected families.

ACA has specialization and qualified staff in the areas of irrigation engineering, water supply, building and road construction, agriculture and technical survey.

A number of irrigation projects in Nangarhar and Khost areas have been undertaken by $A C A$ with the financial assistance of FAO. More irrigation projects including rehabilitation of canals and construction of structures have been approved by FAO which will be implemented in the near future. UNDP has agreed to train staff of ACA in road repairing which will follow by funding a $15 \mathrm{~km}$ road project.

ACA has been registered with the provincial governments of Nangarhar and Khost and enjoys their full support and cooperation. 
ABADY CONSTRUCTION AGENCY-ACA

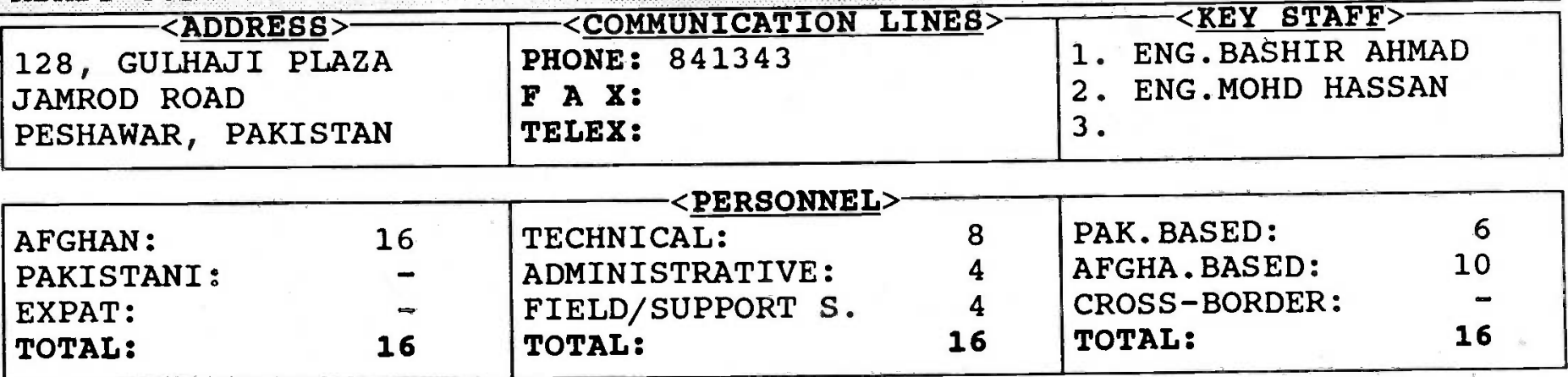

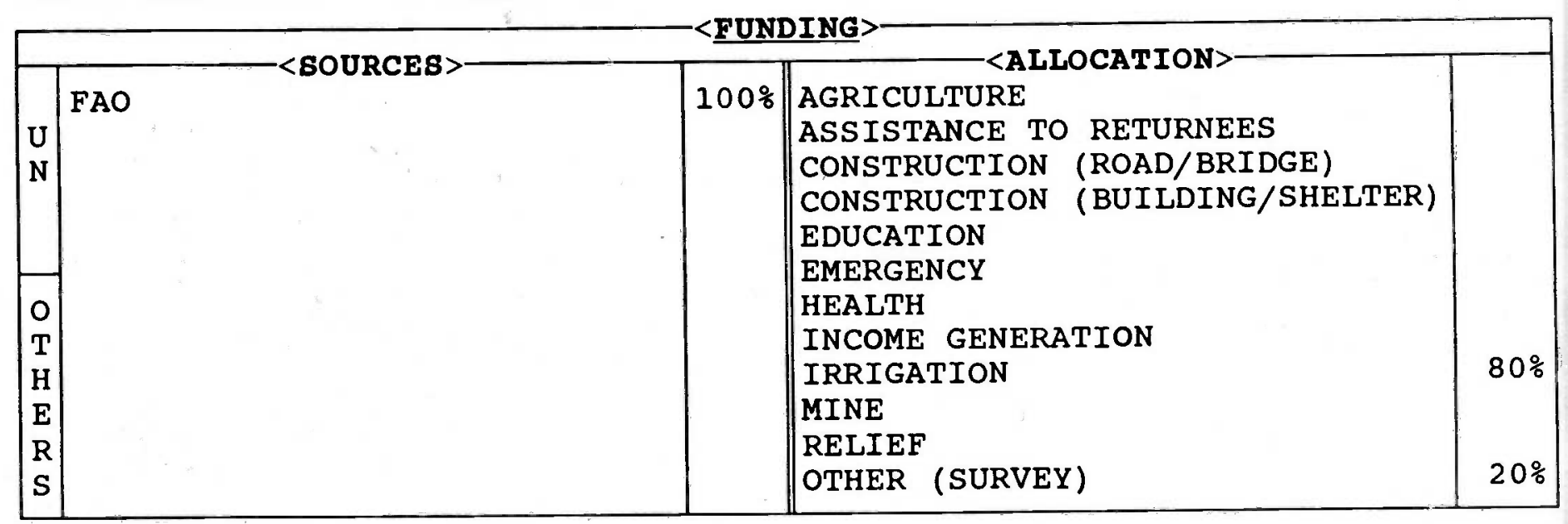

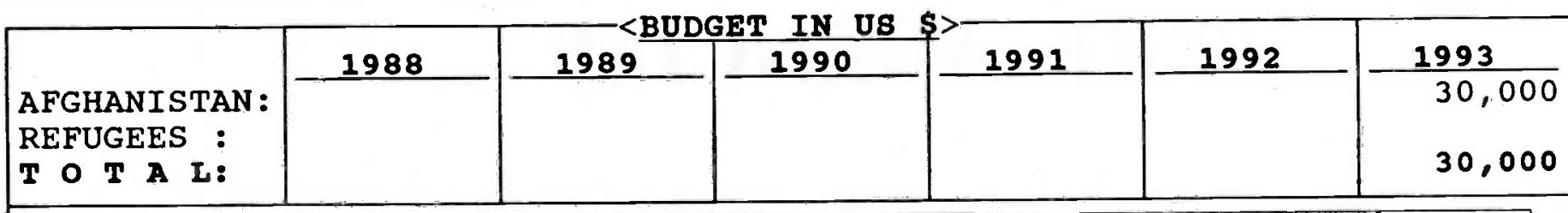

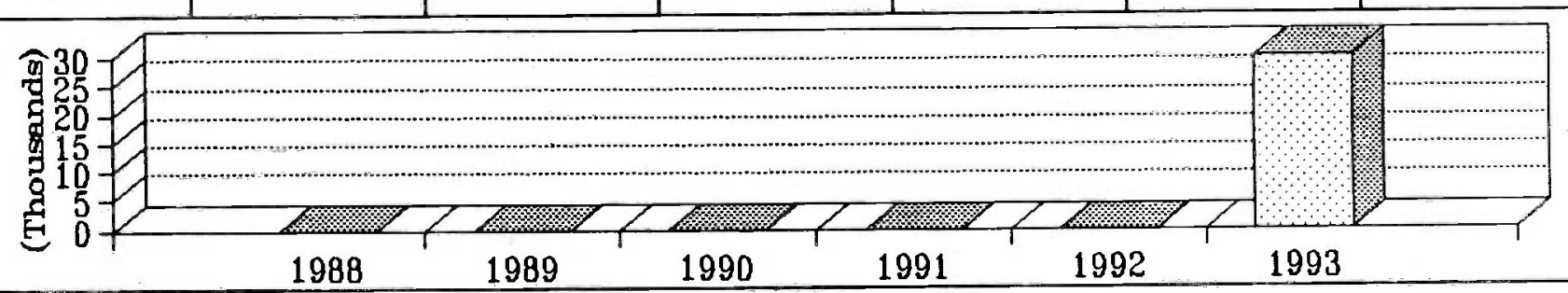

\begin{tabular}{|c|c|c|c|c|c|}
\hline PROVINCES & SECTOR & $\% \mathrm{AGE}$ & PROVINCES & SECTOR & $\% A G E$ \\
\hline $\begin{array}{l}\text { BADAKSHAN } \\
\text { BADGHIS } \\
\text { BAGHLAN } \\
\text { BALKH } \\
\text { BAMYAN } \\
\text { FARAH } \\
\text { FARYAB } \\
\text { GHAZNI } \\
\text { GHOR } \\
\text { HELMAND } \\
\text { HERAT } \\
\text { JAWZJAN } \\
\text { KABUL } \\
\text { KANDAHAR } \\
\text { KAPISA }\end{array}$ & & & \begin{tabular}{|l|} 
KUNAR \\
KUNDUZ \\
LAGHMAN \\
LOGAR \\
NANGARHAR \\
NIMROZ \\
ORUZGAN \\
PAKTEKA \\
PAKTIA \\
PARWAN \\
SAMANGAN \\
TAKHAR \\
WARDAK \\
ZABUL
\end{tabular} & $\begin{array}{l}\text { Irrign/survey } \\
\text { Irrign }\end{array}$ & $\begin{array}{l}40 \% \\
60 \%\end{array}$ \\
\hline
\end{tabular}


AFGHAY AGENCY FOR INTEGRATED DEVELOPMENT-AAID

CADDRE88>- CCOMMUNICATION LINES>

131, 1ST FLOOR, GULHAJI PLAZA, JAMROD ROAD

PHONE: 43332

F A X:

TELEX:

1. DR. YUSUF NURSTANI

2 .

3 .

AFGHAN :

PAKISTANI:

EXPAT:

TOTAL:

\section{0}

2

0

12
TECHNICAL:

ADMINISTRATIVE:

FIELD/SUPPORT $S$.

TOTAL:

\section{$\langle$ PERBONNEL $>$}

\begin{tabular}{|c|c|c|c|c|}
\hline $\begin{array}{l}\mathrm{O} \\
\mathrm{T} \\
\mathrm{H} \\
\mathrm{E} \\
\mathrm{R} \\
\mathrm{S}\end{array}$ & UNDP & 1008 & $\begin{array}{l}\text { AGRICULTURE } \\
\text { ASSISTANCE TO RETURNEES } \\
\text { CONSTRUCTION (ROAD/BRIDGE) } \\
\text { CONSTRUCTION (BUILDING/SHELTER) } \\
\text { EDUCATION } \\
\text { EMERGENCY } \\
\text { HEALTH } \\
\text { INCOME GENERATION } \\
\text { IRRIGATION } \\
\text { MINE } \\
\text { RELIEF } \\
\text { OTHER }\end{array}$ & 1008 \\
\hline
\end{tabular}

5

2

12
PAK. BASED:

AFGHA . BASED:

CROSS-BORDER:

TOTAL:
5

2

5

12

\begin{tabular}{|l|l|l|l|l|l|l|}
\hline & 1988 & 1989 & 1990 & 1991 & 1992 & $\frac{1993}{100,000}$ \\
AFGHANISTAN : & & & & & & 100,000 \\
TEFUEES :
\end{tabular}
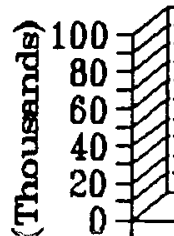


\section{AFGHAN AGENCY FOR INTEGRATED} DEVELOPMENT (AAID)

initially started its reconstruction activities in 1987 under a different name in Nooristan. Due to some problems the reconstruction activities were temporarily postponed. However, in 1991 it started its activities under the name of Afghan Care. But the beginning of September 1993 the members of Board decided to change the name of Afghan Care to Afghan Agency for Integrated Development (AAID) .

AAID is a non-government, nonpolitical and non-profit organization, run by a team of Afghan who have vast knowledge of the problems and requirements of the area they work.

The major aims of the organization is the help the target group to act independently, to tap and make better use of the available resources and to advocate the use of local experts and products wherever possible.

The promotion of awareness regarding the use of renewable resources energy and the environmentally sound use of eco-system are important elements in the activities of AAID for the rehabilitation of Afghanistan.

Due to the uncertain security reason, the agency has concentrated only in the eastern region of the country but with the improvement of the security conditions, it intends to serve and expand its operation to other parts of the country.

Presently AAID's cross border activities consist agriculture, engineering/construction \& education programs.

AAID has successfully completed an irrigation canal at a length of $3 \mathrm{~km}$ in Shinagal, Peche valley, Kunar province. This project initially sponsored by the Federal Republic of Germany and completed with additional financial aid from
In the field of education the organization has assisted to mobilize the community for educational activities. Five schools were established and the Swedish Committee for Afghanistan has been approached for future funding.

In 1992, AAID sponsored a primary school in Amesh Desh, Nooristan for one year.

In the field of construction the organization is currently involved in two flood protection walls in the villages of Amla and Lundi in Darae-Noor district of Nangarhar. $60 \%$ of the work has been completed. Work on another flood protection wall will start soon in Mulayan village, Laghman province. The project is pending for final signature of the memorandum of agreement. AAID has also submitted many proposals to different UN agencies and other donor organizations with promising $r \quad e \quad s \quad u \quad l \quad t \quad s$. 
AFGHAN AGENCY FOR WAR DISABLED AND VICTIMS-AAWDV

<ADDRESS >- $=$ COMMUNICATION LINES>

180, GHAZALI RD, D-1, PHASE I, HAYATABAD GHAZNI, AFGHANISTAN
PHONE: 811488

F A X:

TELEX:
1. MR. M. ISMAIL OSMAN

2. MR. M. NAIM QASIM

3 .

AFGHAN :

PAKISTANI :

EXPAT:

TOTAL:

9

$<$ PERSONNEL $>$

TECHNICAL:

ADMINISTRATIVE:

FIELD/SUPPORT $S$. TOTAL :
PAK. BASED:

AFGHA . BASED:

CROSS-BORDER :

TOTAL:
2

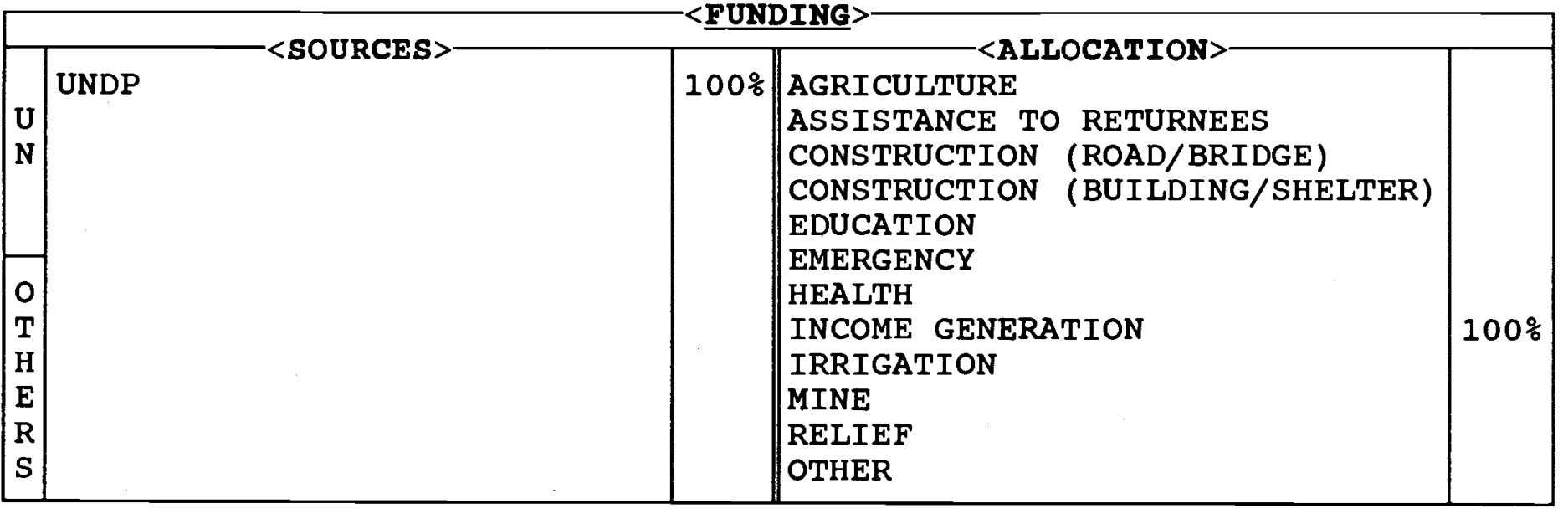

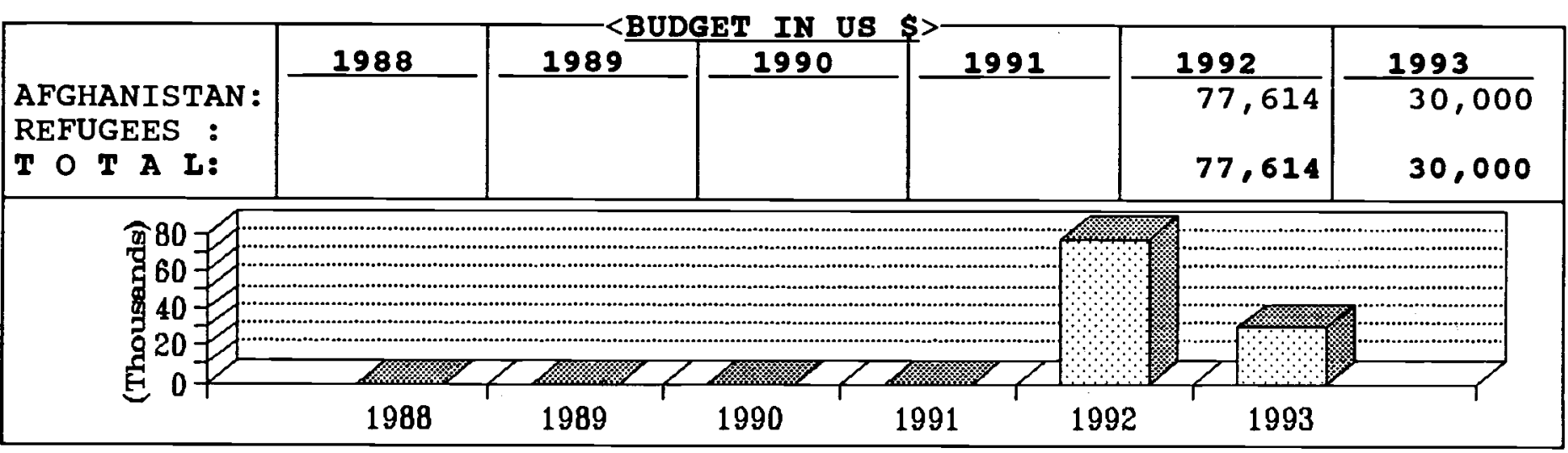

<TARGET PROVINCES IN AFGHANISTAN>

\begin{tabular}{|c|c|c|c|c|c|}
\hline PROVINCES & SECTOR & $\%$ AGE & PROVINCES & SECTOR & $\because A G E$ \\
\hline $\begin{array}{l}\text { BADAKSHAN } \\
\text { BADGHIS } \\
\text { BAGHLAN } \\
\text { BALKH } \\
\text { BAMYAN } \\
\text { FARAH } \\
\text { FARYAB } \\
\text { GHAZNI } \\
\text { GHOR } \\
\text { HELMAND } \\
\text { HERAT } \\
\text { JAWZJAN } \\
\text { KABUL } \\
\text { KANDAHAR } \\
\text { KAPISA }\end{array}$ & Income gen & $100 \%$ & \begin{tabular}{|l} 
KUNAR \\
KUNDUZ \\
LAGHMAN \\
LOGAR \\
NANGARHAR \\
NIMROZ \\
ORUZGAN \\
PAKTEKA \\
PAKTIA \\
PARWAN \\
SAMANGAN \\
TAKHAR \\
WARDAK \\
ZABUL
\end{tabular} & & \\
\hline
\end{tabular}


AFGHAN AGENCY FOR WAR DISABLED AND VICTIMS (AAWDV)

is a non-profit, non-political and nongovernmental humanitarian organization established in 1992.

The aim of AAWDV is social integration of war disabled people and providing protection and services to the families of war victims in Afghanistan.

AAWDV has an Executive Board members of which are all Afghan. It also has a local Advisory Board on the project site in the center of Ghazi province.

The Agency under its voluntary training program which started in January 1992 trained 39 disabled persons in different skills such as tailoring and carpentry. The instructors were locally recruited. 50 more disabled people were trained in 1993. The main purpose of the training programs is to enable the trainees to become active members of the community by carrying out gainful activities. 
AFGHAN AGRICULTURE AND ENGINEERING AGENCY-AAEA

<ADDRESS>- - <COMMUNICATION LINES $>$

30，3RD FLOOR, SPINZAR PLAZA, JAMROD ROAD PESHAWAR, PAKISTAN

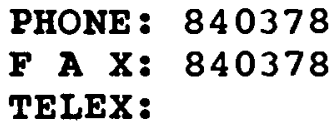

1. MR. ABDUL RAHIM

2. ENG. KHALIL

3. ENG. DILAWAR

\begin{tabular}{|lr|lr|lr|}
\hline AFGHAN : & 15 & TECHNICAL: & 4 & PAK. BASED: & 0 \\
PAKISTANI : & 0 & ADMINISTRATIVE: & 4 & AFGHA.BASED: & 8 \\
EXPAT: & 0 & FIELD/SUPPORT S. & 7 & CROSS-BORDER: & 7 \\
TOTAL: & 15 & TOTAL: & 15 & TOTAL: & 15 \\
\hline
\end{tabular}

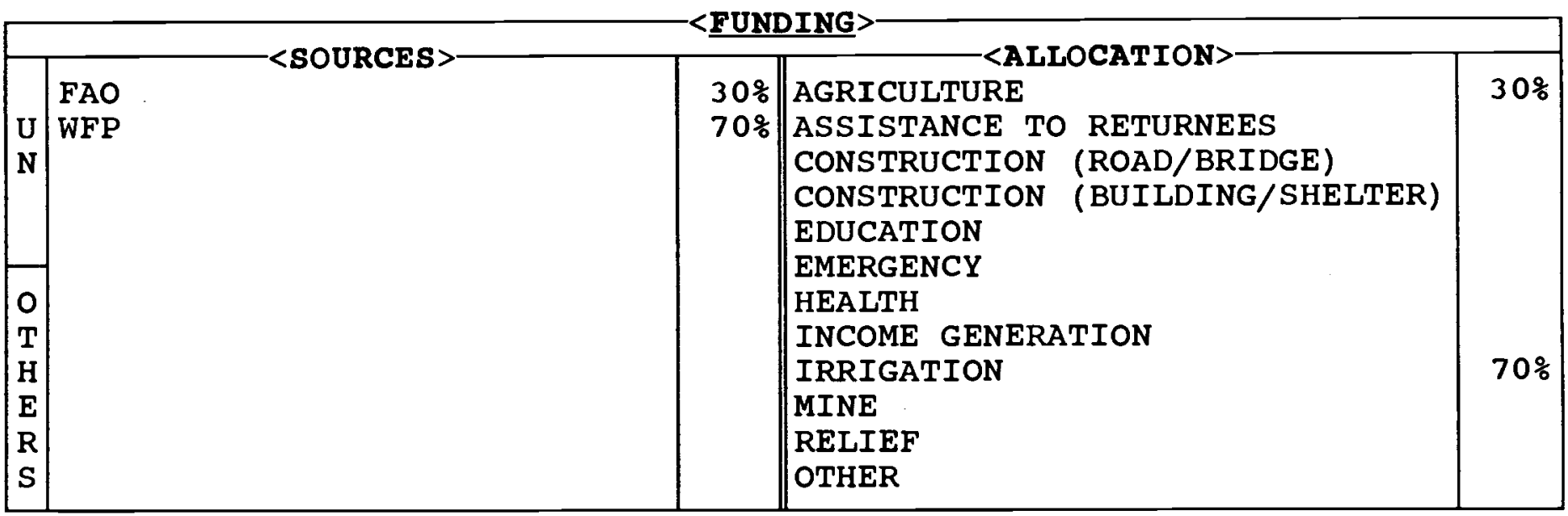

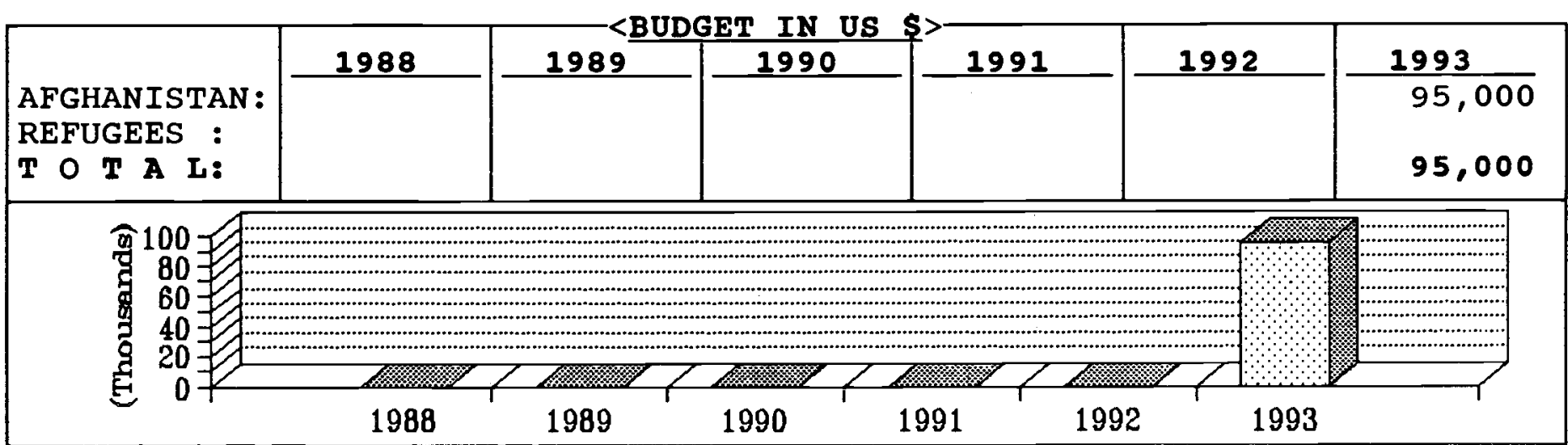

\begin{tabular}{|c|c|c|c|c|c|}
\hline PROVINCES & SECTOR & $\% A G E$ & PROVINCES & SECTOR & $\because A G E$ \\
\hline $\begin{array}{l}\text { BADAKSHAN } \\
\text { BADGHIS } \\
\text { BAGHLAN } \\
\text { BALKH } \\
\text { BAMYAN } \\
\text { FARAH } \\
\text { FARYAB } \\
\text { GHAZNI } \\
\text { GHOR } \\
\text { HELMAND } \\
\text { HERAT } \\
\text { JAWZJAN } \\
\text { KABUL } \\
\text { KANDAHAR } \\
\text { KAPISA }\end{array}$ & & & $\begin{array}{l}\text { KUNAR } \\
\text { KUNDUZ } \\
\text { LAGHMAN } \\
\text { LOGAR } \\
\text { NANGARHAR } \\
\text { NIMROZ } \\
\text { ORUZGAN } \\
\text { PAKTEKA } \\
\text { PAKTIA } \\
\text { PARWAN } \\
\text { SAMANGAN } \\
\text { TAKHAR } \\
\text { WARDAK } \\
\text { ZABUL }\end{array}$ & $\begin{array}{l}\text { Agr/irrign } \\
\text { Agr/irrign }\end{array}$ & $\begin{array}{l}40 \% \\
60 \%\end{array}$ \\
\hline
\end{tabular}




\section{AFGHAN AGRICULTURAL AND ENGINEERING AGENCY (AAEA)}

was founded in 1992, it is an Afghan managed and operated organization dedicated to the sustainable rehabilitation and reconstruction of Afghanistan with the headquarters in Peshawar, Pakistan. It has suboffices in Jalalabad, Laghman and Kabul.

Afghan Agriculture and Engineering Agency is strongly qualified in implementing all types of agriculture and engineering projects inside Afghanistan.

AAEA's projects have so far been mainly supported by United Nations organizations (WFP, FAO, UNDP and UNDCP) - An outline of AAEA projects is as follows:

Irrigation: cleaning of three canals (Naghrak, Mirzayan and Sawaty) in surkhrod district and cleaning of karezes in Rodat district of Nangarhar province have been completed. cleaning of a canal in Rodat district of Nangarhar and cleaning of three canals in Qarghaie district of Laghman province are ongoing.

Agriculture: wheat seed multiplication in Qarghaie district of Laghman province has been completed.

AAEA has a team of well qualified technical staff including engineers, agriculturists, finance and Administration officers who very closely supervise the ongoing projects and arrange new surveys, designs and proposals.

AAEA is in the process of expanding its activities to other provinces of Afghanistan e.g. Kabul, Logar, Wardak, Paktia, Ghazni and Mazar-isharif. 
AFGHAN AID ASSOCIATION-AAA

\begin{tabular}{|l|l|l|}
\hline ABO NOMAN PLAZA, JAMROD & PHONE: 45519 & COMMUNICATION LINES \\
RD, GPO BOX 299, & F A X: & 1. DR. FAROOQ MIRRANAY \\
PESHAWAR, PAKISTAN & TELEX: & 2. DR. KHUSHAL \\
\hline
\end{tabular}

\begin{tabular}{|lr|lr|lr|}
\hline AFGHAN: & 26 & TECHNICAL: & 10 & PAK.BASED: & 18 \\
PAKISTANI: & 2 & ADMINISTRATIVE: & 6 & AFGHA.BASED: & 0 \\
EXPAT: & 0 & FIELD/SUPPORT S. & 12 & CROSS-BORDER: & 10 \\
TOTAL: & 28 & TOTAL: & 28 & TOTAL: & 28 \\
\hline
\end{tabular}

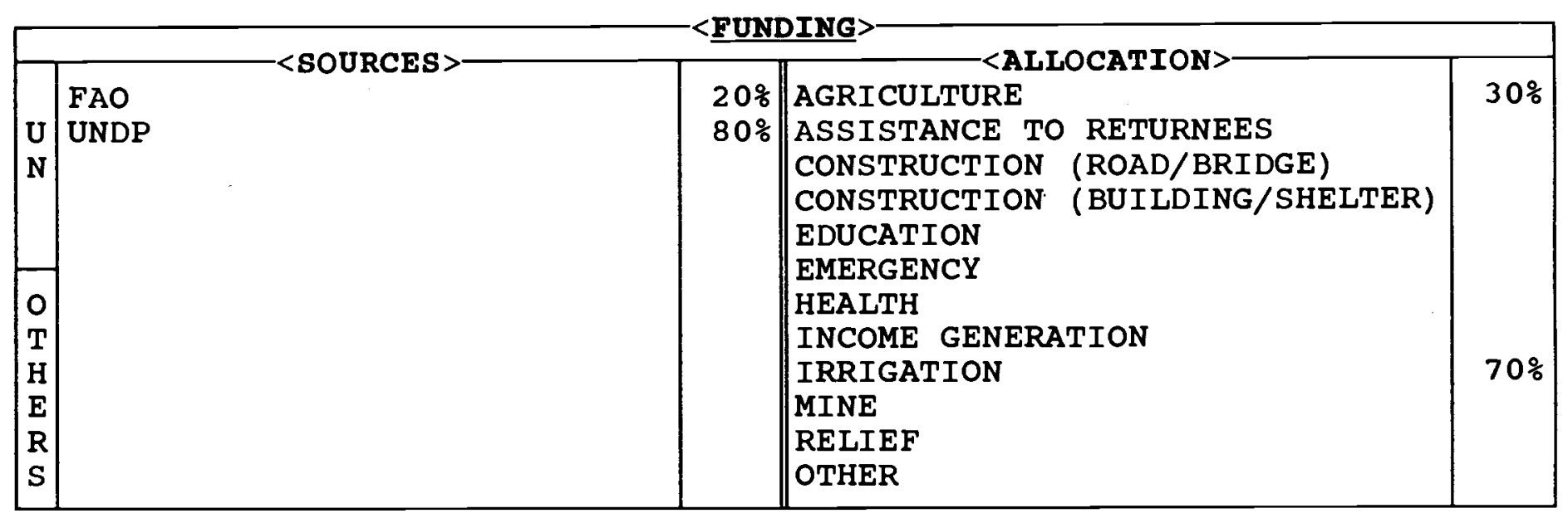

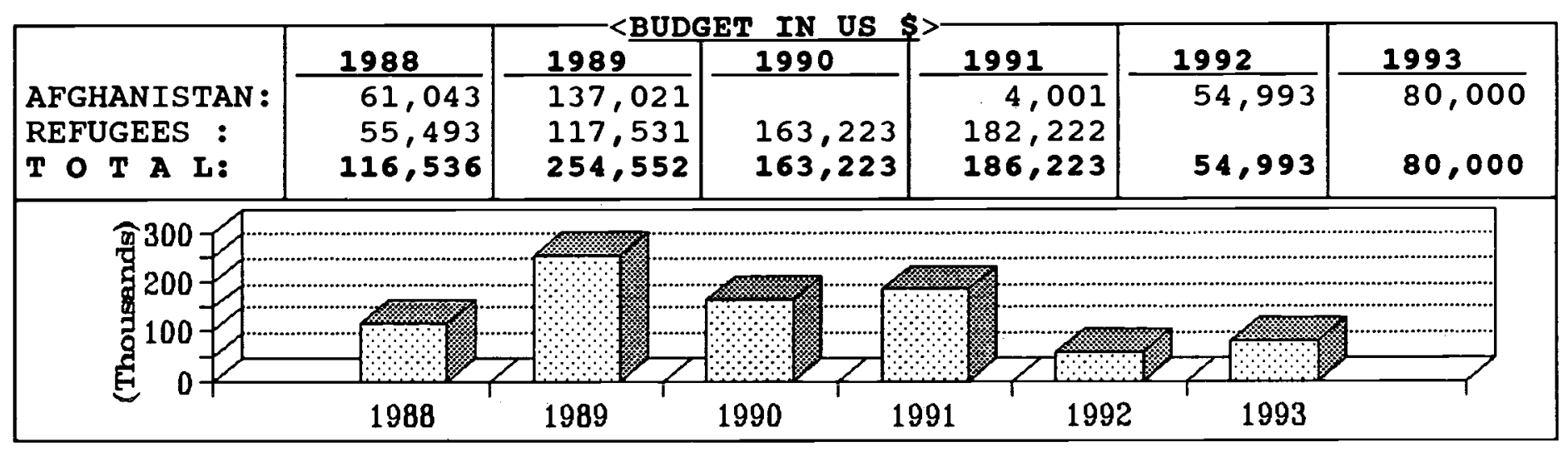

\begin{tabular}{|c|c|c|c|c|c|}
\hline PROVINCES & SECTOR & \&AGE & PROVINCES & SECTOR & $\because \mathrm{AGE}$ \\
\hline $\begin{array}{l}\text { BADAKSHAN } \\
\text { BADGHIS } \\
\text { BAGHLAN } \\
\text { BALKH } \\
\text { BAMYAN } \\
\text { FARAH } \\
\text { FARYAB } \\
\text { GHAZNI } \\
\text { GHOR } \\
\text { HELMAND } \\
\text { HERAT } \\
\text { JAWZJAN } \\
\text { KABUL } \\
\text { KANDAHAR } \\
\text { KAPISA }\end{array}$ & & & $\begin{array}{l}\text { KUNAR } \\
\text { KUNDUZ } \\
\text { LAGHMAN } \\
\text { LOGAR } \\
\text { NANGARHAR } \\
\text { NIMROZ } \\
\text { ORUZGAN } \\
\text { PAKTEKA } \\
\text { PAKTIA } \\
\text { PARWAN } \\
\text { SAMANGAN } \\
\text { TAKHAR } \\
\text { WARDAK } \\
\text { ZABUL }\end{array}$ & Agr/irrign & $100 \%$ \\
\hline
\end{tabular}




\section{AFGHAN AID ASSOCIATION (AAA)}

was founded in 1983. It works in health, agriculture, irrigation and construction sectors for the rehabilitation and development of Afghanistan. AAA has completed several projects in the above mentioned sectors funded by different UN agencies.

In the health sector, AAA opened a clinic in 1987 which provided medical treatment to between 4,500 and 5,000 men, women and children monthly. AAA also conducted a male health worker training program; one course was for a three-month period, another for six months. AAA had 4 clinics one each in Laghman, Parwan, Jawzjan and Nangarhar province.

AAA ran an Obs/Gyn clinic in refugee camps in Peshawar till December 1991 which provided medical treatment to 600 to 700 women and children patients each month.

AAA trained 53 female students in a mid-level health course for one year during 1990-91.

In the agricultural sector, AAA has distributed improved seeds, fertilizer and fruit trees to the farmers in Nangarhar province. Technical advice is given to the farmers by AAA professional staff. AAA has ongoing seed multiplication and fruit tree improvement projects in Nangarhar province.

Afghan Aid Association has completed several irrigation rehabilitation projects which irrigate thousands of jeribs of agricultural land in Nangarhar.

At present, AAA is working on the rehabilitation of four irrigation canals in Waziri of Khogyani district in Nangarhar.

Surveys of several canals have been conducted in different parts of Nangarhar and Paktia provinces and proposals for rehabilitation have been submitted to different d 0 n $\quad 0 \quad r \quad r \quad s$ 
AFGHAN AMPUTEE BICYCLISTS FOR REHABILITATION AND RECREATION-AABRAR

CADDRES8 $>$

106, GULHAJI PLAZA,

JAMROD RD,

PESHAWAR, PAKISTAN
COMMUNICATION LINES $>$ PHONE : 42417

F A X:

TELEX:
1. MR. ISAAC H. WILLIAM

2. MR. FAZEL H. BABER

3. DR. ABDUL BASIR

\begin{tabular}{|lr|lr|lr|}
\hline AFGHAN : & 27 & TECHNICAL: & 5 & PAK. BASED: & 5 \\
PAKISTANI: & 3 & ADMINISTRATIVE: & 4 & AFGHA.BASED: & 25 \\
EXPAT: & 1 & FIELD/SUPPORT S. & 22 & CROSS-BORDER: & 1 \\
TOTAL: & 31 & TOTAL: & 31 & TOTAL: & 31 \\
\hline
\end{tabular}

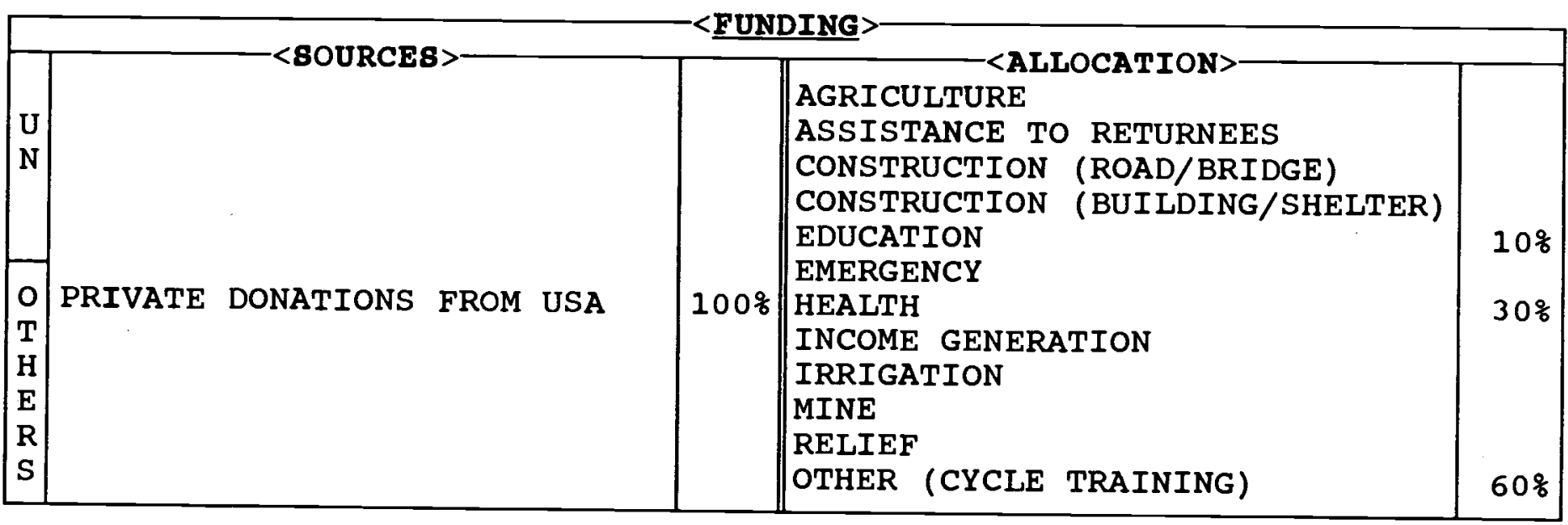

\begin{tabular}{|l|l|l|l|l|l|l|}
\hline & 1988 & 1989 & 1990 & 1991 & 1992 & 1993 \\
\hline $\begin{array}{l}\text { AFGHANISTAN : } \\
\text { TOUGEES : }\end{array}$ & & & & & 118,926 & 79,000 \\
T T A L: & & & & 118,926 & 79,000 \\
\hline
\end{tabular}

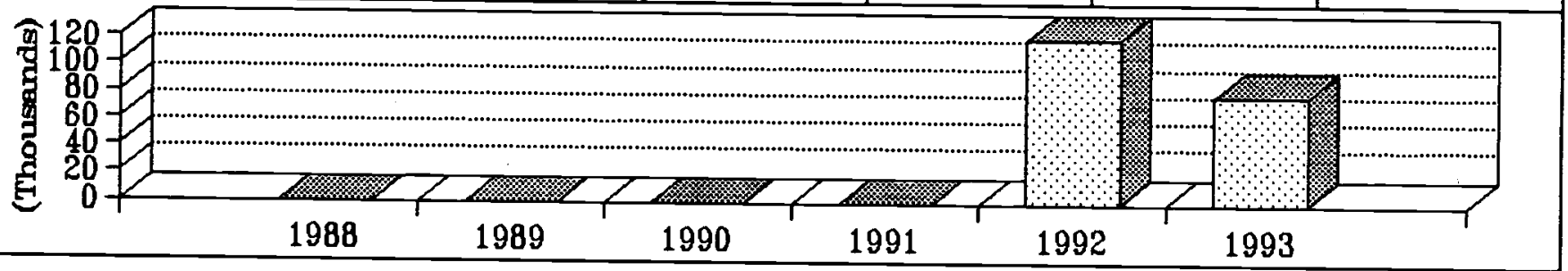

\begin{tabular}{|c|c|c|c|c|c|}
\hline PROVINCES & SECTOR & 号AGE & PROVINCES & SECTOR & \%AGE \\
\hline $\begin{array}{l}\text { BADAKSHAN } \\
\text { BADGHIS } \\
\text { BAGHLAN } \\
\text { BALKH } \\
\text { BAMYAN } \\
\text { FARAH } \\
\text { FARYAB } \\
\text { GHAZNI } \\
\text { GHOR } \\
\text { HELMAND } \\
\text { HERAT } \\
\text { JAWZJAN } \\
\text { KABUL } \\
\text { KANDAHAR } \\
\text { KAPISA }\end{array}$ & & & \begin{tabular}{|l|} 
KUNAR \\
KUNDUZ \\
LAGHMAN \\
LOGAR \\
NANGARHAR \\
NIMROZ \\
ORUZGAN \\
PAKTEKA \\
PAKTIA \\
PARWAN \\
SAMANGAN \\
TAKHAR \\
WARDAK \\
ZABUL
\end{tabular} & Educ/health/cycle tr. & $100 \%$ \\
\hline
\end{tabular}


AFGHAN AMPUTEE BICYCLISTS FOR REHABILITATION AND RECREATION (AABRAR)

was founded in July 1992 in Peshawar. A center was established in Jalalabad in August 1992.

The organization is financed mainly by private donations from the USA.

The objective of AABRAR is to train Afghan lower limb amputees to ride bicycles as a means for physical rehabilitation, social and economic advancement and contribution, recreational enjoyment and psychological well-being. AABRAR also provides physiotherapy services to male, female and children patients in two separate rooms. A one month rehabilitation course is offered to 20 to 24 disabled persons. The courses include bicycle skills, safety training, preliminary Pushto and literacy, first aid and basic health care.

AABRAR is operating cross-border at the moment. It has received requests from more than five provinces asking it to extend its services for which AABRAR is seeking funds. It is also looking for a site in Jalalabad for a wheelchair production workshop. 
AFGHAN BUREAU FOR RECONSTRUCTION-ABR

\begin{tabular}{|l|l|l|}
\hline IST FLOOR, NOMI PLAZA & PHONE: & 1. \\
OPPOS. HAJI CAMP, GT RD & F A X: & 2. \\
PESHAWAR, PAKISTAN & TELEX: & 3. \\
\hline
\end{tabular}

\begin{tabular}{|lr|lr|lr|}
\hline AFGHAN : & 10 & TECHNICAL: & 5 & PAK. BASED: & 4 \\
PAKISTANI : & 0 & ADMINISTRATIVE: & 3 & AFGHA.BASED: & 6 \\
EXPAT: & 0 & FIELD/SUPPORT S. & 2 & CROSS-BORDER: & 0 \\
TOTAL: & 10 & TOTAL: & 10 & TOTAL: & 10 \\
\hline
\end{tabular}

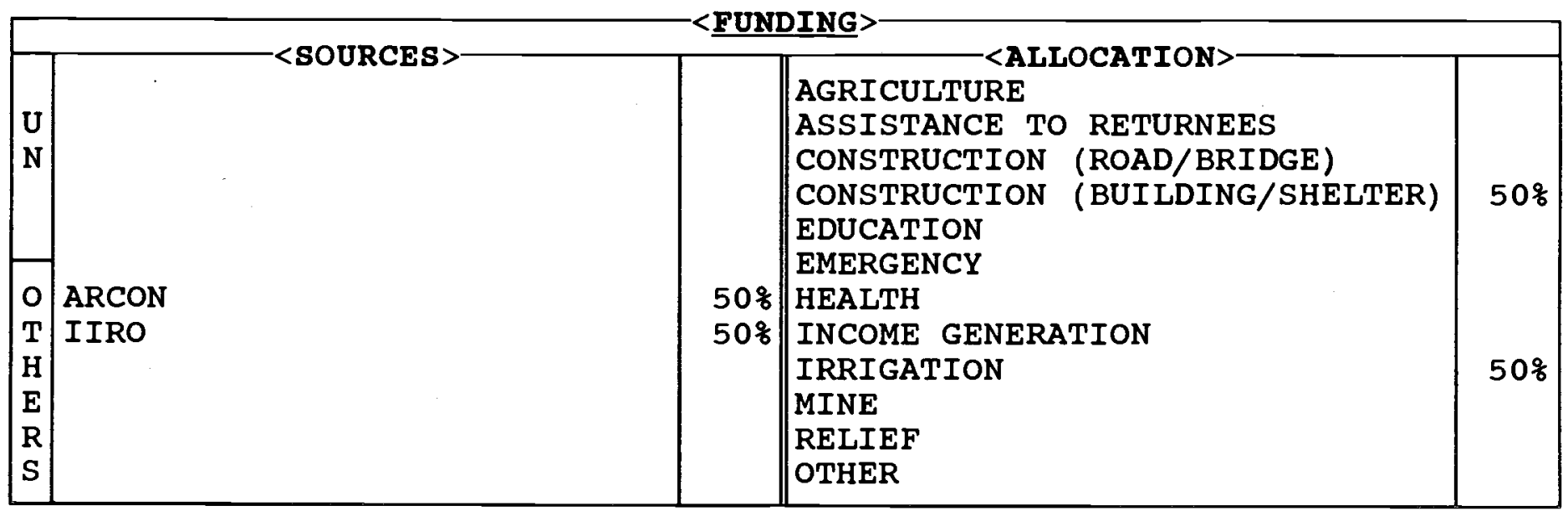

\begin{tabular}{|c|c|c|c|c|c|c|}
\hline & 1988 & 1989 & 1990 & 1991 & 1992 & 1993 \\
\hline $\begin{array}{l}\text { AFGHANISTAN: } \\
\text { REFUGEES : } \\
\text { T O T A L: }\end{array}$ & & & & & $\begin{array}{l}8,000 \\
8,000\end{array}$ & $\begin{array}{l}8,000 \\
8,000\end{array}$ \\
\hline
\end{tabular}

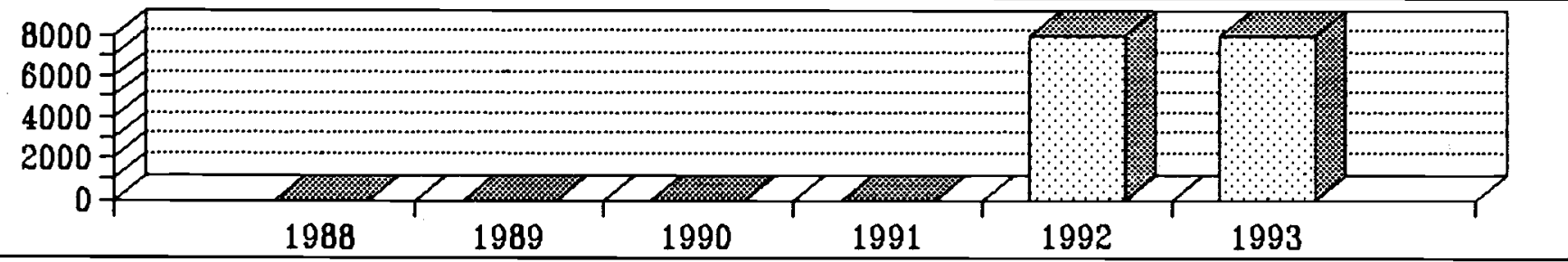

\begin{tabular}{|c|c|c|c|c|c|}
\hline PROVINCES & SECTOR & \&AGE & PROVINCES & SECTOR & \% $\mathrm{AGE}$ \\
\hline $\begin{array}{l}\text { BADAKSHAN } \\
\text { BADGHIS } \\
\text { BAGHLAN } \\
\text { BALKH } \\
\text { BAMYAN } \\
\text { FARAH } \\
\text { FARYAB } \\
\text { GHAZNI } \\
\text { GHOR } \\
\text { HELMAND } \\
\text { HERAT } \\
\text { JAWZJAN } \\
\text { KABUL } \\
\text { KANDAHAR } \\
\text { KAPISA }\end{array}$ & & & $\begin{array}{l}\text { KUNAR } \\
\text { KUNDUZ } \\
\text { LAGHMAN } \\
\text { LOGAR } \\
\text { NANGARHAR } \\
\text { NIMROZ } \\
\text { ORUZGAN } \\
\text { PAKTEKA } \\
\text { PAKTIA } \\
\text { PARWAN } \\
\text { SAMANGAN } \\
\text { TAKHAR } \\
\text { WARDAK } \\
\text { ZABUL }\end{array}$ & Const/irrign & $100 \%$ \\
\hline
\end{tabular}


AFGHAN BUREAU FOR RECONSTRUCTION (ABR)

was founded in 1992 to take active part in the reconstruction and rehabilitation affairs of war torn Afghanistan.

ABR has applied for registration to the Government of Pakistan and has a certificate from the Commissionerate for Afghan Refugees.

Over the past two years, ABR has been working as an implementing partner to the Afghanistan Reconstruction Consultants (ARCON) and the Islamic International Relief Organization (IIRO) implementing a number of reconstruction projects inside Afghanistan.

A Board of Directors consisting of prominent Afghans holds quarterly and annual meetings to make decisions and assess the progress of ABR.

$A B R^{\prime} s$ sectors of work are construction, irrigation, agriculture and drug control. 


\begin{tabular}{|l|l|l|}
\hline 1, STREET 2, NEAR FAIZ & PHONE: 40729 & 1. MR. HASAN SHERZAD \\
SONS FLATS, JAMROD RD & F A X: & LOMEY STAFF>- \\
PESHAWAR, PAKISTAN & TELEX: & 3R. MOHD JAFAR EMAL \\
\hline
\end{tabular}

\begin{tabular}{|ll|ll|ll|}
\hline AFGHAN : & 6 & TECHNICAL: & 2 & PAK.BASED: & 2 \\
PAKISTANI : & - & ADMINISTRATIVE: & 3 & AFGHA.BASED: & 1 \\
EXPAT: & - & FIELD/SUPPORT S. & 1 & CROSS BORDER: & 3 \\
TOTAL: & $\mathbf{6}$ & TOTAL: & $\mathbf{6}$ & TOTAL: & $\mathbf{6}$ \\
\hline
\end{tabular}

\begin{tabular}{|c|c|c|c|c|}
\hline & & & & \\
\hline & $<$ BOURCES & & $=<A L L O C A T I O N$ & \\
\hline & FAO & $q$ & AGRICULTURE & $\%$ \\
\hline $\mathbf{U}$ & UNCHS & $q$ & ASSISTANCE TO RETURNEES & \\
\hline $\mathbf{N}$ & UNDCP & 5 & CONSTRUCTION (ROAD/BRIDGE) & $\%$ \\
\hline & UNDP & $50 \%$ & CONSTRUCTION (BUILDING/SHELTER) & $q$ \\
\hline & WFP & $q$ & EDUCATION & 8 \\
\hline & & & EMERGENCY & \\
\hline 0 & PRIVATE DONATIONS & $50 \%$ & HEALTH & \\
\hline $\mathrm{T}$ & & & INCOME GENERATION & \\
\hline $\mathrm{H}$ & & & IRRIGATION & $100 \%$ \\
\hline $\mathbf{E}$ & & & MINE & \\
\hline $\mathbf{R}$ & & & RELIEF & \\
\hline $\mathbf{S}$ & & & OTHER & \\
\hline
\end{tabular}

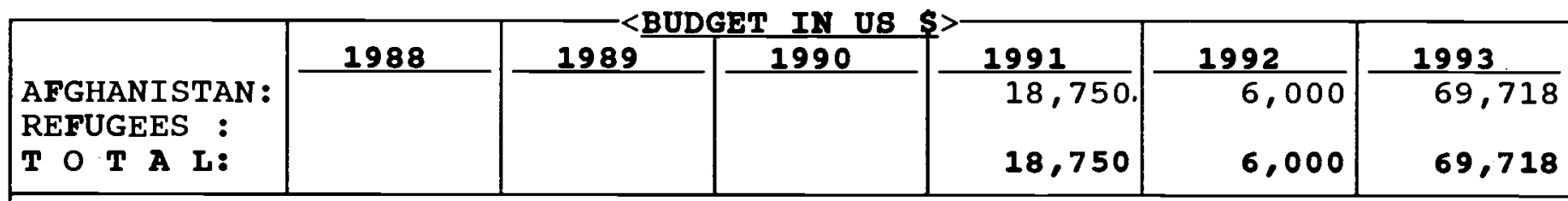

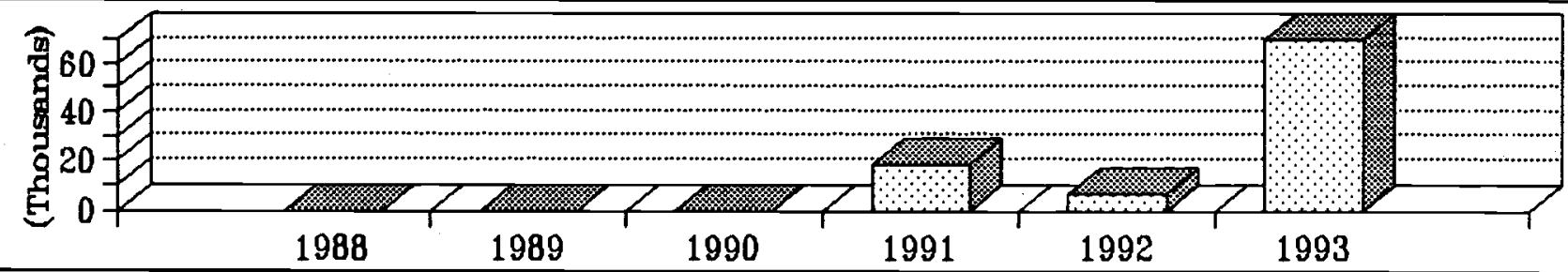

\begin{tabular}{|c|c|c|c|c|c|}
\hline PROVINCES & SECTOR & \&AGE & PROVINCES & SECTOR & $\% A G E$ \\
\hline $\begin{array}{l}\text { BADAKSHAN } \\
\text { BADGHIS } \\
\text { BAGHLAN } \\
\text { BALKH } \\
\text { BAMYAN } \\
\text { FARAH } \\
\text { FARYAB } \\
\text { GHAZNI } \\
\text { GHOR } \\
\text { HELMAND } \\
\text { HERAT } \\
\text { JAWZJAN } \\
\text { KABUL } \\
\text { KANDAHAR } \\
\text { KAPISA }\end{array}$ & & & $\begin{array}{l}\text { KUNAR } \\
\text { KUNDUZ } \\
\text { LAGHMAN } \\
\text { LOGAR } \\
\text { NANGARHAR } \\
\text { NIMROZ } \\
\text { ORUZGAN } \\
\text { PAKTEKA } \\
\text { PAKTIA } \\
\text { PARWAN } \\
\text { SAMANGAN } \\
\text { TAKHAR } \\
\text { WARDAK } \\
\text { ZABUL }\end{array}$ & $\begin{array}{l}\text { Agr/const/educ/irrign } \\
\text { Agr/const/educ/irrign } \\
\text { Agr/const/educ/irrign }\end{array}$ & $\begin{array}{l}60 \% \\
20 \% \\
20 \%\end{array}$ \\
\hline
\end{tabular}




\section{AFGHAN CARE (AC)}

is a non-profit, non-political and non-governmental organization founded in January 1991. Its sole objective is to participate, support and contributed actively in the rehabilitation, reconstruction and developmental programs of the war torn Afghanistan.

AC undertakes planning, designing and implementation of programs in social and economic fields in rural areas of the country. The main activities of the organization are:

a. Reconstruction of damaged infrastructure such as irrigation systems, roads and bridges.

b. Rehabilitation of agricultural system and provision of agricultural inputs and services.

c. Construction and repairing schools and encouraging education particularly vocational training among the rural population.

d. Improving existing health facilities and establishing new ones. Mobilizing rural communities to take active part in preventive health care through improving sanitation and environmental conditions.

e. Introducing specific programs for the female population to encourage their participation in home income and overall economy.

The organization has on its payroll a number of highly qualified engineers, agronomists, education experts, health workers and administrators some of whom have years of experience with foreign as well as Afghan organizations. Additionally, $A C$ is in permanent contact with many experts in different fields who can be hired on a temporary basis if needed.

Afghan Care's main office is located in Peshawar. In the near future it will open an office in Kunar province.

It has so far implemented one irrigation project $(3 \mathrm{~km}$ shinagal channel in Waygal valley of Kunar).

A number of projects in the provinces of Nangarhar, Laghman and Kunar has been proposed to different donor

organizations. 
AFGHAN CENTER FOR RURAL DEVELOPMENT-ACRD

\begin{tabular}{|c|c|c|}
\hline$-<$ ADDRESS & $-\langle$ COMMUNICATION LINES $\rangle$ & STAFF> \\
\hline $\begin{array}{l}\text { 3, ST. 4, JAHANGIRABAD, } \\
\text { U P O BOX } 849, \\
\text { PESHAWAR, PAKISTAN }\end{array}$ & $\begin{array}{l}\text { PHONE: } 44933 \\
\text { F A X: } \\
\text { TELEX: }\end{array}$ & $\begin{array}{l}\text { 1. MR. QASEEM ZARAE } \\
\text { 2. } \\
\text { 3. }\end{array}$ \\
\hline
\end{tabular}

\begin{tabular}{|lr|lr|ll|}
\hline AFGHAN : & 95 & TECHNICAL: & 85 & PAK. BASED: \\
PAKISTANI : & 0 & ADMINISTRATIVE: & 10 & AFGHA.BASED: \\
EXPAT: & 0 & FIELD/SUPPORT S & 0 & CROSS-BORDER: & $:$ \\
TOTAL: & 95 & TOTAL: & 95 & TOTAL: & 95 \\
\hline
\end{tabular}

\begin{tabular}{|c|c|c|c|c|}
\hline & & & & \\
\hline & $<$ SOURCES $>$ & & <ALLOCATION $>$ & \\
\hline & FAO & 8 & AGRICULTURE & $24 \%$ \\
\hline $\mathrm{U}$ & UNDP & $\%$ & ASSISTANCE TO RETURNEES & \\
\hline $\mathrm{N}$ & WFP & $\%$ & CONSTRUCTION (ROAD/BRIDGE) & \\
\hline & & & CONSTRUCTION (BUILDING/SHELTER) & 98 \\
\hline & & & EDUCATION & $\%$ \\
\hline 0 & ASSOC, SUISSE DES AMIS DEL AF. & 9 & $\begin{array}{l}\text { EMERGENCY } \\
\text { HEALTH }\end{array}$ & 432 \\
\hline $\mathbf{T}$ & IRC/RAP & 8 & INCOME GENERATION & \\
\hline $\mathrm{H}$ & MDM & q & IRRIGATION & $24 \%$ \\
\hline $\mathbf{E}$ & SOLIDERTES AFGHANISTAN & $\%$ & MINE & \\
\hline $\mathbf{R}$ & USAID & & RELIEF & \\
\hline $\mathbf{S}$ & & & OTHER & \\
\hline
\end{tabular}

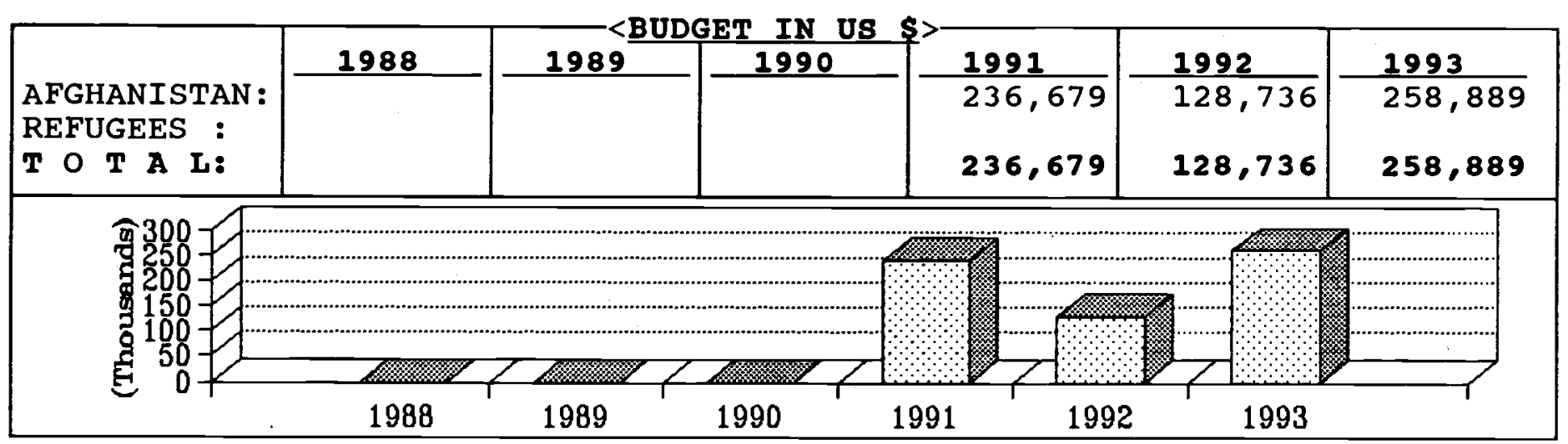

\begin{tabular}{|c|c|c|c|c|c|}
\hline PROVINCES & SECTOR & 官AGE & PROVINCES & SECTOR & $\because A G E$ \\
\hline $\begin{array}{l}\text { BADAKSHAN } \\
\text { BADGHIS } \\
\text { BAGHLAN } \\
\text { BALKH } \\
\text { BAMYAN } \\
\text { FARAH } \\
\text { FARYAB } \\
\text { GHAZNI } \\
\text { GHOR } \\
\text { HELMAND } \\
\text { HERAT } \\
\text { JAWZJAN } \\
\text { KABUL } \\
\text { KANDAHAR } \\
\text { KAPISA }\end{array}$ & Health & 108 & \begin{tabular}{|l} 
KUNAR \\
KUNDUZ \\
LAGHMAN \\
LOGAR \\
NANGARHAR \\
NIMROZ \\
ORUZGAN \\
PAKTEKA \\
PAKTIA \\
PARWAN \\
SAMANGAN \\
TAKHAR \\
WARDAK \\
ZABUL
\end{tabular} & 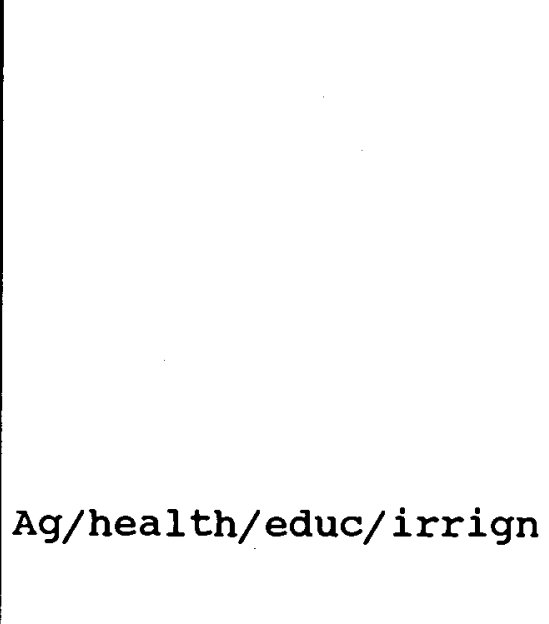 & $90 \%$ \\
\hline
\end{tabular}




\section{AFGHAN CENTER FOR RURAL DEVELOPMENT (ACRD)}

has existed for the past ten years and was active in development and rehabilitation programs in Afghanistan through the joint efforts of expatriate relief bodies (VSF, MDM and SOLAF) and Afghan specialists. ACRD started its work officially as an Afghan NGO in 1990 and took over these projects with the aim of assisting Afghans in the rehabilitation of the rural economy by undertaking various multisectoral projects in poor areas.

ACRD runs several cross-border programs such as agricultural development, livestock and veterinary services, irrigation repair, health/education and construction/engineering projects. The core of its activities has been in Jaghatu district though the program has supplied other areas such as Sayed Abad, Dai Mirdad, Chak in Wardak and Zena Khan and Khwaja Omri in Ghazni province with material assistance.

Agriculture: tree saplings, seeds/fertilizer have been distributed and advice and training offered. 50,000 saplings have been distributed in the past three years. ACRD maintains a trial of 14 species of improved wheat seed acquired from CRC Switzerland. Nurseries of both fruit and non-fruit trees have been established to overcome the problem of deforestation $(50,000$ poplar cuttings were planted in 1991). ACRD was the first agency to introduce farm machinery into the rural communities in Wardak. Currently 8 threshers, 12 tractors and 3 harvesters are being operated. It also assisted farmers in connection with poultry disease control, orchard development and wheat price stabilization. The Cereal Bank is a completely new innovation in the field of relief activities and was established by ACRD to assist in stabilizing the economic conditions of the rural community.
A total of $437,800 \mathrm{MT}$ wheat has been distributed to 3,750 families in 170 villages under the cereal Bank project.

Livestock Program: is composed of poultry and dairy cattle production. A network system, a stationary clinic and mobile vet facilities are in place to provide veterinary services covering Jaghatu and part of Sayed Abad and Chak.

Irrigation: ACRD has completed cleaning 81 karezes in Jaghatu, sayed Abad and chak under its irrigation program.

Medical Programs: encompass curative and preventive practice through a hospital in Jaghatu and three satellite clinics in Jaghatu, Chak and Laghari areas. The hospital is equipped with anaesthesia, OT, hospitalization and $x$-ray facilities. The clinics provide services such as consultation, laboratory, dentistry and gynaecology. Immunization and TB control campaigns are also launched from the clinics.

Education: ACRD currently runs 8 primary schools (677 students). Books (from UNO), educational materials and stationary are provided. ACRD has also repaired and constructed buildings for the schools.

Construction/engineering: ACRD has been active in surveying and construction of community storage buildings and roads in addition to office buildings for its own purposes (offices, workshops, schools and clinics).

The engineering department started a modern and well equipped auto workshop to meet the growing needs in the field of vehicle and machinery repair.

ACRD has proposed several projects to donor organizations to be implemented in Wardak, Ghazni, Kabul and Logar provinces. 


\begin{tabular}{|c|c|c|c|c|c|}
\hline \multirow{2}{*}{\multicolumn{2}{|c|}{$\begin{array}{l}\text { 6-A, KHALIL TOWN, } \\
\text { G P O BOX 858, } \\
\text { PESHAWAR, PAKISTAN }\end{array}$}} & \multicolumn{2}{|c|}{ <COMMUNICATION LINES $>$} & \multicolumn{2}{|c|}{$<<$ KEY STAFF $>=$} \\
\hline & & $\begin{array}{l}\text { PHONE: } 43449 \\
\text { F A X: } \\
\text { TELEX : }\end{array}$ & & $\begin{array}{ll}\text { 1. } & \text { MR. GUL WA } \\
\text { 2. MR. MIR WA } \\
\text { 3. MR. MATIUI }\end{array}$ & \\
\hline $\begin{array}{l}\text { AFGHAN : } \\
\text { PAKISTANI : } \\
\text { EXPAT: } \\
\text { TOTAL: }\end{array}$ & $\begin{array}{r}30 \\
0 \\
0 \\
30\end{array}$ & $\begin{array}{l}\text { TECHNICAL: } \\
\text { ADMINISTRATIVE: } \\
\text { FIELD/SUPPORT S. } \\
\text { TOTAL: }\end{array}$ & $\begin{array}{r}9 \\
8 \\
13 \\
30\end{array}$ & $\begin{array}{l}\text { PAK. BASED: } \\
\text { AFGHA. BASED: } \\
\text { CROSS-BORDER: } \\
\text { TOTAL : }\end{array}$ & $\begin{array}{r}0 \\
15 \\
15 \\
30\end{array}$ \\
\hline
\end{tabular}

\begin{tabular}{|c|c|c|c|c|}
\hline & & & 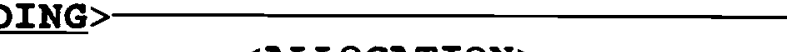 & \\
\hline & CSOURCES & $12 \%$ & $\begin{array}{l}\text { AGRICULTURE } \\
\text { AGLOCATION }>-\end{array}$ & $12 \%$ \\
\hline $\mathbf{U}$ & UNDP & $70 \%$ & ASSISTANCE TO RETURNEES & $12 \%$ \\
\hline $\mathbf{N}$ & UNDCP & $6 \%$ & CONSTRUCTION (ROAD/BRIDGE) & \\
\hline & & & CONSTRUCTION (BUILDING/SHELTER) & \\
\hline & & & EDUCATION & $29 \%$ \\
\hline & & & EMERGENCY & \\
\hline 0 & THE ASIA FOUNDATION & $12 \%$ & HEALTH & \\
\hline $\mathrm{T}$ & & & INCOME GENERATION & \\
\hline $\mathrm{H}$ & & & IRRIGATION & $58 \%$ \\
\hline $\mathbf{E}$ & & & MINE & \\
\hline $\mathbf{R}$ & & & RELIEF & \\
\hline$S$ & & & OTHER & $1 \%$ \\
\hline
\end{tabular}

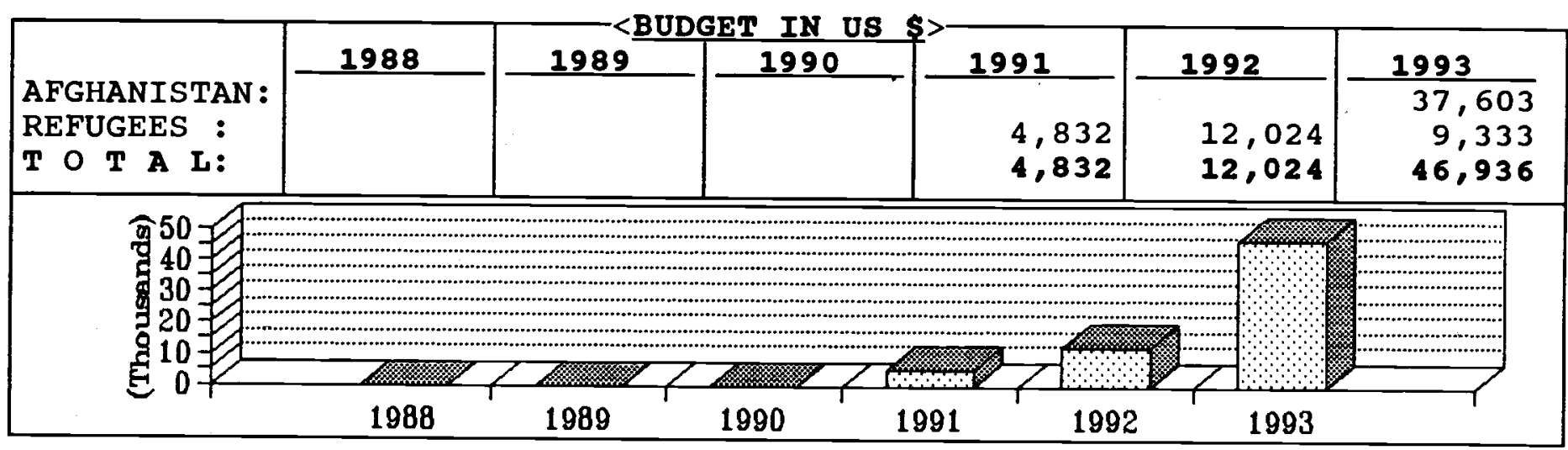

\begin{tabular}{|c|c|c|c|c|c|}
\hline PROVINCES & SECTOR & $\% \mathrm{AGE}$ & PROVINCES & SECTOR & $\%$ AGE \\
\hline $\begin{array}{l}\text { BADAKSHAN } \\
\text { BADGHIS } \\
\text { BAGHLAN } \\
\text { BALKH } \\
\text { BAMYAN } \\
\text { FARAH } \\
\text { FARYAB } \\
\text { GHAZNI } \\
\text { GHOR } \\
\text { HELMAND } \\
\text { HERAT } \\
\text { JAWZJAN } \\
\text { KABUL } \\
\text { KANDAHAR } \\
\text { KAPISA }\end{array}$ & & & \begin{tabular}{|l} 
KUNAR \\
KUNDUZ \\
LAGHMAN \\
LOGAR \\
NANGARHAR \\
NIMROZ \\
ORUZGAN \\
PAKTEKA \\
PAKTIA \\
PARWAN \\
SAMANGAN \\
TAKHAR \\
WARDAK \\
ZABUL
\end{tabular} & $\begin{array}{l}\text { Agr } \\
\text { Irrign } \\
\text { Agr/educ }\end{array}$ & $\begin{array}{l}10 \% \\
58 \% \\
32 \%\end{array}$ \\
\hline
\end{tabular}




\section{AFGHAN COMMUNITY DEVELOPMENT ORGANIZATION (ACDO)}

is a non-profit, non-political and non-governmental organization. It was founded in september 1991 and has been working in the sectors of education, irrigation, construction, agriculture and social-welfare programs in different provinces of Afghanistan.

An outline of ACDO projects is as follows:

EDUCATION: In education (English Language Development, Public Administration and Literacy), ACDO has been running English Language Program \& Public Administration classes in Kurram Agency, Pakistan since 1991 where around 1500 students have been trained in English Language and 800 students in Public Administration (accounting/management \& typing skills).

In 1992, ACDO established an Educational Institute in Jalalabad city which provides classes in accounting, management and English language. A total of 500 students have completed courses in Jalalabad so far.

Management, language and science courses for Khost and Gardaiz and literacy courses for Nangarhar province are planned for the future and discussion is ongoing with the Norwegian Afghanistan Committee, the Asia Foundation and other donors for funding.

CONSTRUCTION/IRRIGATION: In the sectors of construction and irrigation several project proposals have been submitted to, and are under consideration by several different donor organizations including canada Fund, WFP and UNDP for both Nangarhar and Khost provinces.

AGRICULTURE: ACDO has implemented 12 improved wheat seed multiplication projects in different provinces for autumn sowing $1993 / 94$.
It is planning to implement 10 improved sugarcane projects in different provinces of Afghanistan next season. Proposals for poultry and bee farms have been submitted to UNDP and the Asia Foundation/USAID. Discussions are going on with SERVE for a forestry project.

As part of social welfare exercises, ACDO is planning to establish tailoring and other vocational training courses for women. 
AFGHAN CONSTRUCTION \& LOGISTICS UNIT-ACLU

- CADDRESS >- - COMMUNICATION LINES>

4-AC, JAMROD LANE, U/T, PHONE: $41205 / 44578$

$P$ O BOX .......

PESHAWAR, PAKISTAN
$F$ A X:

TELEX:
1. ENG. M. KARIM

2. ENG. S. A. M. HAMIDI

3. ENG. ROHULLAH AHMADI

\begin{tabular}{|lr|lr|lr|}
\hline AFGHAN : & 210 & TECHNICAL: & 45 & PAK. BASED: & 65 \\
PAKISTANI : & 1 & ADMINISTRATIVE: & 16 & AFGHA.BASED: & 13 \\
EXPAT: & - & FIELD/SUPPORT S. & 150 & CROSS-BORDER: & 133 \\
TOTAL: & 211 & TOTAL: & 211 & TOTAL: & 211 \\
\hline
\end{tabular}

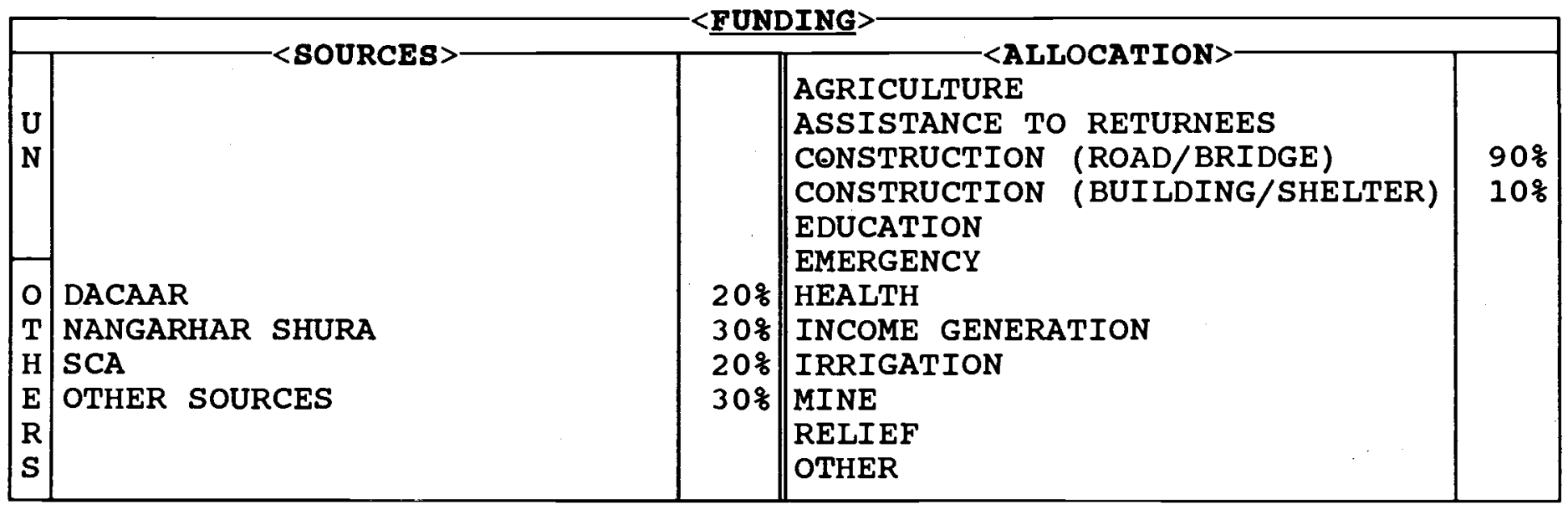

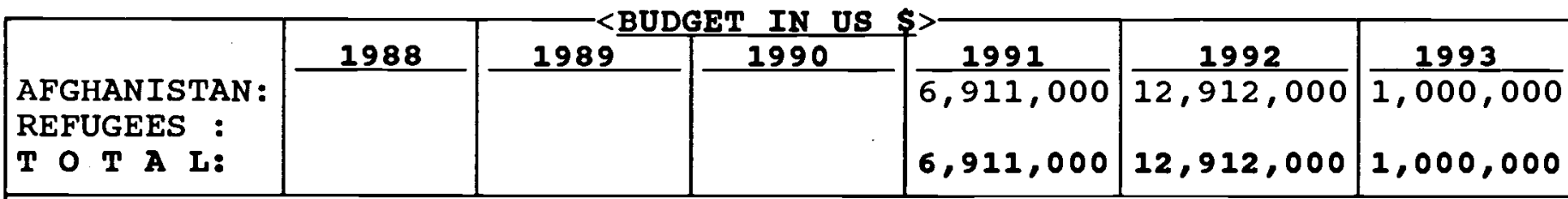

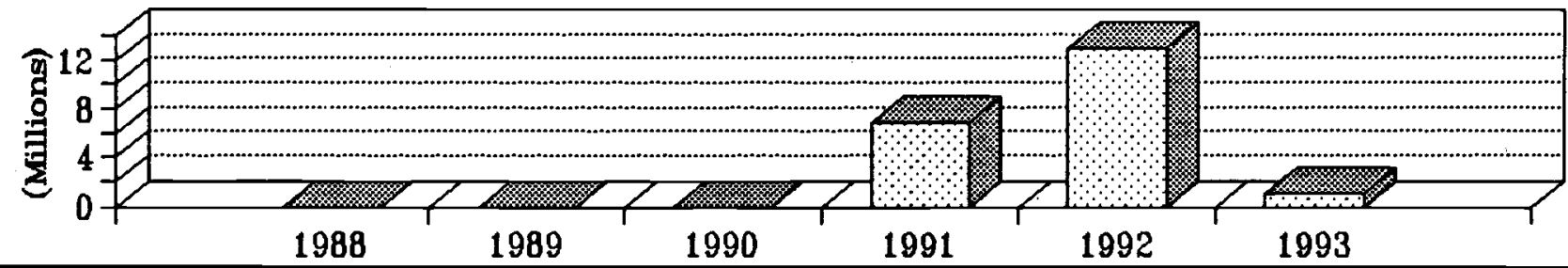

\begin{tabular}{|c|c|c|c|c|c|}
\hline PROVINCES & SECTOR & \%AGE & PROVINCES & SECTOR & \&AGE \\
\hline $\begin{array}{l}\text { BADAKSHAN } \\
\text { BADGHIS } \\
\text { BAGHLAN } \\
\text { BALKH } \\
\text { BAMYAN } \\
\text { FARAH } \\
\text { FARYAB } \\
\text { GHAZNI } \\
\text { GHOR } \\
\text { HELMAND } \\
\text { HERAT } \\
\text { JAWZJAN } \\
\text { KABUL } \\
\text { KANDAHAR } \\
\text { KAPISA }\end{array}$ & Survey of 4 bridges & $5 \%$ & $\begin{array}{l}\text { KUNAR } \\
\text { KUNDUZ } \\
\text { LAGHMAN } \\
\text { LOGAR } \\
\text { NANGARHAR } \\
\text { NIMROZ } \\
\text { ORUZGAN } \\
\text { PAKTEKA } \\
\text { PAKTIA } \\
\text { PARWAN } \\
\text { SAMANGAN } \\
\text { TAKHAR } \\
\text { WARDAK } \\
\text { ZABUL }\end{array}$ & $\begin{array}{l}\text { Const/irrign } \\
\text { Const (road/bridge) } \\
\text { Const (bridge) }\end{array}$ & $\begin{array}{l}15 \% \\
10 \%\end{array}$ \\
\hline
\end{tabular}


AFGHAN CONSTRUCTION AND LOGISTICS UNIT (ACLU)

was founded in 1988 with the following objectives:

* To assess the condition of primary and secondary road systems in Afghanistan.

* To assemble construction teams to repair and reconstruct roads and bridges when conditions permit.

* To plan and design work to be accomplished.

ACLU has four Construction Units (three for road work and one for construction of bridges). The construction work includes: widening, cutting, filling and surfacing roads and constructing culverts, retaining walls, washes and bridges.

With the support of USAID and supervision of CCSC, the organization has completed the following projects:

* A total of $836 \mathrm{~km} \mathrm{road}$ repairing/reconstruction including construction of structures in the provinces of Kunar, Badakhshan, Paktia, Khost, Nangarhar and Kabul including Kabul-Jalalabad highway and Nawa Pass-Barikot road.

* Construction and/or repair of 26 bridges in Kunar, Nangarhar, Khost, Laghman and Wardak provinces.

In June 1993, USAID project support to ACLU ended and the agency reorganized itself as an Afghan NGO. since then ACLU has implemented a number of projects with the financial assistance of different organizations:

* Kama Irrigation scheme, Phase $I$, with the assistance of SCA.

* Kama Irrigation scheme, Phase II, with the assistance of DACAAR.
Construction of roads and Islamic University Building in Jalalabad with the financial assistance of the Nangarhar Provincial Authorities.

* Survey/repair of $21 \mathrm{~km}$ road (Islamabad-Faizabad-Muree) as a sub-contract to a Pakistan Construction Company (Karkun).

ACLU is well-equipped with all types of construction machinery and has the capacity of designing and implementing different construction projects. It is ready to accept any construction orders and contracts from donor organizations, NGOs, companies and governmental bodies. 


\begin{tabular}{|l|l|l|}
\hline OPPOSITE GULHAJI PLAZA, & PHONE: $40743 / 841743$ & COMEY STAFF> \\
P O BOX 695, & F A X: & 2. MR. QAMARUDDIN \\
PESHAWAR, PAKISTAN & TELEX: & MR. SAADULLAH SAFI \\
\hline
\end{tabular}

\begin{tabular}{|lr|lr|lr|}
\hline AFGHAN : & 13 & TECHNICAL: & 6 & PAK.BASED: & 7 \\
PAKISTANI : & 2 & ADMINISTRATIVE: & 4 & AFGHA.BASED: & 5 \\
EXPAT: & 0 & FIELD/SUPPORT S. & 5 & CROSS-BORDER: & 3 \\
TOTAL: & 15 & TOTAL: & 15 & TOTAL: & 15 \\
\hline
\end{tabular}

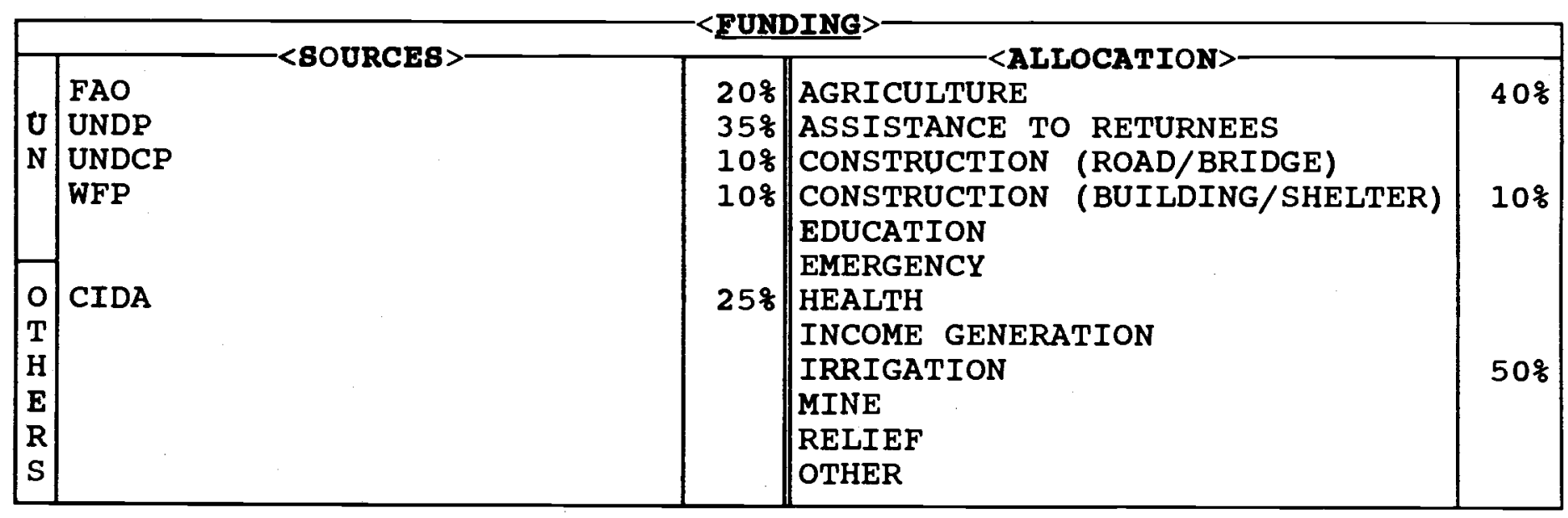

\begin{tabular}{|c|c|c|c|c|c|c|}
\hline $\begin{array}{l}\text { AFGHANISTAN: } \\
\text { REFUGEES : } \\
\text { T O T A I: }\end{array}$ & 1988 & 1989 & 1990 & $\begin{array}{r}\frac{1991}{34,800} \\
34,800\end{array}$ & $\begin{array}{l}\frac{1992}{86,000} \\
86,000\end{array}$ & $\begin{array}{l}\frac{1993}{69,615} \\
69,615\end{array}$ \\
\hline 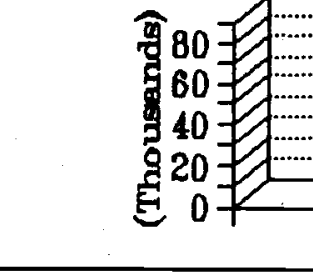 & 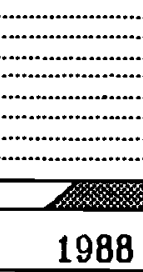 & 1989 & 1990 & 1991 & $\ldots$ & (1) \\
\hline
\end{tabular}

\begin{tabular}{|c|c|c|c|c|c|}
\hline PROVINCES & SECTOR & \&AGE & PROVINCES & SECTOR & $\%$ AGE \\
\hline $\begin{array}{l}\text { BADAKSHAN } \\
\text { BADGHIS } \\
\text { BAGHLAN } \\
\text { BALKH } \\
\text { BAMYAN } \\
\text { FARAH } \\
\text { FARYAB } \\
\text { GHAZNI } \\
\text { GHOR } \\
\text { HELMAND } \\
\text { HERAT } \\
\text { JAWZJAN } \\
\text { KABUL } \\
\text { KANDAHAR } \\
\text { KAPISA }\end{array}$ & 列 & 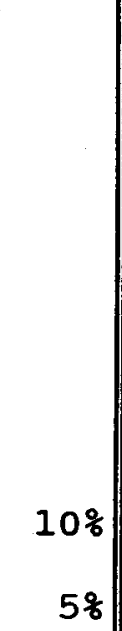 & \begin{tabular}{|l} 
KUNAR \\
KUNDUZ \\
LAGHMAN \\
LOGAR \\
NANGARHAR \\
NIMROZ \\
ORUZGAN \\
PAKTEKA \\
PAKTIA \\
PARWAN \\
SAMANGAN \\
TAKHAR \\
WARDAK \\
ZABUL
\end{tabular} & $\begin{array}{l}\text { Agr/irrign } \\
\text { Agr/irrign/const }\end{array}$ & $\begin{array}{r}5 \% \\
80 \%\end{array}$ \\
\hline
\end{tabular}




\begin{abstract}
AFGHAN DEVELOPMENT AGENCY (ADAg)
is a non-profit, non-political humanitarian and non-governmental organization established in May 1990.

ADAg aims to contribute to the rehabilitation and development of Afghanistan through planning, designing and undertaking of economic and humanitarian assistance programs.

ADAg started work in Afghanistan on lst July, 1991.

ADAg cross-border rehabilitation and development projects in Afghanistan include:

- Rehabilitation and improvement of irrigation systems and structures in Hesarak, Surkhrod and Mohmand Dara districts of Nangarhar with the assistance of UNDP/OPS and the canada Fund.

- Provision of agricultural inputs and multiplication of improved varieties of different seeds (wheat, sugar cane, maize and rice), fruit tree saplings and poultry in several districts of Nangarhar, Tagab district of Kapisa and Baraki district of Logar province with the support of FAO, UNDP/OPS and Canada Fund.
\end{abstract}

ADAg is registered by the NWFP government. 


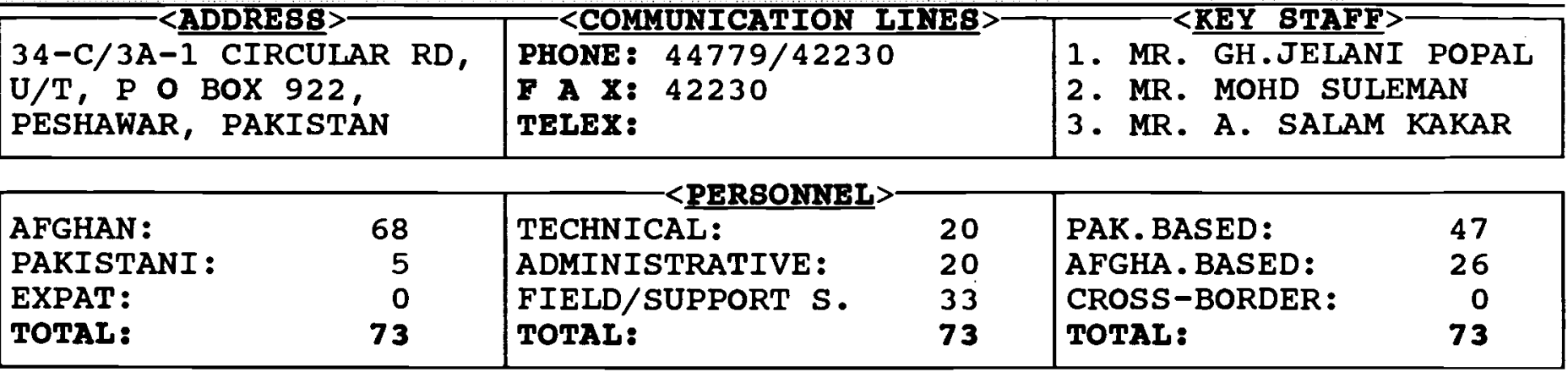

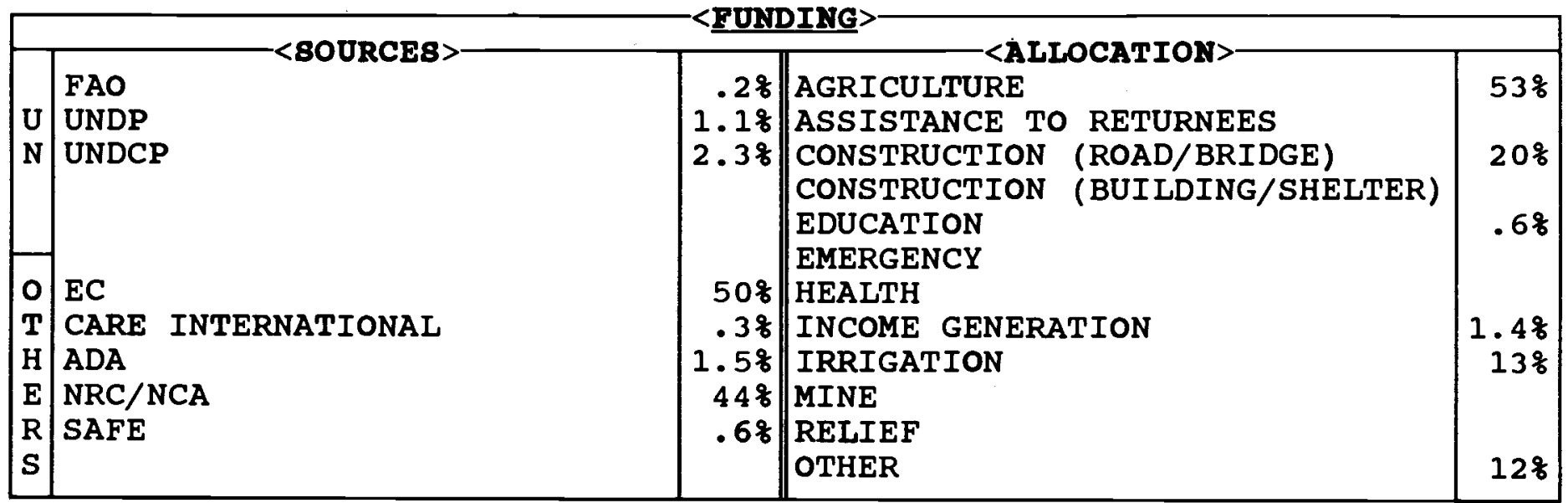

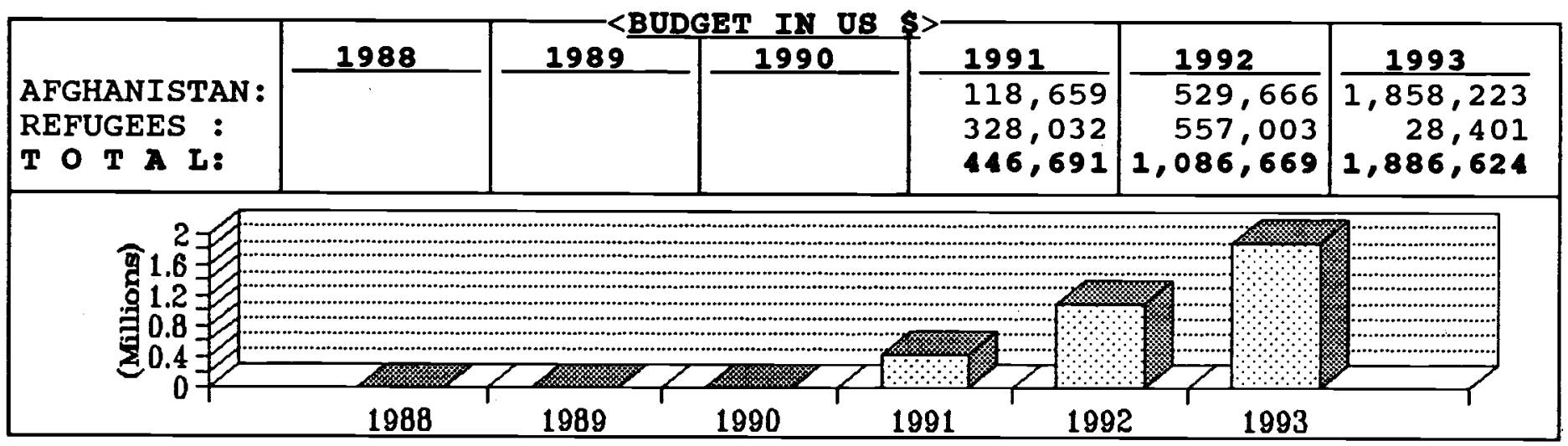

\begin{tabular}{|c|c|c|c|c|c|}
\hline PROVINCES & SECTOR & \&AGE & PROVINCES & SECTOR & $\% A G E$ \\
\hline $\begin{array}{l}\text { BADAKSHAN } \\
\text { BADGHIS } \\
\text { BAGHLAN } \\
\text { BALKH } \\
\text { BAMYAN } \\
\text { FARAH } \\
\text { FARYAB } \\
\text { GHAZNI } \\
\text { GHOR } \\
\text { HELMAND } \\
\text { HERAT } \\
\text { JAWZJAN } \\
\text { KABUL } \\
\text { KANDAHAR } \\
\text { KAPISA }\end{array}$ & Agr/const/irrign/v.t. & 238 & \begin{tabular}{|l|} 
KUNAR \\
KUNDUZ \\
LAGHMAN \\
LOGAR \\
NANGARHAR \\
NIMROZ \\
ORUZGAN \\
PAKTEKA \\
PAKTIA \\
PARWAN \\
SAMANGAN \\
TAKHAR \\
WARDAK \\
ZABUL
\end{tabular} & $\begin{array}{l}\text { Agr/cons/educ/irr/v.t } \\
\text { Agr/educ } \\
\text { Agr }\end{array}$ & $\begin{array}{r}13 \% \\
1 \%\end{array}$ \\
\hline
\end{tabular}


AFGHAN DEVELOPMENT ASSOCIATION

(ADA)

is a non-profit, non-governmental, non-political organization created to enable Afghans to help themselves in meeting their future requirements in the areas of health, agriculture, income generation, construction and vocational training.

ADA was founded on October 31,1990 and commenced implementing projects in Afghanistan later that year. The aim of ADA is to assist the Afghan people, whether in refugee camps or in Afghanistan, in the rehabilitation and development of the rural economy by implementing multi-sectoral projects and by establishing and promoting sustainable enterprises. ADA has implemented/is implementing the following projects.

1) Shahwalikot Khas Uruzgan, Chorah, Khakrez agriculture project funded by $\mathrm{NRC} / \mathrm{NCA}$

2) Wardak agriculture project funded by FAO

3) Spina wialah irrigation rehabilitation project funded by NRC/NCA

4) Daman irrigation development project: tube-wells funded by European Community

5) Markaz canal rehabilitation and development project funded by EC

6) Trinkot irrigation rehabilitation and development project funded by EC

7) Khas Uruzgan irrigation rehabilitation and development project funded by NRC/NCA and EC

8) Agricultural land protection on Arghandab River funded by UNDP
10) Shahwalikot water supply and sanitation project funded by European Community

9) Daman water supply and sanitation project funded by European Community

11) Khas Uruzgan water supply and sanitation project funded by European Community

12) Trinkot water supply and sanitation project funded by European Community

13) Kandahar/Uruzgan and Uruzgan/Zabul road survey and repair project funded by EC

14) Khas Uruzgan veterinary project funded by UNDP

15) S.W.A. vocational training project funded by EC

16) Khas Uruzgan and Shahwalikot primary schools funded by ADA

17) Health services - project funded by EC

18) Said Abad field office project funded by ADA

19) Income generation and vocation funded by ADA. 
AFGHAN DEVELOPMENT PROGRAM-ADP

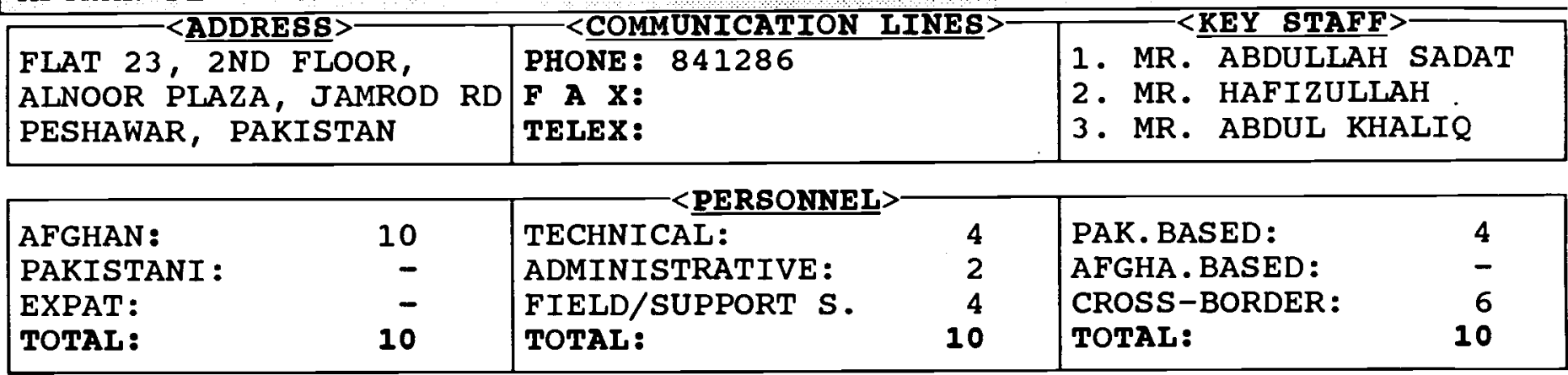

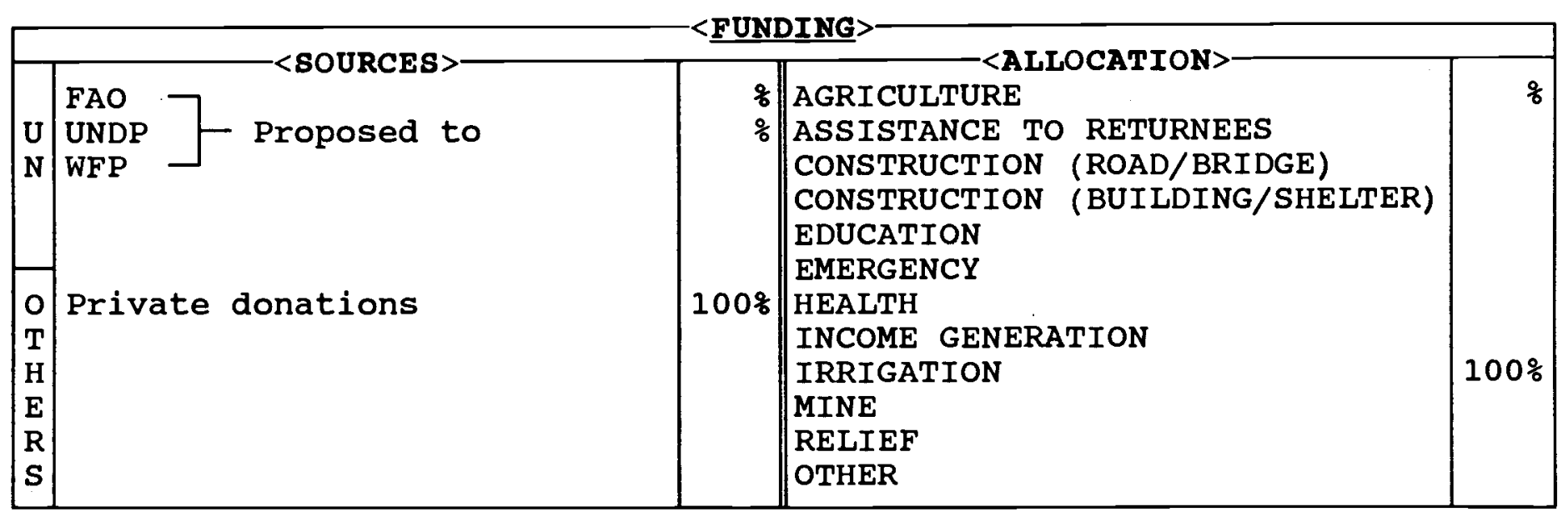

\begin{tabular}{|c|c|c|c|c|c|c|}
\hline & 1988 & 1989 & 1990 & 1991 & 1992 & 1993 \\
\hline $\begin{array}{l}\text { AFGHANISTAN : } \\
\text { REFUGEES : }\end{array}$ & & & & & 31,666 & 10,000 \\
\hline
\end{tabular}

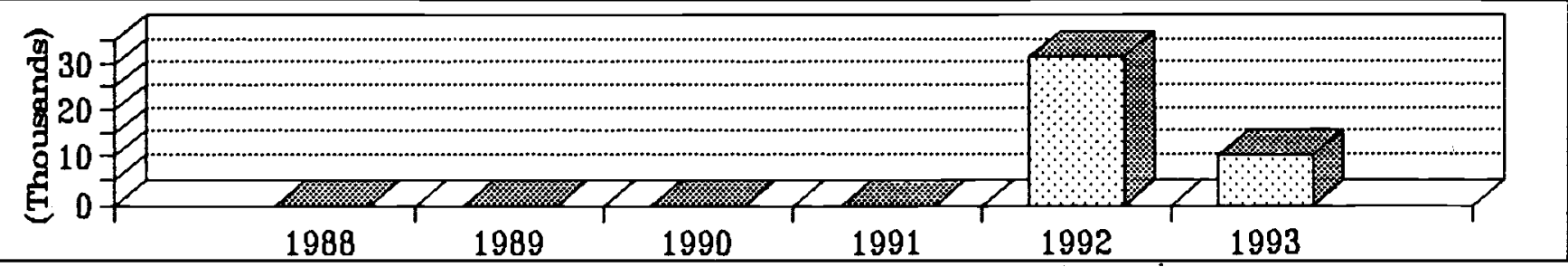

\begin{tabular}{|c|c|c|c|c|c|}
\hline PROVINCES & SECTOR & $\because \mathrm{AGE}$ & PROVINCES & SECTOR & $\because A G E$ \\
\hline $\begin{array}{l}\text { BADAKSHAN } \\
\text { BADGHIS } \\
\text { BAGHLAN } \\
\text { BALKH } \\
\text { BAMYAN } \\
\text { FARAH } \\
\text { FARYAB } \\
\text { GHAZNI } \\
\text { GHOR } \\
\text { HELMAND } \\
\text { HERAT } \\
\text { JAWZJAN } \\
\text { KABUL } \\
\text { KANDAHAR } \\
\text { KAPISA }\end{array}$ & & & $\begin{array}{l}\text { KUNAR } \\
\text { KUNDUZ } \\
\text { LAGHMAN } \\
\text { LOGAR } \\
\text { NANGARHAR } \\
\text { NIMROZ } \\
\text { ORUZGAN } \\
\text { PAKTEKA } \\
\text { PAKTIA } \\
\text { PARWAN } \\
\text { SAMANGAN } \\
\text { TAKHAR } \\
\text { WARDAK } \\
\text { ZABUL }\end{array}$ & Agr/irrign & $100 \%$ \\
\hline
\end{tabular}




\begin{abstract}
AFGHAN DEVELOPMENT PROGRAM (ADP)
is an Afghan non-profit, nonpartisan, non-governmental and nonpolitical humanitarian organization established in 1992.

The sole aim of Afghan Development Program is to contribute actively in rehabilitation, reconstruction and future development of war ravaged Afghanistan.
\end{abstract}

Although it is a small agency it aims to plan, design and implement a number of social and economic projects in the rural areas of Afghanistan. It undertakes work in the following areas:

* reconstruction of infrastructure, damaged irrigation systems and communication net-work

* rehabilitation and revival of agriculture and provision of its services to contribute to the well-being and prosperity of the farming community and other lower classes in the rural communities

* provide opportunities and encourage women to take active part in community development and home economics.

ADP's main office is located in Peshawar for the time being. It has a sub-office in Jalalabad.

The organization, whilst small, employs a few well-qualified engineers and an agriculturalist. These staff have considerable experience in the fields of agriculture and education amongst others.

ADP has the support of other NGOs, provincial authorities and local shuras in its target areas.

ADP has a number of proposals in economic and social fields which are currently under process by the donor agencies. 
AFGHAN DISABLED SOCIETY-ADS

- 2 ADDRESS $>->$ COMMUNICATION LINES $>$

1 CANAL BANK RD, KHALIL TOWN, NEAR B.I.S.E. PESHAWAR, PAKISTAN

PHONE: 43517
F A X:
TELEX:

PHONE : 43517

TELEX :
1. MR. A. RAHMAN SAHAK

2. MR. N. R. LIWAL

3. MR. SARDAR WALI

\begin{tabular}{|lr|lr|lr|}
\hline AFGHAN : & 21 & TECHNICAL: & 5 & PAK.BASED: & 12 \\
PAKISTANI: & - & ADMINISTRATIVE: & 10 & AFGHA.BASED: & 8 \\
EXPAT: & - & FIELD/SUPPORT S. & 6 & CROSS-BORDER: & 1 \\
TOTAL: & 21 & TOTAL: & 21 & TOTAL: & 21 \\
\hline
\end{tabular}

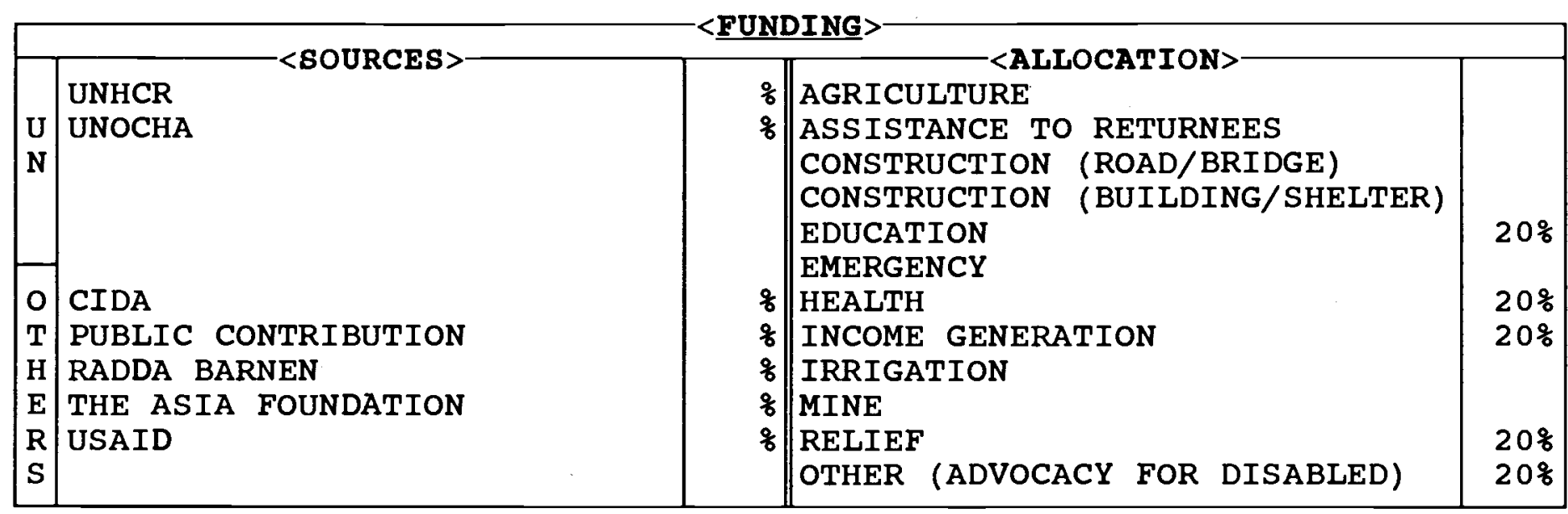

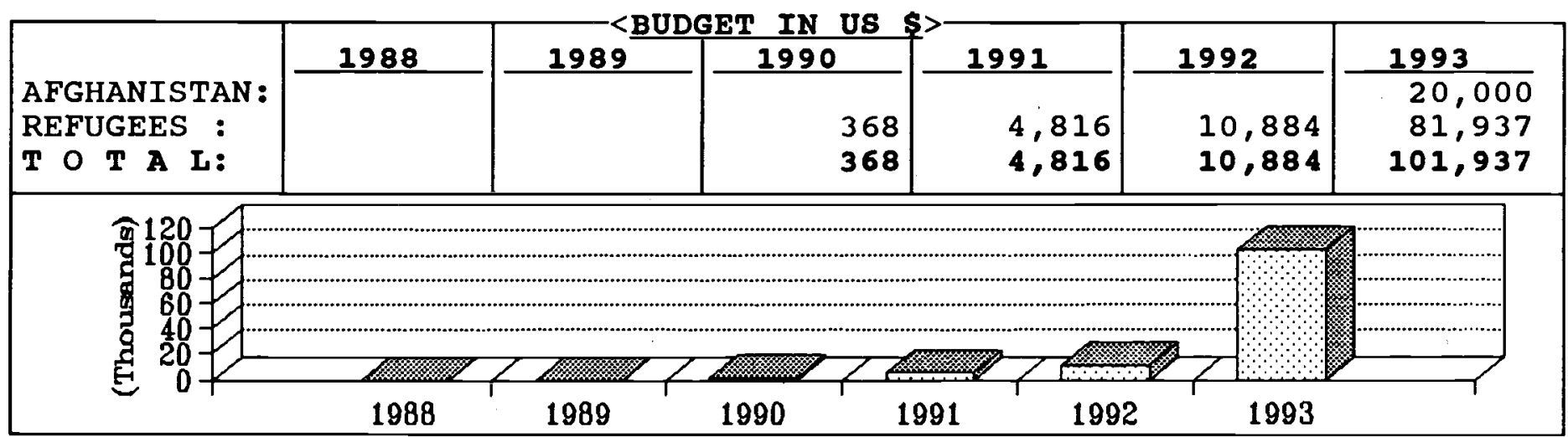

\begin{tabular}{|c|c|c|c|c|c|}
\hline PROVINCES & SECTOR & \%AGE & |PROVINCES & SECTOR & $\% \mathrm{AGE}$ \\
\hline $\begin{array}{l}\text { BADAKSHAN } \\
\text { BADGHIS } \\
\text { BAGHIAN } \\
\text { BALKH } \\
\text { BAMYAN } \\
\text { FARAH } \\
\text { FARYAB } \\
\text { GHAZNI } \\
\text { GHOR } \\
\text { HELMAND } \\
\text { HERAT } \\
\text { JAWZJAN } \\
\text { KABUL } \\
\text { KANDAHAR } \\
\text { KAPISA }\end{array}$ & $\begin{array}{l}\text { Disabled programs } \\
\text { Disabled programs } \\
\text { Disabled programs } \\
\\
\text { Disabled programs } \\
\text { Disabled programs }\end{array}$ & $\begin{array}{l}3 \% \\
3 \% \\
3 \%\end{array}$ & \begin{tabular}{||l} 
KUNAR \\
KUNDUZ \\
LLAGHMAN \\
LOGAR \\
NANGARHAR \\
NIMROZ \\
ORUZGAN \\
PAKTEKA \\
PAKTIA \\
PARWAN \\
SAMANGAN \\
TAKHAR \\
WARDAK \\
ZABUL
\end{tabular} & $\begin{array}{l}\text { Disabled programs } \\
\text { Disabled programs } \\
\text { Disabled programs } \\
\text { Disabled programs } \\
\text { Disabled programs }\end{array}$ & $\begin{array}{r}10 \% \\
10 \% \\
3 \% \\
3 \% \\
27 \%\end{array}$ \\
\hline
\end{tabular}




\section{AFGHAN DIBABLED SOCIETY (ADS) formerly}

Free Welfare society for Afghan Disabled (FWSAD)

The overall objectives of ADS are to assist the disabled Afghans assure that they have access to everything and their rights are respected in all sectors of community. ADS is committed to independent living, economic independence, fuli participation, equalization of opportunities and empowerment of disabled persons. ADS undertakes projects which meet the above objectives.

ADS was created with the initiative of Abdul Rahman Sahak (a triple amputee) at the end of 1989, largely with the financial support of $\mathrm{Mr}$. Sahak's well-wishers (UNOCHA and Radda Barnen). The society is an implementing NGo of Afghan disabled working through its community based approaches promoting the social model of disability.

80 camps have been surveyed so far from where approximately 8,000 disabled people have been registered belonging to Logar, Paktia and Kandahar provinces. A computerized program of recording the disabled people and their relevant issues has been established. Volunteer Committees of Disabled have been established in 25 camps as well as in 6 provinces of Afghanistan (Paktia, Kandahar, Kabul, Nangarhar, Laghman and Kunar). 1,024 disabled people have been referred and introduced to different skill training courses. Counseling aid has been provided to 5,00 more disabled. 300 disabled people have completed ADS skill courses. A database has been developed containing information on disabled people trained by different organizations. Scholarships have been provided to 300 disabled for different vocational courses, schools and universities. People have ben trained for advocacy and promotion of rights of disabled.

ADS has established two regional offices; one in Kandahar for the southwest and one in Paktia for the southeast to survey, provide advocacy, awareness, counseling and other facilities to disabled. 10 have been visited where the possibilities of establishing Volunteer Communities of Disabled have been discussed.

As part of its relief exercise, ADS has . distributed wheelchairs, crutches, blankets and other clothing items to 5,000 disabled.

A magazine is published under the name of "Disability" focusing on the interest of disabled in social, economic and cultural affairs.

All of the mentioned activities are currently continuing. ADS will make efforts to improve them and expand them throughout the country. 


\section{AFGHAN ENGINEERING AGENCY-AEA}

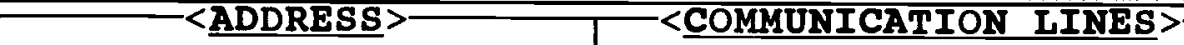

360, STREET 11, E-2, PHASE-I, HAYATABAD PESHAWAR, PAKISTAN
PHONE: 814068

F A X:

TELEX:
KEY STAFF $>$

1. ENG. A. H. LATIFY

2. ENG . ROOHULLAH

3. ENG. M. QASEM

\begin{tabular}{|lr|lr|lr|}
\hline AFGHAN : & 20 & TECHNICAL: & 5 & PAK.BASED: & 5 \\
PAKISTANI : & 1 & ADMINISTRATIVE: & 4 & AFGHA.BASED: & 3 \\
EXPAT: & - & FIELD/SUPPORT S. & 12 & CROSS-BORDER: & 13 \\
TOTAL: & 21 & TOTAL: & 21 & TOTAL: & 21 \\
\hline
\end{tabular}

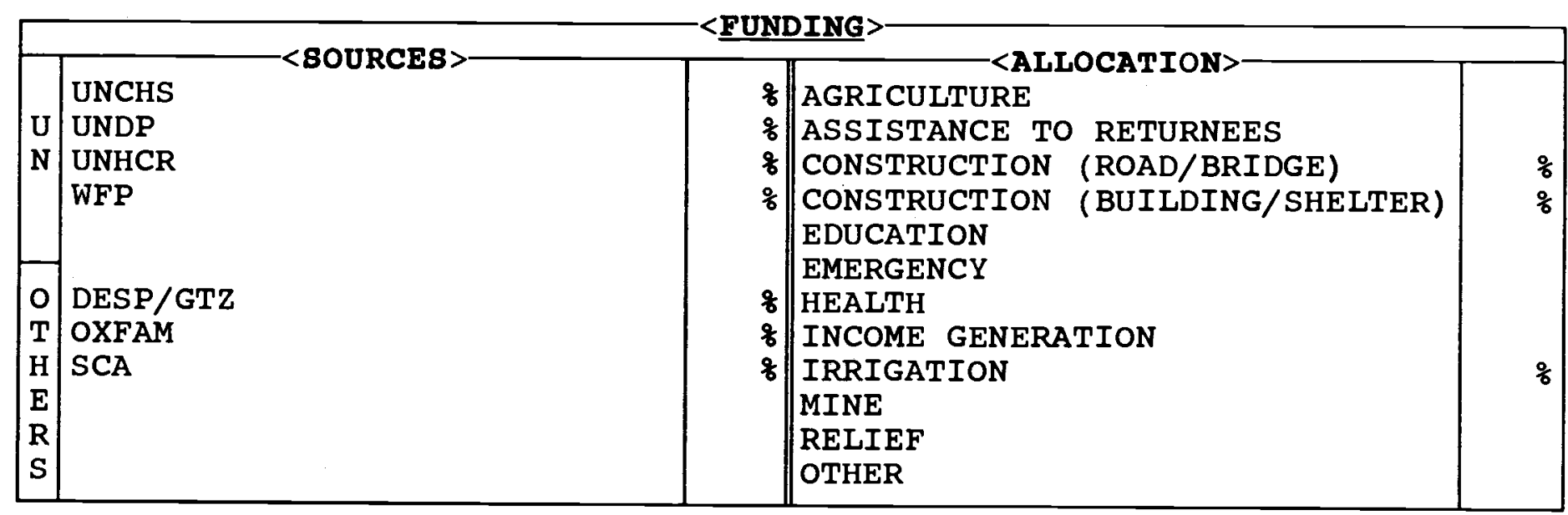

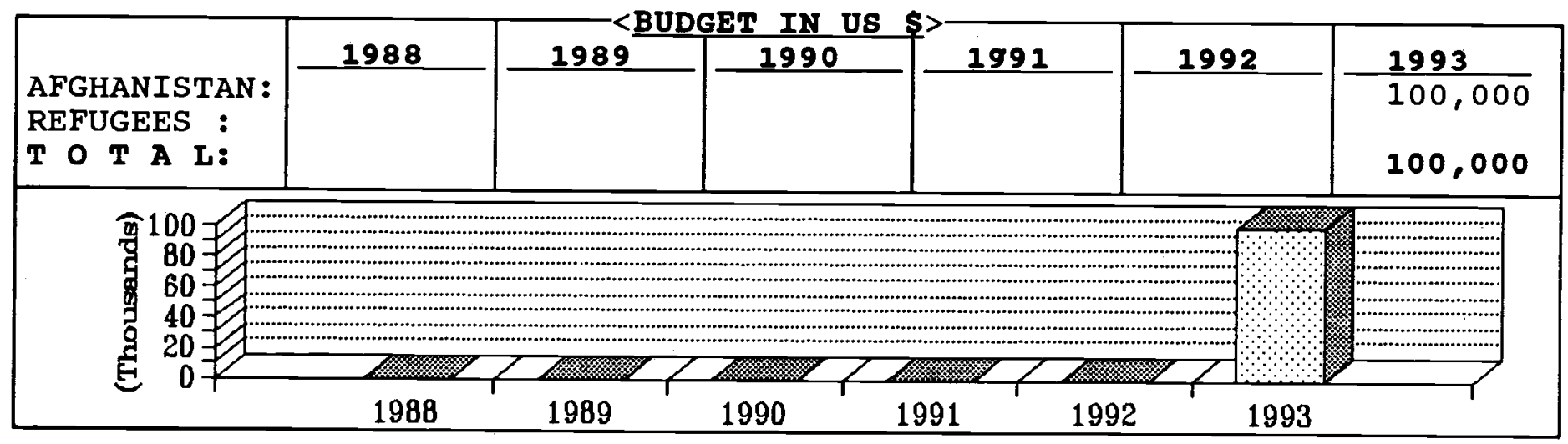

\begin{tabular}{|c|c|c|c|c|c|}
\hline PROVINCES & SECTOR & 官AGE & PROVINCES & SECTOR & $\%$ AGE \\
\hline $\begin{array}{l}\text { BADAKSHAN } \\
\text { BADGHIS } \\
\text { BAGHLAN } \\
\text { BALKH } \\
\text { BAMYAN } \\
\text { FARAH } \\
\text { FARYAB } \\
\text { GHAZNI } \\
\text { GHOR } \\
\text { HELMAND } \\
\text { HERAT } \\
\text { JAWZJAN } \\
\text { KABUL } \\
\text { KANDAHAR } \\
\text { KAPISA }\end{array}$ & $\begin{array}{l}\text { Const } \\
\text { Const } \\
\text { Const }\end{array}$ & $\begin{array}{l}q \\
q \\
8 \\
5 \%\end{array}$ & \begin{tabular}{|l} 
KUNAR \\
KUNDUZ \\
LAGHMAN \\
LOGAR \\
NANGARHAR \\
NIMROZ \\
ORUZGAN \\
PAKTEKA \\
PAKTIA \\
PARWAN \\
SAMANGAN \\
TAKHAR \\
WARDAK \\
ZABUL
\end{tabular} & $\begin{array}{l}\text { Const } \\
\text { Const } \\
\text { Const } \\
\text { Const }\end{array}$ & $\begin{array}{r}5 \% \\
25 \% \\
5 \% \\
60 \%\end{array}$ \\
\hline
\end{tabular}


is an Afghan NGo with qualified staff established in February 1993. $A E A$ is a non political and non profit organization.

The main objective of AEA is to contribute to reconstruction and rehabilitation of Afghanistan

(with the active participation of the community in implementation of projects) in the following sectors with the priority set by the community:

- rehabilitation and reconstruction of public buildings e.g. schools, health facilities and administrative offices using environmentally sound construction technologies.

- shelter, low cost and environmentally sound housing construction.

- rehabilitation of water supply and improvement of sanitation systems and other public health activities including community awareness regarding health education.

human resource development by training people in the fields of masonry, carpentry, leather work and tailoring.

- rehabilitation of irrigation systems for increasing agricultural production.

- rehabilitation of secondary (roads) for establishing and improving links between different parts of the country.

providing consultancy in the field of building designs and supervisory jobs.

consultancy in the field of problem analysis on project implementation and planning new phases using the problem analysis zOPP system. (GTZ method). 
AFGHAN FARMERS RELIEF ORGANI ZATION-AFRO

\begin{tabular}{|c|c|c|}
\hline <ADDRESB $>$ & $-<$ COMMUNICATION LINES $>$ & $-<\underline{\text { KEY STAFF }}>$ \\
\hline $\begin{array}{l}\text { 205, GULHAJI PLAZA } \\
\text { JAMROD RD } \\
\text { PFSHAWAR }\end{array}$ & $\begin{array}{l}\text { PHONE : } \\
\text { F A X: }\end{array}$ & $\begin{array}{l}\text { 1. MR. SHAH MAHMOOD } \\
\text { 2. MR. ABDULLAH }\end{array}$ \\
\hline
\end{tabular}

\begin{tabular}{|lr|lr|lr|}
\hline AFGHAN : & 9 & TECHNICAL: & 5 & PAK. BASED: & 4 \\
PAKISTANI: & 1 & ADMINISTRATIVE: & 2 & AFGHA.BASED: & 5 \\
EXPAT: & - & FIELD/SUPPORT S. & 3 & CROSS-BORDER: & 1 \\
TOTAL: & 10 & TOTAL: & 10 & TOTAL: & 10 \\
\hline
\end{tabular}

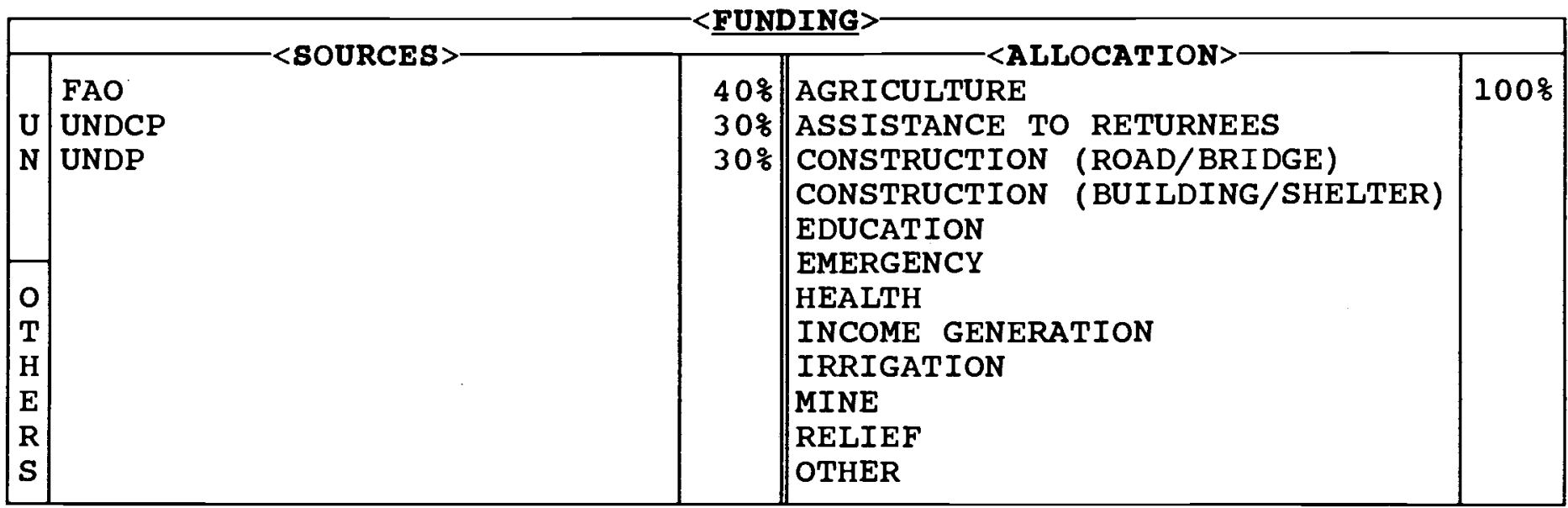

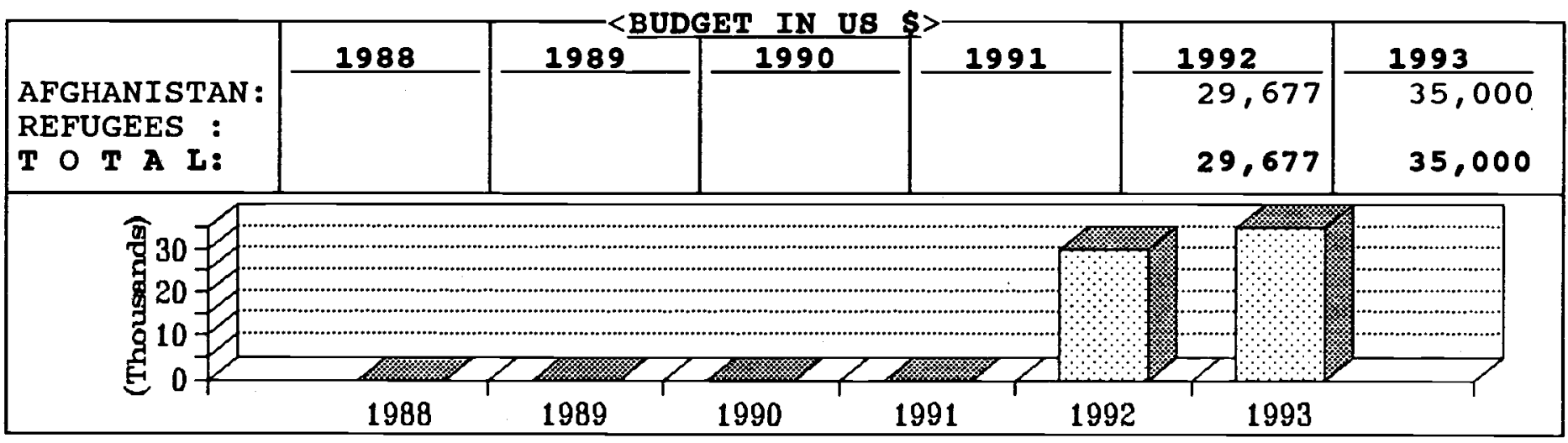

\begin{tabular}{|c|c|c|c|c|c|}
\hline PROVINCES & SECTOR & $\%$ AGE & PROVINCES & SECTOR & $\%$ AGE \\
\hline $\begin{array}{l}\text { BADAKSHAN } \\
\text { BADGHIS } \\
\text { BAGHLAN } \\
\text { BALKH } \\
\text { BAMYAN } \\
\text { FARAH } \\
\text { FARYAB } \\
\text { GHAZNI } \\
\text { GHOR } \\
\text { HELMAND } \\
\text { HERAT } \\
\text { JAWZJAN } \\
\text { KABUL } \\
\text { KANDAHAR } \\
\text { KAPISA }\end{array}$ & & & $\begin{array}{l}\text { KUNAR } \\
\text { KUNDUZ } \\
\text { LAGHMAN } \\
\text { LOGAR } \\
\text { NANGARHAR } \\
\text { NIMROZ } \\
\text { ORUZGAN } \\
\text { PAKTEKA } \\
\text { PAKTIA } \\
\text { PARWAN } \\
\text { SAMANGAN } \\
\text { TAKHAR } \\
\text { WARDAK } \\
\text { ZABUL }\end{array}$ & Agr & $100 \%$ \\
\hline
\end{tabular}


is an Afghan non-governmental organization (NGO) established in 1992 with the main objective of taking active part in the rehabilitation of agriculture sectors in the devastated country of Afghanistan. AFRO's long term objective is to improve the living status of farmers in the rural parts of the country.

AFRO implements any projects which supports the farmer community including improved seed multiplication and extension, fertilizer distribution, fruit sapling distribution, forestry programs, provision of agro-chemical and plant protection services, traction and farm machinery. The organization also provides animal husbandry services.

The farmers are selected based on their needs for the relief projects. However, for multiplication and extension purposes, the selection is made based on the capabilities and performance of farmers.

Currently, AFRO works in the province of Nangarhar. It plans to expand its programs to other areas in the future. 
AFGHAN/GERMAN TECHNICAL TRAINING PROGRAM-AG-TTP

C/O TTC GULBAHAR 1, G P O BOX 656, PESHAWAR, PAKISTAN
PHONE: $213865 / 60638$

F A X:

TELEX:
1. MR. ABDUL WAHID

2. MR. ATTA M. TANIWAL

3. MR. MIZANUR RAHMAN

\begin{tabular}{|lc|lr|lr|}
\hline AFGHAN: & 20 & TECHNICAL: & 8 & PAK.BASED: & 6 \\
PAKISTANI: & - & ADMINISTRATIVE: & 5 & AFGHA.BASED: & 12 \\
EXPAT: & - & FIELD/SUPPORT S. & 7 & CROSS-BORDER: & 2 \\
TOTAL: & 20 & TOTAL: & 20 & TOTAL: & 20 \\
\hline
\end{tabular}

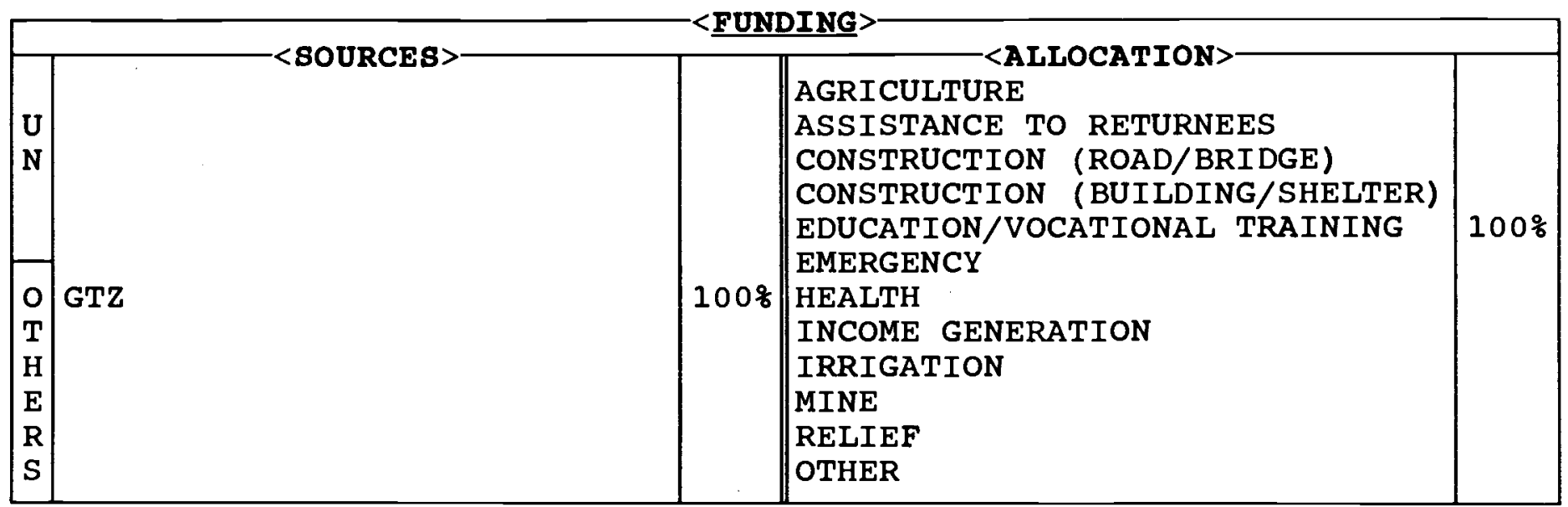

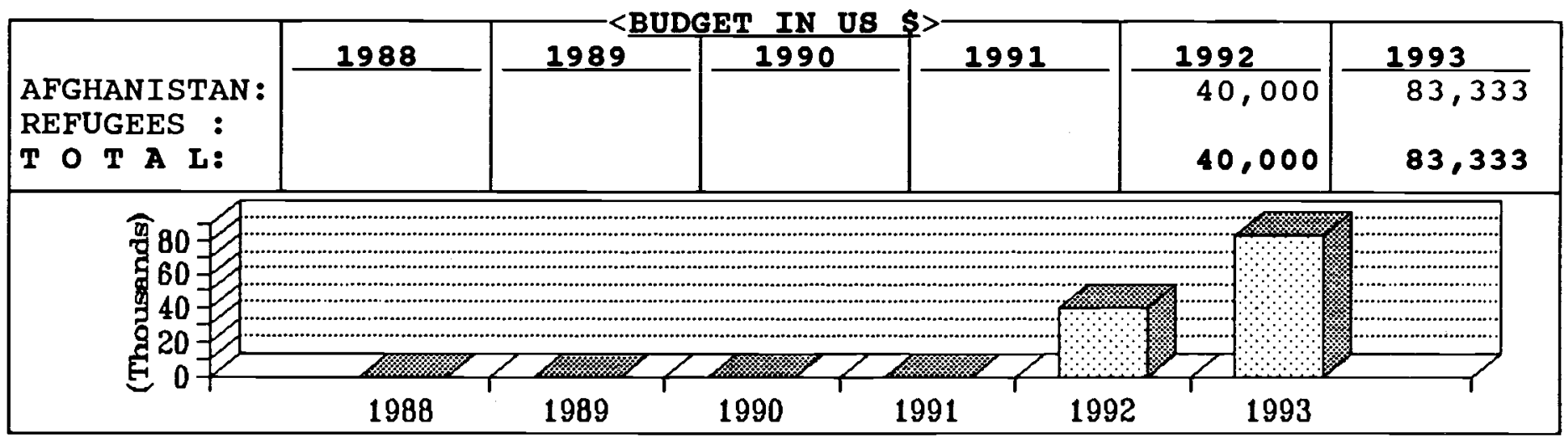

\begin{tabular}{|c|c|c|c|c|c|}
\hline PROVINCES & SECTOR & \&AGE & PROVINCES & SECTOR & \%AGE \\
\hline $\begin{array}{l}\text { BADAKSHAN } \\
\text { BADGHIS } \\
\text { BAGHLAN } \\
\text { BALKH } \\
\text { BAMYAN } \\
\text { FARAH } \\
\text { FARYAB } \\
\text { GHAZNI } \\
\text { GHOR } \\
\text { HELMAND } \\
\text { HERAT } \\
\text { JAWZJAN } \\
\text { KABUL } \\
\text { KANDAHAR } \\
\text { KAPISA }\end{array}$ & & & $\begin{array}{l}\text { KUNAR } \\
\text { KUNDUZ } \\
\text { LAGHMAN } \\
\text { LOGAR } \\
\text { NANGARHAR } \\
\text { NIMROZ } \\
\text { ORUZGAN } \\
\text { PAKTEKA } \\
\text { PAKTIA } \\
\text { PARWAN } \\
\text { SAMANGAN } \\
\text { TAKHAR } \\
\text { WARDAK } \\
\text { ZABUL }\end{array}$ & $\begin{array}{l}\text { Voc. training } \\
\text { Voc. training }\end{array}$ & $50 \%$ \\
\hline
\end{tabular}


is a non-governmental organization registered with the Government of Islamic state of Afghanistan. It was formed by the Afghan staff of the Pak-German Technical Training Program in 1991 with the objective of promoting the SES concept (skills for Employment and Self-employment) vocational training in Afghanistan. This concept has proven highly successful in the North-West Frontier Province (NWFP) for Pakistanis and Afghan refugees.

Afghan-German TTP is presently running two training units in Afghanistan:

* in Bak area of Khost

* in the Khas Kunar district of Kunar province.

Training courses are offered of four months in carpentry and masonry. These units have been set up with the help of local administrations and the people. Afghan-German TTP will follow the implementation pattern developed by the Pak-German Technical Training Program.

Each center trains 240 people per year. The trainees are selected from amongst the unskilled Afghan youth. The follow up study of the training units in Afghanistan shows that $76 \%$ of the trainees are employed.

The head office of the organization is for the moment located in the premises of the Pak-German TTP.

Afghan-German TTP intends to open more training centers in different parts of the country in the near future. The first target area will be Khogyani district of Nangarhar. 
AFGHAN HEALTH \& DEVELOPMENT BERVICEB-AHD8

\begin{tabular}{|c|c|c|}
\hline < $<$ ADDRESB $>$ & -<COMMUNICATION IINES $>$ & $-<\underline{\text { KEY STAFF }}>$ \\
\hline $\begin{array}{l}178 \text { D1, } \overline{\text { PH } 1, \text { HAYATABAD }} \\
\text { G P O BOX } 631, \\
\text { PESHAWAR, PAKISTAN }\end{array}$ & $\begin{array}{l}\text { PHONE: } 810151 / 810559 \\
\text { F A X: } \\
\text { TELEX: }\end{array}$ & $\begin{array}{l}\text { 1. MR. AZIZ R. QARGHA } \\
\text { 2. ENG. GHAFAR MOBINZAI } \\
\text { 3. }\end{array}$ \\
\hline
\end{tabular}

\begin{tabular}{|lc|lr|lr|}
\hline AFGHAN: & 98 & TECHNICAL: & 9 & PAK. BASED: & 10 \\
PAKISTANI: & - & ADMINISTRATIVE: & 12 & AFGHA.BASED: & 85 \\
EXPAT: & - & FIELD/SUPPORT S. & 77 & CROSS-BORDER: & 3 \\
TOTAL: & 98 & TOTAL: & 98 & TOTAL: & 98 \\
\hline
\end{tabular}

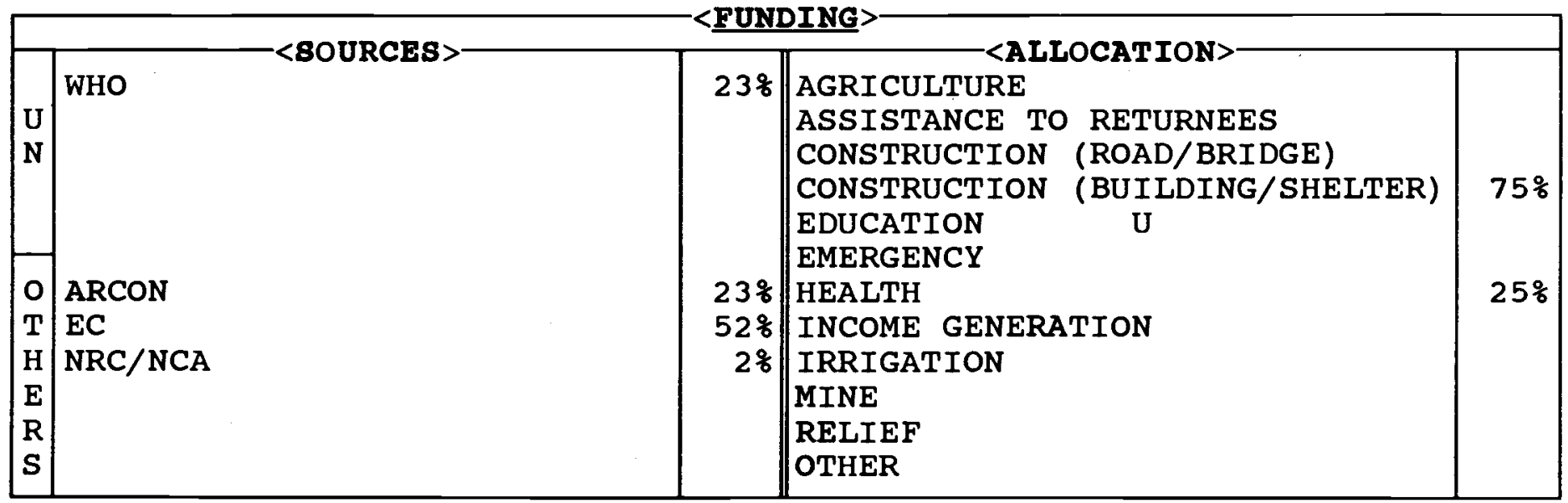

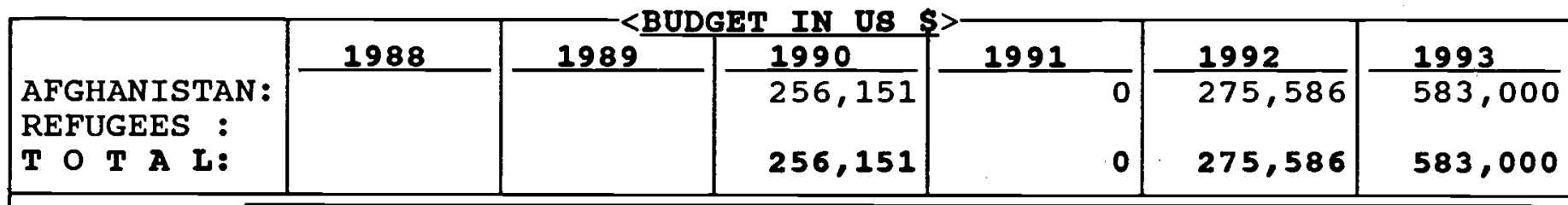

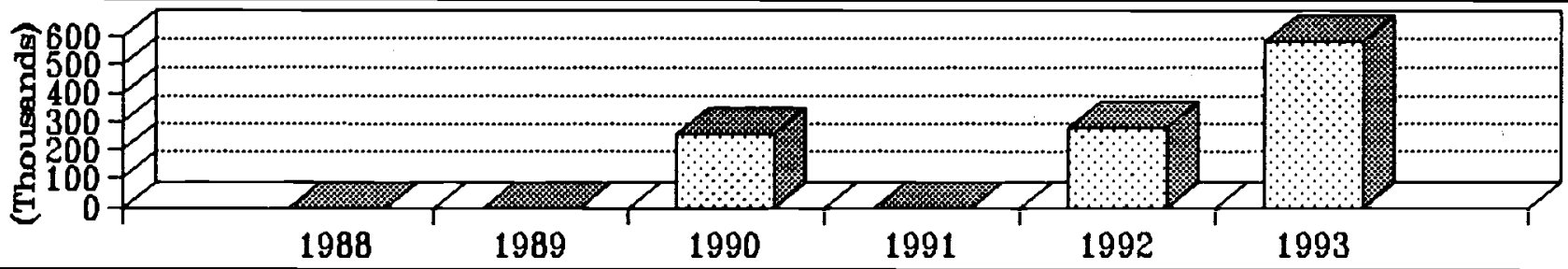

\begin{tabular}{|c|c|c|c|c|c|}
\hline PROVINCES & SECTOR & \&AGE & PROVINCES & SECTOR & \&AGE \\
\hline $\begin{array}{l}\text { BADAKSHAN } \\
\text { BADGHIS } \\
\text { BAGHLAN } \\
\text { BALKH } \\
\text { BAMYAN } \\
\text { FARAH } \\
\text { FARYAB } \\
\text { GHAZNI } \\
\text { GHOR } \\
\text { HELMAND } \\
\text { HERAT } \\
\text { JAWZJAN } \\
\text { KABUL } \\
\text { KANDAHAR } \\
\text { KAPISA }\end{array}$ & Const/health & $16 \%$ & $\begin{array}{l}\text { KUNAR } \\
\text { KUNDUZ } \\
\text { LAGHMAN } \\
\text { LOGAR } \\
\text { NANGARHAR } \\
\text { NIMROZ } \\
\text { ORUZGAN } \\
\text { PAKTEKA } \\
\text { PAKTIA } \\
\text { PARWAN } \\
\text { SAMANGAN } \\
\text { TAKHAR } \\
\text { WARDAK } \\
\text { ZABUL }\end{array}$ & $\begin{array}{l}\text { Const/health } \\
\text { Const/health } \\
\text { Const/health } \\
\text { Const/health }\end{array}$ & $\begin{array}{l}10 \% \\
15 \%\end{array}$ \\
\hline
\end{tabular}




\section{AFGHAN HEALTH AND DEVELOPMENT SERVICES (AHDS)}

is a non-profit, non-governmental and non-political organization founded by Afghans with expertise and training in health, education and development fields. It was established in April 1990 and began to work inside Afghanistan in July 1990. AHDS's primary goals are the rehabilitation of Afghanistan's health care system and the provision of development services to meet the current and future needs of Afghan people.

Since AHDS's establishment, the staff of the organization has worked tirelessly in collecting data and information from numerous sources in order to prepare proposals which will satisfy the health care needs inside Afghanistan.

AHDS has a proven track record of building and administering health facilities in Afghanistan, including the hiring and supporting health workers. AHDS has worked cooperatively with other NGOs to jointly manage some of the health facilities. It has also successfully worked with the Ministry of Public Health of Afghan Interim and the Government of Islamic state of Afghanistan to turn over operation of other facilities. The organization has also provided clean drinking water to these health facilities through reservoir construction and digging of wells.

AHDS has completed the Logar project. The work on Wardak 4 health facilities is ongoing and will be completed by September 1994 . Construction of three basic health facilities has been completed and AHDS will continue running them up to July 1994 .

The work on two approved health facilities in Zabul province was supposed to start early 1993. Duet to administrative changes in ARCON, an Arab donor agency, AHDS decided to postpone the execution of these projects.
A total of 10 health related has been submitted to different agencies during 1993. Also an Integrated Rural Development project in collaboration with Afghan Development Association has been submitted to the European committee who has principally agreed to the project. Negotiations are going on for the final technical aspect of $t h e \quad p \quad r \quad j \quad e \quad c t$. 


\section{AFGHAN INFORMATION CENTER-AIC}

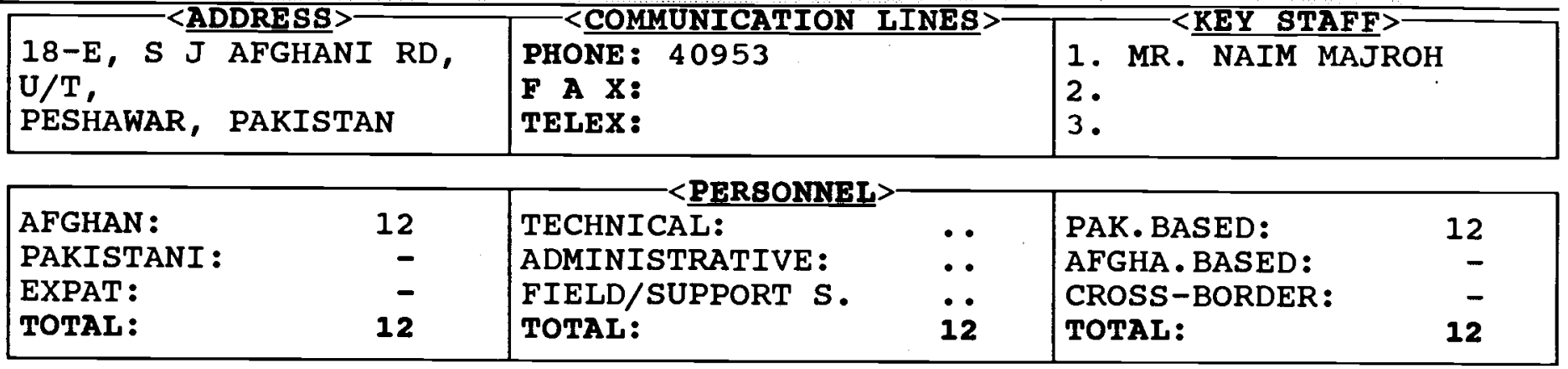

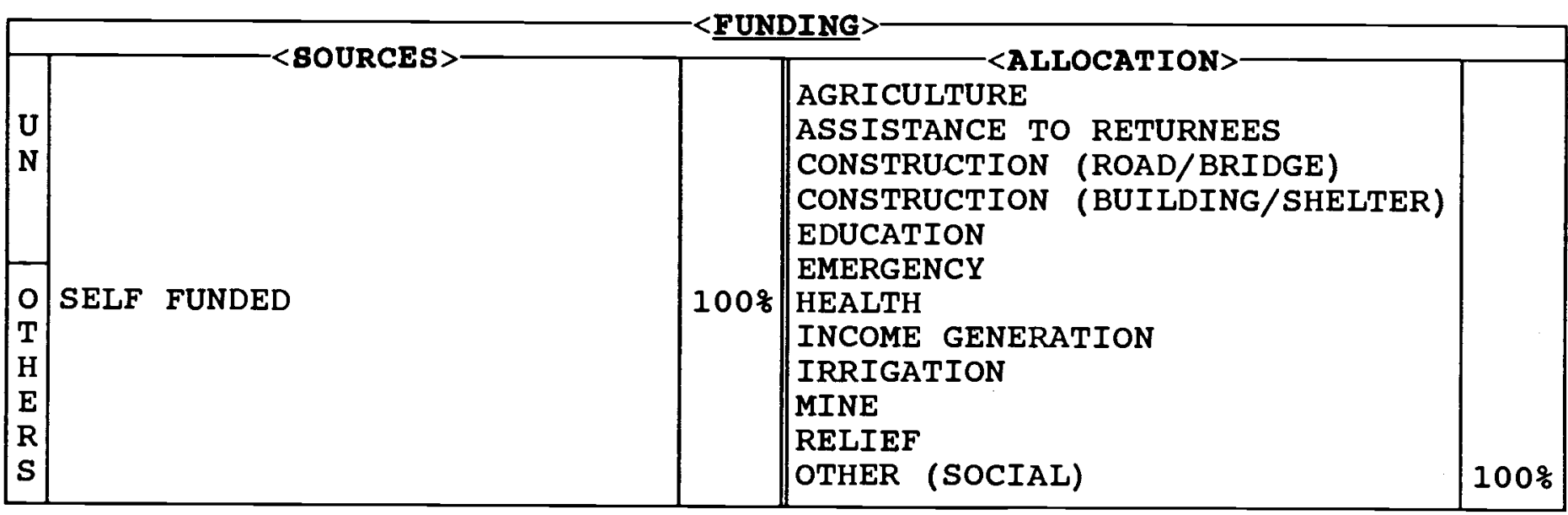

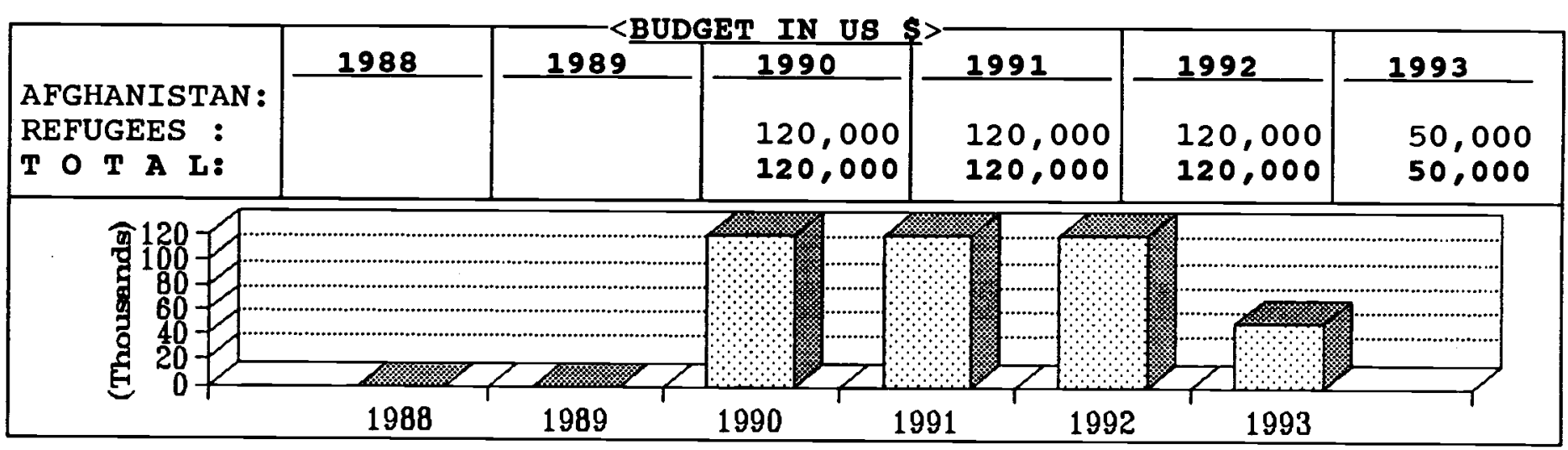

\begin{tabular}{|c|c|c|c|c|c|}
\hline PROVINCES & SECTOR & \&AGE & PROVINCES & SECTOR & \%AGE \\
\hline $\begin{array}{l}\text { BADAKSHAN } \\
\text { BADGHIS } \\
\text { BAGHLAN } \\
\text { BALKH } \\
\text { BAMYAN } \\
\text { FARAH } \\
\text { FARYAB } \\
\text { GHAZNI } \\
\text { GHOR } \\
\text { HELMAND } \\
\text { HERAT } \\
\text { JAWZJAN } \\
\text { KABUL } \\
\text { KANDAHAR } \\
\text { KAPISA }\end{array}$ & & & \begin{tabular}{|l|} 
KUNAR \\
KUNDUZ \\
LAGHMAN \\
LOGAR \\
NANGARHAR \\
NIMROZ \\
ORUZGAN \\
PAKTEKA \\
PAKTIA \\
PARWAN \\
SAMANGAN \\
TAKHAR \\
WARDAK \\
ZABUL
\end{tabular} & & \\
\hline
\end{tabular}


AFGHAN INFORMATION CENTER (ATC)

was established in 1981 with the purpose of producing publications regarding the crises in Afghanistan.

Afghan scholars and writers have got together and made efforts to promote the concept of the people against the Russians and communists. In order to help them, the AIC has provided them with the facilities for publishing their papers.

Besides publishing papers and books of Afghan scholars and writers, AIC issues a quarterly bulletin which contains information on politics, culture and literature of Afghanistan.

The publications are given free to those who visit the center. They are also distributed to Afghans abroad and to foreign organizations. The subscription to the bulletin is US $\$ 100$ per year. Currently 1,200 people have subscriptions which is the main funding for the center. Since August 1991, AIC has not received any assistance from any other sources.

AIC intends to -work inside Afghanistan when the situation allows. 
AFGHAN INRI SHAFEE TARBIAWEE MARKAZ-AITM

\begin{tabular}{|c|c|c|}
\hline$<$ ADDRESS $>-$ & $-<$ COMMUNICATION LINES $>$ & $=<$ KEY STAFF $>$ \\
\hline $\begin{array}{l}\text { 7-E, MULBERRY RD, U/T } \\
\text { P O BOX . . . . . . } \\
\text { PESHAWAR, PAKISTAN }\end{array}$ & $\begin{array}{l}\text { PHONE: } 45306 \\
\text { F A X: } \\
\text { TELEX: }\end{array}$ & $\begin{array}{ll}\text { 1. MR. MOHD SHAFI } \\
\text { 2. MR. SARDAR MOHAMMAD } \\
\text { 3. MR. NAIK MOHAMMAD }\end{array}$ \\
\hline
\end{tabular}

\begin{tabular}{|lc|lr|lr|}
\hline AFGHAN : & 9 & TECHNICAL: & 4 & PAK.BASED: & 11 \\
PAKISTANI : & 2 & ADMINISTRATIVE: & 2 & AFGHA.BASED: & - \\
EXPAT: & - & FIELD/SUPPORT S. & 5 & CROSS-BORDER: & - \\
TOTAL: & 11 & TOTAL: & 11 & TOTAL: & 11 \\
\hline
\end{tabular}

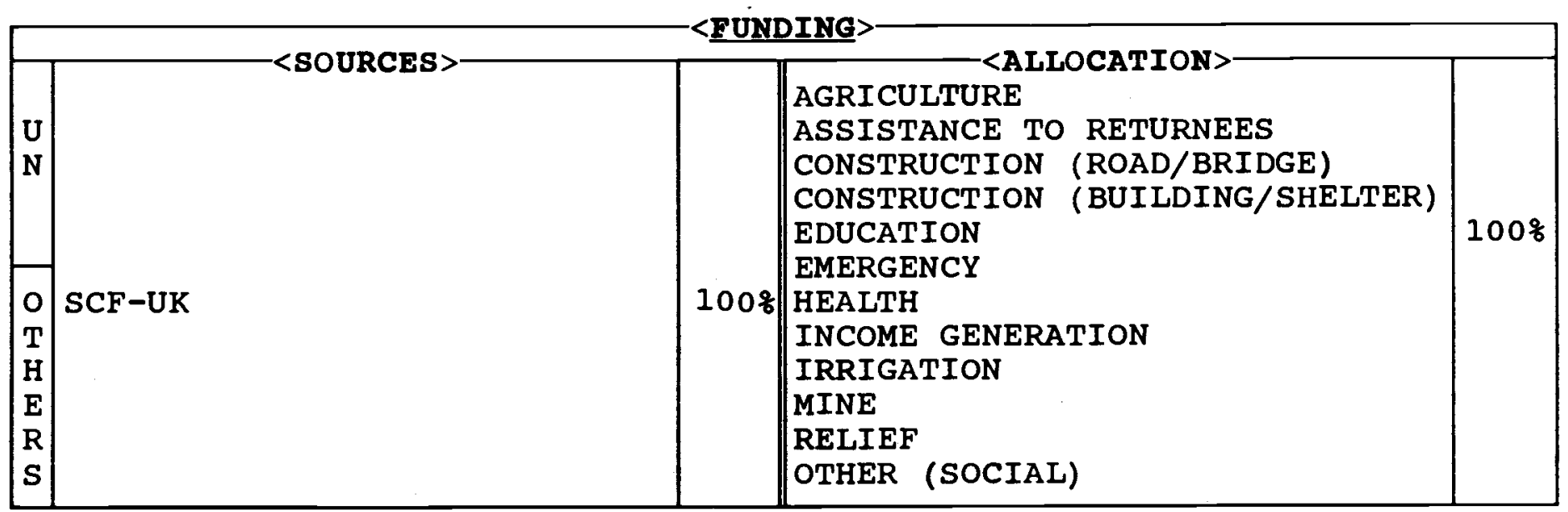

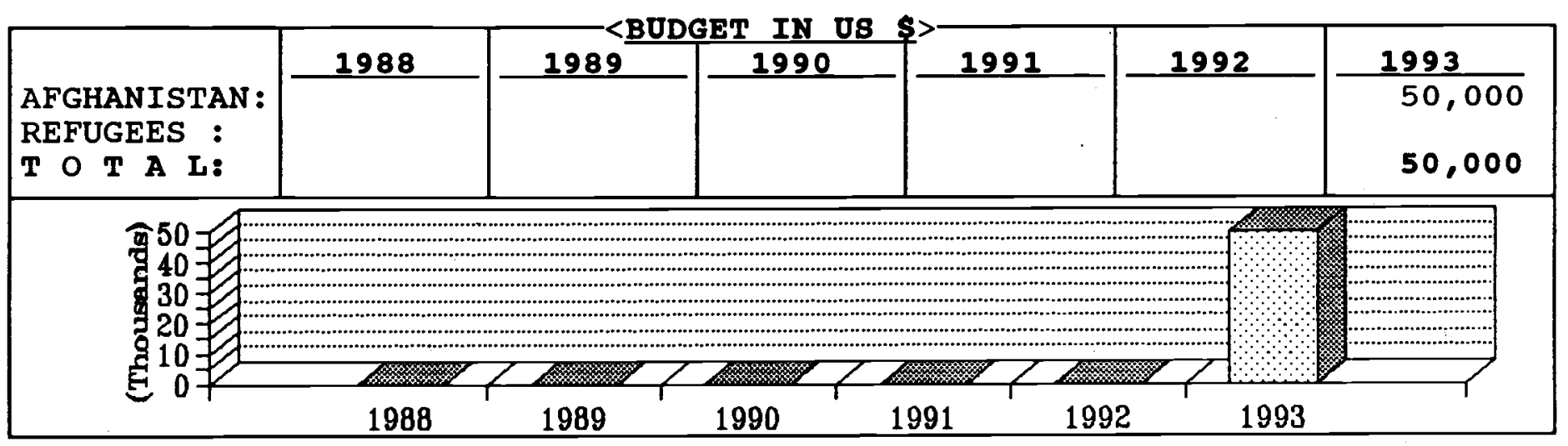

\begin{tabular}{|c|c|c|c|c|c|}
\hline PROVINCES & SECTOR & \&AGE & PROVINCES & SECTOR & qAGE \\
\hline $\begin{array}{l}\text { BADAKSHAN } \\
\text { BADGHIS } \\
\text { BAGHLAN } \\
\text { BALKH } \\
\text { BAMYAN } \\
\text { FARAH } \\
\text { FARYAB } \\
\text { GHAZNI } \\
\text { GHOR } \\
\text { HELMAND } \\
\text { HERAT } \\
\text { JAWZJAN } \\
\text { KABUL } \\
\text { KANDAHAR } \\
\text { KAPISA }\end{array}$ & & & $\begin{array}{l}\text { KUNAR } \\
\text { KUNDUZ } \\
\text { LAGHMAN } \\
\text { LOGAR } \\
\text { NANGARHAR } \\
\text { NIMROZ } \\
\text { ORUZGAN } \\
\text { PAKTEKA } \\
\text { PAKTIA } \\
\text { PARWAN } \\
\text { SAMANGAN } \\
\text { TAKHAR } \\
\text { WARDAK } \\
\text { ZABUL }\end{array}$ & Educ (manag./comm.par) & $100 \%$ \\
\hline
\end{tabular}


AFGHAN INRISHAFEE TARBIAWEE MARKAZ (AITM)

(formally sCF-UR Training Unit)

has run successful courses in development skills since 1989. 4,127 staff members of more than 85 local and international NGOs, UN organizations and government agencies have been trained by this organization (March 1989 - October 1993). The aim of the courses is to develop skills in management, communication, motivation, community participation and extension. The philosophy of the courses is to provide participants with practical skills, ideas and knowledge that they can use to improve work performance.

Participants of the courses come from different parts of Afghanistan and Pakistan (NWFP and Baluchistan). They are generally involved in the implementation of NGO, UN and government projects concerned with all aspects of rehabilitation, e.g. agriculture, health, veterinary, income generating projects, social welfare and women issues.

Training comprises input and practical work and is highly participatory, drawing on the experience of the participants. The training techniques used include discussion sessions, case-studies, role play, lectures, films, story telling, demonstrations, individual projects, group projects, practical exercises, simulation exercises, and presentations. Participants are provided with a set of printed outlines and reference materials for further self-study. The courses contain options and can therefor cater for individual training needs. The courses are carried out in Pushto/Dari, according to the needs of the participants.

The tutors teaching in the courses are highly educated and experienced Afghans who have had a long experience in training and curricula designing from Afghanistan and working with SCF-UK for more than seven years. Some of them also attended courses in management and training in the UK/Brighton, and sri Lanka. Guest tutors are invited from credible organizations as well. 
AFGHAN MEDIA RESOURCE CENTER-AMRC

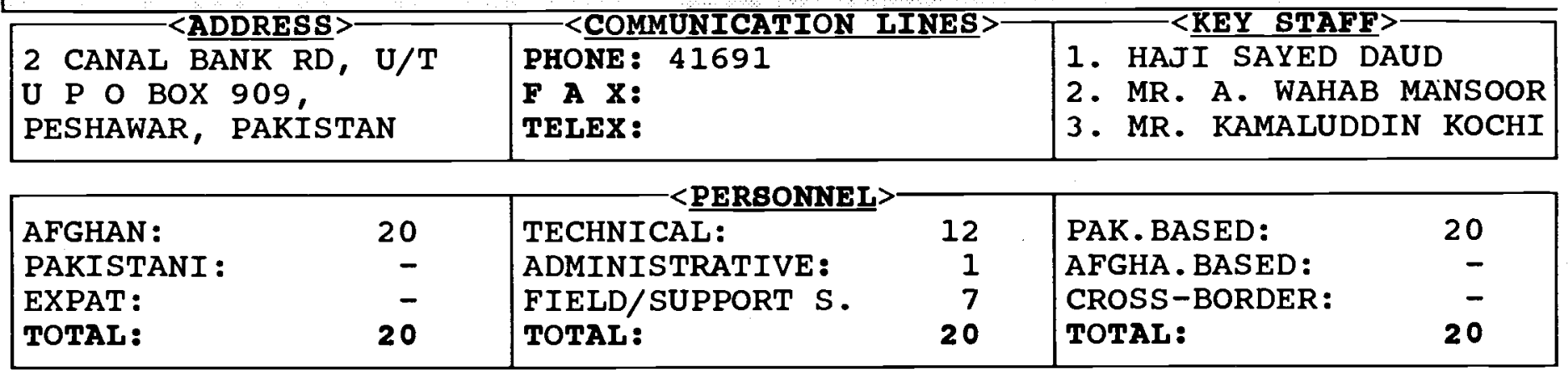

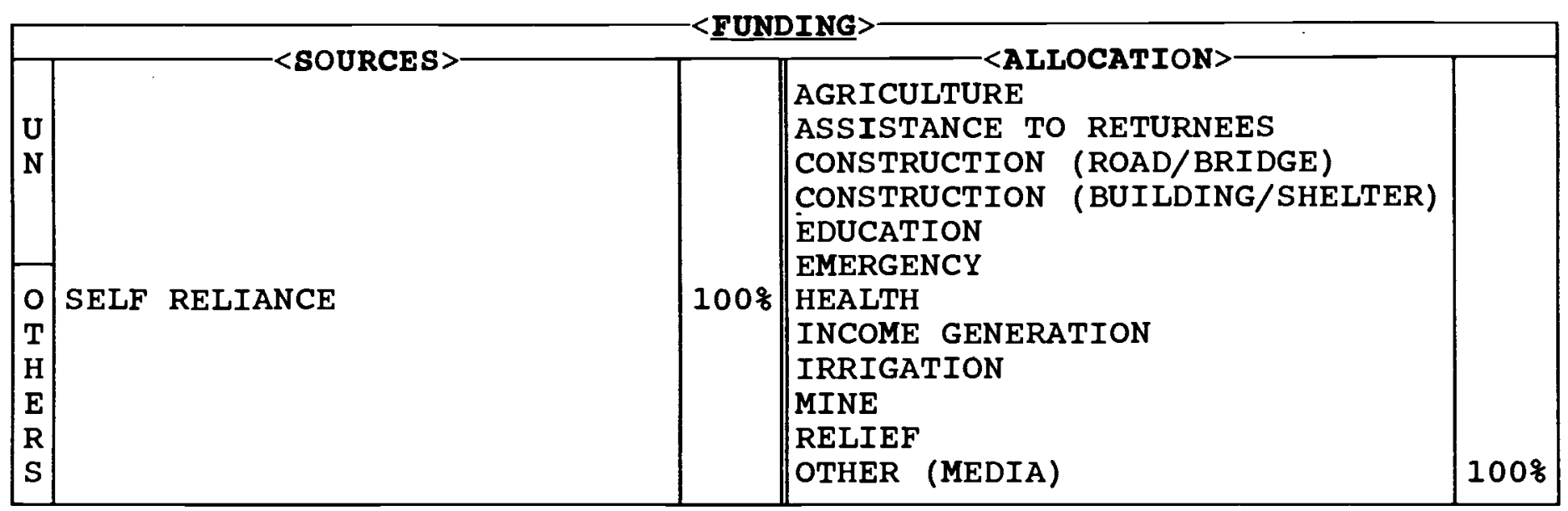

\begin{tabular}{|c|c|c|c|c|c|c|}
\hline & 1988 & 1989 & 1990 & 1991 & 1992 & 1993 \\
\hline $\begin{array}{l}\text { AFGHANISTAN : } \\
\text { REFUGEES : } \\
\text { T O T A L: }\end{array}$ & & & & & & \\
\hline
\end{tabular}

\begin{tabular}{|c|c|c|c|c|c|}
\hline PROVINCES & SECTOR & $\%$ AGE & PROVINCES & SECTOR & \&AGE \\
\hline $\begin{array}{l}\text { BADAKSHAN } \\
\text { BADGHIS } \\
\text { BAGHLAN } \\
\text { BALKH } \\
\text { BAMYAN } \\
\text { FARAH } \\
\text { FARYAB } \\
\text { GHAZNI } \\
\text { GHOR } \\
\text { HELMAND } \\
\text { HERAT } \\
\text { JAWZJAN } \\
\text { KABUL } \\
\text { KANDAHAR } \\
\text { KAPISA }\end{array}$ & & & $\begin{array}{l}\text { KUNAR } \\
\text { KUNDUZ } \\
\text { LAGHMAN } \\
\text { LOGAR } \\
\text { NANGARHAR } \\
\text { NIMROZ } \\
\text { ORUZGAN } \\
\text { PAKTEKA } \\
\text { PAKTIA } \\
\text { PARWAN } \\
\text { SAMANGAN } \\
\text { TAKHAR } \\
\text { WARDAK } \\
\text { ZABUL }\end{array}$ & & \\
\hline
\end{tabular}


is an Afghan entity which was established with the objectives of collecting and recording information on events of Afghanistan war and provide to different media channels.

Efforts were made to relay the true picture of Afghan Jehad to the world community.

At the early days of establishment, AMRC had a contract with USIS under which it provided TV news-films for the CNN-International.

AMRC has now a collection of over three thousand hours films on different events relating to the war in Afghanistan.

Currently, AMRC provides the following services:

- Video film production

- Radio programs production

- Photography

- Photo processing/printing, color and black \& white, 3 "X 4", 8"X 10" and contact sheet system

- slide film processing and mounting

- Video editing, narration, dubbing, lighting and music

- Maintenance of video/photo cameras, VCR and television

AMRC is equipped with all modern recording facilities and has well experienced professional staff. Services are provided at a subsidy cost and special discount will be provided for NGOs and other humanitarian organizations working for Afghans. 


\section{AFGHAN MEDICAL AID-AMA}

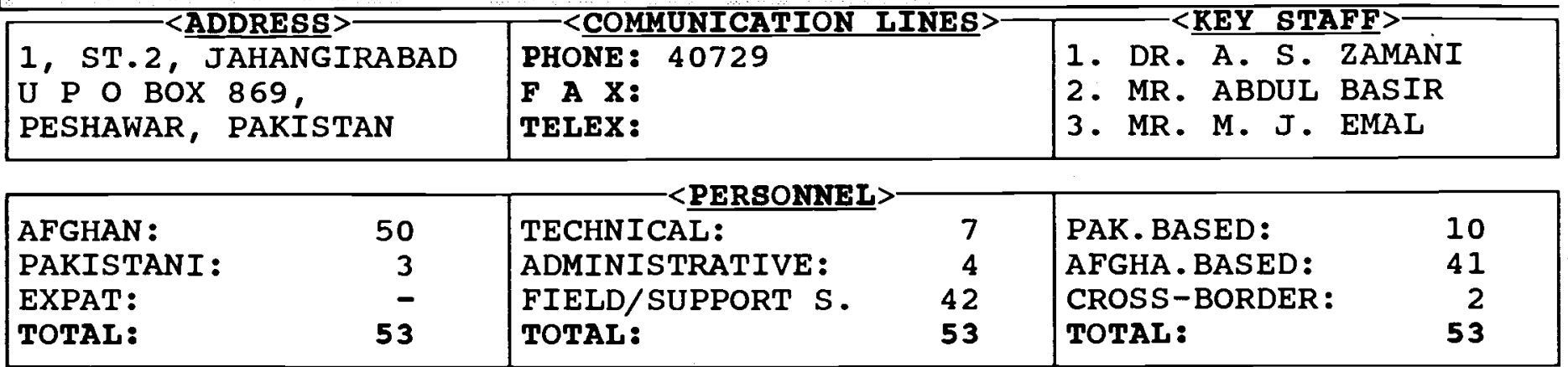

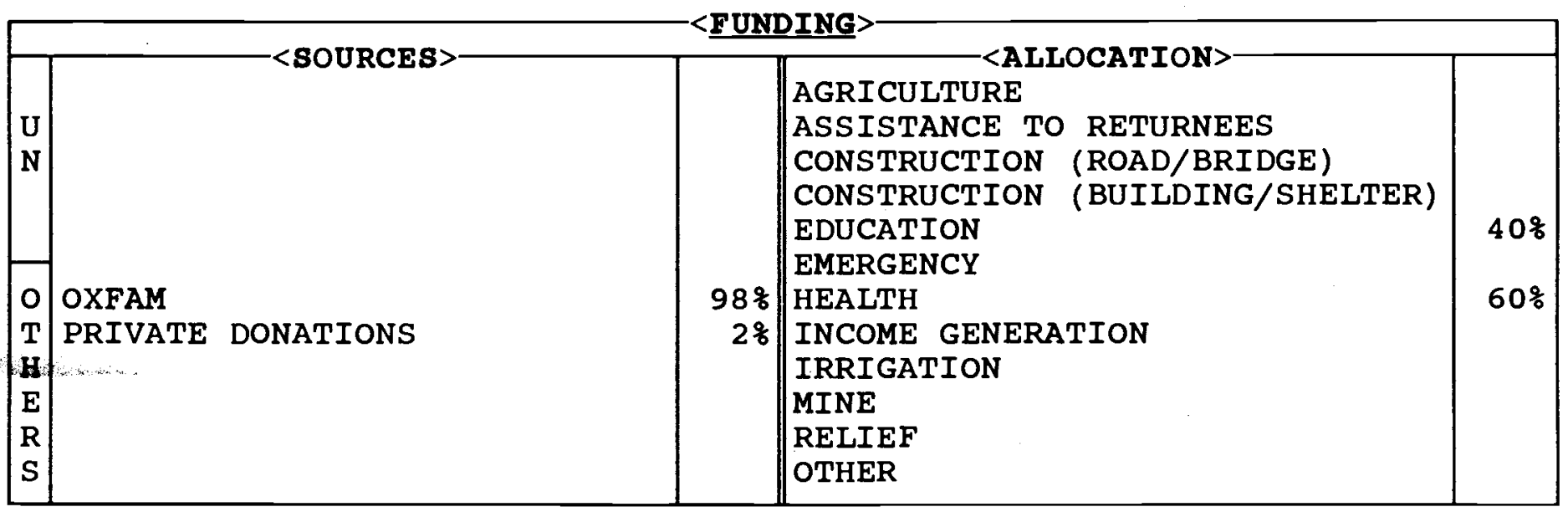

\begin{tabular}{|c|c|c|c|c|c|c|}
\hline & 1988 & 1989 & 1990 & 1991 & 1992 & 1993 \\
\hline $\begin{array}{l}\text { AFGHANISTAN : } \\
\text { REFUGEES : } \\
\text { T O T A L: }\end{array}$ & $\begin{array}{l}75,439 \\
75,439\end{array}$ & $\begin{array}{r}82,509 \\
330,037 \\
412,546\end{array}$ & $\begin{array}{r}65,451 \\
271,154 \\
336,605\end{array}$ & $\begin{array}{l}220,000 \\
220,000\end{array}$ & $\begin{array}{r}8,746 \\
71,474 \\
80,220\end{array}$ & 72,800 \\
\hline
\end{tabular}

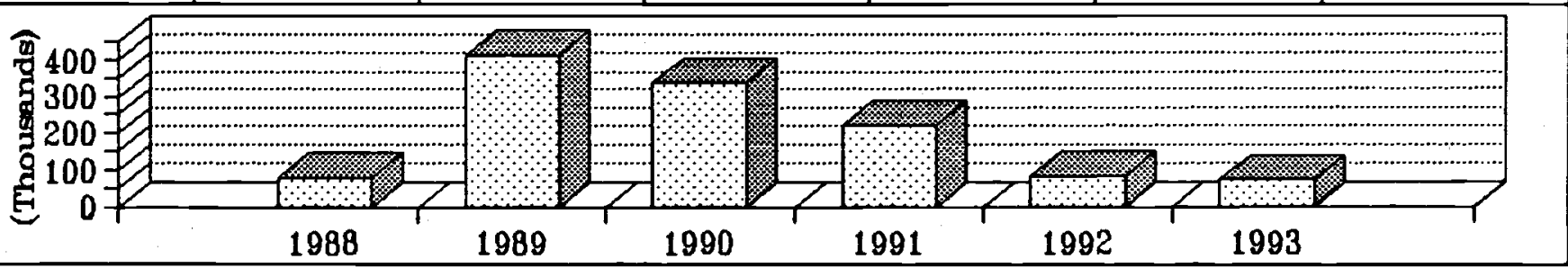

\begin{tabular}{|c|c|c|c|c|c|}
\hline PROVINCES & SECTOR & \&AGE & PROVINCES & SECTOR & $\% \mathrm{AGE}$ \\
\hline $\begin{array}{l}\text { BADAKSHAN } \\
\text { BADGHIS } \\
\text { BAGHLAN } \\
\text { BALKH } \\
\text { BAMYAN } \\
\text { FARAH } \\
\text { FARYAB } \\
\text { GHAZNI } \\
\text { GHOR } \\
\text { HELMAND } \\
\text { HERAT } \\
\text { JAWZJAN } \\
\text { KABUL } \\
\text { KANDAHAR } \\
\text { KAPISA }\end{array}$ & Health & $5 \%$ & $\begin{array}{l}\text { KUNAR } \\
\text { KUNDUZ } \\
\text { LAGHMAN } \\
\text { LOGAR } \\
\text { NANGARHAR } \\
\text { NIMROZ } \\
\text { ORUZGAN } \\
\text { PAKTEKA } \\
\text { PAKTIA } \\
\text { PARWAN } \\
\text { SAMANGAN } \\
\text { TAKHAR } \\
\text { WARDAK } \\
\text { ZABUL }\end{array}$ & Educ/health & $95 \%$ \\
\hline
\end{tabular}




\section{AFGHAN MEDICAL AID (AMA)}

was established in November 1983 in Peshawar and was registered with the Government of Pakistan in 1985. It works both in the refugee camps in Pakistan, and inside Afghanistan. The sectors of work are health, agriculture, irrigation, relief, education and construction.

Presently it is running the following projects:

- a BHU in Khas Kunar district of Kunar province, a clinic in Ganjgal area of Kunar,

two primary schools in Sirkanay district of Kunar,

a health clinic in Mazar-iSharif, Balkh province and

a tailoring center in Mazar Sharif, Balkh.

The health and education facilities have recently been shifted from the refugee camps of Bajaur Agency (Ganjgal) into Afghanistan.

AMA provided a milk distribution service for children. In the past it ran $\mathrm{TB}$ and $\mathrm{MCH}$ (ob/gyn) programs. AMA also completed a Dai (Traditional Birth Attendant) training program, repair of Asadabad hospital and Sirkanay-Khas Kunar road. It extended a mobile paramedic service and malaria control program in Peche valley, Nooristan and Narang.

As part of its emergency relief programs, AMA provided some food, water cans and medical services to the Kabul displaced families in Jalalabad and Sarobi areas in 1992 .

For 1994, AMA has two programs to be implemented: a drinking water project in Ganjgal area of Kunar province and an $\mathrm{MCH}$ clinic in Mazar Sharif of Balkh province. Project proposals have been submitted to the Canada Fund and AMI-A.
AMRAN has also distributed emergency relief assistance to the poor and needy families in Nangarhar province.

11 projects including 5 canal rehabilitation, 3 gabion production projects and 3 carpentry training courses have been submitted to different donor organizations. 
- 2 ADDRESS $>->$ COMMUNICATION LINE B

306，3RD FLOOR， GULHAJI

PIAAZA, JAMROD RD

PESHAWAR， PAKISTAN
PHONE: 44279

F A X:

TELEX:
KEEY STAFF>

1. MR. QAYUM SAYEDI

2. ENG.KARIMULIAH

3. MR. SAYED ABDUL HAQ

\begin{tabular}{|lr|lr|lr|}
\hline AFGHAN : & 17 & TECHNICAL: & 9 & PAK. BASED: & 10 \\
PAKISTANI : & 2 & ADMINISTRATIVE: & 4 & AFGHA.BASED: & 4 \\
EXPAT: & - & FIELD/SUPPORT S. & 6 & CROSS-BORDER: & 5 \\
TOTAL: & 19 & TOTAL: & 19 & TOTAL: & 19 \\
\hline
\end{tabular}

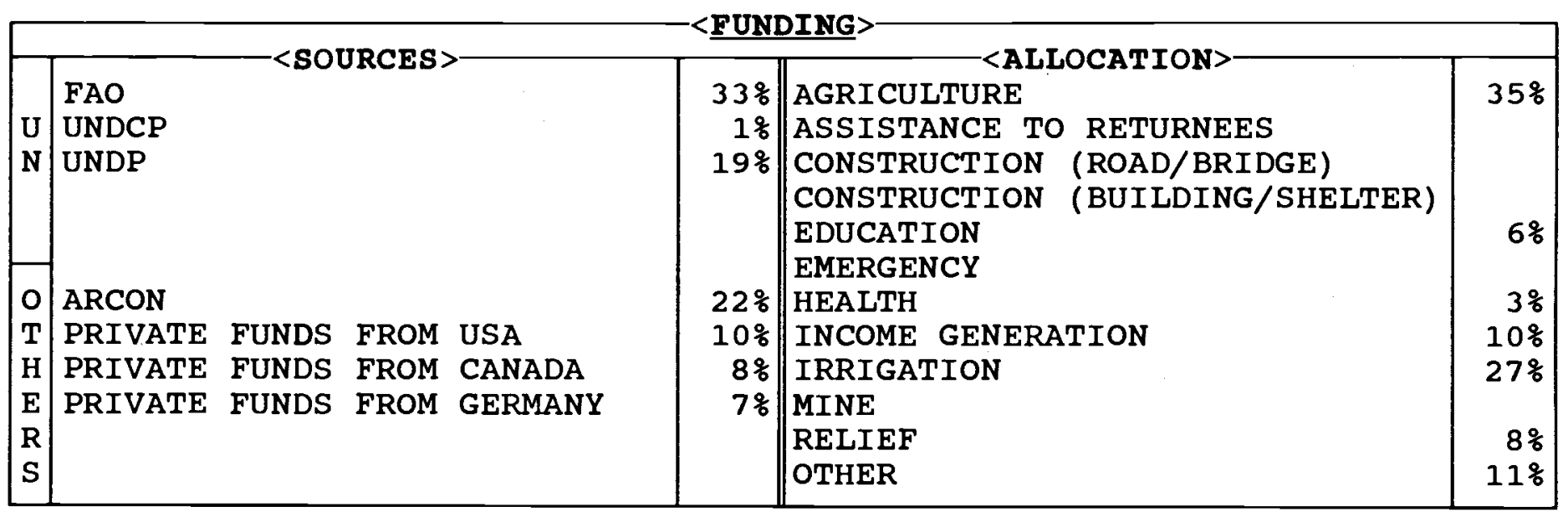

\begin{tabular}{|l|l|r|r|r|r|r|}
\hline & 1988 & 1989 & 1990 & 1991 & \multicolumn{1}{c|}{1992} & 1993 \\
\hline $\begin{array}{l}\text { AFGHANISTAN: } \\
\text { REFUGEES : }\end{array}$ & & 51,400 & 69,550 & 82,500 & 112,200 & 168,800 \\
T O T A L: & & 51,400 & 69,550 & 82,500 & 112,200 & 168,800 \\
\hline
\end{tabular}

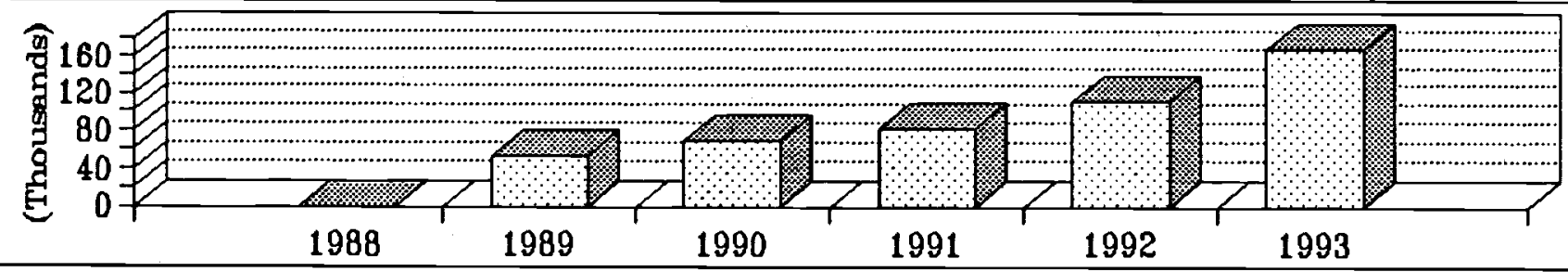

\begin{tabular}{|c|c|c|c|c|c|}
\hline PROVINCES & SECTOR & \%AGE & PROVINCES & SECTOR & $\because \mathrm{AGE}$ \\
\hline $\begin{array}{l}\text { BADAKSHAN } \\
\text { BADGHIS } \\
\text { BAGHLAN } \\
\text { BALKH } \\
\text { BAMYAN } \\
\text { FARAH } \\
\text { FARYAB } \\
\text { GHAZNI } \\
\text { GHOR } \\
\text { HELMAND } \\
\text { HERAT } \\
\text { JAWZJAN } \\
\text { KABUL } \\
\text { KANDAHAR } \\
\text { KAPISA }\end{array}$ & & & $\begin{array}{l}\text { KUNAR } \\
\text { KUNDUZ } \\
\text { LAGHMAN } \\
\text { LOGAR } \\
\text { NANGARHAR } \\
\text { NIMROZ } \\
\text { ORUZGAN } \\
\text { PAKTEKA } \\
\text { PAKTIA } \\
\text { PARWAN } \\
\text { SAMANGAN } \\
\text { TAKHAR } \\
\text { WARDAK } \\
\text { ZABUL }\end{array}$ & $\begin{array}{l}\text { Health } \\
\text { Agr/irrign/relief } \\
\text { Agr/irrign/relief } \\
\text { Educ/relief }\end{array}$ & $\begin{array}{l}11 \% \\
38 \% \\
45 \%\end{array}$ \\
\hline
\end{tabular}




\section{AFGHAN MOBILE RECONSTRUCTION ASSOCIATION (AMRAN)}

is a non-political, non-profit humanitarian Afghan NGo. It was founded in 1992. The main office of the Association is for the time being located in Peshawar. It has branch/field offices in Khogyani, Surkhrod, Alishang, Qarghaie and Jaji districts.

With the aim of participating in the rehabilitation and reconstruction exercise in Afghanistan AMRAN is active in the sectors of housing, agriculture, road construction, irrigation, education and health. AMRAN is committed to close coordination with other organizations.

AMRAN has an Executive Board which plans and supervises all activities of the organization. projects are surveyed, designed and implemented in consultation with the local shuras of the target areas.

A total of 36 projects have been implemented so far mainly in the eastern provinces of Afghanistan (Nangarhar, Laghman and Kunar). An outline of the completed project is as follows:

AGRICUITURE: Distribution, multiplication and extension of improved seeds (wheat, rice, maize, cotton, sugarcane, vegetable, oil seed rape and berseem clover); honey been project, poultry distribution, fruit saplings distribution.

\section{IRRIGATION : \\ Repair and} rehabilitation of 11 canals.

HEALTH: Operating a mobile health clinic in Kamdesh district of Kunar and assessment/survey on opium addiction in Nangarhar and Kunar provinces.

EDUCATION: Establishment of a primary school in Jaji district of Paktia.

8KILL TRAINING: Hand bags (purse) and sandle making training program for women in Kabul city.
AMRAN has also distributed emergency relief assistance to the poor and needy families in Nangarhar province.

11 projects including 5 canal rehabilitation, 3 gabion production projects and 3 carpentry training courses have been submitted to different donor organizations. 
AFGHAN NARCOTICS CONTROL ORGANIZATION-ANCO

<ADDRESS

$27, \mathrm{~N} / 4, \mathrm{PH} 4$, HAY.ABAD

U P O BOX 948,

PESHAWAR, PAKISTAN

PCOMMUNICAT
PHONE: 811449
F A X:
TELEX:

PHONE: 811449

TELEX:
1. MR. AKBAR SADAT

2. MR. ABDUL AHAD SADAT 3 .

\begin{tabular}{|lc|lr|lr|}
\hline AFGHAN: & 17 & TECHNICAL: & 7 & PAK. BASED: & 7 \\
PAKISTANI : & - & ADMINISTRATIVE: & 4 & AFGHA.BASED: & 7 \\
EXPAT: & - & FIELD/SUPPORT S. & 6 & CROSS-BORDER: & 3 \\
TOTAL: & 17 & TOTAL: & 17 & TOTAL: & 17 \\
\hline
\end{tabular}

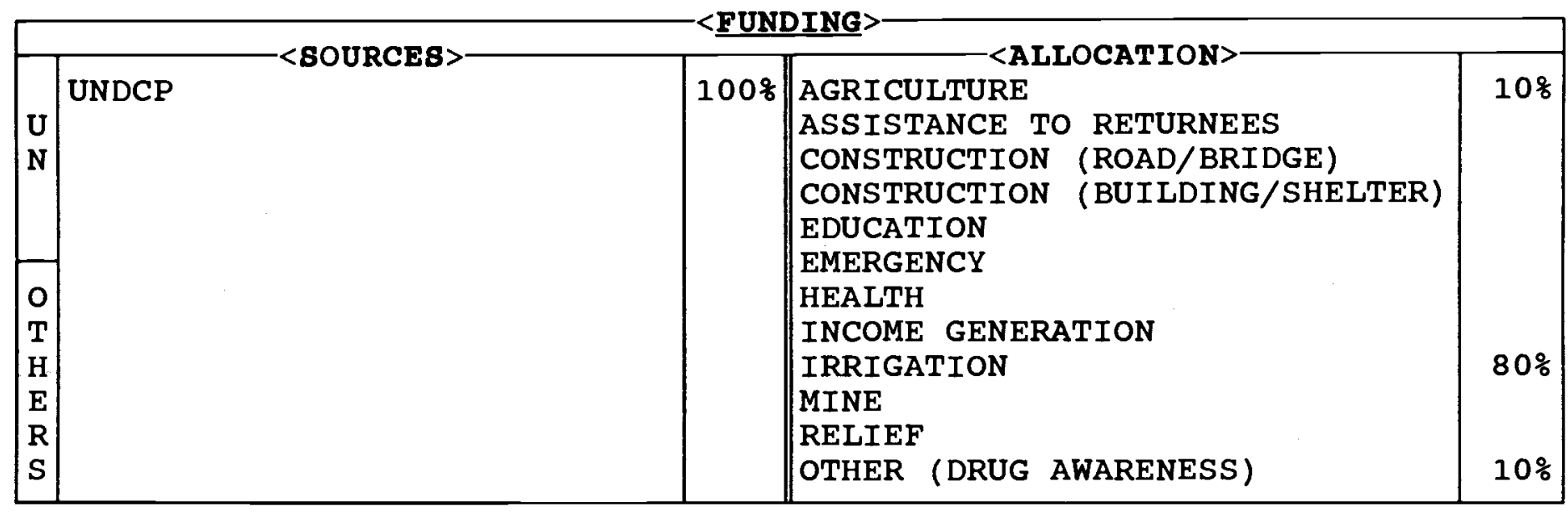

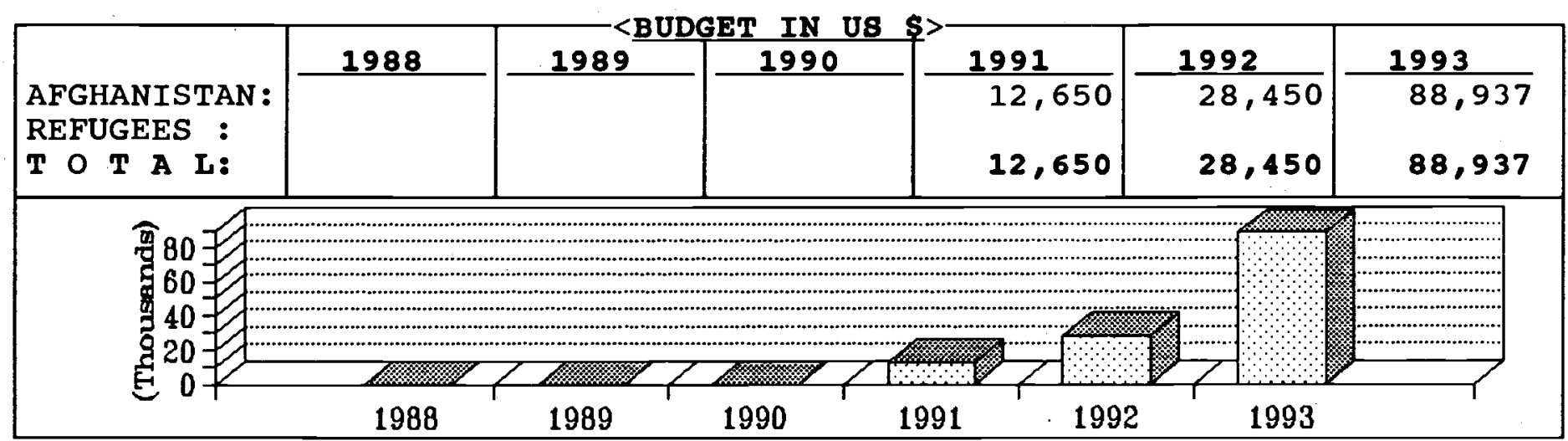

\begin{tabular}{|c|c|c|c|c|c|}
\hline PROVINCES & SECTOR & 宂AGE & PROVINCES & SECTOR & $\% \mathrm{AGE}$ \\
\hline $\begin{array}{l}\text { BADAKSHAN } \\
\text { BADGHIS } \\
\text { BAGHLAN } \\
\text { BALKH } \\
\text { BAMYAN } \\
\text { FARAH } \\
\text { FARYAB } \\
\text { GHAZNI } \\
\text { GHOR } \\
\text { HELMAND } \\
\text { HERAT } \\
\text { JAWZJAN } \\
\text { KABUL } \\
\text { KANDAHAR } \\
\text { KAPISA }\end{array}$ & & & $\begin{array}{l}\text { KUNAR } \\
\text { KUNDUZ } \\
\text { LAGHMAN } \\
\text { LOGAR } \\
\text { NANGARHAR } \\
\text { NIMROZ } \\
\text { ORUZGAN } \\
\text { PAKTEKA } \\
\text { PAKTIA } \\
\text { PARWAN } \\
\text { SAMANGAN } \\
\text { TAKHAR } \\
\text { WARDAK } \\
\text { ZABUL }\end{array}$ & Agr/drug awar./irrign & $100 \%$ \\
\hline
\end{tabular}


AFGHAN NARCOTICS CONTROL

ORGANIZATION (ANCO)

is an Afghan non-partisan, nongovernmental and non-political voluntary humanitarian organization. Its sole aim is to replace the opium and hashish cultivation with useful agricultural crops, which are seriously needed for the people and to contribute to the economic wellbeing of the farming community.

ANCO will actively contribute in the development programs and reconstruction of the war-ravaged Afghanistan. The main fields of its activities are:

1) Reconstruction of infrastructure, damaged irrigation systems, communication and educational establishment, shelter, health clinics and hospitals.

2) Rehabilitation and revival of agriculture:

a. Provision of needed agricultural inputs and incentives, free as well as at a highly subsidized price, and services to the famers.

Surveys revealed lack of irrigation water, fortified seeds, fertilizer, agrochemicals, extension services and expertise. These are the main hurdles in the way of normalization of agriculture in the country.

The introduction of tried and tested agricultural inputs and appropriate technology may contribute to the replacement of poppy in the project area by Setting up of small scale agribased undertakings such as poultry, honey bee-keeping, nurseries, silk worm and others. The organization will also study feasibility of small scale agri-based industries such as carpet weaving, jelly and jam making and juice extracting units.

c. Providing assistance to animal husbandry in parts of the country where the numbers of livestock were drastically reduced due to the effects of war.

3) Reactivation of schools, enhancing adult and vocational technical education among the adult population.

ANCo's headquarters for the time being are located in Peshawar. It plans to open a branch in quetta.

The organization intends to work in provinces where poppy cultivation is common and where the least relief aid has been extended, particularly Nangarhar, Laghman, Zabul, Uruzgan, Paktia, Logar and Badakhshan.

The organization has highly qual ified engineers, agriculturists, education experts, with seven persons on the directorate board, most of whom have vast experience in their related fields of activities.

ANCO is registered with UNOCHA and has a No objection certificate from the Government of NWFP.

ANCO has affiliation and close cooperation with shuras, community influential and other Afghan and international non-governmental organizations.

ANco's policy is to benefit the local people inside Afghanistan and minimize expenses outside.

The organization has completed rehabilitation of a number of irrigation canals including repair of their structures mainly in Hesarak district of Nangarhar. A number of similar projects in the same area is ongoing. ANCO has also conducted drug awareness campaigns in the Hesarak and Khogyani districts of Nangarhar. 
AFGHAN OBSTETRICS AND GYNAECOLOGY HOSPITAL-AOGH

\begin{tabular}{|c|c|c|c|c|c|}
\hline \multirow{2}{*}{\multicolumn{2}{|c|}{$\begin{array}{l}\text { 8-A RAILWAY RD, U/T, } \\
\text { G P O BOX } 448 \text {, } \\
\text { PESHAWAR, PAKISTAN }\end{array}$}} & \multicolumn{2}{|c|}{$-<$ COMMUNICATION LINES $>$} & \multicolumn{2}{|c|}{$<\underline{\text { KEY BTAFF }}>$} \\
\hline & & $\begin{array}{l}\text { PHONE: } 43912 \\
\text { F A X: } \\
\text { TELEX : }\end{array}$ & & $\begin{array}{ll}\text { 1. DR. Q. MOJ } \\
\text { 2. DR. M. H. } \\
\text { 3. }\end{array}$ & ND \\
\hline $\begin{array}{l}\text { AFGHAN : } \\
\text { PAKISTANI : } \\
\text { EXPAT: } \\
\text { TOTAL: }\end{array}$ & $\begin{array}{r}86 \\
1 \\
3 \\
90\end{array}$ & $\begin{array}{l}\text { TECHNICAL: } \\
\text { ADMINISTRATIVE: } \\
\text { FIELD/SUPPORT S. } \\
\text { TOTAL: }\end{array}$ & $\begin{array}{r}45 \\
5 \\
40 \\
90\end{array}$ & $\begin{array}{l}\text { PAK. BASED: } \\
\text { AFGHA. BASED : } \\
\text { CROSS-BORDER: } \\
\text { TOTAL: }\end{array}$ & $\begin{array}{r}6 \\
84 \\
9 \\
90\end{array}$ \\
\hline
\end{tabular}

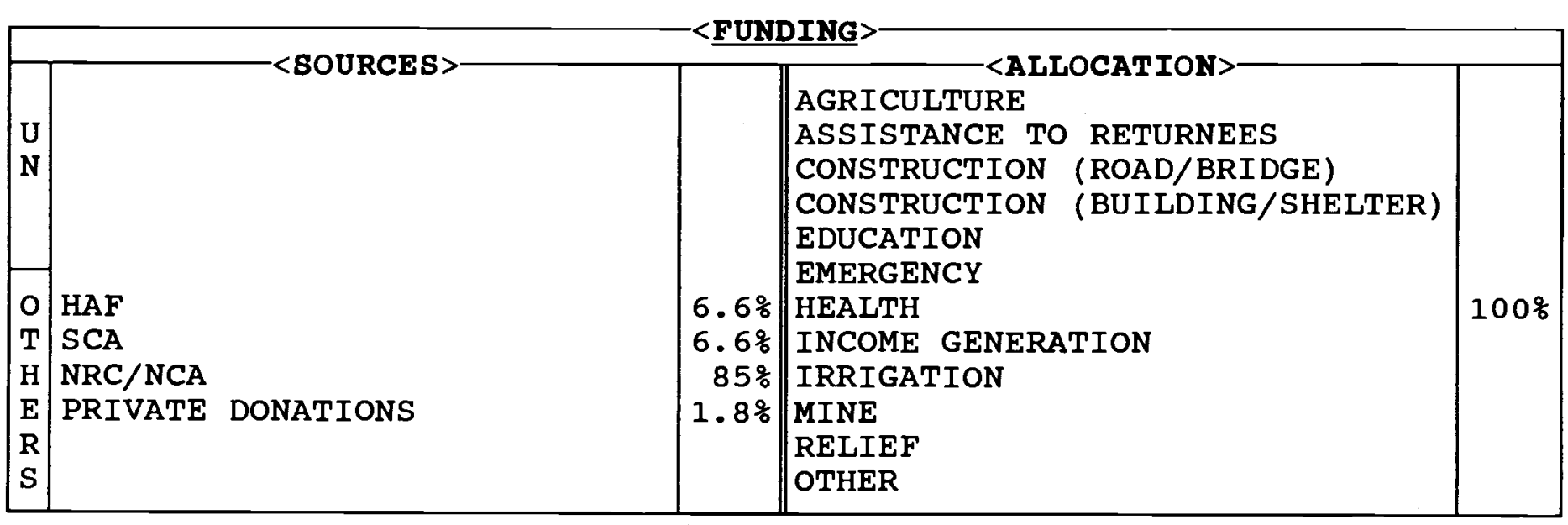

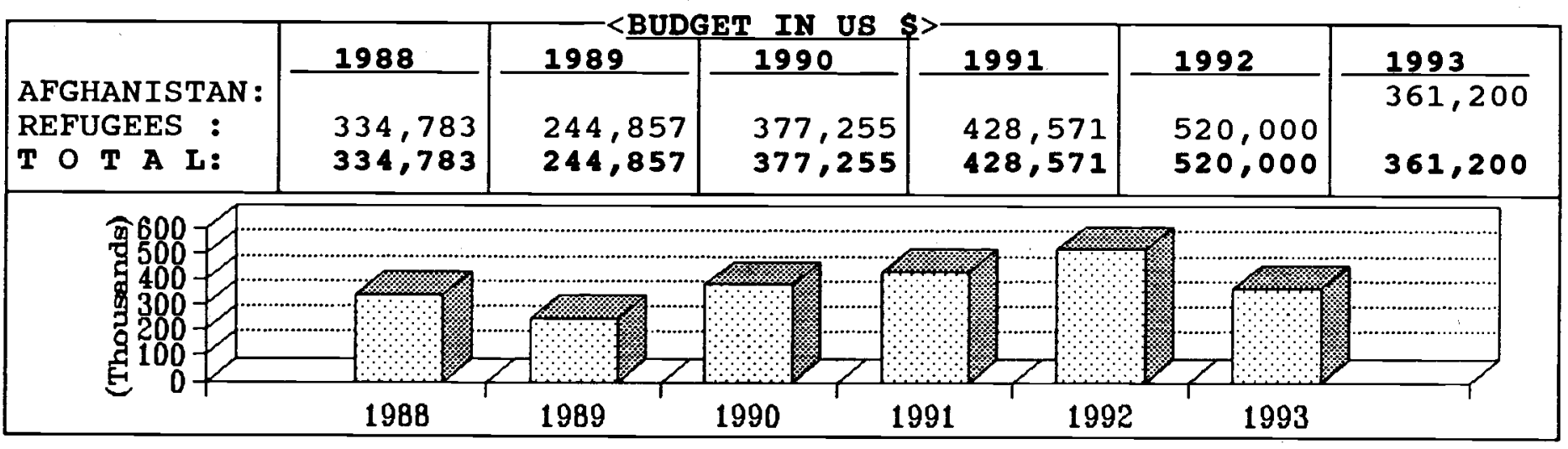

\begin{tabular}{|c|c|c|c|c|c|}
\hline PROVINCES & SECTOR & \&AGE & PROVINCES & SECTOR & $\because A G E$ \\
\hline $\begin{array}{l}\text { BADAKSHAN } \\
\text { BADGHIS } \\
\text { BAGHLAN } \\
\text { BALKH } \\
\text { BAMYAN } \\
\text { FARAH } \\
\text { FARYAB } \\
\text { GHAZNI } \\
\text { GHOR } \\
\text { HELMAND } \\
\text { HERAT } \\
\text { JAWZJAN } \\
\text { KABUL } \\
\text { KANDAHAR } \\
\text { KAPISA }\end{array}$ & & & $\begin{array}{l}\text { KUNAR } \\
\text { KUNDUZ } \\
\text { LAGHMAN } \\
\text { LOGAR } \\
\text { NANGARHAR } \\
\text { NIMROZ } \\
\text { ORUZGAN } \\
\text { PAKTEKA } \\
\text { PAKTIA } \\
\text { PARWAN } \\
\text { SAMANGAN } \\
\text { TAKHAR } \\
\text { WARDAK } \\
\text { ZABUL }\end{array}$ & Health & $100 \%$ \\
\hline
\end{tabular}




\section{AFGHAN OBSTETRICS/GYNECOLOGY HOSPITAL (AOGH)}

is an Afghan NGo founded in 1984 to provide obstetric and gynecological care to Afghan women. In February 1993 the hospital closed in Peshawar and the facility was moved to a newly renovated building in Jalalabad city.

A large percentage of the Afghan population $\left.{ }^{\wedge} U^{\wedge}\right] \% 26^{\prime} \star \wedge U^{\wedge} \wedge \wedge$ Sf women and children. Harshness of life contributes to malnutrition, anaemia and diseases which create a difficult climate for women of child bearing age. since at any given time an estimated $40 \%$ of the women, aged between 16 and 45, are pregnant, the provision of an obstetric and gynaecological facility is an essential element of any attempt to assist them.

The hospital consists of a busy 22 bed inpatient unit with major and minor operating rooms, 24 hour ward coverage and emergency operating team available around the clock, the 5 bedded labor and delivery area also has 24 hour coverage. There is also a daily outpatient clinic, clinical laboratory and blood bank, immunization facilities, pharmacy and health education department. Besides patient care a wealth of practical teaching is offered for young female health professionals seconded from other organizations.

Over the years in Peshawar the numbers of women coming for antenatal care with the intention of delivering their babies in the hospital had greatly increased, latest statistics prove this wili also be the case in Jalalabad. 
AFGHAN PLANNING AGENCY-APA

<ADDRESS >

7 PAWAKA RD, U/T,

$P$ O BOX 865

PESHAWAR, PAKISTAN
PHONE: 41115

$F$ A X:

TELEX:
1. ENG. ABDUL AHAD

2 .

3 .

\begin{tabular}{|lr|lr|lr|}
\hline AFGHAN : & 16 & TECHNICAL: & 6 & PAK.BASED: & 8 \\
PAKISTANI: & 0 & ADMINISTRATIVE: & 3 & AFGHA.BASED: & 0 \\
EXPAT: & 0 & FIELD/SUPPORT S. & 7 & CROSS-BORDER: & 8 \\
TOTAL: & 16 & TOTAL: & 16 & TOTAL: & 16 \\
\hline
\end{tabular}

0

8

16

\begin{tabular}{|c|c|c|c|c|}
\hline \\
\hline \multirow{6}{*}{$\begin{array}{l}\mathrm{U} \\
\mathrm{N}\end{array}$} & - SUURCDO & & AGRICULTURE & $302+2>$ \\
\hline & UNDP & $50 \%$ & ASSISTANCE TO RETURNEES & \\
\hline & UNDCP & $10 \%$ & CONSTRUCTION (ROAD/BRIDGE) & $50 \%$ \\
\hline & WFP & $5 \%$ & CONSTRUCTION (BUILDING/SHELTER) & \\
\hline & & & EDUCATION & $=0$ \\
\hline & & & EMERGENCY & $5 \%$ \\
\hline 0 & RAP & $5 \%$ & HEALTH & \\
\hline $\mathbf{T}$ & & & INCOME GENERATION & \\
\hline $\mathrm{H}$ & & & IRRIGATION & $15 \%$ \\
\hline $\mathbf{E}$ & & & MINE & \\
\hline $\mathbf{R}$ & & & RELIEF & \\
\hline$S$ & & & OTHER & \\
\hline
\end{tabular}

\begin{tabular}{|c|c|c|c|c|c|c|}
\hline \multirow{3}{*}{$\begin{array}{l}\text { AFGHANISTAN : } \\
\text { REFUGEES : }\end{array}$} & \multirow{2}{*}{1988} & \multirow{3}{*}{1989} & \multirow{2}{*}{1990} & \multirow{3}{*}{$\frac{1991}{164,583}$} & \multirow{3}{*}{$\frac{1992}{174,000}$} & \multirow{3}{*}{$\frac{1993}{75,000}$} \\
\hline & & & & & & \\
\hline & & & & & & \\
\hline $\begin{array}{l}\text { REFUGEES : } \\
\text { T O T A L: }\end{array}$ & & & & & 174,000 & 75,000 \\
\hline
\end{tabular}

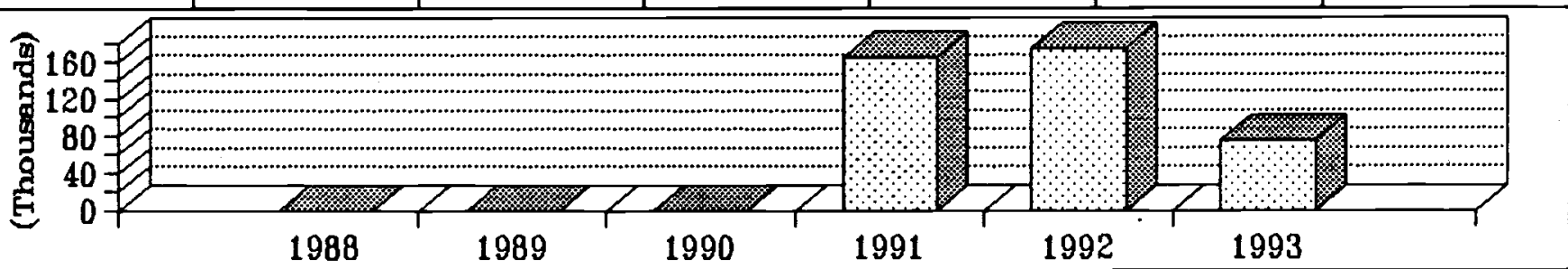

\begin{tabular}{|c|c|c|c|c|c|}
\hline PROVINCES & SECTOR & \&AGE & PROVINCES & SECTOR & $\& \mathrm{AGE}$ \\
\hline $\begin{array}{l}\text { BADAKSHAN } \\
\text { BADGHIS } \\
\text { BAGHLAN } \\
\text { BALKH } \\
\text { BAMYAN } \\
\text { FARAH } \\
\text { FARYAB } \\
\text { GHAZNI } \\
\text { GHOR } \\
\text { HELMAND } \\
\text { HERAT } \\
\text { JAWZJAN } \\
\text { KABUL } \\
\text { KANDAHAR } \\
\text { KAPISA }\end{array}$ & Emergency & $\frac{9}{6}$ & \begin{tabular}{|l} 
KUNAR \\
KUNDUZ \\
LAGHMAN \\
LOGAR \\
NANGARHAR \\
NIMROZ \\
ORUZGAN \\
PAKTEKA \\
PAKTIA \\
PARWAN \\
SAMANGAN \\
TAKHAR \\
WARDAK \\
ZABUL
\end{tabular} & $\begin{array}{l}\text { Agr } \\
\text { Irrign } \\
\text { Const (road) }\end{array}$ & $\begin{array}{l}25 \\
25\end{array}$ \\
\hline
\end{tabular}




AFGHAN PLANNING AGENCY (APA)
was established in 1989 . It is a
non-governmental, non-political and
non-profit organization. The main
objective of this organization
initially was to gather data and
draw sectoral perspective plans for
Afghanistan. The idea was supported
by the then uNocA at that time, but
later on funds for the realization
of this program were not made
available by the donor community.
ApA later on was registered as an
implementing counter part of the
United Nations organizations in
reconstruction work in Afghanistan.
Despite some of the set backs APA
has managed to establish good
working relations in various
provinces of Afghanistan and trained
active and dedicated young Afghans
in several fields such as road
construction, agriculture and
irrigation schemes, etc.

APA has also been supported by USAID and other donor sources.

APA's fields of specialization are as follows:
- Road rehabilitation and construction Irrigation engineering and water supply Agriculture
- Agriculture
- Statistics and data collection for development and rehabilitation activities in Afghanistan
- Building construction
- River training.

APA has successfully executed the following projects inside Afghanistan.

- cleaning of karezes in Chamkani, zadran Paktia. Rehabilitation of irrigation canals in Zadran, Ismail Khel, Gedawara, Nader Shah Kot, Paktia.

Rehabilitation of roads in Wardak, Paktia and Nangarhar provinces.
Fruit trees and improved seed distribution in Wardak, Paktia, Nangarhar, Kabul and Logar provinces. 


\begin{tabular}{|l|l|l|}
\hline BANGASH HS, NEW ARBAB & PHONE: 40504 & 1. ENG. S. RAHEM SATTAR \\
COLONY, ARBAB RD, & F A X: & 2. ENG. JUMA GUL \\
PESHAWAR, PAKISTAN & TELEX: & 3. MR. LAL PACHA
\end{tabular}

\begin{tabular}{|lc|lr|lr|}
\hline AFGHAN: & 27 & TECHNICAL: & 12 & PAK.BASED: & 11 \\
PAKISTANI : & - & ADMINISTRATIVE : & 10 & AFGHA.BASED: & 6 \\
EXPAT: & - & FIELD/SUPPORT S. & 5 & CROSS-BORDER: & 10 \\
TOTAL: & $\mathbf{2 7}$ & TOTAL: & $\mathbf{2 7}$ & TOTAL: & $\mathbf{2 7}$ \\
\hline
\end{tabular}

\begin{tabular}{|c|c|c|c|c|}
\hline & & FU1 & 20 & \\
\hline & $-<$ SOURCES $>$ & $5 \%$ & $\begin{array}{l}\text { AGRICULTURE } \\
\text { ALLOATION }>-\end{array}$ & $3 \%$ \\
\hline $\mathbf{U}$ & UNDP & $30 \%$ & ASSISTANCE TO RETURNEES & \\
\hline $\mathbf{N}$ & WFP & $60 \%$ & CONSTRUCTION (ROAD/BRIDGE) & \\
\hline & & & CONSTRUCTION (BUILDING/SHELTER) & $12 \%$ \\
\hline & & & $\begin{array}{l}\text { EDUCATION } \\
\text { EMERGENCY }\end{array}$ & $50 \%$ \\
\hline 0 & AFGHAN SUPPORTING COMMITTEE & $1 \%$ & HEALTH & \\
\hline $\mathrm{T}$ & ISRA & 48 & INCOME GENERATION & \\
\hline $\mathrm{H}$ & & & IRRIGATION & $35 \%$ \\
\hline $\mathbf{E}$ & & & MINE & \\
\hline $\mathbf{R}$ & & & RELIEF & \\
\hline $\mathbf{S}$ & & & OTHER & \\
\hline
\end{tabular}

\begin{tabular}{|c|c|c|c|c|c|c|}
\hline & 1988 & 1989 & 1990 & 1991 & 1992 & 1993 \\
\hline $\begin{array}{l}\text { AFGHANISTAN : } \\
\text { REFUGEES : }\end{array}$ & & & 156,090 & 205,836 & 157,974 & 388,833 \\
\hline T O $\mathbf{T} \mathbf{A} \mathbf{L}$ & & & 156,090 & 205,836 & 157,974 & 388,833 \\
\hline
\end{tabular}

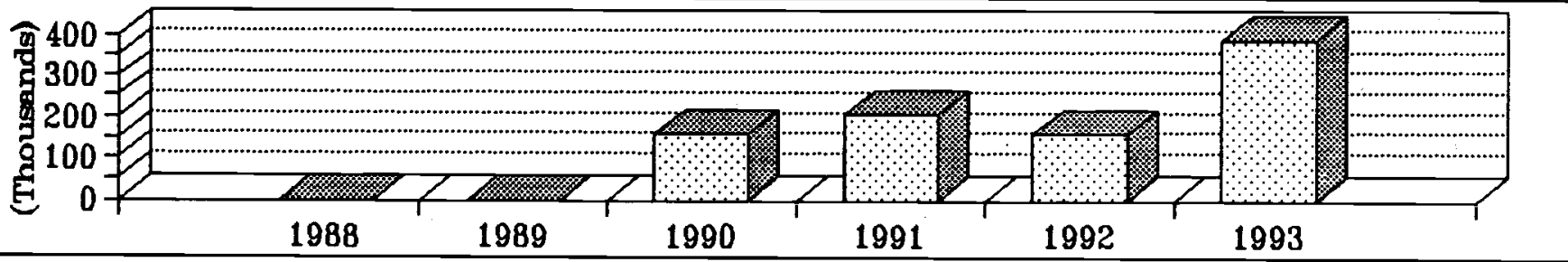

\begin{tabular}{|c|c|c|c|c|c|}
\hline PROVINCES & SECTOR & $\% \mathrm{AGE}$ & PROVINCES & SECTOR & $\because A G E$ \\
\hline $\begin{array}{l}\text { BADAKSHAN } \\
\text { BADGHIS } \\
\text { BAGHLAN } \\
\text { BALKH } \\
\text { BAMYAN } \\
\text { FARAH } \\
\text { FARYAB } \\
\text { GHAZNI } \\
\text { GHOR } \\
\text { HELMAND } \\
\text { HERAT } \\
\text { JAWZJAN } \\
\text { KABUL } \\
\text { KANDAHAR } \\
\text { KAPISA }\end{array}$ & & & $\begin{array}{l}\text { KUNAR } \\
\text { KUNDUZ } \\
\text { LAGHMAN } \\
\text { LOGAR } \\
\text { NANGARHAR } \\
\text { NIMROZ } \\
\text { ORUZGAN } \\
\text { PAKTEKA } \\
\text { PAKTIA } \\
\text { PARWAN } \\
\text { SAMANGAN } \\
\text { TAKHAR } \\
\text { WARDAK } \\
\text { ZABUL }\end{array}$ & $\begin{array}{l}\text { Agr/const/irrign } \\
\text { Const/emerg } \\
\text { Agr/irrign } \\
\text { Agr/emerg/irrign }\end{array}$ & $\begin{array}{l}\% \\
\% \\
\% \\
\%\end{array}$ \\
\hline
\end{tabular}


AFGHAN PUBLIC WELFARE ORGANIZATION (APWO)

established in 1989, has its headquarters in Peshawar and suboffices in Jalalabad and Khost areas.

The major aim for the establishment of the organization was to assist the oppressed people inside Afghanistan in different fields e.g. agriculture, irrigation, construction and emergency feeding to the returnees and internally displaced people.

At the beginning this organization started work in refugee camps inside Pakistan. In 1990, practical work was started inside Afghanistan.

A total number of approximately 50 projects have been implemented by APWO in the last few years in different sectors in different parts of the country. These include:

- Construction of super passages, dikes, retaining walls and cleaning of canals in Bak, Trayzai and Alishir districts of Paktia pr and Rodat district of Nangarhar province.

- Provision of agricultural inputs in Gurbuz district of Paktia province.

- Cleaning of several canals in Musahi/Char Asyab district of Kabul province.

- Construction of a mosque in Kulangar district of Logar province.

- Poultry distribution project in Alishir, Bak and Trayzai districts of Paktia province.

APWO has proposed a large number of projects to different donor agencies which are under consideration. 
AFGHAN RECONSTRUCTION SERVICES-ARS

\begin{tabular}{|l|l|l|}
\hline 209 GULHAJI PLAZA, & PHONE: 45262 & <COMEY STAFF>- \\
JAMROD RD, & F A X: & 1. ENG.SARDAR M. ISAQZAI \\
PESHAWAR, PAKISTAN & TELEX: & 2. ENG.G.RAZA KOHISTANI \\
\hline
\end{tabular}

\begin{tabular}{|ll|ll|l|l|}
\hline AFGHAN: & $\mathbf{8}$ & TECHNICAL: & 4 & PAK.BASED: & 4 \\
PAKISTANI : & - & ADMINISTRATIVE: & 4 & AFGHA.BASED: & - \\
EXPAT: & - & FIELD/SUPPORT S. & - & CROSS-BORDER: & 4 \\
TOTAL: & $\mathbf{8}$ & TOTAL: & $\mathbf{8}$ & TOTAL: & $\mathbf{8}$ \\
\hline
\end{tabular}

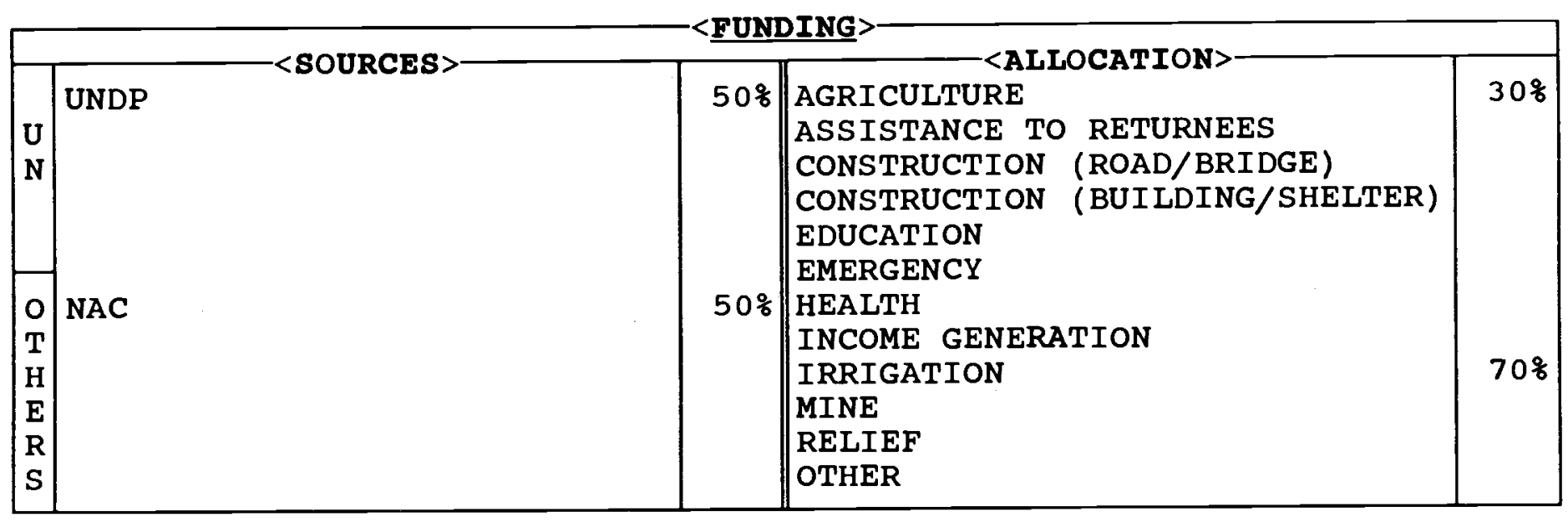

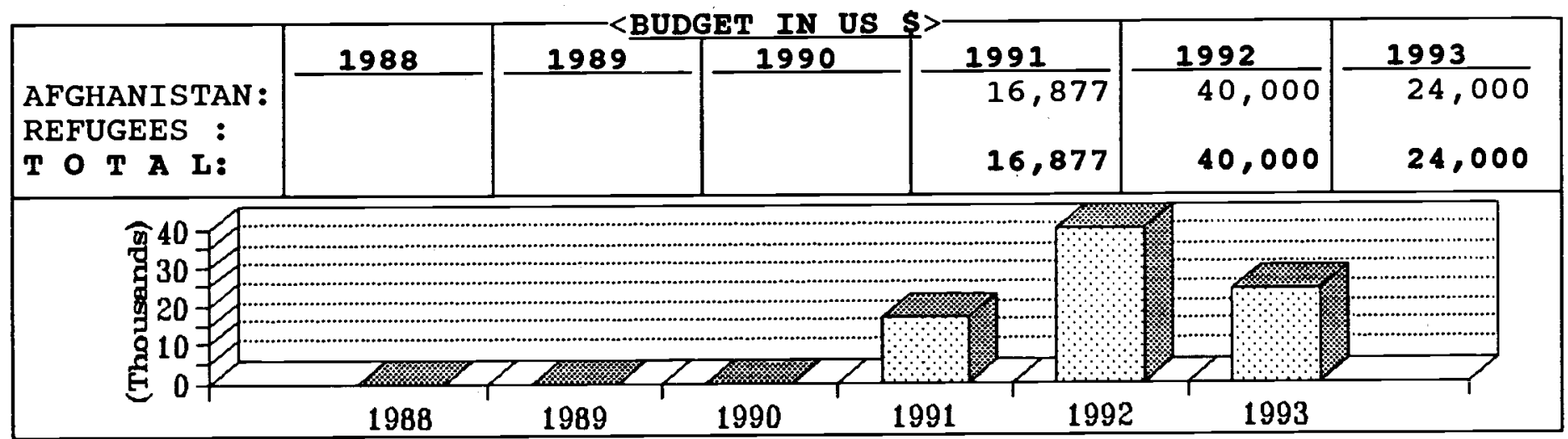

\begin{tabular}{|c|c|c|c|c|c|}
\hline PROVINCES & SECTOR & \&AGE & PROVINCES & SECTOR & $\% \mathrm{AGE}$ \\
\hline $\begin{array}{l}\text { BADAKSHAN } \\
\text { BADGHIS } \\
\text { BAGHLAN } \\
\text { BALKH } \\
\text { BAMYAN } \\
\text { FARAH } \\
\text { FARYAB } \\
\text { GHAZNI } \\
\text { GHOR } \\
\text { HELMAND } \\
\text { HERAT } \\
\text { JAWZJAN } \\
\text { KABUL } \\
\text { KANDAHAR } \\
\text { KAPISA }\end{array}$ & & & $\begin{array}{l}\text { KUNAR } \\
\text { KUNDUZ } \\
\text { LAGHMAN } \\
\text { LOGAR } \\
\text { NANGARHAR } \\
\text { NIMROZ } \\
\text { ORUZGAN } \\
\text { PAKTEKA } \\
\text { PAKTIA } \\
\text { PARWAN } \\
\text { SAMANGAN } \\
\text { TAKHAR } \\
\text { WARDAK } \\
\text { ZABUL }\end{array}$ & Agr/irrign & $100 \%$ \\
\hline
\end{tabular}


AFGHAN RECONSTRUCTION SERVICES (ARB)

began its activities in March 1991. ARS currently implements crossborder projects in the sectors of agriculture, irrigation rehabilitation and construction programs. It has successfully completed a number of projects in host area of Paktia province.

Currently, ARS has a staff of 8 out of which four are on the project site and the remaining work in the central office in Peshawar.

The following projects have been implemented:

1) Cleaning of 19 karezes in Lakan area.

2) Cleaning of 7 canals in Lakan area.

3) Distribution of 6,000 fruit tree saplings in the same area.

Construction work on four intakes in Lakan area of host is in progress.

So far, ARS has been financially supported by UNDP, Norwegian Afghanistan committee and FAO. Efforts are made to obtain contribution from other sources as well. 
AFGHAN RED CRESCENT SOCIETY-ARCB

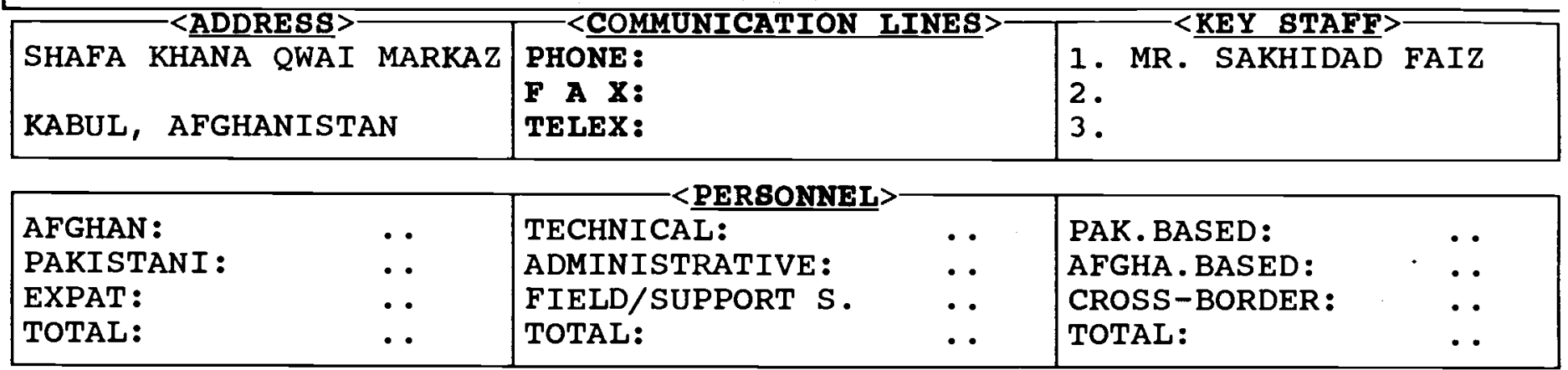

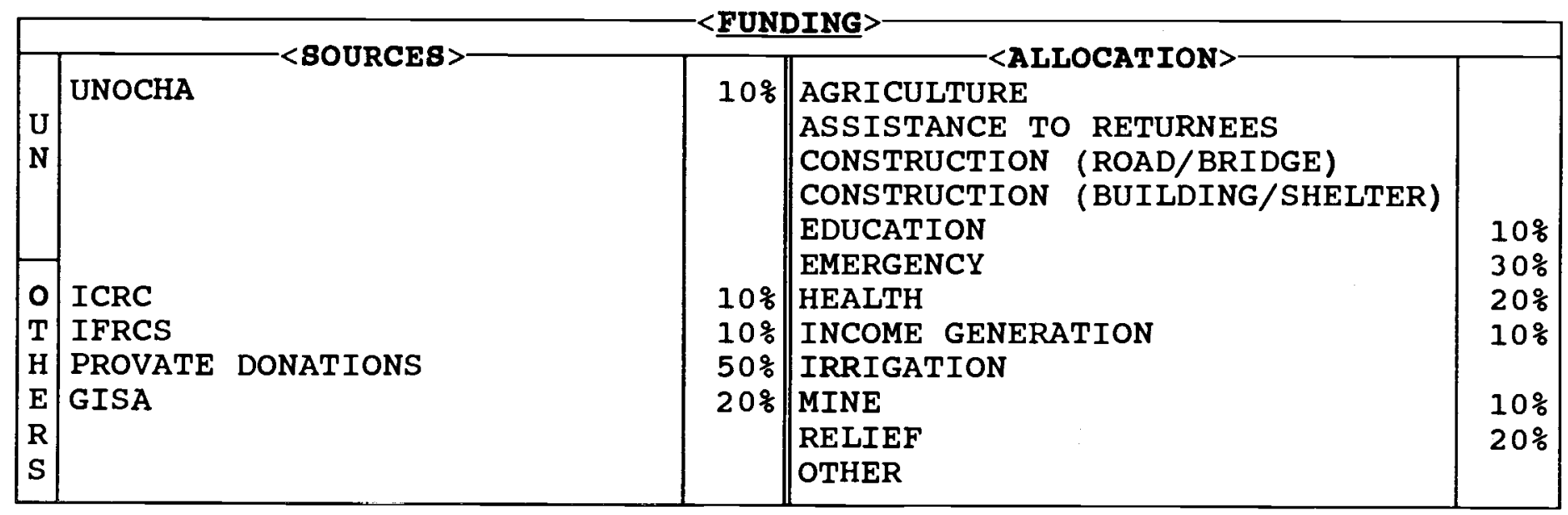

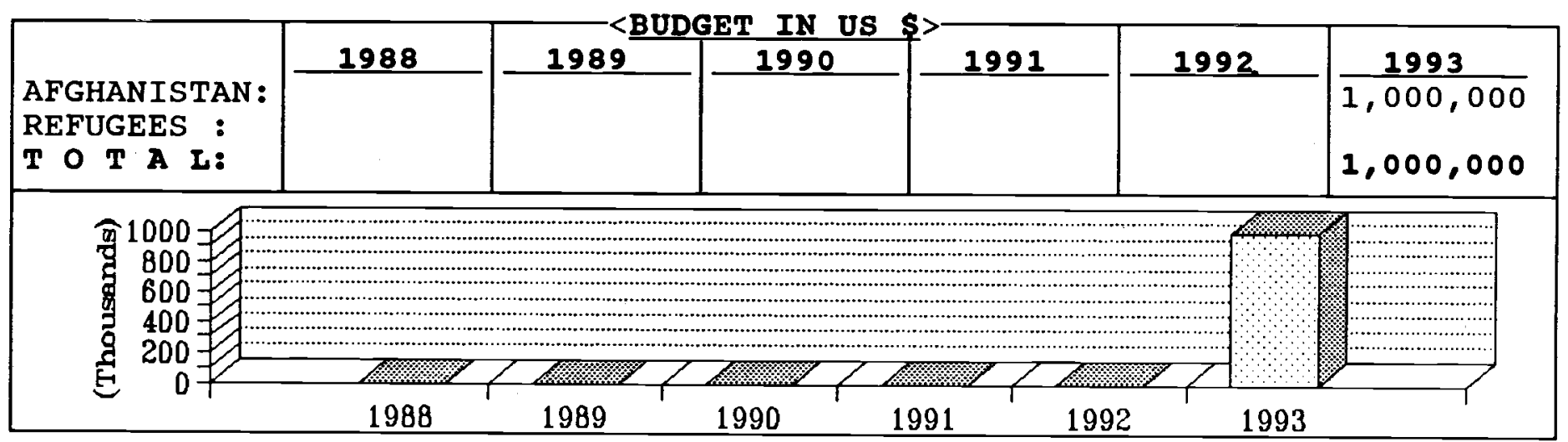

\begin{tabular}{|c|c|c|c|c|c|}
\hline PROVINCES & SECTOR & \&AGE & PROVINCES & SECTOR & \&AGE \\
\hline $\begin{array}{l}\text { BADAKSHAN } \\
\text { BADGHIS } \\
\text { BAGHLAN } \\
\text { BALKH } \\
\text { BAMYAN } \\
\text { FARAH } \\
\text { FARYAB } \\
\text { GHAZNI } \\
\text { GHOR } \\
\text { HELMAND } \\
\text { HERAT } \\
\text { JAWZJAN } \\
\text { KABUL } \\
\text { KANDAHAR } \\
\text { KAPISA }\end{array}$ & $\begin{array}{l}\text { Health } \\
\text { Health/relief } \\
\text { Health/relief } \\
\text { Health } \\
\text { Health } \\
\text { Educ/health/IG/min/re } \\
\text { Health } \\
\text { Health/relief }\end{array}$ & $\begin{array}{r}2 \% \\
56 \% \\
2 \% \\
5 \%\end{array}$ & \begin{tabular}{||l} 
KUNAR \\
KUNDUZ \\
LAGHMAN \\
LOGAR \\
NANGARHAR \\
NIMROZ \\
ORUZGAN \\
PAKTEKA \\
PAKTIA \\
PARWAN \\
SAMANGAN \\
TAKHAR \\
WARDAK \\
ZABUL
\end{tabular} & $\begin{array}{l}\text { Health } \\
\text { Health/relief } \\
\text { Health } \\
\text { Health } \\
\text { Health/releif } \\
\text { Health/relief }\end{array}$ & $\begin{array}{l}2 \% \\
2 \% \\
5 \% \\
5 \%\end{array}$ \\
\hline
\end{tabular}


Afghan Red Crescent society is the only official charity organization in the country.

It is governed by a Grand and a Central assemblies who select the Director General and key staff. It has 4 main departments (health, relief, Marastoon and voluntary self help) and 8 supporting sections with 16 branches in the provinces.

With an annual budget of Afs. 527 million its activities in 1992 were twice as big as in previous years.

The funds for ARCS come from 27 different sources e.g. one day's salary contribution from all government employees, 2 percent of excise duties and 1 percent of taxation.

However, for 1993 it had only managed to collect 20 percent of the expected contributions but had continued its work at the intended level by utilizing savings from previous years.

ARCS has spent a lot of time and energy developing a well organized system of listing and identifying those families where severe hardship was faced.

ARCS is a member of the International Federation of Red Cross and Red Crescent Societies. The Director General of the ARCS had recently attended an annual meeting of the Federation and had requested support and assistance. ARCS has also received medical assistance from Swedish Committee for Afghanistan (SCA) Health Department and the Islimc Coordination Council (ICC) and other materials from RONCO and US Embassy in Islamabad. 
AFGHAN REHABILITATION TEAM-ART

\begin{tabular}{|l|l|l|}
\hline 254, A/N, BLOCK 3, & PHONE: 442579 & COMMUNICATION LINES \\
SATELLITE TOWN & F A X: & KRY STAFF \\
QUETTA, PAKISTAN & TELEX: & 3. \\
\hline
\end{tabular}

\begin{tabular}{|ll|ll|ll|}
\hline AFGHAN: & 4 & TECHNICAL: & 2 & PAK. BASED: & 3 \\
PAKISTANI : & - & ADMINISTRATIVE: & 1 & AFGHA.BASED: & 1 \\
EXPAT: & - & FIELD/SUPPORT S. & 1 & CROSS-BORDER: & - \\
TOTAL: & 4 & TOTAL: & 4 & TOTAL: & 4 \\
\hline
\end{tabular}

\begin{tabular}{|c|c|c|c|c|}
\hline $\begin{array}{l} \\
\mathrm{O} \\
\mathrm{T} \\
\mathrm{H} \\
\mathrm{E} \\
\mathrm{R} \\
\mathrm{S}\end{array}$ & UNESCO & $100 \%$ & $\begin{array}{l}\text { AGRICULTURE } \\
\text { ASSISTANCE TO RETURNEES } \\
\text { CONSTRUCTION (ROAD/BRIDGE) } \\
\text { CONSTRUCTION (BUILDING/SHELTER) } \\
\text { EDUCATION } \\
\text { EMERGENCY } \\
\text { HEALTH } \\
\text { INCOME GENERATION } \\
\text { IRRIGATION } \\
\text { MINE } \\
\text { RELIEF } \\
\text { OTHER }\end{array}$ & $100 \%$ \\
\hline
\end{tabular}

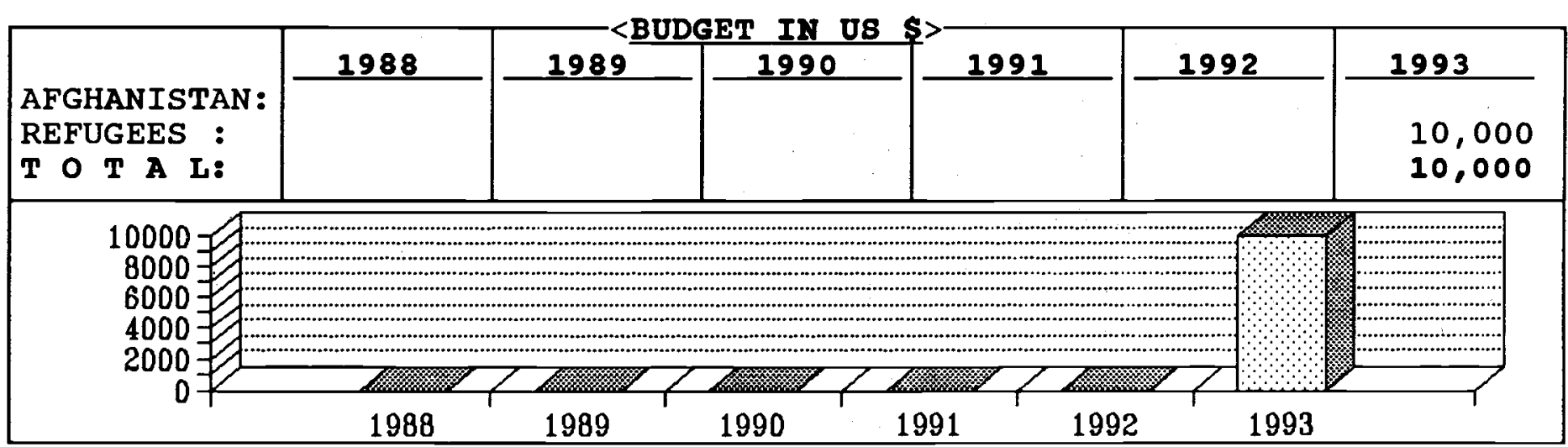

\begin{tabular}{|c|c|c|c|c|c|}
\hline PROVINCES & SECTOR & \&AGE & PROVINCES & SECTOR & $\%$ AGE \\
\hline $\begin{array}{l}\text { BADAKSHAN } \\
\text { BADGHIS } \\
\text { BAGHLAN } \\
\text { BALKH } \\
\text { BAMYAN } \\
\text { FARAH } \\
\text { FARYAB } \\
\text { GHAZNI } \\
\text { GHOR } \\
\text { HELMAND } \\
\text { HERAT } \\
\text { JAWZJAN } \\
\text { KABUL } \\
\text { KANDAHAR } \\
\text { KAPISA }\end{array}$ & & & $\begin{array}{l}\text { KUNAR } \\
\text { KUNDUZ } \\
\text { LAGHMAN } \\
\text { LOGAR } \\
\text { NANGARHAR } \\
\text { NIMROZ } \\
\text { ORUZGAN } \\
\text { PAKTEKA } \\
\text { PAKTIA } \\
\text { PARWAN } \\
\text { SAMANGAN } \\
\text { TAKHAR } \\
\text { WARDAK } \\
\text { ZABUL }\end{array}$ & & \\
\hline
\end{tabular}




\section{AFGHAN REHABILITATION TEAM (ART)}

was founded in January 1993. The main objective of the organization is to contribute to the rehabilitation, reconstruction, and development of education, agriculture, health and infrastructure. sectors in Afghanistan by planning, designing and undertaking economic and humanitarian assistance programs.

ART maintains a library - funded by UNESCO - for Afghan refugees in quetta, Baluchistan. The Afghan Education Program (AEP) of this organization aims to contribute to the rehabilitation of the education sector in Afghanistan and is willing to extend its educational programs to rural areas of the country. 
-

42, STREET 5, G-3, PHASE II, HAYATABAD PESHAWAR, PAKISTAN
PHONE: 811261/810105

F A X: 812138

TELEX:
1. MR. S. I. GAILANI

2. ENG. NIZAM

3. PROF.A.R. JALILI

\begin{tabular}{|lc|lr|lr|}
\hline AFGHAN : & 90 & TECHNICAL: & 53 & PAK.BASED: & 41 \\
PAKISTANI : & - & ADMINISTRATIVE: & 31 & AFGHA.BASED: & 46 \\
EXPAT: & - & FIELD/SUPPORT S. & 6 & CROSS-BORDER: & 3 \\
TOTAL: & 90 & TOTAL: & 90 & TOTAL: & 90 \\
\hline
\end{tabular}

\begin{tabular}{|c|c|c|c|c|}
\hline & & & -"-חת & \\
\hline & $-<$ SOURCES & & <ALLOCATION> & \\
\hline $\mathbf{U}$ & $\begin{array}{l}\text { FAO } \\
\text { UNDP }\end{array}$ & $10 \%$ & $\begin{array}{l}\text { AGRICULTURE } \\
\text { ASSISTANCE TO RFTURNFFS }\end{array}$ & $10 \%$ \\
\hline $\mathbf{N}$ & & & CONSTRUCTION (ROAD/BRIDGE) & $5 \%$ \\
\hline & & & CONSTRUCTION (BUILDING/SHELTER) & $5 \%$ \\
\hline & & & EDUCATION & \\
\hline & & & EMERGENCY & \\
\hline 0 & MSH & $10 \%$ & HEALTH & $40 \%$ \\
\hline $\mathrm{T}$ & USAID & $10 \%$ & INCOME GENERATION & \\
\hline $\mathrm{H}$ & PRIVATE DONATIONS & $30 \%$ & IRRIGATION & $35 \%$ \\
\hline $\mathbf{E}$ & & & MINE & \\
\hline $\mathbf{R}$ & & & RELIEF & $5 \%$ \\
\hline $\mathbf{S}$ & & & OTHER & \\
\hline
\end{tabular}

\begin{tabular}{|c|c|c|c|c|c|c|}
\hline $\begin{array}{l}\text { AFGHANISTAN: } \\
\text { REFUGEES : } \\
\text { T O T A L: }\end{array}$ & $\begin{array}{r}1988 \\
110,987 \\
79,861 \\
190,848\end{array}$ & $\begin{array}{r}1989 \\
146,941 \\
41,625 \\
188,566\end{array}$ & \begin{tabular}{r}
\multicolumn{1}{c}{1990} \\
364,000 \\
87,200 \\
451,200
\end{tabular} & $\begin{array}{r}1991 \\
140,000 \\
86,400 \\
226,400\end{array}$ & $\begin{array}{r}1992 \\
364,000 \\
87,200 \\
451,200\end{array}$ & $\begin{array}{r}1993 \\
120,000 \\
30,000 \\
150,000\end{array}$ \\
\hline 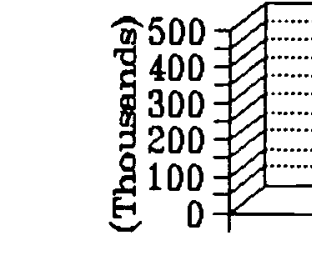 & 1988 & 1989 & 1990 & 199 & 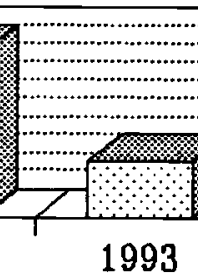 & (1) \\
\hline
\end{tabular}

\begin{tabular}{|c|c|c|c|c|c|}
\hline PROVINCES & SECTOR & \% AGE & PROVINCES & SECTOR & $\%$ AGE \\
\hline $\begin{array}{l}\text { BADAKSHAN } \\
\text { BADGHIS } \\
\text { BAGHLAN } \\
\text { BALKH } \\
\text { BAMYAN } \\
\text { FARAH } \\
\text { FARYAB } \\
\text { GHAZNI } \\
\text { GHOR } \\
\text { HELMAND } \\
\text { HERAT } \\
\text { JAWZJAN } \\
\text { KABUL } \\
\text { KANDAHAR } \\
\text { KAPISA }\end{array}$ & 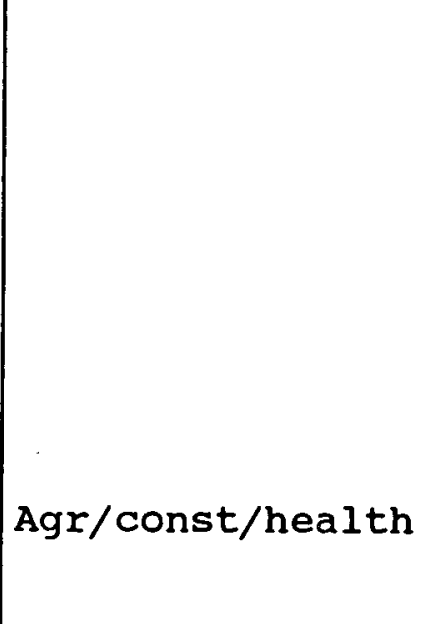 & $40 \%$ & \begin{tabular}{|l|} 
KUNAR \\
KUNDUZ \\
LAGHMAN \\
LOGAR \\
NANGARHAR \\
NIMROZ \\
ORUZGAN \\
PAKTEKA \\
PAKTIA \\
PARWAN \\
SAMANGAN \\
TAKHAR \\
WARDAK \\
ZABUL
\end{tabular} & Agr/const/irrign & $60 \%$ \\
\hline
\end{tabular}


AFGHAN RELIEF FOUNDATION (ARF)

is an Afghan run non-governmental organization founded in 1986 with the support of Help the Afghans Foundation (the Netherlands).

Afghan Relief Foundation started its relief work for the destitute people of Afghanistan by providing food commodities like wheat, rice, edible oil, tea, soap, etc. Later on the Foundation established a Mother and child Health care clinic.

The Mother and Child Health Care clinic is run by three doctors, five nurses and 14 other staff. In this clinic, situated in Peshawar, about 100 to 150 out-patients per day come for consultation and treatment.

In Afghanistan, ARF has provided emergency aid in various provinces including Kabul (recently). In all cases food commodities and used clothes were distributed among the destitute families. All programs have taken place under the supervision of a representative of the organization at all times and with the help and full cooperation of commanders and chiefs of the tribes.

In 1991, ARF started rehabilitation programs by establishing an engineering service section. with its 8 technical staff, this section is responsible for carrying out projects in rehabilitation and construction of irrigation systems, roads and buildings.

In June 1992, ARF started running an OB/GYN Hospital in Kabul. The hospital with a team of 40 staff ( 29 technical and 11 administrative) provide services to approximately 250 patients daily.

ARF established an agricultural section in 1993. The agricultural section has carried out a poultry production and distribution project. It plans to distribute seeds and fertilizer and establish fruit and non-fruit trees in surkhrod and Shewa districts of Nangarhar.
In 1993, ARF also established a school for refugees in Peshawar. The school has 10 teachers and 350 students. 
AFGHAN RELIEF AND REHABILITATION-ARR

\begin{tabular}{|l|l|l|}
\hline 3 CANAL LANE, CANAL RD & PHONE: 44916 & <COMMUNICATION LINEB $>$ KEY BTAFF>- MR. MOOSA RAFEY \\
U/T & FA X: & 2. ENG. AJMAL SHAIRZAI \\
PESHAWAR, PAKISTAN & TELEX: & 3. ENG. NASIRULLAH
\end{tabular}

\begin{tabular}{|lc|lr|lr|}
\hline AFGHAN : & 27 & TECHNICAL: & 5 & PAK. BASED: & 11 \\
PAKISTANI : & - & ADMINISTRATIVE: & 5 & AFGHA.BASED: & - \\
EXPAT: & 1 & FIELD/SUPPORT S. & 18 & CROSS-BORDER: & 17 \\
TOTAL: & $\mathbf{2 8}$ & TOTAL: & $\mathbf{2 8}$ & TOTAL: & $\mathbf{2 8}$ \\
\hline
\end{tabular}

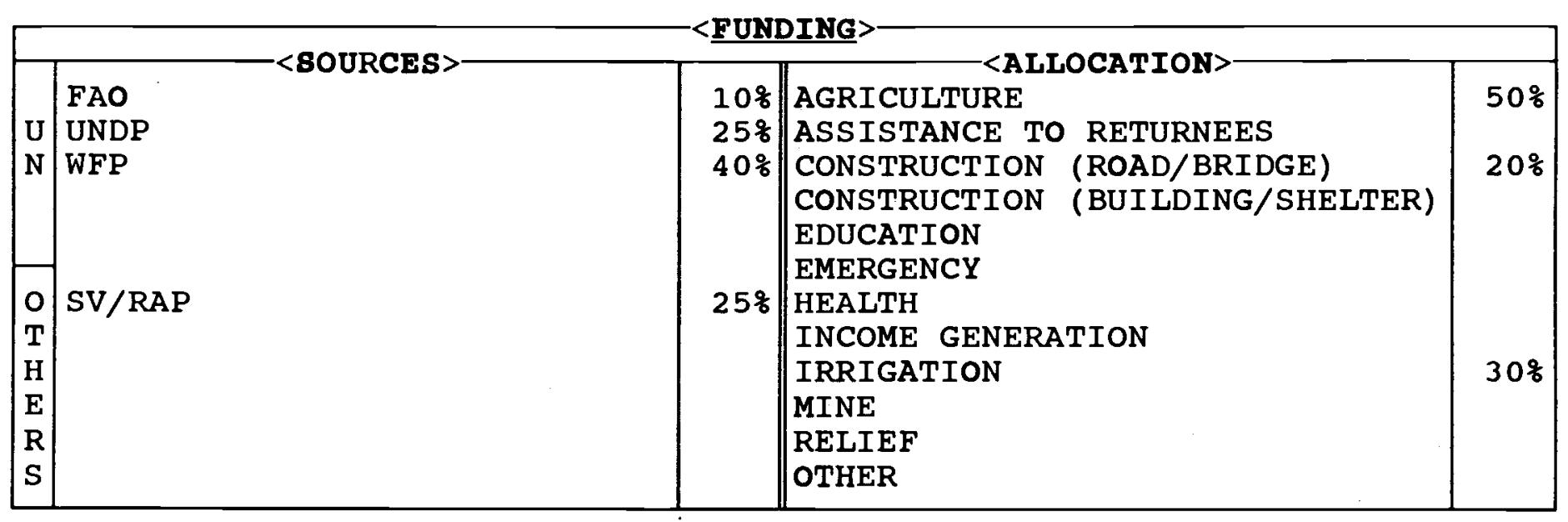

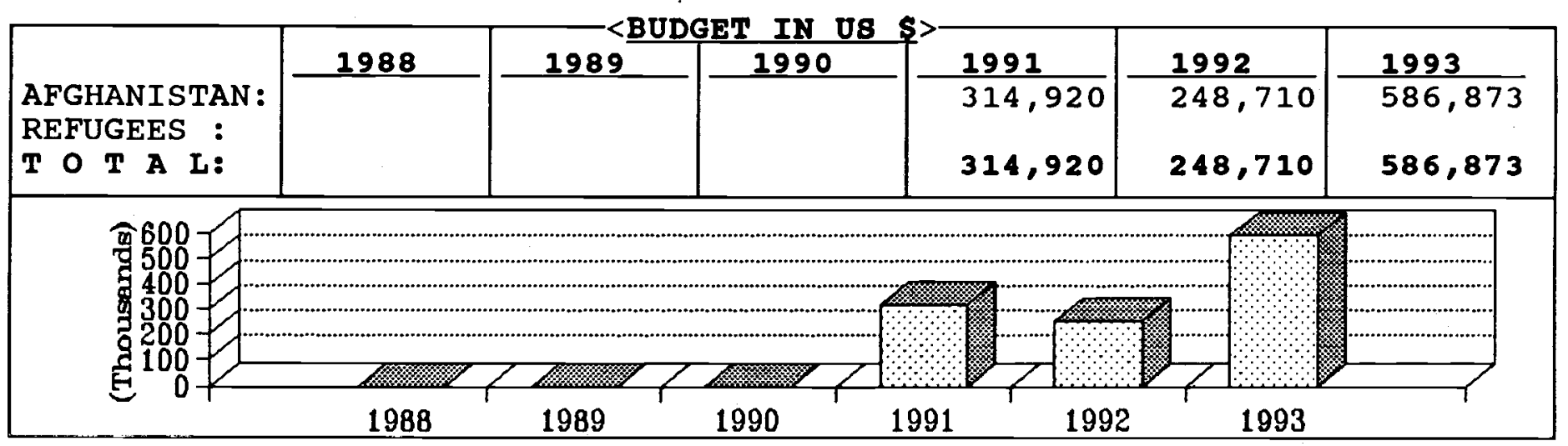

\begin{tabular}{|c|c|c|c|c|c|}
\hline PROVINCES & SECTOR & $\% \mathrm{AGE}$ & PROVINCES & SECTOR & $\% \mathrm{AGE}$ \\
\hline $\begin{array}{l}\text { BADAKSHAN } \\
\text { BADGHIS } \\
\text { BAGHLAN } \\
\text { BALKH } \\
\text { BAMYAN } \\
\text { FARAH } \\
\text { FARYAB } \\
\text { GHAZNI } \\
\text { GHOR } \\
\text { HEIMAND } \\
\text { HERAT } \\
\text { JAWZJAN } \\
\text { KABUL } \\
\text { KANDAHAR } \\
\text { KAPISA }\end{array}$ & Agr/irrign & $10 \%$ & \begin{tabular}{|l} 
KUNAR \\
KUNDUZ \\
LAGHMAN \\
LOGAR \\
NANGARHAR \\
NIMROZ \\
ORUZGAN \\
PAKTEKA \\
PAKTIA \\
PARWAN \\
SAMANGAN \\
TAKHAR \\
WARDAK \\
ZABUL
\end{tabular} & $\begin{array}{l}\text { Agr/irrign } \\
\text { Agr/irrign } \\
\text { Agr/const/irrign } \\
\text { Const/irrign }\end{array}$ & $\begin{array}{l}30 \% \\
35 \% \\
15 \% \\
10 \%\end{array}$ \\
\hline
\end{tabular}


was founded in 1990 in Quetta, Pakistan. Due to increased activities, a second office was established in Peshawar, in 1991.

The main goal of ARR is to provide services in the fields of agriculture, reconstruction, health, and education for the people of Afghanistan.

At present ARR is working in Kandahar, zabul, Helmand, Paktia, Wardak and Nangarhar provinces, mainly in rehabilitation of agriculture and reconstruction of public buildings, repairing of irrigation systems and roads. ARR is willing to work in other provinces in the future.

ARR staff in the Peshawar office number 23 Afghan employees including 6 engineers, four agriculturists, two surveyors, one administrator, one accountant, one computer operator and 5 support staff.

ARR is registered with UNOCHA and is a member of ACBAR and SWABAC. At present ARR's funding sources are UNOCHA, UNDP, FAO, WFP, IRC/RAP and some private sources. 


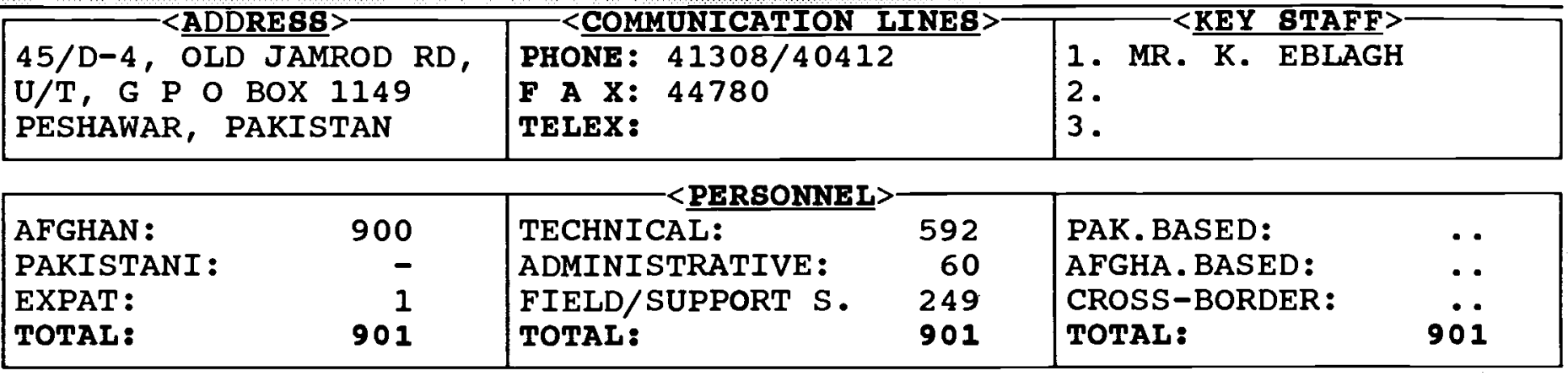

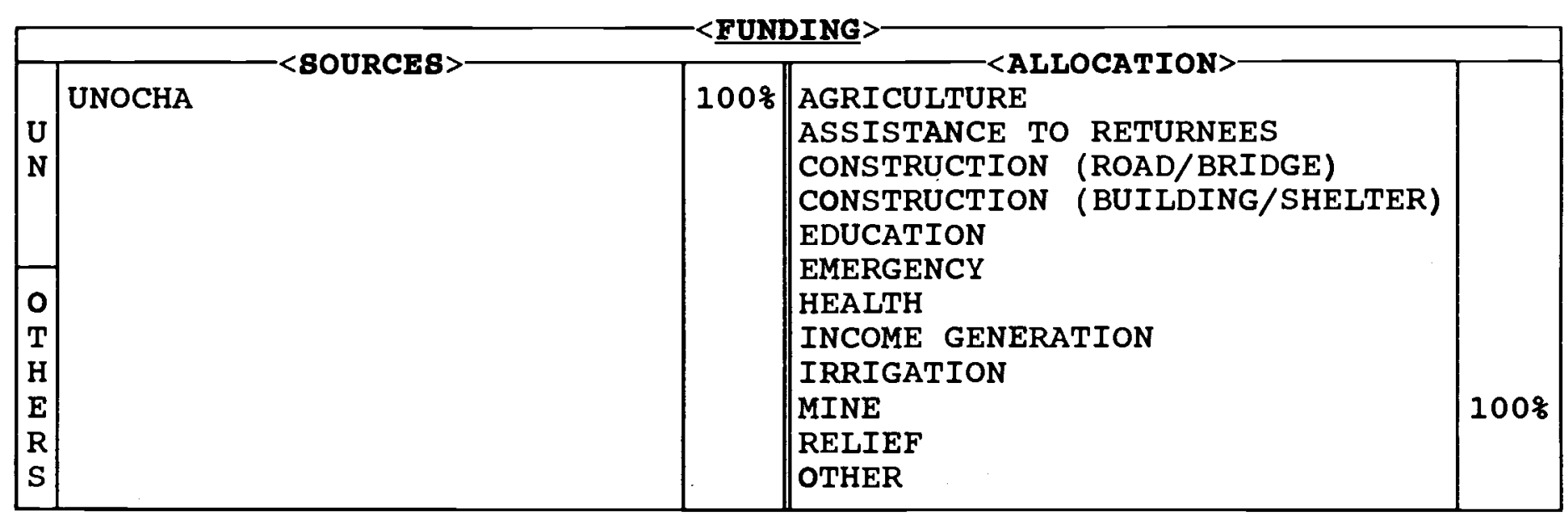

\begin{tabular}{|c|c|c|c|c|c|c|}
\hline $\begin{array}{l}\text { AFGHANISTAN: } \\
\text { REFUGEES : } \\
\text { T O T A I: }\end{array}$ & 1988 & 1989 & $\begin{array}{l}\frac{1990}{4,013,000} \\
4,013,000\end{array}$ & $\begin{array}{l}\frac{1991}{3,647,000} \\
3,647,000\end{array}$ & $\begin{array}{l}\frac{1992}{4,550,000} \\
4,550,000\end{array}$ & $\begin{array}{l}\frac{1993}{5,699,500} \\
5,699,500\end{array}$ \\
\hline & 1988 & 1989 & 1990 & 991 & al & a \\
\hline
\end{tabular}

\begin{tabular}{|c|c|c|c|c|c|}
\hline PROVINCES & SECTOR & \&AGE & |PROVINCES & SECTOR & \%AGE \\
\hline $\begin{array}{l}\text { BADAKSHAN } \\
\text { BADGHIS } \\
\text { BAGHLAN } \\
\text { BALKH } \\
\text { BAMYAN } \\
\text { FARAH } \\
\text { FARYAB } \\
\text { GHAZNI } \\
\text { GHOR } \\
\text { HELMAND } \\
\text { HERAT } \\
\text { JAWZJAN } \\
\text { KABUL } \\
\text { KANDAHAR } \\
\text { KAPISA }\end{array}$ & $\begin{array}{l}\text { Demining } \\
\text { Demining } \\
\text { Demining } \\
\text { Demining } \\
\text { Demining }\end{array}$ & $\begin{array}{l}q \\
q \\
q\end{array}$ & \begin{tabular}{|l|} 
KUNAR \\
KUNDUZ \\
LAGHMAN \\
LOGAR \\
NANGARHAR \\
NIMROZ \\
ORUZGAN \\
PAKTEKA \\
PAKTIA \\
PARWAN \\
SAMANGAN \\
TAKHAR \\
WARDAK \\
ZABUL
\end{tabular} & $\begin{array}{l}\text { Demining } \\
\text { Demining } \\
\text { Demining } \\
\text { Demining } \\
\text { Demining } \\
\\
\text { Demining } \\
\text { Demining } \\
\text { Demining } \\
\text { Demining } \\
\text { Demining }\end{array}$ & $\begin{array}{l}\frac{8}{6} \\
q \\
q \\
q \\
q \\
\frac{8}{6} \\
q\end{array}$ \\
\hline
\end{tabular}


is an implementing agency for demining activities funded by UNOCHA, in the eastern, central and southern provinces of Afghanistan. ATC was founded in October 1989 with a staff of 35 personnel, including one twenty four man demining team. ATC undertook the first demining project in Kunar in January 1990.

Since its establishment, ATC has undergone significant changes and expanded considerably. Since 1990 it has completed three development projects through UNOCHA. These projects began with a small scale demining operation inside Afghanistan i.e. pilot project, and culminated with the expansion to eighteen manual demining teams and deployment of two mechanical flail machines. Each manual team consists of 30 deminers while 4 operators and 2 mechanics run the 2 flail machines.

So far ATC has cleared $16,140,786$ sq. meters agricultural/grazing land, airports, canals, roads, hills and residential areas in 15 provinces and divisions (Kunar, Nangarhar, Paktia/Khost, Pakteka, Bamyan, Takhar, Ghazni, Badakhshan, Parwan, Wardak, Kunduz, Kapisa, Kabul, Logar and Laghman).

Depending on availability of funds, ATC hopes to expand into other provinces in the north as well as the central parts of Afghanistan.

ATC currently employs 900 Afghans, and one Australian. Its headquarters are in Peshawar and it maintains 9 mobile offices in different provinces of Afghanistan. 
AFGHAN WOMEN EDUCATION CENTER-AWEC

\begin{tabular}{|c|c|c|c|c|c|}
\hline $\begin{array}{l}\text { 195, STREET } \\
\text { U P O BOX.. } \\
\text { ISLAMABAD, }\end{array}$ & $\begin{array}{l}\text { G9/4 } \\
\text { TAN }\end{array}$ & $\begin{array}{l}\text { PHONE: } 859489 \\
\text { F A X: } \\
\text { TELEX: }\end{array}$ & & $\begin{array}{l}\text { 1. MS. MAHBOOB } \\
\text { 2. MS. ROQIA F } \\
\text { 3. MS. PALWASH }\end{array}$ & ROKHIL \\
\hline $\begin{array}{l}\text { AFGHAN : } \\
\text { PAKISTANI: } \\
\text { EXPAT: } \\
\text { TOTAL: }\end{array}$ & $\begin{array}{l}40 \\
- \\
40\end{array}$ & $\begin{array}{l}\text { TECHNICAL: } \\
\text { ADMINISTRATIVE: } \\
\text { FIELD/SUPPORT S. } \\
\text { TOTAL: }\end{array}$ & $\begin{array}{r}34 \\
4 \\
2 \\
40\end{array}$ & $\begin{array}{l}\text { PAK. BASED: } \\
\text { AFGHA. BASED: } \\
\text { CROSS-BORDER: } \\
\text { TOTAL: }\end{array}$ & $\begin{array}{r}40 \\
- \\
40\end{array}$ \\
\hline
\end{tabular}

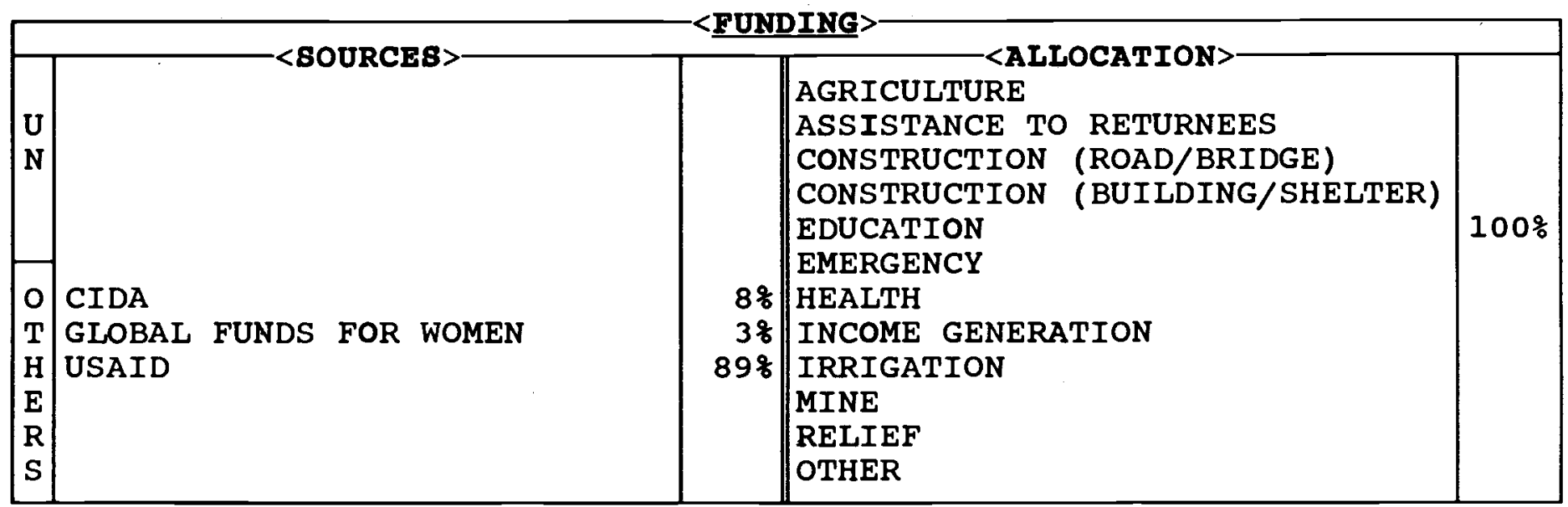

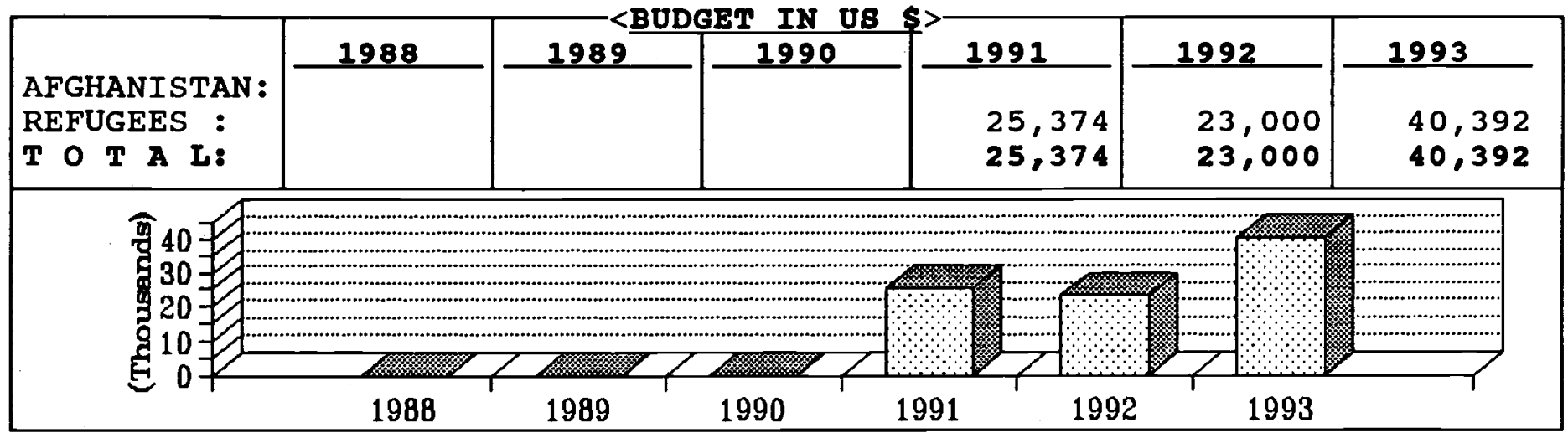

\begin{tabular}{|c|c|c|c|c|c|}
\hline PROVINCES & SECTOR & \&AGE & PROVINCES & SECTOR & $\% A G E$ \\
\hline $\begin{array}{l}\text { BADAKSHAN } \\
\text { BADGHIS } \\
\text { BAGHLAN } \\
\text { BALKH } \\
\text { BAMYAN } \\
\text { FARAH } \\
\text { FARYAB } \\
\text { GHAZNI } \\
\text { GHOR } \\
\text { HELMAND } \\
\text { HERAT } \\
\text { JAWZJAN } \\
\text { KABUL } \\
\text { KANDAHAR } \\
\text { KAPISA }\end{array}$ & & & $\begin{array}{l}\text { KUNAR } \\
\text { KUNDUZ } \\
\text { LAGHMAN } \\
\text { LOGAR } \\
\text { NANGARHAR } \\
\text { NIMROZ } \\
\text { ORUZGAN } \\
\text { PAKTEKA } \\
\text { PAKTIA } \\
\text { PARWAN } \\
\text { SAMANGAN } \\
\text { TAKHAR } \\
\text { WARDAK } \\
\text { ZABUL }\end{array}$ & & \\
\hline
\end{tabular}


AFGHAN WOMEN'S EDUCATIONAL CENTER (AWED)

was founded in February 1991 and is mainly involved in the education sector for Afghan females based in Rawalpindi and Islamabad.

The agency is supporting a primary school, but due to unavailability of funds, fees are collected from the students. The agency also conducts various types of courses such as English Language, Women's Rights awareness, Literacy, Tailoring and English Typing.

So far, 1,160 students have graduated from different fields and more than 400 students are currently receiving training.

The agency plans to move to Afghanistan as soon as the situation allows. 
AFGHAN WOMEN RESOURCE CENTER (AWRC)

is an organization for Afghan women run by Afghan women. The opening of the Center was in response to demands from the Afghan community and the women who attended meetings held earlier in 1989. The center works to improve literacy levels and health care amongst Afghan women; provides them with vocational skills and trains teachers of literacy and knitting and sewing. The first course began in November, 1989. At first, opening the center was a daunting task. However, with a nonaligned Advisory Board, it has gained respect within the community.

The center has already completed several semesters and 1,377 students have completed courses.

At its main center in Peshawar, AWRC has the following components:

1) Education and training program includes literacy, numeracy, the Quran/Islamic studies, knitting, sewing and basic health classes.

2) News/information service involves production and distribution of a monthly newsletter Basheer-ul-Momenat or the Afghan Women's Herald.

3) Library contains over 1,300 books and many leaflets on different subjects e.g. health care, women's issues, literature, English language, sociology, politics, religion and basic readers for both children and adults.

4) Job placement office facilitates contacts between Afghan women and prospective employers and maintains a database of women's educational and employment histories $(1,161$ women have registered and 202 have been placed in jobs so far).

5) Day care center takes care of some 50 under five children of the staff and students. staff training includes offering training to the administrative staff of the Center in program planning, monitoring, budgeting, report writing and computer skills.

Income generating project has veterinarians who training to Afghan poultry production, poultry f e m a le provide women in control and improved ways of breeding with the objective of making them self-sufficient.

In January 1991, the Center opened an outreach program at Akora Camp. since then nine more outreach centers have been established in the camps around Peshawar (Akora No 6 and 8, Zangali, Tajabad, Khazana, Adizo, Newkalai and Kababian). The outreach centers offer education courses to women. The response from the women who have participated in the courses has been very encouraging.

AWRC is keen to develop its camp program and open more centers in future. AWRC would welcome advice from other NGOs experienced in income generation programs. AWRC also hope to open a center for educating women inside Afghanistan, and would appreciate advice about this from others involved in education.

AWRC has an Advisory Board which meets three times a year. A president and a secretary are chosen in the January meeting of the Advisory Board who then regularly attend the meetings of the Executive Committee where most decisions about the Center are made.

Funding for AWRC initially came from USIS and from USAID through International Rescue Committee which also provided some management support in the first year. since then donations have come from a variety of sources including embassies of Saudi Arabia and Lebanon, International Women's Development Agency (an Australian NGO), NAC, SCA and UNDP. 


\begin{tabular}{|c|c|c|}
\hline$=<$ ADDRE88 $>$ & -<COMMUNICATION LINES > & $=<$ KEY STAFF $>$ \\
\hline $\begin{array}{l}\text { 5B GULMOHAR RD, U/T, } \\
\text { P O BOX . . . … } \\
\text { PESHAWAR, PAKISTAN }\end{array}$ & $\begin{array}{l}\text { PHONE: } 42030 / 841083 \\
\text { F A X: } 840322 \\
\text { TELEX: }\end{array}$ & $\begin{array}{l}\text { 1. MR. WYNN FLATEN } \\
\text { 2. } \\
\text { 3. }\end{array}$ \\
\hline
\end{tabular}

\begin{tabular}{|lr|lr|lr|}
\hline AFGHAN : & 168 & TECHNICAL: & 10 & PAK. BASED: & 53 \\
PAKISTANI : & 12 & ADMINISTRATIVE: & 48 & AFGHA.BASED: & 48 \\
EXPAT: & 5 & FIELD/SUPPORT S. & 127 & CROSS-BORDER: & 84 \\
TOTAL: & 185 & TOTAL: & 185 & TOTAL: & 185 \\
\hline
\end{tabular}

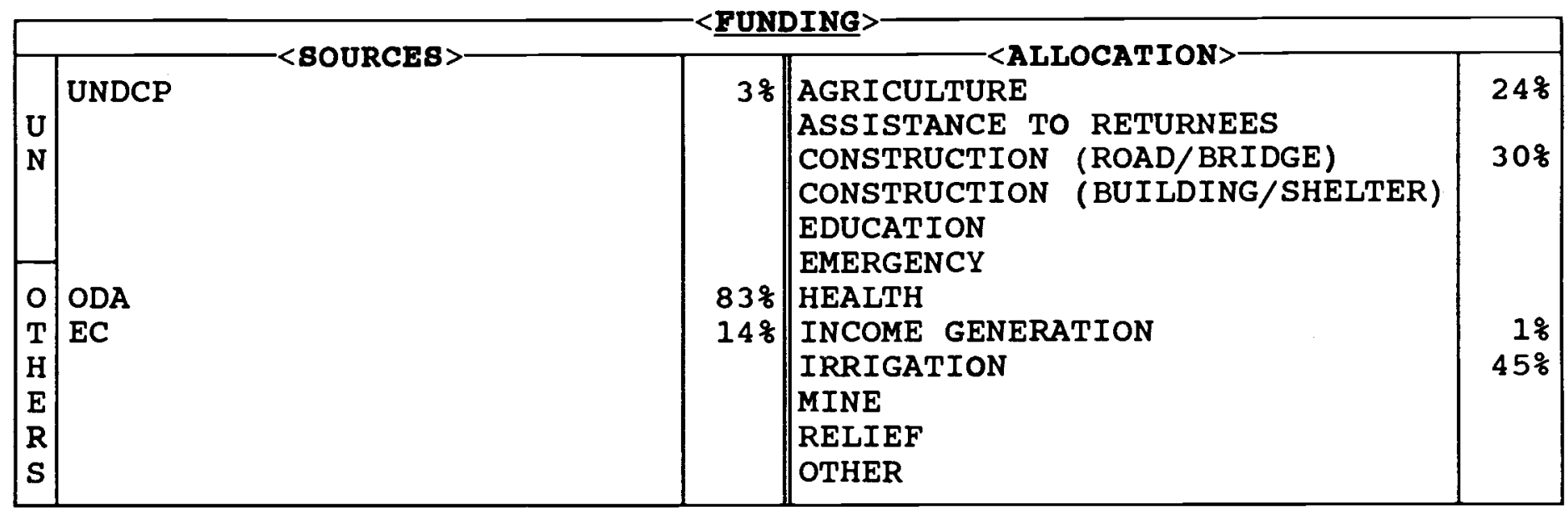

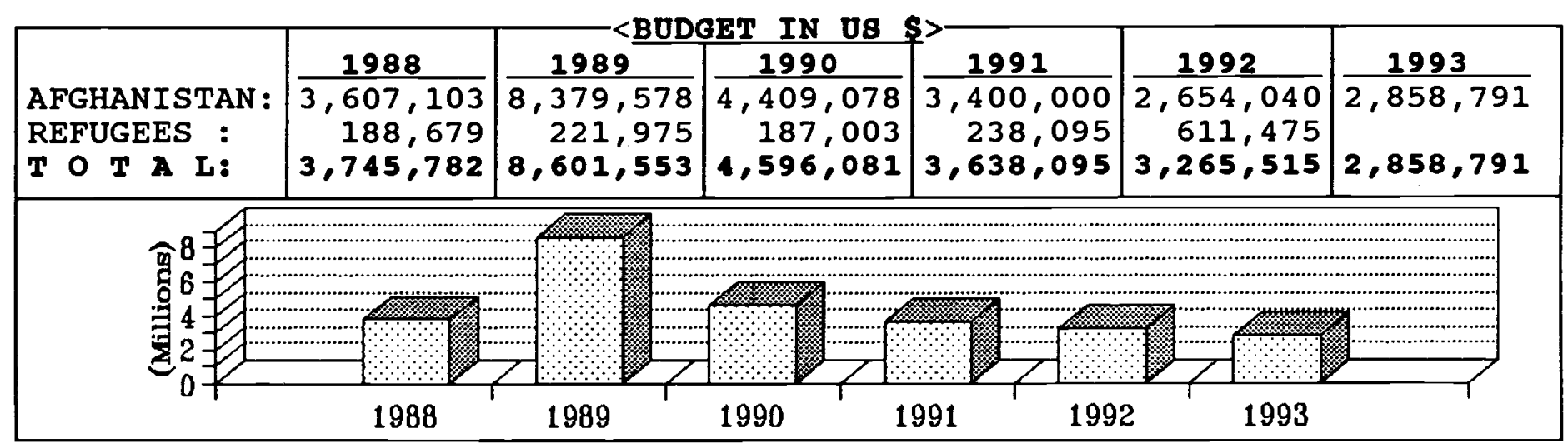

\begin{tabular}{|c|c|c|c|c|c|}
\hline PROVINCES & SECTOR & \&AGE & PROVINCES & SECTOR & \&AGE \\
\hline $\begin{array}{l}\text { BADAKSHAN } \\
\text { BADGHIS } \\
\text { BAGHLAN } \\
\text { BALKH } \\
\text { BAMYAN } \\
\text { FARAH } \\
\text { FARYAB } \\
\text { GHAZNI } \\
\text { GHOR } \\
\text { HELMAND } \\
\text { HERAT } \\
\text { JAWZJAN } \\
\text { KABUL } \\
\text { KANDAHAR } \\
\text { KAPISA }\end{array}$ & Agr./const./irrign & $\begin{array}{r}19 \% \\
8 \%\end{array}$ & $\begin{array}{l}\text { KUNAR } \\
\text { KUNDUZ } \\
\text { LAGHMAN } \\
\text { LOGAR } \\
\text { NANGARHAR } \\
\text { NIMROZ } \\
\text { ORUZGAN } \\
\text { PAKTEKA } \\
\text { PAKTIA } \\
\text { PARWAN } \\
\text { SAMANGAN } \\
\text { TAKHAR } \\
\text { WARDAK } \\
\text { ZABUL }\end{array}$ & $\begin{array}{l}\text { Agr./irrign. } \\
\text { Agr./irrign. } \\
\text { Agr./Const./irrign. }\end{array}$ & $\begin{array}{l}11 \% \\
21 \%\end{array}$ \\
\hline
\end{tabular}




\section{AFGHANAID (A-AID)}

was set up in 1984 \& runs a crossborder program. Afghanaid provides assistance to the people of Afghanistan through sustainable rehabilitation and development of agriculture and small scale infrastructure. Activities include repair of irrigation systems, flood control projects to protect agricultural land, the multiplication and distribution of improved seed, provision of fertilizer, horticulture projects, a small scale apiculture scheme, and a housing project. To supplement this program and to encourage the growth of markets through improved communications, Afghanaid undertakes small-scale projects involving the repair and improvement of roads and bridges. In addition Afghanaid devotes such resources as are available to emergency relief in certain areas.

Afghanaid works in six provinces of Afghanistan; Badakhshan, Baghlan, Kapisa, Kunduz, Parwan and Takhar. Requests for assistance are submitted by communities to Afghanaid provincial offices, and professional surveyors collect data on the area to find out whether the proposed project fits within Afghanaid criteria and capabilities. Technical experts then design and cost the projects and a socioeconomist identifies and analyzes the impact on the beneficiaries. Those projects which are most suitable are submitted to the shura, who in turn choose the final list of projects according to their priorities. An annual program for the province is then finalized.

In Peshawar, in addition to its main field office, Afghanaid maintains a technical services unit comprising agricultural, engineering, and socio-economict technical specialists. These specialists offer expert backup to the field teams in the development and implementation of projects, carry out on-site monitoring of the projects, and assess future training needs of staff. This unit also organizes a comprehensive jobrelated training program for Afghanaid staff, houses an information center and database of essential information on Afghanaid's programs, and a small technical library for use by project staff.

In January 1993 Afghanaid signed a protocol agreement with the Government of Afghanistan. The long term objective of establishing field headquarters in Kabul will be realized only after the security situation improves. In the meantime a small transit base is in operation in Kabul to facilitate communications and travel for Afghanaid staff between Peshawar and project sites in northern Afghanistan. During 1993, Afghanaid teams are surveying other districts in preparation for the 1994 program, which will be developed in consultation with Afghan authorities and other members of the NGO community. 
AFGHANISTAN HUNAN RESOURCES DEVELOPMENT PROJECT-HRD/AED

<ADDRE88>- CCOMMUNICATION LINES> $\mathrm{U} / \mathrm{T}$ PESHAWAR, PAKISTAN
PHONE: 841437-8/841537

F A X: 43249 TELEX:
1. MR. DAVID BENEDETTI

2. MR. J. E. HEALY

3. MS. M. A. JAVED

\begin{tabular}{|lr|lr|lr|}
\hline AFGHAN : & 123 & TECHNICAL: & 54 & PAK. BASED: & 114 \\
PAKISTANI : & 3 & ADMINISTRATIVE: & 75 & AFGHA.BASED: & 15 \\
EXPAT: & 3 & FIELD: & - & CROSS-BORDER: & - \\
TOTAL: & 129 & TOTAL: & 129 & TOTAL: & 129 \\
\hline
\end{tabular}

\begin{tabular}{|c|c|c|c|c|}
\hline \\
\hline $\begin{array}{l}0 \\
T \\
H \\
E \\
R \\
S\end{array}$ & USAID & $100 \%$ & $\begin{array}{l}\text { AGRICULTURE } \\
\text { ASSISTANCE TO RETURNEES } \\
\text { CONSTRUCTION (ROAD/BRIDGE) } \\
\text { CONSTRUCTION (BUILDING/SHELTER) } \\
\text { EDUCATION/VOCATIONAL TRAINING } \\
\text { EMERGENCY } \\
\text { HEALTH } \\
\text { INCOME GENERATION } \\
\text { IRRIGATION } \\
\text { MINE } \\
\text { RELIEF } \\
\text { OTHER }\end{array}$ & $100 \%$ \\
\hline
\end{tabular}

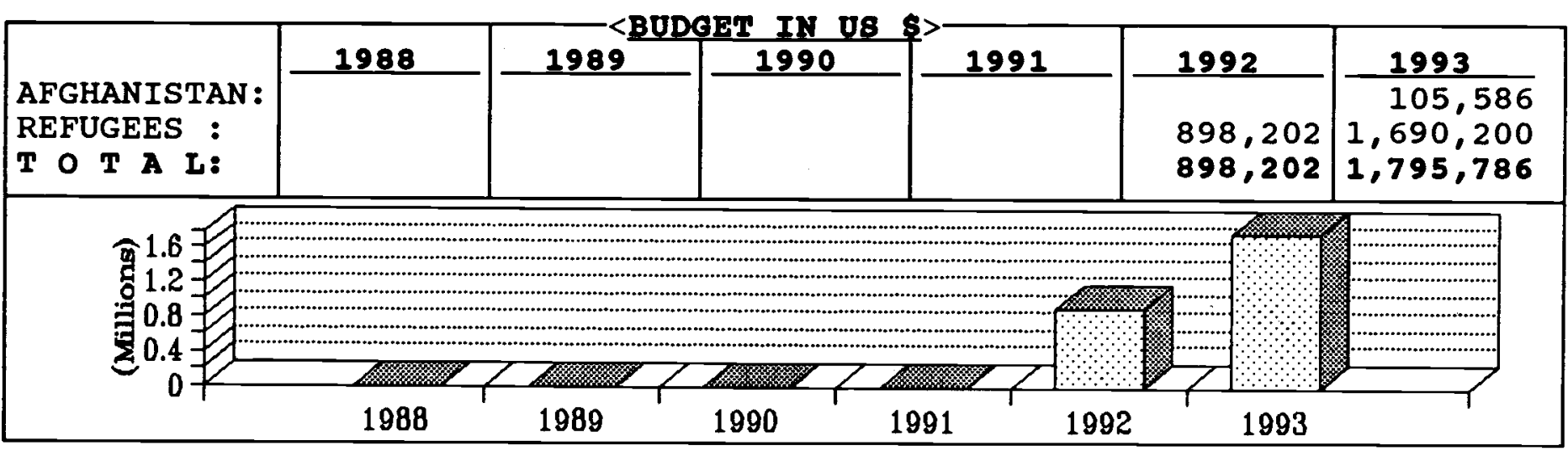

\begin{tabular}{|c|c|c|c|c|c|}
\hline PROVINCES & SECTOR & \&AGE & PROVINCES & SECTOR & \&AGE \\
\hline $\begin{array}{l}\text { BADAKSHAN } \\
\text { BADGHIS } \\
\text { BAGHLAN } \\
\text { BALKH } \\
\text { BAMYAN } \\
\text { FARAH } \\
\text { FARYAB } \\
\text { GHAZNI } \\
\text { GHOR } \\
\text { HELMAND } \\
\text { HERAT } \\
\text { JAWZJAN } \\
\text { KABUL } \\
\text { KANDAHAR } \\
\text { KAPISA }\end{array}$ & $\begin{array}{l}\text { Voc. training } \\
\text { Voc. training }\end{array}$ & $\begin{array}{c}958 \\
5 q\end{array}$ & \begin{tabular}{|l} 
KUNAR \\
KUNDUZ \\
LAGHMAN \\
LOGAR \\
NANGARHAR \\
NIMROZ \\
ORUZGAN \\
PAKTEKA \\
PAKTIA \\
PARWAN \\
SAMANGAN \\
TAKHAR \\
WARDAK \\
ZABUL
\end{tabular} & & \\
\hline
\end{tabular}




\section{AFGHANISTAN HUMAN RESOURCES \\ DEVELOPMENT PROJECT-HRD/AED}

The Construction Related Training for Afghanistan-CRTA program is funded by the United states Agency for International Development (USAID) through its Human Resources Development (HRD) Project administered by the Academy for Educational Development (AED). The objective is to help meet Afghanistan's reconstruction needs by providing an expanded pool of Civil Engineers, Assistant Engineers and Construction Supervisors who can participate effectively in construction-related endeavors.

CRTA has two parts:

a) Construction supervision Program, which includes a ninemonth Construction supervisor course and an 18-month Assistant Engineer course; and

b) Construction Engineering, which is a 36-month degree program.

The Construction Supervisor Program equips graduates to work as construction foremen, able to supervise crews of construction workers or manage small rural projects. The Assistant Engineer Program equips graduates to manage entire projects of small-to mediumsize and to perform a variety of technical tasks. The construction Engineering program parallels the curriculum of the university-level program offered at Kabul University prior to the wari graduates are qualified to design and manage construction projects related to building roads, canals, bridges, public buildings and other facilities.

The Basic Training skills program of HRD/AED offers courses in different trades to young Afghans. Centers have been established in Peshawar and Quetta for refugees. Also centers have been opened in Ghazni and Kabul provinces inside Afghanistan. 
AFGHANI BTAN NOTHI LFE $\Theta . V$.

DANISHABAD, CANAL RD, U/T, G P O BOX 679, PESHAWAR, PAKISTAN

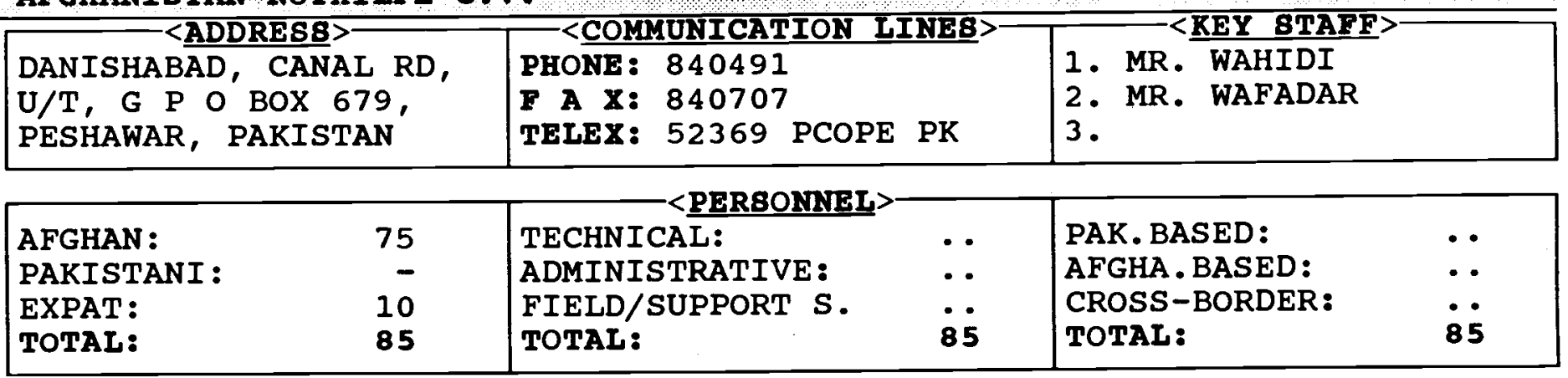

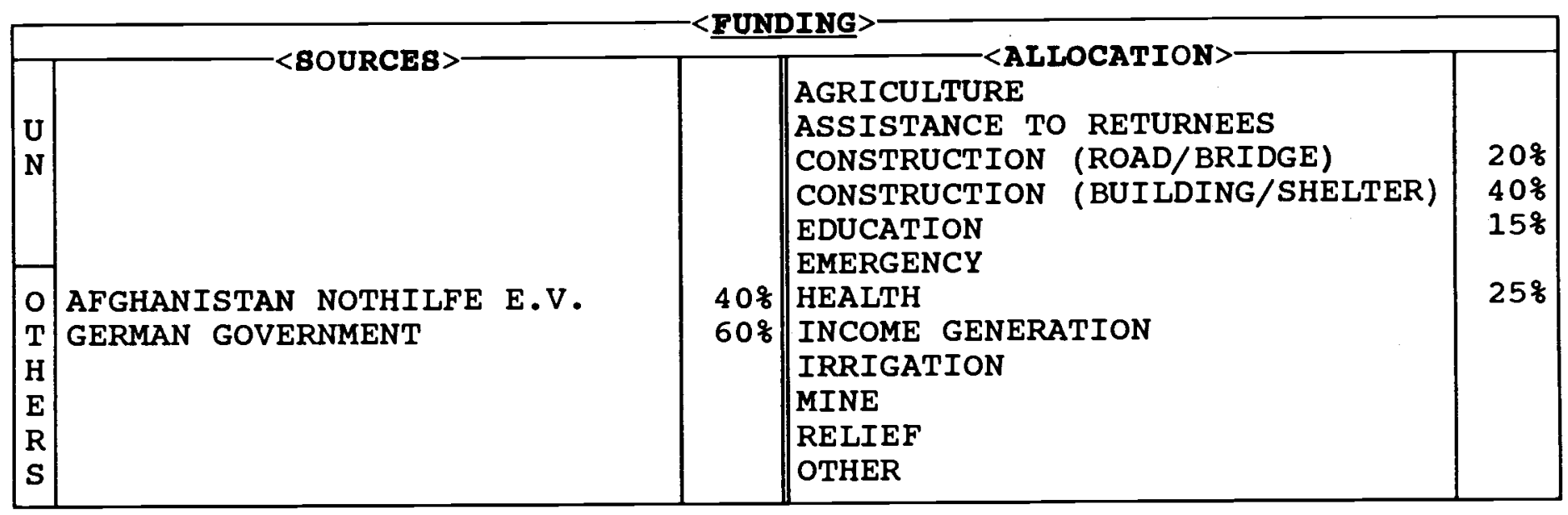

\begin{tabular}{|c|c|c|c|c|c|c|}
\hline $\begin{array}{l}\text { AFGHANISTAN: } \\
\text { REFUGEES : } \\
\text { T O T A L: }\end{array}$ & 1988 & 1989 & $\begin{array}{l}1990 \\
238,095 \\
104,762 \\
342,857\end{array}$ & $\begin{array}{l}\frac{1991}{238,095} \\
104,762 \\
342,857\end{array}$ & $\begin{array}{r}1992 \\
370,000 \\
65,000 \\
435,000\end{array}$ & $\begin{array}{r}1993 \\
3,000,000 \\
120,000 \\
3,120,000\end{array}$ \\
\hline 7 & 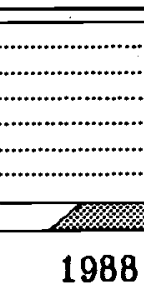 & 1989 & 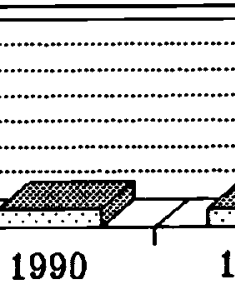 & $\ldots \cdots \cdots \cdots \cdots$ & $\begin{array}{l}\text { को } \\
1993\end{array}$ & (1) \\
\hline
\end{tabular}

\begin{tabular}{|c|c|c|c|c|c|}
\hline PROVINCES & SECTOR & \&AGE & PROVINCES & SECTOR & \&AGE \\
\hline $\begin{array}{l}\text { BADAKSHAN } \\
\text { BADGHIS } \\
\text { BAGHLAN } \\
\text { BALKH } \\
\text { BAMYAN } \\
\text { FARAH } \\
\text { FARYAB } \\
\text { GHAZNI } \\
\text { GHOR } \\
\text { HELMAND } \\
\text { HERAT } \\
\text { JAWZJAN } \\
\text { KABUL } \\
\text { KANDAHAR } \\
\text { KAPISA }\end{array}$ & 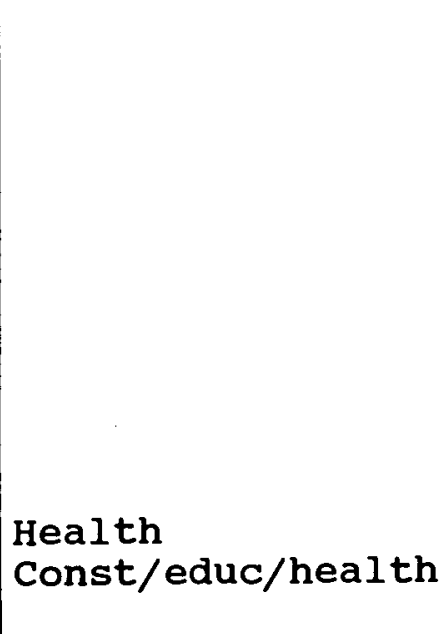 & $\begin{array}{l}10 \% \\
208\end{array}$ & $\begin{array}{l}\text { KUNAR } \\
\text { KUNDUZ } \\
\text { LAGHMAN } \\
\text { LOGAR } \\
\text { NANGARHAR } \\
\text { NIMROZ } \\
\text { ORUZGAN } \\
\text { PAKTEKA } \\
\text { PAKTIA } \\
\text { PARWAN } \\
\text { SAMANGAN } \\
\text { TAKHAR } \\
\text { WARDAK } \\
\text { ZABUL }\end{array}$ & $\begin{array}{l}\text { Const/health } \\
\text { Const } \\
\text { Const/health }\end{array}$ & $\begin{array}{l}20 \% \\
10 \% \\
40 \%\end{array}$ \\
\hline
\end{tabular}




\section{AFGHANI BTAN NOTHILFE e.V. (ANH)}

was founded in 1983 through the joint efforts of German and Afghan doctors. In 1987, ANH began administering to Afghans in Pakistan and Afghanistan. Its board of directors consists of members of political parties and medical specialists.

The medical services \& facilities of ANH consist of: an 80-bed hospital which was previously located in Peshawar but has now been shifted to Jalalabad; three primary health units at refugee camps in NWFP; a polyclinic with a training center in Quetta; BHUs in Kunar, Nangarhar and Kandahar provinces.

The hospital in Jalalabad offers surgical treatment, internal medicine, eye and dental treatment, x-ray, ultra-sound and laboratory facilities. Each month, approximately 150 surgical cases are admitted, and 300-350 patients are admitted in the hospital. More than 6000 patients are seen at the polyclinic. Since December 1988, the health units have rehabilitated between 800 to 1300 patients. Since 1983, ANH has sent 248 physically handicapped children to West Germany for appropriate treatment. The Ultrasound Examination Center was added to the clinic in 1989.

A milk distribution program has been undertaken.

In 1989 a 25-bed hospital was established in Kunar province which is a referral unit for 8 BHUs in different parts of the province.

Another 25-bed hospital plus 8 BHUs were set up in Kandahar in late 1990-early 1991.

During 1990, some young Afghan doctors who work inside Afghanistan were trained by German and Afghan specialists and sent back to their working areas.
Through the support of CARE, a German committee, Afghanistan Nothilfe provided one- and two-year medical nursing courses in Peshawar which graduated more than 600 male and female students. The courses in Peshawar have now ended, but a similar program in Quetta, which started in 1987, is still running. It has trained 400 pupils for working inside Afghanistan.

Each year the people of West Germany and their government contribute 8 to 9 million rupees and 1.5 million respectively. Since 1987, 96 German doctors and nurses have worked with Afghanistan Nothilfe.

Also in April 1992, a 30 bed hospital was established in Nangarhar province and another 10 bed hospital in Sarobi district of Kabul were set up.

During 1990/91 a secondary school and seven primary schools were established in Kandahar province.

Since August 1992, ANH has been implementing an intensive, food-forwork rehabilitation program with the cooperation of GTZ. Through this program, ANH reconstructs/ repairs public buildings, bridges and irrigation systems. Buildings of Nangarhar Lycee, Nursing School, Surkhrod Lycee, Medical University Hospital, Alayee Girls' High School, Kunar Public Health Hospital, Laghman Public Health Hospital, Mirwais Lycee and Arghandab Mechanic School in Kandahar. A number of houses for vulnerable groups (widows and orphans) has been reconstructed. Several canals in Surkhrod, Behsud, Karhala and Narang areas have been rehabilitated. Spin Boldak Bridge has been repaired. 


\begin{tabular}{|l|l|l|}
\hline 3 GULMOHAR RD, U/T, & PHONE: $45413 / 45406$ & <COMMUNICATION LINES \\
U P O BOX 991, & F A X: 840231 & 2. \\
PESHAWAR PAKISTAN & TELEX: & S. A. FARID MOSTAPHA \\
\hline
\end{tabular}

\begin{tabular}{|lr|lr|lr|}
\hline AFGHAN : & 56 & TECHNICAL: & 60 & PAK.BASED: & 73 \\
PAKISTANI : & - & ADMINISTRATIVE: & 3 & AFGHA.BASED: & - \\
EXPAT: & 17 & FIELD/SUPPORT S. & 10 & CROSS-BORDER: & - \\
TOTAL: & 73 & TOTAL: & 73 & TOTAL: & 73 \\
\hline
\end{tabular}

\begin{tabular}{|c|c|c|c|c|}
\hline \multicolumn{5}{|c|}{ 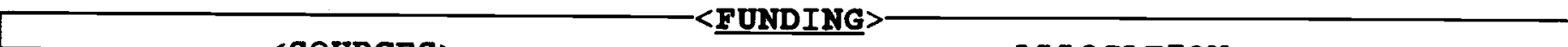 } \\
\hline $\begin{array}{l} \\
\mathrm{O} \\
\mathrm{T} \\
\mathrm{H} \\
\mathrm{E} \\
\mathrm{R} \\
\mathrm{S}\end{array}$ & $\begin{array}{l}\text { SAUDI ARABIA } \\
\text { PRIVATE DONATIONS }\end{array}$ & $\begin{array}{r}998 \\
18\end{array}$ & $\begin{array}{l}\text { AGRICULTURE } \\
\text { ASSISTANCE TO RETURNEES } \\
\text { CONSTRUCTION (ROAD/BRIDGE) } \\
\text { CONSTRUCTION (BUILDING/SHELTER) } \\
\text { EDUCATION } \\
\text { EMERGENCY } \\
\text { HEALTH } \\
\text { INCOME GENERATION } \\
\text { IRRIGATION } \\
\text { MINE } \\
\text { RELIEF } \\
\text { OTHER }\end{array}$ & $100 \%$ \\
\hline
\end{tabular}

\begin{tabular}{|c|c|c|c|c|c|c|}
\hline $\begin{array}{l}\text { AFGHANISTAN: } \\
\text { REFUGEES : } \\
\text { T O T A I: }\end{array}$ & 1988 & 1989 & $\begin{array}{l}\frac{1990}{1,400,000} \\
1,400,000\end{array}$ & $\begin{array}{l}\frac{1991}{20,000,000} \\
20,000,000\end{array}$ & $\begin{array}{l}\frac{1992}{20,000,000} \\
20,000,000\end{array}$ & $\begin{array}{l}1993 \\
350,000 \\
350,000\end{array}$ \\
\hline $\begin{array}{r}20 \\
16 \\
12 \\
8 \\
8\end{array}$ & 1988 & 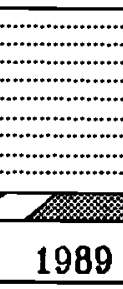 & 1900 & 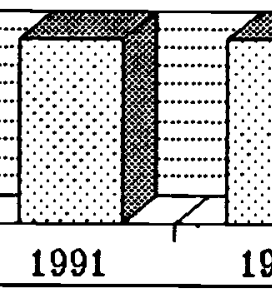 & / & (1) \\
\hline
\end{tabular}

\begin{tabular}{|c|c|c|c|c|c|}
\hline PROVINCES & SECTOR & \&AGE & PROVINCES & SECTOR & \&AGE \\
\hline $\begin{array}{l}\text { BADAKSHAN } \\
\text { BADGHIS } \\
\text { BAGHLAN } \\
\text { BALKH } \\
\text { BAMYAN } \\
\text { FARAH } \\
\text { FARYAB } \\
\text { GHAZNI } \\
\text { GHOR } \\
\text { HELMAND } \\
\text { HERAT } \\
\text { JAWZJAN } \\
\text { KABUL } \\
\text { KANDAHAR } \\
\text { KAPISA }\end{array}$ & & & \begin{tabular}{|l} 
KUNAR \\
KUNDUZ \\
LAGHMAN \\
LOGAR \\
NANGARHAR \\
NIMROZ \\
ORUZGAN \\
PAKTEKA \\
PAKTIA \\
PARWAN \\
SAMANGAN \\
TAKHAR \\
WARDAK \\
ZABUL
\end{tabular} & & \\
\hline
\end{tabular}



CONSULTANTS (ARCON)

opened its branch office in Peshawar in 1987.

As a donor and also implementor of its own projects, ARCON undertook a number of projects in rehabilitation and reconstruction of different sectors including education, health, agriculture, public buildings and irrigation systems. It also provided relief assistance on different occasions based on needs.

ARCON aims for an even distribution of projects relevant to province and population distribution. Provinces with fewer programs were given more priority.

During 1991 and 1992, ARCON provided financial support to more than 15 local NGOs who implemented hundreds of projects mainly in the sector of infrastructure, including construction of public buildings (mosques, schools, clinics, hospitals, etc.), road repair and irrigation systems rehabilitation. ARCON also provided funds to public institutions and invested money to restore governmental revenue making set-ups such as small industries and state farms.

For the time being, ARCON's rehabilitation activities inside Afghanistan have been suspended awaiting a more stable and secure situation in the country. However, it continues to support a university for Afghan refugees in Peshawar. 


\section{AFGHANISTAN RECONSTRUCTION AND PLANNING DEPARTMENT-ARPD}

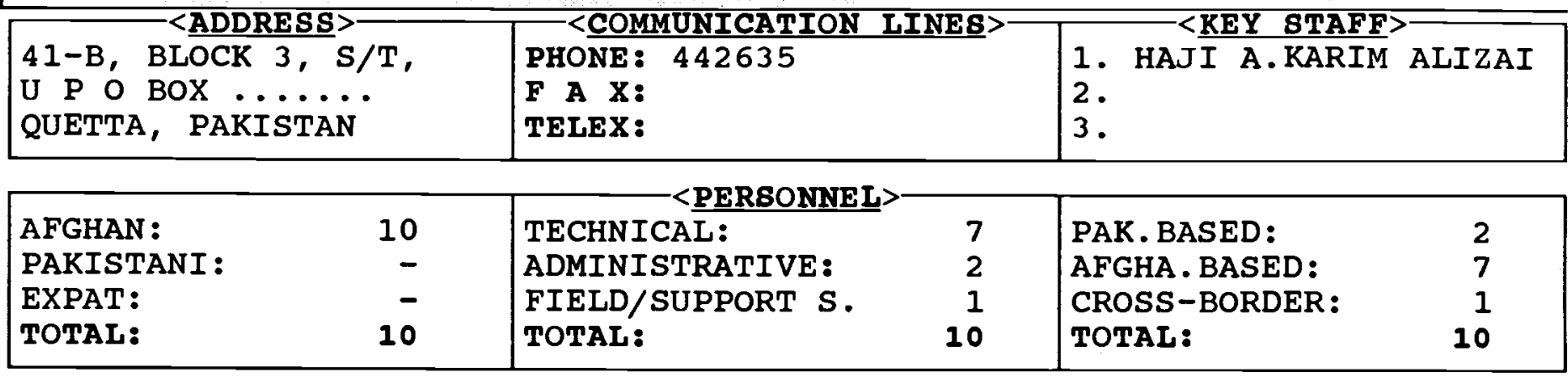

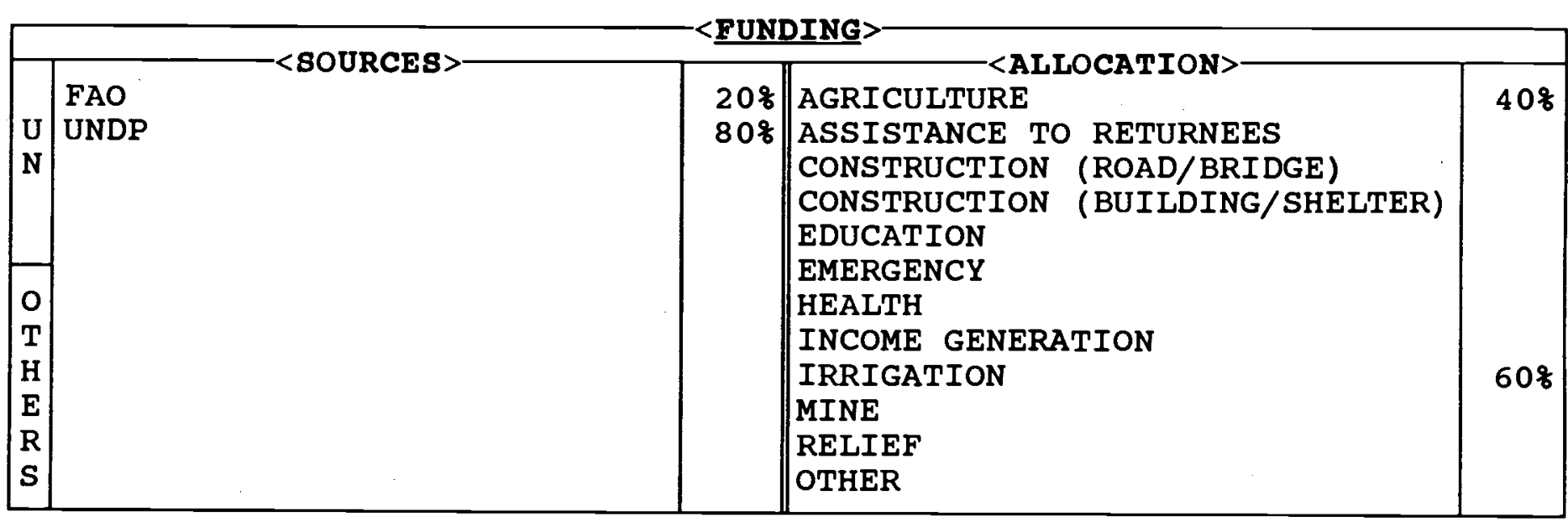

\begin{tabular}{|c|c|c|c|c|c|c|}
\hline $\begin{array}{l}\text { AFGHANISTAN: } \\
\text { REFUGEES : } \\
\text { T O T A L: }\end{array}$ & 1988 & 1989 & 1990 & 1991 & $\begin{array}{l}\frac{1992}{50,000} \\
50,000\end{array}$ & $\begin{array}{l}\frac{1993}{50,000} \\
50,000\end{array}$ \\
\hline 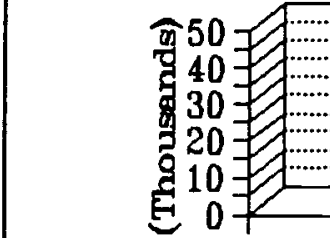 & 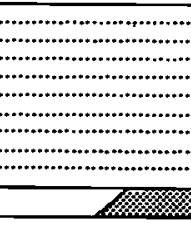 & 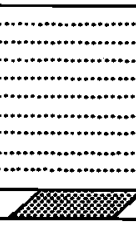 & ㅂ.t- & $\ldots$ & 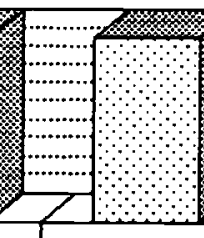 & (u) \\
\hline & 1988 & 1989 & 1990 & 1991 & 1993 & \\
\hline
\end{tabular}

\begin{tabular}{|c|c|c|c|c|c|}
\hline PROVINCES & SECTOR & \%AGE & PROVINCES & SECTOR & \&AGE \\
\hline $\begin{array}{l}\text { BADAKSHAN } \\
\text { BADGHIS } \\
\text { BAGHIAN } \\
\text { BALKH } \\
\text { BAMYAN } \\
\text { FARAH } \\
\text { FARYAB } \\
\text { GHAZNI } \\
\text { GHOR } \\
\text { HELMAND } \\
\text { HERAT } \\
\text { JAWZJAN } \\
\text { KABUL } \\
\text { KANDAHAR } \\
\text { KAPISA }\end{array}$ & Agr/irrign & 508 & $\begin{array}{l}\text { KUNAR } \\
\text { KUNDUZ } \\
\text { LAGHMAN } \\
\text { LOGAR } \\
\text { NANGARHAR } \\
\text { NIMROZ } \\
\text { ORUZGAN } \\
\text { PAKTEKA } \\
\text { PAKTIA } \\
\text { PARWAN } \\
\text { SAMANGAN } \\
\text { TAKHAR } \\
\text { WARDAK } \\
\text { ZABUL }\end{array}$ & & \\
\hline
\end{tabular}


AFGHANISTAN RECONSTRUCTION AND PLANNING DEPARTMENT (ARD)

is an Afghan NGO established in 1992. ARPD works in the sectors of agriculture and irrigation.

The organization gives more emphasis and importance on proper planning of projects in order to make sure that maximum benefit be obtained with the limited resources available. ARPD makes efforts to select its beneficiaries from amongst the most needy and vulnerable groups in the community. Involving the shuras, commanders and other influential people in the area ARPD has developed a system of work which relies mostly on the community participation and contribution.

Currently ARPD implements projects in the provinces of Helmand and Kandahar: 
AFGHANI BTAY REKABILITATION MND DEVELOPMENT PROGRAM-ARDP

\begin{tabular}{|c|c|c|c|c|c|}
\hline \multirow{2}{*}{\multicolumn{2}{|c|}{$\begin{array}{l}311 \text { GULHAJI PLAZA, } \\
\text { JAMROD RD, } \\
\text { PESHAWAR, PAKISTAN }\end{array}$}} & \multirow{2}{*}{\multicolumn{2}{|c|}{$\begin{array}{l}\text { CCOMMUNICATION LINES } \\
\text { PHONE: } 44750 \\
\text { F A X: } \\
\text { TELEX: }\end{array}$}} & \multirow{2}{*}{\multicolumn{2}{|c|}{$\begin{array}{l}\text { 1. ENG. ENAM WAK } \\
\text { 2. } \\
\text { 3. }\end{array}$}} \\
\hline & & & & & \\
\hline $\begin{array}{l}\text { AFGHAN : } \\
\text { PAKISTANI : } \\
\text { EXPAT: } \\
\text { TOTAL: }\end{array}$ & $\begin{array}{r}14 \\
1 \\
15\end{array}$ & $\begin{array}{l}\text { TECHNICAL: } \\
\text { ADMINISTRATIVE: } \\
\text { FIELD/SUPPORT S. } \\
\text { TOTAL: }\end{array}$ & $\begin{array}{r}6 \\
3 \\
6 \\
15\end{array}$ & $\begin{array}{l}\text { PAK. BASED: } \\
\text { AFGHA. BASED: } \\
\text { CROSS-BORDER: } \\
\text { TOTAL : }\end{array}$ & $\begin{array}{l}5 \\
- \\
10 \\
15\end{array}$ \\
\hline
\end{tabular}

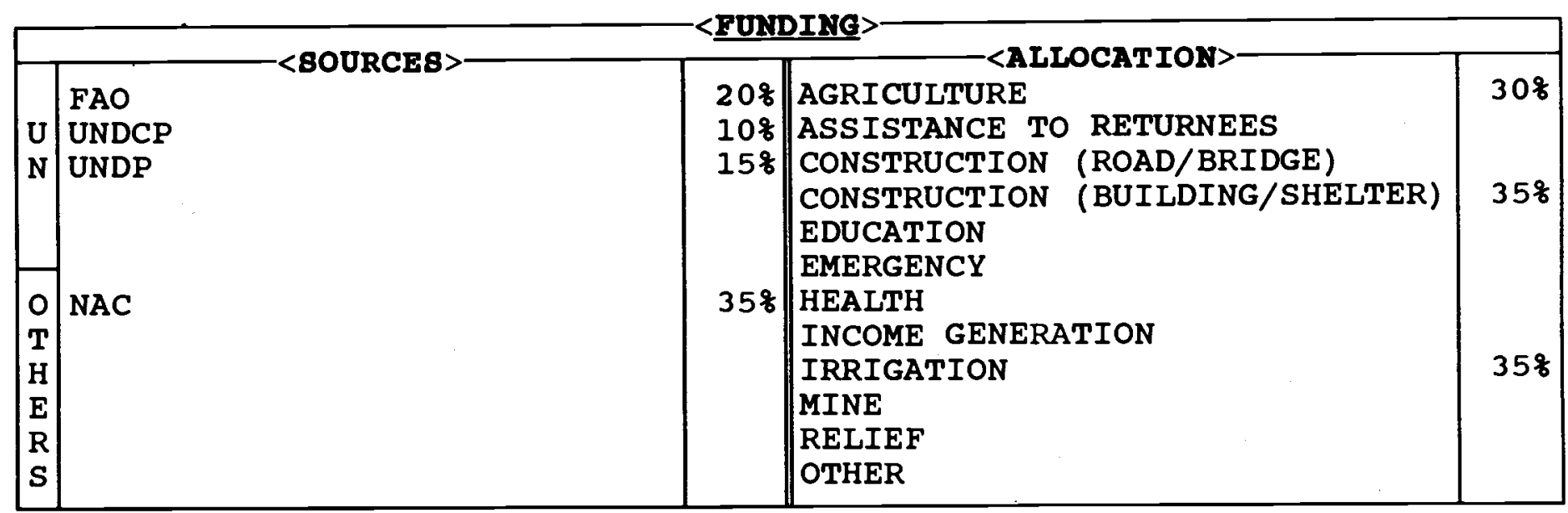

\begin{tabular}{|c|c|c|c|c|c|c|}
\hline & 1988 & 1989 & 1990 & 1991 & 1992 & 1993 \\
\hline $\begin{array}{l}\text { AFGHANISTAN : } \\
\text { REFUGEES : }\end{array}$ & & & 140,000 & $\bar{z}$ & 50,000 & 48,333 \\
\hline T O T A $\mathrm{L}:$ & & & 140,000 & - & 50,000 & 48,333 \\
\hline
\end{tabular}

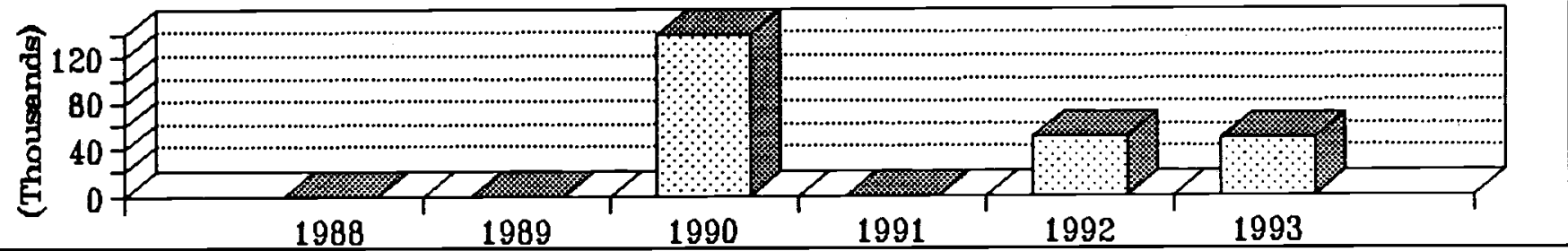

\begin{tabular}{|c|c|c|c|c|c|}
\hline PROVINCES & SECTOR & \&AGE & PROVINCES & SECTOR & \&AGE \\
\hline $\begin{array}{l}\text { BADAKSHAN } \\
\text { BADGHIS } \\
\text { BAGHLAN } \\
\text { BALKH } \\
\text { BAMYAN } \\
\text { FARAH } \\
\text { FARYAB } \\
\text { GHAZNI } \\
\text { GHOR } \\
\text { HELMAND } \\
\text { HERAT } \\
\text { JAWZJAN } \\
\text { KABUL } \\
\text { KANDAHAR } \\
\text { KAPISA }\end{array}$ & & & $\begin{array}{l}\text { KUNAR } \\
\text { KUNDUZ } \\
\text { LAGHMAN } \\
\text { LOGAR } \\
\text { NANGARHAR } \\
\text { NIMROZ } \\
\text { ORUZGAN } \\
\text { PAKTEKA } \\
\text { PAKTIA } \\
\text { PARWAN } \\
\text { SAMANGAN } \\
\text { TAKHAR } \\
\text { WARDAK } \\
\text { ZABUL }\end{array}$ & $\begin{array}{l}\text { Agr/irrign } \\
\text { Const }\end{array}$ & $\begin{array}{l}65 \% \\
35 \%\end{array}$ \\
\hline
\end{tabular}


is an Afghan non-governmental, nonpolitical and non-profit organization established in 1989.

The objective of the program is to take part in rehabilitation, reconstruction and development of war torn Afghanistan.

ARDP implements projects in the sectors of agriculture, irrigation rehabilitation and infrastructure reconstruction. It has distributed different varieties of improved wheat and maize seeds and DAP and urea fertilizers to farmers in Khogyani and sherzad districts of Nangarhar and in Pakteka province. Fruit trees have been distributed to farmers in Khogyani and surkhrod districts.

ARDP has also started rehabilitation programs in Khushamand area of Pakteka province.

Based on the surveys and assessments conducted by ARDP staff, project proposals have been prepared and submitted to different donor organizations in the sectors of irrigation, agriculture, health and training for previous and new target areas. 


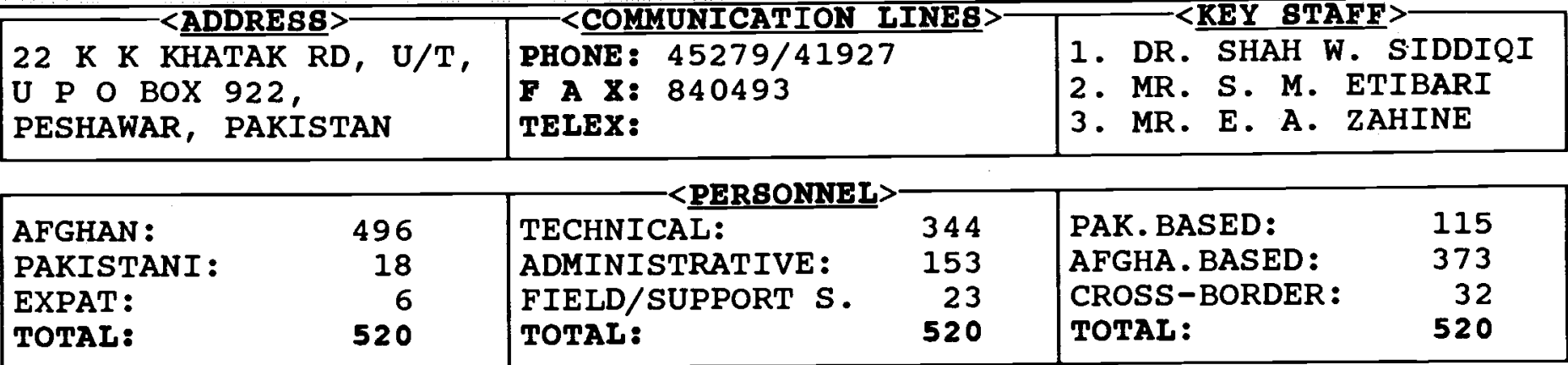

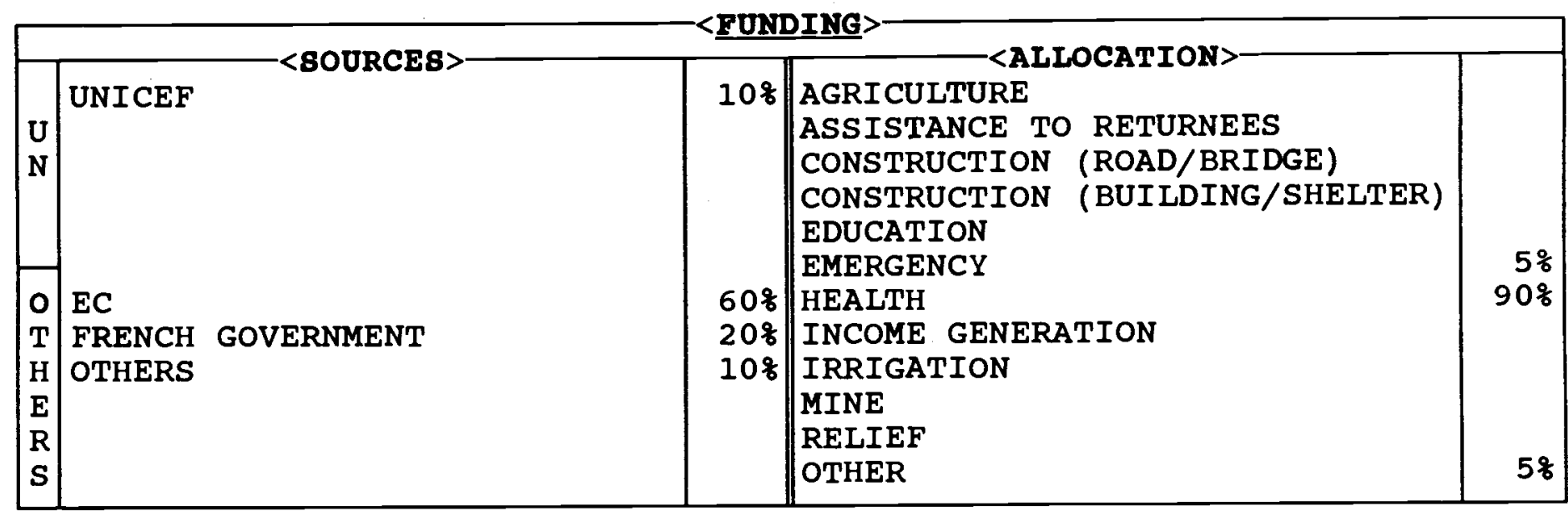

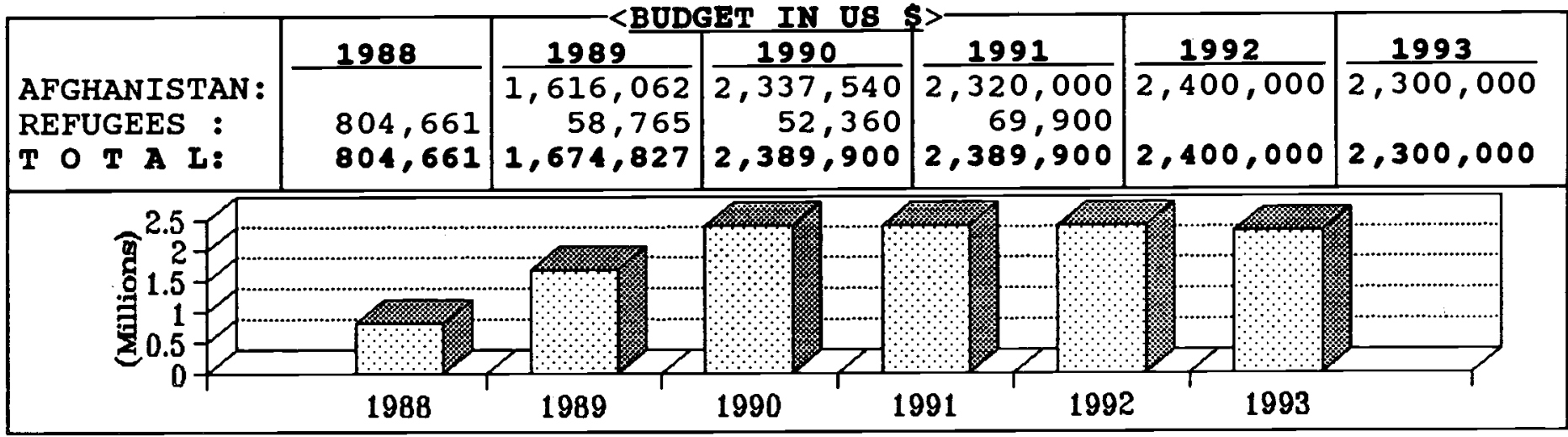

\begin{tabular}{|c|c|c|c|c|c|}
\hline PROVINCES & SECTOR & \&AGE & PROVINCES & SECTOR & $\% A G E$ \\
\hline $\begin{array}{l}\text { BADAKSHAN } \\
\text { BADGHIS } \\
\text { BAGHLAN } \\
\text { BALKH } \\
\text { BAMYAN } \\
\text { FARAH } \\
\text { FARYAB } \\
\text { GHAZNI } \\
\text { GHOR } \\
\text { HELMAND } \\
\text { HERAT } \\
\text { JAWZJAN } \\
\text { KABUL } \\
\text { KANDAHAR } \\
\text { KAPISA }\end{array}$ & $\begin{array}{l}\text { Health } \\
\text { Health } \\
\text { Health } \\
\text { Health } \\
\text { Health } \\
\text { Health } \\
\text { Health } \\
\\
\text { Health } \\
\text { Health } \\
\text { Health }\end{array}$ & $\begin{array}{r}6 \% \\
3 q \\
3 q \\
12 \% \\
\\
10 \% \\
2 \% \\
28 \\
\\
14 \% \\
6 \% \\
3 q\end{array}$ & \begin{tabular}{|l|} 
KUNAR \\
KUNDUZ \\
LAGHMAN \\
LOGAR \\
NANGARHAR \\
NIMROZ \\
ORUZGAN \\
PAKTEKA \\
PAKTIA \\
PARWAN \\
SAMANGAN \\
TAKHAR \\
WARDAK \\
ZABUL
\end{tabular} & $\begin{array}{l}\text { Health } \\
\text { Health } \\
\text { Health } \\
\text { Health } \\
\text { Health } \\
\text { Health } \\
\text { Health } \\
\text { Health } \\
\text { Health }\end{array}$ & $\begin{array}{r}5 \% \\
3 \% \\
4 \% \\
4 \% \\
4 \% \\
10 \% \\
2 \%\end{array}$ \\
\hline
\end{tabular}


AFGHANISTAN VACCINATION AND IMMUNIZATION CENTER (AVICEN)

has its main operational of fices in Peshawar, its Headquarters in Marseilles, France and Regional Delegations combined with vaccine Storage Facilities in 18 provinces throughout Afghanistan.

The organization was created in 1987 and its goal is the immunization of children under two against the six target diseases, i.e. tuberculosis, tetanus, polio, diphtheria, measles and whooping cough, and the immunization of women of child bearing age against neonatal tetanus.

AVICEN trains vaccinators for its own program, and for other NGOS working in Expanded Program of Immunization, in its two training centers: one in Band-e-Sarde, Ghazni province and one in Peshawar. 258 vaccinators selected from their home areas have been trained and work in those areas.

They work in mobile teams and travel throughout their areas; They are delivering the inhabitants with vaccine and information on the six above mentioned target diseases. Regional supervisors assess the work done by the vaccination teams and bring the vaccine and equipment supplies to the teams from the Vaccine storage Facilities (VSF). The teams are supported by a network of cold chain technicians, logistics personnel, administrators and medical doctors. AVICEN delivers training courses for cold chain technicians and repair technicians as well. A course for upgrading 14 vaccinators to middle level health workers is in process in fall 1993.

The essential component of a vaccination program is the quality of the vaccine. vaccines are fragile and the storage temperature is very important. To increase the efficiency of the cold chain and of the teams, Vaccine storage Facilities (VSFs) have been set up in different parts of the country. The supply is made from Peshawar, to the zonal store in Band-e-Sarde and then to the VSFs.

AVICEN/IBN SINA as it has been called since May 1993, with an Afghan Direction of 3 members (General Director, Administration Director and Program Director), Signed a collaboration agreement with the ministry of Public Health of the Islamic State of Afghanistan in July 1993 and will offer its expertise and know-how in technical assistance, training, information service and supervision to the MOPH. An office was opened in Kabul in summer 1993 to coordinate with the MOPH .

AVICEN/IBN SINA will continue its immunization program throughout Afghanistan in the rural areas and in coordination with other NGOs and MOPH work in urban areas, the final goal being the institutionalization of EPI is to facilitate the take over by the Afghan Government. 
AFGHANS' HEALTH \& SOCIAL ASSISTANCE ORGANIZATION-AHSAO

\begin{tabular}{|c|c|c|}
\hline <ADDRESS $>$ & $=<$ COMMUNICATION LINES $>$ & $\overline{2}<\underline{\text { KEY STAFF }}>-$ \\
\hline $\begin{array}{l}\text { 1426-T OLD BARA RD, U/T } \\
\text { U P O BOX 753, } \\
\text { PESHAWAR, PAKISTAN }\end{array}$ & $\begin{array}{l}\text { PHONE : } 42152 / 45577 \\
\text { F A X: } \\
\text { TELEX: }\end{array}$ & $\begin{array}{l}\text { 1. MR. MOHD WASIM LUDIN } \\
2 . \\
3 .\end{array}$ \\
\hline
\end{tabular}

\begin{tabular}{|lc|lc|ll|}
\hline AFGHAN : & 103 & TECHNICAL: & & PAK.BASED: \\
PAKISTANI : & 4 & ADMINISTRATIVE : & $\cdot$ & AFGHA.BASED: \\
EXPAT: & - & FIELD/SUPPORT S. &. & CROSS-BORDER: \\
TOTAL: & 107 & TOTAL: & 103 & TOTAL: & 103 \\
\hline
\end{tabular}

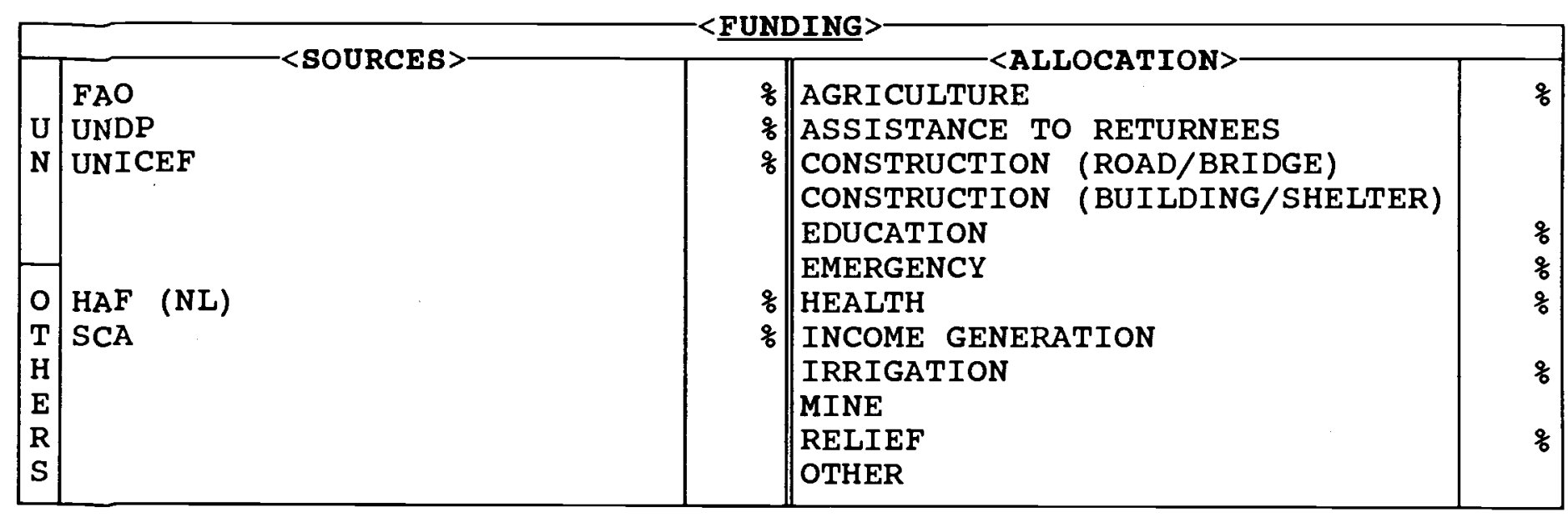

\begin{tabular}{|c|c|c|c|c|c|c|}
\hline & 1988 & 1989 & 1990 & 1991 & 1992 & 1993 \\
\hline AFGHANISTAN : & 1,664 & 178,423 & 22,660 & 29,871 & 45,004 & 119,660 \\
\hline REFUGEES : & 430,127 & 415,075 & 407.675 & 388,530 & 333,883 & 244,400 \\
\hline T O T A L: & 431,791 & 593,498 & 430,335 & 418,401 & 378,887 & 364,060 \\
\hline
\end{tabular}

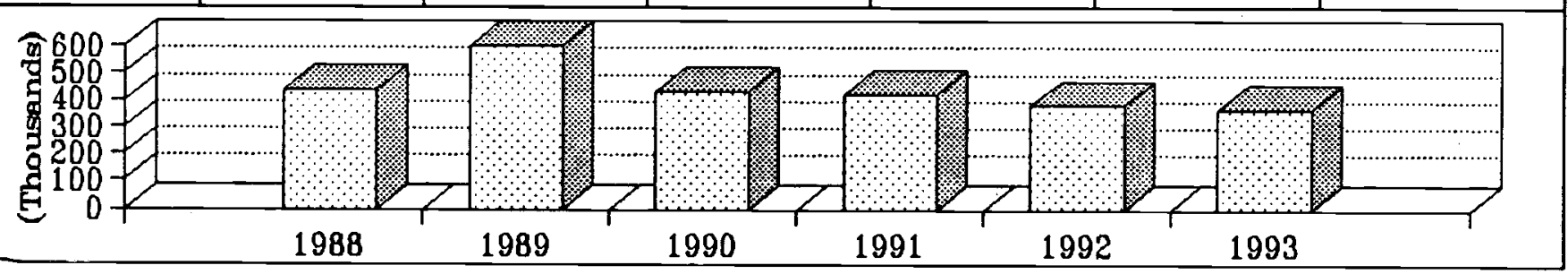

\begin{tabular}{|c|c|c|c|c|c|}
\hline PROVINCES & SECTOR & \&AGE & PROVINCES & SECTOR & \&AGE \\
\hline $\begin{array}{l}\text { BADAKSHAN } \\
\text { BADGHIS } \\
\text { BAGHLAN } \\
\text { BALKH } \\
\text { BAMYAN } \\
\text { FARAH } \\
\text { FARYAB } \\
\text { GHAZNI } \\
\text { GHOR } \\
\text { HELMAND } \\
\text { HERAT } \\
\text { JAWZJAN } \\
\text { KABUL } \\
\text { KANDAHAR } \\
\text { KAPFSA }\end{array}$ & & & $\begin{array}{l}\text { KUNAR } \\
\text { KUNDUZ } \\
\text { LAGHMAN } \\
\text { LOGAR } \\
\text { NANGARHAR } \\
\text { NIMROZ } \\
\text { ORUZGAN } \\
\text { PAKTEKA } \\
\text { PAKTIA } \\
\text { PARWAN } \\
\text { SAMANGAN } \\
\text { TAKHAR } \\
\text { WARDAK } \\
\text { ZABUL }\end{array}$ & $\begin{array}{l}\text { Health } \\
\text { Agr } \\
\text { Agr/health/irrign } \\
\text { Health }\end{array}$ & $\begin{array}{l}q \\
q \\
q\end{array}$ \\
\hline
\end{tabular}


AFGHANS ' HEALTH/SOCIAL ASSISTANCE ORGANIZATION (AHSAO)

was organized in June 1985 to meet the various health and education needs of Afghan Refugees. In Peshawar, a children's clinic with an OPD and a 40-bed IPD provides a broad range of services for children as well as for adults.

The out-patient department of the children's unit examines, diagnoses and treats mild to severe disorders and diseases through its following programs :

Malnutrition.

Malnourished children are treated, issued food and given health education.

Special care for children who need continuous/prolonged medical care for illnesses such as polio, epilepsy, diabetes, asthma and blood problems.

Vaccination. Afghan children and their mothers are provided with all vaccines.

TB. In this department male and female adults and children suffering from $T B$ are examined and treated.

Health Education. A health educator works with two groups of 20 women each day for 45minute periods, teaching hygiene, sanitation, nutrition, treatment of diarrhoea and communicable diseases. Also in the in-patient department, a health educator teaches mothers about the prevention/treatment of diarrhoea and dehydration including the use of oral Rehydration Therapy (ORT), hygiene, vaccination, nutrition and general health care. Daily demonstrations are held to teach mothers how to prepare nutritious meals using ingredients available at low cost.

ORT Corner. It has been set up in an attempt to teach mothers the importance of replacing fluid as a life-saving measure in the prevention/treatment of dehydration. A fresh container of ORS (UNICEF formula) is prepared everyday and mothers are encouraged to use the fluid as a vital part of child's therapy.

When treatment is not possible in the OPD, children are admitted for extended care in the IPD.

Two BHUs operate in Aza Khel camp, in which, between 300-400 patients (male, female and children) are treated daily. The same range of health care services are offered in the BHUs as are in the children's clinic. In addition, there is a malaria control program and a mobile vaccination team attached to the units. In the past, AHSAO ran 16 clinics in Nangarhar and Kunar Provinces.

A TBA Training Program has been started in Aza Khel to train Afghan women. After training, these women work in Aza Khel. 221 women have been trained so far. other education programs include one primary school in Pakistan in Badaber near Badaber scheme.

An EPI program has been undertaken in the following three provinces of Afghanistan:

Chawki district of Kunar. Surkhrod, Mohmand Dara, Goshta and Kama areas of Nangarhar. Khost.

A team, (5 vaccinators $+a$ team leader) operates in each area.

The following agricultural projects are ongoing:
Field
Nangarhar.
Crops
in Goshta,
Reforestation in Jaji, Paktia. Nurseries in Khogyani, in Siraj-ul-Emarat garden, Jalalabad, Nangarhar and Tani, Paktia. 
AGENCY FOR FARMING SUPPORT-AFS

\begin{tabular}{|l|l|l|}
\hline 133, GULHAJI PLAZA & PHONE: & <COMMUNICATION LINES \\
G P O BOX 615 & F A X: & 1. MR. ABDUL STAFF $>$ AZIZ \\
PESHAWAR, PAKISTAN & TELEX: & 2. MR. GUL A. HOSHMAND \\
\hline
\end{tabular}

\begin{tabular}{|lr|lr|lr|}
\hline AFGHAN : & 17 & TECHNICAL: & 12 & PAK. BASED: & 7 \\
PAKISTANI: & - & ADMINISTRATIVE: & 3 & AFGHA.BASED: & 9 \\
EXPAT: & - & FIELD/SUPPORT S. & 2 & CROSS-BORDER: & 1 \\
TOTAL: & 17 & TOTAL: & 17 & TOTAL: & 17 \\
\hline
\end{tabular}

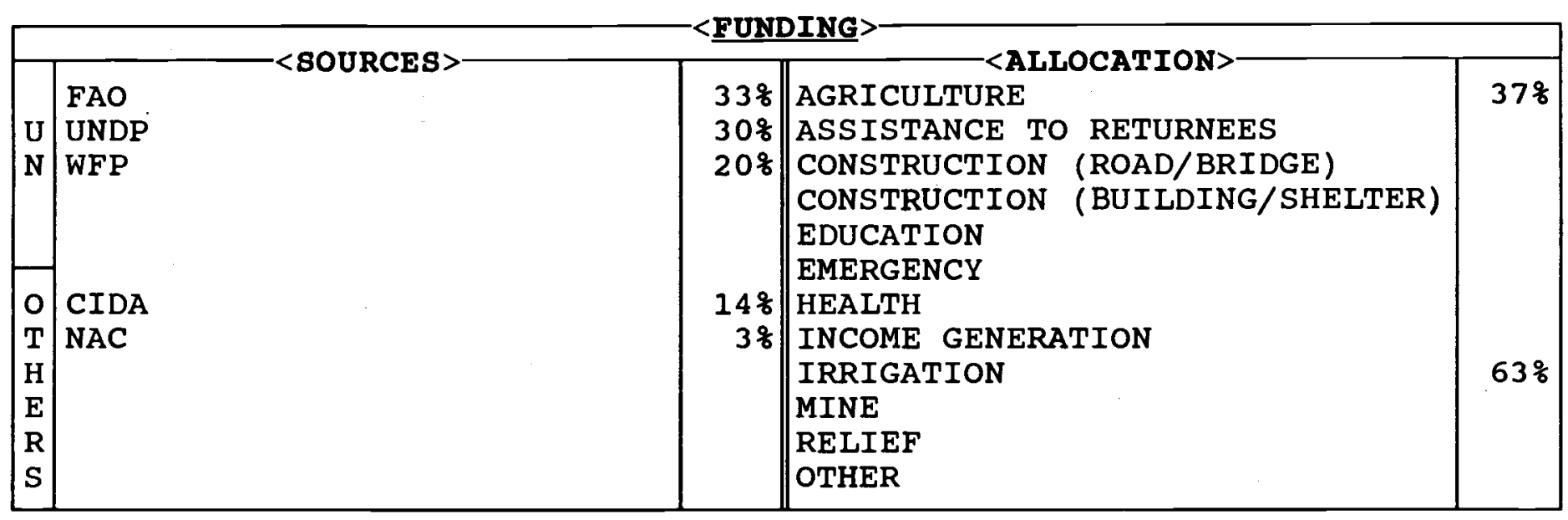

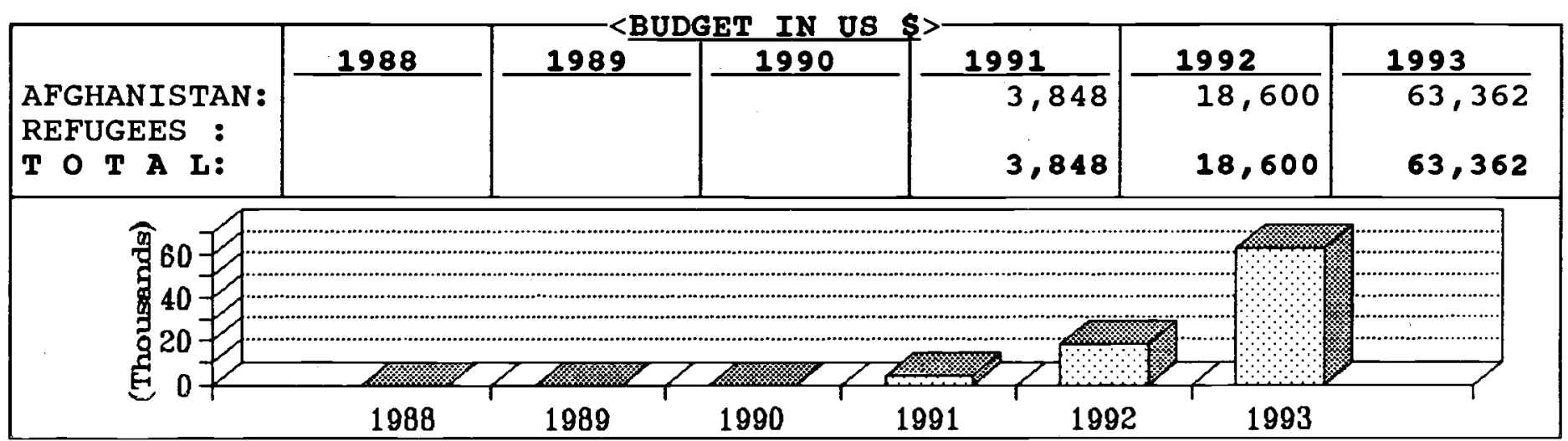

\begin{tabular}{|c|c|c|c|c|c|}
\hline PROVINCES & SECTOR & \% $\mathrm{AGE}$ & |PROVINCES & SECTOR & $\% A G E$ \\
\hline $\begin{array}{l}\text { BADAKSHAN } \\
\text { BADGHIS } \\
\text { BAGHLAN } \\
\text { BALKH } \\
\text { BAMYAN } \\
\text { FARAH } \\
\text { FARYAB } \\
\text { GHAZNI } \\
\text { GHOR } \\
\text { HELMAND } \\
\text { HERAT } \\
\text { JAWZJAN } \\
\text { KABUL } \\
\text { KANDAHAR } \\
\text { KAPISA }\end{array}$ & $\begin{array}{l}\text { Agr/irrign } \\
\text { Agr }\end{array}$ & $\begin{array}{l}53 \% \\
16 \%\end{array}$ & \begin{tabular}{|l} 
KUNAR \\
KUNDUZ \\
LAGHMAN \\
LOGAR \\
NANGARHAR \\
NIMROZ \\
ORUZGAN \\
PAKTEKA \\
PAKTIA \\
PARWAN \\
SAMANGAN \\
TAKHAR \\
WARDAK \\
ZABUL
\end{tabular} & \begin{tabular}{|l} 
Agr \\
Agr/irrign
\end{tabular} & $27 \%$ \\
\hline
\end{tabular}


is an Afghan voluntary organization which has no affiliation with any political party. Its sole objective is to take an active role in reconstruction and rehabilitation of war ravaged Afghanistan by providing agricultural, construction and educational services, technical advice and relief assistance to deserving farming families.

AFS undertakes planning, designing and execution of projects with the aim of helping the farmers to help themselves through individual and community participation.

Among the agricultural services AFS has been providing and will provide in the future are provision of improved seeds, fertilizers, fruit tree saplings, relief goods and agro-chemical. Meanwhile, restoration of damaged infrastructure $i . e$. roads leading to farming communities, irrigation channels and educational programs, especially for women and adult men have also been the priorities.

The target provinces for AFS are: Kabul and its surrounding districts, Ghazni, Laghman, Nangarhar, Logar, Pakteka, Paktia and northern provinces of Afghanistan. This is because AFS professional staff are originally from these provinces and they are well familiar with the local set ups, influential and physical environments.

There are some qualified and experienced engineers and agriculturists working with AFS who have ability to implement projects inside Afghanistan.

A total of 13 projects has so far been successfully completed; 11 project proposals have been submitted to donor organizations for funding and 14 more projects are in the planning stage. 
AGENCY FOR REHABILITATION ASSISTANCE \& DEVELOPMENT OF AFGHANIGTAN-ARADA

\begin{tabular}{|c|c|c|c|c|}
\hline $\begin{array}{l}2 \text { CANAL BADDRESS }> \\
\text { GANK RD, U/T } \\
\text { G P O BOX } 644 \\
\text { PESHAWAR, PAKISTAN }\end{array}$ & $\begin{array}{l}\text { <COMMUNICATION } \\
\text { PHONE: } 45256 \\
\text { F A X: } \\
\text { TELEX: }\end{array}$ & 887 & $\begin{array}{l}\text { 1. MR. MOHD I } \\
\text { 2. ENG. MOHD N } \\
\text { 3. MR. AHMAD }\end{array}$ & \\
\hline $\begin{array}{l}\text { AFGHAN : } \\
\text { PAKISTANI : } \\
\text { EXPAT : } \\
\text { TOTAL: }\end{array}$ & $\begin{array}{l}\text { TECHNICAL: } \\
\text { ADMINISTRATIVE: } \\
\text { FIELD/SUPPORT S. } \\
\text { TOTAL: }\end{array}$ & $\begin{array}{l}3 \\
2 \\
3 \\
8\end{array}$ & $\begin{array}{l}\text { PAK. BASED: } \\
\text { AFGHA. BASED: } \\
\text { CROSS-BORDER: } \\
\text { TOTAL: }\end{array}$ & $\begin{array}{l}5 \\
3 \\
- \\
8\end{array}$ \\
\hline
\end{tabular}

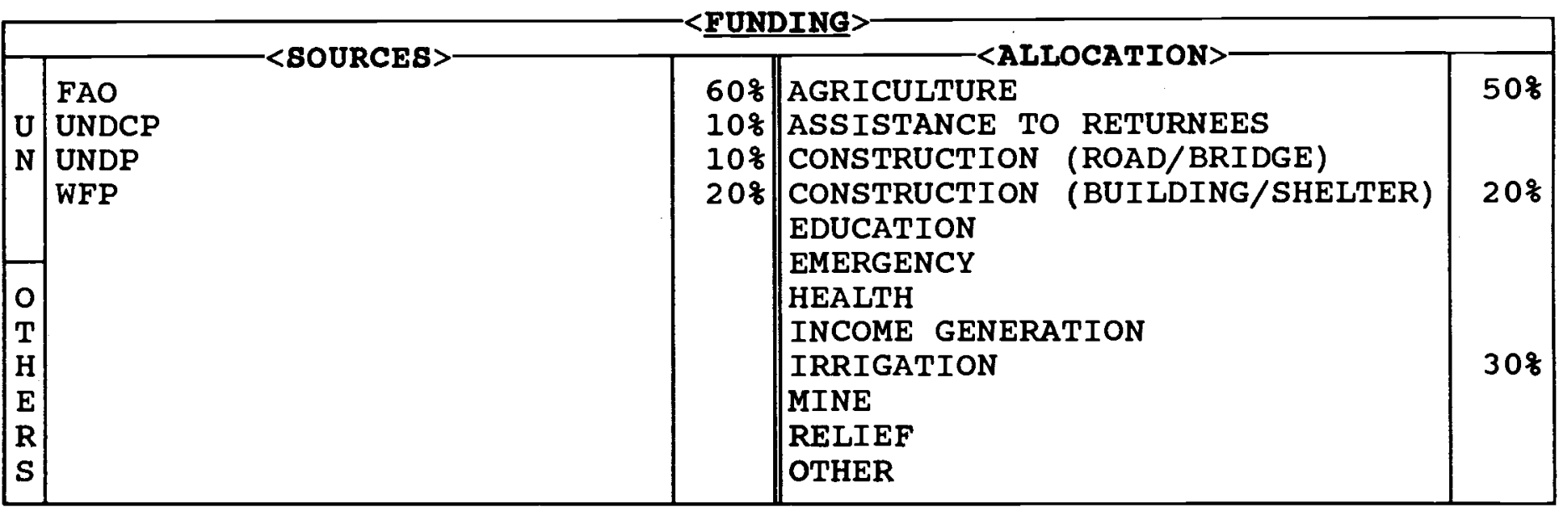

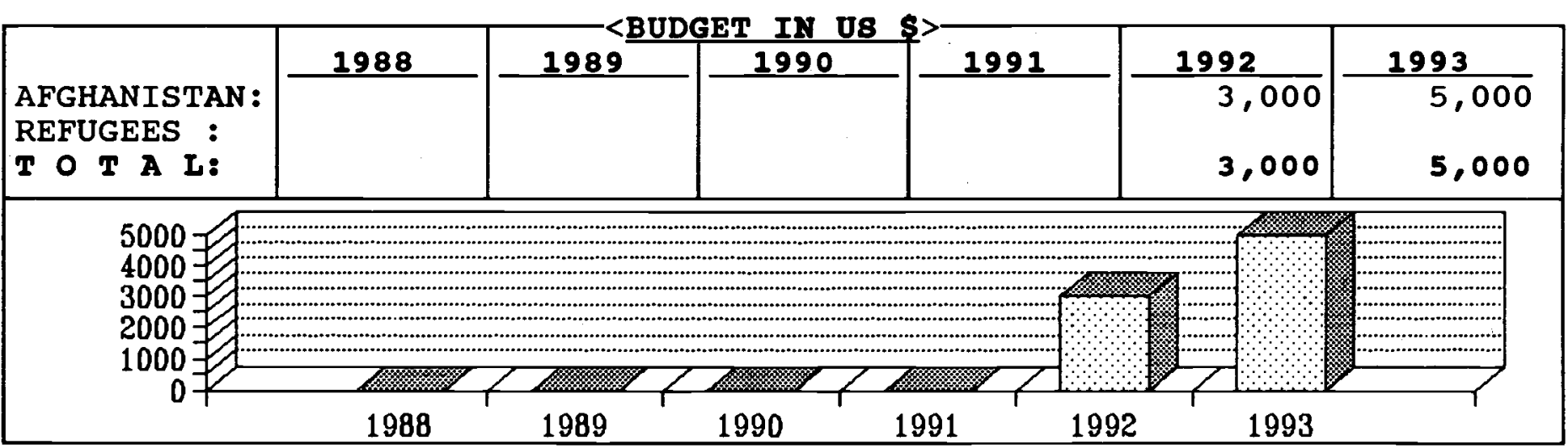

\begin{tabular}{|c|c|c|c|c|c|}
\hline PROVINCES & SECTOR & \&AGE & PROVINCES & SECTOR & \&AGE \\
\hline $\begin{array}{l}\text { BADAKSHAN } \\
\text { BADGHIS } \\
\text { BAGHLAN } \\
\text { BALKH } \\
\text { BAMYAN } \\
\text { FARAH } \\
\text { FARYAB } \\
\text { GHAZNI } \\
\text { GHOR } \\
\text { HELMAND } \\
\text { HERAT } \\
\text { JAWZJAN } \\
\text { KABUL } \\
\text { KANDAHAR } \\
\text { KAPISA }\end{array}$ & & & \begin{tabular}{|l} 
KUNAR \\
KUNDUZ \\
LAGHMAN \\
LOGAR \\
NANGARHAR \\
NIMROZ \\
ORUZGAN \\
PAKTEKA \\
PAKTIA \\
PARWAN \\
SAMANGAN \\
TAKHAR \\
WARDAK \\
ZABUL
\end{tabular} & $\begin{array}{l}\text { Agr } \\
\text { Agr/const/irrign } \\
\text { Agr }\end{array}$ & $\begin{array}{l}20 \% \\
60 \%\end{array}$ \\
\hline
\end{tabular}




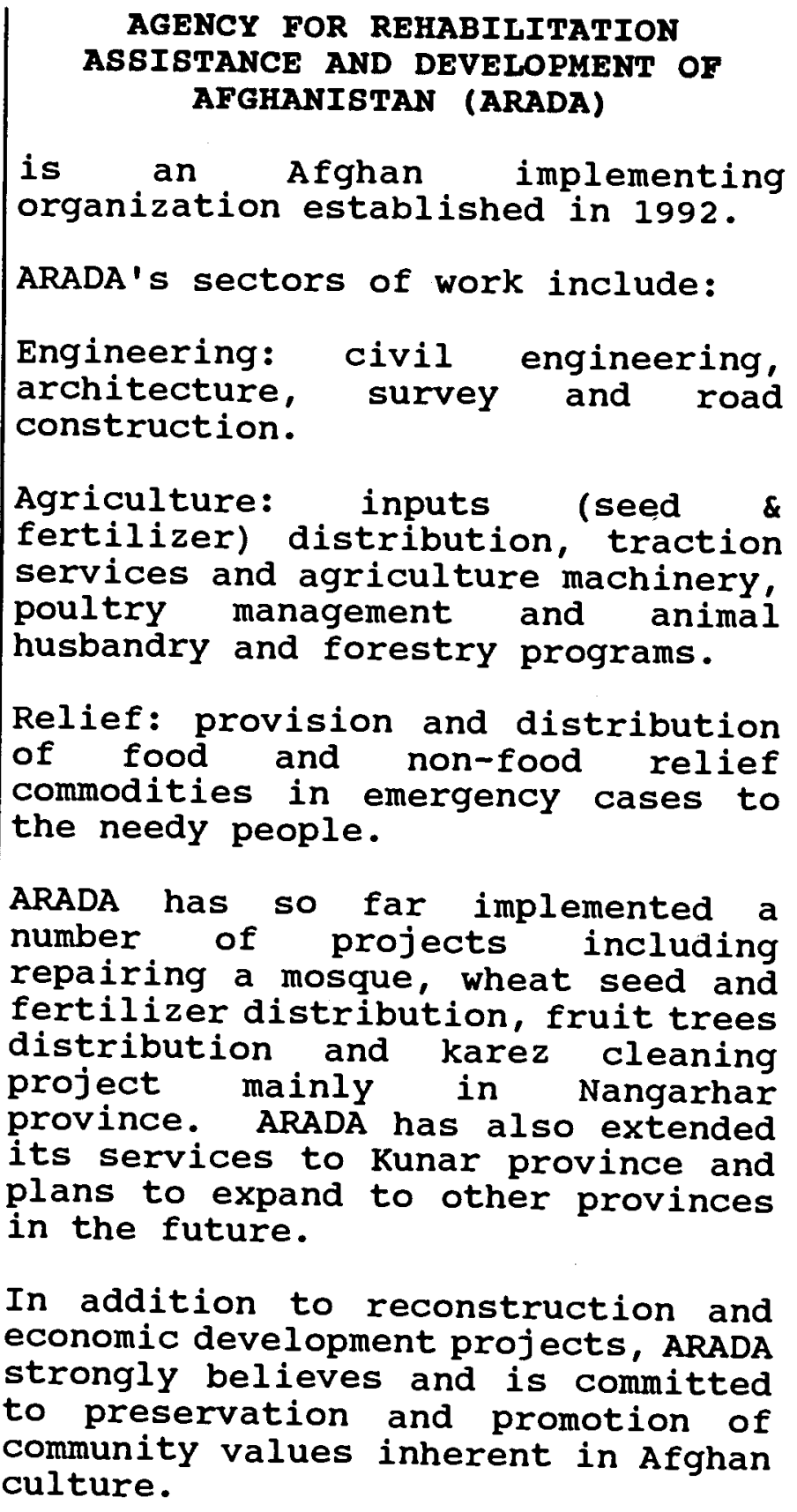


AGENCY FOR REHABILITATION AND RECONSTRUCTION OF AFGHANISTAN-ARRA

\begin{tabular}{|l|l|l|l}
\hline $618-A$, BLOCK 3, S.TOWN & PHONE: 41143 & 1. MR. H. TOKHI
\end{tabular}

$P$ O BOX 452

QUETTA, PAKISTAN

F A X:

TELEX:
1. MR. H. TOKHI
2. ENG. MOHD YOUNUS

3. MR. GHULAM FAROOQ

\begin{tabular}{|lr|lr|lr|}
\hline AFGHAN: & 40 & TECHNICAL: & 38 & PAK.BASED: & 5 \\
PAKISTANI : & 1 & ADMINISTRATIVE: & 2 & AFGHA.BASED: & 36 \\
EXPAT: & - & FIELD/SUPPORT S. & 1 & CROSS-BORDER: & - \\
TOTAL: & 41 & TOTAL: & 41 & TOTAL: & 41 \\
\hline
\end{tabular}

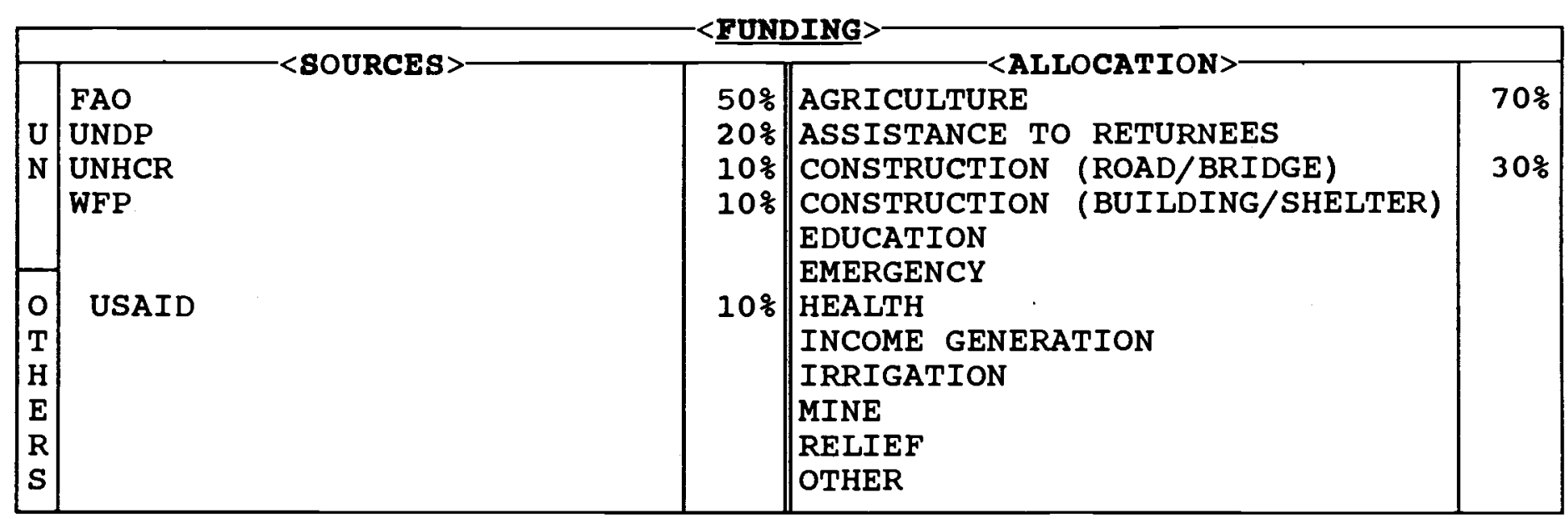

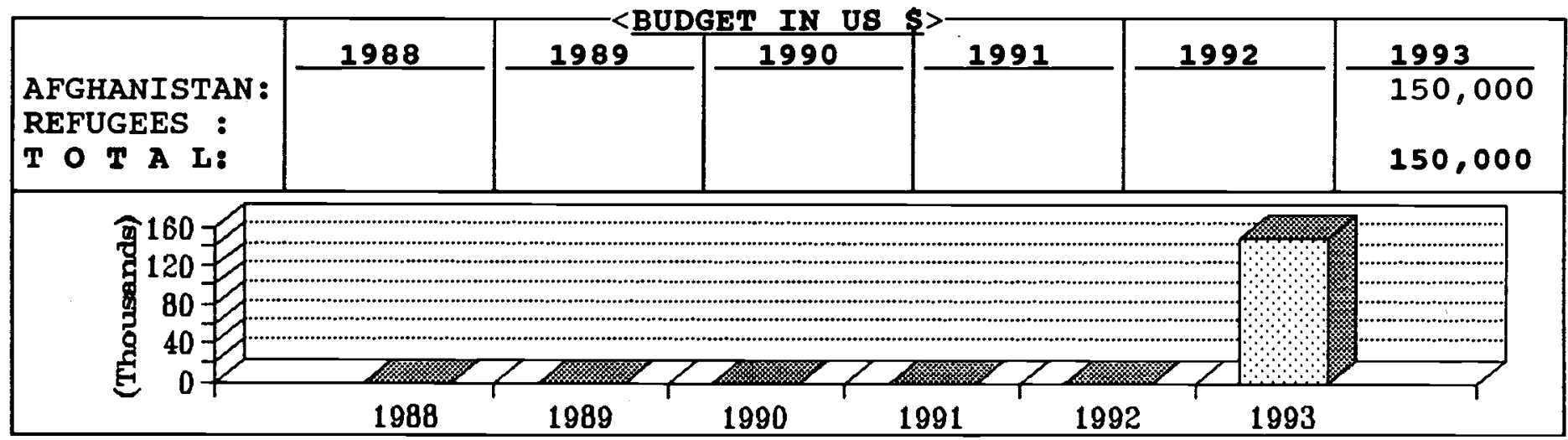

\begin{tabular}{|c|c|c|c|c|c|}
\hline PROVINCES & SECTOR & \&AGE & PROVINCES & SECTOR & \%AGE \\
\hline $\begin{array}{l}\text { BADAKSHAN } \\
\text { BADGHIS } \\
\text { BAGHLAN } \\
\text { BALKH } \\
\text { BAMYAN } \\
\text { FARAH } \\
\text { FARYAB } \\
\text { GHAZNI } \\
\text { GHOR } \\
\text { HELMAND } \\
\text { HERAT } \\
\text { JAWZJAN } \\
\text { KABUL } \\
\text { KANDAHAR } \\
\text { KAPISA }\end{array}$ & & & $\begin{array}{l}\text { KUNAR } \\
\text { KUNDUZ } \\
\text { LAGHMAN } \\
\text { LOGAR } \\
\text { NANGARHAR } \\
\text { NIMROZ } \\
\text { ORUZGAN } \\
\text { PAKTEKA } \\
\text { PAKTIA } \\
\text { PARWAN } \\
\text { SAMANGAN } \\
\text { TAKHAR } \\
\text { WARDAK } \\
\text { ZABUL }\end{array}$ & Agr/const & $100 \%$ \\
\hline
\end{tabular}


AGENCY FOR REHABILITATION AND RECONSTRUCTION OF AFGHANISTAN (ARRA)

is an Afghan nongovernmental organization founded on 1 october 1991. It took over the catholic Relief services (CRS) agricultural facilities and activities.

ARRA' areas of work are agriculture, veterinary, irrigation and housing. Currently, the agency is operational in six districts of kabul province. If the situation allows and funds are available, it plans to expand the activities to other provinces of Afghanistan.

The agency has a veterinary project in zabul province where one doctor, seven paravets and 23 BOWs are working. The project covers the whole province. 
AGENCY FOR RURAL DEVELOPMENT OF AFGHAHI STAN-ARDA

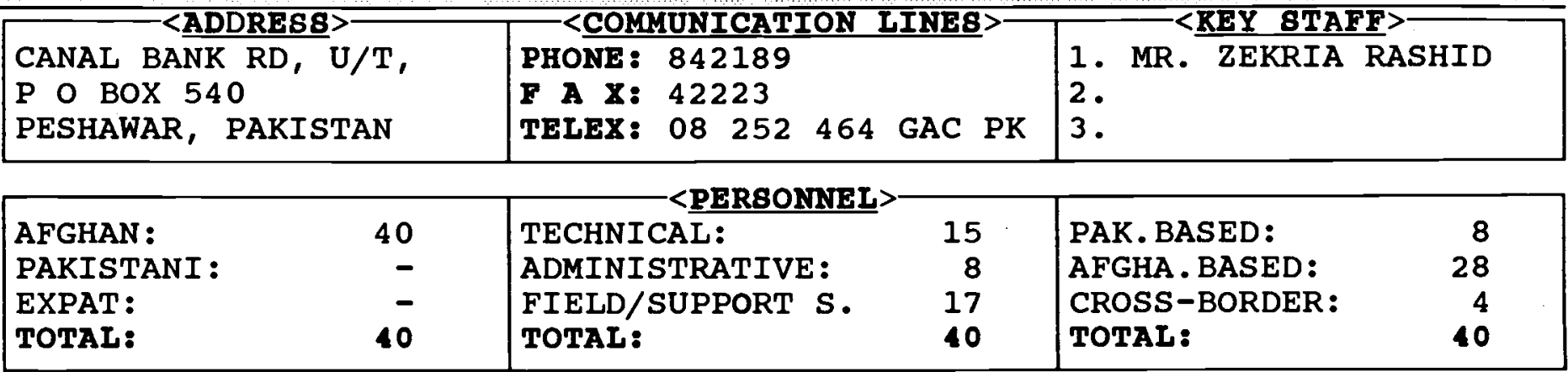

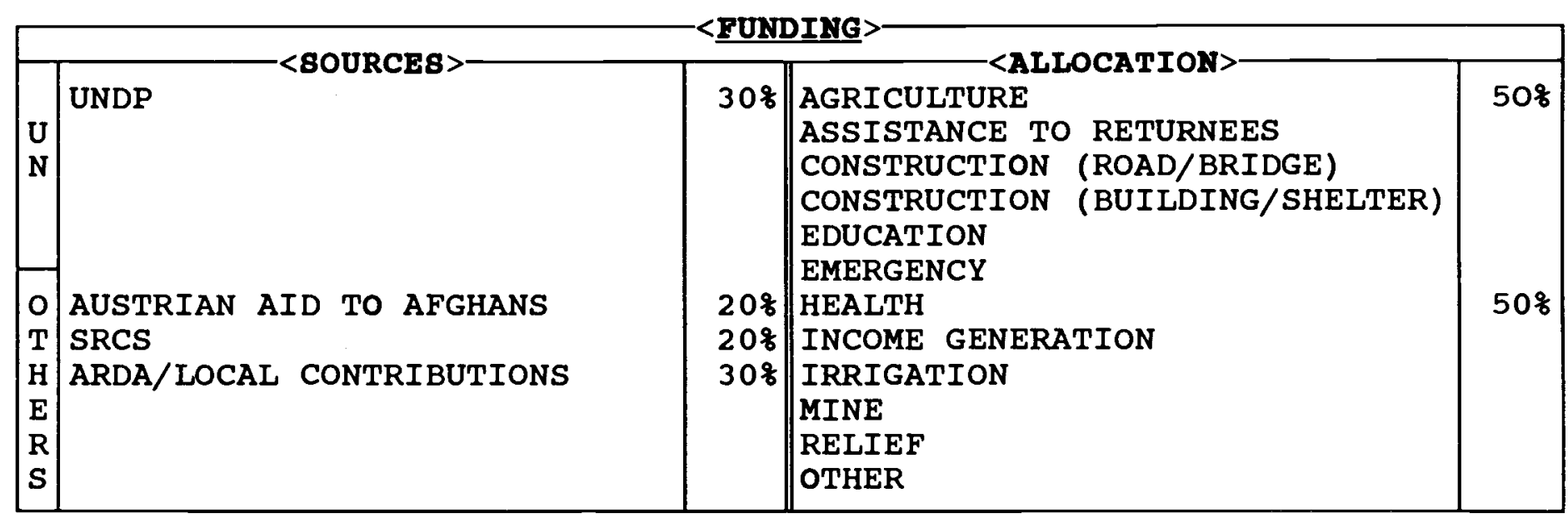

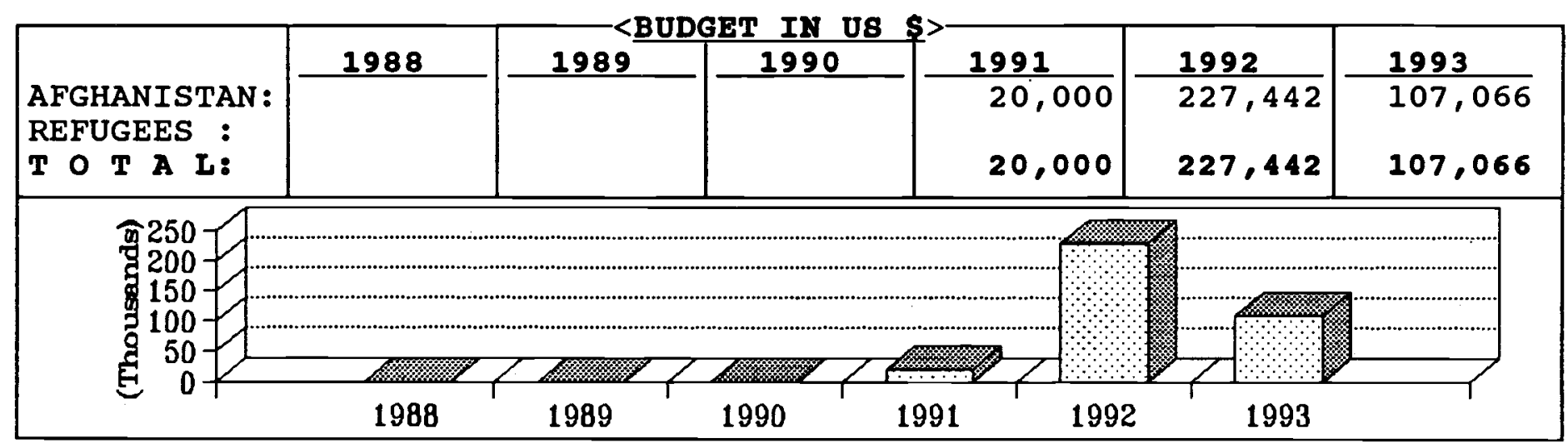

\begin{tabular}{|c|c|c|c|c|c|}
\hline PROVINCES & SECTOR & \&AGE & PROVINCES & SECTOR & $\% A G E$ \\
\hline $\begin{array}{l}\text { BADAKSHAN } \\
\text { BADGHIS } \\
\text { BAGHIAN } \\
\text { BALKH } \\
\text { BAMYAN } \\
\text { FARAH } \\
\text { FARYAB } \\
\text { GHAZNI } \\
\text { GHOR } \\
\text { HELMAND } \\
\text { HERAT } \\
\text { JAWZJAN } \\
\text { KABUL } \\
\text { KANDAHAR } \\
\text { KAPISA }\end{array}$ & $\begin{array}{l}\text { Health } \\
\text { Agr/health }\end{array}$ & $\begin{array}{l}108 \\
208 \\
108\end{array}$ & \begin{tabular}{|l} 
KUNAR \\
KUNDUZ \\
LAGHMAN \\
LOGAR \\
NANGARHAR \\
NIMROZ \\
ORUZGAN \\
PAKTEKA \\
PAKTIA \\
PARWAN \\
SAMANGAN \\
TAKHAR \\
WARDAK \\
ZABUL
\end{tabular} & $\begin{array}{l}\text { Health } \\
\text { Agr/health }\end{array}$ & $50 \%$ \\
\hline
\end{tabular}


was founded in January 1991 to take part in the reconstruction and development of rural Afghanistan which was destroyed during the years of war.

In 1991, ARDA started medical programs in Ghazni and Paktia (zurmat) with the support of the council for International Development. Later on it expanded its medical programs in other areas. Currently it operates a hospital and seven clinics:

* Khogyani Hospital in Nangarhar

* Zawa, Wazir and Pachier clinics in Nangarhar

* Shorak and Khalazi clinics in Baghlan

* Karmol clinic in Kunar

* Shalez clinic in Ghazni province.

Khogyani hospital which was originally established by AIME is now operated by ARDA staff as AIME were unable to continue running the hospital.

ARDA constructed an irrigation dam and cleaned a canal in Lander area of Khost with the support of German Afghanistan Committee. In 1992, ARDA constructed surkham (Uruzgan) dam and cleaned its canal with funding from the Canadian High Commission.

A poultry production and training project is being sponsored by UNDP/OPS which aims to train 180 people within a period of 10 months. After successful completion of the course the trainees will each receive an incubator and a kerosine operated machine (hatches more than 400 chicks in 20 days).

ARDA has also recently started nursery programs with the support of UNDP/OPS. The nursery farms are in the following areas:

Jalalabad city

Khogyani district in Nangarhar Istalef district in Kabul and Qulaghuch in Ghazni. 


\section{AGRICULTURE REHABILITATION OF AFGHANISTAN-ARA}

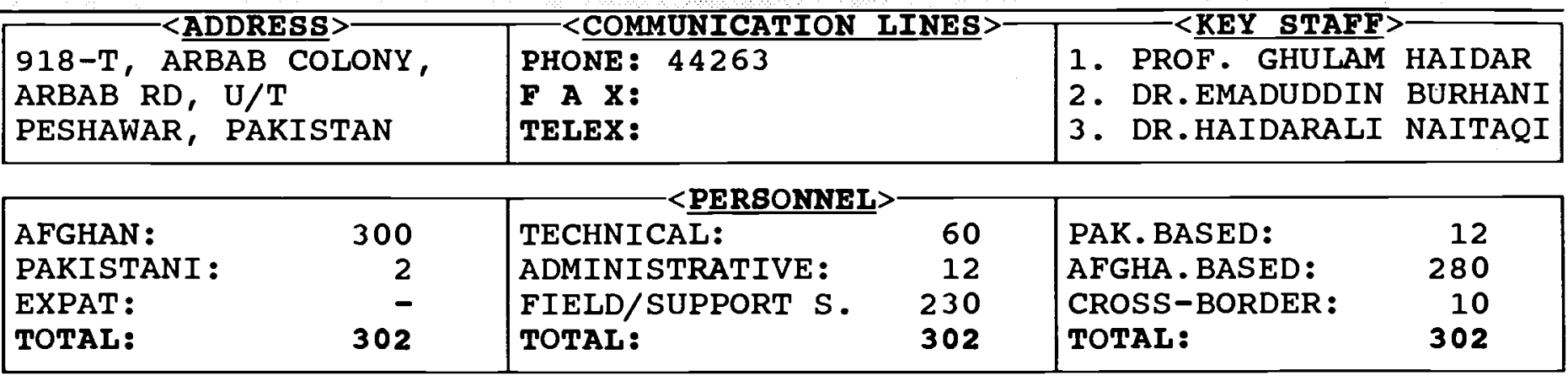

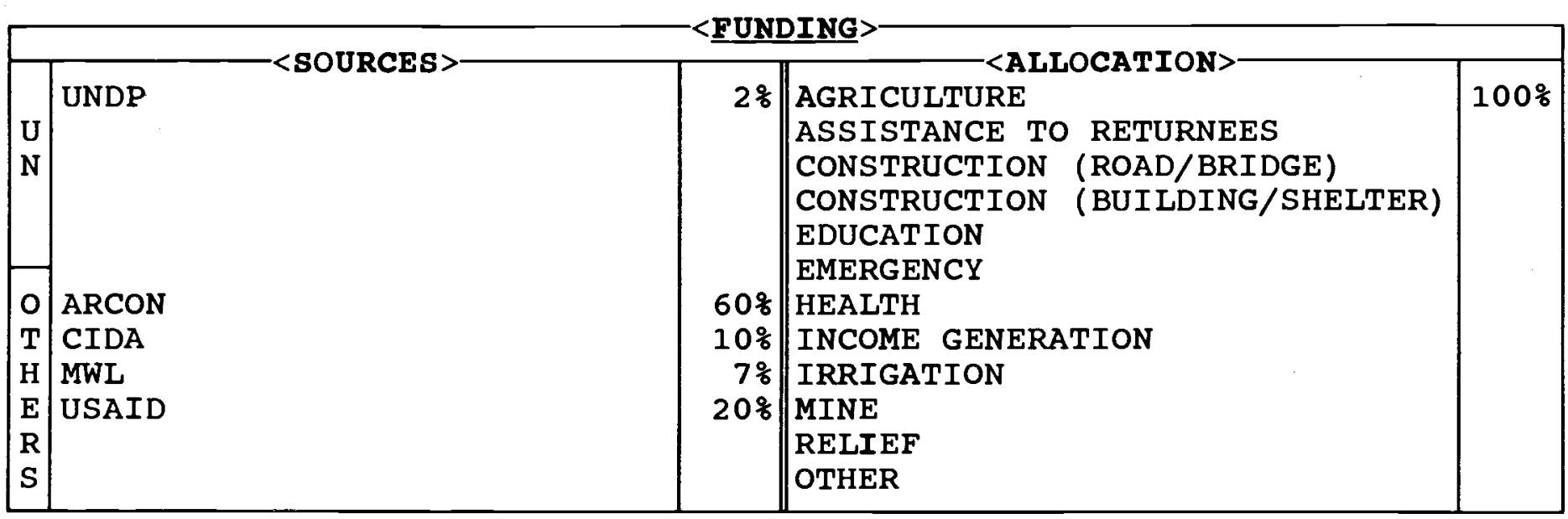

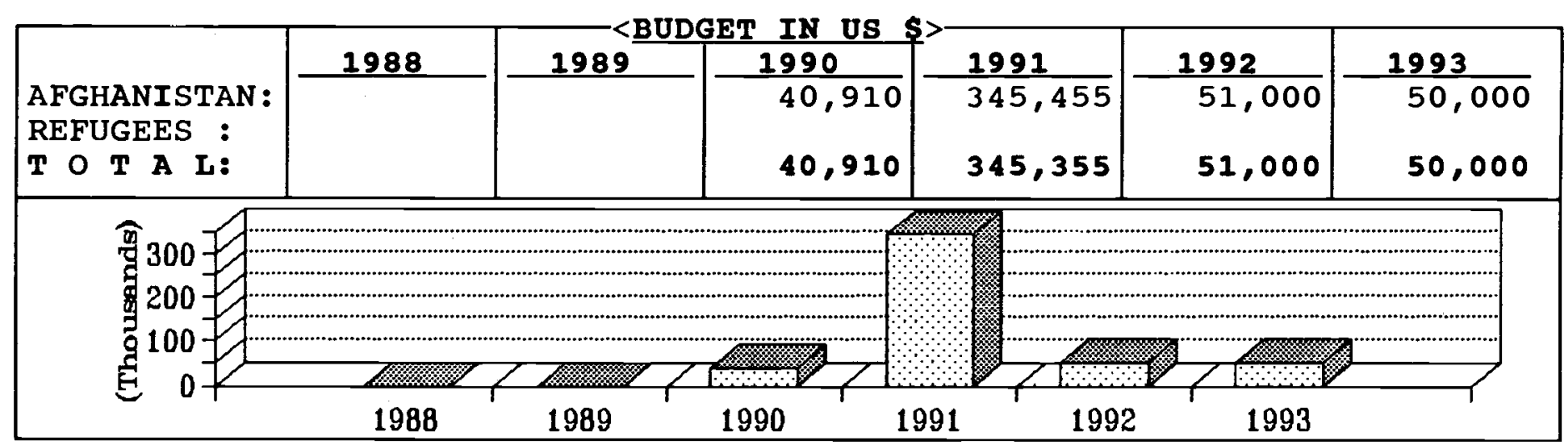

\begin{tabular}{|c|c|c|c|c|c|}
\hline PROVINCES & SECTOR & $\%$ AGE & PROVINCES & SECTOR & $\%$ AGE \\
\hline $\begin{array}{l}\text { BADAKSHAN } \\
\text { BADGHIS } \\
\text { BAGHLAN } \\
\text { BALKH } \\
\text { BAMYAN } \\
\text { FARAH } \\
\text { FARYAB } \\
\text { GHAZNI } \\
\text { GHOR } \\
\text { HELMAND } \\
\text { HERAT } \\
\text { JAWZJAN } \\
\text { KABUL } \\
\text { KANDAHAR } \\
\text { KAPISA }\end{array}$ & $\begin{array}{l}\text { Agr } \\
\text { Agr }\end{array}$ & $\begin{array}{l}15 \% \\
20 \%\end{array}$ & $\begin{array}{l}\text { KUNAR } \\
\text { KUNDUZ } \\
\text { LAGHMAN } \\
\text { LOGAR } \\
\text { NANGARHAR } \\
\text { NIMROZ } \\
\text { ORUZGAN } \\
\text { PAKTEKA } \\
\text { PAKTIA } \\
\text { PARWAN } \\
\text { SAMANGAN } \\
\text { TAKHAR } \\
\text { WARDAK } \\
\text { ZABUL }\end{array}$ & $\begin{array}{l}\text { Agr } \\
\text { Agr } \\
\text { Agr } \\
\text { Agr } \\
\text { Agr } \\
\text { Agr }\end{array}$ & $\begin{array}{l}10 \% \\
10 \% \\
10 \% \\
15 \% \\
10 \% \\
10 \%\end{array}$ \\
\hline
\end{tabular}


AGRICULTURE REHABILITATION OF AFGHANI STAN (ARA)

is an Afghan NGo founded in 1990 to restore and promote agriculture in Afghanistan. ARA has 302 personnel of which 60 are well-qualified agricultural experts. The field staff are very experienced in tree grafting and nursery management activities. ARA has trained over 400 rural experts in grafting fruit trees and horticulture management Services.

ARA has successfully undertaken the following activities:

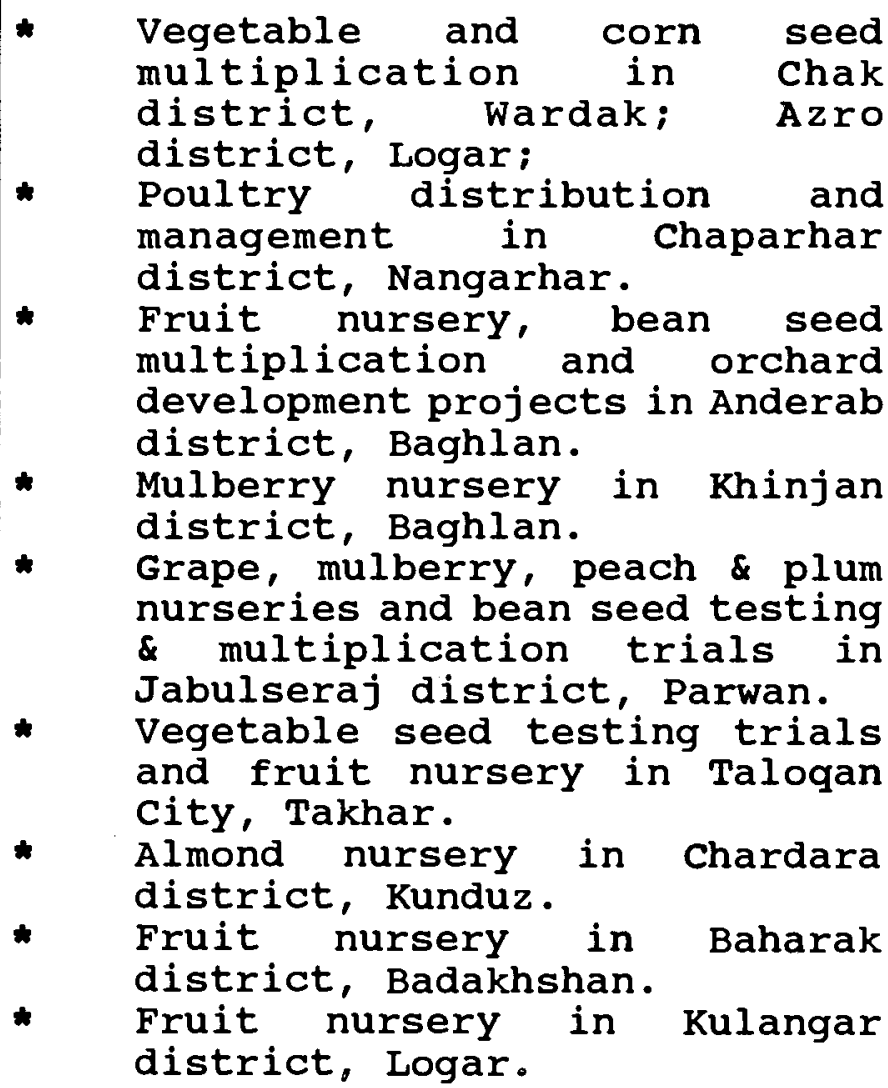

ARA currently has four million fruit trees in its nurseries. It transplanted 150,000 grafted fruit trees in Baghlan in February and March 1993. At least $1,500,000$ fruit trees are ready for transplantation in fall 1993 to spring 1994. By fall 1994 a further 2 million grafted trees will be ready for transplanting.

The propagated fruits are all superior varieties with high commercial value. The have already proved successful and adaptable to soil and climatic conditions of Afghanistan.

Fruit varieties selected and propagated are:

Apples: Golden Delicious, Red Delicious, Yellow Delicious, Rakhash

Pears: winter types (Nazuk Balkhi, Kadoo Balkhi, Chapchi, Sarghailan, Warsaji), summer types American/French origin.

Peaches: Italian, American and large size local types.

Almonds: Sattar Boyee, A. Wahidi, Kaghazi, Double Kaghazi, Majidi, American types.

Plums: Large fruit size yellow, red, \& yellowish red imported from USA and Farmosa.

Walnuts: early fruiting Russian \& British and huge sizes early fruiting types such as Eshkameshi Gharoo, Kaghazi. ARA propagated walnuts give fruit from the first year of transplantation.

Grapes: Keshmeshi, Shundokhani, Husaini.

Quinces: apple-quince, pearquince, soft cotton quince.

Mulberry: Mirzatari, Kaboutak, Ebrahim Khani, shirtoot, Shatoot, Murwareetak, Khoodi, Faryabi.

Apricots: Sardar Nabijohni \& Amiri.

Vegetable seeds and 70 varieties of beans imported from Australia and the USA together with some local varieties have been multiplied. Farmers have shown keen interest in the ARA plantation. Follow up programs should hopefully relieve protein shortage \& malnutrition problems in Afghanistan within a few years.

ARA is facing a financial crisis at the moment with regard to the nurseries and fruit trees. An estimated US\$ 3 million is needed for proper continuation of the nurseries and scientific utilization of 4 million trees in new orchards within the period November 1993 to

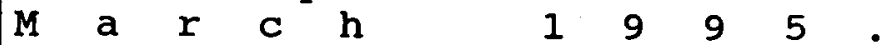


AIDE MEDICALE INTERNATIONALE/AFGHANISTAN-AMI/A

\begin{tabular}{|c|c|c|c|c|c|}
\hline \multirow{2}{*}{\multicolumn{2}{|c|}{$\begin{array}{l}\text { ITC, PH. V, HAYATABAD, } \\
\text { G P O BOX } 326, \\
\text { PESHAWAR, PAKISTAN }\end{array}$}} & \multirow{2}{*}{\multicolumn{2}{|c|}{$\begin{array}{l}\text { <COMMUNICATION LINES> } \\
\text { PHONE: } 812456-7 / 810027 \\
\text { F A X: } 840419 \\
\text { TELEX: }\end{array}$}} & \multirow{2}{*}{\multicolumn{2}{|c|}{$\begin{array}{l}\text { 1. MS. FIONA GALL } \\
\text { 2. } \\
\text { 3. }\end{array}$}} \\
\hline & & & & & \\
\hline $\begin{array}{l}\text { AFGHAN : } \\
\text { PAKISTANI : } \\
\text { EXPAT: } \\
\text { TOTAL: }\end{array}$ & $\begin{array}{r}37 \\
3 \\
40\end{array}$ & $\begin{array}{l}\text { TECHNICAL: } \\
\text { ADMINISTRATIVE: } \\
\text { FIELD/SUPPORT S. } \\
\text { TOTAL: }\end{array}$ & $\begin{array}{r}19 \\
8 \\
13 \\
40\end{array}$ & $\begin{array}{l}\text { PAK. BASED: } \\
\text { AFGHA. BASED: } \\
\text { CROSS-BORDER: } \\
\text { TOTAL: }\end{array}$ & $\begin{array}{r}4 \\
28 \\
8 \\
40\end{array}$ \\
\hline
\end{tabular}

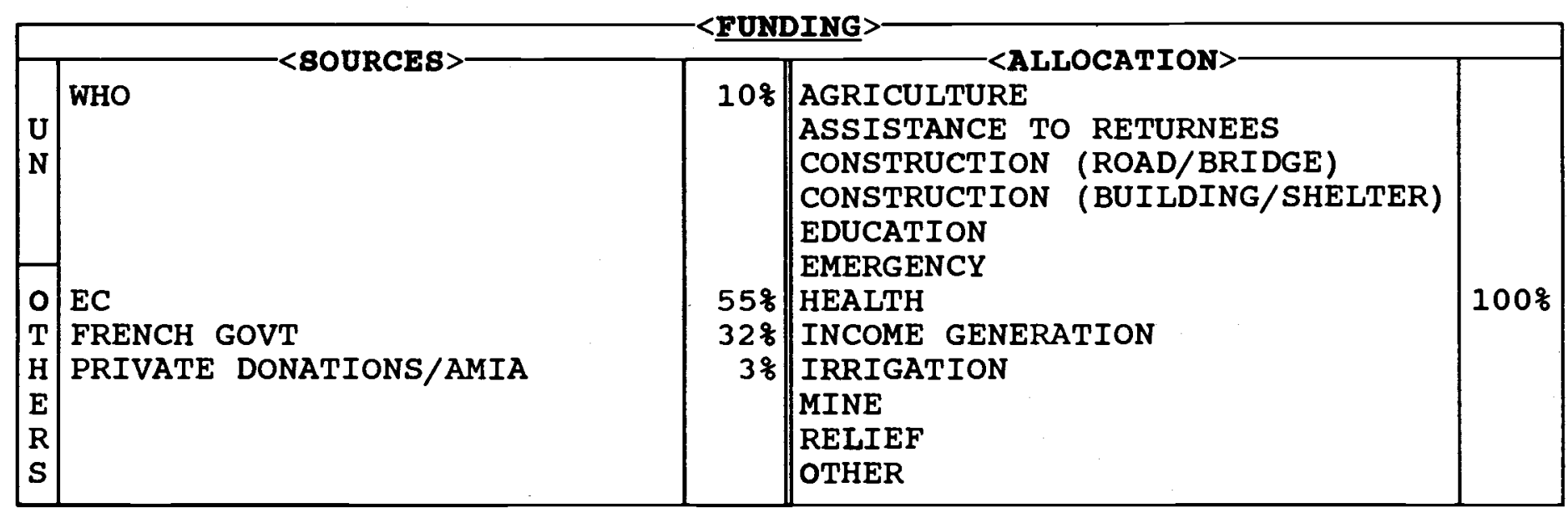

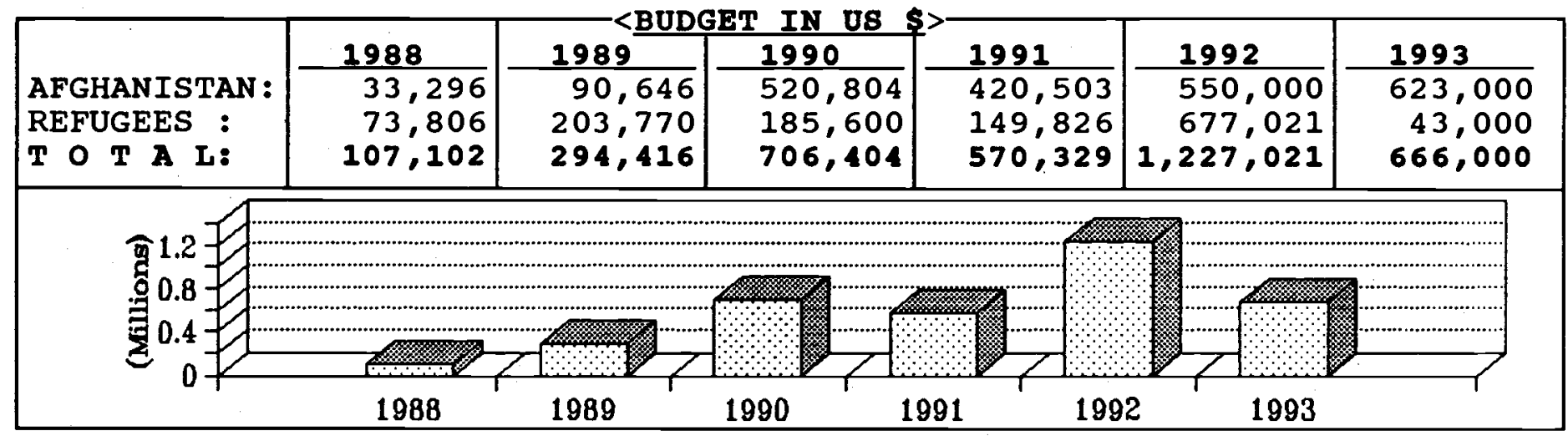

\begin{tabular}{|c|c|c|c|c|c|}
\hline PROVINCES & SECTOR & $\% \mathrm{AGE}$ & PROVINCES & SECTOR & $\because A G E$ \\
\hline $\begin{array}{l}\text { BADAKSHAN } \\
\text { BADGHIS } \\
\text { BAGHLAN } \\
\text { BALKH } \\
\text { BAMYAN } \\
\text { FARAH } \\
\text { FARYAB } \\
\text { GHAZNI } \\
\text { GHOR } \\
\text { HELMAND } \\
\text { HERAT } \\
\text { JAWZJAN } \\
\text { KABUL } \\
\text { KANDAHAR } \\
\text { KAPISA }\end{array}$ & & & $\begin{array}{l}\text { KUNAR } \\
\text { KUNDUZ } \\
\text { LAGHMAN } \\
\text { LOGAR } \\
\text { NANGARHAR } \\
\text { NIMROZ } \\
\text { ORUZGAN } \\
\text { PAKTEKA } \\
\text { PAKTIA } \\
\text { PARWAN } \\
\text { SAMANGAN } \\
\text { TAKHAR } \\
\text { WARDAK } \\
\text { ZABUL }\end{array}$ & Health & $\begin{array}{l}10 \% \\
90 \%\end{array}$ \\
\hline
\end{tabular}




\section{AIDE MEDICALE INTERNATIONALE- AFGHANISTAN (AMI-A)}

is a French humanitarian agency, based in Paris. It provides emergency relief and medical training assistance to rural populations in developing countries. In 1980 AMI sent the first of its medical teams inside Afghanistan to assist in an emergency medical mission for the rural population. Subsequently a separate program was set up specifically for Afghanistan known as Aide Medicale Internationale Afghanistan, (AMIA).

AMIA focuses on medical training. From 1982 onwards AMIA's expatriate medical volunteers started short training programs during their missions to train health workers and TBAs. As the war continued it became impractical to carry out intensive training courses inside Afghanistan and in 1985 AMIA started Medical Training for Afghans (MTA) in conjunction with Solidarite Afghanistan Belgium in order to train health workers in Peshawar. It also started separate courses for lab, X-ray and dental technicians. Since 1989 these courses have been based at the ITC, Hayatabad, which is funded by the European Community.

Between 1985 and 1993 AMIA trained 104 assistant doctors at MTA on 16 month courses, 26 lab technicians trained on 4-month courses and 9 other lab technicians who have followed one month refresher courses, 25 x-ray technicians trained on 4-month courses in conjunction with MRCA and 66 dental students trained on 3 month courses.

In June 1993 AMIA closed all its training programs in Peshawar because it was clear that the emergency need for training assistant doctors and other medical technicians had ended, AMIA now focuses on upgrading the skills of existing health staff in the rural areas of Afghanistan.

Inside Afghanistan, AMIA's major project remains the installation of a 40 bed hospital in Baraki, Logar.
This is a district hospital with surgical and medical activities and also services as a training center for the local health personnel. The construction of this hospital was started in mid-1990 in collaboration with CoAR and funding from WHO. During 1993 AMIA has equipped and prepared the hospital for medical activities which commenced in July 1993. The hospital is funded by the European Community, the French Government and the Ministry of Public Health, Afghanistan.

During 1993 Community Public Health Courses for mid-level health workers were prepared and carried out in Baraki and Charkh districts, Logar, by AMIA. The practical part of these courses for upgrading the skills of the health-workers will be based in the hospital in the future. During 1993 AMIA also carried out a dai training and monitoring program in Baraki, Logar.

In April 1993 an evaluation mission was carried out in caner and Nooristan in conjunction with MADERA agency and as a result of this a basic health clinic was established in October 1993 in Kamdesh, Nooristan. The clinic will serve the basic medical needs of the local rural population who have very little access to medical facilities in the region.

since June 1993 AMIA has continued to offer medical refresher courses in Peshawar for mid-level health workers. These six week courses are designed to upgrade the skills of the health workers and to focus their attention on long term preventative health care for the local population.

During 1993 AMIA has continued to monitor its former students in order to evaluate their work and to review its own training programs. One AMIA medical team visited former MTA students in the Hazarajat region in August and september 1993 and evaluated the needs for medical assistance in that area. other evaluation missions were also

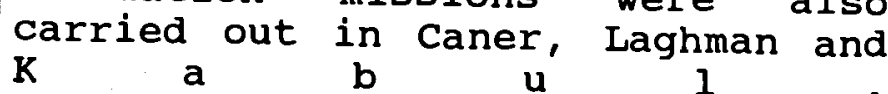


AL-DAWA ISLAMIC CULTURAL CENTER-AICC

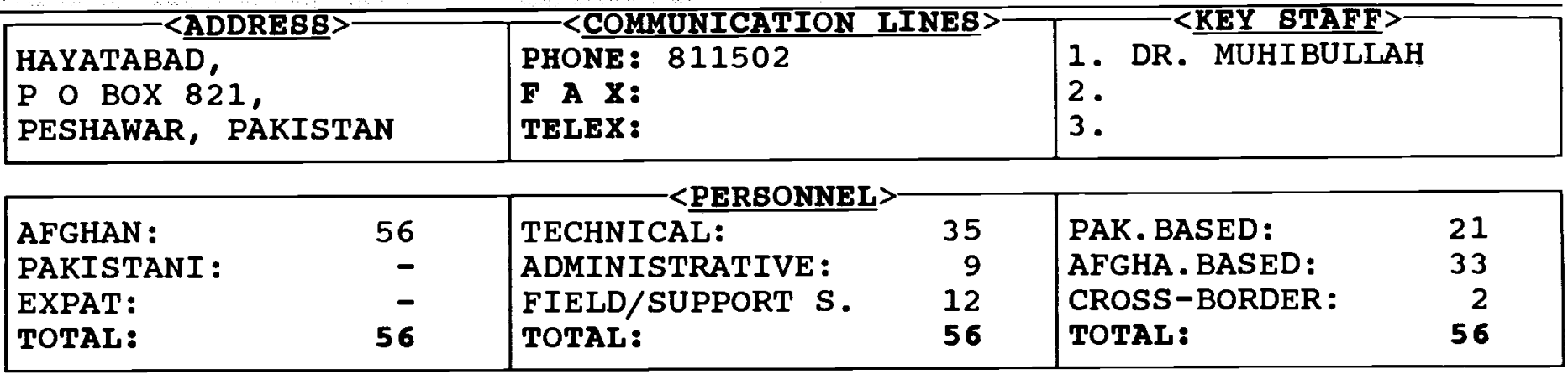

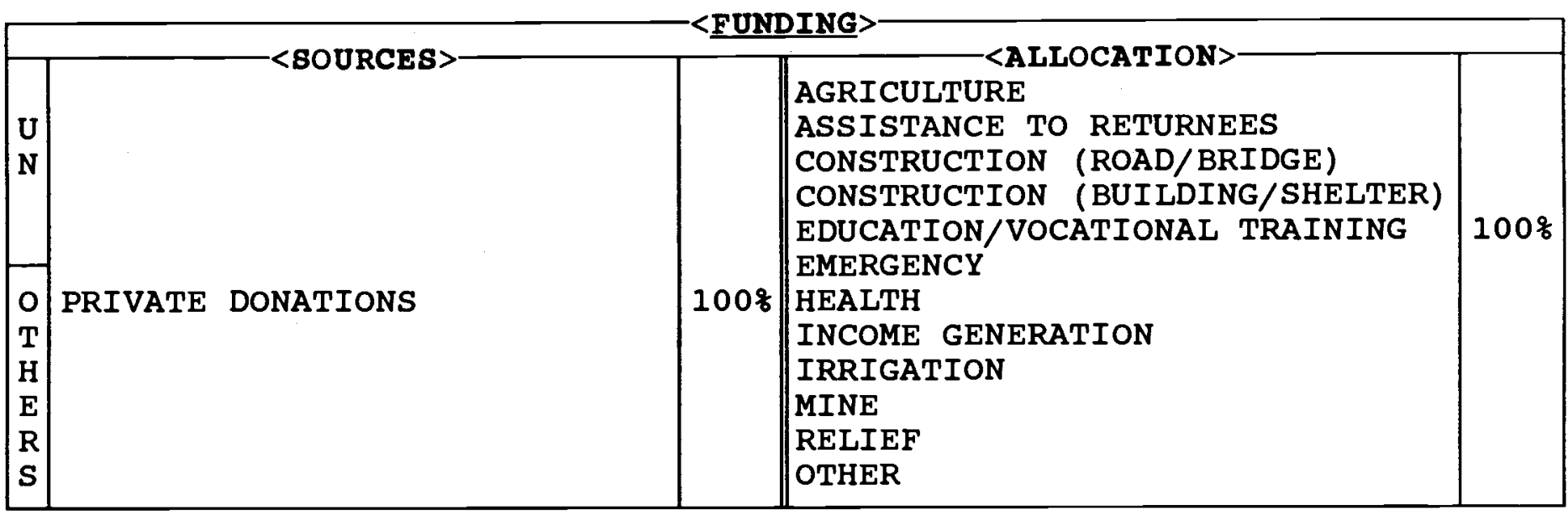

\begin{tabular}{|c|c|c|c|c|c|c|}
\hline & 1988 & 1989 & 1990 & 1991 & 1992 & 1993 \\
\hline $\begin{array}{l}\text { AFGHANISTAN: } \\
\text { REFUGEES : } \\
\text { T O T A L: }\end{array}$ & & & $\begin{array}{l}6,000 \\
6,000\end{array}$ & $\begin{array}{l}12,000 \\
12,000\end{array}$ & $\begin{array}{l}20,000 \\
20,000\end{array}$ & $\begin{array}{l}12,000 \\
23,000 \\
35,000\end{array}$ \\
\hline
\end{tabular}

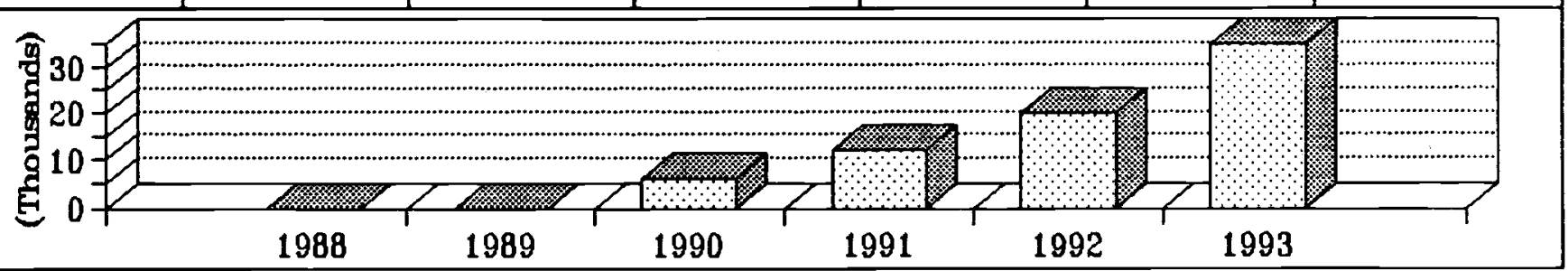

\begin{tabular}{|c|c|c|c|c|c|}
\hline PROVINCES & SECTOR & \&AGE & PROVINCES & SECTOR & $\because \mathrm{AGE}$ \\
\hline $\begin{array}{l}\text { BADAKSHAN } \\
\text { BADGHIS } \\
\text { BAGHLAN } \\
\text { BALKH } \\
\text { BAMYAN } \\
\text { FARAH } \\
\text { FARYAB } \\
\text { GHAZNI } \\
\text { GHOR } \\
\text { HELMAND } \\
\text { HERAT } \\
\text { JAWZJAN } \\
\text { KABUL } \\
\text { KANDAHAR } \\
\text { KAPISA }\end{array}$ & & & $\begin{array}{l}\text { KUNAR } \\
\text { KUNDUZ } \\
\text { LAGHMAN } \\
\text { LOGAR } \\
\text { NANGARHAR } \\
\text { NIMROZ } \\
\text { ORUZGAN } \\
\text { PAKTEKA } \\
\text { PAKTIA } \\
\text { PARWAN } \\
\text { SAMANGAN } \\
\text { TAKHAR } \\
\text { WARDAK } \\
\text { ZABUL }\end{array}$ & Educ (voc training) & $100 \%$ \\
\hline
\end{tabular}


AL-DAWA ISLAMIC CULTURAL CENTER (AICC)

is an Afghan academic institution founded in Peshawar in 1989 with the following objectives:

1) To strengthen the Islamic ideology of the Afghan society, and work for the growth of positive theory among the people.

2) To eliminate all kinds of racial, linguistic, territorial prejudices.

3) To educate the youth and increase their knowledge regarding the Afghan crisis in particular and the international problems of the Islamic World in general.

4) To increase the knowledge and information among the people and make them aware of the great dangers of nationalism, communism and the spread of Christianity among the Muslims.

5) To encourage the Afghan youth to restore education which was discontinued due to Jihad for 13 years against the infidels.

AICC has the following sections:

GENERAL LIBRARY: There are thousands of books mainly on Islamic subjects and literature, medical and culture. The books are in Arabic, Urdu, English, Pushto and Dari languages.

AUDIO-VISUAL: It has televisions, video-cassette recorders, taperecorders and films on imminent happenings and events (lectures, meetings and seminars throughout the Islamic World).

TRANSLATION/PUBLICATION: The mandate of this section is to encourage those writers who have a wide knowledge but who have retired due to financial weaknesses. Also, this section translates interesting subjects into Afghan languages. It selects and prints papers for distribution in the seminars, lectures and congregations held by AICC. A magazine called "Iman" which means 'Belief' is published by this section. 5 editions of the magazine have been published so far.
Courses: Language courses including Arabic and English are offered. Also, courses in Tabligh and Dawat (Preaching and Invitation) and other religious courses e.g. Tajwid, Tafsir, Sunnah and Islamic history are organized.

CONFERENCES/BEMINARS/TRIPS: This department is responsible for organizing public debates, seminars and Islamic conferences, meetings and travels.

VOCATIONAL COURSES: Provides opportunities for Afghan youths to learn new technology such as computer skills.

8CHOLARSHIP8: Afghan professionals are sent abroad for scientific and academic training and research.

CULTURE AND FAMILY ENLIGHTENMENT: works towards providing basic Islamic education in the families using faithful and well-educated Afghan women.

In 1992, AICC opened a branch in Jalalabad city. Jalalabad center has reconstruction section as well as training program including English and Arabic courses, mathematics, calligraphy and computer skills. The "Culture and Family Enlightenment" section has also established tailoring and Islamic education courses in Jalalabad center which trains 40 women for 4 month sessions. The 3 session of the course will be completed in the near future.

AICC has prepared a number of project proposals, but no donor organization has shown any interest in funding them.

The center is run by a director, three organizational members and 12 consulting members. 
AMITE FRANCO-AFGHANE AIDE HUMANITAIRE ET INFORMATION-AFRANE

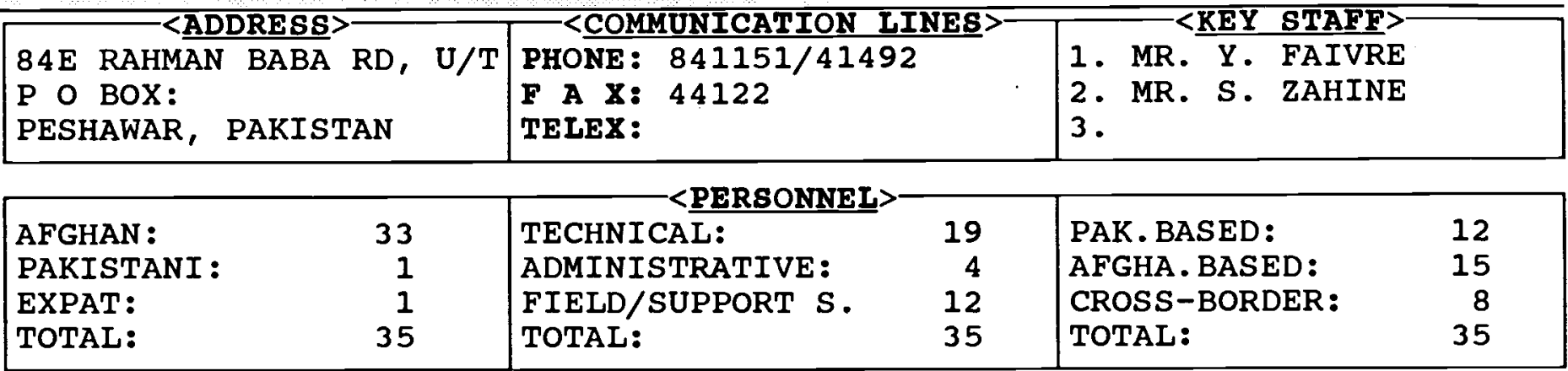

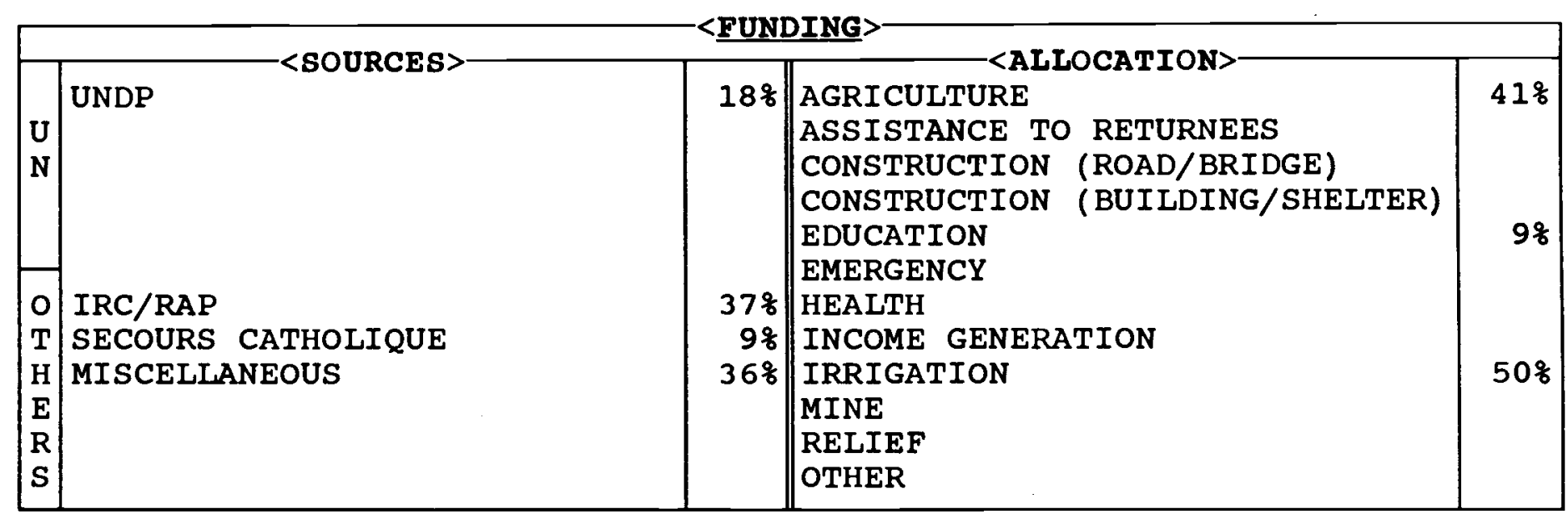

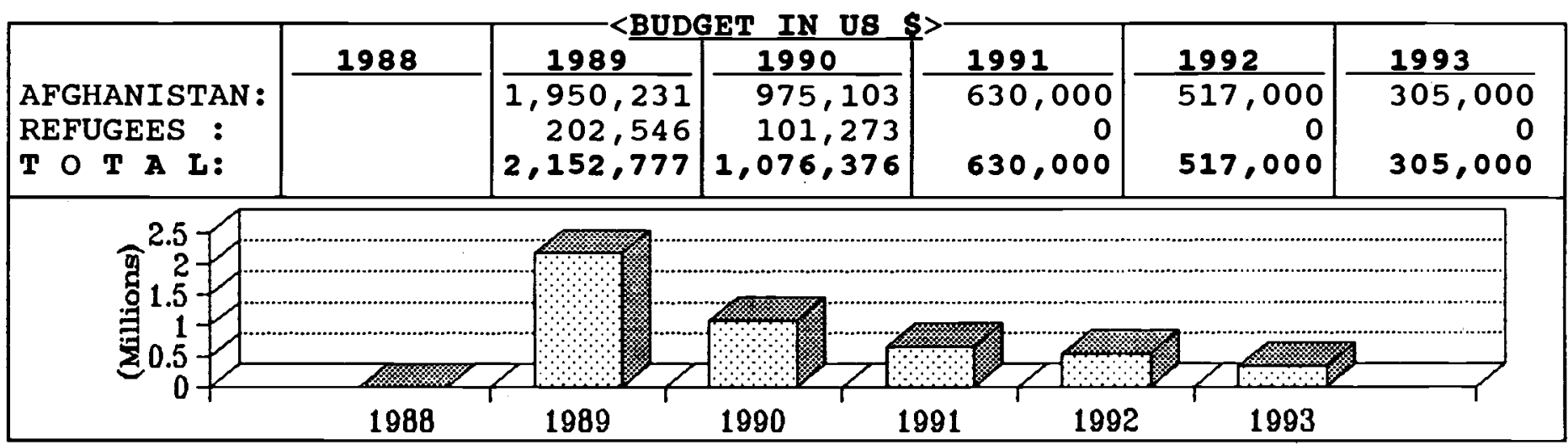

\begin{tabular}{|c|c|c|c|c|c|}
\hline PROVINCES & SECTOR & \% & PROVINCES & SECTOR & 号AGE \\
\hline $\begin{array}{l}\text { BADAKSHAN } \\
\text { BADGHIS } \\
\text { BAGHLAN } \\
\text { BALKH } \\
\text { BAMYAN } \\
\text { FARAH } \\
\text { FARYAB } \\
\text { GHAZNI } \\
\text { GHOR } \\
\text { HELMAND } \\
\text { HERAT } \\
\text { JAWZJAN } \\
\text { KABUL } \\
\text { KANDAHAR } \\
\text { KAPISA }\end{array}$ & $\begin{array}{l}\text { Agr./irrign } \\
\text { Agr./irrign }\end{array}$ & $35 \%$ & \begin{tabular}{|l} 
KUNAR \\
KUNDUZ \\
LAGHMAN \\
LOGAR \\
NANGARHAR \\
NIMROZ \\
ORUZGAN \\
PAKTEKA \\
PAKTIA \\
PARWAN \\
SAMANGAN \\
TAKHAR \\
WARDAK \\
ZABUL
\end{tabular} & Agr/educ/irrign & $64 \%$ \\
\hline
\end{tabular}




\section{AMITE FRANCO-AFGHANE AIDE HUMANITAIRE ET INFORMATION (AFRANE)}

was founded in 1979 by people familiar with Afghanistan and, for the most, who had worked there previously.

From its foundation to 1986, AFRANE focused on humanitarian help and information to people in France about the situation in Afghanistan, through a periodical review "Les Nouvelles d'Afghanistan", and through the collection of documentation in collaboration with CEREDAF (Center de Recherches et d'Etudes Documentaires sur l'Afghanistan).

The first humanitarian aid missions were launched in 1980 inside Afghanistan by providing cash for food, clothes and food stocks to the population, under difficult and perilous circumstances; they were conducted by expatriate volunteers. From 1986, the programs moved from pure humanitarian help towards agricultural assistance, with the emphasis on irrigation rehabilitation and the implementation of a mechanization program, with tractors, equipment and workshops. From this period, the activities of AFRANE became more and more specialized with permanent staff inside Afghanistan based in its Rural Development Centers, and increased its cooperation with Afghan and European Agencies working in neighboring areas.

Its Rural Development Centers established in Logar and Ghazni Provinces are now running continuous programs in the following different areas: water management, preservation of soils and reforestation, communications, cereals, meat and dairy, vegetables, fruit, mechanization, energy saving programs and education. some of these programs are producing income and employment and enable field research, in the frame of AAEC
(Afghan Agriculture Experimental Center, created by COAR and AFRANE in 1991) which is presently running some 50 field experiments on cereals, vegetables and fruit trees; they also enable financing of pilot projects (e.g. soils rehabilitation in lalmi areas) which are not traditionally funded by the institutional donors. 
ANTI-TB ASSOCIATION, GENEVA/AFGHANISTAN PROJECT-ATA

\begin{tabular}{|c|c|c|}
\hline$-\langle$ ADDRESS $>$ & <COMMUNICATION LINES $\rangle$ & < KEY STAFF $>$ \\
\hline $\begin{array}{l}\text { FLAT 4, FIRST FLOOR, } \\
\text { KHYBER VIEW PLAZA, }\end{array}$ & $\begin{array}{l}\text { PHONE: } 840126 \\
\text { F A X: } 840126\end{array}$ & $\begin{array}{l}\text { 1. DR. MOHD AYUB ZHIAN } \\
\text { 2. } \\
3\end{array}$ \\
\hline
\end{tabular}

\begin{tabular}{|lc|lr|lr|}
\hline AFGHAN : & 9 & TECHNICAL: & 7 & PAK.BASED: & 5 \\
PAKISTANI : & 3 & ADMINISTRATIVE: & 4 & AFGHA.BASED: & 7 \\
EXPAT: & 0 & FIELD/SUPPORT S. & 1 & CROSS-BORDER: & 0 \\
TOTAL: & 12 & TOTAL: & 12 & TOTAL: & 12 \\
\hline
\end{tabular}

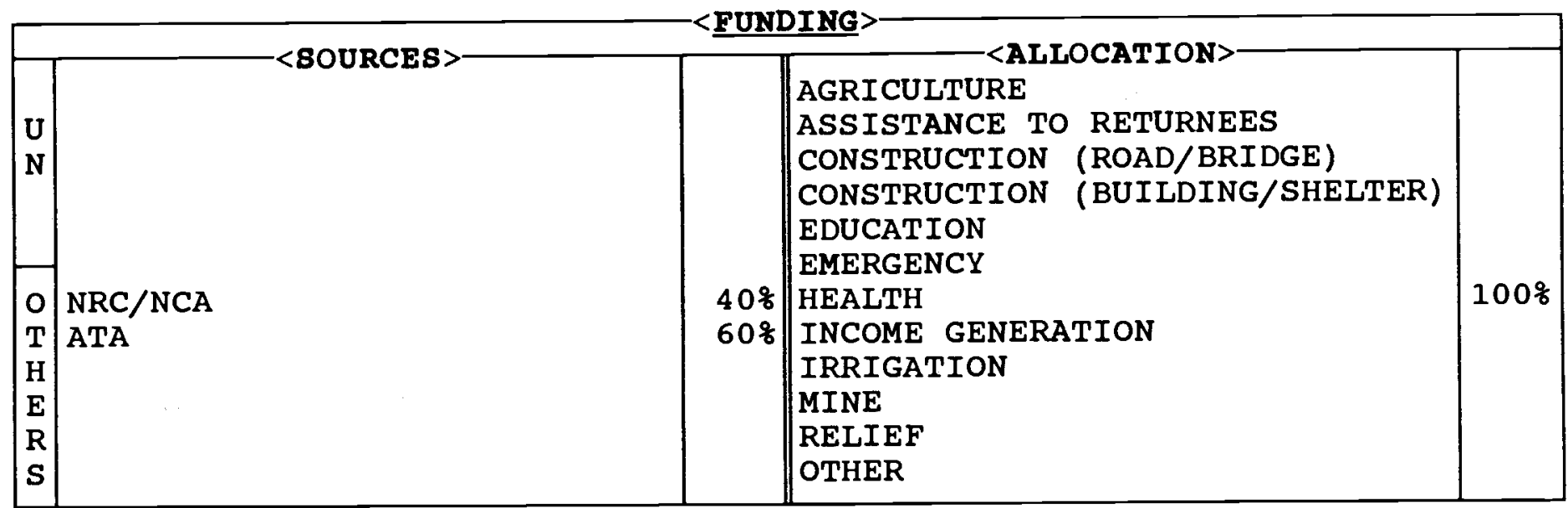

\begin{tabular}{|c|c|c|c|c|c|c|}
\hline & 1988 & 1989 & 1990 & 1991 & 1992 & 1993 \\
\hline $\begin{array}{l}\text { AFGHANISTAN : } \\
\text { REFUGEES : }\end{array}$ & & & $\begin{array}{r}108,000 \\
52,000\end{array}$ & $\begin{array}{r}108,000 \\
52,000\end{array}$ & $\begin{array}{r}120,000 \\
72,000 \\
192,000\end{array}$ & $\begin{array}{r}120,000 \\
72,000 \\
192,000\end{array}$ \\
\hline
\end{tabular}

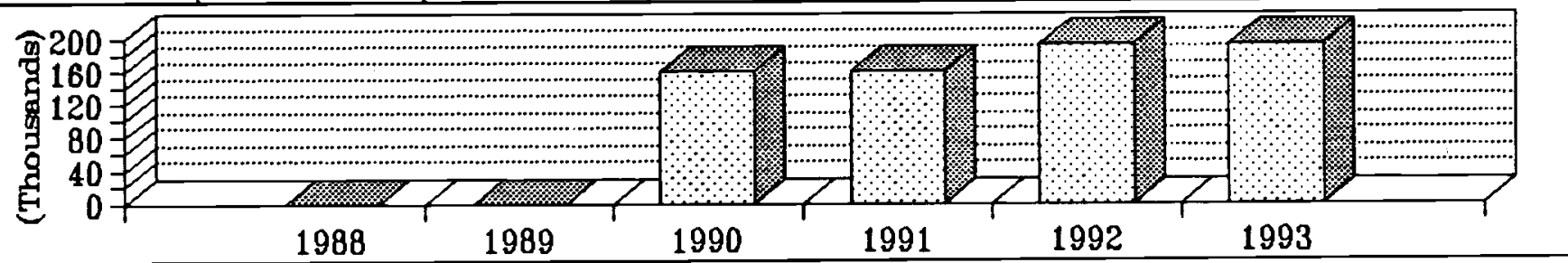

\begin{tabular}{|c|c|c|c|c|c|}
\hline PROVINCES & SECTOR & \&AGE & PROVINCES & SECTOR & $\because \mathrm{AGE}$ \\
\hline $\begin{array}{l}\text { BADAKSHAN } \\
\text { BADGHIS } \\
\text { BAGHLAN } \\
\text { BALKH } \\
\text { BAMYAN } \\
\text { FARAH } \\
\text { FARYAB } \\
\text { GHAZNI } \\
\text { GHOR } \\
\text { HELMAND } \\
\text { HERAT } \\
\text { JAWZJAN } \\
\text { KABUL } \\
\text { KANDAHAR } \\
\text { KAPISA }\end{array}$ & & & $\begin{array}{l}\text { KUNAR } \\
\text { KUNDUZ } \\
\text { LAGHMAN } \\
\text { LOGAR } \\
\text { NANGARHAR } \\
\text { NIMROZ } \\
\text { ORUZGAN } \\
\text { PAKTEKA } \\
\text { PAKTIA } \\
\text { PARWAN } \\
\text { SAMANGAN } \\
\text { TAKHAR } \\
\text { WARDAK } \\
\text { ZABUL }\end{array}$ & Health & $100 \%$ \\
\hline
\end{tabular}


ANTI TUBERCULOSIS ASSOCIATION GENEVA-AFGHANISTAN PROJECTS (ATA/AFG)

was formed in 1983 in Geneva. It established its first TB Hospital in Baghdada-Mardan on January 1, 1984 .

The aim of the Association is to combat $T B$ in the developing countries of Asia and Africa. The TB Hospital Mardan, started work for the local people, as well as Afghan Refugees. Later on, the Association established another hospital at Danu which also serves the local people and Afghan Refugees.

In June 1990, ATA established another TB hospital in Asadabad, the center of Lunar province of Afghanistan. It is the only wellequipped TB hospital in the whole country, excluding Kabul.

The "Afghanistan Projects" wing of the Association was established in May 1992, when Afghanistan became free. The aim of the "Afghanistan Projects" wing of the Association is to coordinate TB control programs inside Afghanistan.

An assessment of the TB situation has been conducted in Nangarhar province and the establishment of a $T B$ center in Jalalabad is under consideration. 
ARIANA REHABILITATION COMMITTEE FOR AFGHANISTAN RECONSTRUCTION ARCAR

\begin{tabular}{|c|c|c|}
\hline$<$ A & $=<$ COMMUNICATION LINES $>$ & $<$ KEY STAFF $>-$ \\
\hline $\begin{array}{l}\text { 18-b SPINZAR PLAZA, } \\
\text { JAHANGIRABAD, } \\
\text { PESHAWAR, PAKISTAN }\end{array}$ & $\begin{array}{l}\text { PHONE: } 44986 \\
\text { F A X: } \\
\text { TELEX: }\end{array}$ & $\begin{array}{l}\text { 1. DR. MOHAMMAD HUMAYUN } \\
\text { 2. ENG. RAHMATULLAH } \\
\text { 3. MR. BARYALLY }\end{array}$ \\
\hline
\end{tabular}

\begin{tabular}{|lc|lr|lr|}
\hline AFGHAN : & 15 & TECHNICAL: & 6 & PAK. BASED: & 5 \\
PAKISTANI : & - & ADMINISTRATIVE : & 5 & AFGHA.BASED: & 6 \\
EXPAT: & - & FIELD/SUPPORT S. & 4 & CROSS-BORDER: & 4 \\
TOTAL: & 15 & TOTAL: & 15 & TOTAL: & 15 \\
\hline
\end{tabular}

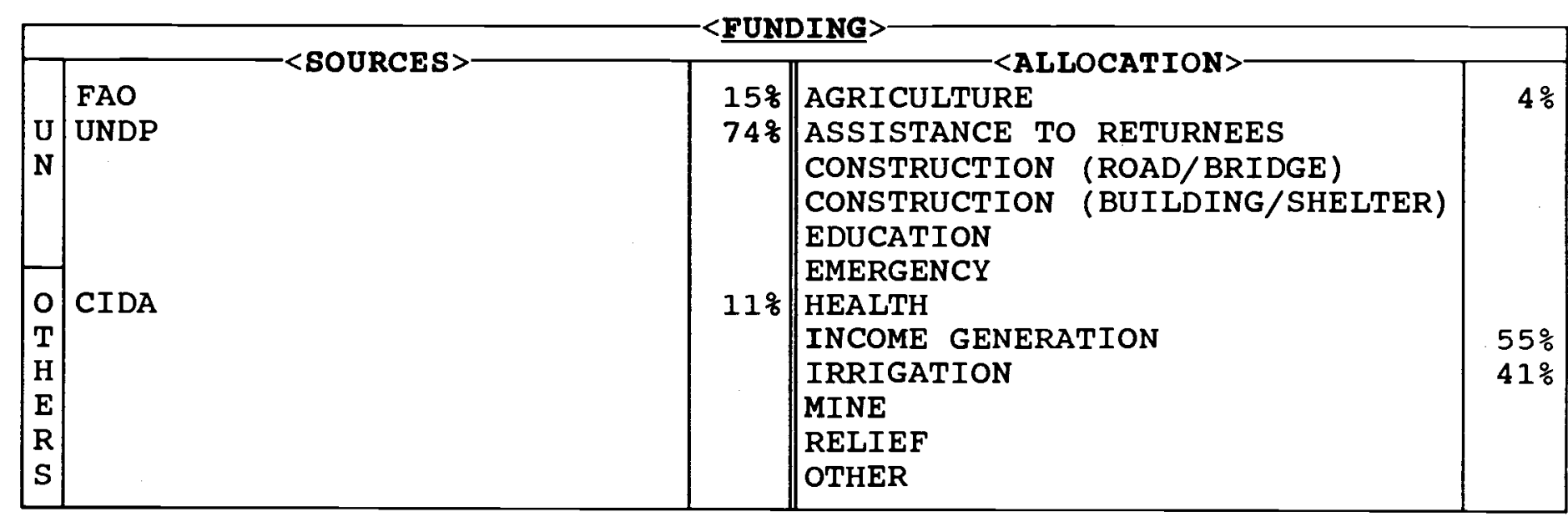

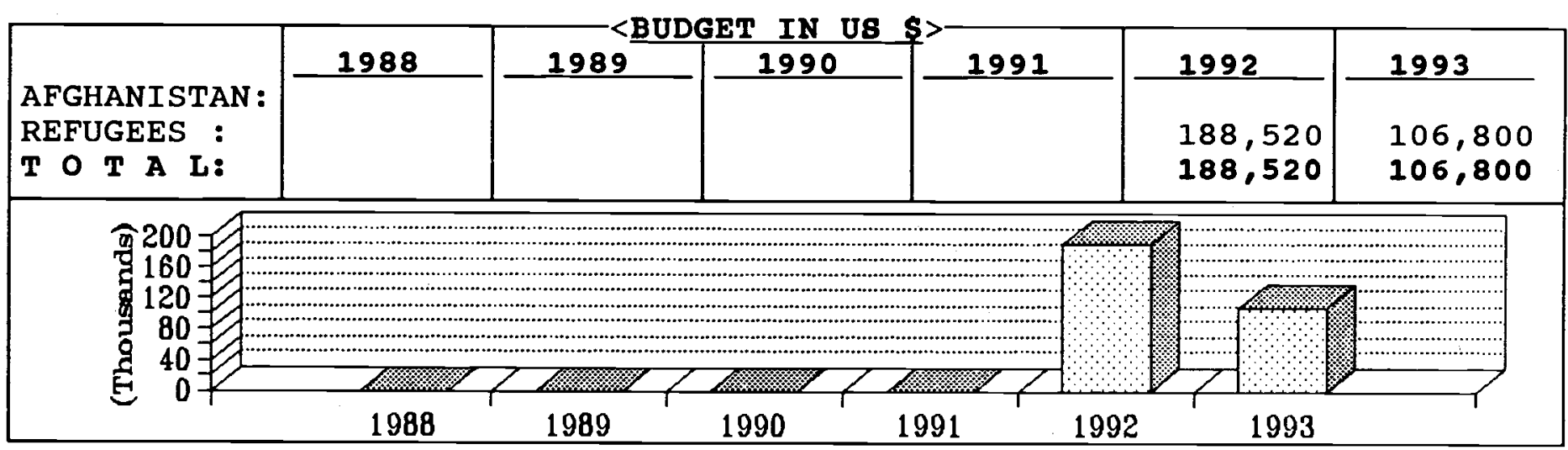

\begin{tabular}{|c|c|c|c|c|c|}
\hline PROVINCES & SECTOR & $\because \mathrm{AGE}$ & PROVINCES & SECTOR & $\because A G E$ \\
\hline $\begin{array}{l}\text { BADAKSHAN } \\
\text { BADGHIS } \\
\text { BAGHLAN } \\
\text { BALKH } \\
\text { BAMYAN } \\
\text { FARAH } \\
\text { FARYAB } \\
\text { GHAZNI } \\
\text { GHOR } \\
\text { HELMAND } \\
\text { HERAT } \\
\text { JAWZJAN } \\
\text { KABUL } \\
\text { KANDAHAR } \\
\text { KAPISA }\end{array}$ & Const & $30 \%$ & $\begin{array}{l}\text { KUNAR } \\
\text { KUNDUZ } \\
\text { LAGHMAN } \\
\text { LOGAR } \\
\text { NANGARHAR } \\
\text { NIMROZ } \\
\text { ORUZGAN } \\
\text { PAKTEKA } \\
\text { PAKTIA } \\
\text { PARWAN } \\
\text { SAMANGAN } \\
\text { TAKHAR } \\
\text { WARDAK } \\
\text { ZABUL }\end{array}$ & $\begin{array}{l}\text { Voc.training } \\
\text { Agr/voc.training } \\
\text { Irrign }\end{array}$ & $\begin{array}{l}11 \% \\
45 \% \\
11 \%\end{array}$ \\
\hline
\end{tabular}




\section{ARIANA REHABIIITATION COMMITTEE FOR} AFGHANI BTAN RECONSTRUCTION (ARCAR)

is an Afghan non-governmental and non-political organization established in 1991 with the sole aim of helping international organization in the rehabilitation and reconstruction of war ravaged Afghanistan. ARCAR is a group of expert and skilled Afghans who have a strong desire to use their professions and experience in serving their countrymen.

ARCAR has the following objectives:

1) To take direct and active part in the reconstruction of devastated Afghanistan.

2) To improve the social and economic status of the people of Afghanistan.

3) To provide opportunities for income generation for skilled Afghans to support their families.

4) To offer training to Afghans and make them self sufficient.

ARCAR's staff are proficient in different sectors including agriculture, irrigation systems, infrastructure, health, education/training and other rehabilitation and development programs in which ARCAR has undertaken/intends to undertake projects.

A summary of ARCAR projects is listed as follows:

\section{Nangarhar:}

* Reh abilitation and reconstruction of shewa main canal

* Rehabilitation of zangoie canal

\section{Logar:}

* Carpentry and masonry training project in Mohd Agha district Improved wheat seed multiplication project in Puli Alam and Mohd Agha.
Runar:

* Construction of a secondary school in Sheegal

\section{Laghman:}

* Carpentry and masonry training project

\section{Jawz jan:}

* Construction of Yangi Qala reservoir

* Construction of Beshpakar reservoir

Balkh:

* Construction of water intake in Chemtal district.

\section{Paktia:}

* Poultry distribution in sabari district. 
ARIANA UNITY RECONSTRUCTION COUNCIL-AURC <ADDRESS $>-<$ COMMUNICATIO

171, BLOCK 3, STREET J SATELLITE TOWN QUETTA, PAKISTAN

PHONE: 442922

F A X:

TELEX:
1. MR. NIAMATULLAH

2 .

3 .

\begin{tabular}{|lc|lr|lr|}
\hline AFGHAN : & 22 & TECHNICAL: & 7 & PAK. BASED: & 7 \\
PAKISTANI : & - & ADMINISTRATIVE: & 7 & AFGHA.BASED: & 7 \\
EXPAT: & - & FIELD/SUPPORT S. & 8 & CROSS-BORDER: & 8 \\
TOTAL: & 22 & TOTAL: & $\mathbf{2 2}$ & TOTAL: & $\mathbf{2 2}$ \\
\hline
\end{tabular}

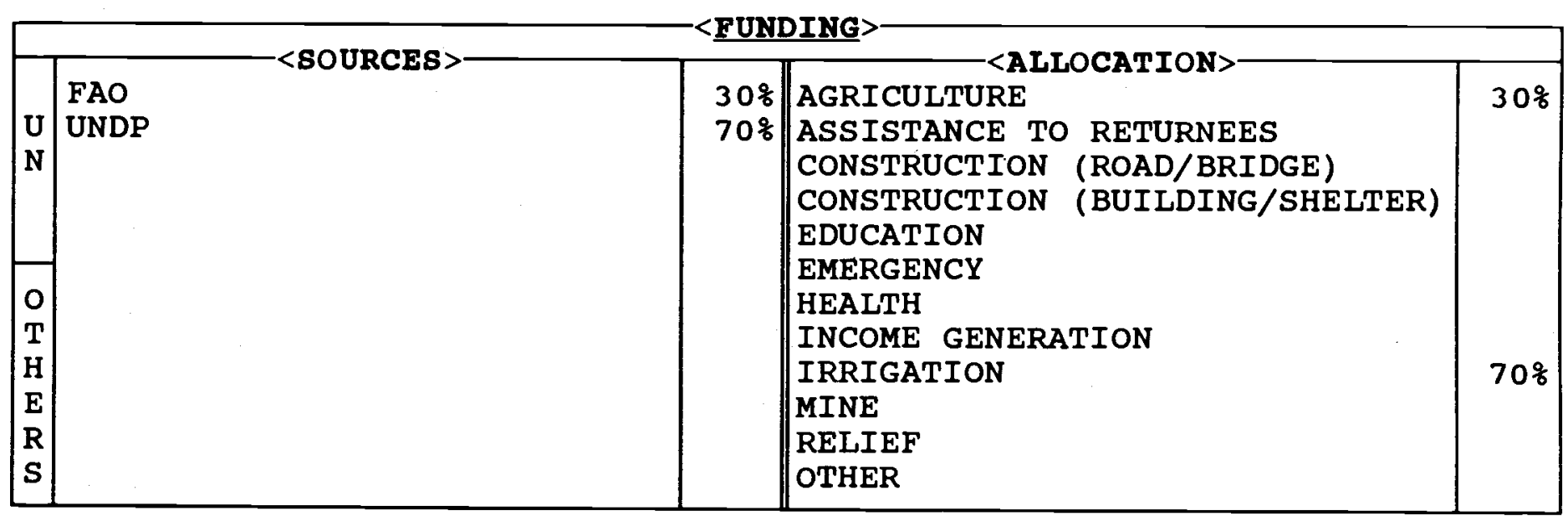
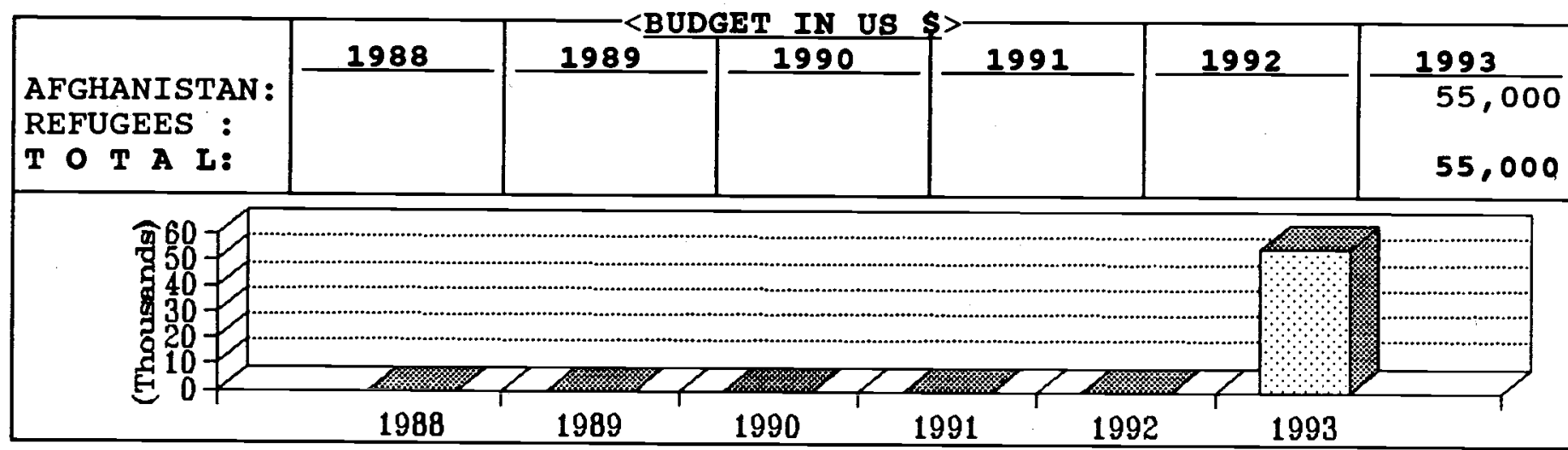

<TARGET PROVINCES IN AFGHANISTAN>

\begin{tabular}{|c|c|c|c|c|c|}
\hline PROVINCES & SECTOR & \%AGE & |PROVINCES & SECTOR & \%AGE \\
\hline $\begin{array}{l}\text { BADAKSHAN } \\
\text { BADGHIS } \\
\text { BAGHLAN } \\
\text { BALKH } \\
\text { BAMYAN } \\
\text { FARAH } \\
\text { FARYAB } \\
\text { GHAZNI } \\
\text { GHOR } \\
\text { HELMAND } \\
\text { HERAT } \\
\text { JAWZJAN } \\
\text { KABUL } \\
\text { KANDAHAR } \\
\text { KAPISA }\end{array}$ & Agr/irrign & 列 & \begin{tabular}{|l} 
KUNAR \\
KUNDUZ \\
LAGHMAN \\
LOGAR \\
NANGARHAR \\
NIMROZ \\
ORUZGAN \\
PAKTEKA \\
PAKTIA \\
PARWAN \\
SAMANGAN \\
TAKHAR \\
WARDAK \\
ZABUL
\end{tabular} & & \\
\hline
\end{tabular}


ARIANA UNITY RECONSTRUCTION COUNCIL (AURA)

is an Afghan NGo founded in 1993. The agency has expertise in agriculture, irrigation, construction, health and veterinary sectors.

Cleaning of two canals - irrigating 10,000 Jeribs of land - in Bust district, Helmand province is ongoing.

A proposal for a tailoring course for women in Helmand has been approved by the Canadian International Development Agency (CIDA) and will be started in the near future.

A monthly publication under the name of AURC is being planned. Details of the activities of the agency and the needs of Afghans will be published in this publication so as to better inform the donor agencies about the real needs of Afghan society. 
AUSTRIAN RELIEF COMMITTEE FOR AFGHANS-ARC

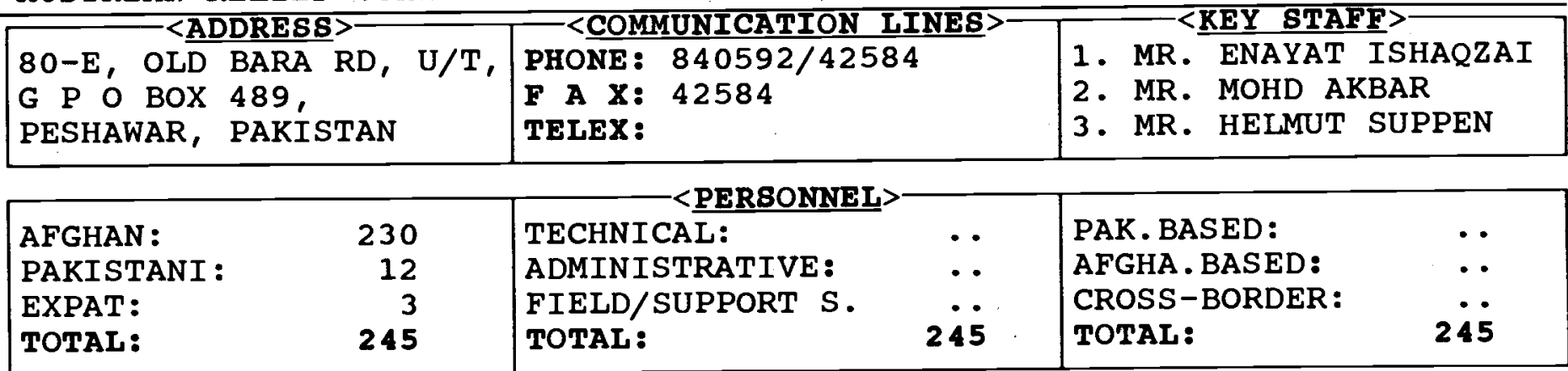

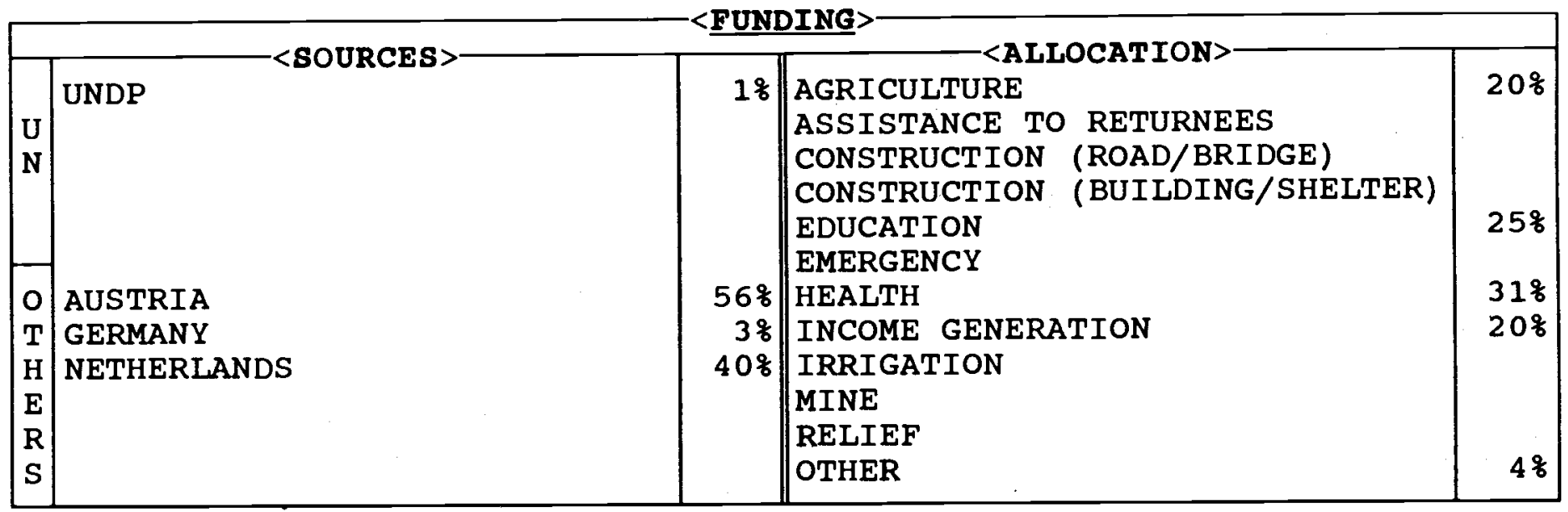

\begin{tabular}{|c|c|c|c|c|c|c|}
\hline & 1000 & 1000 & 1000 & & $100 ?$ & 1003 \\
\hline $\begin{array}{l}\text { AFGHANISTAN: } \\
\text { REFUGEES : }\end{array}$ & $\begin{array}{r}832,408 \\
1,259,771\end{array}$ & $\begin{array}{l}979,431 \\
783,545\end{array}$ & $\begin{array}{l}804,562 \\
891,877\end{array}$ & $\begin{array}{r}1,072,923 \\
940,597\end{array}$ & $\begin{array}{l}765,000 \\
635,000\end{array}$ & $\begin{array}{l}433,590 \\
543,770\end{array}$ \\
\hline T O T A L: & $2,092,179$ & $1,762,976$ & $1,696,439$ & $2,013,520$ & $1,400,000$ & 977,360 \\
\hline
\end{tabular}

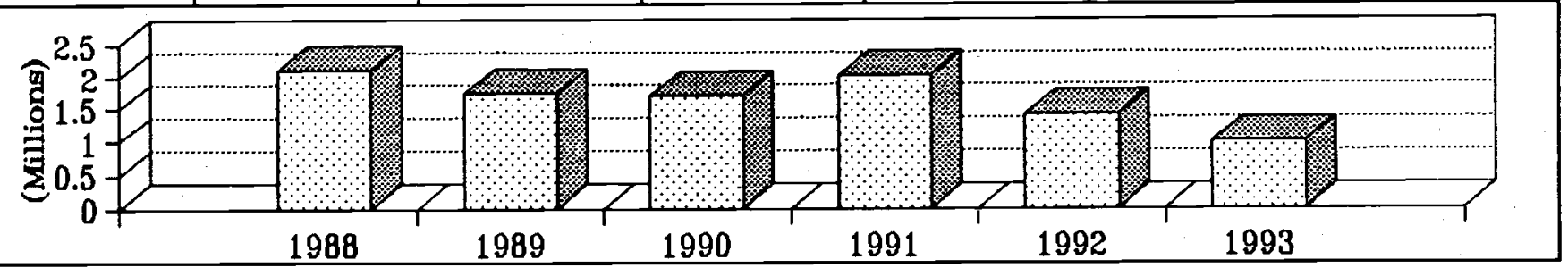

\begin{tabular}{|c|c|c|c|c|c|}
\hline PROVINCES & SECTOR & $\% \mathrm{AGE}$ & PROVINCES & SECTOR & $\% A G E$ \\
\hline $\begin{array}{l}\text { BADAKSHAN } \\
\text { BADGHIS } \\
\text { BAGHLAN } \\
\text { BALKH } \\
\text { BAMYAN } \\
\text { FARAH } \\
\text { FARYAB } \\
\text { GHAZNI } \\
\text { GHOR } \\
\text { HELMAND } \\
\text { HERAT } \\
\text { JAWZJAN } \\
\text { KABUL } \\
\text { KANDAHAR } \\
\text { KAPISA }\end{array}$ & Agr/health/voc.train. & $60 \%$ & \begin{tabular}{|l} 
KUNAR \\
KUNDUZ \\
LAGHMAN \\
LOGAR \\
NANGARHAR \\
NIMROZ \\
ORUZGAN \\
PAKTEKA \\
PAKTIA \\
PARWAN \\
SAMANGAN \\
TAKHAR \\
WARDAK \\
ZABUL
\end{tabular} & $\begin{array}{l}\text { Agr/health } \\
\text { Health }\end{array}$ & $\begin{array}{l}30 \% \\
10 \%\end{array}$ \\
\hline
\end{tabular}


AUSTRIAN RELIEF COMMITTEE (ARC)

was established in Vienna in 1980 as a relief organization to help Afghan refugees in Pakistan and Afghans in Afghanistan.

ARC initially offered medical assistance to refugees, but later on expanded its activities into sanitation and technical training. It has now become involved in longterm development programs inside Afghanistan.

ARC's aim is to "Help Afghans to Help Themselves" through a comprehensive management and staff training program.

It operates primary health care programs in Baghicha, Kagan and Gandaf areas at Mardan as well as cross-border in Nangarhar and Ghazni provinces. The programs involve curative and protective medicines, rehabilitation and improvement of nutrition.

Two technical training centers at Akora Khatak and Canal Road Peshawar are being operated to provide vocational training in the field of welding carpentry, tinsmithery, blacksmithery and radio repairing.

ARC has operated a sanitation program since 1982 in many refugee villages in the North-West Frontier Province of Pakistan. The project aims to reduce the incidence of sanitation-related diseases by the construction and maintenance of latrines, and provision of health education. The program has built around 100,000 latrines over the last ten years.

ARC runs rural development program in Ghazni, Logar and Nangarhar Provinces of Afghanistan. The aim is to increase food production and rural incomes, to encourage families to remain in their homes and to promote refugee returns. The activities include agriculture, irrigation, veterinary and incomegenerating projects.
In 1991-92, ARC's Primary Health Care, Technical Training and Sanitation programs established cross-border pilot programs in Logar. In 1993 ARC developed this integrated community-based program and plans to further develop them in 1994. As repatriation increases ARC plans to transfer its refugee programs inside Afghanistan concentrating first on its existing cross-border project areas. 


\begin{tabular}{|c|c|c|}
\hline <ADDRE88 $>-$ & $-<$ COMMUNICATION LINES & $-<$ REY STAFF $>$ \\
\hline $\begin{array}{l}589, \text { ST. } 30, \text { D/4, PH. I } \\
\text { HAYATABAD, P O BOX } 856 \\
\text { PESHAWAR, PAKISTAN }\end{array}$ & $\begin{array}{l}\text { PHONE: } \\
\text { F A X: } \\
\text { TELEX: }\end{array}$ & $\begin{array}{l}\text { 1. MR. MOHD HAIDAR } \\
\text { 2. } \\
\text { 3. }\end{array}$ \\
\hline
\end{tabular}

\begin{tabular}{|lr|lr|lr|}
\hline AFGHAN : & 12 & TECHNICAL: & 6 & PAK.BASED: & 1 \\
PAKISTANI: & - & ADMINISTRATIVE: & 2 & AFGHA.BASED: & 10 \\
EXPAT: & - & FIELD/SUPPORT S. & 4 & CROSS-BORDER: & 1 \\
TOTAL: & 12 & TOTAL: & 12 & TOTAL: & 12 \\
\hline
\end{tabular}

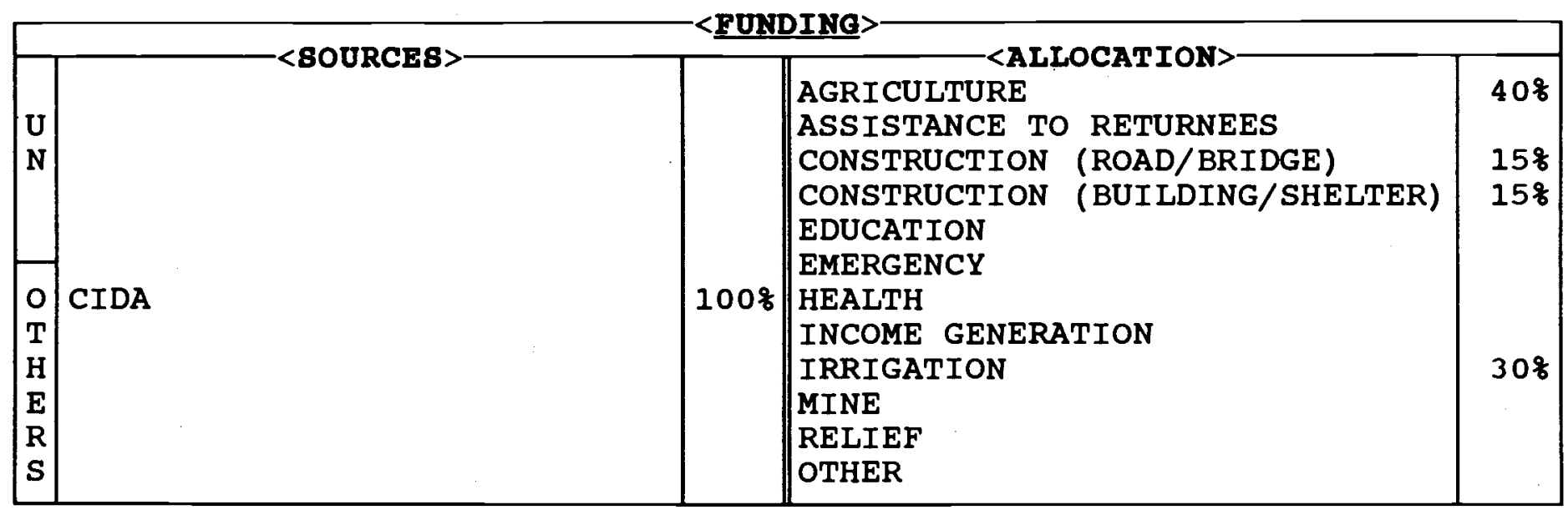

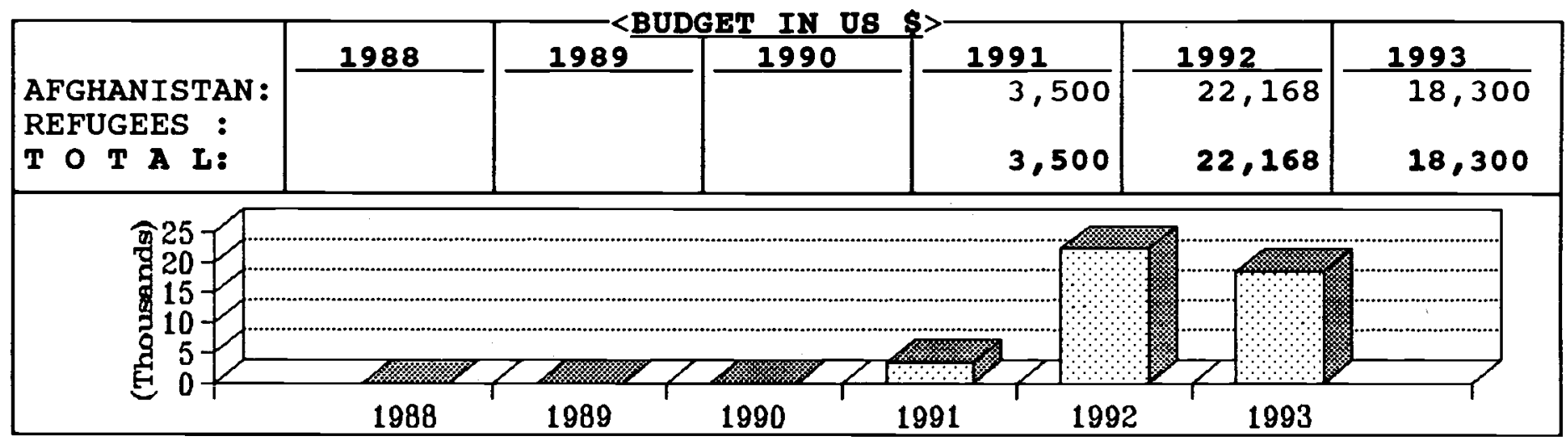

\begin{tabular}{|c|c|c|c|c|c|}
\hline PROVINCES & SECTOR & \&AGE & PROVINCES & SECTOR & $\%$ AGE \\
\hline $\begin{array}{l}\text { BADAKSHAN } \\
\text { BADGHIS } \\
\text { BAGHLAN } \\
\text { BALKH } \\
\text { BAMYAN } \\
\text { FARAH } \\
\text { FARYAB } \\
\text { GHAZNI } \\
\text { GHOR } \\
\text { HELMAND } \\
\text { HERAT } \\
\text { JAWZJAN } \\
\text { KABUL } \\
\text { KANDAHAR } \\
\text { KAPISA }\end{array}$ & Agr/const/irrign & $100 \%$ & $\begin{array}{l}\text { KUNAR } \\
\text { KUNDUZ } \\
\text { LAGHMAN } \\
\text { LOGAR } \\
\text { NANGARHAR } \\
\text { NIMROZ } \\
\text { ORUZGAN } \\
\text { PAKTEKA } \\
\text { PAKTIA } \\
\text { PARWAN } \\
\text { SAMANGAN } \\
\text { TAKHAR } \\
\text { WARDAK } \\
\text { ZABUL }\end{array}$ & & \\
\hline
\end{tabular}


BAGHLAN REHABILITATION COMMITTEE (BRO)

is an Afghan nongovernmental organization founded in May 1989. A number of experienced and committed persons from Baghlan province came together to establish the organization through which rehabilitation and reconstruction activities could be undertaken in the province.

The main fields of BRC's activities are agriculture, irrigation and infrastructure rehabilitation.

The main funding source for BRC has so far been the Canada Fund.

BRC has successfully completed a road repair project in Industrial Baghlan. Repair of Industrial Baghlan High School, construction of a clinic building in Industrial Baghlan, repair of Central Baghlan High school for girls, provision of chairs and tables for schools and rehabilitation of several canals in the province of Baghlan are in the planning process.

The main base of the organization is Baghlan province. It has a branch office in Peshawar.

BRC is a member of Afghan NaOs coordination Bureau (ANCB). 
BAKHTAR DEVELOPMENT AGENCY-BDA

\begin{tabular}{|c|c|c|}
\hline$-<\underline{\text { ADDRESB }}>$ & $-<$ COMMUNICATION LINES $>$ & $-\langle$ REY BTAFF $\rangle$ \\
\hline 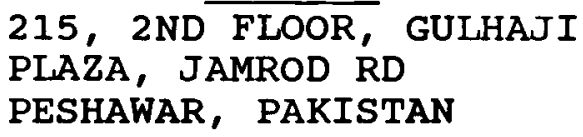 & $\begin{array}{l}\text { PHONE: } 44332 \\
\text { F A X: } \\
\text { TELEX: }\end{array}$ & $\begin{array}{lll}\text { 1. MR. M. H. JALALZAI } \\
\text { 2. DR. A. SAMAD ASHRATI } \\
\text { 3. ENG.M. NADAR }\end{array}$ \\
\hline
\end{tabular}

\begin{tabular}{|lr|lr|lr|}
\hline AFGHAN : & 10 & TECHNICAL: & 6 & PAK. BASED: & 3 \\
PAKISTANI : & - & ADMINISTRATIVE: & 2 & AFGHA. BASED: & 3 \\
EXPAT: & - & FIELD/SUPPORT S. & 2 & CROSS-BORDER: & 4 \\
TOTAL: & 10 & TOTAL: & 10 & TOTAL: & 10 \\
\hline
\end{tabular}

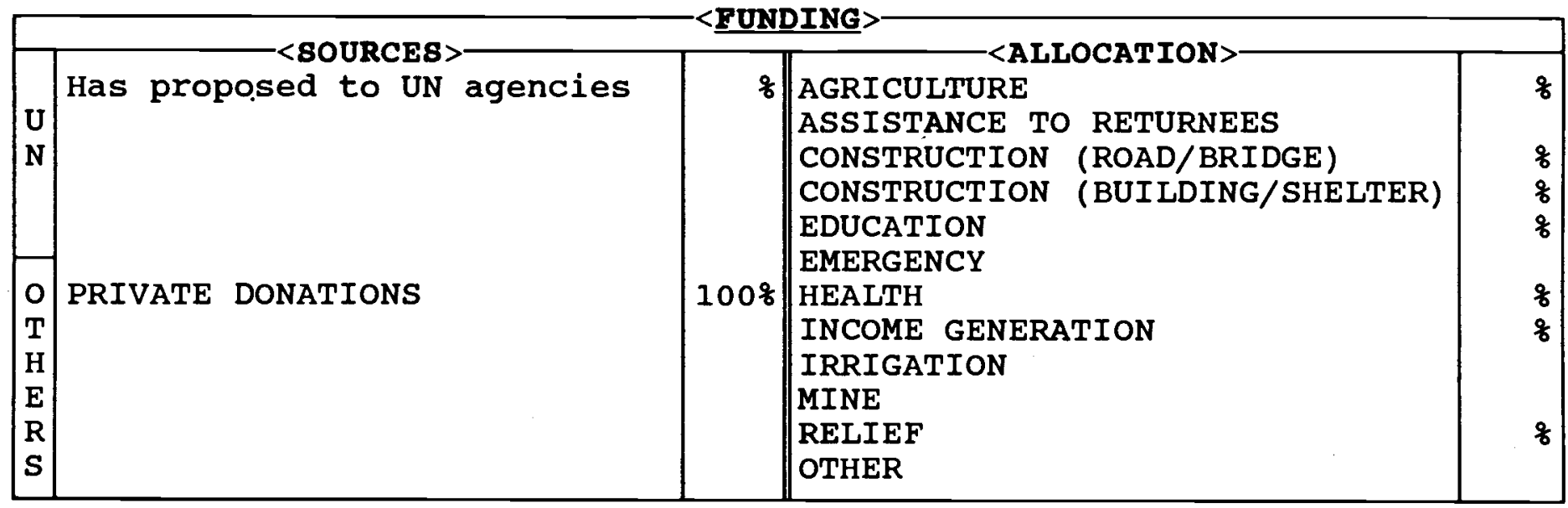

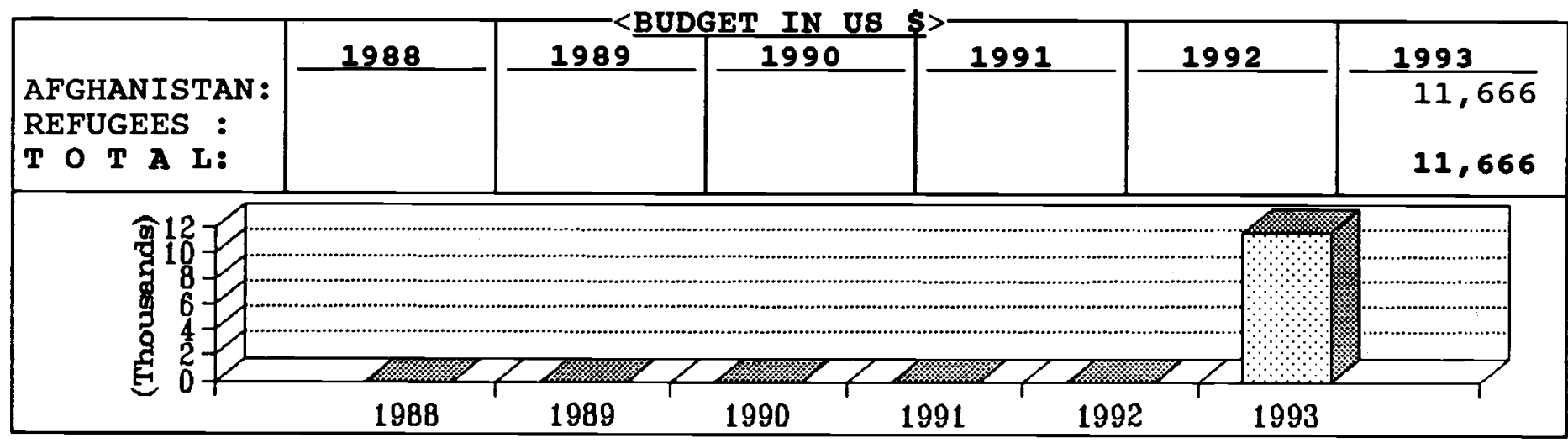

\begin{tabular}{|c|c|c|c|c|c|}
\hline PROVINCES & SECTOR & \&AGE & PROVINCES & SECTOR & $\& A G E$ \\
\hline $\begin{array}{l}\text { BADAKSHAN } \\
\text { BADGHIS } \\
\text { BAGHLAN } \\
\text { BALKH } \\
\text { BAMYAN } \\
\text { FARAH } \\
\text { FARYAB } \\
\text { GHAZNI } \\
\text { GHOR } \\
\text { HELMAND } \\
\text { HERAT } \\
\text { JAWZJAN } \\
\text { KABUL } \\
\text { KANDAHAR } \\
\text { KAPISA }\end{array}$ & Survey/assessment & $\begin{array}{r}\frac{8}{8} \\
8 \\
100 \frac{8}{8}\end{array}$ & \begin{tabular}{|l} 
KUNAR \\
KUNDUZ \\
LAGHMAN \\
LOGAR \\
NANGARHAR \\
NIMROZ \\
ORUZGAN \\
PAKTEKA \\
PAKTIA \\
PARWAN \\
SAMANGAN \\
TAKHAR \\
WARDAK \\
ZABUL
\end{tabular} & & $q$ \\
\hline
\end{tabular}


BAKHTAR DEVELOPMENT AGENCY (BDA)

is an Afghan non-profit, nonpartisan, non-governmental and nonpolitical humanitarian organization established in 1993.

The sole aim of the Agency is to actively contributed to the rehabilitation and reconstruction of Afghanistan. It works towards assisting Afghans to help themselves and averting the effects of the damages inflicted on the Afghan nation as a whole.

BDA undertakes surveying, planning, designing and actual implementation of programs in the sectors of:

Repairing and construction of infrastructure, e.g. roads, bridges, irrigation systems and public buildings (schools, clinics, hospitals).

Rehabilitation and revival of agriculture through provision of inputs and services with the purpose of contributing to the well-being and prosperity of farming families and improving the economy of the lower classes in the rural areas.

- Reactivation and provision of support to schools and enhancing adult education and technical/vocational training to meet the challenges of rebuilding Afghanistan.

Reopening of health facilities, improving community sanitation and provision of services to disabled and destitute people.

Women welfare project and projects which develop home economy.

Provision of relief goods to the victims of natural disasters and war to the most remote part of the country.

BDA headquarters for the time being is located in Peshawar with branch offices in Ghazni and Jalalabad staffed with qualified agriculturalists, engineers, social workers, health workers and education experts.

The organization works in regions where least relief aid has been provided, particularly the areas of minorities and under-privileged groups.

BDA has affiliations and close cooperation with local authorities, shuras and community influential of its project areas and with Afghan and international NGOs.

A number of project proposals has been submitted to donor o $\quad r \quad g \quad a \quad n \quad i \quad z \quad a \quad t \quad i \quad o \quad n \quad s$. 
BAKHTAR UNITY RECONSTRUCTION COUNCIL-BURC

\begin{tabular}{|l|l|l|}
\hline KASSI RD, OPPOSITE HAJI & PHONE: 75439 & <COMEY STAFF> \\
FATEH KHAN ROAD & F A X: & 1. MR. S. A. MALIK \\
QUETTA, PAKISTAN & TELEX: & 2. ENG.AKBAR \\
3. DR. NAZIFA
\end{tabular}

\begin{tabular}{|lr|lr|lr|}
\hline AFGHAN : & 16 & TECHNICAL: & 5 & PAK. BASED: & 11 \\
PAKISTANI : & - & ADMINISTRATIVE: & 2 & AFGHA.BASED: & 3 \\
EXPAT: & - & FIELD/SUPPORT S. & 9 & CROSS-BORDER: & 2 \\
TOTAL: & 16 & TOTAL: & 16 & TOTAL: & 16 \\
\hline
\end{tabular}

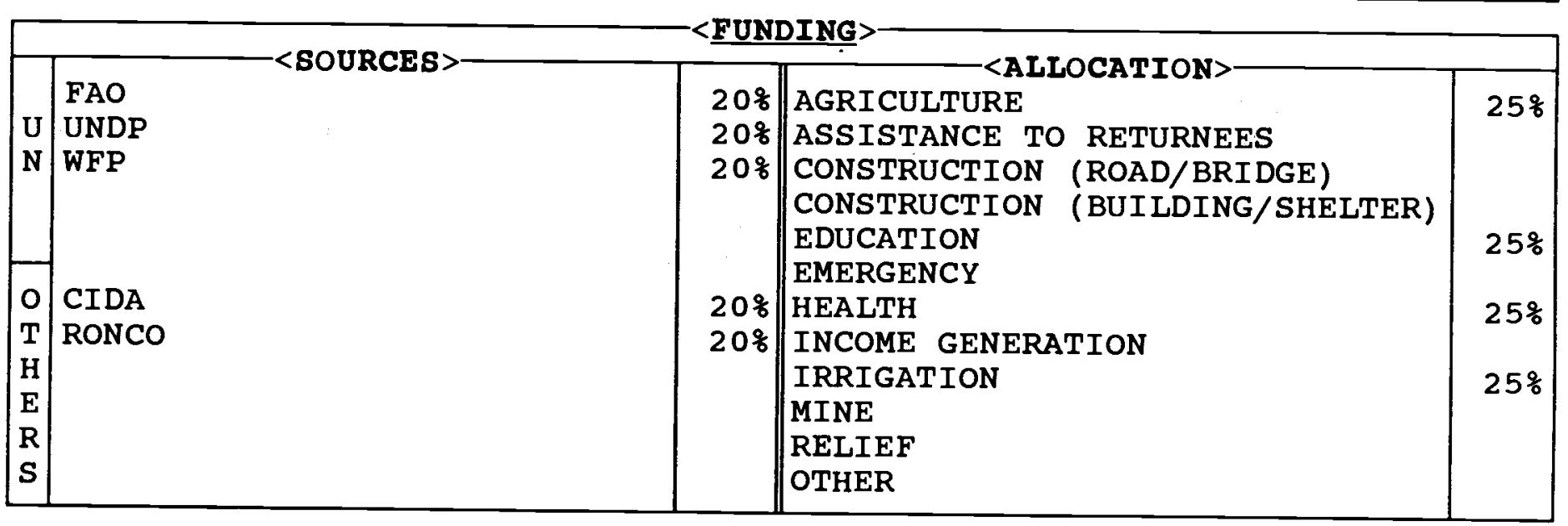

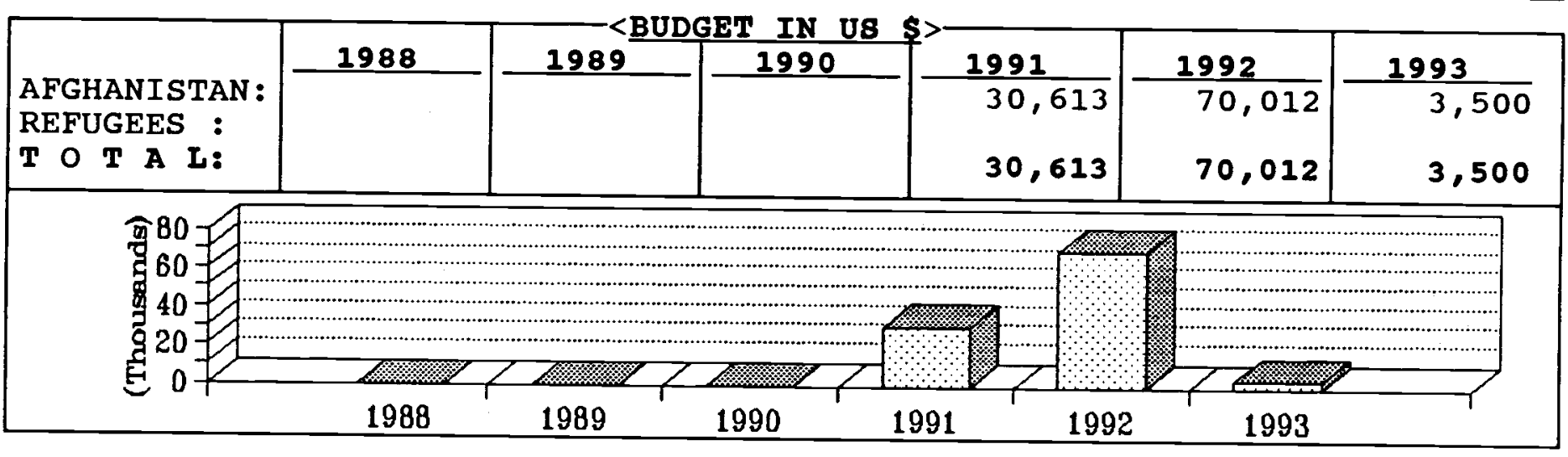

\begin{tabular}{|c|c|c|c|c|c|}
\hline PROVINCES & SECTOR & $\%$ AGE & PROVINCES & SECTOR & $\% \mathrm{AGE}$ \\
\hline $\begin{array}{l}\text { BADAKSHAN } \\
\text { BADGHIS } \\
\text { BAGHLAN } \\
\text { BALKH } \\
\text { BAMYAN } \\
\text { FARAH } \\
\text { FARYAB } \\
\text { GHAZNI } \\
\text { GHOR } \\
\text { HELMAND } \\
\text { HERAT } \\
\text { JAWZJAN } \\
\text { KABUL } \\
\text { KANDAHAR } \\
\text { KAPISA }\end{array}$ & $\begin{array}{l}\text { Agr/educ/health/irrig } \\
\text { Agr/health/irrign }\end{array}$ & $40 \%$ & \begin{tabular}{||l|} 
KUNAR \\
KUNDUZ \\
LAGHMAN \\
LOGAR \\
NANGARHAR \\
NIMROZ \\
ORUZGAN \\
PAKTEKA \\
PAKTIA \\
PARWAN \\
SAMANGAN \\
TAKHAR \\
WARDAK \\
ZABUL
\end{tabular} & Agr/const/health & $20 \%$ \\
\hline
\end{tabular}



(BURC)

is an Afghan NGo founded in 1990 with the objective of taking part in the rehabilitation and reconstruction of Afghanistan.

BURC is currently working in the sectors of agriculture, health, irrigation, education and training. It intends to implement programs in animal husbandry, construction including roads, mine and relief programs for disabled Afghans and returnees.

In agriculture, BURC is involved in seed multiplication and fertilizer distribution. It is planned to provide agricultural machinery and work towards promotion of agriculture in the area by providing agricultural training to the farmers. BURC also works in rehabilitation of irrigation systems including canals, karezes, and springs.

In the health sector, BURC is running a TBA/midwife training course. 58 students have completed the course. A 13 bed hospital is operated in Quetta for Afghan refugees. The hospital has operation theater, laboratory and 2 out patient clinics for children and women.

BURC has constructed $5 \mathrm{~km}$ of road in Uruzgan province.

400 families have repatriated to Ghor province with the assistance of BURC.

The current target provinces in Afghanistan are Uruzgan, Kandahar and Helmand.

A number of project proposals have been submitted to different United Nations organizations.

If the security situation improves, BURC will move its central office to Kabul and open sub-offices in Ghor and Kandahar provinces. 
BALUCHISTAN MODEL TEACHER TRAINING CENTER-BMTTC

\begin{tabular}{|l|l|l|}
\hline 6-9/380 A SHHRAHI & PHONE: 75773 & 1. DR. TURRELL \\
GULISTAN & F A X: & 2. \\
QUETTA, PAKISTAN & TELEX: & 3. \\
\hline
\end{tabular}

\begin{tabular}{|ll|ll|ll|}
\hline AFGHAN: & 7 & TECHNICAL: & 4 & PAK. BASED: & 5 \\
PAKISTANI : & - & ADMINISTRATIVE: & 2 & AFGHA.BASED: & - \\
EXPAT: & 1 & FIELD/SUPPORT S. & 2 & CROSS-BORDER: & 3 \\
TOTAL: & $\mathbf{8}$ & TOTAL: & $\mathbf{8}$ & TOTAL: & $\mathbf{8}$ \\
\hline
\end{tabular}

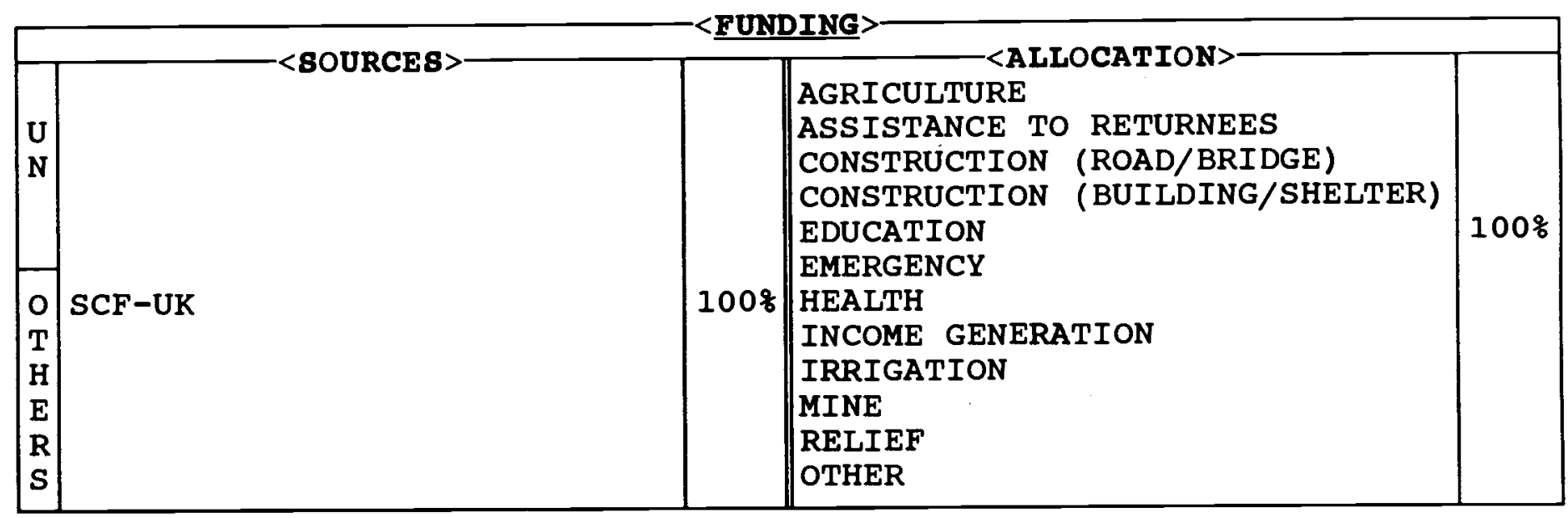

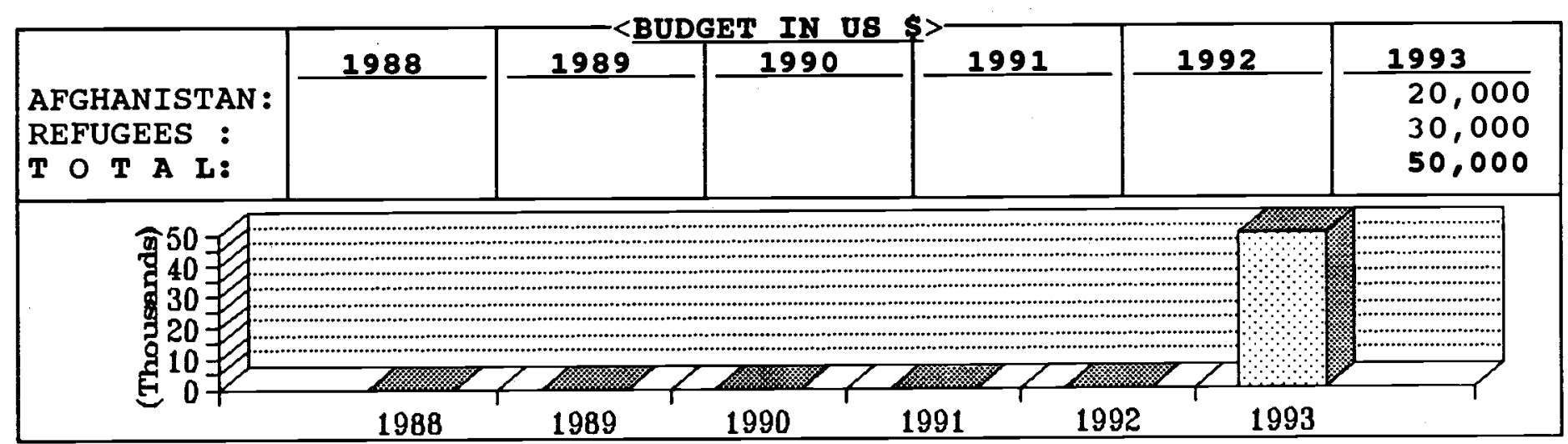

\begin{tabular}{|c|c|c|c|c|c|}
\hline PROVINCES & SECTOR & \&AGE & PROVINCES & SECTOR & \&AGE \\
\hline $\begin{array}{l}\text { BADAKSHAN } \\
\text { BADGHIS } \\
\text { BAGHLAN } \\
\text { BALKH } \\
\text { BAMYAN } \\
\text { FARAH } \\
\text { FARYAB } \\
\text { GHAZNI } \\
\text { GHOR } \\
\text { HELMAND } \\
\text { HERAT } \\
\text { JAWZJAN } \\
\text { KABUL } \\
\text { KANDAHAR } \\
\text { KAPISA }\end{array}$ & $\begin{array}{l}\text { Educ } \\
\text { Educ }\end{array}$ & 408 & $\begin{array}{l}\text { KUNAR } \\
\text { KUNDUZ } \\
\text { LAGHMAN } \\
\text { LOGAR } \\
\text { NANGARHAR } \\
\text { NIMROZ } \\
\text { ORUZGAN } \\
\text { PAKTEKA } \\
\text { PAKTIA } \\
\text { PARWAN } \\
\text { SAMANGAN } \\
\text { TAKHAR } \\
\text { WARDAK } \\
\text { ZABUL }\end{array}$ & Educ & $20 \%$ \\
\hline
\end{tabular}


was founded on December 10, 1989. Its main objective is to provide in-service training to teachers of schools inside Afghanistan as well as teachers of schools in the refugee camps in Baluchistan.

Non-professional teachers (baccalaureate) are trained by this agency and at the end of the course they are provided with instructional materials as well as necessary materials for students and schools such as carpets, blackboards, notebooks, pens, pencils, rubbers, buckets, water trunks, glasses, etc.

So far 130 teachers have been trained and 28 teachers have completed refresher courses. Each course is of three months duration and is held at the main office.

After sending the teachers to schools they are observed for a month and follow-up work is done with them for another month. The teachers are once again invited for a two month refresher course. The above mentioned process is completed in a year period.

BMTTC is studying the possibilities of undertaking appropriate projects inside Afghanistan. 
BASIC EDUCATION FOR AFGHAN REFUGEES-BEFARE

\begin{tabular}{|c|c|c|c|c|c|}
\hline$\longrightarrow<\underline{\mathrm{AD}}$ & & $-<$ COMMUNICATIOI & [NES & $-<$ KEY STR & AFF $>$ \\
\hline $\begin{array}{l}\text { 8-TATRA } \\
\text { P O BOX } 14 \\
\text { PESHAWAR, }\end{array}$ & $\begin{array}{l}\text { ATABAD } \\
\text { TAN }\end{array}$ & $\begin{array}{l}\text { PHONE: } 840631 \\
\text { F A X: } 841047 \\
\text { TELEX: }\end{array}$ & & $\begin{array}{lll}\text { 1. } & \text { DR. } & \text { MICHAE } \\
\text { 2. DR. YUSUF } \\
\text { 3. DR. SAYED }\end{array}$ & $\begin{array}{l}\text { EL HIRTH } \\
\text { NURISTANI } \\
\text { BAKHTARI }\end{array}$ \\
\hline $\begin{array}{l}\text { AFGHAN : } \\
\text { PAKISTANI : } \\
\text { EXPAT: } \\
\text { TOTAL: }\end{array}$ & $\begin{array}{r}472 \\
25 \\
1 \\
498\end{array}$ & $\begin{array}{l}\text { TECHNICAL: } \\
\text { ADMINISTRATIVE: } \\
\text { FIELD/SUPPORT S. } \\
\text { TOTAL: }\end{array}$ & $\begin{array}{r}35 \\
23 \\
440 \\
498\end{array}$ & $\begin{array}{l}\text { PAK. BASED : } \\
\text { AFGHA. BASED: } \\
\text { CROSS-BORDER: } \\
\text { TOTAL : }\end{array}$ & $\begin{array}{r}418 \\
- \\
80 \\
498\end{array}$ \\
\hline
\end{tabular}

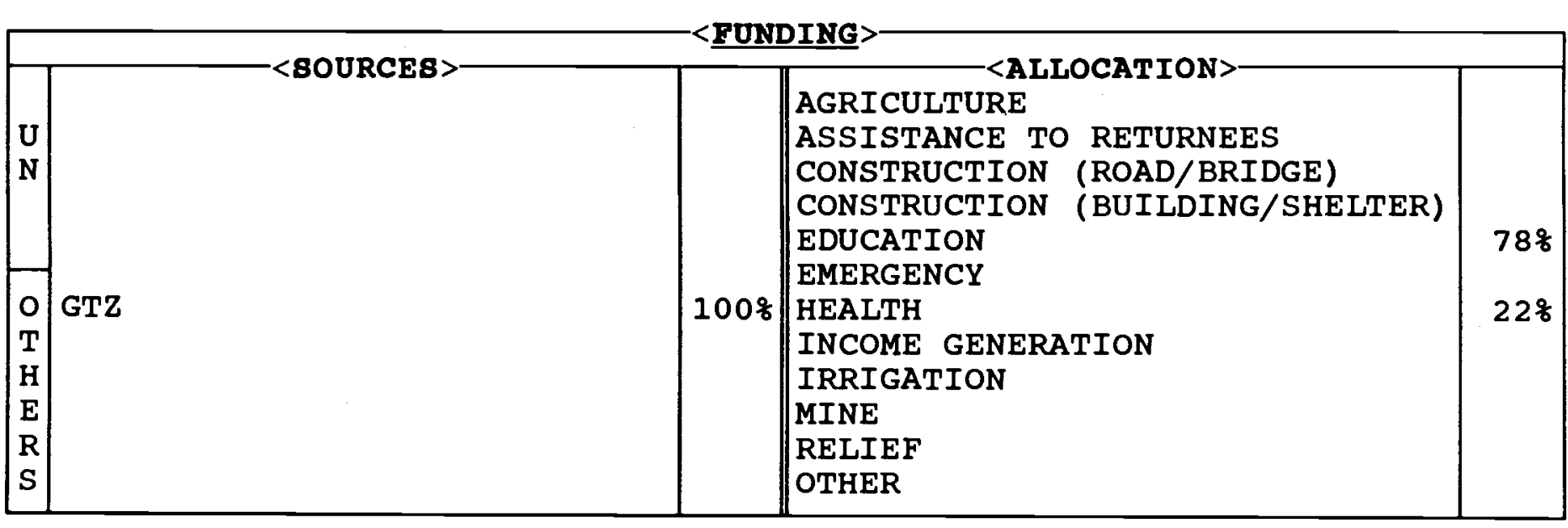

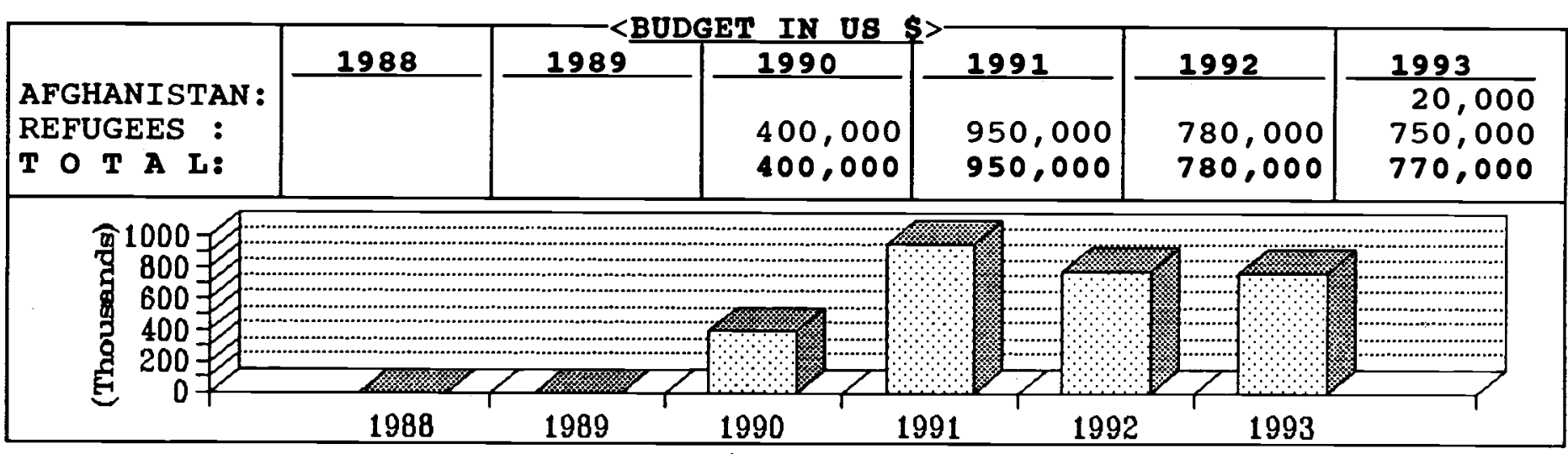

\begin{tabular}{|c|c|c|c|c|c|}
\hline PROVINCES & SECTOR & \&AGE & PROVINCES & SECTOR & $\%$ AGE \\
\hline $\begin{array}{l}\text { BADAKSHAN } \\
\text { BADGHIS } \\
\text { BAGHLAN } \\
\text { BALKH } \\
\text { BAMYAN } \\
\text { FARAH } \\
\text { FARYAB } \\
\text { GHAZNI } \\
\text { GHOR } \\
\text { HELMAND } \\
\text { HERAT } \\
\text { JAWZJAN } \\
\text { KABUL } \\
\text { KANDAHAR } \\
\text { KAPISA }\end{array}$ & & & $\begin{array}{l}\text { KUNAR } \\
\text { KUNDUZ } \\
\text { LAGHMAN } \\
\text { LOGAR } \\
\text { NANGARHAR } \\
\text { NIMROZ } \\
\text { ORUZGAN } \\
\text { PAKTEKA } \\
\text { PAKTIA } \\
\text { PARWAN } \\
\text { SAMANGAN } \\
\text { TAKHAR } \\
\text { WARDAK } \\
\text { ZABUL }\end{array}$ & $\begin{array}{l}\text { Educ } \\
\text { Educ } \\
\text { Educ }\end{array}$ & $\begin{array}{l}25 \% \\
50 \% \\
25 \%\end{array}$ \\
\hline
\end{tabular}


BASIC EDUCATION FOR AFGHAN REFUGEES (BEFARe)

is a bilateral government project, agreed between the Governments of the Islamic Republic of Pakistan and the Federal Republic of Germany, to support Afghan refugees in Pakistan's North-West Frontier Province. The project started as Pak-German Basic-Education in late 1984. This project aims at the improvement of basic education for children (through formal education) and for adults (through non-formal education), for both male and female learners.

Based on government agreement the project is jointly administered by the Commissioner Afghan Refugees (Education + Social Welfare Cells) in all UNHCR sponsored schools in almost all districts of NWFP with the main office in Peshawar with branches in Timergare, Bannu, Kurram and Miranshah.

The project is designed to contribute to the overall improvement of basic education of Afghan refugees.

To achieve this objective, the project carries out a number of activities which can be outlined into three areas:

1. Formal Education:

The project regularly trains MTs, TTs, head masters, teachers and supervisors at different levels who work in about 330 schools of the Education cell (530 before repatriation of the refugees) and supports about 50,000 students $(80,000$ before repatriation) with textbooks, teacher's guides and other teaching aids.

Since 1989 during school vacations more than 4,000 teachers of grades I, II and III have received two weeks of training in the most important pedagogical topics. The teachers are also prepared to face the difficult conditions that they will face in Afghanistan.

2. Non-formal Education:

The child care course, covering the main aspects of mother and child health, physical and mental child development. In this area the project has trained 473 group leaders and 60,000 Afghan refugee women have participated in the program in 2,030 courses since April 1989. The current (CCC) program is under revision and it is planned that the new $\mathrm{MCH}$ training with revised material, will begin January, 1994.

3. Literacy:

The literacy program started in January, 1992 after long and careful preparation. More than 400 literacy instructors have received one week of training for each level i.e. Primer and reader. 11,000 registered participants have been reached of whom more than 4,000 have completed their courses and successfully passed the final tests. 


\section{BAZ CONSTRUCTION UNIT FOR REHABIIITATION OF AFGHANIBTAN \\ (BCURA)}

is an Afghan NGo staffed with professional, well-educated, experienced and competent engineers and agrarians. It has implemented a handful projects in different provinces of Afghanistan particularly in Nangarhar.

BCURA maintairis cordial contacts with all local shuras and has faced no problems in implementing projects. BCURA's projects are implemented by full participation of the community members who are also responsible for the security of its staff and property.

The work areas of BCURA include agriculture, animal husbandry and engineering.

BCURA has also established a shoe factory in Board Peshawar. shoes produced at the factory are provided at a subsidy price to Afghans in the refugee camps as well as inside Afghanistan.

The main office of the agency is in Peshawar and it has a sub-office in Jalal abad.

An outline of BCURA's projects is as follows:

1. Cleaning of karezes in Ghazni

2. Distribution of wheat in Ghazni

3. Construction of primary school in Kunar

4. Distribution of rice, maize and wheat seeds and fruit trees in Nangarhar

5. Canal cleaning in Nangarhar

6. Road repair in Nangarhar

7. Repair of a secondary school in Nangarhar

8. Establishment of a nursery farm in Nangarhar province. 
BEHZAD REHABILITATION-CONSTRUCTION ORGANIZATION-BRCO

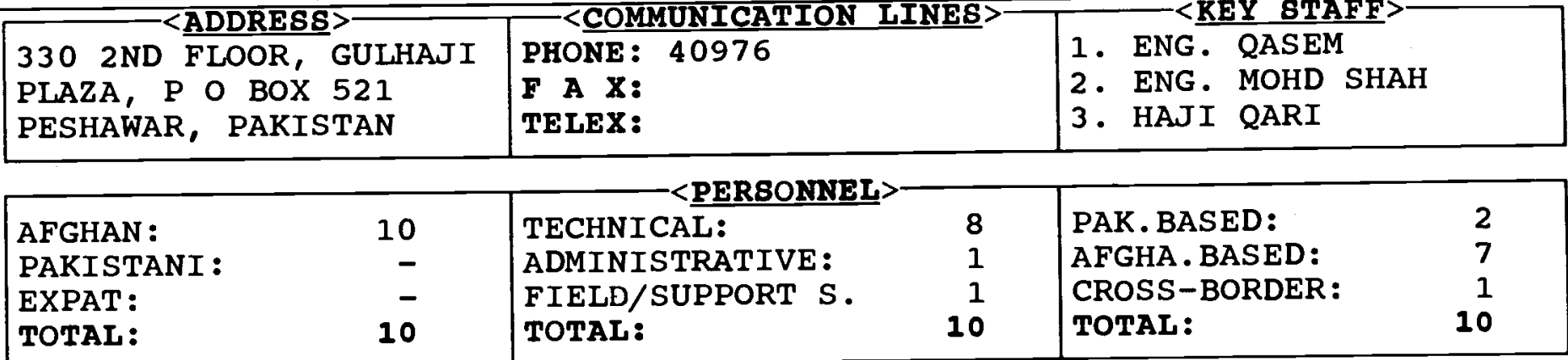

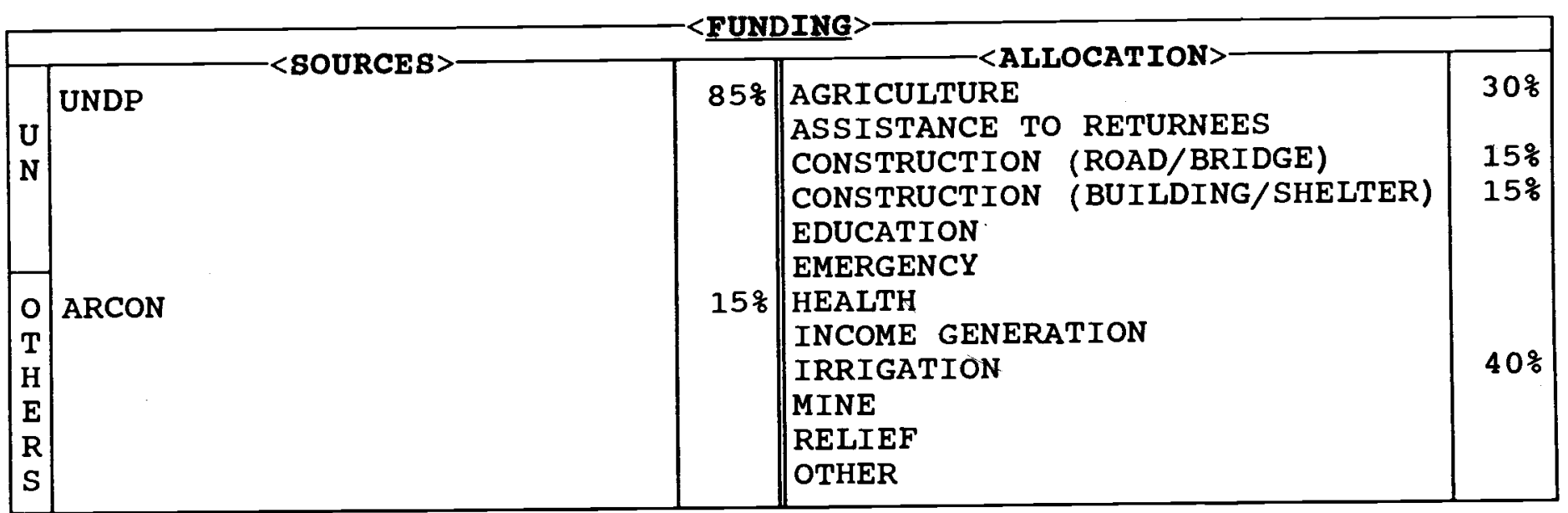

\begin{tabular}{|c|c|c|c|c|c|c|}
\hline \multirow{3}{*}{$\begin{array}{l}\text { AFGHANISTAN : } \\
\text { REFUGEES : } \\
\text { TOT A L: }\end{array}$} & \multirow{3}{*}{1988} & \multirow{3}{*}{1989} & \multirow{3}{*}{1990} & \multirow{3}{*}{$\begin{array}{l}\frac{1991}{166,670} \\
166,670\end{array}$} & \multirow{2}{*}{$\frac{1992}{308,000}$} & \multirow{2}{*}{$\frac{1993}{66,667}$} \\
\hline & & & & & & \\
\hline & & & & & 308,000 & 66,667 \\
\hline
\end{tabular}

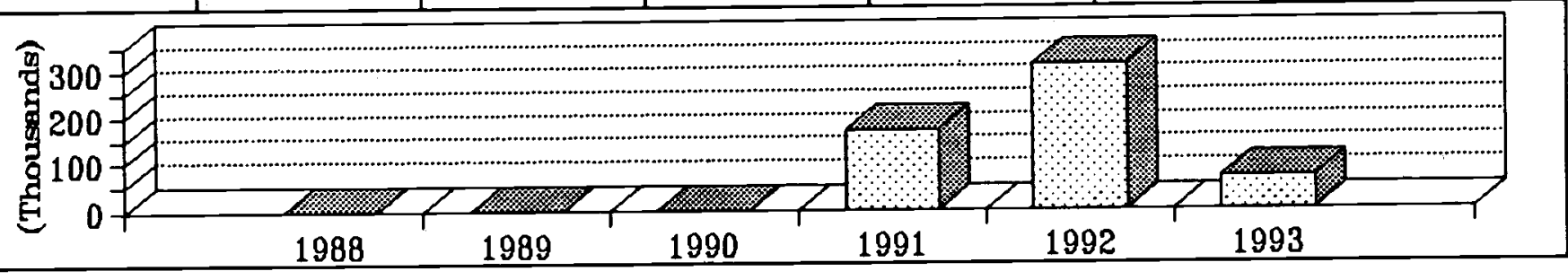

\begin{tabular}{|c|c|c|c|c|c|}
\hline PROVINCES & SECTOR & \&AGE & PROVINCES & SECTOR & $\because A G E$ \\
\hline $\begin{array}{l}\text { BADAKSHAN } \\
\text { BADGHIS } \\
\text { BAGHLAN } \\
\text { BALKH } \\
\text { BAMYAN } \\
\text { FARAH } \\
\text { FARYAB } \\
\text { GHAZNI } \\
\text { GHOR } \\
\text { HELMAND } \\
\text { HERAT } \\
\text { JAWZJAN } \\
\text { KABUL } \\
\text { KANDAHAR } \\
\text { KAPISA }\end{array}$ & Agr/const/irrign & $100 \%$ & $\begin{array}{l}\text { KUNAR } \\
\text { KUNDUZ } \\
\text { LAGHMAN } \\
\text { LOGAR } \\
\text { NANGARHAR } \\
\text { NIMROZ } \\
\text { ORUZGAN } \\
\text { PAKTEKA } \\
\text { PAKTIA } \\
\text { PARWAN } \\
\text { SAMANGAN } \\
\text { TAKHAR } \\
\text { WARDAK } \\
\text { ZABUL }\end{array}$ & & \\
\hline
\end{tabular}


is an Afghan NGo founded in 1991. The organization was established for rehabilitation and construction of the western provinces of Afghanistan (Herat, Badghis, Ghor, Farah and Nimroz).

The agency is based in Herat and works in cooperation and consultation with the target communities and local authorities.

BRCO believes in full assessment of needs, survey and study of conditions before undertaking any projects. To achieve its objectives, BRCO invites and welcomes the advice and suggestions of experts and scholars and request their participation in the exercise of rehabilitation.

The main sectors of BRCO work include:

1. Agriculture and animal husbandry

2. Construction (roads, buildings and bridges)

3. Rehabilitation and improvement of irrigation net-work

4. Sanitation and water-supply

5. Provision and development of heating facilities

6. Training of professional personnel and producing technical publications

7. Development of local and national industries.

The organization is composed of a General Assembly, a Board of Directors and an Executive Council.

Over the past 3 years, BRCO has carried out a number of projects in its specialized sectors. 
BOMB DISPOSAL SERVICES-BDS

\begin{tabular}{|c|c|c|}
\hline$=<$ ADDRESS $>-$ & $=<$ COMMUNICATION LINEB $>$ & $=<$ KEY BTAFF $>-$ \\
\hline $\begin{array}{l}\text { CHAR RAHI HAJI YAQOOB } \\
\text { SHAHR NAW } \\
\text { KABUL, AFGHANISTAN }\end{array}$ & $\begin{array}{l}\text { PHONE: } \\
\text { F A X: } \\
\text { TELEX: }\end{array}$ & $\begin{array}{l}\text { 1. MR. PETER JAWORISKY } \\
\text { 2. } \\
\text { 3. }\end{array}$ \\
\hline
\end{tabular}

\begin{tabular}{|ll|ll|ll|}
\hline AFGHAN : & 5 & TECHNICAL: & 2 & PAK.BASED: & - \\
PAKISTANI : & - & ADMINISTRATIVE : & 1 & AFGHA.BASED: & 6 \\
EXPAT: & 1 & FIELD/SUPPORT S. & 3 & CROSS BORDER: & - \\
TOTAL: & 6 & TOTAL: & 6 & TOTAL: & 6 \\
\hline
\end{tabular}

\begin{tabular}{|c|c|c|c|c|}
\hline $\begin{array}{l} \\
\mathrm{O} \\
\mathrm{T} \\
\mathrm{H} \\
\mathrm{E} \\
\mathrm{R} \\
\mathrm{S}\end{array}$ & UNOCHA & 1008 & $\begin{array}{l}\text { AGRICULTURE } \\
\text { ASSISTANCE TO RETURNEES } \\
\text { CONSTRUCTION (ROAD/BRIDGE) } \\
\text { CONSTRUCTION (BUILDING/SHELTER) } \\
\text { EDUCATION } \\
\text { EMERGENCY } \\
\text { HEALTH } \\
\text { INCOME GENERATION } \\
\text { IRRIGATION } \\
\text { MINE } \\
\text { RELIEF } \\
\text { OTHER }\end{array}$ & $100 \%$ \\
\hline
\end{tabular}

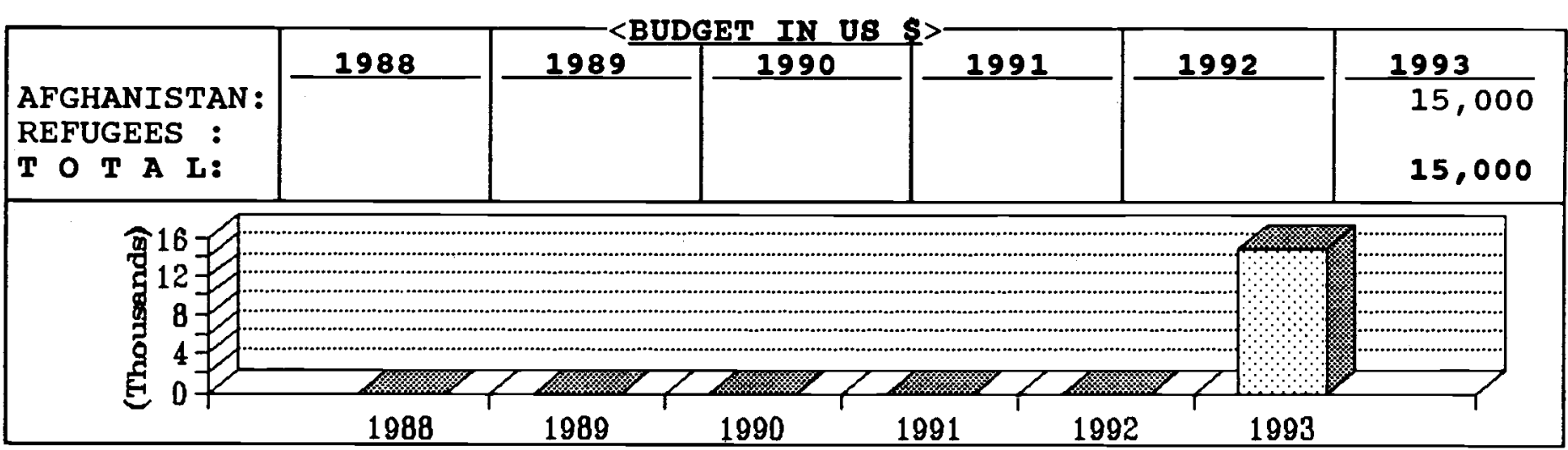

\begin{tabular}{|c|c|c|c|c|c|}
\hline PROVINCES & SECTOR & \&AGE & PROVINCES & SECTOR & 을 \\
\hline $\begin{array}{l}\text { BADAKSHAN } \\
\text { BADGHIS } \\
\text { BAGHLAN } \\
\text { BALKH } \\
\text { BAMYAN } \\
\text { FARAH } \\
\text { FARYAB } \\
\text { GHAZNI } \\
\text { GHOR } \\
\text { HELMAND } \\
\text { HERAT } \\
\text { JAWZJAN } \\
\text { KABUL } \\
\text { KANDAHAR } \\
\text { KAPISA }\end{array}$ & Mine & . & \begin{tabular}{|l} 
KUNAR \\
KUNDUZ \\
LAGHMAN \\
LOGAR \\
NANGARHAR \\
NIMROZ \\
ORUZGAN \\
PAKTEKA \\
PAKTIA \\
PARWAN \\
SAMANGAN \\
TAKHAR \\
WARDAK \\
ZABUL
\end{tabular} & & \\
\hline
\end{tabular}




\section{BOMB DIBPOSAL SERVICES (BDS)}

is set up to operate in Afghanistan as part of the UN Mine clearance Program. Funding for operations is to come from the UN, the British overseas Development Agency, the European Community and private donations from the UK.

The UN recognizes that there is a shortfall in its ordnance disposal capability, and BDS will cover this by giving priority to bomb disposal work in and around Kabul, where the threat to life is deemed to be most urgent.

BDS's work will comprise Conventional Munitions Disposal (CMD), Air-Dropped Weapons Disposal (ADD), Improvised Explosive Device Disposal (IEDD), as well as boobytrap disposal, and mine disposal where specialist switching is suspected or where specifically required.

BDS will be tasked by four sources; direct liaison with the 12 administrative districts of Kabul and their individual safety departments: reconnaissance of suspected contaminated areas by BDS team members on the ground; direct reports from members of the public, and reports by staff of the UN and other international agencies in the Kabul area. BDS will assess the threat level and likelihood of function of known and reported devices, and establish a priority order of clearance.

Work in this field will require a high level of technical expertise, as well as specialist equipment currently unavailable in Afghanistan. BDS will therefore import equipment including remote wrenches, de-armors and radiographic instruments.

Techniques employed will be the most up-to-date available, but will be constantly re-appraised and developed in the light of specific Afghan experience, and BDS anticipate initiating on-going trials to formulate new procedures. In support of technical development work, BDS intends to produce, use and to constantly update standard operating Procedures (SOPs) and technical Explosive Ordnance Disposal (EOD) manuals.

Development will consist of evaluating and improving BDS's service, techniques and equipment until they meet the highest standards. Growth and expansion will not form part of its early planning unless donor organizations, the UN Mine clearance Program or Afghan authorities insist on it. 


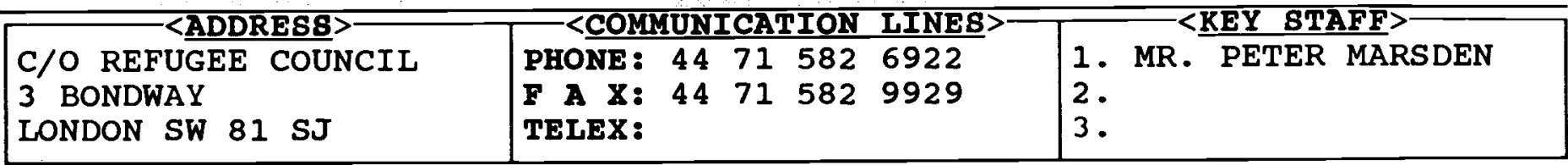

\begin{tabular}{|c|c|c|c|c|c|}
\hline $\begin{array}{l}\text { AFGHAN : } \\
\text { PAKISTANI: } \\
\text { EXPAT: } \\
\text { TOTAL: }\end{array}$ & $\begin{array}{l}- \\
- \\
1 \\
1\end{array}$ & $\begin{array}{l}\text { TECHNICAL: } \\
\text { ADMINISTRATIVE: } \\
\text { FIELD/SUPPORT S. } \\
\text { TOTAL: }\end{array}$ & $\begin{array}{l}\overline{1} \\
\overline{1}\end{array}$ & $\begin{array}{l}\text { PAK. BASED: } \\
\text { AFGHA. BASED: } \\
\text { CROSS-BORDER: } \\
\text { TOTAL: }\end{array}$ & $\begin{array}{l}- \\
- \\
1\end{array}$ \\
\hline
\end{tabular}

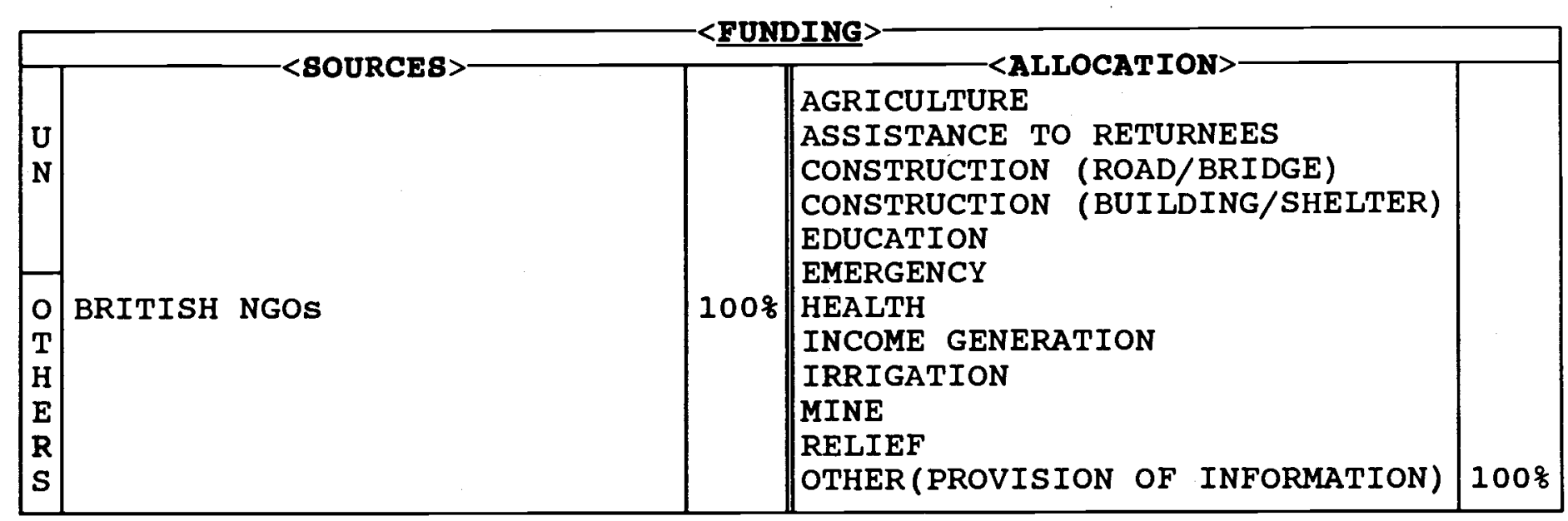

\begin{tabular}{|c|c|c|c|c|c|c|}
\hline & 1988 & 1989 & 1990 & 1991 & 1992 & 1993 \\
\hline $\begin{array}{l}\text { AFGHANISTAN : } \\
\text { REFUGEES : } \\
\text { T O T A I: }\end{array}$ & & & & 47,197 & 53,644 & 56,295 \\
\hline
\end{tabular}

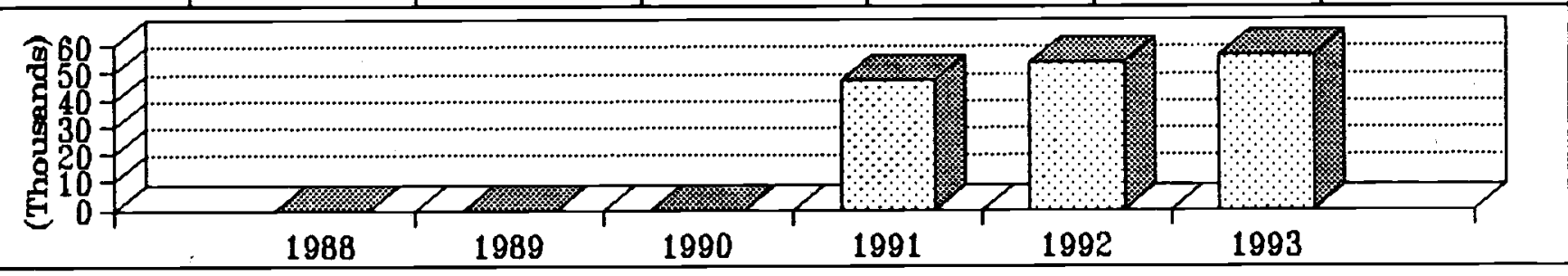

\begin{tabular}{|c|c|c|c|c|c|}
\hline PROVINCES & SECTOR & $\because \mathrm{AGE}$ & PROVINCES & SECTOR & \%AGE \\
\hline $\begin{array}{l}\text { BADAKSHAN } \\
\text { BADGHIS } \\
\text { BAGHLAN } \\
\text { BALKH } \\
\text { BAMYAN } \\
\text { FARAH } \\
\text { FARYAB } \\
\text { GHAZNI } \\
\text { GHOR } \\
\text { HELMAND } \\
\text { HERAT } \\
\text { JAWZJAN } \\
\text { KABUL } \\
\text { KANDAHAR } \\
\text { KAPISA }\end{array}$ & & & $\begin{array}{l}\text { KUNAR } \\
\text { KUNDUZ } \\
\text { LAGHMAN } \\
\text { LOGAR } \\
\text { NANGARHAR } \\
\text { NIMROZ } \\
\text { ORUZGAN } \\
\text { PAKTEKA } \\
\text { PAKTIA } \\
\text { PARWAN } \\
\text { SAMANGAN } \\
\text { TAKHAR } \\
\text { WARDAK } \\
\text { ZABUL }\end{array}$ & & \\
\hline
\end{tabular}


BRITISH AGENCIES AFGHANISTAN GROUP (BAAG)

was initiated by the Refugee Council's Asia committee to coordinate British agencies involved in Afghanistan. Its primary objectives were to promote a sharing of information between agencies and to raise the profile of Afghanistan with policy makers, donors and the wider public. The membership of the British Agencies Afghanistan Group is open to all British agencies who are working or are considering working with the people of Afghanistan, subject to acceptance of certain limited criteria.

Among the member agencies are those which are operational and those which have a purely funding role. Most of the agencies are also members of ACBAR or SWABAC.

BAAG employs one member of staff, an information coordinator, whose function is

1) to provide a focal point for the network of British agencies and to improve communication and cooperation between them,

2) to keep the members of the British Agencies Afghanistan Group informed by monitoring developments that might affect the future of their projects, analyzing information, producing briefing papers and liaising with other networks and agencies,

3) to raise the profile of Afghanistan and its needs with policy makers, donors and the wider public.

The project has been found particularly useful as a means of keeping Afghanistan on the agenda of agencies and funders with competing world-wide responsibilities and in enabling Desk officers to be well briefed in their efforts to seek tresources within their organizations. It has also been found useful as a means of maintaining an attentive liaison with the British Government and the EC in Brussels. It is increasingly used as an information resource within the UK by a wide range of organizations and individuals, adding to the general level of

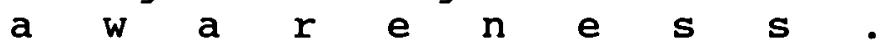


BUREAU FOR RURAL REHABILITATION-BRR

\begin{tabular}{|l|l|l|}
\hline 766-T, STREET 3, & PHONE: 42825 & < KEY STAFF> \\
JAMAL RD, SHAHEEN TOWN & F A X: & 1. ENG. YAR MOHD SHEFA \\
PESHAWAR, PAKISTAN & TELEX: & 2. DR. MOHAMMAD DIN \\
\hline
\end{tabular}

\begin{tabular}{|lr|lr|lr|}
\hline AFGHAN : & 13 & TECHNICAL: & 5 & PAK. BASED: & 5 \\
PAKISTANI : & - & ADMINISTRATIVE: & 3 & AFGHA.BASED: & 8 \\
EXPAT: & - & FIELD/SUPPORT S. & 5 & CROSS-BORDER: & - \\
TOTAL: & 13 & TOTAL: & 13 & TOTAL: & 13 \\
\hline
\end{tabular}

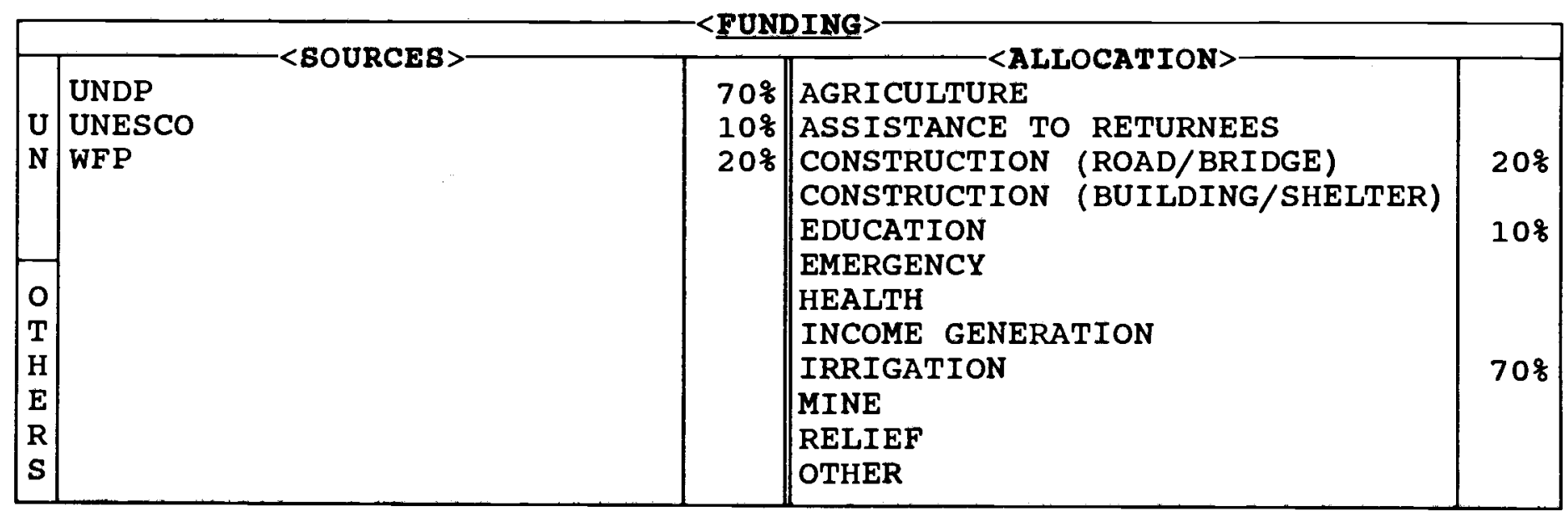

\begin{tabular}{|c|c|c|c|c|c|c|}
\hline & 1988 & 1989 & 2990 & 1991 & 1992 & 1993 \\
\hline $\begin{array}{l}\text { AFGHANISTAN : } \\
\text { REFUGEES : }\end{array}$ & & & & & & \\
\hline T O T A L: & & & & & 10,400 & 32,133 \\
\hline
\end{tabular}

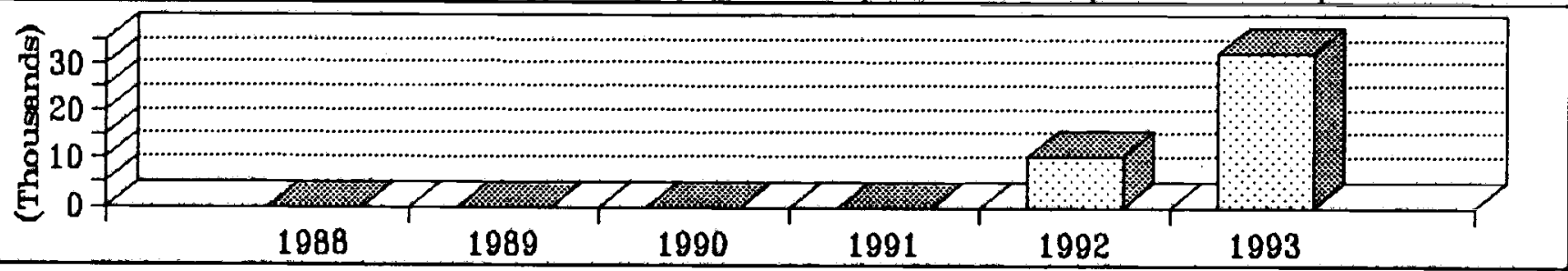

\begin{tabular}{|c|c|c|c|c|c|}
\hline PROVINCES & SECTOR & \&AGE & PROVINCES & SECTOR & $\%$ AGE \\
\hline $\begin{array}{l}\text { BADAKSHAN } \\
\text { BADGHIS } \\
\text { BAGHLAN } \\
\text { BALKH } \\
\text { BAMYAN } \\
\text { FARAH } \\
\text { FARYAB } \\
\text { GHAZNI } \\
\text { GHOR } \\
\text { HELMAND } \\
\text { HERAT } \\
\text { JAWZJAN } \\
\text { KABUL } \\
\text { KANDAHAR } \\
\text { KAPISA }\end{array}$ & Irrign & $\begin{array}{l}35 \% \\
10 \%\end{array}$ & \begin{tabular}{|l|} 
KUNAR \\
KUNDUZ \\
LAGHMAN \\
LOGAR \\
NANGARHAR \\
NIMROZ \\
ORUZGAN \\
PAKTEKA \\
PAKTIA \\
PARWAN \\
SAMANGAN \\
TAKHAR \\
WARDAK \\
ZABUL
\end{tabular} & $\begin{array}{l}\text { Const/irrign } \\
\text { Const }\end{array}$ & $\begin{array}{l}45 \% \\
10 \%\end{array}$ \\
\hline
\end{tabular}


BUREAU FOR RURAL REHABILITATION (BRR)

was established as an Afghan NGO in 1992. The staff of this agency are well experienced and qualified Afghan engineers.

BRR focuses on the rehabilitation and reconstruction of agriculture, irrigation systems, roads and bridges, public buildings and other infrastructure in the rural parts of the country.

since its establishment the agency has implemented a number of rehabilitation projects funded by UNDP/OPS Peshawar, UN agencies located in Mazar-i-Sharif, WFP Peshawar and other donor agencies.

A number of project proposals have been submitted to different funding agencies. These projects could play vital role in rehabilitation program of BRR's target provinces. 
CARE INTERNATIONAL-CI

1237, ALI RD, ACADEMY TOWN, P O BOX 926 PESHAWAR, PAKISTAN
PHONE: $43875 / 45217 / 40614$

F A X: 841826

TELEX :
1. MR. WILLIAM HUTH

2. ENG. ASIF RAHIMI

3. JALAL BHUIYAN

\begin{tabular}{|lr|ll|lr|}
\hline AFGHAN : & 84 & TECHNICAL: & $\ldots$ & PAK. BASED: & 40 \\
PAKISTANI : & 9 & ADMINISTRATIVE: & $\ldots$ & AFGHA.BASED: & 56 \\
EXPAT: & 3 & FIELD/SUPPORT S. & . & CROSS-BORDER: & - \\
TOTAL: & 96 & TOTAL: & 96 & TOTAL: & 96 \\
\hline
\end{tabular}

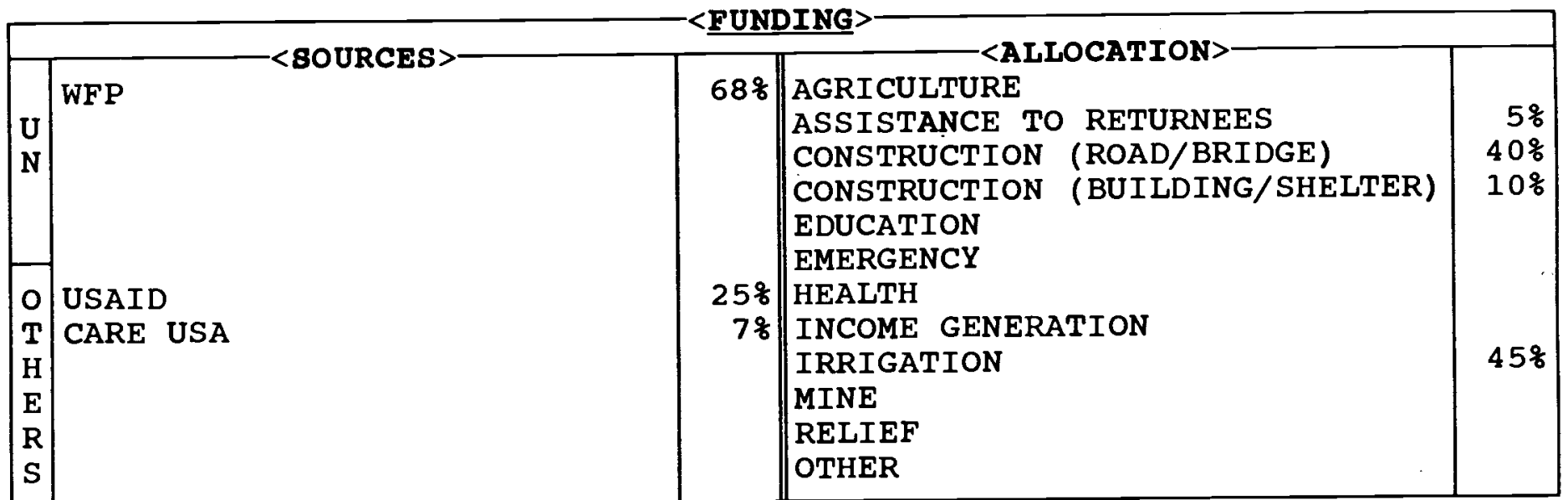

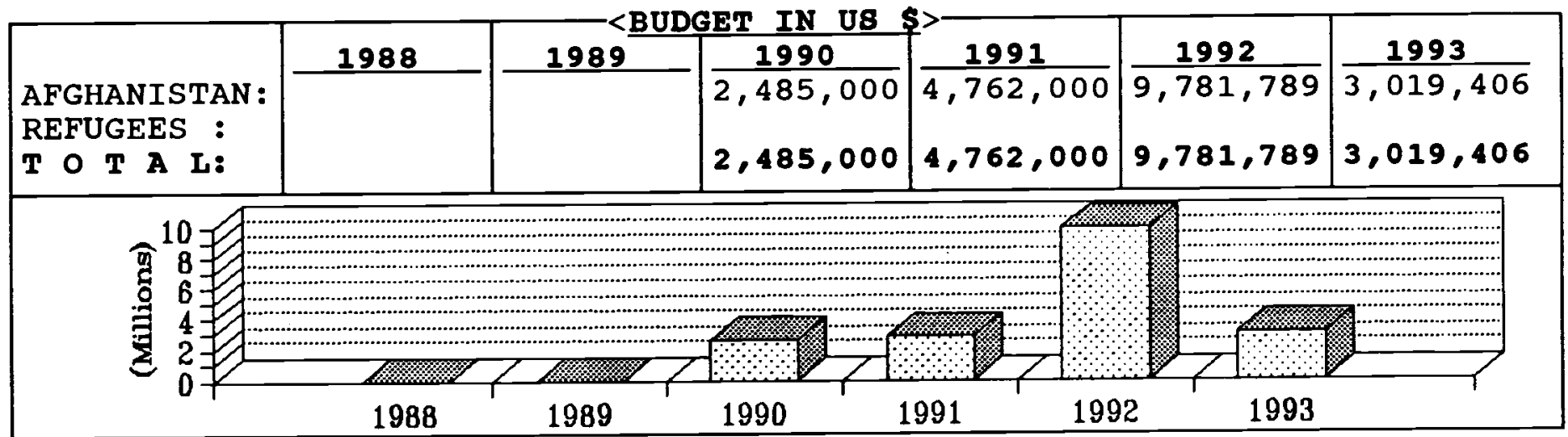

\begin{tabular}{|c|c|c|c|c|c|}
\hline PROVINCES & SECTOR & $\% A G E$ & PROVINCES & SECTOR & \%AGE \\
\hline $\begin{array}{l}\text { BADAKSHAN } \\
\text { BADGHIS } \\
\text { BAGHLAN } \\
\text { BALKH } \\
\text { BAMYAN } \\
\text { FARAH } \\
\text { FARYAB } \\
\text { GHAZNI } \\
\text { GHOR } \\
\text { HELMAND } \\
\text { HERAT } \\
\text { JAWZJAN } \\
\text { KABUL } \\
\text { KANDAHAR } \\
\text { KAPISA }\end{array}$ & Const/irrign & $10 \%$ & $\begin{array}{l}\text { KUNAR } \\
\text { KUNDUZ } \\
\text { LAGHMAN } \\
\text { LOGAR } \\
\text { NANGARHAR } \\
\text { NIMROZ } \\
\text { ORUZGAN } \\
\text { PAKTEKA } \\
\text { PAKTIA } \\
\text { PARWAN } \\
\text { SAMANGAN } \\
\text { TAKHAR } \\
\text { WARDAK } \\
\text { ZABUL }\end{array}$ & $\begin{array}{l}\text { Irrign. } \\
\text { Const/irrign } \\
\text { Const/irrign } \\
\text { Const/irrign }\end{array}$ & $\begin{array}{l}30 \% \\
20 \%\end{array}$ \\
\hline
\end{tabular}




\section{CARE INTERNATIONAL (CI)}

founded in 1945, is an international relief and development organization working in Africa, Asia and Latin America. Through a worldwide network CARE manages over 200 selfhelp projects in 40 developing countries, employing 9,500 national and international staff. CARE is non-political and non-sectarian.

Around the world, CARE provides training in primary health care, agriculture, conservation of the environment, income generation, education, and brings relief during emergencies. All projects are based on the key principles of self-help and sustainability.

CARE was involved in Afghanistan from 1960 - 1979, providing health care and medical training. In 1988 a team was sent to pakistan to assess the situation facing Afghan refugees upon their eventual repatriation, and to determine how CARE could best provide repatriation assistance. The Afghan Village Assistance Program was developed soon after.

CARE Afghanistan's mission for the Afghan Village Assistance Program is to create conditions conducive to sustained repatriation though a range of Food and Cash for work activities. CARE operates from a base in Peshawar, and out of four provinces inside Afghanistan: Logar, Khost, Pakteka, and Maidan. From these offices the provinces of Paktia and Kabul are also served. CARE is now in the process of establishing an office in Kabul as well. In addition to the Afghan Village Assistance Program, CARE is also working with HABITAT, producing concrete roofing beams in Logar.

CARE's training activities are vocational in nature. on the site training exists for each of the following activities, as well as in the office in project management.
1. Reconstruction of irrigation systems

2. Building of village to market roads and tracks

3. Construction of Village Level storehouses

4. Reconstruction and construction of erosion barriers

5. Restoration of government experimental farms and public parks

6. Rebuilding of low-cost houses for war widowed and disabled families.

7. Wheat seed production

8. Agriculture and natural resource program work

9. Concrete roof beam production

CARE's training plans for 1994 include training unskilled workers from the project areas of Khost, Gardaiz, Pakteka and Maidan-Shar to become carpenters, masons and iron workers. This will create work opportunities for residents in project areas, contributing to the sustainability of the project while stimulating the economy of the $p r \circ j$ e c $t \quad a \quad r$ e $a$. 

$G$ P O BOX 581 PESHAWAR, PAKISTAN
PHONE : 45296

F A X:

TELEX:
1. MR. SALEEM FRANK

2 .

3 .

\begin{tabular}{|lr|lr|lr|}
\hline AFGHAN: & 2 & TECHNICAL: & 10 & PAK. BASED: & 14 \\
PAKISTANI : & 12 & ADMINISTRATIVE: & 2 & AFGHA.BASED: & - \\
EXPAT: & - & FIELD/SUPPORT S. & 2 & CROSS -BORDER: & - \\
TOTAL: & 14 & TOTAL: & 14 & TOTAL: & 14 \\
\hline
\end{tabular}

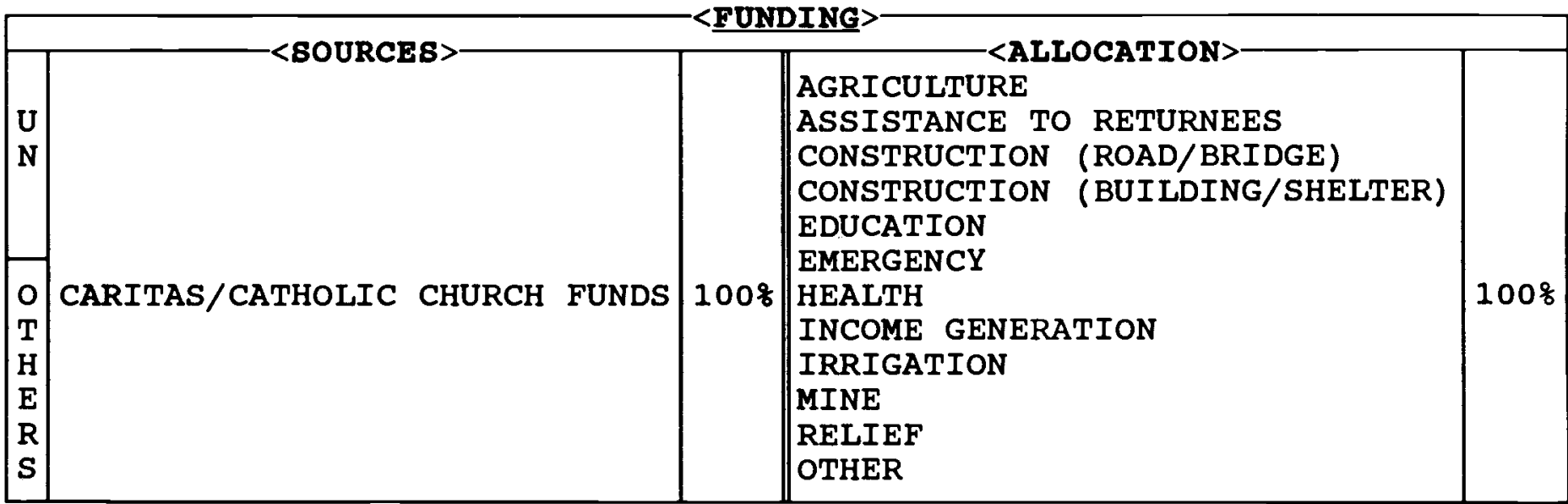

\begin{tabular}{|c|c|c|c|c|c|c|}
\hline & 1988 & 1989 & 1990 & 1991 & 1992 & 1993 \\
\hline $\begin{array}{l}\text { AFGHANISTAN: } \\
\text { REFUGEES : } \\
\text { T O T A I: }\end{array}$ & & & $\begin{array}{l}75,000 \\
75,000\end{array}$ & $\begin{array}{l}55,000 \\
55,000\end{array}$ & $\begin{array}{l}150,000 \\
150,000\end{array}$ & $\begin{array}{l}35,730 \\
35,730\end{array}$ \\
\hline
\end{tabular}

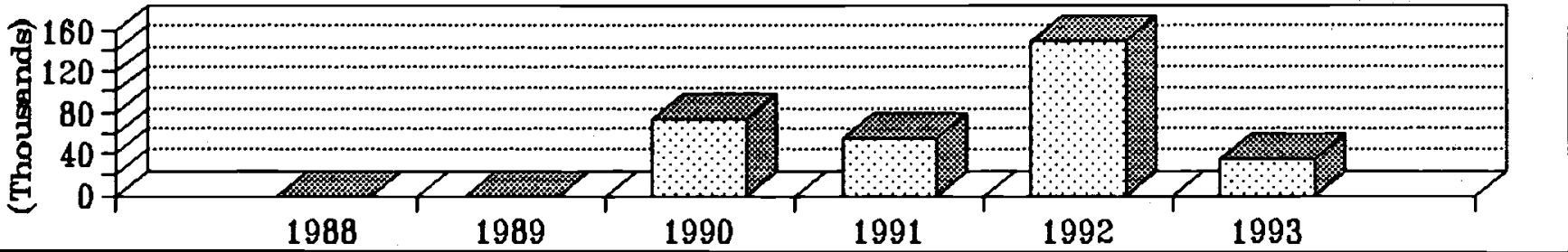

<TARGET PROVINCES IN AFGHANISTAN>

\begin{tabular}{|c|c|c|c|c|c|c|}
\hline PROVINCES & SECTOR & \&AGE & PROVINCES & & SECTOR & $\because A G E$ \\
\hline $\begin{array}{l}\text { BADAKSHAN } \\
\text { BADGHIS } \\
\text { BAGHLAN } \\
\text { BALKH } \\
\text { BAMYAN } \\
\text { FARAH } \\
\text { FARYAB } \\
\text { GHAZNI } \\
\text { GHOR } \\
\text { HELMAND } \\
\text { HERAT } \\
\text { JAWZJAN } \\
\text { KABUL } \\
\text { KANDAHAR } \\
\text { KAPISA }\end{array}$ & & & $\begin{array}{l}\text { KUNAR } \\
\text { KUNDUZ } \\
\text { LAGHMAN } \\
\text { LOGAR } \\
\text { NANGARHAR } \\
\text { NIMROZ } \\
\text { ORUZGAN } \\
\text { PAKTEKA } \\
\text { PAKTIA } \\
\text { PARWAN } \\
\text { SAMANGAN } \\
\text { TAKHAR } \\
\text { WARDAK } \\
\text { ZABUL }\end{array}$ & under & 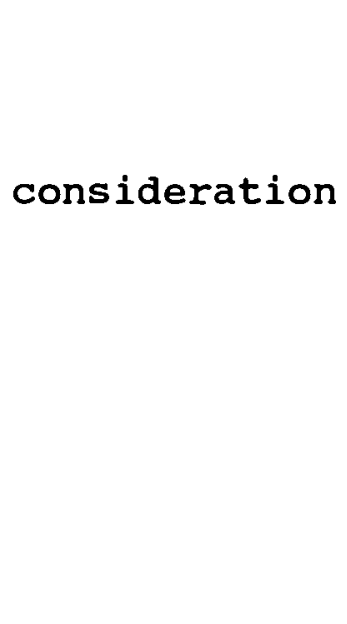 & \\
\hline
\end{tabular}


CARITAS-AFGHANISTAN REFUGEE

PROGRAM (CARP)

is the official organization of the Catholic church in Pakistan for justice, peace, development and emergency aid, operating under the mandate of the Catholic Bishops' Conference of Pakistan.

In late 1979 Caritas Pakistan, as an organization sensitive to needs, immediately responded to the emergency arrival of several hundred thousand Afghan refugees into the NWFP. Caritas-ARP has implemented/is running the following programs:

\section{BHELTER :}

12,500 residential tents, 22,000 blankets, 100 tents (for dispensaries), 40,000 clothing sets of (shalwar kameeze) were distributed as emergency aid through 1983 .

\section{HEALTH:}

I. Caritas Pakistan (ARP) established a BHU in Jehad Kali camp, NWFP, in Oct/Nov. 1979, to look after the medical/ health needs of Afghan refugees which is working successfully.

II. Expanded program of Immunization (EPI): In June 1981, Caritas started a program of immunization for refugees in camps of Peshawar district with two mobile units.

III. Orthopedic Workshop: In early 1981, funds were provided for machinery and installation of an orthopedic workshop in Lady Reading Hospital to furnish orthopedic prostheses for war wounded mujahideen and others maimed by the fighting and land-mines.

IV. Mobile Dental Unit: From August 1983 until now, a Caritas Mobile Dental Unit has been visiting the camps daily.

V. Medical Supplies: During the first three years of the refugee emergency in Pakistan, Caritas distributed large amounts of donated medicines, and some purchased medicines throughout NWFP for Afghan refugees.

\section{EDUCATION :}

473 scholarships were provided to Afghan students, studying in primary and secondary schools, up to 1986 . The program was closed down because of the lack funds.

\section{INDIVIDUAL ASSISTANCE:}

Medicines and medical equipment were provided to Afghan doctors, and sewing machines to Afghan widows to enable them to earn their living. This program was also discontinued in June 1986 due to lack of funds.

Caritas is presently investigating the needs in the health field in Afghanistan to see what cross-border support can be provided by caritas. 
CATHOLIC RELIEF SERVICES-CRS

\begin{tabular}{|l|l|l|}
\hline $21 / B$, STREET 44, F-8/1 & PHONE: 254336/7 & 1. MR. JOHN G. CONNOLLY \\
P O BOX 1657 & F A X: 822313/81429 & 2. \\
ISLAMABAD, PAKISTAN & TELEX: 5668 AMXCO PK & 3. \\
\hline
\end{tabular}

\begin{tabular}{|c|c|c|c|c|c|}
\hline $\begin{array}{l}\text { AFGHAN : } \\
\text { PAKISTANI : } \\
\text { EXPAT: } \\
\text { TOTAL: }\end{array}$ & $\begin{array}{r}47 \\
25 \\
3 \\
75\end{array}$ & $\begin{array}{l}\text { TECHNICAL: } \\
\text { ADMINISTRATIVE: } \\
\text { FIELD/SUPPORT S. } \\
\text { TOTAL: }\end{array}$ & $\begin{array}{l}\ddot{ } \\
\ddot{75}\end{array}$ & $\begin{array}{l}\text { PAK. BASED: } \\
\text { AFGHA. BASED: } \\
\text { CROSS-BORDER: } \\
\text { TOTAL : }\end{array}$ & $\begin{array}{r}75 \\
- \\
75\end{array}$ \\
\hline
\end{tabular}

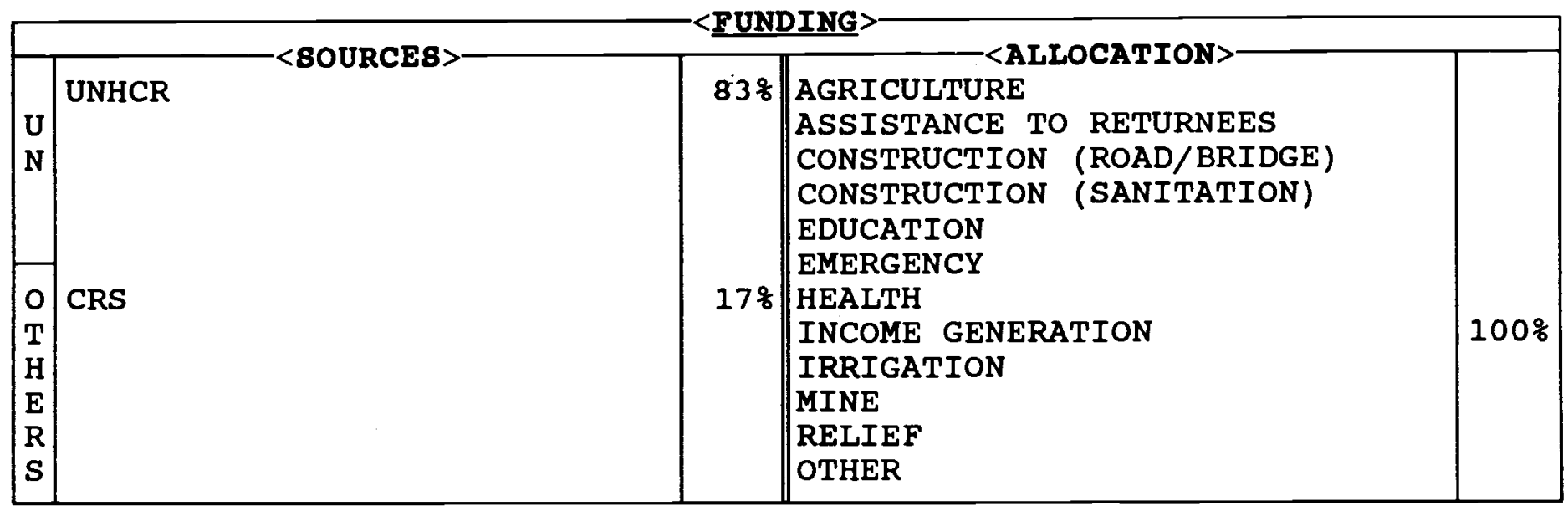

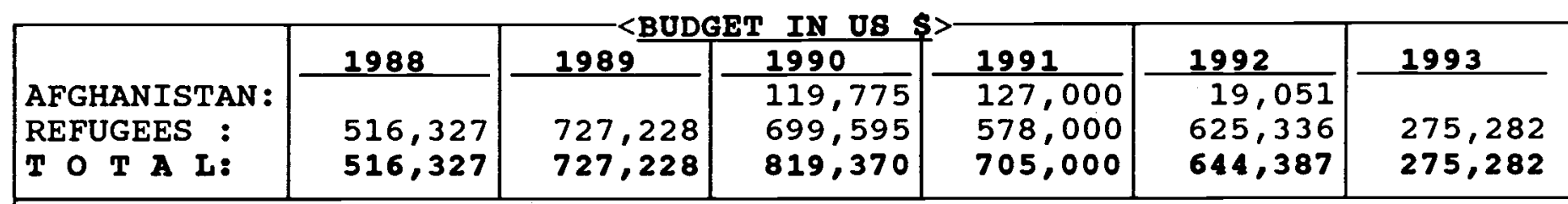

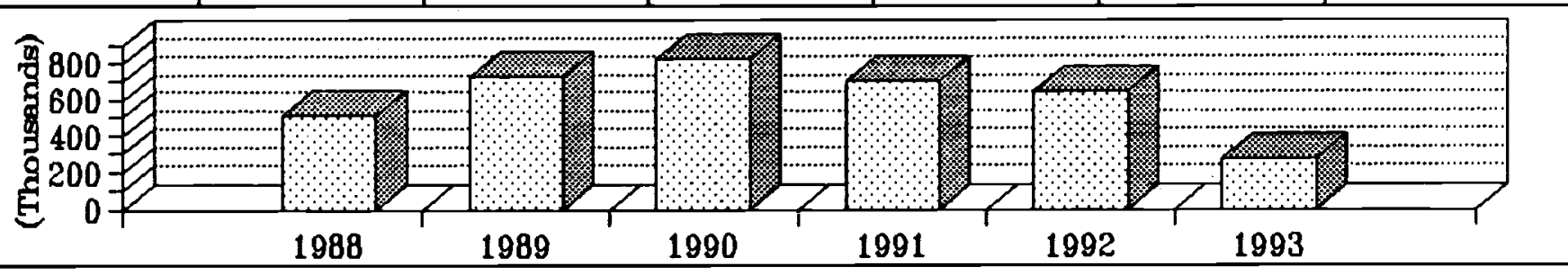

\begin{tabular}{|c|c|c|c|c|c|}
\hline PROVINCES & SECTOR & \&AGE & PROVINCES & SECTOR & $\%$ AGE \\
\hline $\begin{array}{l}\text { BADAKSHAN } \\
\text { BADGHIS } \\
\text { BAGHLAN } \\
\text { BALKH } \\
\text { BAMYAN } \\
\text { FARAH } \\
\text { FARYAB } \\
\text { GHAZNI } \\
\text { GHOR } \\
\text { HELMAND } \\
\text { HERAT } \\
\text { JAWZJAN } \\
\text { KABUL } \\
\text { KANDAHAR } \\
\text { KAPISA }\end{array}$ & & & $\begin{array}{l}\text { KUNAR } \\
\text { KUNDUZ } \\
\text { LAGHMAN } \\
\text { LOGAR } \\
\text { NANGARHAR } \\
\text { NIMROZ } \\
\text { ORUZGAN } \\
\text { PAKTEKA } \\
\text { PAKTIA } \\
\text { PARWAN } \\
\text { SAMANGAN } \\
\text { TAKHAR } \\
\text { WARDAK } \\
\text { ZABUL }\end{array}$ & & \\
\hline
\end{tabular}




\section{CATHOLIC RELIEF SERVICES (CRB)}

is an international relief and development NGO with headquarters in the United states and projects in over fifty countries worldwide. CRS has been active in Pakistan since 1954 .

Initial involvement with Afghan refugee relief in Pakistan began in 1983, with CRS as a funding agency. However, since 1986, CRS has been fully operational in implementing Pakistan-refugee projects.

CRS had four projects for Afghan refugees in Pakistan. Two projects were in the health and sanitation sector, one based in Baluchistan and the other in Mianwali. These two projects concentrated on providing sanitation facilities to the Afghan refugees, health education and the training of community health workers, sanitation outreach workers and traditional birth attendants.

The combined achievements of these two projects have been more than 12,000 latrines constructed, 238 male community health workers trained, 314 female community health workers trained, 1,200 traditional birth attendants trained, and 20 outreach workers trained, 12 wells at Madrasas rehabilitated.

The third relief project, based in Baluchistan, supported Afghan refugee training and income generation. This project provided training in the production of clothing and related items to needy Afghan women and disabled men, and also offered them a marketing outlet for their production. Since the inception of the project in 1986, more than 3,500 Afghan refugee women and 1,300 disabled men participated in the project. In 1991, 402 young men (ages 17-35 years) were trained in carpentry, welding, diesel mechanics, motorcycle repair and tin-smithry. 262 more were trained in 1992 .

An agricultural rehabilitation and development project was carried out in Zabul province, Afghanistan. The project provided seeds, fertilizer, animal vaccinations, and related agricultural support. of great importance to this project was the development of the local counter parts' abilities to manage sustainable development programs. The Afghan staff of this project has now developed their own NGO.

All CRS Afghan Refugee programs ended as of september 30, 1993 because of UNHCR funding constraints and its prioritization of other sectors. 
CENTER FOR RURAL REHABILITATION-CRR

\begin{tabular}{|c|c|c|}
\hline$-<$ ADDRESS $>-$ & $-<$ COMMUNICATION LINES $>$ & STAFF> \\
\hline PESHAWAR， PAKISTAN & $\begin{array}{l}\text { PHONE: } \\
\text { F A X: } \\
\text { TELEX: }\end{array}$ & $\begin{array}{l}\text { 1. ENG.MOHAMMAD QASEEM } \\
\text { 2. ENG.WALI } \\
\text { 3. }\end{array}$ \\
\hline
\end{tabular}

\begin{tabular}{|lc|lr|lr|}
\hline AFGHAN: & 27 & TECHNICAL: & 7 & PAK. BASED: & 3 \\
PAKISTANI : & - & ADMINISTRATIVE: & 10 & AFGHA.BASED: & - \\
EXPAT: & - & FIELD/SUPPORT S. & 10 & CROSS-BORDER: & 24 \\
TOTAL: & 27 & TOTAL: & 27 & TOTAL: & 46 \\
\hline
\end{tabular}

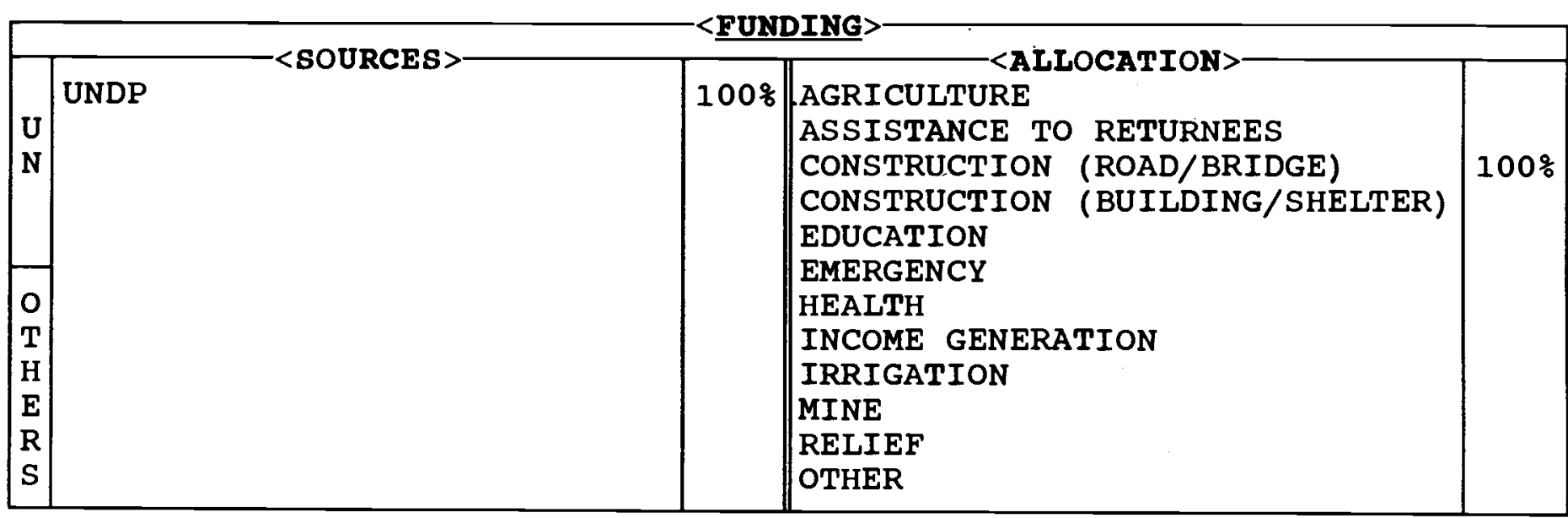

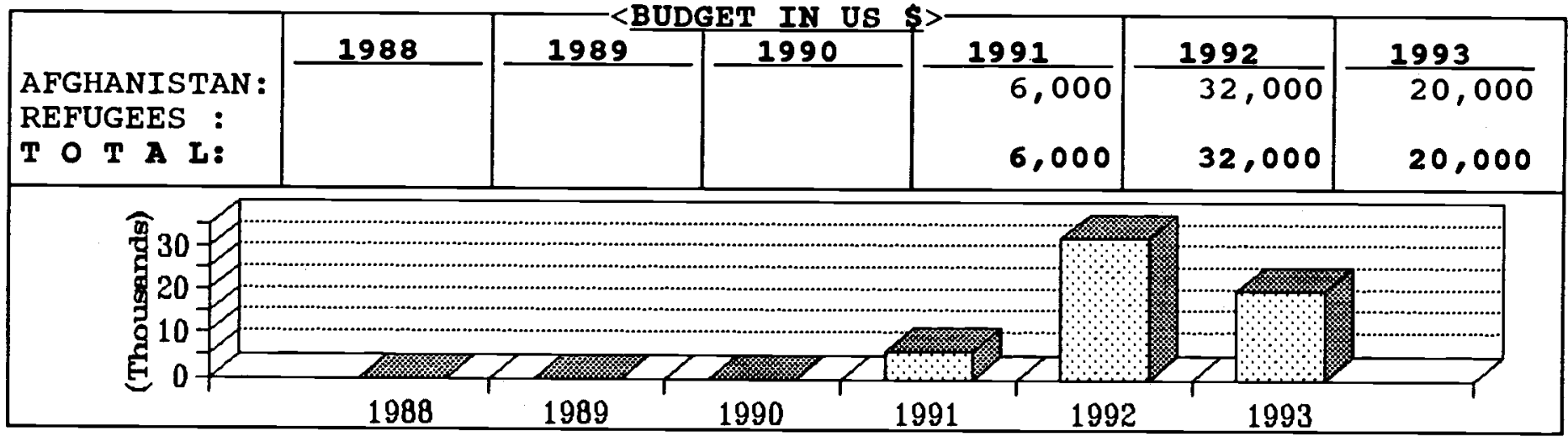

\begin{tabular}{|c|c|c|c|c|c|}
\hline PROVINCES & SECTOR & \&AGE & PROVINCES & SECTOR & \&AGE \\
\hline $\begin{array}{l}\text { BADAKSHAN } \\
\text { BADGHIS } \\
\text { BAGHLAN } \\
\text { BALKH } \\
\text { BAMYAN } \\
\text { FARAH } \\
\text { FARYAB } \\
\text { GHAZNI } \\
\text { GHOR } \\
\text { HELMAND } \\
\text { HERAT } \\
\text { JAWZJAN } \\
\text { KABUL } \\
\text { KANDAHAR } \\
\text { KAPISA }\end{array}$ & & & \begin{tabular}{|l} 
KUNAR \\
KUNDUZ \\
LAGHMAN \\
LOGAR \\
NANGARHAR \\
NIMROZ \\
ORUZGAN \\
PAKTEKA \\
PAKTIA \\
PARWAN \\
SAMANGAN \\
TAKHAR \\
WARDAK \\
ZABUL
\end{tabular} & Const & $100 \%$ \\
\hline
\end{tabular}


CENTER FOR RURAL RECONSTRUCTION

(CRR)

is an Afghan non-governmental organization set up in 1990. The organization started practical work in 1991.

CRR is a group of Afghan engineers who want to use their knowledge for rehabilitation and reconstruction of Afghanistan. CRR concentrates primarily on construction projects and specifically on roads.

Technical surveys on approximately $130 \mathrm{~km}$ of secondary roads have been completed in the following areas:

1) Musa Khel area of Paktia province.

2) Nangalam area of Kunar province.

3) Surkhrod, Hisar shahi and Khogyani areas of Nangarhar province.

In 1993, CRR constructed 10 structures in $50 \mathrm{~km}$ road in Dumanda - Khost area. The project was supported by UNDP.

Currently CRR has no ongoing projects. The founders of the organization are considering shifting it to Herat province. 
COMITE AFGHAN DE SOLIDARITE-CAS

\begin{tabular}{|l|l|l|}
\hline OFF JAMROD RD, TAMBUAN & PHONE: 44510/44610 & 1. RAEES GHULAM QADIR \\
G P O BOX 86 & F A X: 841610 & 2. \\
PESHAWAR, PAKISTAN & TELEX: & 3. \\
\hline
\end{tabular}

\begin{tabular}{|lr|lr|lr|}
\hline AFGHAN : & 28 & TECHNICAL: & 4 & PAK. BASED: & 20 \\
PAKISTANI : & 2 & ADMINISTRATIVE: & 5 & AFGHA.BASED: & - \\
EXPAT: & - & FIELD/SUPPORT S. & 21 & CROSS-BORDER: & 10 \\
TOTAL: & 30 & TOTAL: & 30 & TOTAL: & 20 \\
\hline
\end{tabular}

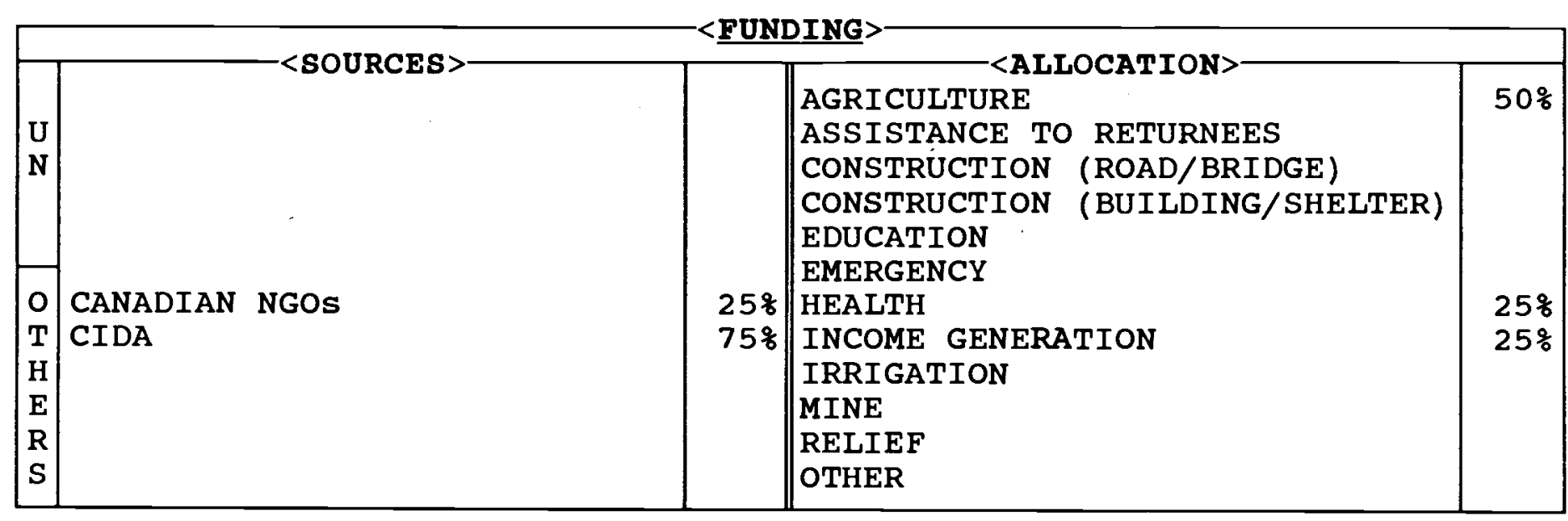

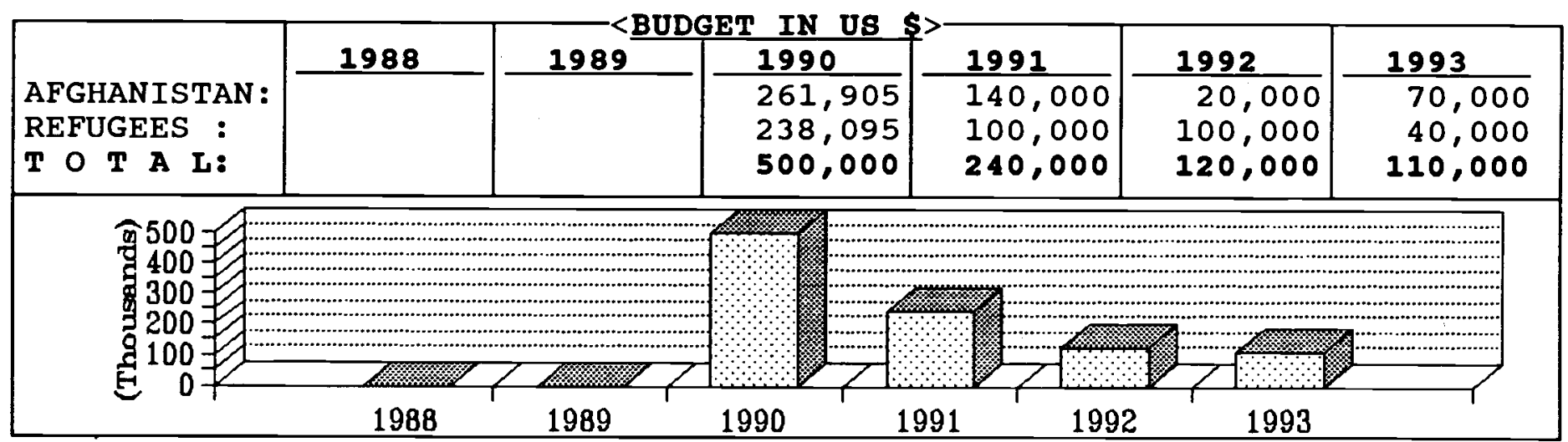

\begin{tabular}{|c|c|c|c|c|c|}
\hline PROVINCES & SECTOR & \&AGE & PROVINCES & SECTOR & $\% \mathrm{AGE}$ \\
\hline $\begin{array}{l}\text { BADAKSHAN } \\
\text { BADGHIS } \\
\text { BAGHLAN } \\
\text { BALKH } \\
\text { BAMYAN } \\
\text { FARAH } \\
\text { FARYAB } \\
\text { GHAZNI } \\
\text { GHOR } \\
\text { HELMAND } \\
\text { HERAT } \\
\text { JAWZJAN } \\
\text { KABUL } \\
\text { KANDAHAR } \\
\text { KAPISA }\end{array}$ & & & \begin{tabular}{|l} 
KUNAR \\
KUNDUZ \\
LAGHMAN \\
LOGAR \\
NANGARHAR \\
NIMROZ \\
ORUZGAN \\
PAKTEKA \\
PAKTIA \\
PARWAN \\
SAMANGAN \\
TAKHAR \\
WARDAK \\
ZABUL
\end{tabular} & $\begin{array}{l}\text { Agr } \\
\text { Agr/health }\end{array}$ & $\begin{array}{l}35 \% \\
65 \%\end{array}$ \\
\hline
\end{tabular}


COMTE AFGHAN DE SOLIDARITE (CAB)

was founded in January 1988 and was duly registered as a Voluntary Agency by the Government of Pakistan.

The aim of the Comite was to assist the Afghan refugees living in the camps in Peshawar district, particularly new arrivals. As at that time the new arrivals were placed in Badaber No 6, Jalozai and Khairabad camps the Comite started its activities in these camps.

Initially the activities of the Comite were confined to basic health care, education and income generation (carpet weaving) programs. Later programs such as milk distribution through mechanical cows and distribution of relief goods in the camps were also undertaken.

After the liberation of Afghanistan and establishment of Islamic Government in the country, cIs conducted assessment and surveys in different parts of Afghanistan primarily in the eastern provinces (Laghman and Nangarhar). Based on the findings of the surveys, a number of projects have been designed and submitted to donor organizations. A few agriculture and irrigation projects have been established in the mentioned areas. CA will also consider implementation of health and education projects. It will also consider expanding its programs to other provinces provided that funds are available. 
COMMITTEE FOR REHABILITATION AID TO AFGHANISTAN-CRAA

<ADDRES8 $>$

130, 1ST FLOOR, GULHAJI PLAZA， JAMROD RD PESHAWAR, PAKISTAN

PHONE: 840169

F A X:

TELEX :
1. DR.SANAULHAQ AHMADZI

2 .

3.

\begin{tabular}{|lr|lr|lr}
\hline AFGHAN : & 150 & TECHNICAL: & 20 & PAK.BASED: & 14 \\
PAKISTANI : & 2 & ADMINISTRATIVE: & 4 & AFGHA.BASED: & - \\
EXPAT: & - & FIELD/SUPPORT S. & 128 & CROSS-BORDER: & 138 \\
TOTAL: & 152 & TOTAL: & 152 & TOTAL: & 152 \\
\hline
\end{tabular}

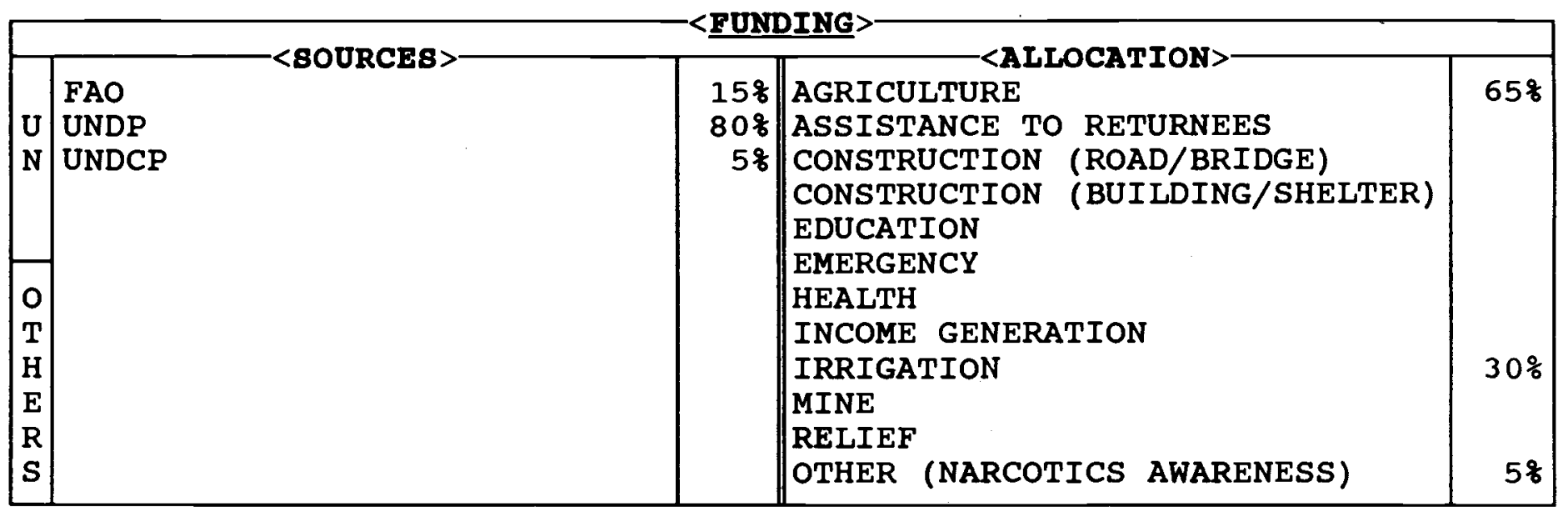

\begin{tabular}{|c|c|c|c|c|c|c|}
\hline & 1988 & 1989 & 1990 & 1991 & 1992 & 1993 \\
\hline $\begin{array}{l}\text { AFGHANISTAN : } \\
\text { REFUGEES : }\end{array}$ & & & 72,000 & 281,000 & 331,000 & 481,692 \\
\hline T 0 T A L: & & & 72,000 & 281,000 & 331,000 & 481,692 \\
\hline
\end{tabular}

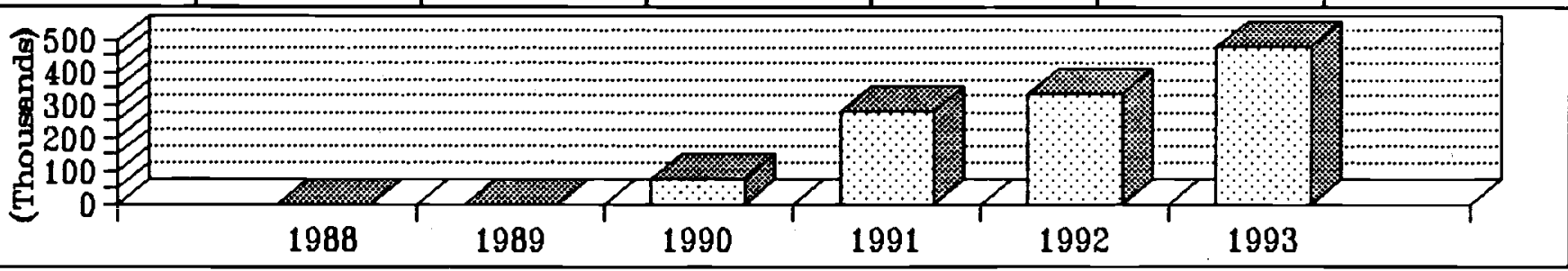

\begin{tabular}{|c|c|c|c|c|c|}
\hline PROVINCES & SECTOR & \&AGE & PROVINCES & SECTOR & \&AGE \\
\hline $\begin{array}{l}\text { BADAKSHAN } \\
\text { BADGHIS } \\
\text { BAGHLAN } \\
\text { BALKH } \\
\text { BAMYAN } \\
\text { FARAH } \\
\text { FARYAB } \\
\text { GHAZNI } \\
\text { GHOR } \\
\text { HELMAND } \\
\text { HERAT } \\
\text { JAWZJAN } \\
\text { KABUL } \\
\text { KANDAHAR } \\
\text { KAPISA }\end{array}$ & $\begin{array}{l}\text { Narcotics awareness } \\
\text { Agr } \\
\text { Narcotics awareness } \\
\text { Narcotics awareness }\end{array}$ & $\begin{array}{r}158 \\
3 \% \\
78\end{array}$ & $\begin{array}{l}\text { KUNAR } \\
\text { KUNDUZ } \\
\text { LAGHMAN } \\
\text { LOGAR } \\
\text { NANGARHAR } \\
\text { NIMROZ } \\
\text { ORUZGAN } \\
\text { PAKTEKA } \\
\text { PAKTIA } \\
\text { PARWAN } \\
\text { SAMANGAN } \\
\text { TAKHAR } \\
\text { WARDAK } \\
\text { ZABUL }\end{array}$ & $\begin{array}{l}\text { Agr/Narcotics awaren. } \\
\text { Agr/irrign/narcot.aw. }\end{array}$ & $37 \%$ \\
\hline
\end{tabular}


COMMITTEE FOR REHABILITATION AID TO AFGHANISTAN (CRAA)

is a non-profit, non-governmental and non-political organization founded in 1990. It is composed of Afghans who have experience and expertise in the planning and implementation of relief and development projects.

CRAA works in agriculture, veterinary, irrigation, health and narcotics awareness.

In view of the future return of refugees, CRAA supports the rural populace in Afghanistan which composes approximately $85 \%$ of the country's total population. The rural people mainly depend on agriculture and livestock breeding and raising. CRAA helps them with providing agriculture inputs, veterinary services and rehabilitating their irrigation system.

CRAA's activities are mainly concentrated in Nangarhar and Kunar provinces. It also has small scale projects in Laghman, Kapisa, Kabul, Helmand and Kandahar provinces.

Agriculture: In the agriculture sector, CRAA has distributed improved seeds, fertilizer and fruit trees. Technical advice is given to the farmers. It has ongoing seed multiplication and fruit trees improvement projects.

Veterinary/Animal Husbandry: In the veterinary section, CRAA is presently providing services to 5 different provinces through a network of 20 Veterinary Field Units. Curative and preventive services are provided to livestock and poultry.

Irrigation/water supply: The Committee has completed a number of irrigation rehabilitation projects (canals and karezes) which now irrigate thousands of jeribs of agricultural land. survey of several projects has been conducted in different parts of Nangarhar and Kunar provinces and project proposals have been submitted to donor organizations.

Narcotics Awareness: With the assistance of UNDCP, CRAA is implementing Narcotics Awareness Program in four provinces of Nangarhar, Kunar, Helmand and Kandahar. 44 extension agents and two supervisors carry out the program by educating the local masses in destructive effects of drug addiction and its linkage with the production and trafficking of illicit drugs. Distribution of ACC publicity materials is also included in the program.

CRAA has been registered with UNOCHA, ACBAR, ANCB, Home Department of NWFP Government and the Commissionerate for Afghan Refugee. 
COMMITTEE SHURA-I-FARHANGI ISLAMI AFGHANISTAN-CSFIA

UPSTAIRS OF MCB MARIABAD CHOWK, ALAMDAR QUETTA, PAKISTAN
PHONE: C/O 823265

F A X:

TELEX:
1. MR. MOHAMMAD ISHAQ

2 .

3 .

\begin{tabular}{|c|c|c|c|c|c|}
\hline $\begin{array}{l}\text { AFGHAN : } \\
\text { PAKISTANI : } \\
\text { EXPAT: } \\
\text { TOTAL: }\end{array}$ & $\begin{array}{r}13 \\
- \\
13\end{array}$ & $\begin{array}{l}\text { TECHNICAL: } \\
\text { ADMINISTRATIVE: } \\
\text { FIELD/SUPPORT S. } \\
\text { TOTAL: }\end{array}$ & $\begin{array}{r}3 \\
1 \\
9 \\
13\end{array}$ & $\begin{array}{l}\text { PAK. BASED: } \\
\text { AFGHA. BASED: } \\
\text { CROSS-BORDER: } \\
\text { TOTAL: }\end{array}$ & $\begin{array}{r}5 \\
8 \\
- \\
13\end{array}$ \\
\hline
\end{tabular}

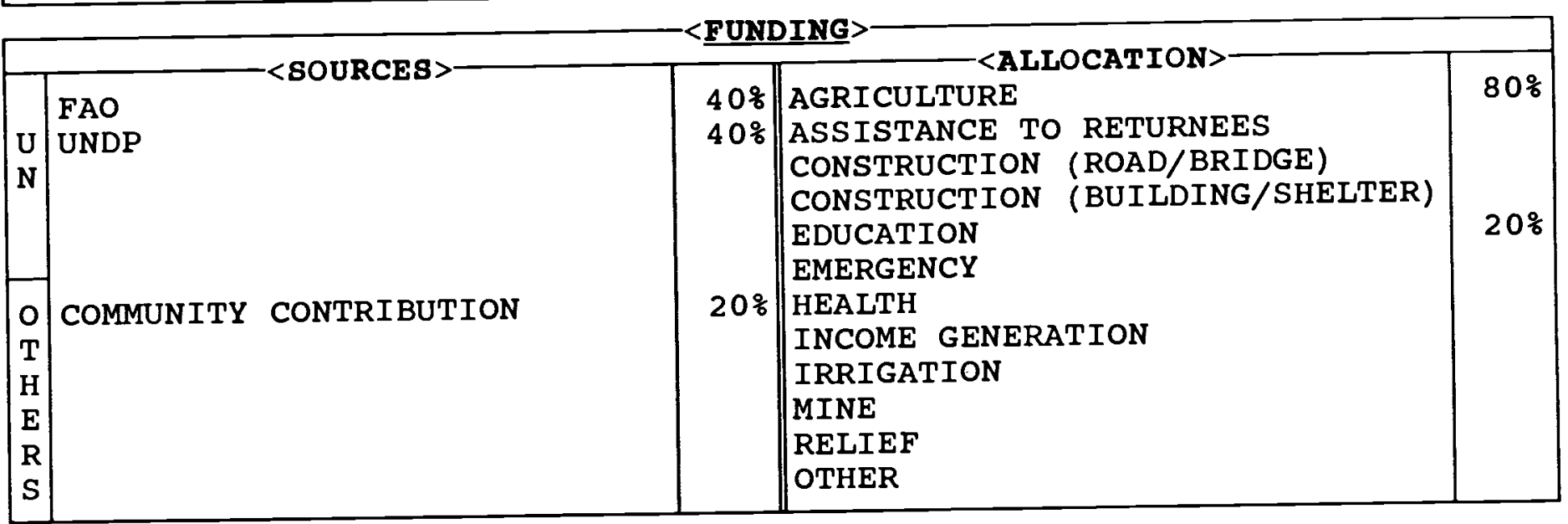

\begin{tabular}{|c|c|c|c|c|c|c|}
\hline & & 1080 & 1990 & 1991 & 1992 & 1993 \\
\hline $\begin{array}{l}\text { AFGHANISTAN: } \\
\text { REFUGEES : } \\
\text { T O T A L: }\end{array}$ & & & & & & \\
\hline
\end{tabular}

\begin{tabular}{|c|c|c|c|c|c|}
\hline PROVINCES & SECTOR & \%ิAGE & PROVINCES & SECTOR & $\because A G E$ \\
\hline $\begin{array}{l}\text { BADAKSHAN } \\
\text { BADGHIS } \\
\text { BAGHLAN } \\
\text { BALKH } \\
\text { BAMYAN } \\
\text { FARAH } \\
\text { FARYAB } \\
\text { GHAZNI } \\
\text { GHOR } \\
\text { HELMAND } \\
\text { HERAT } \\
\text { JAWZJAN } \\
\text { KABUL } \\
\text { KANDAHAR } \\
\text { KAPISA }\end{array}$ & Agr/educ & & $\begin{array}{l}\text { KUNAR } \\
\text { KUNDUZ } \\
\text { LAGHMAN } \\
\text { LOGAR } \\
\text { NANGARHAR } \\
\text { NIMROZ } \\
\text { ORUZGAN } \\
\text { PAKTEKA } \\
\text { PAKTIA } \\
\text { PARWAN } \\
\text { SAMANGAN } \\
\text { TAKHAR } \\
\text { WARDAK } \\
\text { ZABUL }\end{array}$ & & \\
\hline
\end{tabular}


is an Afghan NGo founded in 1993. The agency is currently involved in agriculture and education sectors. CSFIA is committed to serve the least favored groups in Afghanistan and thus focuses on Hazarajat area.

The Committee is supporting a primary school in Malestan district of Ghazni province where 120 students (girls \& boys) receive education. 6 teachers and one headmaster are employed at the school.

CSFIA is led by a community shura that determines its direction and formulates its policies. CSFIA not only gives importance to community participation in its projects but also considers community contribution as a vital tool for its rehabilitation, reconstruction and development activities.

Surveys and assessments have been conducted on a number of projects and donor organizations have been approached for funding some of them. 
CONSULTANT BUREAU FOR RECONSTRUCTION-CBR

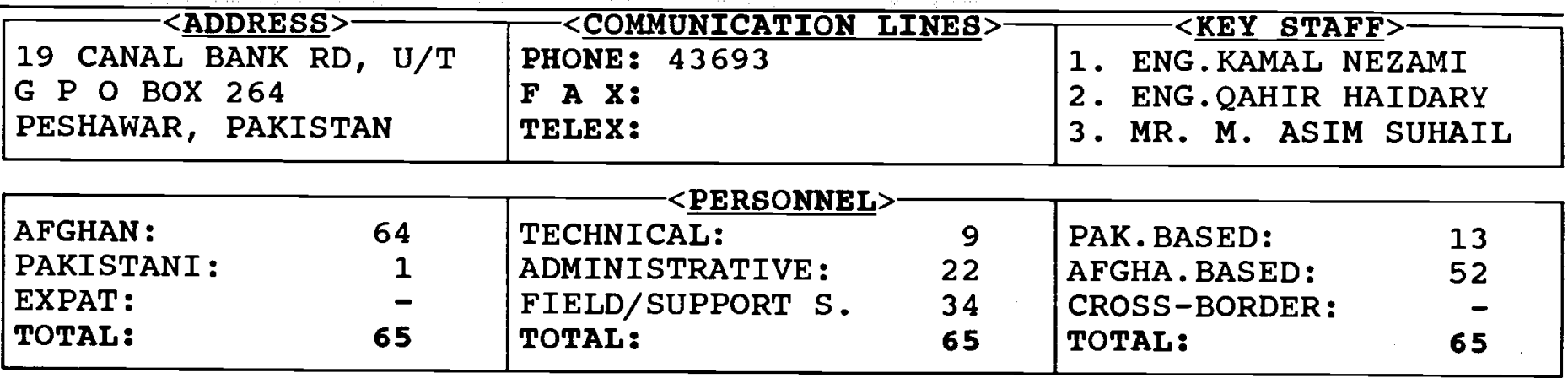

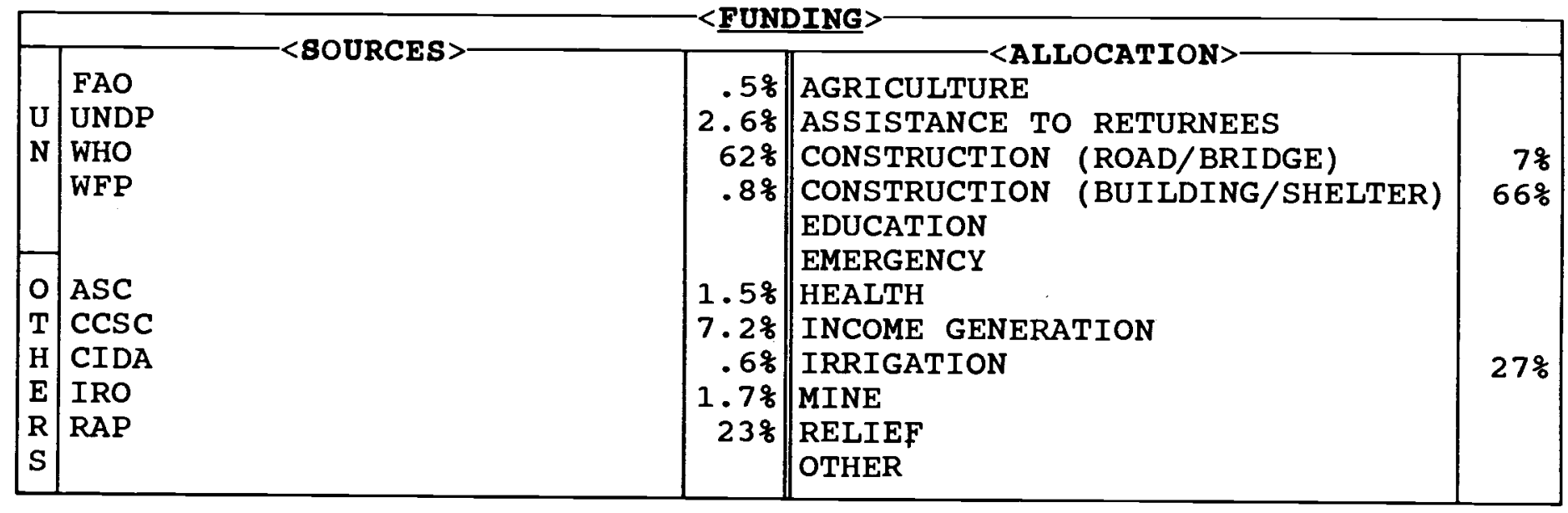

\begin{tabular}{|c|c|c|c|c|c|c|}
\hline & 1988 & 1989 & 1990 & 1991 & 1992 & 1993 \\
\hline $\begin{array}{l}\text { AFGHANISTAN : } \\
\text { REFUGEES : }\end{array}$ & & & 450,000 & $1,600,000$ & $\overline{1,443,332}$ & 775,664 \\
\hline $\mathbf{T} O \mathbf{T} \mathbf{A} \mathbf{L}:$ & & & 450,000 & $1,600,000$ & $1,443,332$ & 775,664 \\
\hline
\end{tabular}

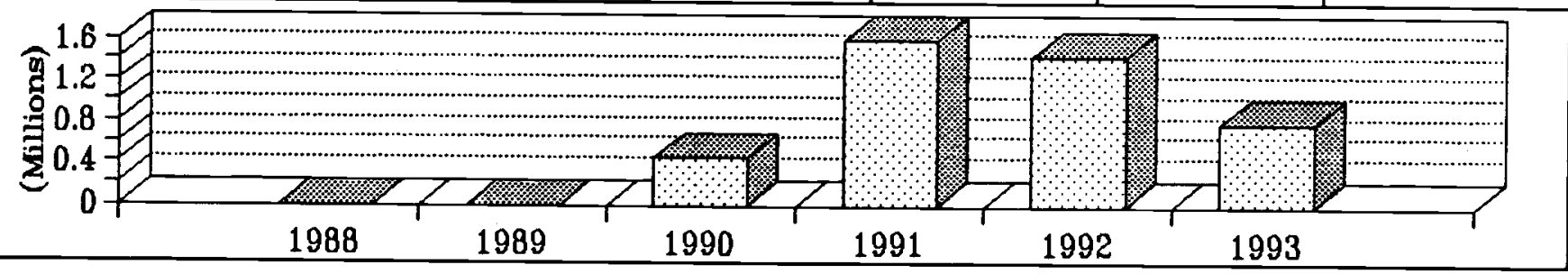

\begin{tabular}{|c|c|c|c|c|c|}
\hline PROVINCES & SECTOR & \&AGE & PROVINCES & SECTOR & \&AGE \\
\hline $\begin{array}{l}\text { BADAKSHAN } \\
\text { BADGHIS } \\
\text { BAGHLAN } \\
\text { BALKH } \\
\text { BAMYAN } \\
\text { FARAH } \\
\text { FARYAB } \\
\text { GHAZNI } \\
\text { GHOR } \\
\text { HELMAND } \\
\text { HERAT } \\
\text { JAWZJAN } \\
\text { KABUL } \\
\text { KANDAHAR } \\
\text { KAPISA }\end{array}$ & $\begin{array}{l}\text { Const (building) } \\
\text { Const (building) }\end{array}$ & $\begin{array}{l}8.4 \% \\
5.5 \%\end{array}$ & \begin{tabular}{|l|} 
KUNAR \\
KUNDUZ \\
LAGHMAN \\
LOGAR \\
NANGARHAR \\
NIMROZ \\
ORUZGAN \\
PAKTEKA \\
PAKTIA \\
PARWAN \\
SAMANGAN \\
TAKHAR \\
WARDAK \\
ZABUL
\end{tabular} & $\begin{array}{l}\text { Const (building) } \\
\text { Const (building) } \\
\text { Irrign } \\
\text { Irrign } \\
\text { Const (building) }\end{array}$ & $\begin{array}{r}34 \% \\
1.6 \%\end{array}$ \\
\hline
\end{tabular}




\section{CONSULTANTS BUREAU FOR \\ RECONSTRUCTION (CBR)}

was formed in September 1988 inside Afghanistan and was funded by local sources (the Supervisory Council).

CBR initiated its activities mainly in Kapisa and Parwan provinces and expanded to most of the northern provinces of the country, Nangarhar in the east and Logar and Paktia in the southern part.

In order to draw the attention of the international donors, CBR's headquarters were moved to Peshawar in 1989. It has a branch office in Chitral and sub-offices in Takhar, Kunduz and Panjshair valley of Kapisa province.

According to the charter of the organization outlined by its Board of Directors, CBR's work directions are as follows:

1. CBR is a technical and engineering oriented organization and aims to take part in construction/ reconstruction of public buildings, roads and bridges inside Afghanistan.

2. Nature of its work is opencompetitive based.

3. CBR can work in joint venture projects proposed by foreign charity/donor organizations.

4. CBR can accept orders from individuals, government departments and organizations against a specific fee and implement projects within its own capabilities.

5. Priorities identified and requested by local people can be proposed to donors for funding after completing the technical aspects.

A nine member Board of Directors/ Decision Making Council has the authority of selecting the chief executive. The Board meets quarterly. There is also an annual meeting of the Board. The Board reviews the progress of the organization. It also plays a role in the public relations, administration and financial management of the organization.

Three types of contracts have been agreed/are made with donor agencies:

a) Joint venture

b) Lump sum cost contracts

c) Contracts with administration support provision.

The projects undertaken by CBR so far include construction of 17 health clinics/centers, road construction, conducting technical surveys on roads, irrigation rehabilitation and repair, construction of mosques, schools and other public buildings.

CBR's main funding sources have been WHO, USAID, IRC/RAP, ARCON, UNOCHA, UNDP, IIRO, FAO and ASC.

CBR's accounts are audited by both independent chartered accountants assigned by the Board of Directors and some of the donor organizations e.g. USAID and WHO. 
CONTEMPORARY JEHAD ENCYCLOPEDIA OF AFGHANISTAN-CJEA

\begin{tabular}{|l|l|l|}
\hline 118, STREET 11, H-1 & PHONE: 810165 & <COMEY BTAFF>- \\
PHASE II, HAYATABAD & F A X: & 1. QAZI NAJIULLAH \\
PESHAWAR, PAKISTAN & TELEX: & 2. MR. M. AMAN MUZAMIL \\
\hline
\end{tabular}

\begin{tabular}{|lc|ll|lr|}
\hline AFGHAN : & 25 & TECHNICAL: & $\ldots$ & PAK. BASED: & 25 \\
PAKISTANI : & - & ADMINISTRATIVE: & $\cdots$ & AFGHA.BASED: & - \\
EXPAT: & - & FIELD/SUPPORT S. & C. & CROSS-BORDER: & - \\
TOTAL: & 25 & TOTAL: & TOTAL: & 25 \\
\hline
\end{tabular}

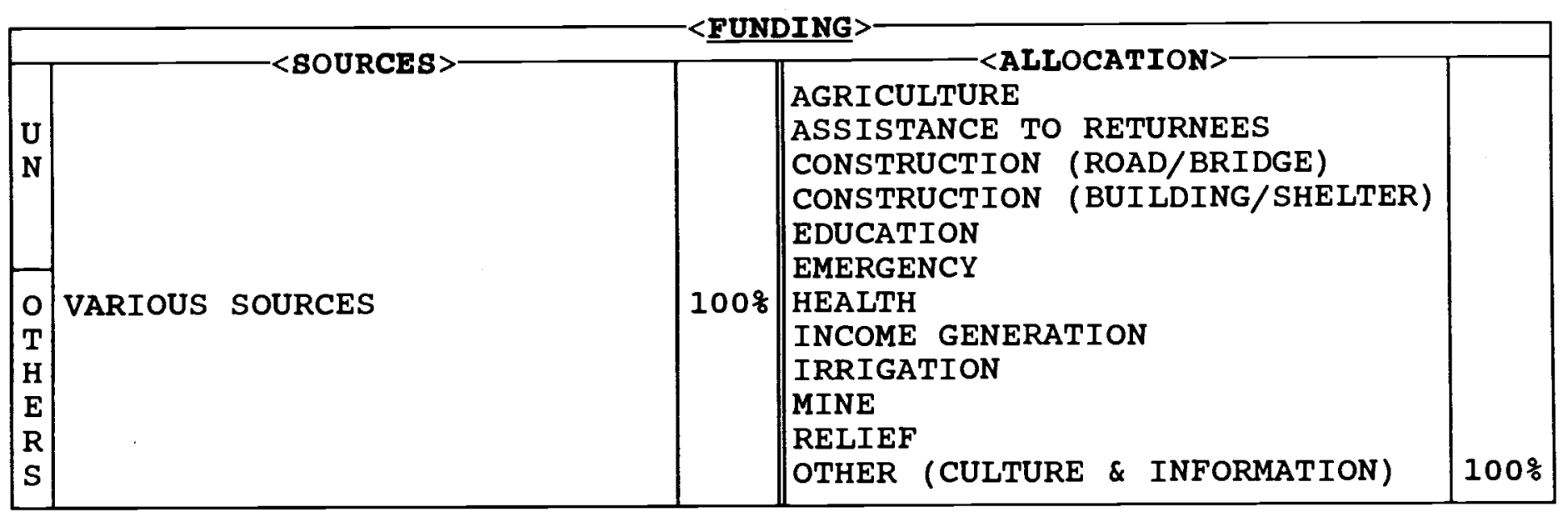

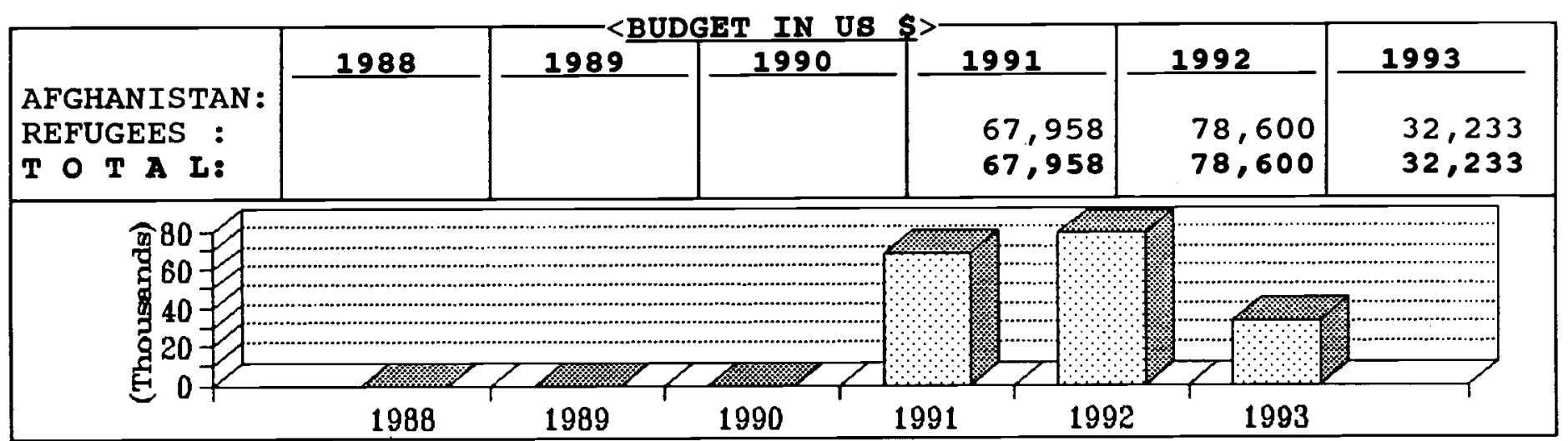

\begin{tabular}{|c|c|c|c|c|c|}
\hline PROVINCES & SECTOR & \&AGE & PROVINCES & SECTOR & $\% \mathrm{AGE}$ \\
\hline $\begin{array}{l}\text { BADAKSHAN } \\
\text { BADGHIS } \\
\text { BAGHLAN } \\
\text { BALKH } \\
\text { BAMYAN } \\
\text { FARAH } \\
\text { FARYAB } \\
\text { GHAZNI } \\
\text { GHOR } \\
\text { HELMAND } \\
\text { HERAT } \\
\text { JAWZJAN } \\
\text { KABUL } \\
\text { KANDAHAR } \\
\text { KAPISA }\end{array}$ & & & $\begin{array}{l}\text { KUNAR } \\
\text { KUNDUZ } \\
\text { LAGHMAN } \\
\text { LOGAR } \\
\text { NANGARHAR } \\
\text { NIMROZ } \\
\text { ORUZGAN } \\
\text { PAKTEKA } \\
\text { PAKTIA } \\
\text { PARWAN } \\
\text { SAMANGAN } \\
\text { TAKHAR } \\
\text { WARDAK } \\
\text { ZABUL }\end{array}$ & & \\
\hline
\end{tabular}


CONTEMPORARY JEHAD ENCYCLOPEDIA OF AFGHANIBTAN (CJEA)

was established in 1990 with the following objectives:

1. to study dimension of colonialist (Russian) forces invasion of Afghanistan and the stand of the countries of the world in face of the invasion. Also to study the impacts and effects of the invasion on Afghanistan, on the region as well as on the world,

2. to analyze the upraising of the people of Afghanistan against the Russians and the impacts of the upraising at regional and international levels,

3. to record jehad events for the coming generation,

4. to project the cause and dimension of Afghans migration and their living situation in the camps,

5. to introduce jehad forces, parties, leadership and organizations that have been rendering assistance in the field of jehad and immigration.

Information is collected from their original sources inside the country as well as the refugee camps and sources in Pakistan. A total of 50 permanent staff of eminent writers and reporters have been employed. Another 150 people are hired on contract basis to collect information from the camps and Afghanistan who are paid after each assignment after evaluation of their work.

Data collection from the refugee camps has been completed and a total of 5,000 pages information has been gathered. The collected data has also been reconfirmed by the CJEA inspecting reporters.

Some 2,000 copies of a set of questions under the name of "White Book" has been produced and over 800 of them have so far been distributed to the field commanders of different resistance groups and different areas. A one day seminar was held in August 1992 to persuade the field commanders to provide information. The importance of producing an encyclopedia was explained to them.

The Encyclopedia has been divided in 13 chapters each covering a certain subject-matter. The collected data is delivered to the Archive Department which will compare the data to the news-clippings from the parties newspapers. The confirmed information is then sent to the Compilation and Review Department (CRD). The CRD members undertake writing for each chapter based on the information received

The Executive Committee of the CJEA reviews and finalize the chapters. The work is then translated and published into four languages of Arabic, English, Persian and Pushto. 
1. DR. MAJBOOR

2. MR. SADIQ KAZIMI

3. MR . SARWAR HUSSAINI
HAYATABAD, P O BOX 1378 PESHAWAR, PAKISTAN
PHONE: 812530

F A X:

TELEX:
$<$ PERSONNEL

\begin{tabular}{|lc|ll|lr}
\hline AFGHAN : & 55 & TECHNICAL: & $\ldots$ & PAK. BASED: & 4 \\
PAKISTANI: & - & ADMINISTRATIVE: & $\ldots$ & AFGHA.BASED: & 48 \\
EXPAT: & - & FIELD/SUPPORT S. & $\ldots$ & CROSS-BORDER: & 3 \\
TOTAL: & 55 & TOTAL: & $\mathbf{5 5}$ & TOTAL: & $\mathbf{5 5}$ \\
\hline
\end{tabular}

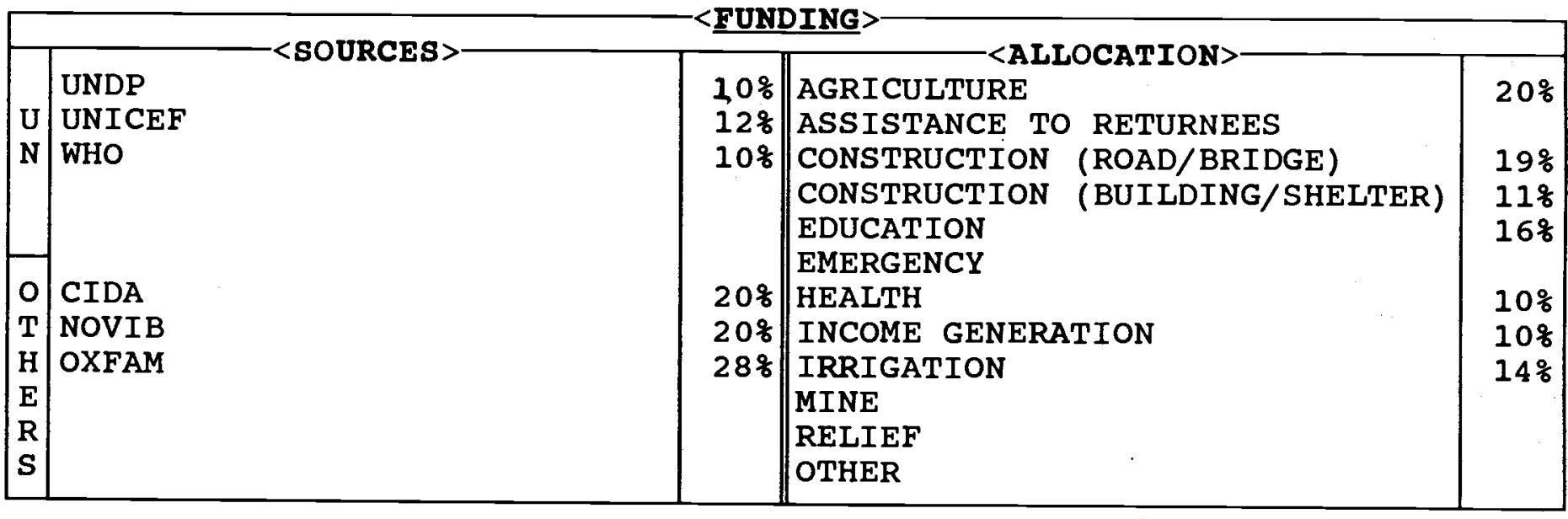

\begin{tabular}{|c|c|c|c|c|c|c|}
\hline & 1988 & 1989 & 1990 & 1991 & 1992 & 1993 \\
\hline $\begin{array}{l}\text { AFGHANISTAN : } \\
\text { REFUGEES : }\end{array}$ & & & 248,754 & 116,850 & 131,904 & 154,288 \\
\hline T O T A L: & & & 248,754 & 116,850 & 131,904 & 154,288 \\
\hline
\end{tabular}

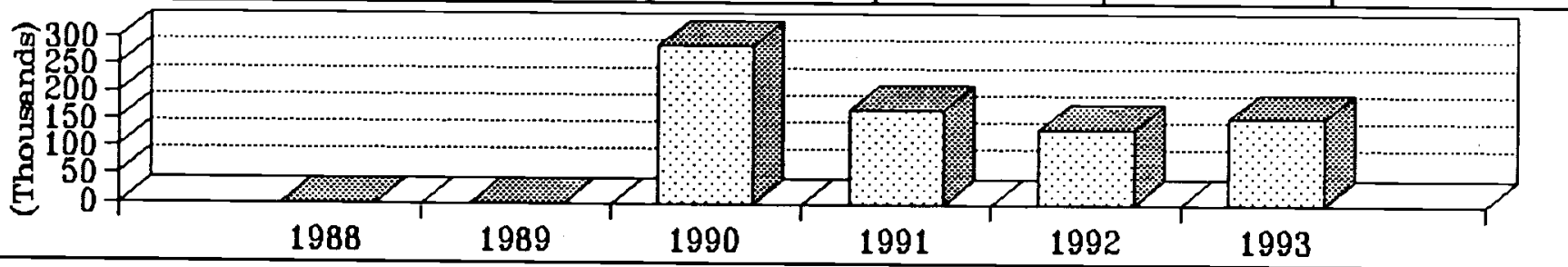

\begin{tabular}{|c|c|c|c|c|c|}
\hline PROVINCES & SECTOR & $\because \mathrm{AGE}$ & PROVINCES & SECTOR & \&AGE \\
\hline $\begin{array}{l}\text { BADAKSHAN } \\
\text { BADGHIS } \\
\text { BAGHLAN } \\
\text { BALKH } \\
\text { BAMYAN } \\
\text { FARAH } \\
\text { FARYAB } \\
\text { GHAZNI } \\
\text { GHOR } \\
\text { HELMAND } \\
\text { HERAT } \\
\text { JAWZJAN } \\
\text { KABUL } \\
\text { KANDAHAR } \\
\text { KAPISA }\end{array}$ & $\begin{array}{l}\text { Irrign } \\
\text { Agr/educ/health/i.g. } \\
\text { Agr/educ/health/irrig }\end{array}$ & $\begin{array}{l}11 \% \\
19 \% \\
29 \%\end{array}$ & \begin{tabular}{|l|} 
KUNAR \\
KUNDUZ \\
LAGHMAN \\
LOGAR \\
NANGARHAR \\
NIMROZ \\
ORUZGAN \\
PAKTEKA \\
PAKTIA \\
PARWAN \\
SAMANGAN \\
TAKHAR \\
WARDAK \\
ZABUL
\end{tabular} & Const/educ/health & $42 \%$ \\
\hline
\end{tabular}


COOPERATION CENTER FOR AFGHANISTAN (CCA)

was formed in July 1990 as an Afghan Charitable organization with full regards to the Universal Declaration of Human Rights 1948. CCA started its activities in central parts of Afghanistan (Hazarajat), and accepts any unconditional assistance from different sources. Considering the primary needs of the region, CCA is working in the four sectors of agriculture, education, health and infrastructure.

CCA has operated shaheed sayed Abdullah Hospital in Bamyan city since 1989 as a self-sufficient hospital. Two midwifery training courses have been completed in Qasem-i-Shaheed clinic in Shashpul, Bamyan. There are two female health workers working in Behsud and Khwaja Omari. A training course for village health workers is run in Kabul. Tow TBA training courses are currently running one in each Behsud and Bamyan areas. It is planned to organize several FHW centers in different parts of Hazarajat.

$\mathrm{CCA}$ is implementing irrigation rehabilitation projects in Baghlan and Ghazni provinces. It has distributed improved seeds and fertilizer in Behsud area.

CCA has repaired the SadbargShashpul road which was blocked for the past twenty years. Survey and repairing of another road between Bamyan and wardak provinces is in progress. A school has been constructed in Shashpul. Extensions to Bamyan hospital and clinics have been built. Repairing work on a mosque in Yakawlang is in progress. Construction of a building for $a$ Technical Training Center was completed in November 1993.

In the education sector, CCA runs two primary schools and two technical courses in Bamyan and Behsud. A total of 90 students graduate every year from these courses.
CCA has completed a handicrafts project and is currently running another one in Ghazni. A spinning wheel project in Behsud and another in Yakawlang districts are ongoing.

A human right promotion program has been undertaken which is implemented by organizing seminars and doing publicity.

CCA has a technical team of 9 engineers, a medical team of 5 MD doctors (including 3 lady doctors), surveyors, education specialists and agriculturalists who work in the field implementing projects and doing research in Hazarajat.

CCA's Head office is in Mazar-iSharif and has sub-offices in Peshawar and Bamyan. 
COORDINATION OF AFGHAN RELIEF-COAR

\begin{tabular}{|c|c|c|c|c|}
\hline$=<$ ADDRESS $>$ & $<$ COMMUNICATIO & CNES & KEY STI & \\
\hline $\begin{array}{l}\text { 84-E RAHMAN BABA RD U/T } \\
\text { P O BOX.... . . . . . } \\
\text { PESHAWAR, PAKISTAN }\end{array}$ & $\begin{array}{l}\text { PHONE: } 41188 \\
\text { F A X: } 44122 \\
\text { TELEX: }\end{array}$ & & $\begin{array}{ll}\text { 1. } & \text { ENG. M. NZ } \\
\text { 2. HAJI ABDUI } \\
\text { 3. MR. M. A. }\end{array}$ & $\begin{array}{l}\text { SALIMEE } \\
\text { JRI }\end{array}$ \\
\hline $\begin{array}{l}\text { AFGHAN : } \\
\text { PAKISTANI: } \\
\text { EXPAT: } \\
\text { TOTAL: }\end{array}$ & $\begin{array}{l}\text { TECHNICAL: } \\
\text { ADMINISTRATIVE: } \\
\text { FIELD/SUPPORT S } \\
\text { TOTAL: }\end{array}$ & $\begin{array}{r}6 \\
12 \\
112 \\
130\end{array}$ & $\begin{array}{l}\text { PAK. BASED: } \\
\text { AFGHA. BASED: } \\
\text { CROSS-BORDER } \\
\text { TOTAL: }\end{array}$ & $\begin{array}{r}12 \\
118 \\
130\end{array}$ \\
\hline
\end{tabular}

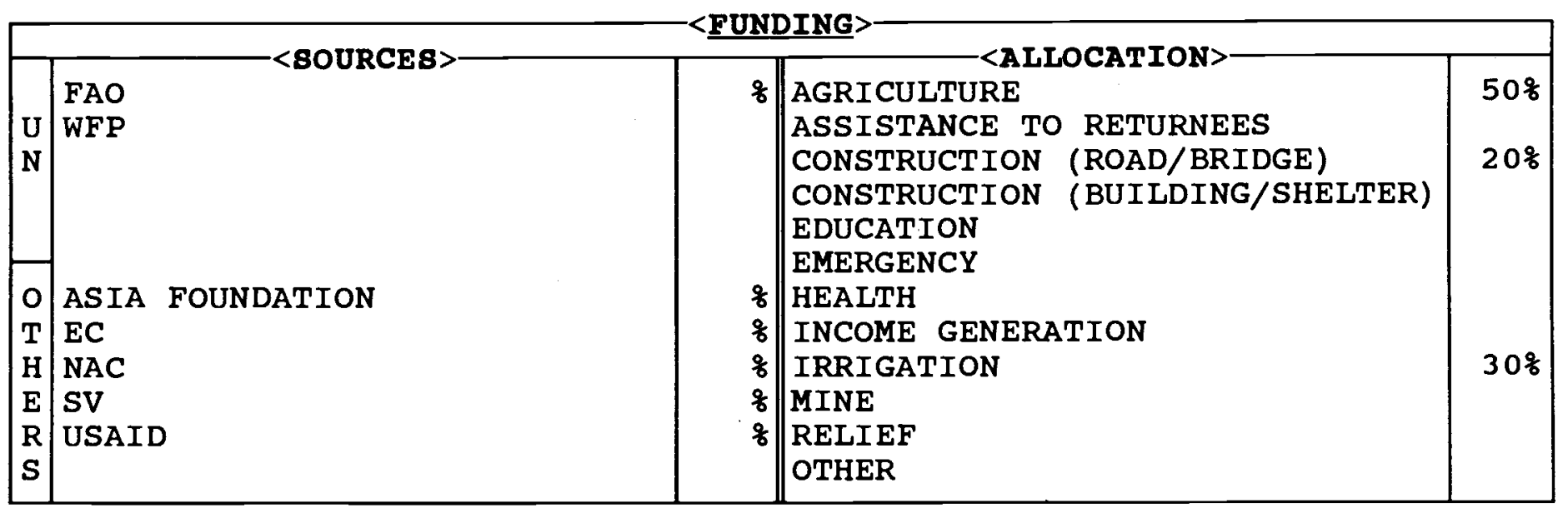

\begin{tabular}{|c|c|c|c|c|c|c|}
\hline $\begin{array}{l}\text { AFGHANISTAN : } \\
\text { REFUGEES : } \\
\text { TOT A L: }\end{array}$ & 1988 & $\begin{array}{r}1989 \\
1,000 \\
1,000\end{array}$ & $\begin{array}{l}\frac{1990}{300,000} \\
300,000\end{array}$ & $\begin{array}{l}\frac{1991}{430,000} \\
430,000\end{array}$ & $\begin{array}{l}\frac{1992}{600,000} \\
600,000\end{array}$ & $\begin{array}{l}\frac{1993}{300,000} \\
300,000\end{array}$ \\
\hline 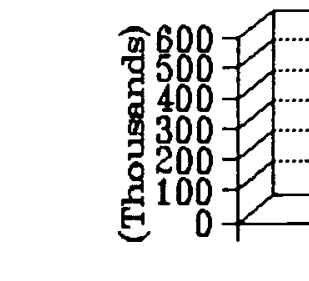 & 1988 & 1989 & 1990 & 199 & 1993 & 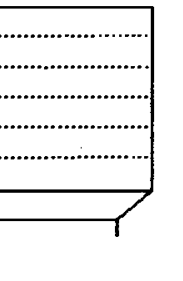 \\
\hline
\end{tabular}

\begin{tabular}{|c|c|c|c|c|c|}
\hline PROVINCES & SECTOR & \%AGE & PROVINCES & SECTOR & \% $\mathrm{AGE}$ \\
\hline $\begin{array}{l}\text { BADAKSHAN } \\
\text { BADGHIS } \\
\text { BAGHLAN } \\
\text { BALKH } \\
\text { BAMYAN } \\
\text { FARAH } \\
\text { FARYAB } \\
\text { GHAZNI } \\
\text { GHOR } \\
\text { HELMAND } \\
\text { HERAT } \\
\text { JAWZJAN } \\
\text { KABUL } \\
\text { KANDAHAR } \\
\text { KAPISA }\end{array}$ & Agr/const/irrign & $55 \frac{8}{8}$ & $\begin{array}{l}\text { KUNAR } \\
\text { KUNDUZ } \\
\text { LAGHMAN } \\
\text { LOGAR } \\
\text { NANGARHAR } \\
\text { NIMROZ } \\
\text { ORUZGAN } \\
\text { PAKTEKA } \\
\text { PAKTIA } \\
\text { PARWAN } \\
\text { SAMANGAN } \\
\text { TAKHAR } \\
\text { WARDAK } \\
\text { ZABUL }\end{array}$ & $\begin{array}{l}\text { Agr } \\
\text { Agr/const }\end{array}$ & $40 \%$ \\
\hline
\end{tabular}


is an Afghan NGO, established in December 1989 with the aim of providing appropriate assistance to Afghanistan which could lead to thes possibility of long term community development. The main objective of this organization is to work in the field of development and reconstruction projects in Afghanistan.

The work of COAR over the past four years has resulted in the setting up of the Foundations for Rural Development (FRDs) and Rural Development Centers (RDCs) in Afghanistan. The FRDs and RDCs were established following the recommendations of a conference held in Moqor district of Ghazni in 1991.

COAR's achievements and its "Social Welfare Activities", in the spring of 1993 are the main activity of Rural Development Center (details are provided in the First Quarterly Narrative Report published by COAR).

In October 1992, COAR organized another conference in sayed Abad district of Wardak. In this conference the following three objectives were determined for the RDCs :

\section{* To improve cost/efficient ratio. \\ * To improve mid-term capacity for self-financing. \\ * To improve project impact of least favored groups.}

CoAR has been mainly involved in agriculture, irrigation and infrastructure rehabilitation and development.

starting up of COAR/AVICEN EPI activities funded by local resources in 1993, was well received by the local community.

CoAR has also started two new experiments in the field of Education and Health since early
1993 through its Welrare Cetitèrs in RDCs, with partial field contribution of the Swedish Committee for Afghanistan and Aide Medicale Internationale-Afghanistan. 


\begin{tabular}{|l|l|l|}
\hline 13-A, BLOCK 4, SAT TOWN & PHONE: 440004 & <COMMUNICATION LINES $>-$ MTAFF \\
P O BOX. ABDUL SALAM \\
QUETTA PAKISTAN & F A X: 443481 & 2. \\
\hline
\end{tabular}

\begin{tabular}{|lr|lr|lr|}
\hline AFGHAN : & 44 & TECHNICAL: & 4 & PAK. BASED: & 8 \\
PAKISTANI : & 2 & ADMINISTRATIVE: & 8 & AFGHA.BASED: & 3 \\
EXPAT: & 0 & FIELD/SUPPORT S. & 34 & CROSS-BORDER: & 35 \\
TOTAL: & 46 & TOTAL: & 46 & TOTAL: & 46 \\
\hline
\end{tabular}

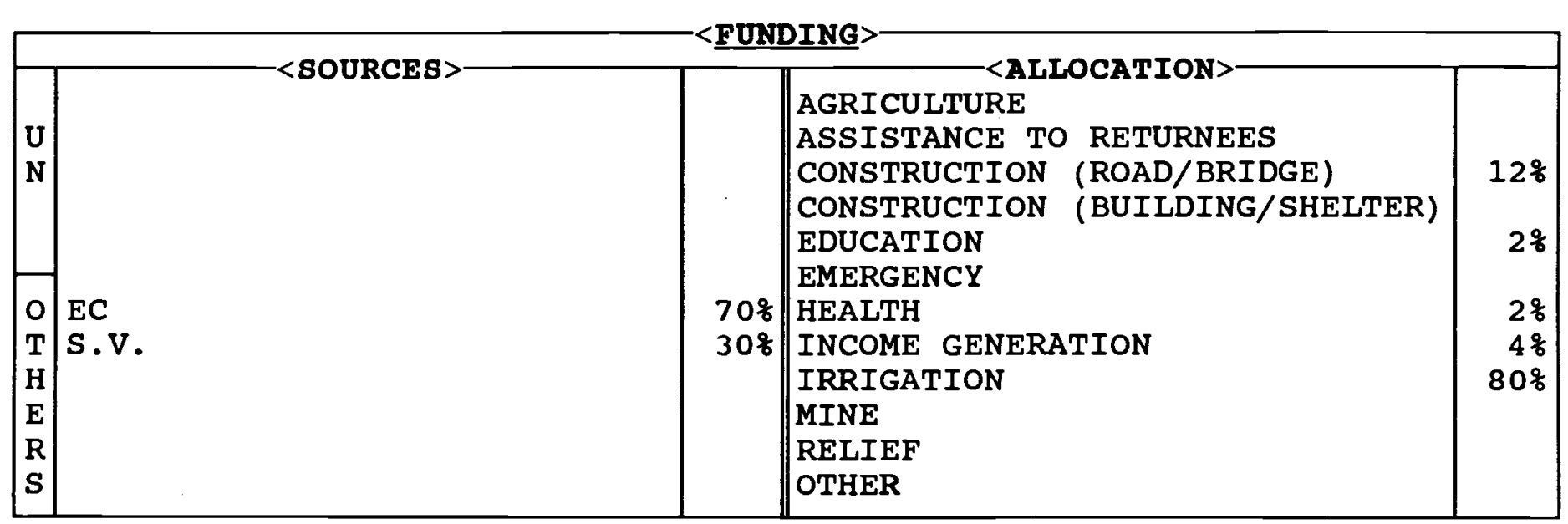

\begin{tabular}{|c|c|c|c|c|c|c|}
\hline $\begin{array}{l}\text { AFGHANISTAN: } \\
\text { REFUGEES : } \\
\text { T O T A L: }\end{array}$ & 1988 & 1989 & $\begin{array}{l}\frac{1990}{654,510} \\
654,510\end{array}$ & {$\left[\begin{array}{l}\frac{1991}{1,026,117} \\
1,026,117\end{array}\right.$} & $\begin{array}{l}\frac{1992}{1,654,419} \\
1,654,419\end{array}$ & $\begin{array}{l}\frac{1993}{150,000} \\
150,000\end{array}$ \\
\hline $\begin{array}{l}1.6 \\
1.2 \\
0.8 \\
0.4\end{array}$ & 1988 & 1989 & 1990 & 991 & 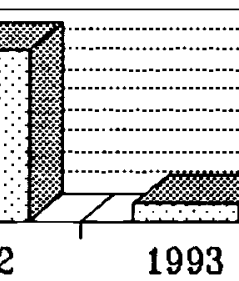 & 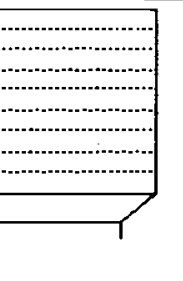 \\
\hline
\end{tabular}

\begin{tabular}{|c|c|c|c|c|c|}
\hline PROVINCES & SECTOR & \&AGE & PROVINCES & SECTOR & \&AGE \\
\hline $\begin{array}{l}\text { BADAKSHAN } \\
\text { BADGHIS } \\
\text { BAGHLAN } \\
\text { BALKH } \\
\text { BAMYAN } \\
\text { FARAH } \\
\text { FARYAB } \\
\text { GHAZNI } \\
\text { GHOR } \\
\text { HELMAND } \\
\text { HERAT } \\
\text { JAWZJAN } \\
\text { KABUL } \\
\text { KANDAHAR } \\
\text { KAPISA }\end{array}$ & $\begin{array}{l}\text { Agr/health/IG/irrign } \\
\text { Irrign }\end{array}$ & $\begin{array}{l}90 \% \\
10 z\end{array}$ & \begin{tabular}{|l} 
KUNAR \\
KUNDUZ \\
LAGHMAN \\
LOGAR \\
NANGARHAR \\
NIMROZ \\
ORUZGAN \\
PAKTEKA \\
PAKTIA \\
PARWAN \\
SAMANGAN \\
TAKHAR \\
WARDAK \\
ZABUL
\end{tabular} & & \\
\hline
\end{tabular}


was established in 1988. The objective is to work for the rehabilitation and reconstruction of Afghanistan.

CHA is involved in agriculture, irrigation/infrastructure rehabilitation, health and vocational training programs.

In agriculture, CHA distributes improved seeds and fertilizer. In irrigation, it cleans/repairs karezes and canals and constructs small dams (diversion dams). CHA constructs public buildings including schools. It also implements road repair projects. In the health sector, CHA is involved in a vaccination program.

CHA established a vocational training center (carpet weaving) for war-widows in Farah province.

An auto workshop for repairing vehicles and machinery in Farah province is ongoing.

In 1993, CHA implemented a number of agricultural projects in Farah province including tree distribution, nursery and poultry farms.

CHA will shift its office to Afghanistan as soon as the security situation improves and the government's policy towards NGOs is declared. 
COUNCIL FOR DISPLACED PEOPLE-CDP

\begin{tabular}{|l|l|l|}
\hline C/O WFP KABUL & CCOMMUNICATION LINES $>$ <REY STAFF> \\
SHAHR NAW & PHONE: C/O 61968 & 1. MR. S. A. MUBAREZ \\
KABUL, AFGHANISTAN & FA X: & 2. MR. S. M. KAZEMI \\
\hline
\end{tabular}

\begin{tabular}{|lr|lr|lr|}
\hline AFGHAN : & 50 & TECHNICAL: & 30 & PAK. BASED: & - \\
PAKISTANI : & - & ADMINISTRATIVE: & 7 & AFGHA.BASED: & 50 \\
EXPAT: & - & FIELD/SUPPORT S. & 13 & CROSS-BORDER: & - \\
TOTAL: & 50 & TOTAL: & 50 & TOTAL: & 50 \\
\hline
\end{tabular}

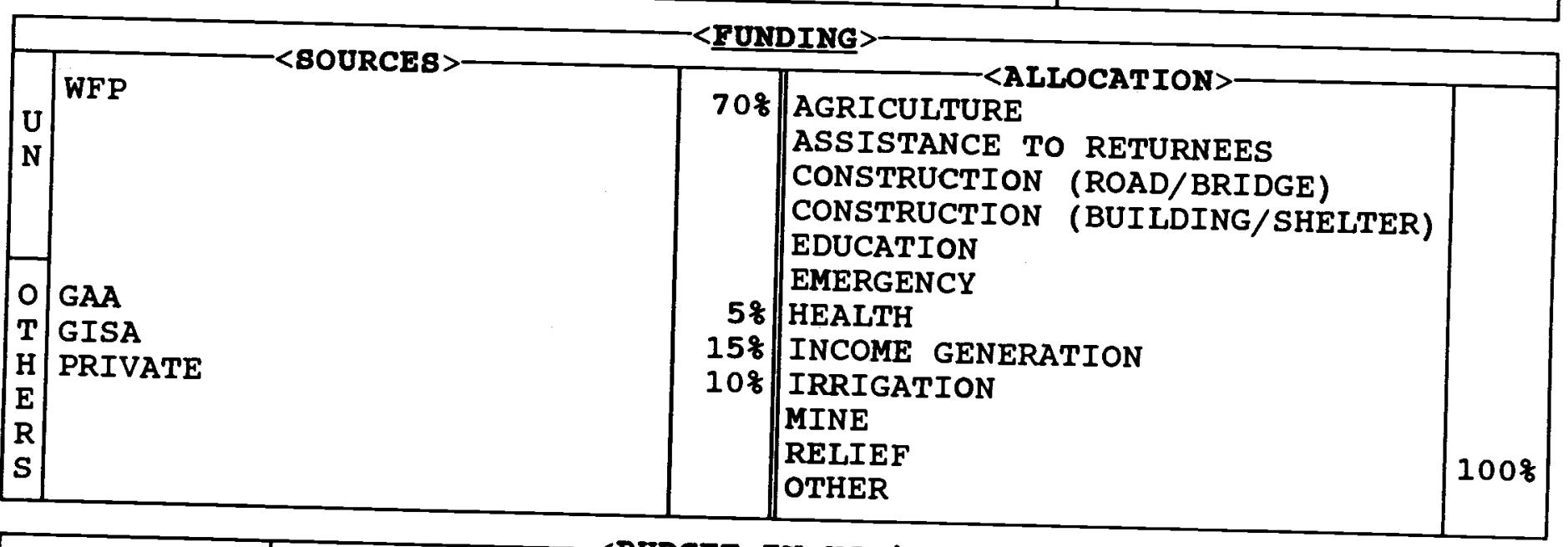

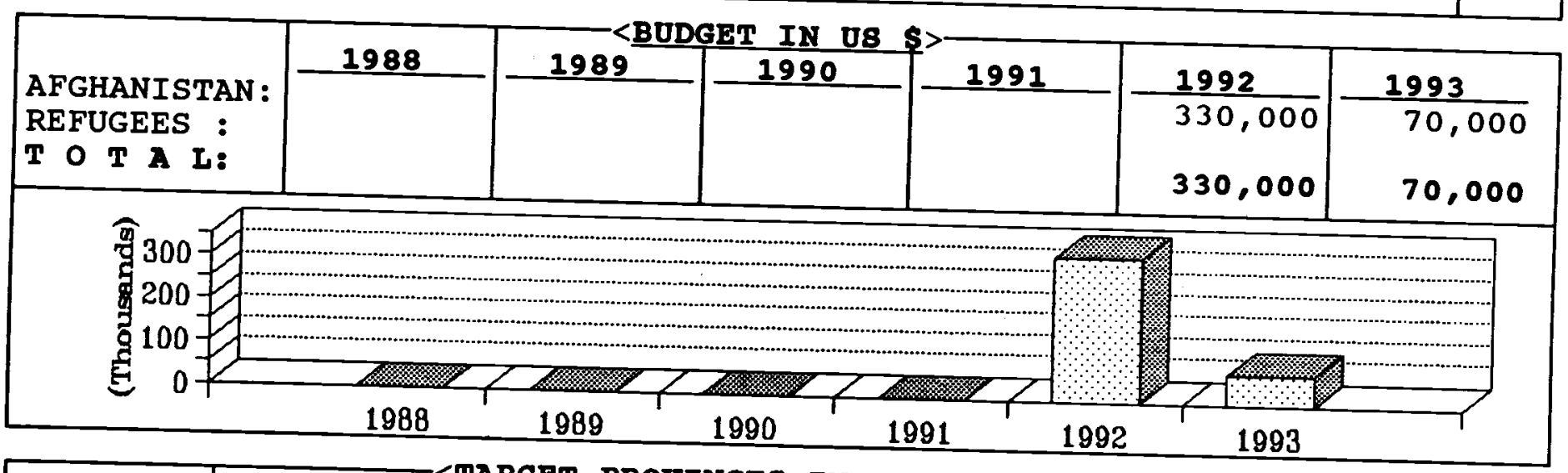

\begin{tabular}{|c|c|c|c|c|c|}
\hline \multirow{2}{*}{ PROVINCES } & \multicolumn{2}{|c|}{ SFCT $<$ TARGET PROVINCEE } & \\
\hline & SECTOR & \&AGE & PROVINCES & SECTOR & \&AGE \\
\hline \begin{tabular}{|l|} 
BADAKSHAN \\
BADGHIS \\
BAGHLAN \\
BALKH \\
BAMYAN \\
FARAH \\
FARYAB \\
GHAZNI \\
GHOR \\
HELMAND \\
HERAT \\
JAWZJAN \\
KABUL \\
KANDAHAR \\
KAPISA
\end{tabular} & $\mid$ & 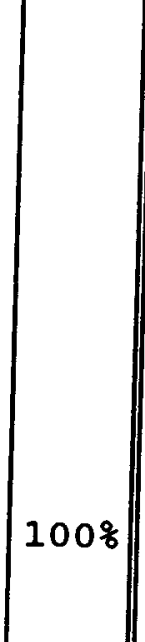 & \begin{tabular}{||l} 
KUNAR \\
KUNDUZ \\
LLAGHMAN \\
LOGAR \\
NANGARHAR \\
NIMROZ \\
ORUZGAN \\
PAKTEKA \\
PAKTIA \\
PARWAN \\
SAMANGAN \\
TAKHAR \\
WARDAK \\
ZABUL
\end{tabular} & & \\
\hline
\end{tabular}


was established in Kabul with the efforts of a number elders, professors of Kabul University and some other influential people. When the fighting intensified in Kabul in mid 1992, these people came together and formed the council to mediate between warring factions. With the efforts of the council, some 200 prisoners of war were released and peace negotiations started between the different factions.

Later on the Council started helping the war affected families with the cooperation of the United Nations Organizations, German Agro Action and other agencies.

A total of 400 MT food has been distributed to the displaced families in district 1 , part of districts 4 and 6 of Kabul city. 1,500 families receive regular monthly rations.

Moreover, CDP distributed cash (Afs. 500 million) donated by the Government of Islamic state of Afghanistan to the people whose houses were damaged in the 1992 fighting. Afghan merchants, businessmen and traders also made some contributions to the relief fund for displaced and war affected families.

CDP has the capacity and is ready to undertake any emergency relief projects in the area. It invites monitoring and supervision, by donor organizations, of its activities. Detailed records of CDP's activities including video films, are maintained by the CDP administration.

The Council has a central Board of 50 people, an Executive Board of 11 people and a general membership of over 200 volunteers. 
CULTURAL AND RELIEF FOUNDATION OF AFGHANIBTAN-CRFA

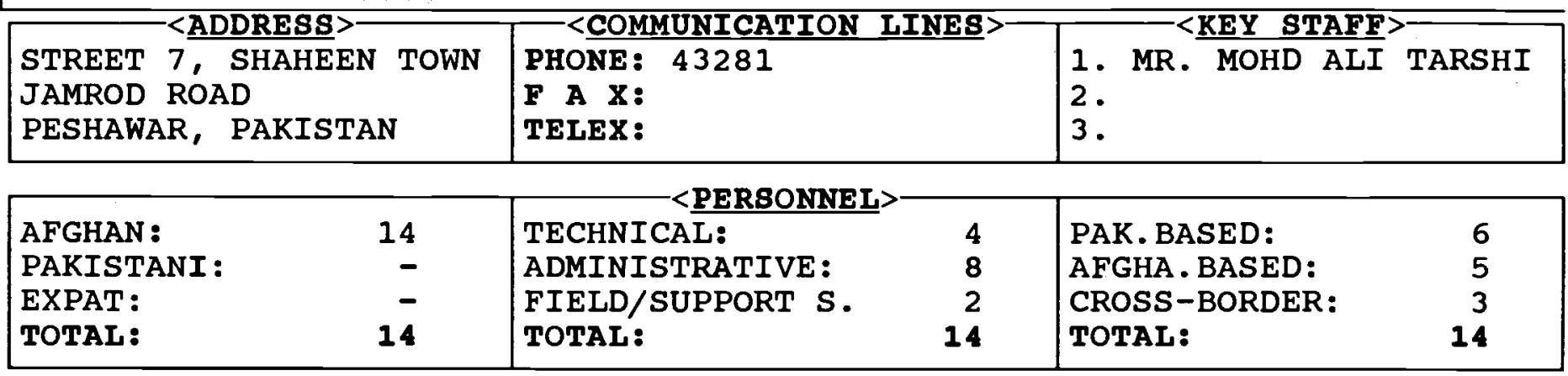

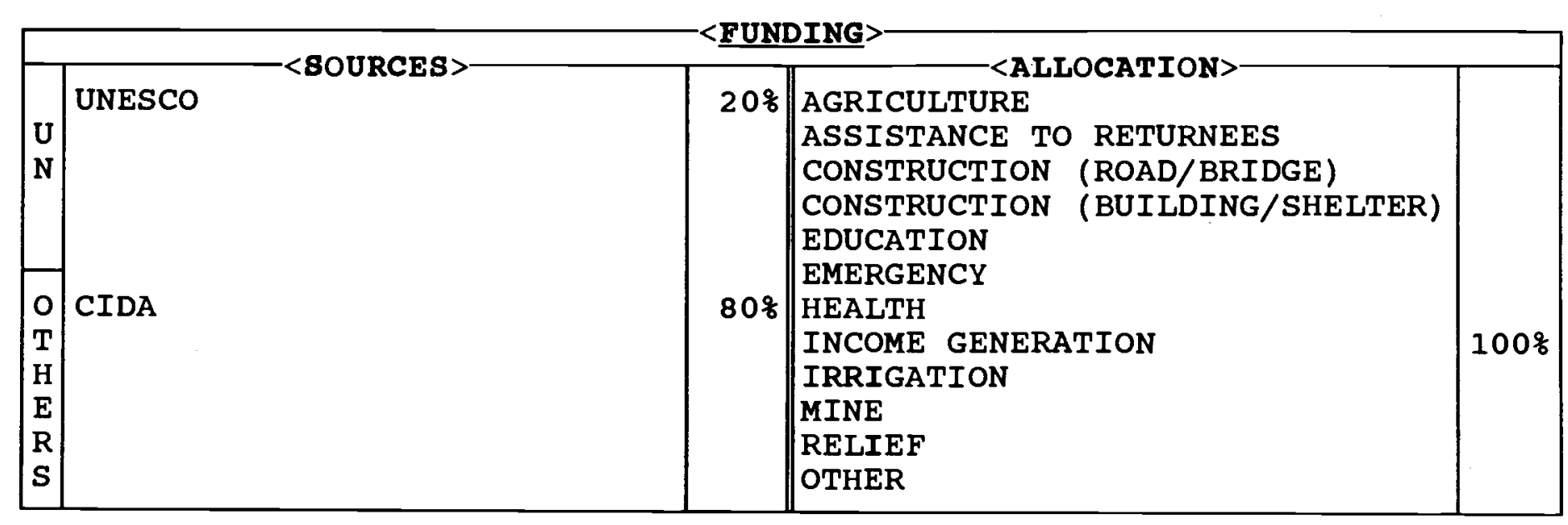

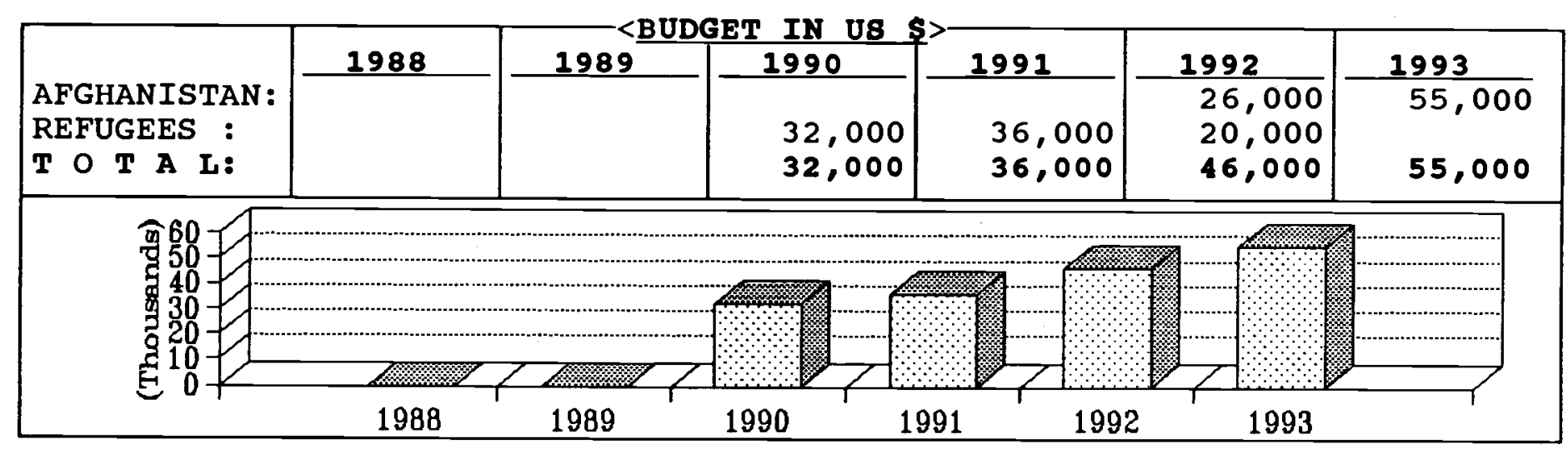

\begin{tabular}{|c|c|c|c|c|c|}
\hline PROVINCES & SECTOR & \&AGE & PROVINCES & SECTOR & $\% A G E$ \\
\hline $\begin{array}{l}\text { BADAKSHAN } \\
\text { BADGHIS } \\
\text { BAGHLAN } \\
\text { BALKH } \\
\text { BAMYAN } \\
\text { FARAH } \\
\text { FARYAB } \\
\text { GHAZNI } \\
\text { GHOR } \\
\text { HELMAND } \\
\text { HERAT } \\
\text { JAWZJAN } \\
\text { KABUL } \\
\text { KANDAHAR } \\
\text { KAPISA }\end{array}$ & Income gen. & . & \begin{tabular}{|l} 
KUNAR \\
KUNDUZ \\
LAGHMAN \\
LOGAR \\
NANGARHAR \\
NIMROZ \\
ORUZGAN \\
PAKTEKA \\
PAKTIA \\
PARWAN \\
SAMANGAN \\
TAKHAR \\
WARDAK \\
ZABUL
\end{tabular} & & \\
\hline
\end{tabular}


is an Afghan non-governmental organization established in 1990 .

CRFA has been providing opportunities for Afghan refugee families to generate income.

A vocational training center was established in Swabi camp which trained refugee women/girls in carpet weaving skills. More than 150 students completed the training. A carpet production system was organized through which 40 women were paid to produce carpets which were then marketed by CRFA locally as well as overseas. Both, the carpet training and carpet production projects have been financed by CIDA. CRFA also produced silk clothes and shals. 12 crafts-women produced items which were marketed locally and/or overseas. This project was supported by UNESCO.

In mid 1992, CRFA moved the carpet training project to Jawzjan province. A silk weaving project (training and production) has also been recently established in Aqcha area with the financial support of UNESCO. 40 students are trained in the center for six months by 7 experts. The products are marketed overseas through CRFA Peshawar office.

CRFA plans to extend its work to rehabilitation and reconstruction and to other provinces of Afghanistan primarily in the North. 
DANISH COMMITTEE FOR AID TO AFGHAN REFUGEES-DACAAR

\begin{tabular}{|l|l|l|}
\hline 10 GULMOHAR LANE, U/T & PHONE: $840516 / 40731$ & 1. MR. K. ULTICH LARSEN \\
U P O BOX 855 & F A X: 840516 & 2. MR. SVEN JOHNSSON \\
PESHAWAR, PAKISTAN & TELEX: & 3. MR. A. B. AFZALI
\end{tabular}

\begin{tabular}{|lr|lc|ll|}
\hline AFGHAN : & 539 & TECHNICAL: & $\ldots$ & PAK. BASED: & \\
PAKISTANI : & 93 & ADMINISTRATIVE : & $\ldots$ & AFGHA.BASED: & $\ldots$ \\
EXPAT: & 7 & FIELD/SUPPORT S. & $\ldots$ & CROSS-BORDER: & $\ldots$ \\
TOTAL: & 639 & TOTAL: & 639 & TOTAL: & 639 \\
\hline
\end{tabular}

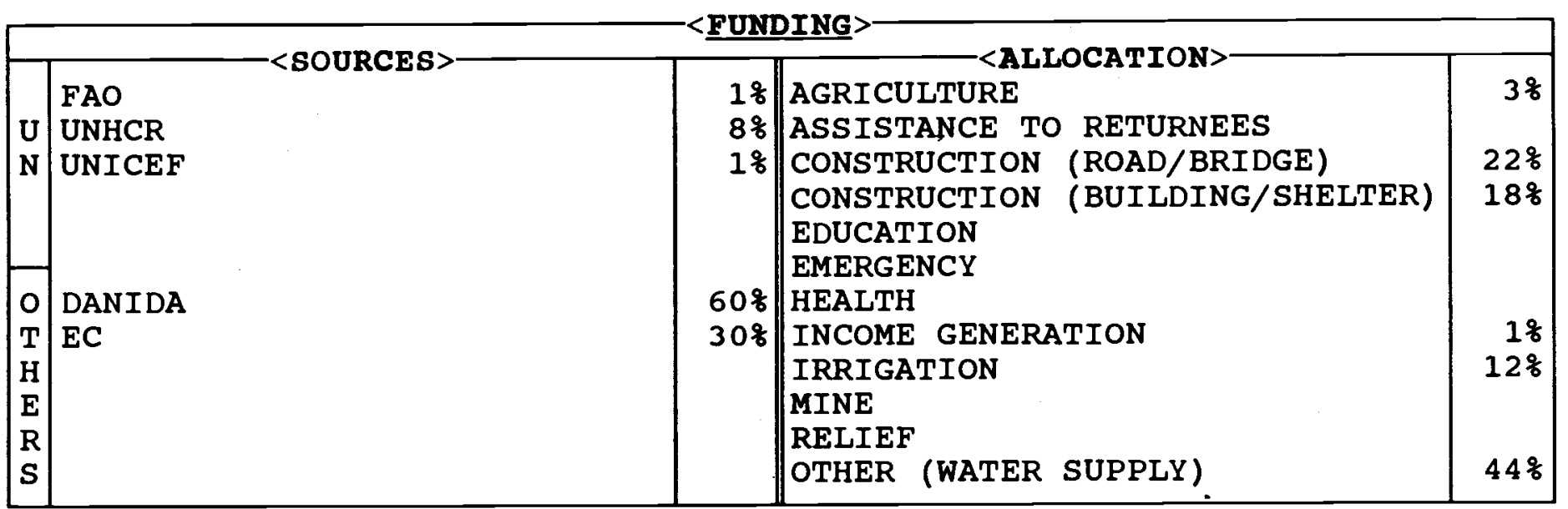

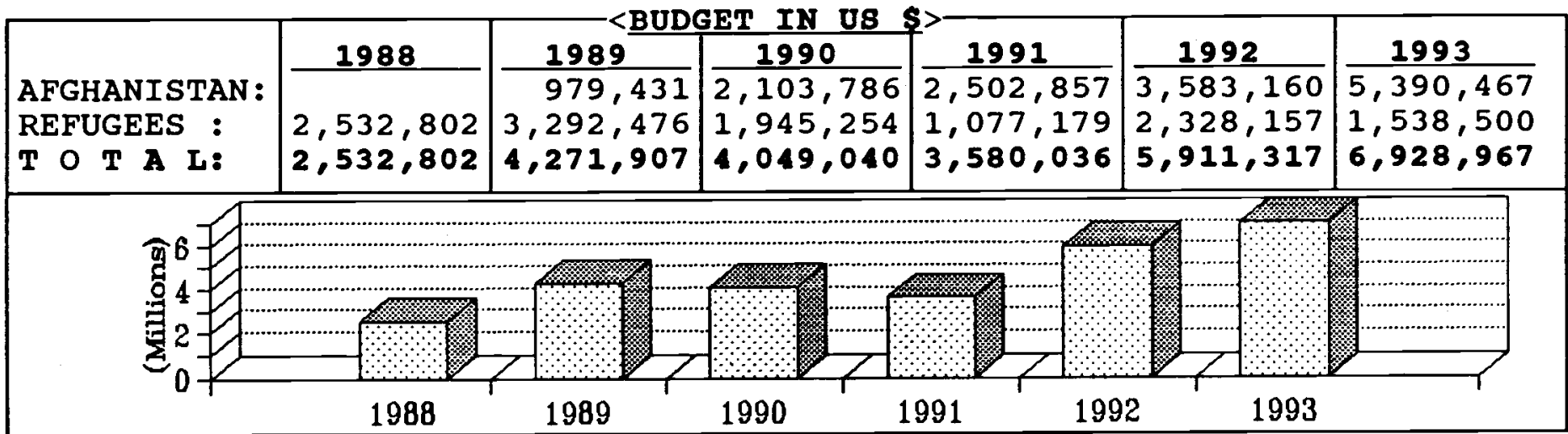

\begin{tabular}{|c|c|c|c|c|c|}
\hline PROVINCES & SECTOR & \&AGE & PROVINCES & SECTOR & \&AGE \\
\hline $\begin{array}{l}\text { BADAKSHAN } \\
\text { BADGHIS } \\
\text { BAGHLAN } \\
\text { BALKH } \\
\text { BAMYAN } \\
\text { FARAH } \\
\text { FARYAB } \\
\text { GHAZNI } \\
\text { GHOR } \\
\text { HELMAND } \\
\text { HERAT } \\
\text { JAWZJAN } \\
\text { KABUL } \\
\text { KANDAHAR } \\
\text { KAPISA }\end{array}$ & $\begin{array}{l}\text { Const } \\
\text { Agr/rural engineering }\end{array}$ & $2 \%$ & \begin{tabular}{|l} 
KUNAR \\
KUNDUZ \\
LAGHMAN \\
LOGAR \\
NANGARHAR \\
NIMROZ \\
ORUZGAN \\
PAKTEKA \\
PAKTIA \\
PARWAN \\
SAMANGAN \\
TAKHAR \\
WARDAK \\
ZABUL
\end{tabular} & $\begin{array}{l}\text { Agr/cons/irrign/w.S. } \\
\text { Agr/const/irrign/w.s. } \\
\text { Agr/const/irrign/w.s. }\end{array}$ & $52 \%$ \\
\hline
\end{tabular}




\section{DANISH COMMITTEE FOR AID TO AFGHAN REFUGEES (DACAAR)}

is a consortium set up to aid Afghan refugees, composed of four Danish NGOs: Danish People's Relief organization, Danish Association for International Cooperation, Caritas Denmark and Danish Refugee Council.

It has run its own projects in Pakistan since 1984 and during 1988 began a rehabilitation program inside Afghanistan.

The DACAAR sewing project in the refugee camps gives an income to 747 Afghan women, from embroidery and tailoring, by producing items for export, local sales, and UNHCR contracts. Mobile teams teach embroidery and new designs as well as looking after quality control of the work done by women in the camps, and a six month course trains women to work in the finishing workshop in Peshawar.

DACAAR employs refugees in construction teams for site planning and the provision of improved access roads in the camps. They took over the UNICEF water supply project in 1986 to improve and maintain shallow wells, install hand-pumps, build bathrooms and produce health education materials relating to water and hygiene.

DACAAR is also responsible for the maintenance of all piped water systems to refugee camps which have been installed by the NWFP Public Health Engineering Department. In 1988 their factory in Swabi began production of Indus hand-pumps, including a large number for UNHCR in 1993 supplemented with the smaller Kabul hand-pump.

The cross-border activities of DACAAR include irrigation, drinking water supply, roads, construction and agriculture in the provinces of Kunar, Ghazni, Nangarhar and Paktia.
In 1992, an office was set-up in Herat province and a number of rehabilitation projects were undertaken in the above mentioned sectors. Using its Herat office as a base, DACAAR plans to expand its activities in the western provinces of Afghanistan. 


\section{DARUS SALAM}

\begin{tabular}{|l|l|l|}
\hline GULABAD, BOARD, & PHONE: 42464 & <COMMUNICATION LINES $>$ DEY STAFF> \\
U P O BOX 1491 & F A X: & 2. \\
PESHAWAR, PAKISTAN & TELEX: & 3.
\end{tabular}

\begin{tabular}{|lr|ll|ll|}
\hline AFGHAN : & 25 & TECHNICAL: & $\ldots$ & PAK. BASED: & \\
PAKISTANI : & 12 & ADMINISTRATIVE: & $\ldots$ & AFGHA.BASED: & $\ldots$ \\
EXPAT: & 0 & FIELD/SUPPORT S. & $\ldots$ & CROSS-BORDER: & $\ldots$ \\
TOTAL: & 37 & TOTAL: & $\mathbf{3 7}$ & TOTAL: & $\mathbf{3 7}$ \\
\hline
\end{tabular}

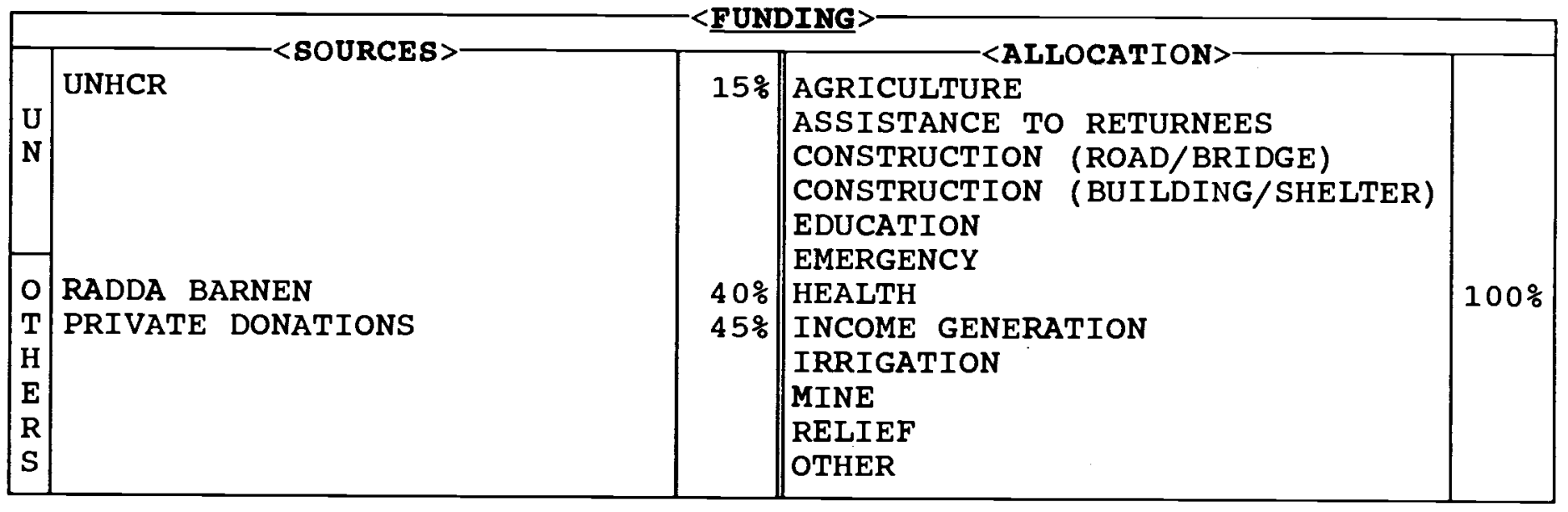

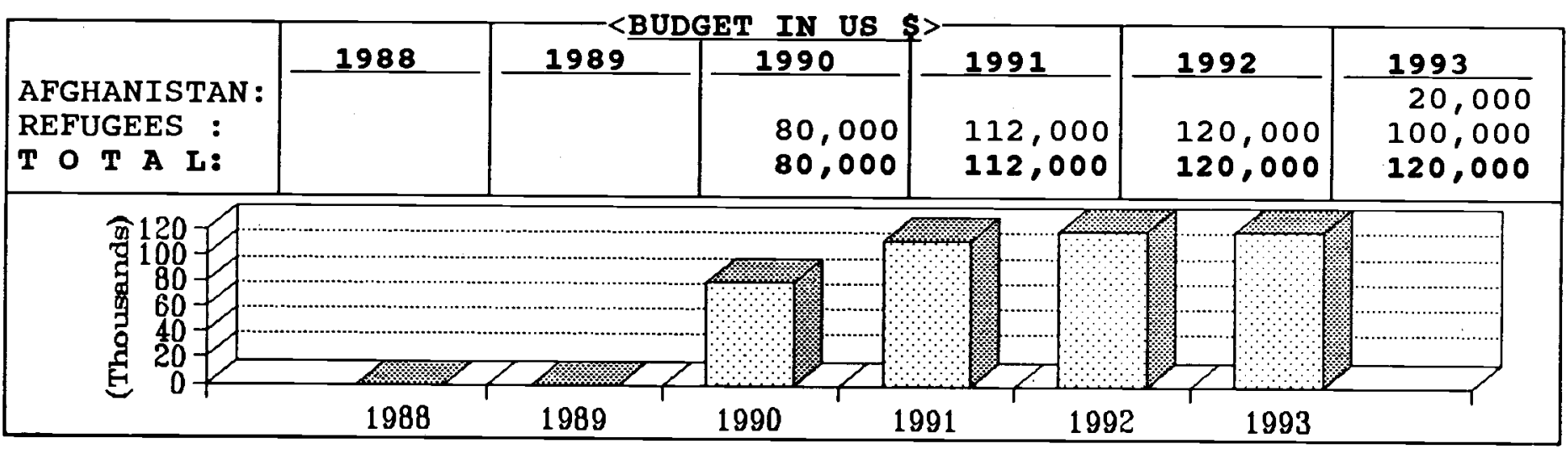

\begin{tabular}{|c|c|c|c|c|c|}
\hline PROVINCES & SECTOR & $\% A G E$ & PROVINCES & SECTOR & $\% A G E$ \\
\hline $\begin{array}{l}\text { BADAKSHAN } \\
\text { BADGHIS } \\
\text { BAGHLAN } \\
\text { BALKH } \\
\text { BAMYAN } \\
\text { FARAH } \\
\text { FARYAB } \\
\text { GHAZNI } \\
\text { GHOR } \\
\text { HELMAND } \\
\text { HERAT } \\
\text { JAWZJAN } \\
\text { KABUL } \\
\text { KANDAHAR } \\
\text { KAPISA }\end{array}$ & & & $\begin{array}{l}\text { KUNAR } \\
\text { KUNDUZ } \\
\text { LAGHMAN } \\
\text { LOGAR } \\
\text { NANGARHAR } \\
\text { NIMROZ } \\
\text { ORUZGAN } \\
\text { PAKTEKA } \\
\text { PAKTIA } \\
\text { PARWAN } \\
\text { SAMANGAN } \\
\text { TAKHAR } \\
\text { WARDAK } \\
\text { ZABUL }\end{array}$ & Health & $100 \%$ \\
\hline
\end{tabular}


is a humanitarian trust. The main objectives are as follows:

1) to rehabilitate the burnt, disabled, disfigured and mutilated persons through reconstructive surgery, physiotherapy, social, psychiatric and educational support;

2) to train Afghan and Pakistani doctors in reconstructive surgery so that they can open reconstructive surgery clinics in their areas;

3) to train Afghan paramedical (anaesthesia and operation room) technicians to assist these surgeons;

4) to conduct surveys on health matters in Afghanistan and Pakistan;

5) to advocate the rights of the children.

Darus Salam works both for refugees and cross-border. In Afghanistan it has conducted surveys of malnutrition, disability, immunization and war damage in 85 villages in Kunar and Paktia provinces.

According to the survey $40 \%$ of the disabled are children under 18 , and $20 \%$ of all disabled persons in Afghanistan (estimated to be over one million) can have their disability corrected through reconstructive surgery. However, there is no provision for this effort in the mandate of any donor agency contacted so far. 


\section{DEMINING AGENCY FOR AFGHANISTAN-DAFA}

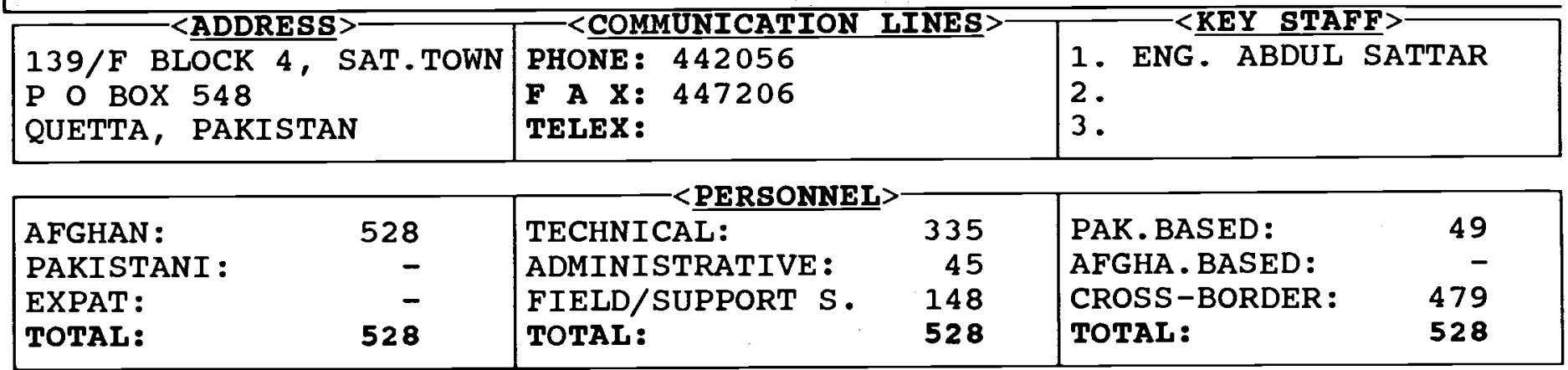

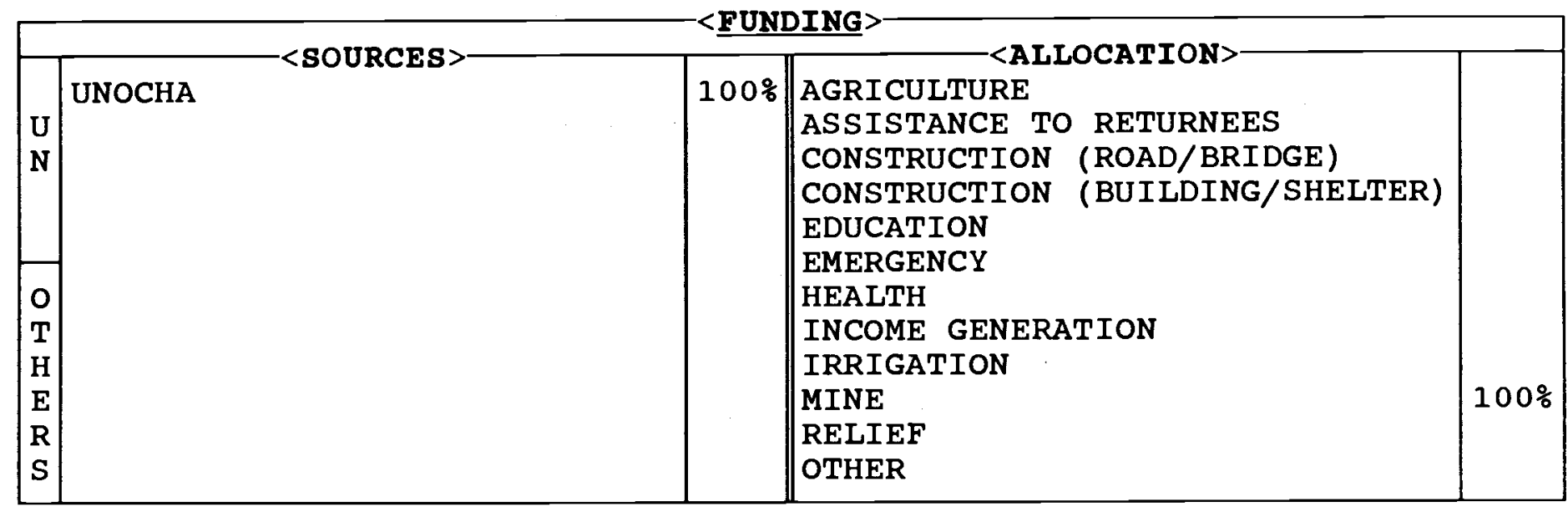

\begin{tabular}{|c|c|c|c|c|c|c|}
\hline & 1988 & 1989 & 1990 & 1991 & 1992 & 1993 \\
\hline $\begin{array}{l}\text { AFGHANISTAN : } \\
\text { REFUGEES : }\end{array}$ & & & & & & \\
\hline T O T A L: & & & $1,000,000$ & $1,600,000$ & $1,800,000$ & $1,650,000$ \\
\hline
\end{tabular}

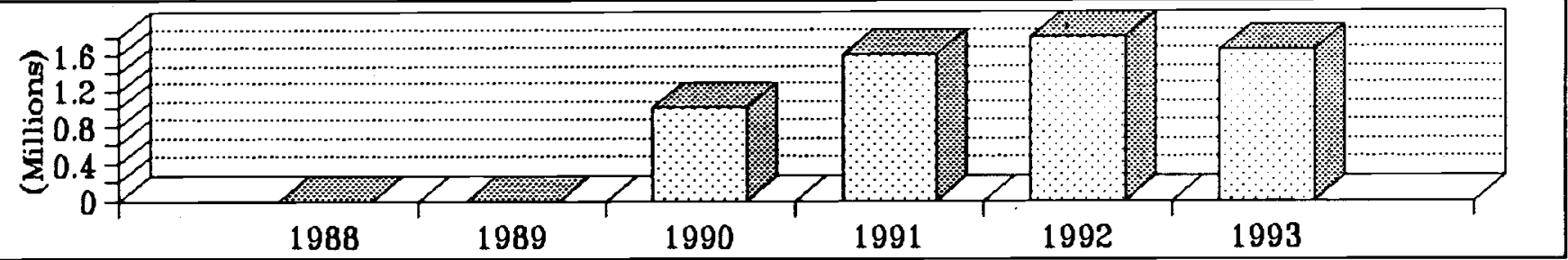

\begin{tabular}{|c|c|c|c|c|c|}
\hline PROVINCES & SECTOR & \&AGE & PROVINCES & SECTOR & $\% A G E$ \\
\hline $\begin{array}{l}\text { BADAKSHAN } \\
\text { BADGHIS } \\
\text { BAGHLAN } \\
\text { BALKH } \\
\text { BAMYAN } \\
\text { FARAH } \\
\text { FARYAB } \\
\text { GHAZNI } \\
\text { GHOR } \\
\text { HELMAND } \\
\text { HERAT } \\
\text { JAWZJAN } \\
\text { KABUL } \\
\text { KANDAHAR } \\
\text { KAPISA }\end{array}$ & $\begin{array}{l}\text { Demining } \\
\text { Demining } \\
\text { Demining }\end{array}$ & $50 \frac{8}{6}$ & $\begin{array}{l}\text { KUNAR } \\
\text { KUNDUZ } \\
\text { LAGHMAN } \\
\text { LOGAR } \\
\text { NANGARHAR } \\
\text { NIMROZ } \\
\text { ORUZGAN } \\
\text { PAKTEKA } \\
\text { PAKTIA } \\
\text { PARWAN } \\
\text { SAMANGAN } \\
\text { TAKHAR } \\
\text { WARDAK } \\
\text { ZABUL }\end{array}$ & $\begin{array}{l}\text { Demining } \\
\text { Demining }\end{array}$ & $\begin{array}{l}10 \% \\
10 \%\end{array}$ \\
\hline
\end{tabular}


is an Afghan NGO founded in 1990. The name of agency was changed from the South-West Afghanistan Agency for Demining (SWAAD) to Demining Agency for Afghanistan (DAFA) in June 1993.

The agency is supported by UNOCHA Demining Program and is operating in Kandahar, Zabul, Helmand, Farah and Nimroz provinces. A total of $11,287,115$ sqm area was cleared by 30 June 1993. 3,428 anti-personnel mines, 184 anti-tank mines and 7,742 pieces unexploded ordinance have been cleared. A large number of fragments were also found.

The agency has a total of 528 staff out of which 49 are working in the main office in quetta and 479 are working in six mobile camps operating inside Afghanistan. Each camp has a Field Medical Unit (FMU) consisting of a doctor, 6 nurses and an ambulance. The FMU is for the treatment of DAFA personnel as well as helping the local inhabitants. Injured deminers are evacuated to ICRC hospital in Quetta for further treatment.

Priorities for demining are set by UNOCHA Mine Clearance Program which are for the time being residential areas, roads and public pathways, irrigation channels, agricultural and grazing lands. priority is given to NGO project sites and to the areas where refugees are planning to return. 
DENTAL CLINIC FOR AFGHANISTAN REFUGEES-DCAR

\begin{tabular}{|c|c|c|}
\hline <ADDRESS > & $-\langle$ COMMUNICATION IINES $\rangle$ & $-\langle$ KEY 8TAFF> \\
\hline $\begin{array}{l}1 \text { JAMAL RD SHAHEEN TOWN } \\
\text { G P O BOX } 356 \\
\text { PESHAWAR, PAKISTAN }\end{array}$ & $\begin{array}{l}\text { PHONE: } 43358 \\
\text { F A X: } 841816 \\
\text { TELEX: }\end{array}$ & $\begin{array}{l}\text { 1. DR. SHER A. BALUCH } \\
\text { 2. } \\
\text { 3. }\end{array}$ \\
\hline
\end{tabular}

\begin{tabular}{|c|c|c|c|c|c|}
\hline $\begin{array}{l}\text { AFGHAN : } \\
\text { PAKISTANI: } \\
\text { EXPAT: } \\
\text { TOTAL: }\end{array}$ & $\begin{array}{r}62 \\
2 \\
1 \\
65\end{array}$ & $\begin{array}{l}\text { TECHNICAL: } \\
\text { ADMINISTRATIVE: } \\
\text { FIELD/SUPPORT S. } \\
\text { TOTAL: }\end{array}$ & $\begin{array}{l}\cdots \\
\ddot{65}\end{array}$ & $\begin{array}{l}\text { PAK. BASED: } \\
\text { AFGHA. BASED: } \\
\text { CROSS-BORDER: } \\
\text { TOTAL: }\end{array}$ & $\begin{array}{l}\cdots \\
\dot{65}\end{array}$ \\
\hline
\end{tabular}

\begin{tabular}{|c|c|c|c|c|}
\hline & $-\langle 800 R C F 8\rangle$ & & $-<$ ALLOCATION $>$ & \\
\hline $\begin{array}{l}\mathrm{U} \\
\mathbf{N}\end{array}$ & & & $\begin{array}{l}\text { AGRICULTURE (VETERINARY) } \\
\text { ASSISTANCE TO RETURNEES } \\
\text { CONSTRUCTION (ROAD/BRIDGE) } \\
\text { CONSTRUCTION (BUILDING/SHELTER) } \\
\text { EDUCATION } \\
\text { EMERGENCY }\end{array}$ & \\
\hline 0 & HELP-GERMANY & 238 & HEALTH & $100 \%$ \\
\hline $\mathbf{T}$ & $\mathrm{NRC} / \mathrm{NCA}$ & $34 \%$ & INCOME GENERATION & \\
\hline $\mathbf{H}$ & OCKENDEN VENTURE & $7 \%$ & IRRIGATION & \\
\hline $\mathbf{E}$ & NAC & $6 \%$ & MINE & \\
\hline $\mathbf{R}$ & SCAENI & $7 \%$ & RELIEF & \\
\hline S & VERENI FRUENFELDER (SWITZER.) & $23 \%$ & OTHER & \\
\hline
\end{tabular}

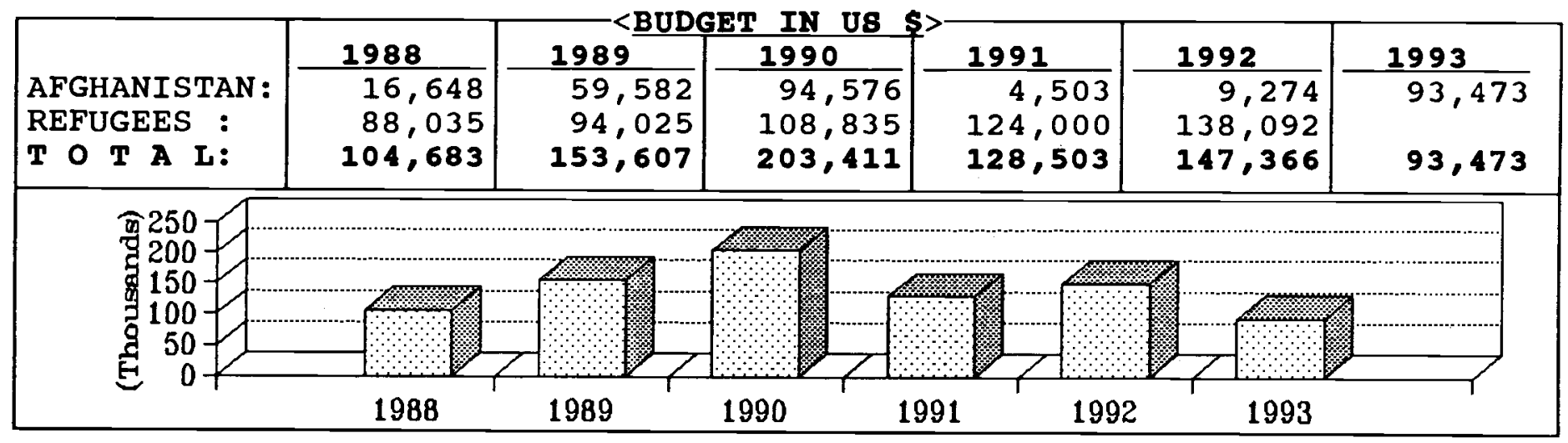

\begin{tabular}{|c|c|c|c|c|c|}
\hline PROVINCES & SECTOR & \%AGE & PROVINCES & SECTOR & $\because \mathrm{AGE}$ \\
\hline $\begin{array}{l}\text { BADAKSHAN } \\
\text { BADGHIS } \\
\text { BAGHLAN } \\
\text { BALKH } \\
\text { BAMYAN } \\
\text { FARAH } \\
\text { FARYAB } \\
\text { GHAZNI } \\
\text { GHOR } \\
\text { HELMAND } \\
\text { HERAT } \\
\text { JAWZJAN } \\
\text { KABUL } \\
\text { KANDAHAR } \\
\text { KAPISA }\end{array}$ & Health & $5 \%$ & \begin{tabular}{|l} 
KUNAR \\
KUNDUZ \\
LAGHMAN \\
LOGAR \\
NANGARHAR \\
NIMROZ \\
ORUZGAN \\
PAKTEKA \\
PAKTIA \\
PARWAN \\
SAMANGAN \\
TAKHAR \\
WARDAK \\
ZABUL
\end{tabular} & $\begin{array}{l}\text { Health } \\
\text { Health } \\
\text { Health }\end{array}$ & $\begin{array}{r}5 \% \\
85 \%\end{array}$ \\
\hline
\end{tabular}


started its activities in January 1984. In November 1986, in addition to the main clinic, dental care to refugees was extended with the operation of three dental mobile units, which provide a service to various camps and are funded by Madam Vereni Fruenfelder from Switzerland.

The main clinic consists of fifteen sections sponsored by HELP Germany, Norwegian Refugee Council and Norwegian Church Aid, and an E.N.T. Department which started its activities in 1989. Since 1988, a Dental Training Course has been conducted. In 1992, a Dental Refresher Course was also added to the program.

In addition to the above, three dental clinics are operating in Logar, Maidan and Mazar-i-sharif inside Afghanistan.

Under the sponsorship of UNHCR, the organization carried out an agricultural assistance program in Mohammad Agha District, Logar Province, to increase the crop production of the farmers.

In 1992, a Maxillofacial and ENT Surgical Hospital started its work with 16 beds and one operating theater. This hospital is sponsored by NRC/NCA.

DCAR has a kindergarten for the children of its staff which is supported by the Ockenden Venture.

In 1993, most of the activities were shifted cross-border. In Jalalabad one dental and ENT health center and a dental training course for female trainees have been established which are sponsored by NAC. 
DEVELOPMENT SERVICES FOR AFGHANISTAN-DSA

\begin{tabular}{|c|c|c|}
\hline $\begin{array}{l}\text { OLD CAR BUILDING, NEW } \\
\text { BUS STATION, GT RD } \\
\text { PESHAWAR, PAKISTAN }\end{array}$ & $\begin{array}{l}\text { <COMMUNICATION LINES } \\
\text { PHONE: } 65389 \\
\text { F A X: } \\
\text { TELEX: }\end{array}$ & $\begin{array}{l}\text { 1. ENG.A. WADOOD AZIZI } \\
\text { 2. } \\
\text { 3. }\end{array}$ \\
\hline
\end{tabular}

\begin{tabular}{|lr|lr|lr|}
\hline AFGHAN : & 24 & TECHNICAL: & 5 & PAK. BASED: & 13 \\
PAKISTANI : & - & ADMINISTRATIVE: & 5 & AFGHA.BASED: & 9 \\
EXPAT: & - & FIELD/SUPPORT S. & 14 & CROSS-BORDER: & 2 \\
TOTAL: & 24 & TOTAL: & 13 & TOTAL: & 24 \\
\hline
\end{tabular}
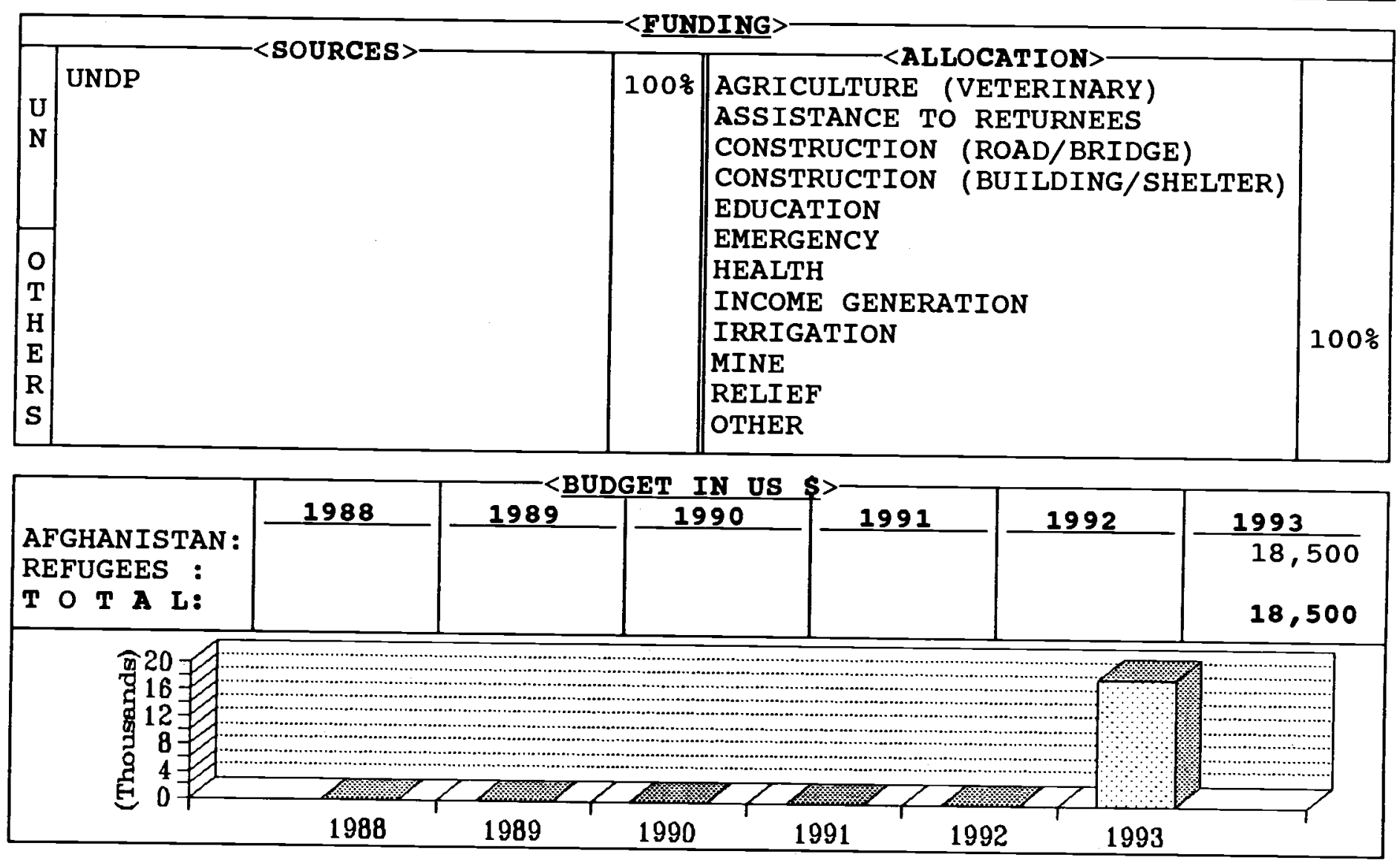

\begin{tabular}{|c|c|c|c|c|c|}
\hline PROVINCES & SECTOR & \&AGE & PROVTNCFS & 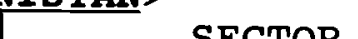 & \\
\hline $\begin{array}{l}\text { BADAKSHAN } \\
\text { BADGHIS } \\
\text { BAGHLAN } \\
\text { BALKH } \\
\text { BAMYAN } \\
\text { FARAH } \\
\text { FARYAB } \\
\text { GHAZNI } \\
\text { GHOR } \\
\text { HELMAND } \\
\text { HERAT } \\
\text { JAWZJAN } \\
\text { KABUL } \\
\text { KANDAHAR } \\
\text { KAPISA }\end{array}$ & & & \begin{tabular}{|l|} 
KUNAR \\
KUNDUZ \\
LAGHMAN \\
LOGAR \\
NANGARHAR \\
NIMROZ \\
ORUZGAN \\
PAKTEKA \\
PAKTIA \\
PARWAN \\
SAMANGAN \\
TAKHAR \\
WARDAK \\
ZABUL
\end{tabular} & Irrign & $100 \%$ \\
\hline
\end{tabular}


is an Afghan non-governmental, nonpolitical and non-profitable Afghan organization established in 1993. DSA has been formed to participate in the rehabilitation, reconstruction and further improvement and development of irrigation systems, road networks, agriculture, public buildings and other infrastructure set ups in Afghanistan.

Since its establishment, BDS has conducted surveys and assessment on a number of projects including 59 karezes in wardak, Logar and Nangarhar provinces; 15 aqueducts in Baraki Barak of Logar and two road projects in the provinces of Logar and Nangarhar. Also an agriculture survey for wheat production has been completed in the provinces of wardak, Logar, Nangarhar, Laghman and Parwan.

Irrigation rehabilitation activity has started in the province of Wardak and BDS hopes to soon commence further projects in Wardak as well other target provinces. 
DIAGNOSTIC CENTER FOR AFGHAN REFUGEES-DGCAR

\begin{tabular}{|l|l|l|}
\hline STREET 5, JAMAL RD, & PHONE: 42987 & 1. DR. A. GHAFOOR SANA \\
SHAHEEN TOWN & F A X: & 2. \\
PESHAWAR, PAKISTAN & TELEX: & 3.
\end{tabular}

\begin{tabular}{|ll|ll|ll|}
\hline AFGHAN : & 3 & TECHNICAL: & 2 & PAK. BASED: & 3 \\
PAKISTANI : & - & ADMINISTRATIVE: & 1 & AFGHA.BASED: & - \\
EXPAT: & - & FIELD/SUPPORT S. & - & CROSS-BORDER: & - \\
TOTAL: & 3 & TOTAL: & 3 & TOTAL: & - \\
\hline
\end{tabular}

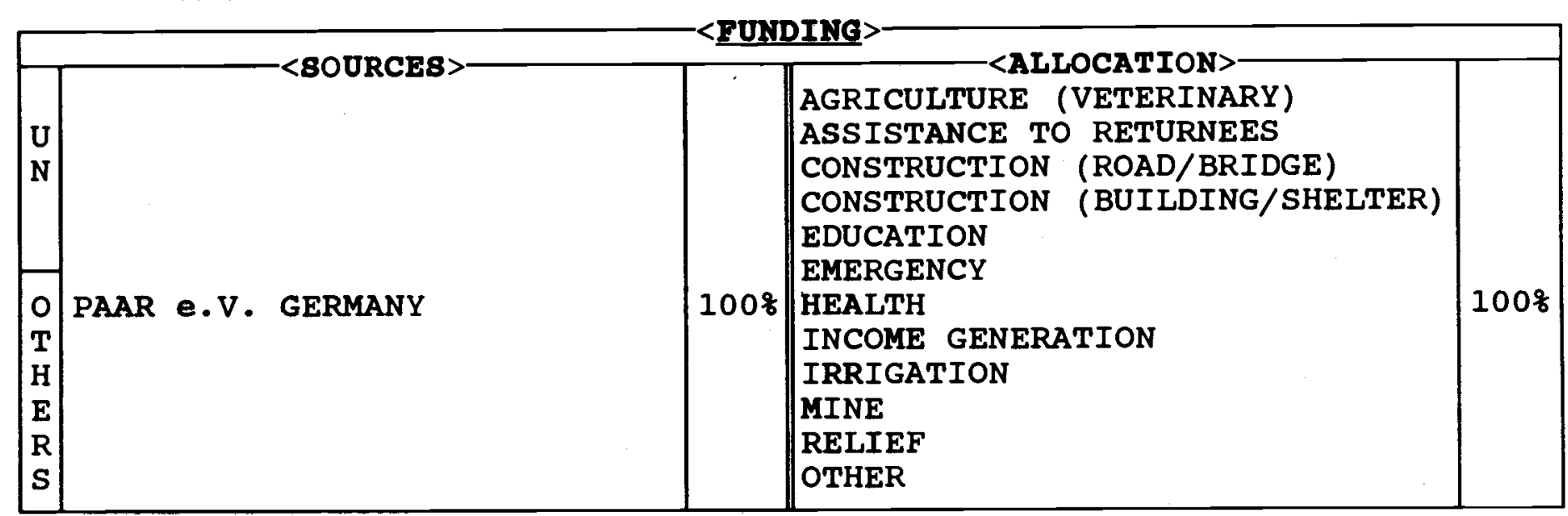

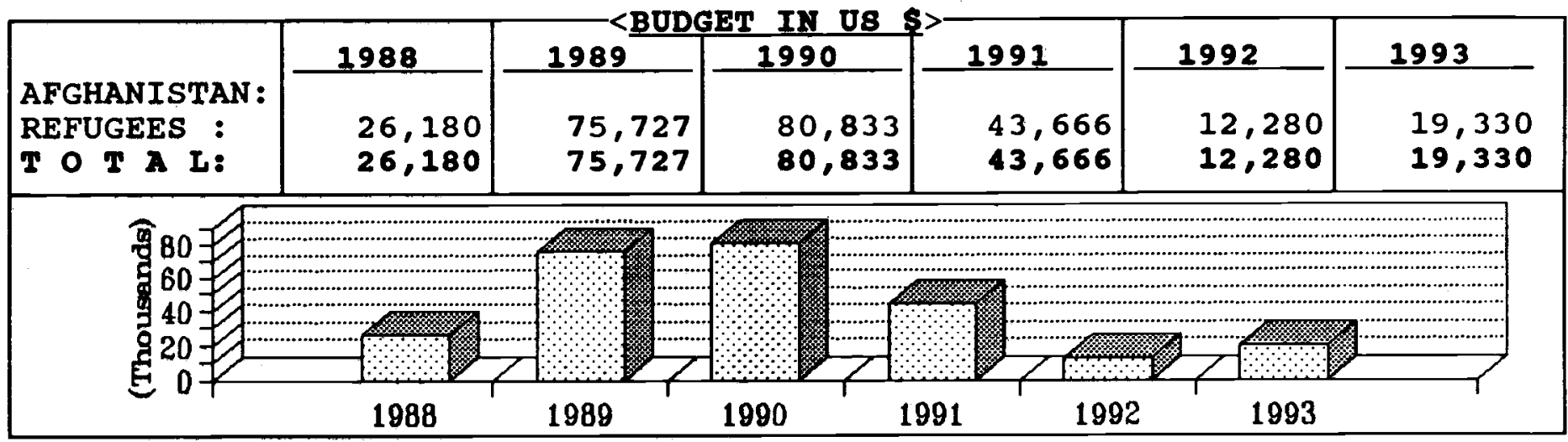

\begin{tabular}{|c|c|c|c|c|c|}
\hline PROVINCES & SECTOR & \&AGE & PROVINCES & SECTOR & $\% A G E$ \\
\hline $\begin{array}{l}\text { BADAKSHAN } \\
\text { BADGHIS } \\
\text { BAGHLAN } \\
\text { BALKH } \\
\text { BAMYAN } \\
\text { FARAH } \\
\text { FARYAB } \\
\text { GHAZNI } \\
\text { GHOR } \\
\text { HELMAND } \\
\text { HERAT } \\
\text { JAWZJAN } \\
\text { KABUL } \\
\text { KANDAHAR } \\
\text { KAPISA }\end{array}$ & & & \begin{tabular}{|l} 
KUNAR \\
KUNDUZ \\
LAGHMAN \\
LOGAR \\
NANGARHAR \\
NIMROZ \\
ORUZGAN \\
PAKTEKA \\
PAKTIA \\
PARWAN \\
SAMANGAN \\
TAKHAR \\
WARDAK \\
ZABUL
\end{tabular} & & \\
\hline
\end{tabular}


is an Afghan medical entity established in December 1987. The sole aim of the center is to extend health and medical services to Afghan refugees mainly women and children in Peshawar.

Over the past six years DgCAR has been operating an out-patient clinic in Shaheen Town which provides free consultations and limited amount of medicines to the refugee families. The clinic has a small laboratory which conducts routine tests. The clinic is open 5 days a week.

DgCAR is financially supported by the Physician Eustachian for Afghan Refugees (a union of Afghan medical doctors in Germany).

The Center is registered with the Government of Afghanistan. 


\begin{tabular}{|l|l|l|}
\hline F-27 K K K RD, U/T & PHONE: 45417 & < C KEY STAFF> \\
P O BOX 709 & F A X: & 1. MR. WILFRIED HERRICH \\
PESHAWAR, PAKISTAN & TELEX: & 2. MR. RAFAT LUDDIN \\
\hline
\end{tabular}

\begin{tabular}{|lr|lr|lr|}
\hline AFGHAN : & 60 & TECHNICAL: & 20 & PAK. BASED: & 58 \\
PAKISTANI: & 1 & ADMINISTRATIVE: & 9 & AFGHA.BASED: & 4 \\
EXPAT: & 1 & FIELD/SUPPORT S. & 33 & CROSS-BORDER: & - \\
TOTAL: & 62 & TOTAL: & 62 & TOTAL: & $\mathbf{6 2}$ \\
\hline
\end{tabular}

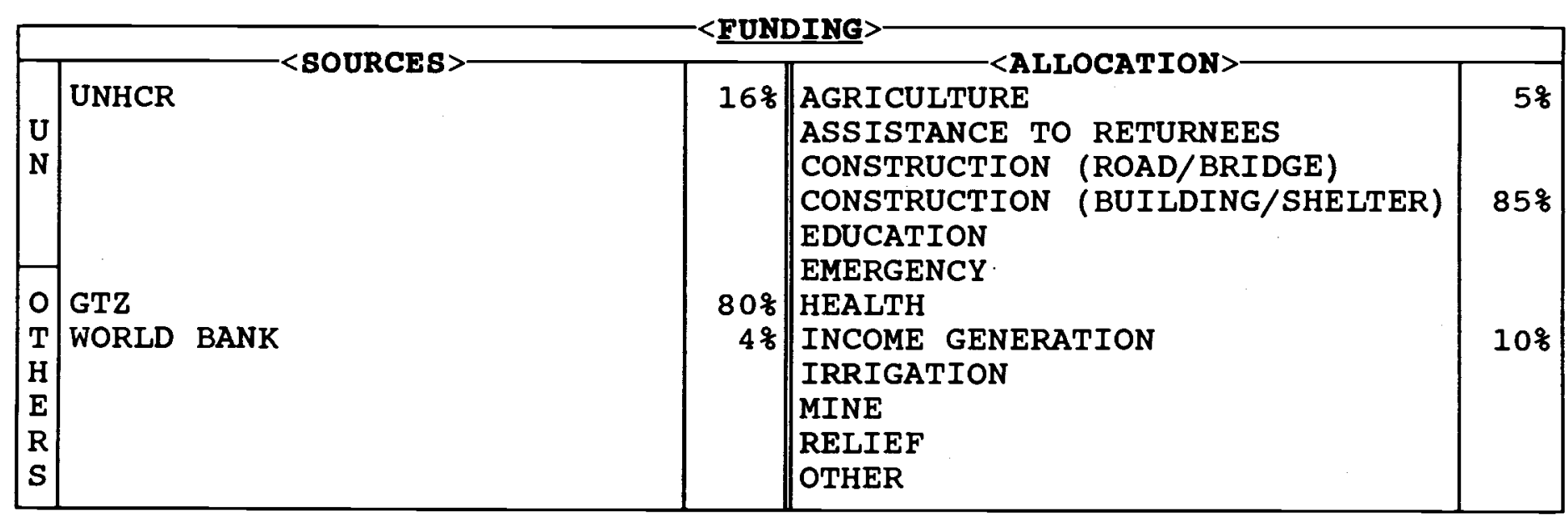

\begin{tabular}{|c|c|c|c|c|c|c|}
\hline & 1988 & 1989 & 1990 & 1991 & 1992 & 1993 \\
\hline $\begin{array}{l}\text { AFGHANISTAN : } \\
\text { REFUGEES : } \\
\text { T O T A L: }\end{array}$ & $\begin{array}{l}554,938 \\
554,938\end{array}$ & $\begin{array}{l}489,715 \\
489,715\end{array}$ & $\begin{array}{l}490,000 \\
490,000\end{array}$ & $\begin{array}{l}328,289 \\
328,289\end{array}$ & $\begin{array}{l}228,000 \\
330,000 \\
558,000\end{array}$ & $\begin{array}{r}85,330 \\
243,330 \\
328,660\end{array}$ \\
\hline
\end{tabular}

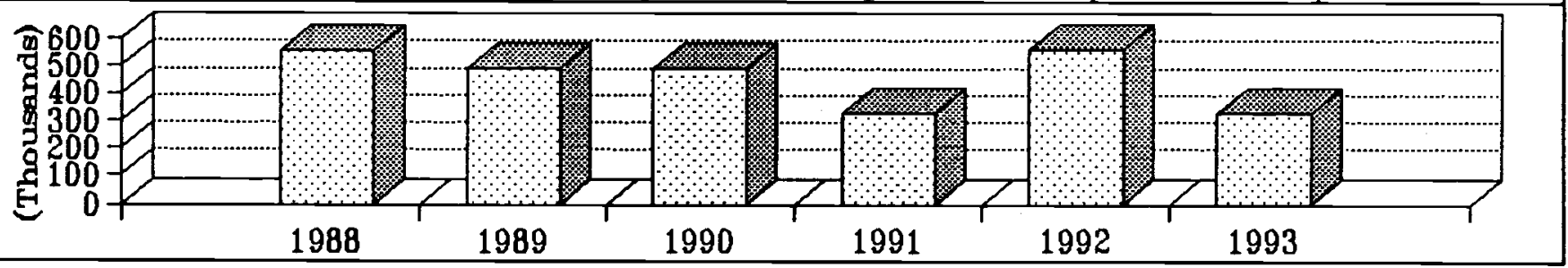

\begin{tabular}{|c|c|c|c|c|c|}
\hline PROVINCES & SECTOR & \&AGE & PROVINCES & SECTOR & $\% \mathrm{AGE}$ \\
\hline $\begin{array}{l}\text { BADAKSHAN } \\
\text { BADGHIS } \\
\text { BAGHLAN } \\
\text { BALKH } \\
\text { BAMYAN } \\
\text { FARAH } \\
\text { FARYAB } \\
\text { GHAZNI } \\
\text { GHOR } \\
\text { HELMAND } \\
\text { HERAT } \\
\text { JAWZJAN } \\
\text { KABUL } \\
\text { KANDAHAR } \\
\text { KAPISA }\end{array}$ & & & $\begin{array}{l}\text { KUNAR } \\
\text { KUNDUZ } \\
\text { LAGHMAN } \\
\text { LOGAR } \\
\text { NANGARHAR } \\
\text { NIMROZ } \\
\text { ORUZGAN } \\
\text { PAKTEKA } \\
\text { PAKTIA } \\
\text { PARWAN } \\
\text { SAMANGAN } \\
\text { TAKHAR } \\
\text { WARDAK } \\
\text { ZABUL }\end{array}$ & Const./income gen. & $100 \%$ \\
\hline
\end{tabular}


DOMESTIC ENERGY SAVING PROJECT (DESP)

has been working for 8 years with Afghan refugees in NWFP and started cross-border programs in Nangarhar province recently.

The project is developing and disseminating wood/fuel saving technology in the field of construction and cooking/baking/ heating. It also provides training to Afghan refugees to enable them to produce and disseminate such technology independently from the project in the future. In this way Afghan refugees are better prepared for a future in Afghanistan.

The Project's programs are community based with a strong self-help component. They comprise:

- research and development of low cost and wood/fuel saving technology in the domestic sphere: stoves, ovens, construction materials and building techniques,

training of engineers, masons, potters and metal workers,

dissemination of fuel-efficient cooking/heating stoves of clay and metal,

establishment of bakeries with improved ovens,

planting of trees,

construction of public buildings,

reconstruction of villages in Afghanistan.

A cornerstone in the Project's approach is the systematic integration of environmental issues into its development concept in order to achieve a long term impact and sustainability with its activities.

In many regions in Afghanistan the degradation of the natural environment has reached a very critical point and endangers, for example, the resettlement of refugees due to a lack of timber, which is traditionally used for the construction of houses.

But beyond such practical and urgent reasons the project wants to contribute to beneficiaries and decision makers of funding and supporting agencies and institutions becoming more sensitive and aware with regard to environmental issues and its place in development programs.

The Project's technologies are appropriate and affordable to the poor, and they convince the beneficiaries with regard to the benefits.

They also prove to be financially competitive when introduced into the open market. 
DUTCH CONOMTIEE FOR AFGHANIBTAH-DCA

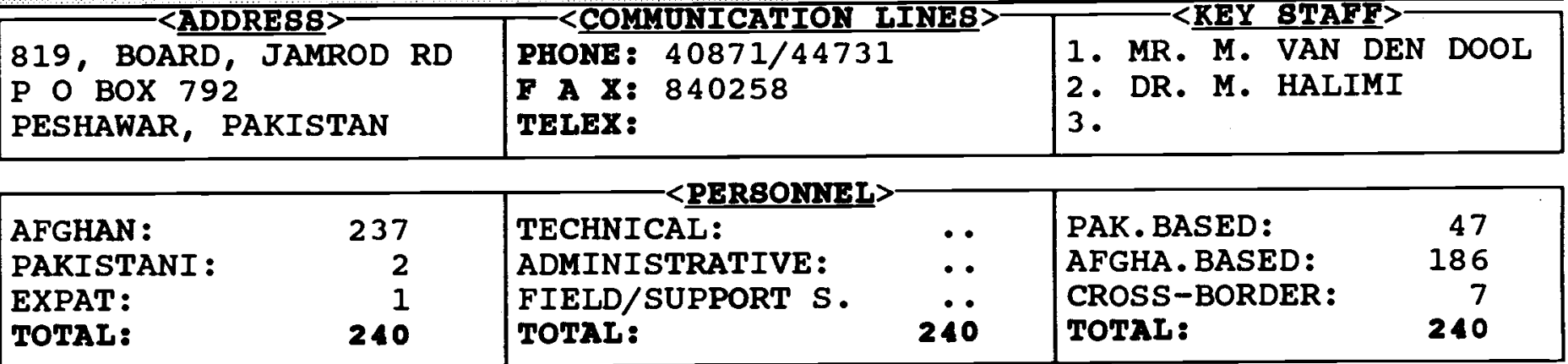

\begin{tabular}{|c|c|c|c|c|}
\hline & & & & \\
\hline & UNDP & $33 \%$ & AGRICULTURE (VETERINARY) & $100 \%$ \\
\hline $\mathbf{U}$ & & & ASSISTANCE TO RETURNEES & \\
\hline $\mathbf{N}$ & & & CONSTRUCTION (ROAD/BRIDGE) & \\
\hline & & & CONSTRUCTION (BUILDING/SHELTER) & \\
\hline & & & EDUCATION & \\
\hline 0 & DUTCH GOVERNMENT & $22 \%$ & HEALTH & \\
\hline $\mathbf{T}$ & LOCAL CONTRIBUTION & $45 \%$ & INCOME GENERATION & \\
\hline $\mathrm{H}$ & & & IRRIGATION & \\
\hline $\mathbf{E}$ & & & MINE & \\
\hline $\mathbf{R}$ & & & RELIEF & \\
\hline $\mathbf{s}$ & & & OTHER & \\
\hline
\end{tabular}

\begin{tabular}{|l|l|l|l|l|l|l|}
\hline & 1988 & 1989 & 1990 & 1991 & 1992 & 1993 \\
\cline { 2 - 2 } & 249,722 & 393,159 & 375,236 & 477,026 & 835,146 & 734,725 \\
REFUGEES : & 320,310 & 529,355 & 830,792 & 360,693 & 231,207 & 484,081 \\
T OTA T: & 570,032 & 922,514 & $1,206,028$ & 837,719 & $1,066,353$ & $1,218,806$ \\
\hline
\end{tabular}

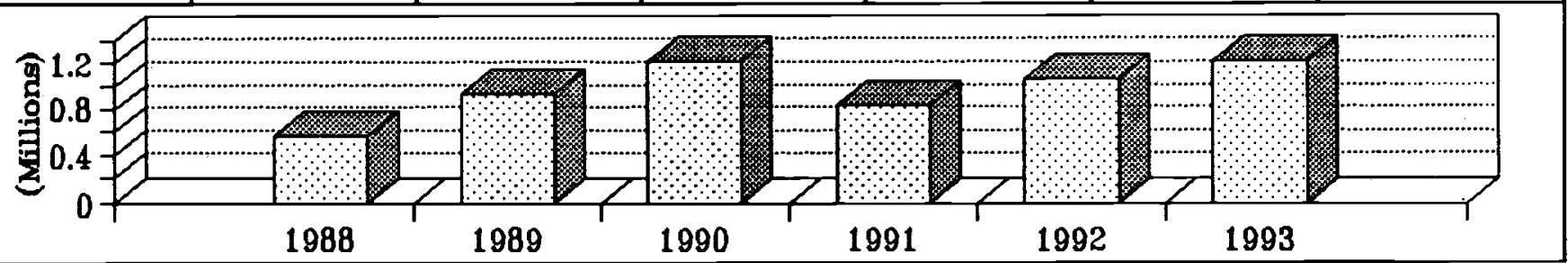

\begin{tabular}{|c|c|c|c|c|c|}
\hline PROVINCES & SECTOR & \%AGE & PROVINCES & SECTOR & $\because A G E$ \\
\hline $\begin{array}{l}\text { BADAKSHAN } \\
\text { BADGHIS } \\
\text { BAGHLAN } \\
\text { BALKH } \\
\text { BAMYAN } \\
\text { FARAH } \\
\text { FARYAB } \\
\text { GHAZNI } \\
\text { GHOR } \\
\text { HELMAND } \\
\text { HERAT } \\
\text { JAWZJAN } \\
\text { KABUL } \\
\text { KANDAHAR } \\
\text { KAPISA }\end{array}$ & $\begin{array}{l}\text { Agr (vet) } \\
\text { Agr (vet) } \\
\text { Agr (vet) } \\
\text { Agr (vet) } \\
\text { Agr (vet) } \\
\text { Agr (vet) }\end{array}$ & $\begin{array}{c}48 \\
38 \\
158 \\
28\end{array}$ & $\begin{array}{l}\text { KUNAR } \\
\text { KUNDUZ } \\
\text { LAGHMAN } \\
\text { LOGAR } \\
\text { NANGARHAR } \\
\text { NIMROZ } \\
\text { ORUZGAN } \\
\text { PAKTEKA } \\
\text { PAKTIA } \\
\text { PARWAN } \\
\text { SAMANGAN } \\
\text { TAKHAR } \\
\text { WARDAK } \\
\text { ZABUL }\end{array}$ & $\begin{array}{l}\text { Agr (vet) } \\
\text { Agr (vet) } \\
\text { Agr (vet) } \\
\text { Agr (vet) } \\
\text { Agr (vet) } \\
\text { Agr (vet) } \\
\text { Agr (vet) }\end{array}$ & $\begin{array}{r}2 \% \\
8 \% \\
16 \% \\
2 \% \\
13 \% \\
7 \% \\
208\end{array}$ \\
\hline
\end{tabular}


DUTCH COMMITTEE FOR AFGHANISTAN (DCA)

is based in Peshawar with its head office in Amsterdam, The Netherlands, under the name "stichting Afghanistan comite Nederland".

Since 1985, DCA has largely concentrated its assistance inside Afghanistan through cross-border assistance projects. Operations started with cash-for-food assistance mainly in northeast Afghanistan (Panjshair). This type of assistance was over the following years extended to 15 areas in north, east and northeast Afghanistan.

Beginning in 1988, other types of assistance were planned in order to meet new requirements caused by the changing political-military situation. An increasing demand for more structural types of assistance in the veterinary and agricultural sector was emerging, and there was a need for programs to be designed to begin rehabilitation of the agricultural economy.

A major constraint perceived by farmers was their loss of livestock, including draught animals, caused by the war, epidemic diseases and random slaughtering. Rehabilitation began in the veterinary sector by developing a system of preventive animal health care in the rural areas.

DCA entered the first phase of the project in september 1988, with the establishment of the veterinary Training and support Center (VTSC), an institute, training approximately 40 vaccinators and 45 paravets a year for various NGO's interested in integrating animal care into their agricultural programs. Advanced paravet courses will be organized according to the needs. The training component of the VTSC provides tailor-made refresher courses for Afghan veterinarians and other field staff. The support component provides standardized field kits for each level of veterinary assistance (Basic Village Workers, Vaccinators, Paravets, Veterinarians).

DCA has established field units that integrate the different levels into one coordinated structure, making it possible to cover large areas and to react quickly to major out-breaks of animal diseases. By the end of 1993 DCA is planning to have established 40 field units covering the same number of districts.

The second phase of DCA assistance started in the early part of 1989 included veterinary-related projects - distribution of draught animals and milk cows, and breeding programs for livestock - and those related to other sectors of agriculture, such as irrigation, seed and fertilizer, and tractor power. These projects have been transferred to Helping Afghan Farmers Organization (HAFO). 
EMERGELCY RELIEF 8 ERVICES FOR ATGHANS-ERSA

\begin{tabular}{|l|l|l|}
\hline T-926, NEXT TO PASSCO & PHONE: 45289 & <COMMUNICATION LINE8 $>$ \\
BEHIND JABBAR FLATS & F A X: 840304 & 1. MR. WAKIL AKBARZAI \\
PESHAWAR, PAKISTAN & TELEX: & 2. ENG. ABDUL SATTAR \\
\end{tabular}

\begin{tabular}{|lr|ll|ll|}
\hline AFGHAN: & 76 & TECHNICAL: & 16 & PAK. BASED: \\
PAKISTANI: & 1 & ADMINISTRATIVE : & 12 & AFGHA.BASED: & $\ldots$ \\
EXPAT: & - & FIELD/SUPPORT S. & 49 & CROSS-BORDER: & $\ldots$ \\
TOTAL: & $\mathbf{7 7}$ & TOTAL: & $\mathbf{7 7}$ & TOTAL: & $\mathbf{7 7}$ \\
\hline
\end{tabular}

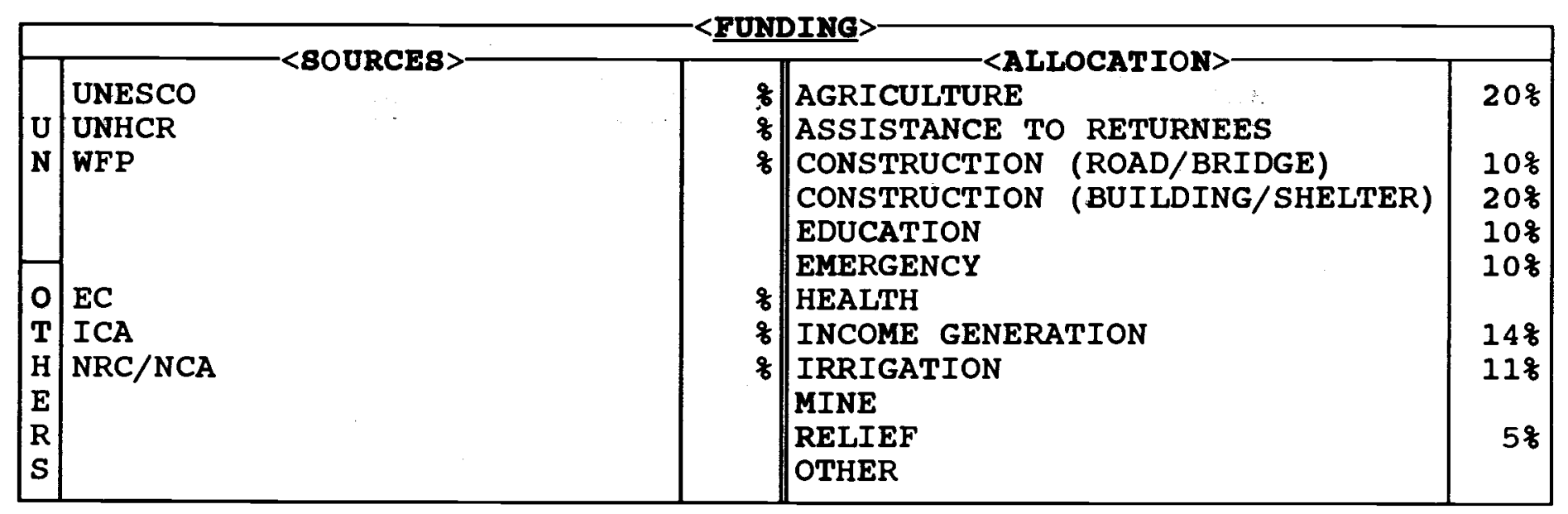

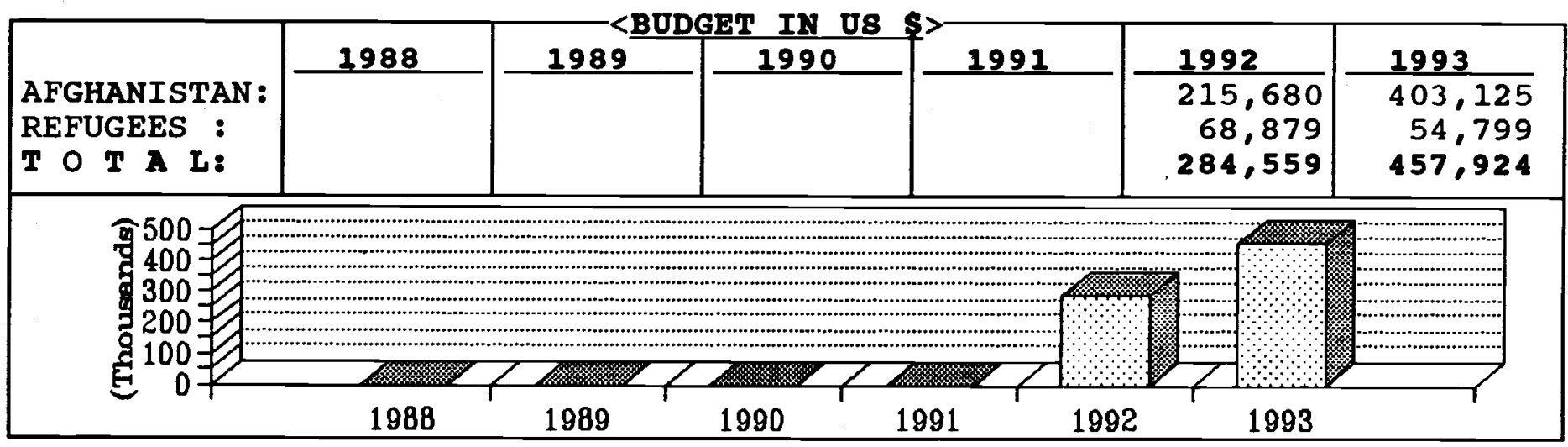

\begin{tabular}{|c|c|c|c|c|c|}
\hline PROVINCES & SECTOR & SAGE & PROVINCES & SECTOR & \%AGE \\
\hline $\begin{array}{l}\text { BADAKSHAN } \\
\text { BADGHIS } \\
\text { BAGHLAN } \\
\text { BALKH } \\
\text { BAMYAN } \\
\text { FARAH } \\
\text { FARYAB } \\
\text { GHAZNI } \\
\text { GHOR } \\
\text { HELMAND } \\
\text { HERAT } \\
\text { JAWZJAN } \\
\text { KABUL } \\
\text { KANDAHAR } \\
\text { KAPISA }\end{array}$ & Emerg & 列 & $\begin{array}{l}\text { KUNAR } \\
\text { KUNDUZ } \\
\text { LAGHMAN } \\
\text { LOGAR } \\
\text { NANGARHAR } \\
\text { NIMROZ } \\
\text { ORUZGAN } \\
\text { PAKTEKA } \\
\text { PAKTIA } \\
\text { PARWAN } \\
\text { SAMANGAN } \\
\text { TAKHAR } \\
\text { WARDAK } \\
\text { ZABUL }\end{array}$ & Agr/const/emerg/irrig & $90 \%$ \\
\hline
\end{tabular}


is an Afghan non-profit, voluntary organization. It was founded in 1991 .

ERSA has three departments as follows:

Rural Development:

It works in the sectors of agriculture, road repair, school construction, water supply and irrigation rehabilitation in

Nangarhar province.

Emergency Relief:

This department has qualified teams (20 people) who have worked in the fields of emergency and relief for the past several years. Food commodities are distributed to new arrivals in Pakistan. In Afghanistan, ERSA address any emergency cases, e.g. it has been providing relief assistance to Kabul displaced families in Puli Charkhi, Sarobi and Jalalabad.

Women's Welfare:

The Women Welfare Department works in the sectors of education and income generation. It supports schools for girls in Peshawar. A quilt making project has been established to provide income generation opportunities to refugee women (mostly widows). 
ENGINEERING SERVICES FOR AFGHANISTAN RECONSTRUCTION-ESAR

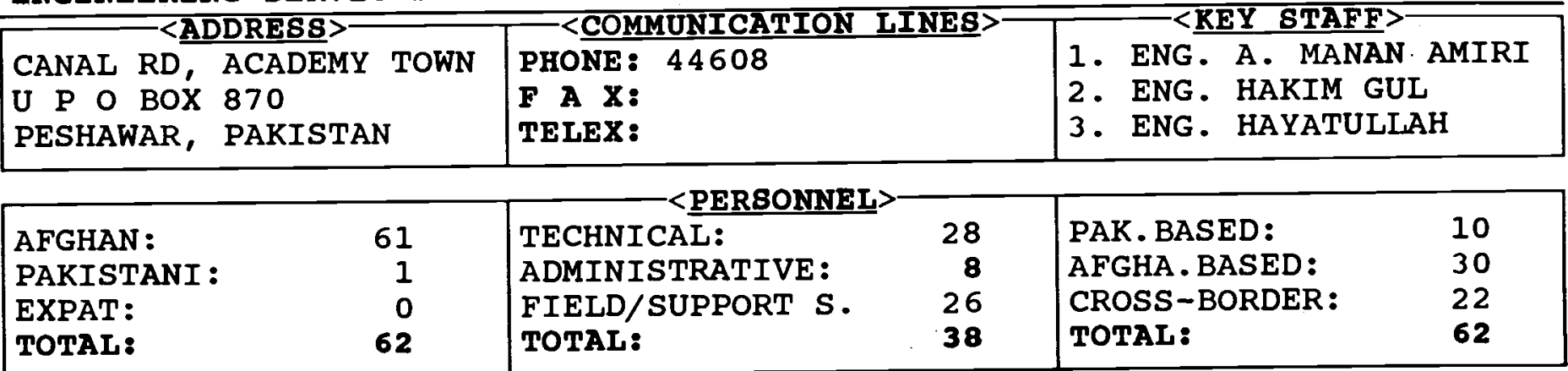

\begin{tabular}{|c|c|c|c|c|}
\hline & 19anganga & & & \\
\hline & IINCHS & 248 & AGRICULTURE & \\
\hline $\mathbf{U}$ & UNDP & $7 \%$ & ASSISTANCE TO RETURNEES & \\
\hline $\mathbf{N}$ & UNDCP & $48 \%$ & CONSTRUCTION (ROAD/BRIDGE) & $7 \%$ \\
\hline & WFP & 88 & (BUILDING/SHELTER) & $77 \%$ \\
\hline & & & $\begin{array}{l}\text { EDUCATION } \\
\text { EMERGENCY }\end{array}$ & $2 \%$ \\
\hline 0 & PRIVATE DONATIONS & $13 \%$ & HEALTH & \\
\hline $\mathbf{T}$ & & & INCOME GENERATION & \\
\hline $\mathrm{H}$ & & & IRRIGATION & $14 \%$ \\
\hline $\mathbf{E}$ & & & MINE & \\
\hline $\mathbf{R}$ & & & RELIEF & \\
\hline $\mathbf{S}$ & & & OTHER & \\
\hline
\end{tabular}
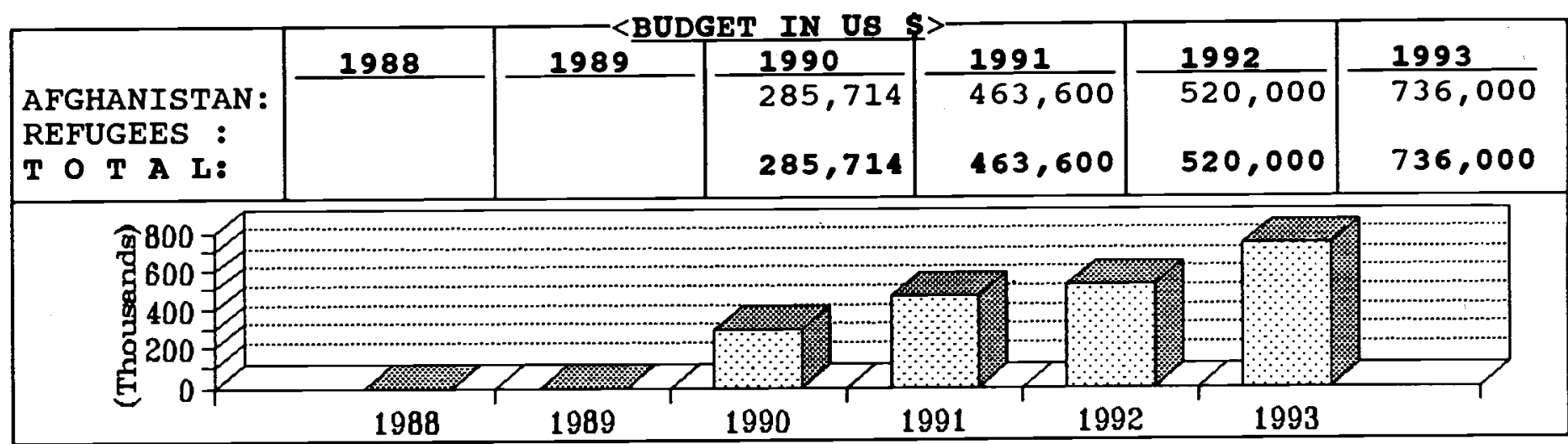

\begin{tabular}{|c|c|c|c|c|c|}
\hline PROVINCES & SECTOR & $\because A G E$ & PROVINCES & SECTOR & $\checkmark A G E$ \\
\hline $\begin{array}{l}\text { BADAKSHAN } \\
\text { BADGHIS } \\
\text { BAGHLAN } \\
\text { BALKH } \\
\text { BAMYAN } \\
\text { FARAH } \\
\text { FARYAB } \\
\text { GHAZNI } \\
\text { GHOR } \\
\text { HELMAND } \\
\text { HERAT } \\
\text { JAWZJAN } \\
\text { KABUL } \\
\text { KANDAHAR } \\
\text { KAPISA }\end{array}$ & Const & 78 & $\begin{array}{l}\text { KUNAR } \\
\text { KUNDUZ } \\
\text { LAGHMAN } \\
\text { LOGAR } \\
\text { NANGARHAR } \\
\text { NIMROZ } \\
\text { ORUZGAN } \\
\text { PAKTEKA } \\
\text { PAKTIA } \\
\text { PARWAN } \\
\text { SAMANGAN } \\
\text { TAKHAR } \\
\text { WARDAK } \\
\text { ZABUL }\end{array}$ & $\begin{array}{l}\text { Const/irrign } \\
\text { Const/shelter } \\
\text { Const/irrign } \\
\text { Const/shelter }\end{array}$ & $\begin{array}{l}218 \\
298 \\
278\end{array}$ \\
\hline
\end{tabular}


ENGINEERING SERVICES FOR AFGHANISTAN RECONSTRUCTION (ESAR)

is a private, non-profit, nonpolitical voluntary organization. It was founded in 1989.

ESAR implements cross-border programs in connection with the reconstruction and rehabilitation of Afghanistan. Its main areas of work are:

- Reconstruction a nd
rehabilitation of roads to
facilitate transportation.
Producing pre-cast concrete
beams, slabs for domestic
housing to assist returning
refugees and internally
displaced people in
resettlement. It is also
involved in construction/
providing maintenance for
public buildings such as
schools, hospitals/clinics and
warehouses.
Rehabilitation of irrigation
systems e.g. karezes, canals
and conducting technical
surveys of irrigation systems
for donors and other NGos.

It has implemented 19 cross border rehabilitation projects inside Afghanistan since it's establishment in Pakteka, Paktia, Wardak, Ghazni, Kandahar, Nangarhar and Laghman provinces. An outline of the completed activities includes rehabilitation of $65 \mathrm{~km}$ road, construction of 4 warehouses with 2,000 MT capacity each, 2 basic education centers, establishment of 2 pre-cast concrete factories, conducting surveys of irrigation systems, roads and a number of irrigation rehabilitation projects.

ESAR has 12 ongoing projects in the above stated sectors.

A road rehabilitation team is operating in Kandahar Province currently implementing a $51.5 \mathrm{~km}$ road project in spin BoldakArghestan. This team has all the basic road repair tools and equipment including 6 tractors,
2 dump trucks, a water tanker, 2 road rollers (tailed to tractor) and small tools.

A pre-cast factory was established in zurmat in 1989. This factory has the capacity of producing 200 precast RCC beams per day. In addition, different pre-cast components such as heavy concrete girders up to $6 \mathrm{~m}$ length (different designs for different purposes), PC lintels, slabs, hollow blocks, pit latrine slabs and shallow well rings could be produced in this facility. Currently ESAR is producing roofing beams for domestic housing.

ESAR established another pre-cast concrete factory unit in Qarghaie district of Laghman province in 1992. This factory produces only roofing beams for housing. The present production capacity of the factory is 50 beams per day. ESAR plans to double it's production capacity.

The organization is currently working in Paktia, Kandahar, Nangarhar, Kunar, Khost and Laghman provinces.

The technical staff of the agency conducts surveys, to assess needs and implement programs in cooperation with the local community in the target areas.

Local leaders and elders are consulted at the regional and village level. People are employed in the field from the community to work with ESAR staff in implementation and administration of programs. Programs are also periodically monitored by the key staff of ESAR from Peshawar. 
EYE CLINIC FOR AFGHAN REFUGEES-ECAR

STREET 2, JAMAL RD SHAHEEN TOWN PESHAWAR, PAKISTAN
PHONE: 841454

F A X:

TELEX:
1. DR. MUJAHID

2. DR. OMER ASKARYAR

3. DR. FAIQUE

\begin{tabular}{|lr|lr|lr|}
\hline AFGHAN : & 16 & TECHNICAL: & 10 & PAK. BASED: & 16 \\
PAKISTANI : & - & ADMINISTRATIVE: & 1 & AFGHA.BASED: & - \\
EXPAT: & - & FIELD/SUPPORT S. & 5 & CROSS-BORDER: & - \\
TOTAL: & 16 & TOTAL: & 16 & TOTAL: & 16 \\
\hline
\end{tabular}

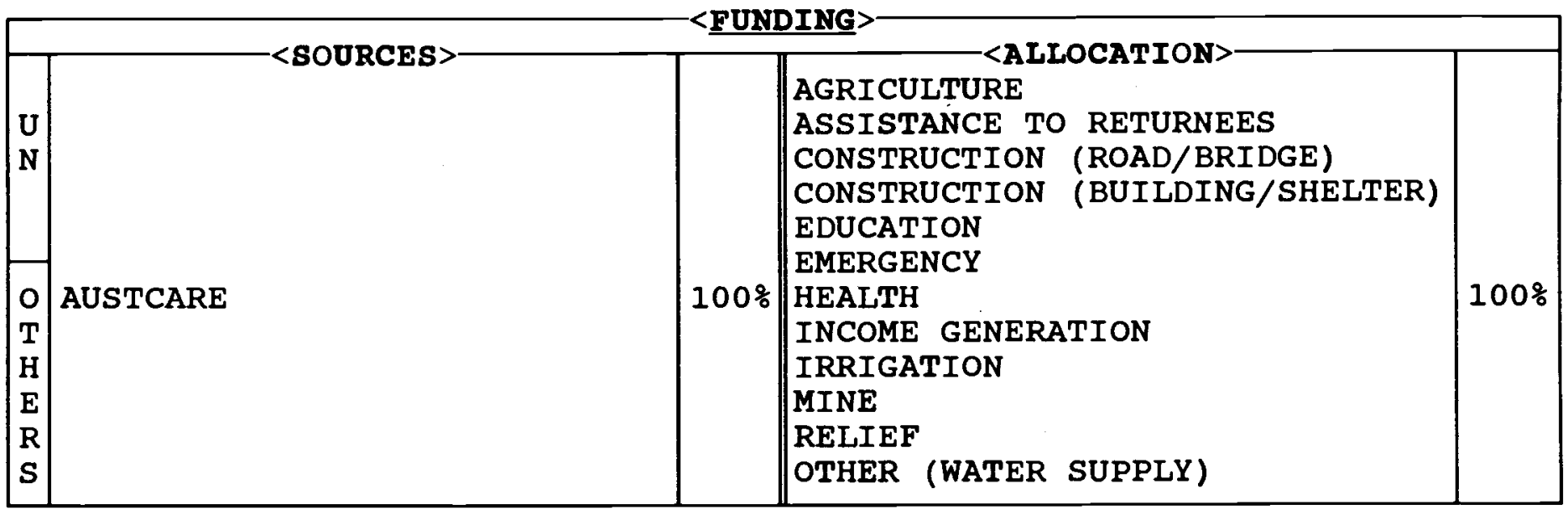

\begin{tabular}{|l|l|l|l|l|l|l|}
\hline & 1988 & 1989 & 1990 & 1991 & 1992 & 1993 \\
AFGHANISTAN: & & & & & & \\
REFUGEES : & & & & & & \\
T T A L & & & & & & \\
\hline
\end{tabular}

\begin{tabular}{|c|c|c|c|c|c|}
\hline PROVINCES & SECTOR & \% $\mathrm{AGE}$ & PROVINCES & SECTOR & \&AGE \\
\hline $\begin{array}{l}\text { BADAKSHAN } \\
\text { BADGHIS } \\
\text { BAGHLAN } \\
\text { BALKH } \\
\text { BAMYAN } \\
\text { FARAH } \\
\text { FARYAB } \\
\text { GHAZNI } \\
\text { GHOR } \\
\text { HELMAND } \\
\text { HERAT } \\
\text { JAWZJAN } \\
\text { KABUL } \\
\text { KANDAHAR } \\
\text { KAPISA }\end{array}$ & & & $\begin{array}{l}\text { KUNAR } \\
\text { KUNDUZ } \\
\text { LAGHMAN } \\
\text { LOGAR } \\
\text { NANGARHAR } \\
\text { NIMROZ } \\
\text { ORUZGAN } \\
\text { PAKTEKA } \\
\text { PAKTIA } \\
\text { PARWAN } \\
\text { SAMANGAN } \\
\text { TAKHAR } \\
\text { WARDAK } \\
\text { ZABUL }\end{array}$ & & \\
\hline
\end{tabular}


ENGINEERING SERVICES FOR AFGHANISTAN RECONSTRUCTION (ESAR)

is a private, non-profit, nonpolitical voluntary organization. It was founded in 1989.

ESAR implements cross-border programs in connection with the reconstruction and rehabilitation of Afghanistan. Its main areas of work are:

- Reconstruction a d
rehabilitation of roads to
facilitate transportation.
Producing pre-cast concrete
beams, slabs for domestic
housing to assist returning
refugees and internally
displaced people in
resettlement. It is also
involved in construction/
providing maintenance for
public buildings such as
schools, hospitals/clinics and
warehouses.
Rehabilitation of irrigation
systems e.g. karezes, canals
and conducting technical
surveys of irrigation systems
for donors and other NGos.

It has implemented 19 cross border rehabilitation projects inside Afghanistan since it's establishment in Pakteka, Paktia, Wardak, Ghazni, Kandahar, Nangarhar and Laghman provinces. An outline of the completed activities includes rehabilitation of $65 \mathrm{~km}$ road, construction of 4 warehouses with 2,000 MT capacity each, 2 basic education centers, establishment of 2 pre-cast concrete factories, conducting surveys of irrigation systems, roads and a number of irrigation rehabilitation projects.

ESAR has 12 ongoing projects in the above stated sectors.

A road rehabilitation team is operating in Kandahar Province currently implementing a $51.5 \mathrm{~km}$ road project in spin BoldakArghestan. This team has all the basic road repair tools and equipment including 6 tractors,
2 dump trucks, a water tanker, 2 road rollers (tailed to tractor) and small tools.

A pre-cast factory was established in Zurmat in 1989. This factory has the capacity of producing 200 precast RCC beams per day. In addition, different pre-cast components such as heavy concrete girders up to $6 \mathrm{~m}$ length (different designs for different purposes), PC lintels, slabs, hollow blocks, pit latrine slabs and shallow well rings could be produced in this facility. Currently ESAR is producing roofing beams for domestic housing.

ESAR established another pre-cast concrete factory unit in Qarghaie district of Laghman province in 1992. This factory produces only roofing beams for housing. The present production capacity of the factory is 50 beams per day. ESAR plans to double it's production capacity.

The organization is currently working in Paktia, Kandahar, Nangarhar, Kunar, Khost and Laghman provinces.

The technical staff of the agency conducts surveys, to assess needs and implement programs in cooperation with the local community in the target areas.

Local leaders and elders are consulted at the regional and village level. People are employed in the field from the community to work with ESAR staff in implementation and administration of programs. Programs are also periodically monitored by the key staff of ESAR from Peshawar. 


\begin{tabular}{|c|c|c|}
\hline$=<$ ADDRESS $>-$ & $<$ COMMUNICATION LINEB $>$ & $-\langle$ KEY 8TAFF $>$ \\
\hline $\begin{array}{l}\text { 103-F, BLOCK 5, S. TOWN } \\
\text { P O BOX } 36 \\
\text { QUETTA, PAKISTAN }\end{array}$ & $\begin{array}{l}\text { PHONE: } 442489 \\
\text { F A X: } \\
\text { TELEX: }\end{array}$ & $\begin{array}{l}\text { 1. ENG. MOHAMMAD YOUNUS } \\
2 . \\
\text { 3. }\end{array}$ \\
\hline
\end{tabular}

\begin{tabular}{|lr|lr|lr|}
\hline AFGHAN: & 23 & TECHNICAL: & 20 & PAK. BASED: & 4 \\
PAKISTANI : & - & ADMINISTRATIVE: & 2 & AFGHA.BASED: & 19 \\
EXPAT: & - & FIELD/SUPPORT S. & 1 & CROSS-BORDER: & - \\
TOTAL: & 23 & TOTAL: & 23 & TOTAL: & 23 \\
\hline
\end{tabular}

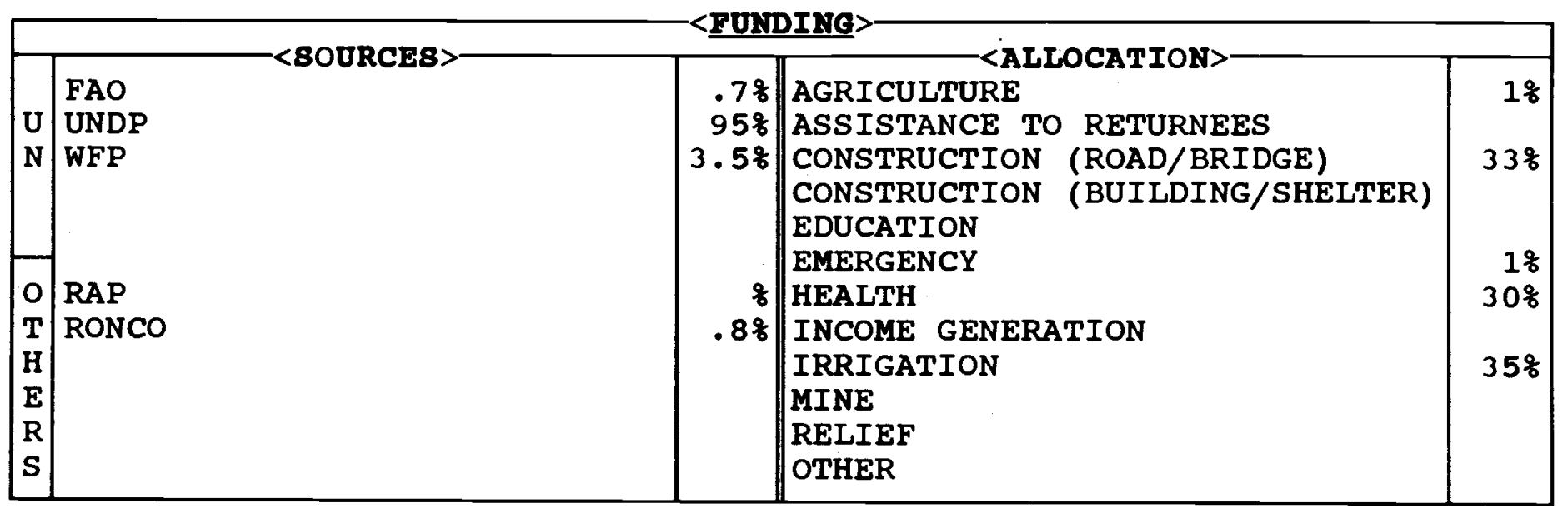

\begin{tabular}{|c|c|c|c|c|c|c|}
\hline $\begin{array}{l}\text { AFGHANISTAN: } \\
\text { REFUGEES : } \\
\text { TO T A L: }\end{array}$ & 1988 & 1989 & $\begin{array}{l}1990 \\
111,671 \\
111,671\end{array}$ & $\begin{array}{l}\frac{1991}{71,887} \\
71,887\end{array}$ & $\begin{array}{l}\frac{1992}{187,489} \\
187,489\end{array}$ & $\begin{array}{l}\frac{1993}{306,917} \\
306,917\end{array}$ \\
\hline 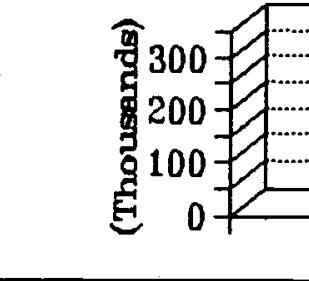 & 1988 & 1989 & 1990 & 199 & 1993 & (1) \\
\hline
\end{tabular}

\begin{tabular}{|c|c|c|c|c|c|}
\hline PROVINCES & SECTOR & \&AGE & PROVINCES & SECTOR & \&AGE \\
\hline $\begin{array}{l}\text { BADAKSHAN } \\
\text { BADGHIS } \\
\text { BAGHLAN } \\
\text { BALKH } \\
\text { BAMYAN } \\
\text { FARAH } \\
\text { FARYAB } \\
\text { GHAZNI } \\
\text { GHOR } \\
\text { HELMAND } \\
\text { HERAT } \\
\text { JAWZJAN } \\
\text { KABUL } \\
\text { KANDAHAR } \\
\text { KAPISA }\end{array}$ & $\begin{array}{l}\text { Agr/irrign } \\
\text { Agr/irrign } \\
\text { Agr/const/irrign }\end{array}$ & $\begin{array}{l}16 \% \\
5 \% \\
79 q\end{array}$ & \begin{tabular}{|l|} 
KUNAR \\
KUNDUZ \\
LAGHMAN \\
LOGAR \\
NANGARHAR \\
NIMROZ \\
ORUZGAN \\
PAKTEKA \\
PAKTIA \\
PARWAN \\
SAMANGAN \\
TAKHAR \\
WARDAK \\
ZABUL
\end{tabular} & & \\
\hline
\end{tabular}


is an Afghan non-governmental organization established with the sole purpose of providing health services to Afghan refugees in Peshawar and the surrounding camps.

For the past several years an eye clinic has been working in shaheen Town Peshawar. Two mobile clinics are visiting different camps on a regular basis. In both the stationary and the mobile clinics in addition to consultation some limited amount of medicine and glasses are provided to patients free of charge.

ECAR has been receiving financial assistance from Austcare and some small donations from private sources in Germany and other countries.

The Clinic is considering establishing new clinics and/or shifting and existing clinics to Afghanistan at a time when the security situation improves. 
is an Afghan non-governmental organization established in 1989. The elders and commanders of Farah province and part of Nimroz province formed the Foundation to work in the reconstruction of Afghanistan particularly Farah province.

FRF works in the sectors of agriculture and irrigation rehabilitation and infrastructure reconstruction. It has also undertaken health services, veterinary activities and emergency relief programs. In the agricultural sector, FRF distributes improved wheat, maize seeds and fertilizer. It cleans karezes and canals. It plans to construct dams in Farah province in the future.

The current target areas of FRF are Farah, Helmand and Kandahar provinces. It intends to expand its programs to other provinces in the region.

In 1991 FRF started school construction; two have been completed so far and it is anticipated that work will begin on more in the near future.

The head-office of the organization is currently in Quetta, Pakistan. When the security conditions are suitable, FRF will move its office to Farah province. It has suboffices in Farah city and in Kandahar city. 
GERMAN AGRO ACTION-GAA

\begin{tabular}{|c|c|c|c|c|c|}
\hline \multicolumn{2}{|c|}{$\begin{array}{l}\text { WAZIR AKBAR KHAN } \\
\text { KABUL, AFGHANISTAN }\end{array}$} & \multicolumn{2}{|c|}{$\begin{array}{l}\text { CCOMMUNICATION LINES> } \\
\text { PHONE : } \\
\text { F A X: } \\
\text { TELEX: }\end{array}$} & \multicolumn{2}{|l|}{$\begin{array}{l}\text { 1. ENG. SALAH } \\
\text { 2. } \\
\text { 3. }\end{array}$} \\
\hline $\begin{array}{l}\text { AFGHAN : } \\
\text { PAKISTANI : } \\
\text { EXPAT: } \\
\text { TOTAL: }\end{array}$ & $\begin{array}{r}10 \\
\frac{2}{2} \\
12\end{array}$ & $\begin{array}{l}\text { TECHNICAL: } \\
\text { ADMINISTRATIVE: } \\
\text { FIELD/SUPPORT S. } \\
\text { TOTAL: }\end{array}$ & $\begin{array}{r}- \\
6 \\
6 \\
12\end{array}$ & $\begin{array}{l}\text { PAK. BASED: } \\
\text { AFGHA. BASED: } \\
\text { CROSS-BORDER: } \\
\text { TOTAL: }\end{array}$ & $1 \overline{2}$ \\
\hline
\end{tabular}

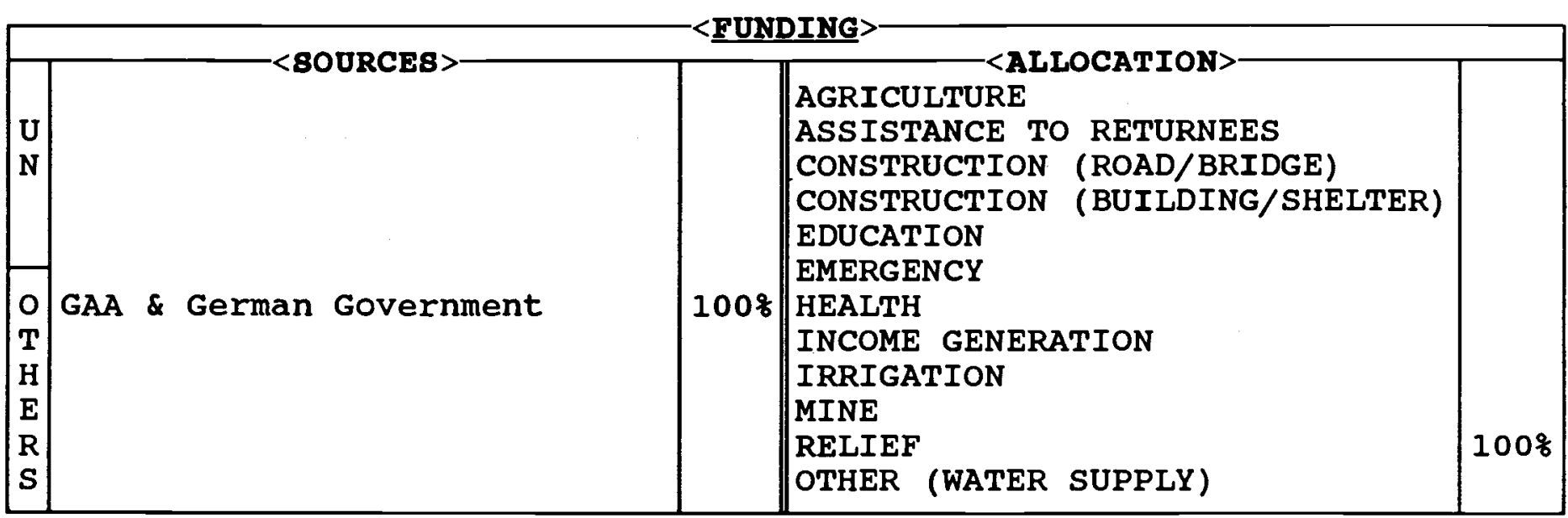

\begin{tabular}{|c|c|c|c|c|c|c|}
\hline & 1988 & 1989 & 1990 & 1991 & 1992 & 1993 \\
\hline $\begin{array}{l}\text { AFGHANISTAN: } \\
\text { REFUGEES : } \\
\text { T O T A L: }\end{array}$ & & & & & $\begin{array}{l}1,500,000 \\
1,000,000\end{array}$ & $\begin{array}{l}1,000,000 \\
1,500,000\end{array}$ \\
\hline
\end{tabular}

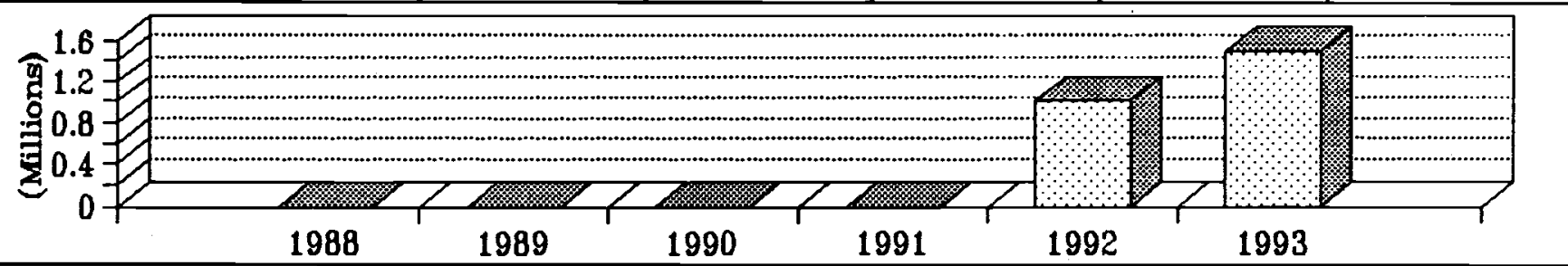

\begin{tabular}{|c|c|c|c|c|c|}
\hline PROVINCES & SECTOR & \&AGE & PROVINCES & SECTOR & \&AGE \\
\hline $\begin{array}{l}\text { BADAKSHAN } \\
\text { BADGHIS } \\
\text { BAGHLAN } \\
\text { BALKH } \\
\text { BAMYAN } \\
\text { FARAH } \\
\text { FARYAB } \\
\text { GHAZNI } \\
\text { GHOR } \\
\text { HELMAND } \\
\text { HERAT } \\
\text { JAWZJAN } \\
\text { KABUL } \\
\text { KANDAHAR } \\
\text { KAPISA }\end{array}$ & $\begin{array}{l}\text { Relief } \\
\text { Relief }\end{array}$ & $\begin{array}{l}10 \% \\
10 \% \\
\end{array}$ & $\begin{array}{l}\text { KUNAR } \\
\text { KUNDUZ } \\
\text { LAGHMAN } \\
\text { LOGAR } \\
\text { NANGARHAR } \\
\text { NIMROZ } \\
\text { ORUZGAN } \\
\text { PAKTEKA } \\
\text { PAKTIA } \\
\text { PARWAN } \\
\text { SAMANGAN } \\
\text { TAKHAR } \\
\text { WARDAK } \\
\text { ZABUL }\end{array}$ & $\begin{array}{l}\text { Relief } \\
\text { Relief }\end{array}$ & $\begin{array}{l}10 \% \\
10 \%\end{array}$ \\
\hline
\end{tabular}




\section{GERMAN AGRO ACTION (GAA)/ \\ DEUTSCHE WELTHUNGERHILFE (D.W.)}

is a non-governmental officially recognized welfare organization in which the most important social groups of the Federal Republic of Germany cooperate to improve the food situation and the rural living conditions in the Third World.

GAA supports self-aid programs in development countries as well as the efforts of the United Nations and the German Federal Government to improve the food situation and to sponsor rural development in the Third World. The aid programs of the Committee benefit above all the poorest sections of the population. The aid makes self-aid possible.

In the aftermath of natural or manmade disasters, when the population affected has lost the economic basis necessary for survival, German Agro Action gives emergency aid, which, in most cases, leads to development projects at the earliest possible stage.

The Committee receives the financial means for these aid programs in the form of private donations and government subsidies or subsidies from the European Economic Commission. The focal point for its donation action is the "Week of Agro Action", which begins each year on Harvest Thanksgiving Day.

A further important task is the compiling and distributing of information, which gives an insight into the social and economic interrelation between the industrial countries and the developing countries, thus strengthening our own joint social responsibility.

All projects implemented shall benefit rural populations and underprivileged urban groups and shall contribute to the improvement of their living conditions. The projects shall, therefore, aim mainly at removing the basic causes of underdevelopment by means of medium and long-term measures.
All projects shall be in accordance with the real needs of the people concerned, who will thus receive assistance towards self-reliance. Economic and technical progress should always result in improving social and, whenever possible, socio-political structures.

Preference should be given to nongovernmental organizations and local groups at grassroots level who will be in charge of planning and implementing the project. Cooperation with government agencies is, however, possible.

An adequate counterpart contribution towards all projects is expected. The committee must be satisfied that, after termination of financial assistance, the project will be continued.

In Afghanistan, GAA provides food aid in forms of free distribution to vulnerable groups and food for work projects in the most affected areas. The current target areas include Kabul, norther provinces and displaced families in Jalalabad. 


\begin{tabular}{|c|c|c|}
\hline$=<$ ADDRESS $>-$ & -<COMMUNICATION LINES $>$ & $=<\underline{\text { KEY STAFF }}>$ \\
\hline $\begin{array}{l}\text { SHAHIN BUILDING ABDARA } \\
\text { RD, U/T, G P O BOX } 1230 \\
\text { PESHAWAR, PAKISTAN }\end{array}$ & $\begin{array}{l}\text { PHONE : } 42613 \\
\text { F A X: } 840348 \\
\text { TELEX: }\end{array}$ & $\begin{array}{l}\text { 1. DR. M. NABI HUSSAINI } \\
\text { 2. QAZI FAZIL RABI } \\
\text { 3. }\end{array}$ \\
\hline
\end{tabular}

\begin{tabular}{|c|c|c|c|c|c|}
\hline $\begin{array}{l}\text { AFGHAN : } \\
\text { PAKISTANI : } \\
\text { EXPAT : } \\
\text { TOTAL : }\end{array}$ & $\begin{array}{r}216 \\
0 \\
0 \\
216\end{array}$ & $\begin{array}{l}\text { TECHNICAL: } \\
\text { ADMINISTRATIVE: } \\
\text { FIELD: } \\
\text { TOTAL: }\end{array}$ & $\begin{array}{l}\ddot{1} \\
\ddot{2} \dot{16}\end{array}$ & $\begin{array}{l}\text { PAK. BASED: } \\
\text { AFGHA. BASED: } \\
\text { CROSS-BORDER: } \\
\text { TOTAL: }\end{array}$ & $\begin{array}{r}\ddot{*} \\
\ddot{2} \dot{6}\end{array}$ \\
\hline
\end{tabular}

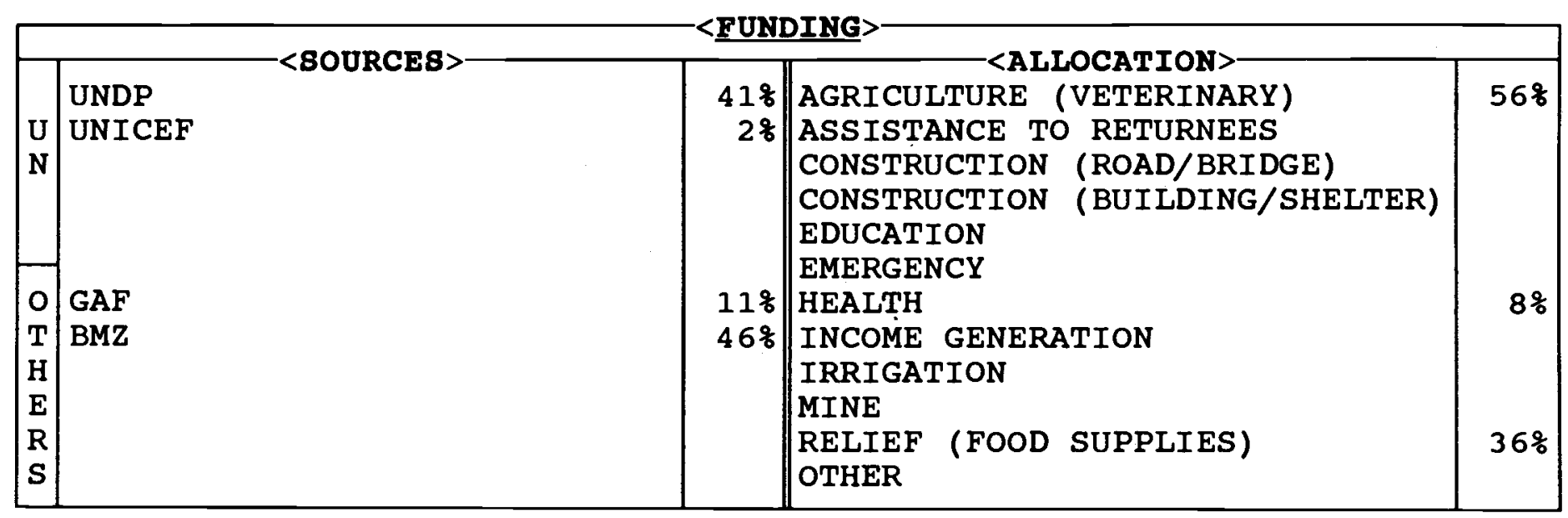

\begin{tabular}{|c|c|c|c|c|c|c|}
\hline $\begin{array}{l}\text { AFGHANISTAN: } \\
\text { REFUGEES : } \\
\text { T O T A L: }\end{array}$ & $\begin{array}{l}1988 \\
214,145 \\
149,623 \\
363,768\end{array}$ & $\begin{array}{l}1989 \\
288,297 \\
101,655 \\
389,952\end{array}$ & $\begin{array}{r}1990 \\
561,009 \\
93,501 \\
654,510\end{array}$ & {$\left[\begin{array}{r}1991 \\
839,554 \\
186,563 \\
1,026,117\end{array}\right.$} & \begin{tabular}{r}
\multicolumn{1}{c}{1992} \\
$1,565,185$ \\
89,234 \\
$1,654,419$
\end{tabular} & $\begin{array}{r}1993 \\
1,131,416 \\
25,725 \\
1,157,141\end{array}$ \\
\hline $\begin{array}{l}1.6 \\
0.2 \\
0.8 \\
0.4\end{array}$ & 1988 & 1989 & 1990 & 1991 & 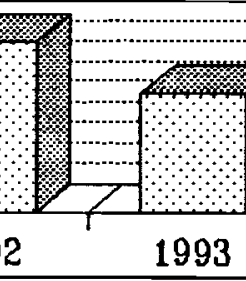 & …-1) \\
\hline
\end{tabular}

\begin{tabular}{|c|c|c|c|c|c|}
\hline PROVINCES & SECTOR & $\because \mathrm{AGE}$ & PROVINCES & SECTOR & $\% A G E$ \\
\hline $\begin{array}{l}\text { BADAKSHAN } \\
\text { BADGHIS } \\
\text { BAGHLAN } \\
\text { BALKH } \\
\text { BAMYAN } \\
\text { FARAH } \\
\text { FARYAB } \\
\text { GHAZNI } \\
\text { GHOR } \\
\text { HELMAND } \\
\text { HERAT } \\
\text { JAWZJAN } \\
\text { KABUL } \\
\text { KANDAHAR } \\
\text { KAPISA }\end{array}$ & $\begin{array}{l}\text { Agr (vet)/Health } \\
\text { Agr (vet) } \\
\text { Health } \\
\text { Relief (food) } \\
\text { Agr (vet) } \\
\text { Agr (vet) }\end{array}$ & $\begin{array}{c}78 \\
18 \\
348 \\
3 q \\
8 \%\end{array}$ & \begin{tabular}{|l} 
KUNAR \\
KUNDUZ \\
LAGHMAN \\
LOGAR \\
NANGARHAR \\
NIMROZ \\
ORUZGAN \\
PAKTEKA \\
PAKTIA \\
PARWAN \\
SAMANGAN \\
TAKHAR \\
WARDAK \\
ZABUL
\end{tabular} & $\begin{array}{l}\text { Health } \\
\text { Agr (vet) } \\
\text { Agr (field crop/vet) } \\
\text { Agr (vet) } \\
\text { Agr (vet) } \\
\text { Agr (vet) } \\
\text { Agr (vet)/health } \\
\text { Agr (vet) }\end{array}$ & $\begin{array}{r}1 \% \\
7 \% \\
12 \% \\
2 \% \\
4 \% \\
5 \% \\
10 \%\end{array}$ \\
\hline
\end{tabular}


GERMAN AFGHANISTAN FOUNDATION (GAF)

is a non governmental, non political humanitarian organization established simultaneously in the Federal Republic of Germany and Pakistan in 1986. GAF is supported by UNDP, UNICEF and the Government of Federal Republic of Germany.

GAF is running projects in:

- veterinary services

- veterinary training

- medical assistance including EPI

- agriculture (crop production)

- food supply

In the veterinary sector, GAF is presently providing services in 10 different provinces through 51 veterinary centers. A paravet training course was established in 1986 in Peshawar and has trained 200 young Afghans. 86 of them are presently employed by GAF at various veterinary centers inside Afghanistan. The remaining paravets have either been employed by other NGOs or have established their private veterinary clinics at refugee camps. The paravet training course has been modified to a better standard. Moreover, a veterinary refresher training course has been established where experts from Germany delivers lectures and seminars, attended not only by GAF veterinarian but also veterinarians from other NGOs involved in veterinary services for Afghanistan.

GAF operates ten EPI centers and two medical clinics inside Afghanistan.

GAF agriculture department implements crop production and karez cleaning projects in Paktia and Pakteka provinces. It is planned to expand crop production program to Nangarhar province. Tractor services are provided in Herat province on charge bases to farmers.
Recently, GAF has distributed food commodities at the cost of Rs. 15 million in Herat province.

GAF implements its projects through whatever infrastructure may be available in the targeted area, i.e. shura, commanders, village elders, etc. 
GHARJESTAN RECONSTRUCTION COUNCIL-GRC

- ADDDRESS >- $-<$ COMMUNICATION LINES $>$

50-C, HAZARA HOUSING SOCIETY, ALAMDAR ROAD QUETTA, PAKISTAN
PHONE : 79368

F A X:

TELEX:
1. MR. M. ZAMAN ATRAFI

2. MR. MOHD HASHIM

3. MR. SAFDAR SOROUSH

\begin{tabular}{|lr|lr|lr|}
\hline AFGHAN : & 9 & TECHNICAL: & 3 & PAK. BASED: & 6 \\
PAKISTANI: & 1 & ADMINISTRATIVE: & 4 & AFGHA.BASED: & 4 \\
EXPAT: & - & FIELD/SUPPORT S. & 3 & CROSS-BORDER: & - \\
TOTAL: & 10 & TOTAL: & 10 & TOTAL: & 10 \\
\hline
\end{tabular}

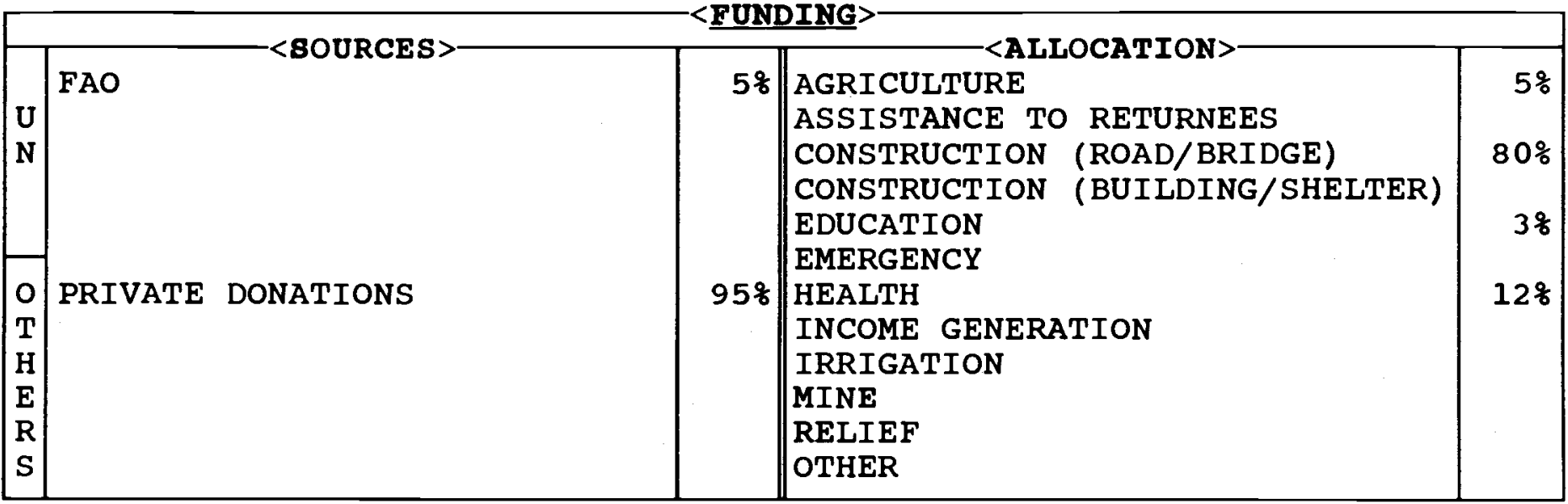

\begin{tabular}{|l|r|r|r|r|r|r|}
\hline & 1988 & 1989 & $\frac{1990}{4,600}$ & $\frac{1991}{32,400}$ & 1992 & $\frac{1993}{30,000}$ \\
AFGHANISTAN: & & & 4,600 & 32,400 & & - \\
TEFUGES : & & & 30,000 \\
\hline
\end{tabular}

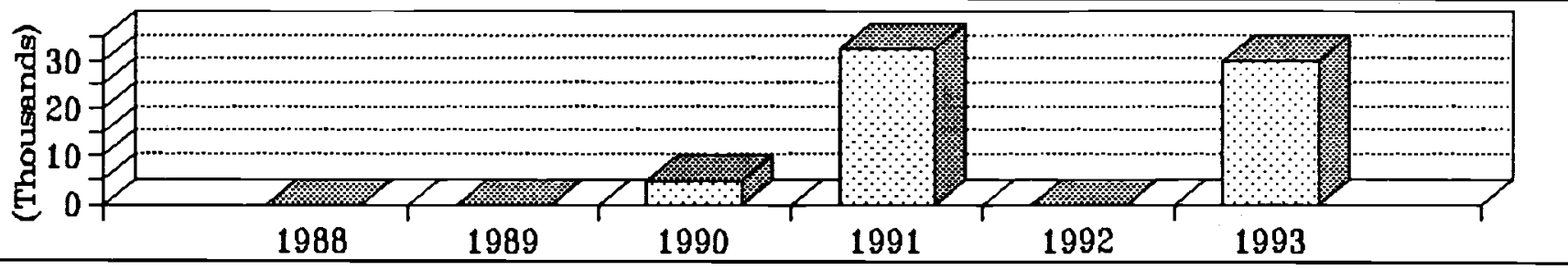

\begin{tabular}{|c|c|c|c|c|c|}
\hline PROVINCES & SECTOR & \% & PROVINCES & SECTOR & \&AGE \\
\hline $\begin{array}{l}\text { BADAKSHAN } \\
\text { BADGHIS } \\
\text { BAGHLAN } \\
\text { BALKH } \\
\text { BAMYAN } \\
\text { FARAH } \\
\text { FARYAB } \\
\text { GHAZNI } \\
\text { GHOR } \\
\text { HELMAND } \\
\text { HERAT } \\
\text { JAWZJAN } \\
\text { KABUL } \\
\text { KANDAHAR } \\
\text { KAPISA }\end{array}$ & & & $\begin{array}{l}\text { KUNAR } \\
\text { KUNDUZ } \\
\text { LAGHMAN } \\
\text { LOGAR } \\
\text { NANGARHAR } \\
\text { NIMROZ } \\
\text { ORUZGAN } \\
\text { PAKTEKA } \\
\text { PAKTIA } \\
\text { PARWAN } \\
\text { SAMANGAN } \\
\text { TAKHAR } \\
\text { WARDAK } \\
\text { ZABUL }\end{array}$ & Agr/const/educ/health & $100 \%$ \\
\hline
\end{tabular}




\section{GHARJISTAN RECONSTRUCTION COUNCIL (GRC)}

is an Afghan Non-Governmental Organization established in 1990. The aim is to take part in the rehabilitation of Afghanistan, particularly the central areas.

GRC works in the sectors of agriculture and irrigation rehabilitation and infrastructure reconstruction. It also distributes relief assistance to poor and needy families.

In the agriculture sector, GRC distributes improved wheat and maize seeds and fertilizer. It cleans karezes and canals.

GRC has implemented road repair projects and constructed school buildings. It will implement similar projects subject to availability of funds.

When the security conditions are suitable, GRC will move its office to Kabul. It also plans to open sub-offices in Mazar-i-Sharif and Bamyan. 
GLOBAL PARTNERS (UR)-GP

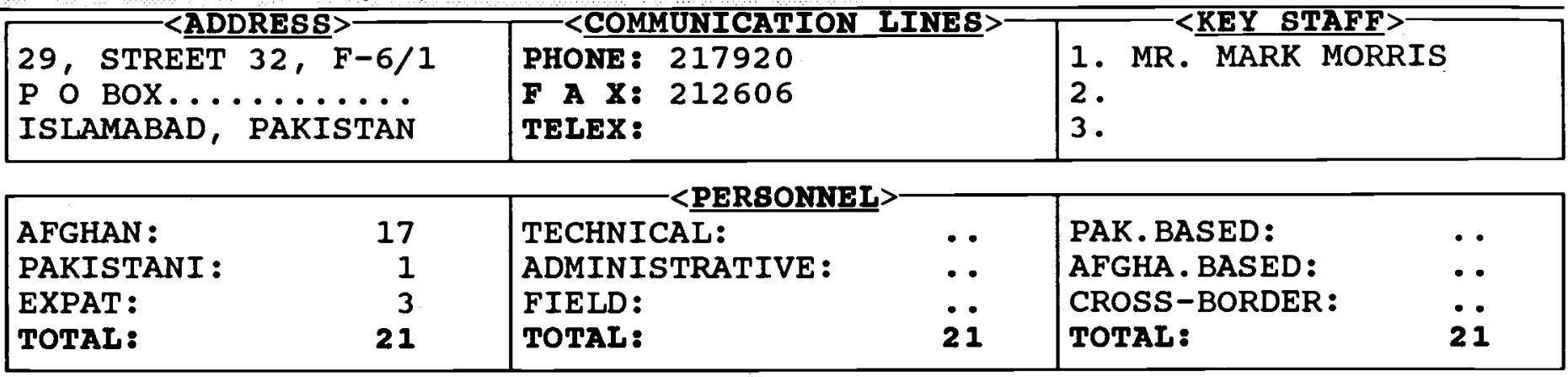

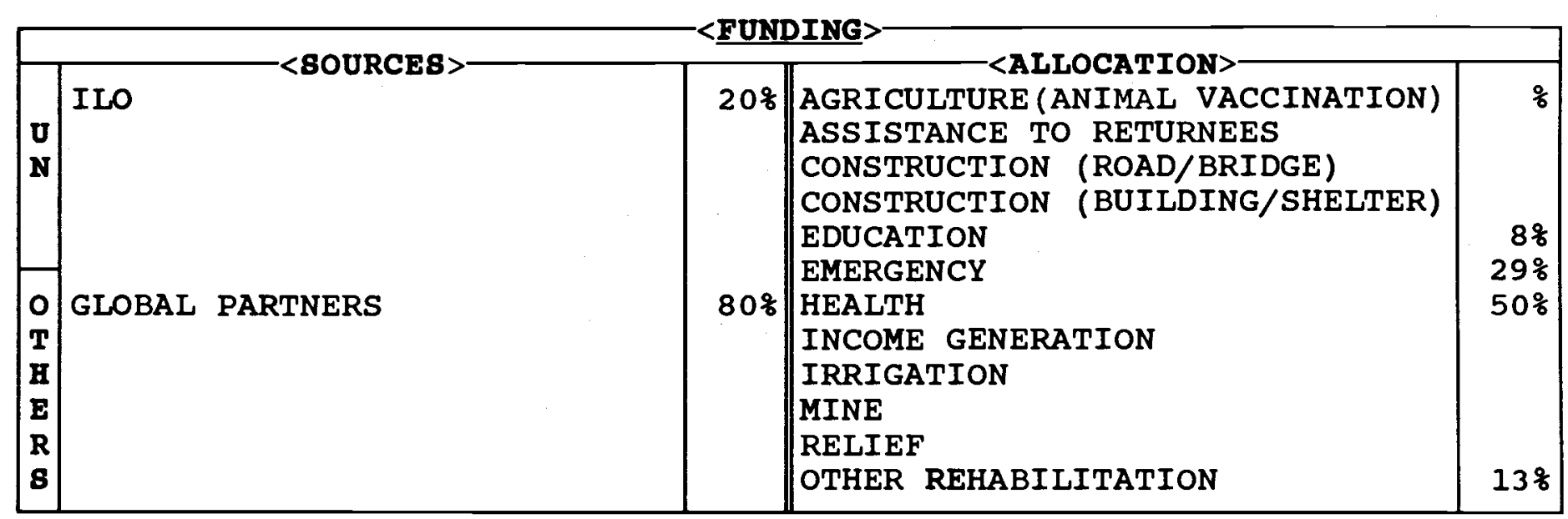

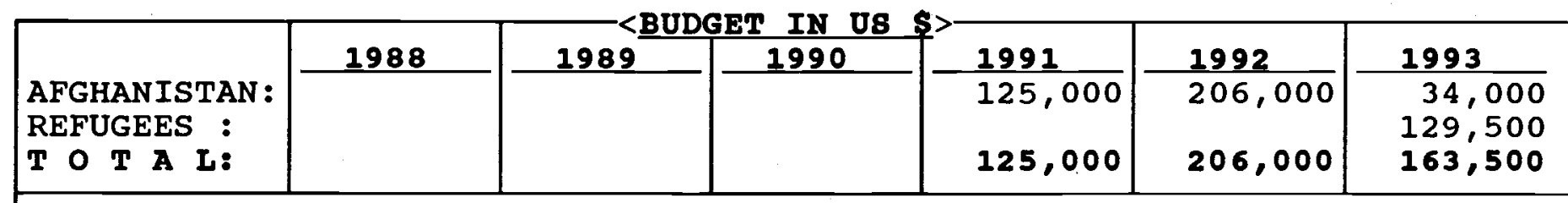

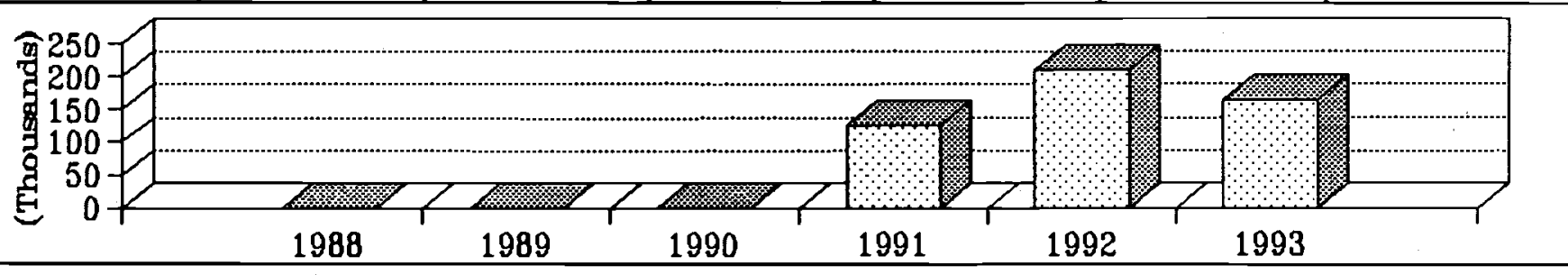

\begin{tabular}{|c|c|c|c|c|c|}
\hline PROVINCES & SECTOR & \&AGE & PROVINCES & SECTOR & \&AGE \\
\hline $\begin{array}{l}\text { BADAKSHAN } \\
\text { BADGHIS } \\
\text { BAGHLAN } \\
\text { BALKH } \\
\text { BAMYAN } \\
\text { FARAH } \\
\text { FARYAB } \\
\text { GHAZNI } \\
\text { GHOR } \\
\text { HELMAND } \\
\text { HERAT } \\
\text { JAWZJAN } \\
\text { KABUL } \\
\text { KANDAHAR } \\
\text { KAPISA }\end{array}$ & $\begin{array}{l}\text { Voc.training } \\
\text { Educ }\end{array}$ & $\begin{array}{l}308 \\
208 \\
208\end{array}$ & \begin{tabular}{|l|} 
KUNAR \\
KUNDUZ \\
LAGHMAN \\
LOGAR \\
NANGARHAR \\
NIMROZ \\
ORUZGAN \\
PAKTEKA \\
PAKTIA \\
PARWAN \\
SAMANGAN \\
TAKHAR \\
WARDAK \\
ZABUL
\end{tabular} & Voc.training & 308 \\
\hline
\end{tabular}


GLOBAL PARTNERS, UR (GP-UR)

is a charitable organization, established to provide benevolent services to the developing world. It is committed to providing resources and services which prevent poverty and preserve human life. It also facilitates international cooperative efforts for educational, agricultural, environmental, health related, disabled vocational training and other projects. Global Partners provides technical assistance through a variety of consultancy programs and encourages the training of national workers.

The organization is registered in the United Kingdom and Pakistan. It is a United Kingdom-based agency which began its work in 1991 largely in response to the plight of Kurdish refugees in Northern Iraq. GP-UK initially provided a channel for resources and technicians to assist the Kurdish areas of Iraq. Even today, it continues its Northern Iraq projects.

GP has offices or sponsored work in Cyprus, Turkey, Northern Iraq (Kurdistan), Afghanistan, Hong Kong, China, Singapore, and Indonesia.

The agency has been serving the Afghans since 1991. In Afghanistan, as in every other country in which it operates, Global Partners serves as a purely non-profit charity for the purpose of funding and implementing humanitarian assistance.

Global Partners is doing everything possible with its own limited resources and personnel to assist the Afghans in benevolent endeavors. The activities undertaken for Afghans include distribution of emergency relief assistance both in the refugee camps in pakistan (Hayatabad and Rawalpindi) and to the displaced families in Jalalabad/Sarobi; support to an elementary school in Malestan of Ghazni; animal vaccination campaign in Malestan and vocational training courses for disabled in Puli Khumri and Shamali areas of Afghanistan. 
CHAR RAHI HAJI YAQOOB SHAHR NW, P O BOX 3036 KABUL, AFGHANISTAN
-<COMMUNICATION LINES>

PHONE: 32436

F A X: C/O $837 \quad 175 \quad 4214$

TELEX:
1. MR. TIM PORTER

2. MR. SAM MACLEOD

3. DR. FARID HOMOUYOUN

\begin{tabular}{|lr|lr|lr|}
\hline AFGHAN: & 120 & TECHNICAL: & 100 & PAK. BASED: & - \\
PAKISTANI: & - & ADMINISTRATIVE: & 20 & AFGHA.BASED: & 126 \\
EXPAT: & 6 & FIELD: & 6 & CROSS-BORDER: & - \\
TOTAL: & 126 & TOTAL: & 126 & TOTAL: & 126 \\
\hline
\end{tabular}

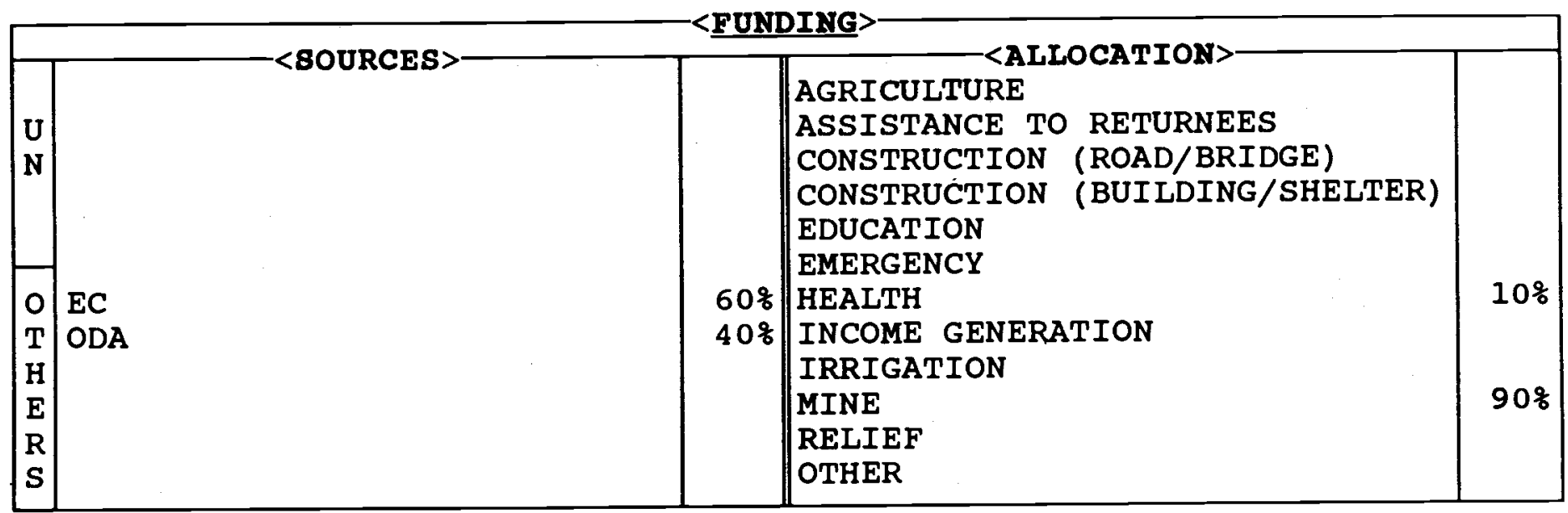
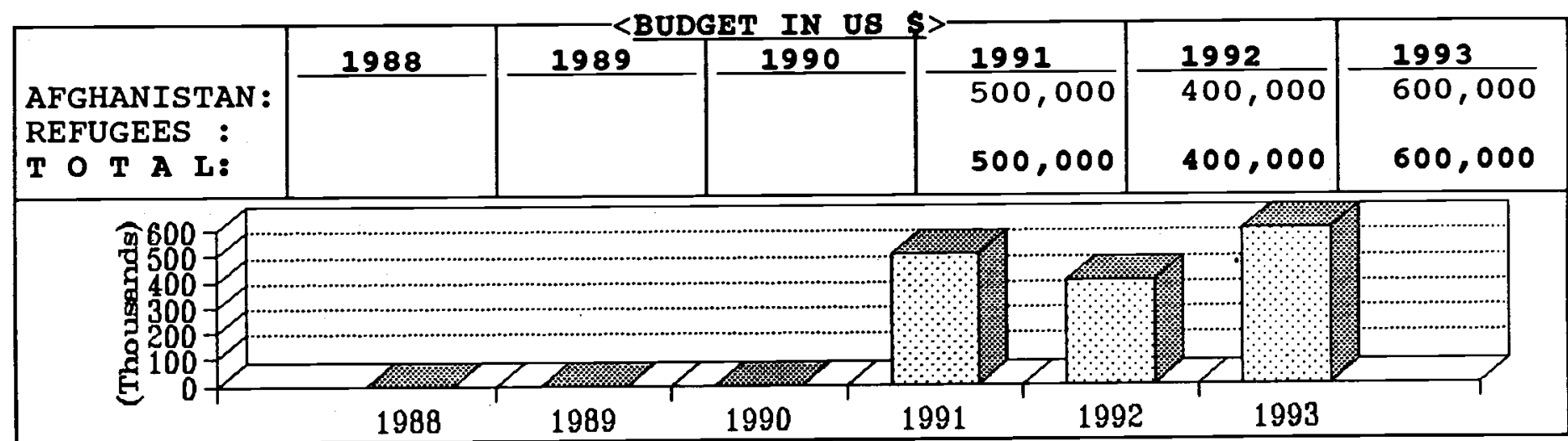

\begin{tabular}{|c|c|c|c|c|c|}
\hline PROVINCES & SECTOR & \&AGE & PROVINCES & SECTOR & $\because A G E$ \\
\hline $\begin{array}{l}\text { BADAKSHAN } \\
\text { BADGHIS } \\
\text { BAGHLAN } \\
\text { BALKH } \\
\text { BAMYAN } \\
\text { FARAH } \\
\text { FARYAB } \\
\text { GHAZNI } \\
\text { GHOR } \\
\text { HELMAND } \\
\text { HERAT } \\
\text { JAWZJAN } \\
\text { KABUL } \\
\text { KANDAHAR } \\
\text { KAPISA }\end{array}$ & Demining/mine awaren. & $35 \%$ & \begin{tabular}{|l|} 
KUNAR \\
KUNDUZ \\
LAGHMAN \\
LOGAR \\
NANGARHAR \\
NIMROZ \\
ORUZGAN \\
PAKTEKA \\
PAKTIA \\
PARWAN \\
SAMANGAN \\
TAKHAR \\
WARDAK \\
ZABUL
\end{tabular} & Demining/mine awaren. & $55 \%$ \\
\hline
\end{tabular}




\section{HALO TRUST (HT)}

established its office in Kabul in 1989. The main component of Halo Trust activities is mine clearance and mine awareness. It also provides medical services to its target areas. Initially, the agency was involved in medical services, but in 1990 started its demining operation.

In the medical sector, it has dispensaries in Kabul, Jabulseraj and Puli-Khumri areas. Various types of diseases are being treated and minor surgeries are done at these dispensaries.

The agency also has clinics in Kabul where malnourished children and pregnant women are provided with treatment.

In the demining sector, the agency focuses mainly in shamali valley (from Kutal-i-Khairkhana to salang Tunnel).

The demining operations are carried out through the Jabulseraj office where there are eight to ten teams involved in demining operation. Twelve teams are carrying out demining operations in Puli-Khumri. Four expatriate doctors are working with the teams in Jabul siraj and Puli-Khumri. The doctors provide treatment if the deminers are injured. They also treat the local people and provide them with free medicine. 
HAMRAR REHABILITATION AND RURAL DEVELOPMENT ORGANIRATION-HRRDO

\begin{tabular}{|c|c|c|}
\hline 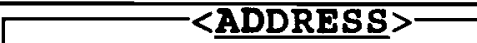 & $-<$ COMMUNICATION LINES $>-$ & $-<$ KEY STAFF $>$ \\
\hline $\begin{array}{l}\text { PHASE } 2, \text { HAYATABAD } \\
\text { P O BOX. . . . . . . . } \\
\text { PESHAWAR, PAKISTAN }\end{array}$ & $\begin{array}{l}\text { PHONE : } 811801 \\
\text { F A X: } \\
\text { TELEX: }\end{array}$ & $\begin{array}{l}\text { 1. DR. DAUD SHAH } \\
\text { 2. DR. A. SATTAR PAKTIS } \\
\text { 3. DR. SAYED MOHAMMAD }\end{array}$ \\
\hline
\end{tabular}

\begin{tabular}{|ll|ll|ll|}
\hline AFGHAN: & 6 & TECHNICAL: & 3 & PAK. BASED: & - \\
PAKISTANI : & - & ADMINISTRATIVE: & 3 & AFGHA.BASED: & - \\
EXPAT: & - & FIELD: & - & CROSS-BORDER: & 6 \\
TOTAL: & 6 & TOTAL: & 6 & TOTAL: & 6 \\
\hline
\end{tabular}

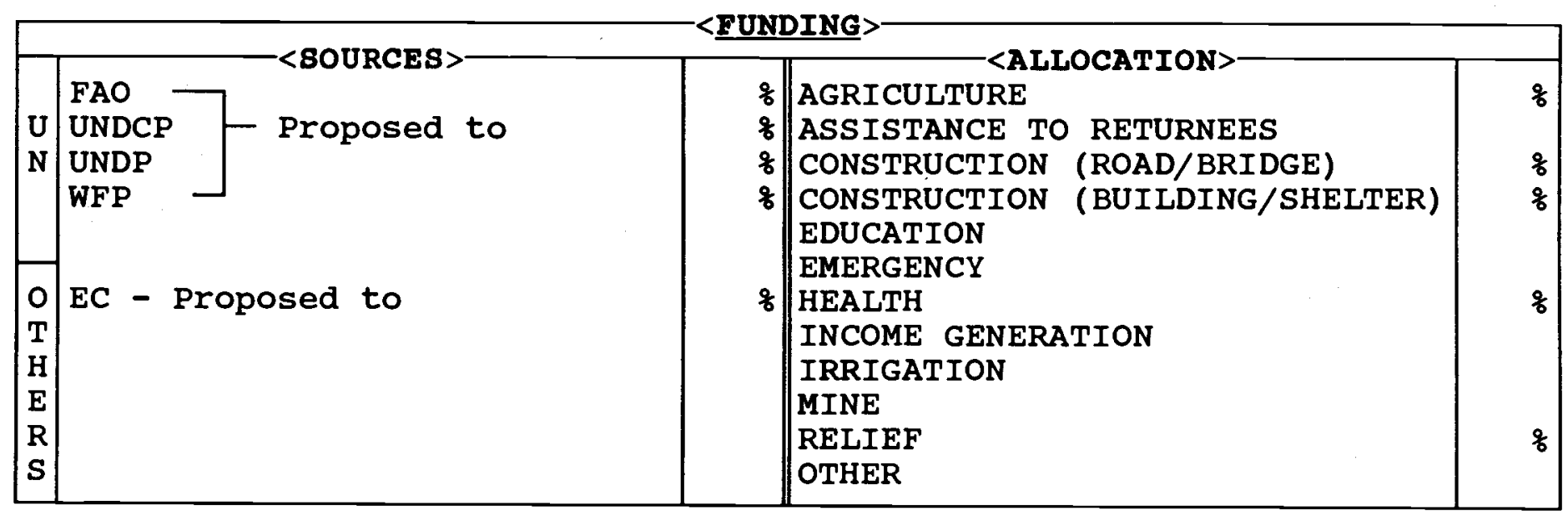

\begin{tabular}{|l|l|l|l|l|l|l|}
\hline & 1988 & 1989 & 1990 & 1991 & 1992 & 1993 \\
RFGHANISTAN: \\
T O T A L:
\end{tabular}

\begin{tabular}{|c|c|c|c|c|c|}
\hline PROVINCES & SECTOR & \%AGE & PROVINCES & SECTOR & \&AGE \\
\hline $\begin{array}{l}\text { BADAKSHAN } \\
\text { BADGHIS } \\
\text { BAGHLAN } \\
\text { BALKH } \\
\text { BAMYAN } \\
\text { FARAH } \\
\text { FARYAB } \\
\text { GHAZNI } \\
\text { GHOR } \\
\text { HELMAND } \\
\text { HERAT } \\
\text { JAWZJAN } \\
\text { KABUL } \\
\text { KANDAHAR } \\
\text { KAPISA }\end{array}$ & & $\begin{array}{l}8 \\
8 \\
8\end{array}$ & \begin{tabular}{|l} 
KUNAR \\
KUNDUZ \\
LAGHMAN \\
LOGAR \\
NANGARHAR \\
NIMROZ \\
ORUZGAN \\
PAKTEKA \\
PAKTIA \\
PARWAN \\
SAMANGAN \\
TAKHAR \\
WARDAK \\
ZABUL
\end{tabular} & & \\
\hline
\end{tabular}


is a non-profit, non-political, nonpolitical and non-governmental organization. The headquarters of the organization are in Kabul. It maintains a contact office in Peshawar and plans to open branch offices in different provinces of Afghanistan.

The aim of the organization is to take active part in the rehabilitation, reconstruction and rural development of Afghanistan through implementing health, agriculture/livestock, engineering, vocational training, income generation projects. The focus is on providing a base for economic development and social welfare of the people of Afghanistan. The agency also undertakes emergency relief programs.

HRRDO will develop a coordinated and integrated approach for planning and implementation of projects and will establish close cooperation with other organizations involved in the same sectors and areas of work.

There is a Board of Directors that makes all decisions about the policies and activities of the organization.

HRRDO has prepared several project proposals and submitted them to different donor organizations. The organization expects to commence project activities early 1994. 
HANDICAP INTERNATIONAL-HI

\begin{tabular}{|l|l|l|}
\hline AHMADZAI COLONY, SARIAB & PHONE: 440002 & CCOMMUNICATION LINES \\
RD, P O BOX 477 & F A X: 444793 & 2. \\
QUETTA PAKISTAN & TELEX: & 3. \\
\hline
\end{tabular}

\begin{tabular}{|lr|lr|lr|}
\hline AFGHAN : & 87 & TECHNICAL: & 30 & PAK. BASED: & 95 \\
PAKISTANI: & 3 & ADMINISTRATIVE: & 7 & AFGHA.BASED: & - \\
EXPAT: & 5 & FIELD: & 58 & CROSS-BORDER: & - \\
TOTAL: & 95 & TOTAL: & 95 & TOTAL: & 95 \\
\hline
\end{tabular}

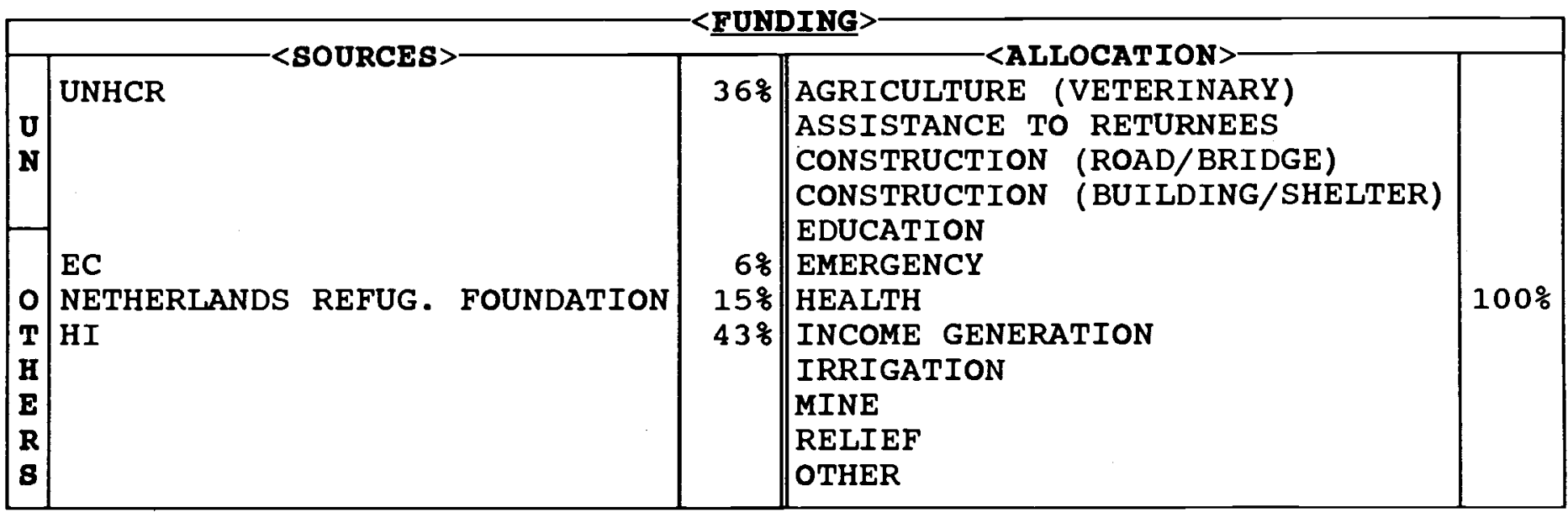

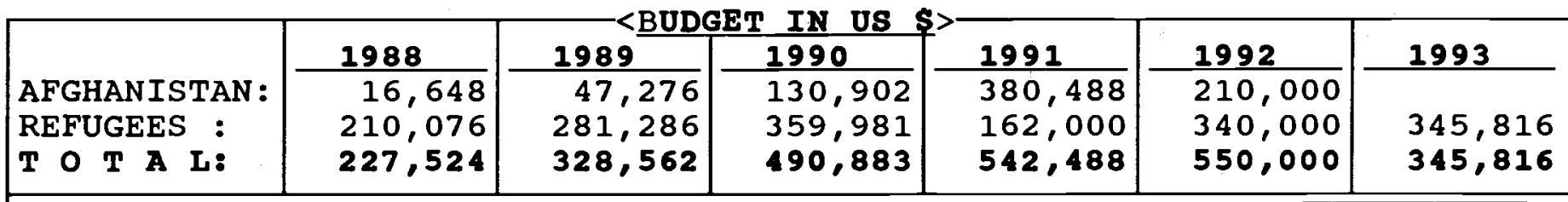

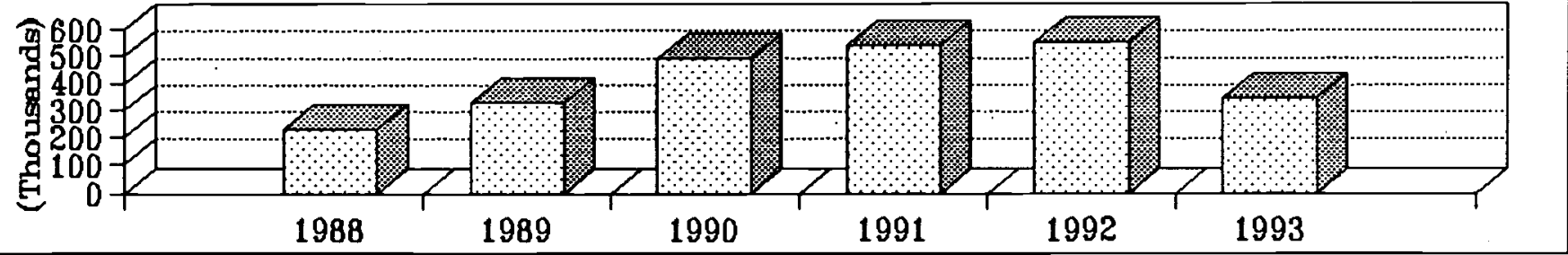

\begin{tabular}{|c|c|c|c|c|c|}
\hline PROVINCES & SECTOR & \&AGE & PROVINCES & SECTOR & $\%$ AGE \\
\hline $\begin{array}{l}\text { BADAKSHAN } \\
\text { BADGHIS } \\
\text { BAGHLAN } \\
\text { BALKH } \\
\text { BAMYAN } \\
\text { FARAH } \\
\text { FARYAB } \\
\text { GHAZNI } \\
\text { GHOR } \\
\text { HELMAND } \\
\text { HERAT } \\
\text { JAWZJAN } \\
\text { KABUL } \\
\text { KANDAHAR } \\
\text { KAPISA }\end{array}$ & $\begin{array}{l}\text { Health } \\
\text { Health }\end{array}$ & $\begin{array}{l}20 \% \\
60 \%\end{array}$ & \begin{tabular}{|l|} 
KUNAR \\
KUNDUZ \\
LAGHMAN \\
LOGAR \\
NANGARHAR \\
NIMROZ \\
ORUZGAN \\
PAKTEKA \\
PAKTIA \\
PARWAN \\
SAMANGAN \\
TAKHAR \\
WARDAK \\
ZABUL
\end{tabular} & & \\
\hline
\end{tabular}




\section{HANDICAP INTERNATIONAL (HI)}

started its program in Baluchistan in 1985, largely at the initiative of UNHCR and out of the awareness that few services existed for handicapped people in Baluchistan, and the large number of disabled persons among Afghan refugees.

One of the priorities of the program is to promote the autonomy of the Center through training of its local staff. To this end, HI has achieved the following: the technicians have acquired the technical expertise necessary to manufacture orthopaedic devices of a high standard, using appropriate technology: the physiotherapist assistants were taught to consult the patients in order to identify their problems and provide appropriate treatment and $d e v i c e$ s $\quad M \circ s t$ technicians/physiotherapist assistants are now able to teach new workers and students. (HI has also provided physiotherapy training for nurses working in various local hospitals.)

From Quetta center, two mobile teams of local physiotherapists assistants make monthly field trips to refugee villages around Baluchistan; 19 are currently visited. A specific network of Afghan outreach workers is working in the various camps, to identify the handicapped population most likely to benefit from the services of $H I$, and to refer them to the monthly consultations. Some patients are treated in the camps and followed up by the outreach workers, while others are directed to the center for extended treatment. Between sep.85 and Dec.91, 16,150 new patients were registered, and 16,120 gait aid and orthopaedic devices have been made.

In December 1988, an HI team consisting of an expatriate physiotherapist, an Afghan orthopaedic technician and an Afghan physiotherapist assistant-trained at Quetta center-set up a small center in $\mathrm{Z}$ indajan, Herat. The replacement team, consisting of one expatriate orthopaedic technician, one |expatriate physiotherapist and three Afghan orthopaedic technicians, was attacked on August 14, 1989 going to Zindajan. The three Afghan technicians and the expatriate technician, Vincent Gernigon, were killed in the attack. After that accident, HI decided not to send anymore staff inside Afghanistan. The Center at $\mathrm{Z}$ indajan continued work under the control of the local delegation of the Jamiat-e-Islami, with only an external consultation from HI and this, until May 1991, during which month the center was completely destroyed after a heavy attack of the government troops. Until April 1992, HI has been unable to get in touch with the Afghan supervisor and all activities have been stopped in this unit.

In 1990, HI began the realization of a partnership program to set up four Rehabilitation Units inside Afghanistan (Helmand, Ghazni, and Kandahar). Therefore, an orthopaedic Training center for Afghan People has been established in Quetta to train Afghan orthopaedic technicians. HI trained for each Unit, four orthopaedic technicians, selected by the implementing partners (MCI and IAHC). The purpose of the training was the manufacture of crutches, above knee and below knee prostheses. HI was also funding the construction of the buildings, furnishing full equipment for one year autonomy of the unit and paying the salaries for technicians during one year. Due to consequent delay in the building of the Units, the project was extended until August 1992 .

Along with many other agencies, HI is planning to shift its activities to Afghanistan as soon as the situation inside gets better. It is likely to set up programs in the south of Afghanistan (Kandahar, Ghazni, Herat...). A team will go to get a better idea of the $s \quad i t u$ a $t$ i o $n$. 
HEALTH AND ENGINEERING SERVICES FOR AFGHANISTAN REHABILITATION-HESAR

\begin{tabular}{|l|l|l|}
\hline 162-A, ST. 16, ROAD 6 & PHONE: 62262 & 1. ENG. NOORULHAQ NIAZI \\
GULBAHAR NO.2 & F A X: & 2. ENG. HAMAYOON DARWISH \\
PESHAWAR, PAKISTAN & TELEX: & 3. DR. ABDULLAH MEHMODY \\
\hline
\end{tabular}

\begin{tabular}{|lr|lr|ll|}
\hline AFGHAN: & 20 & TECHNICAL: & 12 & PAK. BASED: & $\ldots$ \\
PAKISTANI : & - & ADMINISTRATIVE: & 4 & AFGHA. BASED: & $\ldots$ \\
EXPAT: & - & FIELD: & 4 & CROSS B BORDER: & $\cdots$ \\
TOTAL: & 20 & TOTAL: & 20 & TOTAL: & 20 \\
\hline
\end{tabular}

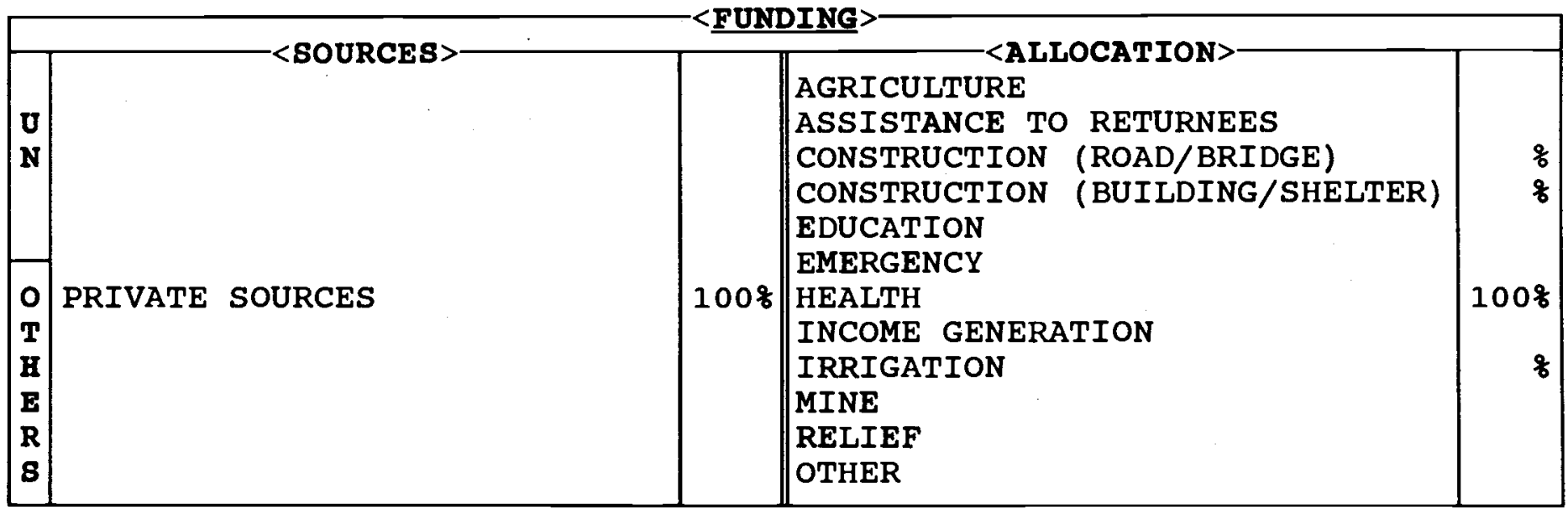

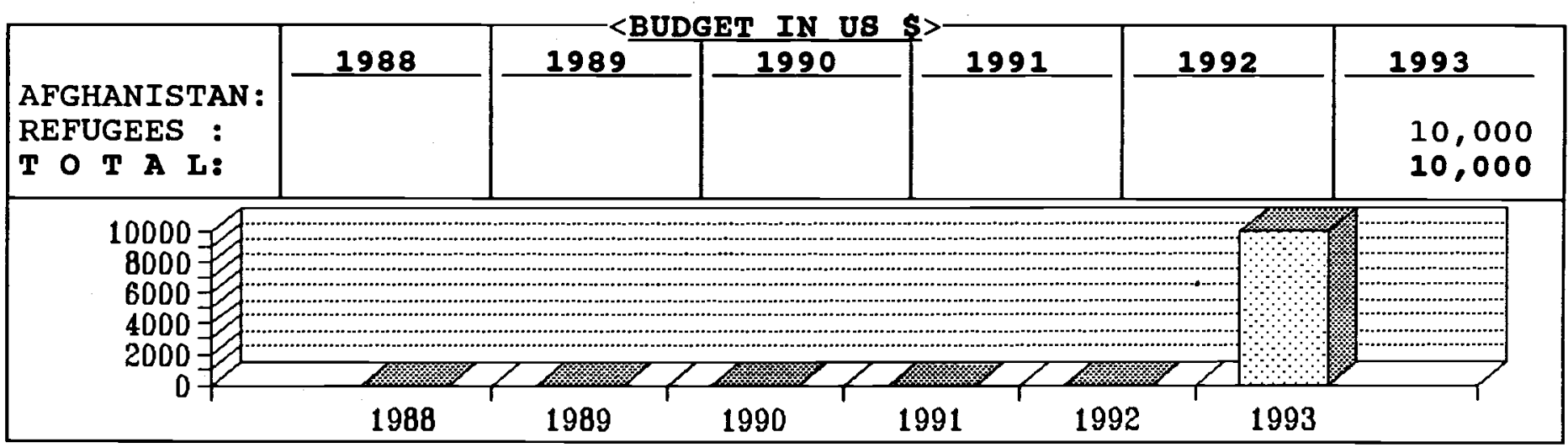

\begin{tabular}{|c|c|c|c|c|c|}
\hline PROVINCES & SECTOR & \&AGE & PROVINCES & SECTOR & $\%$ AGE \\
\hline $\begin{array}{l}\text { BADAKSHAN } \\
\text { BADGHIS } \\
\text { BAGHLAN } \\
\text { BALKH } \\
\text { BAMYAN } \\
\text { FARAH } \\
\text { FARYAB } \\
\text { GHAZNI } \\
\text { GHOR } \\
\text { HELMAND } \\
\text { HERAT } \\
\text { JAWZJAN } \\
\text { KABUL } \\
\text { KANDAHAR } \\
\text { KAPISA }\end{array}$ & 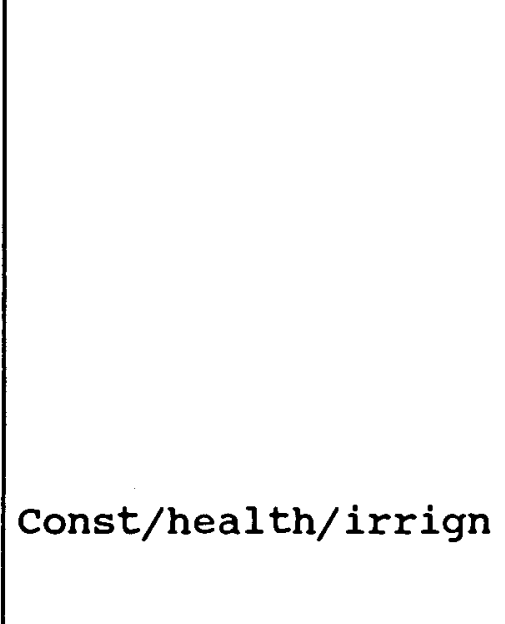 & $q$ & \begin{tabular}{|l} 
KUNAR \\
KUNDUZ \\
LAGHMAN \\
LOGAR \\
NANGARHAR \\
NIMROZ \\
ORUZGAN \\
PAKTEKA \\
PAKTIA \\
PARWAN \\
SAMANGAN \\
TAKHAR \\
WARDAK \\
ZABUL
\end{tabular} & Const/health/irrign & $\%$ \\
\hline
\end{tabular}


is an Afghan NGO set up in 1993 and is operating both from Peshawar, Pakistan and Laghman province, Afghanistan.

The preliminary objective of this organization is to contribute to the rehabilitation and reconstruction of ruined Afghanistan. HESAR concentrates its efforts on the restoration of the three vital sectors of health, engineering and agriculture. Refugee repatriation will be facilitated and the returning families will be assisted to gain the opportunity of a normal and comfortable life in their own villages.

HESAR is currently operational in Laghman and Kabul provinces. However, it intends to expand to as many areas as possible.

For the refugees, HESAR runs an obs/ Gyn clinic in Peshawar city. This clinic provides medical services to Afghan women and children. It charges the patients a nominal fee in order to have a sustainable service.

The organization has been registered with the Ministry of Planning of the Islamic state of Afghanistan.

The Board of Directors is the supreme body of the agency; it holds quarterly meetings to make decisions about the policies of the organization and changes in the key staff. 
HEALTH UNLIMITED-HU

\begin{tabular}{|l|l|l|}
\hline 8-40, BLOC 4, S/T & PHONE: 442015 & 1. ANNE BRADSHALL \\
P O BOX 577 & F A X: & 2. \\
QUETTA, PAKISTAN & TELEX: & 3.
\end{tabular}

\begin{tabular}{|lr|lr|lr|}
\hline AFGHAN : & 29 & TECHNICAL: & 22 & PAK.BASED: & 4 \\
PAKISTANI: & 2 & ADMINISTRATIVE: & 2 & AFGHA.BASED: & 22 \\
EXPAT: & 1 & FIELD: & 8 & CROSS-BORDER: & 6 \\
TOTAL: & 32 & TOTAL: & 32 & TOTAL: & 32 \\
\hline
\end{tabular}

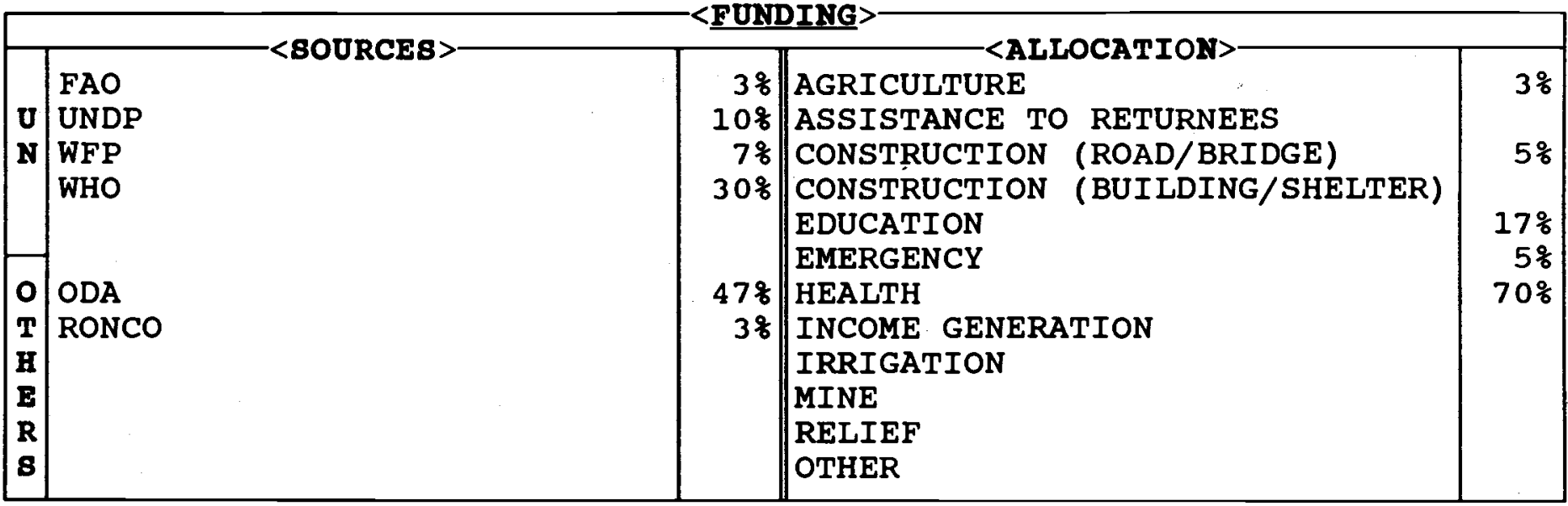

AFGHANISTAN:
$\begin{aligned} & \text { REFUGEES : } \\ & \text { T O T A L: }\end{aligned}$

\begin{tabular}{|c|c|c|c|c|c|}
\hline PROVINCES & SECTOR & \&AGE & |PROVINCES & SECTOR & $\% A G E$ \\
\hline $\begin{array}{l}\text { BADAKSHAN } \\
\text { BADGHIS } \\
\text { BAGHLAN } \\
\text { BALKH } \\
\text { BAMYAN } \\
\text { FARAH } \\
\text { FARYAB } \\
\text { GHAZNI } \\
\text { GHOR } \\
\text { HELMAND } \\
\text { HERAT } \\
\text { JAWZJAN } \\
\text { KABUL } \\
\text { KANDAHAR } \\
\text { KAPISA }\end{array}$ & & & \begin{tabular}{|l} 
KUNAR \\
KUNDUZ \\
LAGHMAN \\
LOGAR \\
NANGARHAR \\
NIMROZ \\
ORUZGAN \\
PAKTEKA \\
PAKTIA \\
PARWAN \\
SAMANGAN \\
TAKHAR \\
WARDAK \\
ZABUL
\end{tabular} & \begin{tabular}{|l} 
Agr/educ/health/relif \\
Agrelith
\end{tabular} & $100 \%$ \\
\hline
\end{tabular}


is a British based NGO founded in 1984. Its mandate is to asisist communities suffering through conflict or discrimination, specifically to develop community based health systems, providing training and support in primary Health care (PHC) and health education.

HU's Area Based Social Development Project has been operating in Zabul province since 1984. The original health program, comprising the development of BHUs staffed by locally trained health workers, has expanded to encompass a livestock program, support for a primary school and the provision of improved seed and fertilizer to local farmers.

In the near future, HU hopes to expand its health activities to other districts in zabul, and perhaps to neighboring provinces. It would be looking to concentrate its activities on developing locally staffed and managed basic health services in partnership with local communities. 
13 ABDARA RD, U/T $P$ O BOX 912 PESHAWAR, PAKISTAN
PHONE: 840770

F A X:

TELEX:
1. DR. ORTWIN JOCH

2 .

3 .

\begin{tabular}{ll|ll|ll|} 
& \multicolumn{2}{|c}{ <PERSONNEL>> } & & & \\
AFGHAN : & 6 & TECHNICAL: & 7 & PAK.BASED: & $\mathbf{8}$ \\
PAKISTANI : & 1 & ADMINISTRATIVE: & 1 & AFGHA.BASED: & - \\
EXPAT: & 1 & FIELD: & - & CROSS-BORDER: & - \\
TOTAL: & $\mathbf{8}$ & TOTAL: & $\mathbf{8}$ & TOTAL: & $\mathbf{8}$ \\
\hline
\end{tabular}

\begin{tabular}{|c|c|c|c|c|}
\hline & ( & & & \\
\hline $\begin{array}{l}\mathrm{U} \\
\mathrm{N}\end{array}$ & 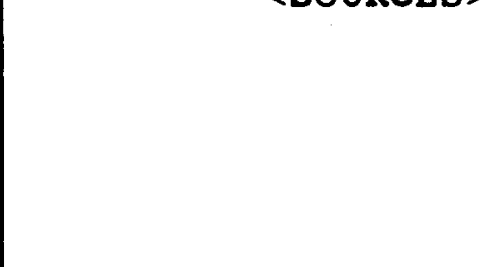 & & \begin{tabular}{|l} 
AGRICULTURE \\
ASSISTANCE TO RETURNEES \\
CONSTRUCTION (ROAD/BRIDGE) \\
CONSTRUCTION (BUILDING/SHELTER) \\
EDUCATION \\
EMERGENCY
\end{tabular} & \\
\hline $\begin{array}{l}0 \\
T \\
H \\
E \\
\text { R } \\
\text { S }\end{array}$ & $\begin{array}{l}\text { EC } \\
\text { PRIVATE DONATIONS }\end{array}$ & $\begin{array}{l}80 \% \\
20 \%\end{array}$ & $\begin{array}{l}\text { HEALTH } \\
\text { INCOME GENERATION } \\
\text { IRRIGATION } \\
\text { MINE } \\
\text { RELIEF } \\
\text { OTHER }\end{array}$ & $100 \%$ \\
\hline
\end{tabular}

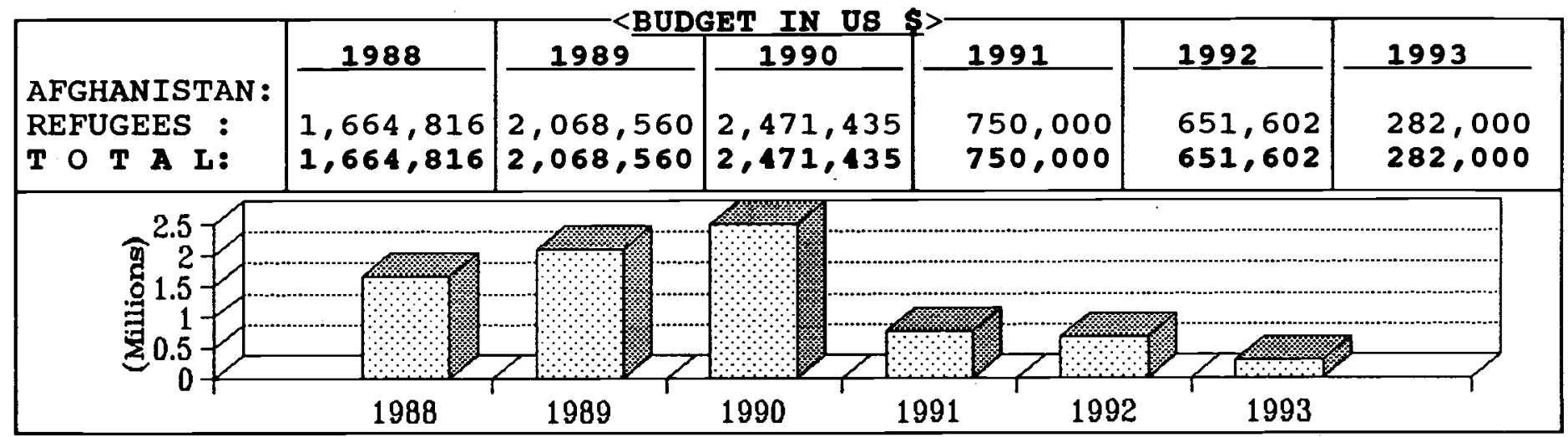

\begin{tabular}{|c|c|c|c|c|c|}
\hline PROVINCES & SECTOR & \&AGE & PROVINCES & SECTOR & \&AGE \\
\hline $\begin{array}{l}\text { BADAKSHAN } \\
\text { BADGHIS } \\
\text { BAGHLAN } \\
\text { BALKH } \\
\text { BAMYAN } \\
\text { FARAH } \\
\text { FARYAB } \\
\text { GHAZNI } \\
\text { GHOR } \\
\text { HELMAND } \\
\text { HERAT } \\
\text { JAWZJAN } \\
\text { KABUL } \\
\text { KANDAHAR } \\
\text { KAPISA }\end{array}$ & & & $\begin{array}{l}\text { KUNAR } \\
\text { KUNDUZ } \\
\text { LAGHMAN } \\
\text { LOGAR } \\
\text { NANGARHAR } \\
\text { NIMROZ } \\
\text { ORUZGAN } \\
\text { PAKTEKA } \\
\text { PAKTIA } \\
\text { PARWAN } \\
\text { SAMANGAN } \\
\text { TAKHAR } \\
\text { WARDAK } \\
\text { ZABUL }\end{array}$ & & \\
\hline
\end{tabular}


was founded in 1981 as a fundraising agency. HELP's main aim is to provide aid for Afghan Refugees. HELP receives funds from private donors and public subsidies.

The following independent, humanitarian relief organizations are currently supported by HELP:

1. Joint project of HELP and Interplast Germany: "Plastic and Reconstructive surgery for Afghans". The project was started in November 1989 and funded by the German Foreign office until April 1992. Since May 1992 it is funded by the European Community. Every month one team of plastic - hand - and microsurgeons comes to Peshawar to operate on patients suffering from:

- war injuries

- remaining deformities of face, hands, arms, feet, legs

- scar contracture after burns

- wounds failing to heal

- congenita l/a cquired malformations (e.g children with cleft lip, club foot, post polio paralysis).

Consultations are available daily (except Friday) at $4.00 \mathrm{pm}$ by:

Dr. Joch (Inter-plast),

13 Abdara Rd, U/T, Peshawar

Tel. 840776

2. Dental Clinic for Afghan Refugees is equipped with six dental chairs, $x$-ray and laboratory, and examines/treats 250 patients per day. Complete or partial dentures are provided. HELP and NRC/NCA are the main sponsors.

From 1993 HELP is considering projects inside Afghanistan. 
HELP THE AFGHANS FOUNDATION-HAF

\begin{tabular}{|c|c|c|}
\hline$<$ ADDRESS $>$ & CCOMMUNICATION LINES & STAFE \\
\hline $\begin{array}{l}\text { 10-B PARK LANE, U/T } \\
\text { P O BOX } 819 \\
\text { PESHAWAR, PAKISTAN }\end{array}$ & $\begin{array}{l}\text { PHONE: } 840621 \\
\text { F A X: } 840621 \\
\text { TELEX: }\end{array}$ & $\begin{array}{l}\text { 1. DR. A. VAN DER BUNT } \\
\text { 2. } \\
\text { 3. }\end{array}$ \\
\hline
\end{tabular}

\begin{tabular}{|ll|ll|ll|}
\hline AFGHAN : & - & TECHNICAL: & 0 & PAK. BASED: & 1 \\
PAKISTANI : & - & ADMINISTRATIVE: & 1 & AFGHA.BASED: & 0 \\
EXPAT: & 1 & FIELD: & 0 & CROSS-BORDER: & 0 \\
TOTAL: & 1 & TOTAL: & 1 & TOTAL: & 1 \\
\hline
\end{tabular}

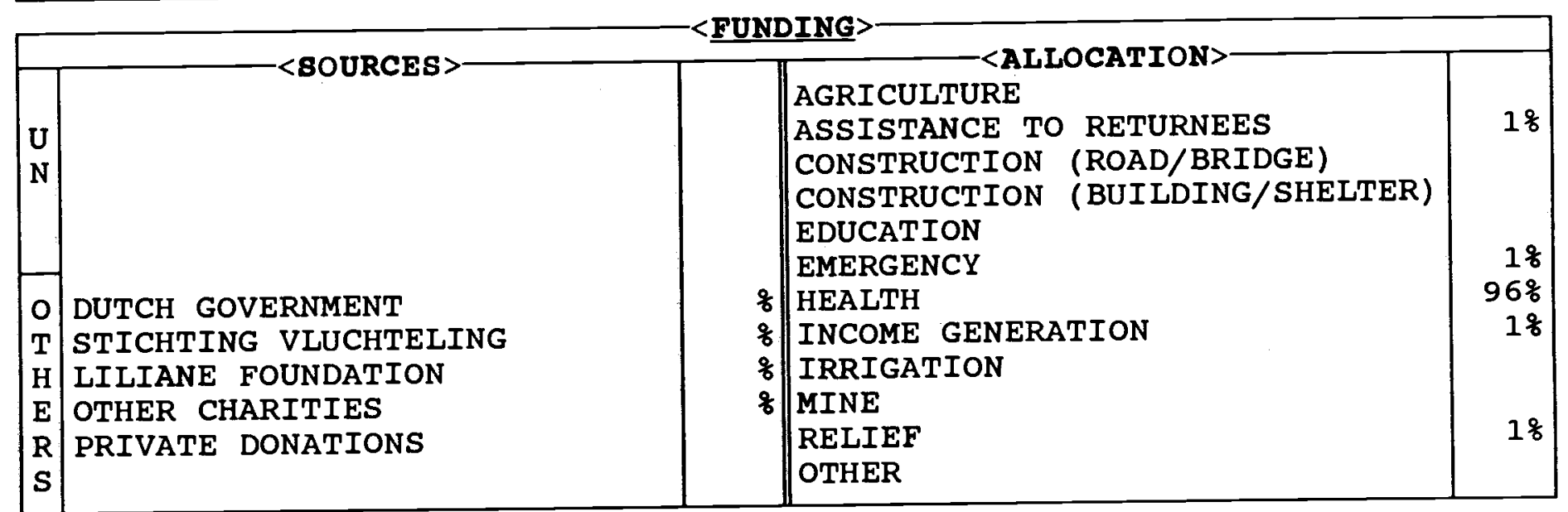

\begin{tabular}{|c|c|c|c|c|c|c|}
\hline & 1988 & 1989 & 1990 & 1991 & 1992 & 1993 \\
\hline $\begin{array}{l}\text { AFGHANISTAN : } \\
\text { REFUGEES : } \\
\text { T O T A L: }\end{array}$ & $\begin{array}{l}421,753 \\
421,753\end{array}$ & $\begin{array}{l}372,184 \\
372,184\end{array}$ & $\begin{array}{l}464,450 \\
464,450\end{array}$ & $\begin{array}{l}391,450 \\
391,450\end{array}$ & $\begin{array}{l}345,450 \\
345,450\end{array}$ & $\begin{array}{l}316,446 \\
316,446\end{array}$ \\
\hline 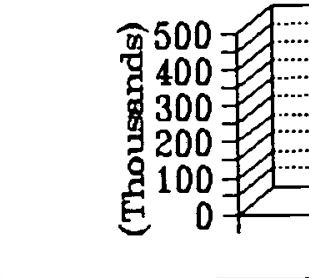 & 1988 & nux & 1990 & 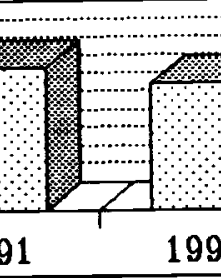 & ( & 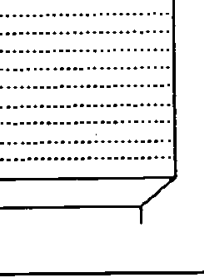 \\
\hline
\end{tabular}

\begin{tabular}{|c|c|c|c|c|c|}
\hline PROVINCES & SECTOR & $8 \mathrm{AGE}$ & PROVINCES & SECTOR & \&AGE \\
\hline $\begin{array}{l}\text { BADAKSHAN } \\
\text { BADGHIS } \\
\text { BAGHLAN } \\
\text { BALKH } \\
\text { BAMYAN } \\
\text { FARAH } \\
\text { FARYAB } \\
\text { GHAZNI } \\
\text { GHOR } \\
\text { HELMAND } \\
\text { HERAT } \\
\text { JAWZJAN } \\
\text { KABUL } \\
\text { KANDAHAR } \\
\text { KAPISA }\end{array}$ & & & $\begin{array}{l}\text { KUNAR } \\
\text { KUNDUZ } \\
\text { LAGHMAN } \\
\text { LOGAR } \\
\text { NANGARHAR } \\
\text { NIMROZ } \\
\text { ORUZGAN } \\
\text { PAKTEKA } \\
\text { PAKTIA } \\
\text { PARWAN } \\
\text { SAMANGAN } \\
\text { TAKHAR } \\
\text { WARDAK } \\
\text { ZABUL }\end{array}$ & & \\
\hline
\end{tabular}




\section{HELP THE AFGHANS FOUNDATION (HAF)}

was established in 1994 in The Hague, The Netherlands, as a relief agency for refugees from the Afghanistan war. Women, children and disabled were selected as target groups, and it was decided to fund Afghan registered non governmental organizations (NGOs) where suitable in Pakistan.

In 1986, it began supporting the children's clinic of the Afghans Health and Social Assistance organization (AHSAO) in University Town, Peshawar. Between 1987 to 1992 HELP-Germany co-sponsored the AHSAO clinic, which in 1987 added an in-patients department (IPD); to the out patient departments, (OPD, vaccination, health education). In 1990 an ORT corner was incorporated in the OPD clinic, which in 1991 was chosen for the UNICEF control of diarrhoeal diseases (CDD) training program. In 1992 Norwegian Refugee Council/Norwegian Church Aid (NRC/NCA) contributed to the budget.

In 1988 HAF took on the funding of 2 Basic Health Units (BHUs) in Aza Khel camp, implemented by AHSAO. In 1989, with the assistance of Swedish Committee for Afghanistan (SCA) and UNICEF, a Mother and Child Health Program was started in the camp. This includes an under - two clinic, nutrition education program, oral rehydration therapy (ORT), antenatal care and vaccination, Traditional Birth Attendants (TBAs) training and midwifery service.

In 1987 to 1993 HAF co-funded the Afghan obstetrics and Gynaecology Hospital (AOGH), including a prenatal unit started up in 1990 in cooperation with AHSAO.

Since 1989 HAF also funds orthopaedic operations for children performed by Dr.Al-Sayyah.
HAF has also provided medicines and medical equipment,

funded vaccination program inside Afghanistan through AVICEN, built a school in Munda Camp through Afghan Relief Foundation (ARF), equipped schools, supported income generation and training of the disabled in Pakistan through The ockenden Venture Tailoring and Carpentry Courses, and in Afghanistan through SERVE Support Services to Blind Afghans, distributed food in Pakistan through AHSAO and in Afghanistan through ARF and Afghan Aid Association.

For 1994 HAF is considering health project proposals inside Afghanistan. 
HELPING AFGKAN FARMERS ORGANIZATION-HAFO

\begin{tabular}{|l|l|l|}
\hline $47-C 1$, S A QAYUM RD, & PHONE: 41950/44677 & <KEY STAFF \\
U/T, U P O BOX 1010 & F A X: & ENG.S JAWED \\
PESHAWAR, PAKISTAN & TELEX: & 2. ENG.SADRUDDIN \\
\hline
\end{tabular}

\begin{tabular}{|lr|ll|lr|}
\hline AFGHAN: & 25 & TECHNICAL: & $\ldots$ & PAK. BASED: & 10 \\
PAKISTANI: & 0 & ADMINISTRATIVE: & $\ldots$ & AFGHA. BASED: & 7 \\
EXPAT: & 0 & FIELD: & $\ldots$ & CROSS-BORDER: & 8 \\
TOTAL: & 25 & TOTAL: & 25 & TOTAL: & 25 \\
\hline
\end{tabular}

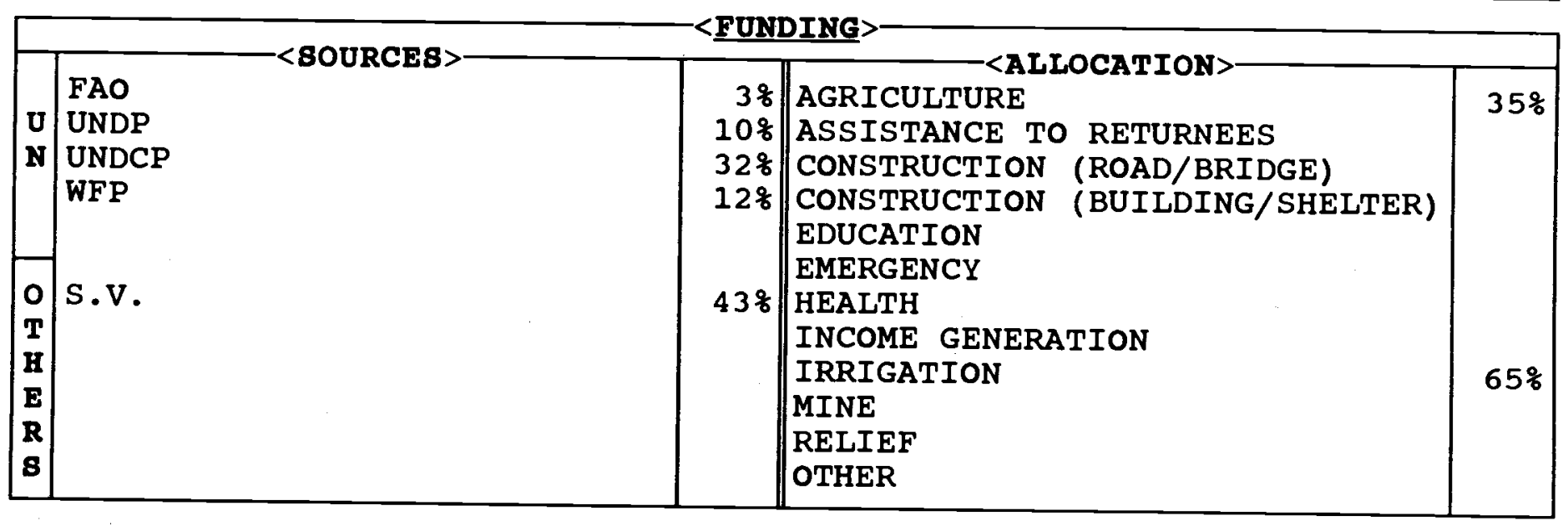

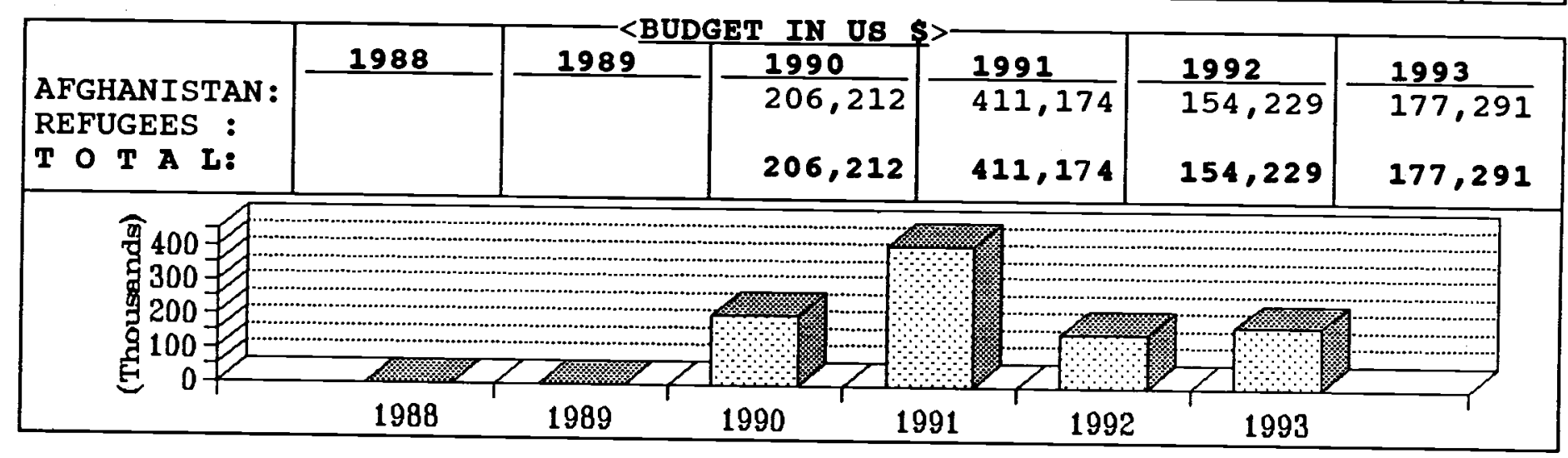

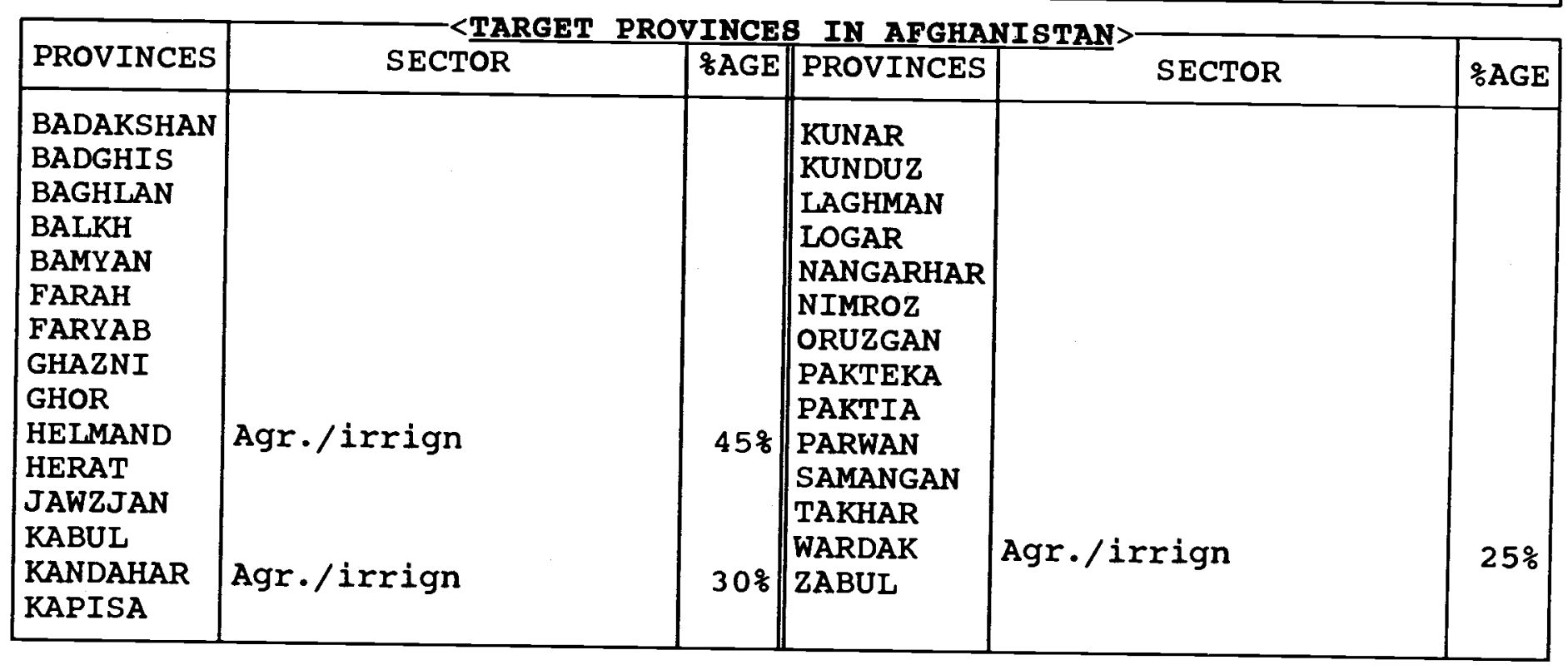




\section{HELPING AFGHAN FARMERS \\ ORGANIZATION (HAFO)}

is an indigenous Afghan nongovernmental organization providing assistance to the Afghan population in Afghanistan. HAFO began as an offshoot from a foreign relief agency, the Dutch Committee for Afghanistan (DCA). When the Dutch Committee found itself unable to continue certain programs, certain senior Afghan staff who were responsible for those programs decided to form their own NGO to continue the program.

HAFO was founded in August 1990. Since its establishment, it has grown considerably and developed its own policies and strategies.

HAFO has projects in agricultural rehabilitation, irrigation and animal husbandry programs in Helmand, Kandahar and Wardak provinces inside, Afghanistan. It intends to extend its programs to Paktia and Nangarhar provinces in 1994.

The agriculture department has one agronomist coordinator and agriculturist team leaders for each project. The irrigation and animal husbandry departments also have their coordinator; with engineers in the irrigation department and veterinary doctors in the animal husbandry department to supervise and implement the projects.

HAFO has field offices in JaghatuWardak, Shahwali Kot-Kandahar and Lashkar Gah-Helmand. By the end of 1993, HAFO will open offices in Nangarhar and Mazar-i-Sharif. Efforts are made to establish strong office structures to enable them to implement projects independently with close cooperation of local shuras.

HAFO plans to bring more land back into cultivation and to restore prewar agriculture productivity and self-sufficiency. It aims to improve local breeds, increase animal products and provide adequate water for drinking and irrigation in the areas where the agency is a $c$ t $i$ v e 
HEWAD ENGINEERING RECONSTRUCTION INSTITUTION-HERI

SHAIKH MUNDA

P O BOX.........

QUETTA, PAKISTAN

PHONE: 5150

F A X:

TELEX:
1. MR. S. H. USMANZAI

2 .

3.

\begin{tabular}{|ll|ll|ll|}
\hline AFGHAN : & 6 & TECHNICAL: & 3 & PAK. BASED: & 3 \\
PAKISTANI : & - & ADMINISTRATIVE: & 2 & AFGHA. BASED: & 1 \\
EXPAT: & - & FIELD: & 1 & CROSS-BORDER: & 2 \\
TOTAL: & 6 & TOTAL: & 6 & TOTAL: & 6 \\
\hline
\end{tabular}

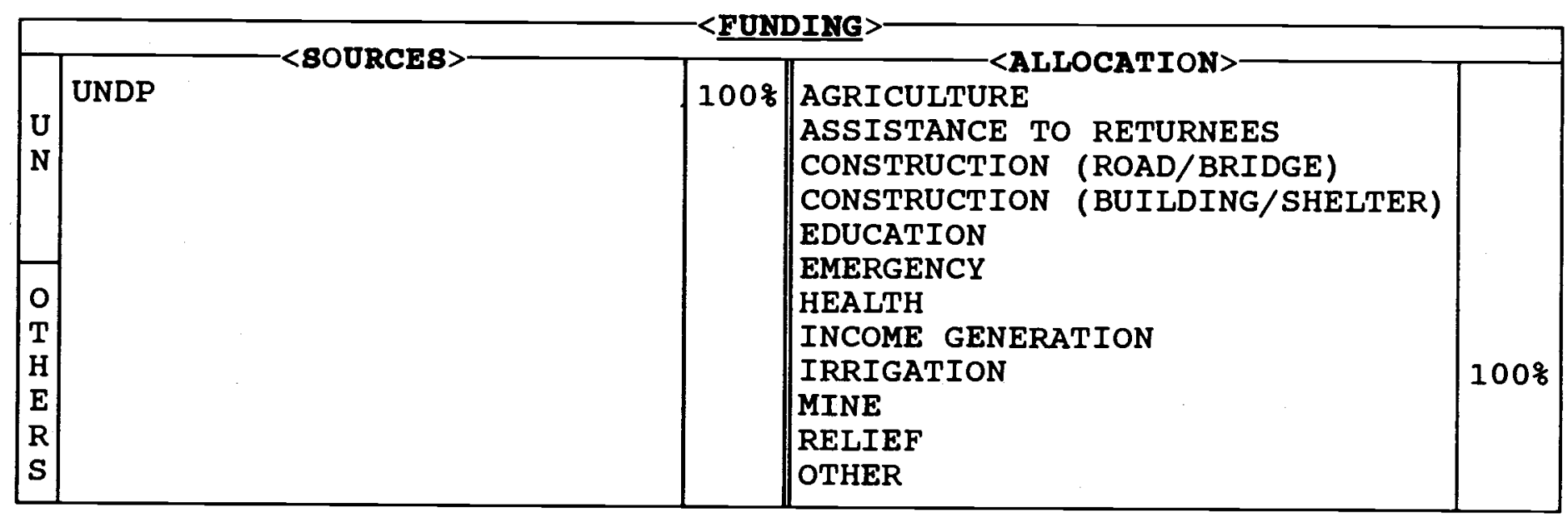

\begin{tabular}{|c|c|c|c|c|c|c|}
\hline $\begin{array}{l}\text { AFGHANISTAN: } \\
\text { REFUGEES : } \\
\text { T O T A L: }\end{array}$ & 1988 & 1989 & 1990 & 1991 & 1992 & $\begin{array}{l}1993 \\
16,600 \\
16,600\end{array}$ \\
\hline $\begin{array}{r}\text { 可16 } \\
12 \\
8 \\
0 \\
0 \\
0\end{array}$ & 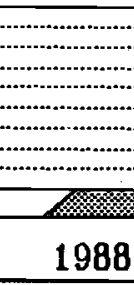 & 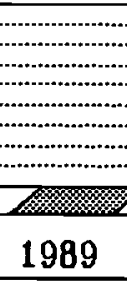 & 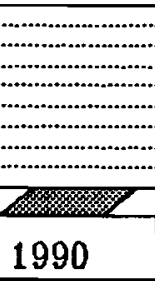 & 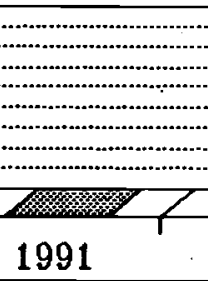 & , & 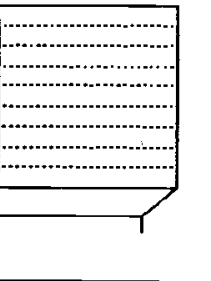 \\
\hline
\end{tabular}

\begin{tabular}{|c|c|c|c|c|c|}
\hline PROVINCES & SECTOR & \&AGE & PROVINCES & SECTOR & $\because A G E$ \\
\hline $\begin{array}{l}\text { BADAKSHAN } \\
\text { BADGHIS } \\
\text { BAGHLAN } \\
\text { BALKH } \\
\text { BAMYAN } \\
\text { FARAH } \\
\text { FARYAB } \\
\text { GHAZNI } \\
\text { GHOR } \\
\text { HELMAND } \\
\text { HERAT } \\
\text { JAWZJAN } \\
\text { KABUL } \\
\text { KANDAHAR } \\
\text { KAPISA }\end{array}$ & Irrign & 1008 & \begin{tabular}{|l} 
KUNAR \\
KUNDUZ \\
LAGHMAN \\
LOGAR \\
NANGARHAR \\
NIMROZ \\
ORUZGAN \\
PAKTEKA \\
PAKTIA \\
PARWAN \\
SAMANGAN \\
TAKHAR \\
WARDAK \\
ZABUL
\end{tabular} & & \\
\hline
\end{tabular}


HEWED ENGINEERING RECONSTRUCTION INSTITUTION (KERI)

is an Afghan nongovernmental organization founded in June 1993 . The agency is involved in engineering, agriculture, veterinary, health and education sectors.

Hewad Engineering Reconstruction Institution is currently cleaning five karezes in Kandahar province. provided that the funds are available, the agency will extend its activities to other provinces of Afghanistan primarily in the southwest provinces. 


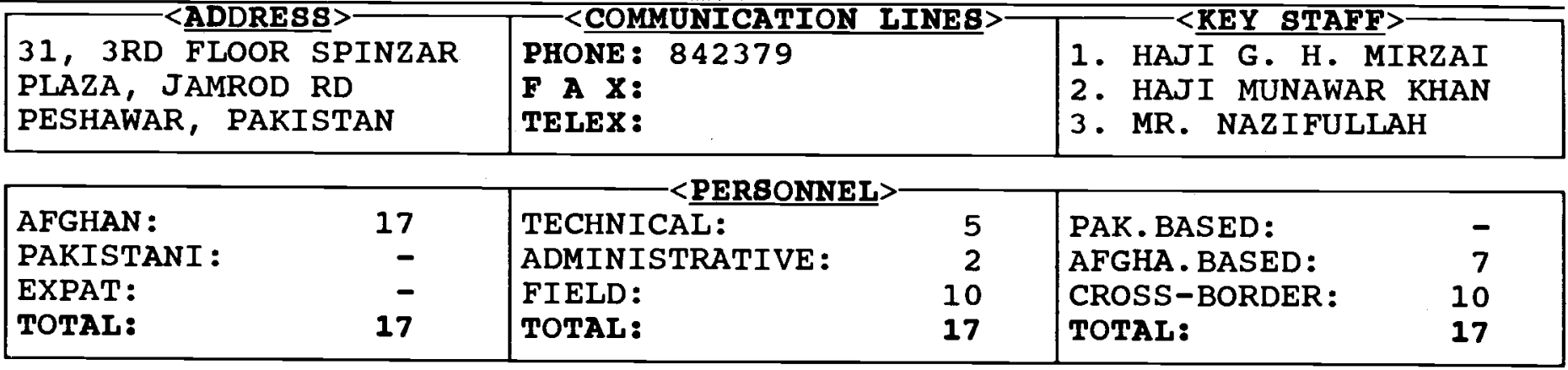

\begin{tabular}{|c|c|c|c|c|}
\hline & \multirow{2}{*}{\multicolumn{4}{|c|}{$\longrightarrow$ SOURCES $>\longrightarrow$}} \\
\hline & & & & \\
\hline $\mathrm{U}$ & UNDCP (ISRA UMBRELIA) & $62 \%$ & AGRICULTURE & $60 \%$ \\
\hline $\mathrm{N}$ & UNDP & 78 & ASSISIANCE TO REIURNEES & \\
\hline & WFP & 248 & CONSTRUCTION (BUILDING/SHELTER) & \\
\hline & & & EDUCATION & \\
\hline & & & EMERGENCY & \\
\hline $\mathrm{o}$ & & & HEALTH & \\
\hline $\mathrm{T}$ & & & INCOME GENERATION & \\
\hline $\mathrm{H}$ & & & IRRIGATION & $40 \%$ \\
\hline $\mathbf{E}$ & & & MINE & \\
\hline $\mathbf{R}$ & & & RELIEF & \\
\hline $\mathbf{S}$ & & & OTHER & \\
\hline
\end{tabular}

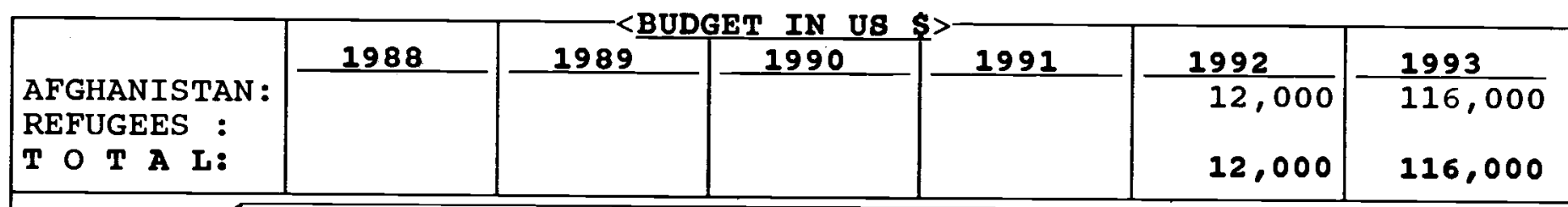

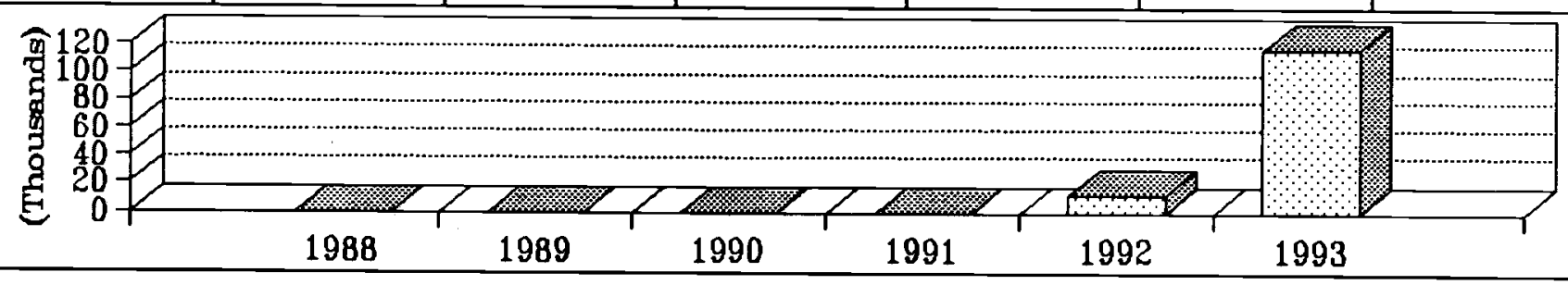

\begin{tabular}{|c|c|c|c|c|c|}
\hline PROVINCES & SECTOR & $8 \mathrm{AGE}$ & PROVINCES & SECTOR & \&AGE \\
\hline $\begin{array}{l}\text { BADAKSHAN } \\
\text { BADGHIS } \\
\text { BAGHLAN } \\
\text { BALKH } \\
\text { BAMYAN } \\
\text { FARAH } \\
\text { FARYAB } \\
\text { GHAZNI } \\
\text { GHOR } \\
\text { HELMAND } \\
\text { HERAT } \\
\text { JAWZJAN } \\
\text { KABUL } \\
\text { KANDAHAR } \\
\text { KAPISA }\end{array}$ & $\begin{array}{l}\text { Agr } \\
\text { Agr }\end{array}$ & $\begin{array}{l}15 \% \\
10 \%\end{array}$ & \begin{tabular}{||l} 
KUNAR \\
KUNDUZ \\
LAGHMAN \\
LOGAR \\
NANGARHAR \\
NIMROZ \\
ORUZGAN \\
PAKTEKA \\
PAKTIA \\
PARWAN \\
SAMANGAN \\
TAKHAR \\
WARDAK \\
ZABUL
\end{tabular} & $\begin{array}{l}\text { Agr/irrign } \\
\text { Agr/irrign } \\
\text { Agr/irrign }\end{array}$ & $\begin{array}{l}30 \% \\
30 \% \\
15 \%\end{array}$ \\
\hline
\end{tabular}


is an Afghan non-governmental and non-political organization established in 1991. The aim of the organization is to take an active part in reconstruction and rehabilitation affairs of war torn Afghanistan.

Hewad Rehabilitation Project has applied for registration to the Government of Pakistan and has a certificate of application from the Commissionerate for Afghan Refugees (CAR) . Over the past three years, HRP has been working as an implementing partner of WFP in connection with the rehabilitation of irrigation systems in eastern Afghanistan, with FAO, UNDP, UNDCP (ISRA-UMBRELLA) in connection with seed multiplication in the northern and eastern provinces of Afghanistan.

A Board of Directors consisting of nine prominent Afghans holds quarterly and annual meetings to take decision and assess the progress of the NGO. HRP plans to extend its work in different parts of Afghanistan and has already submitted proposals to the donor agencies. HRP's fields of work is construction, irrigation, agriculture and drug control. 
HUMAN CONCERN INTERNATIONAL-HCI

MATTA HOUSE, J. ABAD $P$ O BOX 880

PESHAWAR, PAKISTAN

\begin{tabular}{|c|c|}
\hline$<$ COMMUNICATION & $-<$ KEY STAFF $>$ \\
\hline $\begin{array}{l}\text { PHONE: } 840524 / 840557 \\
\text { F A X: } 840544 \\
\text { TELEX: }\end{array}$ & $\begin{array}{l}\text { 1. MR. A. S. KHADAR } \\
\text { 2. } \\
\text { 3. }\end{array}$ \\
\hline
\end{tabular}

$\begin{array}{lr}\text { AFGHAN : } & 115 \\ \text { PAKISTANI : } & 10 \\ \text { EXPAT: } & 5 \\ \text { TOTAL: } & 130\end{array}$

<PERSONNEL $>$

\begin{tabular}{lr|lr} 
TECHNICAL: & 90 & PAK. BASED: & 110 \\
ADMINISTRATIVE: & 20 & AFGHA.BASED: & 20 \\
FIELD: & 20 & CROSS-BORDER: & - \\
TOTAL: & 130 & TOTAL: & 130
\end{tabular}

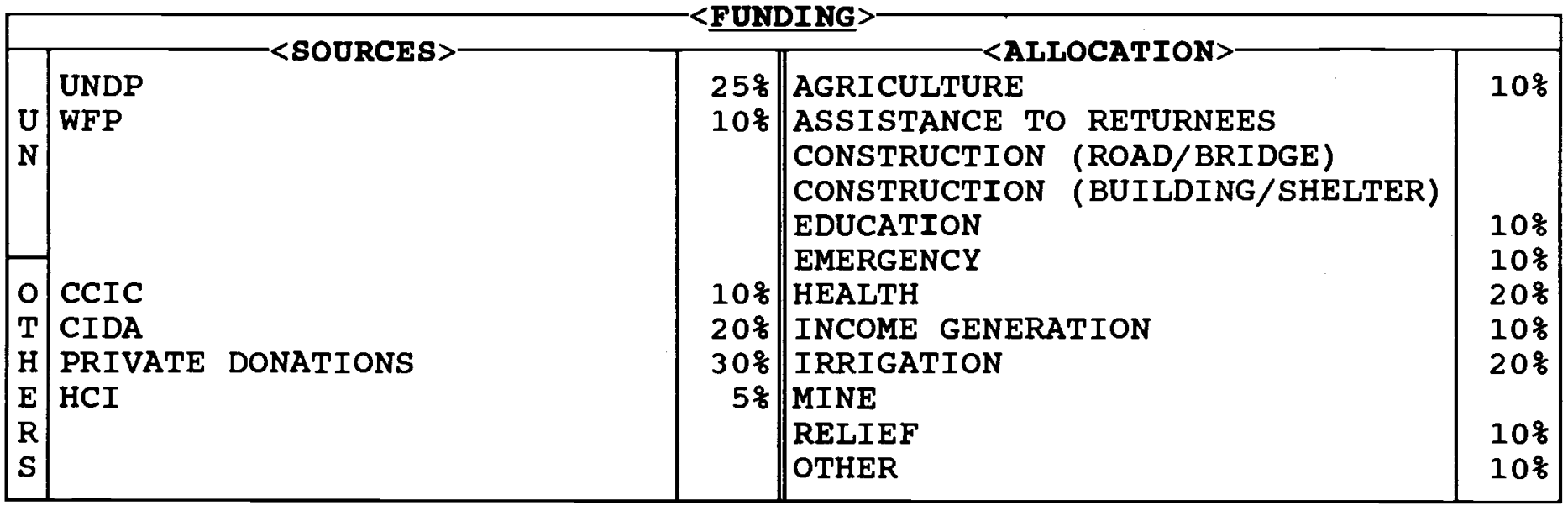

\begin{tabular}{|c|c|c|c|c|c|c|}
\hline \multirow{5}{*}{$\begin{array}{l}\text { AFGHANISTAN: } \\
\text { REFUGEES : } \\
\text { T O T A L: }\end{array}$} & & \multirow[b]{2}{*}{1991} & \multirow[b]{2}{*}{1992} & \multirow[b]{2}{*}{1993} \\
\hline & 1988 & 1989 & 1990 & & & \\
\hline & 104,554 & 827,913 & 98,010 & 109,771 & 493,236 & 400,000 \\
\hline & 716,981 & 515,670 & 588,600 & 676,890 & 463,357 & 300,000 \\
\hline & 821,535 & $1,343,583$ & 686,610 & 786,661 & 956,593 & 700,000 \\
\hline
\end{tabular}

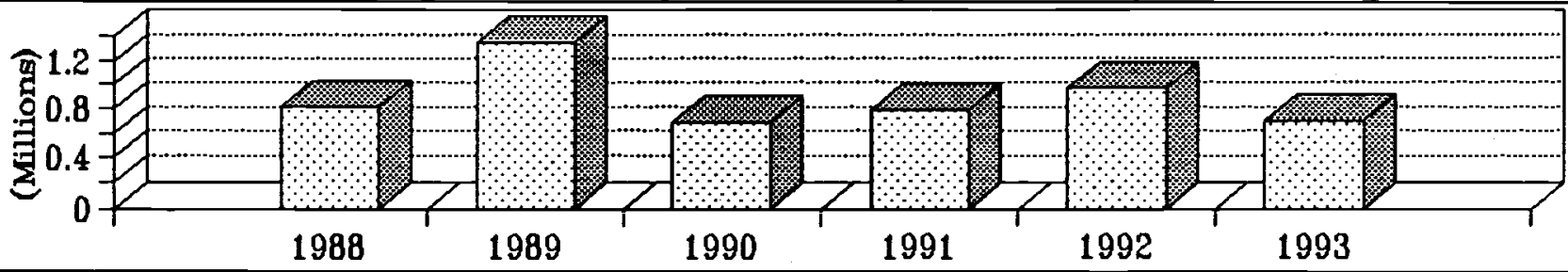

\begin{tabular}{|c|c|c|c|c|c|}
\hline PROVINCES & SECTOR & \&AGE & PROVINCES & SECTOR & $\%$ AGE \\
\hline $\begin{array}{l}\text { BADAKSHAN } \\
\text { BADGHIS } \\
\text { BAGHLAN } \\
\text { BALKH } \\
\text { BAMYAN } \\
\text { FARAH } \\
\text { FARYAB } \\
\text { GHAZNI } \\
\text { GHOR } \\
\text { HELMAND } \\
\text { HERAT } \\
\text { JAWZJAN } \\
\text { KABUL } \\
\text { KANDAHAR } \\
\text { KAPISA }\end{array}$ & & & $\begin{array}{l}\text { KUNAR } \\
\text { KUNDUZ } \\
\text { LAGHMAN } \\
\text { LOGAR } \\
\text { NANGARHAR } \\
\text { NIMROZ } \\
\text { ORUZGAN } \\
\text { PAKTEKA } \\
\text { PAKTIA } \\
\text { PARWAN } \\
\text { SAMANGAN } \\
\text { TAKHAR } \\
\text { WARDAK } \\
\text { ZABUL }\end{array}$ & $\begin{array}{l}\text { Health/Irrign } \\
\text { Engineering/health } \\
\text { Emerg/health/irrign } \\
\text { Const/educ/emerg/heal } \\
\text { Educ/irrign } \\
\text { Educ/voc.training }\end{array}$ & $\begin{array}{l}20 \% \\
15 \% \\
10 \% \\
20 \%\end{array}$ \\
\hline
\end{tabular}




\section{HUMAN CONCERN INTERNATIONAL (HCI)}

is a charitable organization headquartered in ottawa, Canada.

Human Concern International Peshawar, has been carrying out a variety of projects for Afghan Refugees since 1985 in NWFP and inside Afghanistan. It offers financial help to Afghan orphans, and educates and trains them in certain trades to enable them to earn a livelihood for themselves and their dependents. Since 1987, HCI has operated rehabilitation programs inside Afghanistan.

A school is provided for Afghan children up to the seventh grade in Akora Khattak. Hundreds of students are studying there. These students are provided with stationery and books needed for their respective classes. Lunch is served daily to about 375 orphan students.

A Vocational Center at Akora Khattak provides training facilities to Afghan boys to learn carpet making, leather work (hand bags and shoes), tailoring, carpentry, etc. These products are then exported to Middle Eastern countries, thereby earning foreign exchange for Pakistan as well as a good income for Human Concern. HCI also disburses cash money to orphan children on a monthly basis.

The mother and child care project has four Basic Health Units in Akora Khatak, where medical facilities are provided to Afghan women and children as well as training to the older and middle-aged women on the Traditional Birth Systems. Due to a lack of education, Afghan women generally will not avail themselves of services at a gynaecological center. They prefer to give birth through traditional dais. HCI undertook the training of Afghan women in traditional birth methods.

Human Concern carries out irrigation and agricultural projects inside Afghanistan and successfully completed one such project in Logar province on 31 July 1989. A Crop Production Program (Farm Power Machinery), was implemented in the same province. The project was completed by the end of October 1989. Surveys relative to agricultural, irrigation and reconstruction needs were carried out in Logar, Ghazni, Wardak and Kunar provinces.

Currently, Basic Health Units, organized by HCI, operate outpatient departments one day per week with an average of 90 patients per day.

Furthermore, HCI is running construction of irrigation projects, roads, mosques, schools and tubewells, emergency assistance, food aid and food-for-work projects, BHUs in upper Nooristan and Logar. Some immunization and veterinary projects are in the planning stage.

HCI has extended its relief program to the Kabul displaced families in Nangarhar, Logar and Paghman areas. 
HUNANITARIAN ASSISTANCE FOR AFGHANISTAN REHABILITATION-HAAR

\begin{tabular}{|l|l|l|}
\hline 6-1, PHASE 3, HAYATABAD & PHONE: 813396 & 1. QAZI UZAIR \\
P O BOX . K..... & F A X: & 2. \\
PESHAWAR, PAKISTAN & TELEX: & 3. \\
\hline
\end{tabular}

\begin{tabular}{|ll|ll|ll|}
\hline AFGHAN : & $\mathbf{8}$ & TECHNICAL: & 6 & PAK. BASED: & 3 \\
PAKISTANI: & - & ADMINISTRATIVE: & 1 & AFGHA. BASED: & - \\
EXPAT: & - & FIELD: & 1 & CROSS-BORDER: & 5 \\
TOTAL: & $\mathbf{8}$ & TOTAL: & $\mathbf{8}$ & TOTAL: & $\mathbf{8}$ \\
\hline
\end{tabular}

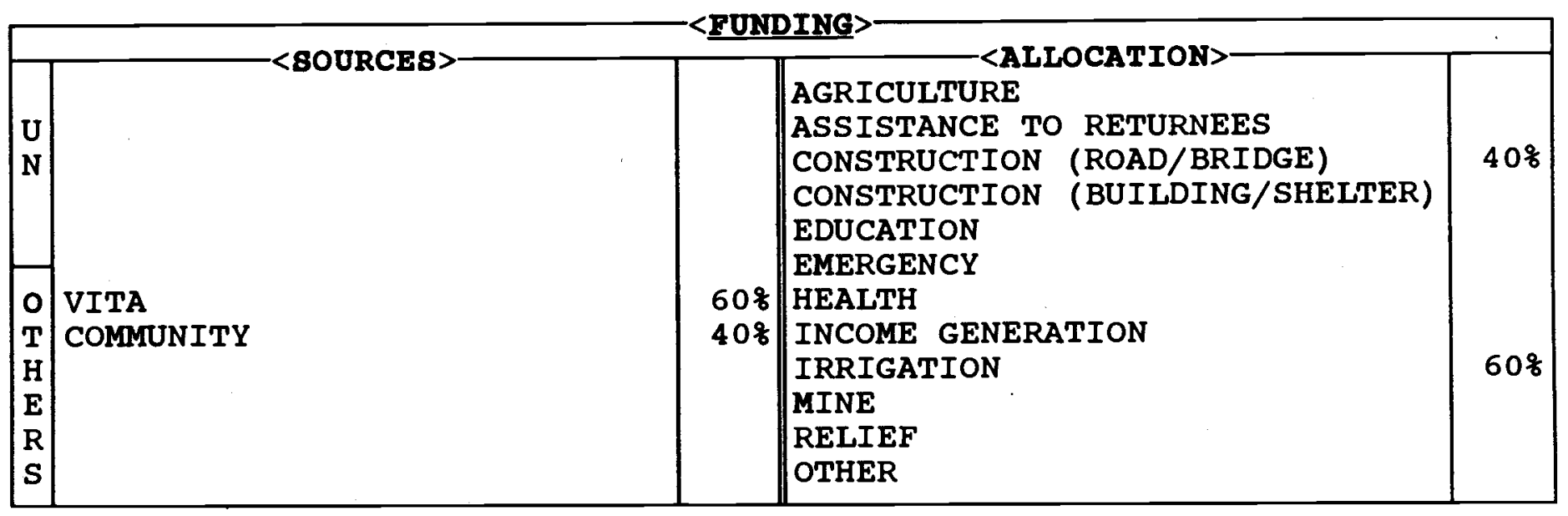

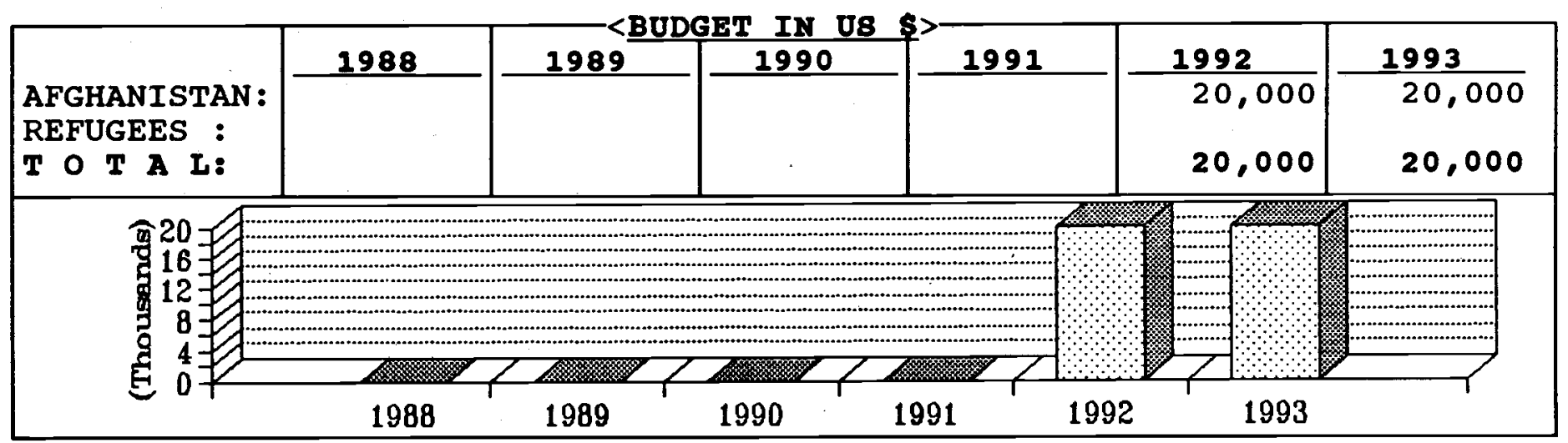

\begin{tabular}{|c|c|c|c|c|c|}
\hline PROVINCES & SECTOR & \&AGE & PROVINCES & SECTOR & \&AGE \\
\hline $\begin{array}{l}\text { BADAKSHAN } \\
\text { BADGHIS } \\
\text { BAGHLAN } \\
\text { BALKH } \\
\text { BAMYAN } \\
\text { FARAH } \\
\text { FARYAB } \\
\text { GHAZNI } \\
\text { GHOR } \\
\text { HELMAND } \\
\text { HERAT } \\
\text { JAWZJAN } \\
\text { KABUL } \\
\text { KANDAHAR } \\
\text { KAPISA }\end{array}$ & Irrign & 1008 & $\begin{array}{l}\text { KUNAR } \\
\text { KUNDUZ } \\
\text { LAGHMAN } \\
\text { LOGAR } \\
\text { NANGARHAR } \\
\text { NIMROZ } \\
\text { ORUZGAN } \\
\text { PAKTEKA } \\
\text { PAKTIA } \\
\text { PARWAN } \\
\text { SAMANGAN } \\
\text { TAKHAR } \\
\text { WARDAK } \\
\text { ZABUL }\end{array}$ & & \\
\hline
\end{tabular}




\section{HUMANITARIAN ASBISTANCE FOR AFGHANISTAN REHABILITATION (HAAR)}

is an Afghan non-political, nongovernmental and non-profit organization established in 1993.

HAAR, while sensitive to the needs of Afghans, understands their aspirations, capabilities and potential and thus it aims to play a positive role, with the support of international agencies, in the reconstruction of Afghanistan.

The organization helps in strengthening the educational and agricultural systems. It also makes efforts for building up infrastructure systems that are crucially vital to the national progress and human advancement.

Acting as a catalyst, HAAR will motivate the Afghan people to organize themselves and undertake development work on self help basis and will induce the international aid agencies to join hands with the people at grass root level for comprehensive development in Afghanistan.

The focus or Humanitarian Assistance for Afghanistan Rehabilitation is mainly on small and selected farmers, landless labor, artisans, craftsmen, un-employed women and youth and those living in poverty who constitute the vast majority of the population of Afghanistan.

HAAR fulfills its aims and objectives and transacts business through its council, executive committee, technical committee and rural volunteer corps. The organization is still in a formative stage and is passing through initial teething trouble. However, work both in the field as well as in research has started in a modest way. The village profiles will lead to the preparation of small projects with the help of the village development committees.

The comprehensive development plans will be according to the priorities fixed by the people and will be divided in three parts:

1. Projects which can be implemented on self help basis.

2. Projects which need marginal support from outside.

3. Projects which would require major support from international donors and other agencies for execution and completion.

HAAR financial resources rely on membership fees, donations, aid and consultancy services. The agency encourages the people to mobilize and manage their local resources. Participation of the people of the target villages is a must in HAAR projects. It gives more emphasis on upgrading the skills of the people and gives importance to the types of projects which create more employment opportunities for men and women. 
IDARA AHYA-UL-ULOOM-IAU

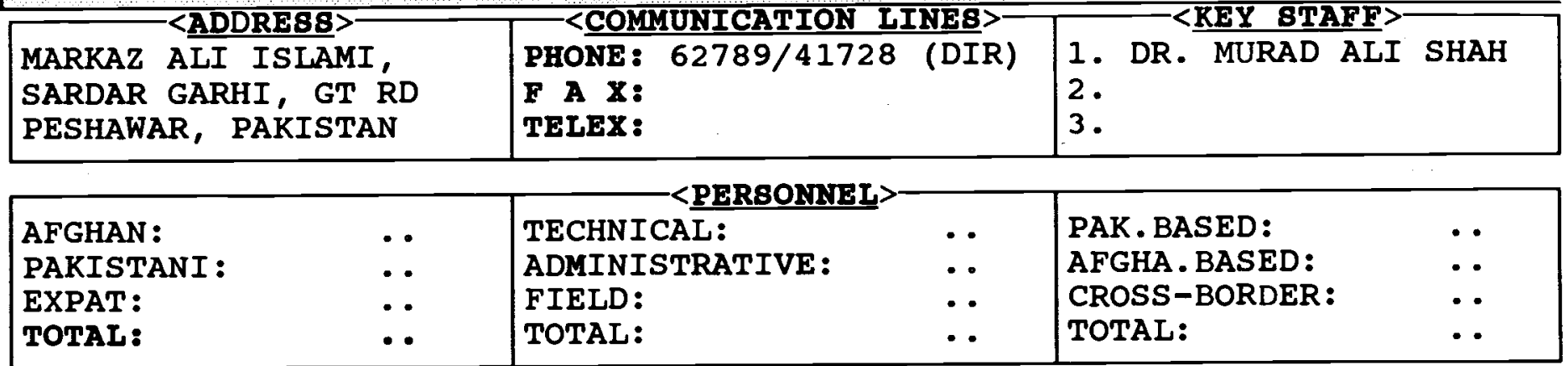

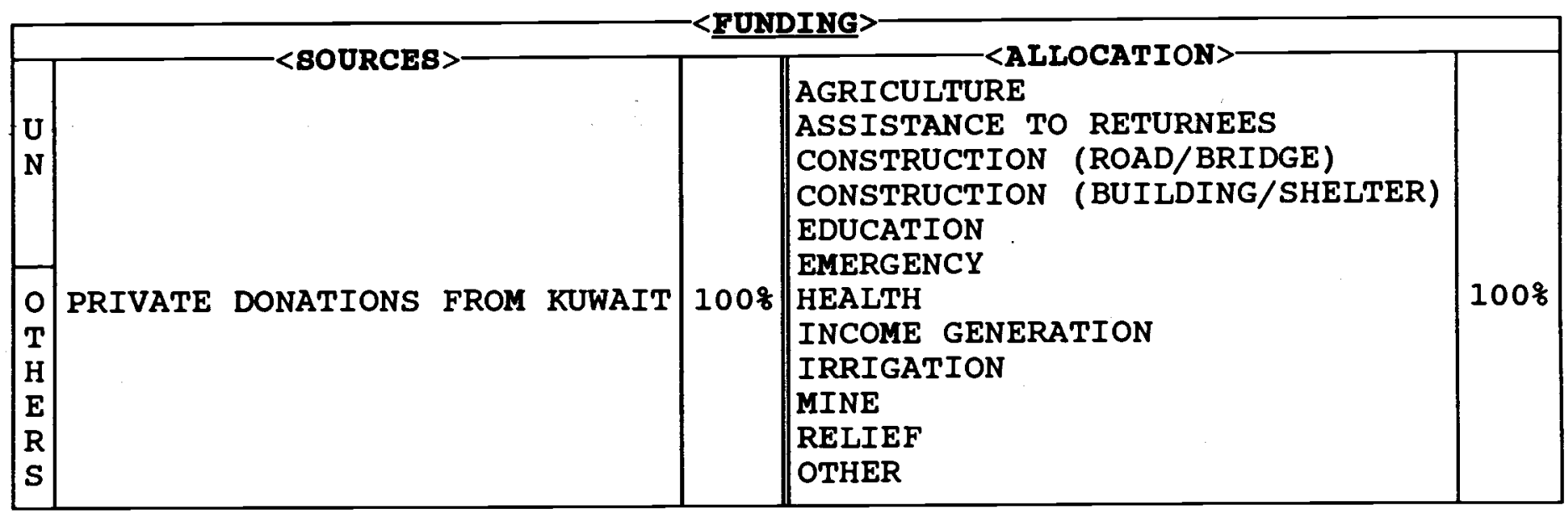

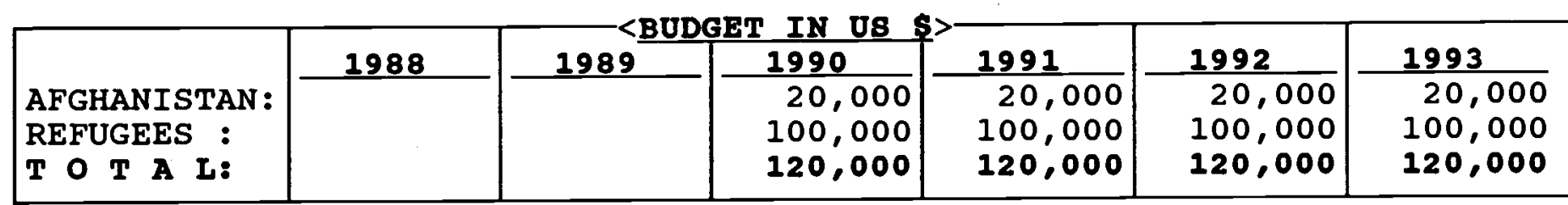

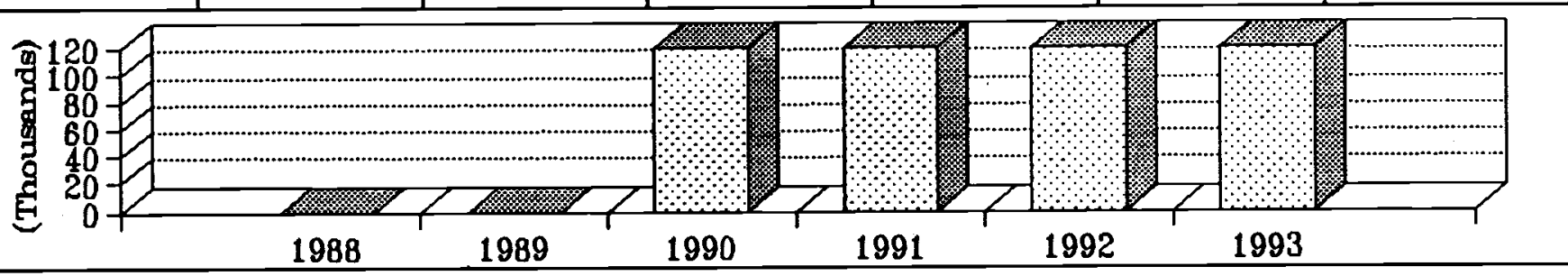

\begin{tabular}{|c|c|c|c|c|c|}
\hline PROVINCES & SECTOR & \&AGE & PROVINCES & SECTOR & \&AGE \\
\hline $\begin{array}{l}\text { BADAKSHAN } \\
\text { BADGHIS } \\
\text { BAGHLAN } \\
\text { BALKH } \\
\text { BAMYAN } \\
\text { FARAH } \\
\text { FARYAB } \\
\text { GHAZNI } \\
\text { GHOR } \\
\text { HELMAND } \\
\text { HERAT } \\
\text { JAWZJAN } \\
\text { KABUL } \\
\text { KANDAHAR } \\
\text { KAPISA }\end{array}$ & & & \begin{tabular}{|l|} 
KUNAR \\
KUNDUZ \\
LAGHMAN \\
LOGAR \\
NANGARHAR \\
NIMROZ \\
ORUZGAN \\
PAKTEKA \\
PAKTIA \\
PARWAN \\
SAMANGAN \\
TAKHAR \\
WARDAK \\
ZABUL
\end{tabular} & Health & $100 \%$ \\
\hline
\end{tabular}


is a Pakistani non-governmental organization which has been working for Afghans for the past several years.

IAU is involved in the field of health. For refugees, IAU runs a 100 bed surgical hospital for males and a 70 bed surgical hospital for females. Both hospitals are located in Peshawar. The two hospitals which are housed in one compound also provide services to the Kashmiri refugees.

In Afghanistan, a health post is operating in Jalalabad city. The post, which was originally located in Barikab, was shifted to Jalalabad after the establishment of mujahideen government in the area. The post provides first-aid treatment. There is an ambulance which evacuates seriously wounded people and bring them to the IAU Surgical Hospitals.

In the past, IAU supported 100 primary schools in different RTVs. The schools were handed over to the coalition of Mujahideen parties.

IAU is assessing the security situation in Afghanistan and would like to establish further projects in the future. 
INDEPENDENT HUMANITARIAN SERVICES ASSOCIATION-IHSAN

\begin{tabular}{|l|l|l|}
\hline NOOR FLAT, OPPOSITE TO & PHONE: 44091 & <KEY STAFF>- \\
BOARD COLONY & F A X: & 1. ENG. RAZ MOHD \\
PESHAWAR, PAKISTAN & TELEX: & 3. ENG. NOORUL HAQ \\
\hline
\end{tabular}

\begin{tabular}{|lr|lr|lr|}
\hline AFGHAN : & 26 & TECHNICAL: & 13 & PAK. BASED: & 12 \\
PAKISTANI : & 1 & ADMINISTRATIVE: & 4 & AFGHA.BASED: & 12 \\
EXPAT: & - & FIELD: & 10 & CROSS-BORDER: & 3 \\
TOTAL: & 27 & TOTAL: & 27 & TOTAL: & 27 \\
\hline
\end{tabular}

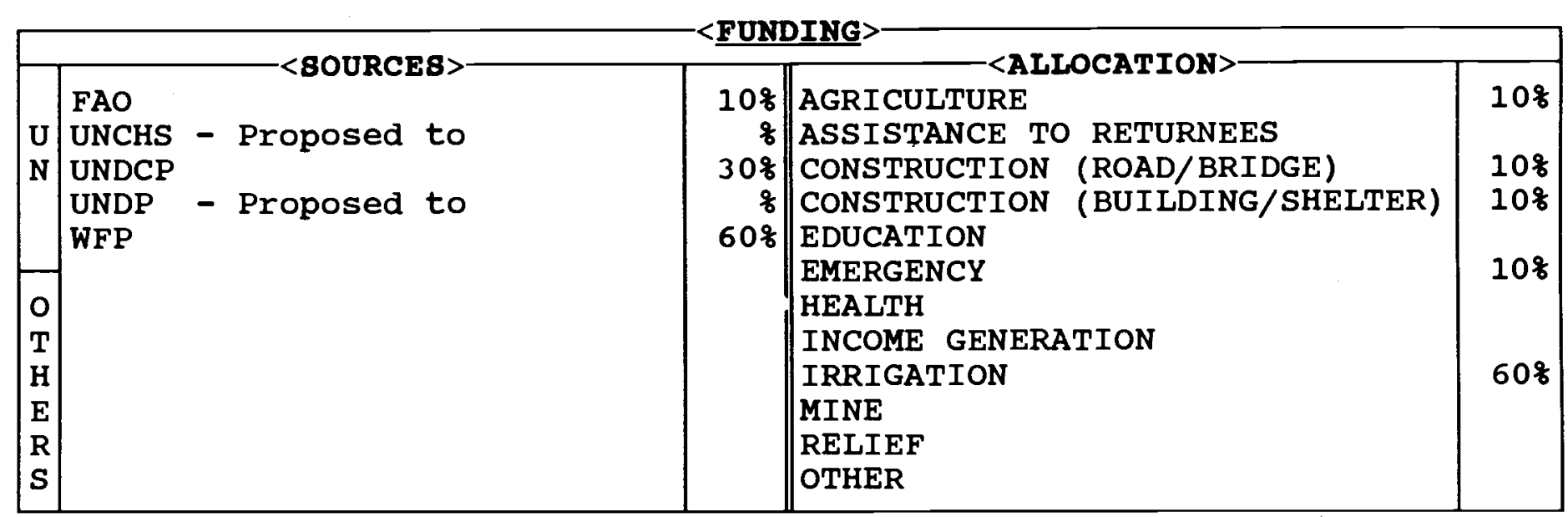

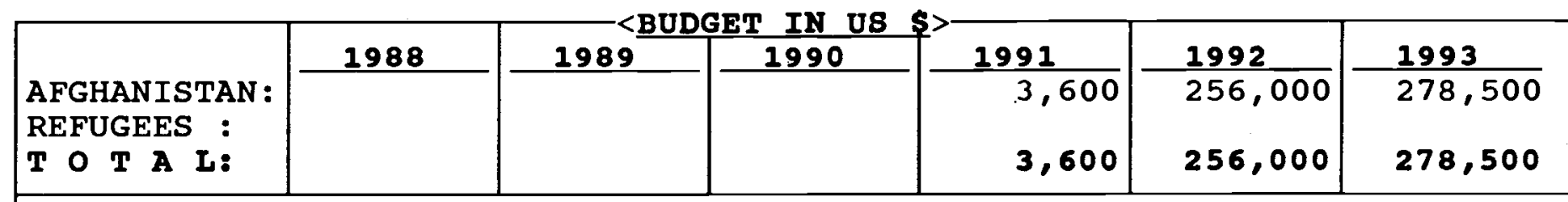

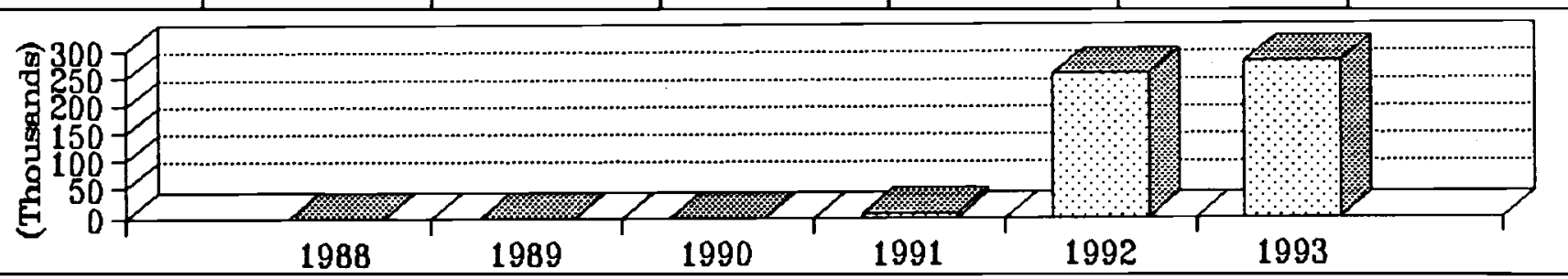

\begin{tabular}{|c|c|c|c|c|c|}
\hline PROVINCES & SECTOR & \&AGE & PROVINCES & SECTOR & \&AGE \\
\hline $\begin{array}{l}\text { BADAKSHAN } \\
\text { BADGHIS } \\
\text { BAGHLAN } \\
\text { BALKH } \\
\text { BAMYAN } \\
\text { FARAH } \\
\text { FARYAB } \\
\text { GHAZNI } \\
\text { GHOR } \\
\text { HELMAND } \\
\text { HERAT } \\
\text { JAWZJAN } \\
\text { KABUL } \\
\text { KANDAHAR } \\
\text { KAPISA }\end{array}$ & Emerg & (1) & \begin{tabular}{|l|} 
KUNAR \\
KUNDUZ \\
LAGHMAN \\
LOGAR \\
NANGARHAR \\
NIMROZ \\
ORUZGAN \\
PAKTEKA \\
PAKTIA \\
PARWAN \\
SAMANGAN \\
TAKHAR \\
WARDAK \\
ZABUL
\end{tabular} & $\begin{array}{l}\text { Agr } \\
\text { Const/irrign } \\
\text { Irrign } \\
\text { Agr/Const/irrign }\end{array}$ & $\begin{array}{r}58 \\
158 \\
58 \\
708\end{array}$ \\
\hline
\end{tabular}


is an Afghan NGO staffed with professional, well-educated, experienced and competent engineers, agrarians and qualified doctors.

The Association was established in 1991 with the basic objective of working for rehabilitation and reconstruction of Afghanistan.

The first project of the organization was an orthopedic workshop in Board, Peshawar. The workshop produced orthopedic appliances for disabled Afghans. Later on IHSAN expended its activities and started implementation of cross-border rehabilitation programs.

Over the past three years IHSAN has implemented a number of projects in different provinces but mainly in Nangarhar. The sectors vary from provision of relief commodities to Kabul displaced and needy families in Jalalabad/sarobi, to rehabilitation of irrigation channels (karezes and canals), construction of school buildings and provision of agriculture inputs (seeds, fertilizer and fruit trees).

IHSAN maintains close contacts with all local shuras and has no problems in implementing projects in the field. Local communities have helped IHSAN in implementing the projects by taking part in decision making and maintaining security for IHSAN staff and property at project sites. 


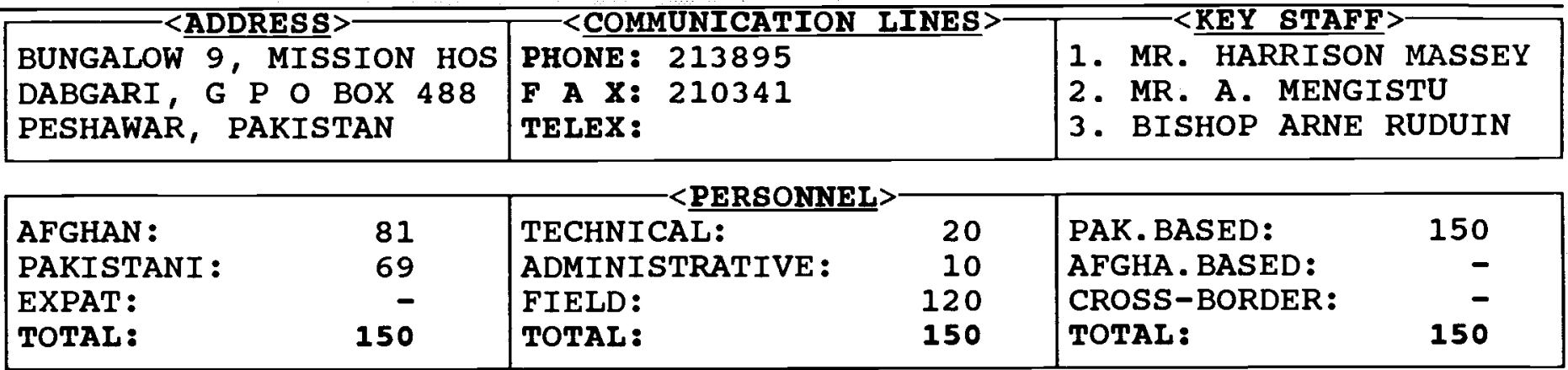

\begin{tabular}{|c|c|c|c|c|}
\hline & & & & \\
\hline & $-<$ SOURCES $>$ & & $-2<A L L O C A T I O N>-$ & \\
\hline $\mathbf{U}$ & & & $\begin{array}{l}\text { AGRICULTURE } \\
\text { ASSTSTANCE TO RETURNEES }\end{array}$ & \\
\hline $\mathbf{N}$ & & & CONSTRUCTION (ROAD/BRIDGE) & \\
\hline & & & CONSTRUCTION (BUILDING/SHELTER) & \\
\hline & BREAD FOR THE WORLD GERMANY & q & EDUCATION & \\
\hline & CEC & 8 & EMERGENCY & \\
\hline 0 & CHURCH WORLD SERVICE NY & 8 & HEALTH & $\frac{8}{8}$ \\
\hline $\mathrm{T}$ & CHRISTIAN AID UK & 8 & INCOME GENERATION & $\%$ \\
\hline $\mathrm{H}$ & DANISH CHURCH AID & $\%$ & IRRIGATION & \\
\hline $\mathbf{E}$ & ICCO HOLLAND & $\%$ & MINE & \\
\hline $\mathbf{R}$ & NRC/NCA & $\%$ & RELIEF & $\%$ \\
\hline $\mathbf{S}$ & SIDA/SWEDISH LUTHER HELPEN & \% & OTHER & \\
\hline
\end{tabular}

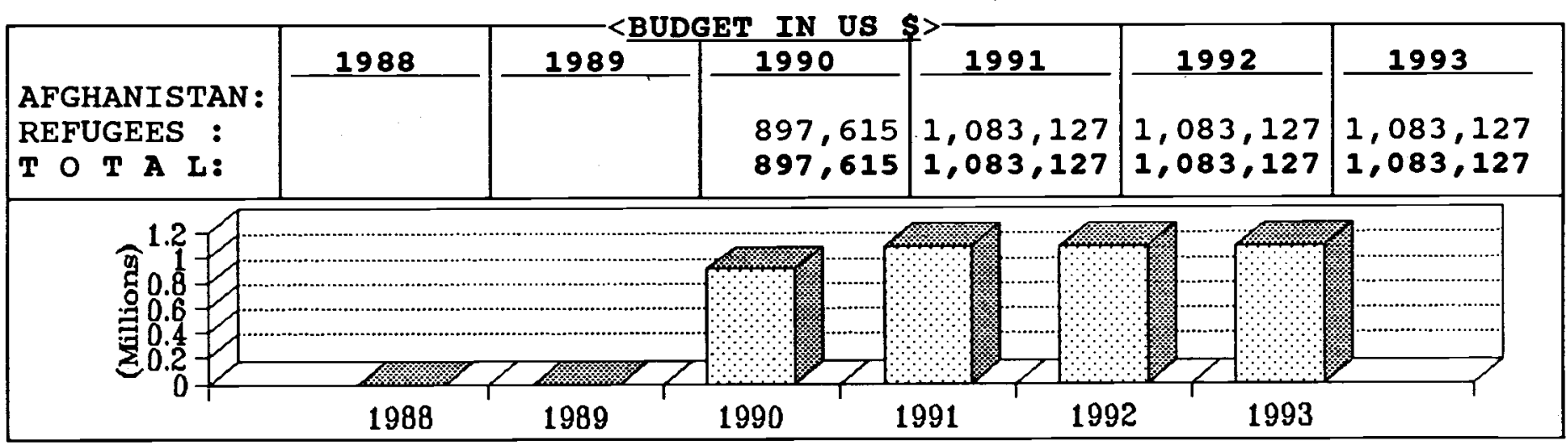

\begin{tabular}{|c|c|c|c|c|c|}
\hline PROVINCES & SECTOR & \&AGE & PROVINCES & SECTOR & \%AGE \\
\hline $\begin{array}{l}\text { BADAKSHAN } \\
\text { BADGHIS } \\
\text { BAGHLAN } \\
\text { BALKH } \\
\text { BAMYAN } \\
\text { FARAH } \\
\text { FARYAB } \\
\text { GHAZNI } \\
\text { GHOR } \\
\text { HELMAND } \\
\text { HERAT } \\
\text { JAWZJAN } \\
\text { KABUL } \\
\text { KANDAHAR } \\
\text { KAPISA }\end{array}$ & & & $\begin{array}{l}\text { KUNAR } \\
\text { KUNDUZ } \\
\text { LAGHMAN } \\
\text { LOGAR } \\
\text { NANGARHAR } \\
\text { NIMROZ } \\
\text { ORUZGAN } \\
\text { PAKTEKA } \\
\text { PAKTIA } \\
\text { PARWAN } \\
\text { SAMANGAN } \\
\text { TAKHAR } \\
\text { WARDAK } \\
\text { ZABUL }\end{array}$ & & \\
\hline
\end{tabular}




\section{INTER CHURCH AID (ICA)}

started its programs for Afghans in 1978 with the first influx of refugees and has since become one of the longest standing and most efficient and competent NGOs involved in Afghan refugee aid. Programs launched by ICA spread over many fields ranging from emergency relief assistance to unregistered, fresh and vulnerable refugees and medical/public health projects to income generation, education and reconstruction activities.

EMERGENCY: Food items (wheat flour, edible ghee and other items) and temporary housing (tents and quilts) were provided to a total of 45,000 families $(270,000$ individuals $)$

during 1991.

INCOME GENERATION: 160 Afghan women are involved in an ICA Quilt Making Project. The women are paid for their work and the quilts are distributed to poor refugees.

RECONSTRUCTION: Around 1,000 houses in northern Pakistan and adjacent border areas in Afghanistan damaged by the earthquake in February 1991 were reconstructed through INDOORS (a branch office of ICA based in Quetta).

HEALTH/MEDICAL: ICA sponsors Mission Hospitals in Peshawar and Tank in extending their medical services towards Afghan refugees. Until the end of 1990, ICA had a number of BHUs in Kheshgi camp and an emergency health center in Kababyan.

EDUCATION: ICA supports 3 schools in Peshawar (Nazo Ana and Naheed Shaheed for girls and Mawlana Jalaludin Balkhi for boys). 5 other schools are supported in association with NRC/NCA in NWFP (Hazrat Siddiq Akbar, Hazrat Omar Farooq, Hazrat Osman, Hazrat Ali and Immam Abu Hanifa schools). Expenses covered by ICA funds include staff salaries, buildings rental, miscellaneous expenses (electricity, gas, telephone charges) and office supplies for the schools plus transportation costs for the three girls schools. The total number of students in these 8 schools is 9,104 and the number of staff is more than 350 . 
INTERNATIONAL ASSISTANCE MISSION-IAM

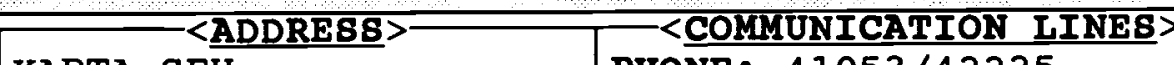

KARTA SEH

$P$ O BOX 625

KABUL, AFGHANISTAN
PHONE: $41053 / 42225$

F X: 840621

TELEX :
1. MR. BRUCE GIBBS

2. MR. HANS RONNLUND

3. MR. CLIVE UPTON

\begin{tabular}{|lr|lc|lr|}
\hline AFGHAN : & 100 & TECHNICAL: & $\ldots$ & PAK. BASED: & - \\
PAKISTANI : & - & ADMINISTRATIVE: & $\cdots$ & AFGHA.BASED: & 153 \\
EXPAT: & 53 & FIELD: & $\cdots$ & CROSS-BORDER: & - \\
TOTAL: & 153 & TOTAL: & 153 & TOTAL: & 153 \\
\hline
\end{tabular}

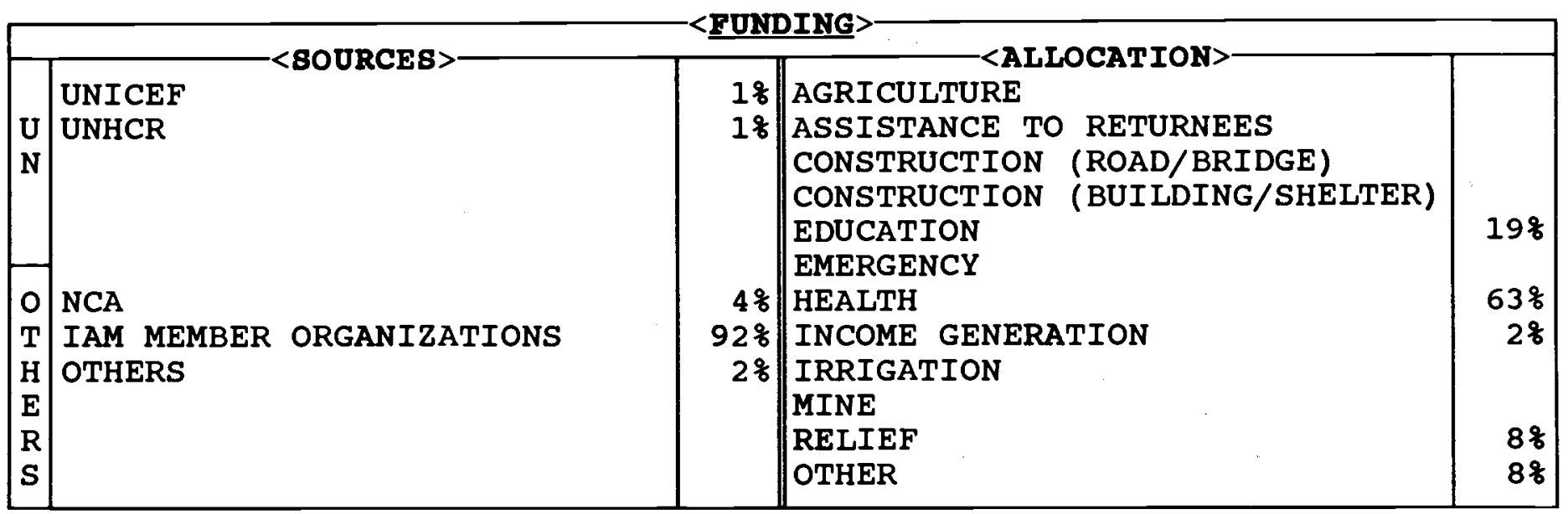

\begin{tabular}{|c|c|c|c|c|c|c|}
\hline $\begin{array}{l}\text { AFGHANISTAN: } \\
\text { REFUGEES : } \\
\text { T O T A L: }\end{array}$ & 1988 & 1989 & 1990 & 1991 & $\begin{array}{l}\frac{1992}{500,000} \\
500,000\end{array}$ & $\begin{array}{l}\frac{1993}{1,000,000} \\
1,000,000\end{array}$ \\
\hline \multirow[t]{2}{*}{ 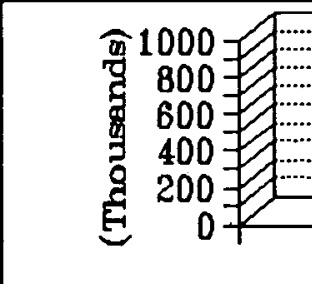 } & (1) & 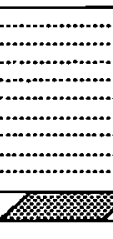 & $\cdots$ & $+1+1$ & 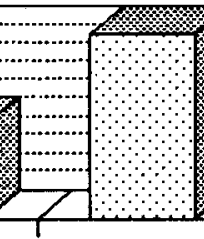 & (n) \\
\hline & 1988 & 1989 & 1990 & 1991 & 1993 & \\
\hline
\end{tabular}

\begin{tabular}{|c|c|c|c|c|c|}
\hline PROVINCES & SECTOR & \&AGE & PROVINCES & SECTOR & $\because A G E$ \\
\hline $\begin{array}{l}\text { BADAKSHAN } \\
\text { BADGHIS } \\
\text { BAGHLAN } \\
\text { BALKH } \\
\text { BAMYAN } \\
\text { FARAH } \\
\text { FARYAB } \\
\text { GHAZNI } \\
\text { GHOR } \\
\text { HELMAND } \\
\text { HERAT } \\
\text { JAWZJAN } \\
\text { KABUL } \\
\text { KANDAHAR } \\
\text { KAPISA }\end{array}$ & $\begin{array}{l}\text { Relief } \\
\text { Health } \\
\text { Health/educ/relief }\end{array}$ & $\begin{array}{r}1 \% \\
18 \\
98 \%\end{array}$ & $\begin{array}{l}\text { KUNAR } \\
\text { KUNDUZ } \\
\text { LAGHMAN } \\
\text { LOGAR } \\
\text { NANGARHAR } \\
\text { NIMROZ } \\
\text { ORUZGAN } \\
\text { PAKTEKA } \\
\text { PAKTIA } \\
\text { PARWAN } \\
\text { SAMANGAN } \\
\text { TAKHAR } \\
\text { WARDAK } \\
\text { ZABUL }\end{array}$ & . & \\
\hline
\end{tabular}


has been working in Afghanistan for the past several years.

From its base in Kabul, IAM operates in Kabul city, Mazar-i-sharif and Herat.

In Kabul IAM carries out the following projects:

* Noor eye hospital.

* Mobile eye care, 1 day clinics and 2-week camps.

* Mother and child health care with the cooperation of the MOPH. The center receives approximately 100 patients a day.

* Orthopaedic clinic

* Physiotherapy school - trains 16 students per year.

* Education and rehabilitation program for visually handicapped.

* Solar technology project produces 96 (100 liters) and 294 (50 liters) solar water heaters per year.

English language courses.

A cooperation workshop with 30 trainees (mainly blind).

In Mazar-i-Sharif, IAM operates an eye clinic, mobile health clinics for displaced families (covering 50 schools) and a community based development program.

In Herat city, support is extended to the MOPH in operating an ophthalmic center.

IAM is considering community based development projects in Bamyan province and micro-hydropower plants in Kapisa province. 
INTERNATIONAL FEDERATION OF THE RED CROSB \& RED CRESCENT SOCIETIES-IFRCS

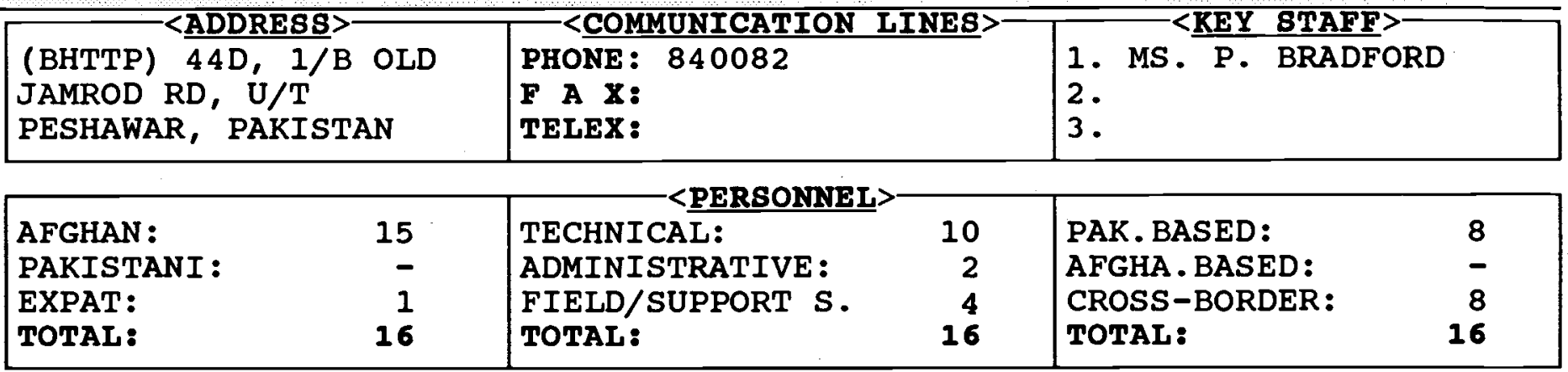
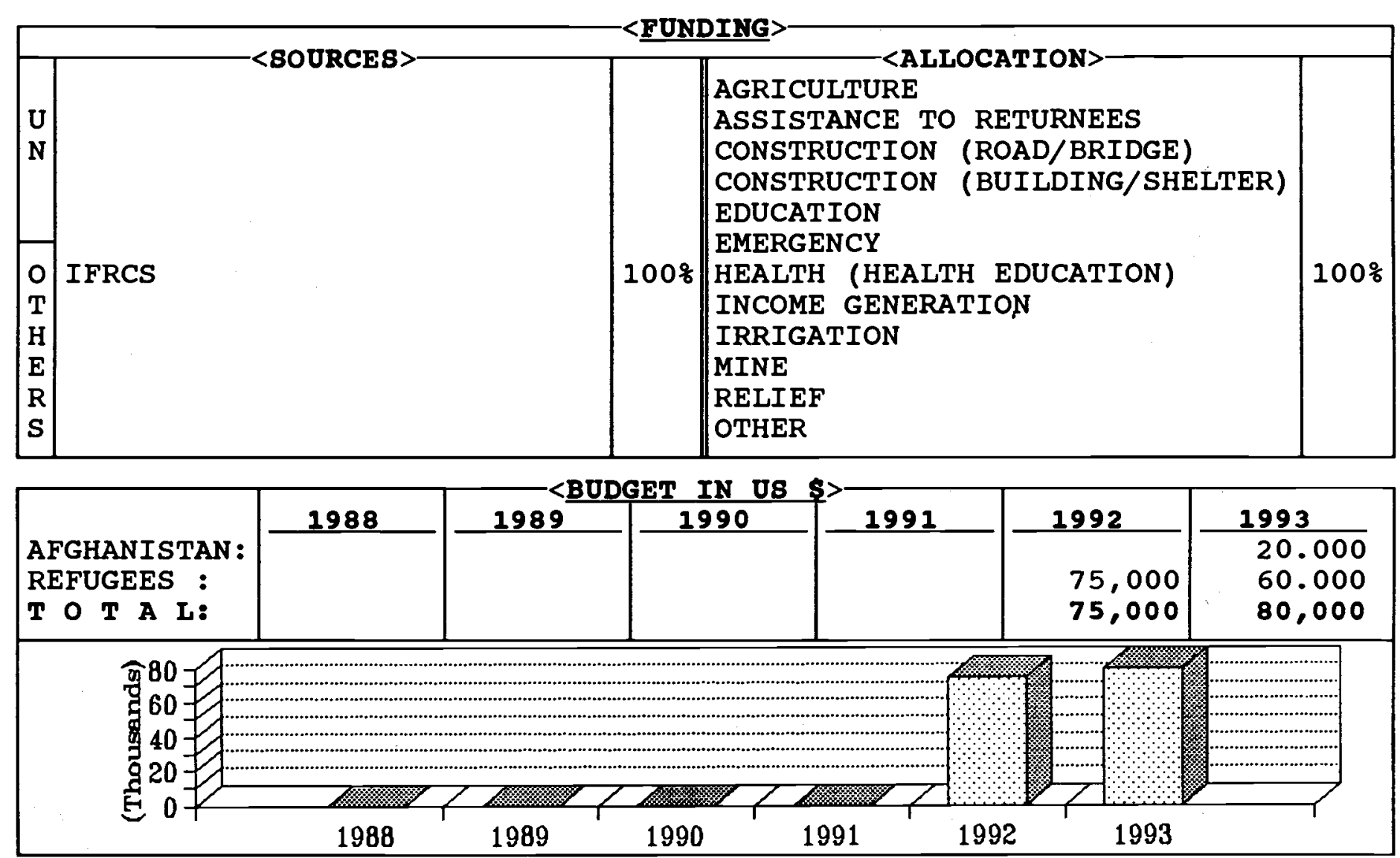

\begin{tabular}{|c|c|c|c|c|c|}
\hline PROVINCES & SECTOR & 字AGE & PROVINCES & SECTOR & $\because A G E$ \\
\hline $\begin{array}{l}\text { BADAKSHAN } \\
\text { BADGHIS } \\
\text { BAGHLAN } \\
\text { BALKH } \\
\text { BAMYAN } \\
\text { FARAH } \\
\text { FARYAB } \\
\text { GHAZNI } \\
\text { GHOR } \\
\text { HELMAND } \\
\text { HERAT } \\
\text { JAWZJAN } \\
\text { KABUL } \\
\text { KANDAHAR } \\
\text { KAPISA }\end{array}$ & $\begin{array}{l}\mathrm{H}-\mathrm{E} \\
\mathrm{H}-\mathrm{E}\end{array}$ & $\begin{array}{l}10 \% \\
20 \% \\
108\end{array}$ & $\begin{array}{l}\text { KUNAR } \\
\text { KUNDUZ } \\
\text { LAGHMAN } \\
\text { LOGAR } \\
\text { NANGARHAR } \\
\text { NIMROZ } \\
\text { ORUZGAN } \\
\text { PAKTEKA } \\
\text { PAKTIA } \\
\text { PARWAN } \\
\text { SAMANGAN } \\
\text { TAKHAR } \\
\text { WARDAK } \\
\text { ZABUL }\end{array}$ & $\begin{array}{l}\mathrm{H}-\mathrm{E} \\
\mathrm{H}-\mathrm{E} \\
\mathrm{H}-\mathrm{E} \\
\mathrm{H}-\mathrm{E} \\
\\
\mathrm{H}-\mathrm{E}\end{array}$ & $\begin{array}{l}10 \% \\
10 \% \\
10 \% \\
20 \% \\
10 \%\end{array}$ \\
\hline
\end{tabular}


The Federation and the PRCS began developing a strategy towards the improvement of basic health conditions for Afghan refugee in 1989 .

The Basic Health Training Program (BHTP) trained Afghan refugee school children to play an active role in maintaining their own health. A school health curriculum and teaching aids were field tested and revised to attain a high quality comprehensive program for Afghan refugee children.

The BHTP program has succeeded in influencing the attitudes and behavior of thousands of Afghan refugee children who will shape the future of Afghanistan.

Since 1992, a large number of Afghan refugees have returned to Afghanistan. To adapt the operation to the changing situation, the BHTP program has become the Basic Health Teacher Training Program (BHTTP) with focus being shifted to school teachers to carry out basic health training in Afghanistan. Field testing has been conducted in Jalalabad.

While the BHTTP program is continuing to be operated from Peshawar, Pakistan, it is intended to move it to Afghanistan in stages when the security situation permits. By the end of 1993, the BHTTP should have established centers in Nangarhar, Kabul, Paktia, Logar and Kunar. In early 1994 the BHTTP will begin preparing a training center in Mazar-i-Sharif which will also serve the provinces of Kunduz and Baghlan.

The program has received funding from the European Community for three years, beginning lst september 1993, and will carry out operations in Afghanistan under the auspices of the Afghan Red Crescent society. 


\begin{tabular}{|c|c|c|}
\hline$-\langle\underline{A D D R E B S}\rangle$ & <COMMUNICATION LINES> & BTAFF \\
\hline $\begin{array}{l}68 \text { E-2, ABDARA RD, U/T } \\
\text { U P O BOX } 897 \\
\text { PESHAWAR, PAKISTAN }\end{array}$ & $\begin{array}{l}\text { PHONE: } 41922 \\
\text { F A X: } 840272 \\
\text { TELEX: }\end{array}$ & $\begin{array}{l}\text { 1. MR. YUSUF AL HAMDAN } \\
\text { 2. } \\
\text { 3. }\end{array}$ \\
\hline
\end{tabular}

\begin{tabular}{|c|c|c|c|c|c|}
\hline $\begin{array}{l}\text { AFGHAN: } \\
\text { PAKISTANI: } \\
\text { EXPAT: } \\
\text { TOTAL: }\end{array}$ & $\begin{array}{l}\cdots \\
\cdots \\
\cdots\end{array}$ & $\begin{array}{l}\text { TECHNICAL: } \\
\text { ADMINISTRATIVE: } \\
\text { FIELD: } \\
\text { TOTAL: }\end{array}$ & $\begin{array}{l}\bullet \\
\ddot{\bullet} \\
\ddot{\bullet} \\
\bullet\end{array}$ & $\begin{array}{l}\text { PAK. BASED: } \\
\text { AFGHA. BASED: } \\
\text { CROSS-BORDER: } \\
\text { TOTAL: }\end{array}$ & $\begin{array}{l}\cdots \\
\cdots \\
\cdots\end{array}$ \\
\hline
\end{tabular}

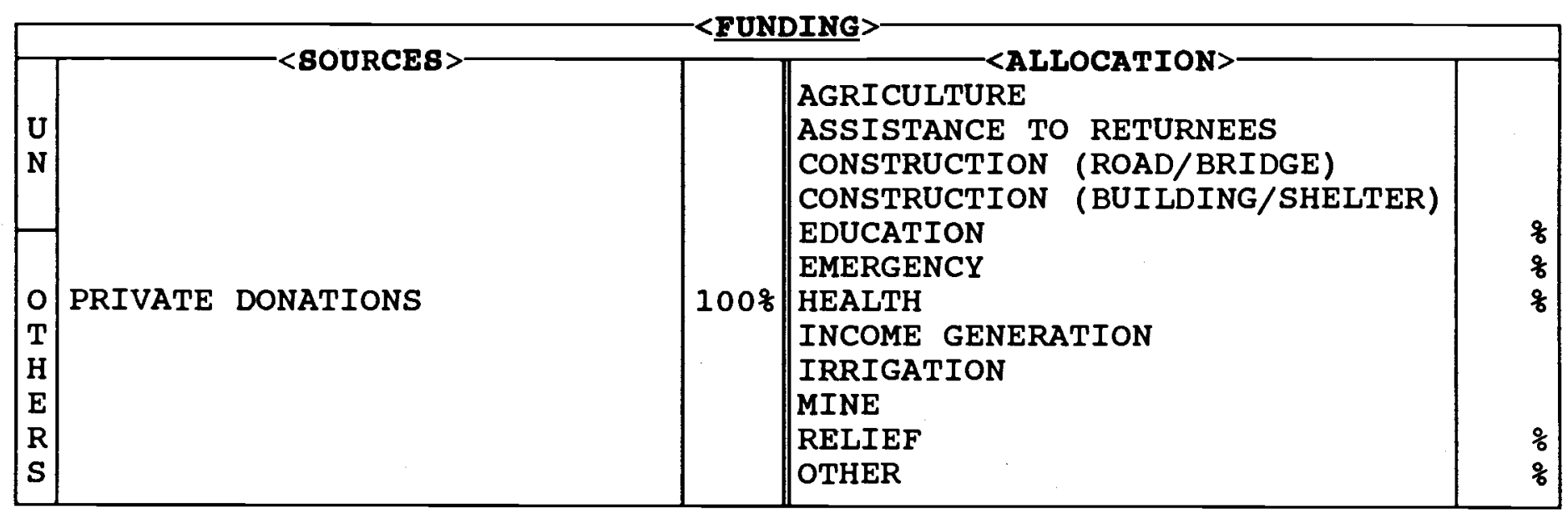

\begin{tabular}{|c|c|c|c|c|c|c|}
\hline & 1988 & 1989 & 1990 & 1991 & 1992 & 1993 \\
\hline $\begin{array}{l}\text { AFGHANISTAN: } \\
\text { REFUGEES : } \\
\text { T O T A L: }\end{array}$ & & & & & & \\
\hline
\end{tabular}

\begin{tabular}{|c|c|c|c|c|c|}
\hline PROVINCES & SECTOR & \%AGE & PROVINCES & SECTOR & \&AGE \\
\hline $\begin{array}{l}\text { BADAKSHAN } \\
\text { BADGHIS } \\
\text { BAGHLAN } \\
\text { BALKH } \\
\text { BAMYAN } \\
\text { FARAH } \\
\text { FARYAB } \\
\text { GHAZNI } \\
\text { GHOR } \\
\text { HELMAND } \\
\text { HERAT } \\
\text { JAWZJAN } \\
\text { KABUL } \\
\text { KANDAHAR } \\
\text { KAPISA }\end{array}$ & & & $\begin{array}{l}\text { KUNAR } \\
\text { KUNDUZ } \\
\text { LAGHMAN } \\
\text { LOGAR } \\
\text { NANGARHAR } \\
\text { NIMROZ } \\
\text { ORUZGAN } \\
\text { PAKTEKA } \\
\text { PAKTIA } \\
\text { PARWAN } \\
\text { SAMANGAN } \\
\text { TAKHAR } \\
\text { WARDAK } \\
\text { ZABUL }\end{array}$ & & \\
\hline
\end{tabular}


INTERNATIONAL ISLAMIC RELIEP

ORGANIZATION (IIRO)

is a non-governmental organization headquartered in Jeddah, Saudi Arabia. IIRO has been working for Afghan refugees in Pakistan, Iran and Afghans inside the country for the past several years.

IIRO's areas of work include health, education/training, orphan care and social welfare.

A health institute is run in Peshawar, which trains approximately 75 Afghans in four different sections ( $X$-ray, anesthesia, laboratory and preventive medicine).

IIRO operates four hospitals for Afghan refugees:

1) A 30 bed hospital for female and children in Miranshah.

2) A 40 bed hospital for male in Miranshah.

3) A 40 bed hospital for female and children in Dara, Peshawar.

4) A 40 bed hospital for female and children in Quetta Baluchistan.

Moreover, IIRO runs a dental clinic and an $\mathrm{MCH}$ clinic in Shamshatu camp, a dental clinic in Warsak, a clinic in Kohat area, an $\mathrm{MCH}$ clinic in Gilgit and a BHU in Khardand, Kurram Agency.

In Afghanistan, IIRO operates 3 hospitals:

1) A 40 bed hospital in Khost of Paktia.

2) An 18 bed hospital in Parwan province.

3) A 14 bed hospital in Jawzjan province.

Re-establishment work on a hospital in Jalalabad is in progress.

Furthermore, IIRO supports the following health facilities in different parts of Afghanistan:

$A$ BHU and a first aid post in
Paktia province.

3 BHUs and 2 first aid posts in Laghman province.

4 first aid posts in Kabul.

6 BHUs in Kunar province.

7 BHUs and 2 first aid posts in Nangarhar province.

A first aid post in Farah.

5 first aid posts in Herat province.

2 first aid posts in Ghor.

A BHU in Kunduz province.

3 first aid posts in Jawzjan province.

IIRO has an orphan support program through which more than 11,000 Afghan orphans and 300 widows in Pakistan, Iran and Afghanistan are given monthly financial assistance to support their families.

IIRO runs a higher education institute in Hayatabad called Islamic Academy for Science and Technology. The Academy offers courses for B.A. and M.SC. degrees. 24 schools and 45 Quranic centers are supported by IIRO in different refugee camps and provinces of Afghanistan.

starting rehabilitation programs e.g. irrigation system rehabilitation is under consideration. 
14-F K K KHATAK RD, U/T

$G$ P O BOX 562

PESHAWAR, PAKISTAN
PHONE: 43512

F A X: 840250 TELEX:
1. MR. STEPHEN TOMLIN

2. DR. ANWARULHAQ

3. MR. SHERZAD MEHMOOD

\begin{tabular}{|lr|lr|lr|}
\hline AFGHAN: & 177 & TECHNICAL: & 99 & PAK. BASED: & 22 \\
PAKISTANI: & 3 & ADMINISTRATIVE: & 14 & AFGHA.BASED: & 150 \\
EXPAT: & 1 & FIELD: & 68 & CROSS-BORDER: & 9 \\
TOTAL: & 181 & TOTAL: & 181 & TOTAL: & 181 \\
\hline
\end{tabular}

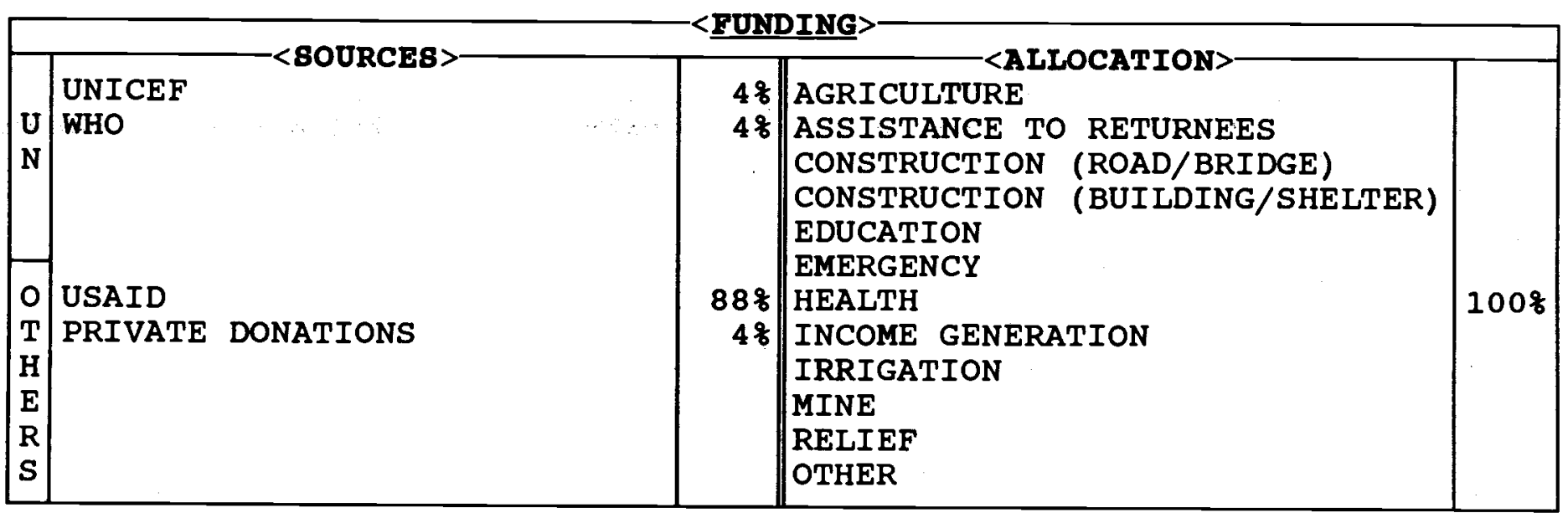

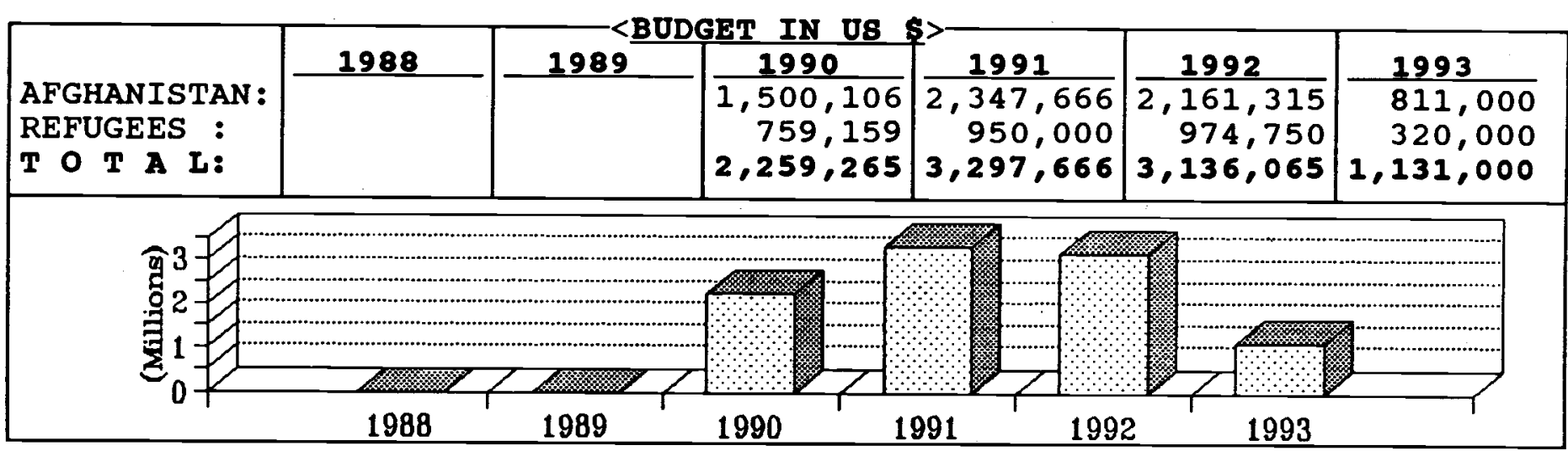

\begin{tabular}{|c|c|c|c|c|c|}
\hline PROVINCES & SECTOR & \&AGE & PROVINCES & SECTOR & \&AGE \\
\hline $\begin{array}{l}\text { BADAKSHAN } \\
\text { BADGHIS } \\
\text { BAGHLAN } \\
\text { BALKH } \\
\text { BAMYAN } \\
\text { FARAH } \\
\text { FARYAB } \\
\text { GHAZNI } \\
\text { GHOR } \\
\text { HELMAND } \\
\text { HERAT } \\
\text { JAWZJAN } \\
\text { KABUL } \\
\text { KANDAHAR } \\
\text { KAPISA }\end{array}$ & $\begin{array}{l}\text { Health } \\
\text { Health } \\
\text { Health } \\
\text { Health } \\
\text { Health } \\
\text { Health } \\
\text { Health } \\
\text { Health }\end{array}$ & $\begin{array}{c}3 \% \\
18 \\
\\
1 \% \\
6 \% \\
3 q \\
1 \% \\
15 \% \\
18\end{array}$ & \begin{tabular}{|l|} 
KUNAR \\
KUNDUZ \\
LAGHMAN \\
LOGAR \\
NANGARHAR \\
NIMROZ \\
ORUZGAN \\
PAKTEKA \\
PAKTIA \\
PARWAN \\
SAMANGAN \\
TAKHAR \\
WARDAK \\
ZABUL
\end{tabular} & $\begin{array}{l}\text { Health } \\
\text { Health } \\
\text { Health } \\
\text { Health }\end{array}$ & $\begin{array}{l}1 \% \\
3 \% \\
7 \%\end{array}$ \\
\hline
\end{tabular}




\section{INTERNATIONAL MEDICAL CORPS (IMC)}

is a private, nonpolitical, humanitarian nonsectarian, nonprofit, established in 1984 by US physicians and nurses to provide health care and training to devastated areas worldwide. Head-quartered in Los Angeles, California, IMC implements health projects in Angola, Somalia, Namibia, Bosnia and Cambodia, as well as in Afghanistan.

The philosophy behind IMC is to empower people with the knowledge to rebuild their lives and health care systems. Dedicated to the principle of helping people help themselves, it works towards the goal of encouraging self-sufficiency. The fundamental purpose of is to provide health care through training to those at highest risk.

To date, the operations of the organization in Afghanistan have been partially funded by private individuals, foundations and corporations as well as by who and UNICEF. However, the bulk of IMC operations has been funded by USAID.

Between 1985 and 1993, an extensive primary health care network was established throughout the provinces of Afghanistan, maintaining 59 clinics and hospitals. It has also operated training centers in Pakistan for the Afghan mid-level health workers, physicians, vaccinators and lab technicians that staff these facilities. More than 500 Afghan health workers will have received training by the close of 1993.

The nine years of training experience has been institutionalized under Afghan management through the Institute for Public Health, whereby IMC has transferred a model for mid-level health-worker and field microscopist refresher training to the East Zone MOPH in Jalalabad, Nangarhar Province.
The phasing-out of USAID support during 1993, however, means that IMC will approach the winter with just 18 health facilities, and support to 17 of these facilities will end by April 30, 1994. Also by this time, the organization's involvement in refresher training activities in Jalalabad will have been phased-out.

Only limited private funding to date has been secured for 1994. With this, the activities next year will focus on the delivery of curative and preventive services from the recently constructed district-level hospital in the Qarabagh district of Kabul Province. These services include an $\mathrm{MCH}$ program and a clinicbased EPI program, as well as a full range of medical and surgical services.

The 30-bed Qarabagh Hospital makes essential services available to a large number of population who were previously without medical care. The hospital is now fully staffed and equipped, and able to provide high quality medical care at an appropriate level of technology. Utilization of the facility is high, particularly in the out-Patient Department.

Over the coming year, IMC will seek ways to utilize the Qarabagh Hospital's potential to serve as a model for district hospitals throughout Afghanistan. By developing further training courses to be delivered from the Training Center that has been constructed adjacent to the hospital, IMC will seek to extend the facility's impact far beyond its immediate catchment area. A long-term goal is to be able to transfer a sustainable training model that emphasizes child survival, maternal health and environmental sanitation to the MOPH's Department of Intermediate Medical Training in Kabul. 
INTERNATIONAL ORPHANS CARE-IOC

< $>$ ADDRESS >- COMMUNICATION LINES>

JALALABAD CITY

PHONE : 811488

NANGARHAR, AFGHANISTAN

F A X: (714) 586-2217

1. DR. ABDULLAH OSMAN

2. MR. KHALILULAH POPAL

TELEX:

3. ENG.MOHD KABIR WASIL

\begin{tabular}{|lr|lr|lr}
\hline AFGHAN : & 16 & TECHNICAL: & 5 & PAK. BASED: & 2 \\
PAKISTANI: & - & ADMINISTRATIVE: & 4 & AFGHA.BASED: & 14 \\
EXPAT: & - & FIELD: & 7 & CROSS-BORDER: & - \\
TOTAL: & 16 & TOTAL: & 16 & TOTAL: & 16 \\
\hline
\end{tabular}

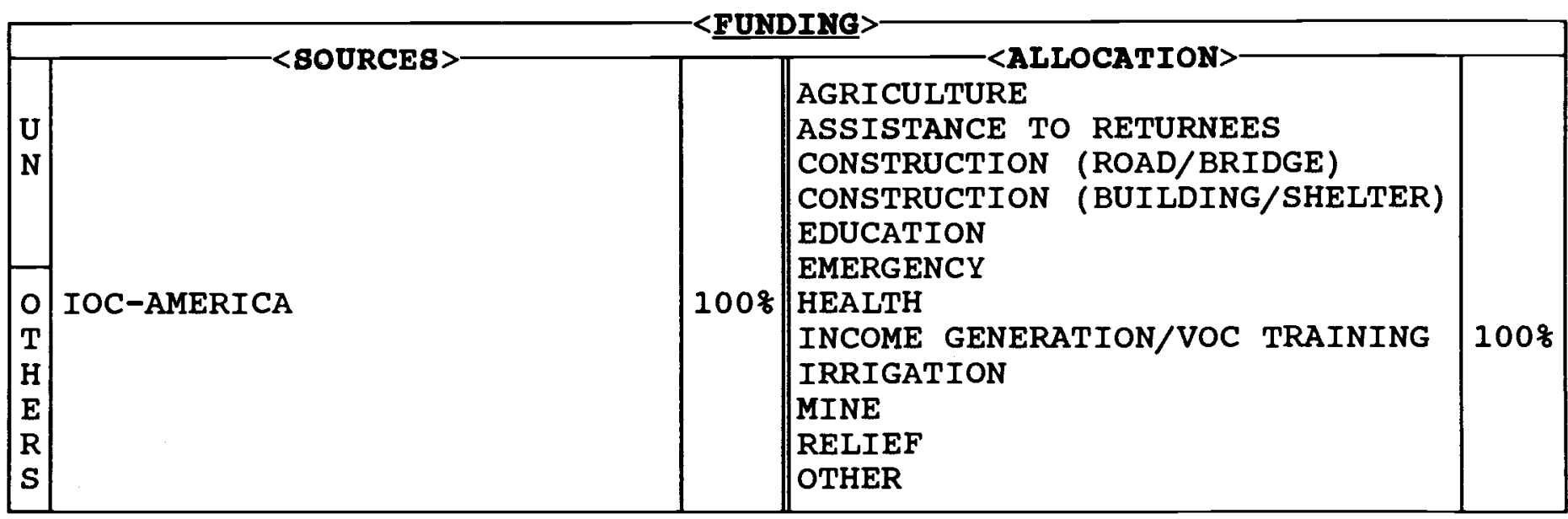

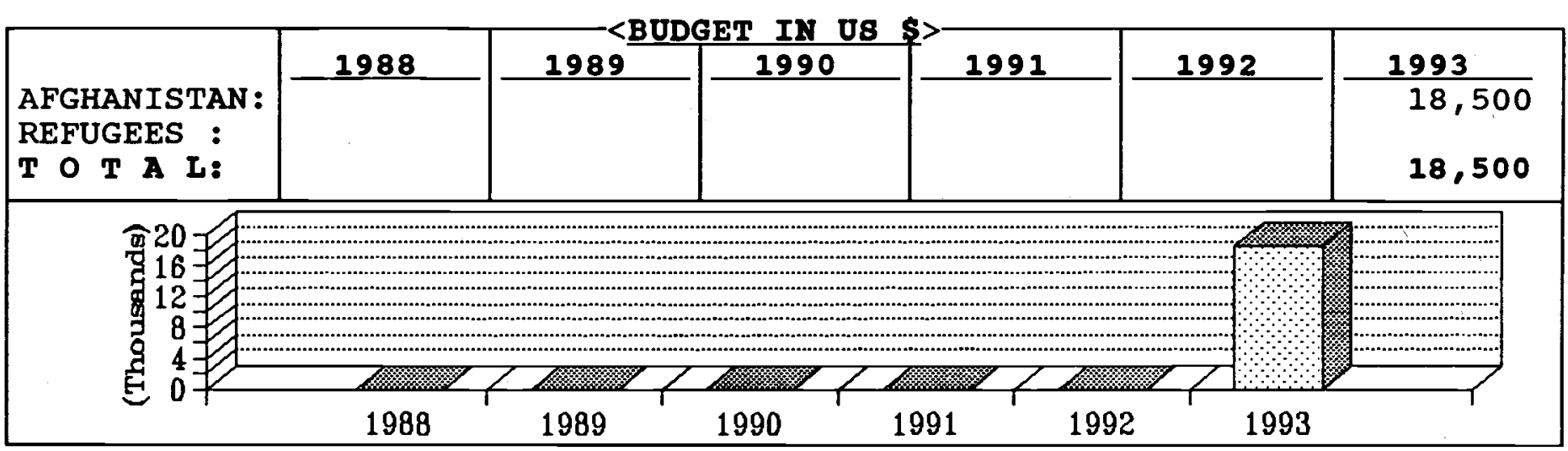

\begin{tabular}{|c|c|c|c|c|c|}
\hline PROVINCES & SECTOR & \% $\mathrm{AGE}$ & PROVINCES & SECTOR & FAGE \\
\hline $\begin{array}{l}\text { BADAKSHAN } \\
\text { BADGHIS } \\
\text { BAGHLAN } \\
\text { BALKH } \\
\text { BAMYAN } \\
\text { FARAH } \\
\text { FARYAB } \\
\text { GHAZNI } \\
\text { GHOR } \\
\text { HELMAND } \\
\text { HERAT } \\
\text { JAWZJAN } \\
\text { KABUL } \\
\text { KANDAHAR } \\
\text { KAPISA }\end{array}$ & & & \begin{tabular}{|l} 
KUNAR \\
KUNDUZ \\
LAGHMAN \\
LOGAR \\
NANGARHAR \\
NIMROZ \\
ORUZGAN \\
PAKTEKA \\
PAKTIA \\
PARWAN \\
SAMANGAN \\
TAKHAR \\
WARDAK \\
ZABUL
\end{tabular} & Voc. training & $100 \%$ \\
\hline
\end{tabular}




\section{INTERNATIONAL ORPHANS CARE (IOC)}

is an non-governmental organization headquartered in California, the USA.

In 1993, IOC established an Afghan Project. It has a sub-office in Jalalabad, Nangarhar from where it supports vocational training courses for women and children.

Estimations show that over half a million children have lost their parents over the past fourteen years of war. These children have now become a social problem to the community. IOC will focus to solve this problem by helping the Afghan orphans.

IOC has been registered with the Government Islamic state of Afghanistan and has opened an office in Kabul.

The following orphans have been registered with the organization so far:

\section{* 406 in Nangarhar \\ * 120 in Logar \\ * $\quad 27$ in Paktia \\ * $\quad 115$ in Kabul}

Ioc will make efforts to:

1. create a family like environment for the orphans,

2. impart vocational training to them,

3. provide health facilities,

4. place the orphans in foster homes and pay a small monthly stipend to cover their basic living expenses,

5. provide pre-school training in Kindergartens

6. sponsor each child with a family abroad.

At present five different courses including typing, tape repair, leather hand work, literacy and English.
For each child sponsored by a family in the USA a monthly allowance of US $\$ 15.00$ is paid.

IOC has also established a joint Kindergarten with the Relief organization for Afghan orphans and Widows (ROAOW) in Jalalabad where IOC also supports a clinic. 


\begin{tabular}{|l|l|l|l|}
\hline 41-F, S A QAYUM RD, U/T & PHONE: $41845 / 41247$ & 1. MR. JOHN DIXON \\
G P O BOX 504 & F A X: 840283 & 2. MR. ALLEN JELICH \\
PESHAWAR, PAKISTAN & TELEX: 52448 IRC PE PK & 3. MS. TOC DUNLAP
\end{tabular}

\begin{tabular}{|lr|lc|lr}
\hline AFGHAN: & 1,235 & TECHNICAL: & $\ldots$ & PAK. BASED: & 1,372 \\
PAKISTANI: & 266 & ADMINISTRATIVE: & $\ldots$ & AFGHA. BASED: & 69 \\
EXPAT: & 16 & FIELD: & 1,517 & CROSS-BORDER: & 76 \\
TOTAL: & 1,517 & TOTAL: & TOTAL: & 1,517 \\
\hline
\end{tabular}

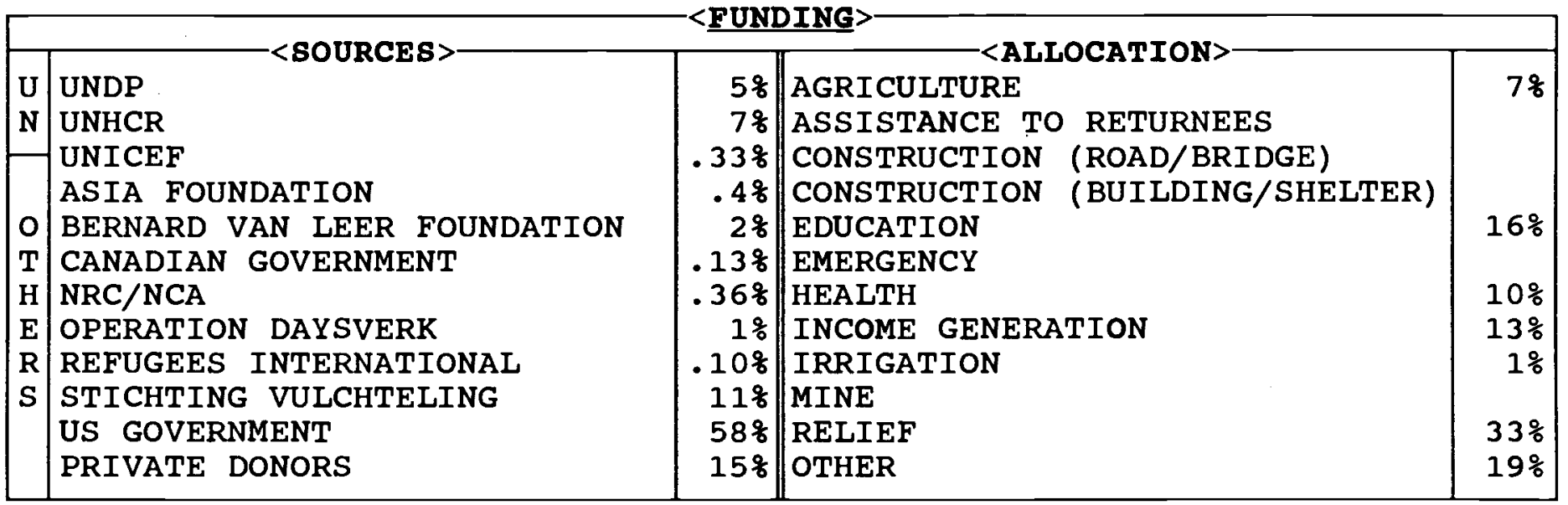

\begin{tabular}{|c|c|c|c|c|c|c|}
\hline $\begin{array}{l}\text { AFGHANI: } \\
\text { REFUGEE: } \\
\text { TOTAL: }\end{array}$ & $\begin{array}{c}\frac{1988}{2,838,188} \\
6,410,654 \\
9,248,842\end{array}$ & $\begin{array}{r}1989 \\
6,897,000 \\
4,933,000 \\
11,830,000\end{array}$ & $\begin{array}{r}1990 \\
6,981,000 \\
4,919,000 \\
11,900,000\end{array}$ & $\begin{array}{r}1991 \\
8,360,000 \\
4,685,000 \\
13,045,000\end{array}$ & $\begin{array}{r}1992 \\
8,100,000 \\
5,900,000 \\
14,000,000\end{array}$ & \begin{tabular}{r}
\multicolumn{1}{c}{1993} \\
$6,544,485$ \\
$5,159,831$ \\
$11,704,316$
\end{tabular} \\
\hline 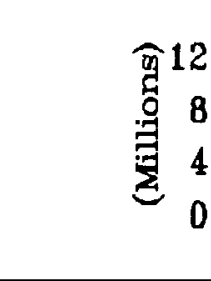 & ㄱ..-1-. & 1989 & … & 1991 & 䅗 & 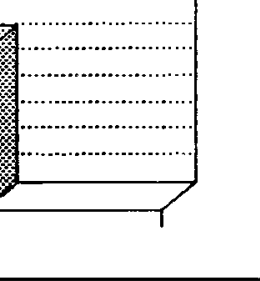 \\
\hline
\end{tabular}

\begin{tabular}{|c|c|c|c|c|c|}
\hline PROVINCES & SECTOR & \&AGE & PROVINCES & SECTOR & $\% \mathrm{AGE}$ \\
\hline $\begin{array}{l}\text { BADAKSHAN } \\
\text { BADGHIS } \\
\text { BAGHLAN } \\
\text { BALKH } \\
\text { BAMYAN } \\
\text { FARAH } \\
\text { FARYAB } \\
\text { GHAZNI } \\
\text { GHOR } \\
\text { HELMAND } \\
\text { HERAT } \\
\text { JAWZJAN } \\
\text { KABUL } \\
\text { KANDAHAR } \\
\text { KAPISA }\end{array}$ & & $\begin{array}{r}3 \% \\
5 \% \\
4 \% \\
.5 \%\end{array}$ & $\begin{array}{l}\text { KUNAR } \\
\text { KUNDUZ } \\
\text { LAGHMAN } \\
\text { LOGAR } \\
\text { NANGARHAR } \\
\text { NIMROZ } \\
\text { ORUZGAN } \\
\text { PAKTEKA } \\
\text { PAKTIA } \\
\text { PARWAN } \\
\text { SAMANGAN } \\
\text { TAKHAR } \\
\text { WARDAK } \\
\text { ZABUL }\end{array}$ & & $\begin{array}{r}27 \% \\
\% \\
3 \% \\
43 \% \\
9 \% \\
5 \% \\
.5 \%\end{array}$ \\
\hline
\end{tabular}


INTERNATIONAL RESCUE COMMITTEE

(IRC)

has assisted refugees fleeing violence \& persecution since 1933. In over 13 countries worldwide, IRC provides relief aid to refugees in the country of first asylum, rehabilitation aid to support repatriation and resettlement opportunities when other options are not viable.

IRC began its Program for Afghans in 1980 \& has since become one of the longest standing \& most diverse NGOs involved in Afghan refugee aid. Programs initiated by IRC span from medical \& public health to educational \& income-generating projects. In 1988, IRC began to assist communities in Afghanistan with rehabilitation projects. IRC's 9 major programs are outlined below: 1.RPA supports community development projects in Paktia, Pakteka, Khost, Logar and Nangarhar. Projects include: irrigation repair, agricultural training and extension, EPI, water \& sanitation programs and primary and secondary education.

2.RAP provides financial, administrative and technical support to NGOs implementing economic rehabilitation projects in Afghanistan. In 1993, the program is targeting agricultural projects that aim to increase food production and cash incomes.

3. Hangu Education Program focuses on developing community education resources by training primary school teachers and providing material support to schools in Afghanistan and Pakistan. In 1993, the program is contributing to the education of over 60,000 primary students through teacher training and textbooks/supplies distribution, and also directly supports over 1,300 primary-aged students.

4. Female Education Program incorporates 5 educational and vocational programs for refugee girls/women including teacher training and support for pre-schools and girls' primary schools, public administration courses, health educator training, English language courses and teacher training.

5.Science/Technology Training Prog. seeks to improve secondary education for Afghan students through a) support of a refugee boys' secondary high school with a focus on math and science, b) provision of in-service teacher training to middle and secondary math and science teachers in Pakistan and Afghanistan, and c) development and distribution of math and science textbooks (grades 7-12) to secondary schools in both countries.

6.CRTA currently operates two component programs: a) the Construction Engineerinj Program, which offers a 36-month civil engineering course which parallels the curriculum offered at the Kabul University Faculty of Engineering before the war; and b) the Construction Supervision Program, which offers two sequential ninemonth courses that prepare Afghans to be construction foremen and assistant engineers.

7. Public Administration operates a training center which offers semester courses and intensive workshops in administration, management, and office and computer skills to twelfth-grade graduates and to NGO employees.

8. Hangu Medical Program operates 12 BHUs in Kohat district serving approximately 170,000 refugees. In addition to curative services, IRC has a comprehensive public health program including community \& female health workers, EPI, $\mathrm{MCH}$ programs, and water and sanitation. In 1993, IRC completed phase III of a wheat-based oral rehydration solution research project.

8.HERC produces visual aids, including silk-screened posters and flip-charts, with public health messages in Dari and Pushto. The program has also expanded its repertoire by developing materials for use in drug education, mine awareness, and veterinary and agriculture programs.

9.Self-Reliance program creates income-generating and vocational training opportunities for Afghan refugees. The beneficiaries of the program work in construction, gabion production, carpet weaving, agriculture, wood/metal crafts, auto mechanics and printing. others set up their own small businesses through participation in IRC's credit scheme. 
IBLAMIC AID HEALTH CENTER-IAHC

<ADDRESS>- $>$ COMMUNICATION LINES>

$\mathrm{P}$ O BOX 293

QUETTA, PAKISTAN
PHONE : 444780

F A X:

TELEX:
1. DR. A. BAQI HAQANI

2. MR. MOHD SAYED

3. ENG.M. RABI

\begin{tabular}{|lr|lr|lr|}
\hline AFGHAN : & 39 & TECHNICAL: & 8 & PAK. BASED: & 25 \\
PAKISTANI : & 1 & ADMINISTRATIVE : & 10 & AFGHA.BASED: & 20 \\
EXPAT: & - & FIELD/SUPPORT S. & 22 & CROSS-BORDER: & 5 \\
TOTAL: & 40 & TOTAL: & 40 & TOTAL: & 40 \\
\hline
\end{tabular}

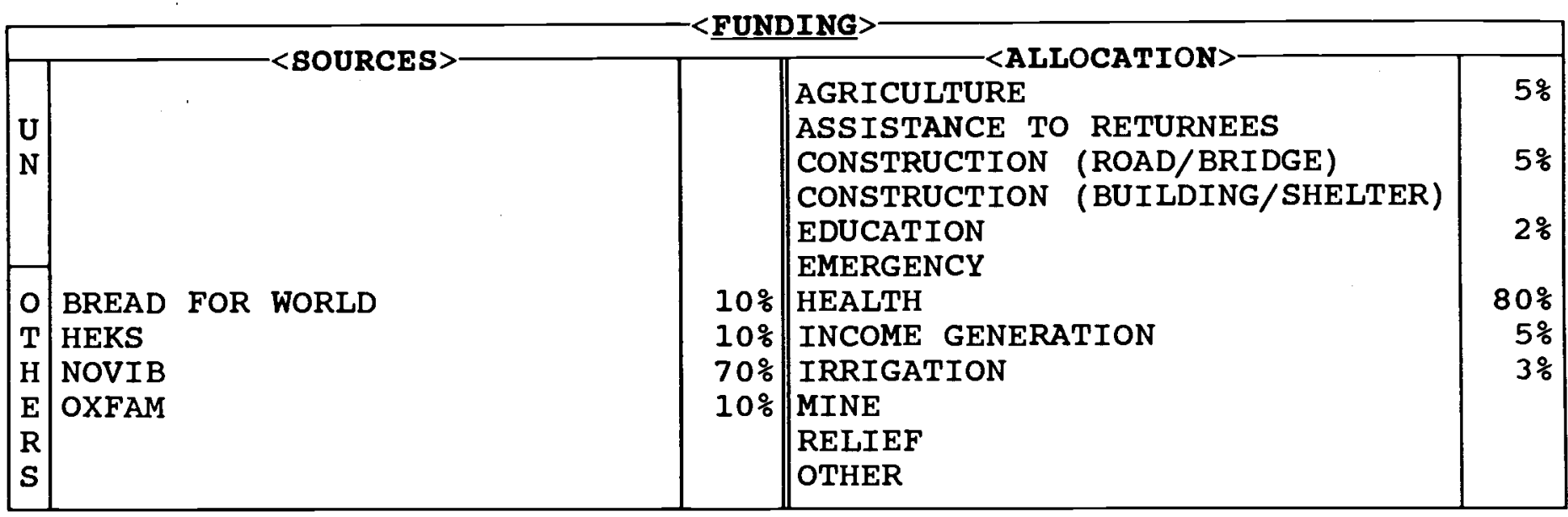

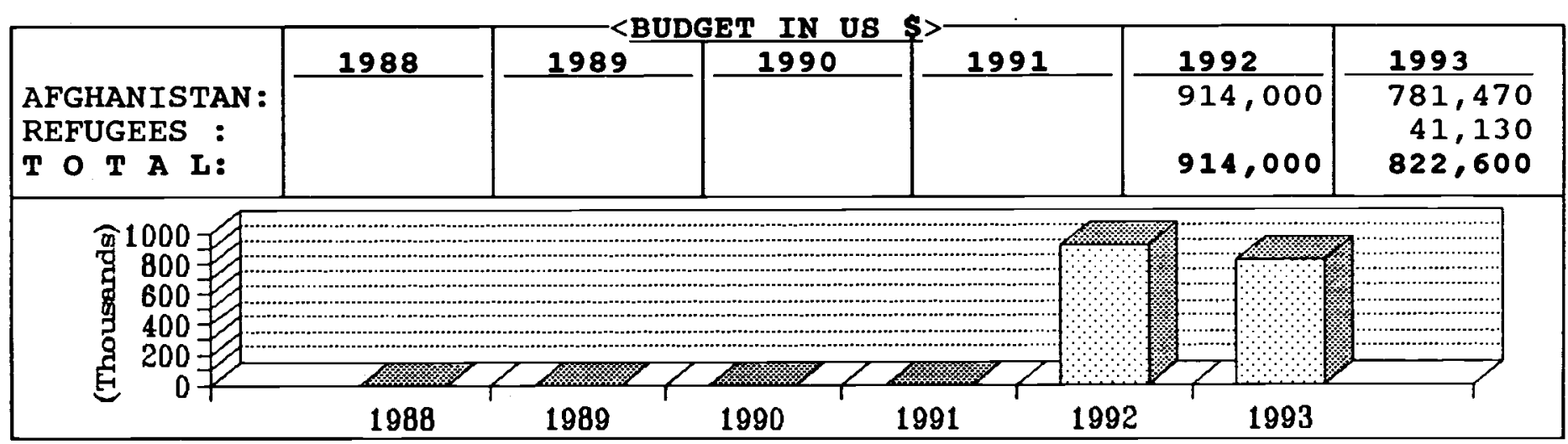

\begin{tabular}{|c|c|c|c|c|c|}
\hline PROVINCES & SECTOR & \&AGE & PROVINCES & SECTOR & \&AGE \\
\hline $\begin{array}{l}\text { BADAKSHAN } \\
\text { BADGHIS } \\
\text { BAGHLAN } \\
\text { BALKH } \\
\text { BAMYAN } \\
\text { FARAH } \\
\text { FARYAB } \\
\text { GHAZNI } \\
\text { GHOR } \\
\text { HELMAND } \\
\text { HERAT } \\
\text { JAWZJAN } \\
\text { KABUL } \\
\text { KANDAHAR } \\
\text { KAPISA }\end{array}$ & $\begin{array}{l}\text { Agr/educ/health/in.g. } \\
\text { Agr/health } \\
\text { Health }\end{array}$ & $\begin{array}{l}40 \% \\
25 \% \\
30 \%\end{array}$ & $\begin{array}{l}\text { KUNAR } \\
\text { KUNDUZ } \\
\text { LAGHMAN } \\
\text { LOGAR } \\
\text { NANGARHAR } \\
\text { NIMROZ } \\
\text { ORUZGAN } \\
\text { PAKTEKA } \\
\text { PAKTIA } \\
\text { PARWAN } \\
\text { SAMANGAN } \\
\text { TAKHAR } \\
\text { WARDAK } \\
\text { ZABUL }\end{array}$ & Health & $5 \%$ \\
\hline
\end{tabular}


is an Afghan Non-Governmental organization founded in 1981. The objective of the organization is to provide health and agriculture assistance to Afghans.

In the health sector, IAHC runs health facilities and provides vaccination in different parts of Afghanistan (currently in the provinces of Ghazni, Helmand, Kandahar and Uruzgan) and in the refugee camps in Baluchistan. The Center plans to rehabilitate Bust Hospital in Lashkargah.

The agriculture section started operation in 1987. Deep wells have been dug in the governmental farms in Ghazni province. The farms are cultivated and the produce is sold, the income of which is utilized for purchasing medicines for IAHC clinics as well as other expenses of the projects. Part of the income is also spent to support schools and madrasas inside Afghanistan.

The agriculture section has also distributed tractors.

In Ghazni province, IAHC has also started income generation programs.

IAHC will move its office to Afghanistan when the security situation improves. 
ISLAMIC ASSOCIATION OF AFGHAN ARCHITECTS AND ENGINEERS-IAAAE

\begin{tabular}{|c|c|c|}
\hline$\langle<$ ADDRESS $>=$ & $-<$ COMMUNICATION LINES $>$ & $-<\underline{\text { KEY STAFF }}>$ \\
\hline $\begin{array}{l}\text { 35, ST. } 2, \text { El, PH.I, } 2 \text { ND } \\
\text { LALAZAR RD, HAYATABAD } \\
\text { PESHAWAR, PAKISTAN }\end{array}$ & $\begin{array}{l}\text { PHONE: } 810193 \\
\text { F A X: } 810193 \\
\text { TELEX: }\end{array}$ & $\begin{array}{l}\text { 1. ENG. G. H. MUTAWAZI } \\
\text { 2. } \\
\text { 3. }\end{array}$ \\
\hline
\end{tabular}

\begin{tabular}{|lr|lr|ll|}
\hline AFGHAN : & 38 & TECHNICAL: & 20 & PAK. BASED: & $\ldots$ \\
PAKISTANI : & - & ADMINISTRATIVE: & 10 & AFGHA.BASED: & $\ldots$ \\
EXPAT: & - & FIELD: & 8 & CROSS-BORDER: & $\ldots$ \\
TOTAL: & 38 & TOTAL: & 38 & TOTAL: & 38 \\
\hline
\end{tabular}

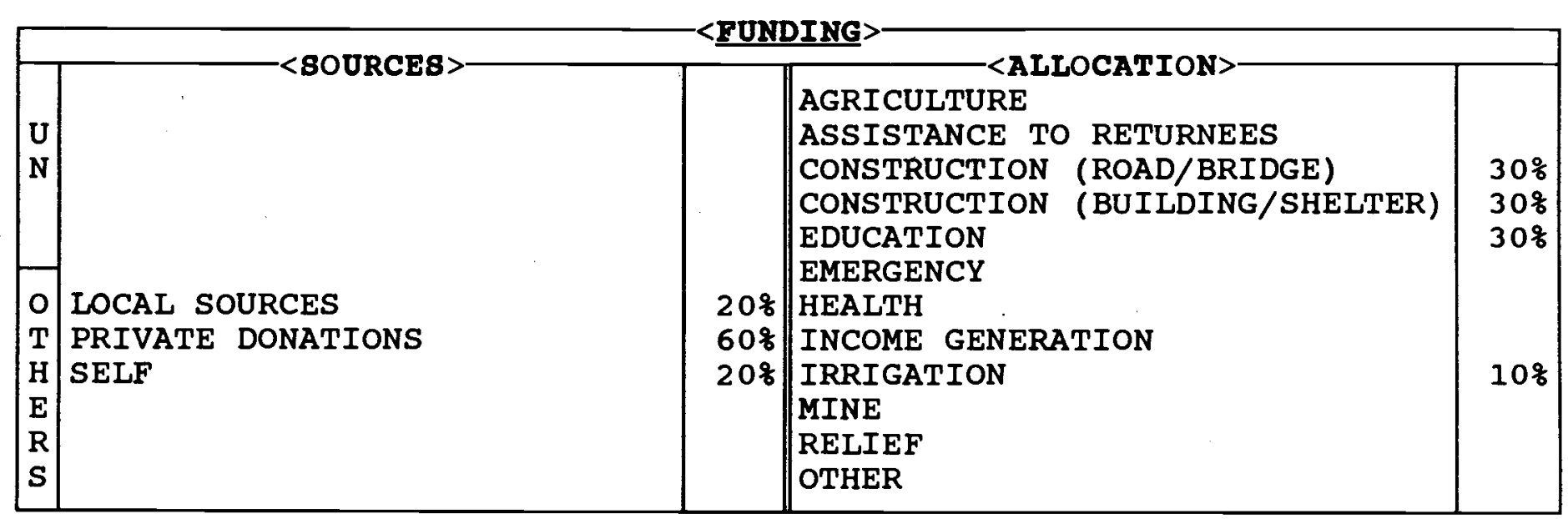

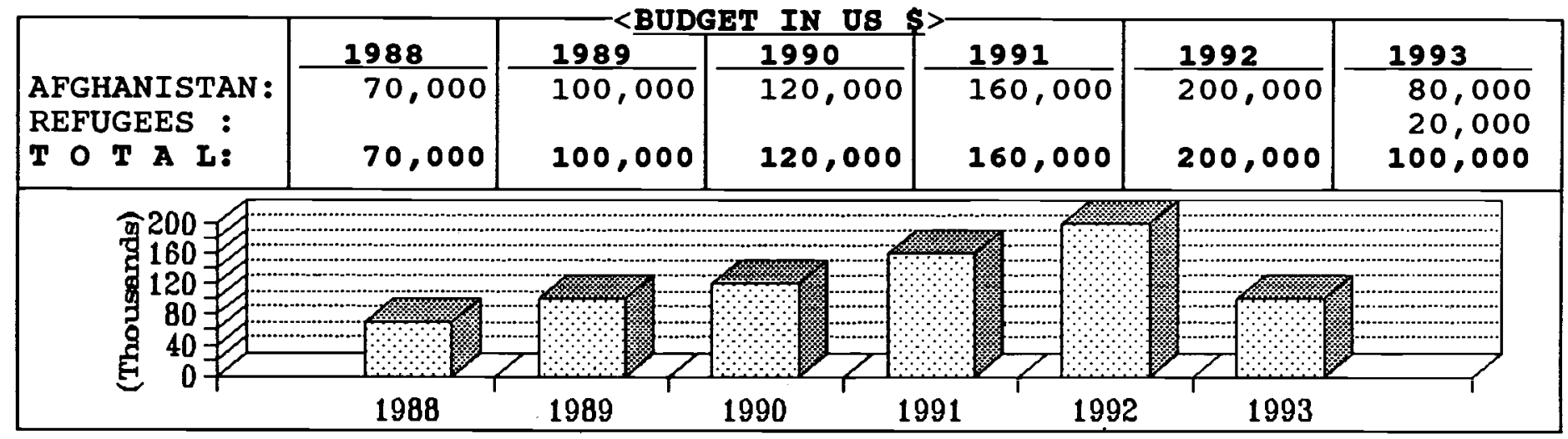

\begin{tabular}{|c|c|c|c|c|c|}
\hline PROVINCES & SECTOR & \%AGE & PROVINCES & SECTOR & $\%$ AGE \\
\hline $\begin{array}{l}\text { BADAKSHAN } \\
\text { BADGHIS } \\
\text { BAGHLAN } \\
\text { BALKH } \\
\text { BAMYAN } \\
\text { FARAH } \\
\text { FARYAB } \\
\text { GHAZNI } \\
\text { GHOR } \\
\text { HELMAND } \\
\text { HERAT } \\
\text { JAWZJAN } \\
\text { KABUL } \\
\text { KANDAHAR } \\
\text { KAPISA }\end{array}$ & $\begin{array}{l} \\
\text { Survey } \\
\text { Const/irrign }\end{array}$ & $\begin{array}{l}12 q \\
36 q\end{array}$ & $\begin{array}{l}\text { KUNAR } \\
\text { KUNDUZ } \\
\text { LAGHMAN } \\
\text { LOGAR } \\
\text { NANGARHAR } \\
\text { NIMROZ } \\
\text { ORUZGAN } \\
\text { PAKTEKA } \\
\text { PAKTIA } \\
\text { PARWAN } \\
\text { SAMANGAN } \\
\text { TAKHAR } \\
\text { WARDAK } \\
\text { ZABUL }\end{array}$ & $\begin{array}{l}\text { Const } \\
\text { Const } \\
\text { Const/irrign }\end{array}$ & $\begin{array}{l}20 \% \\
20 \%\end{array}$ \\
\hline
\end{tabular}


ISLAMIC ASSOCIATION OF AFGHAN ARCHITECTS AND ENGINEERS (IAAAE)

was established in 1983 in Peshawar, Pakistan.

This organization has cooperative relations with all Jehadic parties of Afghanistan but maintains a neutral policy and is not affiliated with anyone.

It has membership of the Federation of Engineering Institutions of Islamic countries as a representative of Afghanistan. It is also a member of the Federation of Engineering Institutions of South and Central Asia. The Chairman of the Association is a member of the Executive Committee of the Federation of Engineering Institutions of the Islamic Countries.

The basic goals of the Association are:

1. To serve Afghanistan in connection with reconstruction activities through the coordination of engineering associates.

2. To organize and assist qualified professional staff.

3. To upgrade the technical standard and scientific knowledge of engineers by launching seminars, conferences and courses.

4. To provide educational facilities for those Afghans who did not complete their engineering degree due to the war.

5. To seek job opportunities for engineers and architects.

6. To establish an atmosphere of harmony and cooperation among engineers and links with other professional and scientific societies abroad.

7. To give technical advice to those who are dealing with reconstruction programs in Afghanistan.
8. To design and supervise reconstruction projects inside Afghanistan.

9. To deal with other matters relevant to the profession.

IAAAE has implemented the following projects :

1. Construction of a mosque in Jalozai Camp.

2. Construction of a mosque in Khogyani, Nangarhar Province.

3. Construction of mosque in Chawni Jaji, Paktia.

4. Construction of mosque in Kishiktan, Kapisa Province. 
ISLAMIC RELIEF AGENCY-ISRA

<ADDRESS>-

18-A， PARK RD， U/T

UPO BOX 887, CODE 25000

PESHAWAR， PAKISTAN
PHONE : $42245 / 840365 / 42549$

F A X: 840249

TELEX: 52383 ISRA
1. MR. A. RAAB HASSAN

2. MR. SIDDIQ MOHD ALI

3. DR. ISAM E. MIRGHANI

\begin{tabular}{|lr|lr|lr|}
\hline AFGHAN: & 224 & TECHNICAL: & 87 & PAK. BASED: & 122 \\
PAKISTANI: & 118 & ADMINISTRATIVE: & 227 & AFGHA.BASED: & - \\
EXPAT: & 10 & FIELD: & 38 & CROSS-BORDER: & 230 \\
TOTAL: & 352 & TOTAL: & 352 & TOTAL: & 352 \\
\hline
\end{tabular}

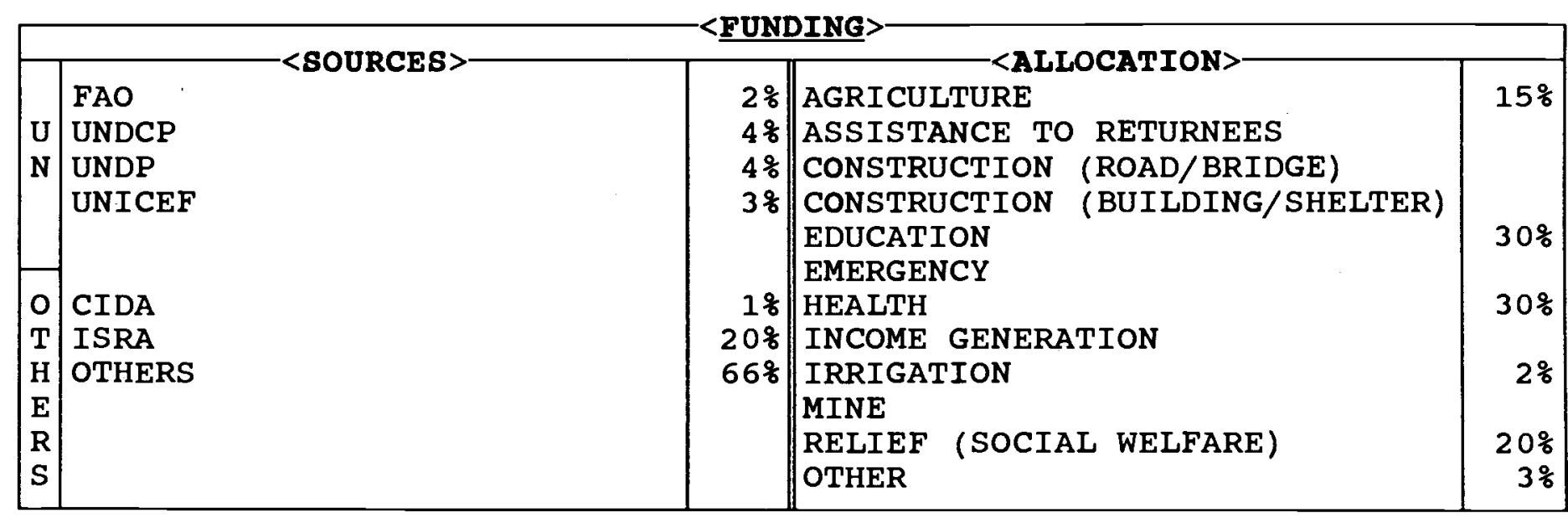

\begin{tabular}{|c|c|c|c|c|c|c|}
\hline & 1988 & 1989 & 1990 & 1991 & 1992 & 1993 \\
\hline $\begin{array}{l}\text { AFGHANISTAN: } \\
\text { REFUGEES : } \\
\text { T O T A L: }\end{array}$ & $\begin{array}{l}1,800,000 \\
5,000,000 \\
6,800,000\end{array}$ & $\begin{array}{l}1,600,000 \\
5,000,000 \\
6,600,000\end{array}$ & $\begin{array}{l}1,600,000 \\
4,000,000 \\
5,600,000\end{array}$ & $\begin{array}{l}2,000,000 \\
3,400,000 \\
5,400,000\end{array}$ & $\begin{array}{l}2,200,000 \\
3,000,000 \\
5,200,000\end{array}$ & $\begin{array}{l}2,200,000 \\
2,000,000 \\
4,200,000\end{array}$ \\
\hline
\end{tabular}

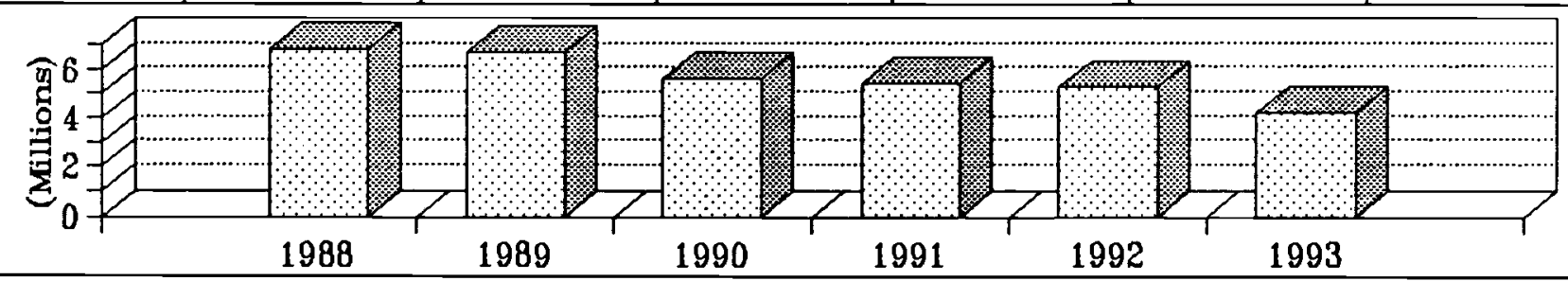

\begin{tabular}{|c|c|c|c|c|c|}
\hline PROVINCES & SECTOR & $\because \mathrm{AGE}$ & PROVINCES & SECTOR & $\% A G E$ \\
\hline $\begin{array}{l}\text { BADAKSHAN } \\
\text { BADGHIS } \\
\text { BAGHLAN } \\
\text { BALKH } \\
\text { BAMYAN } \\
\text { FARAH } \\
\text { FARYAB } \\
\text { GHAZNI } \\
\text { GHOR } \\
\text { HELMAND } \\
\text { HERAT } \\
\text { JAWZJAN } \\
\text { KABUL } \\
\text { KANDAHAR } \\
\text { KAPISA }\end{array}$ & Const & $4 \%$ & $\begin{array}{l}\text { KUNAR } \\
\text { KUNDUZ } \\
\text { LAGHMAN } \\
\text { LOGAR } \\
\text { NANGARHAR } \\
\text { NIMROZ } \\
\text { ORUZGAN } \\
\text { PAKTEKA } \\
\text { PAKTIA } \\
\text { PARWAN } \\
\text { SAMANGAN } \\
\text { TAKHAR } \\
\text { WARDAK } \\
\text { ZABUL }\end{array}$ & $\begin{array}{l}\text { Ag/cons/educ/heal/irr } \\
\text { Ag/cons/educ/heal/irr } \\
\text { Ag/cons/educ/heal/irr } \\
\text { Ag/cons/educ/heal/irr } \\
\text { Ag/cons/educ/heal/irr } \\
\text { Ag/cons/educ/heal/irr } \\
\text { Ag/cons/educ/heal/irr }\end{array}$ & $\begin{array}{r}8 \% \\
5 \% \\
10 \% \\
40 \% \\
3 \% \\
10 \%\end{array}$ \\
\hline
\end{tabular}




\section{İLAMIC R̃ELLIEF AGENCY (ISRA)}

is an international NGO offering assistance irrespective of caste, creed, religion color or race to those affected by natural disasters and physical disruption or foreign aggression, and who are compelled to take refuge in other countries.

The work for Afghan refugees started in 1984 .

ISRA has four main departments the activities of which could be outlined as follows:

\section{HEALTH :}

* Ten clinics are operated in 9 provinces of Afghanistan and one clinic in Peshawar for refugees.

* Two drop-in centers for vulnerable children (orphans, disabled, destitute and street working children) in Kunar and Nangarhar. The two centers provide hygiene, basic education or vocational training to approximately 1,000 children.

* The Health Department provides training courses for religious leaders on drug abuse prevention. 175 people will be trained in Jalalabad and Kunar with the aim of creating community awareness.

* ISRA donates medicines and medical equipment to different hospitals in Afghanistan.

It is planned to open a clinic in Kabul and another one in Baghlan province. Primary Health care Services will be added to the existing clinics.

\section{EDUCATION :}

Between 1985 and 1992, ISRA supported 22 primary schools in different refugee camps which provided education to 5,000 students. Two vocational training centers for women were operated in Quetta and Peshawar. A vocational center was for boy was operated in Sardar Garhi Peshawar providing courses in 8 different trades. 700 boys and 200 widows were trained in this center. Moreover, an institute was established which trained over 3,000 Afghans in teacher training, office management, type writing, book keeping and tailoring.

Since 1992, ISRA has established a number of primary schools in Laghman, Wardak, Logar, Khost and Nangarhar which provide education to over 800 students. A middle school in Chawki, Kuanr is operated. The vocational training centers for boys and women were also shifted to Jalalabad. Primary schools in Parwan and Kunduz and two Quranic centers in Kabul will be established in the near future.

\section{SOCIAL WELFARE:}

This is the most important project of ISRA. 7,000 orphans plus their widow mothers have been registered in this program so far. 2 centers for orphans in NWFP and 8 more inside Afghanistan are currently supervised.

\section{RURAL DEVELOPMENT:}

ISRA has offered agricultural training courses. Moreover, 3,000 Afghan families, who have returned to their homes in Kunar, Nangarhar, Paktia, Wardak and Logar provinces, have been provided with agricultural materials such as traction facilities, fruit trees, seeds and fertilizer and agro-chemicals. 100 mosques have been constructed and 150 shallow wells have been dug in different project areas. 
ITALIAN COOPERATION FOR DEVELOPMENT-ICD

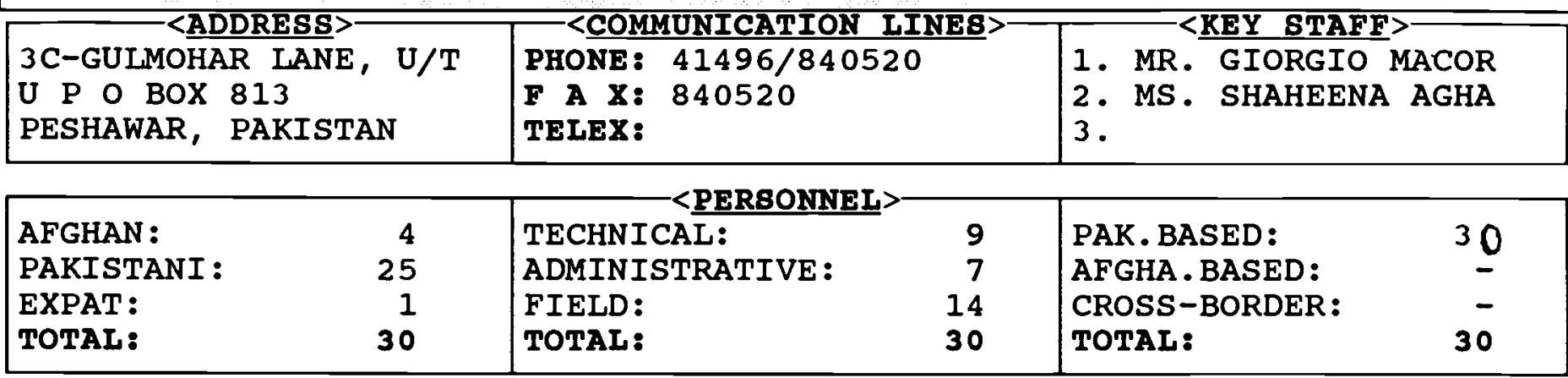

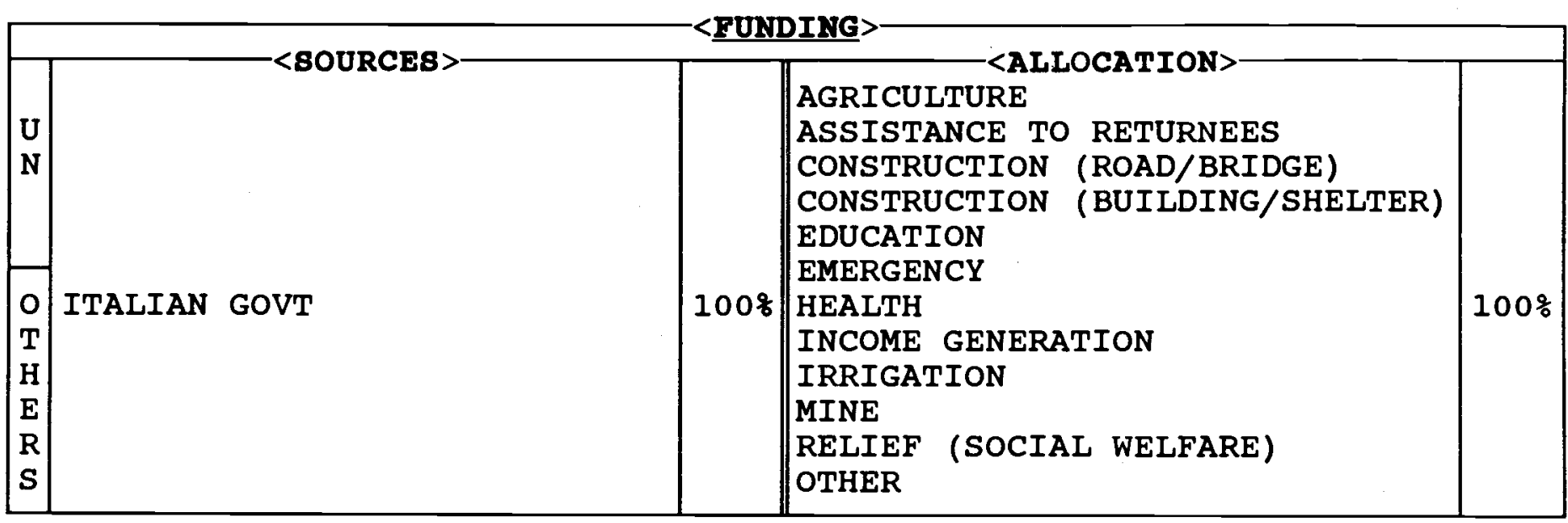

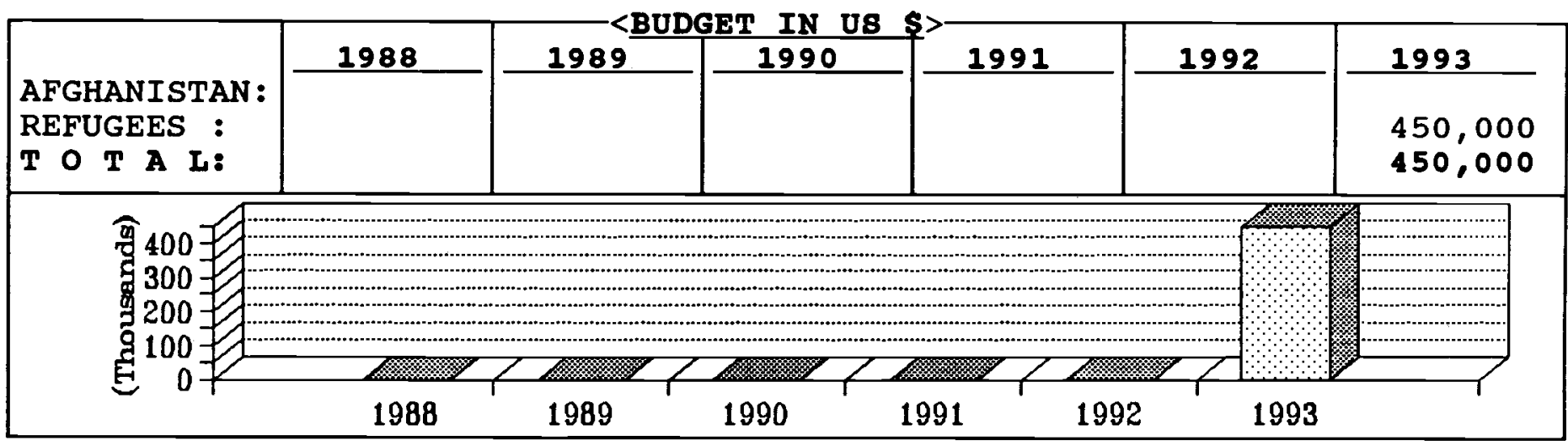

\begin{tabular}{|c|c|c|c|c|c|}
\hline PROVINCES & SECTOR & \&AGE & PROVINCES & SECTOR & $\because \mathrm{AGE}$ \\
\hline $\begin{array}{l}\text { BADAKSHAN } \\
\text { BADGHIS } \\
\text { BAGHLAN } \\
\text { BALKH } \\
\text { BAMYAN } \\
\text { FARAH } \\
\text { FARYAB } \\
\text { GHAZNI } \\
\text { GHOR } \\
\text { HELMAND } \\
\text { HERAT } \\
\text { JAWZJAN } \\
\text { KABUL } \\
\text { KANDAHAR } \\
\text { KAPISA }\end{array}$ & & & $\begin{array}{l}\text { KUNAR } \\
\text { KUNDUZ } \\
\text { LAGHMAN } \\
\text { LOGAR } \\
\text { NANGARHAR } \\
\text { NIMROZ } \\
\text { ORUZGAN } \\
\text { PAKTEKA } \\
\text { PAKTIA } \\
\text { PARWAN } \\
\text { SAMANGAN } \\
\text { TAKHAR } \\
\text { WARDAK } \\
\text { ZABUL }\end{array}$ & & \\
\hline
\end{tabular}


ITALIAN COOPERATION FOR DEVELOPMENT (ID)

is a governmental organization of Italy.

In Pakistan, ICD provides anti tuberculosis services and has extended these services to refugees for the past several years.

A training center has been established which trains microscopist in basic courses as well as in refresher courses.

The TB centers and Basic Health Units which have laboratories are provided TB materials e.g. slides. Follow up work is done with the laboratories to record the positive cases of TB and provide proper treatment for them. The hospitals and clinics are also provided with anti TB medicines. In the past, ICD also provided microscopes to hospitals and clinics serving Afghan refugees. 


\begin{tabular}{|c|c|c|c|c|}
\hline$=<$ ADDRESS $>$ & $=<$ COMMUNICATION & $\mathbf{E S}>$ & $-<\underline{\operatorname{REY}} \mathbf{S T A}$ & \\
\hline $\begin{array}{l}\text { 31, STREET 8, QALAI } \\
\text { FATHULLAH, P O BOX } 1832 \\
\text { KABUL, AFGHANISTAN }\end{array}$ & $\begin{array}{l}\text { PHONE: } 32919 \\
\text { F A X: } \\
\text { TELEX: }\end{array}$ & & $\begin{array}{l}\text { 1. MS. EILLEE } \\
\text { 2. } \\
\text { 3. }\end{array}$ & TERS \\
\hline $\begin{array}{l}\text { AFGHAN : } \\
\text { PAKISTANI : } \\
\text { EXPAT: } \\
\text { TOTAL: }\end{array}$ & $\begin{array}{l}\text { TECHNICAL: } \\
\text { ADMINISTRATIVE: } \\
\text { FIELD/SUPPORT S. } \\
\text { TOTAL: }\end{array}$ & $\begin{array}{l}\cdots \\
\cdots \\
\cdots\end{array}$ & $\begin{array}{l}\text { PAK. BASED: } \\
\text { AFGHA. BASED: } \\
\text { CROSS-BORDER: } \\
\text { TOTAL: }\end{array}$ & $\begin{array}{l}\cdots \\
\cdots \\
\cdots\end{array}$ \\
\hline
\end{tabular}

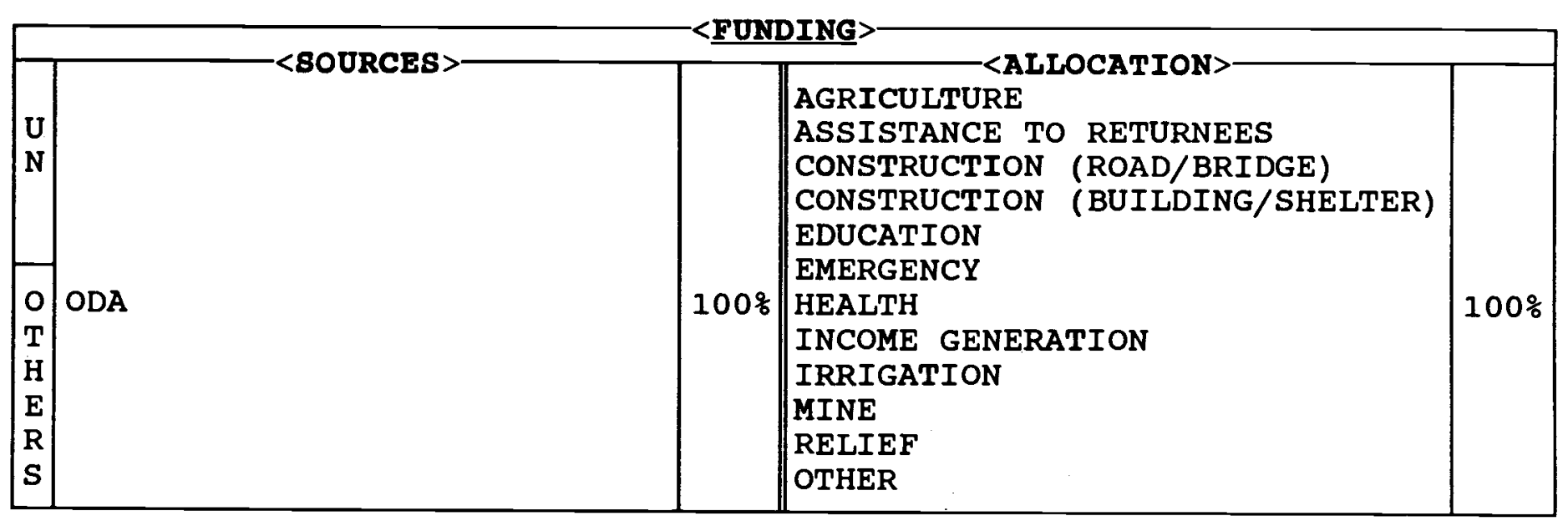

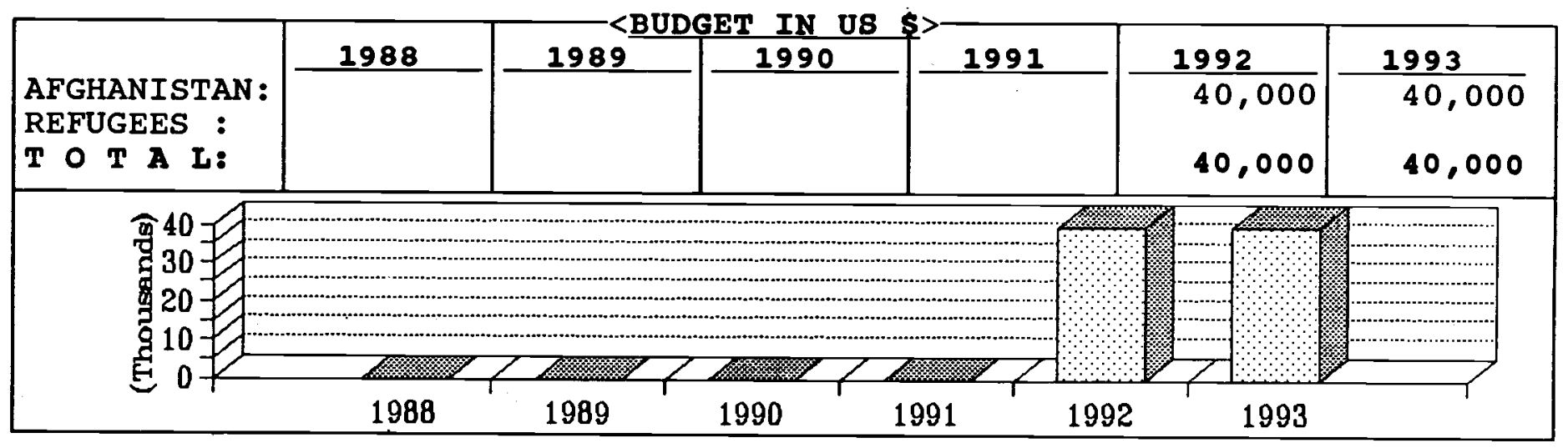

\begin{tabular}{|c|c|c|c|c|c|}
\hline PROVINCES & SECTOR & \%AGE & PROVINCES & SECTOR & $\%$ AGE \\
\hline $\begin{array}{l}\text { BADAKSHAN } \\
\text { BADGHIS } \\
\text { BAGHLAN } \\
\text { BALKH } \\
\text { BAMYAN } \\
\text { FARAH } \\
\text { FARYAB } \\
\text { GHAZNI } \\
\text { GHOR } \\
\text { HELMAND } \\
\text { HERAT } \\
\text { JAWZJAN } \\
\text { KABUL } \\
\text { KANDAHAR } \\
\text { KAPISA }\end{array}$ & Health & . & \begin{tabular}{|l} 
KUNAR \\
KUNDUZ \\
LAGHMAN \\
LOGAR \\
NANGARHAR \\
NIMROZ \\
ORUZGAN \\
PAKTEKA \\
PAKTIA \\
PARWAN \\
SAMANGAN \\
TAKHAR \\
WARDAK \\
ZABUL
\end{tabular} & & \\
\hline
\end{tabular}


JACOB'S WELL MEDICAL MISSION (JWMM)

is a British charity organization which has been working in Afghanistan for the past 4 years operating mainly in Kabul.

JWMM works through Afghan Red Crescent society (ARCS) and provides medicines and medical instruments to different hospitals and clinics in Kabul city. JWMM delivered medicines of approximately 40,000 US $\$$ to the Afghan Red crescent Society (ARCS). 
JAPAN AFGHAN MEDICAL SERVICES-JAMS

\begin{tabular}{|c|c|c|c|c|c|}
\hline \multirow{2}{*}{\multicolumn{2}{|c|}{$\begin{array}{l}\text { 3-C II CIRCULAR RD, U/T } \\
\text { U P O BOX } 847 \\
\text { PESHAWAR, PAKISTAN }\end{array}$}} & & \\
\hline & & \multicolumn{2}{|c|}{$\begin{array}{l}\text { PHONE: } 44350 / 41544 \\
\text { F A X: } 841167 \\
\text { TELEX: }\end{array}$} & \multicolumn{2}{|c|}{$\begin{array}{l}\text { 1.DR. SHAHWALI WALIZARIF } \\
\text { 2.HAJI MOHD YAQUB SAFI } \\
\text { 3.MR. WAZIR BEG }\end{array}$} \\
\hline \multirow{4}{*}{$\begin{array}{l}\text { AFGHAN : } \\
\text { PAKISTANI : } \\
\text { EXPAT: } \\
\text { TOTAL: }\end{array}$} & 76 & TECHNICAL: & 50 & PAK. BASED: & 50 \\
\hline & - & ADMINISTRATIVE: & 3 & AFGHA. BASED: & 19 \\
\hline & 3 & FIELD: & 23 & CROSS-BORDER: & 7 \\
\hline & 79 & TOTAL: & 76 & TOTAL: & 76 \\
\hline
\end{tabular}

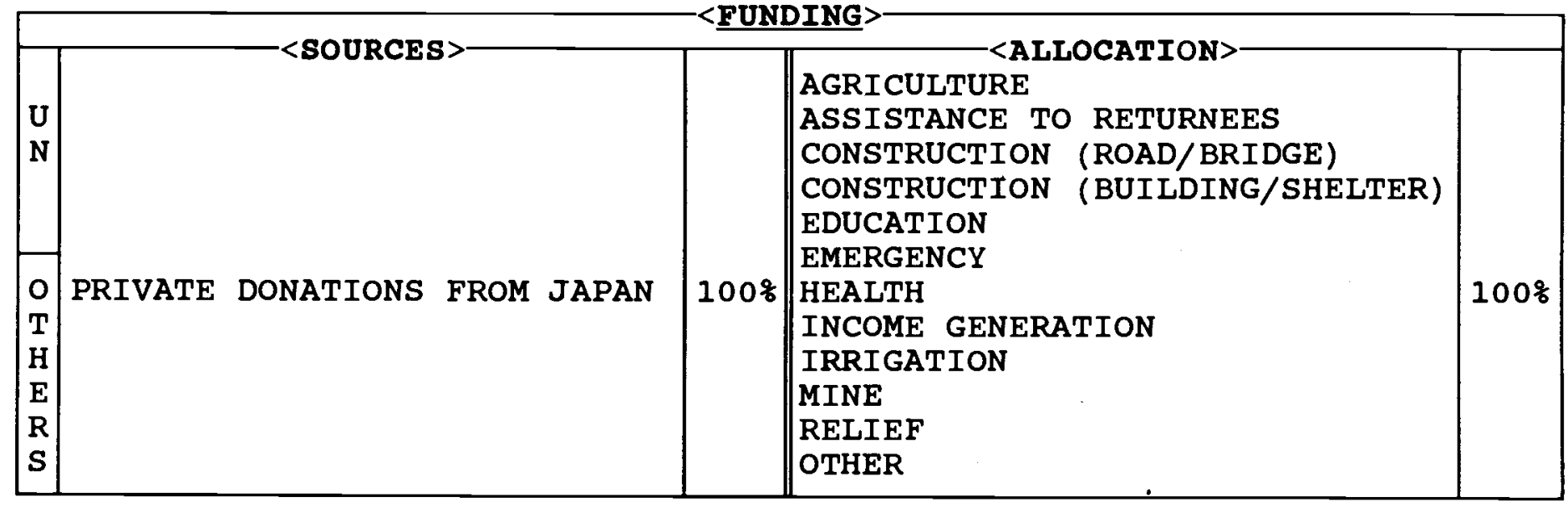

\begin{tabular}{|c|c|c|c|c|c|c|}
\hline & 1988 & 1989 & 1990 & 1991 & 1992 & 1993 \\
\hline $\begin{array}{l}\text { AFGHANISTAN: } \\
\text { REFUGEES : } \\
\text { T O T A L: }\end{array}$ & $\begin{array}{l}40,149 \\
40,149\end{array}$ & $\begin{array}{l}73,475 \\
73,475\end{array}$ & $\begin{array}{l}93,501 \\
93,501\end{array}$ & $\begin{array}{l}149,396 \\
149,396\end{array}$ & $\begin{array}{r}44,827 \\
134481 \\
179,308\end{array}$ & $\begin{array}{l}165,000 \\
255,000 \\
420,000\end{array}$ \\
\hline
\end{tabular}

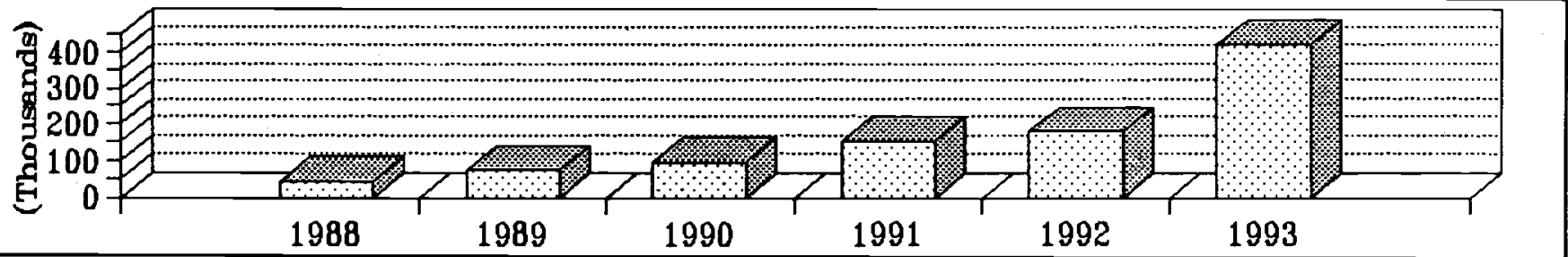

\begin{tabular}{|c|c|c|c|c|c|}
\hline PROVINCES & SECTOR & 字AGE & PROVINCES & SECTOR & 号AGE \\
\hline $\begin{array}{l}\text { BADAKSHAN } \\
\text { BADGHIS } \\
\text { BAGHLAN } \\
\text { BALKH } \\
\text { BAMYAN } \\
\text { FARAH } \\
\text { FARYAB } \\
\text { GHAZNI } \\
\text { GHOR } \\
\text { HELMAND } \\
\text { HERAT } \\
\text { JAWZJAN } \\
\text { KABUL } \\
\text { KANDAHAR } \\
\text { KAPISA }\end{array}$ & & & $\begin{array}{l}\text { KUNAR } \\
\text { KUNDUZ } \\
\text { LAGHMAN } \\
\text { LOGAR } \\
\text { NANGARHAR } \\
\text { NIMROZ } \\
\text { ORUZGAN } \\
\text { PAKTEKA } \\
\text { PAKTIA } \\
\text { PARWAN } \\
\text { SAMANGAN } \\
\text { TAKHAR } \\
\text { WARDAK } \\
\text { ZABUL }\end{array}$ & Health & $100 \%$ \\
\hline
\end{tabular}


was founded in October 1986 as Afghan Leprosy Service. In the beginning it operated as an extension program for leprosy control in North-West Frontier Province (NWFP) of Pakistan. The service was in response to the influx of Afghan refugees and an increase of registered leprosy patients.

Initially, the activity in the camps was primarily the treatment of skin diseases and leprosy. However, since it was difficult to look after only leprosy patients, leaving aside other infectious diseases, JAMS expanded its activity to include other common diseases, minor and reconstructive surgery, and at this point, the name of the organization changed.

The Japan Afghan Medical Service operates a 20 bed hospital, a daily out-patient department and conducts a medical survey program in the camps as a regular outreach program. JAMS has supplied its hospital/clinic with a wellfunctioning laboratory with modern diagnostic equipment. Expatriate doctors have joined the team and provide education and information to enhance the knowledge and capabilities of doctors and medical assistants.

A clinic and a mobile health facility are operating in Malakand camp.

A medical training course began in January 1989. In a training program which began in September 1989, medical workers were trained to work in the rural areas of Afghanistan. Currently JAMS offers training on tropical diseases to 18 Afghan doctors. The period would initially be 4 months.

In late 1991, JAMS started crossborder operations by opening a clinic in Dara Noor area of Nangarhar. The clinic receives 180 to 200 patients a day. A TB control program would be shortly added to the clinic to follow the TB treatment for the returnees who have been registered with TB control programs in peshawar. 
JAPANESE INTERNATIONAL FRIENDSHIP AND WELFARE FOUNDATION-JIFF

\begin{tabular}{|c|c|c|}
\hline$-<$ ADDRESS & $-\langle$ COMMUNICATION LINES $>$ & STAFE> \\
\hline $\begin{array}{l}\text { 1, RAHMAN BABA RD, U/T } \\
\text { P O BOX.......... } \\
\text { PESHAWAR, PAKISTAN }\end{array}$ & $\begin{array}{l}\text { PHONE: } 41278 \\
\text { F A X: } 41278 \\
\text { TELEX: }\end{array}$ & $\begin{array}{l}\text { 1. DR. S.KAZIM AHMADYAR } \\
\text { 2. MR. K.AHMAD SHEIKH } \\
\text { 3. }\end{array}$ \\
\hline
\end{tabular}

\begin{tabular}{|lr|lr|lr|}
\hline AFGHAN : & 9 & TECHNICAL: & 13 & PAK. BASED: & 15 \\
PAKISTANI : & 3 & ADMINISTRATIVE: & 2 & AFGHA.BASED: & - \\
EXPAT: & 3 & FIELD: & - & CROSS-BORDER: & - \\
TOTAL: & 15 & TOTAL: & 15 & TOTAL: & 15 \\
\hline
\end{tabular}

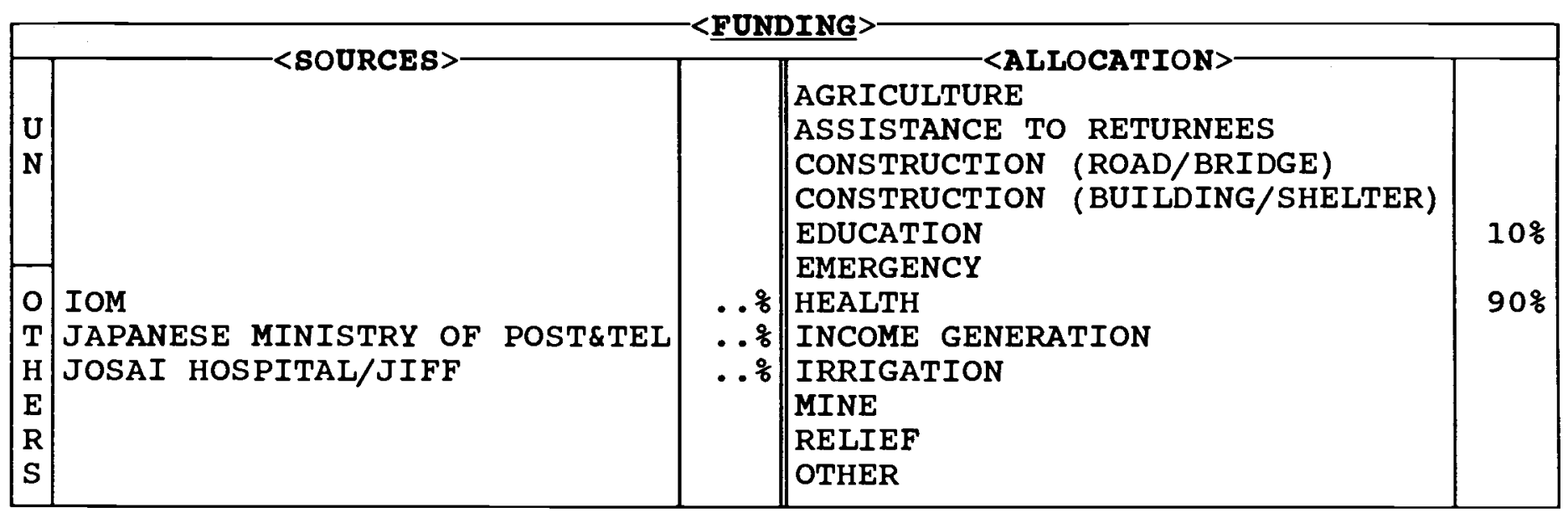

\begin{tabular}{|c|c|c|c|c|c|c|}
\hline & 1988 & 1989 & 1990 & 1991 & 1992 & 1993 \\
\hline $\begin{array}{l}\text { AFGHANISTAN : } \\
\text { REFUGEES : } \\
\text { T O T A L: }\end{array}$ & & & & & $\begin{array}{l}200,000 \\
200,000\end{array}$ & $\begin{array}{l}100,000 \\
100,000\end{array}$ \\
\hline
\end{tabular}

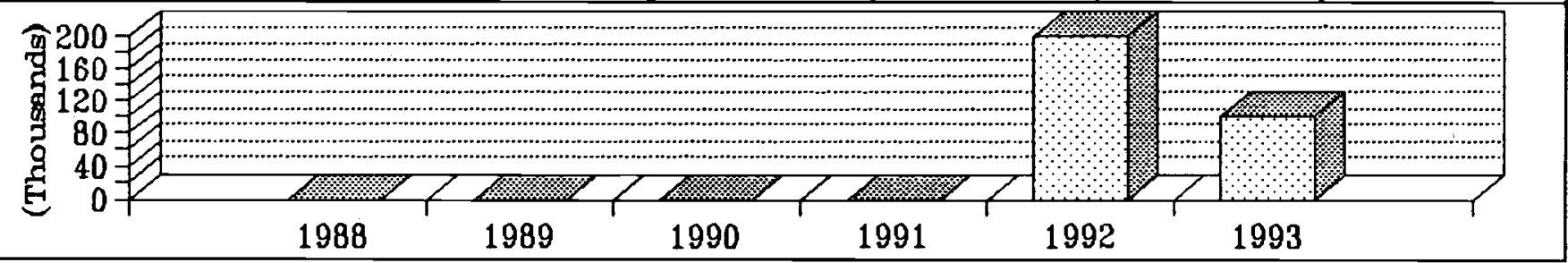

\begin{tabular}{|c|c|c|c|c|c|}
\hline PROVINCES & SECTOR & $\% A G E$ & PROVINCES & SECTOR & \&AGE \\
\hline $\begin{array}{l}\text { BADAKSHAN } \\
\text { BADGHIS } \\
\text { BAGHIAN } \\
\text { BALKH } \\
\text { BAMYAN } \\
\text { FARAH } \\
\text { FARYAB } \\
\text { GHAZNI } \\
\text { GHOR } \\
\text { HELMAND } \\
\text { HERAT } \\
\text { JAWZJAN } \\
\text { KABUL } \\
\text { KANDAHAR } \\
\text { KAPISA }\end{array}$ & & & \begin{tabular}{|l} 
KUNAR \\
KUNDUZ \\
LAGHMAN \\
LOGAR \\
NANGARHAR \\
NIMROZ \\
ORUZGAN \\
PAKTEKA \\
PAKTIA \\
PARWAN \\
SAMANGAN \\
TAKHAR \\
WARDAK \\
ZABUL
\end{tabular} & & \\
\hline
\end{tabular}


JÁAANESE INTERNATIONAL WELFARE FOUNDATION (JIFF)

opened a Physiotherapy center in Peshawar in August 1991.

In 1988, based on the request of International organization for Migration, JIFF invited an Afghan boy, hit by a bullet in arm, to Japan. He was provided extensive operation and medical care and returned fully recovered after three months. Since then, JIFF has continued the project to send those Afghans to Japan whose treatment is not possible locally. The JIFF Physiotherapy center was established firstly because heavy expenses were incurred keeping and providing post-operative treatment to Afghan patients in Japan: second, the main focus was to speed up the cycle of patients because physiotherapy is a long term treatment.

JIFF Center in Peshawar is the result of joint efforts by JIFF and IOM. After one year of effective and successful operations the Japanese Ministry of Post and Telecommunications also provided financial help for this virtuous and humanitarian cause.

In the beginning the center started its work with very little locally made equipment and a few workers. In March 1992 a consignment of medical equipment was received from Japan which dramatically boosted the performance of the center.

The number of patients was also small in the beginning but after introducing JIFF to other foreign missions, these missions started sending their patients to JIFF's Center and the number of patients rose dramatically.

JIFF coordinates with the other foreign missions and NGOs and works with them jointly for the rehabilitation of patients. JIFF receives patients introduced by other foreign missions, NGOs and Afghan groups for advice and treatment. If treatment and advice is not possible, then the patients are referred to other concerned hospitals.

Now, at regular intervals, patients are screened whose operation cannot be done locally. IOM with JIFF's expert doctors from Japan conduct the screening. The selected patients are sent to Japan for treatment. on their return, they are admitted to the JIFF Center for post operative treatment and physiotherapy.

From the date of commencement till 17th August 1992, (a period of one year), the center assisted 3,711 OPD patients among which were $\underline{49}$ admission cases, 270 referral cases, 95 prescription cases and $\underline{3,297}$ physiotherapy cases.

In June 1992, JIFF extended the pick and drop facility for the patients. This has resulted in an increase in the number of patients from 12 to 40 patients per day in one year.

As part of cooperation with other foreign missions, JIFF's physiotherapist and nurse regularly visit other medical and rehabilitation centers and provide physiotherapy training to their personnel and services to the patients who are unable to go to any other physiotherapy centers.

JIFF is also involved in education. It provides stipends to the students for their education in Afghan refugee camps.

After restoration of peace, JIFF will extend its services inside $A \quad f \quad g \quad h \quad a \quad n \quad i \quad s \quad t \quad a \quad n$. 
JEHAD CONSULTING ENGINEERS-JCE

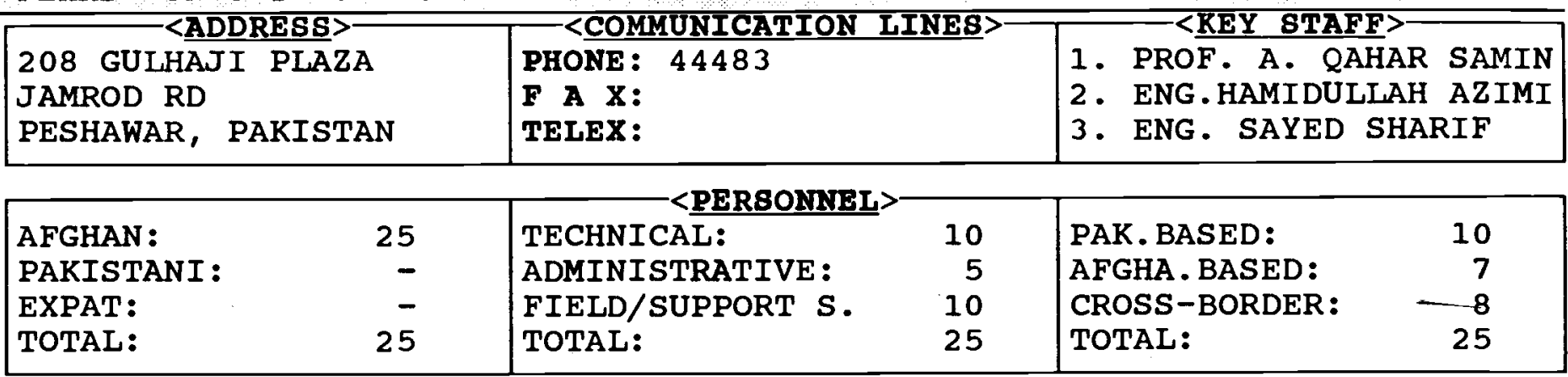

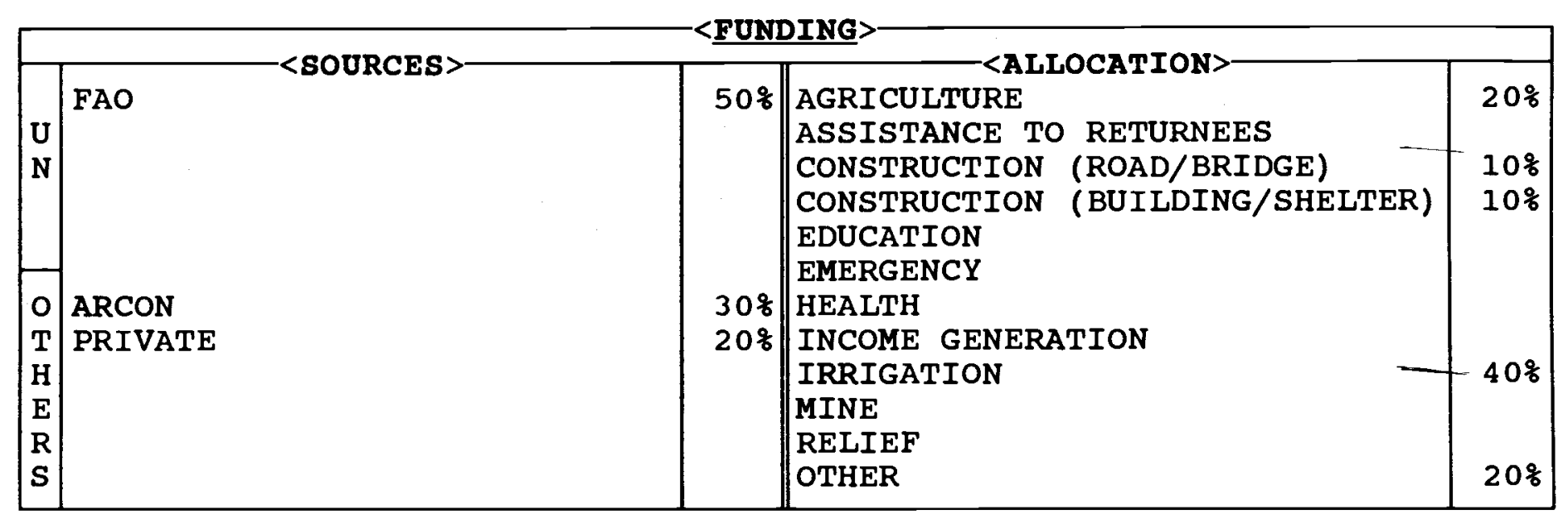

\begin{tabular}{|c|c|c|c|c|c|c|}
\hline & 1988 & 1989 & 1990 & 1991 & 1992 & 1993 \\
\hline $\begin{array}{l}\text { AFGHANISTAN : } \\
\text { REFUGEES : }\end{array}$ & & & $\begin{array}{l}2,800 \\
2,800\end{array}$ & 285,244 & 263,075 & 24,013 \\
\hline
\end{tabular}

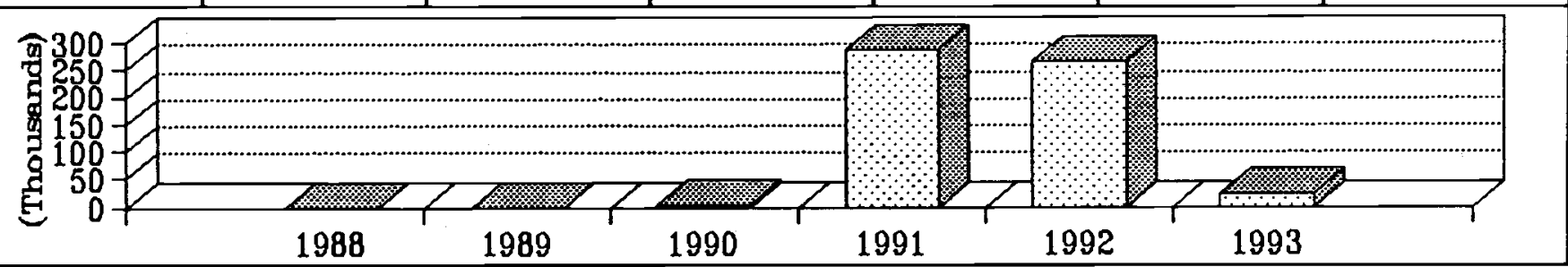

\begin{tabular}{|c|c|c|c|c|c|}
\hline PROVINCES & SECTOR & \&AGE & PROVINCES & SECTOR & \& AGE \\
\hline $\begin{array}{l}\text { BADAKSHAN } \\
\text { BADGHIS } \\
\text { BAGHLAN } \\
\text { BALKH } \\
\text { BAMYAN } \\
\text { FARAH } \\
\text { FARYAB } \\
\text { GHAZNI } \\
\text { GHOR } \\
\text { HELMAND } \\
\text { HERAT } \\
\text { JAWZJAN } \\
\text { KABUL } \\
\text { KANDAHAR } \\
\text { KAPISA }\end{array}$ & & & $\begin{array}{l}\text { KUNAR } \\
\text { KUNDUZ } \\
\text { LAGHMAN } \\
\text { LOGAR } \\
\text { NANGARHAR } \\
\text { NIMROZ } \\
\text { ORUZGAN } \\
\text { PAKTEKA } \\
\text { PAKTIA } \\
\text { PARWAN } \\
\text { SAMANGAN } \\
\text { TAKHAR } \\
\text { WARDAK } \\
\text { ZABUL }\end{array}$ & $\begin{array}{l}\text { Const } \\
\text { Agr/const/irrign } \\
\text { Agr/irrign } \\
\text { Const }\end{array}$ & $\begin{array}{l}20 \% \\
40 \% \\
30 \% \\
10 \%\end{array}$ \\
\hline
\end{tabular}




\section{JEHAD CONSULTING ENGINEERS (JCE)}

is an Afghan non-governmental organization founded in 1990. JCE's main objective is to contribute to the rehabilitation and reconstruction of Afghanistan.

JCE's areas of work include agriculture, rehabilitation, irrigation repair and infrastructure reconstruction. JCE intends to develop an integrated program.

The agency currently works in 4 different provinces and plans to expand its activities to other areas soon. JCE's projects can be briefly outlined as follows:

1) Paktia: In Khost, JCE has an agriculture program which includes provision of agriculture inputs (improved wheat seed and fertilizer).

2) Nangarhar: In Nangarhar JCE works in Bati Kot, Mohmand Dara, Lalpur and Kama areas. Activities cover seed and fertilizer distribution, provision of traction services, rehabilitation of irrigation systems (cleaning karezes and building retaining walls and dikes) and construction of public buildings such as schools, mosques and clinics.

3) Kunar: In Bar Kunar, JCE has constructed rope-carriers over the Kunar river. A pathway has also been repaired between Neshagam and Helaqee areas.

4) Takhar: In the capital of Takhar, JCE has built a madrasa (religious school) building. The building has 11 rooms.

In 1993, JCE focused on the following projects in Khost:

1. Construction of 11 structures ( 8 flumes and 3 culverts).

2. Cleaning Serkay canal in Lakan $(4.1 \mathrm{~km})$.

3. Construction of different irrigation system structures including cleaning syphons, construction of wash crossing and $r e t a$ a $i n g$ w $g$ a $l i$. 
KABUL PROVINCE RECONSTRUCTION ORGANIZATION-KPRO

\begin{tabular}{|c|c|c|}
\hline 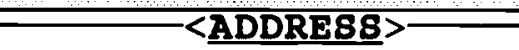 & -<COMMUNICATION LINES $>$ & $-<$ KEY 8TAFF $>$ \\
\hline $\begin{array}{l}\text { TANGI GHARU, DEHSABZ } \\
\text { P O BOX } 3170 \\
\text { KABUL, AFGHANISTAN }\end{array}$ & $\begin{array}{l}\text { PHONE: } \\
\text { F A X: } \\
\text { TELEX: }\end{array}$ & $\begin{array}{l}\text { 1. MS. DEABRA SCHETTNO } \\
\text { 2. MR. B. BABAKARKHEL } \\
\text { 3. MR. ZALMAI }\end{array}$ \\
\hline
\end{tabular}

\begin{tabular}{|lr|lr|lr|}
\hline AFGHAN: & 10 & TECHNICAL: & 2 & PAK. BASED: & - \\
PAKISTANI: & - & ADMINISTRATIVE: & 3 & AFGHA.BASED: & 11 \\
EXPAT: & 1 & FIELD/SUPPORT S. & 6 & CROSS-BORDER: & - \\
TOTAL: & 11 & TOTAL: & 11 & TOTAL: & 11 \\
\hline
\end{tabular}

\begin{tabular}{|c|c|c|c|c|}
\hline & <8OURCE & & <ATTOCATTON & \\
\hline $\begin{array}{l}U \\
N\end{array}$ & $\begin{array}{l}\text { UNICEF } \\
\text { WFP - Proposed to }\end{array}$ & $10 \%$ & $\begin{array}{l}\text { AGRICULTURE } \\
\text { ASSISTANCE TO RETURNEES } \\
\text { CONSTRUCTION (ROAD/BRIDGE) } \\
\text { CONSTRUCTION (BUILDING/SHELTER) } \\
\text { EDUCATION } \\
\text { EMERGENCY }\end{array}$ & \\
\hline $\begin{array}{l}\text { O } \\
\text { T } \\
\text { H } \\
\text { E } \\
\text { R } \\
\text { S }\end{array}$ & $\begin{array}{l}\text { ICRC } \\
\text { MSF } \\
\text { PRIVATE DONATIONS }\end{array}$ & $\begin{array}{l}108 \\
108 \\
708\end{array}$ & $\begin{array}{l}\text { HEALTH } \\
\text { INCOME GENERATION } \\
\text { IRRIGATION } \\
\text { MINE } \\
\text { RELIEF } \\
\text { OTHER }\end{array}$ & $100 \%$ \\
\hline
\end{tabular}

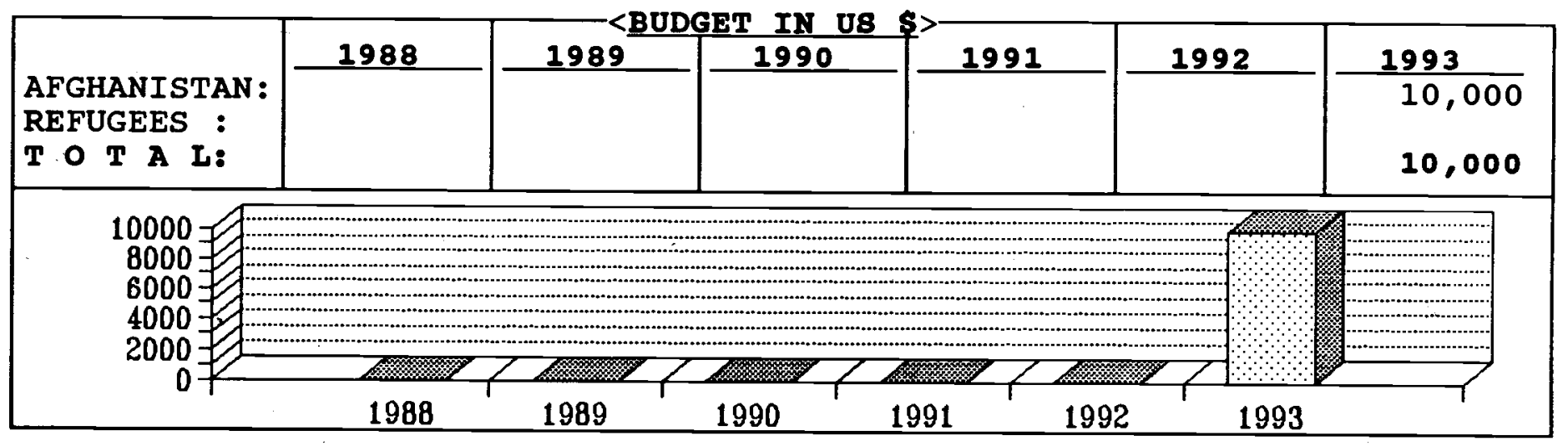

\begin{tabular}{|c|c|c|c|c|c|}
\hline PROVINCES & SECTOR & \&AGE & PROVINCES & SECTOR & $\& A G E$ \\
\hline $\begin{array}{l}\text { BADAKSHAN } \\
\text { BADGHIS } \\
\text { BAGHLAN } \\
\text { BALKH } \\
\text { BAMYAN } \\
\text { FARAH } \\
\text { FARYAB } \\
\text { GHAZNI } \\
\text { GHOR } \\
\text { HELMAND } \\
\text { HERAT } \\
\text { JAWZJAN } \\
\text { KABUL } \\
\text { KANDAHAR } \\
\text { KAPISA }\end{array}$ & Health & 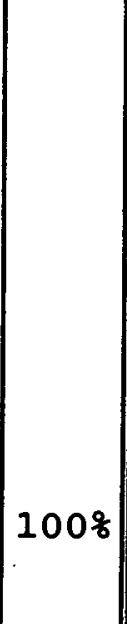 & \begin{tabular}{||l} 
KUNAR \\
KUNDUZ \\
LAGHMAN \\
LOGAR \\
NANGARHAR \\
NIMROZ \\
ORUZGAN \\
PAKTEKA \\
PAKTIA \\
PARWAN \\
SAMANGAN \\
TAKHAR \\
WARDAK \\
ZABUL
\end{tabular} & & \\
\hline
\end{tabular}


is an Afghan non-governmental organization established in Kabul in 1992. The organization focuses on rehabilitation and reconstruction activities primarily in easter parts of Kabul province.

Currently KPRO operates a clinic in Tangi Gharu an eastern suburb of Kabul where its main office is located. The clinic has a doctor and a nurse and is supported by ICRC, MSF and UNICEF. It provides services to 10 surrounding villages and will expand further in the future.

KPRO has conducted surveys on war destruction to irrigation systems, roads and bridges and public buildings e.g. schools and clinics in the districts of Deh Sabz and Bagrami. WFP and UNDP/OPS Mazar have been approached for funding and some of the projects are under consideration.

Surveys have also been conducted on the needs of some 20,000 families who have recently returned to their villages in the eastern districts of Kabul. KPRO will make efforts to contact various sources to provide some emergency assistance for these families.

KPRO is registered with UNOCHA and has been approved by the Government of Afghanistan as an NGO. 
KANDAHAR YOYETYAR AGEYCY - KMA

\begin{tabular}{|c|c|c|c|c|c|}
\hline$=<\mathrm{ADI}$ & & $=<$ COMMUNICATION & NEB & $=<$ REY $\mathbf{8 T A}$ & \\
\hline $\begin{array}{l}97 \text { BLOCK } 1 \\
\text { TOWN } \\
\text { QUETTA, PA] }\end{array}$ & LLITE & $\begin{array}{l}\text { PHONE: } 441209 \\
\text { F A X: } \\
\text { TELEX: }\end{array}$ & & $\begin{array}{l}\text { 1. HAJI MOHD } \\
\text { 2. } \\
\text { 3. }\end{array}$ & \\
\hline $\begin{array}{l}\text { AFGHAN: } \\
\text { PAKISTANI : } \\
\text { EXPAT: } \\
\text { TOTAL: }\end{array}$ & $\begin{array}{r}30 \\
- \\
30\end{array}$ & $\begin{array}{l}\text { TECHNICAL: } \\
\text { ADMINISTRATIVE: } \\
\text { FIELD/SUPPORT S. } \\
\text { TOTAL: }\end{array}$ & $\begin{array}{r}10 \\
12 \\
8 \\
30\end{array}$ & $\begin{array}{l}\text { PAK. BASED: } \\
\text { AFGHA. BASED: } \\
\text { CROSS-BORDER: } \\
\text { TOTAL: }\end{array}$ & $\begin{array}{r}15 \\
7 \\
8 \\
30\end{array}$ \\
\hline
\end{tabular}

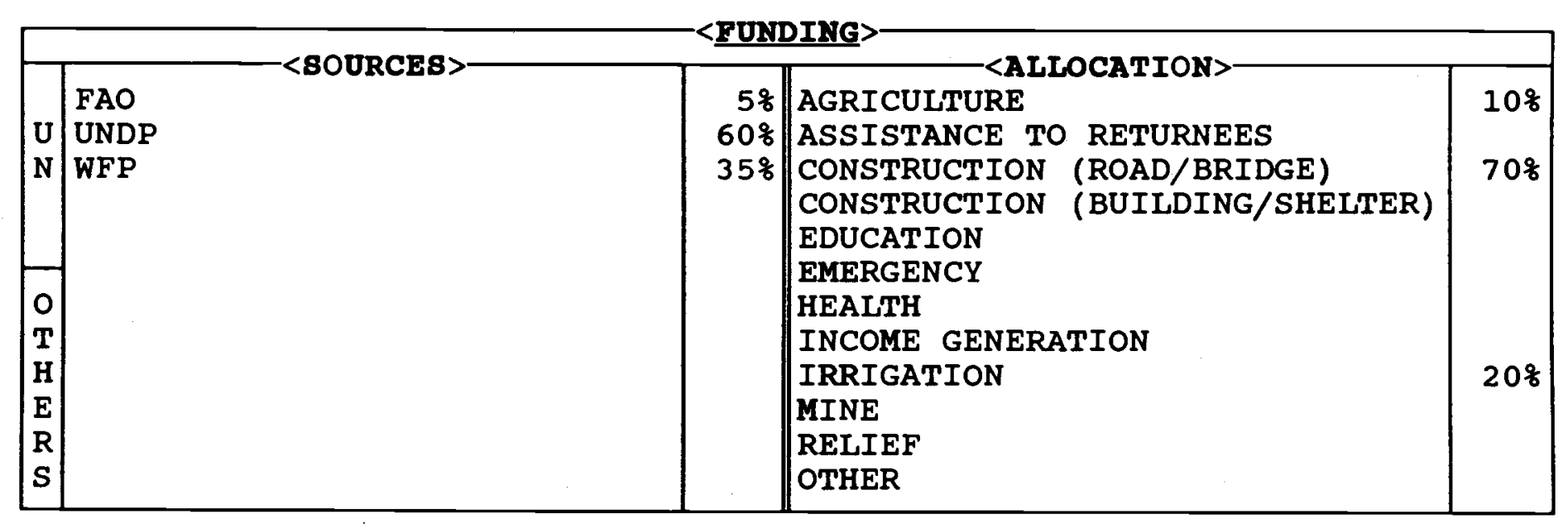

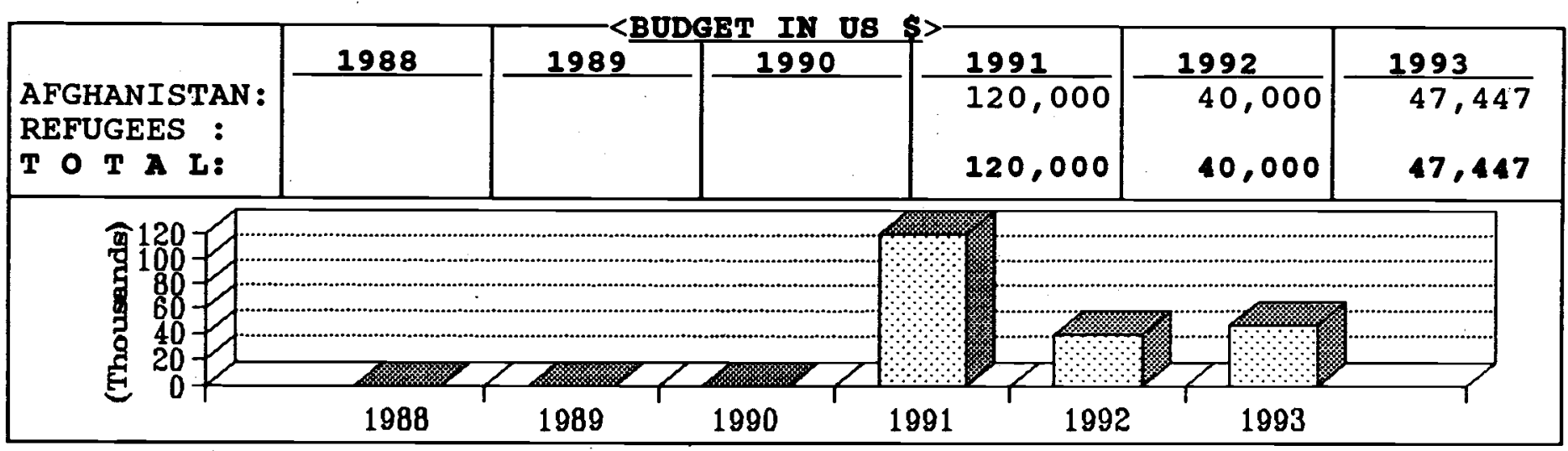

\begin{tabular}{|c|c|c|c|c|c|}
\hline PROVINCES & SECTOR & \% $\mathrm{AGE}$ & PROVINCES & SECTOR & \&AGE \\
\hline $\begin{array}{l}\text { BADAKSHAN } \\
\text { BADGHIS } \\
\text { BAGHLAN } \\
\text { BALKH } \\
\text { BAMYAN } \\
\text { FARAH } \\
\text { FARYAB } \\
\text { GHAZNI } \\
\text { GHOR } \\
\text { HELMAND } \\
\text { HERAT } \\
\text { JAWZJAN } \\
\text { KABUL } \\
\text { KANDAHAR } \\
\text { KAPISA }\end{array}$ & 政 & . & $\begin{array}{l}\text { KUNAR } \\
\text { KUNDUZ } \\
\text { LAGHMAN } \\
\text { LOGAR } \\
\text { NANGARHAR } \\
\text { NIMROZ } \\
\text { ORUZGAN } \\
\text { PAKTEKA } \\
\text { PAKTIA } \\
\text { PARWAN } \\
\text { SAMANGAN } \\
\text { TAKHAR } \\
\text { WARDAK } \\
\text { ZABUL }\end{array}$ & & \\
\hline
\end{tabular}


KANDAHAR MOMENYAR AGENCY (MA)

is an Afghan nongovernmental organization established in 1989 . The objective of the organization is to work for the rehabilitation and reconstruction of Afghanistan.

Kandahar Momenyar Agency works in the sectors of agriculture (distributing seeds, fertilizer and fruit trees), irrigation (cleaning and repairing canals and karezes and constructing dams) and construction (building houses for returnees and repairing roads and bridges).

So far, KMA has implemented a number of projects in agriculture, construction and irrigation in Kandahar province. It intends to expand its programs to other provinces of Afghanistan including Baghlan, Balkh and Faryab.

KMA is currently based in quetta and has a sub-office in Kandahar city. When the situation improves KMA will move the main office to Kabul and open sub-offices in other provinces of Afghanistan. 
KHORASAN ASSISTANCE GROUP-KAG

\begin{tabular}{|l|l|l|}
\hline $7-66 / 23$, ALAMDAR RD & PHONE: 75965 & 1. ENG \\
P O BOXY STAFF $>$ M. H. ABDULLAHI \\
QUETTA, PAKISTAN & F A X: & 2. \\
\hline
\end{tabular}

\begin{tabular}{|lc|ll|lr|}
\hline AFGHAN: & 74 & TECHNICAL: & 45 & PAK. BASED: & 9 \\
PAKISTANI: & - & ADMINISTRATIVE: & 19 & AFGHA.BASED: & 65 \\
EXPAT: & - & FIELD/SUPPORT S. & 10 & CROSS-BORDER: & - \\
TOTAL: & 74 & TOTAL: & 74 & TOTAL: & 74 \\
\hline
\end{tabular}

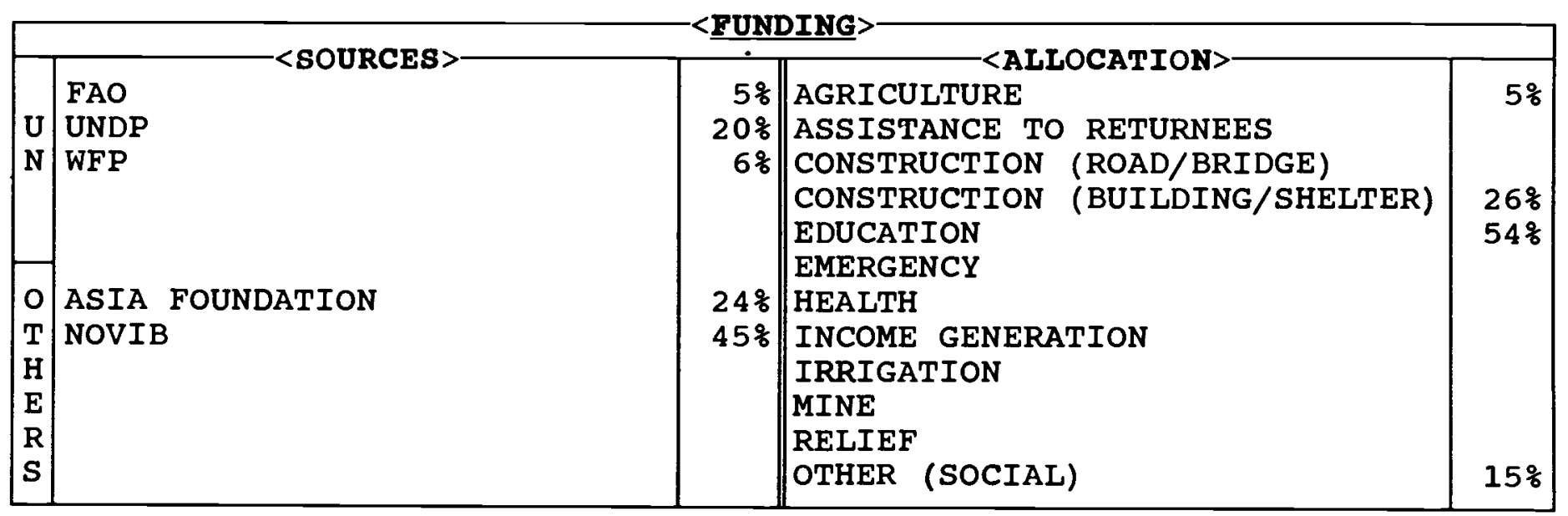

\begin{tabular}{|c|c|c|c|c|c|c|}
\hline $\begin{array}{l}\text { AFGHANISTAN: } \\
\text { REFUGEES : } \\
\text { T O T A L: }\end{array}$ & 1988 & 1989 & $\begin{array}{l}1990 \\
25,000 \\
25,000\end{array}$ & $\begin{array}{l}\frac{1991}{50,000} \\
50,000\end{array}$ & $\begin{array}{l}\frac{1992}{97,000} \\
97,000\end{array}$ & $\begin{array}{l}1993 \\
85,500 \\
85,500\end{array}$ \\
\hline 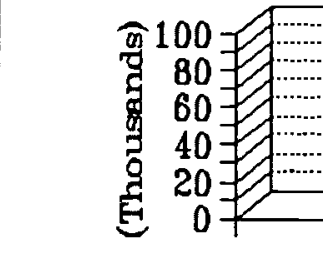 & ר. & :ivivi:i: & n) $/ 7$ & 济 & - & (1) \\
\hline
\end{tabular}

\begin{tabular}{|c|c|c|c|c|c|}
\hline PROVINCES & SECTOR & \% & PROVINCES & SECTOR & $\because \mathrm{AGE}$ \\
\hline $\begin{array}{l}\text { BADAKSHAN } \\
\text { BADGHIS } \\
\text { BAGHLAN } \\
\text { BALKH } \\
\text { BAMYAN } \\
\text { FARAH } \\
\text { FARYAB } \\
\text { GHAZNI } \\
\text { GHOR } \\
\text { HELMAND } \\
\text { HERAT } \\
\text { JAWZJAN } \\
\text { KABUL } \\
\text { KANDAHAR } \\
\text { KAPISA }\end{array}$ & $\ddot{\text { Agrr/const/educ/income }}$ & $\begin{array}{l}22 \% \\
78 \%\end{array}$ & \begin{tabular}{|l} 
KUNAR \\
KUNDUZ \\
LAGHMAN \\
LOGAR \\
NANGARHAR \\
NIMROZ \\
ORUZGAN \\
PAKTEKA \\
PAKTIA \\
PARWAN \\
SAMANGAN \\
TAKHAR \\
WARDAK \\
ZABUL
\end{tabular} & & \\
\hline
\end{tabular}


is an Afghan non-governmental organization established in May 1988. The objective is to work for the rehabilitation and reconstruction of Afghanistan and provide assistance in the field of education and social services. It also provides some income generation opportunities for poor and needy families.

KAG runs 6 primary schools in Ghazni province which educate a total of 1,500 students. The schools have 60 personnel. One school is also supported in Mariabad, Quetta for refugee children. It has 150 students. Books are provided freely to the students and sometimes stationary to exceptional students. Literacy courses for both men and women are also offered.

A magazine is published in Dari called Sadai Rosta and distributed to the villages in Afghanistan.

KAG has repaired and upgraded a high school building in Jaghori area and reconstructed damaged schools in Malestan and Qarabagh. KAG has surveyed roads and will repair them in the near future.

In agriculture, KAG has distributed seeds and fertilizer. Fruit trees have also been distributed. Karezes have been rehabilitated to promote agriculture.

KAG plans to organize MCH/TBA training and a vaccination program.

The main office of the organization is based in quetta. It has two suboffices in Ghazni province (Jaghori and Qarabagh districts) where most of its activities have been focused so far. In 1993, KAG opened a suboffice in Mazar-i-Sharif from where it implements projects in Faryab province. 


\begin{tabular}{|l|l|l|}
\hline 1, 2ND FLR KHYBER VIEW & PHONE: 841439/44600 & 1. HAJI M. DAWEY BTAFF> \\
P O BOX........ & F A X: & 2. \\
PESHAWAR, PAKISTAN & TELEX: & 3. \\
\hline
\end{tabular}

\begin{tabular}{|lr|lr|lrr|}
\hline AFGHAN : & 62 & TECHNICAL: & 10 & PAK.BASED: & 12 \\
PAKISTANI : & - & ADMINISTRATIVE : & 5 & AFGHA.BASED: & 45 \\
EXPAT: & - & FIELD/SUPPORT S. & 47 & CROSS-BORDER: & 5 \\
TOTAL: & 62 & TOTAL: & 62 & TOTAL: & 62 \\
\hline
\end{tabular}

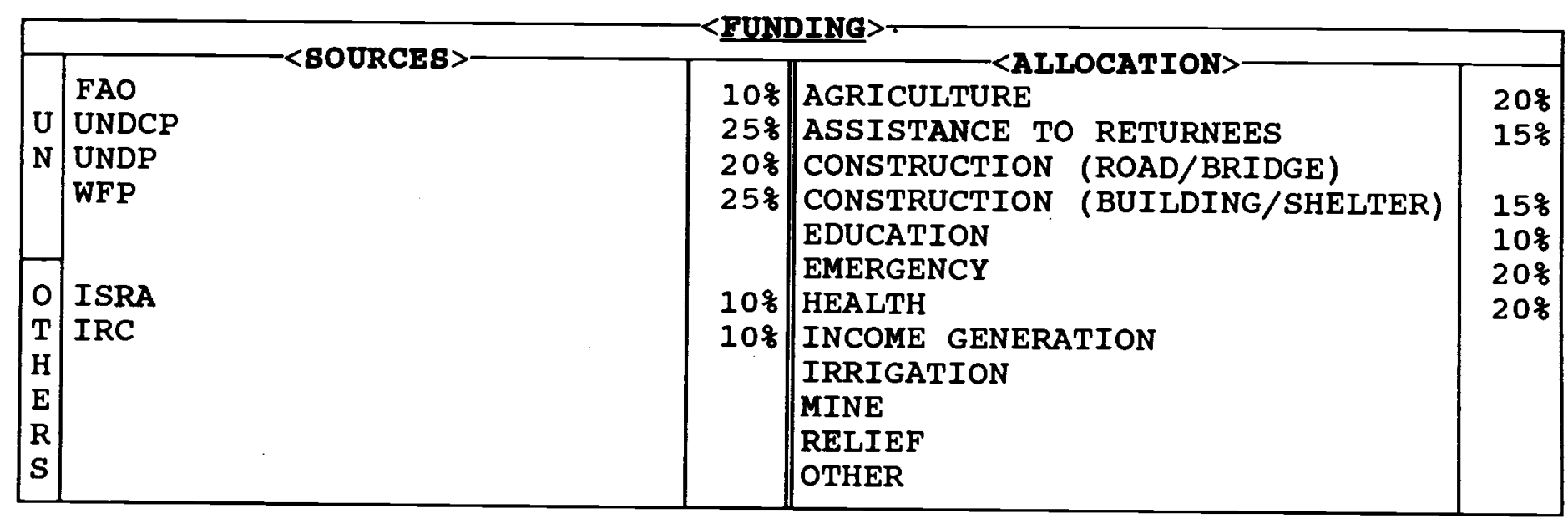

\begin{tabular}{|c|c|c|c|c|c|c|}
\hline $\begin{array}{l}\text { AFGHANISTAN: } \\
\text { REFUGEES : } \\
\text { T O T A L: }\end{array}$ & 1988 & 1989 & 1990 & $\begin{array}{l}\frac{1991}{1,000,000} \\
1,000,000\end{array}$ & $\begin{array}{l}\frac{1992}{158,530} \\
158,530\end{array}$ & $\begin{array}{l}\frac{1993}{146,322} \\
146,322\end{array}$ \\
\hline 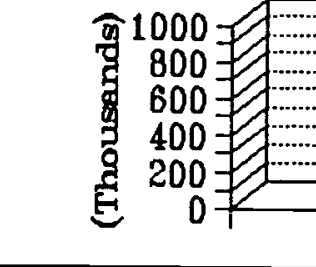 & 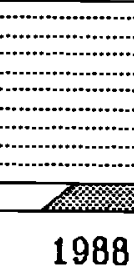 & $\cdots$ & wivi: & 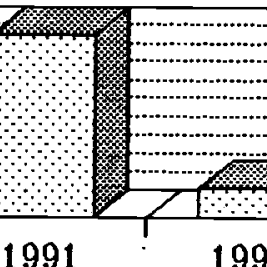 & … & (1) \\
\hline
\end{tabular}

\begin{tabular}{|c|c|c|c|c|c|}
\hline PROVINCES & SECTOR & \&AGE & PROVINCES & SECTOR & \&AGE \\
\hline $\begin{array}{l}\text { BADAKSHAN } \\
\text { BADGHIS } \\
\text { BAGHLAN } \\
\text { BALKH } \\
\text { BAMYAN } \\
\text { FARAH } \\
\text { FARYAB } \\
\text { GHAZNI } \\
\text { GHOR } \\
\text { HELMAND } \\
\text { HERAT } \\
\text { JAWZJAN } \\
\text { KABUL } \\
\text { KANDAHAR } \\
\text { KAPISA }\end{array}$ & & & $\begin{array}{l}\text { KUNAR } \\
\text { KUNDUZ } \\
\text { ILAGHMAN } \\
\text { LOGAR } \\
\text { NANGARHAR } \\
\text { NIMROZ } \\
\text { ORUZGAN } \\
\text { PAKTEKA } \\
\text { PAKTIA } \\
\text { PARWAN } \\
\text { SAMANGAN } \\
\text { TAKHAR } \\
\text { WARDAK } \\
\text { ZABUL }\end{array}$ & Agr/emergency/health & $100 \%$ \\
\hline
\end{tabular}




\section{KOH-I-HOOR FOUNDATION (RNF)}

is an Afghan non-governmental organization which took over the projects of the Council for International Development (CID) in July, 1991.

$\mathrm{KNF}$ main office is in Peshawar and has a sub-office in Jalalabad.

$\mathrm{KNF}$ is active in the sectors of health, agriculture, irrigation, rehabilitation and relief commodities distribution.

KNF areas of specialization are:

- reconstruction activities

- agriculture programs

- medical services.

Currently KNF runs saber clinic in Pachier/Agam district; 3 schools in Achin district; rehabilitation of Farms No. 2, 3 and 4 in Bati Kot; fruit trees distribution in sayedan Arabi, Araban and Kushkak areas of Nangarhar province.

In the past, KNF implemented several projects in the state Farms in Bati Kot including field crops, horticulture and farm maintenance where it cultivated 124 hectares of land with improved wheat seeds and hired 900 persons to take care of 2500 hectares of olive trees and 500 hectares of citrus. Moreover, KNF has several times distributed improved seeds and fertilizer and budded trees to farmers in Eshpora, Surkhrod, Lalpur, Lakhi and Pachier/Agam, area of Nangarhar with the support of different UN agencies, IRC/RAP and ISRA. A tree plantation project was completed in Surkhrod with the assistance of WFP. A number of irrigation projects (canal rehabilitation and intake construction) have been completed in Pachier/Agam with the assistance of UNDCP. Basic health centers were operated in Deh Bala and Surkhrod areas with financial support of USAID and WHO respectively.

As part of its relief and emergency program, KNF has distributed hundreds of tons of food wheat to war affected and displaced families in different parts of Nangarhar Province mainly with the support of WFP. 
KUWAIT RED CRESCENT SOCIETY-KRCS

<ADDRESS>

ABDARA CHOWK, JAMROD RD P O BOX 782

PESHAWAR, PAKISTAN

<COMMUNICATION LINE8 $>$

F A $X: 840521$

TELEX:
1. MR. AHMAD SANOSI

2. DR. GULSHER ABID

3. MR. ABDULLAH KHAN

\begin{tabular}{|lr|lr|lr|}
\hline AFGHAN: & 129 & TECHNICAL: & 41 & PAK. BASED: & 187 \\
PAKISTANI : & 52 & ADMINISTRATIVE: & 9 & AFGHA. BASED: & - \\
EXPAT: & 6 & FIELD/SUPPORT S. & 137 & CROSS-BORDER: & - \\
TOTAL: & 187 & TOTAL: & 187 & TOTAL: & 187 \\
\hline
\end{tabular}

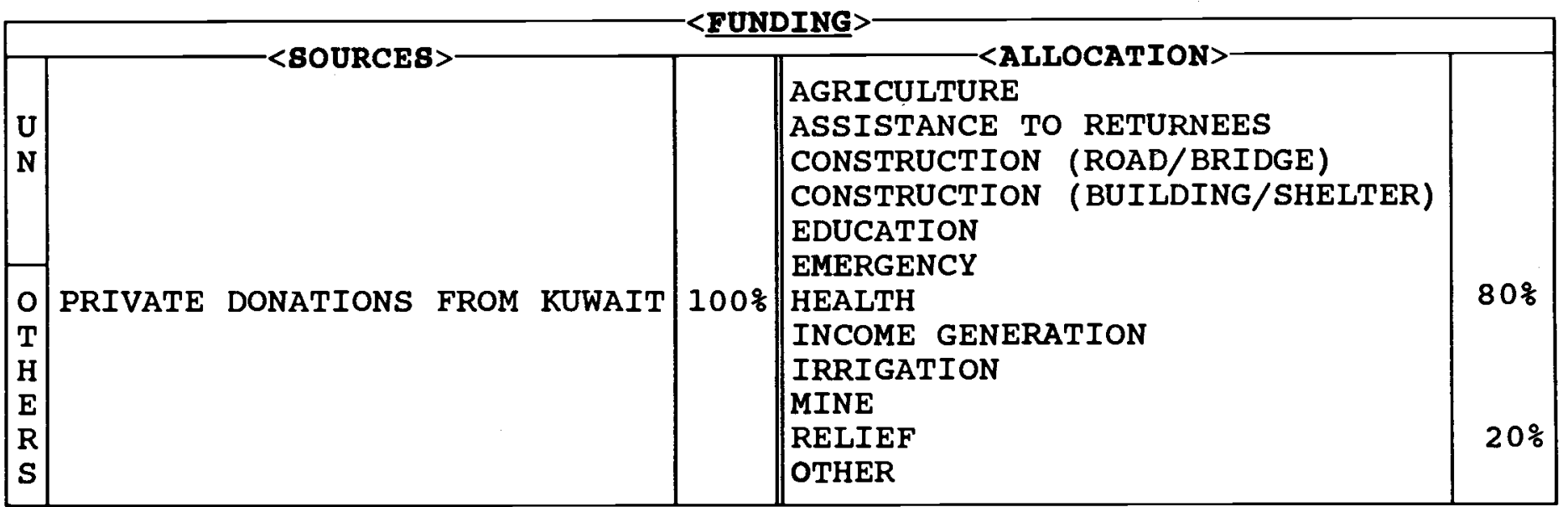

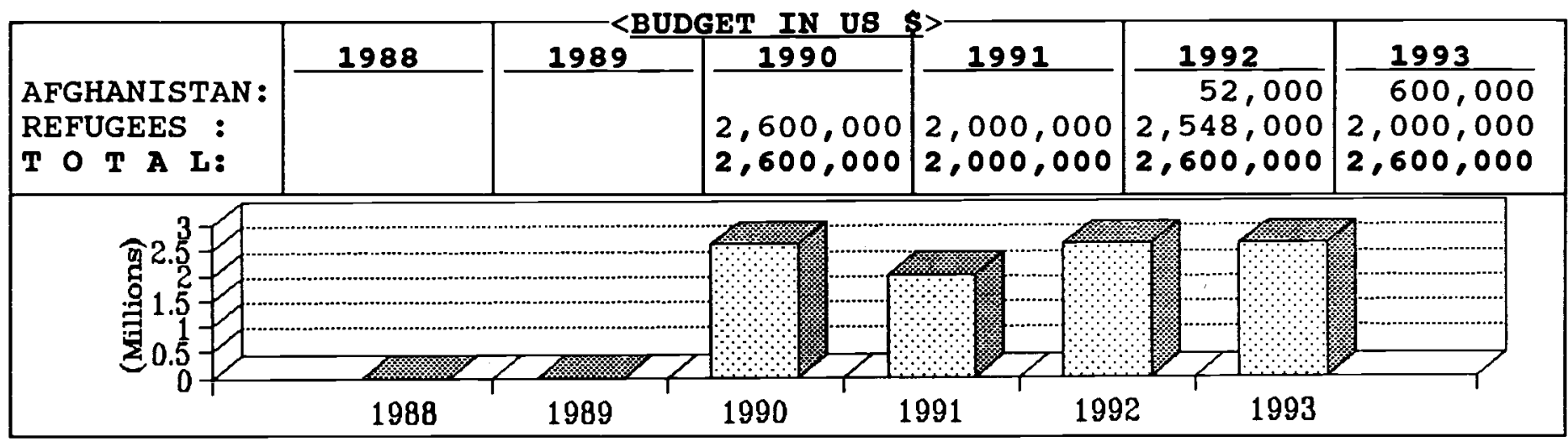

\begin{tabular}{|c|c|c|c|c|c|}
\hline PROVINCES & SECTOR & \&AGE & PROVINCES & SECTOR & $\% A G E$ \\
\hline $\begin{array}{l}\text { BADAKSHAN } \\
\text { BADGHIS } \\
\text { BAGHLAN } \\
\text { BALKH } \\
\text { BAMYAN } \\
\text { FARAH } \\
\text { FARYAB } \\
\text { GHAZNI } \\
\text { GHOR } \\
\text { HELMAND } \\
\text { HERAT } \\
\text { JAWZJAN } \\
\text { KABUL } \\
\text { KANDAHAR } \\
\text { KAPISA }\end{array}$ & Health & . & \begin{tabular}{|l} 
KUNAR \\
KUNDUZ \\
LAGHMAN \\
LOGAR \\
NANGARHAR \\
NIMROZ \\
ORUZGAN \\
PAKTEKA \\
PAKTIA \\
PARWAN \\
SAMANGAN \\
TAKHAR \\
WARDAK \\
ZABUL
\end{tabular} & Health & $80 \%$ \\
\hline
\end{tabular}


KUWAIT RED CRESCENT SOCIETY (RRCS)

established an office in Peshawar in 1983 and started different projects for Afghan refugees in the border between Afghanistan and Pakistan. Most of donations for KRCS's projects come from individuals who prefer to be un-known as they seek only the grace of Allah.

KRCS's projects are in three different sectors:

HEALTH: KRCS operates the following facilities :

KRCS Hospital in Peshawar: It is a 220 bed hospital functioning since 1985. Different sections of the hospital (IPD and OPD) include orthopaedic, neuro-surgery, plastic surgery and general surgery, medical ward, ICU, ophthalmology, OT, sterilization department, x-ray, lab, casualty department, dental clinic, plaster room, pharmacy, gymnasium, physiotherapy and electrotherapy. The hospital also has a large workshop for limb fitting. Recently a small paraplegic unit has been added to the hospital.

KRCS has a teaching program through which Afghan and Pakistani medical staff are given training in different sections in the form of clinical tutorials, meetings and ground rounds.

KRCS also ran a first aid school which trained Afghans as OT assistants, physiotherapy technicians, orthopaedic technicians and lab technicians. The course graduated 245 people and stopped in 1988 .

Front Line Health Posts: 2 health posts are operating in Trimangal and Nawagah areas to provide first aid and evacuate war wounded. A 30 bed hospital with the same objective was functioning in Miranshah which discontinued in January 1992.

Health centers in RTVS: KRCS runs 8 health centers in Jalala, Akora
Khatak and Zangali refugee camps. Moreover, two dental clinics are operated for the refugees.

In addition to the above mentioned programs, KRCS contributes in building some small hospitals, in donating drugs, medical and laboratory equipment, ambulances, $\mathrm{x}-$ ray films and equipment and in supporting hospitals by regular monthly donations.

SOCIAL SERVICES: KRCS has distributed relief items including tents, blankets, shoes, garments, assorted food-stuffs, Holy Quran, note books and pens to Afghan refugees.

As part of its relief operation, KRCS has dug 357 wells for drinking water in different RTVs in NWFP.

KRCS has an orphan care program which provides Afghan orphans with shelter, food and education.

EDUCATION: 10 mosques and 2 schools have been constructed and many others have been repaired by KRCS. KRCS has translated and printed important Islamic books in Farsi and Pushto and distributed them to Afghans.

34 scholarships have been arranged in different Pakistani medical schools to help Afghan students to continue their medical studies.

KRCS has opened a medical rehabilitation center ( 10 beds for the moment) in Jalalabad which has an orthopedic workshop and a physiotherapy center. A paraplegic unit will be added shortly.

Some of KRCS projects, including orphan care program, digging wells, scholarship program and part of medical relief are supported by Kuwaiti Bait-al-zakat. 
IATHAT AL-BIRR AI-I8IAMIA-IBI

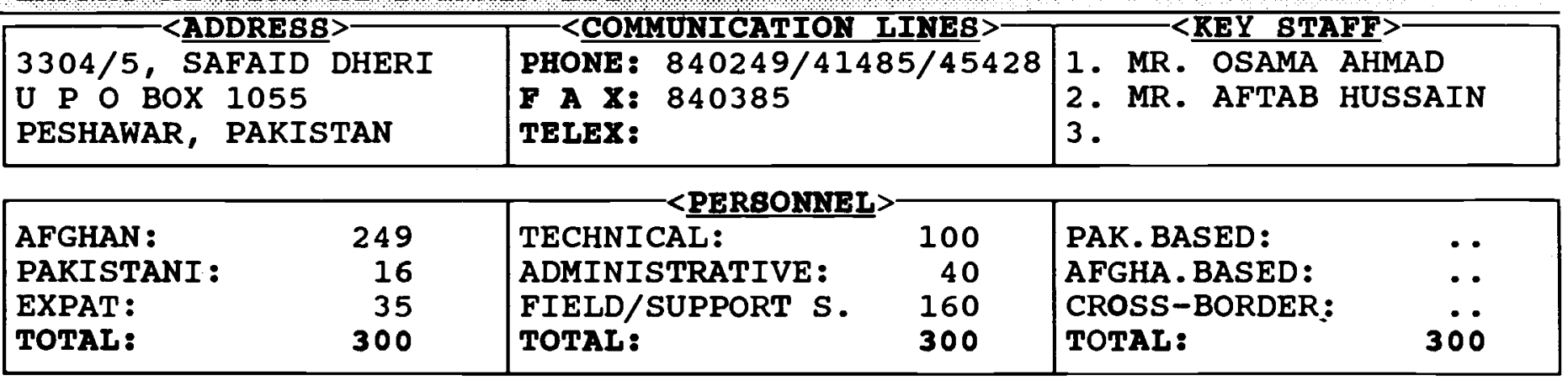

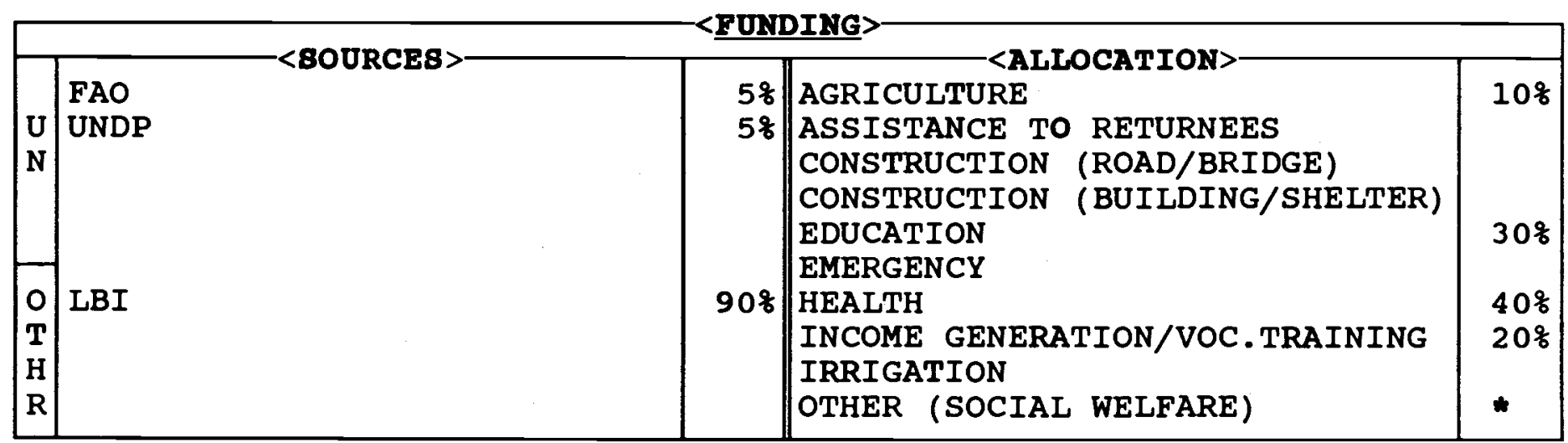

\begin{tabular}{|c|c|c|c|c|c|c|}
\hline $\begin{array}{l}\text { AFGHANISTAN: } \\
\text { REFUGEES : } \\
\text { T O T A L: }\end{array}$ & 1988 & 1989 & $\begin{array}{l}1990 \\
1,200,000 \\
1,000,000 \\
2,200,000\end{array}$ & $\frac{1991}{1,200,000}=$ & $\begin{array}{l}\frac{1992}{1,200,000} \\
1,000,000 \\
2,200,000\end{array}$ & $\begin{array}{r}1993 \\
595,668 \\
500,000 \\
1,095,668\end{array}$ \\
\hline 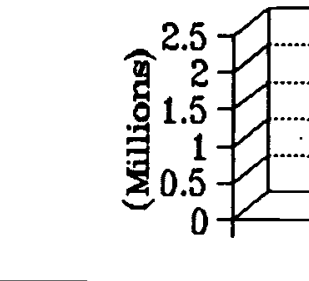 & 1988 & 1989 & 1990 & 991 & 1993 & $\ldots \ldots$ \\
\hline
\end{tabular}

\begin{tabular}{|c|c|c|c|c|c|}
\hline PROVINCES & SECTOR & \%AGE & PROVINCES & SECTOR & $\because A G E$ \\
\hline $\begin{array}{l}\text { BADAKSHAN } \\
\text { BADGHIS } \\
\text { BAGHLAN } \\
\text { BALKH } \\
\text { BAMYAN } \\
\text { FARAH } \\
\text { FARYAB } \\
\text { GHAZNI } \\
\text { GHOR } \\
\text { HELMAND } \\
\text { HERAT } \\
\text { JAWZJAN } \\
\text { KABUL } \\
\text { KANDAHAR } \\
\text { KAPISA }\end{array}$ & & & $\begin{array}{l}\text { KUNAR } \\
\text { KUNDUZ } \\
\text { LAGHMAN } \\
\text { LOGAR } \\
\text { NANGARHAR } \\
\text { NIMROZ } \\
\text { ORUZGAN } \\
\text { PAKTEKA } \\
\text { PAKTIA } \\
\text { PARWAN } \\
\text { SAMANGAN } \\
\text { TAKHAR } \\
\text { WARDAK } \\
\text { ZABUL }\end{array}$ & $\begin{array}{l}\text { Agr/educ } \\
\text { Agr/educ } \\
\text { Agr/educ/health }\end{array}$ & $\begin{array}{l}20 \% \\
20 \% \\
60 \%\end{array}$ \\
\hline
\end{tabular}

* NOTE: In addition to the above budget figures US\$ $1.190,000$ has been given to orphans as cash. 
LAJNAT ÁL-BIRR ĀL-ISLAMIAH (LBI)

was founded in 1988 in the Kingdom of Saudi Arabia by a group of intellectuals who felt that the Islamic world badly needed charitable assistance for the resettlement and rehabilitation of their refugees all over the world. Lajnat Al-Birr is part of a group of similar relief and charitable organizations, called World Assembly of Muslim Youth. The head office is located in Jeddah, Saudi Arabia and there is a regional office in Peshawar. It is non-political organization.

LBI started operations for Afghans in January 1988. It carries out programs in different sectors both in Peshawar and inside Afghanistan. The major activities are in the fields of social welfare, education, rural development, health services and emergency relief operations.

During the years of war in Afghanistan, five fully staffed hospitals were run by LBI; and a specialized Plastic Surgery Hospital at Hayatabad served Afghans for years.

At present, LBI maintains the following programs in Afghanistan:

1. Two major hospitals in Chamkani and Jaji districts of Paktia.

2. Funds distribution to orphans at centers in Kunar, Nangarhar, Kapisa (Panjshair), Wardak and Kabul.

3. An orphanage in Kunar and another one in Panjshair.

4. Five Quran memorization centers in Nangarhar and six in Wardak.

5. As an implementing partner of FAO, UNDP and UNDCP, LBI carries out agricultural activities e.g. inputs distribution, traction and extension services, establishing and maintaining fruit orchards and animal husbandry programs in Kunar, Nangarhar and Paktia provinces. LBI is also involved in irrigation rehabilitation in Nangarhar.

6. Construction of public buildings (schools, mosques other buildings and tube-wells) and their maintenance.

For the refugees, LBI maintains a Religious Teaching Institute (200 to 250 students) and a Technical School plus a workshop.

Emergency relief assistance (meat, wheat, sugar, tea and beans) is distributed in refugee camps in Peshawar and in Afghanistan from time to time.

Most of the staff members of LBI are specialists in their fields. 
LAJ NAT AL-DAWA AL-ISLAMIA-LDI

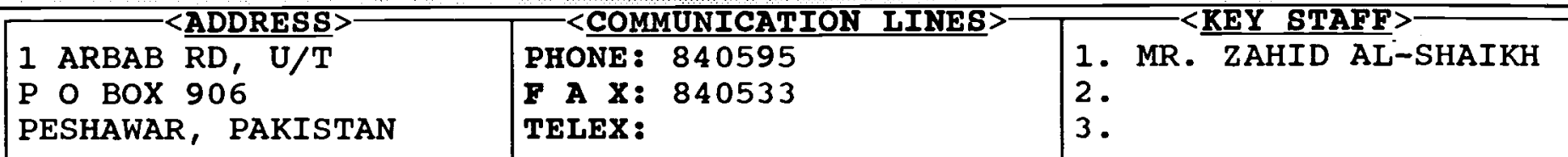

\begin{tabular}{|c|c|c|c|c|c|}
\hline $\begin{array}{l}\text { AFGHAN : } \\
\text { PAKISTANI : } \\
\text { EXPAT : } \\
\text { TOTAL: }\end{array}$ & $\begin{array}{r}1,130 \\
\pm \quad 10 \\
50 \\
1,190\end{array}$ & $\begin{array}{l}\text { TECHNICAL: } \\
\text { ADMINISTRATIVE: } \\
\text { FIELD/SUPPORT S. } \\
\text { TOTAL: }\end{array}$ & $\begin{array}{r}\dot{\cdots} \\
1,19 \dot{0}\end{array}$ & $\begin{array}{l}\text { PAK. BASED: } \\
\text { AFGHA. BASED: } \\
\text { CROSS-BORDER: } \\
\text { TOTAL : }\end{array}$ & $\begin{array}{r}\dot{\cdots} \\
1,1 \dot{9}\end{array}$ \\
\hline
\end{tabular}

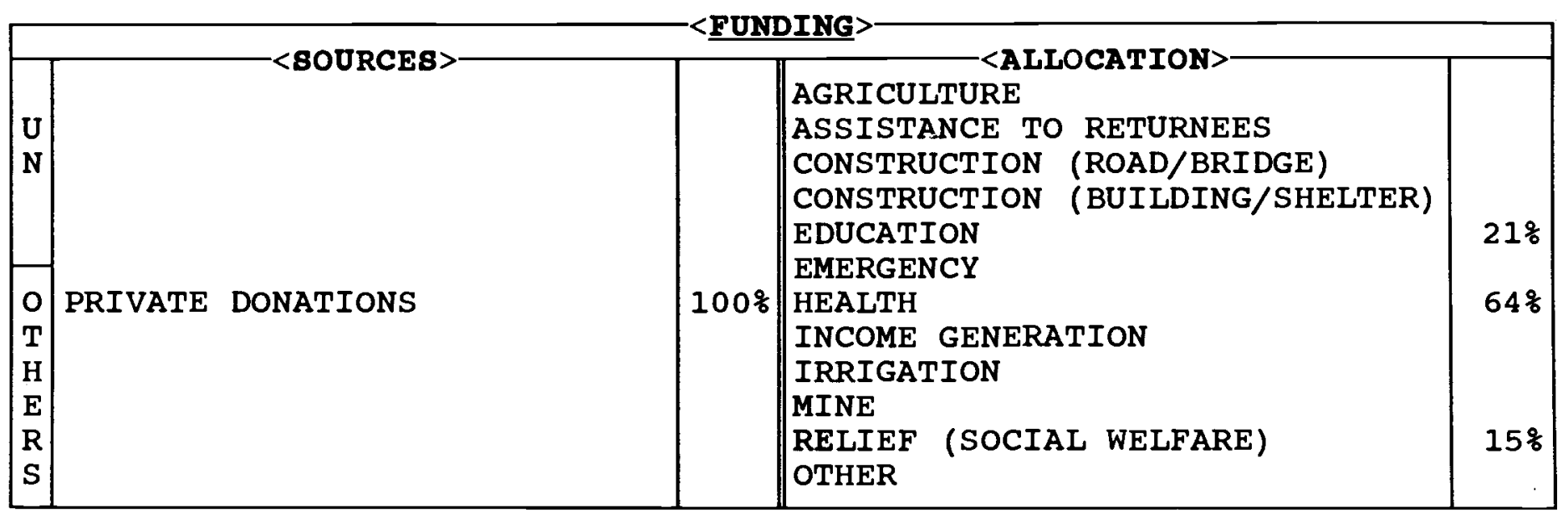

\begin{tabular}{|c|c|c|c|c|c|c|}
\hline $\begin{array}{l}\text { AFGHANISTAN: } \\
\text { REFUGEES : } \\
\text { T O T A L: }\end{array}$ & 1988 & 1989 & $\begin{array}{l}\frac{1990}{1,224,000} \\
2,670,000 \\
3,894,000\end{array}$ & 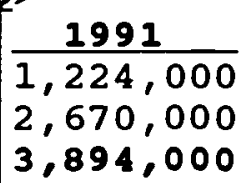 & $\begin{array}{l}\frac{1992}{1,224,000} \\
2,670,000 \\
3,894,000\end{array}$ & $\begin{array}{l}\frac{1993}{1,224,000} \\
2,670,000 \\
3,894,000\end{array}$ \\
\hline 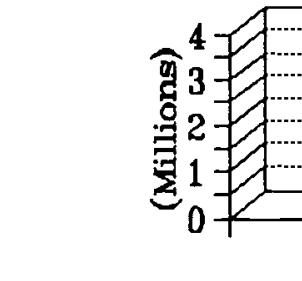 & 1988 & $\begin{array}{l}\text { 26x.x } \\
1989\end{array}$ & 1990 & 991 & $\cdots \cdots$ & (1) \\
\hline
\end{tabular}

\begin{tabular}{|c|c|c|c|c|c|}
\hline PROVINCES & SECTOR & \%AGE & PROVINCES & SECTOR & \&AGE \\
\hline $\begin{array}{l}\text { BADAKSHAN } \\
\text { BADGHIS } \\
\text { BAGHLAN } \\
\text { BALKH } \\
\text { BAMYAN } \\
\text { FARAH } \\
\text { FARYAB } \\
\text { GHAZNI } \\
\text { GHOR } \\
\text { HELMAND } \\
\text { HERAT } \\
\text { JAWZJAN } \\
\text { KABUL } \\
\text { KANDAHAR } \\
\text { KAPISA }\end{array}$ & $\begin{array}{l}\text { Health } \\
\text { Health } \\
\text { Health }\end{array}$ & $\begin{array}{r}10 \% \\
5 \% \\
5 \%\end{array}$ & \begin{tabular}{|l} 
KUNAR \\
KUNDUZ \\
LAGHMAN \\
LOGAR \\
NANGARHAR \\
NIMROZ \\
ORUZGAN \\
PAKTEKA \\
PAKTIA \\
PARWAN \\
SAMANGAN \\
TAKHAR \\
WARDAK \\
ZABUL
\end{tabular} & $\begin{array}{l}\text { Health } \\
\text { Health } \\
\text { Health }\end{array}$ & $\begin{array}{l}10 \% \\
35 \%\end{array}$ \\
\hline
\end{tabular}




\section{LAJNAT AL-DAWA AL-ISLAMIAH (LDI)}

is an Islamic charity organization working for Afghans for the past several years. LDI has been working in the field of health, education and relief.

In health, LDI runs many facilities both for refugees and in Afghanistan:

- A 200 bed hospital in Peshawar.

- A hospital in Sadda - Kohat.

- 3 comprehensive clinics in Baluchistan one in each Abadini, Chaman and Gerdi Jangal areas.

- A hospital in Azam Warsak.

- A comprehensive clinic in Landi Kotal.

- A hospital in Tangi, Wardak.

- A hospital in Sharan, Pakteka.

Moreover, LDI supports $19 \mathrm{clinics}$ of different types (comprehensive clinics to basic health posts) in 8 different provinces of Afghanistan.

LDI ran a medical training program in Peshawar which discontinued in 1990. The program trained Afghans in $x$-ray, lab, anesthesia and operation theater.

In the field of education, LDI supports 10 secondary and 2 primary schools in Pakistan. A teacher training institute is operational in Peshawar. LDI also supports 22 Quranic centers in the refugee camps. LDI has informal education activities including training electricians ( 51 have been trained so far), publication service which translates and prints literature into Farsi and pushto, maintaining a cultural center (collection of printed, audio and visual materials) and organizing lectures in the refugee camps.

In Afghanistan, LDI supports two secondary schools and 11 primary/middle schools (5 of them are for girls) in the provinces of Paktia, Ghazni and Wardak.
LDI, as part of its relief operation, has a drinking water program which builds tube wells in $t h$ e ref uge e c a mps. 
IAJNAT AL-QATAR FOR ORPHANS-LQO

\begin{tabular}{|c|c|c|}
\hline <ADDRESS> & $\langle$ COMMUNICATION LINES $\rangle$ & $<\mathrm{KE}$ \\
\hline $\begin{array}{l}\text { ARBAB RD， U/T } \\
\text { PESHAWAR， PAKISTAN }\end{array}$ & $\begin{array}{l}\text { PHONE : } 43681 \\
\text { F A X: } \\
\text { TELEX: }\end{array}$ & $\begin{array}{l}\text { 1. MR. ABO AHMAD } \\
\text { 2. } \\
\text { 3. }\end{array}$ \\
\hline
\end{tabular}

\begin{tabular}{|lr|lr|lr|}
\hline AFGHAN : & 16 & TECHNICAL: & 5 & PAK. BASED: & 15 \\
PAKISTANI : & 5 & ADMINISTRATIVE: & 15 & AFGHA. BASED: & 15 \\
EXPAT: & 9 & FIELD/SUPPORT S. & 10 & CROSS-BORDER: & - \\
TOTAL: & 30 & TOTAL: & 30 & TOTAL: & 30 \\
\hline
\end{tabular}

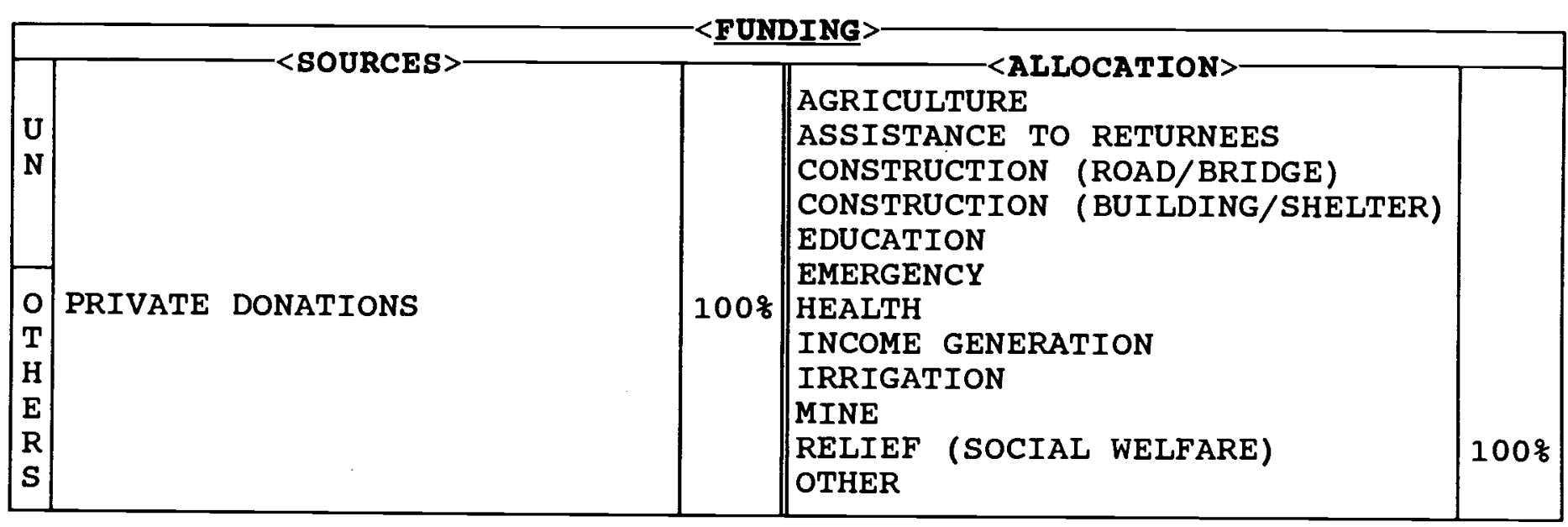

\begin{tabular}{|l|l|l|l|l|l|l|}
\hline & 1988 & 1989 & 1990 & 1991 & 1992 & 1993 \\
AFGHANISTAN : & & & & & & \\
TOTUEES : & & & & & & \\
\hline
\end{tabular}

\begin{tabular}{|c|c|c|c|c|c|c|}
\hline PROVINCES & SECTOR & \% AGE & PROVINCES & & SECTOR & $\because \mathrm{AGE}$ \\
\hline $\begin{array}{l}\text { BADAKSHAN } \\
\text { BADGHIS } \\
\text { BAGHLAN } \\
\text { BALKH } \\
\text { BAMYAN } \\
\text { FARAH } \\
\text { FARYAB } \\
\text { GHAZNI } \\
\text { GHOR } \\
\text { HELMAND } \\
\text { HERAT } \\
\text { JAWZJAN } \\
\text { KABUL } \\
\text { KANDAHAR } \\
\text { KAPISA }\end{array}$ & & & $\begin{array}{l}\text { KUNAR } \\
\text { KUNDUZ } \\
\text { LAGHMAN } \\
\text { LOGAR } \\
\text { NANGARHAR } \\
\text { NIMROZ } \\
\text { ORUZGAN } \\
\text { PAKTEKA } \\
\text { PAKTIA } \\
\text { PARWAN } \\
\text { SAMANGAN } \\
\text { TAKHAR } \\
\text { WARDAK } \\
\text { ZABUL }\end{array}$ & $\begin{array}{l}\text { Social } \\
\text { Social }\end{array}$ & $\begin{array}{l}\text { welfare } \\
\text { welfare }\end{array}$ & $\begin{array}{l}30 \% \\
70 \%\end{array}$ \\
\hline
\end{tabular}


IAAJNAT AL-QATAR FOR ORPHANS (LQO)

is an Islamic charity organization which started programs for Afghans in $1991 / 92$.

LQO supports orphanages in the following areas:

- Jalalabad city, Nangarhar - a total of 750 orphans

- Chawki district, Kunar - 150 orphans

- Munda Refugee Camp, Peshawar

- Nasir Bagh Refugee Camp, Peshawar, and

- Kacha Garhi Refugee Camp, Peshawar.

In each center, the orphans are provided health and educational facilities, food and clothing and a monthly cash allowance to support their families. 


\begin{tabular}{|l|l|l|}
\hline 2 (LEFT) AKDAR STREET & PHONE: 44278 & \multicolumn{1}{|c|}{ < KEY STAFF>- MR. KAZIM NIAZI } \\
ACADEMY TOWN, U/T & F A X: & 2. \\
PESHAWAR, PAKISTAN & TELEX: & 3. \\
\hline
\end{tabular}

\begin{tabular}{|lr|lr|lr|}
\hline AFGHAN : & 20 & TECHNICAL: & 12 & PAK. BASED: & 6 \\
PAKISTANI : & - & ADMINISTRATIVE: & 2 & AFGHA.BASED: & 11 \\
EXPAT: & - & FIELD/SUPPORT S. & 6 & CROSS-BORDER: & 3 \\
TOTAL: & 20 & TOTAL: & 20 & TOTAL: & 20 \\
\hline
\end{tabular}

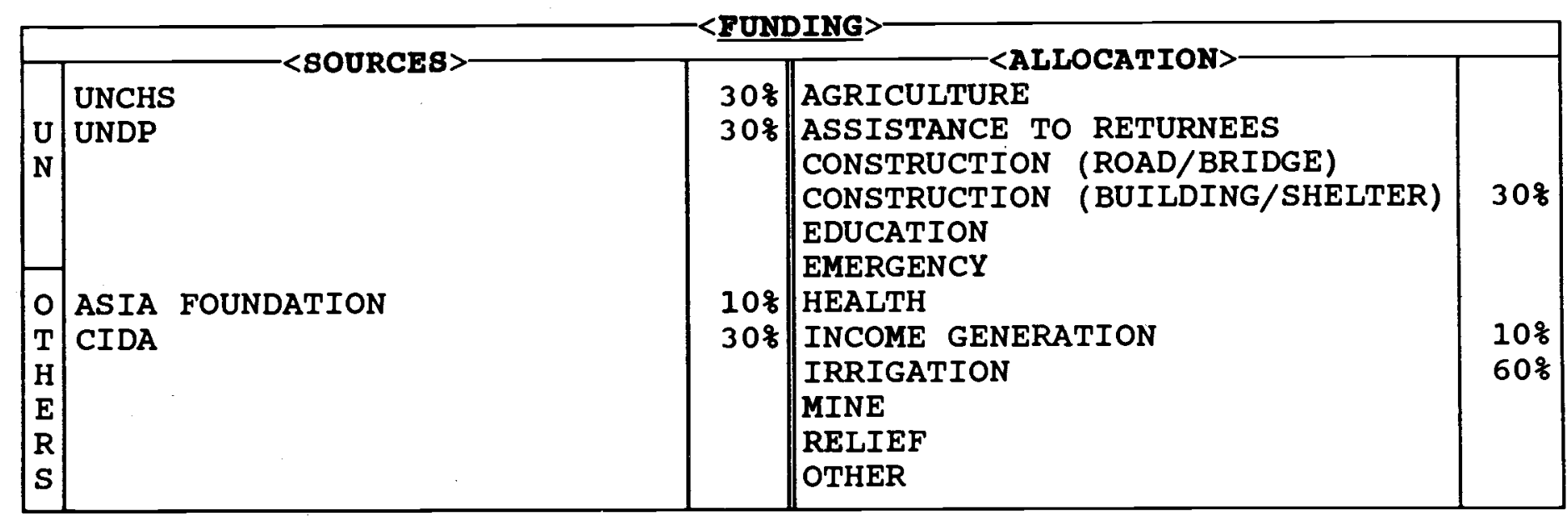

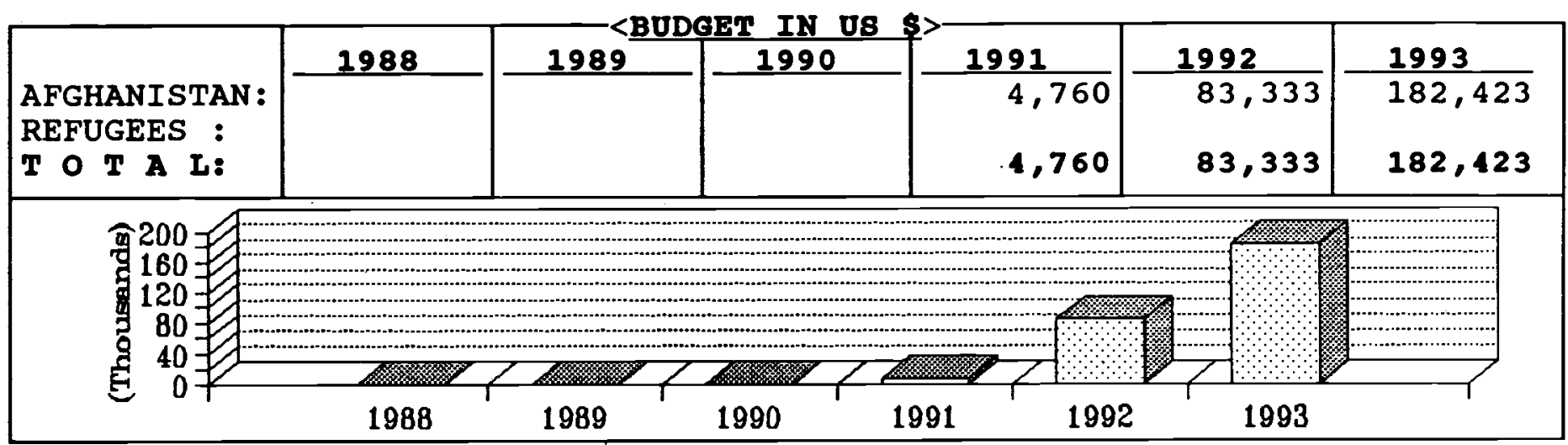

\begin{tabular}{|c|c|c|c|c|c|}
\hline PROVINCES & SECTTOR & \&AGE & PROVINCES & SECTOR & $\because A G E$ \\
\hline $\begin{array}{l}\text { BADAKSHAN } \\
\text { BADGHIS } \\
\text { BAGHLAN } \\
\text { BALKH } \\
\text { BAMYAN } \\
\text { FARAH } \\
\text { FARYAB } \\
\text { GHAZNI } \\
\text { GHOR } \\
\text { HELMAND } \\
\text { HERAT } \\
\text { JAWZJAN } \\
\text { KABUL } \\
\text { KANDAHAR } \\
\text { KAPISA }\end{array}$ & & & $\begin{array}{l}\text { KUNAR } \\
\text { KUNDUZ } \\
\text { LAGHMAN } \\
\text { LOGAR } \\
\text { NANGARHAR } \\
\text { NIMROZ } \\
\text { ORUZGAN } \\
\text { PAKTEKA } \\
\text { PAKTIA } \\
\text { PARWAN } \\
\text { SAMANGAN } \\
\text { TAKHAR } \\
\text { WARDAK } \\
\text { ZABUL }\end{array}$ & $\begin{array}{l}\text { Agr/inc.gen/irrign } \\
\text { Irrign }\end{array}$ & $\begin{array}{l}80 \% \\
20 \%\end{array}$ \\
\hline
\end{tabular}




\section{LIFELINE AND RELIEF ORGANIZATION \\ (LRO)}

is a non-partisan, non-political and public service oriented organization founded in response to the needs and requests of local people from Laghman province in 1990. It started work in January 1991. The basic aims of the organization are:

1) To provide economic support into Afghanistan.

2) To rehabilitate and improve the irrigation systems and increase the flow of irrigation water and thus increase crop production.

3) To improve conditions of women by implementing women's welfare projects.

4) To facilitate repatriation of refugees.

LRO is governed by an Executive Board of Directors (five well-known Afghan individuals). LRO's main scope of work is in the field of agriculture, irrigation and women's welfare projects. The organization has relevant experience in implementing development projects under adverse political and development conditions.

So far, LRO's main donors have been Canadian High Commission, the Asia Foundation, UNCHS (Habitat), UNDP and FAO. LRO is currently seeking funds from USAID.

The staff of each project except chief engineers have been hired from the target areas in order to provide closer follow-up of the projects. LRO implements projects through commanders, elders and shuras depending on the situation inside Afghanistan.

LRO has so far successfully implemented five irrigation, two agricultural and two women's welfare projects.

Proposals in different sectors have been prepared and submitted to different donors. 


\begin{tabular}{|c|c|c|}
\hline$-\langle$ ADDRESB $\rangle$ & $-\langle$ COMMUNICATION LINES $>$ & BTAFF> \\
\hline $\begin{array}{l}53 \text { C-II, GULMOHAR LANE } \\
\text { P O BOX... . . . . . . . } \\
\text { PESHAWAR, PAKISTAN }\end{array}$ & $\begin{array}{l}\text { PHONE: } 45405 \\
\text { F A X: } 840234 \\
\text { TELEX: }\end{array}$ & $\begin{array}{l}\text { 1. MR. BERNARD DELPUECH } \\
\text { 2. } \\
\text { 3. }\end{array}$ \\
\hline
\end{tabular}

\begin{tabular}{|lr|lr|lr|}
\hline AFGHAN : & 300 & TECHNICAL: & 100 & PAK. BASED: & 50 \\
PAKISTANI: & 4 & ADMINISTRATIVE: & 50 & AFGHA.BASED: & 260 \\
EXPAT: & 6 & FIELD: & 160 & CROSS-BORDER: & - \\
TOTAL: & 310 & TOTAL: & 310 & TOTAL: & 310 \\
\hline
\end{tabular}

\begin{tabular}{|c|c|c|c|c|}
\hline & & & & \\
\hline & $\angle 800 R C E S$ & & $<$ CALLOCATION> & \\
\hline $\mathrm{U}$ & $\begin{array}{l}\text { FAO } \\
\text { UNDCP }\end{array}$ & 18 & AGRICULTURE & $55 \%$ \\
\hline $\mathbf{N}$ & IINHCR & 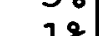 & 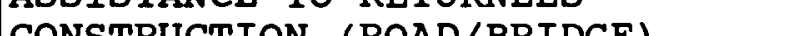 & \\
\hline & 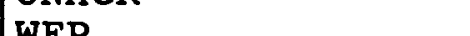 & 10 & 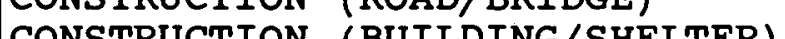 & 200 \\
\hline & $12=$ & & EDUCATION/TRAINING & $10 \%$ \\
\hline & & & EMERGENCY & \\
\hline 0 & & $68 \%$ & HEALTH & 3\% \\
\hline $\mathbf{T}$ & FRENCH GOVERNMENT & 178 & INCOME GENERATION & \\
\hline $\mathrm{H}$ & NGOS & $4 \%$ & IRRIGATION & $17 \%$ \\
\hline $\mathbf{E}$ & & & MINE & \\
\hline $\mathbf{R}$ & & & RELIEF & \\
\hline $\mathbf{S}$ & & & OTHER & \\
\hline
\end{tabular}

\begin{tabular}{|c|c|c|c|c|c|c|}
\hline $\begin{array}{l}\text { AFGHANISTAN: } \\
\text { REFUGEES : } \\
\text { T O T A L: }\end{array}$ & 1988 & 1989 & $\begin{array}{l}\frac{1990}{1,000,000} \\
1,000,000\end{array}$ & $\frac{1991}{1,500,000}=$ & $\begin{array}{l}\frac{1992}{3,200,000} \\
3,200,000\end{array}$ & $\begin{array}{l}\frac{1993}{3,000,000} \\
3,000,000\end{array}$ \\
\hline$\stackrel{8}{\exists}$ & 1988 & 1989 & 1990 & 991 & - में & (1) \\
\hline
\end{tabular}

\begin{tabular}{|c|c|c|c|c|c|}
\hline PROVINCES & SECTOR & \&AGE & PROVINCES & SECTOR & $\because \mathrm{AGE}$ \\
\hline $\begin{array}{l}\text { BADAKSHAN } \\
\text { BADGHIS } \\
\text { BAGHLAN } \\
\text { BALKH } \\
\text { BAMYAN } \\
\text { FARAH } \\
\text { FARYAB } \\
\text { GHAZNI } \\
\text { GHOR } \\
\text { HELMAND } \\
\text { HERAT } \\
\text { JAWZJAN } \\
\text { KABUL } \\
\text { KANDAHAR } \\
\text { KAPISA }\end{array}$ & & & $\begin{array}{l}\text { KUNAR } \\
\text { KUNDUZ } \\
\text { LAGHMAN } \\
\text { LOGAR } \\
\text { NANGARHAR } \\
\text { NIMROZ } \\
\text { ORUZGAN } \\
\text { PAKTEKA } \\
\text { PAKTIA } \\
\text { PARWAN } \\
\text { SAMANGAN } \\
\text { TAKHAR } \\
\text { WARDAK } \\
\text { ZABUL }\end{array}$ & $\begin{array}{l}\text { Agr+vet/const/health } \\
\text { Agr+vet/const } \\
\text { Agr+vet } \\
\text { Agr+vet }\end{array}$ & $\begin{array}{l}40 \% \\
40 \% \\
10 \%\end{array}$ \\
\hline
\end{tabular}




\section{MADERA}

is a French NGO founded when it took over the agro-pastoral program initiated by the Bureau International Afghanistan in 1984. MADERA has a strong involvement in Laghman (Alingar and Alishang) and in Kunar valley including the high valleys like Kamdesh, Waygal and upper Peche where few NGOs are working. MADERA has recently started implementation of an agricultural project in Behsud of wardak.

Its general strategy is to link present reconstruction with long term development, and to commit itself to a long-lasting integrated development effort on every location where it starts working. This is done through the establishment of mutual understanding and clear agreements with the local shuras, through a ban, as complete as possible, on any favoritism towards one particular family or village, and by the establishment of a network of 30 permanent agroveterinary and forestry centers. This network is now quite dense in Kunar and Laghman. The Afghan and expatriate staff are hired on a long term basis. Most of them have been working for several years within MADERA.

A danger of the integrated development approach is that it may lead to becoming over-extended in too many technical fields. MADERA's technical scope is now restricted to a hard-core of 5 sectors: veterinary, agriculture, forestry, hydraulics and construction (roads and tracks). other activities include administration, training and evaluation, which have been strengthened in 1992 by the assignment of a permanent expatriate.

Most of the construction sector is in fact sub-contracted to DACAAR. MADERA works in close cooperation with the NAC for the Afghan Social Forestry Project (ASFP), the only project working on Afghan wild forest together with agro-forestry.

The veterinary sector is in cooperation with the DCA for staff training and running of the veterinary structure in Laghman and Behsud. OXFAM is also working in close coordination with MADERA in Behsud.

MADERA is currently in the process of increasing local participation in all of its projects. All transport beyond the road network are paid and organized by the beneficiaries. In any construction work which is not an emergency (new canals, water supply schemes), beneficiaries pay for the unskilled labor. Animal medicines, pesticides, trees, seeds and fertilizers are charged to the farmers. The prices currently asked for most inputs will reach actual prices by 1993. In agriculture, emphasis is currently being shifted from material help towards knowledge resources; research, extension and training. Material investments in the future will mainly concern infrastructure. 


\begin{tabular}{|l|l|l|}
\hline FAISAL WORKSHOP & PHONE: 45553 & 1. MR. MOHD Y. SHARAFAT \\
TAMBUAN, TAHKAL BALA & F A X: 40558 & 2. \\
PESHAWAR, PAKISTAN & TELEX: & 3.
\end{tabular}

\begin{tabular}{|lr|lr|lr|}
\hline AFGHAN: & 12 & TECHNICAL: & 4 & PAK. BASED: & 5 \\
PAKISTANI: & - & ADMINISTRATIVE: & 4 & AFGHA.BASED: & 3 \\
EXPAT: & - & FIELD: & 4 & CROSS-BORDER: & 4 \\
TOTAL: & 12 & TOTAL: & 12 & TOTAL: & 12 \\
\hline
\end{tabular}

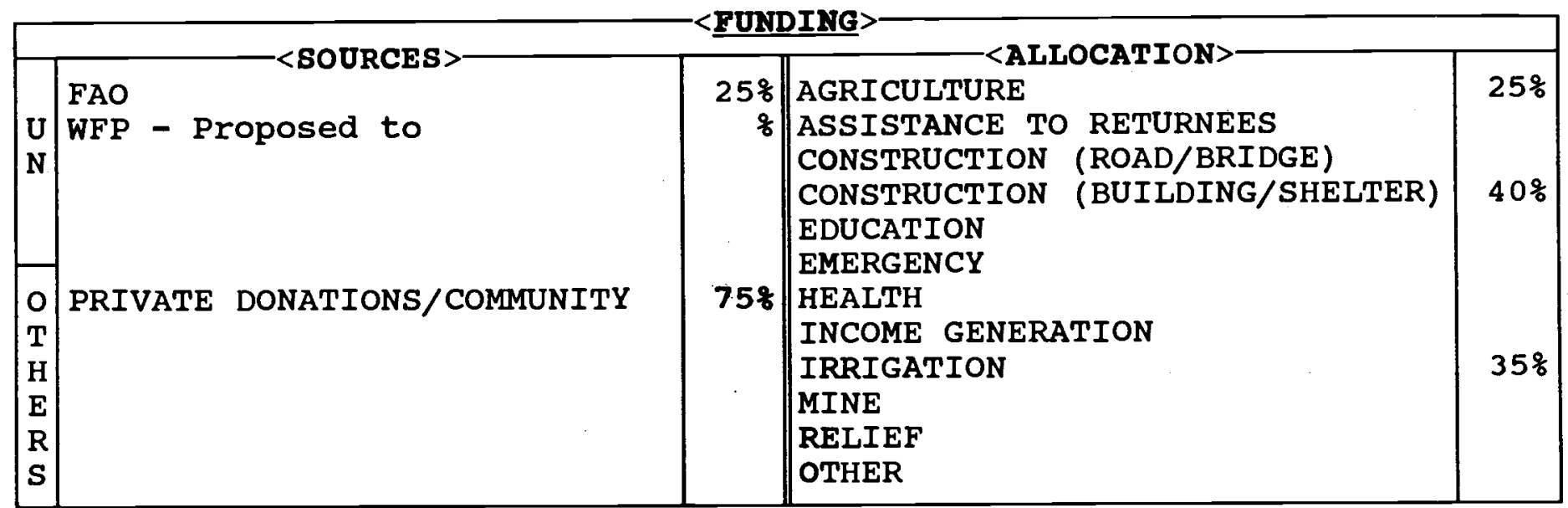

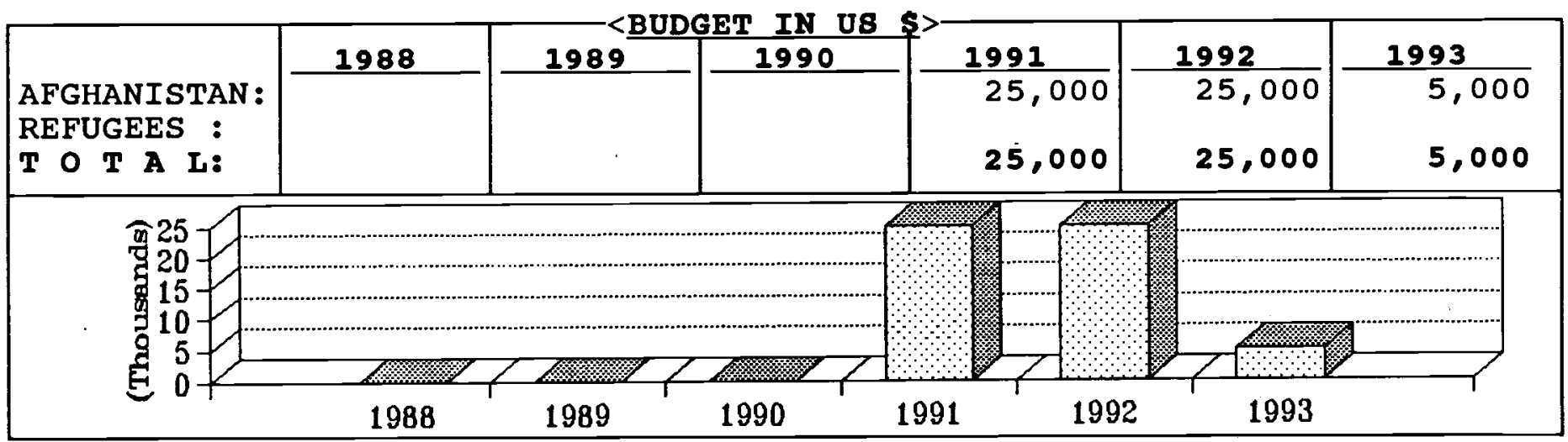

\begin{tabular}{|c|c|c|c|c|c|}
\hline PROVINCES & SECTOR & \&AGE & PROVINCES & SECTOR & \& $\mathrm{AGE}$ \\
\hline $\begin{array}{l}\text { BADAKSHAN } \\
\text { BADGHIS } \\
\text { BAGHLAN } \\
\text { BALKH } \\
\text { BAMYAN } \\
\text { FARAH } \\
\text { FARYAB } \\
\text { GHAZNI } \\
\text { GHOR } \\
\text { HELMAND } \\
\text { HERAT } \\
\text { JAWZJAN } \\
\text { KABUL } \\
\text { KANDAHAR } \\
\text { KAPISA }\end{array}$ & Agr/const & $100 \%$ & \begin{tabular}{|l|} 
KUNAR \\
KUNDUZ \\
LAGHMAN \\
LOGAR \\
NANGARHAR \\
NIMROZ \\
ORUZGAN \\
PAKTEKA \\
PAKTIA \\
PARWAN \\
SAMANGAN \\
TAKHAR \\
WARDAK \\
ZABUL
\end{tabular} & & \\
\hline
\end{tabular}


is an Afghan non-governmental, nonpolitical and non-profit organization established in 1991 .

The organization aims to assist the people of Afghanistan by taking part in construction, engineering, agricultural activities and eradication of poppy cultivation and elimination of narcotics. MDO also works to help the process of smooth repatriation of Afghan refugees.

The headquarters of the organization is temporarily based in Peshawar, Pakistan. Based on the need, it is planned to open branch offices in different provinces of Afghanistan.

A Board of Directors comprised of ten members is the highest authority of the organization. All important decisions regarding the agency are made by the Board in its regular quarterly meetings where it also reviews the activities and achievements of the organization.

Currently MDo has an agricultural project supported by FAO. Improved vegetable seeds have been multiplied in the Mahipar area.

In the past MDO completed construction of a mosque and a clinic building with community support. 
MAMAR CONSTRUCTION MATERIALB PRODUCTION ORGANIZATION-MAMAR

\begin{tabular}{|c|c|c|}
\hline 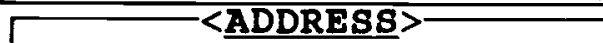 & - <COMMUNICATION LINES & $<\underline{\text { REY }}$ \\
\hline $\begin{array}{l}19 \text { A-C, } 03, \text { GURMOHAR L. } \\
\text { P O BOX } \ldots \text {. . . . } \\
\text { PESHAWAR, PAKISTAN }\end{array}$ & $\begin{array}{l}\text { PHONE: } 44867 \\
\text { F A X: } \\
\text { TELEX: }\end{array}$ & $\begin{array}{ll}\text { 1. DR. NOOR AHMAD } \\
\text { 2. } \text { ENG. NAIK MOHAMMAD } \\
\text { 3. } \text { MR. SUBHAN }\end{array}$ \\
\hline
\end{tabular}

\begin{tabular}{|lr|lr|lr|}
\hline AFGHAN : & 17 & TECHNICAL: & 9 & PAK. BASED: & 9 \\
PAKISTANI : & - & ADMINISTRATIVE: & 3 & AFGHA.BASED: & 8 \\
EXPAT: & - & FIELD: & 5 & CROSS-BORDER: & - \\
TOTAL: & 17 & TOTAL: & 17 & TOTAL: & 17 \\
\hline
\end{tabular}

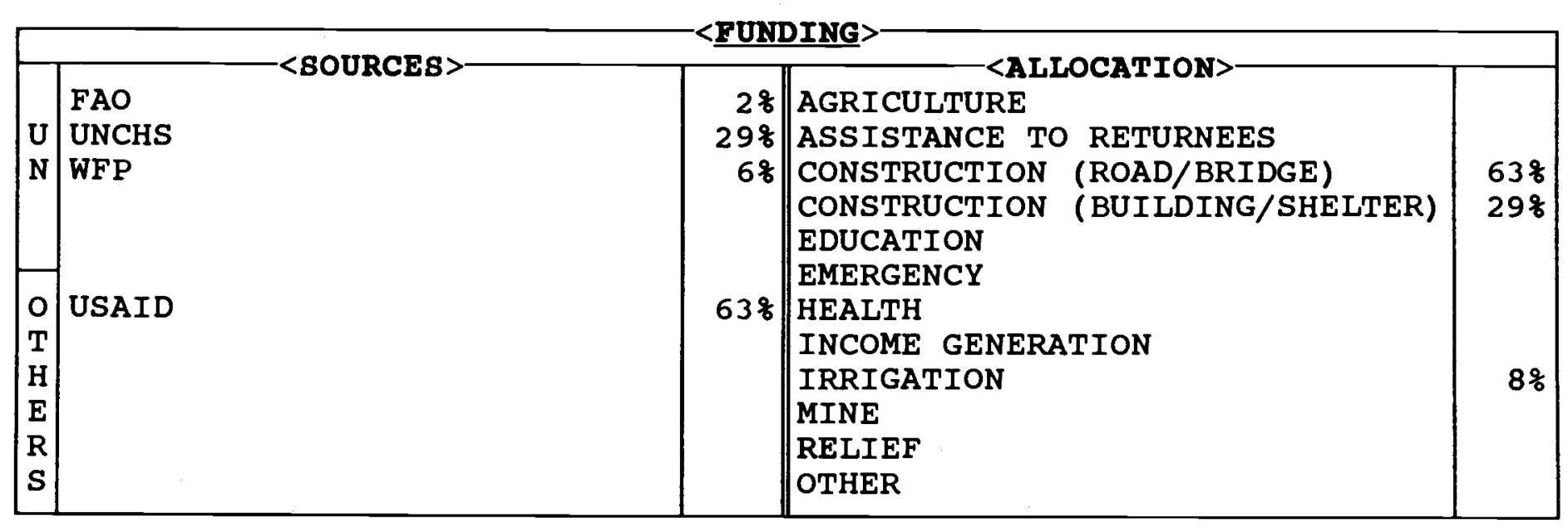

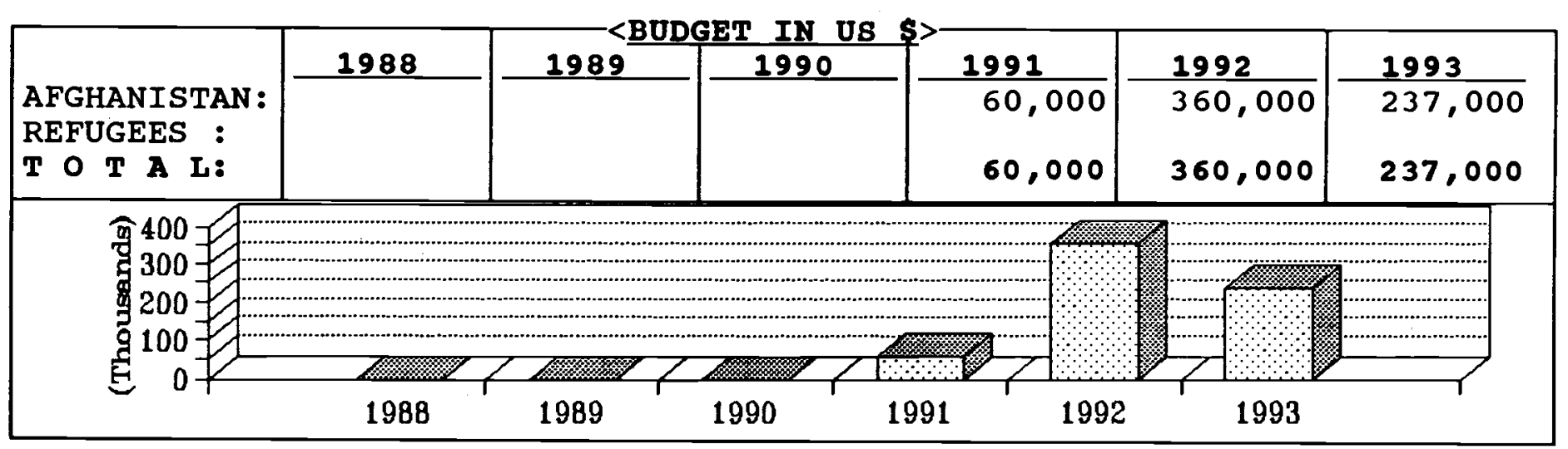

\begin{tabular}{|c|c|c|c|c|c|}
\hline PROVINCES & SECTOR & \&AGE & PROVINCES & SECTOR & \&AGE \\
\hline $\begin{array}{l}\text { BADAKSHAN } \\
\text { BADGHIS } \\
\text { BAGHLAN } \\
\text { BALKH } \\
\text { BAMYAN } \\
\text { FARAH } \\
\text { FARYAB } \\
\text { GHAZNI } \\
\text { GHOR } \\
\text { HELMAND } \\
\text { HERAT } \\
\text { JAWZJAN } \\
\text { KABUL } \\
\text { KANDAHAR } \\
\text { KAPISA }\end{array}$ & & & $\begin{array}{l}\text { KUNAR } \\
\text { KUNDUZ } \\
\text { LAGHMAN } \\
\text { LOGAR } \\
\text { NANGARHAR } \\
\text { NIMROZ } \\
\text { ORUZGAN } \\
\text { PAKTEKA } \\
\text { PAKTIA } \\
\text { PARWAN } \\
\text { SAMANGAN } \\
\text { TAKHAR } \\
\text { WARDAK } \\
\text { ZABUL }\end{array}$ & $\begin{array}{l}\text { Irrign } \\
\text { Const } \\
\text { Irrign } \\
\text { Const/irrign }\end{array}$ & $\begin{array}{l}10 \% \\
20 \% \\
20 \%\end{array}$ \\
\hline
\end{tabular}


MAMAR CONSTRUCTION AND BUILDING MATERIALS PRODUCTION ORGANIZATION (MAMAR)

is an Afghan non-governmental, nonpolitical construction organization established in 1991 with the aim of assisting people of Afghanistan by reconstructing and rehabilitating infrastructure. The objectives of the organization are as follows:

1) To participate actively in reconstruction, rehabilitation and development of war torn Afghanistan.

2) To plan, design and undertake $r e h a b i l i t a t i o n$ and reconstruction projects such as irrigation systems, roads and bridges, private and public building etc.

3) To supply and produce building construction materials. Products would be provided for private and governmental sectors.

MAMAR endeavors to make the organization self reliant for the future.

MAMAR intends to develop a coordinated and integrated approach for implementation of projects and maintain friendly relation with other NGOs carrying out similar objectives.

The overall direction and control of the organization is done by a Board of Directors in regular meetings held at MAMAR. An Executive section which is composed of four departments is responsible for conducting surveys, planning, designing, producing materials, implementation and management of projects.

MAMAR established a pre-cast roofing system project as a pilot scheme in Pakistan which proved the capability of the organization.

MAMAR is currently involved in irrigation rehabilitation programs in Paktia, Kunar and Nangarhar provinces. In Paktia a road repair project has also been undertaken.

In 1993, MAMAR started shelter (beams and slabs production) programs.

Proposals for expansion of programs to Laghman and Logar provinces have been submitted to donor

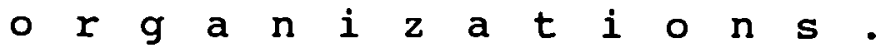




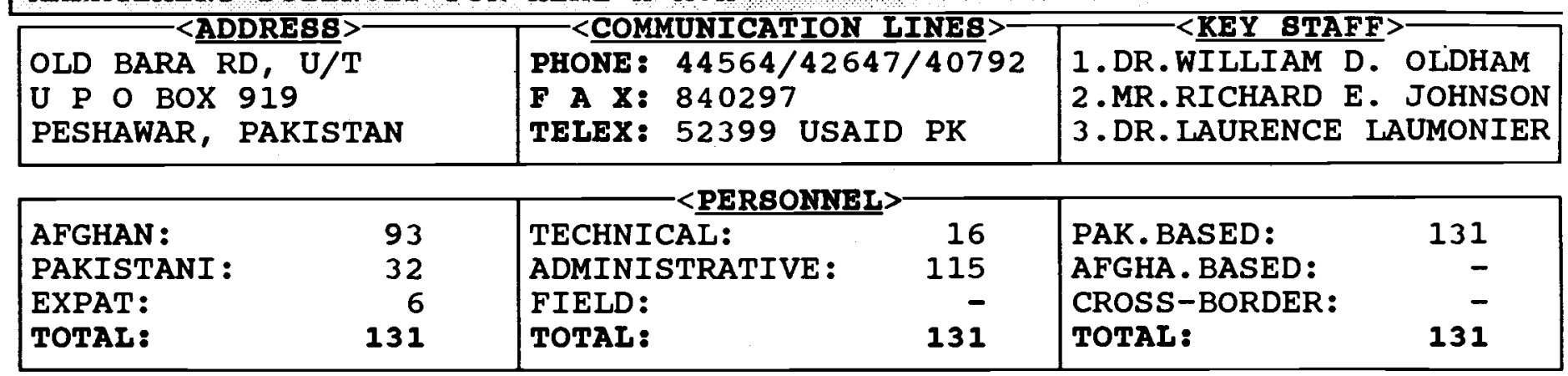

\begin{tabular}{|c|c|c|c|c|}
\hline & רת & & & \\
\hline $\begin{array}{l}\mathrm{O} \\
\mathrm{T} \\
\mathrm{H} \\
\mathrm{E} \\
\mathrm{R} \\
\mathrm{S}\end{array}$ & USAID & $100 \%$ & $\begin{array}{l}\text { AGRICULTURE: } \\
\text { ASSISTANCE TO RETURNEES } \\
\text { CONSTRUCTION (ROAD/BRIDGE) } \\
\text { CONSTRUCTION (BUILDING/SHELTER) } \\
\text { EDUCATION } \\
\text { EMERGENCY } \\
\text { HEALTH } \\
\text { INCOME GENERATION } \\
\text { IRRIGATION } \\
\text { MINE } \\
\text { RELIEF } \\
\text { OTHER }\end{array}$ & $100 \%$ \\
\hline
\end{tabular}

\begin{tabular}{|c|c|c|c|c|c|c|}
\hline $\begin{array}{l}\text { AFGHANISTAN: } \\
\text { REFUGEES : } \\
\text { T O T A L: }\end{array}$ & $\begin{array}{l}\frac{1988}{5,133,185} \\
5,133,185\end{array}$ & $\begin{array}{l}\frac{1989}{8,325,171} \\
8,325,171\end{array}$ & $\begin{array}{l}\frac{1990}{8,620,759} \\
8,620,759\end{array}$ & {$\left[\begin{array}{l}\frac{1991}{7,650,000} \\
7,650,000\end{array}\right.$} & $\begin{array}{l}\frac{1992}{7,861,538} \\
7,861,538\end{array}$ & $\begin{array}{l}\frac{1993}{6,117,684} \\
6,117,684\end{array}$ \\
\hline $\begin{array}{l}\text { 范 } \\
6 \\
0 \\
0\end{array}$ & 1988 & 1989 & 1990 & $\cdots$ & 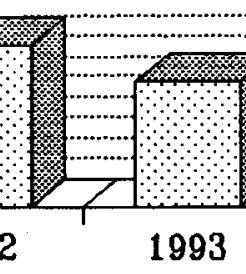 & 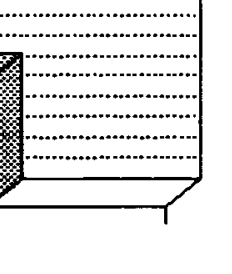 \\
\hline
\end{tabular}

\begin{tabular}{|c|c|c|c|c|c|}
\hline PROVINCES & SECTOR & \% AGE & PROVINCES & SECTOR & \%AGE \\
\hline $\begin{array}{l}\text { BADAKSHAN } \\
\text { BADGHIS } \\
\text { BAGHLAN } \\
\text { BALKH } \\
\text { BAMYAN } \\
\text { FARAH } \\
\text { FARYAB } \\
\text { GHAZNI } \\
\text { GHOR } \\
\text { HELMAND } \\
\text { HERAT } \\
\text { JAWZJAN } \\
\text { KABUL } \\
\text { KANDAHAR } \\
\text { KAPISA }\end{array}$ & $\begin{array}{l}\text { Health } \\
\text { Health } \\
\text { Health } \\
\text { Health } \\
\text { Health } \\
\text { Health } \\
\text { Health } \\
\text { Health } \\
\text { Health } \\
\text { Health } \\
\text { Health } \\
\text { Health } \\
\text { Health } \\
\text { Health } \\
\text { Health }\end{array}$ & $\begin{array}{l}8 \\
8 \\
8 \\
8 \\
8 \\
8 \\
8 \\
8 \\
8 \\
8 \\
8 \\
8 \\
8 \\
8 \\
8 \\
8 \\
8 \\
8 \\
8 \\
8\end{array}$ & \begin{tabular}{|l|} 
KUNAR \\
KUNDUZ \\
LAGHMAN \\
LOGAR \\
NANGARHAR \\
NIMROZ \\
ORUZGAN \\
PAKTEKA \\
PAKTIA \\
PARWAN \\
SAMANGAN \\
TAKHAR \\
WARDAK \\
ZABUL
\end{tabular} & $\begin{array}{l}\text { Health } \\
\text { Health } \\
\text { Health } \\
\text { Health } \\
\text { Health } \\
\text { Health } \\
\text { Health } \\
\text { Health } \\
\text { Health } \\
\text { Health } \\
\text { Health } \\
\text { health } \\
\text { Health } \\
\text { Health }\end{array}$ & 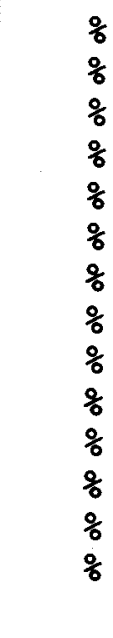 \\
\hline
\end{tabular}


MANAGEMENT SCIENCES FOR HEALTH

(MSH)

was established in 1971 in the USA as a non-profit institution with the broad goal of supporting public health management innovations. Currently the agency has over 100 professional staff employed at its headquarters in Boston and 23 field offices worldwide.

During the 1970s MSH worked in Afghanistan helping to strengthen a national program of basic health care through improvements in training, management systems, and essential drug supply. One enduring legacy of the project was the training of dais (traditional birth attendants) to provide preventive health services to women and children. Many of these health workers who have continued work despite the total disruption of the Afghan health infrastructure over the last decade.

Through a co-operative agreement with USAID, MSH is entrusted to provide technical and financial humanitarian assistance to expand and strengthen primary health services inside Afghanistan as rapidly as possible and to strengthen the capability of the Afghan health service to plan, operate, and monitor these expanded services. To achieve the objectives of the Afghanistan Health Sector Support Project (AHSSP), MSH designed, and is implementing, Basic Health Worker (BHW) training centers, Basic Health Posts, Basic Health centers (clinics), Comprehensive Health centers and small hospitals; child survival, disease control and immunization campaigns, and maternal and child health programs. Afghan institution building is an integral part of the Project.

To rapidly expand and provide primary health care coverage for both civilians and the Mujahideen in Mujahideen controlled areas of Afghanistan, training camps were set up in the camps surrounding Peshawar and a Training Center was developed for training of trainers, continuing educational training for medical personnel and development of curricula and training materials.

Gradually other training centers were established inside Afghanistan and currently all training is provided by the Afghanistan centers. Since the inception of the program in October 1986, over 2,200 BHWs have successfully completed the three month BHW course and have been deployed inside Afghanistan to set up health posts in each of the 29 provinces of Afghanistan. Nearly 37,000 Mujahideen were given training in basic first aid treatment; nine locally administered Vaccine storage Facilities (VSFs) were established inside Afghanistan and facility based and mobile immunization campaigns are in progress. The Project also supports a large provincial hospital, 13 primary care hospitals with up to 20 beds each, over 150 Comprehensive and Basic Health Centers and over 1,000 active Basic Health Posts. More than 1,500 MTs of medical supplies have been repackaged into standard and special kits and shipped inside Afghanistan.

An extensive computerized system is in place to monitor $\mathrm{MSH}$ supported facilities and personnel. A base for developing programs for women and children was established through training of Female Health Workers (dais), establishment of $\mathrm{MCH}$ posts and centers, initiation of Voluntary Health Sisters (VHSs) training, and the introduction of health services for females and children in MSH supported Basic Health Centers and hospitals. The one year $\mathrm{MCH}$ officer (MCHO) course graduated its first class in 1992 and currently 13 trainees are undergoing training in Jalalabad in the second course. The Project also supports 38 active $\mathrm{MCH}$ facilities (posts and centers). An ongoing sustainability study will continue to focus on development of health services that are both technically and economically feasible given foreseeable Afghan resources, supplemented by transitional donor inputs. 
MAROF RELIEF ORGANIZATION FOR RECONSTRUCTION OF AFGHANISTAN-MRORA

\begin{tabular}{|l|l|l|}
\hline 13, BLOCK 5, BILAL & PHONE: 443803 & <COMMUNICATION LINES $>$ \\
COLONY, SATELLITE TOWN & F A X: & 2. \\
QUETTA, PAKISTAN & TELEX: & 3. \\
\hline
\end{tabular}

\begin{tabular}{|lr|lr|lr|}
\hline AFGHAN: & 17 & TECHNICAL: & 7 & PAK. BASED: & 5 \\
PAKISTANI: & - & ADMINISTRATIVE: & 4 & AFGHA.BASED: & - \\
EXPAT: & - & FIELD/SUPPORT S. & 6 & CROSS-BORDER: & 12 \\
TOTAL: & 17 & TOTAL: & 17 & TOTAL: & 17 \\
\hline
\end{tabular}

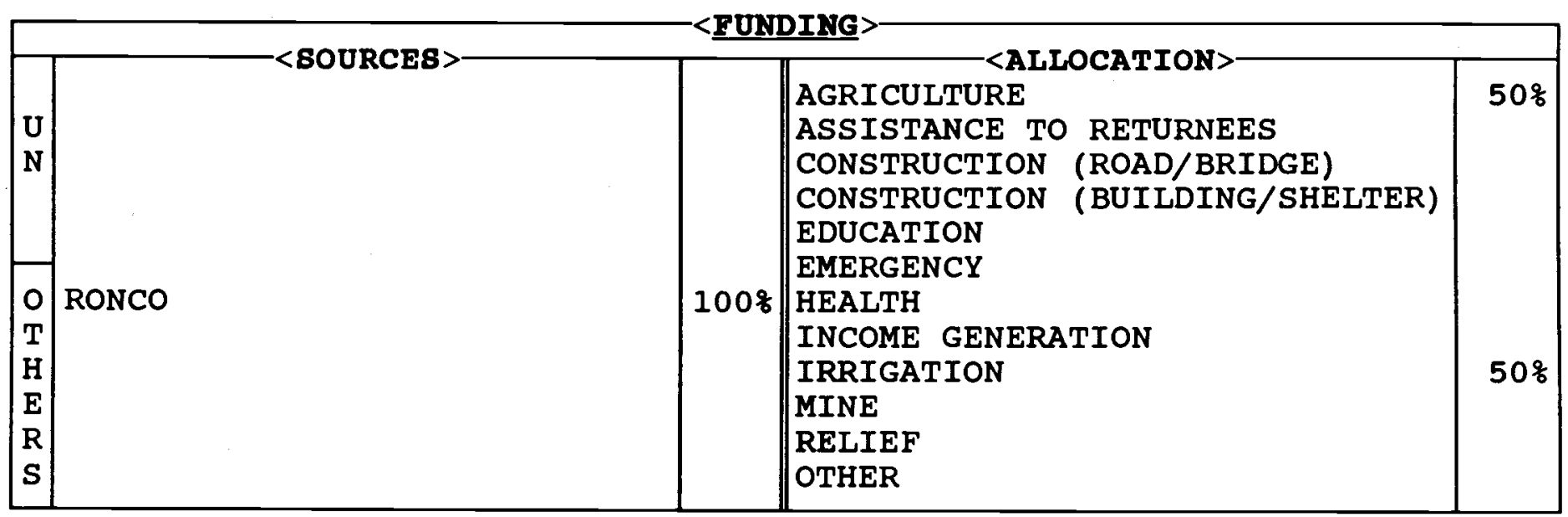

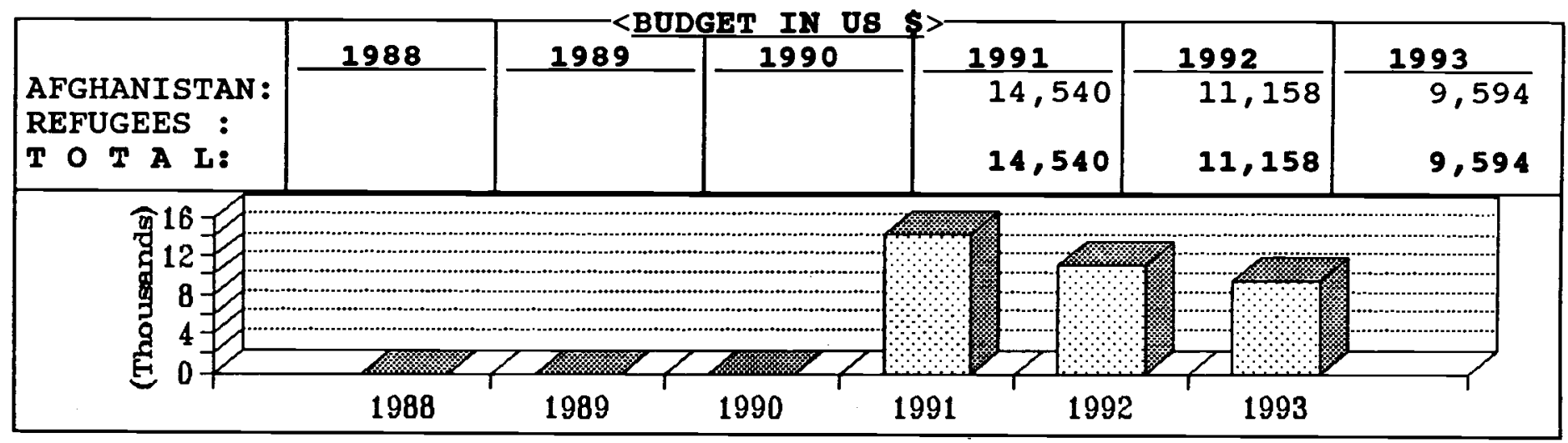

\begin{tabular}{|c|c|c|c|c|c|}
\hline PROVINCES & SECTOR & \&AGE & PROVINCES & SECTOR & \&AGE \\
\hline $\begin{array}{l}\text { BADAKSHAN } \\
\text { BADGHIS } \\
\text { BAGHLAN } \\
\text { BALKH } \\
\text { BAMYAN } \\
\text { FARAH } \\
\text { FARYAB } \\
\text { GHAZNI } \\
\text { GHOR } \\
\text { HELMAND } \\
\text { HERAT } \\
\text { JAWZJAN } \\
\text { KABUL } \\
\text { KANDAHAR } \\
\text { KAPISA }\end{array}$ & $\begin{array}{l}\text { Agr/irrign } \\
\text { Agr/irrign }\end{array}$ & 508 & $\begin{array}{l}\text { KUNAR } \\
\text { KUNDUZ } \\
\text { IAGHMAN } \\
\text { LOGAR } \\
\text { NANGARHAR } \\
\text { NIMROZ } \\
\text { ORUZGAN } \\
\text { PAKTEKA } \\
\text { PAKTIA } \\
\text { PARWAN } \\
\text { SAMANGAN } \\
\text { TAKHAR } \\
\text { WARDAK } \\
\text { ZABUL }\end{array}$ & & \\
\hline
\end{tabular}


is an Afghan NGO established in 1989. It was previously called Maruf Reconstruction Committee (MRC) .

MRORA is implementing agriculture programs and irrigation rehabilitation projects. It distributes improved seeds and fertilizer to farmers, cleans karezes and rehabilitates canals.

In the education sector, MRORA runs two primary schools in Maruf district of Kandahar province. There are 200 students and 6 teachers in the schools.

MRORA started its projects in Kandahar province. In 1993 it expanded its activities to Helmand province where it has undertaken agricultural and irrigation rehabilitation activities. MRORA intends to extend services to other provinces primarily in south-western Afghanistan.

The organization operates from its main office in quetta and suboffices in Maruf and Lashkargah areas. 


\begin{tabular}{|c|c|c|}
\hline$=<$ ADDRESS $>$ & $-<$ COMMUNICATION LINES & $-<$ KEY STAFF $>-$ \\
\hline $\begin{array}{l}\text { ALAMDAR } \\
\text { P O BOX } \ldots \text { BOWK } \\
\text { OUETTA, PAKISTAN }\end{array}$ & $\begin{array}{l}\text { PHONE: } \\
\text { F A X: } \\
\text { TELEX: }\end{array}$ & $\begin{array}{l}\text { 1. HAJI ABDUL ALI } \\
\text { 2. MR. IBRAHIM KHATARI } \\
\text { 3. ENG. NASRULLAH }\end{array}$ \\
\hline
\end{tabular}

\begin{tabular}{|ll|ll|ll|}
\hline AFGHAN : & $\mathbf{8}$ & TECHNICAL: & 2 & PAK. BASED: & 2 \\
PAKISTANI : & - & ADMINISTRATIVE: & 1 & AFGHA.BASED: & 6 \\
EXPAT: & - & FIELD/SUPPORT S. & 5 & CROSS-BORDER: & - \\
TOTAL: & $\mathbf{8}$ & TOTAL: & $\mathbf{8}$ & TOTAL: & $\mathbf{8}$ \\
\hline
\end{tabular}

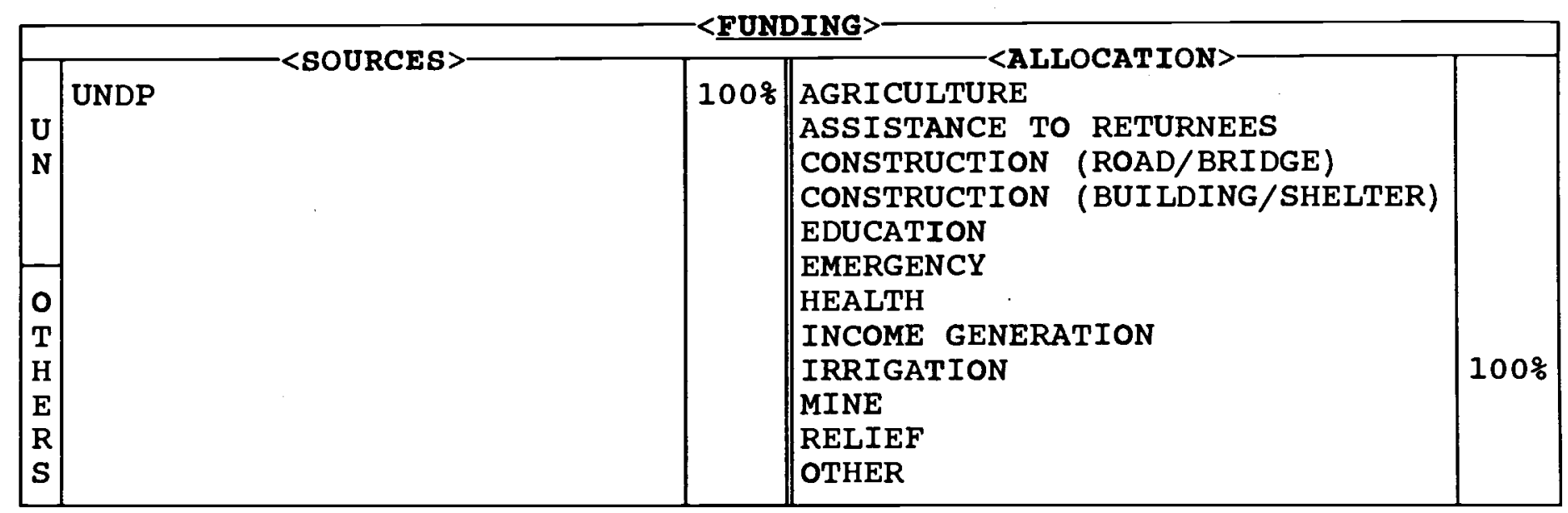

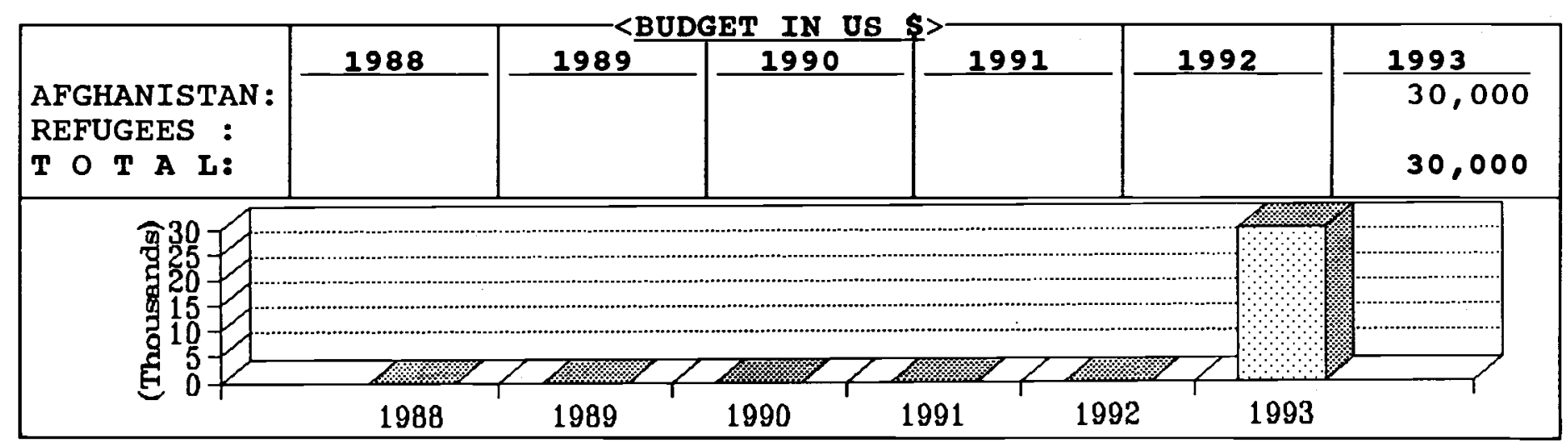

\begin{tabular}{|c|c|c|c|c|c|}
\hline PROVINCES & SECTOR & $\%$ AGE & PROVINCES & SECTOR & $\%$ AGE \\
\hline $\begin{array}{l}\text { BADAKSHAN } \\
\text { BADGHIS } \\
\text { BAGHLAN } \\
\text { BALKH } \\
\text { BAMYAN } \\
\text { FARAH } \\
\text { FARYAB } \\
\text { GHAZNI } \\
\text { GHOR } \\
\text { HELMAND } \\
\text { HERAT } \\
\text { JAWZJAN } \\
\text { KABUL } \\
\text { KANDAHAR } \\
\text { KAPISA }\end{array}$ & Irrign & 1008 & \begin{tabular}{|l|} 
KUNAR \\
KUNDUZ \\
LAGHMAN \\
LOGAR \\
NANGARHAR \\
NIMROZ \\
ORUZGAN \\
PAKTEKA \\
PAKTIA \\
PARWAN \\
SAMANGAN \\
TAKHAR \\
WARDAK \\
ZABUL
\end{tabular} & & \\
\hline
\end{tabular}


is an Afghan non-governmental organization established in November 1992 .

Maywand Development Project is fully committed to serving the people in the needy and remote areas of the country.

The organization has the capability and experience of implementing projects in the sectors of agriculture, engineering, health and education.

MDP has undertaken rehabilitation of three karezes and four canals in the province of Kandahar.

Provided that funds are available, MDP will expand its program to other provinces of Afghanistan. 


\begin{tabular}{|l|l|l|}
\hline $78-E$, BLOCK 5, S/T & PHONE: 442811 & 1. MR. MOHAMY BTAFF \\
P O BOX 572 & F A X: 442811 & 2. MR. JAVID ANWAR \\
QUETTA, PAKISTAN & TELEX: & 3.
\end{tabular}

\begin{tabular}{|lc|lr|lr|}
\hline AFGHAN : & 175 & TECHNICAL: & 28 & PAK. BASED: & 177 \\
PAKISTANI : & - & ADMINISTRATIVE: & 19 & AFGHA.BASED: & - \\
EXPAT: & 2 & FIELD/SUPPORT S. & 130 & CROSS-BORDER: & - \\
TOTAL: & 177 & TOTAL: & 177 & TOTAL: & 177 \\
\hline
\end{tabular}

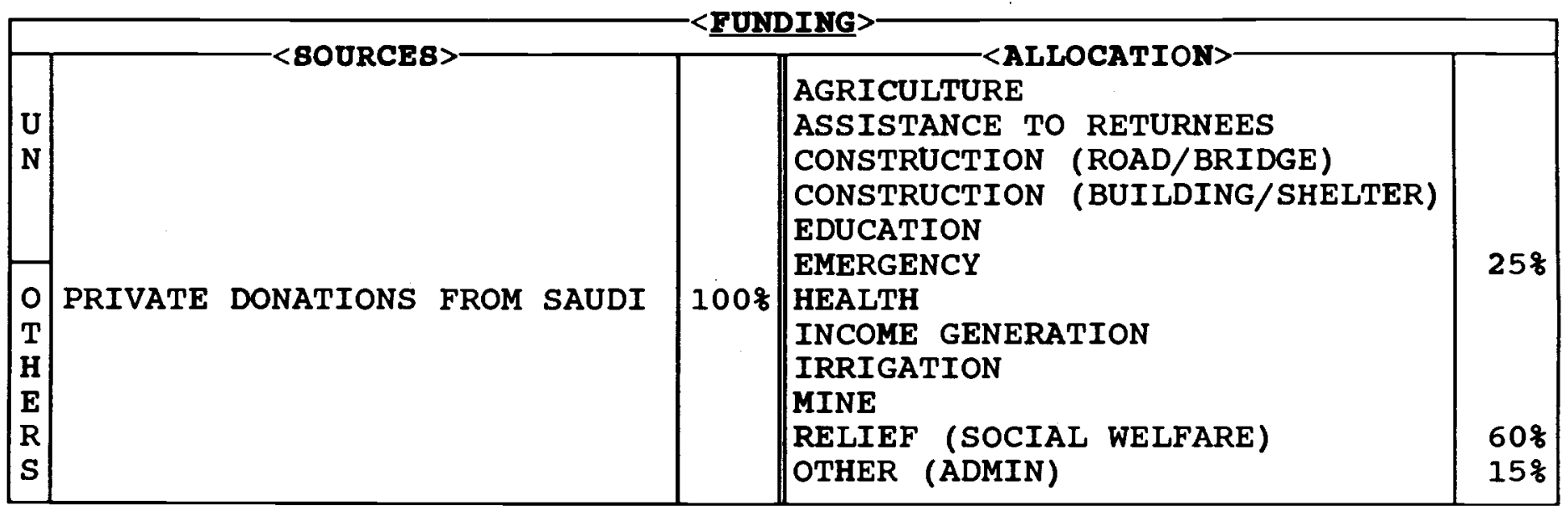

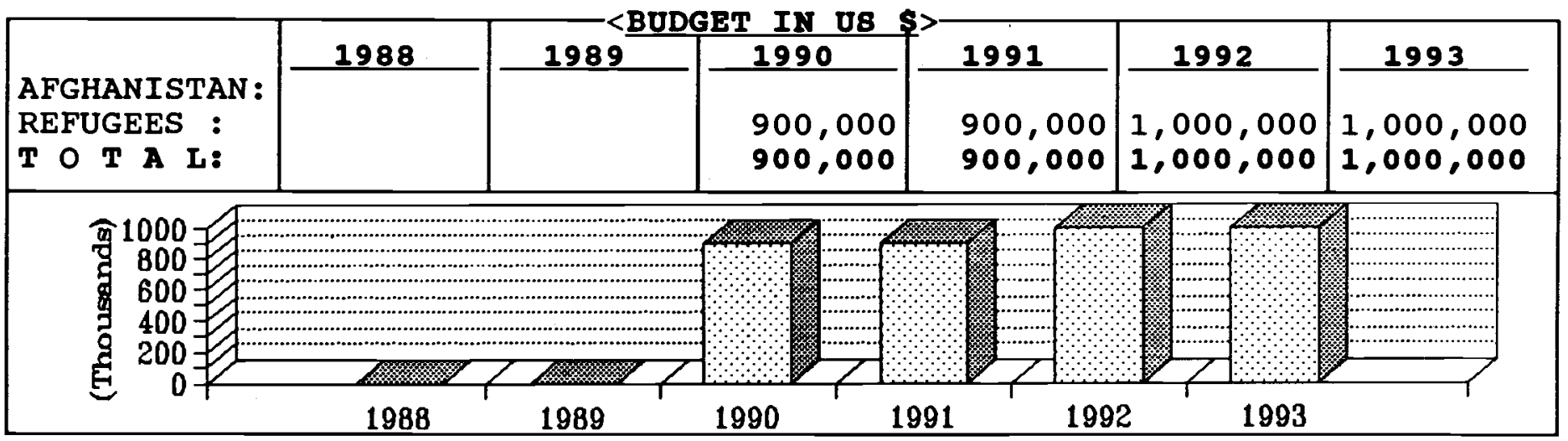

\begin{tabular}{|c|c|c|c|c|c|}
\hline PROVINCES & SECTOR & \&AGE & PROVINCES & SECTOR & \%AGE \\
\hline $\begin{array}{l}\text { BADAKSHAN } \\
\text { BADGHIS } \\
\text { BAGHLAN } \\
\text { BALKH } \\
\text { BAMYAN } \\
\text { FARAH } \\
\text { FARYAB } \\
\text { GHAZNI } \\
\text { GHOR } \\
\text { HELYAND } \\
\text { HERAT } \\
\text { JAWZJAN } \\
\text { KABUL } \\
\text { KANDAHAR } \\
\text { KAPISA }\end{array}$ & & & $\begin{array}{l}\text { KUNAR } \\
\text { KUNDUZ } \\
\text { LAGHMAN } \\
\text { LOGAR } \\
\text { NANGARHAR } \\
\text { NIMROZ } \\
\text { ORUZGAN } \\
\text { PAKTEKA } \\
\text { PAKTIA } \\
\text { PARWAN } \\
\text { SAMANGAN } \\
\text { TAKHAR } \\
\text { WARDAK } \\
\text { ZABUL }\end{array}$ & & \\
\hline
\end{tabular}


is a Saudi organization founded in 1986.

MMCT program for Afghans is mainly focussing on orphan care. orphans are provided with education opportunities. Five madrasas (Islamic schools) have been established in different camps in Quetta which educate approximately 1,000 students (orphans). There are 60 teachers in the schools.

Orphans are also supported with cash to assist their families. A total of 3,300 orphans are registered who each receive Rs. 500 per month. 
WEDECINS SANS FRONTIERES-FRANCE/BELGIUN-MBF-F/B

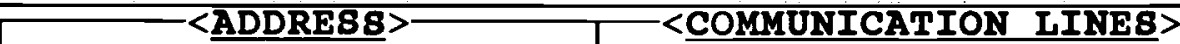

CHAR-RAHI SHERPOOR

SHAHRI NAW

KABUL, AFGHANISTAN
F A X: $873 \quad 140 \quad 473$

TELEX:
PHONE: $873 \quad 140 \quad 472$
1. MR. MATT BRYDEN

2. DR. MARK BIOT

3. MR. TLORENCE TURONET

\begin{tabular}{|lc|ll|lr}
\hline AFGHAN : & 50 & TECHNICAL: & $\ldots$ & PAK. BASED: & - \\
PAKISTANI : & - & ADMINISTRATIVE: & $\ldots$ & AFGHA. BASED: & 70 \\
EXPAT: & 20 & FIELD/SUPPORT S. & $\ldots$ & CROSS-BORDER: & - \\
TOTAL: & 70 & TOTAL: & 70 & TOTAL: & 70 \\
\hline
\end{tabular}

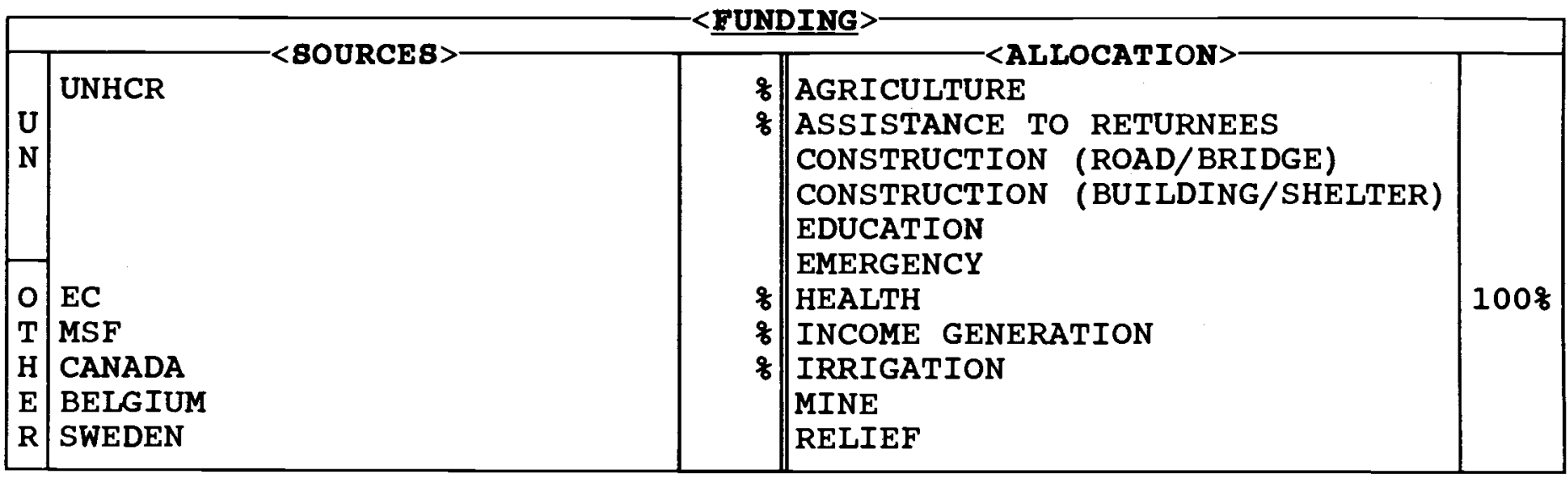

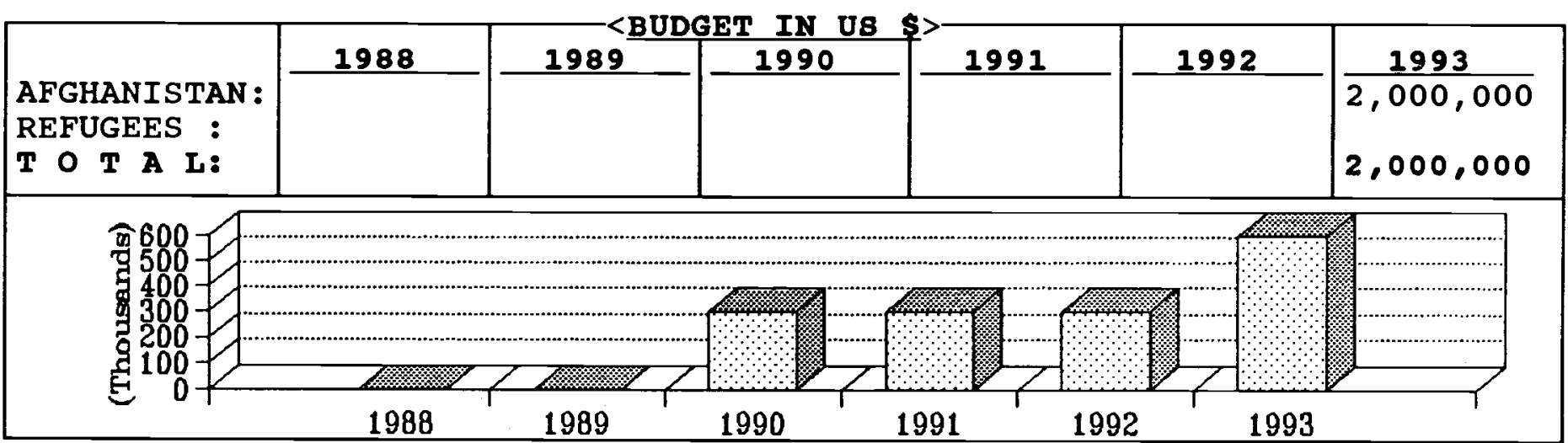

\begin{tabular}{|c|c|c|c|c|c|}
\hline PROVINCES & SECTOR & \&AGE & PROVINCES & SECTOR & \&AGE \\
\hline $\begin{array}{l}\text { BADAKSHAN } \\
\text { BADGHIS } \\
\text { BAGHLAN } \\
\text { BALKH } \\
\text { BAMYAN } \\
\text { FARAH } \\
\text { FARYAB } \\
\text { GHAZNI } \\
\text { GHOR } \\
\text { HELMAND } \\
\text { HERAT } \\
\text { JAWZJAN } \\
\text { KABUL } \\
\text { KANDAHAR } \\
\text { KAPISA }\end{array}$ & $\begin{array}{l}\text { Emerg/health } \\
\text { Emerg/health } \\
\text { Emerg/health }\end{array}$ & $\begin{array}{l}q \\
q \\
q\end{array}$ & \begin{tabular}{|l} 
KUNAR \\
KUNDUZ \\
LAGHMAN \\
LOGAR \\
NANGARHAR \\
NIMROZ \\
ORUZGAN \\
PAKTEKA \\
PAKTIA \\
PARWAN \\
SAMANGAN \\
TAKHAR \\
WARDAK \\
ZABUL
\end{tabular} & Emerg/health & q \\
\hline
\end{tabular}

NOTE: figure on budget does not include staff on incentives or FFW schemes. 
was created in France in 1971. It is currently active in some forty countries where each year around 800 doctors and nurses come to the aid of people in distress, as victims of either man-made or natural disasters. MSF also implements post-emergency rehabilitation of health structures and can provide technical advisers to regional or national health authorities. The Belgian and Dutch sections were created in 1980 and 1984 respectively.

MSF's present program in Afghanistan includes support to Kabul's Jamhuriat Hospital; medical care for displaced people in the capital, in Puli-Khumri, and in Mazar-i-Sharif; health care for Tajik refugees in Sakhi refugee camp, Mazar-i-Sharif, and a health care program for Tajik refugees around Kunduz, started in November, 1993.

MSF has also been active in containing the cholera outbreak in Afghanistan this year, particularly around Mazar-i-Sharif. 
MEDECINS SANS FRONTIERES HEALTHNET-MSF/HN

\begin{tabular}{|l|l|l|}
\hline 19 CHINAR RD, U/T, & PHONE: 44297 & <COMEY STAFF \\
P O BOX.......... & F A X: 840370 & MR. MARK ROWLAND \\
PESHAWAR, PAKISTAN & TELEX: & 2. MR. SEAN HEWITT \\
\hline
\end{tabular}

\begin{tabular}{|lr|lr|lr|}
\hline AFGHAN: & 12 & TECHNICAL: & 18 & PAK. BASED: & 39 \\
PAKISTANI: & 28 & ADMINISTRATIVE: & 4 & AFGHA.BASED: & 2 \\
EXPAT: & 3 & FIELD/SUPPORT S. & 21 & CROSS-BORDER: & 2 \\
TOTAL: & 43 & TOTAL: & 43 & TOTAL: & 43 \\
\hline
\end{tabular}

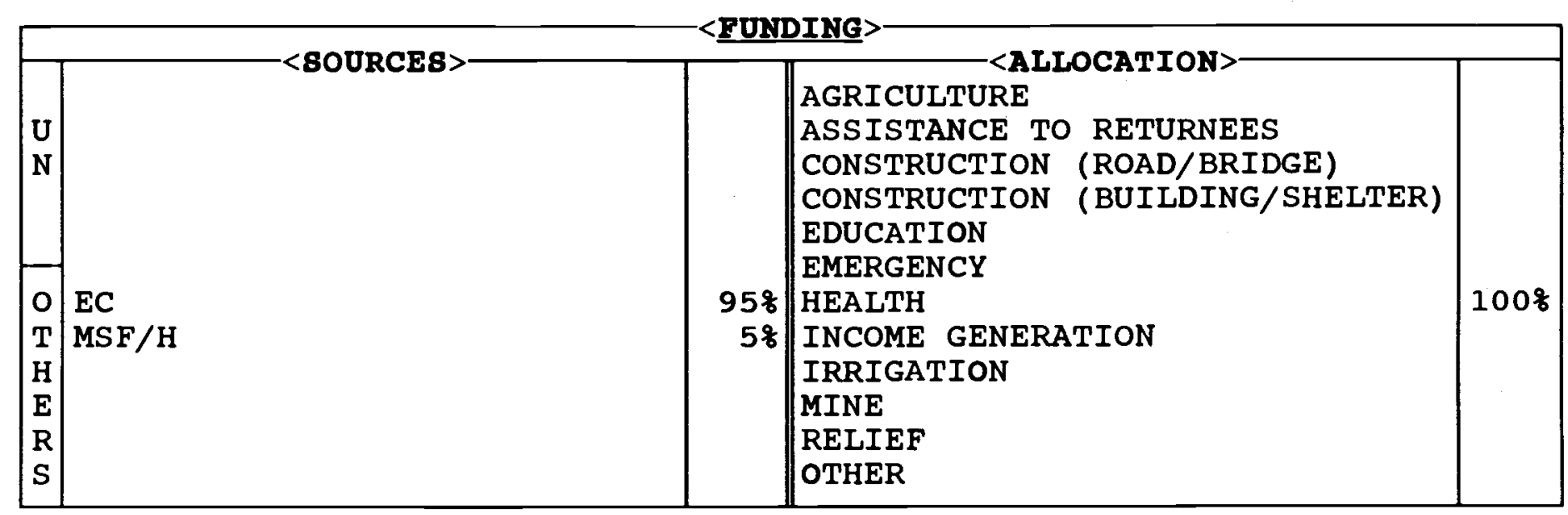

\begin{tabular}{|c|c|c|c|c|c|c|}
\hline & 1988 & 1989 & 1990 & 1991 & 1992 & 1993 \\
\hline $\begin{array}{l}\text { AFGHANISTAN: } \\
\text { REFUGEES : } \\
\text { TO T A L: }\end{array}$ & & & $\begin{array}{l}300,000 \\
300,000\end{array}$ & $\begin{array}{l}300,000 \\
300,000\end{array}$ & $\begin{array}{l}300,000 \\
300,000\end{array}$ & $\begin{array}{l}300,000 \\
300,000 \\
600,000\end{array}$ \\
\hline
\end{tabular}

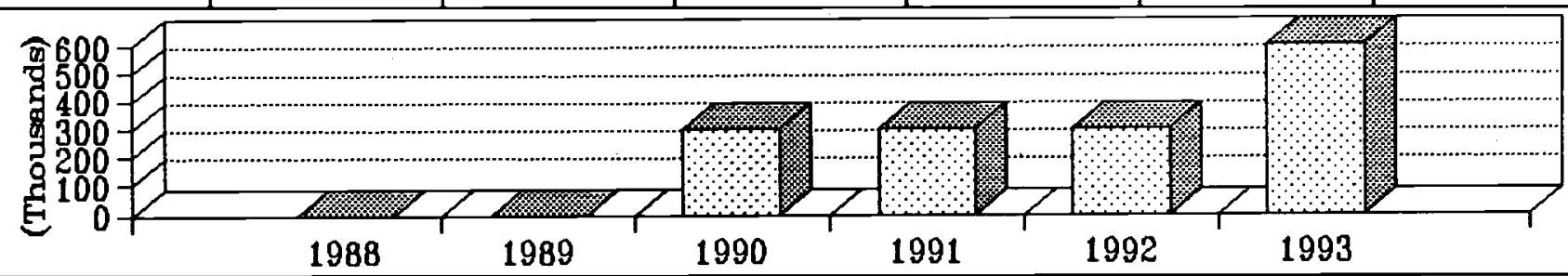

\begin{tabular}{|c|c|c|c|c|c|c|}
\hline PROVINCES & SECTOR & \&AGE & PROVINCES & & SECTOR & \&AGE \\
\hline $\begin{array}{l}\text { BADAKSHAN } \\
\text { BADGHIS } \\
\text { BAGHLAN } \\
\text { BALKH } \\
\text { BAMYAN } \\
\text { FARAH } \\
\text { FARYAB } \\
\text { GHAZNI } \\
\text { GHOR } \\
\text { HELMAND } \\
\text { HERAT } \\
\text { JAWZJAN } \\
\text { KABUL } \\
\text { KANDAHAR } \\
\text { KAPISA }\end{array}$ & Health (bednets) & $16 \%$ & $\begin{array}{l}\text { KUNAR } \\
\text { KUNDUZ } \\
\text { LAGHMAN } \\
\text { LOGAR } \\
\text { NANGARHAR } \\
\text { NIMROZ } \\
\text { ORUZGAN } \\
\text { PAKTEKA } \\
\text { PAKTIA } \\
\text { PARWAN } \\
\text { SAMANGAN } \\
\text { TAKHAR } \\
\text { WARDAK } \\
\text { ZABUL }\end{array}$ & $\begin{array}{l}\text { Health } \\
\text { Health } \\
\text { Health } \\
\text { Health } \\
\text { Health }\end{array}$ & $\begin{array}{l}\text { (bednets) } \\
\text { (bednets) } \\
\text { (bednets) } \\
\text { (bednets) }\end{array}$ & $\begin{array}{l}178 \\
178 \\
168 \\
18 \%\end{array}$ \\
\hline
\end{tabular}




\section{MEDECINS SANS FRONTIERES/HEALTHNET \\ (MSF/Heal thNet)}

MSF's malaria project was established in Peshawar in 1989. Its aim is the control of malaria in the refugee community and in Afghanistan. Elements of the project are as follows:

1. A Laboratory Supervisory Unit monitors the technical work of PDH and NGO laboratories in NWFP and Baluchistan.

2. Training of malaria microscopists and other medical staff for PDH and NGOs in Pakistan and in Afghanistan.

3. Operational research on malaria and mosquitoes.

4. Technical advice on malaria to WHO, PDH, UNHCR and NGOs.

5. Management of technical aspects of an insecticide spray program in the refugee camps.

6. Coordination of impregnated bednet distribution in Afghanistan in conjunction with UNHCR and NGOs. 
MEDECIN8 SANB FRONTIEREB/HOLIAND-M8F/H

17 CHINAR RD, U/T, U P O BOX 994, PESHAWAR, PAKISTAN

PHONE: 44806

F A X: 840251

TELEX:
1. MR. GEOFF PRESCOTT

2. MS. ANS KNAAP

3 .

\begin{tabular}{|lr|lr|lr|}
\hline AFGHAN: & 3 & TECHNICAL: & 1 & PAK. BASED: & 12 \\
PAKISTANI: & 8 & ADMINISTRATIVE: & 2 & AFGHA.BASED: & - \\
EXPAT: & 2 & FIELD/SUPPORT S. & 10 & CROSS-BORDER: & 1 \\
TOTAL: & 13 & TOTAL: & 13 & TOTAL: & 12 \\
\hline
\end{tabular}

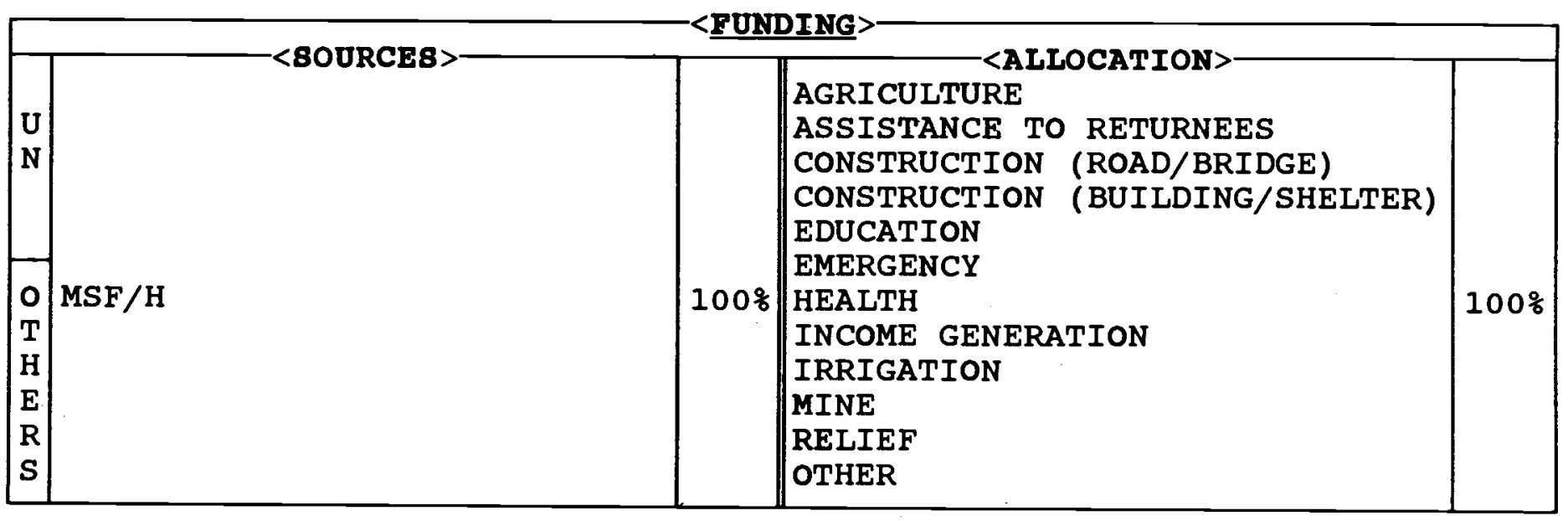

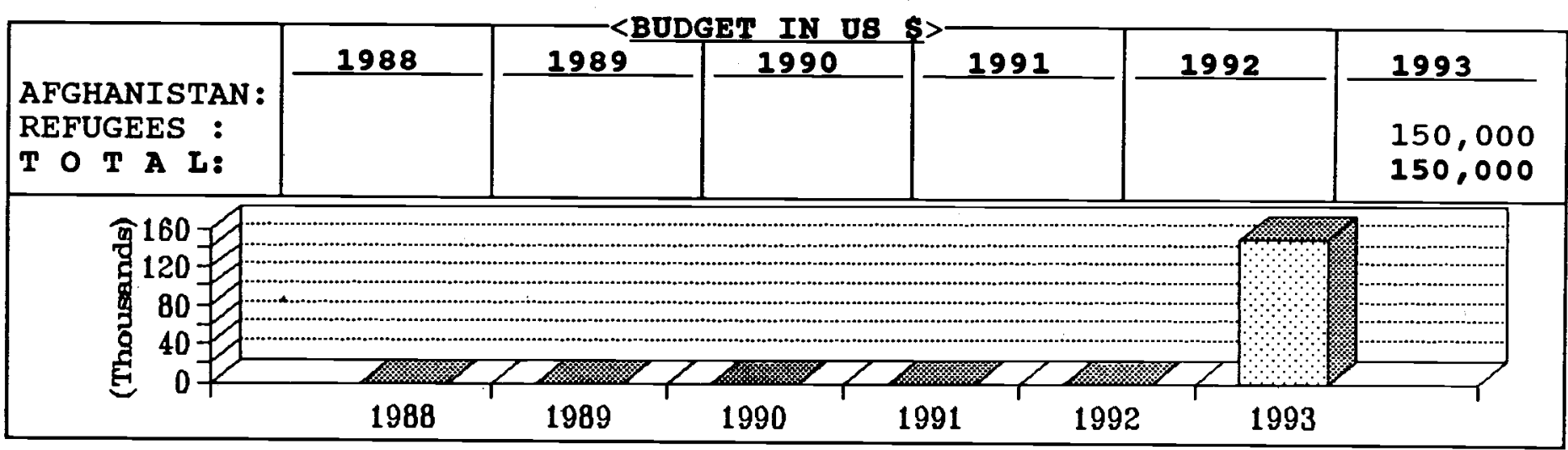

\begin{tabular}{|c|c|c|c|c|c|}
\hline PROVINCES & SECTOR & \&AGE & PROVINCES & SECTOR & \%AGE \\
\hline $\begin{array}{l}\text { BADAKSHAN } \\
\text { BADGHIS } \\
\text { BAGHLAN } \\
\text { BALKH } \\
\text { BAMYAN } \\
\text { FARAH } \\
\text { FARYAB } \\
\text { GHAZNI } \\
\text { GHOR } \\
\text { HELMAND } \\
\text { HERAT } \\
\text { JAWZJAN } \\
\text { KABUL } \\
\text { KANDAHAR } \\
\text { KAPISA }\end{array}$ & & & $\begin{array}{l}\text { KUNAR } \\
\text { KUNDUZ } \\
\text { LAGHMAN } \\
\text { LOGAR } \\
\text { NANGARHAR } \\
\text { NIMROZ } \\
\text { ORUZGAN } \\
\text { PAKTEKA } \\
\text { PAKTIA } \\
\text { PARWAN } \\
\text { SAMANGAN } \\
\text { TAKHAR } \\
\text { WARDAK } \\
\text { ZABUL }\end{array}$ & & \\
\hline
\end{tabular}


MSF/H in conjunction with MSF/France and MSF/Belgium is exclusively dealing with emergency relief activities, primarily in the sector of health.

The following is an outline of MSF's current activities:

Kabul:

- Jamhuriat surgical hospital,

- clinics in Dasht-i-Barchi and Taimany, various dispensaries for displaced families.

Puli Khumri:

- Clinic in the displaced camp.

Kunduz:

- Airport Tajik refugee hospital,

- dispensaries in Imam Bokhari refugee camp,

dispensaries in refugee occupied public buildings, dispensary in sher Khan transit camp.

Mazar-i-Sharif:

- Hospital and dispensaries in Sakhi refugee camp,

- dispensaries in two buildings for displaced.

In addition, MSF was very active during the 1993 cholera epidemic, in various parts of the country. MSF is prepared, however, to assist wherever necessary.

MSF is maintaining an open remit for expanding its emergency activities in the region and continues to investigate new program opportunities.

In Peshawar, MSF/Holland represents the varied MSFs country program (MSF/H, MSF/B, MSF/F and MSF/HealthNet). 
MEDICAL REFRESHER COURSES FOR AFGHANS-MRCA

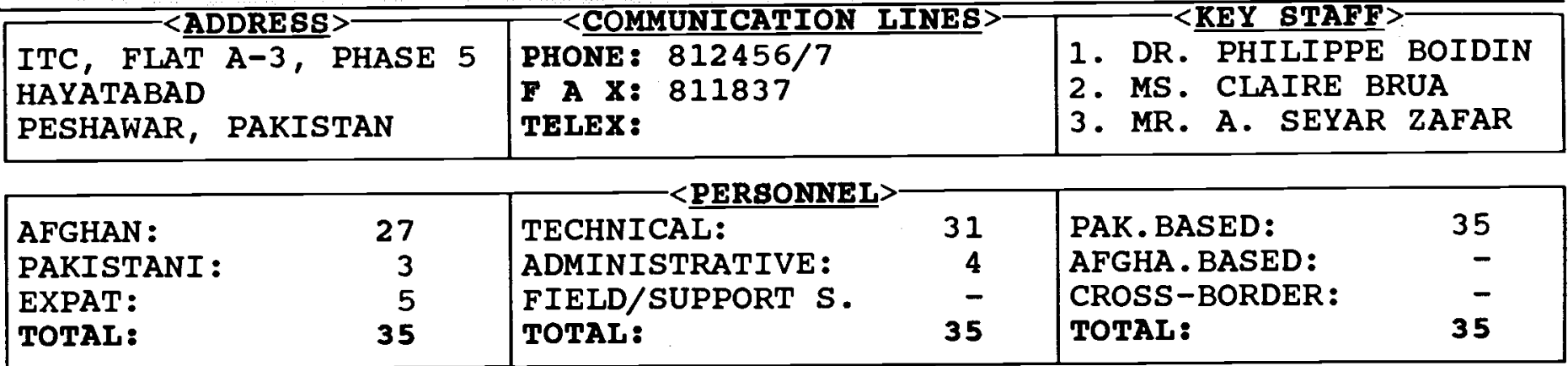

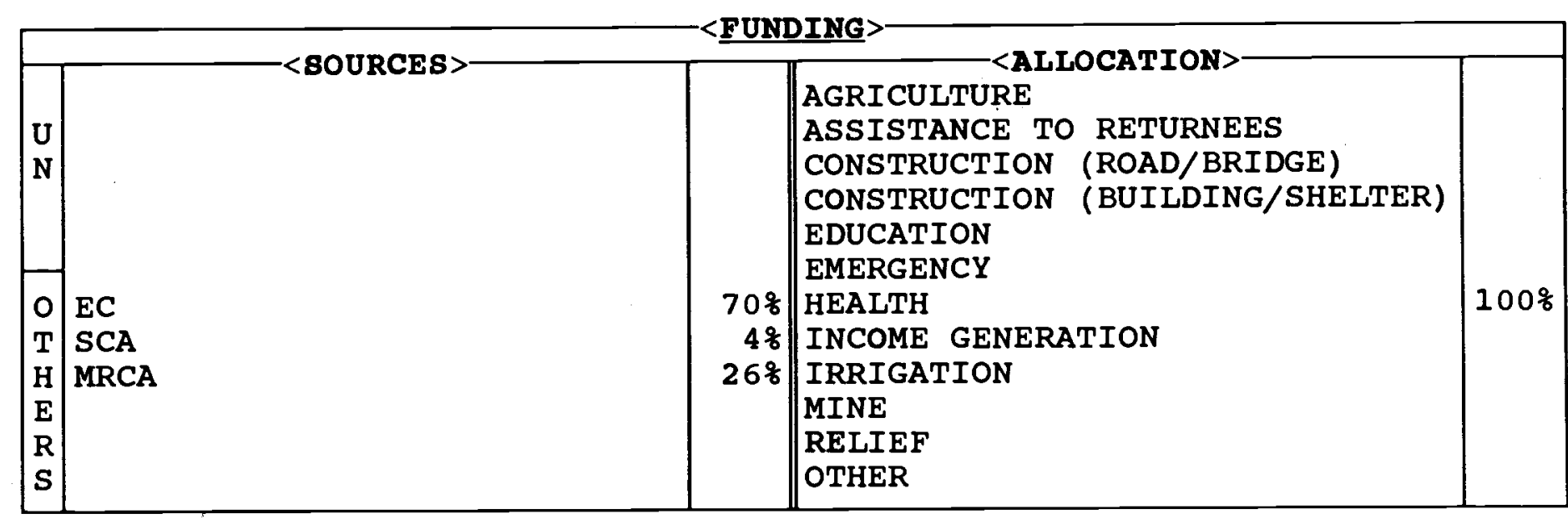

\begin{tabular}{|c|c|c|c|c|c|c|}
\hline $\begin{array}{l}\text { AFGHANISTAN: } \\
\text { REFUGEES : } \\
\text { TOT A L: }\end{array}$ & 1988 & 1989 & 1990 & 1991 & 1992 & $\begin{array}{c}\frac{1993}{30,000} \\
300,000 \\
330,000\end{array}$ \\
\hline 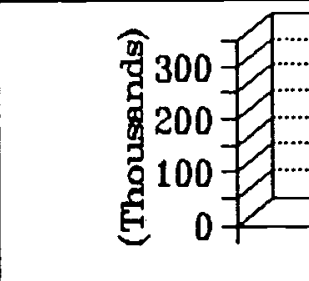 & (n) & $\cdots \cdots \cdots \cdot \cdots \cdot$ & 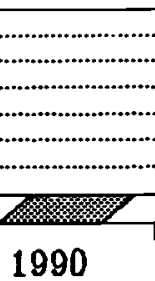 & $\begin{array}{l}1991 \\
1991\end{array}$ & $\cdots$ & (1) \\
\hline
\end{tabular}

\begin{tabular}{|c|c|c|c|c|c|}
\hline PROVINCES & SECTOR & \&AGE & PROVINCES & SECTOR & \%AGE \\
\hline $\begin{array}{l}\text { BADAKSHAN } \\
\text { BADGHIS } \\
\text { BAGHLAN } \\
\text { BALKH } \\
\text { BAMYAN } \\
\text { FARAH } \\
\text { FARYAB } \\
\text { GHAZNI } \\
\text { GHOR } \\
\text { HELMAND } \\
\text { HERAT } \\
\text { JAWZJAN } \\
\text { KABUL } \\
\text { KANDAHAR } \\
\text { KAPISA }\end{array}$ & Project in process & 8 & \begin{tabular}{|l|} 
KUNAR \\
KUNDUZ \\
LAAGMAN \\
LOGAR \\
NANGARHAR \\
NIMROZ \\
ORUZGAN \\
PAKTEKA \\
PAKTIA \\
PARWAN \\
SAMANGAN \\
TAKHAR \\
WARDAK \\
ZABUL
\end{tabular} & Health & $100 \%$ \\
\hline
\end{tabular}




\section{MEDICAL REFRESHER COURSES FOR AFGHAN REFUGEES-MRCA}

is a French non-governmental organization which has been working since 1986 for Afghans in Peshawar, providing medical care to Afghan refugees as a base for training activity. MRCA facilities are located in Hayatabad, Peshawar which include a 40 bed teaching/surgical hospital, x-ray, $1 \mathrm{ab}$ and two dental clinics as part of a training complex (Integrated Training Complex-ITC).

The general objective of MRCA is to contribute to the improvement of health conditions and restoration of the health system in Afghanistan, by providing training to Afghan health workers. MRCA offers tailor-made practical and theoretical training in specialty areas: surgery, anaesthesia, surgical, ward nursing, $x$-ray and dentistry.

MRCA staff are a mixture of Afghan and expatriate health care professionals with Afghan support staff. The team is involved in decision-making, planning and evaluation of the daily activities of both the hospital and the training program.

In 1992, MRCA trained 51 trainees in different medical fields and provided $3,068 \quad$ surgical consultation, 1,060 surgical operations under anaesthesia, 7,948 $x$-rays and 6,435 dental acts.

Following an annual schedule students are referred to MRCA by other NGOs. Students are screened and given a basic general knowledge examination. Accepted students are integrated into the corresponding departments where they are offered a specific curriculum.

Students work under the supervision of both Afghan and expatriate staff. They participate in all daily activities in their field.

Students are evaluated continuously by both formal and informal systems. since the number of students in each area of specialty is small their performance can be closely observed, supervised and evaluated.

Applicants are admitted to the courses if:

they are introduced by an organization

their education is at 10th-12th grade

they are already working in a health structure

they pass the examination tests after graduation they are employed by the introducing organization. 


\begin{tabular}{|c|c|c|}
\hline$=<$ ADDRESS $>$ & $=<$ COMMUNICATION LINES & - $<$ KEY STAFF \\
\hline $\begin{array}{l}10 \text { ARBAB KARAM KHAN RD } \\
\text { P O BOX } 314 \\
\text { QUETTA, PAKISTAN }\end{array}$ & $\begin{array}{l}\text { PHONE: } 440960 / 440905 \\
\text { F A X: } 43019 \\
\text { TELEX: }\end{array}$ & $\begin{array}{l}\text { 1. MR. DON BRADFORD } \\
\text { 2. } \\
\text { 3. }\end{array}$ \\
\hline
\end{tabular}

\begin{tabular}{|lr|lc|ll|}
\hline AFGHAN: & 727 & TECHNICAL: & $\ldots$ & PAK. BASED: & $\ldots$ \\
PAKISTANI : & 9 & ADMINISTRATIVE: & $\ldots$ & AFGHA. BASED: & $\ldots$ \\
EXPAT: & 10 & FIELD/SUPPORT S. & $\ldots$. & CROSS-BORDER: & C \\
TOTAL: & 746 & TOTAL: & 746 & TOTAL: & 746 \\
\hline
\end{tabular}

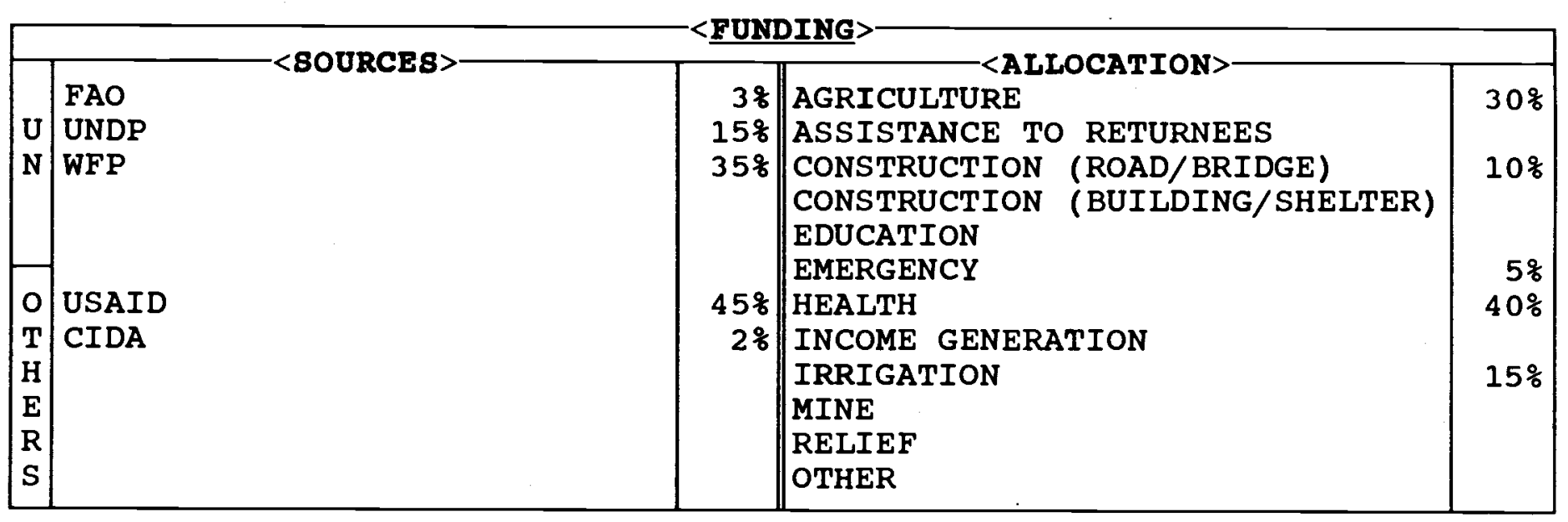

\begin{tabular}{|c|c|c|c|c|c|c|}
\hline $\begin{array}{l}\text { AFGHANISTAN: } \\
\text { REFUGEES : } \\
\text { TO T A L: }\end{array}$ & 1988 & $\begin{array}{r}1989 \\
1,250.840 \\
503,000 \\
1,753,840\end{array}$ & $\begin{array}{r}\frac{1990}{2,000,840} \\
503,000 \\
2,503,840\end{array}$ & $\begin{array}{r}\frac{1991}{3,000,000} \\
500,000 \\
3,500,000\end{array}$ & $\begin{array}{r}\frac{1992}{2,750,000} \\
350,000 \\
3,100,000\end{array}$ & $\begin{array}{r}1993 \\
3,225,000 \\
100,000 \\
3,325,000\end{array}$ \\
\hline 嗃 & 1988 & 1989 & 1990 & (1) & $\cdots$ & 畕 \\
\hline
\end{tabular}

\begin{tabular}{|c|c|c|c|c|c|}
\hline PROVINCES & SECTOR & \&AGE & PROVINCES & SECTOR & \&AGE \\
\hline $\begin{array}{l}\text { BADAKSHAN } \\
\text { BADGHIS } \\
\text { BAGHLAN } \\
\text { BALKH } \\
\text { BAMYAN } \\
\text { FARAH } \\
\text { FARYAB } \\
\text { GHAZNI } \\
\text { GHOR } \\
\text { HELMAND } \\
\text { HERAT } \\
\text { JAWZJAN } \\
\text { KABUL } \\
\text { KANDAHAR } \\
\text { KAPISA }\end{array}$ & $\begin{array}{l}\text { Health } \\
\text { Health } \\
\text { Health } \\
\text { Agr/const/health }\end{array}$ & $\begin{array}{r}48 \\
68 \\
58 \\
25 \%\end{array}$ & \begin{tabular}{|l} 
KUNAR \\
KUNDUZ \\
LAGHMAN \\
LOGAR \\
NANGARHAR \\
NIMROZ \\
ORUZGAN \\
PAKTEKA \\
PAKTIA \\
PARWAN \\
SAMANGAN \\
TAKHAR \\
WARDAK \\
ZABUL
\end{tabular} & $\begin{array}{l}\text { Agr/health } \\
\text { Agr/health }\end{array}$ & 108 \\
\hline
\end{tabular}




\section{MERCY CORPS INTERNATIONAL (MCI)}

has a history of involvement in cross-border assistance in war-torn areas. Its first major project was in sudan. It is also currently working in Honduras and the Philippines.

MCI began implementing its medical work in quetta in 1986 and its agriculture projects in July 1988 .

The medical work in Quetta began in response to the needs of the warwounded and civilian population in southwestern Afghanistan and to the demands for a health infrastructure for the returning refugee population. The further expansion of MCI assistance to include agricultural programs was to provide related assistance to the same population.

The initial aim of the medical program was to train students, selected from inside Afghanistan, in either a three-month Basic Health Worker course or in a more advanced six-month course, offering first aid nursing skills, preventive and primary health care, as well as training in one of 6 specialty areas, e.g. $\mathrm{x}$-ray.

These trained workers were then sent back to Afghanistan to staff medical facilities that MCI supports.

MCI now runs one-year courses for advanced medical assistants. The students are often selected from among those who have previously attended shorter courses. The end of the course includes three months on a specialty area as before, but with one significant area of expansion in the course: Mother/Child Health training.

MCI has 44 clinics with MCI-trained workers in each. Training is ongoing. The medical training programs place a strong emphasis on the integration of theory and practical work. All students are taught the specifics of preventive health care and how to provide such care within their own unique |cultural and social environment.

MCI has begun refresher and supervision missions conducted at clinics inside by its training doctors.

The purpose of the agricultural program is to provide rehabilitation for existing villages and facilities in southwestern Afghanistan which have been severely damaged or destroyed by the war. Types of projects in this sector relate to: irrigation, sanitation, improvement in areas of agronomy, animal husbandry, road repair, rebuilding houses and public buildings, and providing discretionary funds to individuals for survival assistance. 


\begin{tabular}{|c|c|c|c|c|c|}
\hline$=<\underline{\mathbf{A D}]}$ & 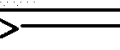 & $=<$ COMMUNICATION & CNES & $=<$ REY STA & \\
\hline $\begin{array}{l}\text { 13. STREET } \\
\text { P O BOX... } \\
\text { ISLAMABAD, }\end{array}$ & $\begin{array}{l}\mathrm{F}-8 / 2 \\
\mathrm{STAN}\end{array}$ & $\begin{array}{l}\text { PHONE: } 253789-92 \\
\text { F A X: } 851717 \\
\text { TELEX: }\end{array}$ & & $\begin{array}{l}\text { 1. ENG. SAYED } \\
\text { 2. } \\
\text { 3. }\end{array}$ & \\
\hline $\begin{array}{l}\text { AFGHAN: } \\
\text { PAKISTANI : } \\
\text { EXPAT: } \\
\text { TOTAL: }\end{array}$ & $\begin{array}{r}199 \\
27 \\
1 \\
227\end{array}$ & $\begin{array}{l}\text { TECHNICAL: } \\
\text { ADMINISTRATIVE: } \\
\text { FIELD/SUPPORT S. } \\
\text { TOTAL: }\end{array}$ & $\begin{array}{r}100 \\
89 \\
38 \\
227\end{array}$ & $\begin{array}{l}\text { PAK. BASED: } \\
\text { AFGHA. BASED: } \\
\text { CROSS-BORDER: } \\
\text { TOTAL: }\end{array}$ & $\begin{array}{r}146 \\
81 \\
227\end{array}$ \\
\hline
\end{tabular}

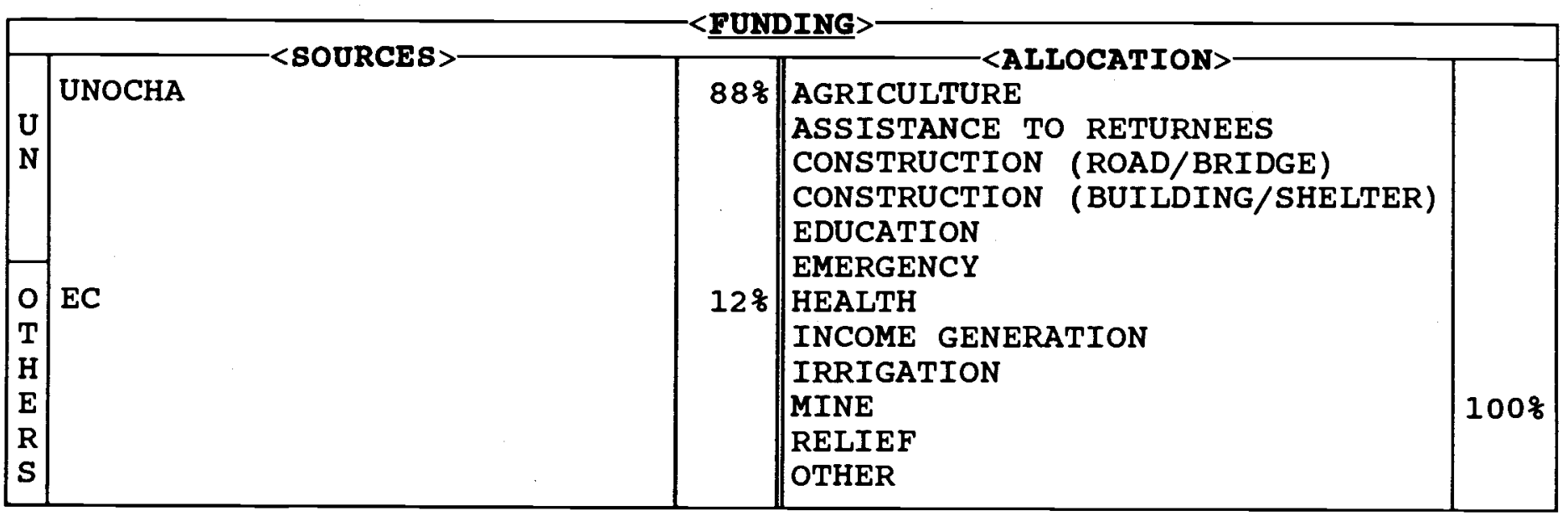

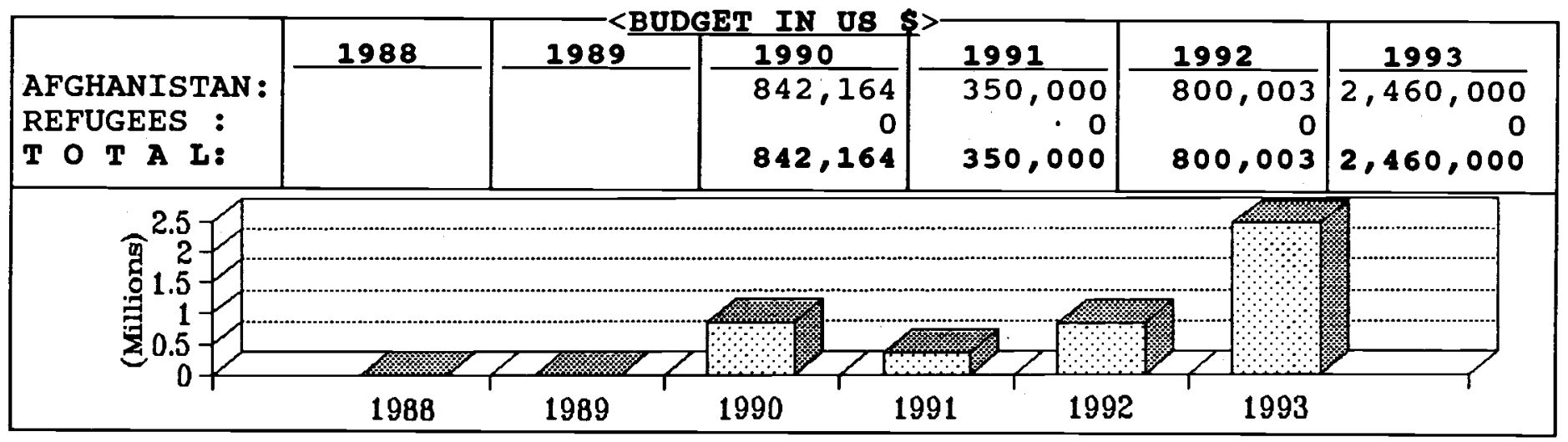

\begin{tabular}{|c|c|c|c|c|c|}
\hline PROVINCES & SECTOR & \&AGE & PROVINCES & SECTOR & $\%$ AGE \\
\hline $\begin{array}{l}\text { BADAKSHAN } \\
\text { BADGHIS } \\
\text { BAGHLAN } \\
\text { BALKH } \\
\text { BAMYAN } \\
\text { FARAH } \\
\text { FARYAB } \\
\text { GHAZNI } \\
\text { GHOR } \\
\text { HELMAND } \\
\text { HERAT } \\
\text { JAWZJAN } \\
\text { KABUL } \\
\text { KANDAHAR } \\
\text { KAPISA }\end{array}$ & $\begin{array}{l}\text { Mine survey } \\
\text { Mine survey } \\
\text { Mine survey } \\
\text { Mine survey } \\
\text { Mine survey } \\
\text { Mine survey } \\
\text { Mine survey }\end{array}$ & $\begin{array}{l}q \\
q \\
q\end{array}$ & \begin{tabular}{|l} 
KUNAR \\
KUNDUZ \\
LAGHMAN \\
LOGAR \\
NANGARHAR \\
NIMROZ \\
ORUZGAN \\
PAKTEKA \\
PAKTIA \\
PARWAN \\
SAMANGAN \\
TAKHAR \\
WARDAK \\
ZABUL
\end{tabular} & $\begin{array}{l}\text { Mine survey } \\
\text { Mine survey } \\
\text { Mine survey } \\
\text { Mine survey } \\
\text { Mine survey } \\
\text { Mine survey } \\
\text { Mine survey } \\
\text { Mine survey }\end{array}$ & $\begin{array}{l}\frac{8}{8} \\
\frac{8}{8} \\
\frac{8}{6} \\
\frac{8}{8} \\
\frac{8}{8}\end{array}$ \\
\hline
\end{tabular}


MINE CLEARANCE PLANNING AGENCY (MCPA)

is an Afghan NGO funded by UNOCHA and The European Community (EC). The main tasks of MCPA are as follows :

- Technical survey of mined

areas in Afghanistan and provision of identification information to demining agencies (ATC, OMAR, and DAFA). Any mine-field which is unlikely to be cleared within six months from the date of survey is permanently marked.

- Nationwide survey of the mine situation in Afghanistan to identify the extent of the mine problem in the country.

- Training of new deminers/ surveyors, periodic monitoring and retraining of the existing survey/ demining teams.

- Advance operational planning of demining activities on a provincial basis in consultation with UNOCHA and other mine clearance agencies. The collection, collation and dissemination of data relating to the Mine Clearance Program.

- Preparation and provision of operational maps and updated information on mined and cleared areas to agencies and returning refugees.

\section{- Technical and advisory}

support to The Islamic state of Afghanistan, provincial shuras and implementing agencies funded by the UN .

During 1990, 1991 and 1992, MCPA surveyed and mapped 667 mine-fields covering an area of about 78 million square meters in the provinces of Badakhshan, Bamyan, Kunar, Kandahar, Ghazni, Paktia, Pakteka, Zabul, Nangarhar, Badghis, Farah, Helmand, Herat, Nimroz, Kabul, Logar, Laghman and Takhar: Priority was given to those areas where refugees were expected to return and where UN or other relief organizations were engaged in rehabilitation work.
In early 1992, MCPA established an operations office in the Demining Headquarters, UNOCHA Islamabad. The main task of the Operations office is to collect, collate and disseminate updated information about the demining activities in Afghanistan. Furthermore, it also assists UNOCHA in planning and coordination of demining activities.

In 1993, MCPA assumed responsibility for the Training Project within the Mine clearance program. The Training Project is responsible for conducting initial training for new surveyors and deminers. The Monitoring and Training Team (MMT) also conduct periodic monitoring and revision courses for the existing survey and demining teams.

In mid 1993 MCPA received funds from the European Community for a Nationwide survey of the Mine Problem in Afghanistan. The project which started in June 1993, is expected to be completed by December 1993. It will assist the refugee return and the long term rehabilitation of Afghanistan by determining the extent of the mine problem and the distribution of mined areas within the country. The data will be used by MCPA for long term planning and coordination of the Mine clearance Program. 
MUJAHID EMERGENCY MEDICAL CENTER-MMC

\begin{tabular}{|c|c|c|c|c|}
\hline$-<$ ADDRESB $>$ & -<COMMUNICATION & ES: & $\angle$ KEY BTA & \\
\hline $\begin{array}{l}124 \text { GULHAJI PLAZA } \\
\text { JAMROD RD } \\
\text { PESHAWAR, PAKISTAN }\end{array}$ & $\begin{array}{l}\text { PHONE: } 44682 \\
\text { F A X: } \\
\text { TELEX: }\end{array}$ & & $\begin{array}{l}\text { 1. DR. ASSADU } \\
\text { 2. } \\
\text { 3. }\end{array}$ & REHA \\
\hline $\begin{array}{l}\text { AFGHAN : } \\
\text { PAKISTANI : } \\
\text { EXPAT: } \\
\text { TOTAL: }\end{array}$ & $\begin{array}{l}\text { TECHNICAL: } \\
\text { ADMINISTRATIVE: } \\
\text { FIELD/SUPPORT } \mathrm{S} \text {. } \\
\text { TOTAL: }\end{array}$ & $\begin{array}{r}23 \\
8 \\
13 \\
44\end{array}$ & $\begin{array}{l}\text { PAK. BASED: } \\
\text { AFGHA. BASED: } \\
\text { CROSS-BORDER: } \\
\text { TOTAL: }\end{array}$ & $\begin{array}{r}8 \\
18 \\
18 \\
44\end{array}$ \\
\hline
\end{tabular}

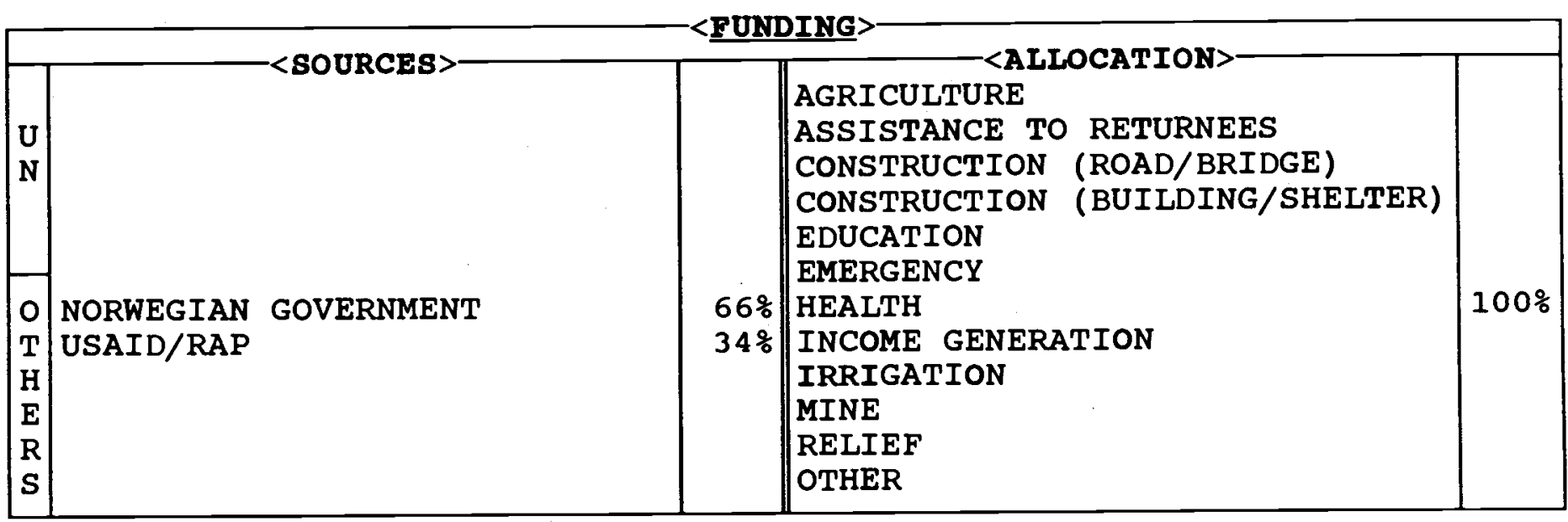

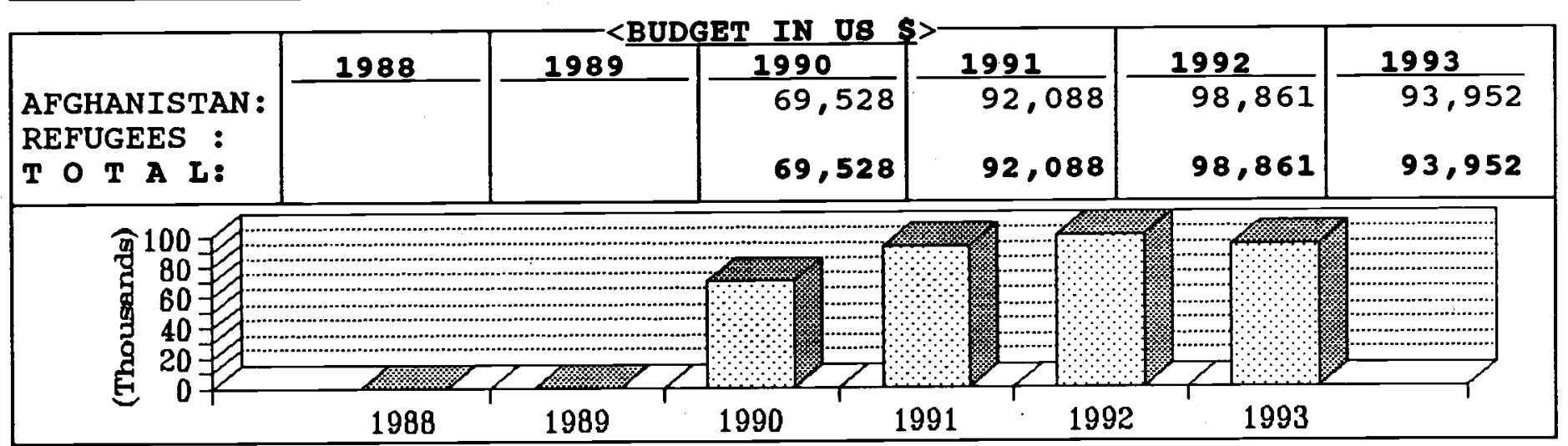

\begin{tabular}{|c|c|c|c|c|c|}
\hline PROVINCES & SECTOR & \&AGE & PROVINCES & SECTOR & \&AGE \\
\hline $\begin{array}{l}\text { BADAKSHAN } \\
\text { BADGHIS } \\
\text { BAGHLAN } \\
\text { BALKH } \\
\text { BAMYAN } \\
\text { FARAH } \\
\text { FARYAB } \\
\text { GHAZNI } \\
\text { GHOR } \\
\text { HELMAND } \\
\text { HERAT } \\
\text { JAWZJAN } \\
\text { KABUL } \\
\text { KANDAHAR } \\
\text { KAPISA }\end{array}$ & 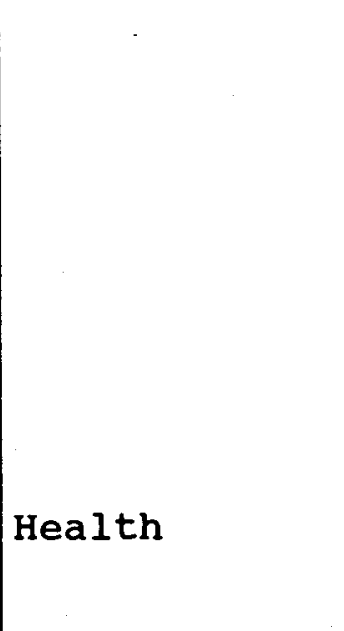 & . & \begin{tabular}{|l} 
KUNAR \\
KUNDUZ \\
LAGHMAN \\
LOGAR \\
NANGARHAR \\
NIMROZ \\
ORUZGAN \\
PAKTEKA \\
PAKTIA \\
PARWAN \\
SAMANGAN \\
TAKHAR \\
WARDAK \\
ZABUL
\end{tabular} & Health & $60 \%$ \\
\hline
\end{tabular}


MUJAHID EMERGENCY MEDICAL CENTER (MMC)

is an Afghan run surgical unit in Jalalabad city of Nangarhar province. MMC was established in March 1989 when the mujahideen started heavy and intensive attacks on Jalalabad. The objective of the organization has been to provide first aid to the war wounded people and evacuate them from the conflict areas to clinics and hospitals for further care.

MMC mobile units which previously were located as close to the mujahideen fronts as possible are now operating from Jalalabad city. MMC was the first NGo to enter Jalalabad after it was occupied by the mujahideen.

From March 1989 up to December 1991, MMC managed to evacuate of 5,532 seriously wounded people, treated 10,416 out patients and 1,438 martyred in the out-skirts of Jalalabad city.

MMC has also operated for different periods in other conflict areas e.g. Khost, Kunar and Kabul.

MMC main center which is now functioning in Jalalabad Red Crescent Building offers OPD, child care, EPI, dental care and laboratory services. one of the mobile units is still in the lower part of Jalalabad on the main KabulTorkham highway. The other mobile unit is covering parts of Kabul.

Services have been provided to Afghan mujahideen and civilians without any favoritism as MMC is a neutral humanitarian body.

MMC health facilities have been sponsored by the Norwegian Government (funds channeled through Norwegian Afghanistan Committee).

In 1993, MMC started a Family Training Program in Jalalabad city. Through regular visits to houses the female members of the families are provided health education and instructions how to feed their children. Children with malnutrition are provided with some nutritious food items and taken under regular observation.

The Home Visiting Team of MMC/FTP visited 140 families in Jalalabad and areas in the vicinity e.g. Qasaba between March 15, 1993 to June 15, 1993.

MMC is intending to establish a complete $\mathrm{MCH}$ program in 1994 and offers better services to the needy people of the area. 
MUSLIM AID INTERNATIONAL-MAI

\begin{tabular}{|l|l|l|}
\hline 309, GULHAJI PLAZA & PHONE: 43203 & CKOMY STAFF>- \\
P O BOX 914 & F A X: & 1. MR. MOHD SALEEM \\
PESHAWAR, PAKISTAN & TELEX: & 2. MR. ABO MAHAZ \\
\hline
\end{tabular}

\begin{tabular}{|c|c|c|c|c|c|}
\hline $\begin{array}{l}\text { AFGHAN : } \\
\text { PAKISTANI : } \\
\text { EXPAT: } \\
\text { TOTAL: }\end{array}$ & $\begin{array}{l}\ddot{ } \\
\cdots \\
\cdots\end{array}$ & $\begin{array}{l}\text { TECHNICAL: } \\
\text { ADMINISTRATIVE: } \\
\text { FIELD/SUPPORT S. } \\
\text { TOTAL: }\end{array}$ & $\begin{array}{l}\cdots \\
\cdots \\
\cdots\end{array}$ & $\begin{array}{l}\text { PAK. BASED: } \\
\text { AFGHA. BASED: } \\
\text { CROSS-BORDER: } \\
\text { TOTAL: }\end{array}$ & 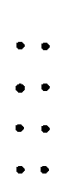 \\
\hline
\end{tabular}

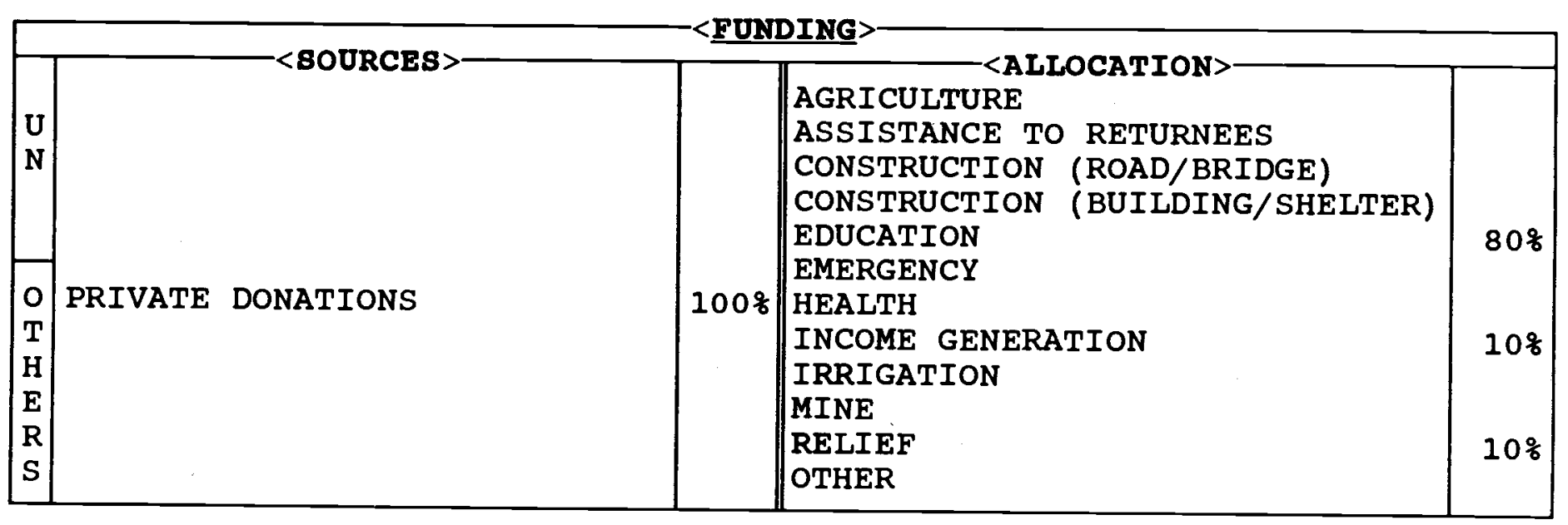

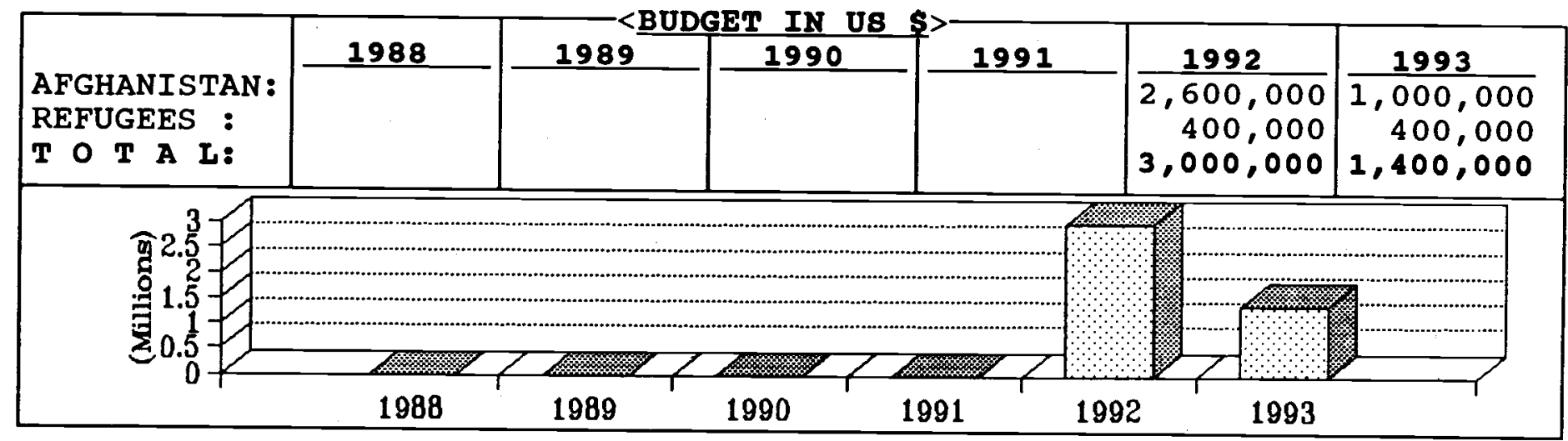

\begin{tabular}{|c|c|c|c|c|c|}
\hline PROVINCES & SECTOR & \&AGE & PROVINCES & SECTOR & \&AGE \\
\hline $\begin{array}{l}\text { BADAKSHAN } \\
\text { BADGHIS } \\
\text { BAGHLAN } \\
\text { BALKH } \\
\text { BAMYAN } \\
\text { FARAH } \\
\text { FARYAB } \\
\text { GHAZNI } \\
\text { GHOR } \\
\text { HELMAND } \\
\text { HERAT } \\
\text { JAWZJAN } \\
\text { KABUL } \\
\text { KANDAHAR } \\
\text { KAPISA }\end{array}$ & & & \begin{tabular}{|l|} 
KUNAR \\
KUNDUZ \\
LAGHMAN \\
LOGAR \\
NANGARHAR \\
NIMROZ \\
ORUZGAN \\
PAKTEKA \\
PAKTIA \\
PARWAN \\
SAMANGAN \\
TAKHAR \\
WARDAK \\
ZABUL
\end{tabular} & $\begin{array}{l}\text { Educ } \\
\text { Educ } \\
\text { Educ } \\
\text { Educ } \\
\text { Educ } \\
\text { Educ } \\
\text { Educ }\end{array}$ & $\begin{array}{l}10 \% \\
10 \% \\
20 \% \\
20 \% \\
10 \% \\
20 \% \\
10 \%\end{array}$ \\
\hline
\end{tabular}


is an NGO based in London. Muslim Aid's Afghanistan program is mainly focused on education and concentrated inside Afghanistan.

There are 218 primary schools currently being supported by Muslim Aid International in 17 provinces of Afghanistan. In the beginning, Muslim Aid International established 41 schools in 7 districts of Nangarhar and 24 schools in 5 district of Laghman as a pilot project. Later on, based on the field report of the inspectors, support was extended to other provinces.

In Peshawar, Muslim Aid International runs a primary school and a secondary school. The secondary school offers technical training besides non-technical education. 155 students are enrolled in the school. An English medium school is supported in Peshawar for refugee children (226 girls). A vocational training center for girls is also supported which trains 45 students in each course. Moreover, Muslim Aid has 27 Quranic study Centers for refugee girls in different parts of NWFP which accommodate a total of 811 students.

Muslim Aid International organizes different seminars inside Afghanistan and for refugees in Pakistan to train teachers and inspectors. The duration of seminars differ from 10 to 45 days. Between 1988 to 1991 a total of 320 teachers and inspectors participated in 7 seminars.

In the field of health, Muslim Aid International has established a Central Medical Laboratory in Peshawar. It is a self-sufficient lab which provides different tests and analysis to all Afghan Hospitals. It carries out an average of 8,030 different tests per month. 
MUSLIM ABSIBTANCE \& WELFARE ASSOCIATION-MAWA

\begin{tabular}{|l|l|l|l}
\hline 391, D-4, ST. 27 PH.1 & PHONE: 810391/810540 & 1. MR. S AMIR TAHSIN \\
HAYATABAD, & FA X: & 2. \\
PESHAWAR, PAKISTAN & TELEX: & 3.
\end{tabular}

\begin{tabular}{|lc|lr|lr|}
\hline AFGHAN: & 30 & TECHNICAL: & 4 & PAK. BASED: & 4 \\
PAKISTANI : & 0 & ADMINISTRATIVE: & 3 & AFGHA.BASED: & 26 \\
EXPAT: & 0 & FIELD/SUPPORT S. & 24 & CROSS-BORDER: & 0 \\
TOTAL: & 30 & TOTAL: & 30 & TOTAL: & 30 \\
\hline
\end{tabular}

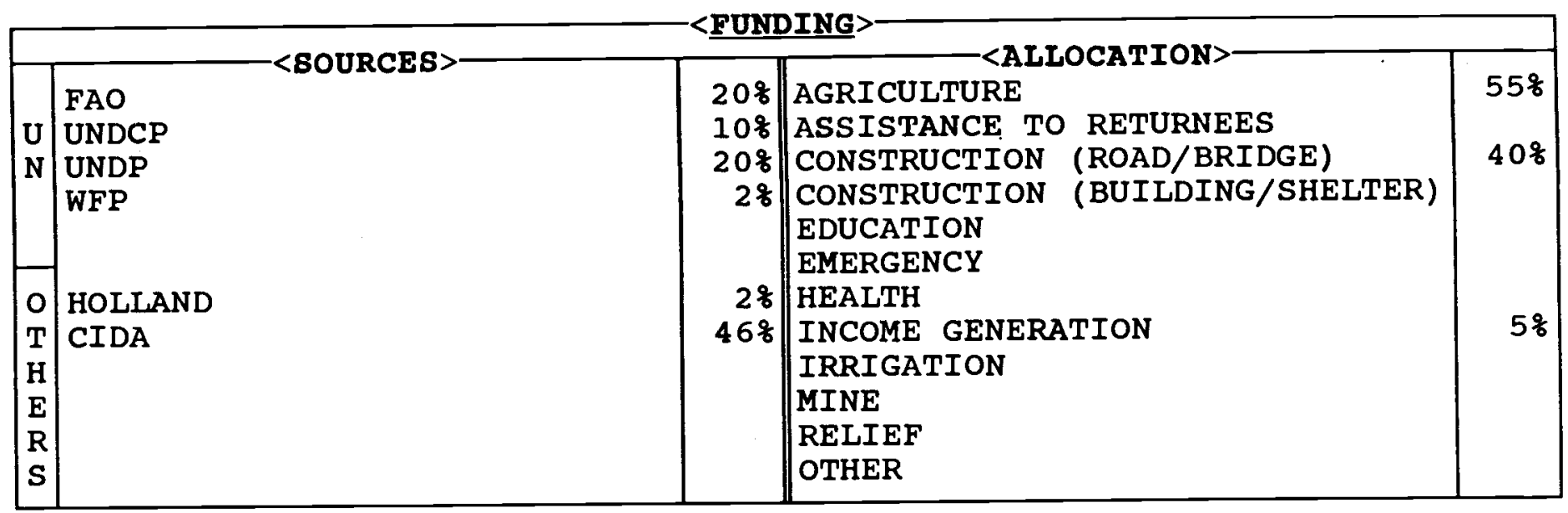

\begin{tabular}{|c|c|c|c|c|c|c|}
\hline $\begin{array}{l}\text { AFGHANISTAN: } \\
\text { REFUGEES : } \\
\text { T O T A L: }\end{array}$ & 1988 & 1989 & 1990 & $\begin{array}{r}1991 \\
76,784 \\
76,784\end{array}$ & $\begin{array}{l}\frac{1992}{187,529} \\
187,529\end{array}$ & $\begin{array}{r}1993 \\
236,933 \\
12,654 \\
249,587\end{array}$ \\
\hline 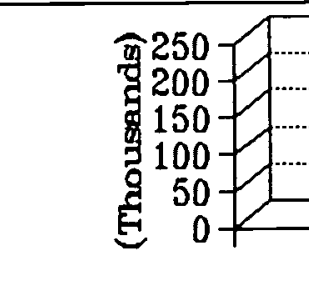 & 198 & 1989 & 1990 & 1 & & C \\
\hline
\end{tabular}

\begin{tabular}{|c|c|c|c|c|c|}
\hline PROVINCES & SECTOR & $8 \mathrm{AGE}$ & PROVINCES & SECTOR & $\%$ AGE \\
\hline $\begin{array}{l}\text { BADAKSHAN } \\
\text { BADGHIS } \\
\text { BAGHLAN } \\
\text { BALKH } \\
\text { BAMYAN } \\
\text { FARAH } \\
\text { FARYAB } \\
\text { GHAZNI } \\
\text { GHOR } \\
\text { HELMAND } \\
\text { HERAT } \\
\text { JAWZJAN } \\
\text { KABUL } \\
\text { KANDAHAR } \\
\text { KAPISA }\end{array}$ & & & $\begin{array}{l}\text { KUNAR } \\
\text { KUNDUZ } \\
\text { LAGHMAN } \\
\text { LOGAR } \\
\text { NANGARHAR } \\
\text { NIMROZ } \\
\text { ORUZGAN } \\
\text { PAKTEKA } \\
\text { PAKTIA } \\
\text { PARWAN } \\
\text { SAMANGAN } \\
\text { TAKHAR } \\
\text { WARDAK } \\
\text { ZABUL }\end{array}$ & $\begin{array}{l}\text { Const } \\
\text { Agr } \\
\text { Agr/irrign }\end{array}$ & $\begin{array}{l}10 \% \\
10 \% \\
80 \%\end{array}$ \\
\hline
\end{tabular}




\section{MUSLIM ASSISTANCE AND WELFARE A88OCIATION (MAWA)}

is an Afghan NGo established in 1989. The main purpose of this association is to take part in the rehabilitation and reconstruction of Afghanistan.

MAWA works in the sectors of agriculture, construction, handicrafts, education and health. It has completed about 30 agricultural and construction projects in Nangarhar and Logar provinces. 10 projects are ongoing. 36 projects are in the planning process.

In the refugee sector, MAWA has training centers for men and women in Hayatabad where courses are offered in lapidary and gems cutting.

MAWA's main office is in Peshawar. It has a sub-office in Mazina village of Rodat district and another office in Jalalabad. 
MUSLIM YOUTH ASSOCIATION FOR REHABILITATION OF AFGHANISTAN-YARA

\begin{tabular}{|l|l|l|}
\hline A/5, CANAL BANK RD & PHONE: & <COMEY STAFF $>$ KRICAPION LINES $>-$ DAD MOHD KHALID \\
G P O BOX 694 & F A X: & 2. \\
PESHAWAR, PAKISTAN & TELEX: & 3. \\
\hline
\end{tabular}

\begin{tabular}{|lr|lr|lr|}
\hline AFGHAN : & 10 & TECHNICAL: & 4 & PAK. BASED: & 3 \\
PAKISTANI: & - & ADMINISTRATIVE: & 3 & AFGHA. BASED: & 3 \\
EXPAT: & - & FIELD/SUPPORT S. & 3 & CROSS-BORDER: & 4 \\
TOTAL: & 10 & TOTAL: & 10 & TOTAL: & 10 \\
\hline
\end{tabular}

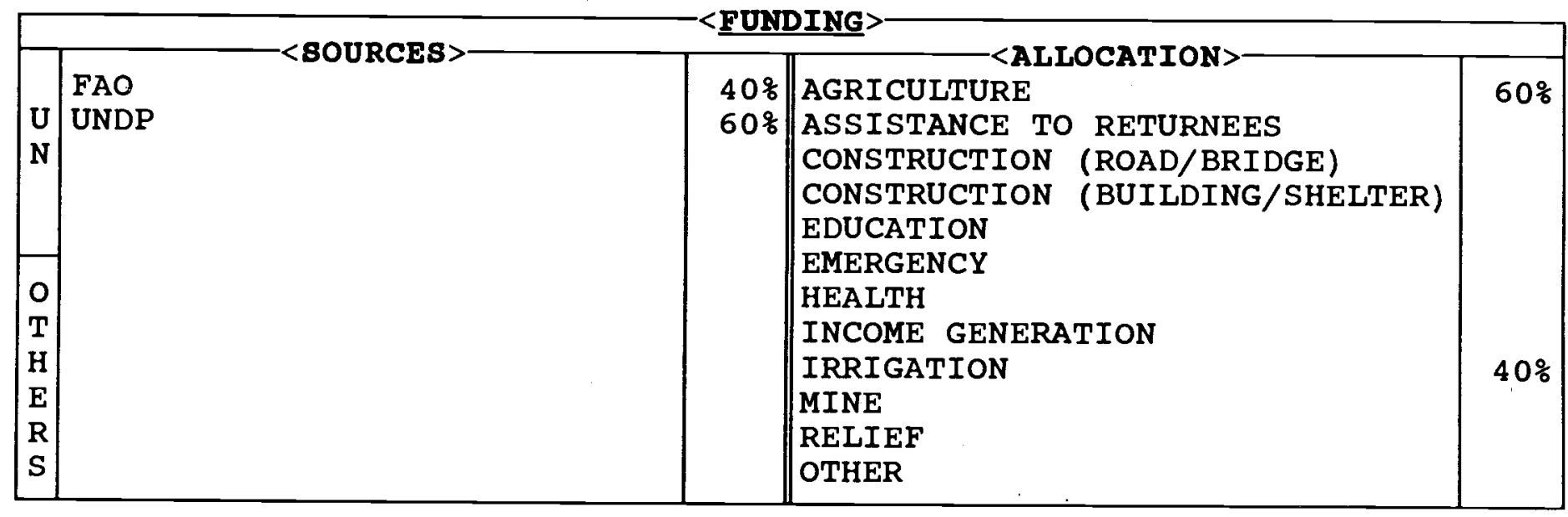

\begin{tabular}{|c|c|c|c|c|c|c|}
\hline & 1988 & 1989 & 1990 & 1991 & 1992 & 1993 \\
\hline $\begin{array}{l}\text { AFGHANISTAN : } \\
\text { REFUGEES : }\end{array}$ & & & & & 9,215 & 25,000 \\
\hline T 0 T $\mathbf{A}:$ & & & & & 9,217 & 25,000 \\
\hline
\end{tabular}

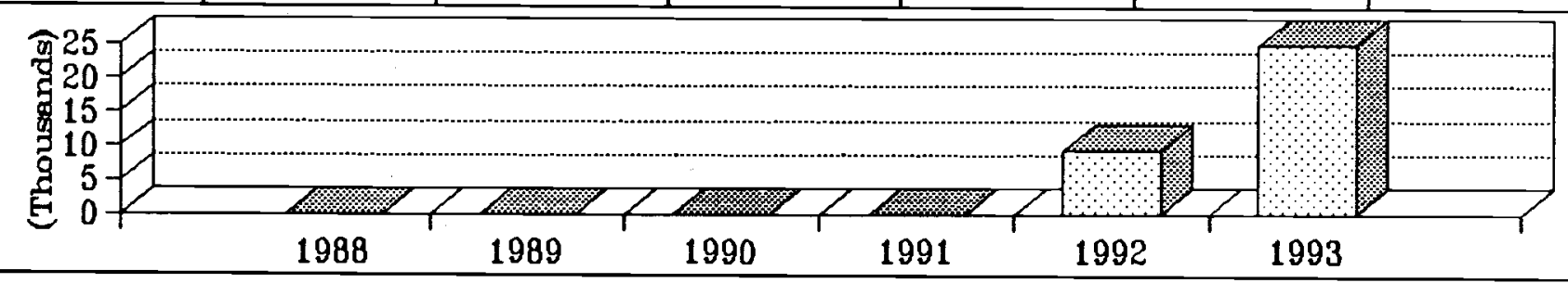

\begin{tabular}{|c|c|c|c|c|c|}
\hline PROVINCES & SECTOR & $\because \mathrm{AGE}$ & PROVINCES & SECTOR & $\% A G E$ \\
\hline $\begin{array}{l}\text { BADAKSHAN } \\
\text { BADGHIS } \\
\text { BAGHLAN } \\
\text { BALKH } \\
\text { BAMYAN } \\
\text { FARAH } \\
\text { FARYAB } \\
\text { GHAZNI } \\
\text { GHOR } \\
\text { HELMAND } \\
\text { HERAT } \\
\text { JAWZJAN } \\
\text { KABUL } \\
\text { KANDAHAR } \\
\text { KAPISA }\end{array}$ & & & \begin{tabular}{|l|} 
KUNAR \\
KUNDUZ \\
LAGHMAN \\
LOGAR \\
NANGARHAR \\
NIMROZ \\
ORUZGAN \\
PAKTEKA \\
PAKTIA \\
PARWAN \\
SAMANGAN \\
TAKHAR \\
WARDAK \\
ZABUL
\end{tabular} & Agr/irrign & $100 \%$ \\
\hline
\end{tabular}




\section{MUSLIM YOUTH ASSOCIATION FOR REHABILITATION OF AFGHANISTAN (YARA)}

is an Afghan non-governmental organization established in 1991. YARA's aim is to contribute to the rehabilitation, reconstruction and development of war torn Afghanistan especially the rural areas.

YARA is interested and has the capacity to implement projects in different sectors including agriculture rehabilitation, irrigation repair and infrastructure reconstruction.

YARA's target of work has so far been Nangarhar province and primarily Achin, Deh Bala, Ghani Khel, Mohmand Dara and Surkhrod districts of Nangarhar where it has distributed improved wheat, sugar cane, maize and rice seeds, fertilizer and fruit trees. Over the past three years, YARA has implemented several agricultural projects mainly multiplication and extension of improved rice, sugar cane, maize and wheat seeds 'with the support of different United Nations organizations. In September 1993, YARA started a poultry management training program for women in Surkhrod district where 480 women will be trained over the next eight months. Each woman will at the end of course receive 15 chicks of two months old.

YARA plans to expand its programs to other districts of Nangarhar and other provinces of Afghanistan in the future. 


\section{NATIONAL ASSOCIATION OF DISABLED OF AFGHANISTAN-NADA}

\begin{tabular}{|c|c|c|c|c|c|}
\hline$-\angle \overline{A D}$ & & $=<$ COMMUNICATION & NES: & $=<$ REY STA & \\
\hline $\begin{array}{l}\text { STREET 1, } \\
\text { KHAN } \\
\text { KABUL, AFG }\end{array}$ & $\begin{array}{l}\text { AKBAR } \\
\text { CAN }\end{array}$ & $\begin{array}{l}\text { PHONE: } 20081 \\
\text { F A X: } \\
\text { TELEX : }\end{array}$ & & $\begin{array}{ll}\text { 1. MR. S. M. } \\
\text { 2. MR. ABDUL } \\
\text { 3. HAJ I JAMDA }\end{array}$ & \\
\hline $\begin{array}{l}\text { AFGHAN : } \\
\text { PAKISTANI: } \\
\text { EXPAT: } \\
\text { TOTAL: }\end{array}$ & $\begin{array}{r}127 \\
- \\
127\end{array}$ & $\begin{array}{l}\text { TECHNICAL: } \\
\text { ADMINISTRATIVE: } \\
\text { FIELD/SUPPORT S. } \\
\text { TOTAL: }\end{array}$ & $\begin{array}{r}75 \\
27 \\
25 \\
127\end{array}$ & $\begin{array}{l}\text { PAK. BASED: } \\
\text { AFGHA. BASED: } \\
\text { CROSS-BORDER: } \\
\text { TOTAL: }\end{array}$ & $\begin{array}{r}12 \overline{7} \\
- \\
127\end{array}$ \\
\hline
\end{tabular}

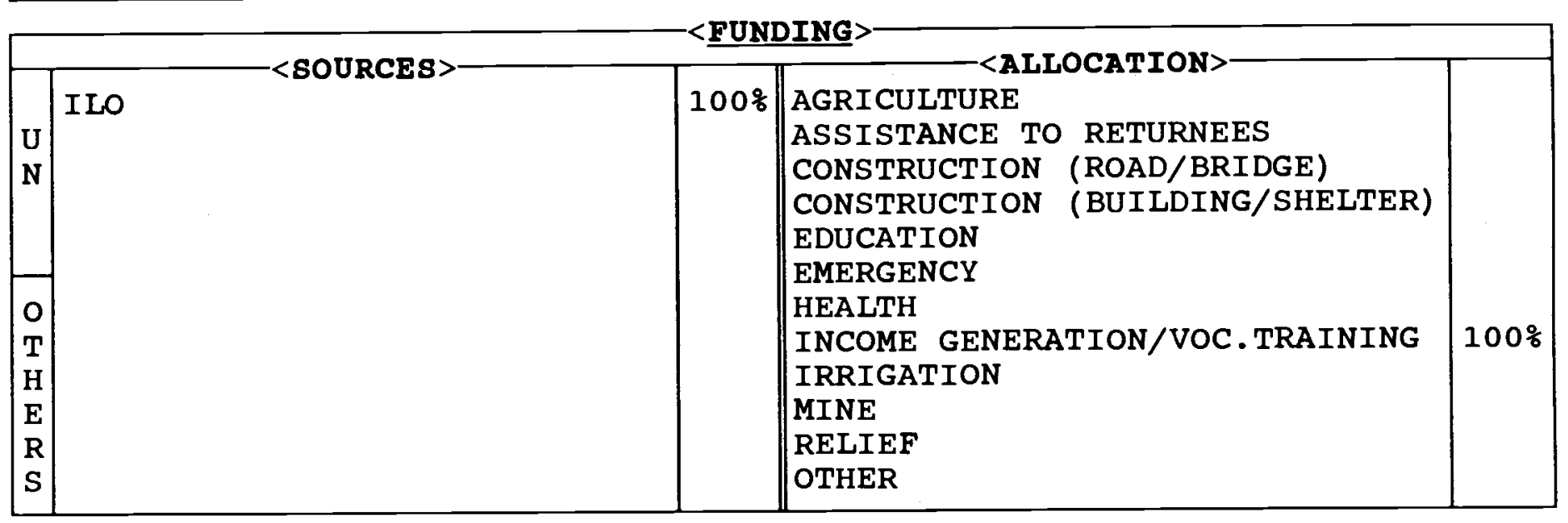

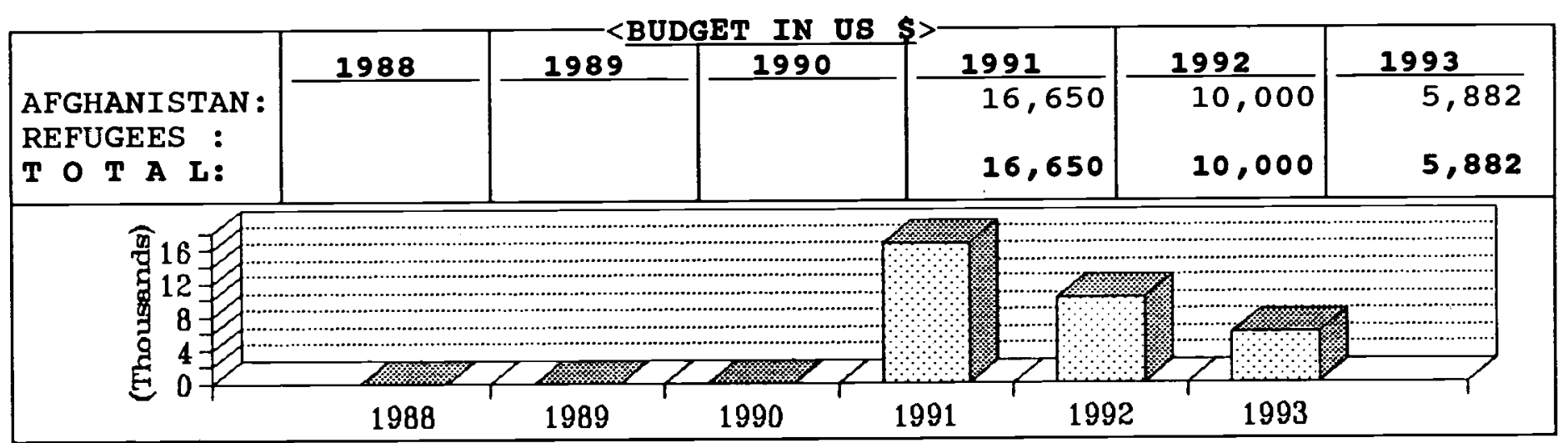

\begin{tabular}{|c|c|c|c|c|c|}
\hline PROVINCES & SECTOR & \&AGE & PROVINCES & SECTOR & \&AGE \\
\hline $\begin{array}{l}\text { BADAKSHAN } \\
\text { BADGHIS } \\
\text { BAGHLAN } \\
\text { BALKH } \\
\text { BAMYAN } \\
\text { FARAH } \\
\text { FARYAB } \\
\text { GHAZNI } \\
\text { GHOR } \\
\text { HELMAND } \\
\text { HERAT } \\
\text { JAWZJAN } \\
\text { KABUL } \\
\text { KANDAHAR } \\
\text { KAPISA }\end{array}$ & $\begin{array}{l}\text { Income gen } \\
\text { Income gen } \\
\text { Income gen } \\
\text { Income gen } \\
\text { Income gen }\end{array}$ & $\begin{array}{l}10 \% \\
10 \%\end{array}$ & \begin{tabular}{|l|} 
KUNAR \\
KUNDUZ \\
LAGHMAN \\
LOGAR \\
NANGARHAR \\
NIMROZ \\
ORUZGAN \\
PAKTEKA \\
PAKTIA \\
PARWAN \\
SAMANGAN \\
TAKHAR \\
WARDAK \\
ZABUL
\end{tabular} & $\begin{array}{l}\text { Income gen } \\
\text { Income gen } \\
\text { Income gen } \\
\text { Income gen } \\
\text { Income gen }\end{array}$ & $\begin{array}{l}10 \% \\
10 \% \\
10 \% \\
10 \%\end{array}$ \\
\hline
\end{tabular}


is an Afghan organization working merely for people with disabilities. NADA was established in 1991 and since then has established a number of projects for disabled Afghans.

The primary task of the Association is to provide work opportunities for disabled Afghans and prepare them for work by providing proper training. NADA organizes placement of disabled people with craftsmen. Both the trainees and the trainers are paid by the Association. It also establishes training courses.

Currently, NADA maintains a carpet weaving center in Mazar-i-sharif and an embroidery course in kabul. A number of bee keeping, poultry and animal farms were established in Kabul which were destroyed during the fighting. The Association has also established clinics for the disabled one in Mazar and another Herat.

A total of 5,086 has been registered with the Association so far. The process of registration is ongoing and it will be expanded throughout the country. The survey and assessment for registration of disabled is conducted by trained surveyors. The surveyors are given a month training on how to assess the status and conditions of the people with disabilities. The people in the provided lists are revisited by NADA supervisors and the based on their recommendations the Association then put the disabled in appropriate places of training. Surveyors for the provinces of Baghlan, Kandahar, Balkh, Herat, Nangarhar, Parwan, Samangan, Takhar and Wardak have been trained who will commence assessment in their respective provinces in the near future.

NADA also provides primary education opportunities to disabled children. 
NATIONAL ENGINEERING RECONSTRUCTION UNIT-NERU

\begin{tabular}{|l|l|l|}
\hline 2 AZEEM HOUSE, GUL MOHD & PHONE: & 1. ENG. JAN MOHAMMAD \\
KILI, AIRPORT RD & F A X: & 2. \\
QUETTA, PAKISTAN & TELEX: & 3. \\
\hline
\end{tabular}

\begin{tabular}{|ll|ll|ll|}
\hline AFGHAN: & 7 & TECHNICAL: & 3 & PAK. BASED: & 5 \\
PAKISTANI : & - & ADMINISTRATIVE: & 1 & AFGHA.BASED: & - \\
EXPAT: & - & FIELD/SUPPORT S. & 3 & CROSS-BORDER: & 2 \\
TOTAL: & 7 & TOTAL: & 7 & TOTAL: & 7 \\
\hline
\end{tabular}

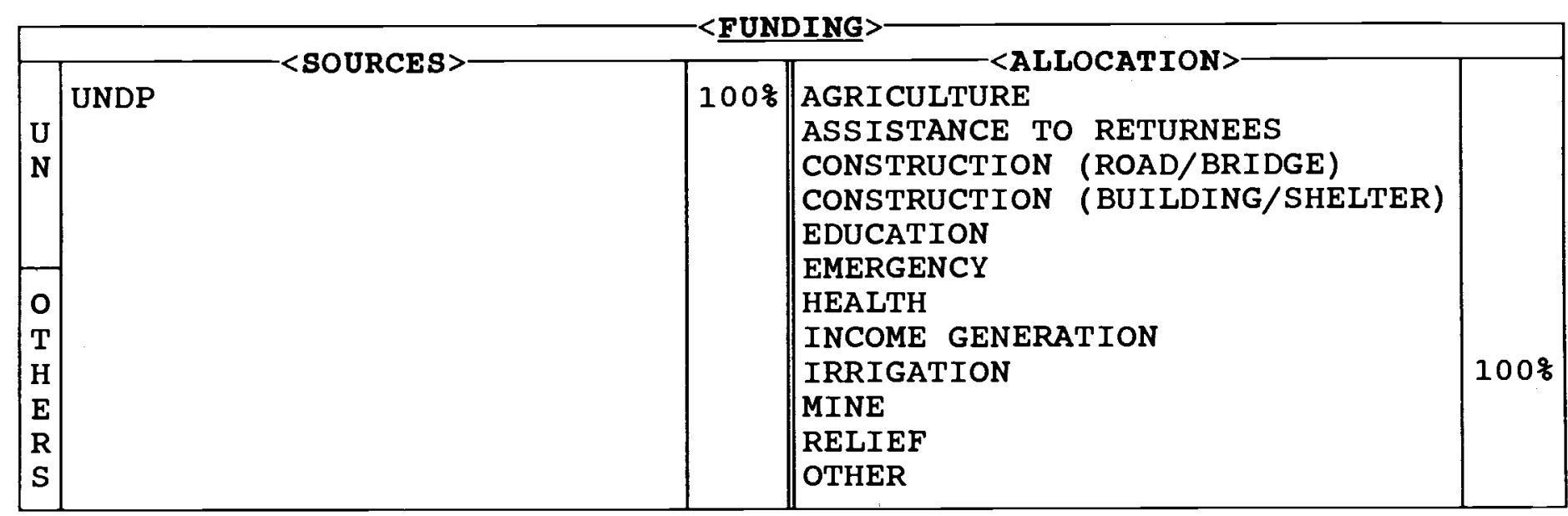

\begin{tabular}{|c|c|c|c|c|c|c|}
\hline & 1000 & 1000 & 1000 & 1001 & $100 ?$ & $100 ?$ \\
\hline $\begin{array}{l}\text { AFGHANISTAN: } \\
\text { REFUGEES : } \\
\text { T O T A L: }\end{array}$ & & & & & & $\begin{array}{l}16,000 \\
16,000\end{array}$ \\
\hline
\end{tabular}

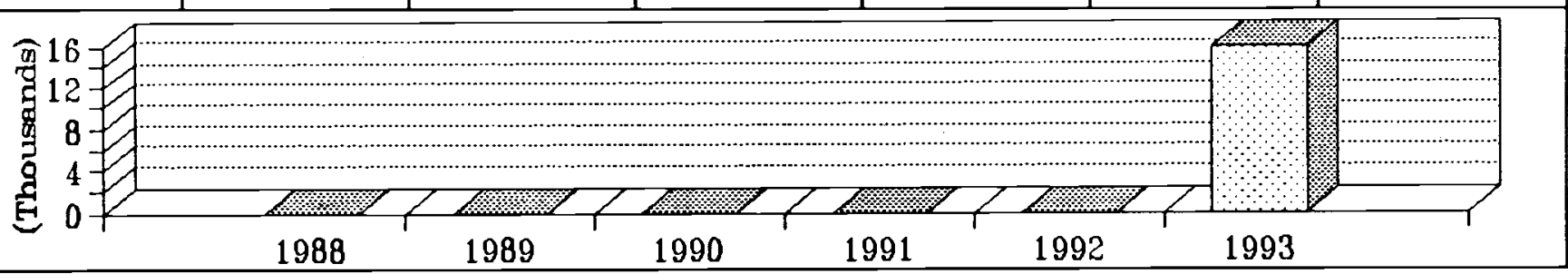

\begin{tabular}{|c|c|c|c|c|c|}
\hline PROVINCES & SECTOR & $\because A G E$ & PROVINCES & SECTOR & \&AGE \\
\hline $\begin{array}{l}\text { BADAKSHAN } \\
\text { BADGHIS } \\
\text { BAGHLAN } \\
\text { BALKH } \\
\text { BAMYAN } \\
\text { FARAH } \\
\text { FARYAB } \\
\text { GHAZNI } \\
\text { GHOR } \\
\text { HELMAND } \\
\text { HERAT } \\
\text { JAWZJAN } \\
\text { KABUL } \\
\text { KANDAHAR } \\
\text { KAPISA }\end{array}$ & Irrign & $100 \%$ & \begin{tabular}{|l} 
KUNAR \\
KUNDUZ \\
LAGHMAN \\
LOGAR \\
NANGARHAR \\
NIMROZ \\
ORUZGAN \\
PAKTEKA \\
PAKTIA \\
PARWAN \\
SAMANGAN \\
TAKHAR \\
WARDAK \\
ZABUL
\end{tabular} & & \\
\hline
\end{tabular}


is an Afghan NGO founded in June 1993 with the objective of participating in the reconstruction exercise of Afghanistan.

The agency is carrying out agricultural, irrigation, road construction and veterinary projects initially in the south-western provinces of Afghanistan.

NERU has started its first project "Rehabilitation of Lower Birtaki canal in Helmand province". The canal will irrigate 5,000 jeribs of land.

For the time being the agency is carrying out cross-border operations from quetta where its main office is based. It will consider moving the office to Afghanistan at a suitable time.

Proposals have been submitted to UNDP, UNHCR, WFP and UNDCP and are under consideration. 
NORWEGIAN AFGHANISTAN COMMITTEE-NAC

\begin{tabular}{|c|c|c|}
\hline$-<$ ADDRESB $>$ & $-<$ COMMUNICATION LINES $>$ & STAFF> \\
\hline $\begin{array}{l}12 \text { A OLD JAMROD RD, U/T } \\
\text { P O BOX } 993 \\
\text { PESHAWAR, PAKISTAN }\end{array}$ & $\begin{array}{l}\text { PHONE: } 840517 / 43717 \\
\text { F A X: } \\
\text { TELEX: }\end{array}$ & $\begin{array}{ll}\text { 1. MR. NILS OLE GAUP } \\
\text { 2. MS. KARI OYEN } \\
\text { 3. }\end{array}$ \\
\hline
\end{tabular}

\begin{tabular}{|c|c|c|c|c|c|}
\hline $\begin{array}{l}\text { AFGHAN : } \\
\text { PAKISTANI : } \\
\text { EXPAT: } \\
\text { TOTAL: }\end{array}$ & $\begin{array}{r}80 \\
1 \\
6 \\
87\end{array}$ & $\begin{array}{l}\text { TECHNICAL: } \\
\text { ADMINISTRATIVE: } \\
\text { FIELD/SUPPORT S. } \\
\text { TOTAL: }\end{array}$ & $\begin{array}{l}\ddot{*} \\
\ddot{87}\end{array}$ & $\begin{array}{l}\text { PAK. BASED: } \\
\text { AFGHA. BASED: } \\
\text { CROSS-BORDER: } \\
\text { TOTAL : }\end{array}$ & $\begin{array}{l}\ddot{.} \\
\ddot{87}\end{array}$ \\
\hline
\end{tabular}

\begin{tabular}{|c|c|c|c|c|}
\hline & - <8OURCFR & & 〈ATTOCATTON> & \\
\hline & FAO & $4 \frac{8}{6}$ & AGRICULTURE & $4 \%$ \\
\hline $\mathbf{U}$ & UNDCP & $2 \%$ & ASSISTANCE TO RETURNEES & \\
\hline $\mathbf{N}$ & UNICEF & $2 \%$ & CONSTRUCTION (ROAD/BRIDGE) & \\
\hline & UNHCR & $2 \%$ & CONSTRUCTION (BUILDING/SHELTER) & $23 \%$ \\
\hline & WFP & $2 \%$ & EDUCATION & $7 \%$ \\
\hline & & & EMERGENCY & $17 \%$ \\
\hline 0 & NORWEGIAN GOVERNMENT & $73 \%$ & HEALTH & $19 \%$ \\
\hline $\mathbf{T}$ & NORAD & $6 \%$ & INCOME GENERATION & \\
\hline $\mathrm{H}$ & ODW & $2 \%$ & IRRIGATION & $12 \%$ \\
\hline $\mathbf{E}$ & TV CAMPAIGN (NORWAY) & & MINE & \\
\hline $\mathbf{R}$ & PRIVATE DONATIONS & $7 \%$ & RELIEF & \\
\hline S & $\mathrm{SCA}$ & & OTHER & $17 \%$ \\
\hline
\end{tabular}

\begin{tabular}{|c|c|c|c|c|c|c|}
\hline $\begin{array}{l}\text { AFGHANISTAN : } \\
\text { REFUGEES : } \\
\text { T O T A L: }\end{array}$ & $\begin{array}{r}1988 \\
1,578,801 \\
231,651 \\
1,810,452\end{array}$ & $\begin{array}{r}1989 \\
1,782,977 \\
222,575 \\
2,005,552\end{array}$ & $\begin{array}{r}1990 \\
2,033,660 \\
287,129 \\
2,320,789\end{array}$ & $\begin{array}{r}\frac{1991}{2,374,181} \\
310,200 \\
2,684,381\end{array}$ & $\begin{array}{r}\frac{1992}{2,158,384} \\
150,728 \\
2,309,112\end{array}$ & $\begin{array}{r}\frac{1993}{1,739,050} \\
361,166 \\
2,100,216\end{array}$ \\
\hline 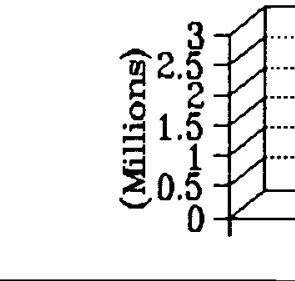 & 1988 & 1989 & 1990 & 991 & 1993 & (1) \\
\hline
\end{tabular}

\begin{tabular}{|c|c|c|c|c|c|}
\hline PROVINCES & SECTOR & \%AGE & PROVINCES & SECTOR & $\%$ AGE \\
\hline \begin{tabular}{l|} 
BADAKSHAN \\
BADGHIS \\
BAGHLAN \\
BALKH \\
BAMYAN \\
FARAH \\
FARYAB \\
GHAZNI \\
GHOR \\
HELMAND \\
HERAT \\
JAWZJAN \\
KABUL \\
KANDAHAR \\
KAPISA
\end{tabular} & $\begin{array}{l}\text { Agr/const/irrign } \\
\text { Const. } \\
\text { Irrign. } \\
\text { Agr/educ/health/irrig } \\
\text { Relief } \\
\text { Const }\end{array}$ & $\begin{array}{r}22 \% \\
3 \% \\
4 \%\end{array}$ & \begin{tabular}{|l|} 
KUNAR \\
KUNDUZ \\
LAGHMAN \\
LOGAR \\
NANGARHAR \\
NIMROZ \\
ORUZGAN \\
PAKTEKA \\
PAKTIA \\
PARWAN \\
SAMANGAN \\
TAKHAR \\
WARDAK \\
ZABUL
\end{tabular} & $\begin{array}{l}\text { Health } \\
\text { Agr/health } \\
\text { Agr/health/irrign } \\
\text { Agr/emerg/irrign }\end{array}$ & $\begin{array}{r}6 \% \\
12 \%\end{array}$ \\
\hline
\end{tabular}


was founded in 1979 in response to the Soviet invasion of Afghanistan. The aim was to provide support to the Afghan people through political pressure in Norway and internationally, and also financial support.

The work of NAC started with medical support and cash for food programs. Later the activities have developed into projects and programs in health, education, reconstruction and agriculture sectors:

EMERGENCY AID: Emergency operations in all parts of the country.

HEALTH: Support local health systems, midwife pilot project under implementation, vaccination programs.

EDUCATION: Direct support to 43 schools.

RECONSTRUCTION: Irrigation system rehabilitation, school reconstruction, infrastructure.

AGRICULTURE: Wheat trials, seed multiplication, vegetable production/ promotion, crop protection, forest protection.

NAC is also maintaining a limited engagement among the Afghan refugees in Peshawar through supporting girls schools and medical training courses.

Inside Afghanistan NAC is running projects in many provinces, but its major working areas are Paktia, Ghazni and Badakhshan, and its aim is to run multi-sectoral community development projects in these areas.

NAC is cooperating with several other NGOs but primarily it implements its own projects. It works with the local communities, and in agreement with the local authorities. 
NORWEGIAN REFUGEE COUNCIL/NORWEGIAN CHURCH AID-NRC/NCA

51-C PARK AVENUE, U/T

P O BOX .........

PHONE: $840304 / 45267$

F A X: 840304

TELEX:

1. MR. THOR ARNE PROIS

2. MR. ARNE STRAND

3 .

\begin{tabular}{|lr|lc|lr|}
\hline AFGHAN: & 165 & TECHNICAL: & $\ldots$ & PAK. BASED: & 60 \\
PAKISTANI : & 13 & ADMINISTRATIVE: & $\ldots$ & AFGHA.BASED: & 120 \\
EXPAT: & 4 & FIELD/SUPPORT S. & $\ldots$ & CROSS-BORDER: & - \\
TOTAL: & $\mathbf{1 8 2}$ & TOTAL: & $\mathbf{1 8 2}$ & TOTAL: & $\mathbf{1 8 2}$ \\
\hline
\end{tabular}

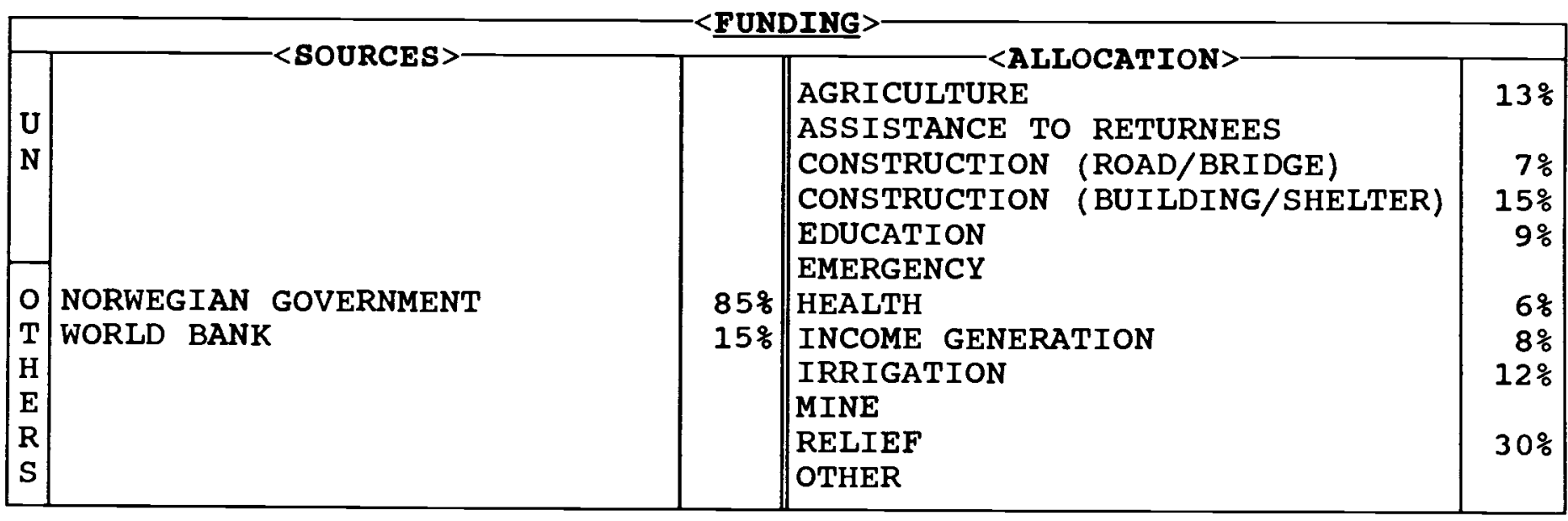

\begin{tabular}{|c|c|c|c|c|c|c|}
\hline & 1988 & 1989 & 1990 & 1991 & 1992 & 1993 \\
\hline AFGHANISTAN : & & 705,190 & $1,075,268$ & $1,636,581$ & $3,260,000$ & $2,871,000$ \\
\hline $\begin{array}{l}\text { REFUGEES : } \\
\text { T O T A L: }\end{array}$ & $\begin{array}{l}3,312,203 \\
3,312,203\end{array}$ & $\begin{array}{l}3,285,994 \\
3,991,184\end{array}$ & $\begin{array}{l}4,184,198 \\
5,259,466\end{array}$ & $\begin{array}{l}4,656,470 \\
6,293,051\end{array}$ & $\begin{array}{l}3,260,000 \\
6,520,000\end{array}$ & $\begin{array}{l}2,349,000 \\
5,220,000\end{array}$ \\
\hline
\end{tabular}

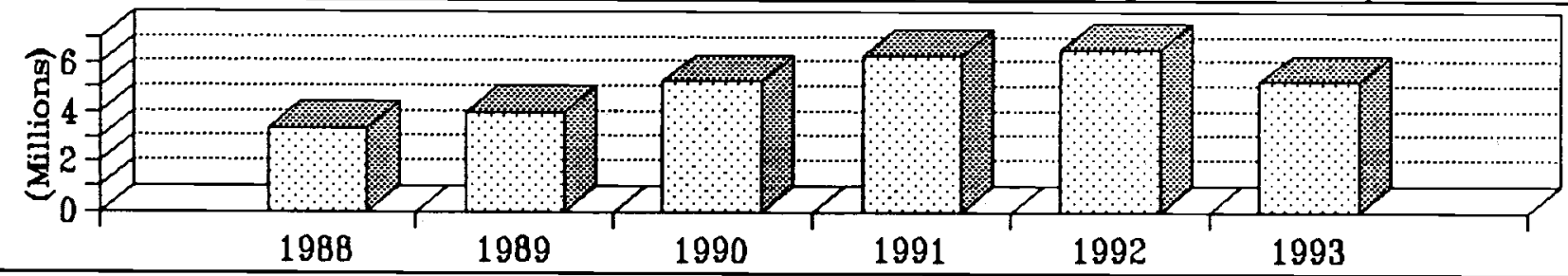

\begin{tabular}{|c|c|c|c|c|c|}
\hline PROVINCES & SECTOR & \%AGE & PROVINCES & SECTOR & $\%$ AGE \\
\hline $\begin{array}{l}\text { BADAKSHAN } \\
\text { BADGHIS } \\
\text { BAGHLAN } \\
\text { BALKH } \\
\text { BAMYAN } \\
\text { FARAH } \\
\text { FARYAB } \\
\text { GHAZNI } \\
\text { GHOR } \\
\text { HELMAND } \\
\text { HERAT } \\
\text { JAWZJAN } \\
\text { KABUL } \\
\text { KANDAHAR } \\
\text { KAPISA }\end{array}$ & Agr/const/sanit & $q$ & $\begin{array}{l}\text { KUNAR } \\
\text { KUNDUZ } \\
\text { LAGHMAN } \\
\text { LOGAR } \\
\text { NANGARHAR } \\
\text { NIMROZ } \\
\text { ORUZGAN } \\
\text { PAKTEKA } \\
\text { PAKTIA } \\
\text { PARWAN } \\
\text { SAMANGAN } \\
\text { TAKHAR } \\
\text { WARDAK } \\
\text { ZABUL }\end{array}$ & $\begin{array}{l}\text { Agr/const/income gen } \\
\text { Agr/const/irrign } \\
\text { Agr/const/income gen } \\
\text { Agr/const/income gen }\end{array}$ & $\begin{array}{l}\% \\
\%\end{array}$ \\
\hline
\end{tabular}


NORẂEGIAN REFUGEE COUNCIL (NRC) and NORWEGIAN CHURCH AID (NCA)

are voluntary, humanitarian organizations involved in relief and development programs throughout the world.

NCA is presently providing assistance to programs in more than 60 countries. Project activities range from emergency relief (distribution of food, tents, clothes and medicines) to involvement in long-term community development programs.

NRC originates from the Norwegian Aid to Europe, established in 1946 after World War II to assist distressed people in Europe. In 1952, the organizations which constituted Norwegian Aid to Europe, along with the Government, formed the Norwegian Refugee Council.

The first assistance given by NRC/NCA to Afghan refugees was in 1979/80. As funds from the Norwegian Government increased, it was decided to establish a joint NRC/NCA office in Peshawar in 1983. The purpose of the office was to keep a close working relationship with the partners receiving Norwegian funds as well as providing accurate reporting to the Norwegian Government on programs and the refugee situation. NRC/NCA has also implemented emergency relief programs among unregistered and newly arrived refugees.

Implementing partners are currently: Inter church Aid, International Rescue Committee, Christian Hospital Refugees Extension Project (CHREP), Afghan Ob/Gyn Hospital (AOGH), Emergency Relief \& Services for Afghanistan (ERSA) and Afghan Development Association (ADA). However, assistance is also given to other organizations and projects based on request and availability of funds.

In 1989, the NRC/NCA Project office (NPO) was established. The following programs are implemented by this office:
1. Assistance to skilled Afghan Refugees (ASAR). This is a UNHCRfunded income-generating project that identifies and provides material assistance to skilled refugees throughout North-West Frontier Province of Pakistan.

2. The Employment Exchange Department (EED) is trying to help educated Afghan refugees find suitable jobs in order to prevent an Afghan brain drain from the area.

3. The Technical Training center, Peshawar, (TTCP) is a UNHCR-funded vocational training school for Afghan refugees. The TTCP also has a program for handicapped refugees.

4. Norwegian Assistance to skilled Afghans (NASA) is identical to the ASAR project but is implemented in Afghanistan.

5. Rehabilitation Program for Afghanistan is implementing the following projects in Afghanistan:

- Technical Training Center

- Training Center for Poultry Farming

- Production of concrete projects

- Construction of schools and health centers

- Karez cleaning, canal repair and construction

- Farm mechanization

- Sanitation (building of wells and latrines). 


\section{OCKENDEN VENTURE-OV}

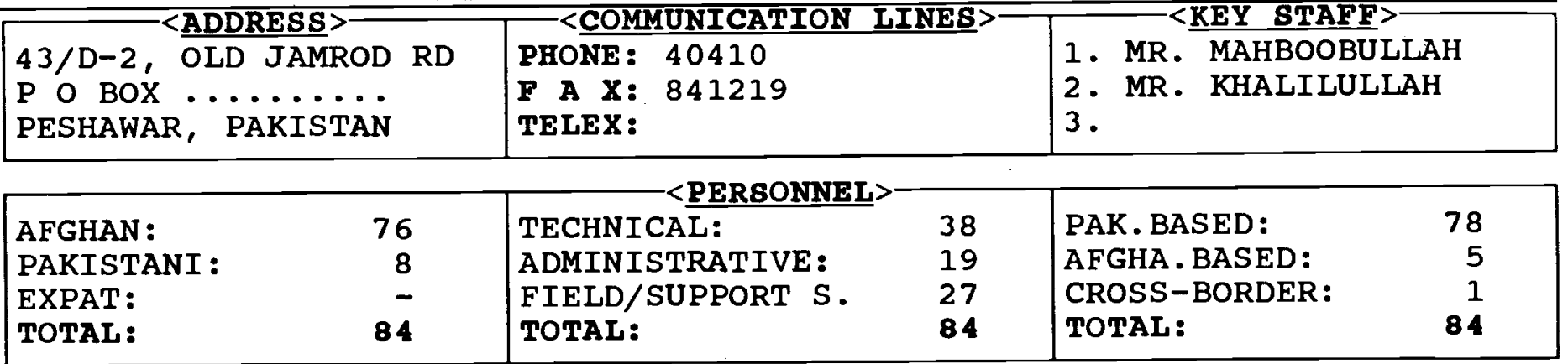

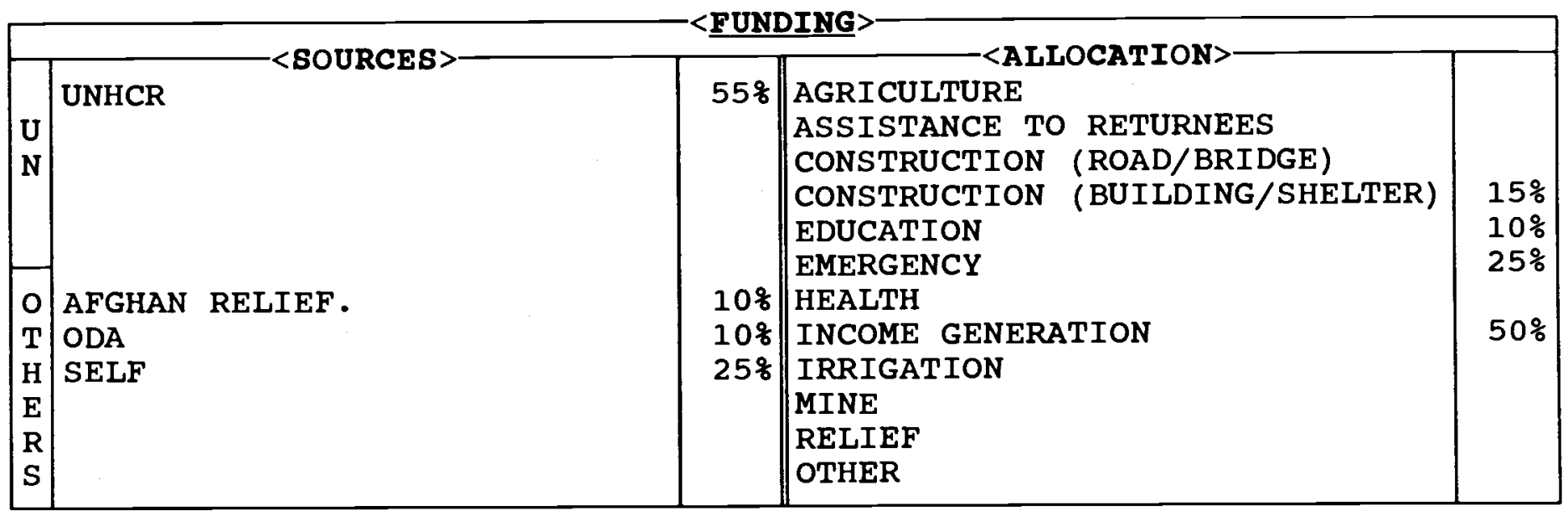

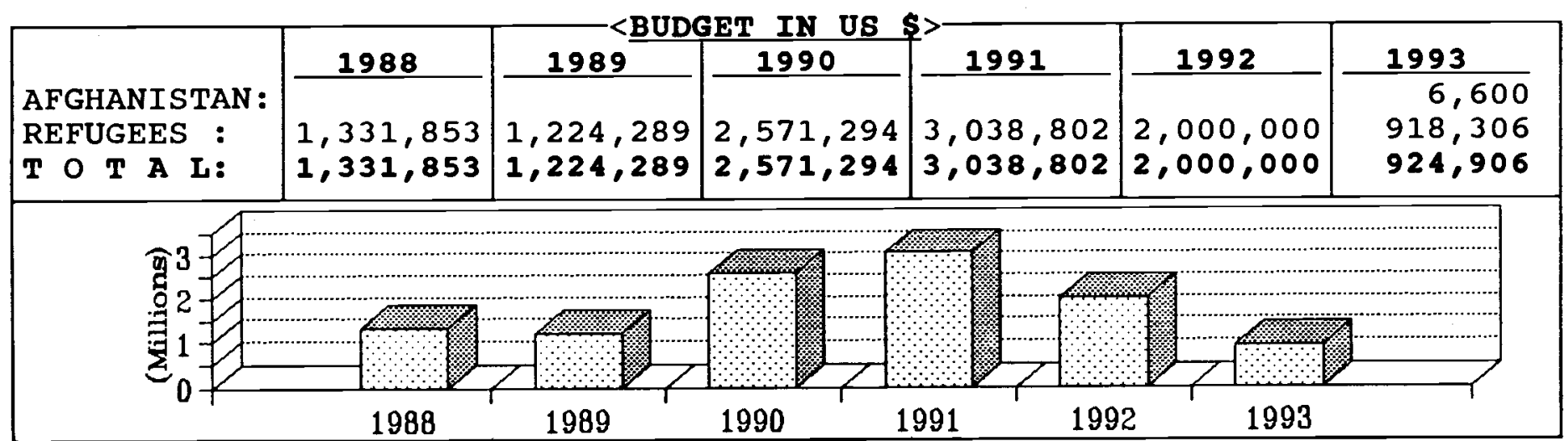

\begin{tabular}{|c|c|c|c|c|c|}
\hline PROVINCES & SECTOR & \&AGE & PROVINCES & SECTOR & $\% A G E$ \\
\hline $\begin{array}{l}\text { BADAKSHAN } \\
\text { BADGHIS } \\
\text { BAGHLAN } \\
\text { BALKH } \\
\text { BAMYAN } \\
\text { FARAH } \\
\text { FARYAB } \\
\text { GHAZNI } \\
\text { GHOR } \\
\text { HELMAND } \\
\text { HERAT } \\
\text { JAWZJAN } \\
\text { KABUL } \\
\text { KANDAHAR } \\
\text { KAPISA }\end{array}$ & Const/income gen & $\begin{array}{l}40 \% \\
\\
50 \% \\
10 \%\end{array}$ & \begin{tabular}{|l} 
KUNAR \\
KUNDUZ \\
LAGHMAN \\
LOGAR \\
NANGARHAR \\
NIMROZ \\
ORUZGAN \\
PAKTEKA \\
PAKTIA \\
PARWAN \\
SAMANGAN \\
TAKHAR \\
WARDAK \\
ZABUL
\end{tabular} & & \\
\hline
\end{tabular}


was founded in England specifically to assist refugees of war-torn Europe and has extensive operations within the UK, sudan, Thailand, India and Macau, and has interests in Tibet, Vietnam and Ethiopia.

Ockenden Pakistan was established in 1984 and is the largest of the overseas operations. ov takes interest in all aspects of refugee assistance, including their emergency emigration, health, education and welfare.

Pakistan programs for Afghan refugees are divided into four areas of assistance:

1. Handicrafts. $O V$ is the largest producer of Afghan handicrafts in Pakistan, employing over 2,700 of the poorest Afghan refugees. They produce over 450 different handicraft items, including: jewellery, embroidered items, knitted socks and gloves, leather bags, toys, art work, carpets, clothes, \& "Bedford trucks". Additionally, ov markets the products of eight other agencies. Seventy percent of the production is now exported.

2. Construction.

ockenden constructs and maintains schools, warehouses, BHUs, roads and bridges. Locations of such projects include: Swat, Dir, Malakand, Chitral and Kohat. Ockenden employs some 2,000 refugee men on construction projects. ov is also undertaking construction for various UN agencies, e.g. making wooden pallets, site preparation and tent erection for UNILOG.

3. Quilt Making. Ockenden is the largest maker of handmade quilts in Pakistan. Its main production facilities are located in Kababyan, Michini and Khazana Camps, from which other camps are also serviced. Over 1,400 Afghan refugees, of which 1,100 are women, are employed by Ockenden when the facility is operating at its full capacity of 2000 quilts daily, or 400,000 per annum.

4. Tailoring. Mostly funded by UNHCR, ockenden operates training centers in ten refugee camps, mostly in the districts of Dir and Chitral. These are tailoring courses, and handicraft apprenticeships. ockenden also operates an expanding tree nursery project producing approximately 200,000 saplings in 1992 .

5. Tent/Tarpaulin Production. Funded mostly by UNHCR, and as part of the repatriation assistance program, Ockenden is producing 600 tarpaulins a day, and 100 tents. The most needy refugees are receiving income and training in this program.

Future. Ockenden works with the most needy refugees, mostly unregistered, who will probably by the last to return to Afghanistan. It expects, funds permitting, to be working in Pakistan for some time to come. 
ORGANIZATION FOR MANAGEMENT OF AID FOR INFRASTRUCTURE DEVELOPMENT-OMAID

21-D/3，STR. 9, PHASE I PHONE: 810277

HAYATABAD, P O BOX 1005 F A X: 810277

1. MR. RAMAZAN ALI QASIM

PESHAWAR, PAKISTAN

TELEX:

2 .

3 .

\begin{tabular}{|c|c|c|c|c|c|}
\hline $\begin{array}{l}\text { AFGHAN : } \\
\text { PAKISTANI: } \\
\text { EXPAT: } \\
\text { TOTAL: }\end{array}$ & $\begin{array}{r}55 \\
0 \\
0 \\
55\end{array}$ & $\begin{array}{l}\text { TECHNICAL: } \\
\text { ADMINISTRATIVE: } \\
\text { FIELD/SUPPORT S. } \\
\text { TOTAL: }\end{array}$ & $\begin{array}{r}45 \\
3 \\
7 \\
55\end{array}$ & $\begin{array}{l}\text { PAK. BASED: } \\
\text { AFGHA. BASED: } \\
\text { CROSS-BORDER: } \\
\text { TOTAL: }\end{array}$ & \\
\hline
\end{tabular}

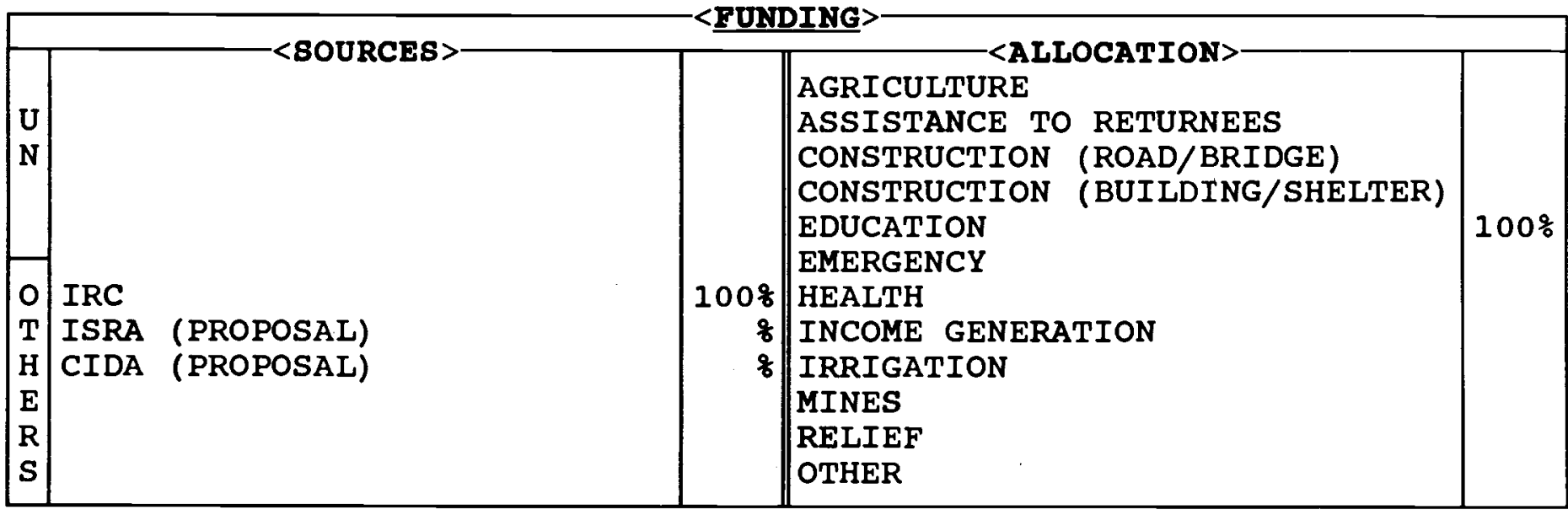

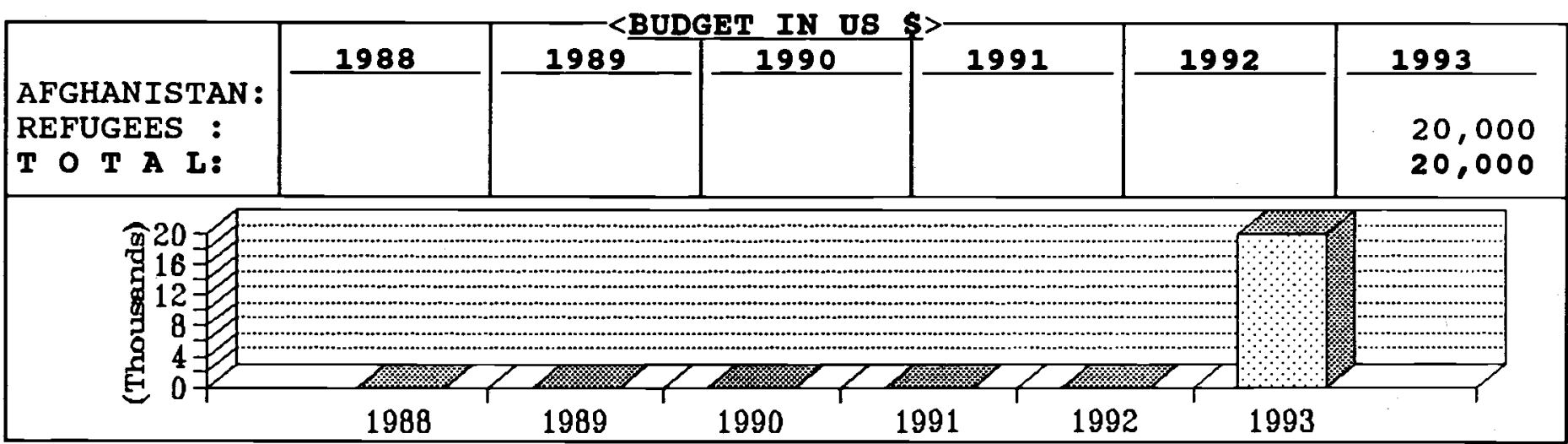

\begin{tabular}{|c|c|c|c|c|c|}
\hline PROVINCES & SECTOR & \&AGE & PROVINCES & SECTOR & $\%$ AGE \\
\hline $\begin{array}{l}\text { BADAKSHAN } \\
\text { BADGHIS } \\
\text { BAGHLAN } \\
\text { BALKH } \\
\text { BAMYAN } \\
\text { FARAH } \\
\text { FARYAB } \\
\text { GHAZNI } \\
\text { GHOR } \\
\text { HELMAND } \\
\text { HERAT } \\
\text { JAWZJAN } \\
\text { KABUL } \\
\text { KANDAHAR } \\
\text { KAPISA }\end{array}$ & & & $\begin{array}{l}\text { KUNAR } \\
\text { KUNDUZ } \\
\text { LAGHMAN } \\
\text { LOGAR } \\
\text { NANGARHAR } \\
\text { NIMROZ } \\
\text { ORUZGAN } \\
\text { PAKTEKA } \\
\text { PAKTIA } \\
\text { PARWAN } \\
\text { SAMANGAN } \\
\text { TAKHAR } \\
\text { WARDAK } \\
\text { ZABUL }\end{array}$ & 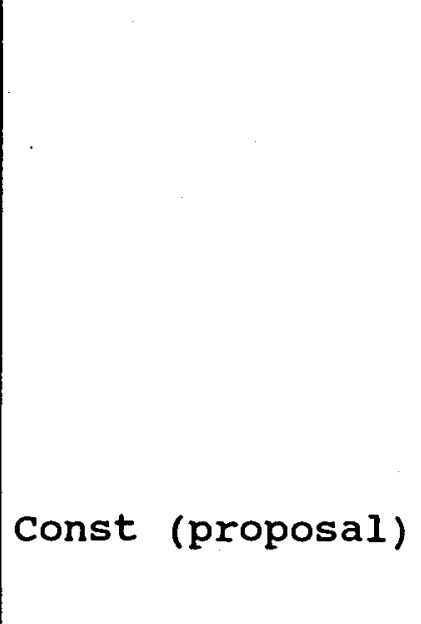 & $q$ \\
\hline
\end{tabular}


ORGANIZATION FOR MANAGEMENT OF AID

FOR INFRASTRUCTURE DEVELOPMENT

(OMAID)

is an Afghan non-governmental organization established in 1993.

OMAID is committed in providing assistance to the most needy people of Afghanistan.

Having established strong relations with the local people, shuras, influential and Jehadic figures, OMAID is confident to be able to implement any types of projects in any parts of Afghanistan successfully and to the most satisfaction of donor organizations.

Currently, OMAID runs two schools for girls; a primary and a secondary in Hayatabad, Peshawar. More than a thousand refugee students are provided education opportunities in these two schools.

Proposal for a mosque construction in Maidan/Wardak province has been submitted to the Islamic Relief Agency (ISRA) which is under review. 
ORGANIZATION FOR MINE-CLEARANCE AND AFGHAN REHABILITATION-OMAR

\begin{tabular}{|l|l|l|}
\hline 21, ST. 2, G-2, PHASE 2 & PHONE: $812919 / 812084$ & 1. MR. FAZEL KARIM FAZEL \\
HAYATABAD, P O BOX 1433 & F A X: 812085 & 2. MR. MOHAMMADULLAH \\
PESHAWAR, PAKISTAN & TELEX: & 3. MR. FARIDUDDIN \\
\hline
\end{tabular}

\begin{tabular}{|lr|lr|lr|}
\hline AFGHAN : & 330 & TECHNICAL: & 280 & PAK. BASED: & 70 \\
PAKISTANI : & 20 & ADMINISTRATIVE: & 30 & AFGHA.BASED: & 280 \\
EXPAT: & - & FIELD/SUPPORT S. & 40 & CROSS-BORDER: & - \\
TOTAL: & 350 & TOTAL: & 350 & TOTAL: & 350 \\
\hline
\end{tabular}

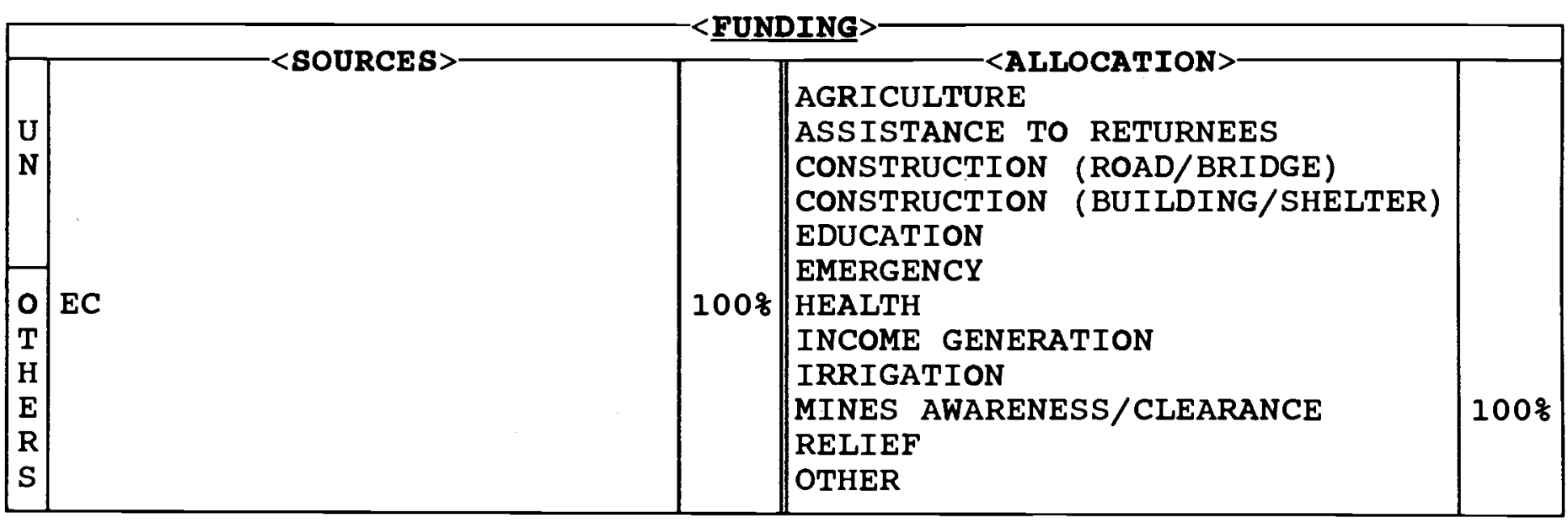

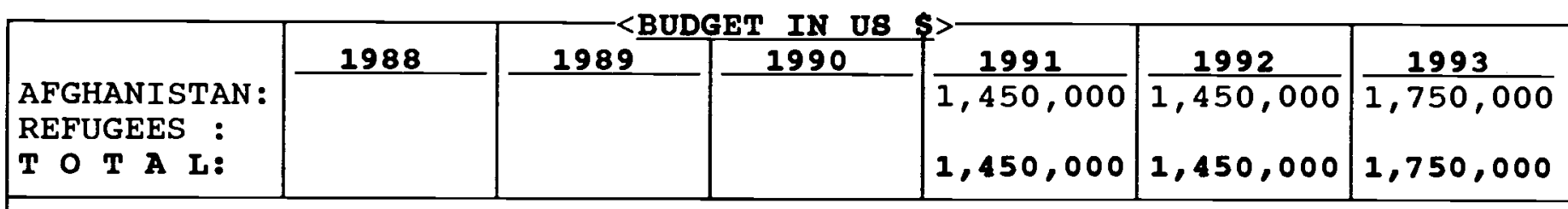

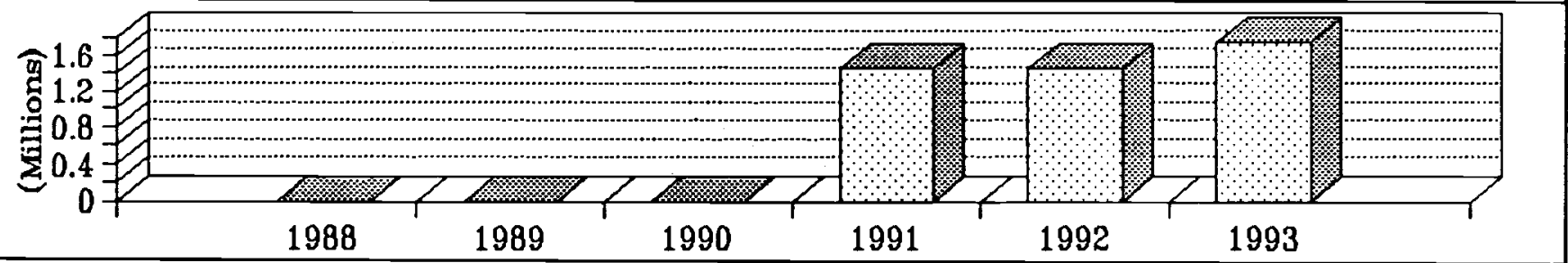

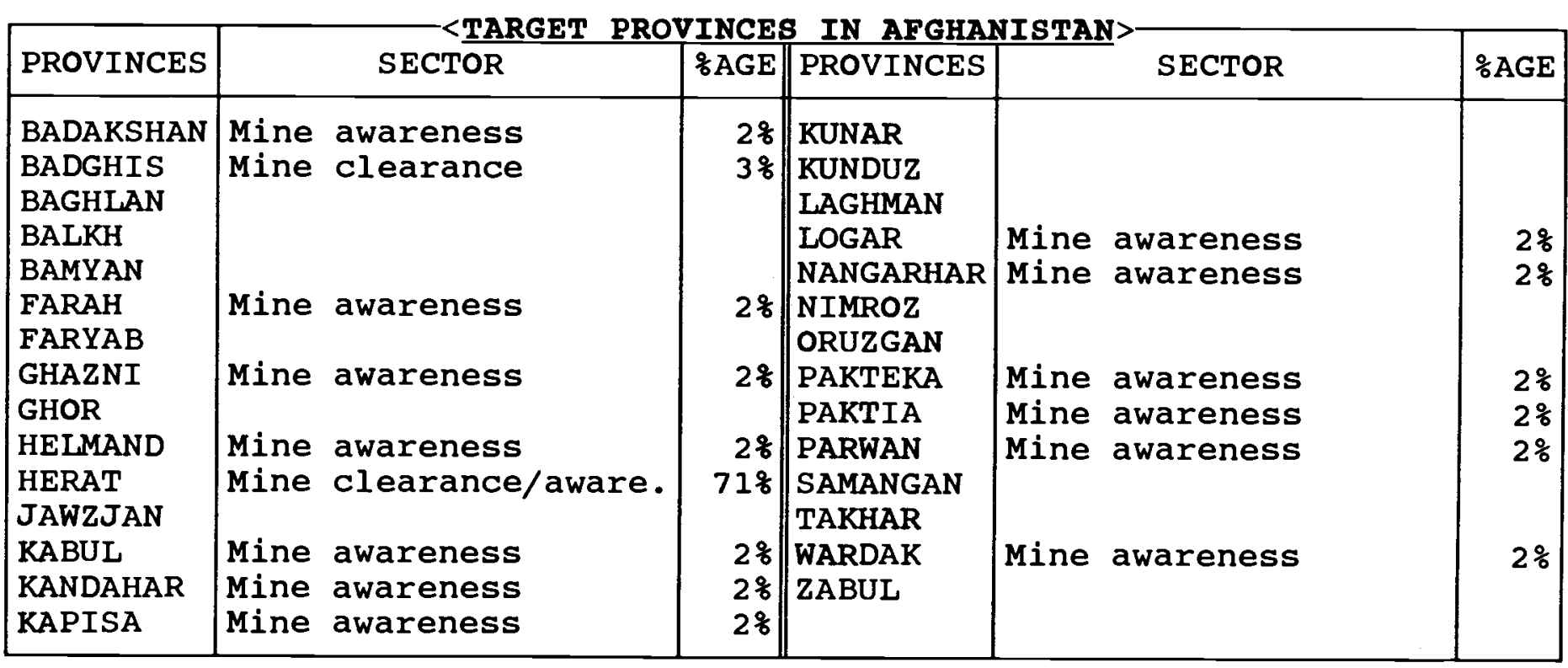


is an Afghan NGo established in late 1990. It took over the Mine Awareness Program (MAP) which was operated by IRC.

OMAR offers different types of mine awareness courses including: 6 hour basic course, 12 day potential teacher trainer's course, women's one hour basic safety course and the women's three hour basic course. Training aids and publications on mine awareness are also distributed.

By the end of 1991, OMAR completed its mine awareness training in the refugee camps in Pakistan (NWFP and Baluchistan). Now, OMAR has mine awareness courses and campaigns inside Afghanistan.

Courses and campaigns have been and are being conducted in the provinces of Farah, Herat, Kabul, Kandahar, Kapisa, Logar, Parwan and Wardak.

OMAR started mine clearance activities in Herat, western Afghanistan in August 1992 with one demining team. Now it has five teams all currently working there. 
ORPHANS REFUGEES \& AID-ORA INTERNATIONAL

\begin{tabular}{|c|c|c|}
\hline$<$ ADDRESS $>$ & $<$ COMMUNICATION LINES $>$ & $<$ KEY \\
\hline $\begin{array}{l}\text { 56D, S J AFGHANI RD U/T } \\
\text { P O BOX } 594 \\
\text { PESHAWAR, PAKISTAN }\end{array}$ & $\begin{array}{l}\text { PHONE: } 841561 \\
\text { F A X: } \\
\text { TELEX: }\end{array}$ & $\begin{array}{l}\text { 1. DR. TONI GROSSHAUSER } \\
\text { 2. } \\
\text { 3. }\end{array}$ \\
\hline
\end{tabular}

\begin{tabular}{|lr|ll|lr|}
\hline AFGHAN: & 28 & TECHNICAL: & $\ldots$ & PAK. BASED: & 15 \\
PAKISTANI: & - & ADMINISTRATIVE: & $\ldots$ & AFGHA. BASED: & 12 \\
EXPAT: & 1 & FIELD/SUPPORT S. & $\ldots$ & CROSS-BORDER: & 2 \\
TOTAL: & 29 & TOTAL: & 29 & TOTAL: & 29 \\
\hline
\end{tabular}

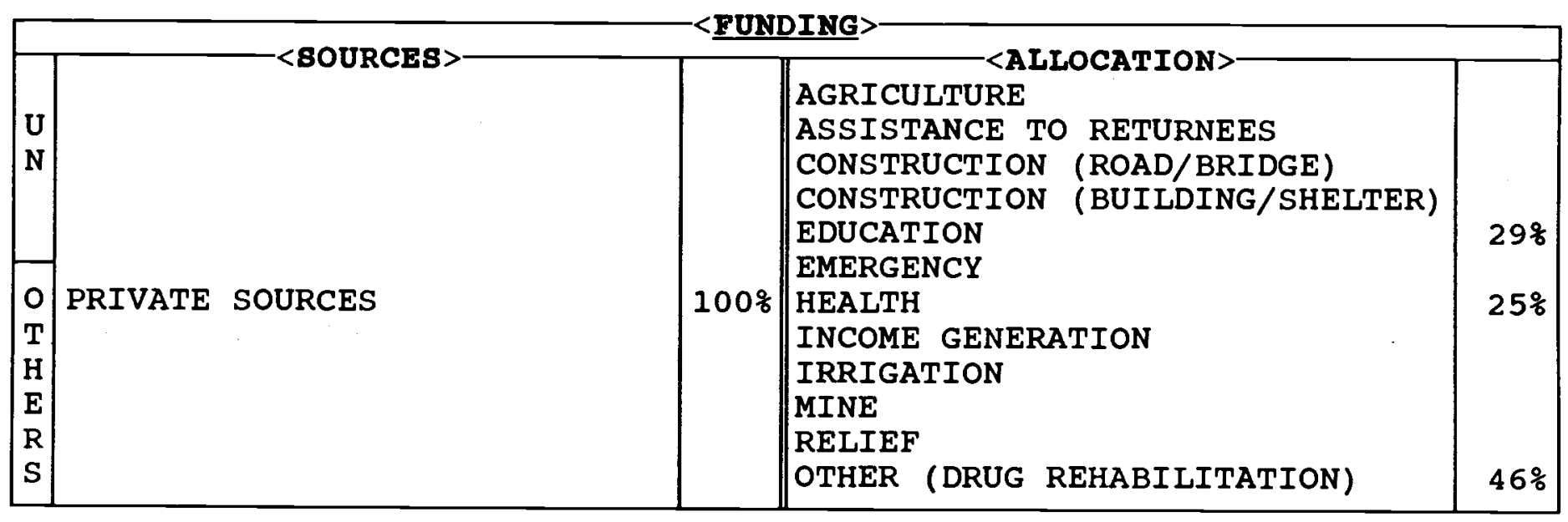

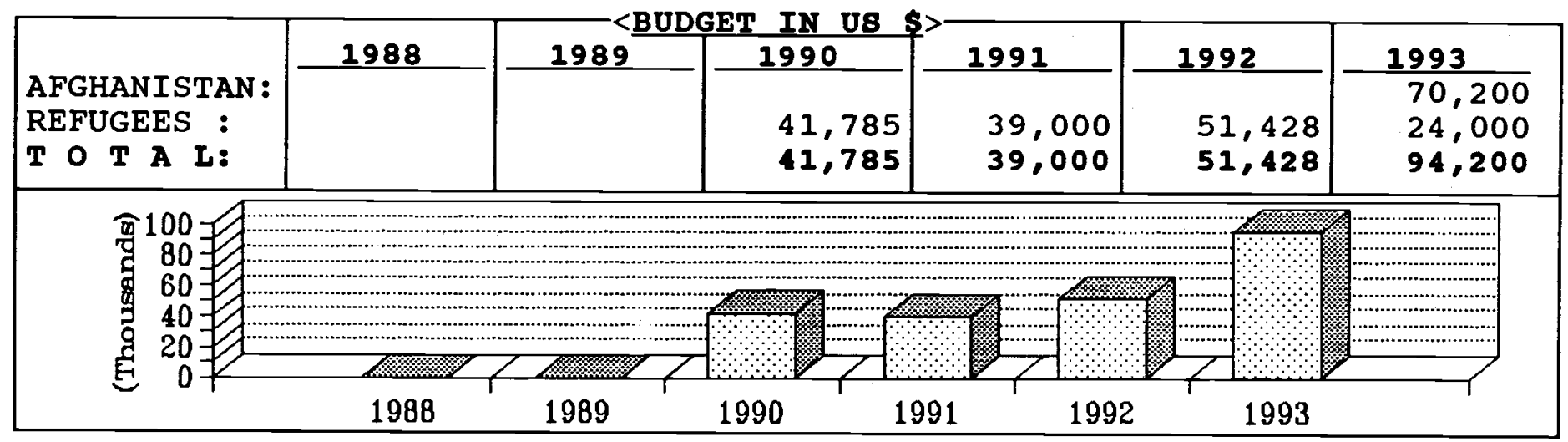

\begin{tabular}{|c|c|c|c|c|c|}
\hline PROVINCES & SECTOR & \&AGE & PROVINCES & SECTOR & \&AGE \\
\hline $\begin{array}{l}\text { BADAKSHAN } \\
\text { BADGHIS } \\
\text { BAGHLAN } \\
\text { BALKH } \\
\text { BAMYAN } \\
\text { FARAH } \\
\text { FARYAB } \\
\text { GHAZNI } \\
\text { GHOR } \\
\text { HELMAND } \\
\text { HERAT } \\
\text { JAWZJAN } \\
\text { KABUL } \\
\text { KANDAHAR } \\
\text { KAPISA }\end{array}$ & $\begin{array}{l}\text { Drug rehab/health } \\
\text { Health }\end{array}$ & 8 & \begin{tabular}{|l} 
KUNAR \\
KUNDUZ \\
LAGHMAN \\
LOGAR \\
NANGARHAR \\
NIMROZ \\
ORUZGAN \\
PAKTEKA \\
PAKTIA \\
PARWAN \\
SAMANGAN \\
TAKHAR \\
WARDAK \\
ZABUL
\end{tabular} & Health & $\%$ \\
\hline
\end{tabular}




\section{ORPHANS REFUGEES AND AID \\ (ORA-International)}

was founded in 1981. It is concerned with assistance to vulnerable groups like orphans and refugees and the delivery of aid into emergency situations. The organization's headquarters are in Germany, where it is also known as Deutscher Hilfsfonds (German Aid Fund). Projects are spread over many countries worldwide.

Assistance to Afghan refugee projects started in 1983 with financial support to a private refugee school. Later on, medical and relief goods were shipped to a medical and a relief agency.

Since 1991, ORA has focussed on Drug Rehabilitation. A treatment center currently with 13 beds has been established and community work was started early 1992. Since the center was started some 240 patients have been treated.

A medical clinic was established close to Kabul at the end of 1992 and a malaria post set up in Nangarhar province in early 1993. Expansion of the existing projects as well as possible new ones is also envisaged.

Present focusses:

1) Drug Rehabilitation: a clinic for addicts and community work.

2) Health: Basic medical services in Afghanistan.

3) Education: support of a school.

ORA has its own finances raised through donations and sponsorship schemes. 


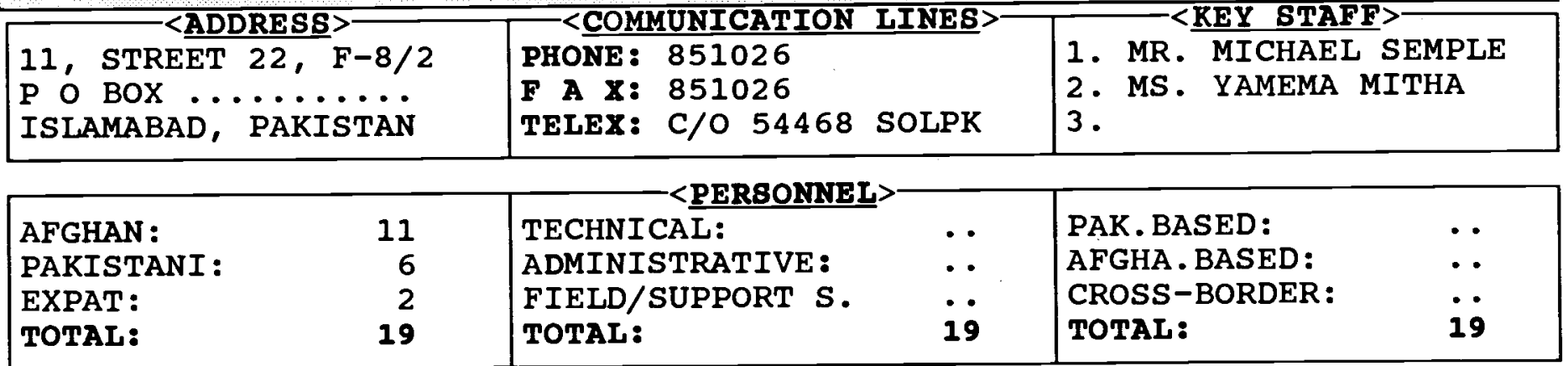

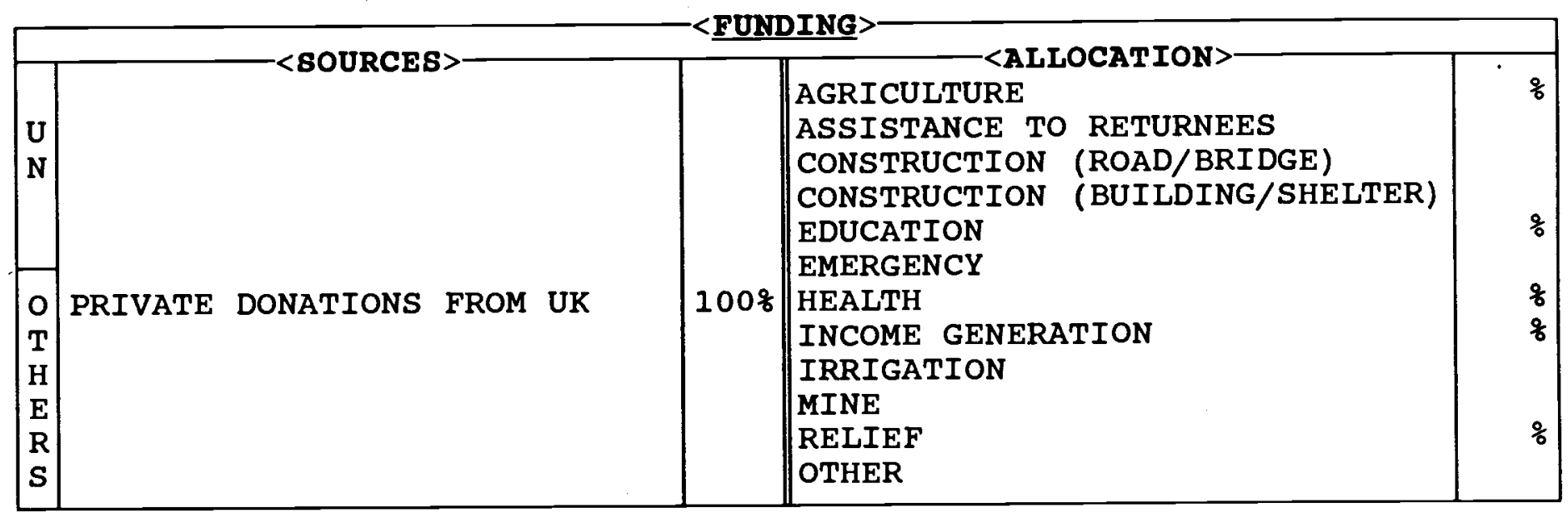

\begin{tabular}{|c|c|c|c|c|c|c|}
\hline & 1988 & 1989 & 1990 & 1991 & 1992 & 1993 \\
\hline $\begin{array}{l}\text { AFGHANISTAN : } \\
\text { REFUGEES : }\end{array}$ & 19,422 & 51,909 & $\begin{array}{l}46,759 \\
66,389\end{array}$ & $\begin{array}{l}20,000 \\
86,000\end{array}$ & $\begin{array}{l}41,200 \\
86,000\end{array}$ & $\begin{array}{l}41,200 \\
86,000\end{array}$ \\
\hline T 0 T A L: & 19,422 & 51,909 & 113,148 & 106,000 & 127,200 & 127,200 \\
\hline
\end{tabular}

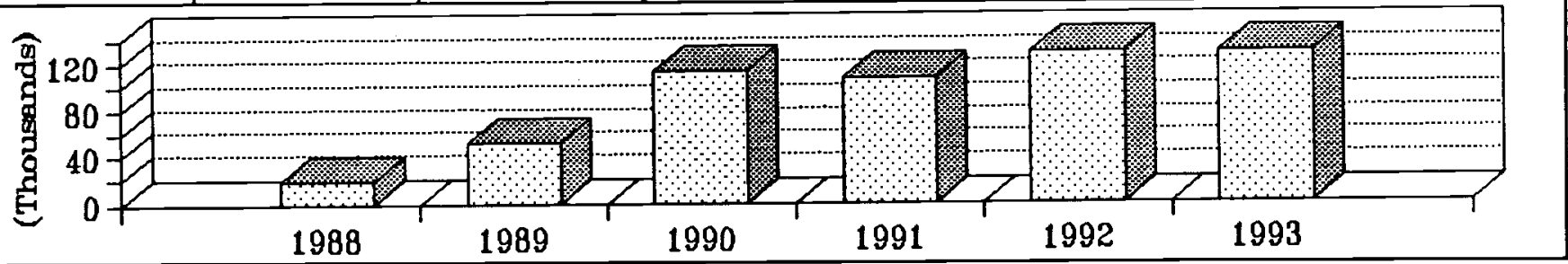

\begin{tabular}{|c|c|c|c|c|c|}
\hline PROVINCES & SECTOR & \% AGE & PROVINCES & SECTOR & \&AGE \\
\hline $\begin{array}{l}\text { BADAKSHAN } \\
\text { BADGHIS } \\
\text { BAGHLAN } \\
\text { BALKH } \\
\text { BAMYAN } \\
\text { FARAH } \\
\text { FARYAB } \\
\text { GHAZNI } \\
\text { GHOR } \\
\text { HELMAND } \\
\text { HERAT } \\
\text { JAWZJAN } \\
\text { KABUL } \\
\text { KANDAHAR } \\
\text { KAPISA }\end{array}$ & $\begin{array}{l}\text { Relief } \\
\text { Agr } \\
\text { Agr }\end{array}$ & $\begin{array}{l}8 \\
8 \\
8\end{array}$ & \begin{tabular}{|l|} 
KUNAR \\
KUNDUZ \\
LAGHMAN \\
LOGAR \\
NANGARHAR \\
NIMROZ \\
ORUZGAN \\
PAKTEKA \\
PAKTIA \\
PARWAN \\
SAMANGAN \\
TAKHAR \\
WARDAK \\
ZABUL
\end{tabular} & $\begin{array}{l}\text { Irrign/relief/voc.tra } \\
\text { Irrign }\end{array}$ & $\%$ \\
\hline
\end{tabular}


is a British humanitarian organization which has been working since 1942 for the relief of poverty and suffering. OXFAM works in partnership with poor people who are struggling to overcome their poverty and to achieve social and economic development in 74 countries. About $93 \%$ of its funds are generated from private donations and other nongovernment sources in the United Kingdom.

OXFAM primarily works through providing funds and other assistance to local non-governmental partners.

In $1988 / 89$ OXFAM made 30 grants to organizations implementing programs for Afghan refugees, engaged in reconstruction activities inside Afghanistan.

OXFAM's target areas in Afghanistan since 1991 have been Bamyan, Ghor, Kunduz, Baghlan, Balkh, Ghazni and Parwan provinces. In these provinces, OXFAM supports small scale agricultural, irrigation schemes, health education, sanitation and water supply projects.

OXFAM was one of the first NGOs to open an office in Kabul. It has now shifted its main office in Afghanistan from Kabul to Mazar-iSharif due to security reasons. 
PAR/GERMAN TECHNICAL TRAINING PROGRAM-PG/TTP

\begin{tabular}{|l|l|l|}
\hline C/O TTC, GULBAHAR 1, & PHONE: $60638 / 213865$ & 1. DR. JIRIK R. LETTE \\
G P O BOX 656 & F A X: & 2. MR. HAMISH KHAN \\
PESHAWAR, PAKISTAN & TELEX: 523852309 PEARL PK & 3.
\end{tabular}

\begin{tabular}{|lr|lr|lr|}
\hline AFGHAN : & 140 & TECHNICAL: & 225 & PAK. BASED: & 282 \\
PAKISTANI : & 140 & ADMINISTRATIVE: & 15 & AFGHA.BASED: & - \\
EXPAT: & 2 & FIELD/SUPPORT S. & 42 & CROSS-BORDER: & - \\
TOTAL: & $\mathbf{2 8 2}$ & TOTAL: & $\mathbf{2 8 2}$ & TOTAL: & $\mathbf{2 8 2}$ \\
\hline
\end{tabular}

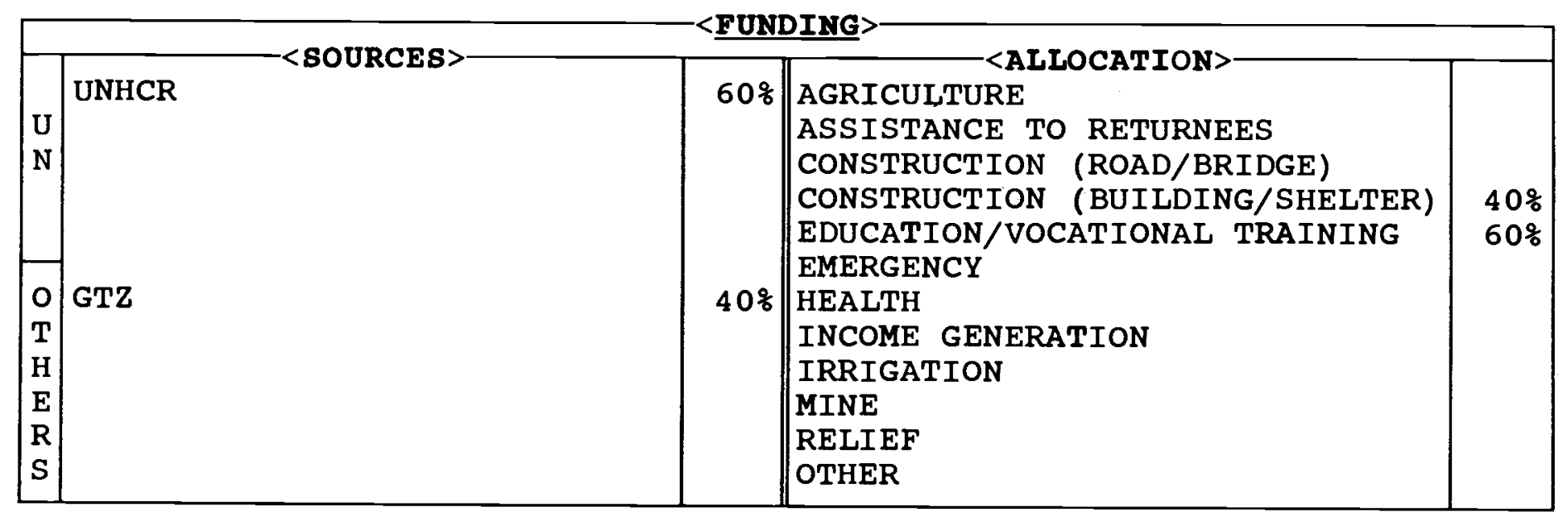

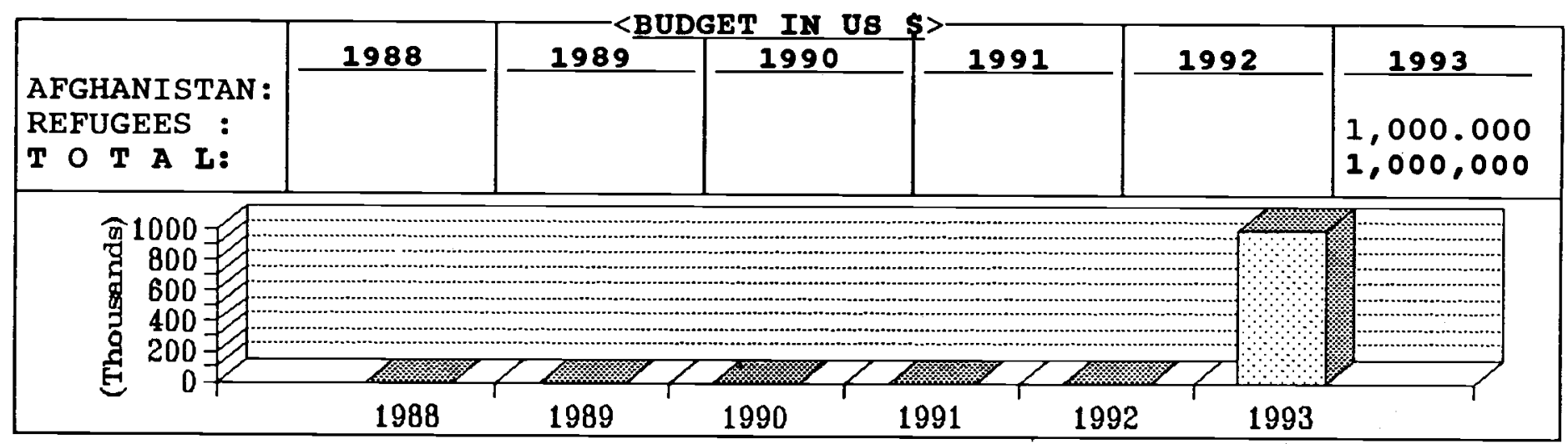

\begin{tabular}{|c|c|c|c|c|c|}
\hline PROVINCES & SECTOR & \&AGE & PROVINCES & SECTOR & $\%$ AGE \\
\hline $\begin{array}{l}\text { BADAKSHAN } \\
\text { BADGHIS } \\
\text { BAGHLAN } \\
\text { BALKH } \\
\text { BAMYAN } \\
\text { FARAH } \\
\text { FARYAB } \\
\text { GHAZNI } \\
\text { GHOR } \\
\text { HELMAND } \\
\text { HERAT } \\
\text { JAWZJAN } \\
\text { KABUL } \\
\text { KANDAHAR } \\
\text { KAPISA }\end{array}$ & & & \begin{tabular}{|l|} 
KUNAR \\
KUNDUZ \\
L_AGHMAN \\
LOGAR \\
NANGARHAR \\
NIMROZ \\
ORUZGAN \\
PAKTEKA \\
PAKTIA \\
PARWAN \\
SAMANGAN \\
TAKHAR \\
WARDAK \\
ZABUL
\end{tabular} & & \\
\hline
\end{tabular}




\section{PÄ $\bar{K}$-GERMAN TECHNICAL TRAINING PROGRAM (PG-TTP)}

is a GTZ Project which started running vocational training courses for Afghan refugees and local Pakistanis in 1982 and since then has trained thousands of people.

The number of people receiving training is at present 3,500 a year of which $50 \%$ are Afghans. Instruction is given in masonry, carpentry, tailoring, plumbing, welding, electrical installation and technical drawing.

The Program has its headquarters and the largest training center in Peshawar. It also operates 16 smaller centers in the rural areas of the North-West Frontier Province (NWFP) of Pakistan. Follow-up studies on the program show that an average of $65 \%$ of the graduates find employment in the trade for which they were trained, or start their own workshops.

TTP is a complex project with the following components:

Basic Training: A short-term course involves four months of vocational training (a total of 360 hours instruction). Trainees are illiterate men without any previous training or experience. After four months, the trainees are tested. Those who pass receive a certificate and a tool kit containing the tools of their chosen trade. The cost of short-term training is about DM 300 per trainee.

Advanced Training: After completing basic training, trainees can opt to continue for a further 360 hours. Trainees who complete a short-term and an advanced course are encouraged to find a job or start their own business. As an alternative they can continue in the practical training scheme, working in groups in supervised workshops.

Practical Training: TTP sets up practical training groups as a means of providing employment for graduates of short-term training courses. With these practical like a contractor and technicians are permanently available to supervise the work and give further instruction. Trainees can stay in these groups for four months and in exceptional cases for as long as eight months.

supervised Workshops: To assist graduates who want to start up their own business, TTP has established 28 supervised workshops in the bazaar. Graduates of short-term training courses work here under market conditions, but they are regularly visited and advised by TTP staff. The rents of the workshops are also paid by TTP.

Apprenticeship Training: In areas where there are not enough trainees to start a rural center, TTP operates an apprenticeship training program with the content and conditions equal to short-term courses. It is for four months but 8 hours a day. A contract is drawn up between an apprentice, a master and TTP.

credit: Graduates who want to start their own workshop can apply to TTP for credit (by 1992, a total of 1,433 individuals were given credit). Credit is granted in kind only (tools and materials). The amount loaned has to be repaid within a year without any interest. The application as well as the applicant's character is scrutinized by the Project management. 


\begin{tabular}{|l|l|l|}
\hline 1, ST. 2, ABSHAR COLONY & PHONE: 274179/0342-385045 & 1. MR. S A SALAM GELANI \\
KABABYAN & F A X: & 2. MR. DASTAGIR \\
PESHAWAR, PAKISTAN & TELEX: & 3.
\end{tabular}

\begin{tabular}{|lr|lr|lr|}
\hline AFGHAN : & 22 & TECHNICAL: & 10 & PAK.BASED: & 12 \\
PAKISTANI: & - & ADMINISTRATIVE: & 6 & AFGHA.BASED: & 7 \\
EXPAT: & - & FIELD/SUPPORT S. & 6 & CROSS-BORDER: & 3 \\
TOTAL: & 22 & TOTAL: & $\mathbf{2 2}$ & TOTAL: & $\mathbf{2 2}$ \\
\hline
\end{tabular}

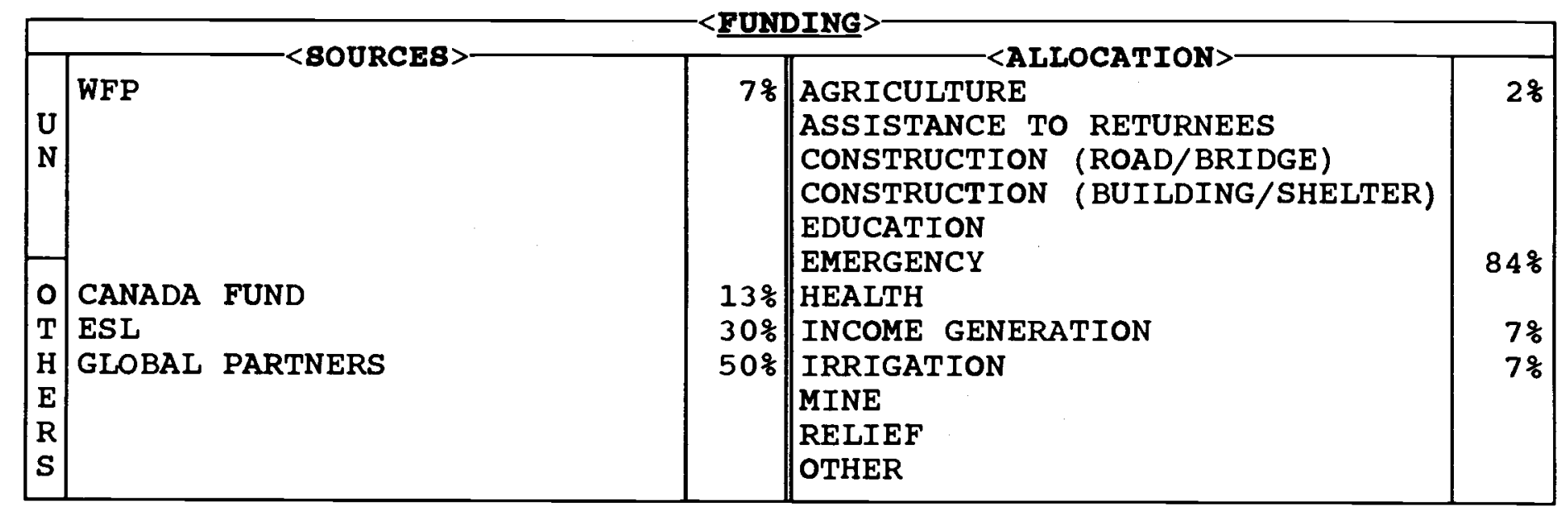

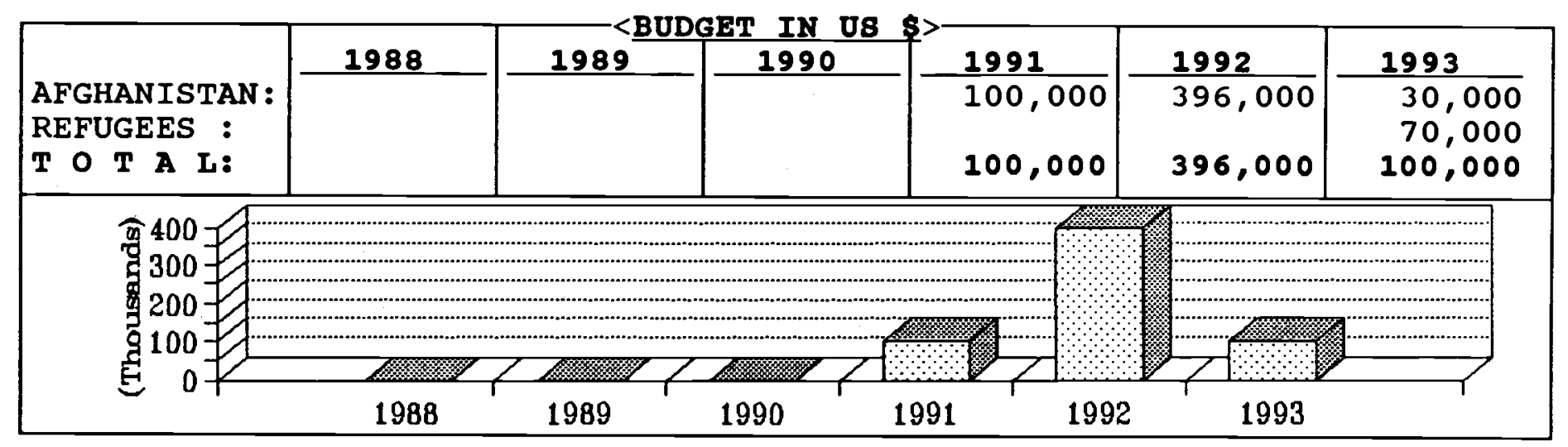

\begin{tabular}{|c|c|c|c|c|c|}
\hline PROVINCES & SECTOR & $\%$ AGE & PROVINCES & SECTOR & $\% \mathrm{AGE}$ \\
\hline $\begin{array}{l}\text { BADAKSHAN } \\
\text { BADGHIS } \\
\text { BAGHLAN } \\
\text { BALKH } \\
\text { BAMYAN } \\
\text { FARAH } \\
\text { FARYAB } \\
\text { GHAZNI } \\
\text { GHOR } \\
\text { HELMAND } \\
\text { HERAT } \\
\text { JAWZJAN } \\
\text { KABUL } \\
\text { KANDAHAR } \\
\text { KAPISA }\end{array}$ & Emerg & 列 & \begin{tabular}{|l} 
KUNAR \\
KUNDUZ \\
LAGHMAN \\
LOGAR \\
NANGARHAR \\
NIMROZ \\
ORUZGAN \\
PAKTEKA \\
PAKTIA \\
PARWAN \\
SAMANGAN \\
TAKHAR \\
WARDAK \\
ZABUL
\end{tabular} & $\begin{array}{l}\text { Emerg/income gen } \\
\text { Irrign }\end{array}$ & $\begin{array}{l}30 \% \\
20 \%\end{array}$ \\
\hline
\end{tabular}


PAKTERA RECONSTRUCTION SERVICES (PRS)

is a non-political, non-profit and non-governmental organization comprised of Afghan professionals who have experience and expertise in the planning and implementation of relief and development projects. The ultimate goal of this organization is to take active part in the reconstruction of Afghanistan.

In addition to implementing reconstruction projects, PRS is primarily assisting with relief, women projects, agriculture, education and medical aid to Afghans.

One of PRS's completed projects is the road repair and reconstruction from Warsak Lakai through Khar Khotai and up to Gomal Bandar (70 $\mathrm{km})$. It is now being used by the majority of people travelling to Ghazni, Moqor, etc.

PRS has established and supported three schools in sharan and one hospital in Yahya Khel. The schools have an overall student population of 270 .

PRS distributed 232.5 tons of flour, rice, ghee, tea and sugar to the most needy people in Kabul in June 1992. It is planned to distribute relief assistance to different provinces of Afghanistan.

The rehabilitation of 60 karezes in Pakteka province is in the process of being started. In the same area, 50 shallow wells for drinking water will be dug and hand-pumps will be fixed.

Pakteka Reconstruction Services is planning to support the employees of two hospitals in Jalalabad. It would be a food for work program. cleaning of $13.5 \mathrm{~km}$ canal in Surkhrod is also planned.

In 1993, because of the security problems in Kabul thousands of people came to Pakistan. PRS assisted some of the very needy families (a total of 500 families) amongst these new arrivals by providing different food and nonfood relief commodities such as wheat flour, ghee, tea, sugar, powder milk, quilts, diesel heaters, plastic sheets and mat (satranji). 
PAMIR DEVELOPMENT AUTHORITY-PDA

<ADDRESS $>-$ COMMUNICATION LINES $>$

105, 2ND FLOOR, GULHAJI P O BOX ..........

PESHAWAR, PAKISTAN
PHONE : 841480

$F$ A X:

TELEX:
1. MR. MUNAWAR KHAN

2 .

3.

\begin{tabular}{ll|ll}
\hline AFGHAN : & $\mathbf{8}$ & TECHNICAL: & 3 \\
PAKISTANI : & - & ADMINISTRATIVE : & 3 \\
EXPAT: & - & FIELD/SUPPORT S. & 2 \\
TOTAL: & $\mathbf{8}$ & TOTAL: & $\mathbf{8}$ \\
\hline
\end{tabular}

PAK. BASED:

AFGHA. BASED:

CROSS-BORDER :

TOTAL:

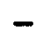

8

$-$

8

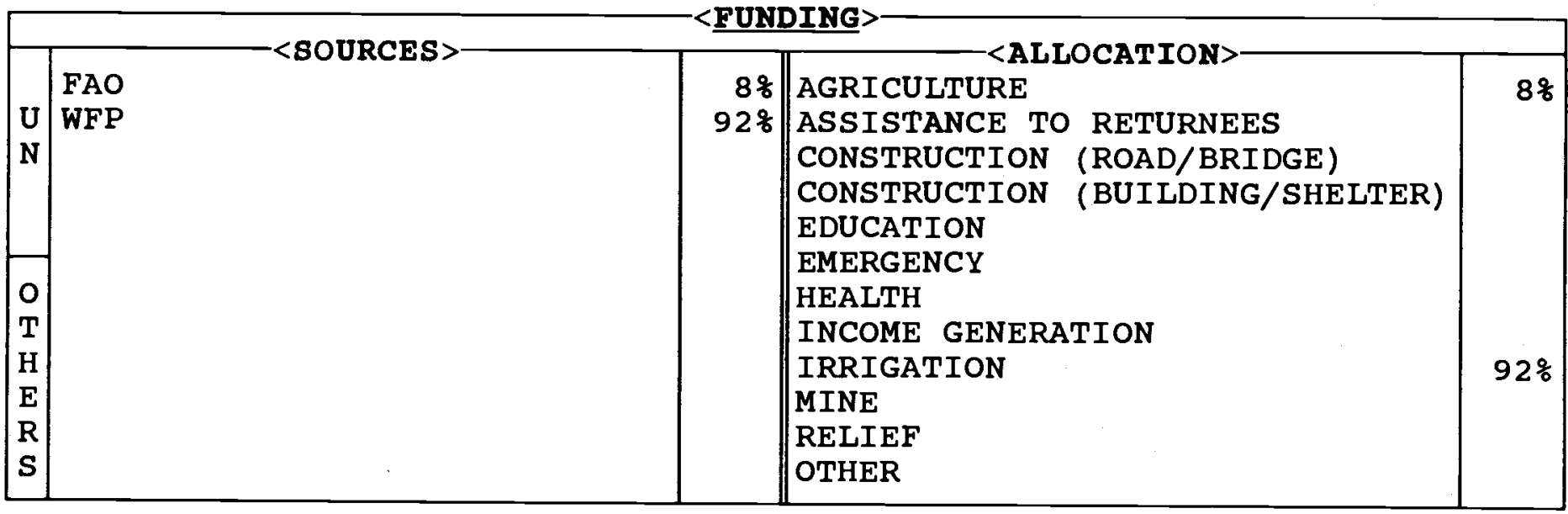

\begin{tabular}{|c|c|c|c|c|c|c|}
\hline & 1988 & 1989 & 1990 & 1991 & 1992 & 1993 \\
\hline $\begin{array}{l}\text { AFGHANISTAN : } \\
\text { REFUGEES : } \\
\text { T O T A L: }\end{array}$ & & & & $\begin{array}{l}6,000 \\
6,000\end{array}$ & $\begin{array}{l}29,320 \\
29,320\end{array}$ & $\begin{array}{l}42,840 \\
42,840\end{array}$ \\
\hline
\end{tabular}

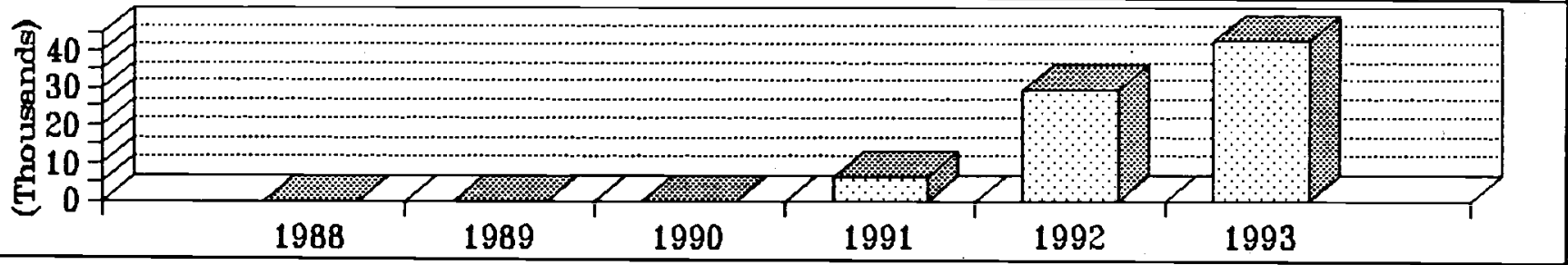

<TARGET PROVINCES IN AFGHANISTAN>

\begin{tabular}{|c|c|c|c|c|c|}
\hline PROVINCES & SECTOR & \%AGE & PROVINCES & SECTOR & $\because A G E$ \\
\hline $\begin{array}{l}\text { BADAKSHAN } \\
\text { BADGHIS } \\
\text { BAGHLAN } \\
\text { BALKH } \\
\text { BAMYAN } \\
\text { FARAH } \\
\text { FARYAB } \\
\text { GHAZNI } \\
\text { GHOR } \\
\text { HELMAND } \\
\text { HERAT } \\
\text { JAWZJAN } \\
\text { KABUL } \\
\text { KANDAHAR } \\
\text { KAPISA }\end{array}$ & 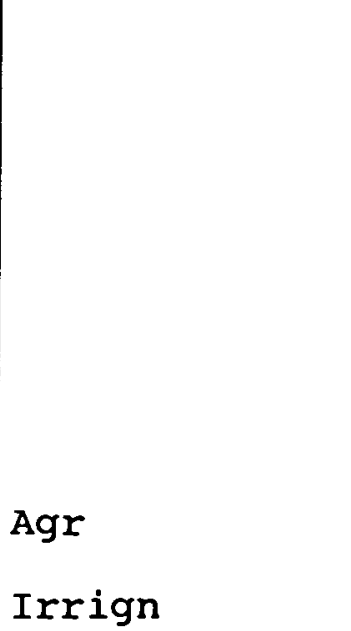 & $\mid$ & \begin{tabular}{|l} 
KUNAR \\
KUNDUZ \\
LAGHMAN \\
LOGAR \\
NANGARHAR \\
NIMROZ \\
ORUZGAN \\
PAKTEKA \\
PAKTIA \\
PARWAN \\
SAMANGAN \\
TAKHAR \\
WARDAK \\
ZABUL
\end{tabular} & $\begin{array}{l}\text { Irrign } \\
\text { Agr }\end{array}$ & $6 \%$ \\
\hline
\end{tabular}


is an Afghan non-profit, nongovernmental non-partisan and nonpolitical voluntary humanitarian organization which was established in 1991. Its sole aim is to contribute in rehabilitation and reconstruction of ravaged Afghanistan. It works towards assisting Afghans to help themselves and averting the effects of the damages inflicted on the Afghan nation as a whole. PDA's headquarters for the time being are located in Peshawar with sub-offices in Jalalabad and Kabul which are staffed with experienced staff.

The organization intends to work in the regions where least relief assistance has been received particularly by minorities and under privileged.

PDA's projects have been funded by United Nations agencies and IIRO, etc. PDA has close relations with local authorities, shuras and community influential as well as other organizations in its project areas.

PDA has been registered with UNOCHA and the Ministry of Planning of Islamic state of Afghanistan. It is a member of ANCB and has applied for ACBAR membership. 
PAMIR RECONSTRUCTION BUREAU-PRB

\begin{tabular}{|c|c|c|c|c|}
\hline $\begin{array}{l}\text { A/E } 83, \frac{\text { ADDRESS }}{\text { ABDARA RD, } U / T} \\
\text { P O BOX. . . . . . . . } \\
\text { PESHAWAR, PAKISTAN }\end{array}$ & $\begin{array}{l}\text { CCOMMUNICATION } \\
\text { PHONE: } 41641 \\
\text { F A X: } 41741 \\
\text { TELEX: }\end{array}$ & $\overline{\text { [NES }>}$ & $\begin{array}{ll}\text { 1. ENG. MOHD } \\
\text { 2. MR. QASIM } \\
\text { 3. ENG. MANAN }\end{array}$ & \\
\hline $\begin{array}{l}\text { AFGHAN : } \\
\text { PAKISTANI : } \\
\text { EXPAT: } \\
\text { TOTAL: }\end{array}$ & $\begin{array}{l}\text { TECHNICAL: } \\
\text { ADMINISTRATIVE: } \\
\text { FIELD/SUPPORT S. } \\
\text { TOTAL: }\end{array}$ & $\begin{array}{r}133 \\
18 \\
100 \\
251\end{array}$ & $\begin{array}{l}\text { PAK. BASED: } \\
\text { AFGHA. BASED: } \\
\text { CROSS-BORDER: } \\
\text { TOTAL: }\end{array}$ & $\begin{array}{r}26 \\
- \\
225 \\
251\end{array}$ \\
\hline
\end{tabular}

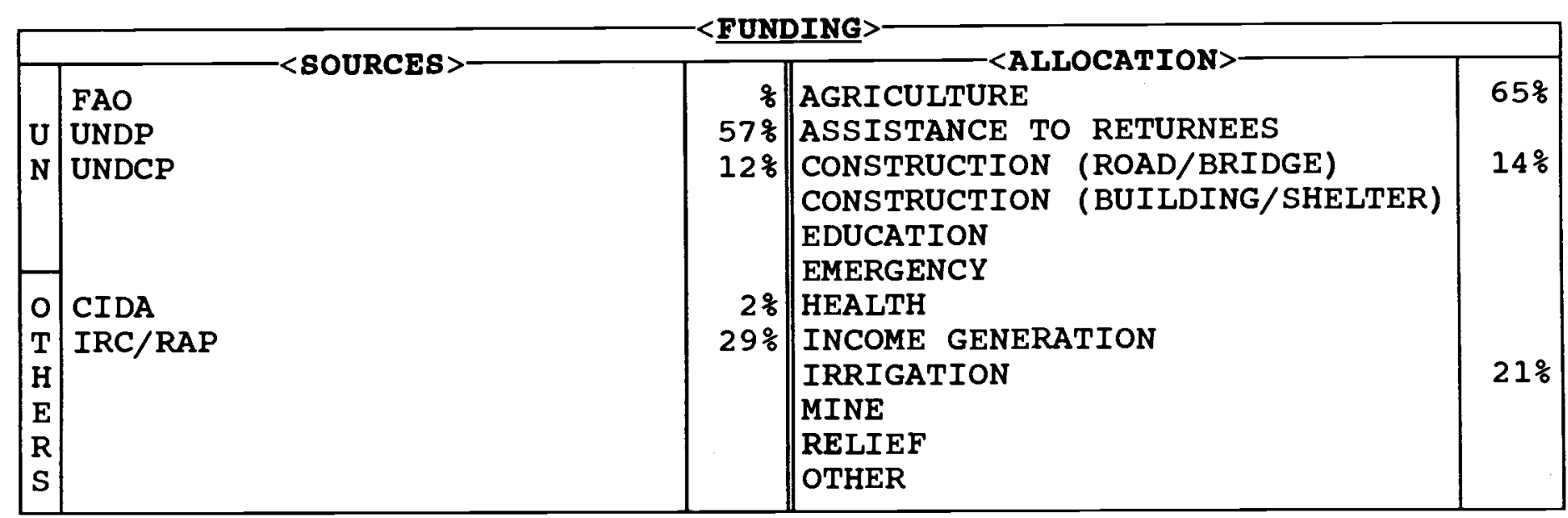

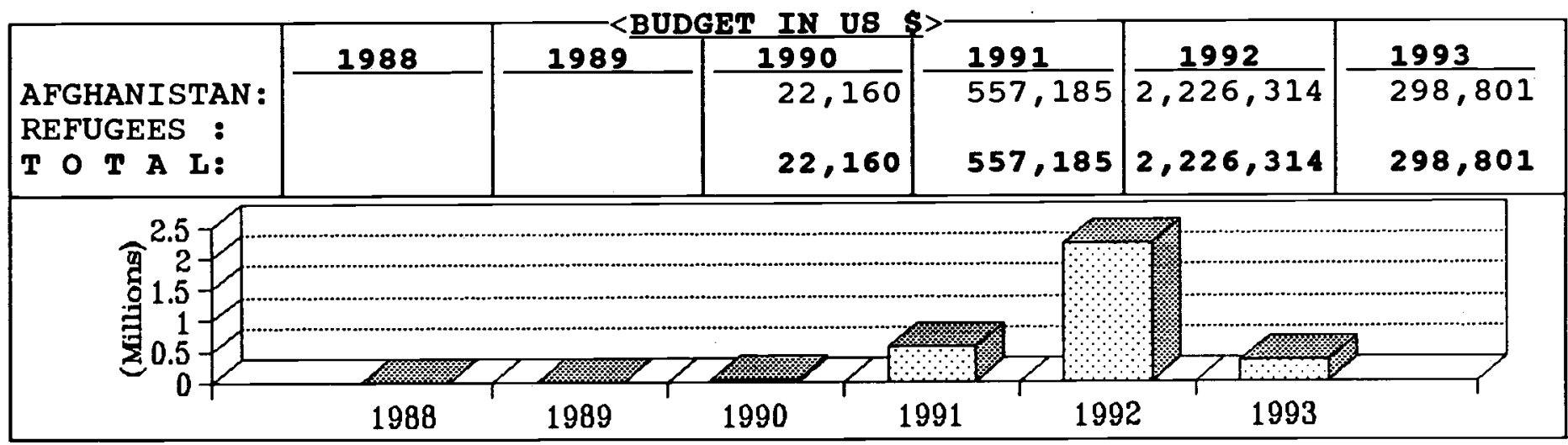

\begin{tabular}{|c|c|c|c|c|c|}
\hline PROVINCES & SECTOR & \%AGE & PROVINCES & SECTOR & $\%$ AGE \\
\hline $\begin{array}{l}\text { BADAKSHAN } \\
\text { BADGHIS } \\
\text { BAGHLAN } \\
\text { BALKH } \\
\text { BAMYAN } \\
\text { FARAH } \\
\text { FARYAB } \\
\text { GHAZNI } \\
\text { GHOR } \\
\text { HELMAND } \\
\text { HERAT } \\
\text { JAWZJAN } \\
\text { KABUL } \\
\text { KANDAHAR } \\
\text { KAPISA }\end{array}$ & $\begin{array}{l}\text { Const/irrign } \\
\text { Agr (vet) } \\
\text { Const./irrign } \\
\text { Agr/const/irrign } \\
\text { Const } \\
\text { Emerg } \\
\text { Agr/const/irrign }\end{array}$ & $\begin{array}{l}4 \% \\
4 \frac{6}{6} \\
5 \%\end{array}$ & \begin{tabular}{|l|} 
KUNAR \\
KUNDUZ \\
LAGHMAN \\
LOGAR \\
NANGARHAR \\
NIMROZ \\
ORUZGAN \\
PAKTEKA \\
PAKTIA \\
PARWAN \\
SAMANGAN \\
TAKHAR \\
WARDAK \\
ZABUL
\end{tabular} & $\begin{array}{l}\text { Agr (vet) } \\
\text { Agr/const } \\
\text { Agr } \\
\text { Agr (vet) } \\
\text { Agr (vet)/Const } \\
\text { Agr (vet)/const/irrig } \\
\text { Const/Samangan } \\
\text { Agr (vet)/const }\end{array}$ & $\begin{array}{r}2 \% \\
13 \% \\
11 \% \\
9 \% \\
11 \%\end{array}$ \\
\hline
\end{tabular}


PAMIR RECONSTRUCTION BUREAU (PRB)

is a non-governmental, non-political and non-profitable organization established in 1990. Its sole aim is to take part in the rehabilitation and reconstruction of rural areas of Afghanistan. The rural programs inside Afghanistan focus on reconstruction of roads, schools, clinics, hospitals and rehabilitation of irrigation systems e.g. construction of retaining walls to control flood and protect farming lands.

PRB is also active in livestock and veterinary services like poultry and animal husbandry. A total of 25 veterinary projects have been running successfully in the provinces of Takhar, Baghlan, Kunduz, Parwan, Paktia and Pakteka.

In agriculture, PRB has implemented different projects such as seeds and fertilizer distribution, nursery management, plant protection training, research on crops varieties. PRB plans to establish seed trials, agriculture machinery programs and training programs for agricultural workers in the provinces of Balkh, Samangan and Parwan.

In construction PRB has reconstructed bridges, roads, primary and secondary schools, basic health units, community health centers, mosques, and retaining wall.

PRB is currently working in 13 provinces: Kabul, Parwan, Kapisa, Badakhshan, Takhar, Baghlan, Samangan, Balkh, Jawzjan, Paktia, Nangarhar, Logar and Paktia. In the near future, PRB intends to expand rehabilitation and reconstruction activities in the south- western provinces of Afghanistan.

For the time being PRB's headquarters are located in Peshawar with branch offices in Kabul, Charikar, Mazar, Kunduz, Taloqan and Faizabad staffed with qualified personnel in the three sectors of agricultural, construction and veterinary services.
PRB is interested in promoting coordination and cooperation with other NGOs and charitable $\begin{array}{llllllllllllll} & r & g & a & n & i & z & a & t & i & 0 & n & s & \end{array}$ 
PROGRAM FOR THE ATARENESS AND ADVANCEMENT OF AFGHAN WOMEN-PAAAW

<ADDRESS>

7 B/ 1, RAILWAY HOUSING SOCIETY, P O BOX 56 QUETTA, PAKISTAN
<COMMUNICATION LINES>

PHONE: $441958 / 442518$

F A X:

TELEX:
1. MS. MINA EHSAN

2. MS. SAMIA KAYOUMI

3. MS. RAZIA NASSERZAI

\begin{tabular}{|lr|lr|lr|}
\hline AFGHAN : & 24 & TECHNICAL: & 14 & PAK. BASED: & 2 \\
PAKISTANI : & 2 & ADMINISTRATIVE: & 4 & AFGHA.BASED: & - \\
EXPAT: & - & FIELD/SUPPORT S. & 8 & CROSS-BORDER: & 24 \\
TOTAL: & 26 & TOTAL: & 26 & TOTAL: & 26 \\
\hline
\end{tabular}

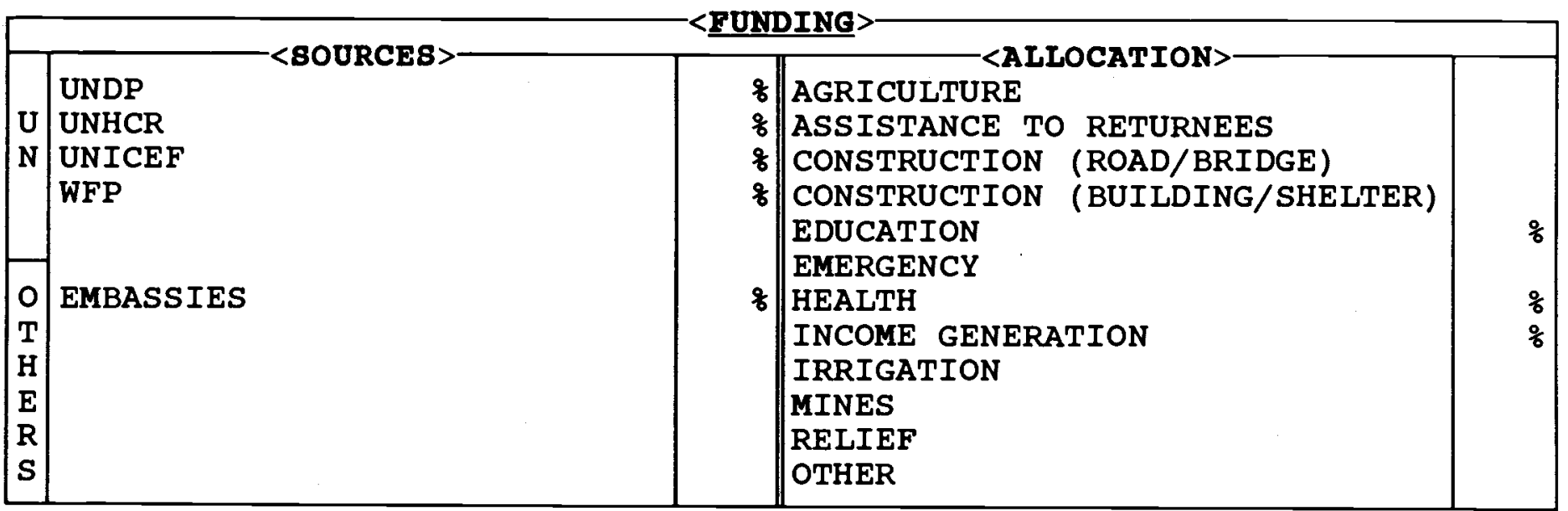

\begin{tabular}{|l|l|l|l|l|l|l|}
\hline & 1988 & 1989 & 1990 & 1991 & 1992 & 1993 \\
AFGHANISTAN : & & & & & & \\
REFUGEES : \\
T T A L:
\end{tabular}

\begin{tabular}{|c|c|c|c|c|c|}
\hline PROVINCES & SECTOR & \&AGE & PROVINCES & SECTOR & $\% A G E$ \\
\hline $\begin{array}{l}\text { BADAKSHAN } \\
\text { BADGHIS } \\
\text { BAGHIAN } \\
\text { BALKH } \\
\text { BAMYAN } \\
\text { FARAH } \\
\text { FARYAB } \\
\text { GHAZNI } \\
\text { GHOR } \\
\text { HELMAND } \\
\text { HERAT } \\
\text { JAWZJAN } \\
\text { KABUL } \\
\text { KANDAHAR } \\
\text { KAPISA }\end{array}$ & 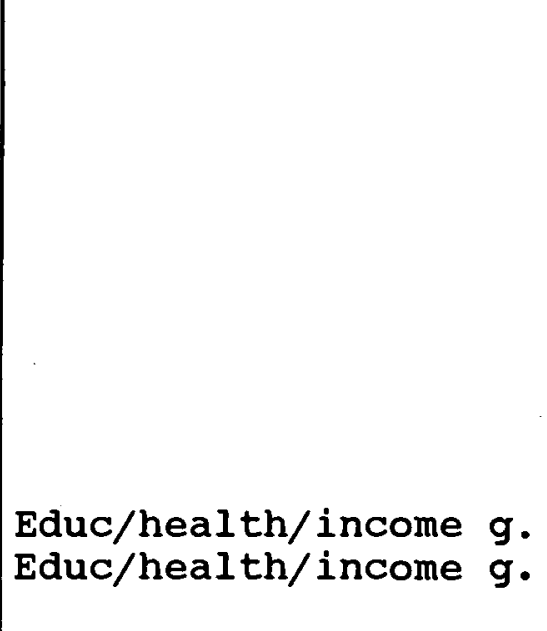 & $\begin{array}{l}q \\
8 \\
8\end{array}$ & \begin{tabular}{||l} 
KUNAR \\
KUNDUZ \\
LAGHMAN \\
LOGAR \\
NANGARHAR \\
NIMROZ \\
ORUZGAN \\
PAKTEKA \\
PAKTIA \\
PARWAN \\
SAMANGAN \\
TAKHAR \\
WARDAK \\
ZABUL
\end{tabular} & & \\
\hline
\end{tabular}


is a non-profit, non-political humanitarian agency with its headquarters temporarily located in Quetta, Pakistan. The HQs shall move to Afghanistan, at the first possible opportunity. Sub-offices are to be established whenever there is need in the future.

The short term goals of the organization are:

1. To help Afghan women in Refugee camps to arrange for a selfsustained economy through the development of their skills.

2. To provide some basic life saving services for the Afghan women and their children.

In the long term, PAAAW aims:

1. To help the Afghan women in the process of repatriation so that they can adapt themselves to the new conditions of rehabilitation comfortably.

2. To provide essential services such as medical care, general literacy and other courses to enhance the power of employment for Afghan women.

PAAAW intends to provide emergency relief and services for Afghan women. in Refugee camps and implements, supervises and runs projects for the reconstruction of those sectors of the socio-economic structures which directly affect Afghan women. It will work to prepare Afghan women, through continuous efforts at all levels to take active part in the rehabilitation of social, economic and (if need be) political structure of Afghan society.

The agencies highest body of decision making is its steering Committee. An Executive Committee, headed by the director, is responsible for the discharge of its responsibilities through the following sections:
a) Health Care
b) Education
c) Income Generation
d) Administration 
RADDA BARNEN (SAVE THE CHILDREN/STEDEN)-RBB

\begin{tabular}{|c|c|c|c|c|c|}
\hline$=<A D$ & & -<COMMUNICATION & NE8 & $-<$ REY $\mathbf{8 T}$ & \\
\hline $\begin{array}{l}228, \text { GULHA } \\
U \text { P O BOX } \\
\text { PESHAWAR, }\end{array}$ & & $\begin{array}{l}\text { PHONE: } 44784 / 840 \\
\text { F A X: } 840349 \\
\text { TELEX: }\end{array}$ & & $\begin{array}{l}\text { 1. MR. JORGEI } \\
\text { 2. MR. NAZIRL } \\
\text { 3. }\end{array}$ & SSON \\
\hline $\begin{array}{l}\text { AFGHAN : } \\
\text { PAKISTANI : } \\
\text { EXPAT: } \\
\text { TOTAL: }\end{array}$ & $\begin{array}{r}15 \\
28 \\
7 \\
50\end{array}$ & $\begin{array}{l}\text { TECHNICAL: } \\
\text { ADMINISTRATIVE: } \\
\text { FIELD/SUPPORT S. } \\
\text { TOTAL: }\end{array}$ & $\begin{array}{r}23 \\
8 \\
19 \\
50\end{array}$ & $\begin{array}{l}\text { PAK. BASED: } \\
\text { AFGHA. BASED: } \\
\text { CROSS-BORDER } \\
\text { TOTAL: }\end{array}$ & $\begin{array}{r}42 \\
1 \\
7 \\
50\end{array}$ \\
\hline
\end{tabular}

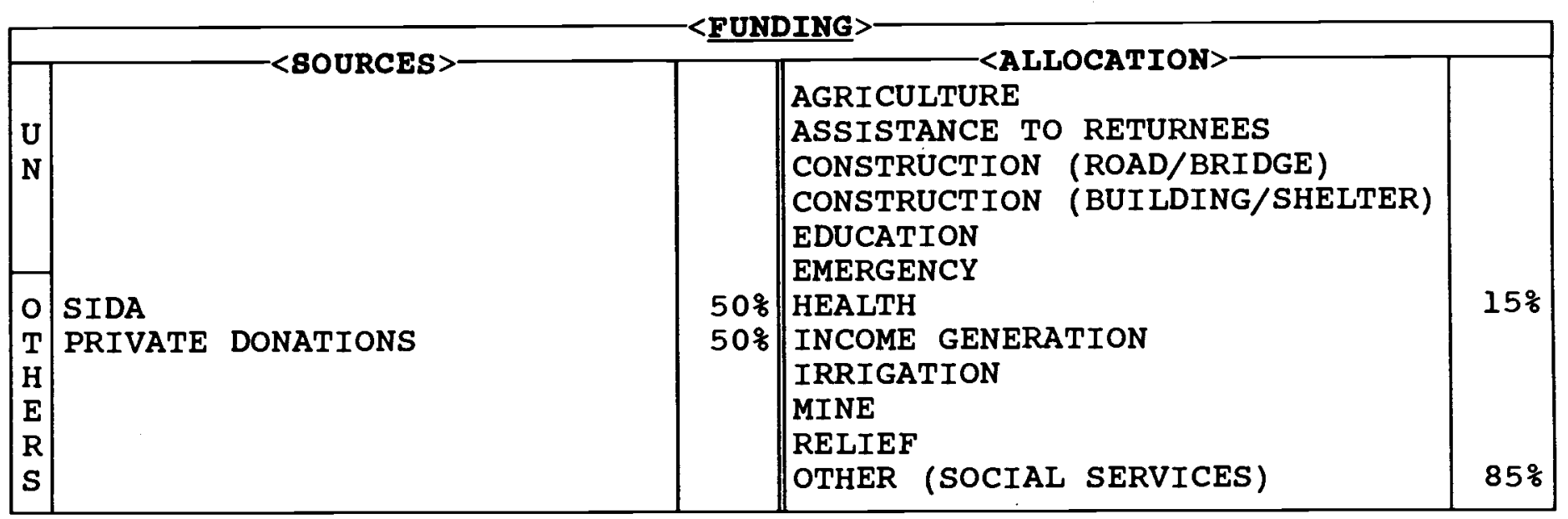

\begin{tabular}{|c|c|c|c|c|c|c|}
\hline & 1988 & 1989 & 1990 & 1991 & 1992 & 1993 \\
\hline $\begin{array}{l}\text { AFGHANISTAN: } \\
\text { REFUGEES : } \\
\text { T O T A L: }\end{array}$ & & & $\begin{array}{l}323,000 \\
323,000\end{array}$ & $\begin{array}{l}456,000 \\
456,000\end{array}$ & $\begin{array}{r}90,000 \\
226,000 \\
316,000\end{array}$ & $\begin{array}{l}118,000 \\
284,000 \\
402,000\end{array}$ \\
\hline
\end{tabular}

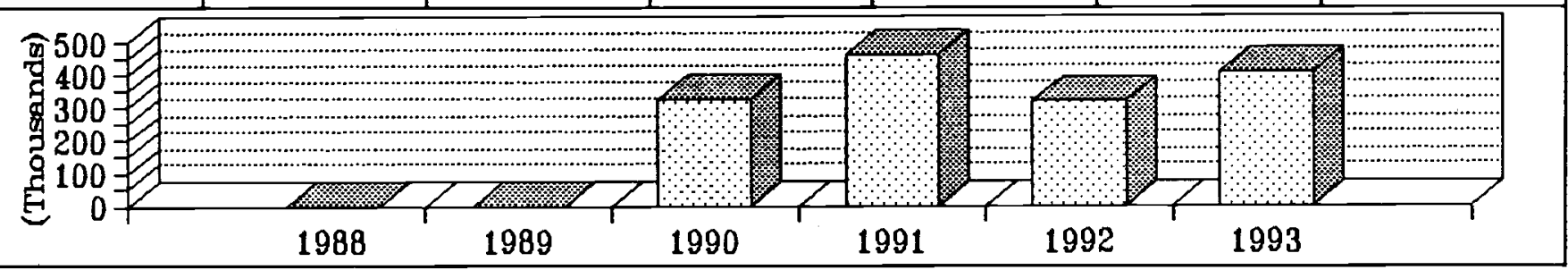

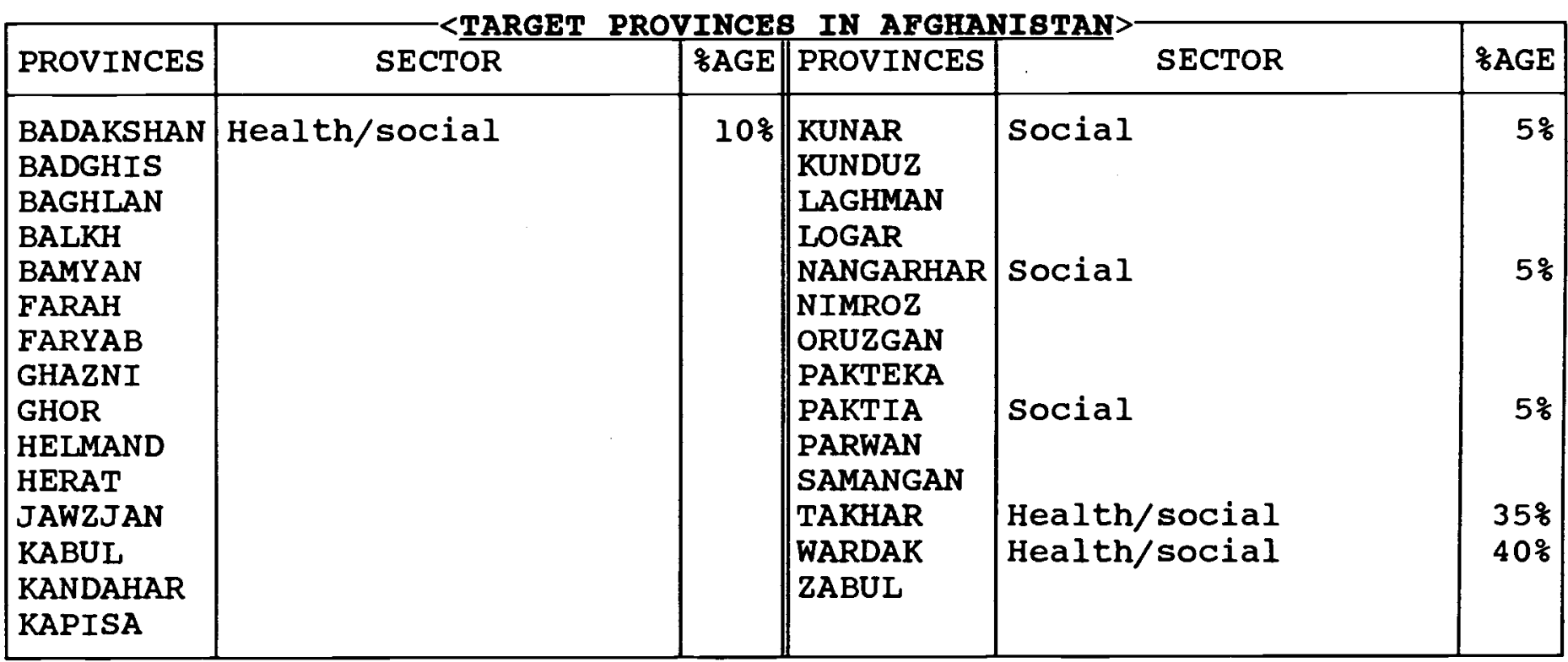




\section{RADDA BARNEN (RBS)}

is a direct translation into Swedish of the English "Save The Children". Radda Barnen works for the rights of children. It was founded in stockholm in 1919 and today is one of Sweden's largest non-governmental organizations (NGOs). It enjoys the popular support of more than a quarter of a million people. It receives regular financial assistance from its 250,000 supporters as well as grants from the swedish International Development Authority (SIDA) and other contribution from Sweden and else where. In 1993, the total annual budget amounts to approximately US\$ 40 million. Its accounts are open to public scrutiny.

The purpose of the organization is to guarantee to children their rights to live and grow up in freedom and good health as independent individuals. The UN declaration and, subsequent convention on the rights of the child is the fundamental tool in Radda Barnen's work to ensure the dignity and welfare of children in a spirit of peace and justice.

Radda Barnen stands on the side of the most vulnerable children in the poorest countries, in areas of armed conflict or in other especially difficult circumstances with particular emphasis on the children of minorities, refugees and the disabled.

Through development assistance (not relief or charity) and the creation of awareness, the objective is always to improve conditions of life within the context of a broader development strategy which respects local culture and aspirations.

In 1988 it joined the International Save The Children Alliance.

Since 1984, Radda Barnen has seconded Social Services Program officers to UNHCR, Peshawar and Quetta. In 1987 it started a Social Services Training Unit which initially guided and trained the
Social Welfare cell (SWC) of the Commissionerate for Afghan Refugees (CAR) .

The Training Unit continued and expanded its activities for Afghan refugees in Pakistan by initiating the process of increased self help, especially for meeting the needs of the most vulnerable refugees, children including retarded, disabled and other children with special needs. This is being achieved by organizing special child groups (clubs), child to child activities and training of over 200 refugee community volunteers.

Radda Barnen Training Unit is also engaged in training social animators for the Disabled Afghan Project in Afghanistan. In Pakistan, Radda Barnen is funding SERVE to implement the children's integration component of the Blind Rehabilitation Project in ten districts of NWFP.

In 1989 the board agreed to designate Pakistan and Afghanistan as a program area, sent a Team Leader to open a Field office in Peshawar, as "Country Representative."

Radda Barnen plans to work crossborder and inside Afghanistan. It will not implement projects but aims to provide training, advice, funding, encouragement to local NGOs implementing projects related to the Radda Barnen philosophy and mandate. 


\section{RECONSTRUCTION AGENCY OF HINDUKUSH-RAH}

\begin{tabular}{|l|l|l|}
\hline 4 AL-SAYED PLAZA & PHONE: 40617 & <OMEY STAFF \\
ABDARA CHOWK, JAMROD RD & F A X: & 1. ENG. KHALIL \\
PESHAWAR, PAKISTAN & TELEX: & 2. \\
\hline
\end{tabular}

\begin{tabular}{|lr|lr|lr|}
\hline AFGHAN: & 15 & TECHNICAL: & 10 & PAK. BASED: & 8 \\
PAKISTANI : & 1 & ADMINISTRATIVE: & 4 & AFGHA.BASED: & 2 \\
EXPAT: & - & FIELD/SUPPORT S. & 2 & CROSS BORDER: & 6 \\
TOTAL: & 16 & TOTAL: & 16 & TOTAL: & 16 \\
\hline
\end{tabular}

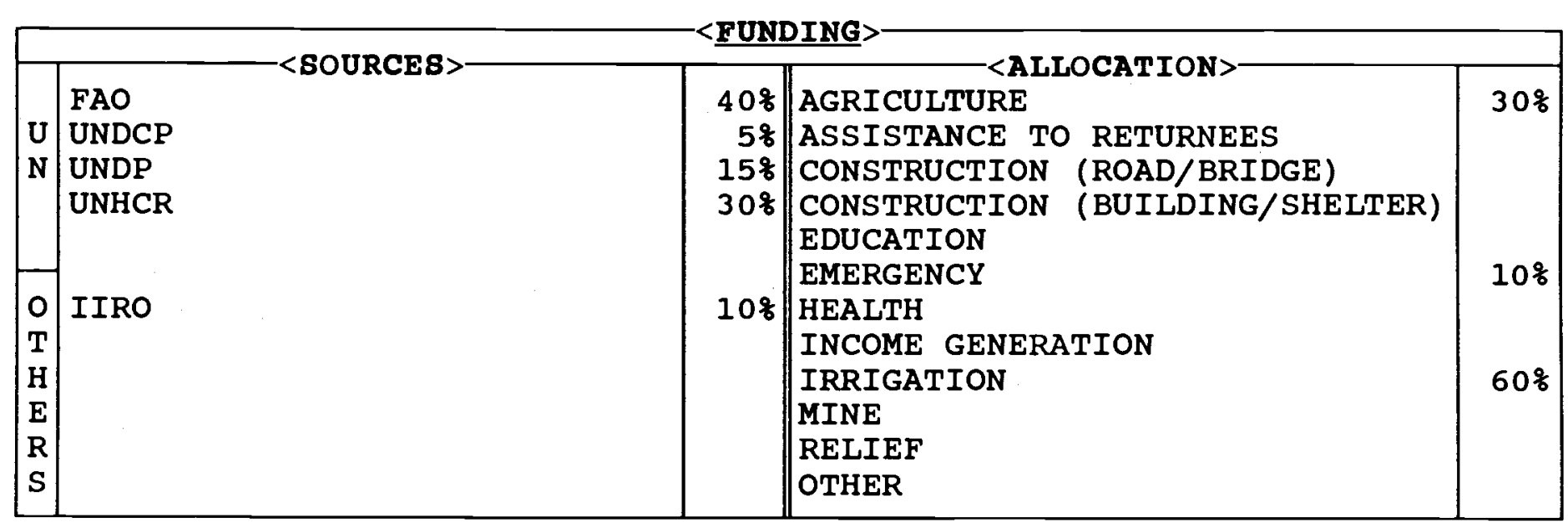

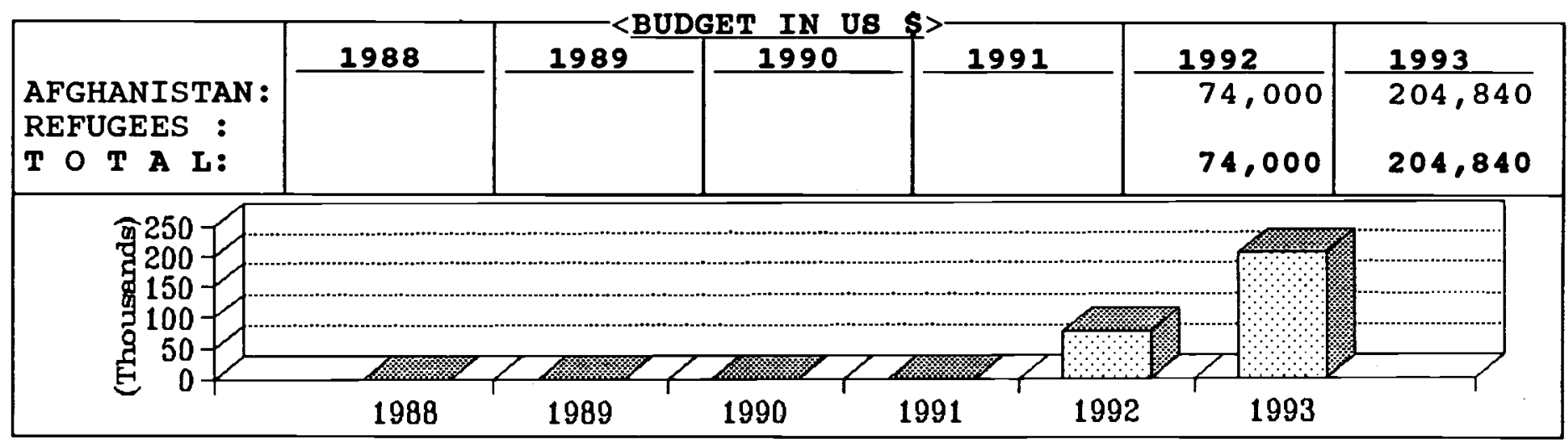

\begin{tabular}{|c|c|c|c|c|c|}
\hline PROVINCES & SECTOR & \&AGE & PROVINCES & SECTOR & \&AGE \\
\hline $\begin{array}{l}\text { BADAKSHAN } \\
\text { BADGHIS } \\
\text { BAGHLAN } \\
\text { BALKH } \\
\text { BAMYAN } \\
\text { FARAH } \\
\text { FARYAB } \\
\text { GHAZNI } \\
\text { GHOR } \\
\text { HELMAND } \\
\text { HERAT } \\
\text { JAWZJAN } \\
\text { KABUL } \\
\text { KANDAHAR } \\
\text { KAPISA }\end{array}$ & & & $\begin{array}{l}\text { KUNAR } \\
\text { KUNDUZ } \\
\text { LAGHMAN } \\
\text { LOGAR } \\
\text { NANGARHAR } \\
\text { NIMROZ } \\
\text { ORUZGAN } \\
\text { PAKTEKA } \\
\text { PAKTIA } \\
\text { PARWAN } \\
\text { SAMANGAN } \\
\text { TAKHAR } \\
\text { WARDAK } \\
\text { ZABUL }\end{array}$ & $\begin{array}{l}\text { Agr/irrign } \\
\text { Agr/emerg/irrign }\end{array}$ & $\begin{array}{l}20 \% \\
80 \%\end{array}$ \\
\hline
\end{tabular}


RECONSTRUCTION AGENCY OF HINDURUSH (RAH)

is a non-governmental, non-political organization founded in December, 1991 in Peshawar to provide humanitarian and agricultural assistance for the Afghan people and take part in rehabilitation programs of Afghanistan.

RAH's major fields of work will include:

a. Encouraging farmers in the areas of agronomy (crops and fruit production) and animal husbandry such as poultry, sheep, goats and dairy cattle.

b. Rehabilitation of irrigation systems (construction of intakes, protection walls, retaining walls, syphons, aqueducts and design of canals, etc.).

c. Water supply (shallow wells).

d. Road repair and construction.

e. Construction of buildings.

f. Operating health facilities and construction of clinic buildings.

Since February 1992 RAH has completed/undertaken the following projects :

* Distribution of rice and maize seeds (multiplication program) in Dara-i-Noor district of Nangarhar province.

* Cleaning Jearam canal in Darai-Noor.

Distribution of 1,250 quilts to new refugees in Jalalabad.

Delivering of 19,000 non-fruit trees to Nangarhar provincial government.

Cleaning of Shagay main canal and construction of temporary intake.

Wheat seed multiplication project in Kouz Kunar.

Wheat seed multiplication project in Dara-i-Noor.

Construction of intake, bank protection and reconstruction of Gardikass road Nangarhar province.

* Shallow well program for drinking water supplies in Shagay village.
Shallow well program for drinking water in Kouz Kunar district.

Sugar cane seed multiplication project in Kouz Kunar district. Budded fruit trees distribution in Kouz Kunar district.

Construction of aqueduct in Mehterlam district.

proposals have been submitted to UNDP for rehabilitation of irrigation systems of Baraki Barak and Puli Alam districts of Logar province.

The organization has obtained a Nonobjection Certificate (NOC) from the Afghan commissionerate. It is registered as an Afghan NGO with UNOCHA as well as the provincial Government of Nangarhar. 


\begin{tabular}{|l|l|l|}
\hline 19/AC-3, GULMOHAR LANE & PHONE: 44867 & 1. ENG. A RAHMAN SALEH \\
P O BOX 1771 & F A X: & 2. ENG. SEDDIQ \\
PESHAWAR, PAKISTAN & TELEX: & 3. ENG. KAMIN \\
\hline
\end{tabular}

\begin{tabular}{|lr|ll|ll|}
\hline AFGHAN : & 45 & TECHNICAL: & $\ldots$ & PAK. BASED: & $\ldots$ \\
PAKISTANI : & - & ADMINISTRATIVE : & $\ldots$ & AFGHA.BASED: & $\ddots$ \\
EXPAT: & - & FIELD/SUPPORT S. & $\cdots$ & CROSS-BORDER: & $\cdots$ \\
TOTAL: & 45 & TOTAL: & 45 & TOTAL: & 45 \\
\hline
\end{tabular}

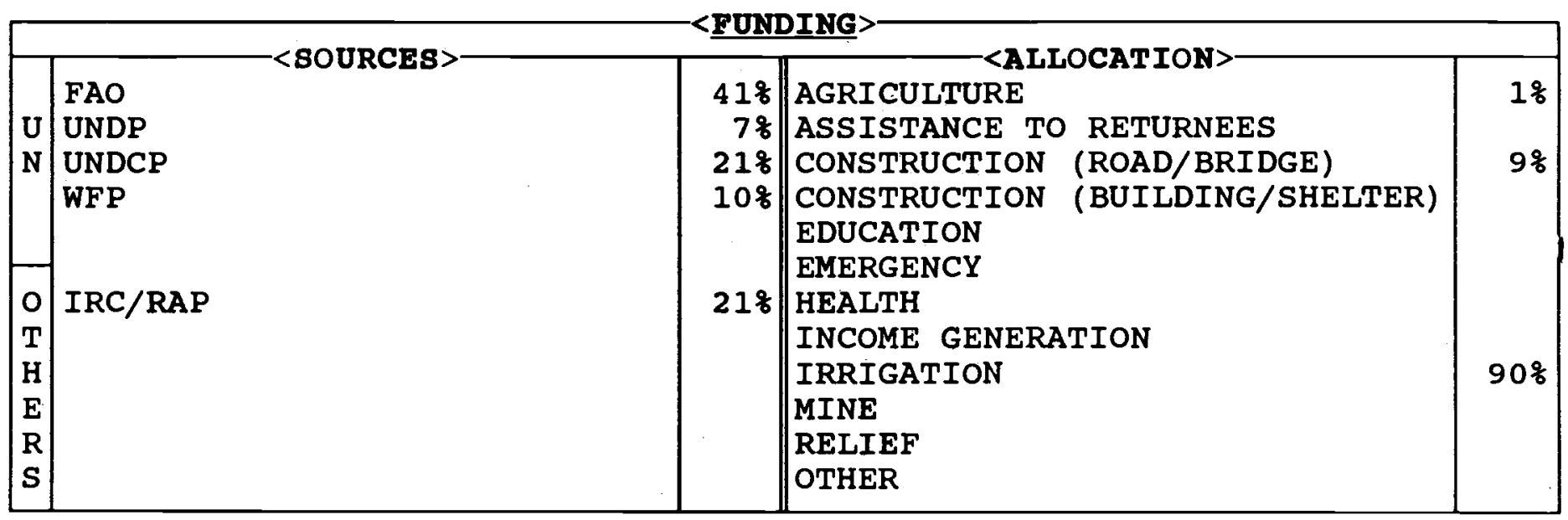

\begin{tabular}{|c|c|c|c|c|c|c|}
\hline & 1988 & 1989 & 1990 & 1991 & 1992 & 1993 \\
\hline $\begin{array}{l}\text { AFGHANISTAN : } \\
\text { REFUGEES : }\end{array}$ & & & $\begin{array}{l}320,000 \\
320,000\end{array}$ & $\begin{array}{l}680,000 \\
680,000\end{array}$ & $\begin{array}{l}760,000 \\
760,000\end{array}$ & $\begin{array}{l}300,000 \\
300,000\end{array}$ \\
\hline
\end{tabular}

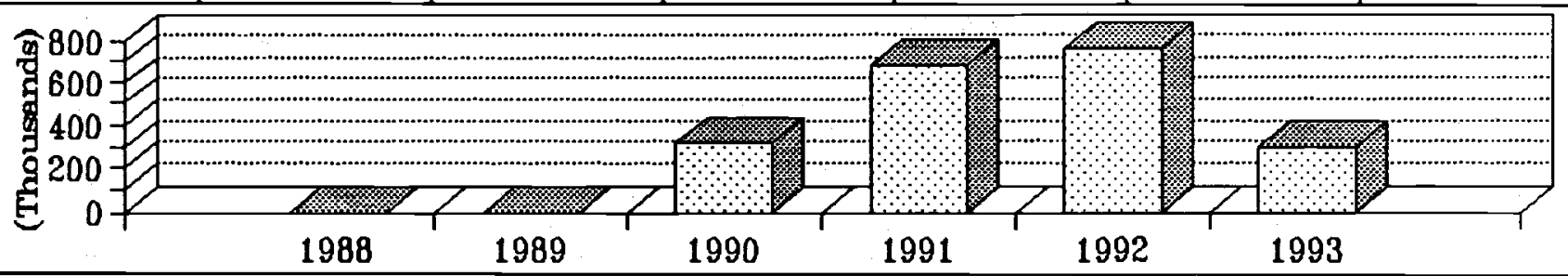

\begin{tabular}{|c|c|c|c|c|c|}
\hline PROVINCES & SECTOR & \&AGE & PROVINCES & SECTOR & $\%$ AGE \\
\hline $\begin{array}{l}\text { BADAKSHAN } \\
\text { BADGHIS } \\
\text { BAGHLAN } \\
\text { BALKH } \\
\text { BAMYAN } \\
\text { FARAH } \\
\text { FARYAB } \\
\text { GHAZNI } \\
\text { GHOR } \\
\text { HELMAND } \\
\text { HERAT } \\
\text { JAWZJAN } \\
\text { KABUL } \\
\text { KANDAHAR } \\
\text { KAPISA }\end{array}$ & Irrign & 218 & \begin{tabular}{|l} 
KUNAR \\
KUNDUZ \\
LAGHMAN \\
LOGAR \\
NANGARHAR \\
NIMROZ \\
ORUZGAN \\
PAKTEKA \\
PAKTIA \\
PARWAN \\
SAMANGAN \\
TAKHAR \\
WARDAK \\
ZABUL
\end{tabular} & $\begin{array}{l}\text { Agr/irrign } \\
\text { Const/irrign } \\
\text { Irrign } \\
\text { Irrign } \\
\text { Agr/irrign }\end{array}$ & $\begin{array}{r}15 \% \\
11 \% \\
24 \% \\
3 \%\end{array}$ \\
\hline
\end{tabular}


was founded in 1989 with the objective of assisting funding organizations in the rehabilitation and reconstruction of irrigation systems and infrastructure in Afghanistan.

At the beginning, RAFA cooperated with WFP in distribution of emergency wheat among needy people in different provinces of Afghanistan. It also undertook and completed a number of irrigation rehabilitation projects (karez and canal cleaning) and other public welfare projects supported by WFP, FAO and UNDP.

RAFA has been working in the provinces of Logar, Ghazni, Pakteka, Paktia, Laghman, Kunar, Badakhshan, Baghlan and Kandahar. Many projects in the sectors of irrigation rehabilitation, road repair and public buildings have been completed in the target areas. Many are in progress and others in the pipeline.

RAFA has very experienced technical staff who are experts in surveying, designing and planning projects.

RAFA has recently opened an office in Kabul and expects to gradually move the main office from Peshawar to Kabul. 
RECONBTRUCTION COUNCIL OF CENTRAL AFGHANISTAN-RCCA

\begin{tabular}{|c|c|c|c|c|c|}
\hline \multirow{2}{*}{\multicolumn{2}{|c|}{$\begin{array}{l}\text { TANZEEM APPARTMENT } \\
\text { ALAMDAR RD } \\
\text { QUETTA, PAKISTAN }\end{array}$}} & \multirow{2}{*}{\multicolumn{2}{|c|}{$\begin{array}{l}\text { <COMMUNICATION LINES } \\
\text { PHONE: } 75519 \\
\text { F A X: } \\
\text { TELEX: }\end{array}$}} & \multirow{2}{*}{\multicolumn{2}{|c|}{$\begin{array}{l}\text { 1. MR. M. H. KHAKYAR } \\
\text { 2. } \\
\text { 3. }\end{array}$}} \\
\hline & & & & & \\
\hline $\begin{array}{l}\text { AFGHAN: } \\
\text { PAKISTANI : } \\
\text { EXPAT: } \\
\text { TOTAL: }\end{array}$ & $\begin{array}{r}115 \\
- \\
115\end{array}$ & $\begin{array}{l}\text { TECHNICAL: } \\
\text { ADMINISTRATIVE: } \\
\text { FIELD/SUPPORT S. } \\
\text { TOTAL: }\end{array}$ & $\begin{array}{r}26 \\
61 \\
28 \\
115\end{array}$ & $\begin{array}{l}\text { PAK. BASED: } \\
\text { AFGHA. BASED: } \\
\text { CROSS-BORDER: } \\
\text { TOTAL: }\end{array}$ & $\begin{array}{r}\dot{ } \\
11 \dot{5}\end{array}$ \\
\hline
\end{tabular}

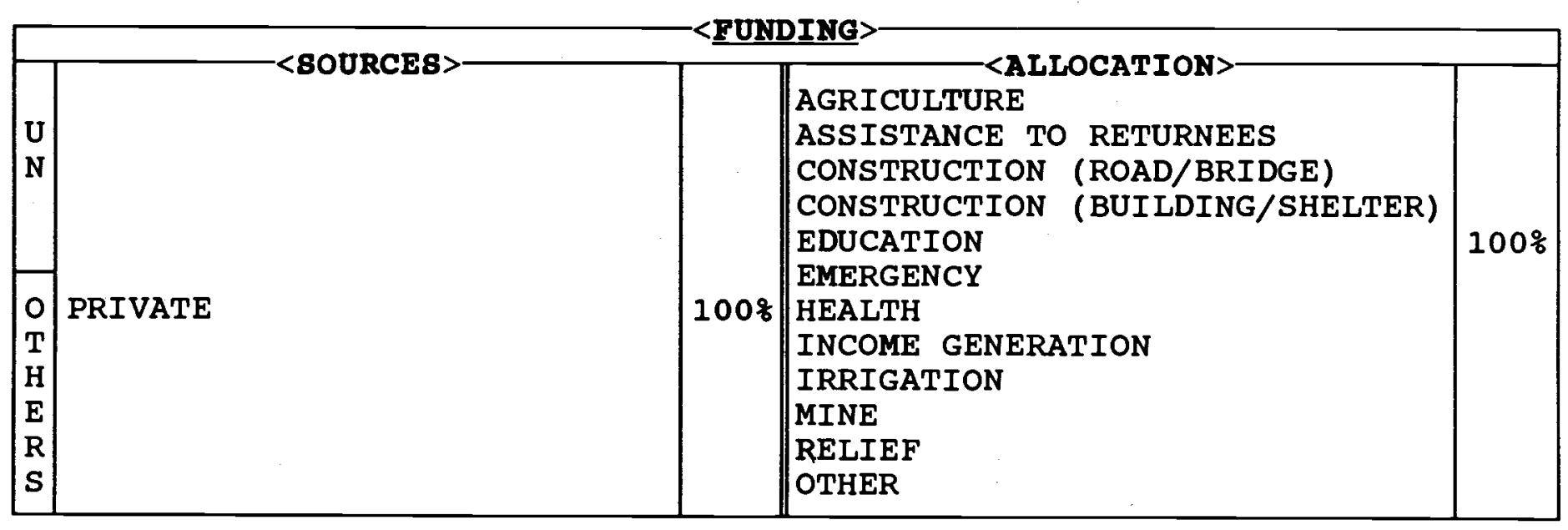

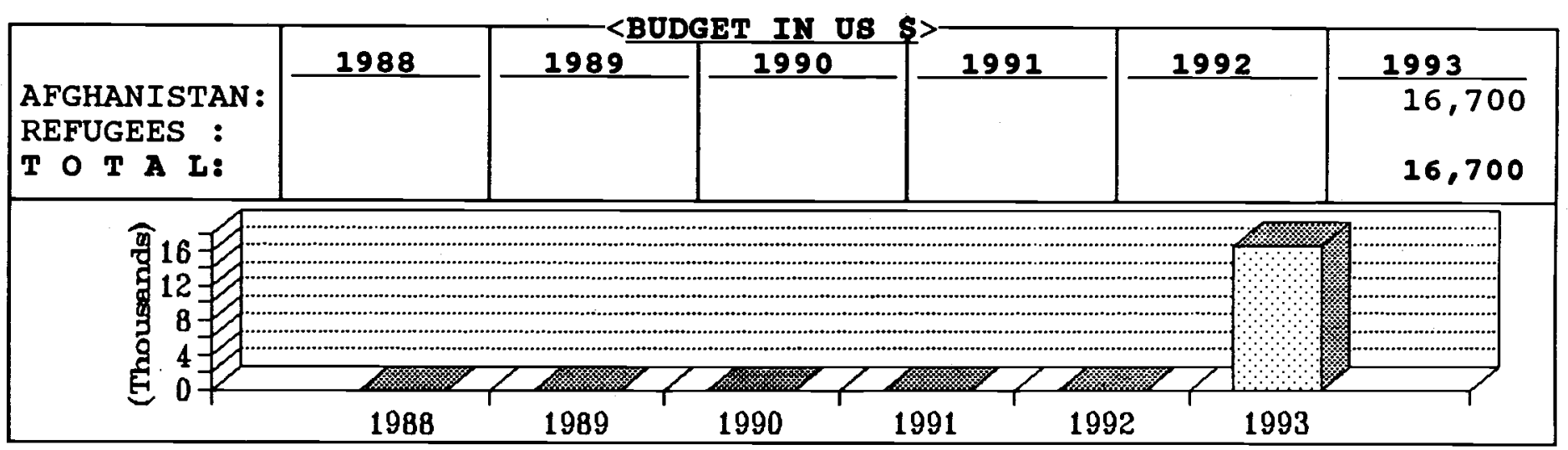

\begin{tabular}{|c|c|c|c|c|c|}
\hline PROVINCES & SECTOR & \%AGE & PROVINCES & SECTOR & $\% A G E$ \\
\hline $\begin{array}{l}\text { BADAKSHAN } \\
\text { BADGHIS } \\
\text { BAGHLAN } \\
\text { BALKH } \\
\text { BAMYAN } \\
\text { FARAH } \\
\text { FARYAB } \\
\text { GHAZNI } \\
\text { GHOR } \\
\text { HELMAND } \\
\text { HERAT } \\
\text { JAWZJAN } \\
\text { KABUL } \\
\text { KANDAHAR } \\
\text { KAPISA }\end{array}$ & Educ & 1008 & \begin{tabular}{|l|} 
KUNAR \\
KUNDUZ \\
LAGHMAN \\
LOGAR \\
NANGARHAR \\
NIMROZ \\
ORUZGAN \\
PAKTEKA \\
PAKTIA \\
PARWAN \\
SAMANGAN \\
TAKHAR \\
WARDAK \\
ZABUL
\end{tabular} & & \\
\hline
\end{tabular}




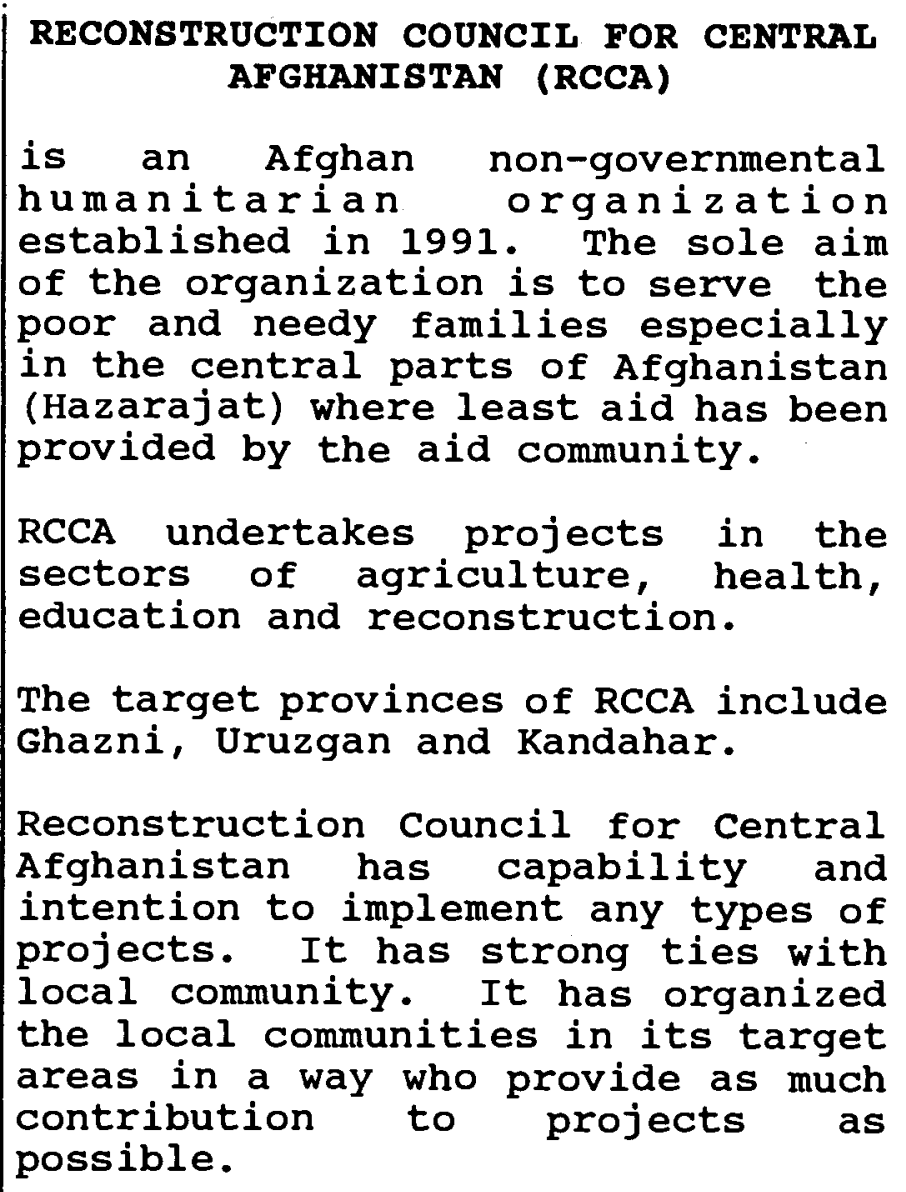


RECONSTRUCTION AND DEVELOPMENT ASSOCIATION-RDA

$1-B$ AFRIDI HOUSE

DOUSE

ABDARA LANE, U/T

PESHAWAR, PAKISTAN
PHONE: 41092

F A X: $41092 / 857886$ TELEX:
1. MR. ZAID HAIDARY

2. MR. WAJID ADIL

3. MR. AMINULLAH MOMAND

\begin{tabular}{|lr|ll|ll|}
\hline AFGHAN : & 60 & TECHNICAL: & 12 & PAK. BASED: & 30 \\
PAKISTANI : & 5 & ADMINISTRATIVE: & 33 & AFGHA.BASED: & 15 \\
EXPAT: & - & FIELD/SUPPORT S. & 20 & CROSS-BORDER: & 20 \\
TOTAL: & 65 & TOTAL: & 65 & TOTAL: & 65 \\
& & &
\end{tabular}

\begin{tabular}{|c|c|c|c|c|}
\hline & & & & \\
\hline & $-\langle$ SOURCES $>$ & & . $<$ ALLOCATION $>$ & \\
\hline & FAO & $20 \%$ & AGRICULTURE & $15 \%$ \\
\hline $\mathbf{U}$ & UNDP & $25 \%$ & ASSISTANCE TO RETURNEES & \\
\hline $\mathbf{N}$ & WFP & $50 \%$ & CONSTRUCTION（ROAD/BRIDGE) & $25 \%$ \\
\hline & & & CONSTRUCTION (BUILDING/SHELTER) & \\
\hline & & & EDUCATION & \\
\hline 0 & IRC/RAP & $5 \%$ & HEALTH & \\
\hline $\mathrm{T}$ & & & INCOME GENERATION & \\
\hline $\mathrm{H}$ & & & IRRIGATION & $50 \%$ \\
\hline $\mathbf{E}$ & & & MINE & \\
\hline $\mathbf{R}$ & & & RELIEF & $10 \%$ \\
\hline $\mathbf{S}$ & & & OTHER & \\
\hline
\end{tabular}

\begin{tabular}{|c|c|c|c|c|c|c|}
\hline \multirow{4}{*}{$\begin{array}{l}\text { AFGHANISTAN : } \\
\text { REFUGEES : } \\
\text { T O T A L: }\end{array}$} & \multirow{4}{*}{1988} & \multirow{4}{*}{1989} & \multirow{4}{*}{1990} & \multirow{3}{*}{$\frac{1991}{283,469}$} & \multirow{3}{*}{$\frac{1992}{570,884}$} & \multirow{3}{*}{$\frac{1993}{620,519}$} \\
\hline & & & & & & \\
\hline & & & & & & \\
\hline & & & & 283,469 & 570,884 & 620,519 \\
\hline
\end{tabular}

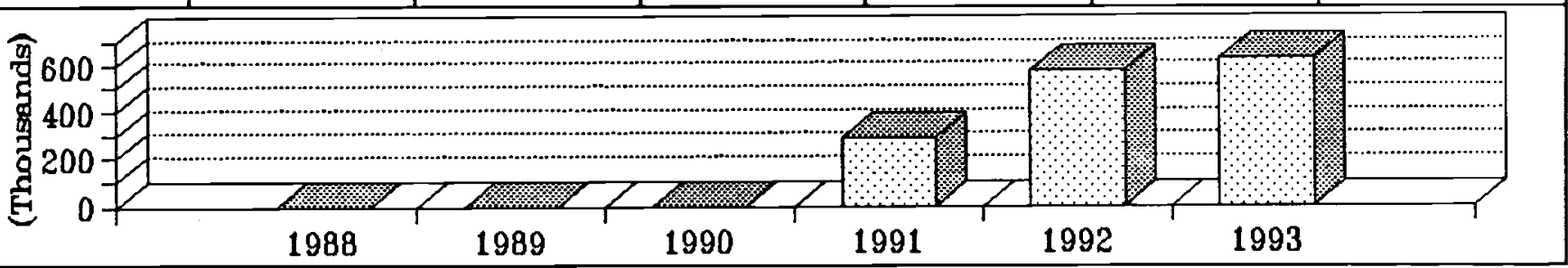

\begin{tabular}{|c|c|c|c|c|c|}
\hline PROVINCES & SECTOR & \&AGE & PROVINCES & SECTOR & $\% A G E$ \\
\hline $\begin{array}{l}\text { BADAKSHAN } \\
\text { BADGHIS } \\
\text { BAGHLAN } \\
\text { BALKH } \\
\text { BAMYAN } \\
\text { FARAH } \\
\text { FARYAB } \\
\text { GHAZNI } \\
\text { GHOR } \\
\text { HELMAND } \\
\text { HERAT } \\
\text { JAWZJAN } \\
\text { KABUL } \\
\text { KANDAHAR } \\
\text { KAPISA }\end{array}$ & $\begin{array}{l}\text { Irrign } \\
\text { Agr/irrign } \\
\text { Emerg } \\
\text { Agr/irrign }\end{array}$ & $\begin{array}{l}9 \% \\
1 \%\end{array}$ & $\begin{array}{l}\text { KUNAR } \\
\text { KUNDUZ } \\
\text { LAGHMAN } \\
\text { LOGAR } \\
\text { NANGARHAR } \\
\text { NIMROZ } \\
\text { ORUZGAN } \\
\text { PAKTEKA } \\
\text { PAKTIA } \\
\text { PARWAN } \\
\text { SAMANGAN } \\
\text { TAKHAR } \\
\text { WARDAK } \\
\text { ZABUL }\end{array}$ & $\begin{array}{l}\text { Irrign } \\
\text { Agr/irrign } \\
\text { Irrign } \\
\text { Agr/irrign } \\
\text { Irrign } \\
\text { Irrign } \\
\text { Const } \\
\text { Agr/irrign }\end{array}$ & $\begin{array}{r}3 \% \\
11 \% \\
6 \% \\
12 \% \\
3 \% \\
5 \% \\
2 \% \\
35 \%\end{array}$ \\
\hline
\end{tabular}




\section{RECONSTRUCTION AND DEVELOPMENT ASSOCIATION (RDA)}

was founded in 1991 as an Afghan managed and operated NGO dedicated to the sustainable reconstruction of Afghanistan. With headquarters in Islamabad and regional operational offices for cross-border activities in Peshawar and Quetta serving numerous local offices throughout Afghanistan, RDA is uniquely qualified to provide the expert services and delivery of both emergency relief and long-term sustainable development assistance urgently required in Afghanistan. RDA's programs are organized into the following major areas:

- Emergency food delivery

- Infrastructure reconstruction

- Agricultural rehabilitation and development.

Utilizing a mixture of traditional Afghan social customs and the latest western managerial and accounting techniques, it has accomplished much including securing safe and accountable passage for all contracted goods and services into Afghanistan, including Kabul.

RDA has completed the following projects :

I. Emergency food deliveries: Despite the unstable environment inside Afghanistan last winter RDA delivered/distributed emergency food shipments (thousands of MTs of food, fuel, ghee and clothes) to Kabul utilizing a transportation/ security arrangement with local commanders along the transport route.

II. Infrastructure reconstruction: RDA has undertaken a number of basic infrastructure projects, including bridges, roads, wash crossings, retaining walls, mosques, diversion dams and karezes. Infrastructure projects are implemented throughout Afghanistan.

III. Agricultural development: RDA has undertaken seed, fertilizer and agro-chemical distribution, fruit tree nurseries and tree seedling distribution as well as small scale sustainable agricultural projects (honey bee, poultry, sheep, and cattle production). RDA plans to expand into the areas of sustainable forestry, agriculture and resource development providing ecological health and income generation for decades to come.

RDA currently employs over a 100 highly qualified Afghans. The staff are highly motivated sharing in RDA's decision-making apparatus through close employee management relations and staff incentive programs. RDA staff are served by an integrated communications network of 14 offices in pakistan and Afghanistan.

RDA projects are funded by UNDP, WFP, UNHCR, USAID and The Asia Foundation. The 1992 annual budget exceeded $\$ 700,000$ with an operating and administrative overhead of less than 15\%. RDA accounting methods and monitoring systems are open and fully in line with international donor specifications.

RDA is a member of ACBAR, a founding member of the Union of Afghan NGO's and is in the process of registration with Government of Pakistan.

RDA aims to expand, its activities in the same sectors as well as undertake some developmental types of projects including forestry through tree nursery establishment and forest growth, fruit products for local and export markets and health care infrastructure reconstruction (hospitals and other structures). 
RECONSTRUCTION AND RURAL DEVELOPMENT OF MAIHAN-RDM

\begin{tabular}{|l|l|l|}
\hline MURAD PLAZA, JAMROD RD & PHONE: 45541 & <COMEUNICATION LINES \\
G P O BOX 615 & F A X: & STAFF>- MR. A. A. MAIHANYAR \\
PESHAWAR, PAKISTAN & TELEX: & 2. \\
\hline
\end{tabular}

\begin{tabular}{|lr|lr|lr|}
\hline AFGHAN : & 22 & TECHNICAL: & 12 & PAK. BASED: & 5 \\
PAKISTANI: & - & ADMINISTRATIVE: & 4 & AFGHA.BASED: & 17 \\
EXPAT: & - & FIELD/SUPPORT S. & 6 & CROSS-BORDER: & - \\
TOTAL: & $\mathbf{2 2}$ & TOTAL: & $\mathbf{2 2}$ & TOTAL: & $\mathbf{2 2}$ \\
\hline
\end{tabular}

\begin{tabular}{|c|c|c|c|c|}
\hline & & & & \\
\hline & - <BOURCES $>$ & & $<<$ ALLOCATION> & \\
\hline & FAO & $70 \%$ & AGRICULTURE & $59 \%$ \\
\hline $\mathbf{U}$ & UNDCP & $10 \%$ & ASSISTANCE TO RETURNEES & \\
\hline $\mathbf{N}$ & UNDP & 58 & CONSTRUCTION (ROAD/BRIDGE) & $5 \%$ \\
\hline & WFP & $5 \%$ & CONSTRUCTION (BUILDING/SHELTER) & 58 \\
\hline & & & EDUCATION & \\
\hline & CIDA & 59 & EMERGENCY & \\
\hline $\mathbf{m}$ & $\begin{array}{l}\text { CIDA } \\
\text { NAC }\end{array}$ & $5 \%$ & HEALTH & \\
\hline $\mathrm{H}$ & & & $\begin{array}{l}\text { IRRIGATION } \\
\text { IRIS }\end{array}$ & $31 \%$ \\
\hline $\mathbf{E}$ & & & MINE & \\
\hline $\mathbf{R}$ & & & RELIEF & \\
\hline $\mathbf{S}$ & & & OTHER & \\
\hline
\end{tabular}

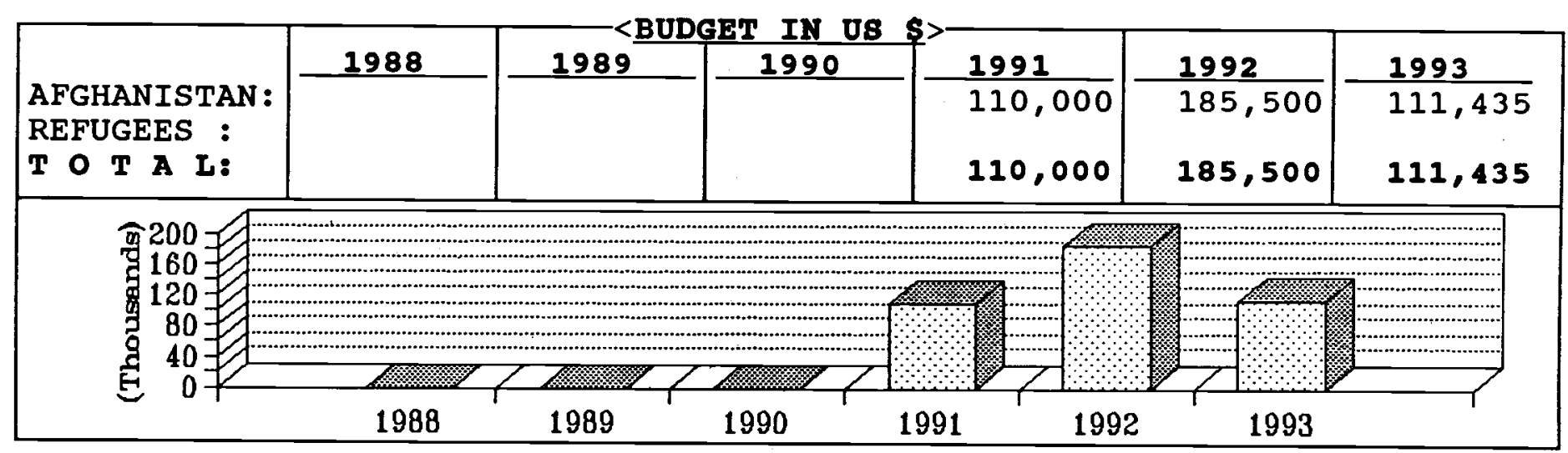

\begin{tabular}{|c|c|c|c|c|c|}
\hline PROVINCES & SECTOR & \&AGE & PROVINCES & SECTOR & \&AGE \\
\hline $\begin{array}{l}\text { BADAKSHAN } \\
\text { BADGHIS } \\
\text { BAGHLAN } \\
\text { BALKH } \\
\text { BAMYAN } \\
\text { FARAH } \\
\text { FARYAB } \\
\text { GHAZNI } \\
\text { GHOR } \\
\text { HELMAND } \\
\text { HERAT } \\
\text { JAWZJAN } \\
\text { KABUL } \\
\text { KANDAHAR } \\
\text { KAPISA }\end{array}$ & $\begin{array}{l}\text { Irrign } \\
\text { Agr } \\
\text { Irrign }\end{array}$ & $\begin{array}{r}23 \% \\
5 \% \\
5 \%\end{array}$ & \begin{tabular}{|l|} 
KUNAR \\
KUNDUZ \\
LAGHMAN \\
LOGAR \\
NANGARHAR \\
NIMROZ \\
ORUZGAN \\
PAKTEKA \\
PAKTIA \\
PARWAN \\
SAMANGAN \\
TAKHAR \\
WARDAK \\
ZABUL
\end{tabular} & $\begin{array}{l}\text { Agr } \\
\text { Agr } \\
\text { Agr/irrign }\end{array}$ & $\begin{array}{r}20 \% \\
5 \% \\
32 \%\end{array}$ \\
\hline
\end{tabular}




\section{RECONSTRUCTION AND RURAL DEVELOPMENT OF MAIHAN (RDM)}

is an Afghan non-governmental humanitarian organization established in 1991. The sole aim of the organization is to serve farming communities and to contribute to the general well-being of the lower and under privileged classes in remote areas of Afghanistan.

RDM's immediate policy is to contribute towards designing and implementing agriculture and irrigation projects. It also provides and distributes relief goods among the under-served populations of farming communities in rural areas.

RDM intends to work and be engaged in the following fields:

Provision of needed
agricultural
services with high subsidized
prices.

2) Setting up small scale agribased undertakings such as poultry, honey bee-keeping, nurseries for both vegetables and fruit as well as non-fruit tree production, silk worm and others. The organization will also study feasibility of small scale agri-based industries like carpet-weaving, jelly, jam and juice extracting units.

3) Rehabilitation and recovery of animal husbandry in areas where livestock has been eliminated. Introduction of improved breeds of dairy cattle is also foreseen by the agency.

4) Supporting farmers to cultivate crops such as beans to improve the diets of the people through provision of better and more nutritious food.

5) Promotion of agriculture by introducing proper and tested technology.

6) Rehabilitation and repair of irrigation systems and other infrastructures such as roads and bridges which can help promotion of agriculture. RDM collects survey results and shares them with organizations working with the same objectives.

Efforts will be made to safeguard the ecology of the country and to promote the environmental situation.

RDM plans to support the education sector by building inexpensive education centers. It also plans to work towards self-sufficiency of the people by establishing vocational training projects in different fields and organizing handicraft centers.

For the time being the headquarters of RDM is located in Peshawar; when conditions permit it will move inside Afghanistan.

The organization is run by a team of highly qualified agricultural experts and engineers who have vast experience in implementation of different projects.

The following projects have been implemented or are in process of implementation:

1) Fruit sapling distribution in Baraki of Logar $(10,000$ saplings supported by FAO).

2) Maize seed multiplication program in surkhrod of Nangarhar supported by UNDP and FAO.

3) Karez cleaning project in sperah district of Paktia financed by NAC.

Three more karez cleaning projects in Waghaz area of Ghazni, Deh Yak area of Ghazni and Gurbuz area of Paktia have been submitted to different donor agencies which are under consideration. 
REHABTLITATION CENTER FOR AFGHANISTAN-RCA

<ADDRES8>- $>$ CCOMMUNICATION LINES>

471, ST.14, E3, PHASE 1 PHONE: 812543

HAYATABAD G P O BOX 128 F A X:

PESHAWAR, PAKISTAN
TELEX:
1. ENG. FARID AHMAD

2. MR. YASEEN

3 .

\begin{tabular}{|lr|lr|lr|}
\hline AFGHAN : & 12 & TECHNICAL: & 6 & PAK. BASED: & 4 \\
PAKISTANI : & - & ADMINISTRATIVE : & 4 & AFGHA. BASED: & - \\
EXPAT: & - & FIELD/SUPPORT S. & 2 & CROSS-BORDER: & 8 \\
TOTAL: & 12 & TOTAL: & 12 & TOTAL: & 12 \\
\hline
\end{tabular}

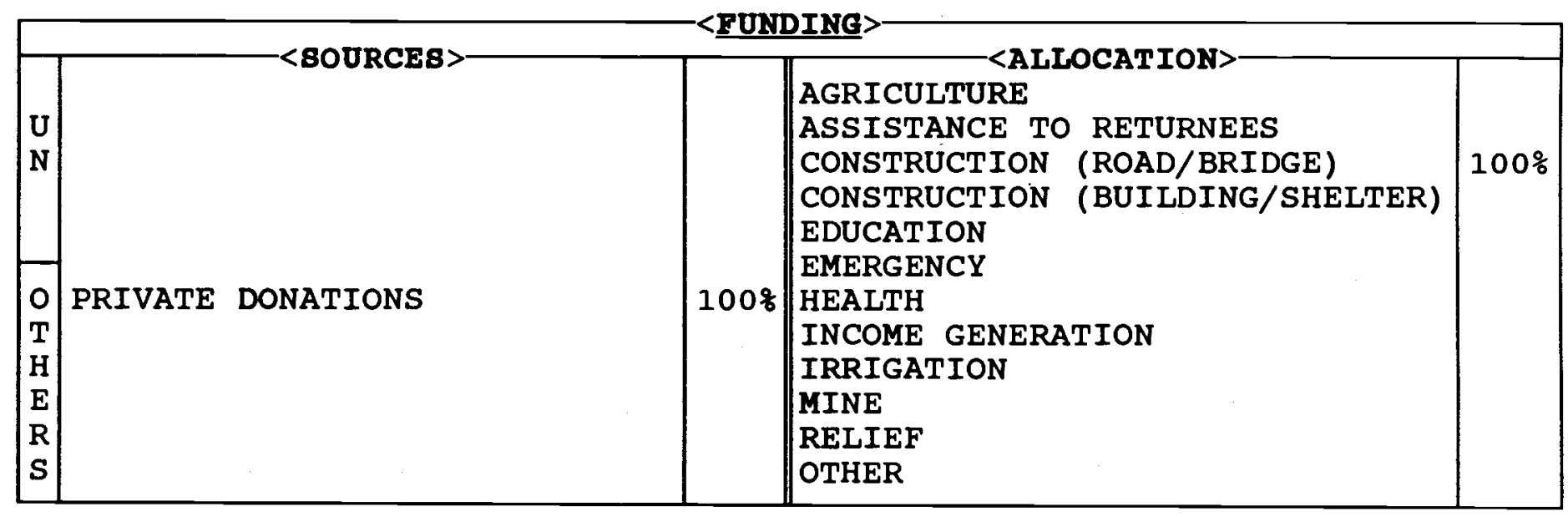

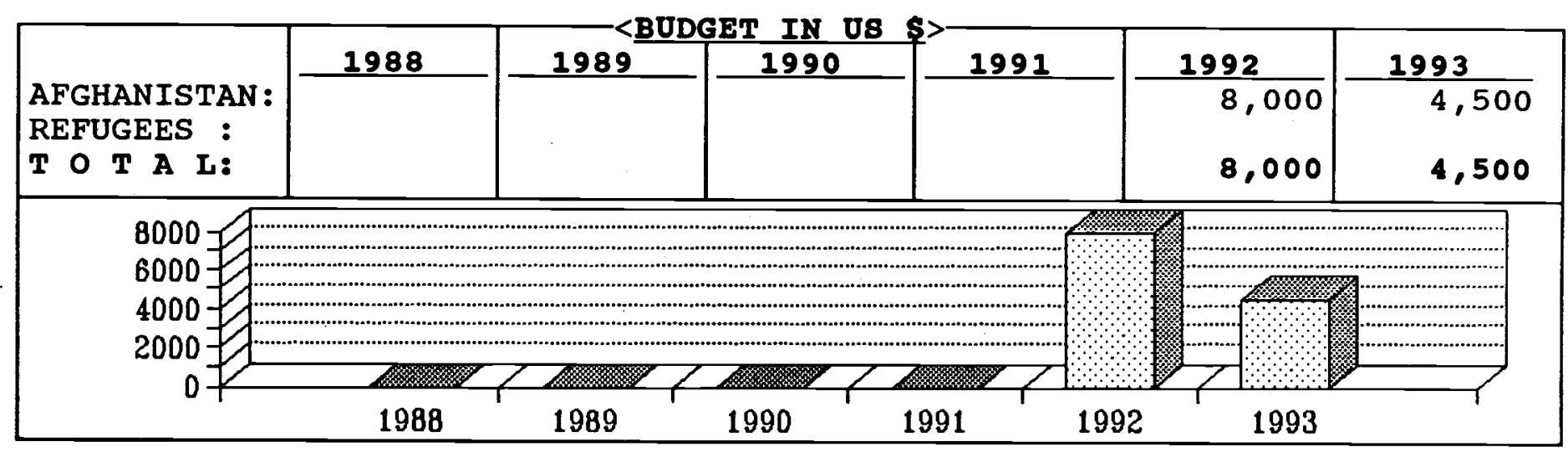

<TARGET PROVINCES IN AFGHANISTAN>

\begin{tabular}{|c|c|c|c|c|c|}
\hline PROVINCES & SECTOR & \&AGE & PROVINCES & SECTOR & 号AGE \\
\hline $\begin{array}{l}\text { BADAKSHAN } \\
\text { BADGHIS } \\
\text { BAGHLAN } \\
\text { BALKH } \\
\text { BAMYAN } \\
\text { FARAH } \\
\text { FARYAB } \\
\text { GHAZNI } \\
\text { GHOR } \\
\text { HELMAND } \\
\text { HERAT } \\
\text { JAWZJAN } \\
\text { KABUL } \\
\text { KANDAHAR } \\
\text { KAPISA }\end{array}$ & $\begin{array}{l}\text { Const (survey) } \\
\text { Const (survey) } \\
\text { Const (survey) }\end{array}$ & $\begin{array}{l}118 \\
118\end{array}$ & $\begin{array}{l}\text { KUNAR } \\
\text { KUNDUZ } \\
\text { LAGHMAN } \\
\text { LOGAR } \\
\text { NANGARHAR } \\
\text { NIMROZ } \\
\text { ORUZGAN } \\
\text { PAKTEKA } \\
\text { PAKTIA } \\
\text { PARWAN } \\
\text { SAMANGAN } \\
\text { TAKHAR } \\
\text { WARDAK } \\
\text { ZABUL }\end{array}$ & $\begin{array}{l}\text { Const (survey) } \\
\text { Const (survey) } \\
\text { Const (survey) } \\
\text { Const (survey) } \\
\text { Const (survey) } \\
\text { Const (survey) }\end{array}$ & $\begin{array}{l}11 \% \\
11 \% \\
12 \%\end{array}$ \\
\hline
\end{tabular}




\section{REHABILITATION CENTER FOR AFGHANISTAN (RCA)}

was established as an Afghan nongovernmental organization in June, 1993. to take active part in rehabilitation and reconstruction affairs of war-torn Afghanistan.

RCA is registered with the Ministry of Planning in the Islamic state of Afghanistan. RCA coordinates its contribution to the reconstruction of Afghanistan with other relief committees.

Over the past several months RCA has surveyed canals roads \& bridges in Laghman, Takhar, Badakhshan, Kunduz, Parwan and Paktia provinces.

A Board of Directors consists of 8 prominent Afghan scholars. They make the key decisions in the organization, and hold quarterly and annual meetings. 
RELIEF INSTITUTION FOR REHABIHITATION OF AFGHANISTAN-RIFRA

\begin{tabular}{|l|l|l|}
\hline $20-A$, BLOCK 4, S/T & PHONE: 443024 & <KEY BTAFF> \\
QUETTA, PAKISTAN & T A X: & 1. MR. GUL AGHA CHIRZI \\
TELEX: & 2. MR. YASEEN \\
\end{tabular}

\begin{tabular}{|lr|lr|lr|}
\hline AFGHAN: & 15 & TECHNICAL: & 5 & PAK. BASED: & 5 \\
PAKISTANI : & - & ADMINISTRATIVE: & 5 & AFGHA.BASED: & 5 \\
EXPAT: & - & FIELD/SUPPORT S. & 5 & CROSS-BORDER: & 5 \\
TOTAL: & 15 & TOTAL: & 15 & TOTAL: & 15 \\
\hline
\end{tabular}

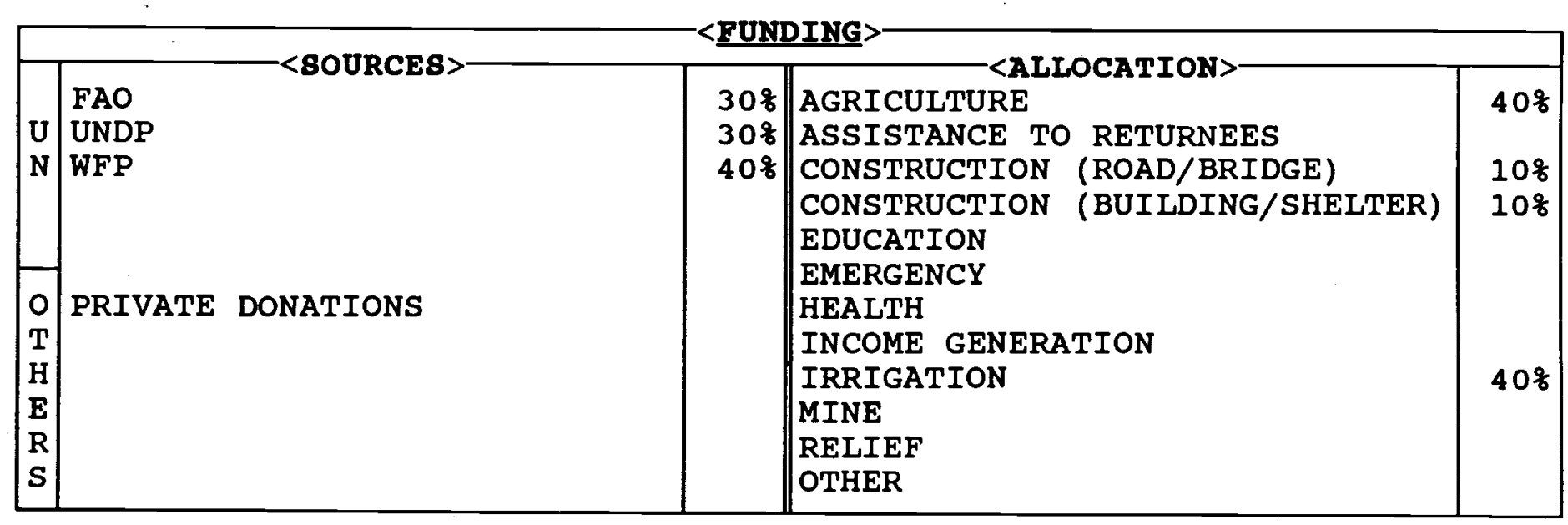
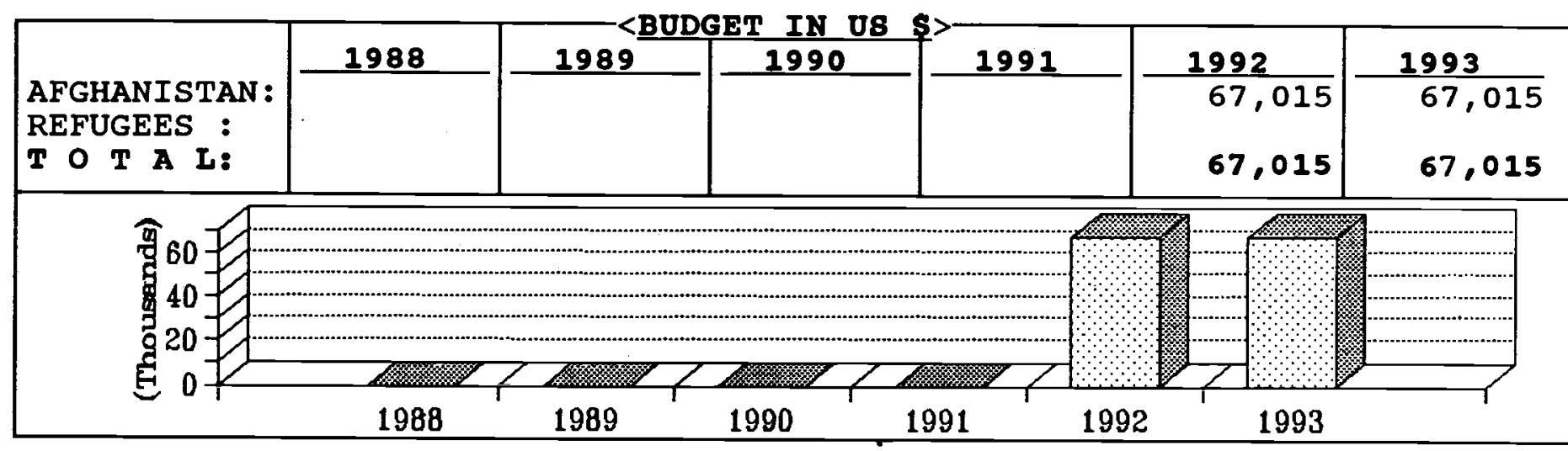

\begin{tabular}{|c|c|c|c|c|c|}
\hline PROVINCES & SECTOR & \&AGE & PROVINCES & SECTOR & \%AGE \\
\hline $\begin{array}{l}\text { BADAKSHAN } \\
\text { BADGHIS } \\
\text { BAGHLAN } \\
\text { BALKH } \\
\text { BAMYAN } \\
\text { FARAH } \\
\text { FARYAB } \\
\text { GHAZNI } \\
\text { GHOR } \\
\text { HELMAND } \\
\text { HERAT } \\
\text { JAWZJAN } \\
\text { KABUL } \\
\text { KANDAHAR } \\
\text { KAPISA }\end{array}$ & $\begin{array}{l}\text { Agr/const/irrign } \\
\text { Agr/irrign }\end{array}$ & $\begin{array}{l}70 \% \\
308\end{array}$ & \begin{tabular}{|l} 
KUNAR \\
KUNDUZ \\
LAGHMAN \\
LOGAR \\
NANGARHAR \\
NIMROZ \\
ORUZGAN \\
PAKTEKA \\
PAKTIA \\
PARWAN \\
SAMANGAN \\
TAKHAR \\
WARDAK \\
ZABUL
\end{tabular} & & \\
\hline
\end{tabular}


is an Afghan NGO established in August 1991. The objective of the agency is to contribute to the rehabilitation of devastated Afghanistan.

RIFRA's areas of work include agricultural programs (provision of improved seeds and fertilizer) and plant protection programs (control of agricultural diseases). RIFRA i $n t e n d s \quad t o \quad h$ a $v e$ a informative/training program to farmers in connection with preservation of raisins. RIFRA is also involved in veterinary programs.

RIFRA has surveyed roads and bridges and has submitted proposals for repairing them.

The target areas of RIFRA currently include districts of Nawae Barakzai, Grishk, Bala Balouk, Ghorak, Dand and Arghandab in south-west Afghanistan. RIFRA maintains a suboffice in each of the mentioned districts.

RIFRA will move its main office to Kandahar province. 
RELIEF ORGANIZATION FOR AFGHAN ORPHANS AND WOMEN-ROAOW

\begin{tabular}{|c|c|c|c|c|}
\hline$=<$ ADDRESS $>$ & $=<C O M M U N I C A T I O N$ & $\sqrt{58}$ & $-<$ REY STA & \\
\hline $\begin{array}{l}\text { ST.9, JAMAL RD, SHAHEEN } \\
\text { TOWN, G P O BOX } 356 \\
\text { PESHAWAR, PAKISTAN }\end{array}$ & $\begin{array}{l}\text { PHONE: } 45458 \\
\text { F A X: } 8418816 \\
\text { TELEX: }\end{array}$ & & $\begin{array}{l}\text { 1. MRS. BELQI } \\
\text { 2. MISS. MARIA } \\
\text { 3. MR. ABDUL }\end{array}$ & $\mathrm{UCH}$ \\
\hline $\begin{array}{l}\text { AFGHAN : } \\
\text { PAKISTANI : } \\
\text { EXPAT: } \\
\text { TOTAL: }\end{array}$ & $\begin{array}{l}\text { TECHNICAL: } \\
\text { ADMINISTRATIVE: } \\
\text { FIELD/SUPPORT S. } \\
\text { TOTAL: }\end{array}$ & $\begin{array}{r}10 \\
2 \\
4 \\
16\end{array}$ & $\begin{array}{l}\text { PAK. BASED: } \\
\text { AFGHA. BASED: } \\
\text { CROSS-BORDER: } \\
\text { TOTAL: }\end{array}$ & $\begin{array}{r}3 \\
13 \\
16\end{array}$ \\
\hline
\end{tabular}

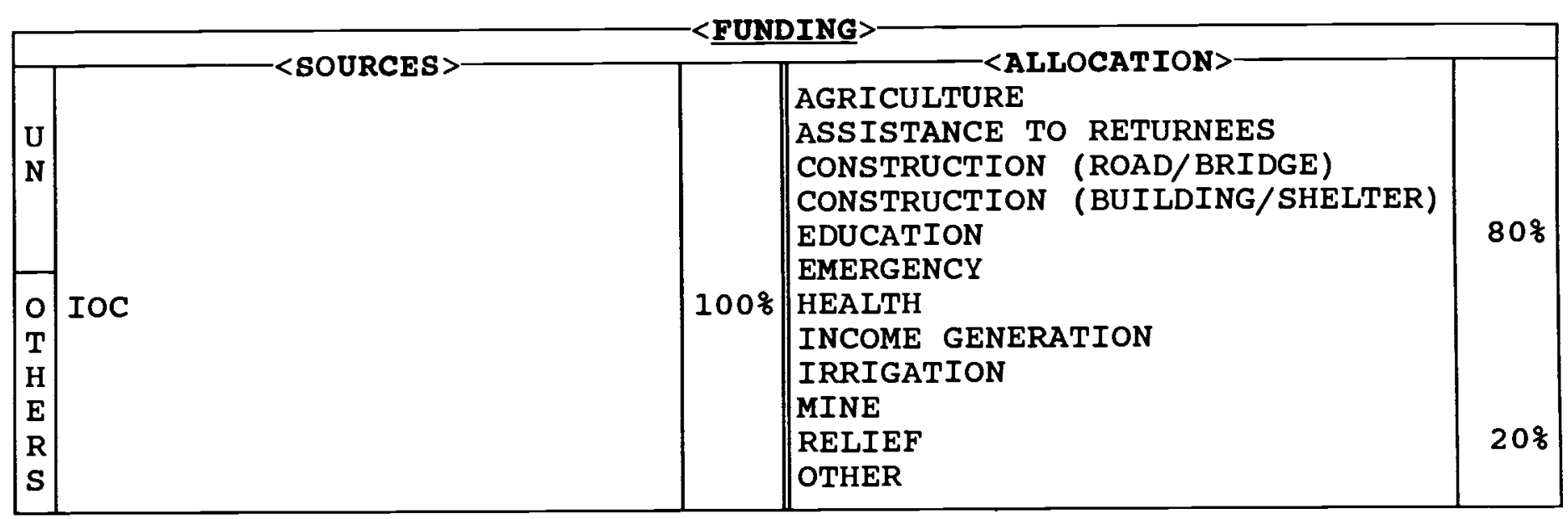

\begin{tabular}{|c|c|c|c|c|c|c|}
\hline & 1988 & 1989 & 1990 & 1991 & 1992 & 1993 \\
\hline $\begin{array}{l}\text { AFGHANISTAN: } \\
\text { REFUGEES : } \\
\text { T O T A L: }\end{array}$ & & & & & & $\begin{array}{l}67,000 \\
67,000\end{array}$ \\
\hline
\end{tabular}

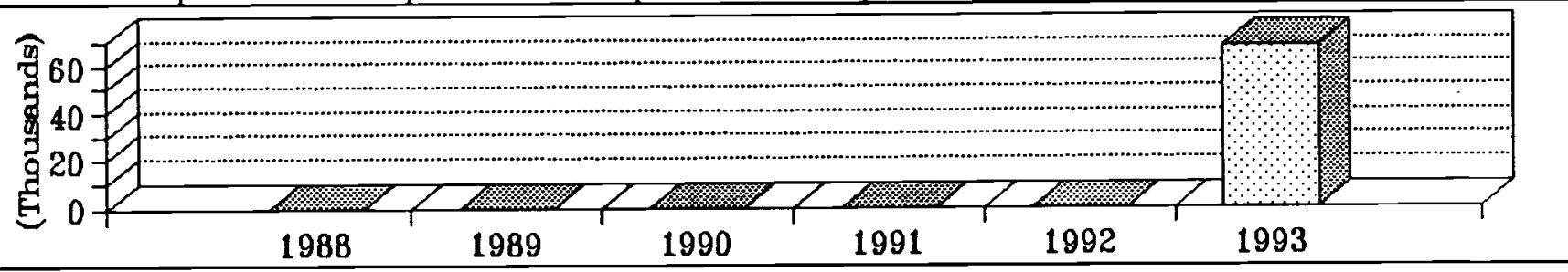

\begin{tabular}{|c|c|c|c|c|c|}
\hline PROVINCES & SECTOR & \&AGE & PROVINCES & SECTOR & $\%$ AGE \\
\hline $\begin{array}{l}\text { BADAKSHAN } \\
\text { BADGHIS } \\
\text { BAGHLAN } \\
\text { BALKH } \\
\text { BAMYAN } \\
\text { FARAH } \\
\text { FARYAB } \\
\text { GHAZNI } \\
\text { GHOR } \\
\text { HELMAND } \\
\text { HERAT } \\
\text { JAWZJAN } \\
\text { KABUL } \\
\text { KANDAHAR } \\
\text { KAPISA }\end{array}$ & & & $\begin{array}{l}\text { KUNAR } \\
\text { KUNDUZ } \\
\text { LAGHMAN } \\
\text { LOGAR } \\
\text { NANGARHAR } \\
\text { NIMROZ } \\
\text { ORUZGAN } \\
\text { PAKTEKA } \\
\text { PAKTIA } \\
\text { PARWAN } \\
\text { SAMANGAN } \\
\text { TAKHAR } \\
\text { WARDAK } \\
\text { ZABUL }\end{array}$ & Educ/relief & $100 \%$ \\
\hline
\end{tabular}



ORPHANS AND WIDOWS (ROAOW)

was established in 1993 as per urgent needs of the oppressed people of Afghanistan.

The ongoing devastating war has not only brought tremendous calamities in the social and economic setups of the society but also left behind thousands of orphans and widows and thousands of families without guardians. The orphans who have been deprived from the love and affections of their parents have been left to the mercy of nature. The widow mothers who are busy earning the living for their children, due to the lack of nonproductive social activities, cannot look after their orphan children's sound rearing and education.

With the sole aim of providing social welfare assistance the above mentioned vulnerable groups (orphans and widows), ROAOW has been established. The primary focus of the organization is making the widows and orphans self-reliant. ROAOW undertakes the following activities:

1. Establishment of kindergarten for orphans.

2. Establishment of orphanages.

3. Providing opportunities for suitable jobs for widows and enabling them to take active part in social activities.

4. Offering different skill courses (i.e. tailoring, embroidery, handicrafts, poultry, soap making, kitchen gardening), health information, literacy and adult education programs for widows.

The organization established its first center in Jalalabad city in mid 1993. The Jalalabad center is currently offering pre-school training to 80 orphans, poultry training to 30 widows and soap making training to 30 other widows.
ROAOW intends to expand its activities in the center by establishing further courses. It also plans to extend its services to other provinces of Afghanistan. 


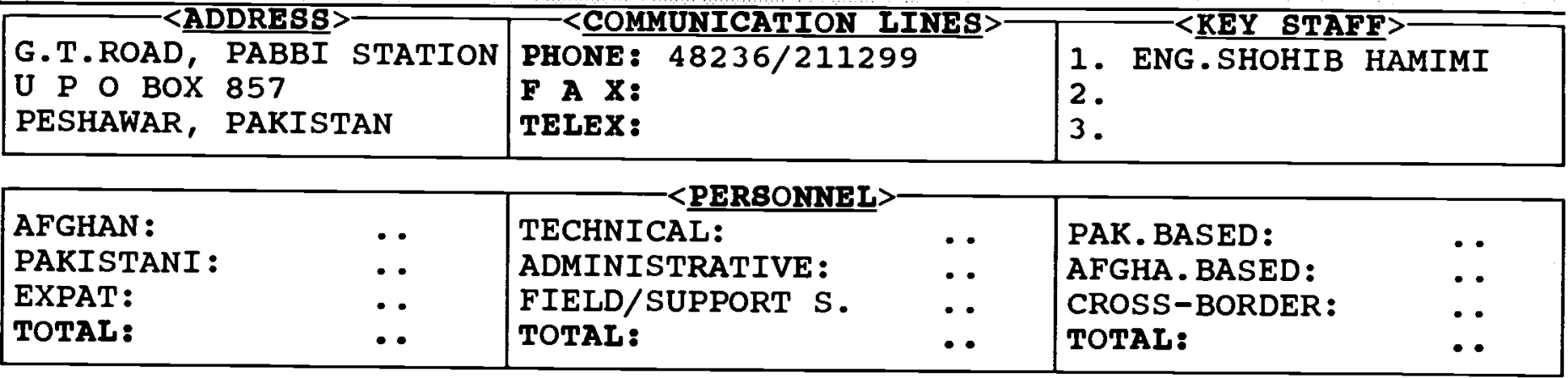

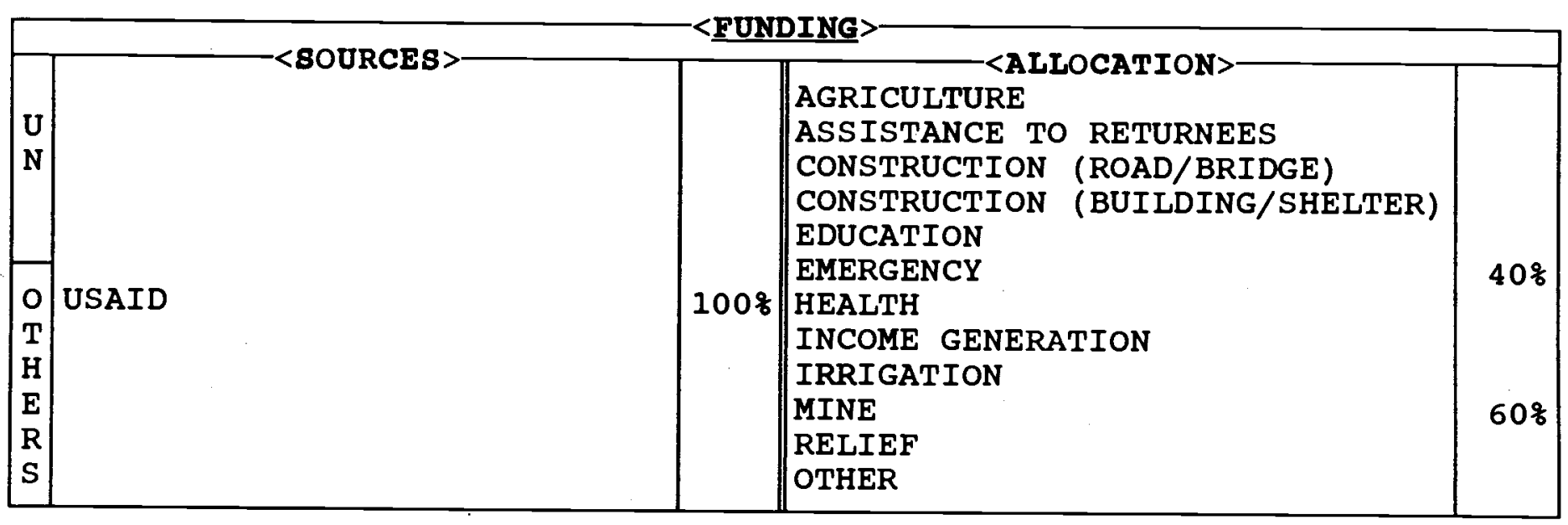

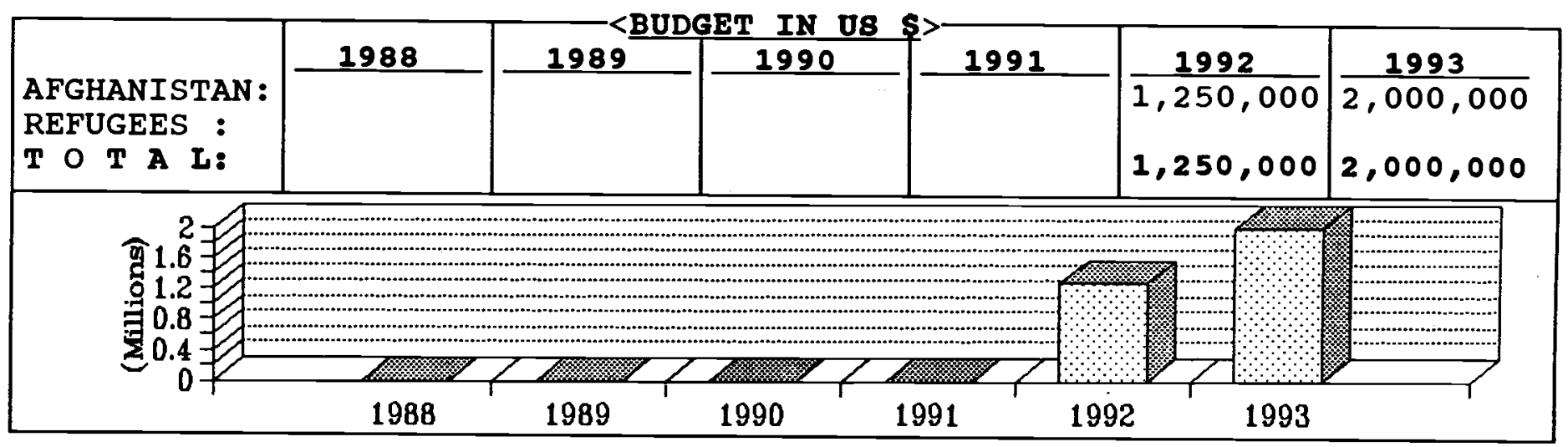

\begin{tabular}{|c|c|c|c|c|c|}
\hline PROVINCES & SECTOR & \&AGE & PROVINCES & SECTOR & \&AGE \\
\hline $\begin{array}{l}\text { BADAKSHAN } \\
\text { BADGHIS } \\
\text { BAGHLAN } \\
\text { BALKH } \\
\text { BAMYAN } \\
\text { FARAH } \\
\text { FARYAB } \\
\text { GHAZNI } \\
\text { GHOR } \\
\text { HELMAND } \\
\text { HERAT } \\
\text { JAWZJAN } \\
\text { KABUL } \\
\text { KANDAHAR } \\
\text { KAPISA }\end{array}$ & $\begin{array}{l}\text { Demining } \\
\text { Demining } \\
\text { Demining } \\
\text { Demining }\end{array}$ & $\begin{array}{l}108 \\
108 \\
108\end{array}$ & \begin{tabular}{|l} 
KUNAR \\
KUNDUZ \\
LAGHMAN \\
LOGAR \\
NANGARHAR \\
NIMROZ \\
ORUZGAN \\
PAKTEKA \\
PAKTIA \\
PARWAN \\
SAMANGAN \\
TAKHAR \\
WARDAK \\
ZABUL
\end{tabular} & $\begin{array}{l}\text { Demining } \\
\text { Demining } \\
\text { Demining } \\
\text { Demining } \\
\text { Demining } \\
\text { Demining }\end{array}$ & $\begin{array}{l}10 \% \\
10 \% \\
10 \% \\
10 \%\end{array}$ \\
\hline
\end{tabular}


is an American Private company contracted by the United states Agency for International Development (USAID) for developing and managing a Mine Detection Dog (MDD) Project.

In 1992, RONCO trained a total of 100 dogs. The trained dogs were then deployed to work along with UNOCHA demining teams who operate in different parts of Afghanistan.

RONCO has developed an Afghan NGO by the name of Mine Detection Dog Center (MDC) who will take over the MDD Project as an independent NGO in February 1994.

RONCO also provides emergency/relief assistance to war and natural disaster affected families. Possessing storage facilities and management capabilities, it has been acting as clearance house for USAID in-kind donations to NGOs and other organizations. 
RURAL DEVELOPMENT PROGRAY-RDP

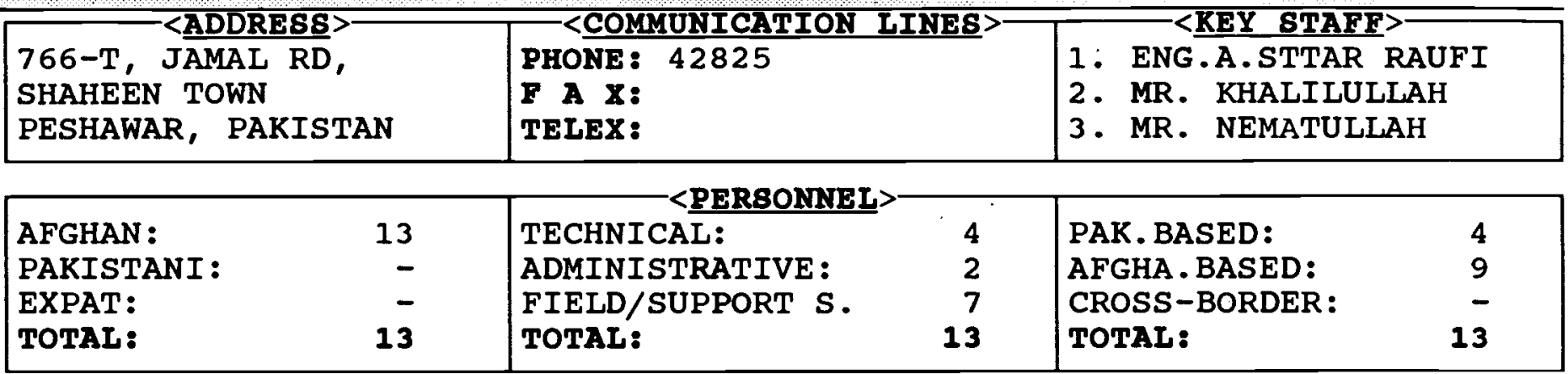

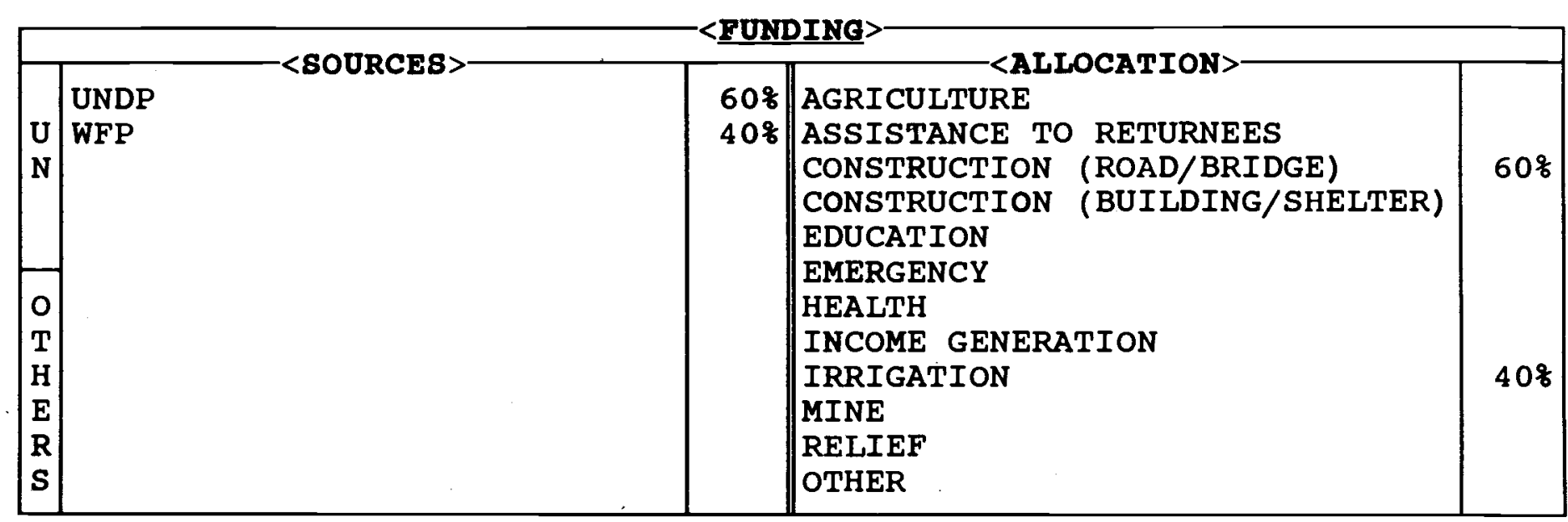

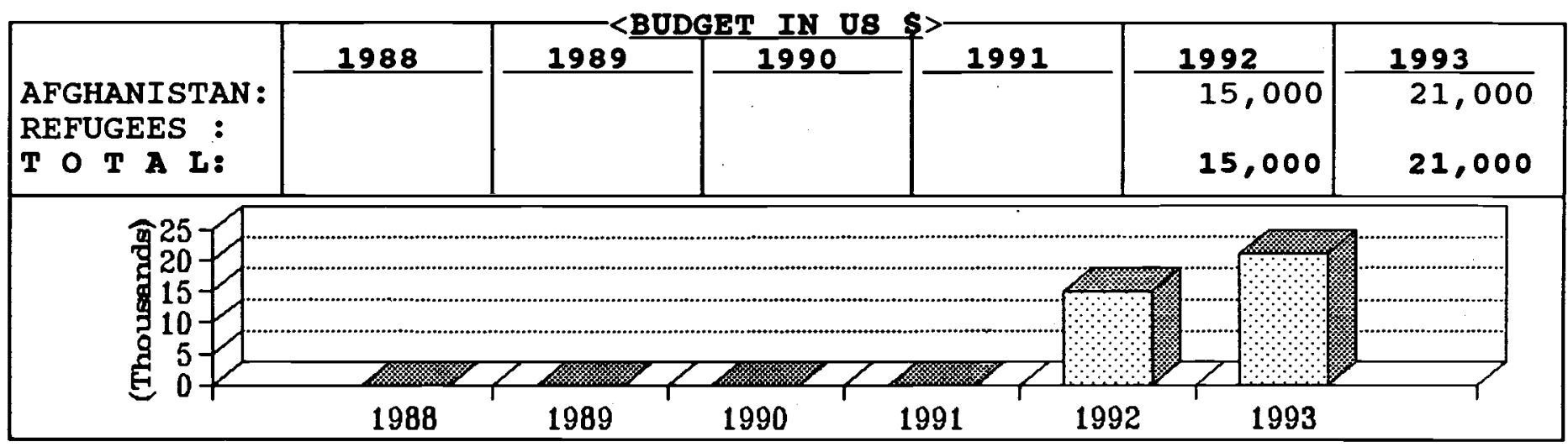

\begin{tabular}{|c|c|c|c|c|c|}
\hline PROVINCES & SECTOR & \%AGE & PROVINCES & SECTOR & $\because A G E$ \\
\hline $\begin{array}{l}\text { BADAKSHAN } \\
\text { BADGHIS } \\
\text { BAGHLAN } \\
\text { BALKH } \\
\text { BAMYAN } \\
\text { FARAH } \\
\text { FARYAB } \\
\text { GHAZNI } \\
\text { GHOR } \\
\text { HELMAND } \\
\text { HERAT } \\
\text { JAWZJAN } \\
\text { KABUL } \\
\text { KANDAHAR } \\
\text { KAPISA }\end{array}$ & & & $\begin{array}{l}\text { KUNAR } \\
\text { KUNDUZ } \\
\text { LAGHMAN } \\
\text { LOGAR } \\
\text { NANGARHAR } \\
\text { NIMROZ } \\
\text { ORUZGAN } \\
\text { PAKTEKA } \\
\text { PAKTIA } \\
\text { PARWAN } \\
\text { SAMANGAN } \\
\text { TAKHAR } \\
\text { WARDAK } \\
\text { ZABUL }\end{array}$ & $\begin{array}{l}\text { Irrign } \\
\text { Const (road) }\end{array}$ & $40 \%$ \\
\hline
\end{tabular}


is än Afghan NGO established in June 1992 to participate in the rehabilitation process of war torn Afghanistan. The agency started its activities after establishing full contacts with the local shuras of target areas and extensive negotiations with NGOs, UN agencies and other organizations working in the same areas.

RDP's sectors of work include reconstruction of roads and bridges; construction of public buildings e.g. schools, hospitals, clinics, mosques and clinics; rehabilitation of irrigation systems and implementation of agricultural projects e.g. seed multiplication and distribution and poultry management.

since its establishment, RDP has implemented a secondary road rehabilitation project $(2.4 \mathrm{~km})$ between Domanda and Khost. It has submitted a number of project proposals to different donor organizations which are pending for approval.

RDP has been registered with the Government of Islamic state of Afghanistan and has applied for registration with the Government of Pakistan. The agency is a member of Afghan NGOs Coordinating Body (ANCB) . 
RURAL DEVELOPKENT OF WARDAK-RDW

\begin{tabular}{|c|c|c|}
\hline$=<$ ADDRESB $>=$ & $-<$ COMMUNICATION LINES $>$ & $-\langle$ REY STAFF \\
\hline $\begin{array}{l}\text { CANAL ROAD, U/T } \\
\text { P O BOX . . . … . . } \\
\text { PESHAWAR, PAKISTAN }\end{array}$ & $\begin{array}{l}\text { PHONE: } 42947 \\
\text { F A X: } 220496 \\
\text { TELEX: }\end{array}$ & $\begin{array}{l}\text { 1. ABDUL WAHAB KAMAL } \\
\text { 2. ZAINUDDIN } \\
\text { 3. FAWADUDDIN }\end{array}$ \\
\hline
\end{tabular}

\begin{tabular}{|lr|lr|lr|}
\hline AFGHAN : & 10 & TECHNICAL: & 4 & PAK. BASED: & 4 \\
PAKISTANI : & 1 & ADMINISTRATIVE: & 2 & AFGHA.BASED: & 7 \\
EXPAT: & - & FIELD/SUPPORT S. & 5 & CROSS-BORDER: & - \\
TOTAL: & 11 & TOTAL: & 11 & TOTAL: & 11 \\
\hline
\end{tabular}

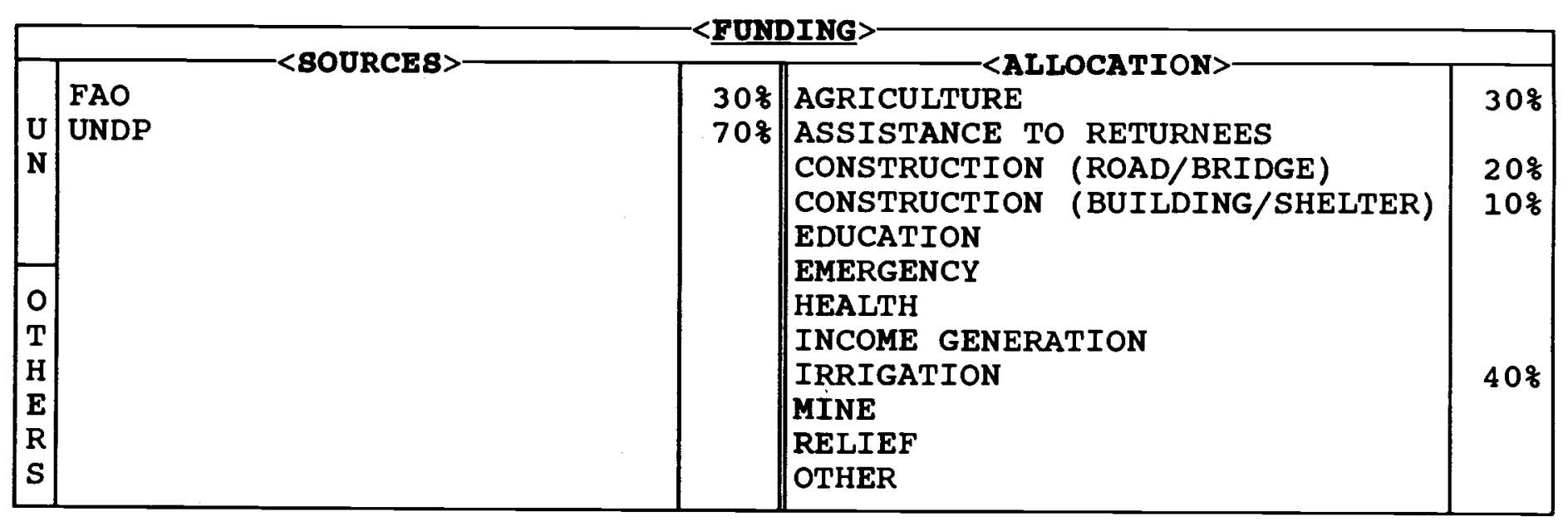

\begin{tabular}{|c|c|c|c|c|c|c|}
\hline $\begin{array}{l}\text { AFGHANISTAN: } \\
\text { REFUGEES : } \\
\text { TO T A L: }\end{array}$ & 1988 & 1989 & $\begin{array}{r}\frac{1990}{50,000} \\
50,000\end{array}$ & $\begin{array}{l}\frac{1991}{50,000} \\
50,000\end{array}$ & $\begin{array}{l}\frac{1992}{50,000} \\
50,000\end{array}$ & $\begin{array}{l}1993 \\
50,000 \\
50,000\end{array}$ \\
\hline 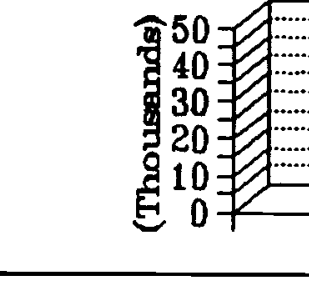 & 1988 & 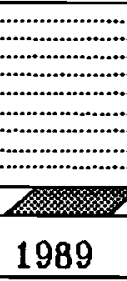 & 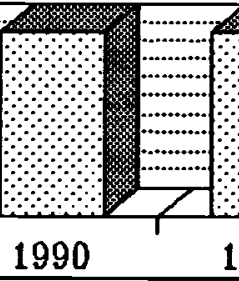 & 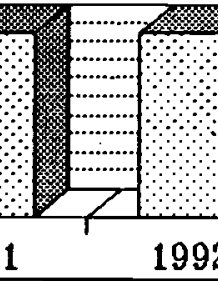 & 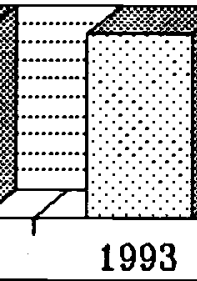 & (N) \\
\hline
\end{tabular}

\begin{tabular}{|c|c|c|c|c|c|}
\hline PROVINCES & SECTOR & \&AGE & PROVINCES & SECTOR & $\%$ AGE \\
\hline $\begin{array}{l}\text { BADAKSHAN } \\
\text { BADGHIS } \\
\text { BAGHLAN } \\
\text { BALKH } \\
\text { BAMYAN } \\
\text { FARAH } \\
\text { FARYAB } \\
\text { GHAZNI } \\
\text { GHOR } \\
\text { HELMAND } \\
\text { HERAT } \\
\text { JAWZJAN } \\
\text { KABUL } \\
\text { KANDAHAR } \\
\text { KAPISA }\end{array}$ & & & $\begin{array}{l}\text { KUNAR } \\
\text { KUNDUZ } \\
\text { LAGHMAN } \\
\text { LOGAR } \\
\text { NANGARHAR } \\
\text { NIMROZ } \\
\text { ORUZGAN } \\
\text { PAKTEKA } \\
\text { PAKTIA } \\
\text { PARWAN } \\
\text { SAMANGAN } \\
\text { TAKHAR } \\
\text { WARDAK } \\
\text { ZABUL }\end{array}$ & $\begin{array}{l}\text { Agr } \\
\text { Agr/const/irrign }\end{array}$ & 158 \\
\hline
\end{tabular}




\section{RURAL DEVELOPMENT OF WARDAR (RDW)}

is an Afghan humanitarian organization established in 1991.

RDW is committed to provide assistance in the fields of agriculture, irrigation, roads/bridges and shelter/buildings. The focus of the organization is primarily the province of Wardak. However, it has extended its programs to Logar province.

over the past three years RDW has implemented several projects including seed multiplication and extension and irrigation rehabilitation. RDW projects have been mostly supported by the United Nations organizations namely UNDP and FAO. RDW is looking forward to receiving funds from other sources. 


\section{BANDY GALL AFGHANIBTAN APPEAL (SGAA)}

is a British NGO set up in 1986 specifically to provide assistance for disabled Afghans.

The organization has a UK office and is based at the Integrated Training Center in Hayatabad, Peshawar where SGAA has an orthopaedic workshop and a physiotherapy department. In the workshop, Afghan orthopaedic technicians are trained for two years to make and fit artificial limbs, splints and calipers from a mixture of local and imported materials. In the physiotherapy department, Afghan physiotherapy technicians are trained for one year to treat patients using predominantly manual physiotherapy techniques. Once the technicians have graduated, they are established in independent workshops, clinics or hospitals in conjunction with the local health authorities inside Afghanistan or in the refugee camps in Pakistan.

Beneficiaries fall into two categories. Firstly, those with war and trauma injuries such as: upper and lower limb amputees, the young disabled suffering from brain damage and peripheral nerve injuries caused by bullet-injury and bomb-blasts, and fracture and burns cases. The second category includes disabled children suffering from the effect of poliomyelitis, cerebral palsy, tuberculosis, spina bifida, meningitis, club foot and scoliosis of the spine.

SGAA also works with Pakistan Red Crescent's (PRC) Project for the Disabled in which 46 physiotherapy technicians have been trained since April 1988 to work in the physiotherapy department at PRC's clinic in Peshawar and in Basic Health Units in the camps. Technicians from PRC are trained and supervised by SGAA's expatriate physiotherapists.

SGAA is running three small orthopaedic workshops inside
Afghanistan, $\begin{gathered}\text { funded } \\ \text { employing }\end{gathered}$ by $\begin{array}{r}\text { wHO, } \\ \text { fully }\end{array}$
trained orthopaedic technicians and 3 physiotherapy technicians. 
SAUDI RED CRESCENT SOCIETY-SRCS

\begin{tabular}{|c|c|c|c|c|}
\hline $\begin{array}{l}2 \text { GULMOHAR RD, U/T, } \\
\text { P O BOX } 347, \\
\text { PESHAWAR, PAKISTAN }\end{array}$ & $\begin{array}{l}\text { CCOMMUNICATION } \\
\text { PHONE: } 840231 / 840 \\
\text { F A X: } 52485 \\
\text { TELEX: } 52482 \text { SRCS }\end{array}$ & $\begin{array}{l}\text { IINES }> \\
07 \\
\text { PK }\end{array}$ & $\begin{array}{l}\text { 1. MR. } \frac{\text { KEY STA }}{\text { I. AL }} \\
\text { 2. } \\
\text { 3. }\end{array}$ & AIN \\
\hline $\begin{array}{l}\text { AFGHAN : } \\
\text { PAKISTANI : } \\
\text { EXPAT: } \\
\text { TOTAL: }\end{array}$ & $\begin{array}{l}\text { TECHNICAL: } \\
\text { ADMINISTRATIVE: } \\
\text { FIELD/SUPPORT S. } \\
\text { TOTAL: }\end{array}$ & $\begin{array}{l}\cdots \\
\cdots \\
\cdots\end{array}$ & $\begin{array}{l}\text { PAK. BASED: } \\
\text { AFGHA. BASED: } \\
\text { CROSS-BORDER: } \\
\text { TOTAL: }\end{array}$ & $\begin{array}{l}\cdots \\
\cdots \\
\cdots\end{array}$ \\
\hline
\end{tabular}

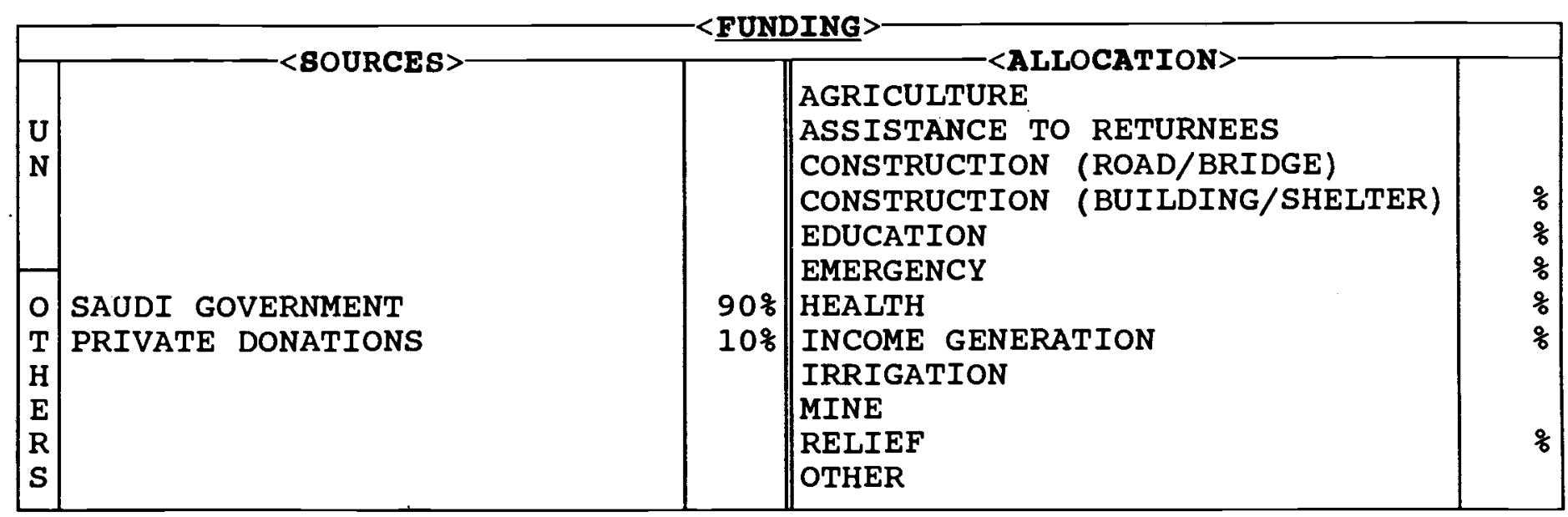

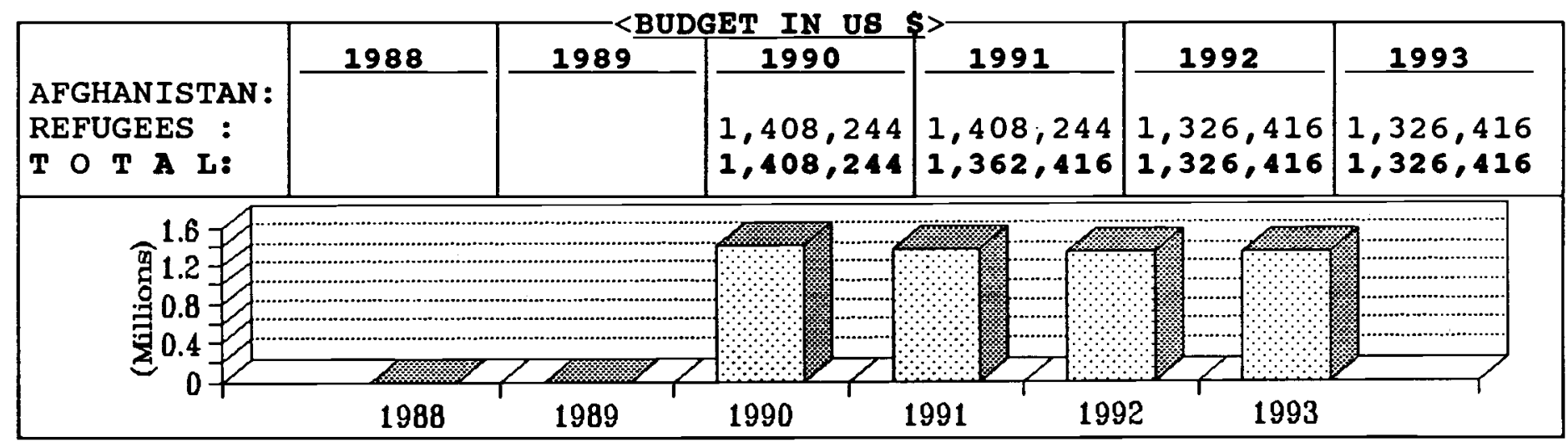

\begin{tabular}{|c|c|c|c|c|c|}
\hline PROVINCES & SECTOR & OAGE & PROVINCES & SECTOR & $\because A G E$ \\
\hline $\begin{array}{l}\text { BADAKSHAN } \\
\text { BADGHIS } \\
\text { BAGHLAN } \\
\text { BALKH } \\
\text { BAMYAN } \\
\text { FARAH } \\
\text { FARYAB } \\
\text { GHAZNI } \\
\text { GHOR } \\
\text { HELMAND } \\
\text { HERAT } \\
\text { JAWZJAN } \\
\text { KABUL } \\
\text { KANDAHAR }\end{array}$ & & & $\begin{array}{l}\text { KUNAR } \\
\text { KUNDUZ } \\
\text { LAGHMAN } \\
\text { LOGAR } \\
\text { NANGARHAR } \\
\text { NIMROZ } \\
\text { ORUZGAN } \\
\text { PAKTEKA } \\
\text { PAKTIA } \\
\text { PARWAN } \\
\text { SAMANGAN } \\
\text { TAKHAR } \\
\text { WARDAK } \\
\text { ZABUL }\end{array}$ & & \\
\hline
\end{tabular}

NOTE: BUDGET FIGURES ONLY INCLUDE MEDICINE COST. 
is a Governmental Agency of Kingdom of Saudi Arabia and is a member of International Committee of Red Cross and Red Crescent Societies. SRCS started its activities for Afghan refugees in Pakistan in health and relief sectors in 1979 .

\section{HEALTH :}

BHUs: provides comprehensive health cover (MCH, TB and malaria control, control of diarrhoeal diseases, health education/environmental sanitation and general patients treatment) in Kacha Garhi, Nasir Bagh, Daag Besud, Jalozai and $\mathrm{zindai}$ camps. During 1992-93 approximately 700,000 patients were treated and some 15,000 doses of vaccines were given under the EPI program.

Hospitals: SRCS runs 3 hospitals for Afghan refugees in Pakistan: a. Prince sultan TB hospital in Kacha Garhi camp, Peshawar. It has 30 beds, a male and a female wards, an emergency observation room, OPD, lab and $\mathrm{X}$-ray services. 85,495 patients were screened for $T B$ in the hospital during 1992-93. b. Mecca Mukarrama Hospital in quetta. It is a 163 bed surgical hospital provides services mainly for war casualties. c. Prince sultan Al-Slam Hospital in Saranan, Quetta. It is a 100 bed hospital which has surgical and medical wards, OPD, $l a b$ and $x$-ray facilities.

Mobile Units: SRCS operates a mobile unit to visit 9 orphan centers established for refugees in different parts of Peshawar; 3 major and 5 minor mobile operation theaters to visit the distant areas of NWFP and Baluchistan.

Field Referral Lab: 3 of them have been established in different parts of Peshawar.

Medicine Aid: a number of hospitals and clinics both for refugees and inside Afghanistan receive medicine supplies from SRCS either regularly or casually.

Programs for Disabled Afghans: A artificial prosthesis supply program were in operation by late 1993 in Peshawar.

Dental Care: A dental unit has been established.

Sponsorship: sponsorship has been provided for the treatment and other expenses of over 500 patients with complicated cases to different hospitals in Pakistan and overseas.

Training: 23 courses have been completed which have graduated 415 students as TB technicians, midlevel HWs, malaria supervisors, vaccinators and field microscopist. Training workshops have also been organized for medical staff.

RELIEF: SRCS has the following activities for income generation and free distribution purposes:

ouilt Making: 1,000 quilts are made daily by widows at Nasir Bagh.

Shoe Making: 700 pairs of shoes are produced daily by 700 Afghans.

Tailoring: 500 sewing machines have been provided to disabled Afghans who produce 1,000 pairs of clothes daily for gents, ladies and babies.

Workshops: 3 carpentry and blacksmith workshops have been established and skilled Afghans work in the workshops and train students on payment basis.

Factories: A 20 loom blanket factory and a 50 man tent factory have been established.

All of the products are distributed to refugees throughout Pakistan. In addition, sRCs distributes roofing materials, sleeping bags and ready made clothing as well as food commodities to refugees.

Training is provided in different skills to disabled Afghans.

Furthermore, SRCS builds mosques and digs tube-wells in refugee camps. It also supports two schools in

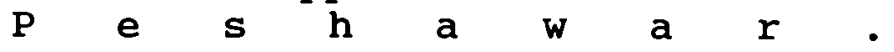


SAVE THE CHILDREN (USA)-SC-OS

- 2 ADDRESS $>-$ - COMMUNICATION LINES $>$

223, ST.50, F-10/4

P O BOX 1952

ISLAMABAD, PAKISTAN
PHONE: $859313 / 856727$

F A X: 824902

TELEX:
1. MR. MARK EDINGTON

2 .

3.

\begin{tabular}{|lr|ll|lr|}
\hline AFGHAN : & 276 & TECHNICAL: & $\ldots$ & PAK. BASED: & 303 \\
PAKISTANI : & 60 & ADMINISTRATIVE : & $\ldots$ & AFGHA. BASED: & 36 \\
EXPAT: & 3 & FIELD/SUPPORT S. & $\ldots$ & CROSS-BORDER: & - \\
TOTAL: & 339 & TOTAL: & 339 & TOTAL: & 339 \\
\hline
\end{tabular}

\begin{tabular}{|c|c|c|c|c|}
\hline & & & $\mathrm{NG}^{\prime}$ & \\
\hline & UNDP & $23 \%$ & $\begin{array}{l}\text { AGRICULTURE } \\
\text { ALLOCATION }>- \\
\end{array}$ & $5 \%$ \\
\hline $\mathrm{U}$ & UNHCR & $15 \%$ & ASSISTANCE TO RETURNEES & \\
\hline $\mathbf{N}$ & & & CONSTRUCTION（ROAD/BRIDGE) & $18 \%$ \\
\hline & & & CONSTRUCTION (BUILDING/SHELTER) & \\
\hline 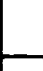 & & & $\begin{array}{l}\text { EDUCATION } \\
\text { EMERGENCY }\end{array}$ & \\
\hline 0 & ASIA FOUNDATION & 18 & HEALTH & 268 \\
\hline $\mathbf{T}$ & AUSTCARE & 68 & INCOME GENERATION & $18 \%$ \\
\hline $\mathrm{H}$ & BRP & $19 \%$ & IRRIGATION & $20 \%$ \\
\hline $\mathbf{E}$ & IRC/RAP & 268 & MINE & \\
\hline $\mathbf{R}$ & SC PRIVATE & $10 \%$ & RELIEF & \\
\hline $\mathbf{s}$ & & & OTHER (ADMIN) & $13 \%$ \\
\hline
\end{tabular}

\begin{tabular}{|c|c|c|c|c|c|c|}
\hline $\begin{array}{l}\text { AFGHANISTAN: } \\
\text { REFUGEES : } \\
\text { T O T A L: }\end{array}$ & $\begin{array}{r}1988 \\
110,987 \\
943,396 \\
1,054,383\end{array}$ & $\begin{array}{c}\frac{1989}{1,224,289} \\
1,126,346 \\
2,350,635\end{array}$ & $\begin{array}{l}1990 \\
1,718,092 \\
1,718,092 \\
3,436,184\end{array}$ & $\begin{array}{r}\frac{1991}{1,453,690} \\
928,338 \\
2,382,028\end{array}$ & $\begin{array}{r}1992 \\
803,638 \\
946,520 \\
1,750,158\end{array}$ & 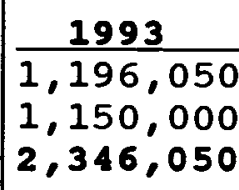 \\
\hline & 1988 & 1989 & 1990 & - & - & 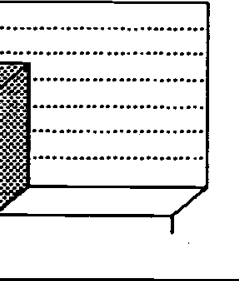 \\
\hline
\end{tabular}

\begin{tabular}{|c|c|c|c|c|c|}
\hline PROVINCES & SECTOR & \&AGE & PROVINCES & SECTOR & $\% \mathrm{AGE}$ \\
\hline $\begin{array}{l}\text { BADAKSHAN } \\
\text { BADGHIS } \\
\text { BAGHLAN } \\
\text { BALKH } \\
\text { BAMYAN } \\
\text { FARAH } \\
\text { FARYAB } \\
\text { GHAZNI } \\
\text { GHOR } \\
\text { HELMAND } \\
\text { HERAT } \\
\text { JAWZJAN } \\
\text { KABUL } \\
\text { KANDAHAR } \\
\text { KAPISA }\end{array}$ & $\begin{array}{l}\text { Health/income gen } \\
\text { Ag/const/irrign/inc.g } \\
\text { Agr/const/irrign }\end{array}$ & 328 & \begin{tabular}{||l} 
KUNAR \\
KUNDUZ \\
LAGHMAN \\
LOGAR \\
NANGARHAR \\
NIMROZ \\
ORUZGAN \\
PAKTEKA \\
PAKTIA \\
PARWAN \\
SAMANGAN \\
TAKHAR \\
WARDAK \\
ZABUL
\end{tabular} & Agr/const/irrign & $14 \frac{8}{6}$ \\
\hline
\end{tabular}




\section{SAVE THE CHILDREN/USA (SC-US)}

was founded in 1932 to help coal miner's children suffering the effects of the Great Depression in Appalachia, United States. SC's mission is to make lasting and positive differences in the lives of disadvantaged children, their families and the communities in which they live. SC is a nonpolitical and non-religious organization that now works in more than 35 countries around the world, both in relief and long-term development. Most country programs focus on primary health, basic education and income generating activities. SC's key working principles are that projects should be women and child focused, and aim for significant community participation and sustainability.

SC began its first projects for Afghan refugees in Pakistan in 1985 and commenced cross border projects in 1988 .

In Pakistan SC operates self-help projects for Afghan refugees in Mianwali, Mansehra, Haripur, Mardan, Islamabad and Quetta which generate income and offer training in a wide range of skills. The skills include basic literacy and numeracy, health and hygiene education, craft production (embroidery, weaving, tailoring, finishing and carpet making), marketing and project administration/management. In addition SC administers a health project which provides clinical and preventative primary health services to Afghan refugees in Ghazi and Haripur refugee camps.

In Afghanistan SC has implemented projects in Zabul, Ghazni, Kandahar, Nangarhar and Baghlan provinces, managed out of offices in Peshawar and Quetta. These projects have focused on assisting communities in agricultural rehabilitation by repairing irrigation systems and providing seed, fertilizer and training to farmers. Training sessions included plant protection and pest control methods, soil conservation, water management and veterinary health. SC also implemented various infrastructure projects including flood control measures, schools, roads and housing. SC's women's programs in Afghanistan included income generating crafts projects and small scale poultry/animal husbandry projects.

SC expects to maintain its commitment to Afghan refugee programs as long as a substantial refugee presence remains in Pakistan.

In Afghanistan SC intends to shift programs away from cross border type projects to integrated development programs managed from offices in Afghanistan. Initially SC will establish an office in Mazar-iSharif to manage existing programs in Baghlan. Additional offices will be established in other parts of the country if and when security $p \quad e \quad r \quad m \quad i \quad t \quad s \quad$ 
BAVE THE CHILDREN FUND/UK-8CF-UR.

\begin{tabular}{|l|l|l|}
\hline 7-E MULBERRY RD, U/T & PHONE: 45306 & < COEY STAFF> \\
P O BOX 1II7 & F A X: C/O (051) 820387 & 1. DR. ZABIHULLAH \\
PESHAWAR, PAKISTAN & TELEX: DR. QUDSIA IFFAMI & 3. MR. MICHAEL SCOTT \\
\hline
\end{tabular}

\begin{tabular}{|lr|ll|ll|}
\hline AFGHAN: & 35 & TECHNICAL: & $\ldots$ & PAK. BASED: & $\ldots$ \\
PAKISTANI: & 25 & ADMINISTRATIVE: & $\ldots$ & AFGHA. BASED: & $\ldots$ \\
EXPAT: & 1 & FIELD/SUPPORT S. & $\cdots$ & CROSS-BORDER: & $\ldots$ \\
TOTAL: & 61 & TOTAL: & 61 & TOTAL: & 61 \\
\hline
\end{tabular}

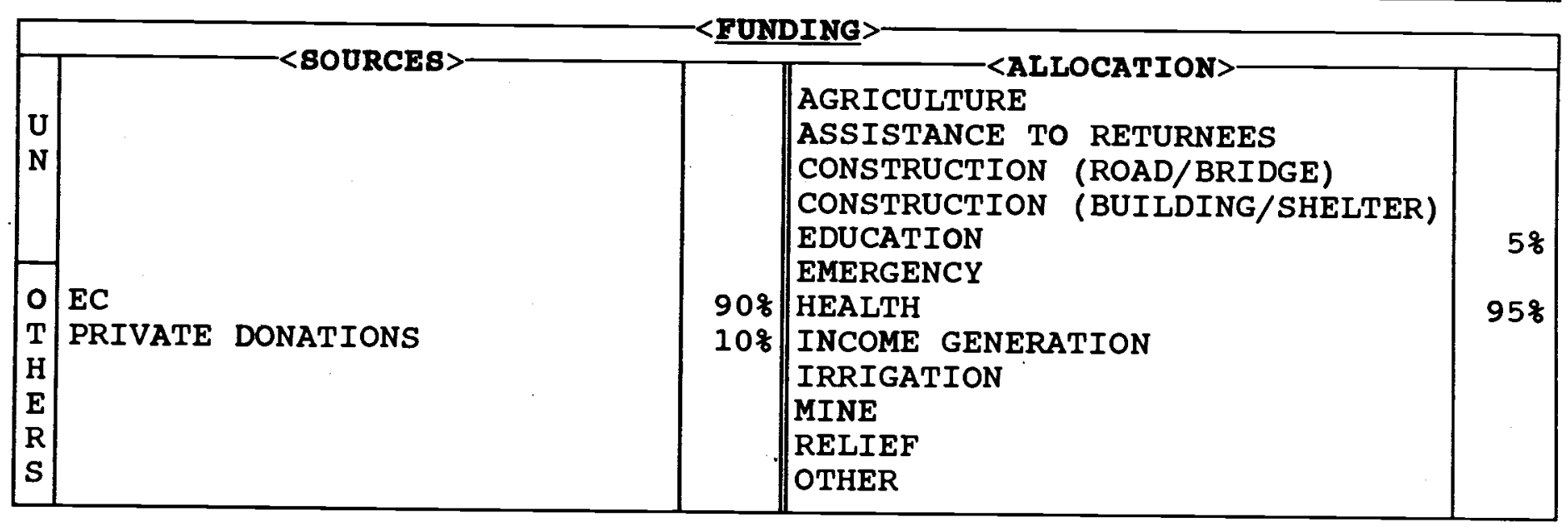

\begin{tabular}{|c|c|c|c|c|c|c|}
\hline \multirow{2}{*}{$\begin{array}{l}\text { AFGHANISTAN: } \\
\text { REFUGEES : } \\
\text { T O T A L: }\end{array}$} & \multirow[t]{2}{*}{1988} & \multirow{2}{*}{$\begin{array}{l}1989 \\
779,351 \\
779,351\end{array}$} & \multirow{2}{*}{$\begin{array}{l}1990 \\
895,455 \\
895,455\end{array}$} & \multirow{2}{*}{$\begin{array}{l}1991 \\
945,455 \\
945,455\end{array}$} & \multirow{2}{*}{$\begin{array}{l}1992 \\
908,466 \\
908,466\end{array}$} & \multirow{2}{*}{$\begin{array}{l}1993 \\
77,000 \\
280,000 \\
357,000\end{array}$} \\
\hline & & & & & & \\
\hline 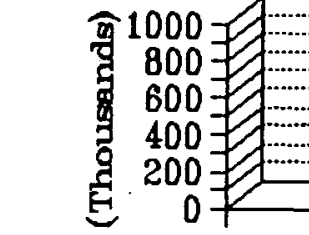 & 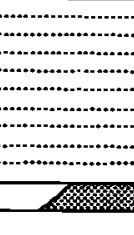 & & ;is & 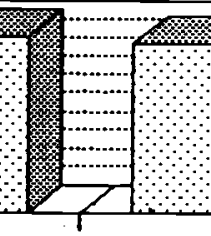 & $a_{1}$ & r.v. \\
\hline & 1988 & 1989 & 1990 & 199 & 1993 & \\
\hline
\end{tabular}

\begin{tabular}{|c|c|c|c|c|c|}
\hline PROVINCES & SECTOR & \&AGE & PROVINCES & SECTOR & \&AGE \\
\hline $\begin{array}{l}\text { BADAKSHAN } \\
\text { BADGHIS } \\
\text { BAGHLAN } \\
\text { BALKH } \\
\text { BAMYAN } \\
\text { FARAH } \\
\text { FARYAB } \\
\text { GHAZNI } \\
\text { GHOR } \\
\text { HELMAND } \\
\text { HERAT } \\
\text { JAWZJAN } \\
\text { KABUL } \\
\text { KANDAHAR } \\
\text { KAPISA }\end{array}$ & Educ (considering) & 8 & \begin{tabular}{||l} 
KUNAR \\
KUNDUZ \\
LAGHMAN \\
LOGAR \\
NANGARHAR \\
NIMROZ \\
ORUZGAN \\
PAKTEKA \\
PAKTIA \\
PARWAN \\
SAMANGAN \\
TAKHAR \\
WARDAK \\
ZABUL
\end{tabular} & & \\
\hline
\end{tabular}


SAVE THE CHILDREN FUND (SCF-UK)

has been involved in primary health care worker training and general health services in the Afghan refugee camps for fourteen years, through its Afghan Refugee Program (ARP). Today, following the closure at the end of August 1993 of the ARP's main office in University Town, Peshawar, SCF is striving to maintain the following health services for Afghan refugees in the NWFP :

- The Badaber Basic Health Unit (BHU) including a highly successful outreach program serving 18,000 Afghan refugees in the Badaber area camps;

- a core PHC training team operating from the Badaber Training center to upgrade and refresh the skills of health workers working in concert with UNHCR-supported BHUs in the Peshawar area.

The decision to seek to maintain these minimal health and training services beyond the end of our EC funding (June 1993) was taken after discussion with health service professionals and senior management in SCF, UNICEF (Pakistan Program) and UNHCR (Peshawar); and after reviewing the rates of repatriation from the area, demand for the BHU, and so on. SCF is also motivated by the desire to ensure that valuable lessons from the accumulated experience of 14 years of work in the area can be invested in new work in the Pakistani communities of the NWFP, as well as to address any new needs as they arise in the changing Afghan refugee context in the area.

The Badaber BHU's outpatient, $\mathrm{MCH}$, EPI, laboratory and outreach work can be maintained until the end of December 1993 using remaining EC funds in the ARP 1992-93 budget; the SCF financial year finishes on March 31 1994, before it is handed over to the PDH/UNHCR.

A core SCF/ARP Primary Health Care Training Team has been retained beyond the closure of ARP's administration office with the hope of receiving financial assistance for this from UNICEF, via UNHCR and other possible donors. The need and feasibility of continued SCF management of both of these activities beyond December 1993 will be assessed over the coming 4 month period.

The new main location of the administrative and logistic support offices of these on-going activities is ARP's "Badaber Training Center". This site is conveniently located on the main Kohat road near the Badaber BHU and serves the most likely areas of extension of outreach to Pakistani villages; it could be an ideal school or training site should all "ARP" activities under discussion come to an end. The staff retained will continue to improve PHCW motivation, monitoring and supervision and are considered some of the best in the field. 
SAYYED-JAMALUDDIN AFGHANI FOUNDATION FOR AFGHANISTAN-8AFA

-
13, ST.1, SARDAR COLONY
P O BOX .........
PHONE : 214960
1. ENG. KHAN M. NIZAM
F A X:
2. ENG. BARIALAY
PESHAWAR, PAKISTAN
TELEX:
3. DR. M. DIN

\begin{tabular}{|lr|lr|lr|}
\hline AFGHAN: & 15 & TECHNICAL: & 6 & PAK. BASED: & 7 \\
PAKISTANI : & - & ADMINISTRATIVE: & 2 & AFGHA.BASED: & 8 \\
EXPAT: & - & FIELD/SUPPORT S. & 7 & CROSS-BORDER: & - \\
TOTAL: & 15 & TOTAL: & 15 & TOTAL: & 15 \\
\hline
\end{tabular}

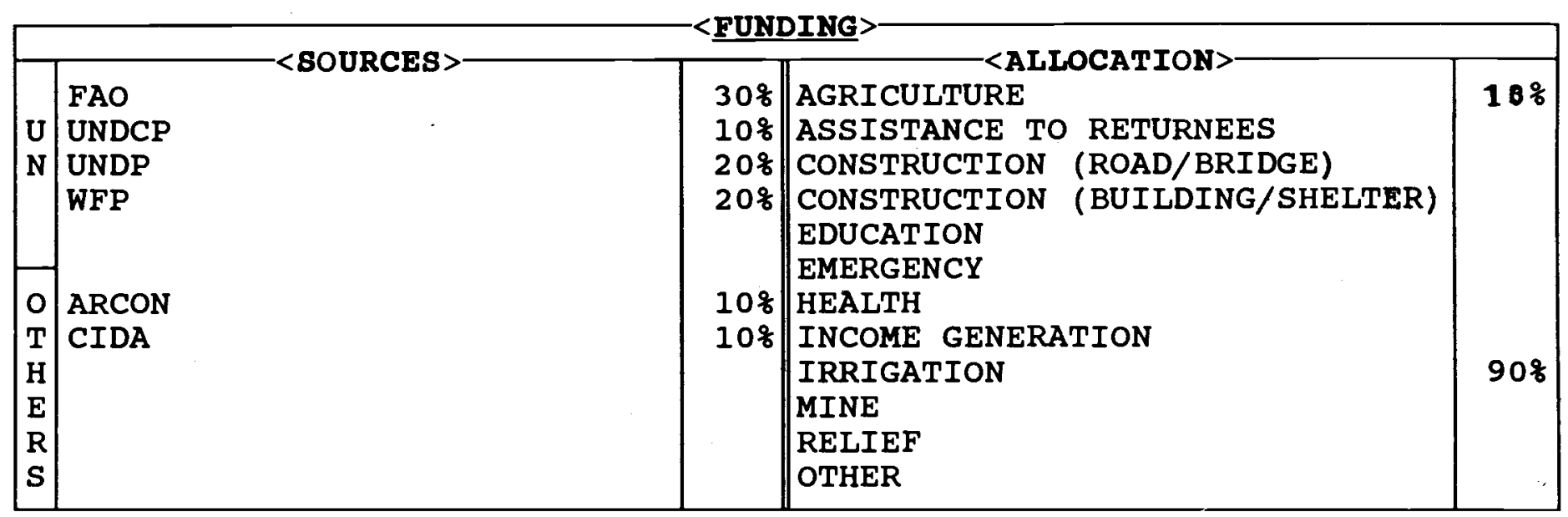

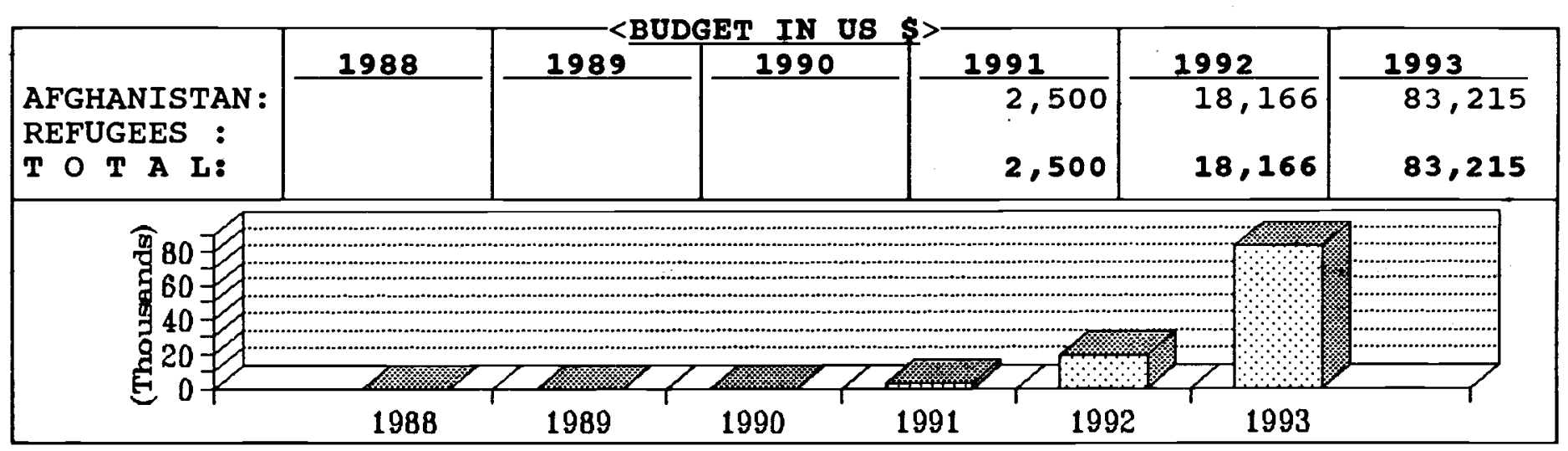

\begin{tabular}{|c|c|c|c|c|c|}
\hline PROVINCES & SECTOR & \&AGE & PROVINCES & SECTOR & $\% A G E$ \\
\hline $\begin{array}{l}\text { BADAKSHAN } \\
\text { BADGHIS } \\
\text { BAGHLAN } \\
\text { BALKH } \\
\text { BAMYAN } \\
\text { FARAH } \\
\text { FARYAB } \\
\text { GHAZNI } \\
\text { GHOR } \\
\text { HELMAND } \\
\text { HERAT } \\
\text { JAWZJAN } \\
\text { KABUL } \\
\text { KANDAHAR } \\
\text { KAPISA }\end{array}$ & & & $\begin{array}{l}\text { KUNAR } \\
\text { KUNDUZ } \\
\text { LAGHMAN } \\
\text { LOGAR } \\
\text { NANGARHAR } \\
\text { NIMROZ } \\
\text { ORUZGAN } \\
\text { PAKTEKA } \\
\text { PAKTIA } \\
\text { PARWAN } \\
\text { SAMANGAN } \\
\text { TAKHAR } \\
\text { WARDAK } \\
\text { ZABUL }\end{array}$ & $\begin{array}{l}\text { Agr/power } \\
\text { Agr/irrign }\end{array}$ & 91 \\
\hline
\end{tabular}


is a relief and voluntary nongovernmental organization founded in 1990 under the name of "Telecommunication and Power Reconstruction program for Afghanistan". The organization was established by a number of professional and experienced Afghan engineers, especially in the sectors of telecommunication and power. since there has not been much interest in the mentioned sectors by donor organizations, the Board of Advisors of the organization in late 1993 decided to change the name and the mandate of the agency. The agency now carries out irrigation, agriculture and construction projects in addition to small activities in the sectors of power and telecommunication.

In agriculture, SAFA undertakes agriculture inputs distribution training and extension services and veterinary activities. In irrigation, rehabilitation, reconstruction and improvement of canals, karezes and irrigation structures are undertaken. SAFA also constructs and repairs public buildings e.g. schools, clinics and mosques and rehabilitates roads, bridges and houses. 
<

DARUL KHAIR NEMAT MAHAL P O BOX 974

PESHAWAR, PAKISTAN

\section{PHONE : 42763}

F A X:

TELEX:
1. HAJI GHULAM DASTAGIR

2 .

3 .

\begin{tabular}{|lr|lr|ll|}
\hline AFGHAN: & 68 & TECHNICAL: & 30 & PAK. BASED: & 30 \\
PAKISTANI : & 3 & ADMINISTRATIVE: & 5 & AFGHA.BASED: & 20 \\
EXPAT: & - & FIELD/SUPPORT S. & 36 & CROSS-BORDER: & 21 \\
TOTAL: & 71 & TOTAL: & 71 & TOTAL: & 71 \\
\hline
\end{tabular}

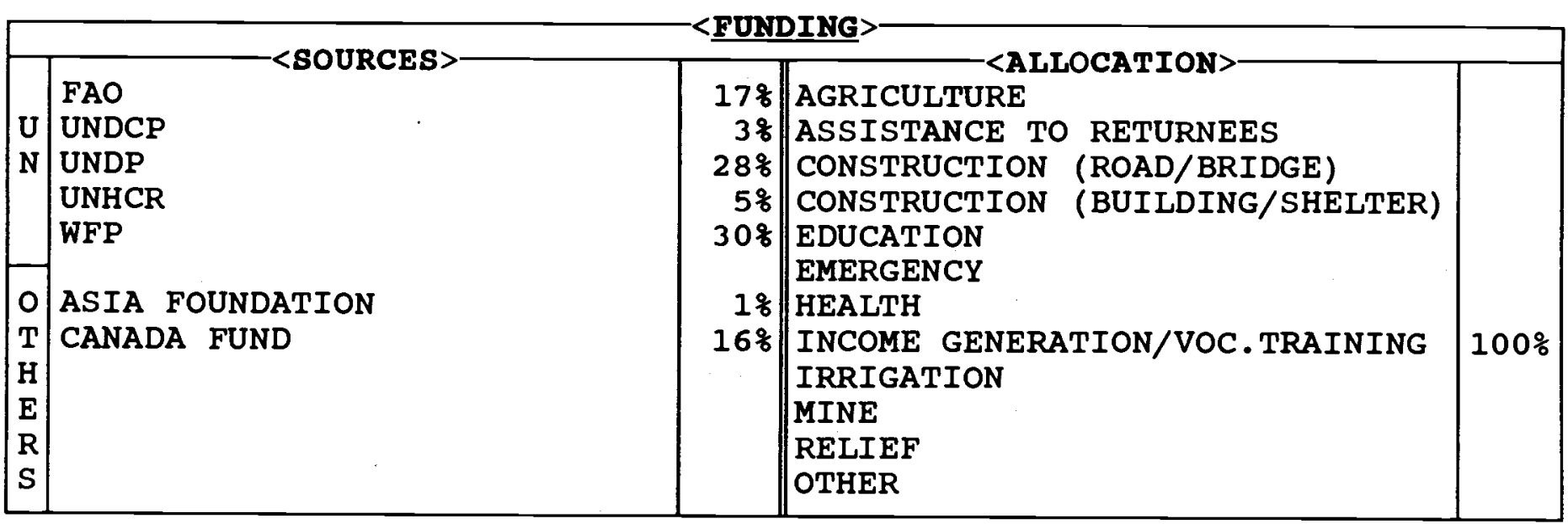

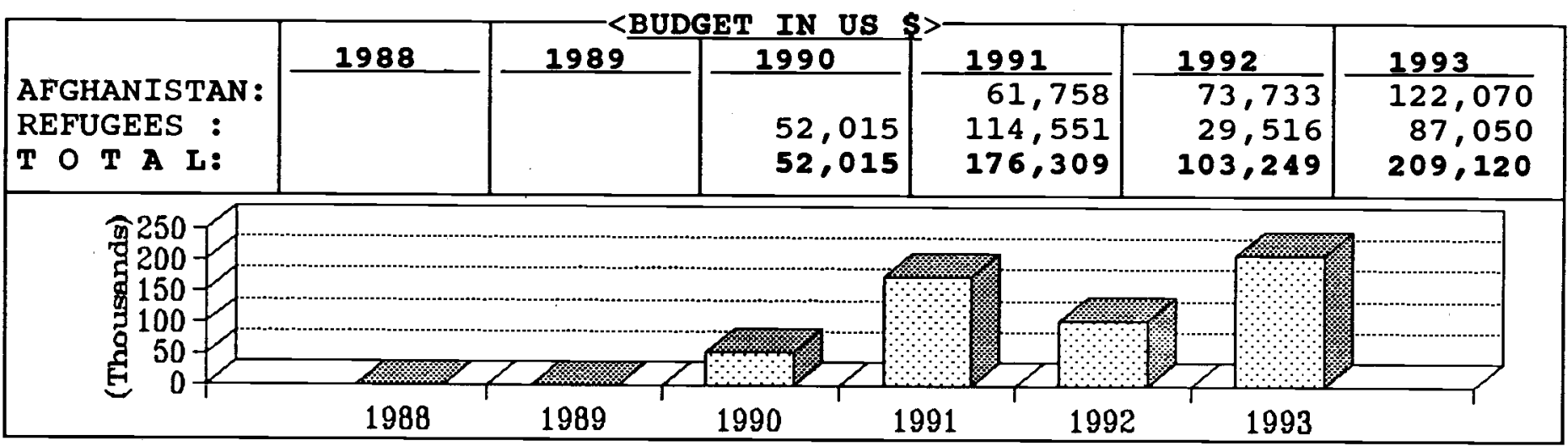

\begin{tabular}{|c|c|c|c|c|c|}
\hline PROVINCES & SECTOR & \&AGE & PROVINCES & SECTOR & $\because A G E$ \\
\hline $\begin{array}{l}\text { BADAKSHAN } \\
\text { BADGHIS } \\
\text { BAGHLAN } \\
\text { BALKH } \\
\text { BAMYAN } \\
\text { FARAH } \\
\text { FARYAB } \\
\text { GHAZNI } \\
\text { GHOR } \\
\text { HELMAND } \\
\text { HERAT } \\
\text { JAWZJAN } \\
\text { KABUL } \\
\text { KANDAHAR } \\
\text { KAPISA }\end{array}$ & Agr & . & \begin{tabular}{l|} 
KUNAR \\
KUNDUZ \\
LAGHMAN \\
LOGAR \\
NANGARHAR \\
NIMROZ \\
ORUZGAN \\
PAKTEKA \\
PAKTIA \\
PARWAN \\
SAMANGAN \\
TAKHAR \\
WARDAK \\
ZABUL
\end{tabular} & $\begin{array}{l}\text { Agr } \\
\text { Agr/irrign/voc.train. } \\
\text { Agr/voc.training }\end{array}$ & $\begin{array}{l}20 \% \\
35 \% \\
35 \%\end{array}$ \\
\hline
\end{tabular}




\section{BAYYED JAMALUDDIN AFGHAN WELFARE ORGANIZATION (SJAWO)}

came into existence in september 1989 as a result of the Russian invasion and over a decade of war in the country.

The organization was founded to take part in the rehabilitation and reconstruction of damaged and destroyed infrastructure through the planning, designing and execution of projects.

A number of projects in the sectors of irrigation, agriculture and health units have been implemented in different parts of Afghanistan notably Kabul, Logar, Nangarhar and Paktia provinces.

SJAWO also undertakes programs in refugees in Pakistan. It has been running several vocational and skill training projects in different trades e.g. welding, carpentry, leather works, black-smithry and carpet weaving, to enable refugees to be able to return home and make a living and take an active part in the rehabilitation of their villages. Some of the training courses are especially designed for disabled and vulnerable groups. Young Afghans are also provided literacy training in the vocational training centers. 
BERVING EMERGENCY RELIEF \& VOCATIONAI ENTERPRISES-SERVE

\begin{tabular}{|c|c|c|}
\hline$-<$ ADDRESS $>$ & $\langle$ <COMMUNICATION LINES & SIA \\
\hline $\begin{array}{l}5 \text { MULBERRY RD, U/T } \\
\text { P O BOX } 477 \\
\text { PESHAWÄR, PAKISTAN }\end{array}$ & $\begin{array}{l}\text { PHONE: } 41706 / 43253 / 40737 \\
\text { F A X: } 840422 \\
\text { TELEX: } 52369 \text { PCO PE PK }\end{array}$ & $\begin{array}{l}\text { 1. MR. STEVE CRAIG } \\
\text { 2. } \\
\text { 3. }\end{array}$ \\
\hline
\end{tabular}

\begin{tabular}{|lr|lc|ll|}
\hline AFGHAN : & 142 & TECHNICAL: & $\ldots$ & PAK. BASED: & $\ldots$ \\
PAKISTANI : & 6 & ADMINISTRATIVE : & $\ldots$ & AFGHA.BASED: & $\cdots$ \\
EXPAT: & 16 & FIELD/SUPPORT S. & $\cdots$ & CROSS-BORDER: & C \\
TOTAL: & 164 & TOTAL: & 164 & TOTAL: & 164 \\
\hline
\end{tabular}

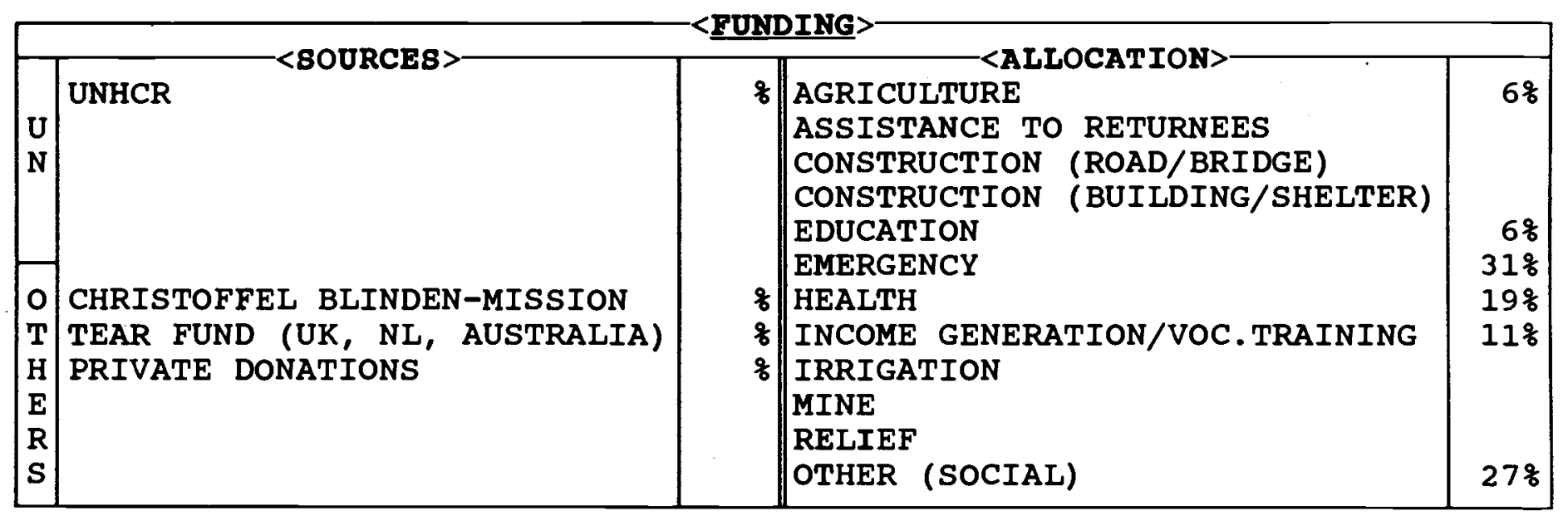

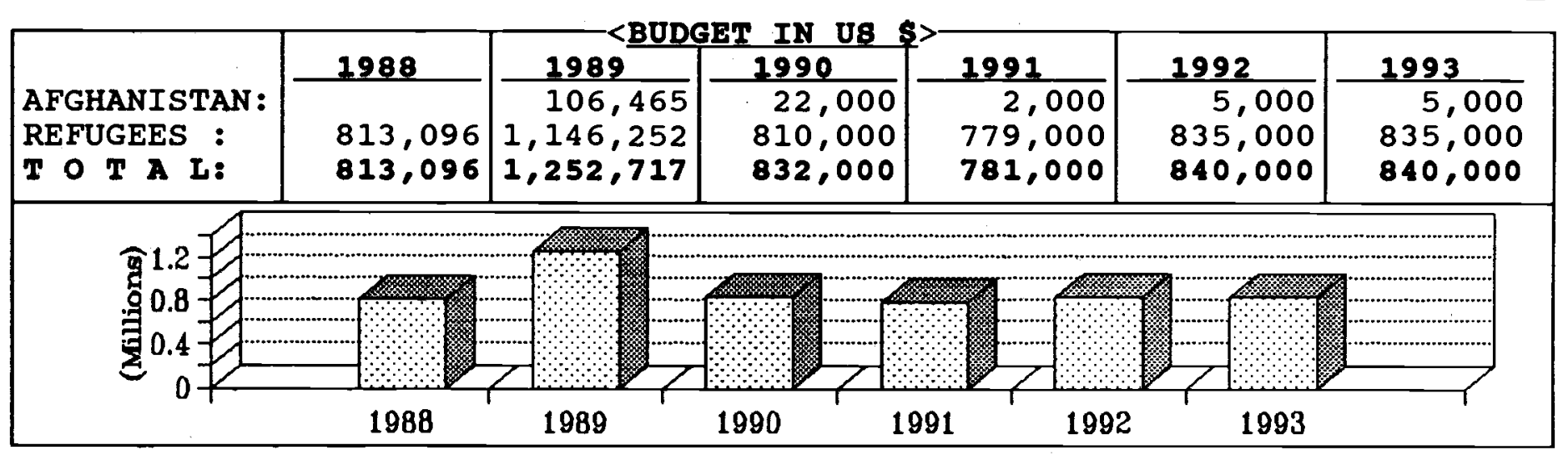

\begin{tabular}{|c|c|c|c|c|c|}
\hline PROVINCES & SECTOR & \&AGE & PROVINCES & SECTOR & \&AGE \\
\hline $\begin{array}{l}\text { BADAKSHAN } \\
\text { BADGHIS } \\
\text { BAGHLAN } \\
\text { BALKH } \\
\text { BAMYAN } \\
\text { FARAH } \\
\text { FARYAB } \\
\text { GHAZNI } \\
\text { GHOR } \\
\text { HELMAND } \\
\text { HERAT } \\
\text { JAWZJAN } \\
\text { KABUL } \\
\text { KANDAHAR } \\
\text { KAPISA }\end{array}$ & $\begin{array}{l}\text { Blind rehab. } \\
\text { Blind rehab. } \\
\text { Relief } \\
\text { Blind rehab. }\end{array}$ & $\begin{array}{l}8 \\
8\end{array}$ & $\begin{array}{l}\text { KUNAR } \\
\text { KUNDUZ } \\
\text { LAGHMAN } \\
\text { LOGAR } \\
\text { NANGARHAR } \\
\text { NIMROZ } \\
\text { ORUZGAN } \\
\text { PAKTEKA } \\
\text { PAKTIA } \\
\text { PARWAN } \\
\text { SAMANGAN } \\
\text { TAKHAR } \\
\text { WARDAK } \\
\text { ZABUL }\end{array}$ & $\begin{array}{l}\text { Agr } \\
\text { Agr } \\
\text { Blind rehab. }\end{array}$ & $\begin{array}{l}q \\
q 8\end{array}$ \\
\hline
\end{tabular}


SERVING EMERGENCY RELIEF AND VOCATIONAL ENTERPRISES (SERVE)

began operations in 1980 in Peshawar. It now consists of 8 projects :

Relief and Development, Public Health, Afghan Eye Hospital, Solar, Carpet Center, Forestry, support Services Blind Afghans and SERVE Hearing Impaired Project.

Major aims of SERVE: To continue providing emergency relief to Afghan refugees arriving in Pakistan, to meet the ongoing needs of refugees dependent on NGO assistance, to assist the Afghan people in reconstruction following repatriation.

Relief and Development project: Emergency Relief-Newly-arrived families receive a one-time distribution of food, clothing, quilts, tarps and tents. Participation in mass-scale feeding programs in cooperation with other agencies. Transportation of emergency medical supplies in pakistan and Afghanistan. Development - Participation in food for work program inside Afghanistan.

The Afghan Eye Hospital (AEH) consists of examining and treatment rooms, pharmacy, male and female wards ( 38 beds), an operating suite and an artificial eye unit. The outpatient clinic functions 5 days a week, 3 for men and 2 for women. over 1,300 operations are performed annually, Glasses are also fitted at the hospital.

The Public Health project produces books in Pushto and Dari for use in camps and schools, with training given to teachers in their use. From 1989 to 1992 PH carried out a basic vaccination program in a camp of approximately 35,000 people. $\mathrm{PH}$ also provides some health education materials and teaching inside Afghanistan.

The solar project distributes solar ovens in the refugee camps in NWFP, Punjab and Baluchistan, and in Afghanistan. These solar ovens are manufactured by Afghan refugees in the Solar workshop in Peshawar. Solar also develops and manufactures solar water heaters for hospitals, community development centers, etc inside Afghanistan.

The carpet center in the past trained 133 Afghan boys to weave carpets. The center is now a source of raw materials and provides a marketing outlet for SERVE trained Afghan weavers.

The Forestry project trains Afghan nurserymen and helps to establish nurseries in the NWFP as income generation activities. In Pakistan, the Project now focuses on school programs, where students are educated in plant science and forestry skilis. Work in Afghanistan has begun, with returning refugees receiving "starter packs" of seeds and training in their use.

support services, Blind Afghans (SSBA) is a community based program to rehabilitate the Afghan blind to become independent members of their family units. children are integrated into the regular school curriculum, using Braille copies of the textbooks. SSBA employs and trains Afghan field workers in orientation and Mobility, Daily Living Skills, Job Related and Agricultural skills, Braille and Education. SSBA has begun working in 5 provinces in Afghanistan.

SERVE's Hearing Impaired project (SHIP) began in 1992 to provide sign language training to the hearing impaired and their family members, medicine for ear problems, help in purchasing hearing aids, literacy training, vocational training assistance and social activities. Also, workers are trained to work with the hearing impaired. 
CADDRESS>

60-E, CANAL RD, U/T

G P O BOX 354

PESHAWAR, PAKISTAN
<COMMUNICATION LINES>

PHONE : 41130/43615/518381 1 l. MR. GEORG TAUBMANN

F A X: 840522

TELEX:
2. MR. GREG GILMORE

3. MR. ANDREW PEVATS

\begin{tabular}{|lr|lr|ll|}
\hline AFGHAN : & 50 & TECHNICAL: & 7 & PAK. BASED: & 22 \\
PAKISTANI : & 6 & ADMINISTRATIVE: & 5 & AFGHA. BASED: & 39 \\
EXPAT: & 5 & FIELD/SUPPORT S. & 49 & CROSS-BORDER: & - \\
TOTAL: & 61 & TOTAL: & 61 & TOTAL: & 61 \\
\hline
\end{tabular}

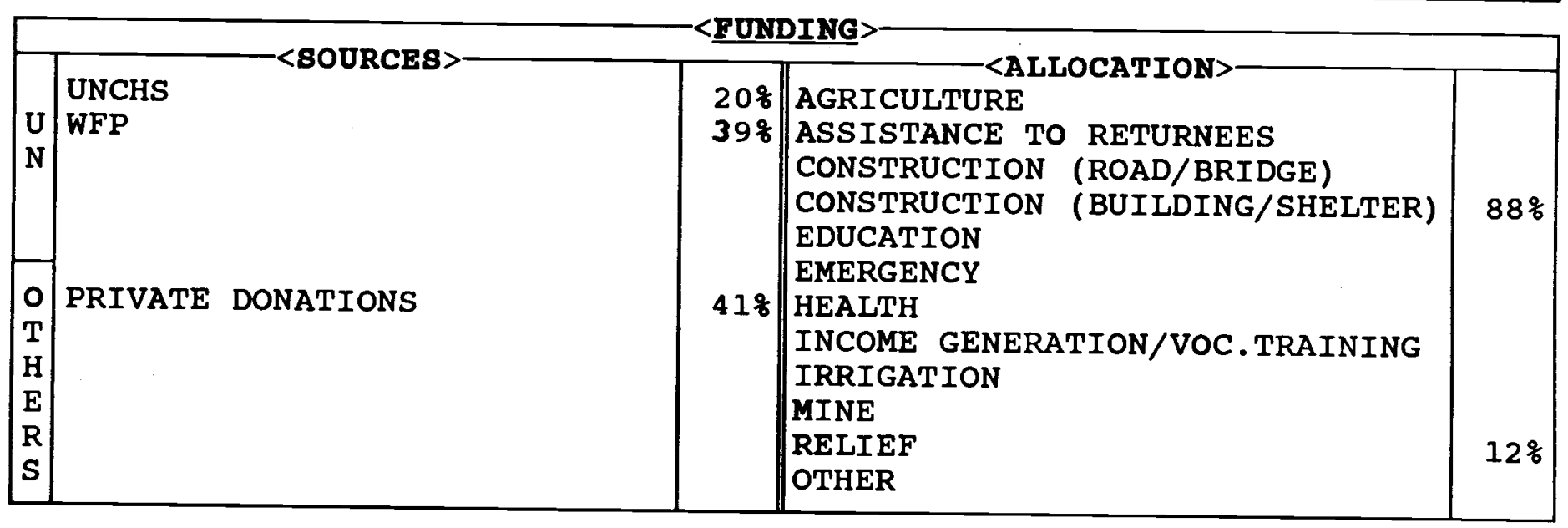

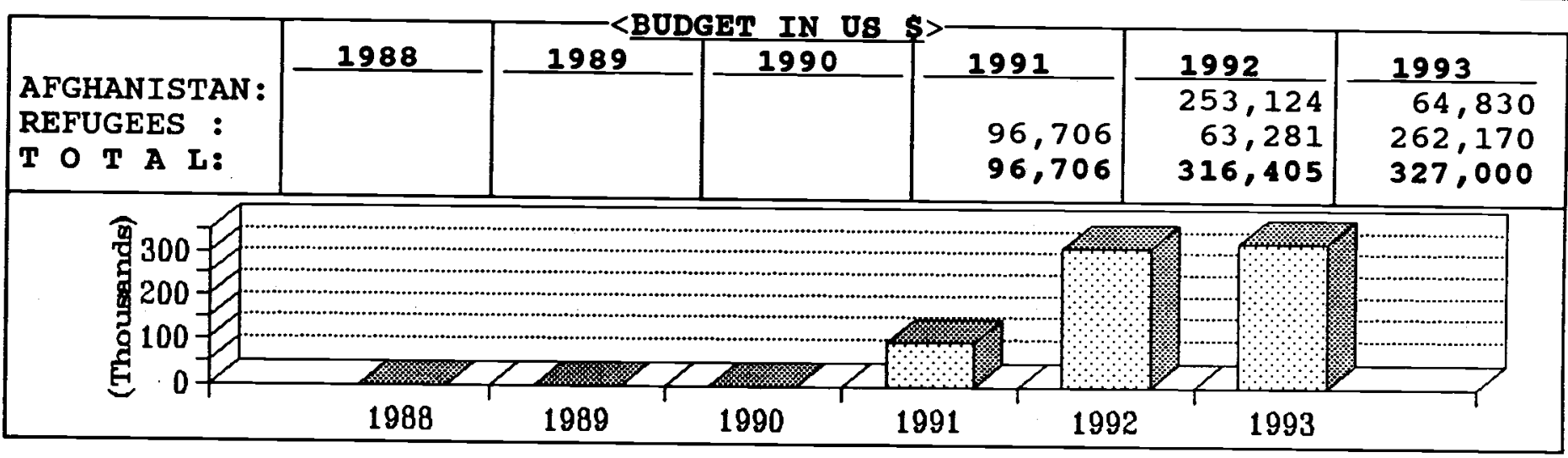

\begin{tabular}{|c|c|c|c|c|c|}
\hline PROVINCES & SECTOR & $\mid$ & DPOVTNCח & תחחתחת & \\
\hline $\begin{array}{l}\text { BADAKSHAN } \\
\text { BADGHIS } \\
\text { BAGHLAN } \\
\text { BALKH } \\
\text { BAMYAN } \\
\text { FARAH } \\
\text { FARYAB } \\
\text { GHAZNI } \\
\text { GHOR } \\
\text { HELMAND } \\
\text { HERAT } \\
\text { JAWZJAN } \\
\text { KABUL } \\
\text { KANDAHAR } \\
\text { KAPISA }\end{array}$ & & & $\begin{array}{l}\text { KUNAR } \\
\text { KUNDUZ } \\
\text { LAGHMAN } \\
\text { LOGAR } \\
\text { NANGARHAR } \\
\text { NIMROZ } \\
\text { ORUZGAN } \\
\text { PAKTEKA } \\
\text { PAKTIA } \\
\text { PARWAN } \\
\text { SAMANGAN } \\
\text { TAKHAR } \\
\text { WARDAK } \\
\text { ZABUL }\end{array}$ & Const & $100 \%$ \\
\hline
\end{tabular}


SHELTER NOW INTERNATIONAL (SNI)

was established in 1979, as an international volunteer relief organization the aim of which was to provide shelter and other forms of humanitarian aid to those in need. SNI is registered in the United States and Australia as a non-profit charitable organization.

Since 1982, SNI has been involved in providing assistance to Afghan refugees in Pakistan. Projects included establishing a pre-cast concrete factory run by Afghans; a housing project for widows, orphans and the disabled; income generation through various construction projects; a milk distribution program; a basic health and literacy program; a counselling service for widows; and a poultry project.

The center of SNI's activities has been construction work. SNI built approximately 3,000 Geodesic domes, a low cost multi purpose structure that is now being widely used in many refugee camps through the NWFP and other parts of Pakistan. They are used in the camps as administration buildings, storage facilities, clinics and residential buildings.

In addition to the domes, many other pre-cast items were produced at the SNI factory, including concrete beams and roof slabs, toilet slabs for sanitation projects and well rings.

In 1989 SNI began implementing projects inside Afghanistan. These projects included road construction, construction of a pre-cast concrete roofing factory in Nangarhar Province, construction of 5 clinics and 2 hospitals and repair of karezes.

After the destruction of the factory in Peshawar in 1990, SNI closed all it's operations for a period of time, but started again in April 1991.

The new pre-cast factory in Peshawar serves as a training facility for
Afghans and the manufacture of roofing components, etc. Besides that SNI continues to produce Geodesic domes, roof beams, roof slabs and toilet slabs.

The milk distribution project was started again and presently supplies 5 refugee camps.

SNI built up a pre-cast concrete factory in Trayzai, Paktia Province and is producing roofing material with personnel, trained at its Peshawar factory.

More pre-cast concrete factories and distribution centers for roofing material are planned inside Afghanistan to assist returning refugees to rebuild their homes.

SNI also maintains a steel workshop at the factory in Peshawar. It produces high quality doors, windows, work tables, etc. on demand. The factory in Peshawar is able to fill special orders for both concrete building components and steel products quickly and economically. These jobs generate income for refugees remaining in $\mathrm{P} \quad \mathrm{a} \quad \mathrm{k} \quad \mathrm{i} \quad \mathrm{s} \quad \mathrm{t} a \mathrm{a}$. 
SHORAWAR REHABILITATION ORGANIZATION-8RO

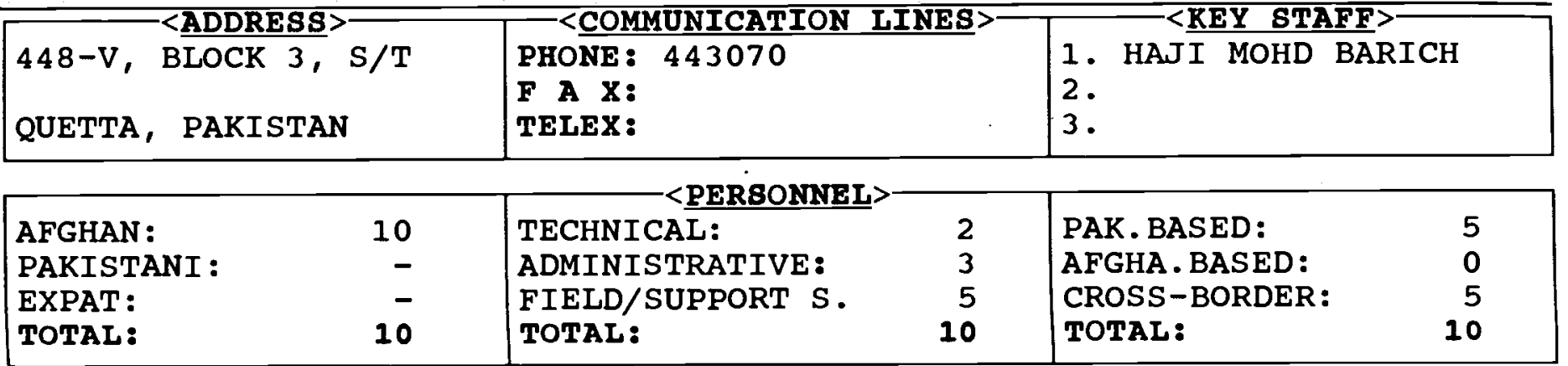

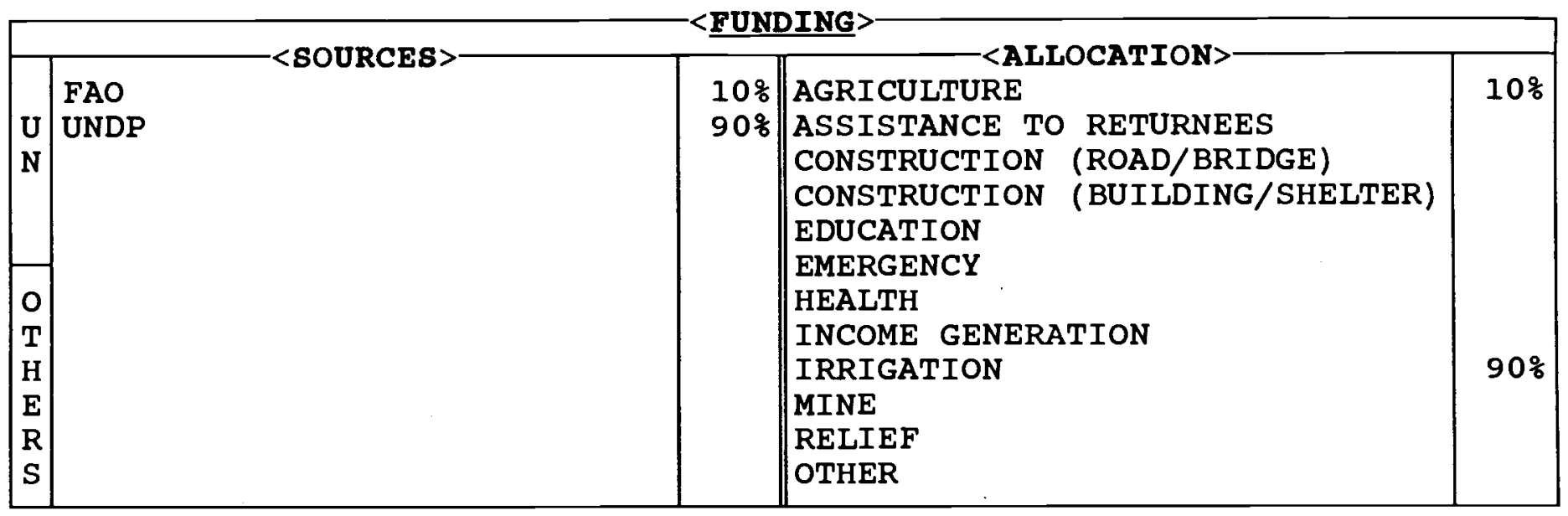

\begin{tabular}{|c|c|c|c|c|c|c|}
\hline $\begin{array}{l}\text { AFGHANISTAN: } \\
\text { REFUGEES : } \\
\text { T O T A L: }\end{array}$ & 1988 & 1989 & 1990 & 1991 & $\begin{array}{r}\frac{1992}{25,000} \\
25,000\end{array}$ & $\begin{array}{l}\frac{1993}{30,000} \\
30,000\end{array}$ \\
\hline 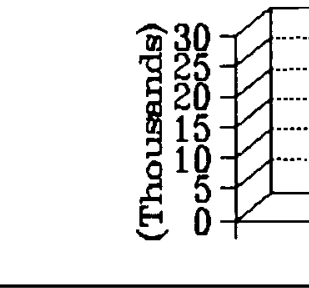 & $\begin{array}{l}2 \\
198 \\
2\end{array}$ & $\begin{array}{l}1989 \\
198\end{array}$ & $\begin{array}{l}1990 \\
190\end{array}$ & 1991 & 1993 & (1) \\
\hline
\end{tabular}

\begin{tabular}{|c|c|c|c|c|c|}
\hline PROVINCES & SECTOR & \&AGE & PROVINCES & SECTOR & $\because A G E$ \\
\hline $\begin{array}{l}\text { BADAKSHAN } \\
\text { BADGHIS } \\
\text { BAGHLAN } \\
\text { BALKH } \\
\text { BAMYAN } \\
\text { FARAH } \\
\text { FARYAB } \\
\text { GHAZNI } \\
\text { GHOR } \\
\text { HELMAND } \\
\text { HERAT } \\
\text { JAWZJAN } \\
\text { KABUL } \\
\text { KANDAHAR } \\
\text { KAPISA }\end{array}$ & Agr/irrign & $100 \%$ & $\begin{array}{l}\text { KUNAR } \\
\text { KUNDUZ } \\
\text { LAGHMAN } \\
\text { LOGAR } \\
\text { NANGARHAR } \\
\text { NIMROZ } \\
\text { ORUZGAN } \\
\text { PAKTEKA } \\
\text { PAKTIA } \\
\text { PARWAN } \\
\text { SAMANGAN } \\
\text { TAKHAR } \\
\text { WARDAK } \\
\text { ZABUL }\end{array}$ & & \\
\hline
\end{tabular}


was formed in November 1991. The purpose of the organization is taking part in the rehabilitation of Afghanistan.

SRO works/intends to work in the sectors of agriculture, education, health and repatriation.

In agriculture, sRo distributes improved seeds and fertilizer (over $40 \mathrm{MT}$ improved wheat seeds and fertilizer have been distributed so far). SRO plans to start veterinary services in its target areas.

In 1992, SRo established two schools in shorawak district of Kandahar province.

In 1993, SRO undertook irrigation projects (karez cleaning).

Proposals have been submitted to provide assistance for returning families and facilitate repatriation. It also plans to undertake veterinary services.

SRo plans to move its office to Shorawak district during the current year. 
BHORT TERY ABSI STANCE FOR REHABILITATION TEAM-8TART

\begin{tabular}{|l|l|l|}
\hline 51/C-1 PARK AVENUE, U/T & PHONE: 41081 & <COMMUNICATION LINES \\
P O BOX 1402 & T X X: 41081 & 2. \\
PESHAWAR, PAKISTAN & TELEX: & 3. \\
\hline
\end{tabular}

\begin{tabular}{|lr|lr|lr|}
\hline AFGHAN: & 35 & TECHNICAL: & 25 & PAK. BASED: & 16 \\
PAKISTANI: & 2 & ADMINISTRATIVE: & 12 & AFGHA. BASED: & 21 \\
EXPAT: & - & FIELD/SUPPORT S. & - & CROSS-BORDER: & - \\
TOTAL: & $\mathbf{3 7}$ & TOTAL: & $\mathbf{3 7}$ & TOTAL: & $\mathbf{3 7}$ \\
\hline
\end{tabular}

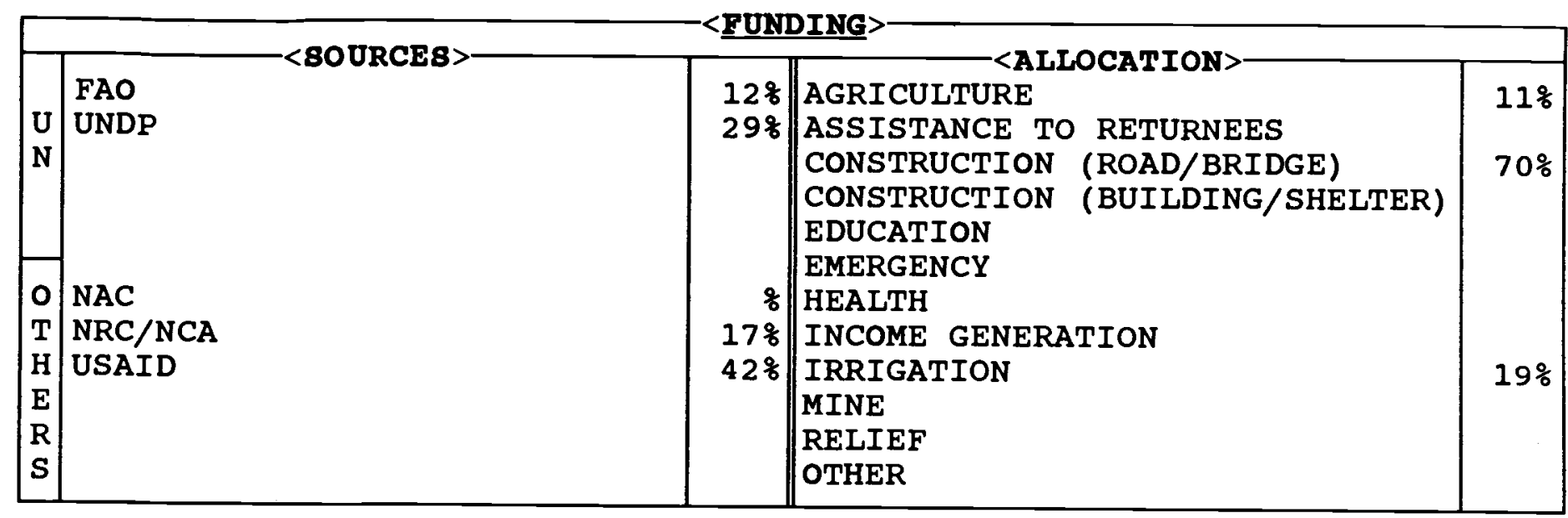

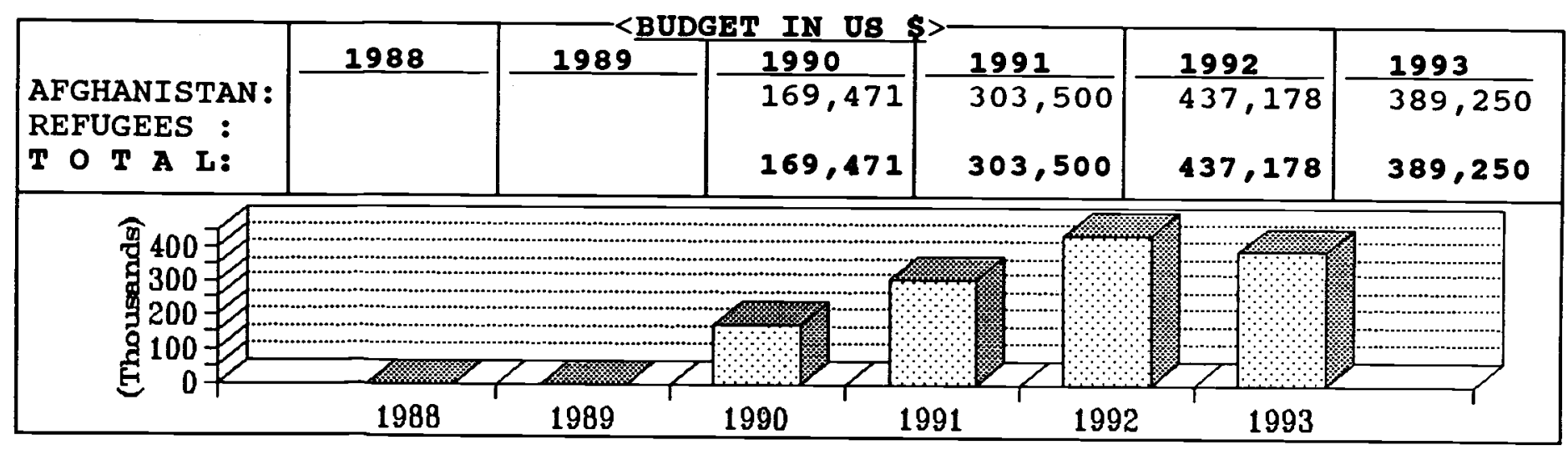

\begin{tabular}{|c|c|c|c|c|c|}
\hline PROVINCES & SECTOR & \&AGE & PROVINCES & SECTOR & $\%$ AGE \\
\hline $\begin{array}{l}\text { BADAKSHAN } \\
\text { BADGHIS } \\
\text { BAGHLAN } \\
\text { BALKH } \\
\text { BAMYAN } \\
\text { FARAH } \\
\text { FARYAB } \\
\text { GHAZNI } \\
\text { GHOR } \\
\text { HELMAND } \\
\text { HERAT } \\
\text { JAWZJAN } \\
\text { KABUL } \\
\text { KANDAHAR } \\
\text { KAPISA }\end{array}$ & $\begin{array}{l}\text { Const/irrign } \\
\text { Const/irrign }\end{array}$ & \begin{tabular}{l|}
$18 \%$ \\
198
\end{tabular} & \begin{tabular}{|l|} 
KUNAR \\
KUNDUZ \\
IAGHMAN \\
LOGAR \\
NANGARHAR \\
NIMROZ \\
ORUZGAN \\
PAKTEKA \\
PAKTIA \\
PARWAN \\
SAMANGAN \\
TAKHAR \\
WARDAK \\
ZABUL
\end{tabular} & $\begin{array}{l}\text { Irrign } \\
\text { Irrign } \\
\text { Agr/const/irrign } \\
\text { Agr/const/irrign } \\
\text { Agr }\end{array}$ & $\begin{array}{l}8 \% \\
10 \% \\
25 \%\end{array}$ \\
\hline
\end{tabular}


came into being in April 1989 at the initiative of a number of experienced Afghan engineers. Its initial objectives were conduct surveys and prepare project designs for rehabilitation activities in Afghanistan.

The organization started work in road construction, housing, power supply, irrigation, drinking water supply and telecommunications in cooperation with NRC/NCA. This first project was for six months. Later on START continued the project with the financial assistance of UNDP/UNOCHA Peshawar which covered the provinces of Paktia, Pakteka, Logar, Ghazni, Kandahar and Herat.

Another survey/assessment project was carried out starting March 1990 for ten months with the support of UNDP/OPS, Peshawar. Surveys which were conducted with a well-equipped team, covered the provinces of Kunar, Paktia, Pakteka, Wardak, Ghazni and Bamyan. At the end of this project in January 1993, START was modified to an Afghan NGo with a Board of Directors of five members overseeing its performance.

Since its establishment as an NGo, START has enjoyed continuous support of NRC/NCA and other donor organizations. Currently START as a well-organized Afghan NGo has three sections; Irrigation/water Supply, Road/Housing and Agriculture. It is equipped with machinery.

With the financial support of donor organizations, START hopes to continue to render valuable services to Afghanistan. 
SHUHADA ORGANIZATION-SO

\begin{tabular}{|l|l|l|}
\hline NASIRABAD, ALAMDAR RD & PHONE: 76934 & 1. DR. SEMA SAMAR \\
& F A X: & 2. \\
QUETTA, PAKISTAN & TELEX: & 3. \\
\hline
\end{tabular}

\begin{tabular}{|lr|ll|lr|}
\hline AFGHAN : & 38 & TECHNICAL: & $\ldots$ & PAK. BASED: & 38 \\
PAKISTANI : & - & ADMINISTRATIVE: & $\ldots$ & AFGHA.BASED: & - \\
EXPAT: & - & FIELD/SUPPORT S. & $\cdots$ & CROSS-BORDER: & - \\
TOTAL: & 38 & TOTAL: & 38 & TOTAL: & 38 \\
\hline
\end{tabular}

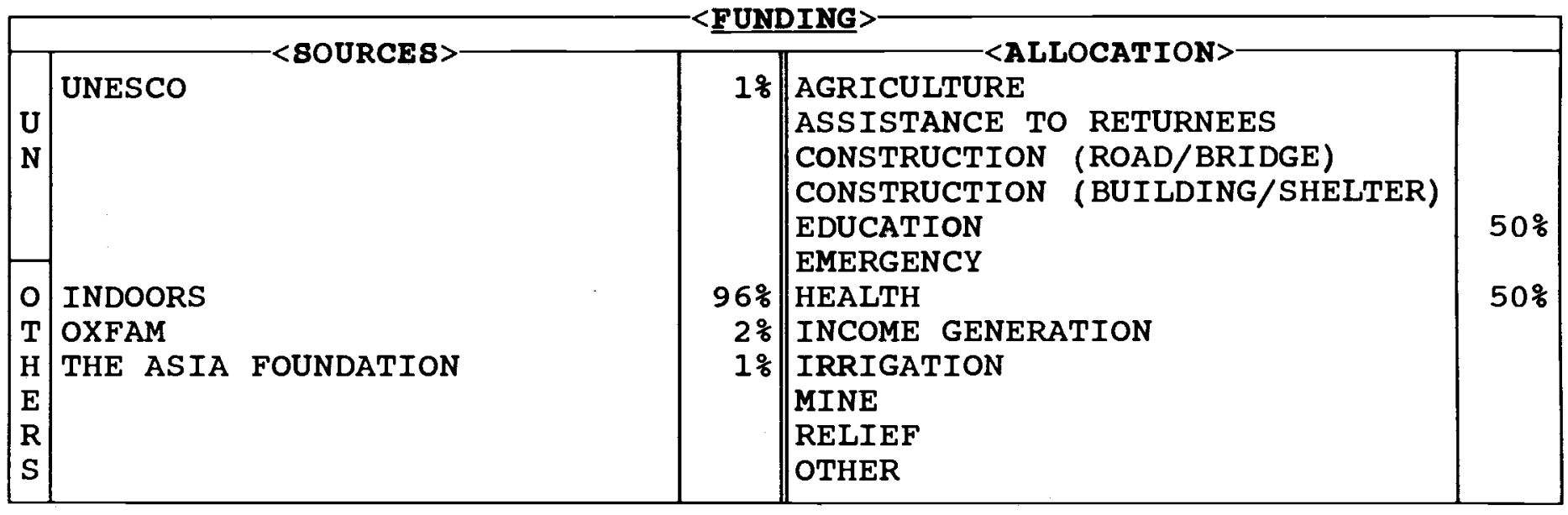

\begin{tabular}{|l|l|l|l|l|l|l|}
\hline & \multicolumn{1}{|c|}{ <BUDGET IN US \$> } & 1990 & 1991 & 1992 & 1993 \\
AFGHANISTAN: & & 1989 & $\frac{1998}{150,000}$ & 150,000 & 125,000 & 125,000 \\
REFUGEES : & & & 150,000 & 150,000 & 125,000 & 125,000 \\
TO T A L: & & & 300,000 & 300,000 & 250,000 & 250,000 \\
\hline
\end{tabular}

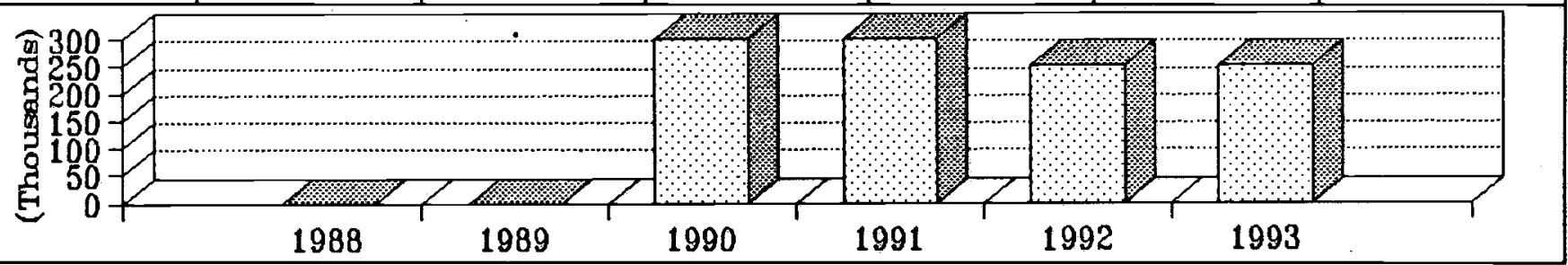

\begin{tabular}{|c|c|c|c|c|c|}
\hline PROVINCES & SECTOR & $\% \mathrm{AGE}$ & PROVINCES & SECTOR & $\because A G E$ \\
\hline $\begin{array}{l}\text { BADAKSHAN } \\
\text { BADGHIS } \\
\text { BAGHLAN } \\
\text { BALKH } \\
\text { BAMYAN } \\
\text { FARAH } \\
\text { FARYAB } \\
\text { GHAZNI } \\
\text { GHOR } \\
\text { HELMAND } \\
\text { HERAT } \\
\text { JAWZJAN } \\
\text { KABUL } \\
\text { KANDAHAR } \\
\text { KAPISA }\end{array}$ & Educ/health & $100 \%$ & $\begin{array}{l}\text { KUNAR } \\
\text { KUNDUZ } \\
\text { LAGHMAN } \\
\text { LOGAR } \\
\text { NANGARHAR } \\
\text { NIMROZ } \\
\text { ORUZGAN } \\
\text { PAKTEKA } \\
\text { PAKTIA } \\
\text { PARWAN } \\
\text { SAMANGAN } \\
\text { TAKHAR } \\
\text { WARDAK } \\
\text { ZABUL }\end{array}$ & & \\
\hline
\end{tabular}




\section{SHUHADA ORGANIZATION (SO) \\ formerly \\ (shuhada clinic)}

was set up in 1989. The aim is to provide services to Afghan refugees and Afghans inside especially women.

so implements health and education programs.

A hospital in Quetta is operational which has OPD, in-patient department (13 beds), OT, delivery room and laboratory. Vaccination is provided to children and pregnant women. Milk and biscuits are given to malnourished children.

A one year nursing course and a three months first-aid course (both for women) are offered. students are paid Rs. 300 each for educational materials. Textbooks have been translated by so doctors and are taught od the courses.

A building for a 50 bed hospital has been constructed by Shuhada Organization in Ghazni province. Equipment, materials and staff will be deployed in the hospital to start work as soon as the situation improves. Currently an OPD clinic is functioning in Ghazni province.

In education sector, so supports the following schools:

- A high school in Jaghori which has 14,000 students including 240 female. The school is operated by 56 staff.

- 8 primary schools in different villages of Jaghori.

- A school in Qarabagh.

- A school in Malestan.

(There are both male and female students in all of the schools.)

A school for females in quetta which has 300 students and 18 teachers.

Moreover, so has a literacy course for women which has 75 students and two teachers. 


\begin{tabular}{|l|l|l|}
\hline HUJRA HOUSE OLD BARA RD & PHONE: 840228 & <COMEY BTAFF>C \\
P O BOX …… MR. RAOUL DE TORCY \\
PESHAWAR, PAKISTAN & F A X: 840228 & 2. MR. NEK MOHD MAYAN \\
\hline
\end{tabular}

\begin{tabular}{|lr|lr|lr|}
\hline AFGHAN : & 9 & TECHNICAL: & 6 & PAK. BASED: & 5 \\
PAKISTANI : & 2 & ADMINISTRATIVE: & 4 & AFGHA.BASED: & 1 \\
EXPAT: & 1 & FIELD/SUPPORT S. & 2 & CROSS-BORDER: & 6 \\
TOTAL: & 12 & TOTAL: & 12 & TOTAL: & 12 \\
\hline
\end{tabular}

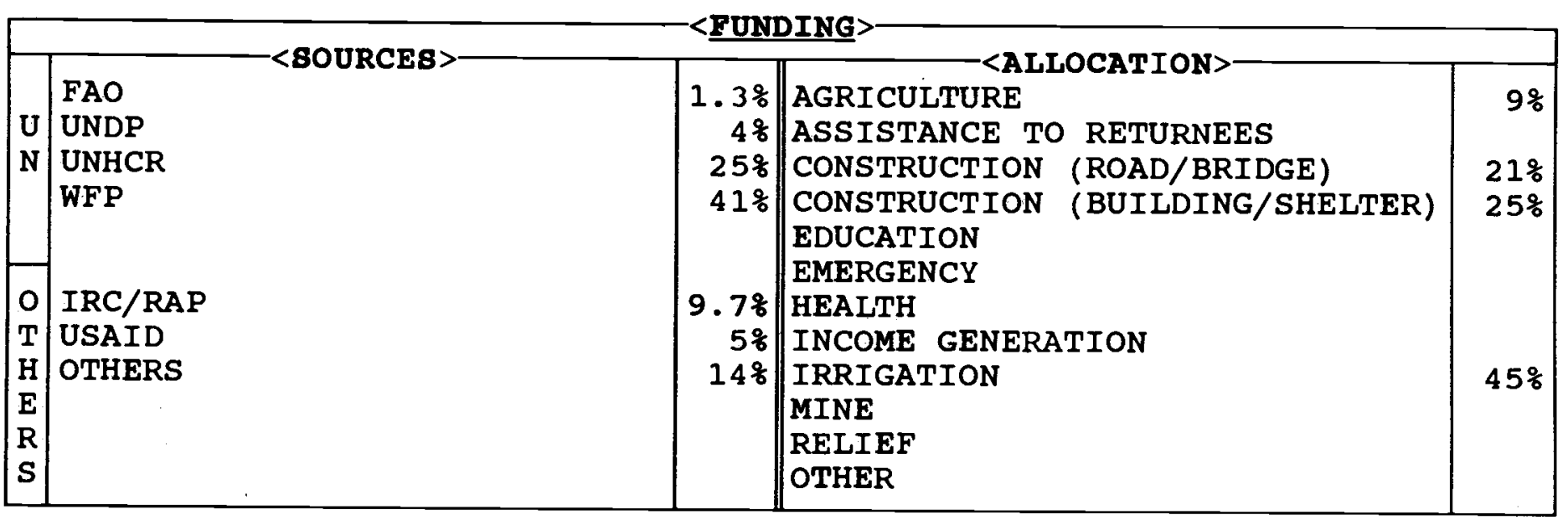

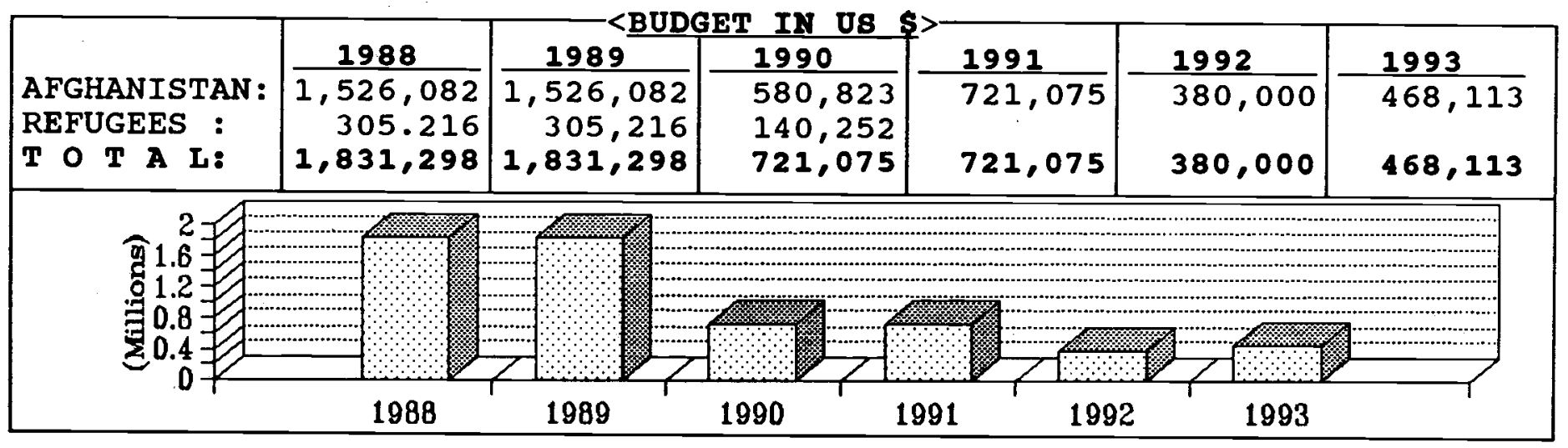

\begin{tabular}{|c|c|c|c|c|c|}
\hline PROVINCES & SECTOR & \&AGE & PROVINCES & SECTOR & \%AGE \\
\hline $\begin{array}{l}\text { BADAKSHAN } \\
\text { BADGHIS } \\
\text { BAGHLAN } \\
\text { BALKH } \\
\text { BAMYAN } \\
\text { FARAH } \\
\text { FARYAB } \\
\text { GHAZNI } \\
\text { GHOR } \\
\text { HELMAND } \\
\text { HERAT } \\
\text { JAWZJAN } \\
\text { KABUL } \\
\text { KANDAHAR } \\
\text { KAPISA }\end{array}$ & Const/irrign & $19 \%$ & $\begin{array}{l}\text { KUNAR } \\
\text { KUNDUZ } \\
\text { LAGHMAN } \\
\text { LOGAR } \\
\text { NANGARHAR } \\
\text { NIMROZ } \\
\text { ORUZGAN } \\
\text { PAKTEKA } \\
\text { PAKTIA } \\
\text { PARWAN } \\
\text { SAMANGAN } \\
\text { TAKHAR } \\
\text { WARDAK } \\
\text { ZABUL }\end{array}$ & $\begin{array}{l}\text { Const (shelter) } \\
\text { Irrign } \\
\text { Agr/const/irrign }\end{array}$ & $43 \%$ \\
\hline
\end{tabular}




\section{SOLIDARITES AFGHANISTAN (SOLAF)}

is a humanitarian association governed under a charter dating from 1991. From 1980 to 1987 it acted under the auspices of the Guilde Europenne du Raid. The mandate of the organization provides for emergency relief to countries where populations are dispossessed due to war or natural disasters. Solidarites-Afghanistan also collects and disseminates information about the population it otherwise serves.

During the soviet occupation of Afghanistan, emergency aid was given in the form of food or cash along with more long-range development programs in education and agriculture. Emphasis was given to re-establishment of physical and social infrastructure.

Today, humanitarian assistance in Afghanistan is offered in the following sectors:

1. Agriculture: technical and financial support in irrigation projects (canals, karezes, dams, retaining walls); technical and material support to development programs (mechanization, seeds and fertilizers, bank of cereal, development centers, extension workers etc.).

2. Infrastructure: assistance in rebuilding physical (roads, bridges, dams) and social infrastructure (communication systems).

Work is done in cooperation with the local commanders, through shuras and political parties. Coordination with other NGOs is maintained with concerned NGOs in the field and in Peshawar.

Aid is always accomplished through on-site representation of the organization and under the local authority of the population representatives through the local structures. Aid is now given less and less freely and contracts for reimbursement of inputs provided are systematically signed with village representatives.

Following the events of April 1992, Solidarites hopes for improved working conditions in Afghanistan. It is also hoped that it will be possible to work from offices based inside Afghanistan.

The new economical and social situation will be closely monitored and necessary steps will be taken in order to support the Afghan population. 
ITC: $3-1$, PH.5 HAYATABAD PHONE: 812456-7/812738-9 $P$ O BOX 799 PESHAWAR, PAKISTAN
F A : 810307

TELEX:
1. MR. T. THEUWISSEN

2. MR. AMIR M. AHMADY

3. MR. GHULAM GUL

\begin{tabular}{|lr|lr|l|l|}
\hline AFGHAN: & 70 & TECHNICAL: &. & PAK. BASED: & 63 \\
PAKISTANI : & 3 & ADMINISTRATIVE: & $\cdot$ & AFGHA.BASED: & 12 \\
EXPAT: & 2 & FIELD/SUPPORT S. & $:$ & CROSS-BORDER: & - \\
TOTAL: & 75 & TOTAL: & $\mathbf{7 5}$ & TOTAL: & 75 \\
\hline
\end{tabular}

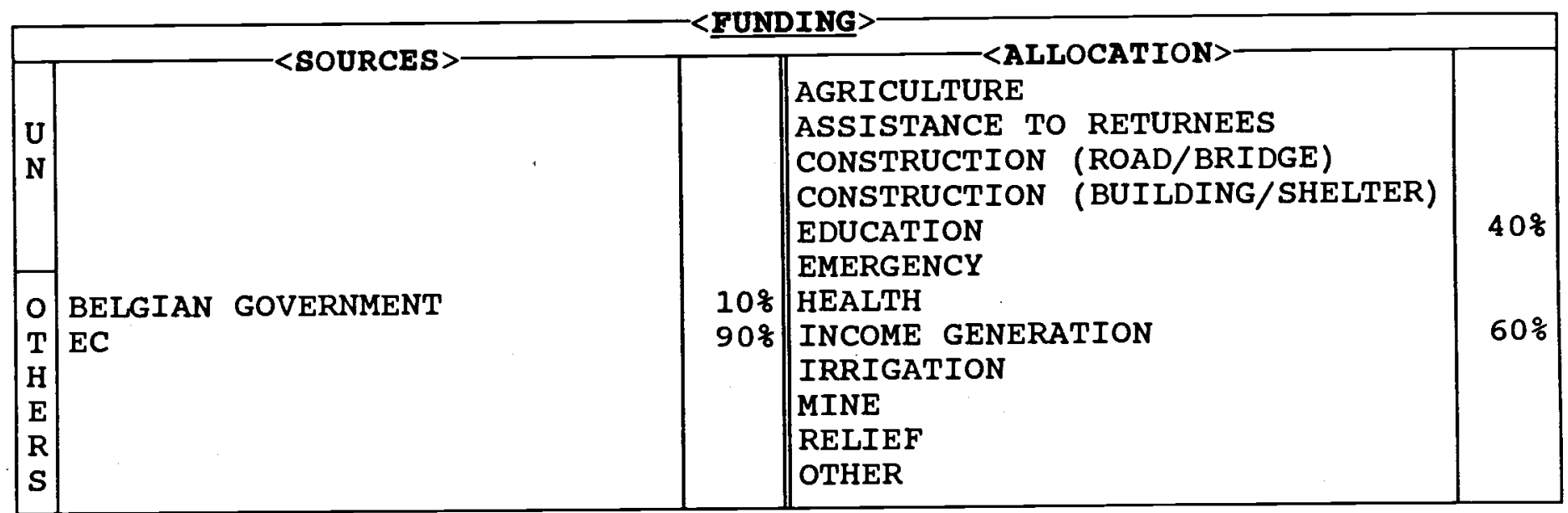

\begin{tabular}{|c|c|c|c|c|c|c|}
\hline & 1988 & 1989 & 1990 & 1991 & 1992 & 1993 \\
\hline AFGHANISTAN : & & & & & 150,000 & 400,000 \\
\hline $\begin{array}{l}\text { REFUGEES : } \\
\text { T O T A L: }\end{array}$ & $\begin{array}{l}460,748 \\
460,748\end{array}$ & $\begin{array}{l}550,614 \\
550,614\end{array}$ & $\begin{array}{l}522,614 \\
522,614\end{array}$ & $\begin{array}{l}1,068,000 \\
1,068,000\end{array}$ & $\begin{array}{r}850,000 \\
1,000,000\end{array}$ & $\begin{array}{r}660,000 \\
1,060,000\end{array}$ \\
\hline
\end{tabular}

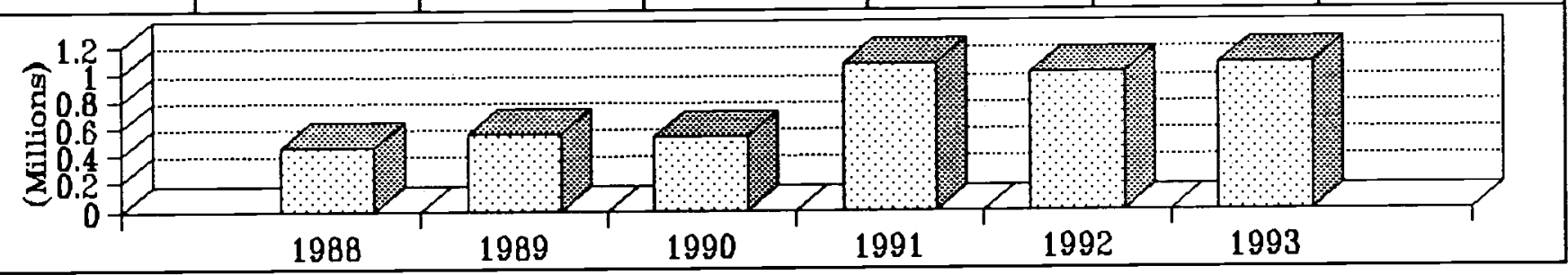

\begin{tabular}{|c|c|c|c|c|c|}
\hline PROVINCES & SECTOR & \% $\mathrm{AGE}$ & PROVINCES & SECTOR & $\% \mathrm{AGE}$ \\
\hline $\begin{array}{l}\text { BADAKSHAN } \\
\text { BADGHIS } \\
\text { BAGHLAN } \\
\text { BALKH } \\
\text { BAMYAN } \\
\text { FARAH } \\
\text { FARYAB } \\
\text { GHAZNI } \\
\text { GHOR } \\
\text { HELMAND } \\
\text { HERAT } \\
\text { JAWZJAN } \\
\text { KABUL } \\
\text { KANDAHAR } \\
\text { KAPISA }\end{array}$ & & & $\begin{array}{l}\text { KUNAR } \\
\text { KUNDUZ } \\
\text { LAGHMAN } \\
\text { LOGAR } \\
\text { NANGARHAR } \\
\text { NIMROZ } \\
\text { ORUZGAN } \\
\text { PAKTEKA } \\
\text { PAKTIA } \\
\text { PARWAN } \\
\text { SAMANGAN } \\
\text { TAKHAR } \\
\text { WARDAK } \\
\text { ZABUL }\end{array}$ & $\begin{array}{l}\text { Teacher/voc.training } \\
\text { Teacher/voc.training } \\
\text { Teacher/voc.training }\end{array}$ & $\begin{array}{l}25 \% \\
25 \% \\
50 \%\end{array}$ \\
\hline
\end{tabular}


was founded on 15 May 1982. It is a non-governmental organization that has provided assistance to Afghan refugees in Pakistan (NWFP/Punjab) since 1985 and began providing assistance for cross-border projects in Afghanistan in 1991 (Nangarhar/Kunar). It is involved in two sectors: Education (Teacher Training) and Vocational Training/Income Generation. Sos's partners are Commissionerate for Afghan Refugees; Afghan political parties in Pakistan; local authorities; provincial Islamic Government of Afghanistan; and other NGOS.

\section{EDUCATION:}

Development objective is to upgrade the standard of education of the Afghan children up to grade 6 (primary level).

Immediate objectives:

1. To upgrade the teaching skills as well as competence in the subjects taught in the primary schools of the primary schools teachers through in-service training program.

2. To support the standard of teaching in the primary schools through providing teaching aid materials after each training.

3. To train primary school teachers through pre-service training programs.

4. To develop teaching materials and teaching aid materials related to the subjects and pedagogical skilis.

There are four types of training offered by four sections, Teacher Training center (TTC), Peshawar, Jalalabad and Bajaur Pedagogic Mobile Teams

(P-PMT/B-PMT/T-PMT) :

- Training through $21 / 2$ months courses by Teacher Training Center (TTC).

- Training through 15 days seminar Pedagogic Mobile Teams (PMTs).
Training

through 8 days Resource center by TTC and PMTs.

Training through practical work by TTC and PMTs.

Beneficiaries are Afghan and Pakistani primary school teachers in Afghanistan and in the refugee camps in Pakistan

Results: So far TTC and PMTs have trained more than 3,800 teachers.

VOCATIONAL TRAINING/INCOME GENERATION (ASYAR):

Development objective is to train qualified personnel through an apprenticeship scheme; support to the labor market and income generation in the informal sector for refugee and displaced population.

Immediate objectives:

1. To train young Afghans by apprenticeship in 25 trades.

2. To introduce trained young Afghans into income generating activities.

3. To support the level of activities of micro Afghan and Pakistani enterprises in the informal sector.

Vocational training is achieved by placement in apprenticeship into a local micro-enterprise. Already existing micro-enterprises are supported in providing a tool-kit to master craftsman for each apprentice placed. Introduction of graduated apprentices in labor market is supported by provision of standard tool-kits. credit facilities are also available for microenterprises: Beneficiaries are young Afghans aged $15-20$ years who are placed as apprentices. 25\% of these beneficiaries are candidates from vulnerable group such as widows, orphans and disabled aged 15-45 years; Afghan and Pakistani micro-enterprises.

Results: Since 1985, ASYAR has trained 3,745 young Afghans. 85\% of them were introduced into the local market. 


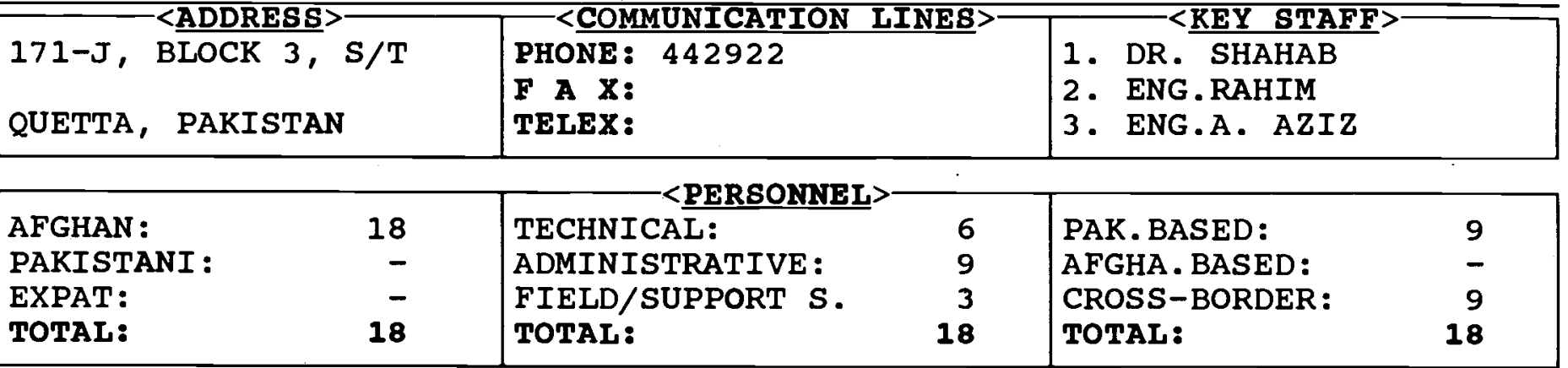

\begin{tabular}{|c|c|c|c|c|}
\hline & & & Alve & \\
\hline & KSOURCES & & $2<$ ALLOCATION $>$ & \\
\hline & FAO & $5 \%$ & AGRICULTURE & $50 \%$ \\
\hline $\mathbf{U}$ & UNDCP & $5 \%$ & ASSISTANCE TO RETURNEES & \\
\hline $\mathbf{N}$ & UNDP & $10 \%$ & CONSTRUCTION (ROAD/BRIDGE) & $20 \%$ \\
\hline & UNHCR & $5 \%$ & CONSTRUCTION (BUILDING/SHELTER) & $10 \%$ \\
\hline & WFP & $5 \%$ & EDUCATION & $5 \%$ \\
\hline 0 & ARCON & $50 \%$ & $\begin{array}{l}\text { EMERGENCY } \\
\text { HEALTH }\end{array}$ & $5 \%$ \\
\hline $\mathbf{T}$ & ISLAMIC RELIEF FUND & 208 & INCOME GENERATION & \\
\hline $\mathrm{H}$ & & & IRRIGATION & $10 \%$ \\
\hline $\mathrm{E}$ & & & MINE & \\
\hline $\mathbf{R}$ & & & RELIEF & \\
\hline $\mathbf{S}$ & & & OTHER & \\
\hline
\end{tabular}

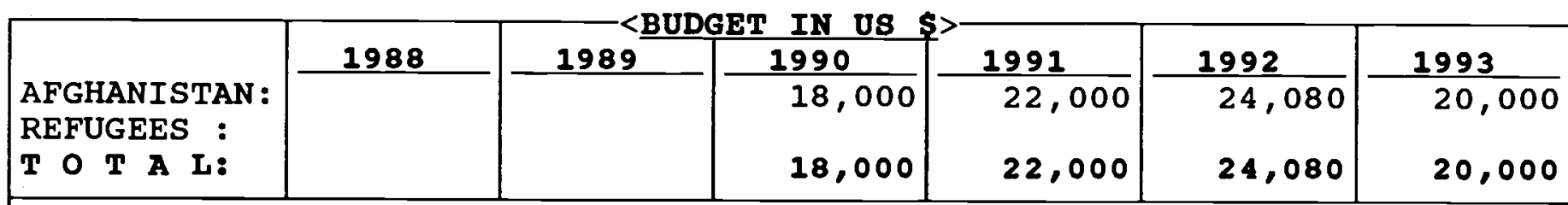

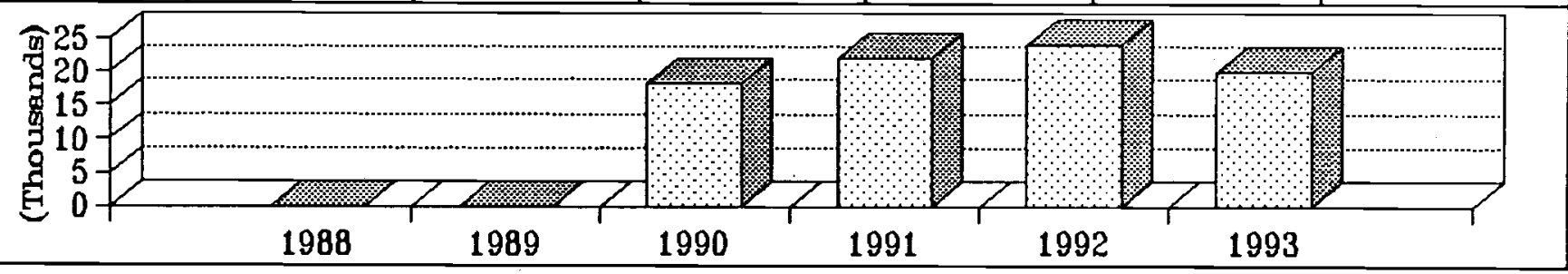

\begin{tabular}{|c|c|c|c|c|c|}
\hline PROVINCES & SECTOR & gिGE & PROVINCES & SECTOR & \&AGE \\
\hline $\begin{array}{l}\text { BADAKSHAN } \\
\text { BADGHIS } \\
\text { BAGHLAN } \\
\text { BALKH } \\
\text { BAMYAN } \\
\text { FARAH } \\
\text { FARYAB } \\
\text { GHAZNI } \\
\text { GHOR } \\
\text { HELMAND } \\
\text { HERAT } \\
\text { JAWZJAN } \\
\text { KABUL } \\
\text { KANDAHAR } \\
\text { KAPISA }\end{array}$ & $\begin{array}{l}\text { Agr } \\
\text { Agr } \\
\text { Educ } \\
\text { Agr/const/irrign }\end{array}$ & $\begin{array}{l}5 \% \\
60 \% \\
10 \%\end{array}$ & $\begin{array}{l}\text { KUNAR } \\
\text { KUNDUZ } \\
\text { LAGHMAN } \\
\text { LOGAR } \\
\text { NANGARHAR } \\
\text { NIMROZ } \\
\text { ORUZGAN } \\
\text { PAKTEKA } \\
\text { PAKTIA } \\
\text { PARWAN } \\
\text { SAMANGAN } \\
\text { TAKHAR } \\
\text { WARDAK } \\
\text { ZABUL }\end{array}$ & $\begin{array}{l}\text { Educ/health } \\
\text { Agr/irrign }\end{array}$ & $\begin{array}{l}5 \% \\
5 \%\end{array}$ \\
\hline
\end{tabular}


was established in 1989. It was originally a sub-office of the Afghan Planning Agency which is headquartered in Peshawar. SWARO was set up as a separate NGO in 1992 .

SWARO's objective is to work in rehabilitation and reconstruction of Afghanistan especially in the southwestern provinces.

SWARO is involved in the sectors of agriculture, education, irrigation and construction of public buildings.

The current target areas of the organization are Ghor, Helmand, Herat, Kandahar, Nimroz, Uruzgan and zabul provinces.

SWARO has also distributed relief commodities to the flood affected families in the south-west provinces in 1991 .

SWARO will move to Afghanistan when other NGOs and the UN agencies relocate their offices. 
SOUTH-WEST FARMERS ASSISTANCE ORGANIZATION-8WFAO

\begin{tabular}{|l|l|l|}
\hline 02C, JINAH TWON & <COMMUNICATION LINES> & <KEY STAFF>- \\
SAMANGALI ROAD & PHONE: $826487 / 0321282717$ & 1. MR. ESSA KHAROTI \\
QUETTA, PAKISTAN & F A X: 826487 & 2. DR. HASSAN \\
TELEX: & 3. MR. OMAR GUL \\
\hline
\end{tabular}

\begin{tabular}{|lr|lr|lr|}
\hline AFGHAN : & 22 & TECHNICAL: & 15 & PAK. BASED: & 9 \\
PAKISTANI : & 3 & ADMINISTRATIVE: & 4 & AFGHA.BASED: & 6 \\
EXPAT: & - & FIELD/SUPPORT S. & 4 & CROSS-BORDER: & 10 \\
TOTAL: & 25 & TOTAL: & 25 & TOTAL: & 25 \\
\hline
\end{tabular}

\begin{tabular}{|c|c|c|c|c|}
\hline & ennpr & & 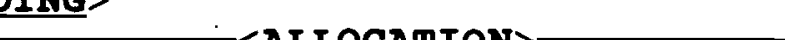 & \\
\hline & FAO & 308 & AGRICULTURE & $30 \%$ \\
\hline $\mathbf{U}$ & UNDP & 188 & ASSISTANCE TO RETURNEES & $10 \%$ \\
\hline $\mathbf{N}$ & UNHCR & $30 \%$ & CONSTRUCTION (ROAD/BRIDGE) & \\
\hline & & & CONSTRUCTION (BUILDING/SHELTER) & $5 \%$ \\
\hline & & & EDUCATION & $5 \%$ \\
\hline & & & EMERGENCY & \\
\hline 0 & BRITISH HIGH COMMISSION & $20 \%$ & HEALTH & \\
\hline $\mathbf{T}$ & THE NEATHERLANDS EMBASSY & $2 \%$ & INCOME GENERATION & $20 \%$ \\
\hline $\mathrm{H}$ & & & IRRIGATION & $30 \%$ \\
\hline $\mathbf{E}$ & & & MINE & \\
\hline $\mathbf{R}$ & & & RELIEF & \\
\hline $\mathbf{S}$ & & & OTHER & \\
\hline
\end{tabular}

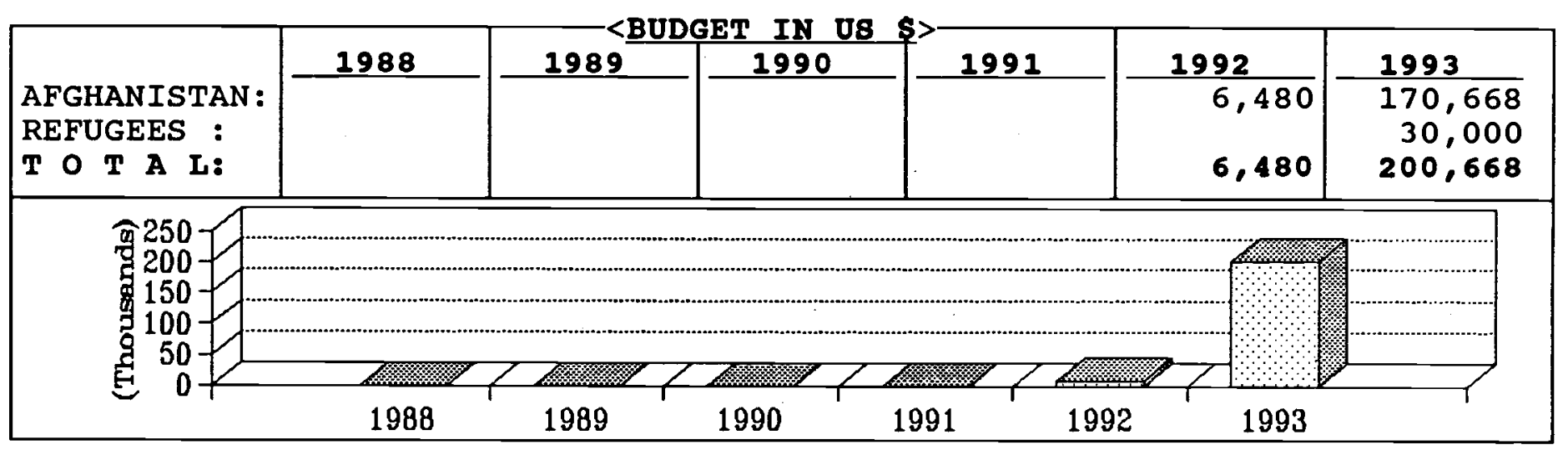

\begin{tabular}{|c|c|c|c|c|c|}
\hline PROVINCES & SECTOR & \&AGE & PROVINCES & SECTOR & $\%$ AGE \\
\hline $\begin{array}{l}\text { BADAKSHAN } \\
\text { BADGHIS } \\
\text { BAGHLAN } \\
\text { BALKH } \\
\text { BAMYAN } \\
\text { FARAH } \\
\text { FARYAB } \\
\text { GHAZNI } \\
\text { GHOR } \\
\text { HELMAND } \\
\text { HERAT } \\
\text { JAWZJAN } \\
\text { KABUL } \\
\text { KANDAHAR } \\
\text { KAPISA }\end{array}$ & $\begin{array}{l}\text { Agr } \\
\text { Agr/educ/inc.gen/irri } \\
\text { Agr/cons/educ/irr/ret }\end{array}$ & 358 & \begin{tabular}{|l|} 
KUNAR \\
KUNDUZ \\
LAGHMAN \\
LOGAR \\
NANGARHAR \\
NIMROZ \\
ORUZGAN \\
PAKTEKA \\
PAKTIA \\
PARWAN \\
SAMANGAN \\
TAKHAR \\
WARDAK \\
ZABUL
\end{tabular} & Agr/irrign & $\begin{array}{r}5 \% \\
20 \%\end{array}$ \\
\hline
\end{tabular}


was set up in october 1991. It is an Afghan non-governmental organization with the objective of working for reconstruction of southwestern parts of Afghanistan.

SWFAO is involved in the sectors of agriculture, irrigation and infrastructure, health and education.

SWFAO has constructed a diversion dam in Helmand province. It has distributed relief commodities to the flood affected families in the south-west provinces.

Implementation of joint projects with the Engineering Services for Afghanistan Reconstruction (ESAR) is under consideration in Kandahar as well as other provinces.

15 karezes have been rehabilitated in Mizan district of Zabul province.

SWFAO has the capacity and interest in implementing agricultural, irrigation systems and income generation projects.

The office will move to Afghanistan when the situation allows. Consultation in this regard will be made with donor agencies and the government of Afghanistan. 
8WEDIBH COMMTTEE FOR AFGHANISTAN-SCA

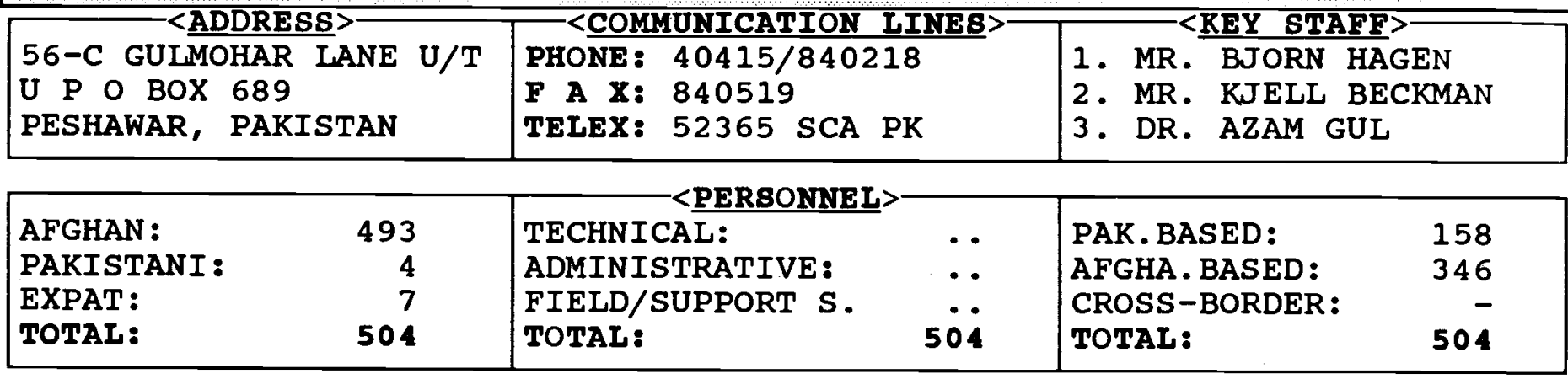

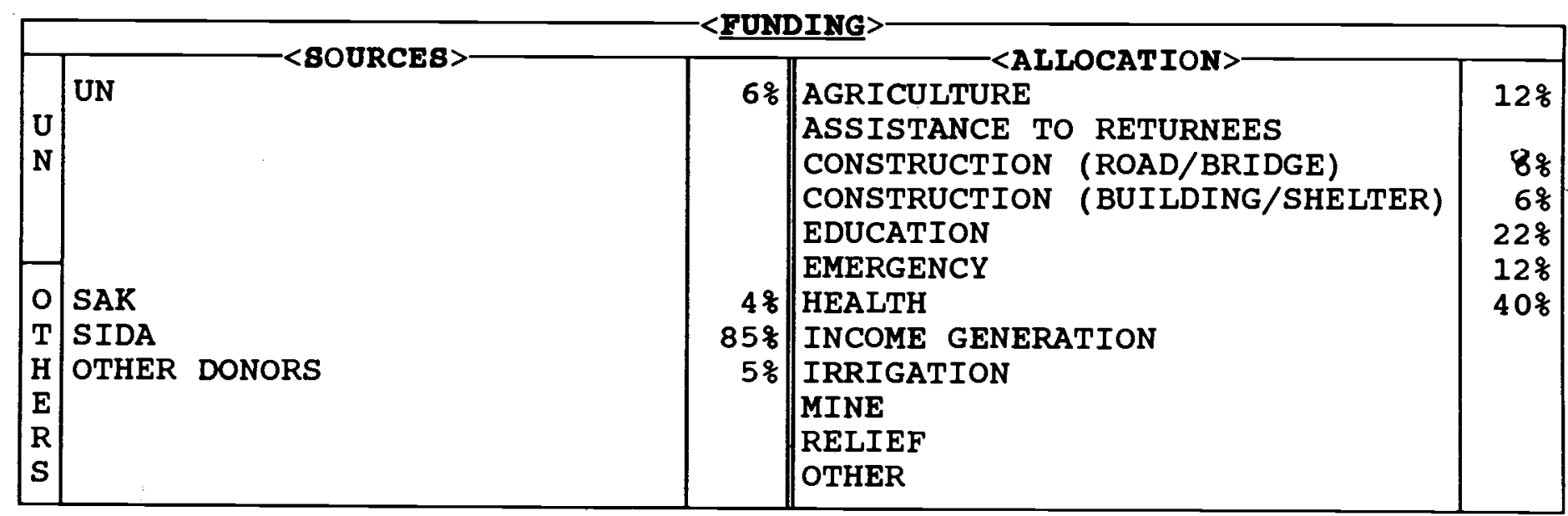

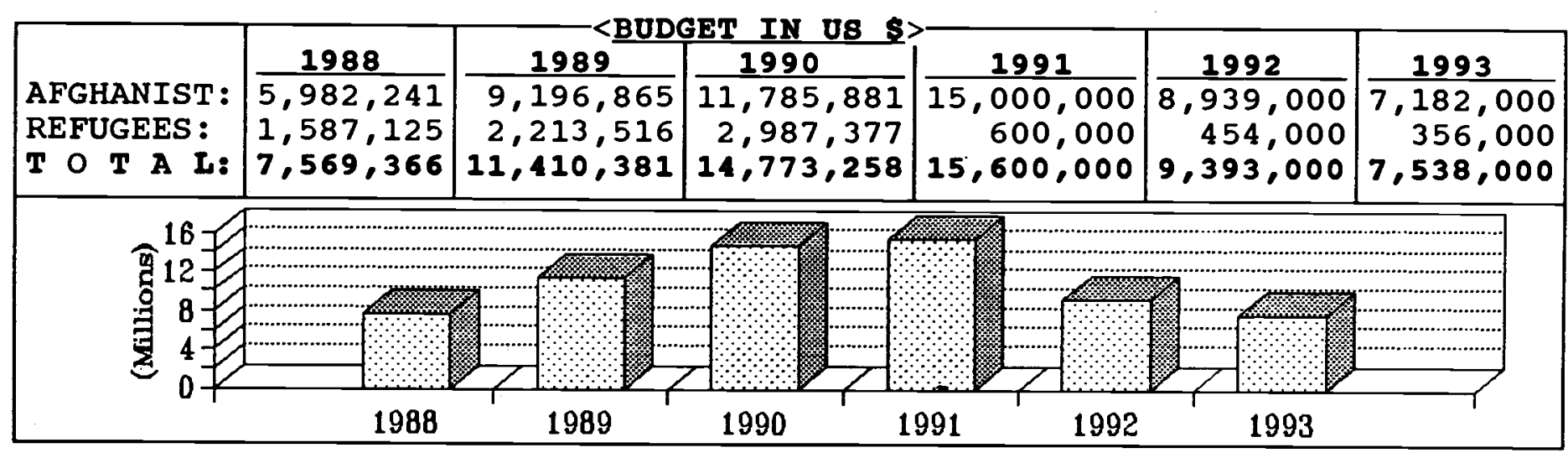

\begin{tabular}{|c|c|c|c|c|c|}
\hline PROVINCES & SECTOR & \&AGE & PROVINCES & SECTOR & $\because \mathrm{AGE}$ \\
\hline \begin{tabular}{l|} 
BADAKSHAN \\
BADGHIS \\
BAGHLAN \\
BALKH \\
BAMYAN \\
FARAH \\
FARYAB \\
GHAZNI \\
GHOR \\
HELMAND \\
HERAT \\
JAWZJAN \\
KABUL \\
KANDAHAR \\
KAPISA
\end{tabular} & $\begin{array}{l}\text { Agr/educ/health/RE } \\
\text { Agr/educ/health/RE } \\
\text { Agr/educ/health } \\
\text { Agr/educ/health } \\
\text { Agr/health } \\
\text { Agr/health } \\
\text { Agr/educ/health/RE } \\
\text { Agr/health } \\
\text { Agr/health } \\
\text { Agr/health } \\
\text { Agr/health } \\
\text { Agr/health/RE } \\
\text { Agr/health } \\
\text { Agr/educ/health }\end{array}$ & \begin{tabular}{l||}
$q$ \\
$q$ \\
$q$ \\
$q$ \\
$q$ \\
$q$ \\
$q$ \\
$q$ \\
$q$ \\
$q$ \\
$q$ \\
$q$ \\
$q$ \\
$q$ \\
$\frac{6}{6}$ \\
$q$ \\
$q$
\end{tabular} & \begin{tabular}{|l} 
KUNAR \\
KUNDUZ \\
LAGHMAN \\
LOGAR \\
NANGARHAR \\
NIMROZ \\
ORUZGAN \\
PAKTEKA \\
PAKTIA \\
PARWAN \\
SAMANGAN \\
TAKHAR \\
WARDAK \\
ZABUL
\end{tabular} & $\begin{array}{l}\text { Agr/educ/health/RE } \\
\text { Agr/educ/health/RE } \\
\text { Agr/health/RE } \\
\text { Agr/educ/health/RE } \\
\text { Agr/educ/health/RE } \\
\text { Agr/health } \\
\text { Educ/health/RE } \\
\text { Educ/health/RE } \\
\text { Agr/educ/health } \\
\text { Agr/educ/health } \\
\text { Agr/educ/health } \\
\text { Agr/educ/health/RE } \\
\text { Agr/health }\end{array}$ & 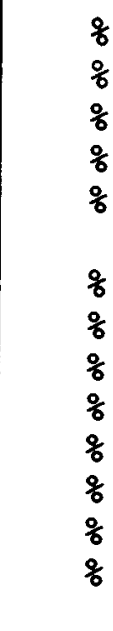 \\
\hline
\end{tabular}



(SCA)

was founded in 1980, shortly after the Soviet invasion, in order to work for the withdrawal of the Soviets from the country and to assist the struggle of the Afghan people for national independence. A campaign was initiated in the fall of 1981 to raise funds for SCA's assistance to Afghanistan and in the following year SCA received its first state subsidy for humanitarian aid to war victims in Afghanistan. In this connection SCA established a permanent office in Peshawar in November 1982 .

Initially the main type of assistance was the distribution of medicines and other medical supplies. Eventually, SCA also began to provide assistance to the educational and agriculture sectors, and in 1993 a separate unit for Rural Engineering was established.

During 1993, a major re-organization of SCA took place. The field offices in Afghanistan have been upgraded to Regional offices headed by Afghan Directors. Each of these offices covers several provinces. They are situated in Ghazni, Jalalabad and Talogan. Afghan staff have been transferred from Peshawar to the Regional offices and the Peshawar offices function as Technical Support Units.

Presently, SCA supports about 200 clinics in Afghanistan and 1,300 health workers; 600 schools with 4,000 teachers and over 100,000 students, and runs teacher training courses at the three regional offices; has undertaken construction of 900 shallow water wells, building 20 schools, a number of clinics and latrines, and has been involved in several irrigation projects. The Agriculture unit is involved in seed testing and multiplication in 6 different climatical zones in Afghanistan, conducted a series of surveys, and carries out extension services to Afghan farmers as well as training both SCA and other extension workers.

An important part of SCA's implementation strategy is to work closely with local communities (Shuras) seeking to achieve an increasing amount of local contribution in order to secure sustainability of the projects. 


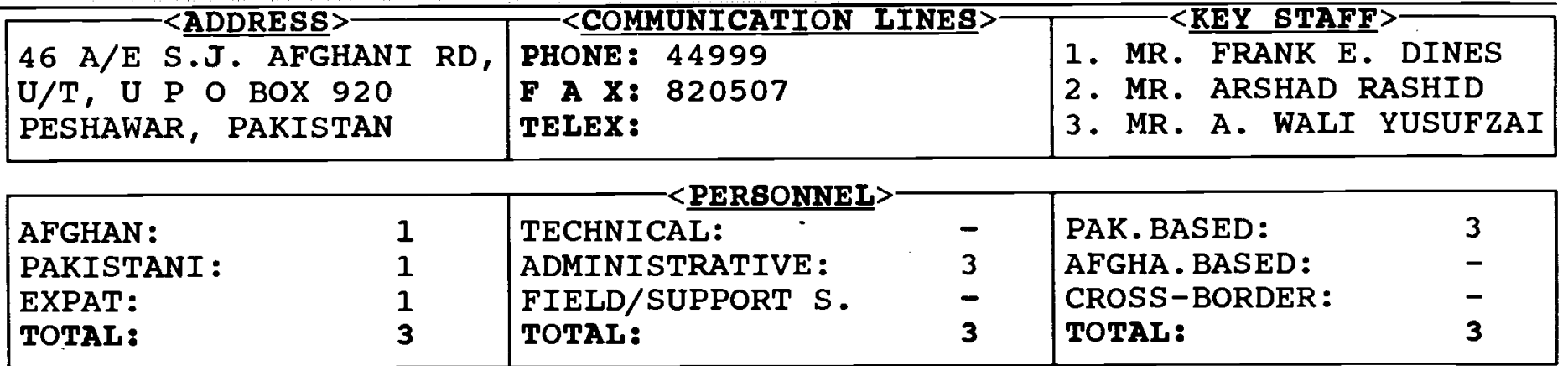

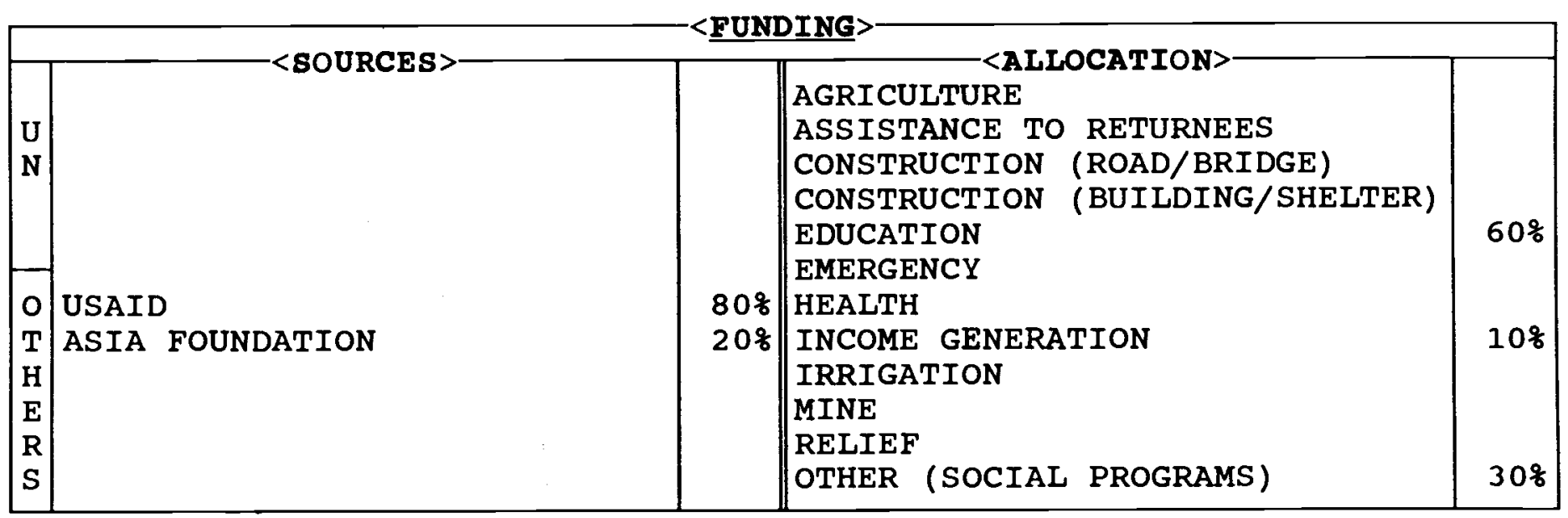

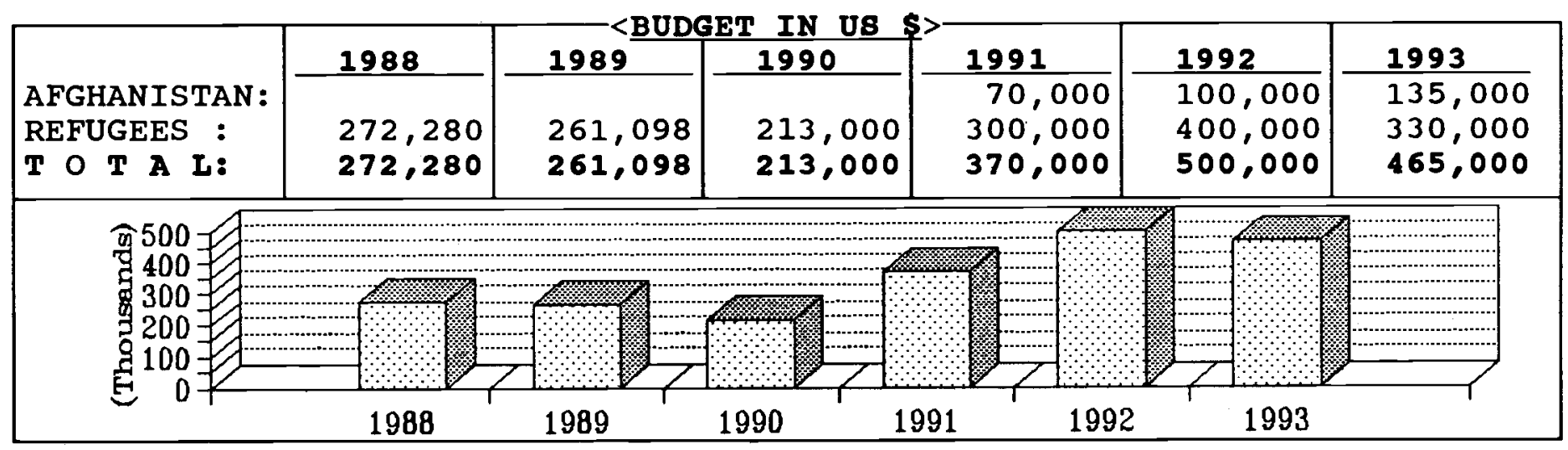

\begin{tabular}{|c|c|c|c|c|c|c|}
\hline PROVINCES & SECTOR & \&AGE & PROVINCES & & SECTOR & $\because A G E$ \\
\hline $\begin{array}{l}\text { BADAKSHAN } \\
\text { BADGHIS } \\
\text { BAGHLAN } \\
\text { BALKH } \\
\text { BAMYAN } \\
\text { FARAH } \\
\text { FARYAB } \\
\text { GHAZNI } \\
\text { GHOR } \\
\text { HELMAND } \\
\text { HERAT } \\
\text { JAWZJAN } \\
\text { KABUL } \\
\text { KANDAHAR } \\
\text { KAPISA }\end{array}$ & $\begin{array}{l}\text { Social } \\
\text { Literacy/Social } \\
\text { Literacy/voc.training }\end{array}$ & 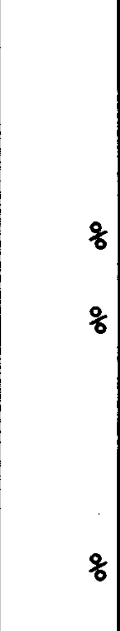 & \begin{tabular}{|l} 
KUNAR \\
KUNDUZ \\
LAGHMAN \\
LOGAR \\
NANGARHAR \\
NIMROZ \\
ORUZGAN \\
PAKTEKA \\
PAKTIA \\
PARWAN \\
SAMANGAN \\
TAKHAR \\
WARDAK \\
ZABUL
\end{tabular} & $\begin{array}{l}\text { Income } \\
\text { Income }\end{array}$ & $\begin{array}{l}\text { gen. } \\
\text { gen./Literacy }\end{array}$ & $\%$ \\
\hline
\end{tabular}


is a private, publicly funded grantmaking organization founded in 1951 and based in San Francisco, California. It has 19 resident offices and 26 country programs in Asia and the Pacific.

Its grant activities are largely concentrated in the areas of human resource development, public administration, education, free enterprise and business management, international relations and diplomacy.

From 1954 until 1979 the Foundation was active in Afghanistan, providing consultants, equipment/materials for institutionalizing, sponsoring exchange programs and training and modernizing public service. It worked with many Government institutions such as the Rural Development Department, the Higher Teachers Training college, the National Archives and Kabul Museum, Nangarhar and Kabul Universities, the Raisin and Karakul Institutes, the Women's Institute, The HelmandArghandab Valley Authority, the Academy of Science, the Ministries of Education, Agriculture, Planning, Finance, Public Health, Foreign Affairs, and others.

Current programming supports an institution of higher education for women; an advocacy and scholarship program for disabled; participation in international forums; incomegenerating and literacy programs for women in Peshawar, Quetta and Afghanistan and a coordinating bureau for Afghan NGOs. Special consideration is given to activities which enhance opportunities for the disabled and women to participate in the reconstruction of Afghanistan. 
UNITED MEDICAL CENTER FOR AFGHANB-UMCA

\begin{tabular}{|l|l|l|}
\hline GULABAD SECONDARY BOARD & PHONE: 41697 & <COMMUNICATION LINES \\
G P O BOX 33 & F A X: & 1. MR. WALI BABAKARKHEL \\
PESHAWAR, PAKISTAN & TELEX: & 2. MR. AMANULLAH NASRAT \\
\hline
\end{tabular}

\begin{tabular}{|lc|lr|lr|}
\hline AFGHAN : & 20 & TECHNICAL: & 12 & PAK. BASED: \\
PAKISTANI: & - & ADMINISTRATIVE: & 6 & AFGHA. BASED: \\
EXPAT: & - & FIELD/SUPPORT S. & 2 & CROSS-BORDER: \\
TOTAL: & 20 & TOTAL: & 20 & TOTAL: \\
\hline
\end{tabular}

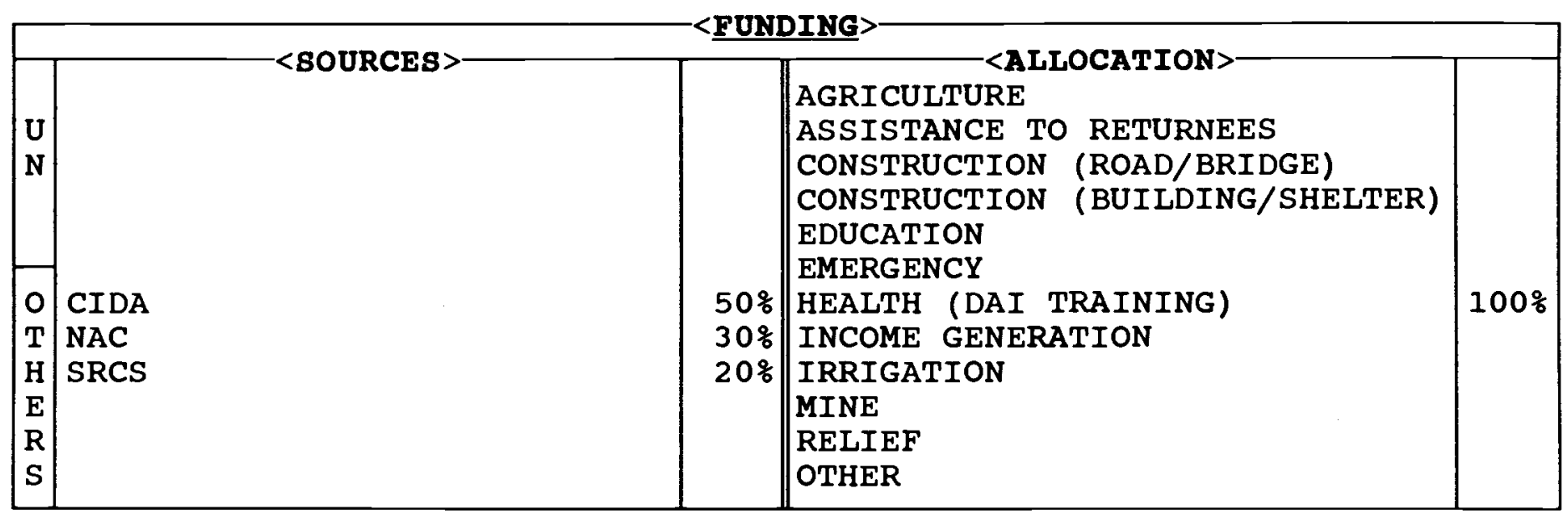

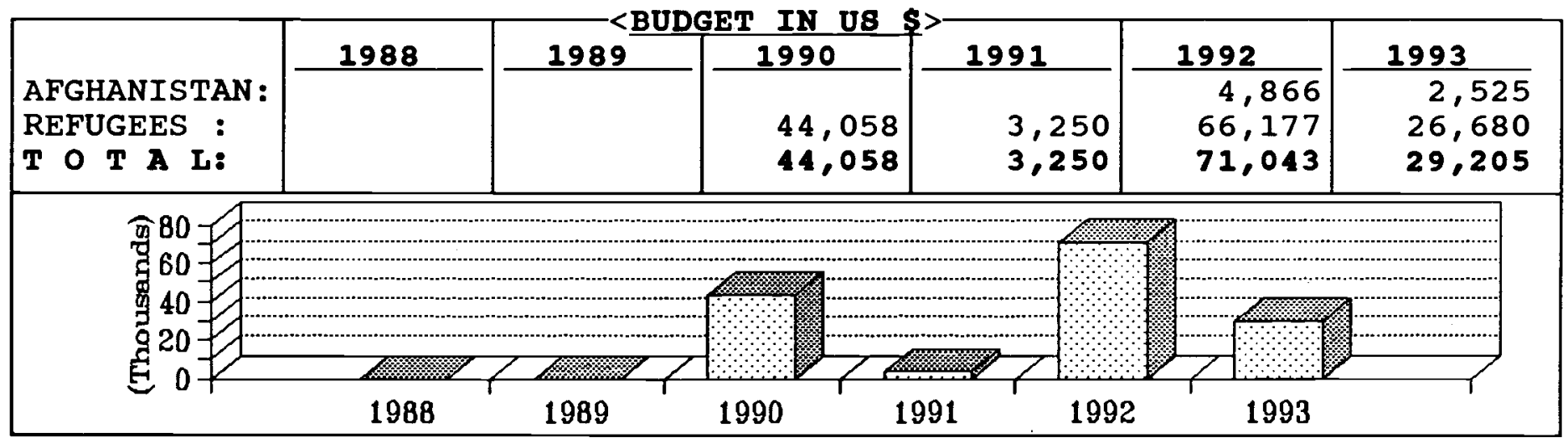

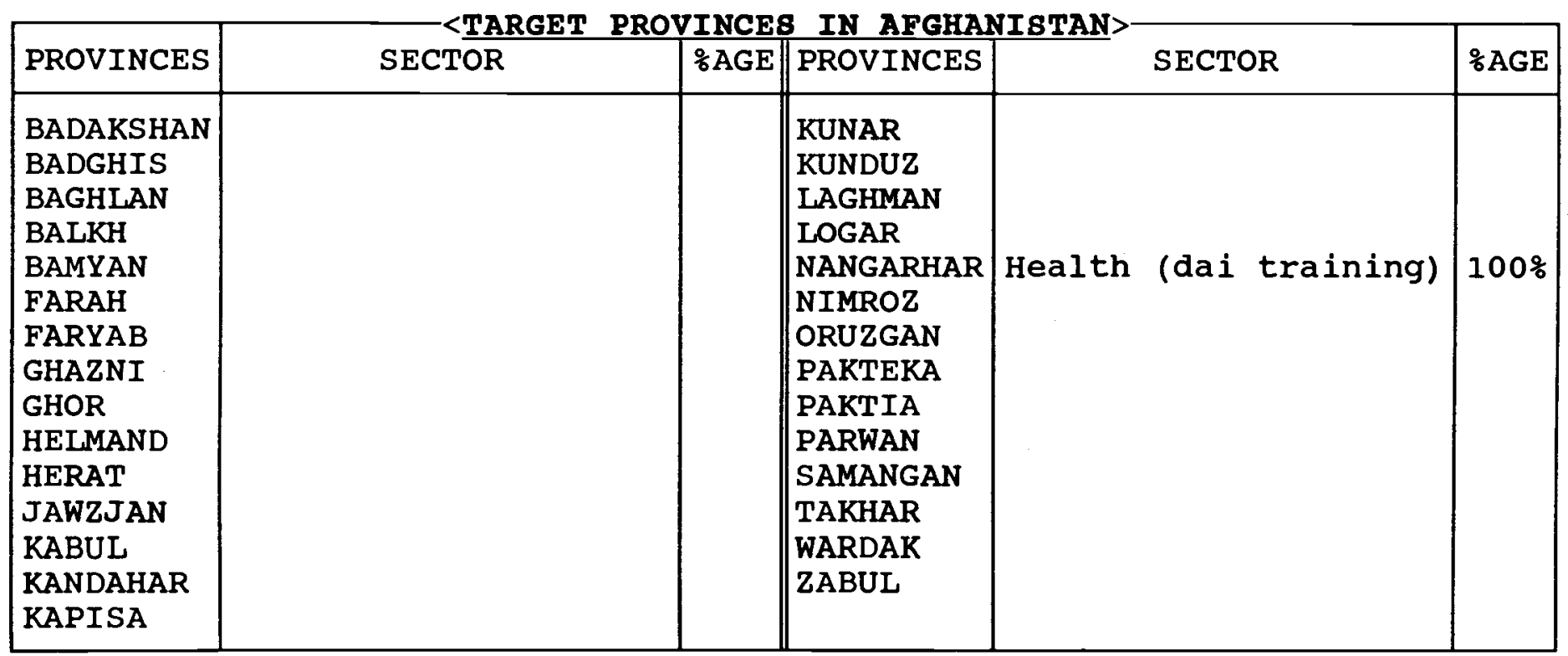


UNITED MEDICAL CENTER FOR AFGHANS (UMCA)

is an Afghan NGO founded in 1987 to provide medical training and health services to Afghans inside Afghanistan as well as in the refugee camps in Pakistan.

UMCA has implemented the following projects :

A one year medical training course. Students were selected from different parties and parts of Afghanistan.

A ten bed hospital which was used as a teaching hospital for the trainees of the course.

An out patient clinic for both male and female patients. The clinic also had a TB control program, EPI and eye program. A TBA training program in Peshawar. In 4 courses the program has trained a total of 180 TBAs.

A TBA training program and a mother and child clinic in Jalalabad, Nangarhar. In 4 courses the program has trained a total of 40 TBAs. The course is presently running satisfactorily in Jalalabad. 


\begin{tabular}{|c|c|c|c|c|c|}
\hline \multirow{2}{*}{\multicolumn{2}{|c|}{$\begin{array}{l}\text { 26-C, CHINAR RD, U/T } \\
\text { G P O BOX } 967 \\
\text { PESHAWAR, PAKISTAN }\end{array}$}} & \multicolumn{2}{|c|}{$-<$ COMMUNICATION LINES $>$} & \multicolumn{2}{|c|}{$=<$ KEY STAFF $>$} \\
\hline & & $\begin{array}{l}\text { PHONE: } 44536 / 840 \\
\text { F A X: } \\
\text { TELEX: }\end{array}$ & & $\begin{array}{l}\text { 1. MR. G. R. } \\
\text { 2. PROF.A.AZI } \\
\text { 3. MR. DAVID }\end{array}$ & $\begin{array}{l}\text { RDMAN } \\
\text { LER }\end{array}$ \\
\hline $\begin{array}{l}\text { AFGHAN : } \\
\text { PAKISTANI : } \\
\text { EXPAT: } \\
\text { TOTAL : }\end{array}$ & $\begin{array}{r}430 \\
3 \\
4 \\
437\end{array}$ & $\begin{array}{l}\text { TECHNICAL: } \\
\text { ADMINISTRATIVE: } \\
\text { FIELD/SUPPORT S. } \\
\text { TOTAL: }\end{array}$ & $43 \dot{ }$ & $\begin{array}{l}\text { PAK. BASED: } \\
\text { AFGHA. BASED: } \\
\text { CROSS-BORDER: } \\
\text { TOTAL : }\end{array}$ & $43 \dot{ }$ \\
\hline
\end{tabular}

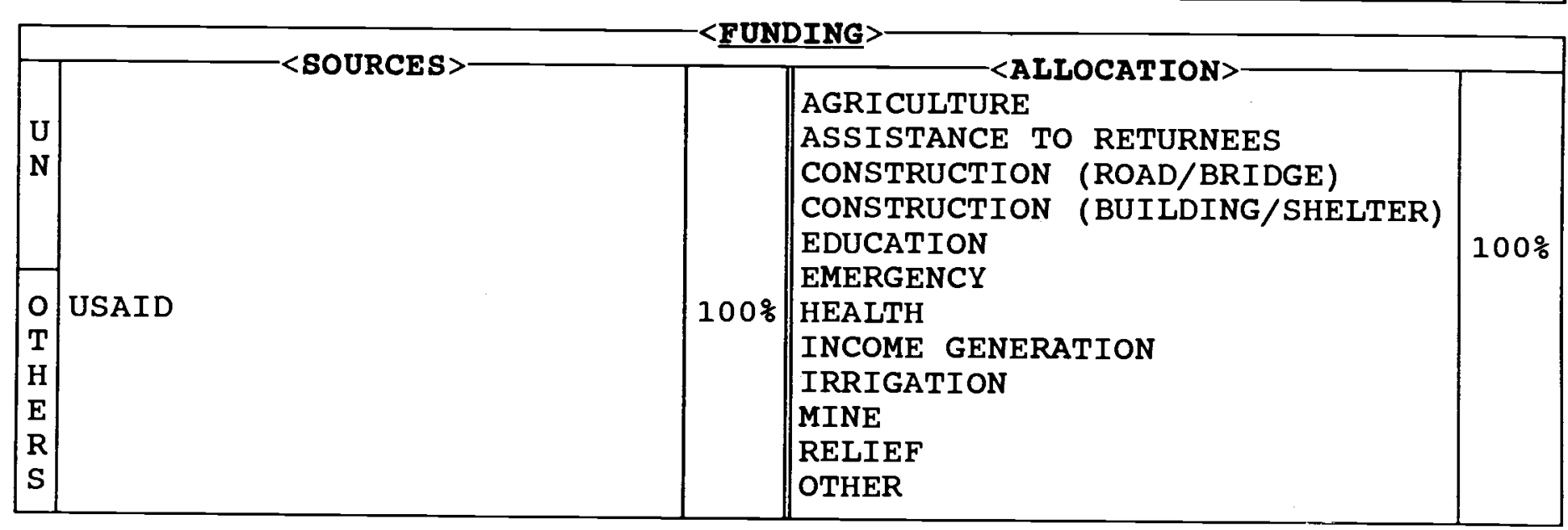

\begin{tabular}{|c|c|c|c|c|c|c|}
\hline & 1988 & 1989 & 1990 & 1991 & 1992 & 1993 \\
\hline $\begin{array}{l}\text { AFGHANISTAN: } \\
\text { REFUGEES : } \\
\text { T O T A L: }\end{array}$ & $\begin{array}{l}3,329,633 \\
3,329,633\end{array}$ & $\begin{array}{r}5,582,761 \\
293,829 \\
5,876,590\end{array}$ & $\begin{array}{r}5,787,210 \\
517,186 \\
6,304,396\end{array}$ & $\begin{array}{r}6,787,174 \\
622,979 \\
7,410,153\end{array}$ & $\begin{array}{l}6,787,174 \\
2,822,000 \\
9\end{array}$ & $\overline{6,290,000}$ \\
\hline
\end{tabular}

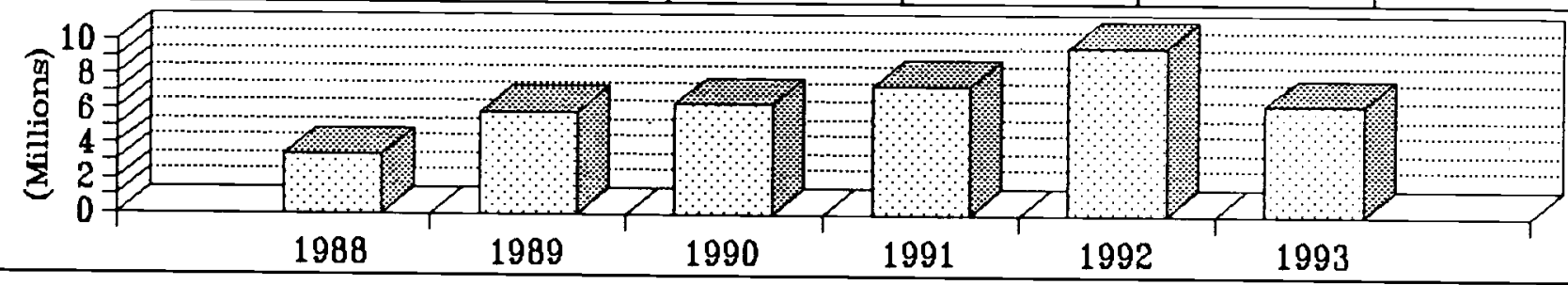

\begin{tabular}{|c|c|c|c|c|c|}
\hline PROVINCES & SECTOR & $\because A G E$ & PROVINCES & SECTOR & $\because A G E$ \\
\hline BADAKSHAN & Education & $3 \%$ & KUNAR & Education & $2.1 \%$ \\
\hline BADGHIS & Education & $.2 \frac{\circ}{6}$ & KUNDUZ & Education & $4.1 \%$ \\
\hline BAGHLAN & Education & $5.3 \%$ & LAGHMAN & Education & $3 \%$ \\
\hline BALKH & Education & $5.4 \%$ & LOGAR & Education & $9.3 \%$ \\
\hline BAMYAN & Education & $2 \%$ & NANGARHAR & Education & $4.2 \%$ \\
\hline FARAH & Education & $1.3 \%$ & NIMROZ & Education & $.1 \%$ \\
\hline FARYAB & Education & $2.2 \%$ & ORUZGAN & Education & $2 \%$ \\
\hline GHAZNI & Education & $10 \%$ & PAKTEKA & Education & $3.1 \%$ \\
\hline GHOR & Education & $1.5 \%$ & PAKTIA & Education & $2.3 \%$ \\
\hline HELMAND & Education & $1.7 \%$ & PARWAN & Education & $6.5 \%$ \\
\hline HERAT & Education & $1.2 \%$ & SAMANGAN & Education & $5.2 \%$ \\
\hline JAWZJAN & Education & $4 \%$ & TAKHAR & Education & $2.2 \%$ \\
\hline KABUL & Education & $1.5 \%$ & WARDAK & Education & $9 \%$ \\
\hline KANDAHAR & Education & $\begin{array}{l}1 \% \\
0\end{array}$ & ZABUL & Education & $.8 \%$ \\
\hline & Education & $5.6 \%$ & & & \\
\hline
\end{tabular}


UNIVERSITY OF NEBRASKA AT OMAHA (UNO)

is the technical assistance contractor for the Education sector Support Project (ESSP). UNO has a long history of support for the Afghan cause; it opened the center for Afghanistan Studies in 1972, was the contractor for the USAID Higher Education Project at Kabul University from 1974 to 1978, was the primary implementor in the Atlas of Afghanistan and the Dari-English Dictionary projects, and has been an implementor for several Afghan participant training programs.

Project implementation of $196^{\prime \wedge 1}$

began in october 1986, with the objective being to provide educational and humanitarian assistance to Afghan people in mujahideen controlled areas. The primary focus was on the liberated areas inside Afghanistan and, in 1991 and 1992 to a limited degree, the refugees in Pakistan. Currently, the objectives of the ESSP project are as follows:

A. To strengthen the primary school network by improving the key elements, including curriculum, textbooks, instructional aids, and teacher training and central capabilities in planning, budgeting, and policy development.

B. To increase the incidence of adult literacy by providing textbooks, instructional materials, and technical guidance to groups engaged in literacy training.

C. To increase access to schools and to remove educational disparities by reaching underserved gender, geographic and ethnic groups.

The main accomplishments of the project include:

A. establishing an Educational Center for Afghanistan (ECA), assisted by the UNO team and representative of the Alliance
B. distribution of more than 12 million textbooks for Afghan primary schools, distribution of more than 70,000 kits of instructional materials, 60,000 reading story books

C. 36,000 math/language boards and 740,000 mine awareness packets.

Additionally, UNO has provided literacy training to 48,000 mujahideen in their winter camps, trained more than 2,800 primary school teachers (4 week sessions), provided English language training for 217 Afghan participant training candidates, sent 105 participants to the US for further study, and provided manpower training (six month program) for more than 2,000 trainees in clerical/administrative skills and trade-construction skills.

Future plans include the further development of textbooks, primary school teacher-training programs, and design and development of further instructional materials. The major focus will continue in basic education, primary education and adult literacy. 
VOLUNTARY ASSOCIATION FOR REHABIIITATION OF AFGHANISTAN-VARA

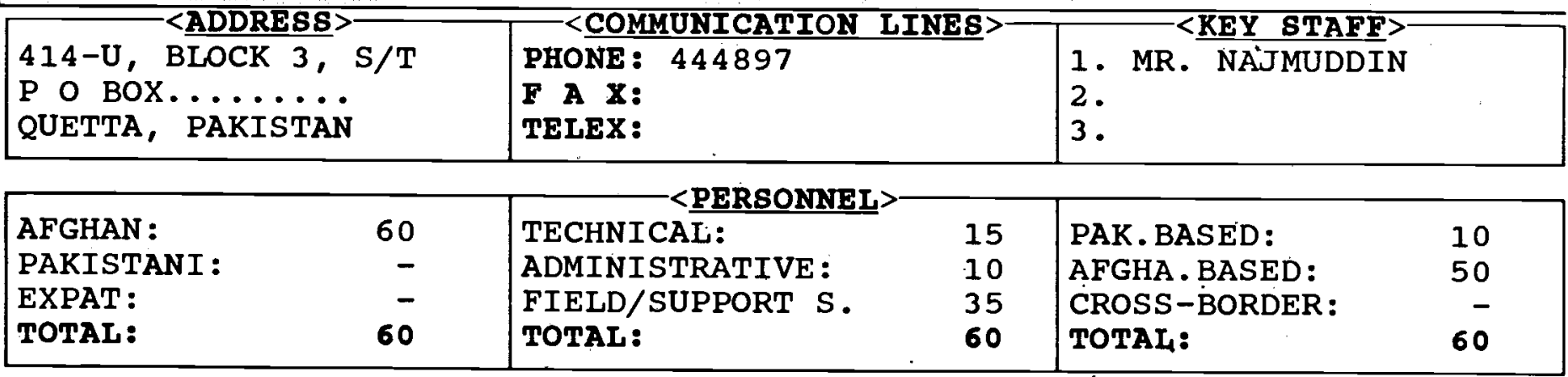

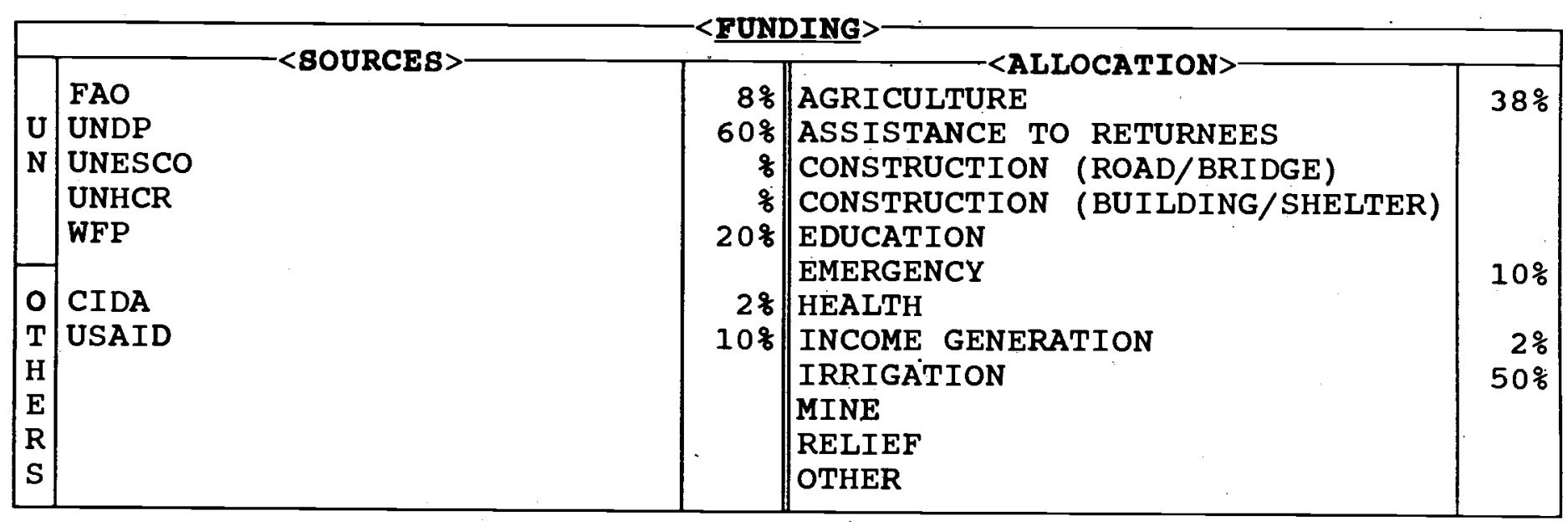

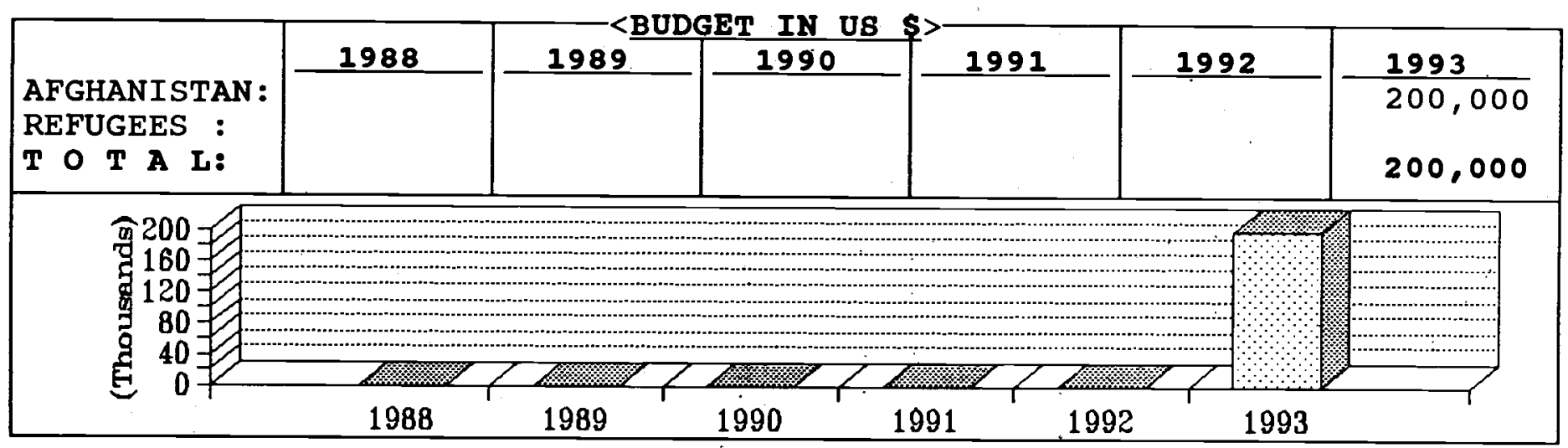

\begin{tabular}{|c|c|c|c|c|c|}
\hline PROVINCES & SECTOR & \&AGE & PROVINCES & SECTOR & \%AGE \\
\hline $\begin{array}{l}\text { BADAKSHAN } \\
\text { BADGHIS } \\
\text { BAGHLAN } \\
\text { BALKH } \\
\text { BAMYAN } \\
\text { FARAH } \\
\text { FARYAB } \\
\text { GHAZNI } \\
\text { GHOR } \\
\text { HELMAND } \\
\text { HERAT } \\
\text { JAWZJAN } \\
\text { KABUL } \\
\text { KANDAHAR } \\
\text { KAPISA }\end{array}$ & $\begin{array}{l}\text { Agr/inc.gen/irrig/rel } \\
\text { Agr/irrign/relief }\end{array}$ & 108 & $\begin{array}{l}\text { KUNAR } \\
\text { KUNDUZ } \\
\text { LAGHMAN } \\
\text { LOGAR } \\
\text { NANGARHAR } \\
\text { NIMROZ } \\
\text { ORUZGAN } \\
\text { PAKTEKA } \\
\text { PAKTIA } \\
\text { PARWAN } \\
\text { SAMANGAN } \\
\text { TAKHAR } \\
\text { WARDAK } \\
\text { ZABUL }\end{array}$ & Agr/income gen/irrign & $20 \%$ \\
\hline
\end{tabular}




\section{VOLUNTARY ASSOCIATION FOR REHABILITATION OF AFGHANISTAN (VARA)}

is an Afghan NGO founded in 1990 with the objective of taking part in the rehabilitation and reconstruction of Afghanistan.

VARA works in the sectors of irrigation rehabilitation, agriculture, income generation/skill training, education and infrastructure reconstruction. The Association also undertakes emergency relief programs.

In irrigation, VARA has cleaned 5 canals including a 10 kilometers long canal (Marja canal) in Helmand province which irrigates over 5,000 jeribs of land. The canals benefit hundreds of farmer families.

In the agriculture sector, it carries out seed distribution and multiplication activities (over 100 MTs wheat and maize seeds and fertilizer have been distributed in the provinces of Farah, Helmand and Nimroz). Extension work is provided to farmers in the 4 target provinces. The Association has established five veterinary centers covering the whole province of Nimroz. It operates agriculture machinery (tractors and threshers).

A carpet weaving project for men and women is going on in Farah and Nimroz provinces.

Two primary schools have been established with the assistance of the communities in Farah and Nimroz provinces.

As part of its relief program, VARA has distributed some 350 MTs of food to the needy people in Farah and 450 pairs of trousers to laborers in Helmand.
VARA has proposed more than 20 projects to different donor organizations and is looking forward to implementing them in the near $f \begin{array}{llllll} & u & t & u & r & e\end{array}$ 


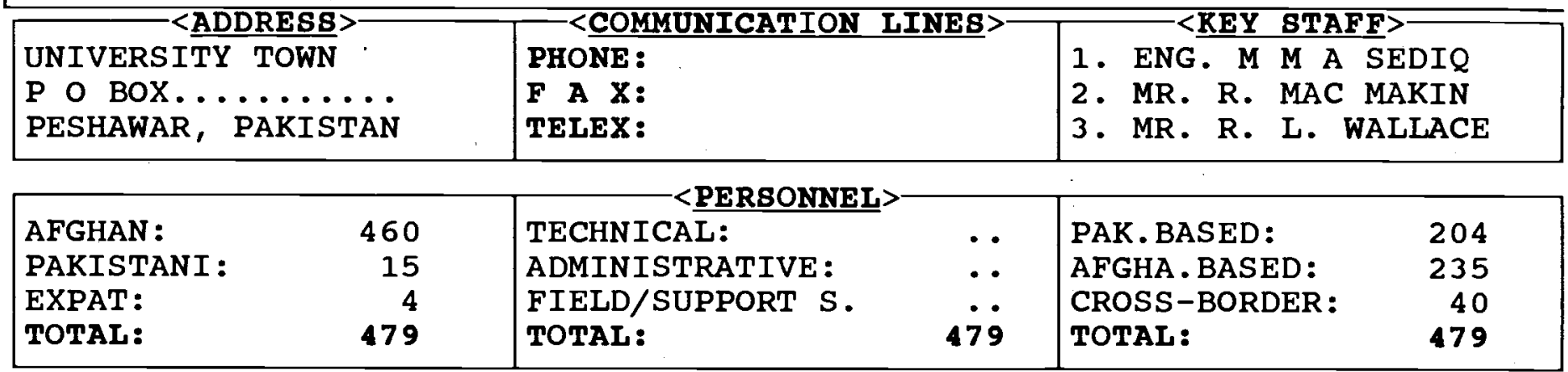

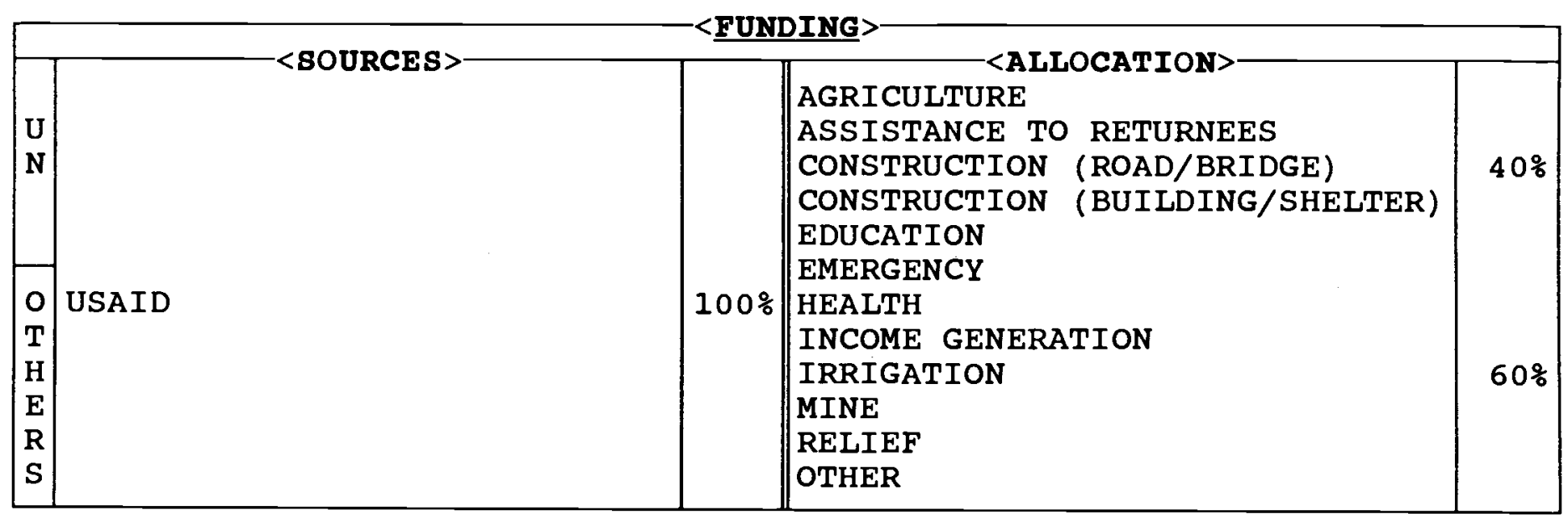

\begin{tabular}{|c|c|c|c|c|c|c|}
\hline & 1988 & 1989 & 1990 & 1991 & 1992 & 1993 \\
\hline $\begin{array}{l}\text { AFGHANISTAN : } \\
\text { REFUGEES : }\end{array}$ & $5,692,144$ & $\overline{5,692, \overline{144}}$ & $5,664,385$ & $5,664,385$ & $\overline{6,000,000}$ & $\overline{5,400,000}$ \\
\hline $\mathbf{T} O \mathbf{T} \mathbf{A} \mathbf{L}$ & $5,692,144$ & $5,692,144$ & $5,664,385$ & $5,664,385$ & $6,000,000$ & $5,400,000$ \\
\hline
\end{tabular}

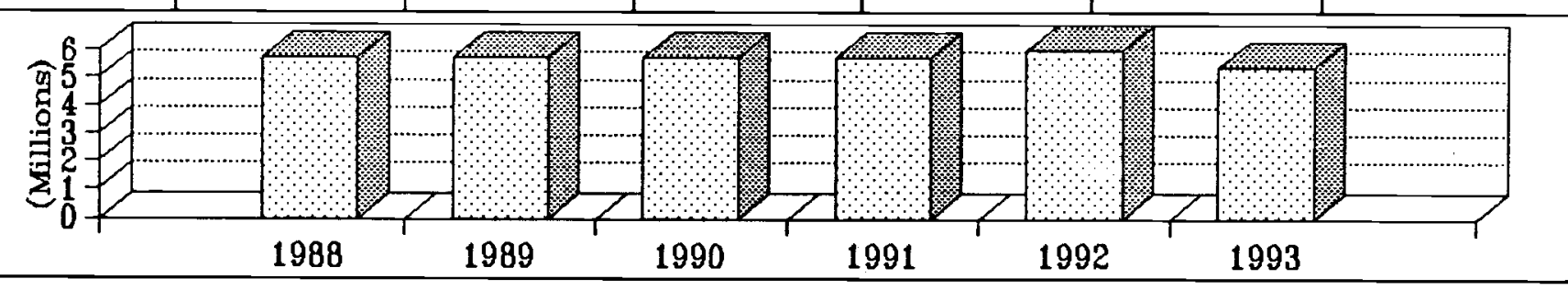

\begin{tabular}{|c|c|c|c|c|c|}
\hline PROVINCES & SECTOR & $\% \mathrm{AGE}$ & PROVINCES & SECTOR & $\%$ AGE \\
\hline $\begin{array}{l}\text { BADAKSHAN } \\
\text { BADGHIS } \\
\text { BAGHLAN } \\
\text { BALKH } \\
\text { BAMYAN } \\
\text { FARAH } \\
\text { FARYAB } \\
\text { GHAZNI } \\
\text { GHOR } \\
\text { HELMAND } \\
\text { HERAT } \\
\text { JAWZJAN } \\
\text { KABUL } \\
\text { KANDAHAR } \\
\text { KAPISA }\end{array}$ & $\begin{array}{l}\text { Const/irrign } \\
\text { Const/irrign } \\
\text { Const } \\
\text { Irrign } \\
\text { Const/irrign } \\
\text { Const/irrign } \\
\text { Const/irrign } \\
\text { Irrign } \\
\text { Const/irrign }\end{array}$ & $\begin{array}{l}\frac{\%}{0} \\
\% \\
\% \\
\% \\
\% \\
\% \\
\% \\
\% \\
\% \\
\frac{\circ}{6}\end{array}$ & \begin{tabular}{|l} 
KUNAR \\
KUNDUZ \\
LAGHMAN \\
LOGAR \\
NANGARHAR \\
NIMROZ \\
ORUZGAN \\
PAKTEKA \\
PAKTIA \\
PARWAN \\
SAMANGAN \\
TAKHAR \\
WARDAK \\
ZABUL
\end{tabular} & $\begin{array}{l}\text { Const/irrign } \\
\text { Irrign } \\
\text { Const/irrign } \\
\text { Irrign } \\
\text { Const/irrign } \\
\text { Const/irrign } \\
\text { Const/irrign } \\
\text { Const/irrign } \\
\text { Const/irrign }\end{array}$ & $\begin{array}{l}\% \\
\% \\
\% \\
\% \\
\% \\
\%\end{array}$ \\
\hline
\end{tabular}


VOLUNTEERS IN TECHNICAL ASBIBTANCE (VITA)

is a private, non-profit, voluntary organization, funded by the US Government. Its headquarters are in Virginia in the US and is locally based in Peshawar. As part of the USAID/Afghan Agricultural sector Support Project, it is primarily organized to help Afghanistan in the field of agriculture. This aim is pursued by providing resources to support increased agricultural productivity inside Afghanistan and to support the growth of institutional mechanisms to use these resources. The focus of VITA is strictly on helping the Afghan farmers inside Afghanistan.

Because of the war, fruit orchards were extensively damaged. VITA initiated the rehabilitation of these orchards by sending in about 2,700 rootstock of apple, peach and almond to seven of the eastern provinces of Afghanistan. As a part of its reforestation program, a total of 551,000 root cuttings of poplar and mulberry were sent to four provinces.

VITA is currently working in 16 Agricultural Rehabilitation Schemes (ARSs) in the south-western and eastern provinces of Afghanistan. Its ARSs are located in the provinces of Kandahar, Ghazni, Wardak, Paktia, Baghlan, Logar, Parwan, Takhar, Herat, Farah, Kunduz, Kabul, Bamyan, Kapisa, Pakteka, and Kunar. Road work and rehabilitation of irrigation canals is underway in Paktia, Kunar, Logar, Kandahar, Parwan, Takhar, Ghazni, Baghlan and Nangarhar provinces.

VITA has in the past sent, by various means, the following supplies/equipment into Afghanistan:

1. 300 wheat threshers and 200 rice huskers;

2. 1,800 water pumps:

3. 15 tractors and implements and

- $\$ 300,000$ of spare parts;

4. Over 500 bullocks;

5. Seed and fertilizer for 1,000 farmers; VITA is planning to send 35 tons of improved wheat seed and 9,000 tons of fertilizer.

In the field of horticulture and agro-forestry, VITA established two nurseries in Pakistan for improved horticultural stock to replace that destroyed during the war. VITA also contracted with farmers to grow 2 million seedlings.

In the rural work sector, VITA has received requests for 37,345 irrigation projects. of these, 3,583 projects, mostly karezes and irrigation canals, have been rehabilitated; work on additional 225 is in progress. Requests for 674 new roads and the rehabilitation of 2580 roads have also been received. Nineteen road projects have been completed and 45 are under construction.

In addition to the above, VITA is conducting training programs of up to three months for technicians and managers. The method of working is through local shuras in each ARS to ensure allocation of project resources in line with local priorities, and the emphasis is on user fees rather than free distribution.

VITA is ready, willing, and able to move operation direction to Kabul as soon as AID/REP gives it a green light. We anticipate a gradual scaling up of Kabul activities and an equally gradual scaling down of Peshawar/Quetta operations. 
- <ADDRESS >- $>$ COMMUNICATION LINES>

ARMINA LODGE \# $8 \mathrm{KH}$. COL PHONE: 44985

TAHKAL, G P O BOX 223

PESHAWAR, PAKISTAN
F A X: 840264

TELEX: 52491 VITA PK
<KEY STAFF>

1. ENG. MOHD AMIN

2 .

3 .

\begin{tabular}{|lr|lr|lr|}
\hline AFGHAN : & 16 & TECHNICAL: & 4 & PAK. BASED: & 16 \\
PAKISTANI : & - & ADMINISTRATIVE: & 12 & AFGHA.BASED: & - \\
EXPAT: & - & FIELD/SUPPORT S. & - & CROSS-BORDER: & - \\
TOTAL: & 16 & TOTAL: & 16 & TOTAL: & 16 \\
\hline
\end{tabular}

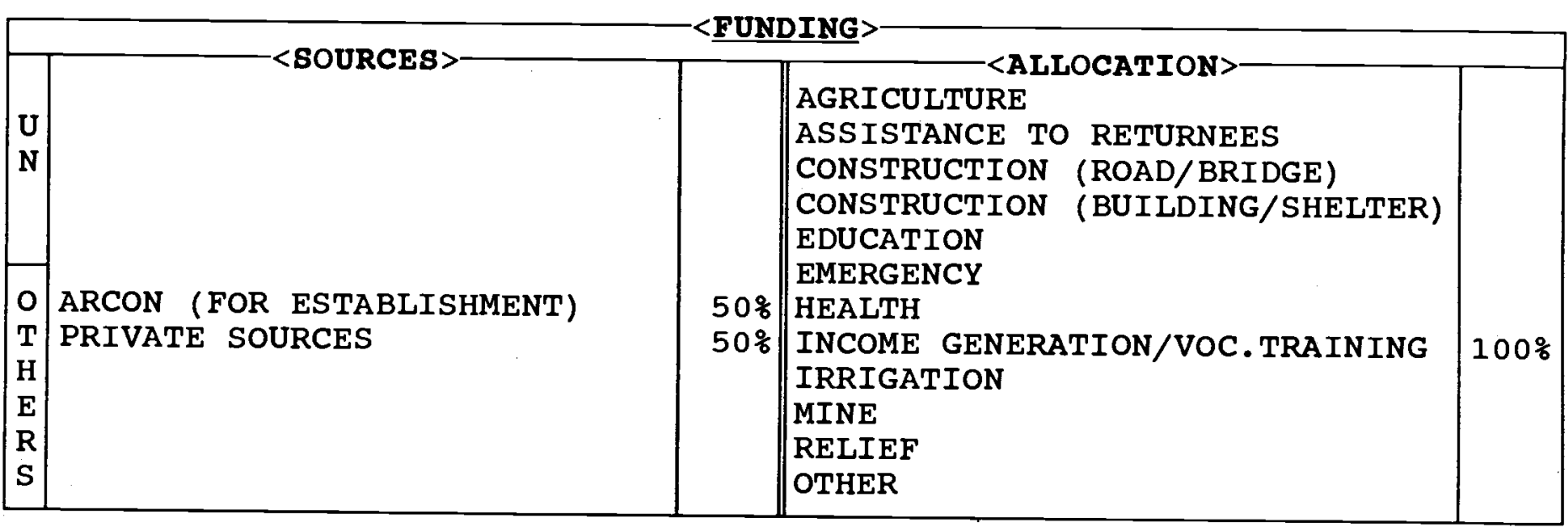

\begin{tabular}{|l|l|l|l|l|l|l|}
\hline & \multicolumn{1}{|c|}{ <BUDGET IN US \$> } & & & \\
AFGHANISTAN: & 1988 & 1989 & 1990 & 1991 & 1992 & 1993 \\
REFUGEES : & & & & & 167,000 \\
T O T A L: & & & & & 167,000 & \\
\hline
\end{tabular}

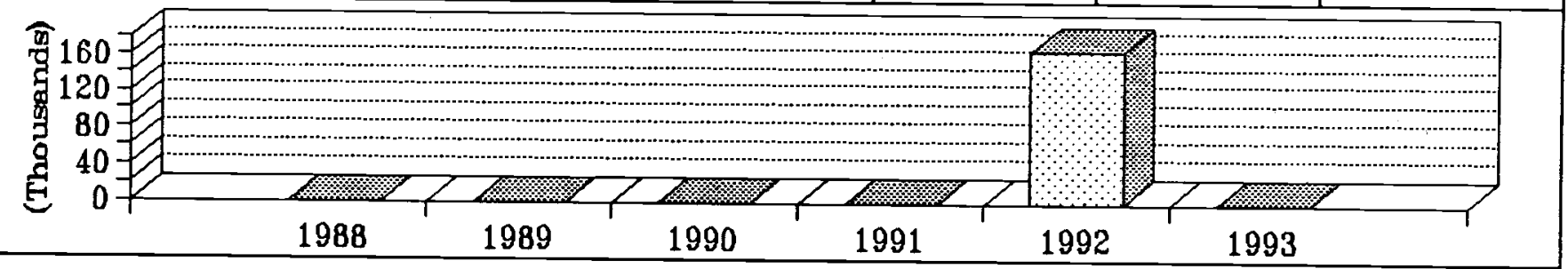

\begin{tabular}{|c|c|c|c|c|c|}
\hline PROVINCES & SECTOR & $8 \mathrm{AGE}$ & PROVINCES & SECTOR & $\%$ AGE \\
\hline $\begin{array}{l}\text { BADAKSHAN } \\
\text { BADGHIS } \\
\text { BAGHLAN } \\
\text { BALKH } \\
\text { BAMYAN } \\
\text { FARAH } \\
\text { FARYAB } \\
\text { GHAZNI } \\
\text { GHOR } \\
\text { HELMAND } \\
\text { HERAT } \\
\text { JAWZJAN } \\
\text { KABUL } \\
\text { KANDAHAR } \\
\text { KAPISA }\end{array}$ & & & \begin{tabular}{|l|} 
KUNAR \\
KUNDUZ \\
LAGHMAN \\
LOGAR \\
NANGARHAR \\
NIMROZ \\
ORUZGAN \\
PAKTEKA \\
PAKTIA \\
PARWAN \\
SAMANGAN \\
TAKHAR \\
WARDAK \\
ZABUL
\end{tabular} & & \\
\hline
\end{tabular}


is a non-governmental, non-political and non-profit Afghan organization.

Afghanistan is one of the poorest countries of the world where the majority of the population is living below substance level. The physical disability of over a million people (mostly young men) caused by the 14 years of war has further deepened its scars and agony. VTS has been established to help people with disabilities and victims of the war. It is committed to assisting them to earn a living, gain respect and become socially and economically confident.

VTS has three sections:

1. Gem cutting, polishing and finishing,

2. Jewellery

3. High quality furniture (from sheeshum wood) production.

The center is for the moment in Peshawar where VTS office is located. Courses are currently offered to male trainees. The female section has recently closed down because of shortage of funds.

VTS welcomes orders for gemstone, jewellery and furniture. 
WARHAN DEVELOPMENT ORGANIZATION-WDO

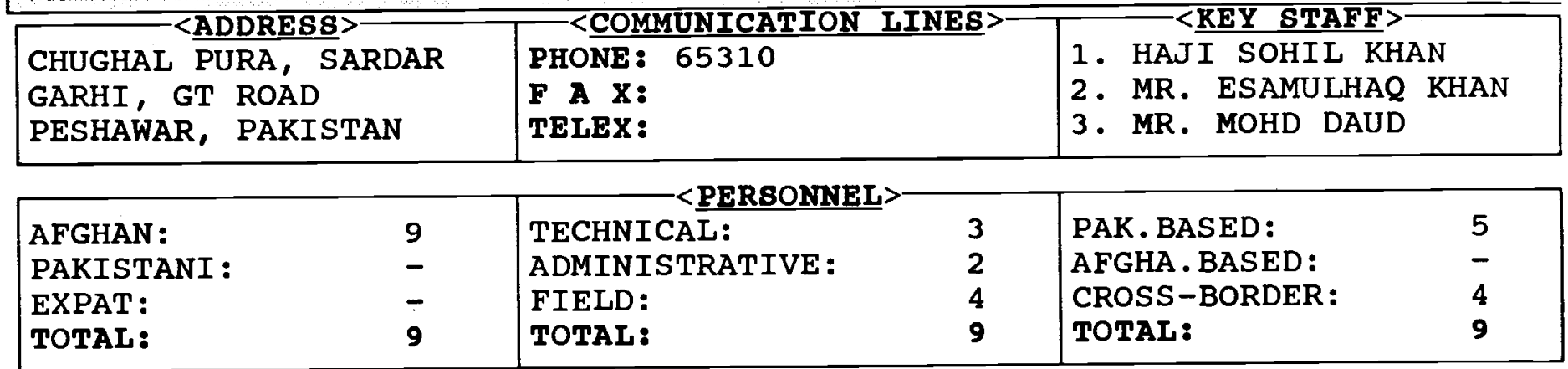

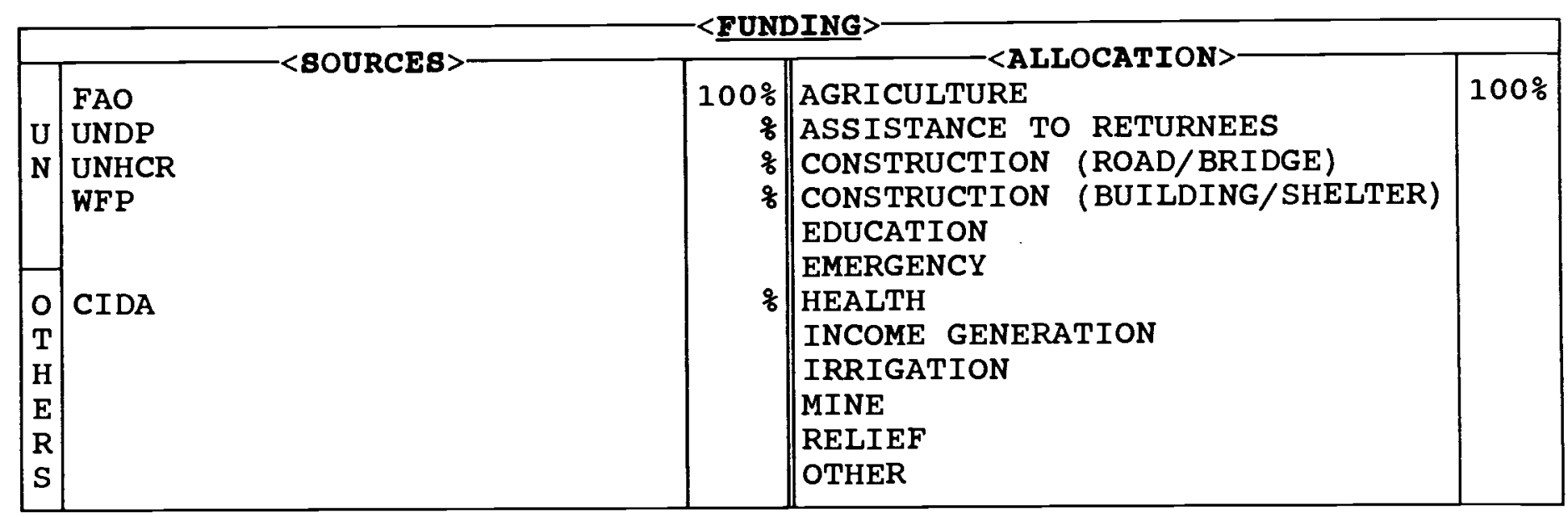

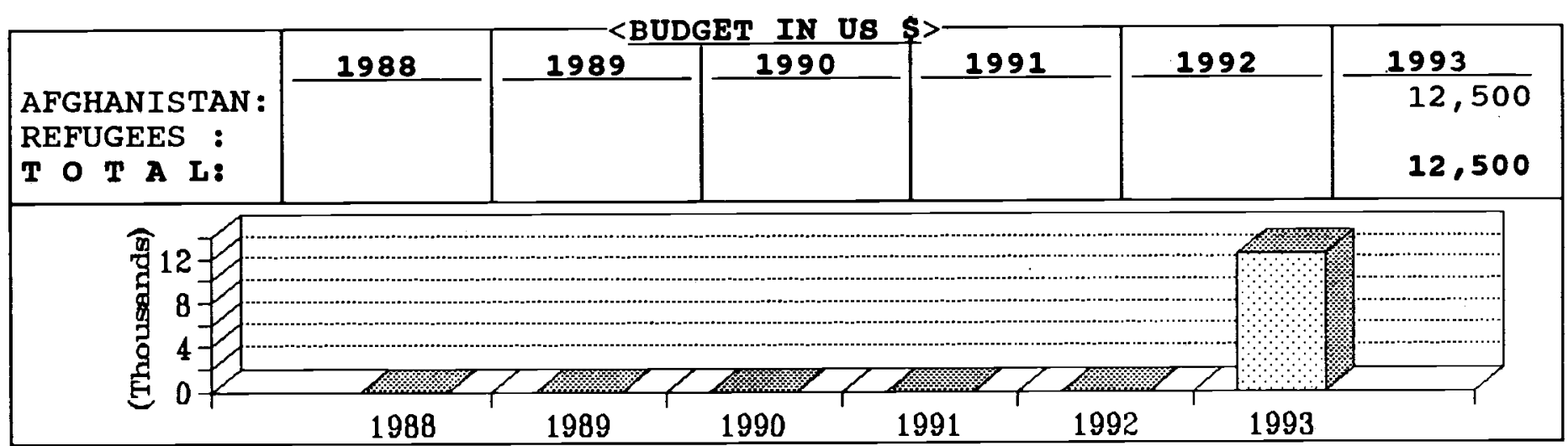

\begin{tabular}{|c|c|c|c|c|c|}
\hline PROVINCES & SECTOR & \&AGE & PROVINCES & SECTOR & $\% A G E$ \\
\hline $\begin{array}{l}\text { BADAKSHAN } \\
\text { BADGHIS } \\
\text { BAGHLAN } \\
\text { BALKH } \\
\text { BAMYAN } \\
\text { FARAH } \\
\text { FARYAB } \\
\text { GHAZNI } \\
\text { GHOR } \\
\text { HELMAND } \\
\text { HERAT } \\
\text { JAWZJAN } \\
\text { KABUL } \\
\text { KANDAHAR } \\
\text { KAPISA }\end{array}$ & $\begin{array}{l}\text { Agr } \\
\text { Agr }\end{array}$ & $25 \%$ & \begin{tabular}{|l|} 
KUNAR \\
KUNDUZ \\
LAGHMAN \\
LOGAR \\
NANGARHAR \\
NIMROZ \\
ORUZGAN \\
PAKTEKA \\
PAKTIA \\
PARWAN \\
SAMANGAN \\
TAKHAR \\
WARDAK \\
ZABUL
\end{tabular} & Agr & $25 \%$ \\
\hline
\end{tabular}


is a non-governmental, non-political and non-commercial organization. It takes an active part in the rehabilitation of Afghanistan. WDO is a member of ANCB and has been registered with the Nangarhar Jehadi Shura. WDO has applied for registration with the Government of Pakistan.

The organization has been implementing projects supported by different United Nations organizations and Canada Fund.

WDO has undertaken improved wheat seeds and fertilizer distribution program in the provinces of Parwan, Kabul, Logar and Paktia.

A number of other project proposals including canal rehabilitation in Laghman, Khost and Nangarhar provinces and public buildings (clinic and school) construction in Paktia and Kunar provinces, have been submitted to donor organizations which and are pending for approval. Furthermore, WDO has surveyed more canals and public buildings in Laghman, Logar and Khost areas. 
WELFARE AND RELIEF COMMITTEE-TRC

\begin{tabular}{|l|l|l|}
\hline 38-D PARK RD, U/T & PHONE: 44300 & <COMEY STAFF \\
U P O BOX 1097 & F A X: 44300 & 1. MR. A. JALIL SEDDIQI \\
PESHAWAR, PAKISTAN & TELEX: & 2. MR. GUL RAHMAN \\
\hline
\end{tabular}

\begin{tabular}{|lr|ll|ll|}
\hline AFGHAN : & 45 & TECHNICAL: & 20 & PAK. BASED: & $\ldots$ \\
PAKISTANI : & 3 & ADMINISTRATIVE: & 15 & AFGHA. BASED: & $\ldots$ \\
EXPAT: & 2 & FIELD: & 15 & CROSS-BORDER: & $\ldots$ \\
TOTAL: & 50 & TOTAL: & 50 & TOTAL: & 50 \\
\hline
\end{tabular}

\begin{tabular}{|c|c|c|c|c|}
\hline & C8OURCES & & -<ATTOCATTON>- & \\
\hline & FAO & 208 & AGRICULTURE & $10 \%$ \\
\hline $\mathbf{U}$ & UNDP & $10 \frac{8}{8}$ & ASSISTANCE TO RETURNEES & \\
\hline $\mathbf{N}$ & WFP & 108 & CONSTRUCTION (ROAD/BRIDGE) & $10 \%$ \\
\hline & & & CONSTRUCTION (BUILDING/SHELTER) & $10 \%$ \\
\hline & & & EDUCATION & $10 \%$ \\
\hline & & & EMERGENCY & 108 \\
\hline O & PRIVATE DONATIONS & 608 & HEALTH & 58 \\
\hline$T$ & & & INCOME GENERATION & \\
\hline $\mathrm{H}$ & & & IRRIGATION & 158 \\
\hline $\mathbf{E}$ & & & MINE & \\
\hline $\mathbf{R}$ & & & RELIEF & $30 \%$ \\
\hline $\mathbf{S}$ & & & OTHER & \\
\hline
\end{tabular}

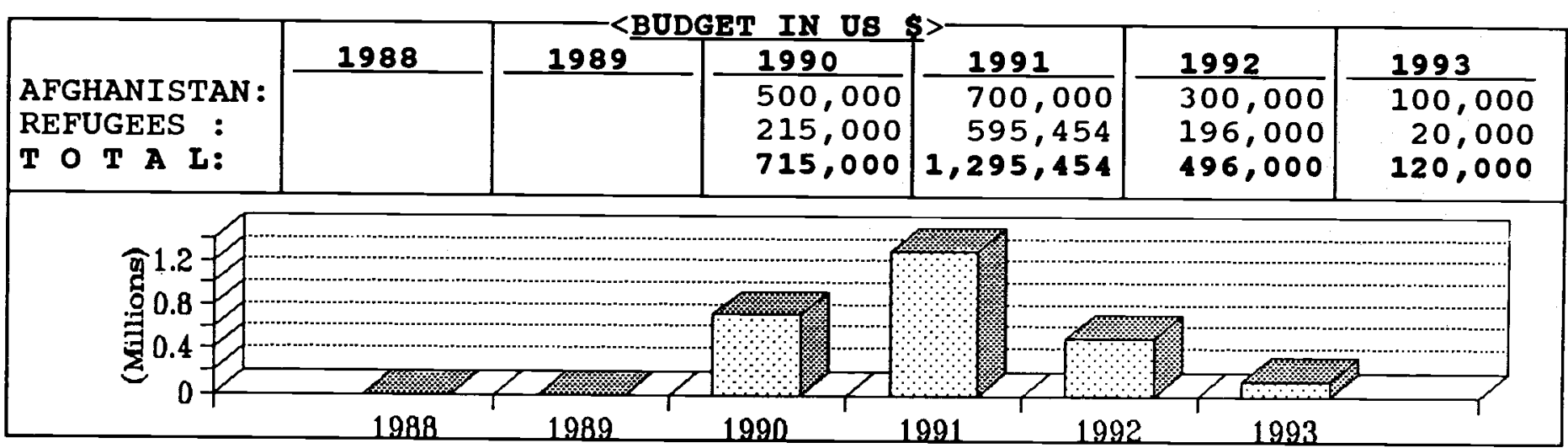

\begin{tabular}{|c|c|c|c|c|c|}
\hline PROVINCES & SECTOR & \&AGE & PROVINCES & SECTOR & \&AGE \\
\hline $\begin{array}{l}\text { BADAKSHAN } \\
\text { BADGHIS } \\
\text { BAGHLAN } \\
\text { BALKH } \\
\text { BAMYAN } \\
\text { FARAH } \\
\text { FARYAB } \\
\text { GHAZNI } \\
\text { GHOR } \\
\text { HELMAND } \\
\text { HERAT } \\
\text { JAWZJAN } \\
\text { KABUL } \\
\text { KANDAHAR } \\
\text { KAPISA }\end{array}$ & & & \begin{tabular}{|l|} 
KUNAR \\
KUNDUZ \\
LAGHMAN \\
LOGAR \\
NANGARHAR \\
NIMROZ \\
ORUZGAN \\
PAKTEKA \\
PAKTIA \\
PARWAN \\
SAMANGAN \\
TAKHAR \\
WARDAK \\
ZABUL
\end{tabular} & $\begin{array}{l}\text { Agr/const/irrign } \\
\text { Agr } \\
\text { Irrign }\end{array}$ & $\begin{array}{l}60 \% \\
20 \%\end{array}$ \\
\hline
\end{tabular}


is a non political Afghan NGO established in 1987 to work for the cause of Afghanistan and take part in the rehabilitation of the country.

WRC has carried out numerous relief, rehabilitation and reconstruction works for Afghan refugees in Pakistan and inside Afghanistan. Its sectors of work include relief and social welfare programs agriculture inputs distribution, operating health facilities, irrigation system rehabilitation and infrastructure construction.

In Kunar, WRC maintains a surgical hospital in Asadabad and a number of sub-clinics in different parts of the valley. It has completed a number of agriculture, irrigation rehabilitation and infrastructure construction projects in different districts e.g. Chawki, Khas Kunar, Asadabad, Peche and Sirkanay.

WRC has also expanded its activities to Logar, Paktia and Kandahar provinces.

WRC has, on its roll, about 8,300 orphans in 1993 out of which 3,044 have been sponsored and are being regularly paid Rs. 500/- per head per month. The orphans are from different provinces of Afghanistan and different camps in Pakistan. 
WELFARE AND RELIEF ORGANIZATION FOR RECONSTRUCTION-WROR

266-T, ST 3, JAMAL RD, SHAHEEN TOWN, PESHAWAR, PAKISTAN

PHONE: 42825

F A X:

TELEX:
1. ENG.AHMAD SHAH

2. MR. AZIZULLAH

3. ENG.GHULAM MOHD

\begin{tabular}{|lr|lr|lr|}
\hline AFGHAN : & 23 & TECHNICAL: & 9 & PAK. BASED: & 12 \\
PAKISTANI : & - & ADMINISTRATIVE: & 4 & AFGHA. BASED: & 11 \\
EXPAT: & - & FIELD: & 10 & CROSS-BORDER: & - \\
TOTAL: & 23 & TOTAL: & 23 & TOTAL: & 23 \\
\hline
\end{tabular}

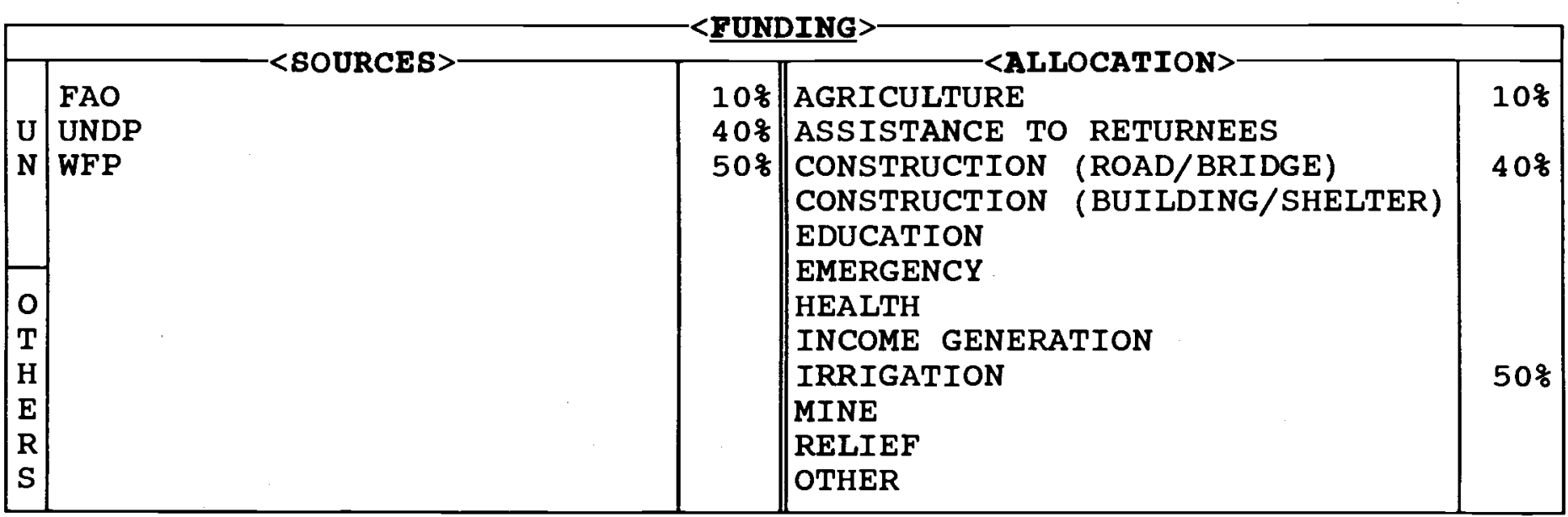

\begin{tabular}{|l|r|r|r|r|r|r|}
\hline & 1988 & 1989 & 1990 & 1991 & \multicolumn{1}{c|}{1992} & \multicolumn{1}{c}{1993} \\
AFGHANISTAN: & & & & 67,440 & 38,000 & 42,000 \\
REFUGEES : & & & & 67,440 & 38,000 & 42,000 \\
\hline
\end{tabular}

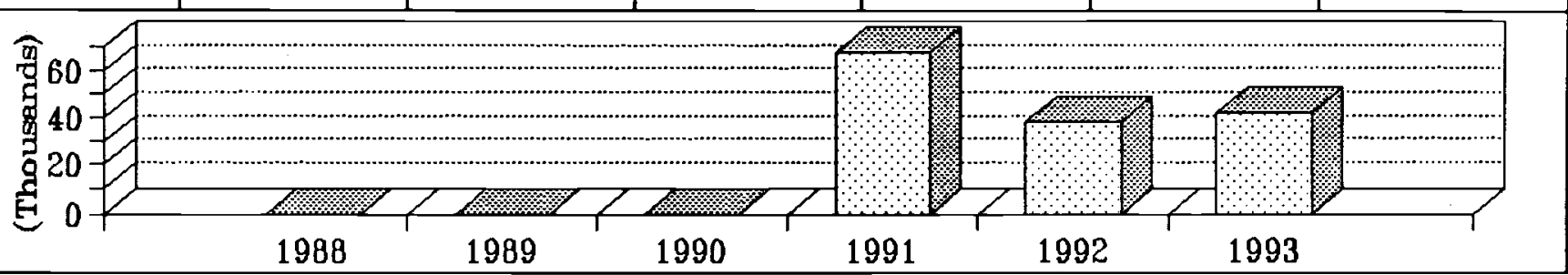

\begin{tabular}{|c|c|c|c|c|c|}
\hline PROVINCES & SECTOR & $\because A G E$ & PROVINCES & SECTOR & $\% \mathrm{AGE}$ \\
\hline $\begin{array}{l}\text { BADAKSHAN } \\
\text { BADGHIS } \\
\text { BAGHLAN } \\
\text { BALKH } \\
\text { BAMYAN } \\
\text { FARAH } \\
\text { FARYAB } \\
\text { GHAZNI } \\
\text { GHOR } \\
\text { HELMAND } \\
\text { HERAT } \\
\text { JAWZJAN } \\
\text { KABUL } \\
\text { KANDAHAR } \\
\text { KAPISA }\end{array}$ & Irrign & $10 \%$ & $\begin{array}{l}\text { KUNAR } \\
\text { KUNDUZ } \\
\text { LAGHMAN } \\
\text { LOGAR } \\
\text { NANGARHAR } \\
\text { NIMROZ } \\
\text { ORUZGAN } \\
\text { PAKTEKA } \\
\text { PAKTIA } \\
\text { PARWAN } \\
\text { SAMANGAN } \\
\text { TAKHAR } \\
\text { WARDAK } \\
\text { ZABUL }\end{array}$ & $\begin{array}{l}\text { Const } \\
\text { Irrign } \\
\text { Irrign } \\
\text { Const/irrign }\end{array}$ & $\begin{array}{l}20 \% \\
20 \% \\
10 \%\end{array}$ \\
\hline
\end{tabular}


is an Afghan NGo established in 1991. The objective of the organization is to take part in rehabilitation and reconstruction of Afghanistan.

WROR's areas of work include road, agriculture and irrigation rehabilitation and infrastructure reconstruction.

Projects have been and are being implemented as follows:

1) Agriculture inputs distribution in Ghazni.

2) Road condition survey project in Nangarhar and Logar provinces.

3) Irrigation rehabilitation program in Nangarhar province.

4) Irrigation rehabilitation and road repair projects in Paktia province.

5) Road repair project in Wardak province.

6) Irrigation rehabilitation project in Ghazni

7) Irrigation rehabilitation project is wardak.

Several project proposals have recently been submitted to different funding agencies for the provinces of Ghazni, Logar, Laghman and Kabul. 
WRITERS UNION OF FREE AFGHANISTAN-WUFA

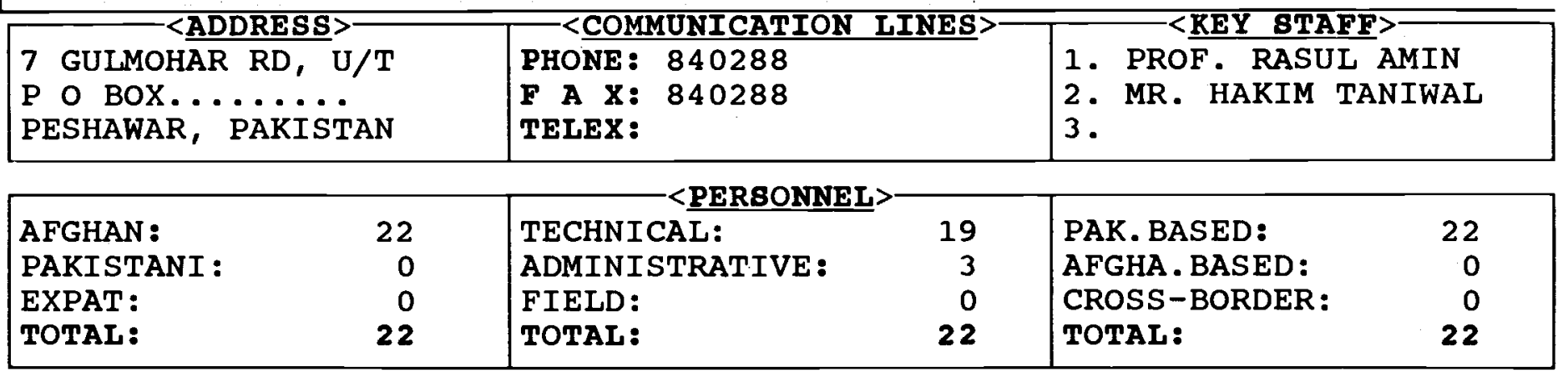

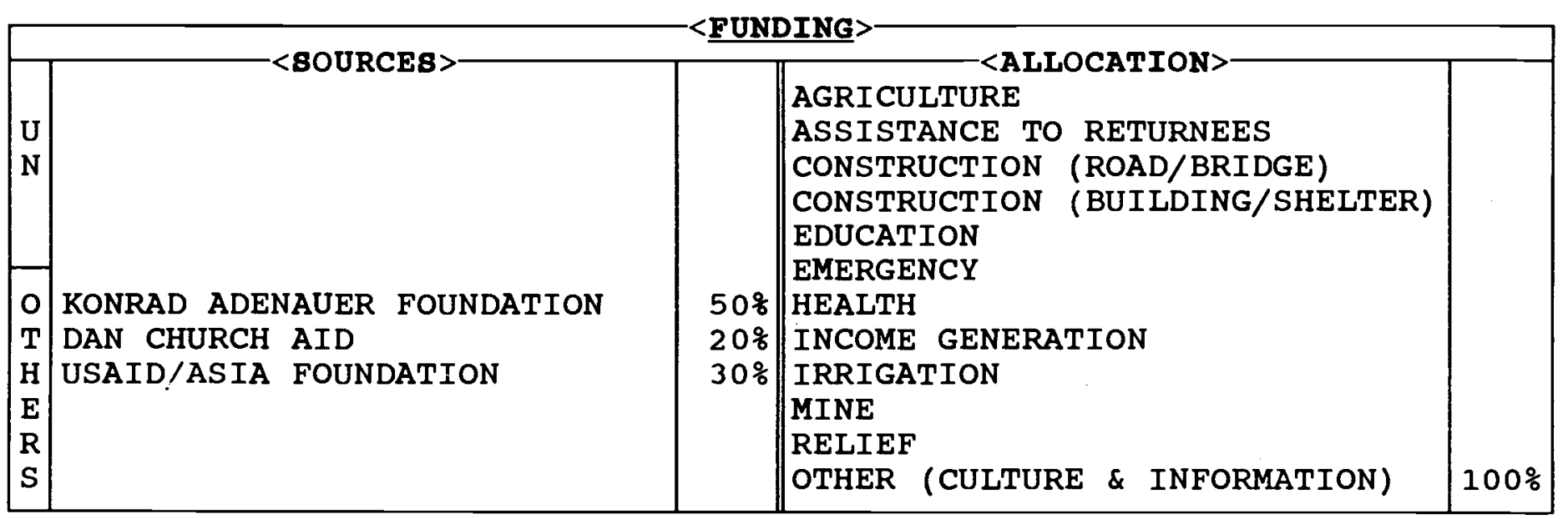

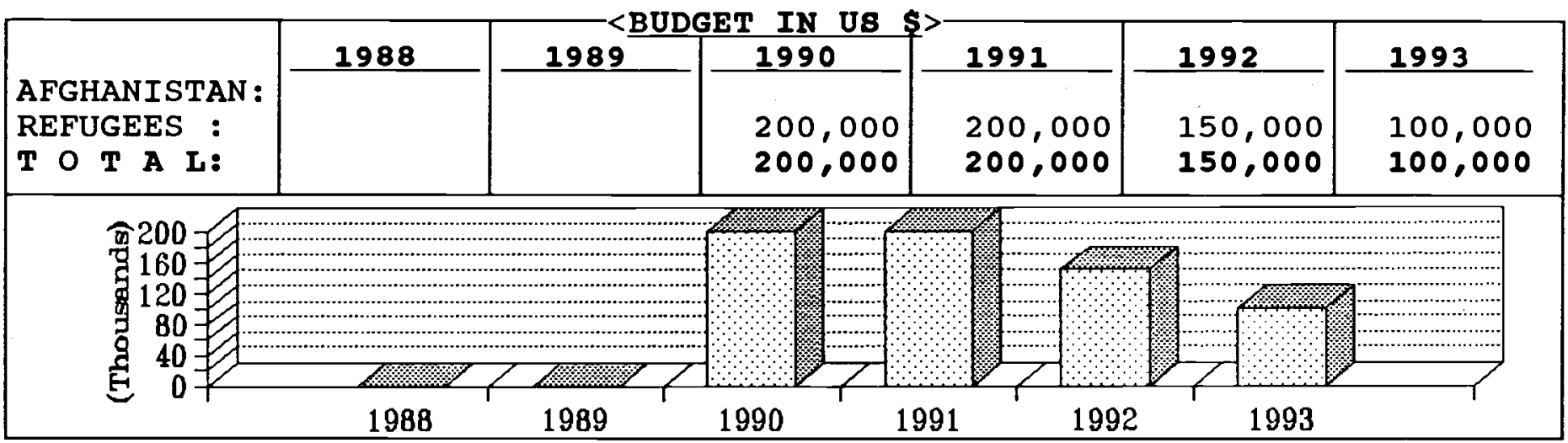

\begin{tabular}{|c|c|c|c|c|c|}
\hline PROVINCES & SECTOR & \&AGE & PROVINCES & SECTOR & $\% A G E$ \\
\hline $\begin{array}{l}\text { BADAKSHAN } \\
\text { BADGHIS } \\
\text { BAGHLAN } \\
\text { BALKH } \\
\text { BAMYAN } \\
\text { FARAH } \\
\text { FARYAB } \\
\text { GHAZNI } \\
\text { GHOR } \\
\text { HELMAND } \\
\text { HERAT } \\
\text { JAWZJAN } \\
\text { KABUL } \\
\text { KANDAHAR } \\
\text { KAPISA }\end{array}$ & & & \begin{tabular}{|l} 
KUNAR \\
KUNDUZ \\
LAGHMAN \\
LOGAR \\
NANGARHAR \\
NIMROZ \\
ORUZGAN \\
PAKTEKA \\
PAKTIA \\
PARWAN \\
SAMANGAN \\
TAKHAR \\
WARDAK \\
ZABUL
\end{tabular} & & \\
\hline
\end{tabular}


is an independent, non-profit and registered organization of Afghan writers, professionals and specialists established in Peshawar on March 21, 1985.

Since its establishment WUFA has focused on Pluralism, Participation, Democracy, Human Rights and Reconstruction of Afghanistan. Its main objectives are to oppose dictatorship, discrimination, foreign surrogates and foreign interference in any form.

It has published two quarterly journals, "The WUFA", in English for foreign consumption; and the "KHPALWAKI" (Independence) in Pushto/Dari for Afghan elite, as well. as books and booklets for readers inside the country, and the Weekly WAFA (Loyalty) for Afghans inside and outside Afghanistan. This letter emphasizes the dangerous results of poppy cultivation and drug trafficking to the Afghan community.

It has also held several local, regional, international seminars and conferences on different aspects of Afghan society. Its members have participated at national and international gatherings and have objectively expressed their views on Afghanistan issues during their interviews with national and international mass media.

Publications are sent to refugee readers inside Afghanistan and those involved with the Afghan affairs in foreign countries. 


\section{THE COORDINATION BODIES}


AGENCY COORDINATING BODY FOR AFGHAY RELIEF-ACBAR

\begin{tabular}{ll|l|l|}
\hline 2 RAHMAN BABA RD, U/T & PHONE: $44392 / 40839 / 45347$ & 1. MR. CHARLES MACFADDEN \\
P O BOX 1084 & F A X: 840471 & 2. \\
PESHAWAR, PAKISTAN & TELEX: 52448 IRC PE PK & 3.
\end{tabular}

\begin{tabular}{|lr|lr|lr|}
\hline AFGHAN : & 25 & TECHNICAL: & 13 & PAK. BASED: & 35 \\
PAKISTANI: & 7 & ADMINISTRATIVE: & 5 & AFGHA.BASED: & - \\
EXPAT: & 3 & FIELD/SUPPORT S. & 17 & CROSS-BORDER: & - \\
TOTAL: & 35 & TOTAL: & 35 & TOTAL: & 35 \\
\hline
\end{tabular}

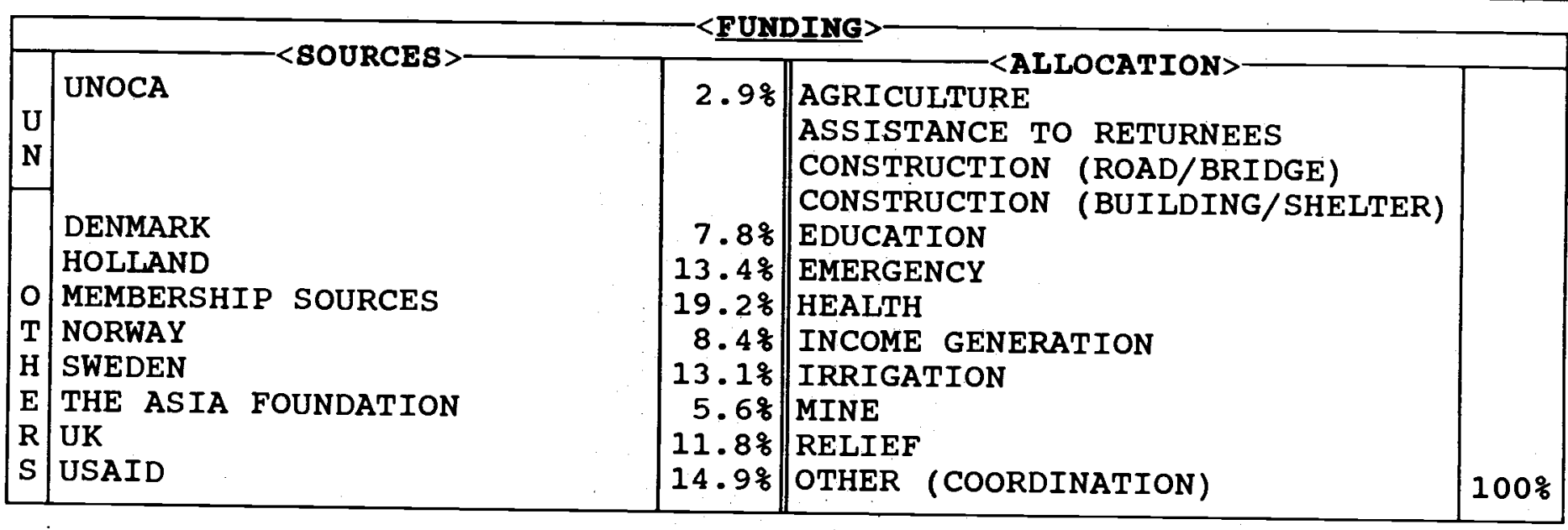

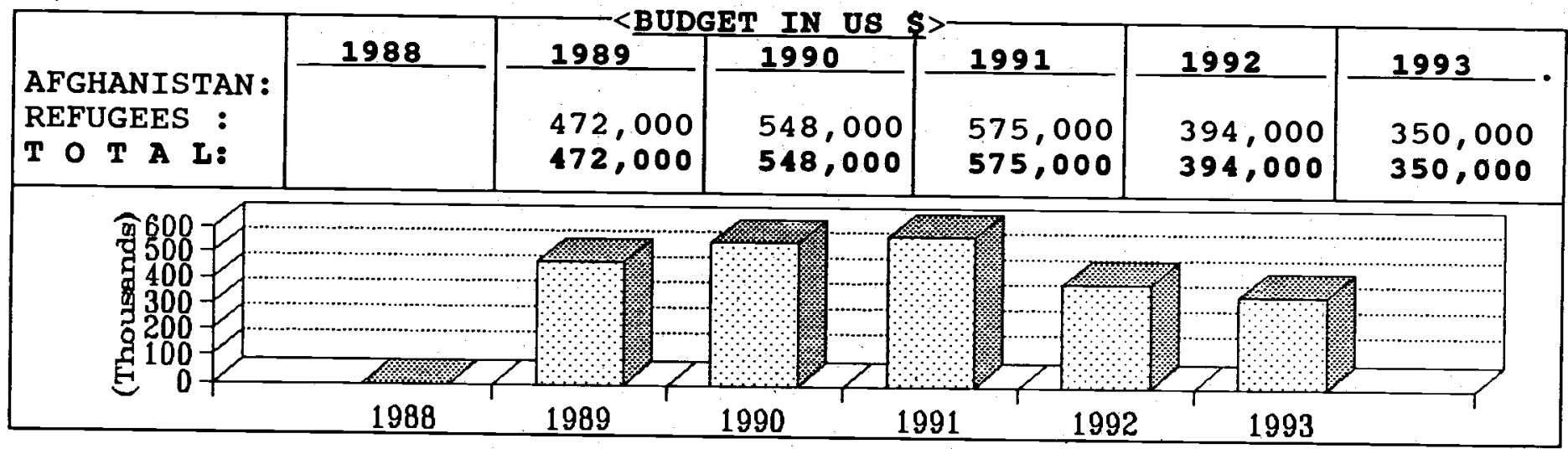

\begin{tabular}{|c|c|c|c|c|c|}
\hline PROVINCES & SECTOR & \&AGE & PROVINCES & SECTOR & \% AGE \\
\hline $\begin{array}{l}\text { BADAKSHAN } \\
\text { BADGHIS } \\
\text { BAGHLAN } \\
\text { BALKH } \\
\text { BAMYAN } \\
\text { FARAH } \\
\text { FARYAB } \\
\text { GHAZNI } \\
\text { GHOR } \\
\text { HELMAND } \\
\text { HERAT } \\
\text { JAWZJAN } \\
\text { KABUL } \\
\text { KANDAHAR } \\
\text { KAPISA }\end{array}$ & $\begin{array}{l}\text { coordination of } \\
\text { all sectors in } \\
\text { all areas }\end{array}$ & & \begin{tabular}{|l} 
KUNAR \\
KUNDUZ \\
LAGHMAN \\
LOGAR \\
NANGARHAR \\
NIMROZ \\
ORUZGAN \\
PAKTEKA \\
PAKTIA \\
PARWAN \\
SAMANGAN \\
TAKHAR \\
WARDAK \\
ZABUL \\
REFUGEES
\end{tabular} & $\begin{array}{l}\text { coordination of } \\
\text { all sectors in } \\
\text { all areas }\end{array}$ & \\
\hline
\end{tabular}


AGENCY COORDINATING BODY FOR

AFGHAN RELIEF (ACBAR)

was founded in July 1988. It currently has a membership of 66 private and non-governmental organizations, with a wider network of 'observer' organizations.

ACBAR was created by its members to provide a framework within which agencies and organizations providing assistance to Afghans - NGOS, UN and bilateral - can exchange information and share expertise in order to allow a more coordinated, efficient and effective use of resources.

The organizational structure of ACBAR has three tiers: General Assembly, the steering committee, and the secretariat.

The General Assembly brings together directors of member agencies approximately six times a year to discuss and decide ACBAR policy issues, and to elect the steering Committee.

The steering committee has nine elected members and three alternate members. The committee meets regularly to discuss and determine the operational policy of ACBAR.

The secretariat is responsible for executing the decisions and directives of the steering Committee and for initiating policy and donor related activities on behalf of the ACBAR membership.

In 1993 ACBAR focussed on four priorities:

* management and policy

* information and database

* coordination

* resource center.

The 1993 budget covers these areas of work. Two further areas have been identified as secondary priorities: technical services and evaluation. These will be undertaken only if there is both the demand from members and the required funding to establish the necessary working groups.
Management Policy: At the request of its members, the ACBAR secretariat undertakes to represent them in discussions of key issues of policy; this involves liaison with the UN, with donors and with the Governments of Afghanistan and Pakistan as well as the press and others.

Information Database: ACBAR is uniquely placed to provide clear, concise and regular reportage on current issues of concern. Discussion documents are written for members, donors, and the press, highlighting on-going debates in the community. An increasing amount of ACBAR information will be translated into Dari to facilitate a more widespread dissemination of information.

A Women's Coordination Unit acts as a research service and resource unit for NGOs seeking information relating to Afghan women, particularly in the field of education, health and employment.

ACBAR will continue to produce updates of the ACBAR Directory of Members and Database of NGO Activities, which cover the sectoral and geographical details of projects currently undertaken by some 240 organizations working cross-border and with refugees.

Coordination: To avoid duplication in cross-border work, and in an attempt to present a coordinated approach to local authorities in Afghanistan, it also holds 15 selected regional meetings which cover 22 provinces and sub-committee meetings in the areas of health agriculture, training, disability and veterinary. coordination efforts are assisted by the production of provincial maps of NGO activities. These sub-committees share information \& produce guidelines on recommended standards for all operational agencies in the field.

In addition to these committees, occasional task-forces are created when an urgency arises. Task-forces for Eastern Paktia and Nangarhar 
Were formed in the last 2 years but have now reverted back to provincial Groups.

The ACBAR Resource and Information Center-ARIC (comprising library and mapping service) gathers, organizes and disseminates information within the community. The library has an ever-expanding range of agency reports, books, journals, articles, press-clippings, bibliographies and reference books, with easy access by author, title, agency and subject catalogue cards. The mapping service is also expanding its range.

special Events: ARIC organizes occasional special events which include lectures, slide shows and exhibitions on historical or contemporary issues of interest to the wider assistance community.

Technical services: ACBAR currently facilitates the coordination of training activities through its Training Sub-committee. ACBAR would also in time consider offering a consultancy service to a limited number of NGOs in need of technical support in the areas of planning, finance and administrative management.

Evaluation: Through its subcommittees ACBAR with participation of member agencies undertook a monitoring and evaluation of NGO activities in Kunar in 1992 and recently a second one in Ghazni. The Kunar report was published early 1993 and Ghazni report will be published in first 3 months of 1994 . Further such studies are envisaged in the future.

The future: ACBAR is now well established as the leading coordination body for Afghanistan. Following recent contacts with the new government in Kabul, it is likely that ACBAR will establish a liaison office in the capital soon.

ACBAR is also looking to setting up representational offices in key parts of the country. This will, of course, depend on the availability of security.
ACBAR signed a protocol with the Government of Islamic state of Afghanistan on 20 October, 1993. 
AFGHAN NGO COORDINATION BODY-ANCB

\begin{tabular}{|c|c|c|c|c|c|}
\hline$<<\underline{\mathrm{AD}}$ & & -<COMMUNICATION & $\overline{\text { NES }>}$ & $=<$ KEY $\mathbf{S T A}$ & \\
\hline $\begin{array}{l}25, \text { CHINAR } \\
\text { P O BOX . } \\
\text { PESHAWAR, }\end{array}$ & $\begin{array}{l}/ \mathrm{T}, \\
\mathrm{AN}\end{array}$ & $\begin{array}{l}\text { PHONE: } 43476 \\
\text { F A X: } \\
\text { TELEX: }\end{array}$ & & $\begin{array}{ll}\text { 1. HAJI GHULA } \\
\text { 2. ENG. MOHD } \\
\text { 3. ENG. S. RAH }\end{array}$ & $\begin{array}{l}\text { DASTAGIR } \\
\text { SATTAR }\end{array}$ \\
\hline $\begin{array}{l}\text { AFGHAN : } \\
\text { PAKISTANI : } \\
\text { EXPAT: } \\
\text { TOTAL: }\end{array}$ & $\begin{array}{r}13 \\
1 \\
14\end{array}$ & $\begin{array}{l}\text { TECHNICAL: } \\
\text { ADMINISTRATIVE: } \\
\text { FIELD/SUPPORT S. } \\
\text { TOTAL: }\end{array}$ & $\begin{array}{r}- \\
13 \\
1 \\
14\end{array}$ & $\begin{array}{l}\text { PAK. BASED: } \\
\text { AFGHA. BASED: } \\
\text { CROSS-BORDER: } \\
\text { TOTAL: }\end{array}$ & $\begin{array}{r}14 \\
- \\
14\end{array}$ \\
\hline
\end{tabular}

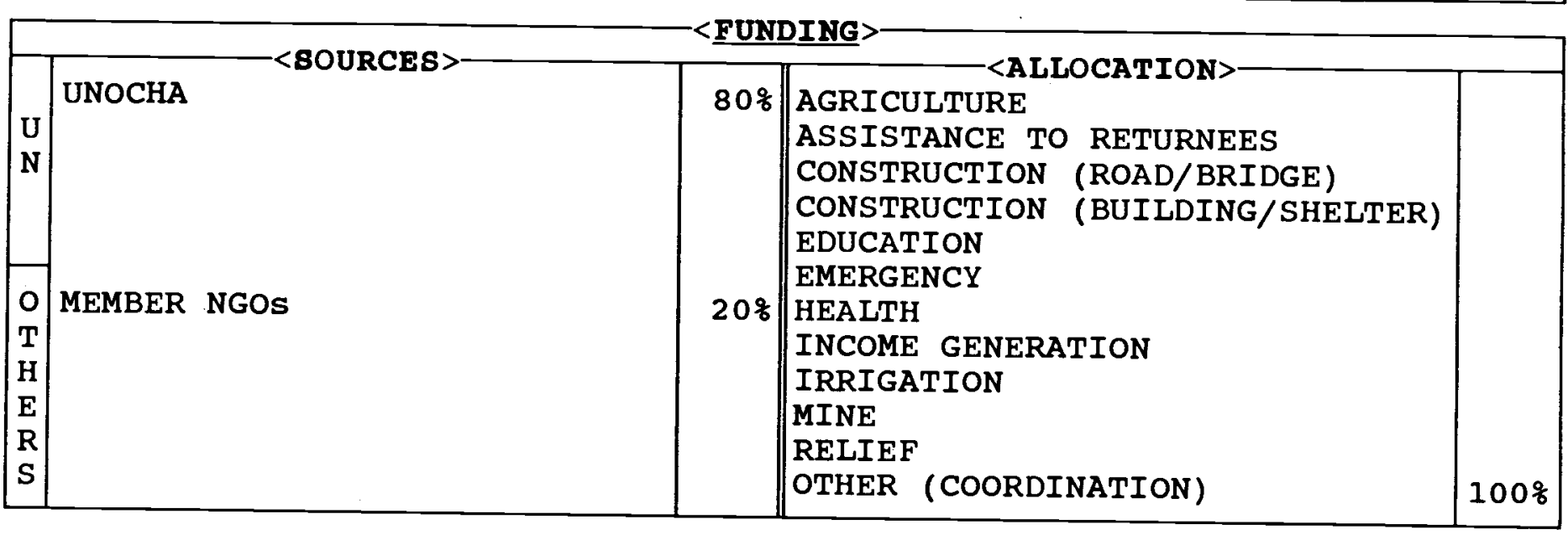

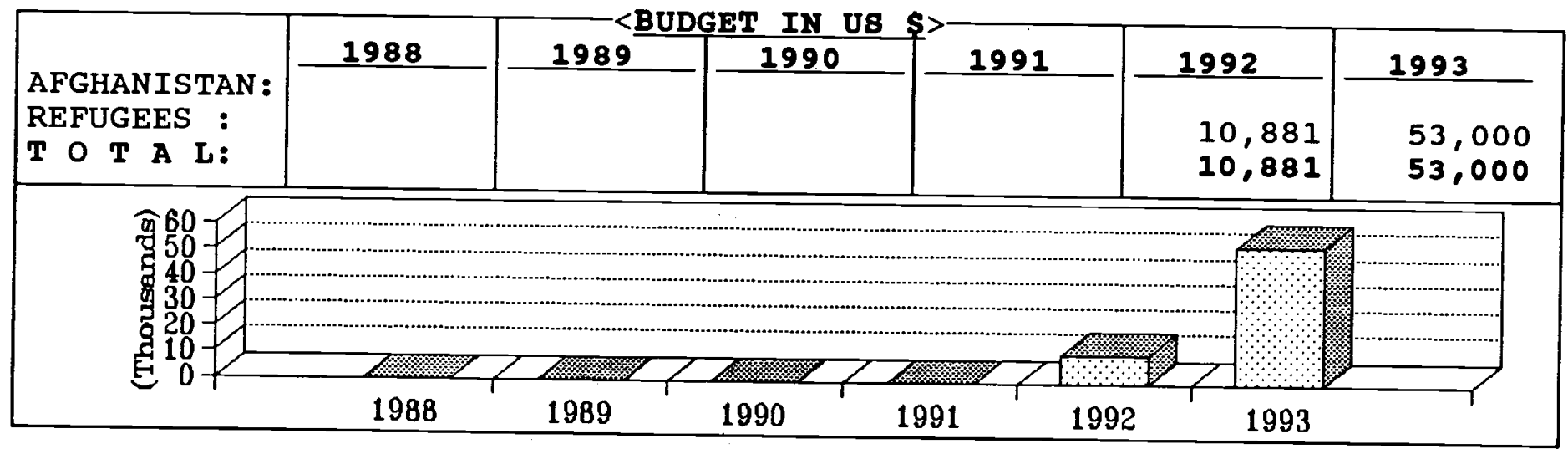

\begin{tabular}{|c|c|c|c|c|c|}
\hline PROVINCES & SECTOR & ח & חתרנידתחיו & & \\
\hline 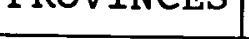 & SECIUR & ₹AGE & PROVINCES & SECTOR & \&AGE \\
\hline $\begin{array}{l}\text { BADAKSHAN } \\
\text { BADGHIS } \\
\text { BAGHLAN } \\
\text { BALKH } \\
\text { BAMYAN } \\
\text { FARAH } \\
\text { FARYAB } \\
\text { GHAZNI } \\
\text { GHOR } \\
\text { HELMAND } \\
\text { HERAT } \\
\text { JAWZJAN } \\
\text { KABUL } \\
\text { KANDAHAR } \\
\text { KAPISA }\end{array}$ & & & \begin{tabular}{|l} 
KUNAR \\
KUNDUZ \\
LAGHMAN \\
LOGAR \\
NANGARHAR \\
NIMROZ \\
ORUZGAN \\
PAKTEKA \\
PAKTIA \\
PARWAN \\
SAMANGAN \\
TAKHAR \\
WARDAK \\
ZABUL
\end{tabular} & & \\
\hline
\end{tabular}


was established in 1991. The ultimate aim of ANCB is to stimulate and promote activities aimed at improving the quality of life of Afghans and persuade voluntary return of Afghan refugees to their home country. Keeping this in view ANCB seeks to achieve the following objectives:

1 to cooperate in the development, growth and welfare activities of Afghan NGO's, to encourage the establishment of new NGOs in Afghanistan and assist them to perform in accordance with the ANCB objectives.

2 to encourage Afghan NGOs in research, scientific planning systemizing, stabilizing the application of norms, and standardizing for the purpose of developing their activities and growth.

3 to collect

statistical information about NGO activities and experience and share it with other concerned agencies

4 to encourage and secure relations of Afghan NGos with the Islamic Government of Afghanistan, Jehad powers, local shuras, donors and international agencies

5 to establish mutual cooperation with similar groups, other international organizations and donor agencies, for the purpose of coordinating activities

6 to support the technical and financial needs of member organizations; facilitate contacts between donor agencies and members; encourage cooperation and information sharing between them and defend their legal rights.

ANCB opened offices in Kabul and Jalalabad in 1993. Administration (accounting, computer skills, management and report writing) and technical training courses have been organized for member organizations. Technical training will be provided based on the needs and requirements of NGOs in the fields of health,
From the beginning of the Russian invasion of Afghanistan, Afghan NGOs were established and they have taken an active part in relief rehabilitation and development inside Afghanistan as well as for refugees. The indigenous Afghan NGOs are a new phenomenon to Afghanistan which previously had none of its. Own humanitarian NGos as they are known in other parts of the world.

To channel the humanitarian resources more effectively, the Afghan NGos formed their own coordination bureau (ANCB). The first election for the Board of Directors occurred on 27 November 1991 and elected nine members. It continued to lead the establishment process very carefully, step by step, laid strong foundation through major community participation and self-help. The second election of the ANCB Board was held in Peshawar on November 30, 1992.

The Board holds regular meetings to formulate guidelines and set standards for ANCB and to build trust and understanding between each other.

ANCB has 54 members that carry out activities in all sectors e.g. agriculture, irrigation, health, education, training, construction and demining. 27 other Afghan NGos have indicated an interest in joining ANCB. The Board will explore ways of bringing them into ANCB.

ANCB is establishing relations with several public bodies such as ACBAR, ICC, SWABAC, donors, political parties and the media and other national and international bodies to explore ways of cooperation and coordination for identification and implementation of needed projects.

ANCB plans to organize an "Afghan NGOs Information Day". It also plans to produce the 1993 directory of $A$ f $g h$ a $n$ N G O $s$. 


\begin{tabular}{|c|c|c|}
\hline$-<$ ADDRESS $>$ & $-\langle$ COMMUNICATION LINES $>$ & STAFF> \\
\hline $\begin{array}{l}3 \text { GULMOHAR RD, U/T } \\
\text { U P O BOX } 991 \\
\text { PESHAWAR, PAKISTAN }\end{array}$ & $\begin{array}{l}\text { PHONE: } 45406 / 45413 \\
\text { F A X: } \\
\text { TELEX: }\end{array}$ & $\begin{array}{l}\text { 1. DR. AHMAD SANOSI } \\
\text { 2. MR. MOHAMMADUL HADI } \\
\text { 3. }\end{array}$ \\
\hline
\end{tabular}

\begin{tabular}{|ll|ll|ll|}
\hline AFGHAN : & - & TECHNICAL: & - & PAK. BASED: & 2 \\
PAKISTANI : & - & ADMINISTRATIVE: & 2 & AFGHA.BASED: & - \\
EXPAT: & 2 & FIELD/SUPPORT S. & - & CROSS-BORDER: & - \\
TOTAL: & 2 & TOTAL: & 2 & TOTAL: & 2 \\
\hline
\end{tabular}

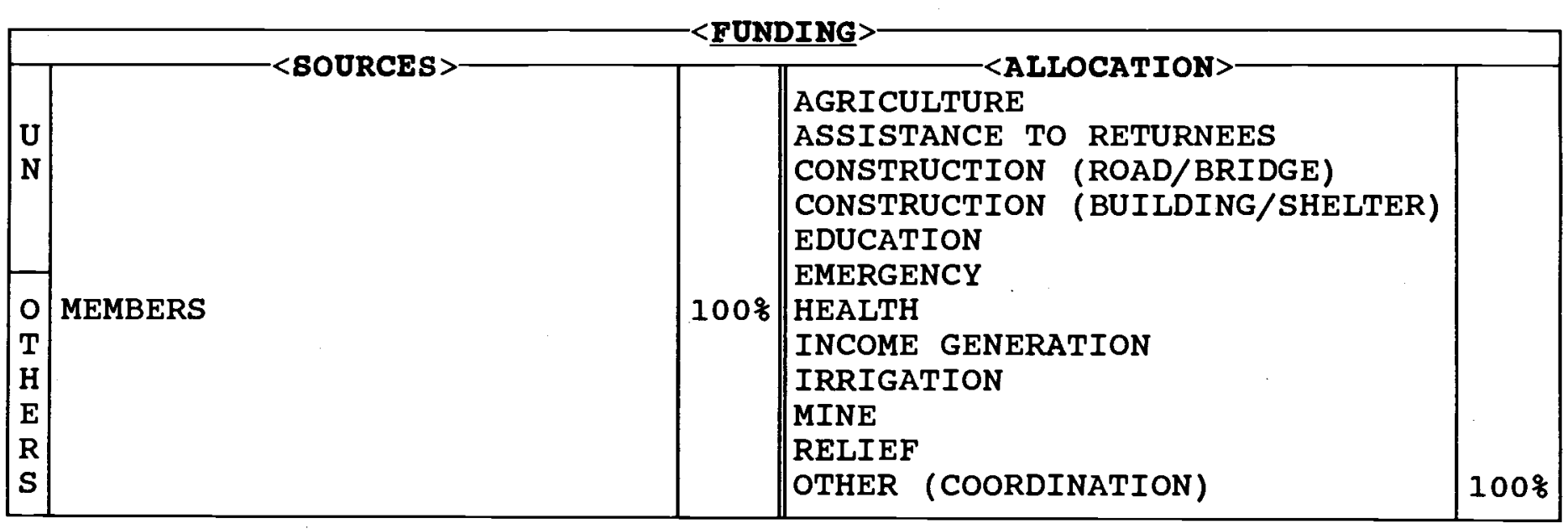

\begin{tabular}{|l|l|l|l|l|l|l|}
\hline & 1988 & 1989 & 1990 & 1991 & 1992 & 1993 \\
AFGHANISTAN : & & & & & & \\
REFUGEES : & & & & & & \\
\hline
\end{tabular}

\begin{tabular}{|c|c|c|c|c|c|}
\hline PROVINCES & SECTOR & \%AGE & PROVINCES & SECTOR & \%AGE \\
\hline $\begin{array}{l}\text { BADAKSHAN } \\
\text { BADGHIS } \\
\text { BAGHLAN } \\
\text { BALKH } \\
\text { BAMYAN } \\
\text { FARAH } \\
\text { FARYAB } \\
\text { GHAZNI } \\
\text { GHOR } \\
\text { HELMAND } \\
\text { HERAT } \\
\text { JAWZJAN } \\
\text { KABUL } \\
\text { KANDAHAR } \\
\text { KAPISA }\end{array}$ & & & $\begin{array}{l}\text { KUNAR } \\
\text { KUNDUZ } \\
\text { LAGHMAN } \\
\text { LOGAR } \\
\text { NANGARHAR } \\
\text { NIMROZ } \\
\text { ORUZGAN } \\
\text { PAKTEKA } \\
\text { PAKTIA } \\
\text { PARWAN } \\
\text { SAMANGAN } \\
\text { TAKHAR } \\
\text { WARDAK } \\
\text { ZABUL }\end{array}$ & & \\
\hline
\end{tabular}


Approaching Muslim donors through a united body to continue their support to the Muslim relief organizations working for Afghans.

is a body coordinating humanitarian organizations working to save the Afghans at places of refuge as well as inside Afghanistan. The Council reflects the concern of the Muslim Ummah for the distressed Afghan people. It makes efforts to maximize the level of assistance to Afghans by encouraging Muslim organizations to avoid overlapping or duplication of resources.

A total of 16 Muslim organizations are members of ICC.

OBJECTIVES: The goal of ICC is to provide a forum in which member organizations can discuss their concerns, design policy guidelines for delivering assistance, resource management and other operational issues with the ultimate purpose of improving coordination in refugee assistance in NWFP and elsewhere as well as for the repatriation and resettlement of Afghan refugees. The specific objectives are:

1) Establishment of a friendly and cooperative environment in accordance with Islam that leads to an effective setup to serve the aims of the Afghan Jihad.

2) Coordination of efforts in the technical fields which in turn leads to increase in the services and its efficiency, and to provide the necessary finances and manpower which can be achieved through the technical sub-committees.

3) Establishment and supporting an open dialogue for the purpose of finding out the best ways for the achievement of goals of the Islamic Voluntary work.

4) Provision of information and evaluation of the needs in different sectors and areas by establishing an information unit.

5) Establishment of an active relation with Afghan government departments, different Muslim governments, UN agencies and other NGOs to gain more support to Afghans.
7) Keeping contacts with international Muslim societies and NGOs to share knowledge, exchange expertise to promote cooperation and gain unconditional support.

8) Facilitating the exchange of information about different activities to avoid duplication.

Any Muslim organization working for Afghans and is committed to the regulations of the council can be a member of the ICC (a written commitment is needed).

ICC has a General Assembly, an Executive Committee, a Secretariat, A Planning and Follow up committee and four Technical Committees (Health, Education, Social Welfare and Construction).

ICC enjoys special relations with Afghans. Visits by Afghan leaders to ICC are very common. Attendance of Afghans in ICC general body or committee meetings is frequent. Afghans are consulted for strategies for helping the Afghans in the refugee camps and inside Afghanistan. Regular meetings, seminars and conferences for members and Afghan leaders are convened $b_{y}$ ICC to bring them together and achieve deeper understanding.

ICC realizes the necessity of working together with the UN agencies. To improve relations, ICC suggests appointing a competent liaison officer whose job will be to initiate contacts, meetings and visits.

ICC intends to continue its 


\begin{tabular}{|c|c|c|}
\hline $\begin{array}{l}\text { 29-B, CHAMAN H. SCHEME } \\
\text { P O BOX ..... } \\
\text { QUETTA, PAKISTAN }\end{array}$ & $\begin{array}{l}\text { PHONE: } 72215 / 76493 \\
\text { F A X: } 76493 \\
\text { TELEX: }\end{array}$ & $\begin{array}{l}\text { 1. MR. NAQIB A. NOORY } \\
\text { 2. } \\
\text { 3. }\end{array}$ \\
\hline
\end{tabular}

\begin{tabular}{|ll|ll|ll|}
\hline AFGHAN : & 2 & TECHNICAL: & - & PAK. BASED: & 3 \\
PAKISTANI : & - & ADMINISTRATIVE: & 2 & AFGHA.BASED: & - \\
EXPAT: & 1 & FIELD/SUPPORT S. & 1 & CROSS-BORDER: & - \\
TOTAL: & 3 & TOTAL: & 3 & TOTAL: & 3 \\
\hline
\end{tabular}

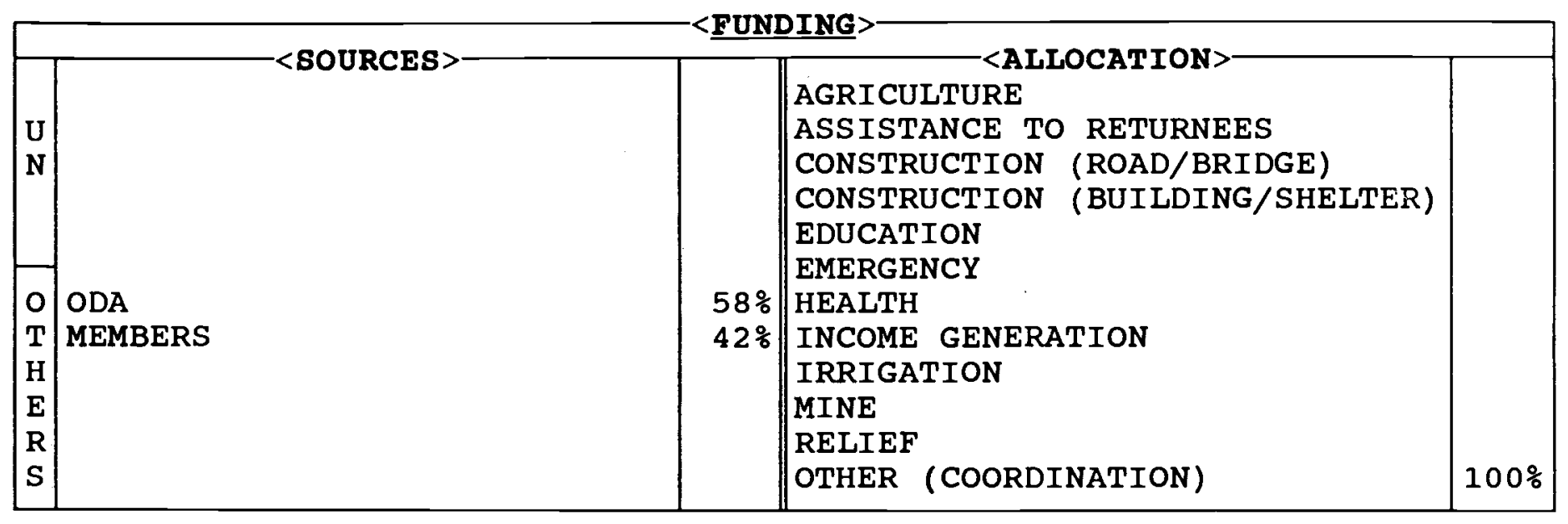

\begin{tabular}{|c|c|c|c|c|c|c|}
\hline & 1988 & 1989 & 1990 & 1991 & 1992 & 1993 \\
\hline $\begin{array}{l}\text { AFGHANISTAN: } \\
\text { REFUGEES : } \\
\text { T O T A L: }\end{array}$ & & & $\begin{array}{l}17,000 \\
17,000\end{array}$ & $\begin{array}{l}28,000 \\
28,000\end{array}$ & $\begin{array}{l}28,000 \\
28,000\end{array}$ & $\begin{array}{l}52,200 \\
52,200\end{array}$ \\
\hline
\end{tabular}

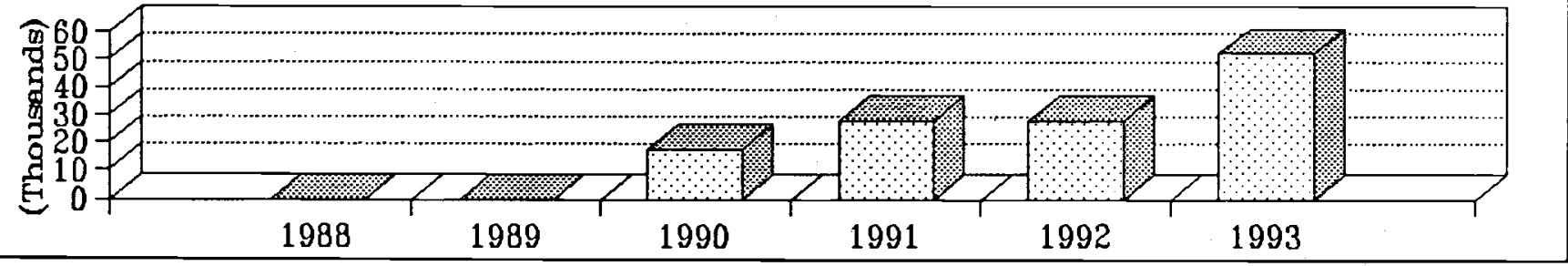

\begin{tabular}{|c|c|c|c|c|c|}
\hline PROVINCES & SECTOR & OAGE & PROVINCES & SECTOR & $\because A G E$ \\
\hline $\begin{array}{l}\text { BADAKSHAN } \\
\text { BADGHIS } \\
\text { BAGHLAN } \\
\text { BALKH } \\
\text { BAMYAN } \\
\text { FARAH } \\
\text { FARYAB } \\
\text { GHAZNI } \\
\text { GHOR } \\
\text { HELMAND } \\
\text { HERAT } \\
\text { JAWZJAN } \\
\text { KABUL } \\
\text { KANDAHAR } \\
\text { KAPISA }\end{array}$ & & & $\begin{array}{l}\text { KUNAR } \\
\text { KUNDUZ } \\
\text { LAGHMAN } \\
\text { LOGAR } \\
\text { NANGARHAR } \\
\text { NIMROZ } \\
\text { ORUZGAN } \\
\text { PAKTEKA } \\
\text { PAKTIA } \\
\text { PARWAN } \\
\text { SAMANGAN } \\
\text { TAKHAR } \\
\text { WARDAK } \\
\text { ZABUL }\end{array}$ & & \\
\hline
\end{tabular}


was formed in Quetta, in August 1988, by non-governmental organizations undertaking relief and rehabilitation assistance in those geographical areas. The organization of SWABAC took place at approximately the same time other organizations working for the Afghan people created a similar body in Peshawar (ACBAR - Agency Coordinating Body for Afghan Relief).

SWABAC, like ACBAR, provides a forum in which member organizations can discuss their concerns of policy guidelines for delivering assistance, resource management and other operational issues - with the ultimate purpose of improving coordination in refugee assistance in Baluchistan as well as in the repatriation and resettlement of Afghan refugees. Additionally, SWABAC is a vehicle through which NGO views and interests are communicated to the various multilateral and bilateral donors and the Government of Pakistan.

Various sub-committees - Medical, Agriculture, Education, Construction - meet every month to exchange information and review sectoral concerns, relating to both refugee and cross-border assistance. SWABAC holds a general meeting of all members once a month. part of the general meeting is an observers section, where representatives of UN agencies, other donors and the Government of Pakistan are invited to make announcements and discuss issues. In late 1992, SWABAC started holding regional meetings covering the provinces in the southwest Afghanistan.

SWABAC is planning to organizes training courses for its member organizations in report writing, proposal writing, basic accounting and computer programs. 